Adoptado en 1995. Revisión 1997, 1999, 2001, 2003, 2004, 2005, 2006, 2007, 2008, 2009, 2010, 2011, 2012, 2013, 2014, 2015, 2016, 2017, 2018, 2019. 


\section{PREÁMBULO}

\section{1. ÁMBITO DE APLICACIÓN}

\subsection{Aditivos alimentarios incluidos en esta Norma}

En los alimentos sólo se reconocerá como adecuado el uso de los aditivos alimentarios que se indican en esta Norma. ${ }^{1}$ Únicamente se estudiará la inclusión en la presente Norma de los aditivos alimentarios a los cuales se ha asignado una ingestión diaria admisible (IDA) o cuya inocuidad ${ }^{2}$ ha quedado establecida, con arreglo a otros criterios, por el Comité Mixto FAO/OMS de Expertos en Aditivos Alimentarios (JECFA) ${ }^{3}$, y de aquellos a los que el Codex ha atribuido una designación con arreglo al Sistema Internacional de Numeración (SIN). Se considera que el uso de aditivos de acuerdo con las disposiciones de esta Norma se encuentra tecnológicamente justificado.

\subsection{Alimentos en los que se pueden utilizar aditivos}

En la presente Norma se establecen las condiciones en que se pueden utilizar aditivos alimentarios en todos los alimentos, se hayan establecido o no anteriormente normas del Codex para ellos. El uso de aditivos en los alimentos para los que existan normas del Codex está sujeto a las condiciones de uso establecidas por las normas para productos del Codex y por la presente Norma. La Norma General para los Aditivos Alimentarios (NGAA) deberá constituir la única referencia de autoridad con respecto a los aditivos alimentarios. Los comités sobre productos del Codex tienen la responsabilidad y competencia para evaluar y justificar la necesidad tecnológica del uso de aditivos en los alimentos regulados por una norma sobre productos. El Comité del Codex sobre Aditivos Alimentarios (CCFA) también puede tener en cuenta la información facilitada por los Comités sobre productos al examinar las disposiciones relativas a los aditivos alimentarios en alimentos similares no sujetos a normas. Cuando un alimento no esté regulado por un Comité del Codex sobre productos, el CCFA evaluará la necesidad tecnológica.

\subsection{Alimentos en los que no se pueden utilizar aditivos}

La presente Norma define las categorías de alimentos o los productos alimenticios individuales en los que el uso de aditivos alimentarios no está permitido o deberá restringirse.

\subsection{Dosis máximas de uso para los aditivos alimentarios}

El objetivo principal de establecer dosis máximas de uso para los aditivos alimentarios en diversos grupos de alimentos es asegurar que la ingestión de un aditivo procedente de todos sus usos no exceda de su IDA.

Los aditivos alimentarios regulados por la presente Norma y sus dosis de uso máximas se basan en parte en las disposiciones sobre aditivos alimentarios establecidas en anteriores normas del Codex para productos o en peticiones de los gobiernos, tras someter las dosis máximas propuestas a un método apropiado a fin de verificar la compatibilidad de la dosis máxima propuesta con la IDA.

Como primera medida, puede utilizarse en este sentido el Anexo A de la presente Norma. Se alienta también la evaluación de datos sobre el consumo efectivo de alimentos.

1 Sin perjuicio de las disposiciones de esta sección de la Norma General, el hecho de que no se haga referencia en la Norma General tal como está redactada actualmente a un aditivo en particular, o a una particular utilización de un aditivo en un alimento, no significa que dicho aditivo sea peligroso o que su utilización en los alimentos sea inadecuada. La Comisión examinará periódicamente la conveniencia de mantener la presente nota de pie de página, con el propósito de suprimirla cuando la Norma General se haya completado en lo esencial.

2 Para los fines de la presente Norma, por "establecida, con arreglo a otros criterios" se entenderá que el uso de un aditivo alimentario no es motivo de preocupación en lo que respecta a la inocuidad en las condiciones de uso que, según la JECFA, no dan lugar a preocupaciones de orden toxicológico (por ejemplo, las relativas a las dosis de utilización).

3 Se puede consultar una base de datos de especificaciones de aditivos alimentarios con su situación de IDA actual, al año de su evaluación más reciente por el JECFA, sus números del SIN asignados, etc. en inglés, en las páginas Web del JECFA en la FAO http://www.fao.org/ag/agn/jecfa-additives/search.html?lang=es . La base de datos tiene una página para formular consultas e información sobre los antecedentes en árabe, chino, español, francés e inglés. Los informes del JECFA están disponibles en el sitio Web del JECFA en la OMS: http://www.who.int/ipcs/food/jecfa/en/ 


\section{DEFINICIONES}

a) Se entiende por aditivo alimentario cualquier sustancia que en cuanto tal no se consume normalmente como alimento, ni tampoco se usa como ingrediente básico en alimentos, tenga o no valor nutritivo, y cuya adición intencionada al alimento con fines tecnológicos (incluidos los organolépticos) en sus fases de fabricación, elaboración, preparación, tratamiento, envasado, empaquetado, transporte 0 almacenamiento, resulte o pueda preverse razonablemente que resulte (directa o indirectamente) por sí o sus subproductos, en un componente del alimento o un elemento que afecte a sus características. Esta definición no incluye "contaminantes" o sustancias añadidas al alimento para mantener o mejorar las cualidades nutricionales. ${ }^{4}$

b) Ingestión diaria admisible (IDA) es una estimación efectuada por el JECFA de la cantidad de aditivo alimentario, expresada en relación con el peso corporal, que una persona puede ingerir diariamente durante toda la vida sin riesgo apreciable para su salud. ${ }^{5}$

c) Ingestión diaria admisible "no especificada" (NE) ${ }^{6}$ es una expresión que se aplica a las sustancias alimentarias de muy baja toxicidad cuya ingestión alimentaria total, derivada de su uso en las dosis necesarias para conseguir el efecto deseado y de su concentración admisible anterior en los alimentos, no representa, en opinión del JECFA, un riesgo para la salud, teniendo en cuenta los datos (químicos, bioquímicos, toxicológicos y de otro tipo) disponibles.

Por el motivo susodicho, así como por las razones expuestas en las distintas evaluaciones del JECFA, este organismo no considera necesario asignar un valor numérico a la ingestión diaria admisible. Todo aditivo que satisfaga el criterio susodicho deberá emplearse conforme a las buenas prácticas de fabricación que se definen más adelante en la Sección 3.3.

d) Dosis máxima de uso de un aditivo es la concentración más alta de éste respecto de la cual la Comisión del Codex Alimentarius ha determinado que es funcionalmente eficaz en un alimento o categoría de alimentos y ha acordado que es inocua. Por lo general se expresa como mg de aditivo por $\mathrm{kg}$ de alimento.

La dosis de uso máxima no suele corresponder a la dosis de uso óptima, recomendada o normal. De conformidad con las buenas prácticas de fabricación, la dosis de uso óptima, recomendada o normal, difiere para cada aplicación de un aditivo y depende del efecto técnico previsto y del alimento específico en el cual se utilizaría dicho aditivo, teniendo en cuenta el tipo de materia prima, la elaboración de los alimentos y su almacenamiento, transporte y manipulación posteriores por los distribuidores, los vendedores al por menor y los consumidores.

\section{PRINCIPIOS GENERALES PARA EL USO DE ADITIVOS ALIMENTARIOS}

El uso de aditivos alimentarios de conformidad con esta Norma exige el cumplimiento de todos los principios que se establecen en las Secciones 3.1 a 3.4.

\subsection{Inocuidad de los aditivos alimentarios}

a) Únicamente se aprobarán e incluirán en la presente Norma los aditivos alimentarios que, en la medida en que puede juzgarse por las pruebas de que dispone el JECFA, no presentan riesgos apreciables para la salud de los consumidores en las dosis de uso propuestas.

4 Manual de Procedimiento del Codex Alimentarius.

5 Principios para evaluar la inocuidad de los aditivos alimentarios y contaminantes en los alimentos, Organización Mundial de la Salud (Criterios de salud ambiental de la OMS, № 70), pág. 111 (1987). A los efectos de esta Norma, por "sin riesgo apreciable para su salud" se entiende que, si un aditivo se usa en una dosis que no excede de la establecida en la presente Norma, hay una certeza razonable de que no será perjudicial para los consumidores. Las disposiciones de la presente Norma no autorizan el uso de un aditivo de manera que repercuta negativamente en la salud de los consumidores.

6 A los efectos de la presente Norma, ingestión diaria admisible (IDA) "no limitada" (NL) tiene el mismo significado que IDA "no especificada". La expresión "IDA admisible" se refiere a una evaluación por el JECFA que haya determinado la inocuidad sobre la base de un nivel de tratamiento aceptable del alimento, limitado numéricamente o mediante BPF, y no a partir de una IDA determinada desde el punto de vista toxicológico. 
b) La inclusión de aditivos alimentarios en esta Norma se efectuará teniendo en cuenta toda IDA, o evaluación equivalente de la inocuidad, establecida para el aditivo por el JECFA y su ingestión diaria probable ${ }^{7}$ proveniente de todas las fuentes. Cuando el aditivo alimentario se emplee en alimentos destinados a grupos especiales de consumidores (por ejemplo, diabéticos, personas con regímenes alimenticios médicos especiales, personas enfermas con regímenes alimenticios líquidos), se tendrá en cuenta la ingestión diaria probable del aditivo alimentario por esos consumidores.

c) La cantidad de aditivo que se añada a un alimento será igual o inferior a la dosis máxima de uso y constituirá la dosis mínima necesaria para lograr el efecto técnico previsto. La dosis máxima de uso podrá basarse en la aplicación de los procedimientos que se establecen en el Anexo A, en las evaluaciones de la ingestión realizadas por los Estados Miembros del Codex o en una valoración independiente de las evaluaciones nacionales de la ingestión solicitada al JECFA por el CCFA.

\subsection{Justificación del uso de aditivos}

El uso de aditivos alimentarios está justificado únicamente si ello ofrece alguna ventaja, no presenta riesgos apreciables para la salud de los consumidores, no induce a error a éstos, y cumple una o más de las funciones tecnológicas establecidas por el Codex y los requisitos que se indican a continuación en los apartados a) a d), y únicamente cuando estos fines no pueden alcanzarse por otros medios que son factibles económica y tecnológicamente:

a) Conservar la calidad nutricional del alimento; una disminución intencionada en la calidad nutricional de un alimento estaría justificada en las circunstancias indicadas en el subpárrafo b) y también en otras circunstancias en las que el alimento no constituye un componente importante de una dieta normal;

b) Proporcionar los ingredientes o constituyentes necesarios para los alimentos fabricados para grupos de consumidores que tienen necesidades dietéticas especiales;

c) Aumentar la calidad de conservación o la estabilidad de un alimento o mejorar sus propiedades organolépticas, a condición de que ello no altere la naturaleza, sustancia o calidad del alimento de forma que engañe al consumidor;

d) Proporcionar ayuda en la fabricación, elaboración, preparación, tratamiento, envasado, transporte o almacenamiento del alimento, a condición de que el aditivo no se utilice para encubrir los efectos del empleo de materias primas defectuosas o de prácticas (incluidas las no higiénicas) o técnicas indeseables durante el curso de cualquiera de estas operaciones.

\subsection{Buenas prácticas de fabricación (BPF) ${ }^{8}$}

Todos los aditivos alimentarios regulados por las disposiciones de esta Norma se emplearán conforme a las condiciones de buenas prácticas de fabricación, que incluyen lo siguiente:

a) La cantidad de aditivo que se añada al alimento se limitará a la dosis mínima necesaria para obtener el efecto deseado;

b) La cantidad de aditivo que pase a formar parte del alimento como consecuencia de su uso en la fabricación, elaboración o envasado de un alimento y que no tenga por objeto obtener ningún efecto físico o técnico en el alimento mismo, se reducirá en la mayor medida que sea razonablemente posible;

c) El aditivo será de una calidad alimentaria apropiada y se preparará y manipulará de la misma forma que un ingrediente alimentario.

7 Los Estados Miembros del Codex podrán facilitar al CCFA información relativa a la ingestión que pueda ser utilizada por éste para establecer las dosis máximas de uso. Además, el JECFA, a petición del CCFA, evaluará la ingestión de aditivos basándose en la información al respecto presentada por los Estados Miembros del Codex en respuesta a una solicitud de datos. El CCFA tendrá en cuenta las evaluaciones del JECFA al establecer las dosis máximas de uso para los aditivos.

8 Para más información, véase el Manual de Procedimiento de la Comisión del Codex Alimentarius, Relaciones entre los Comités del Codex sobre productos y los Comités de asuntos generales - Aditivos alimentarios y contaminantes. 


\subsection{Especificaciones de identidad y pureza de los aditivos alimentarios}

Los aditivos alimentarios empleados de acuerdo con la presente Norma deberán ser de calidad alimentaria apropiada y satisfacer en todo momento las especificaciones de identidad y pureza aplicables recomendadas por la Comisión del Codex Alimentarius, ${ }^{9}$ o bien, en ausencia de tales especificaciones, las especificaciones apropiadas elaboradas por los organismos nacionales e internacionales competentes. Por lo que respecta a la inocuidad, la calidad alimentaria se logra ajustando los aditivos a sus especificaciones en conjunto (y no simplemente mediante criterios individuales) y mediante su producción, almacenamiento, transporte y manipulación en armonía con las BPF.

\section{TRANSFERENCIA DE LOS ADITIVOS ALIMENTARIOS A LOS ALIMENTOS}

4.1 Condiciones aplicables a la transferencia de aditivos alimentarios desde los ingredientes y las materias primas a los alimentos

Aparte de por adición directa, los aditivos pueden estar presentes en un alimento como resultado de la transferencia a partir de materias primas o ingredientes utilizados para producirlo, con sujeción a las siguientes condiciones:

a) El uso del aditivo es aceptable en las materias primas $u$ otros ingredientes (incluidos los aditivos alimentarios) de acuerdo con la presente norma;

b) Que la cantidad de aditivo alimentario presente en las materias primas $u$ otros ingredientes (incluidos los aditivos alimentarios) no exceda de la dosis máxima especificada en la presente Norma;

c) Que el alimento al que se transfiera el aditivo no contenga dicho aditivo en una cantidad mayor que la que se introduciría como resultado del empleo de las materias primas o los ingredientes en condiciones tecnológicas o prácticas de fabricación apropiadas, en consonancia con las disposiciones de la presente Norma.

4.2 Condiciones especiales aplicables al uso de aditivos alimentarios no autorizados directamente en los ingredientes y en las materias primas de los alimentos

Un aditivo podrá utilizarse en o añadirse a una materia prima $u$ otro ingrediente si la materia prima o ingrediente se utiliza exclusivamente en la preparación de un alimento que se ajuste a las disposiciones de esta norma, y que no exceda cualquier dosis máxima aplicable al alimento.

\subsection{Alimentos en los que es inaceptable la transferencia de aditivos alimentarios}

La transferencia de aditivos alimentarios a partir de materias primas o ingredientes es inaceptable en aquellos alimentos pertenecientes a las siguientes categorías, a menos que en los cuadros 1 y 2 de esta Norma figure una disposición sobre aditivos alimentarios para la categoría especificada.

a) 13.1 - Preparados para lactantes, preparados de continuación y preparados para usos medicinales especiales destinados a los lactantes.

b) 13.2 - Alimentos complementarios para lactantes y niños pequeños.

\section{SISTEMA DE CLASIFICACIÓN DE ALIMENTOS 10}

El sistema de clasificación de alimentos es un instrumento para asignar usos a los aditivos alimentarios en esta Norma. El sistema se aplica a todos los alimentos.

Los descriptores de las categorías de alimentos no son denominaciones legales de los productos ni el fin a que están destinados es el etiquetado.

9 En la página web del Codex (http://www.codexalimentarius.org/normas-oficiales/es/), se puede encontrar un índice (CAC/MISC 6) de todas las especificaciones aprobadas por la Comisión del Codex Alimentarius, así como el año de aprobación. Estas especificaciones, preparadas por el JECFA, también se publican en 2006 en el número 1 de las Monografías del JECFA de la FAO, titulado "Compendium of Food Additive Specifications", que consta de cuatro volúmenes publicados y en posteriores Monografías del JECFA. Las especificaciones también están disponibles en la página Web del JECFA (http://www.fao.org/ag/agn/jecfa-additives/search.html?lang=es ). Aunque las especificaciones para los aromatizantes no se incluyen en el compendio impreso, con la excepción de los pocos que poseen una función tecnológica no aromatizante, figuran en una base de datos en línea que se encuentra en el sitio Web del JECFA hospedado por la FAO y en la que se pueden realizar búsquedas. http://www.fao.org/food/foodsafety-quality/scientific-advice/jecfa/jecfa-flav/en/.

10 Anexo B de la presente Norma. 
El sistema de clasificación de alimentos está basado en los siguientes principios:

a) El sistema de clasificación de alimentos es de carácter jerárquico, lo que significa que cuando se reconoce el uso de un aditivo en una categoría general, se reconoce dicho uso en todas sus subcategorías, a menos que se indique otra cosa. Asimismo, cuando se reconoce el uso de un aditivo en una subcategoría, se reconoce su uso en cualquier otra subcategoría o en los distintos alimentos mencionados en una subcategoría.

b) El sistema de clasificación de alimentos se basa en descriptores de productos alimenticios tal como se comercializan, a menos que se indique otra cosa.

c) El sistema de clasificación de alimentos tiene en cuenta el principio de transferencia. En consecuencia no es necesario mencionar específicamente en el sistema de clasificación los alimentos compuestos (por ejemplo las comidas preparadas, como la pizza, porque pueden contener, proporcionalmente, todos los aditivos cuyo uso esté autorizado en sus componentes), a menos que el alimento compuesto necesite un aditivo cuyo uso no esté autorizado en ninguno de sus componentes.

d) El sistema de clasificación de alimentos se utiliza para simplificar la notificación de usos de los aditivos alimentarios con fines de compilación y elaboración de esta Norma.

\section{DESCRIPCIÓN DE LA NORMA}

Esta Norma consta de tres elementos principales:

a) Preámbulo

b) Anexos

i. El Anexo A es una directriz para el examen de las dosis máximas de uso de los aditivos a los que el JECFA ha asignado una IDA numérica.

ii. El Anexo B contiene una lista de categorías del Sistema de Clasificación de Alimentos utilizada para preparar y organizar los Cuadros 1,2 y 3 de la Norma. Se facilitan asimismo los descriptores para cada una de las categorías y subcategorías.

iii. El Anexo $\mathrm{C}$ contiene referencias al Sistema de Clasificación de Alimentos y a las normas para productos del Codex.

c) Disposiciones sobre aditivos alimentarios

i. En el Cuadro 1 se especifica, para cada uno de los aditivos alimentarios o de los grupos de aditivos alimentarios (presentados en orden alfabético) a los que el JECFA ha asignado una IDA numérica, las categorías de alimentos (o los alimentos) en que se reconoce el uso del aditivo, las dosis máximas de uso para cada alimento o categoría de alimentos y su función tecnológica. En el Cuadro 1 figuran también los usos de los aditivos con una IDA no numérica y se especifican sus dosis máximas de uso.

ii. En el Cuadro 2 se ofrece la misma información que en el Cuadro 1, pero presentada en orden numérico de categoría de alimentos.

iii. En el Cuadro 3 figura la lista de los aditivos con una IDA del JECFA no especificada o no limitada cuyo uso en los alimentos en general está autorizado en dosis quantum satis y según los principios de las buenas prácticas de fabricación descritos en el apartado 3.3 del presente preámbulo.

En el Anexo al Cuadro 3 se presenta la lista de los alimentos y categorías de alimentos que están excluidos de las condiciones generales del Cuadro 3. Las disposiciones de los Cuadros 1 y 2 rigen la utilización de los aditivos de las categorías de alimentos enumerados en el anexo al Cuadro 3.

Salvo indicación en contrario, las dosis máximas de uso de los aditivos de los Cuadros 1 y 2 se refieren al producto final, en la forma en que se consume.

En los Cuadros 1, 2 y 3 no se hace referencia a los usos de las sustancias como coadyuvantes de elaboración. ${ }^{11}$

11 Por coadyuvante de elaboración se entiende toda sustancia o materia, excluidos aparatos y utensilios, que en cuanto tal no se utiliza como ingrediente alimentario y que se emplea intencionalmente en la elaboración de materias primas, alimentos o sus ingredientes, para lograr alguna finalidad tecnológica durante el tratamiento o la elaboración, pudiendo dar lugar a la presencia no intencional, pero inevitable, de residuos o derivados en el producto final: Comisión del Codex Alimentarius, Manual de Procedimiento. 


\section{DIRECTRICES PARA LA FORMULACIÓN DE DOSIS MÁXIMAS DE USO DE ADITIVOS ALIMENTARIOS CON INGESTIÓN DIARIA ADMISIBLE NUMÉRICA}

El presente anexo se ha preparado para que sirva de guía en el estudio de las propuestas relativas a la utilización de aditivos, en las que se han tenido en cuenta las dosis máximas de uso y el límite fisiológico máximo de ingestión diaria de alimentos y bebidas. El anexo no tiene por objeto formular disposiciones para la utilización de un determinado aditivo, ni puede utilizarse para calcular con precisión la ingestión de aditivos.

\section{ADITIVOS ALIMENTARIOS, PRINCIPIOS BÁSICOS PARA CALCULAR LAS DOSIS DE USO}

\section{Directriz 1}

Las dosis y las cantidades de los aditivos alimentarios que se utilizan en los cálculos del Método del Presupuesto deben expresarse sobre la misma ${ }^{12}$ base que las substancias para las cuales se ha asignado la IDA (por ejemplo, un ácido o sus sales). En lo que respecta a los alimentos vendidos como concentrados o en polvo que deben reconstruirse antes de ser consumidos, el cálculo del presupuesto de las dosis de utilización de los aditivos alimentarios debe efectuarse en el producto listo para el consumo.

\section{ESTIMACIÓN DE LOS ASPECTOS RELATIVOS A LA INOCUIDAD DE LAS DOSIS DE USO - ADITIVOS} ALIMENTARIOS QUE NO TIENEN IDA NUMÉRICA

\section{Directriz 2}

\section{Aditivos alimentarios con IDA "No especificadas"}

Cuando a un aditivo se le ha asignado una IDA "no especificada", en principio su utilización podría estar permitida en todos los alimentos, sin otra limitación que su conformidad con las Buenas Prácticas de Fabricación (BPF). No obstante, debe tenerse presente que una IDA no especificada no significa que se acepta una ingestión ilimitada. El término es empleado por el JECFA en los casos en que "sobre la base de los datos disponibles (químicos, bioquímicos, toxicológicos, y otros) la ingestión diaria total de la sustancia derivada de su utilización en las dosis necesarias para lograr el efecto deseado, y de acuerdo con sus antecedentes aceptables en la alimentación, no represente, según el Comité, un peligro para la salud"

Por consiguiente, si una sustancia se emplea en cantidades mayores y/o en una serie más amplia de alimentos que la prevista originalmente por el JECFA podría ser necesario consultar al JECFA para asegurar que la evaluación sea aplicable a las nuevas formas de empleo. Por ejemplo, una sustancia puede haberse evaluado como humectante sin considerar su uso posterior como edulcorante a granel, lo cual podría implicar una ingestión mayor.

\section{Directriz 3}

\section{Aditivos alimentarios evaluados como "Aceptables" para ciertos usos}

En algunos casos, el JECFA no ha podido asignar una IDA pero considera, sin embargo, que un cierto uso específico de una sustancia es aceptable. En esos casos, el aditivo de que se trate deberá autorizarse solamente de conformidad con las condiciones especificadas. Si se indicase cualquier otro uso, el CCFA deberá pedir al JECFA que haga una nueva evaluación del aditivo de que se trate a la luz de la nueva información sobre los usos.

12 Principles for the Safety Assessment of Food Additives and Contaminants in Food. Ginebra, Organización Mundial de la Salud, 1987 (Environmental Health Criteria, No. 70), pág. 83. 
III. ESTIMACIÓN DE LOS ASPECTOS RELATIVOS A LA INOCUIDAD DE LAS DOSIS DE USO - ADITIVOS ALIMENTARIOS CON IDA NUMÉRICA

\title{
Directriz 4
}

\author{
Fracciones de la IDA que habrán de utilizarse para los alimentos sólidos y las bebidas, \\ respectivamente
}

Si un aditivo se propone para su empleo tanto en alimentos sólidos como en bebidas, no puede usarse la IDA por entero para los alimentos sólidos y para las bebidas. Es necesario, por tanto, asignar una fracción de la IDA a cada una de las aplicaciones. Como primer paso, puede ser conveniente suponer que la mitad de la IDA se asigne a cada alimento sólido y líquido. No obstante, en casos especiales quizá convendría emplear otras fracciones a condición de que la suma de las fracciones no sobrepase la IDA (por ejemplo, FS $=1 / 4$ y FB $=3 / 4 ; F S=1 / 6$ y FB $=5 / 6$ ), siendo FS la fracción que debe utilizarse en los alimentos sólidos y FB la fracción que ha de utilizarse en las bebidas). Si el aditivo se usa solamente en los alimentos sólidos, entonces $\mathrm{FS}=1$ y $\mathrm{FB}=0$, y si el aditivo se usa sólo en las bebidas, $\mathrm{FS}=0$ y $\mathrm{FB}=1$.

\section{III(a) ADITIVOS ALIMENTARIOS QUE SE EMPLEAN SÓLO EN ALIMENTOS SÓLIDOS (FS)}

\section{Directriz 5}

\section{Dosis de uso menores de FS x IDA x 40}

Si las dosis de uso propuestas son menores de FS $\times$ IDA $\times 40$, las disposiciones relativas a estos aditivos alimentarios podrán ser adecuadas para todos los alimentos.

\section{Directriz 6}

\section{Dosis de uso menores de FS x IDA x 80}

Si las dosis de uso propuestas son menores de FS $\times$ IDA $\times 80$ se consideran aceptables si el consumo diario de los alimentos que contienen el aditivo de que se trata no será habitualmente superior a la mitad de la ingestión total máxima de alimentos sólidos prevista (es decir, $12,5 \mathrm{~g} / \mathrm{kg}$ pc/día)

\section{Directriz 7}

\section{Dosis de uso menores de FS x IDA x 160}

Si las dosis de uso propuestas son menores de FS $\times$ IDA $\times 160$ se consideran aceptables si el consumo diario de los alimentos que contienen el aditivo de que se trata no será habitualmente superior a un cuarto de la ingestión total máxima de alimentos sólidos prevista (es decir, 6,25 g/kg pc/día).

\section{Directriz 8}

\section{Dosis de uso menores de FS x IDA x 320}

Si las dosis de uso propuestas son menores de FS $\times$ IDA x 320 podrían aceptarse a condición de que el consumo diario de los alimentos que contienen el aditivo de que se trata no será habitualmente superior a un octavo de la ingestión total máxima de alimentos sólidos prevista (es decir, 3,13 g/kg pc/día).

\section{Directriz 9}

\section{Dosis de uso mayores de FS $\times$ IDA $\times 320$}

Si las dosis propuestas son mayores de FS $\times$ IDA x 320 deberían aceptarse solamente para productos en los que el cálculo de la ingestión potencial de todos los usos propuestos demuestre que es poco probable que se sobrepase la IDA, o si la estimación de la ingestión del aditivo basada en métodos más exactos de estimación de la ingestión demuestra que las dosis de utilización son aceptables (por ejemplo, encuestas sobre el consumo de alimentos).

\section{III(b) ADITIVOS ALIMENTARIOS QUE SE EMPLEAN EN LAS BEBIDAS (FL)}

\section{Directriz 10}

\section{Dosis de uso menores de FL x IDA x 10}

Si las dosis propuestas son menores de FL x IDA x 10, la utilización del aditivo podría aceptarse para todas las bebidas. 


\section{Directriz 11}

Dosis de uso menores de FL $x$ IDA $\times 20$

Si las dosis de uso propuestas son menores de FL $\times$ IDA $\times 20$ podrían aceptarse a condición de que el consumo diario de las bebidas que contienen el aditivo de que se trata no será habitualmente superior a la mitad de la ingestión total máxima prevista de la bebida (es decir, $50 \mathrm{ml} / \mathrm{kg} \mathrm{pc/día).}$

\section{Directriz 12}

\section{Dosis de uso menores de FL x IDA x 40}

Si las dosis de uso propuestas son menores de FL $\times$ IDA $\times 40$ podrían aceptarse a condición de que el consumo diario de las bebidas que contienen el aditivo de que se trata no será habitualmente superior a un cuarto de la ingestión total máxima prevista de la bebida (es decir, $25 \mathrm{ml} / \mathrm{kg} \mathrm{pc/día).}$

\section{Directriz 13}

\section{Dosis de uso menores de FL x IDA x 80}

Si las dosis propuestas son menores de FL x IDA x 80 podrían aceptarse a condición de que el consumo diario de las bebidas que contienen el aditivo de que se trata no será habitualmente superior a un octavo de la ingestión total máxima prevista de la bebida (es decir, $12,5 \mathrm{ml} / \mathrm{kg} \mathrm{pc} / \mathrm{día}$ ).

\section{Directriz 14}

\section{Dosis de uso mayores de FL $x$ IDA $\times 80$}

Las dosis mayores de FL $\times$ IDA $\times 80$ deberían aceptarse exclusivamente para los productos en los que el cálculo de la ingestión potencial demuestre que es poco probable que se sobrepase la IDA (por ejemplo, bebidas alcohólicas fuertes). 
ANEXO B

\section{SISTEMA DE CLASIFICACIÓN DE LOS ALIMENTOS}

\section{PARTE I: Sistema de Clasificación de los Alimentos}

01.0 Productos lácteos y productos análogos, excluidos los productos de la categoría de alimentos 02.0

01.1 Leche y productos lácteos líquidos

01.1.1 Leche líquida (natural / simple)

01.1.2 Otras leches líquidas (naturales / simples)

01.1.3 Suero de mantequilla líquido (natural / simple)

01.1.4 Bebidas lácteas líquidas aromatizadas

01.2 Productos lácteos fermentados y cuajados (naturales / simples)

01.2.1 Leches fermentadas (naturales / simples)

01.2.1.1 Leches fermentadas (naturales / simples) sin tratamiento térmico después de la fermentación

01.2.1.2 Leches fermentadas (naturales / simples) tratadas térmicamente después de la fermentación

01.2.2 Cuajada (natural / simple)

01.3 Leche condensada y productos análogos (naturales / simples)

01.3.1 Leche condensada (natural / simple)

01.3.2 Blanqueadores de bebidas

01.4 Nata (crema) (natural / simple) y productos análogos

01.4.1 Nata (crema) pasterizada (natural / simple)

01.4.2 Natas (cremas) esterilizadas y UHT, natas (cremas) para batir o batidas y natas (cremas) de contenido de grasa reducido (naturales)

01.4.3 Nata (crema) cuajada (natural / simple)

01.4.4 Productos análogos a la nata (crema)

01.5 Leche en polvo y nata (crema) en polvo y productos análogos en polvo (naturales)

01.5.1 Leche en polvo y nata (crema) en polvo (naturales)

01.5.2 Productos análogos a la leche y la nata (crema) en polvo

01.6 Queso y productos análogos

01.6.1 Queso no madurado

01.6.2 Queso madurado

01.6.2.1 Queso madurado, incluida la corteza

01.6.2.2 Corteza de queso madurado

01.6.2.3 Queso en polvo (para reconstitución; p. ej. para salsas a base de queso)

01.6.3 Queso de suero

01.6.4 Queso elaborado, fundido

01.6.4.1 Queso fundido natural

01.6.4.2 Queso fundido aromatizado, incluido el que contiene fruta, hortalizas, carne, etc.

01.6.5 Productos análogos al queso

01.6.6 Queso de proteínas del suero

01.7 Postres lácteos (como pudines, yogur aromatizado o con fruta) 
01.8 Suero y productos a base de suero, excluidos los quesos de suero

01.8.1 Suero líquido y productos a base de suero líquido, excluidos los quesos de suero

01.8.2 Suero en polvo y productos a base de suero en polvo, excluidos los quesos de suero

02.0 Grasas y aceites y emulsiones grasas

02.1 Grasas y aceites prácticamente exentos de agua

02.1.1 Aceite de mantequilla (manteca), grasa de leche anhidra, "ghee"

02.1.2 Grasas y aceites vegetales

02.1.3 Manteca de cerdo, sebo, aceite de pescado y otras grasas de origen animal

02.2 Emulsiones grasas, principalmente del tipo agua en aceite

02.2.1 Mantequilla (manteca)

02.2.2 Grasas para untar, grasas lácteas para untar y mezclas de grasas para untar

02.3 Emulsiones grasas, principalmente del tipo agua en aceite, incluidos los productos a base de emulsiones grasas mezcladas $\mathrm{y} / \mathrm{o}$ aromatizados

02.4 Postres a base de grasas, excluidos los postres lácteos de la categoría de alimentos 01.7

03.0 Hielos comestibles, incluidos los sorbetes

04.0 Frutas y hortalizas (incluidos hongos y setas, raíces y tubérculos, legumbres y leguminosas y áloe vera), algas marinas y nueces y semillas

04.1 Frutas

04.1.1 Frutas frescas

04.1.1.1 Frutas frescas no tratadas

04.1.1.2 Frutas frescas tratadas en la superficie

04.1.1.3 Frutas frescas peladas $\mathrm{y} / \mathrm{o}$ cortadas

04.1.2 Frutas elaboradas

04.1.2.1 Frutas congeladas

04.1.2.2 Frutas desecadas

04.1.2.3 Frutas en vinagre, aceite o salmuera

04.1.2.4 Frutas en conserva enlatadas o en frascos (pasterizadas)

04.1.2.5 Confituras, jaleas, mermeladas

04.1.2.6 Productos para untar a base de fruta (p. ej. el "chutney"), excluidos los productos de la categoría de alimentos 04.1.2.5

04.1.2.7 Frutas confitadas

04.1.2.8 Preparados a base de fruta, incluida la pulpa, los purés, los revestimientos de fruta y la leche de coco

04.1.2.9 Postres a base de fruta, incluidos los postres a base de agua con aromas de fruta

04.1.2.10 Productos de fruta fermentada

04.1.2.11 Rellenos de fruta para pastelería

04.1.2.12 Frutas cocidas o fritas

04.2 Hortalizas (incluidos hongos y setas, raíces y tubérculos, legumbres y leguminosas y áloe vera), algas marinas y nueces y semillas

04.2.1 Hortalizas (incluidos hongos y setas, raíces y tubérculos, legumbres y leguminosas y áloe vera), algas marinas y nueces y semillas frescas

04.2.1.1 Hortalizas (incluidos hongos y setas, raíces y tubérculos, legumbres y leguminosas y áloe vera), algas marinas y nueces y semillas frescas no tratadas 
04.2.1.2 Hortalizas (incluidos hongos y setas, raíces y tubérculos, legumbres y leguminosas y áloe vera), algas marinas y nueces y semillas frescas tratadas en la superficie

04.2.1.3 Hortalizas (incluidos hongos y setas, raíces y tubérculos, legumbres y leguminosas y áloe vera), algas marinas y nueces y semillas frescas peladas, cortadas o desmenuzadas

04.2.2 Hortalizas (incluidos hongos y setas, raíces y tubérculos, legumbres y leguminosas y áloe vera), algas marinas y nueces y semillas elaboradas

04.2.2.1 Hortalizas (incluidos hongos y setas, raíces y tubérculos, legumbres y leguminosas y áloe vera), algas marinas y nueces y semillas congeladas

04.2.2.2 Hortalizas (incluidos hongos y setas, raíces y tubérculos, legumbres y leguminosas y áloe vera), algas marinas y nueces y semillas desecadas

04.2.2.3 Hortalizas (incluidos hongos y setas, raíces y tubérculos, legumbres y leguminosas y áloe vera) y algas marinas en vinagre, aceite, salmuera o salsa de soja

04.2.2.4 Hortalizas (incluidos hongos y setas, raíces y tubérculos, legumbres y leguminosas y áloe vera) y algas marinas en conserva, en latas o frascos (pasterizadas) o en bolsas de esterilización

04.2.2.5 Purés y preparados para untar elaborados con hortalizas (incluidos hongos y setas, raíces y tubérculos, legumbres y leguminosas y áloe vera), algas marinas y nueces y semillas (p. ej. la mantequilla de maní (cacahuete))

04.2.2.6 Pulpas y preparados de hortalizas (incluidos hongos y setas, raíces y tubérculos, legumbres y leguminosas y áloe vera), algas marinas y nueces y semillas (como los postres y las salsas a base de hortalizas y hortalizas confitadas) distintos de los indicados en la categoría de alimentos 04.2.2.5

04.2.2.7 Productos a base de hortalizas (incluidos hongos y setas, raíces y tubérculos, legumbres y leguminosas y áloe vera) y algas marinas fermentadas, excluidos los productos fermentados de soja de las categorías de alimentos 06.8.6, 06.8.7, 12.9.1, 12.9.2.1 y 12.9.2.3

04.2.2.8 Hortalizas (incluidos hongos y setas, raíces y tubérculos, legumbres y leguminosas y áloe vera) y algas marinas cocidas o fritas

\subsection{Confitería}

05.1 Productos de cacao y chocolate, incluidos los productos de imitación y los sucedáneos del chocolate

05.1.1 Mezclas de cacao (en polvo) y cacao en pasta/torta de cacao

05.1.2 Mezclas de cacao (jarabes)

05.1.3 Productos para untar a base de cacao, incluidos los rellenos a base de cacao

05.1.4 Productos de cacao y chocolate

05.1.5 Productos de imitación y sucedáneos del chocolate

05.2 Dulces distintos de los indicados en las categorías de alimentos 05.1, 05.3 y 05.4, incluidos los caramelos duros y blandos, los turrones, etc.

05.2.1 Caramelos duros

05.2.2 Caramelos blandos

0.5.2.3 Turrón y mazapán

05.3 Goma de mascar

05.4 Decoraciones (p. ej. para productos de pastelería fina), revestimientos (que no sean de fruta) y salsas dulces

06.0 Cereales y productos a base de cereales, derivados de granos de cereales, de raíces y tubérculos, legumbres, leguminosas y médula o corazón blando de palmera, excluidos los productos de panadería de la categoría de alimentos 07.0 
06.1 Granos enteros, triturados o en copos, incluido el arroz

06.2 Harinas y almidones

06.2.1 Harinas

06.2.2 Almidones

06.3 Cereales para el desayuno, incluidos los copos de avena

06.4 Pastas y fideos y productos análogos (p. ej. fécula de arroz en hojas, "vermicelli" de arroz , pastas y fideos de soja)

06.4.1 Pastas y fideos frescos y productos análogos

06.4.2 Pastas y fideos deshidratados y productos análogos

06.4.3 Pastas y fideos precocidos y productos análogos

06.5 Postres a base de cereales y almidón (p. ej. pudines de arroz, pudines de mandioca)

06.6 Mezclas batidas para rebozar (p. ej. para empanar o rebozar pescado o carne de aves de corral)

06.7 Productos a base de arroz precocidos o elaborados, incluidas las tortas de arroz (sólo del tipo oriental)

06.8 Productos a base de soja (excluidos aderezos y condimentos a base de soja de la categoría de alimentos 12.9)

06.8.1 Bebidas a base de soja

06.8.2 Película de bebida a base de soja

06.8.3 Cuajada de soja (tofu)

06.8.4 Cuajada de soja semideshidratada

06.8.4.1 Cuajada de soja semideshidratada dura cocida en salsa espesa

06.8.4.2 Cuajada de soja semideshidratada frita

06.8.4.3 Cuajada de soja semideshidratada distinta de la incluida en las categorías de alimentos 06.8.4.1 y 06.8.4.2

06.8.5 Cuajada de soja deshidratada (kori tofu)

06.8.6 Soja fermentada (por ej. natto, tempe)

06.8.7 Cuajada de soja fermentada

06.8.8 Otros productos a base de proteína de soja

07.0 Productos de panadería

07.1 Pan y productos de panadería ordinaria

07.1.1 Panes y panecillos

07.1.1.1 Panes leudados con levadura y panes especiales

07.1.1.2 Panes leudados con bicarbonato

07.1.2 "Crackers", excluidos los "crackers" dulces

07.1.3 Otros productos de panadería ordinaria (p. ej. "bagels", "pita", "muffins" ingleses, etc.)

07.1.4 Productos similares al pan, incluidos los rellenos a base de pan y el pan rallado

07.1.5 Panes y bollos dulces al vapor

07.1.6 Mezclas para pan y productos de panadería ordinaria

07.2 Productos de panadería fina (dulces, salados, aromatizados) y mezclas

07.2.1 Tortas, galletas y pasteles (p. ej. rellenos de fruta o crema)

07.2.2 Otros productos de panadería fina (p. ej. "donuts", panecillos dulces, "scones" (bollos ingleses) y "muffins")

07.2.3 Mezclas para pastelería fina (p. ej. tortas, tortitas o panqueques) 
08.0 Carne y productos cárnicos, incluidos los de aves de corral y caza

08.1 Carne fresca, incluida la de aves de corral y caza

08.1.1 Carne fresca, incluida la de aves de corral y caza, en piezas enteras o en cortes

08.1.2 Carne fresca picada, incluida la de aves de corral y caza

08.2 Productos cárnicos, de aves de corral y caza elaborados, en piezas enteras o en cortes

08.2.1 Productos cárnicos, de aves de corral y caza elaborados sin tratar térmicamente, en piezas enteras o en cortes

08.2.1.1 Productos cárnicos, de aves de corral y caza elaborados, curados (incluidos los salados) y sin tratar térmicamente, en piezas enteras o en cortes

08.2.1.2 Productos cárnicos, de aves de corral y caza elaborados, curados (incluidos los salados), desecados y sin tratar térmicamente, en piezas enteras o en cortes

08.2.1.3 Productos cárnicos, de aves de corral y caza elaborados, fermentados y sin tratar térmicamente, en piezas enteras o en cortes

08.2.2 Productos cárnicos, de aves de corral y caza elaborados, tratados térmicamente en piezas enteras o en cortes

08.2.3 Productos cárnicos, de aves de corral y caza elaborados, congelados, en piezas enteras o en cortes

08.3 Productos cárnicos, de aves de corral y caza picados y elaborados

08.3.1 Productos cárnicos, de aves de corral y caza picados y elaborados sin tratar térmicamente

08.3.1.1 Productos cárnicos, de aves de corral y caza picados y elaborados, curados (incluidos los salados) desecados y sin tratar térmicamente

08.3.1.2 Productos cárnicos, de aves de corral y caza picados y elaborados, curados (incluidos los salados) y secos, y sin tratar térmicamente

08.3.1.3 Productos cárnicos, de aves de corral y caza picados y elaborados, fermentados y sin tratar térmicamente

08.3.2 Productos cárnicos, de aves de corral y caza picados, elaborados y tratados térmicamente

08.3.3 Productos cárnicos, de aves de corral y caza picados, elaborados y congelados

08.4 Tripas comestibles (p. ej. para embutidos)

09.0 Pescado y productos pesqueros, incluidos moluscos, crustáceos y equinodermos

09.1 Pescado y productos pesqueros frescos, incluidos moluscos, crustáceos y equinodermos

09.1.1 Pescado fresco

09.1.2 Moluscos, crustáceos y equinodermos frescos

09.2 Pescado y productos pesqueros elaborados, incluidos moluscos, crustáceos y equinodermos

09.2.1 Pescado, filetes de pescado y productos pesqueros congelados, incluidos moluscos, crustáceos y equinodermos

09.2.2 Pescado, filetes de pescado y productos pesqueros rebozados congelados, incluidos moluscos, crustáceos y equinodermos

09.2.3 Productos pesqueros picados, amalgamados y congelados, incluidos moluscos, crustáceos y equinodermos

09.2.4 Pescado y productos pesqueros cocidos y/o fritos, incluidos moluscos, crustáceos y equinodermos

09.2.4.1 Pescado y productos pesqueros cocidos

09.2.4.2 Moluscos, crustáceos y equinodermos cocidos 
09.2.4.3 Pescado y productos pesqueros fritos, incluidos moluscos, crustáceos y equinodermos

09.2.5 Pescado y productos pesqueros ahumados, desecados, fermentados y/o salados, incluidos moluscos, crustáceos y equinodermos

09.3 Pescado y productos pesqueros semiconservados, incluidos moluscos, crustáceos y equinodermos

09.3.1 Pescado y productos pesqueros marinados y/o en gelatina, incluidos moluscos, crustáceos y equinodermos

09.3.2 Pescado y productos pesqueros escabechados y/o en salmuera, incluidos moluscos, crustáceos y equinodermos

09.3.3 Sucedáneos de salmón, caviar y otros productos pesqueros a base de huevas

09.3.4 Pescado y productos pesqueros semiconservados, incluidos moluscos, crustáceos y equinodermos (p. ej. la pasta de pescado), excluidos los productos indicados en las categorías de alimentos 09.3.1 a 09.3.3

09.4 Pescado y productos pesqueros (incluidos los moluscos, crustáceos y equinodermos) en conserva, con inclusión de los enlatados y fermentados

10.0 Huevos y productos a base de huevo

10.1 Huevos frescos

10.2 Productos a base de huevo

10.2.1 Productos líquidos a base de huevo

10.2.2 Productos congelados a base de huevo

10.2.3 Productos a base de huevo en polvo y/o cuajados por calor

10.3 Huevos en conserva, incluidos los huevos en álcali, salados y envasados

10.4 Postres a base de huevo (p. ej. flan)

11.0 Edulcorantes, incluida la miel

11.1 Azúcares refinados y en bruto

11.1.1 Azúcar blanco, dextrosa anhidra, dextrosa monohidrato y fructosa

11.1.2 Azúcar en polvo y dextrosa en polvo

11.1.3 Azúcar blanco blando, azúcar moreno blando, jarabe de glucosa, jarabe de glucosa deshidratado y azúcar de caña sin refinar

11.1.3.1 Jarabe de glucosa deshidratado utilizado para la elaboración de golosinas

11.1.3.2 Jarabe de glucosa utilizado para la elaboración de golosinas

11.1.4 Lactosa

11.1.5 Azúcar blanco de plantación o refinería

11.2 Azúcar moreno, excluidos los productos de la categoría de alimentos 11.1.3

11.3 Soluciones azucaradas y jarabes, también azúcares (parcialmente) invertidos, incluida la melaza, excluidos los productos de la categoría de alimentos 11.1.3

11.4 Otros azúcares y jarabes (por ej. xilosa, jarabe de arce y revestimientos de azúcar)

11.5 Miel

11.6 Edulcorantes de mesa, incluidos los que contienen edulcorantes de gran intensidad

12.0 Sales, especias, sopas, salsas, ensaladas y productos proteínicos

12.1 Sal y sucedáneos de la sal

12.1.1 Sal

12.1.2 Sucedáneos de la sal 
12.2 Hierbas aromáticas, especias, aderezos y condimentos (p. ej. el aderezo para fideos instantáneos)

12.2.1 Hierbas aromáticas y especias

12.2.2 Aderezos y condimentos

12.3 Vinagres

12.4 Mostazas

12.5 Sopas y caldos

12.5.1 Sopas y caldos listos para el consumo, incluidos los envasados, embotellados y congelados

12.5.2 Mezclas para sopas y caldos

12.6 Salsas y productos análogos

12.6.1 Salsas emulsionadas y salsas para mojar (p.ej. mayonesa, aderezos para ensaladas, salsa para mojar de cebollas)

12.6.2 Salsas no emulsionadas (p. ej. "ketchup", salsas a base de queso, salsas a base de nata (crema) y salsa "gravy")

\subsubsection{Mezclas para salsas y "gravies"}

12.6.4 Salsas ligeras (p. ej. salsa de pescado)

12.7 Ensaladas (p. ej. la ensalada de macarrones, la ensalada de patatas (papas)) y emulsiones para untar emparedados, excluidas las emulsiones para untar a base de cacao y nueces de las categorías de alimentos 04.2.2.5 y 05.1.3

12.8 Levadura y productos similares

12.9 Aderezos y condimentos a base de soja

12.9.1 Pasta de soja fermentada ("miso")

12.9.2 Salsa de soja

12.9.2.1 Salsa de soja fermentada

12.9.2.2 Salsa de soja no fermentada

12.9.2.3 Otras salsas de soja

12.10 Productos proteínicos distintos a los de soja

13.0 Productos alimenticios para usos nutricionales especiales

13.1 Preparados para lactantes, preparados de continuación y preparados para usos medicinales especiales destinados a los lactantes

\subsubsection{Preparados para lactantes}

13.1.2 Preparados de continuación

13.1.3 Preparados para usos medicinales específicos destinados a los lactantes

13.2 Alimentos complementarios para lactantes y niños pequeños

13.3 Alimentos dietéticos para usos medicinales especiales (excluidos los productos de la categoría de alimentos 13.1)

13.4 Preparados dietéticos para adelgazamiento y control del peso

13.5 Alimentos dietéticos (p. ej. los complementos alimenticios para usos dietéticos), excluidos los indicados en las categorías de alimentos 13.1 a 13.4 y 13.6

13.6 Complementos alimenticios

14.0 Bebidas, excluidos los productos lácteos

14.1 Bebidas no alcohólicas 
14.1.1 Aguas

14.1.1.1 Aguas minerales naturales y aguas de manantial

14.1.1.2 Aguas de mesa y gaseosas

14.1.2 Zumos (jugos) de frutas y hortalizas

14.1.2.1 Zumos (jugos) de frutas

14.1.2.2 Zumos (jugos) de hortalizas

14.1.2.3 Concentrados para zumos (jugos) de frutas

14.1.2.4 Concentrados para zumos (jugos) de hortalizas

14.1.3 Néctares de frutas y hortalizas

14.1.3.1 Néctares de frutas

14.1.3.2 Néctares de hortalizas

14.1.3.3 Concentrados para néctares de frutas

14.1.3.4 Concentrados para néctares de hortalizas

14.1.4 Bebidas a base de agua aromatizadas, incluidas las bebidas para deportistas, bebidas electrolíticas y bebidas con partículas añadidas

14.1.4.1 Bebidas a base de agua aromatizadas con gas

14.1.4.2 Bebidas a base de agua aromatizadas sin gas, incluidos los ponches de fruta y las limonadas y bebidas similares

14.1.4.3 Concentrados (líquidos o sólidos) para bebidas a base de agua aromatizadas

14.1.5 Café, sucedáneos del café, té, infusiones de hierbas y otras bebidas calientes a base de cereales y granos, excluido el cacao

14.2 Bebidas alcohólicas, incluidas las bebidas análogas sin alcohol y con bajo contenido de alcohol

14.2.1 Cerveza y bebidas a base de malta

14.2.2 Sidra y sidra de pera

14.2.3 Vinos de uva

14.2.3.1 Vino de uva no espumoso

14.2.3.2 Vinos de uva espumosos y semiespumosos

14.2.3.3 Vino de uva enriquecido, vino de uva licoroso y vino de uva dulce

14.2.4 Vinos (distintos de los de uva)

14.2.5 Aguamiel

14.2.6 Licores destilados que contengan más de un 15 por ciento de alcohol

14.2.7 Bebidas alcohólicas aromatizadas (p. ej. cerveza, vino y bebidas espirituosas tipo refresco, refrescos con bajo contenido de alcohol)

15.0 Aperitivos listos para el consumo

15.1 Aperitivos a base de patatas (papas), cereales, harina o almidón (derivados de raíces y tubérculos, legumbres y leguminosas)

15.2 Nueces elaboradas, incluidas las nueces revestidas y mezclas de nueces ( $p$. ej. con frutas secas)

15.3 Aperitivos a base de pescado

16.0 Alimentos preparados. 


\section{PARTE II: Descriptores revisados de las categorías de alimentos}

01.0 Productos lácteos y productos análogos, excluidos los productos de la categoría de alimentos 02.0:

Comprende todos los tipos de productos lácteos que se obtienen de la leche de los animales de ordeño (p. ej. la vaca, oveja, cabra, búfala). En esta categoría, con la excepción de la categoría de alimentos 1.1.2, un producto "natural" / "simple" es un producto que no está aromatizado, no contiene frutas, hortalizas u otros ingredientes que no sean lácteos, ni está mezclado con otros ingredientes que no sean lácteos, a no ser que las normas pertinentes lo autoricen. Los productos análogos son aquellos en los que la grasa de la leche se ha sustituido parcial o totalmente por grasas o aceites vegetales

\subsection{Leche y productos lácteos líquidos:}

Comprende todos los productos lácteos líquidos, naturales / simples y aromatizados, a base de leche descremada, parcialmente descremada, con poca grasa y entera, excluidos los productos fermentados naturales / simples y los productos lácteos cuajados naturales de la categoría de alimentos 1.2 Las leches líquidas son "productos lácteos", de acuerdo a la definición de CODEX STAN 206-1999, que se obtienen por la elaboración de la leche y pueden contener aditivos alimentarios y otros ingredientes funcionalmente necesarios para la elaboración. La leche cruda ("leche", tal como se define en CODEX STAN 206-1999) no contendrá ningún aditivo alimentario.

\subsubsection{Leche líquida (natural / simple):}

Leche líquida natural / simple obtenida de los animales de ordeño (p. ej. vacas, ovejas, cabras, búfalas) que se ha elaborado. Comprende pasterización, tratamientos de temperatura ultraelevada (UHT), esterilizada ${ }^{13}$, homogeneizada o con contenido ajustado de grasa. Incluye, pero no se limita a, leche desnatada, leche parcialmente descremada, leche con poca grasa y leche entera.

\subsubsection{Otras leches líquidas (naturales / simples):}

Comprende toda la leche líquida natural / simple, excluidos los productos de las categorías de alimentos 01.1.1 Leche líquida (natural / simple), 01.1.3 Suero de mantequilla liquido (natural / simple) y 01.2 Productos lácteos fermentados y cuajados (naturales / simples). Incluye, pero no se limita a, leches líquidas recombinadas naturales / simples, leches líquidas reconstituidas naturales / simples, leches compuestas naturales / simples, leches líquidas no aromatizadas enriquecidas con vitaminas y minerales, leches con contenido ajustado de proteínas, leche con contenido reducido de lactosa, y bebidas a base de leche natural / simple. En esta categoría de alimentos, los productos naturales / simples no contienen aromatizantes añadidos ni otros ingredientes que intencionalmente impartan sabor, pero pueden contener otros ingredientes no lácteos.

\subsubsection{Suero de mantequilla líquido (natural / simple):}

El suero de mantequilla líquido es el líquido prácticamente sin grasa de la leche que queda tras el proceso de elaboración de la mantequilla (manteca) (es decir, la leche y la nata (crema) fermentada o sin fermentar batida). El suero de mantequilla líquido se obtiene también mediante la fermentación de la leche desnatada líquida, bien mediante la acidificación espontánea por la acción de las bacterias formadoras del ácido láctico o aroma, bien mediante la inoculación de cultivos bacterianos puros en la leche caliente (suero de mantequilla cultivado). ${ }^{14}$ El suero de mantequilla puede pasterizarse 0 esterilizarse.

\subsubsection{Bebidas lácteas líquidas aromatizadas:}

Comprende todas las mezclas y las bebidas listas para el consumo a base de leche fermentada o sin fermentar, con aromatizantes y/o ingredientes alimentarios que imparten sabor, excluidas las mezclas de cacao (mezclas de cacao y azúcar de la categoría 05.1.1). Ejemplos incluyen pero no se limitan a, leche de chocolate, bebidas malteadas con chocolate, bebidas a base de yogur con sabor a fresa, bebidas obtenidas por las bacterias que producen el ácido láctico, bebidas a base de suero, y el lassi (líquido obtenido batiendo la leche cuajada formada a partir de la fermentación láctea y añadiendo azúcar o un edulcorante intenso).

\subsection{Productos lácteos fermentados y cuajados (naturales / simples):}

Comprende todos los productos naturales fermentados o cuajados a base de leche desnatada, parcialmente desnatada, con poca grasa y leche entera, excluida la categoría de alimentos 01.1.4. Se incluyen los productos aromatizados de 01.1 .4 (bebidas) y 01.7 (postres).

13 Food Chemistry, H.-D. Belitz \& W. Grosch, Springer-Verlag, Heidelberg, 1987, pág. 389

14 Food Chemistry, H.-D. Belitz \& W. Grosch, Springer-Verlag, Heidelberg, 1987, pág. 392. 


\subsubsection{Leches fermentadas (naturales / simples):}

Comprende todos los productos naturales / simples, incluida la leche líquida fermentada, la leche acidificada y la leche cultivada. El yogur natural / simple y las bebidas naturales / simples a base de leche fermentada, sin aromatizantes ni colores, pueden figurar en una de las subcategorías de 01.2.1 según tengan tratamiento térmico o no después de la fermentación.

\subsubsection{Leches fermentadas (naturales / simples) sin tratamiento térmico después de la fermentación}

Comprende los productos naturales / simples líquidos y los que no son líquidos, como el yogur y las bebidas a base de leche natural / simple fermentada.

01.2.1.2 Leches fermentadas (naturales / simples) tratadas térmicamente después de la fermentación:

Productos análogos a los de la subcategoría 01.2.1.1, pero que se han tratado térmicamente (a saber, mediante la esterilización o pasterización), después de la fermentación.

01.2.2 Cuajada (natural / simple):

Leche cuajada natural / simple que se obtiene por la acción de enzimas que provocan la coagulación. Comprende la leche cuajada. Los productos a base de cuajada aromatizada figuran en la categoría 01.7.

01.3 Leche condensada y productos análogos (naturales / simples):

Comprende los tipos de leche condensada, evaporada natural / simple, edulcorada y aromatizada, así como los productos análogos (incluidos los blanqueadores de bebidas). Comprende los productos a base de leche desnatada (descremada), parcialmente desnatada, con poca grasa y entera, así como la leche compensada.

01.3.1 Leche condensada (natural / simple):

La leche condensada se obtiene mediante la eliminación parcial del agua de la leche a la cual puede haberse añadido azúcar. En el caso de la leche evaporada, la eliminación del agua puede obtenerse por calentamiento. ${ }^{15}$ Incluye la leche parcialmente deshidratada, evaporada, condensada y edulcorada y el khoa (leche de vaca o búfala concentrada por ebullición).

\subsubsection{Blanqueadores de bebidas:}

Sucedáneos de la leche o de la nata (crema) que consisten en una emulsión del tipo grasa vegetal en agua con proteínas lácteas y lactosa o proteínas vegetales, destinados a utilizarse en bebidas como el café y el té. Incluye también el mismo tipo de productos en polvo. Comprende los productos análogos a la leche condensada y la leche compensada condensada.

\section{$01.4 \mathrm{Nata}$ (crema) (natural / simple) y productos análogos:}

La nata (crema) es un producto lácteo líquido, con un contenido relativamente alto de grasa en comparación con la leche. Incluye todos los productos líquidos, semilíquidos y semisólidos naturales / simples de nata y productos analógos a la nata. Los productos de nata (crema) aromatizados figuran en 01.1.4 (bebidas) y 01.7 (postres).

\subsubsection{Nata (crema) pasterizada (natural / simple):}

Nata (crema) sometida a pasterización mediante un tratamiento térmico adecuado u obtenida de leche pasterizada. ${ }^{16}$ Comprende natas (cremas) y seminatas (semicremas) de leche.

01.4.2 Natas (cremas) esterilizadas y UHT, natas (cremas) para batir o batidas y natas (cremas) de contenido de grasa reducido (naturales / simples):

Comprende todo tipo de natas (cremas), independientemente del contenido de grasa, que se han sometido a tratamiento térmico a temperatura más elevada que la de pasterización. Comprende también las natas (cremas) pasterizadas con un contenido de grasa reducido, así como todos los tipos de natas (cremas) para batir o batidas. Las natas (cremas) esterilizadas son las que se han sometido a un tratamiento térmico adecuado dentro del recipiente en el que se presentan al consumidor. Las natas (cremas) tratadas a temperaturas ultraelevadas (UHT) o las natas ultrapasterizadas son las que se han sometido de modo continuo a un tratamiento térmico adecuado (UHT o ultrapasterización) y envasado en condiciones asépticas. La nata (crema) puede envasarse también a presión (nata batida). ${ }^{16}$ Comprende las natas (cremas) para batir, las natas (cremas) espesas, las natas (cremas) batidas pasterizadas y las decoraciones y rellenos a base de leche análogos a la nata (crema) batida. La subcategoría 01.4.4 (productos análogos a la nata (crema)) incluye las natas (cremas) o decoraciones con sustitución total o parcial de la grasa de leche por otras grasas.

15 Norma para las Leches Evaporadas (CODEX STAN 281-1971).

16 Norma para la Nata (Crema) y las Natas (Cremas) Preparadas (CODEX STAN 288-1976). 
01.4.3 Nata (crema) cuajada (natural / simple):

Crema espesa, viscosa formada por la acción de enzimas coagulantes de la leche. Comprende la nata (crema) ácida (crema sometida a fermentación del ácido láctico obtenida como se describe para el suero de mantequilla (01.1.3)). ${ }^{17}$

01.4.4 Productos análogos a la nata (crema):

Sucedáneos de la nata (crema) consistente en una emulsión de grasa vegetal-agua en forma líquida o en polvo para usos distintos de los de los blanqueadores de bebidas (01.3.2). Comprende los revestimientos instantáneos de nata batida y los sucedáneos de la nata.

\subsection{Leche en polvo y nata (crema) en polvo y productos análogos en polvo (naturales):}

Comprende la leche en polvo natural, la nata (crema) en polvo o combinaciones de ambas, y productos análogos. Incluye los productos a base de leche desnatada (descremada), parcialmente desnatada (descremada), de bajo contenido graso y entera.

\subsubsection{Leche en polvo y nata (crema) en polvo (naturales):}

Productos lácteos obtenidos mediante la eliminación parcial del agua de la leche o de la nata (crema) y producidos en polvo ${ }^{18}$. Incluye caseína y caseinatos. ${ }^{19}$

\subsubsection{Productos análogos a la leche y la nata (crema) en polvo (naturales):}

Productos en forma de emulsión del tipo grasa en agua y deshidratados para un uso distinto del de los blanqueadores de bebidas (01.3.2). Entre ellos se incluye, p. ej. la mezcla de nata (crema) deshidratada de imitación y la leche compensada en polvo.

\subsection{Queso y productos análogos:}

Se entiende por queso y productos análogos al queso los productos que contienen agua y grasa dentro de una estructura de proteína de leche coagulada. Productos como, p. ej. la salsa de queso (12.6.2), los aperitivos con aroma de queso (15.1) y los alimentos compuestos preparados en los que se ha utilizado el queso como ingrediente (p. ej. macarrones y queso; 16.0) se clasifican en otras categorías.

\subsubsection{Queso no madurado:}

Se entiende por quesos no madurados, incluidos los quesos frescos, los productos que están listos para el consumo poco después de su fabricación. ${ }^{20}$ Entre ellos se incluyen, p. ej. el "cottage cheese" (queso blando y sin madurar de leche cuajada coagulada), el "cottage cheese" cremoso ("cottage cheese" cubierto con una mezcla cremosa) ${ }^{21}$, el queso de nata o queso cremoso ("rahmfrischkase", queso sin cuajar, blando para untar) $^{22}$, y los quesos mozzarella y scamorza, así como el paneer (proteína de leche coagulada con ácido cítrico de jugo de limón o de lima o del ácido láctico del suero, que se cuela para obtener una masa sólida y se usa en versiones vegetarianas, por ejemplo, de las hamburguesas). Comprende el queso entero no madurado y la corteza del queso no madurada (en los casos de quesos no madurados con "piel"; p. ej. la mozzarella). La mayoría de los productos son naturales; no obstante, algunos, como el "cottage cheese" y el queso de nata pueden estar aromatizados o contener ingredientes como fruta, hortalizas o carne. Se excluye el queso de nata madurado, en el que la nata (crema) es determinante de un contenido elevado de grasa.

\subsubsection{Queso madurado:}

Se entiende por quesos madurado un producto que no está listo para el consumo poco después de la elaboración, sino que debe mantenerse durante cierto tiempo a una temperatura y en unas condiciones tales que se produzcan los cambios bioquímicos y físicos necesarios y característicos del queso en cuestión. En los quesos madurados con moho, la maduración se produce principalmente como consecuencia del desarrollo característico de mohos por todo el interior y/o en la superficie del queso. ${ }^{20}$ El queso madurado puede ser blando (p. ej. camembert), firme (p. ej. edam, gouda), duro (p. ej. cheddar) o extraduro (p. ej. grana). Incluye el queso en salmuera, que es un queso madurado de semiduro a blando, de color blanco a amarillento, con una textura compacta y sin una corteza propiamente dicha que se conserva en salmuera hasta que se presenta al consumidor (p. ej. feta). ${ }^{23}$

\footnotetext{
Food Chemistry, H.-D. Belitz \& W. Grosch, Springer-Verlag, Heidelberg, 1987, pág. 393.

Norma para las Leches en Polvo y la Nata (Crema) en Polvo (CODEX STAN 207-1999).

Norma para los Productos a Base de Caseína Alimentaria (CODEX STAN 290-1995).

Norma para el Queso (CODEX STAN 283-1978).

Norma para el Queso Cottage (CODEX STAN 273-1968).

22 Norma para el Queso Crema (Queso de Nata, "Cream Cheese") (CODEX STAN 275-1973).

23 Norma de Grupo para Queso en Salmuera (CODEX STAN 208-1999).
} 


\subsubsection{Queso madurado, incluida la corteza:}

Se refiere al queso madurado (incluido el queso madurado con moho) con su corteza o parte de ella, como el queso cortado, desmenuzado, rallado o rebanado. Entre estos quesos madurados se incluyen los siguientes: queso azul, brie, gouda, havarti, queso duro para rallar, parmesano y queso suizo.

\subsubsection{Corteza de queso madurado:}

Se refiere sólo a la corteza del queso. La corteza del queso es la parte exterior de la masa de queso que al principio tiene la misma composición que la parte interior del mismo, pero que puede secarse en los procesos de conservación en salmuera y maduración. ${ }^{24}$

\subsubsection{Queso en polvo (para reconstitución; p. ej. para salsas a base de queso):}

Producto deshidratado preparado con una variedad de queso o queso fundido. No incluye el queso rallado o desmenuzado (categoría 01.6.2.1 para las variedades de queso; categoría 01.6.4 para el queso fundido). El producto se destina a reconstitución con leche o agua para preparar una salsa o utilizarse como ingrediente tal como se presenta ( $p$. ej. con macarrones cocidos, leche y mantequilla para preparar una cazuela de macarrones y queso). Incluye el queso desecado por pulverización.

\subsubsection{Queso de suero:}

Se entiende por queso de suero los productos sólidos o semisólidos obtenidos por concentración del suero, con o sin adición de leche, nata (crema) u otras materias de origen lácteo, y moldeo del producto concentrado. ${ }^{25}$ Incluye el queso entero y la corteza de queso. Distinto del queso de proteínas del suero (01.6.6).

\subsubsection{Queso elaborado, fundido:}

Productos con un tiempo de conservación muy largo obtenido por fusión y emulsificación del queso. Incluye productos elaborados mediante calentamiento y emulsificación de mezclas de quesos, materia grasa de la leche, proteína de leche, leche en polvo y agua en diferentes cantidades. Los productos pueden contener otros ingredientes añadidos como, aromas, aderezos y fruta, hortalizas y/o carne. El producto puede ser para untar o estar cortado en rebanadas y piezas. ${ }^{26}$ Esta categoría no comprende el queso cortado, rallado, desmenuzado, etc. El queso sometido a estos procesos mecánicos se incluye en la categoría de alimentos 01.6.2 (Queso madurado).

\subsubsection{Queso fundido natural:}

Se entiende por queso fundido natural el producto de queso fundido que no contiene aromatizantes, aderezos, fruta, hortalizas o carne añadidos. Entre éstos se incluyen, p. ej. el queso americano, el queso club y las mezclas de queso elaboradas en frío.

\subsubsection{Queso fundido aromatizado, incluido el que contiene fruta, hortalizas, carne, etc.:}

Se entiende por queso fundido aromatizado el producto al que se han añadido aromatizantes, aderezos, fruta, hortalizas y/o carne. Entre éstos se incluyen, p. ej. el queso para untar "Neufchatel" con hortalizas, el queso "Pepper Jack" (queso Monterrey Jack con trozos de pimienta), el queso para untar Cheddar con vino y las bolas de queso (elaboradas con queso fundido cubierto de nueces, hierbas o especias).

\subsubsection{Productos análogos al queso:}

Productos similares al queso pero en los que la grasa de la leche se ha reemplazado parcial o completamente por otras grasas. Incluye el queso de imitación, las mezclas de quesos de imitación y los quesos de imitación en polvo.

\subsubsection{Queso de proteínas del suero:}

Se entiende por queso de proteínas del suero el producto que contiene la proteína extraída del componente de suero de la leche. Estos productos se elaboran principalmente mediante la coagulación de proteínas del suero. Entre ellos se incluye, p. ej. el queso ricotta. ${ }^{25}$ Es diferente del queso de suero (01.6.3).

24 La corteza es diferente del revestimiento del queso. El revestimiento puede ser: 1) una película de material sintético o natural, que ayuda a regular la humedad durante la maduración y protege el queso de los microorganismos, o 2) una capa generalmente de cera, parafina o material plástico, que normalmente es impermeable a la humedad, protege el queso después de la maduración contra los microorganismos y de daños físicos durante la manipulación en la venta al por menor y que, en algunos casos, contribuye a dar una apariencia determinada al queso ( $p$. ej. superficie coloreada).

25 Norma para los Quesos de Suero (CODEX STAN 284-1971).

26 Food Chemistry, H.-D.Belitz \& W. Grosh, Springer-Verlag, Heidelberg, 1987, pág. 400. 


\subsection{Postres lácteos (p. ej. pudines, yogur aromatizado o con fruta):}

Comprende los postres lácteos listos para el consumo y mezclas para postres, aromatizados. Incluye dulces y golosinas lácteas congeladas y rellenos a base de leche, así como el yogur aromatizado (producto lácteo obtenido por la fermentación de leche y productos lácteos a los que se han añadido aromatizantes e ingredientes ( $p$. ej. fruta, cacao, café)) que puede someterse o no a un tratamiento térmico después de la fermentación. ${ }^{27}$ Otros ejemplos son los siguientes: helado (postre congelado que puede estar elaborado con leche entera, leche desnatada (descremada), nata (crema) o mantequilla, azúcar, aceite vegetal, productos a base de huevo y fruta, cacao o café), leche helada (producto análogo al helado con menor contenido de leche entera o desnatada o elaborado con leche desnatada), leche gelificada, yogur aromatizado congelado, leche cuajada (postre dulce similar a la crema elaborado a base de leche aromatizada con cuajo), dulce de leche (leche cocida con azúcar y con adición de otros ingredientes como coco o chocolate), pudín "butterscotch" y "mousse" de chocolate. Comprende dulces a base de leche tradicionales preparados con leche parcialmente concentrada, khoa (leche de vaca o búfala concentrada mediante cocción), o chhena (leche de vaca o de búfala coagulada mediante calor con ayuda de ácidos como ácido cítrico, ácido láctico, ácido málico, etc.), azúcar o edulcorantes artificiales y otros ingredientes (p. ej. maida (harina de trigo refinada), aromatizantes y colorantes (p. ej. peda, burfee, torta de leche, gulab jamun, rasgulla, rasmalai, basundi). Estos productos son diferentes de los de la categoría de alimentos 03.0 (Helados comestibles, incluidos los sorbetes), ya que los alimentos de la categoría 01.7 se elaboran a base de leche, mientras que los de la categoría 03.0 se elaboran a base de agua y no contienen ingredientes lácteos.

\subsection{Suero y productos a base de suero, excluidos los quesos de suero:}

Comprende diversos productos de suero en forma líquida y en polvo.

\subsubsection{Suero líquido y productos a base de suero líquido, excluidos los quesos de suero:}

El suero es el fluido separado de la cuajada tras la coagulación de la leche, nata (crema), leche desnatada (descremada) o suero de mantequilla mediante enzimas de coagulación de la leche durante la fabricación del queso, la caseína o productos similares. El suero ácido se obtiene tras la coagulación de la leche, nata (crema), leche desnatada (descremada) o suero de mantequilla, principalmente con ácidos del tipo usado en la fabricación del queso fresco. ${ }^{28}$

01.8.2 Suero en polvo y productos a base de suero en polvo, excluidos los quesos de suero:

Los sueros en polvo se preparan a partir de suero desecado por pulverización o en rodillos, o de suero ácido del que se ha eliminado la mayor parte de la grasa de leche. ${ }^{28}$

02.0 Grasas y aceites y emulsiones grasas:

Incluye todos los productos a base de grasa de origen vegetal, animal o marino o sus mezclas.

\subsection{Grasas y aceites prácticamente exentos de agua:}

Se entiende por grasas y aceites comestibles los alimentos compuestos principalmente de triglicéridos de ácidos grasos de origen vegetal, animal o marino. ${ }^{29}$

\subsubsection{Aceite de mantequilla (manteca), grasa de leche anhidra, "ghee":}

Se entiende por grasa de leche anhidra, aceite de mantequilla (manteca) anhidra y aceite de mantequilla (manteca) los productos derivados exclusivamente de la leche y/o productos obtenidos de la leche mediante un proceso que elimina casi por completo el agua y el extracto seco magro. El ghee es un producto obtenido exclusivamente de la leche, la nata (crema) o la mantequilla (manteca) mediante un proceso por el que se elimina casi totalmente el agua y el extracto seco magro; posee un sabor y una estructura física especialmente desarrollados. ${ }^{30}$

27 Norma para Leches Fermentadas (CODEX STAN 243-2003).

28 Norma para los Sueros en Polvo (CODEX STAN 289-1995).

29 Norma General para Grasas y Aceites Comestibles No Regulados por Normas Individuales (CODEX STAN 19-1981).

30 Norma para los Productos a base de Grasa de la Leche (CODEX STAN 280-1973). 


\subsubsection{Grasas y aceites vegetales:}

Las grasas y aceites comestibles se obtienen de plantas comestibles. Los productos se pueden obtener de una única fuente vegetal o bien comercializarse y utilizarse como mezcla de aceites que se denominan generalmente aceites comestibles, para cocinar, para freír, de mesa o para ensaladas. ${ }^{31}$ Los aceites vírgenes se obtienen por procedimientos mecánicos ( $p$. ej. prensado o extracción) y por aplicación únicamente de calor de manera que no se modifique la composición natural del aceite. Los aceites vírgenes son idóneos para el consumo en su estado natural. Los aceites prensados en frío se obtienen por procedimientos mecánicos sin aplicación de calor. ${ }^{29,32}$ Entre estos productos se incluyen, p. ej. el aceite de oliva virgen, el aceite de semilla de algodón, el aceite de maní (cacahuete) y el vanaspati.

\subsubsection{Manteca de cerdo, sebo, aceite de pescado y otras grasas de origen animal:}

Todas las grasas y aceites de origen animal deben derivar de animales que estén en buenas condiciones de salud en el momento del sacrificio y estén destinados al consumo humano. Se entiende por manteca de cerdo la grasa obtenida de los tejidos adiposos del cerdo. La grasa de vacuno comestible se obtiene de los tejidos adiposos y frescos de los animales bovinos que cubren la cavidad abdominal y rodean los riñones y el corazón, y de otros tejidos adiposos compactos e intactos. Esta grasa fresca obtenida en el momento del sacrificio es la "grasa de matanza". La grasa de vacuno de primera (primeros jugos u "oleo stock") se obtiene fundiendo a baja temperatura $\left(50-55^{\circ} \mathrm{C}\right)$ la grasa de matanza y cortes seleccionados de grasa (grasa de recortes). La grasa de vacuno de segunda es un producto con olor y sabor típicos de la grasa de vacuno que se obtiene fundiendo $\left(a-60-65^{\circ} \mathrm{C}\right)$ y purificando la grasa de vacuno. La grasa de cerdo fundida es grasa procedente de los tejidos y huesos del cerdo. El sebo comestible (pringue) se obtiene fundiendo los tejidos adiposos (excluida la grasa de recorte) adheridos a los músculos y los huesos de animales bovinos u ovinos. Los aceites de pescado se obtienen de pescado adecuado como arenques, sardinas, espadín y anchoas. ${ }^{33,34}$ Otros ejemplos son el sebo y el tejido adiposo de la carne de vacuno o de cerdo parcialmente desgrasados.

02.2 Emulsiones grasas, principalmente del tipo agua en aceite:

Comprende todos los productos emulsionados, excluidos los productos a base de grasa similares a los productos y postres lácteos.

02.2.1 Mantequilla (manteca):

La mantequilla es un producto graso que consiste principalmente en una emulsión del tipo agua en aceite, derivado exclusivamente de la leche y/o de productos obtenidos de la leche. ${ }^{35}$

02.2.2 Grasas para untar, grasas lácteas para untar y mezclas de grasas para untar:

Comprende las grasas para untar (emulsiones principalmente del tipo agua, grasas y aceites comestibles), grasas lácteas para untar (emulsiones principalmente del tipo agua en grasa de leche), y mezclas de grasas para untar (grasas para untar mezcladas con cantidades mayores de grasa de la leche). ${ }^{36}$ Algunos ejemplos son la margarina (una emulsión de agua en aceite para untar o líquida producida principalmente con grasas y aceites comestibles); los productos derivados de la mantequilla (manteca) (p. ej. la "mantequilla artificial", mezcla para untar de mantequilla y aceites vegetales para untar) ${ }^{37}$; mezclas de mantequilla y margarina; y la minarina (una emulsión para untar del tipo agua en aceite obtenida principalmente a partir de agua, grasas y aceites comestibles que no derivan únicamente de la leche). Comprende productos con contenido reducido de grasa obtenidos de grasa de leche o de grasas de origen animal o vegetal, incluidos los productos similares a la mantequilla que contienen menos grasa que ésta, la margarina y sus mezclas ( $p$. ej. tres cuartas partes de grasa de mantequilla, tres cuartas partes de grasa de margarina o tres cuartas partes de mezclas de grasa de mantequilla y margarina).

31 Food Chemistry, H.-D. Belitz \& W. Grosch, Springer-Verlag, Heidelberg, 1987, págs. 472 a 476.

32 Norma para los Aceites de Oliva y Aceites de Orujo de Oliva (CODEX STAN 33-1981); y Norma para Aceites Vegetales Especificados (CODEX STAN 210-1999).

33 Food Chemistry, H.-D. Belitz \& W. Grosch, Springer-Verlag, Heidelberg, 1987, págs. 472 a 476.

34 Norma para Grasas Animales Especificadas (CODEX STAN 211-1999).

35 Norma para la Mantequilla (Manteca) (CODEX STAN 279-1971).

36 Norma para Materias Grasas Lácteas para Untar (CODEX STAN 253-2006) y Norma para las Grasas para Untar y Mezclas de Grasas para Untar (CODEX STAN 256-2007).

37 Food Chemistry, H.-D. Belitz y W. Grosch, Springer-Verlag, Heidelberg, 1987, pág. 395. 
02.3 Emulsiones grasas principalmente del tipo agua en aceite, incluidos los productos a base de emulsiones grasas mezclados y/o aromatizados:

Comprende los productos a base de grasa similares a alimentos lácteos, excluidos los postres. La parte grasa de estos productos se obtiene de fuentes destintas de la grasa de la leche (p. ej. grasas y aceites vegetales). Entre estos productos se incluyen la leche compensada o sucedáneo de la leche (leche en la que se ha sustituido la grasa, elaborada a partir del extracto seco magro de la leche con adición de grasas vegetales (de aceite de coco, de alazor o de maíz)); ${ }^{13}$ la nata (crema) batida no láctea, los revestimientos no lácteos y la nata (crema) vegetal. La mayonesa se incluye en la categoría de alimentos 12.6.1.

02.4 Postres a base de grasas, excluidos los postres lácteos de la categoría de alimentos 01.7:

Comprende los productos a base de grasa similares a los postres lácteos que figuran en la categoría 01.7. Abarca los productos listos para el consumo y sus mezclas. Comprende además los rellenos no lácteos para postres. Un ejemplo son los helados elaborados con grasas vegetales.

03.0 Hielos comestibles, incluidos los sorbetes:

Esta categoría comprende postres, dulces y golosinas a base de agua congelados, como el sorbete de fruta, los helados de estilo "italiano" y el helado aromatizado. Los postres congelados que contengan ingredientes principalmente lácteos se incluyen en la categoría 01.7.

04.0 Frutas y hortalizas (incluidos hongos y setas, raíces y tubérculos, legumbres y leguminosas y áloe vera), algas marinas y nueces y semillas:

Esta categoría principal se divide en dos categorías: 04.1 (Frutas) y 04.2 (Hortalizas (incluidos hongos y setas, raíces y tubérculos, legumbres y leguminosas y áloe vera), algas marinas y nueces y semillas). Cada una de estas categorías se divide a su vez en subcategorías para productos frescos y elaborados.

\subsection{Frutas:}

Comprende todos los productos frescos (04.1.1) y elaborados (04.1.2).

\subsubsection{Frutas frescas:}

La fruta fresca no contiene generalmente aditivos. Sin embargo, la fruta fresca que se recubre, corta o pela para su presentación al consumidor puede contener aditivos.

\subsubsection{Frutas frescas no tratadas:}

Fruta cruda que una vez recolectada se presenta fresca para su consumo.

04.1.1.2 Frutas frescas tratadas en la superficie:

Las superficies de algunas frutas frescas se recubren de glaseados o ceras o se tratan con otros aditivos alimentarios que actúan como recubrimientos protectores y/o contribuyen a conservar el frescor y la calidad de la fruta. Entre estos productos se incluyen las manzanas, las naranjas, los dátiles y el longán.

\subsubsection{Frutas frescas peladas $\mathrm{y} / \mathrm{o}$ cortadas:}

La fruta fresca que se presenta al consumidor cortada y pelada, $p$. ej. en forma de ensalada de fruta Incluye el coco fresco rallado o en copos.

\subsubsection{Frutas elaboradas:}

Comprende todas las formas de elaboración que no sean pelar y cortar la fruta fresca o tratar la parte externa de la misma.

\subsubsection{Frutas congeladas:}

Frutas que pueden pelarse o no antes de la congelación. El producto puede congelarse en forma de zumo (jugo) o de jarabe azucarado. ${ }^{38}$ Ejemplos: ensalada de fruta congelada, fresas congeladas.

\subsubsection{Frutas desecadas:}

Frutas de las que se ha eliminado el agua para impedir la proliferación microbiana. ${ }^{38}$ Comprende las pieles de fruta desecadas (rollitos de fruta) preparadas secando los purés de fruta. Entre estos productos se incluyen, p. ej. las rodajas de manzana desecadas, las pasas de uva, el coco desecado rallado o en copos y las ciruelas pasas.

38 Food Chemistry, H.-D. Belitz y W. Grosch, Springer-Verlag, Heidelberg, 1987, págs. 613 a 617. 


\subsubsection{Frutas en vinagre, aceite o salmuera:}

Comprende productos encurtidos como las ciruelas encurtidas, el mango encurtido, la lima encurtida, la uva espina encurtida y la corteza de sandía encurtida. Los productos de frutas orientales encurtidos ("curados" o "en conserva") se denominan a veces fruta confitada. ${ }^{39}$ Estos productos no son los mismos que las frutas confitadas de la categoría 04.1.2.7 (esto es, fruta desecada y cubierta de azúcar).

\subsubsection{Frutas en conserva, enlatadas o en frascos (pasterizadas):}

Producto completamente conservado en el que la fruta fresca se ha limpiado y envasado en latas o frascos con zumo (jugo) natural o jarabe azucarado (incluido el jarabe edulcorado artificialmente) y se ha esterilizado térmicamente o pasterizado. ${ }^{38}$ Comprende los productos elaborados en bolsas de envasado al vacío. Ejemplos: ensalada de fruta en lata, confitura de manzana en frascos.

\subsubsection{Confituras, jaleas, mermeladas:}

Las confituras y conservas de fruta son productos espesos para untar que se preparan hirviendo frutas enteras o trozos de frutas, pulpa o puré de fruta, con o sin zumo (jugo) de fruta o zumo (jugo) concentrado de fruta con azúcar para espesarlos, y a los que pueden añadirse pectina y trozos de fruta. La jalea es un producto para untar clarificado, preparado del mismo modo que la compota, pero que tiene una consistencia más fluida y no contiene trozos de fruta. La mermelada es una pasta de fruta espesa y para untar preparada con la fruta entera, la pulpa o el puré de fruta (normalmente cítricos) que se ha hervido con azúcar para espesarla, y a la que puede añadirse pectina y trozos de fruta y trozos de piel de fruta ${ }^{38,40}$. Comprende los productos similares dietéticos elaborados con edulcorantes de gran intensidad no nutritivos. Entre estos productos se incluyen, p. ej. la mermelada de naranja, la jalea de uva y la confitura de fresa.

04.1.2.6 Productos para untar a base de fruta (p. ej. "chutney"), excluidos los productos de la categoría de alimentos 04.1.2.5:

Comprende todos los demás productos para untar a base de frutas, como "apple butter" o "lemon curd". Comprende también productos de frutas utilizados como condimento, como las salsas "chutney" de mango y de pasas.

\subsubsection{Frutas confitadas:}

Comprende las frutas glaseadas (fruta tratada con una solución de azúcar y desecada), fruta confitada (fruta glaseada y desecada que se baña en una solución azucarada y se seca para que quede cubierta con una corteza azucarada parecida a la de un confite) y fruta cristalizada (fruta glaseada desecada que se pasa por azúcar de alcorza o azúcar granulado y se deja secar). ${ }^{38}$ Entre estos productos se incluyen: las cerezas (marrasquino) para cóctel, las pieles de cítricos confitadas, los limones confitados ( $p$. ej. los utilizados en pasteles de fruta) y la "mostarda" de fruta.

39 Asian Foods: Science and Technology, C.Y.W. Ang, K.S. Liu y Y.-W. Huang, eds., Capítulo 11: Fruit Products, J.X. Shi y B.S. Luh, Technomic Publishing Co., Lancaster PA 1999, pág. 290.

40 Norma para las Confituras, Jaleas y Mermeladas (CODEX STAN 296-2009). 
04.1.2.8 Preparados a base de fruta, incluida la pulpa, los purés, los revestimientos de fruta y la leche de coco:

La pulpa de fruta no se destina generalmente al consumo directo. Es una pasta de fruta fresca cocida ligeramente al vapor y colada, con o sin conservantes añadidos. El puré de frutas ( $p$. ej. puré de mango, puré de ciruela) se elabora del mismo modo, pero tiene una textura más lisa y fina y puede utilizarse como relleno para pastelería, aunque no se limita a este uso. La salsa de fruta ( $p$. ej. de piña o de fresa) se elabora con pulpa de fruta hervida con o sin edulcorantes añadidos y puede contener trozos de fruta. La salsa de fruta puede utilizarse como revestimiento de productos finos de pastelería y helados. El jarabe de fruta (p. ej. jarabe de arándano) es una forma más líquida de la salsa de fruta que puede utilizarse, p. ej. como relleno para tortitas tipo "pancake". ${ }^{38}$ Los revestimientos que no son de fruta se incluyen en la categoría 05.4 (revestimientos a base de azúcar y chocolate) y los jarabes de azúcar (p. ej. el jarabe de arce) se incluyen en la categoría 11.4. Se entiende por leche y crema de coco los productos preparados a partir de una cantidad considerable de endosperma fresco (almendra) de la palma de coco, entero, desintegrado, macerado o desmenuzado, del que se ha extraído la mayor parte de las fibras y residuos filtrables, con o sin agua de coco o con adición de agua. La leche y crema de coco se tratan mediante procesos térmicos de pasterización, esterilización o temperatura ultraelevada (UHT). La leche y crema de coco se pueden preparar también concentradas o descremadas ("ligeras"). ${ }^{41}$ Entre los alimentos tradicionales que se incluyen en esta subcategoría figuran los siguientes: tamarindo concentrado (extracto limpio de la fruta del tamarindo con una cantidad de extracto seco soluble total no inferior al 65 por ciento); tamarindo en polvo (pasta de tamarindo mezclada con almidón de tapioca); caramelo de tamarindo (mezcla de pulpa de tamarindo, azúcar, extracto seco de la leche, antioxidantes, aromas, estabilizadores y conservantes) y barritas de fruta (mezcla desecada de pulpa de fruta (mango, piña o guayaba) con azúcar, aromas o conservantes, en barritas planas).

\subsubsection{Postres a base de fruta, incluidos los postres a base de agua con aromas de fruta:}

Comprende los productos y mezclas listos para el consumo. Comprende la gelatina con sabor a fruta, "rote gruze", "frutgrod", la compota de fruta, la crema de coco y el mitsumame (postre gelatinoso a base de jalea de agar, trozos de fruta y jarabe). Esta categoría no comprende los productos de pastelería fina que contienen fruta (categorías de alimentos 07.2.1 y 07.2.2), los hielos comestibles con aroma de fruta (categoría 03.0) ni los postres lácteos congelados con fruta (categoría 01.7).

\subsubsection{Productos de fruta fermentada:}

Tipo de producto encurtido elaborado mediante la fermentación del ácido láctico que se conserva en sal. Un ejemplo son las ciruelas fermentadas.

\subsubsection{Rellenos de fruta para pastelería:}

Comprende los productos y mezclas listos para el consumo. Abarca todos los tipos de rellenos, excluidos los purés (categoría 04.1.2.8). Estos rellenos contienen generalmente fruta entera o trozos de fruta. Entre estos productos se incluyen, p. ej. el relleno para tartas de cereza y el relleno de pasas para galletas de harina de avena.

\subsubsection{Frutas cocidas o fritas:}

Fruta que se presenta al consumidor cocida al vapor, hervida, horneada o frita, con o sin recubrimiento. Entre estos productos se incluyen, p. ej. manzanas al horno, aros de manzana fritos y pastelitos de melocotón (durazno), (melocotones (duraznos) al horno recubiertos de una masa dulce).

04.2 Hortalizas (incluidos hongos y setas, raíces y tubérculos, legumbres y leguminosas y áloe vera), algas marinas y nueces y semillas:

Comprende todos los productos frescos (04.2.1) y elaborados (04.2.2).

04.2.1 Hortalizas (incluidos hongos y setas, raíces y tubérculos, legumbres y leguminosas y áloe vera), algas marinas y nueces y semillas frescas:

Las hortalizas frescas generalmente no contienen aditivos. Sin embargo, las hortalizas frescas que se recubren, cortan o pelan para su presentación al consumidor pueden contener aditivos.

04.2.1.1 Hortalizas (incluidos hongos y setas, raíces y tubérculos, legumbres y leguminosas incluida la soja, y áloe vera), algas marinas y nueces y semillas frescas no tratadas:

Hortalizas crudas que una vez recolectadas se presentan frescas para su consumo.

41 Norma para Productos Acuosos de Coco - Leche de Coco y Crema de Coco (CODEX STAN 240-2003). 
04.2.1.2 Hortalizas (incluidos hongos y setas, raíces y tubérculos, legumbres y leguminosas y áloe vera), algas marinas y nueces y semillas frescas tratadas en la superficie:

Las superficies de algunas hortalizas frescas se recubren con glaseados o ceras o se tratan con otros aditivos alimentarios que actúan como recubrimientos protectores y/o contribuyen a conservar el frescor y la calidad de la hortaliza. Entre estos productos se incluyen, p. ej. los aguacates, los pepinos, los pimientos verdes y los pistachos.

04.2.1.3 Hortalizas (incluidos hongos y setas, raíces y tubérculos, legumbres y leguminosas y áloe vera), algas marinas y nueces y semillas frescas peladas, cortadas o desmenuzadas:

Hortalizas frescas, como las patatas crudas peladas, que se presentan al consumidor para que las cocine en el hogar (p. ej. en la preparación de patatas doradas).

04.2.2 Hortalizas (incluidos hongos y setas, raíces y tubérculos, legumbres y leguminosas [incluida la soja] y áloe vera), algas marinas y nueces y semillas elaboradas:

Comprende todas las formas de elaboración que no sean pelar, cortar las hortalizas frescas o tratar la parte externa de las mismas.

04.2.2.1 Hortalizas (incluidos hongos y setas, raíces y tubérculos, legumbres y leguminosas y áloe vera), algas marinas y nueces y semillas congeladas:

Hortalizas frescas normalmente peladas y congeladas. ${ }^{42}$ Entre estos productos se incluyen, p. ej. el maíz congelado rápidamente, las patatas fritas congeladas rápidamente, los guisantes congelados rápidamente y los tomates elaborados enteros congelados rápidamente.

04.2.2.2 Hortalizas (incluidos hongos y setas, raíces y tubérculos, legumbres y leguminosas y áloe vera), algas marinas y nueces y semillas desecadas:

Productos en los que el contenido natural de agua se ha reducido para que sea inferior al nivel crítico de proliferación de microorganismos, sin afectar a los nutrientes importantes. El producto puede requerir o no rehidratación antes del consumo. Entre estos productos se incluyen las hortalizas en polvo que se obtienen desecando el zumo (jugo), p. ej. tomate en polvo y remolacha en polvo. ${ }^{42}$ Ejemplos: copos de patatas desecadas y lentejas desecadas. Entre los productos desecados orientales pueden citarse la laminaria desecada (fucácea, kombu), la laminaria desecada con condimentos (shio-kombu), las algas marinas desecadas (tororokombu), las tiras de calabaza desecadas (kampyo), las algas comestibles (laver) desecadas (nori) y las algas desecadas de la familia de laminariáceas (wakame).

04.2.2.3 Hortalizas (incluidos hongos y setas, raíces y tubérculos, legumbres y leguminosas y áloe vera) y algas marinas en vinagre, aceite, salmuera o salsa de soja:

Productos preparados tratando las hortalizas crudas con una solución de sal con exclusión de los productos fermentados de soja. Las hortalizas fermentadas, que son un tipo de producto encurtido, se clasifican en la categoría 04.2.2.7. Los productos fermentados de soja se clasifican en las categorías 06.8.6, 06.8.7, 12.9.1, 12.9.2.1 y 12.9.2.3. Entre estos productos se incluyen: la col encurtida, los pepinillos encurtidos, las aceitunas, las cebollas encurtidas, las setas en aceite, los cogollos de alcachofa marinados, achar y piccalilli. Entre las hortalizas encurtidas al estilo oriental figuran las siguientes: tsukemono, como hortalizas encurtidas con salvado de arroz (nuka-zuke), hortalizas encurtidas en koji (koji-zuke), hortalizas encurtidas en sake (kasu-zuke), hortalizas encurtidas en miso (miso-zuke) hortalizas encurtidas en salsa de soja (shoyu-zuke), hortalizas encurtidas en vinagre (su-zuke) y hortalizas encurtidas en salmuera (shio-zuke). Otros ejemplos son: jengibre encurtido, ajo encurtido y chile (ají) encurtido.

04.2.2.4 Hortalizas (incluidos hongos y setas, raíces y tubérculos, legumbres y leguminosas y áloe vera) y algas marinas en conserva, en latas o frascos (pasterizadas) o en bolsas de esterilización:

Productos completamente conservados en los que las hortalizas frescas se limpian y se ponen en latas o frascos con líquido (p. ej. en salmuera, agua, aceite o salsa) y se esterilizan térmicamente o se pasterizan. ${ }^{42}$ Entre estos productos se incluyen, p. ej. las castañas en lata, el puré de castañas en lata, los espárragos envasados en frascos de vidrio, los frijoles enlatados y cocidos, la pasta de tomate en lata (con baja acidez) y los tomates en lata (en trozos o enteros).

42 Food Chemistry, H.-D. Belitz y W. Grosch, Springer-Verlag, Heidelberg, 1987, págs. 572 a 576. 
04.2.2.5 Purés y preparados para untar elaborados con hortalizas (incluidos hongos y setas, raíces y tubérculos, legumbres y leguminosas y áloe vera), algas marinas y nueces y semillas (p. ej. la mantequilla de maní (cacahuete)):

Los purés de hortalizas son pastas finamente dispersas preparadas a base de hortalizas concentradas, que pueden haberse tratado antes térmicamente (p. ej. mediante vapor). Estas pastas pueden filtrarse antes del envasado. Los purés contienen una cantidad menor de extracto seco que las pastas que figuran en la categoría 04.2.2.6.42,43 Entre estos productos se incluyen, p. ej. el puré de tomate, la mantequilla de maní (cacahuete) (pasta para untar elaborada con maní (cacahuete) tostado y molido con adición de aceite de maní (cacahuete), otras mantequillas de nueces ( $p$. ej. la mantequilla de anacardo) y la mantequilla de calabaza.

04.2.2.6 Pulpas y preparados de hortalizas (incluidos hongos y setas, raíces y tubérculos, legumbres y leguminosas y áloe vera), algas marinas y nueces y semillas (p. ej. los postres y las salsas a base de hortalizas y hortalizas confitadas) distintos de los indicados en la categoría de alimentos 04.2.2.5:

Las pastas y pulpas de hortalizas se preparan de la misma manera que se indica para los purés vegetales (categoría 04.2.2.5). Sin embargo, las pastas y pulpas tienen un contenido superior de extracto seco y se utilizan normalmente como componentes de otros alimentos (p. ej. en salsas). Entre estos productos se incluyen los siguientes: pulpa de patata, pulpa de rábano picante, extracto de áloe, salsa ( $p$. ej. tomate troceado, cebolla, pimientos, especias y hierbas), pasta dulce de frijoles rojos (an), pasta dulce de granos de café (rellenos), pasta de tomate, pulpa de tomate, salsa de tomate, jengibre cristalizado y postre de hortalizas a base de frijoles (namagashi).

04.2.2.7 Productos a base de hortalizas (incluidos hongos y setas, raíces y tubérculos, legumbres $y$ leguminosas y áloe vera) y algas marinas fermentadas, excluidos los productos fermentados de soja de las categorías 06.8.6, 06.8.7, 12.9.1, 12.9.2.1 y 12.9.2.3:

Se entiende por hortalizas fermentadas el producto encurtido formado por la acción de bacterias del ácido láctico, generalmente en presencia de sal. ${ }^{42}$ Los productos tradicionales orientales de hortalizas fermentadas se preparan secando las hortalizas al aire y dejándolas a temperatura ambiente para que proliferen los microorganismos; a continuación, las hortalizas se guardan herméticamente en un ambiente anaeróbico y se les añade sal (para generar ácido láctico), especias y condimentos. ${ }^{44}$ Entre estos productos se incluyen la pasta de pimiento rojo, productos de hortalizas fermentadas (algunos tsukemono que no se incluyen en la categoría 04.2.2.3), el kimchi (preparación de col china y hortalizas fermentadas) y la sauerkraut (col fermentada). Se excluyen los productos fermentados de soja que se encuentran en las categorías 06.8.6 (Soja fermentada (p.ej. natto y tempe)), 06.8.7 (Cuajada de soja fermentada), 12.9.1 (Pasta de soja fermentada p.ej. miso), 12.9.2.1 (Salsa de soja fermentada), y 12.9.2.3 (Otras salsas de soja).

04.2.2.8 Hortalizas (incluidos hongos y setas, raíces y tubérculos, legumbres y leguminosas y áloe vera) y algas marinas cocidas o fritas:

Hortalizas que se presentan al consumidor cocidas al vapor, hervidas, cocidas al horno o fritas, con o sin recubrimiento. Entre estos productos se incluyen los siguientes: frijoles cocidos a fuego lento, patatas (papas) prefritas, gombo frito y hortalizas cocidas en salsa de soja (tsukudani).

05.0 Confitería:

Comprende todos los productos de cacao y chocolate (05.1), otros productos de confitería que pueden contener o no cacao (05.2), goma de mascar (05.3) y decoraciones y glaseados (05.4), o alimentos producidos exclusivamente con cualquier combinación de alimentos que correspondan a estas subcategorías.

05.1 Productos de cacao y chocolate, incluidos los productos de imitación y sucedáneos del chocolate:

Esta categoría se ha subdividido para dar cabida a la variedad de productos a base de cacao y chocolate normalizados y no normalizados.

43 Norma para los Concentrados de Tomate Elaborados (CODEX STAN 57-1981).

44 Asian Foods: Science and Technology, C.Y.W. Ang, K.S. Liu y Y.-W. Huang, Eds., Capítulo 11: Vegetable Products, S.L. Wang, Technomic Publishing Co., Lancaster PA 1999, págs. 320 a 323. 


\subsubsection{Mezclas de cacao (en polvo) y cacao en pasta/torta de cacao:}

Comprende una variedad de productos que se utilizan en la elaboración de otros productos de chocolate o en la preparación de bebidas a base de cacao. La mayoría de los productos de cacao tienen su origen en la almendra de cacao descortezada, que se obtiene de los granos de cacao limpios y descascarillados. El cacao en pasta se obtiene mediante la desintegración mecánica de la almendra de cacao descortezada. Según el producto acabado de chocolate que se desee obtener, la almendra de cacao descortezada o el cacao en pasta pueden someterse a un proceso de alcalinización que suavice el sabor. El polvo de cacao es el cacao descascarillado que se obtiene durante el aventamiento y la eliminación de gérmenes. El cacao en polvo se obtiene reduciendo el contenido de grasa del cacao en pasta o licor de cacao mediante el prensado (incluido el prensado con expulsor) y el moldeado en una torta prensada de cacao. La torta prensada de cacao se desmenuza y se muele hasta conseguir cacao en polvo. El licor de cacao es una pasta fluida homogénea producida a partir de la almendra de cacao descortezada, tostada, desecada, desmenuzada y molida. Las mezclas de cacao y azúcar contienen solamente cacao en polvo y azúcar. El chocolate en polvo para bebidas se elabora a base de licor de cacao o cacao en polvo y azúcar, y se le pueden añadir aromas (p. ej. vainillina). ${ }^{45,46}$ Entre estos productos se incluyen los siguientes: chocolate en polvo para bebidas; cacao para el desayuno; polvo de cacao (fino), almendras de cacao descortezadas, pasta y torta de cacao; licor de chocolate; mezclas de cacao (en polvo para preparar la bebida caliente); mezcla de cacao y azúcar y mezclas secas para dulces a base de cacao y azúcar. Las bebidas de cacao y la leche con chocolate acabadas se incluyen en la categoría 01.1.4; la mayoría de los productos de chocolate acabados se incluyen en la categoría 05.1.4.

05.1.2 Mezclas de cacao (jarabes):

Productos que pueden producirse añadiendo amilasa bacteriana al licor de cacao. La enzima evita que el jarabe se espese o se deposite, mediante la solubilización y dextrinización del almidón del cacao. Comprende productos como el jarabe de chocolate utilizado para preparar leche chocolatada o chocolate caliente..$^{48}$ El jarabe de chocolate es diferente de la salsa de chocolate (p. ej. para los helados "sundae") que figura en la categoría 05.4.

\subsubsection{Productos para untar a base de cacao, incluidos los rellenos a base de cacao:}

Productos en los que el cacao se mezcla con otros ingredientes (generalmente a base de grasas) a fin de preparar una pasta para untar que se utiliza para extender en el pan o como relleno de productos de pastelería fina. Entre estos productos se incluyen, p. ej. la manteca de cacao ${ }^{47}$, los rellenos para bombones y chocolatinas, el relleno para tartas de chocolate y las pastas para untar pan a base de chocolate con nueces (producto del tipo Nutella).

\subsubsection{Productos de cacao y chocolate:}

El chocolate se produce a partir de la almendra de cacao descortezada, cacao en pasta, tortas prensadas de cacao, cacao en polvo o licor de cacao con o sin azúcar añadido, manteca de cacao, sustancias aromatizantes o saborizantes e ingredientes optativos (p. ej. nueces). ${ }^{47}$ Esta categoría es para el chocolate de acuerdo a la definición de la Norma para el chocolate y los productos de chocolate (CODEX STAN 871981), y para la confitería que utiliza chocolate que cumple con la norma y puede contener otros ingredientes, por ejemplo, las nueces y la fruta cubiertos de chocolate (como las pasitas). Esta categoría sólo comprende la porción de chocolate de cualquier dulce que corresponda a la categoría de alimentos 05.2. Algunos ejemplos son: los bombones, los dulces de manteca de cacao (compuestos de manteca de cacao, sólidos de leche y azúcar), el chocolate blanco, el chocolate como revestimiento, el chocolate recubierto de azúcar o con decoraciones de colores, el chocolate relleno (chocolate con una textura distinta en el interior y un recubrimiento externo, excluida la confitería de harina y los productos de pastelería fina de las categorías 07.2.1 y 07.2.2) y el chocolate con ingredientes comestibles añadidos. ${ }^{48}$ Esta categoría no incluye las nueces recubiertas de yogurt, cereales o miel (categoría 15.2).

\footnotetext{
45 Norma para Cacao en Polvo (Cacaos) y las Mezclas Secas de Cacao y Azúcares (CODEX STAN 105-1981); Norma para el Cacao en Pasta (Licor de Cacao/Chocolate) y la Torta de Cacao (CODEX STAN 141-1981).

46 Food Chemistry, H.-D. Belitz y W. Grosch, Springer-Verlag, Heidelberg, 1987, págs. 708 a 711.

47 Norma para la Manteca de Cacao (CODEX STAN 86-1981).

48 Norma para el Chocolate y los Productos de Chocolate (CODEX STAN 87-1981).
} 


\subsubsection{Productos de imitación y sucedáneos del chocolate:}

Comprende los productos similares al chocolate que pueden estar elaborados o no a base de cacao pero que tienen propiedades organolépticas parecidas, como las pepitas de algarrobo, y los productos a base de cacao que contienen más del $5 \%$ de grasas vegetales (distintas de la manteca de cacao) que no corresponden a la Norma para el chocolate y los productos de chocolate (CODEX STAN 87-1981). Estos productos similares al chocolate pueden contener otros ingredientes optativos y pueden incluir confitería rellena, como chocolate compuesto, chocolate compuesto aromatizado y pigmentado, revestimientos de chocolate compuesto y nueces y fruta recubiertas de sucedáneos del chocolate ( $p$. ej. pasitas). Esta categoría sólo incluye la porción de sucedáneos del chocolate de cualquier dulce que corresponda a la categoría de alimentos 05.2.

05.2 Dulces distintos de los indicados en las categorías de alimentos $05.1,05.3$ y 05.4, incluidos los caramelos duros y blandos, los turrones, etc.:

Comprende todos los tipos de productos que contienen principalmente azúcar y sus equivalentes dietéticos y pueden contener o no cacao. Incluye los caramelos duros (05.2.1), los caramelos blandos (05.2.2) y los turrones y productos de mazapán (05.2.3).

\subsubsection{Caramelos duros:}

Productos elaborados con agua y azúcar (jarabe simple), colorantes y aromatizantes, que pueden tener o no un relleno, sus equivalentes dietéticos y productos que pueden contener o no cacao. Incluyen pastillas y tabletas (caramelos a base de azúcar laminados, con formas y rellenos). ${ }^{49}$ También incluye la halva de tahini y especialidades orientales como el dulce de pasta de frijoles (yokan) y la pasta de agar para el mitsumame. Estos tipos de productos se pueden usar como rellenos para productos de chocolate que corresponden a las categorías de alimentos 05.1.4 y 05.1.5.

\subsubsection{Caramelos blandos:}

Esta categoría comprende productos blandos masticables a base de azúcar como caramelos que contienen jarabe de azúcar, grasas, colorantes y aromatizantes y sus equivalentes dietéticos; caramelos a base de gelatina (por ej. gominolas en forma de judía, pasta de fruta gelatinizada recubierta de azúcar, fabricada con azúcar, gelatina, pectina, colorantes y aromatizantes); y regaliz. ${ }^{49}$ También incluye especialidades orientales como la gelatina de frijoles dulce (yokan) y la gelatina de agar para el mitsumame. Estos tipos de productos e pueden utilizar como rellenos en productos de chocolate que corresponden a las categorías de alimentos 05.1.4 y 05.1.5.

\subsubsection{Turrón y mazapán:}

El turrón consiste en nueces tostadas y trituradas, azúcar y cacao y sus equivalentes dietéticos, puede consumirse solo o utilizarse como relleno para productos de chocolate que correspondan a las categorías de alimentos 05.1.4 y 05.1.5. El mazapán es un dulce elaborado con pasta de almendras y azúcar y sus equivalentes, que puede moldearse y colorearse para el consumo directo o bien emplearse como relleno en productos de chocolate que correspondan a las categorías de alimentos 05.1.4 y 05.1.5. ${ }^{49}$

\subsection{Goma de mascar:}

Producto a base de goma natural o sintética que contiene saborizantes, edulcorantes (nutritivos o no nutritivos), aromatizantes y otros aditivos. ${ }^{49}$ Comprende el chicle de globos y los productos de goma para refrescar el aliento.

05.4 Decoraciones (p. ej. para productos de pastelería fina), revestimientos (que no sean de fruta) y salsas dulces:

Comprende glaseados y escarchados listos para el consumo, para pasteles, galletas, tartas y pan y repostería a base de harina, así como combinaciones de estos productos. Incluye también recubrimientos a base de azúcar y chocolate para productos al horno. Las salsas dulces y los revestimientos comprenden la salsa de caramelo (butterscotch) que se utiliza, p. ej. en los helados. Estas salsas dulces son diferentes de los jarabes (p. ej. el de arce, de caramelo y los jarabes aromatizados para la pastelería fina y los sorbetes) incluidos en la categoría 11.4. Los revestimientos a base de fruta se incluyen en la categoría 04.1.2.8. La salsa de chocolate se incluye en la categoría 05.1.2.

49 Food Chemistry, H.-D. Belitz \& W. Grosch, Springer-Verlag, Heidelberg, 1987, pp. 634-636. 
06.0 Cereales y productos a base de cereales, derivados de granos de cereales, de raíces y tubérculos, legumbres, leguminosas y médula o corazón blando de palmera, excluidos los productos de panadería de la categoría de alimentos 07.0:

Incluye formas no elaboradas (06.1) y distintas formas elaboradas de cereales y productos a base de cereales.

06.1 Granos enteros, triturados o en copos, incluido el arroz:

Incluye cereales y granos enteros, descascarillados y no elaborados. Son ejemplos de los productos de esta categoría: la cebada, el maíz, el lúpulo (para fabricar cerveza), la avena, el arroz (incluido el arroz enriquecido, instantáneo y sancochado), el sorgo, la soja y el trigo.

\subsection{Harinas y almidones:}

Incluye los productos molidos básicos obtenidos de granos de cereales, raíces, tubérculos, legumbres, médula o corazón blando de palmera o leguminosas vendidos como tales o utilizados como ingredientes ( $p$. ej. en productos horneados).

\subsubsection{Harinas:}

La harina se obtiene de la molturación de granos, cereales, tubérculos ( $p$. ej. la yuca) y médula o corazón blando de palmera. Esta categoría comprende las pastas de harina para pan y para tortas, galletas y pasteles, harina para pan, repostería, fideos y pastas y mezclas de harinas (mezclas de harinas de distintos cereales o granos), que son diferentes de las mezclas para productos de pastelería (mezclas secas que contienen harina y otros ingredientes, categorías 07.1.6 (mezclas para productos de panadería ordinaria) y categoría 07.2.3 (mezclas para pastelería fina). Ejemplos de estos productos son: harina de trigo duro, harina leudante, harina enriquecida, harina instantánea, harina de maíz, salvado, fécula de patata, harina de soja tostada (kinako), harina de «konjac» (gelatina en polvo de "lengua del diablo", konnayaku-ko) y maida (harina de trigo refinada).

\subsubsection{Almidones:}

El almidón es un polímero de glucosa presente en forma granular en determinadas especies vegetales, sobre todo en semillas (por ejemplo) de cereales, legumbres, maíz, trigo, arroz, frijoles, guisantes) y tubérculos (por ejemplo, tapioca, patata). El polímero consta de unidades de anhidro- $\alpha$-D-glucosa unidas. El almidón natural se separa mediante procesos específicos para cada materia prima.

\subsection{Cereales para el desayuno, incluidos los copos de avena:}

Incluye todos los productos de cereales listos para el consumo, instantáneos, y los utilizados normalmente en desayunos calientes. Ejemplos de estos productos son: cereales para el desayuno tipo Granola, harina de avena instantánea, fécula de patata, copos de maíz, trigo o arroz hinchado, cereales mixtos para el desayuno (p. ej. arroz, trigo y maíz), cereales para el desayuno elaborados con soja o salvado y cereales para el desayuno extruidos elaborados con harina o granos de cereales en polvo.

06.4 Pastas y fideos y productos análogos (p. ej. fécula de arroz en hojas, vermicelli de arroz, pastas y fideos de soja):

Se revisó esta categoría de alimentos en el entendimiento de que en las pastas y fideos deshidratados se necesitarían muy pocos o ningún aditivo..$^{50}$ Incluye todas las pastas, los fideos y productos análogos.

\subsubsection{Pastas y fideos frescos y productos análogos:}

Productos que no están tratados (esto es, no están calentados, hervidos, cocidos al vapor, cocidos, pregelatinizados o congelados) ni deshidratados. Se destinan al consumo poco después de su preparación. Entre estos productos se incluyen: fideos sin hervir y "masa" o corteza para rollitos de primavera, wontons y shuo mai.

\subsubsection{Pastas y fideos deshidratados y productos análogos:}

Productos que no están tratados (esto es, que no están calentados, hervidos, cocidos al vapor, cocidos, pregelatinizados o congelados) y que están deshidratados. Ejemplos de estos productos son los siguientes: formas desecadas de espaguetis, vermicelli de frijoles, vermicelli de arroz, macarrones y fideos de arroz.

50 ALINORM 03/12, párr. 55. 


\subsubsection{Pastas y fideos precocidos y productos análogos:}

Productos que están tratados (es decir, calentados, hervidos, cocidos al vapor, cocidos, pregelatinizados o congelados). Estos productos pueden venderse directamente al consumidor (p. ej. ñoquis precocidos y enfriados que deben calentarse antes del consumo) o pueden ser el componente amiláceo de comidas preparadas ( $p$. ej. platos principales congelados que deben calentarse para servir y que contienen espaguetis, macarrones o fideos; espaguetis en lata y platos principales de albóndigas). También se incluyen los fideos instantáneos (sokuseki-men; p. ej. ramen precocido, udon, fideos de arroz), que están pregelatinizados y se calientan y secan antes de venderlos al consumidor.

06.5 Postres a base de cereales y almidón (p. ej. pudines de arroz, pudines de mandioca):

Postres que contienen como ingrediente principal cereales, almidón o granos. Se incluyen también los rellenos para postres a base de cereales o almidón. Ejemplos de estos productos son: el pudín de arroz, el pudín de sémola, el pudín de tapioca, las bolas de harina de arroz (dango), un postre de pasta de harina de trigo fermentada con levadura y cocida al vapor (musipan) y un pudín a base de almidón (namagashi) que se consume como postre.

\subsection{Mezclas batidas para rebozar (p. ej. para empanar o rebozar pescado o carne de aves de corral):}

Productos que contienen cereales o granos en copos o molidos que se combinan con otros ingredientes ( $p$. ej. huevos, agua, leche) y se utilizan para recubrir pescado o aves de corral. Estos productos se suelen vender en forma de mezcla seca del componente de cereal o grano. Entre ellos se incluye la mezcla para rebozar tempura. Las masas (p. ej. para empanar) figuran en la categoría de alimentos 07.1.4, y otras mezclas (p. ej. para pan o tortas) en las categorías 07.1.6 y 07.2.3 respectivamente.

06.7 Productos a base de arroz precocidos o elaborados, incluidas las tortas de arroz (sólo del tipo oriental):

Productos preparados con arroz remojado, escurrido, cocido al vapor y amasado en forma de tortas (p. ej. el mochi japonés y el teuck coreano). ${ }^{51}$ Los aperitivos elaborados con granos de arroz, llamados también «tortas de arroz» se clasifican en la categoría 15.1, y las tortas de arroz para postre en la categoría 06.5. La categoría 06.7 comprendería también los productos de arroz elaborado y de arroz enriquecido, tales como los productos precocidos que se venden en lata, refrigerados o congelados; y los productos de arroz elaborado vendidos en bolsas de esterilización. El objeto es distinguir esta categoría de la del apartado 06.1 (granos enteros, triturados o en copos, incluido el arroz) que debe contener solamente cereales y granos enteros, descascarillados y no elaborados.

06.8 Productos a base de soja (excluidos los aderezos y condimentos a base de soja de la categoría de alimentos 12.9):

Comprende productos de frijoles de soja desecados, cocidos, fritos o fermentados y productos de cuajada de soja.

06.8.1 Bebidas a base de soja:

Productos preparados con frijoles de soja secos remojados en agua, transformados en puré que se hierve y se cuela, o preparados con harina de soja, concentrado de soja, o aislado de soja. En algunos países esta categoría incluye los productos denominados leche de soja. La bebida de soja puede consumirse como tal o utilizarse para preparar otros productos de soja, como los comprendidos en las categorías 06.8.2 (Película de bebida a base de soja), 06.8.3 (Cuajada de soja [tofu]), 06.8.4 (Cuajada de soja semideshidratada), y 06.8.5 (Cuajada de soja deshidratada [kori tofu]). ${ }^{52,53,54}$ Incluye además productos de soja, como las bebidas a base de soja en polvo, que se venden como tales, para reconstituirse, o como mezcla que contiene un coagulante que el consumidor puede reconstituir para preparar tofu blando hecho en casa. ${ }^{52,55}$

\subsubsection{Película de bebida a base de soja:}

Película que se forma en la superficie de la bebida a base de soja hervida, que se deseca. Puede freírse o ablandarse en agua antes de ser utilizada en sopas o alimentos escalfados. También conocida como fuzhu o yuba. $.5,56,57$

51 Asian Foods: Science and Tecnology, C.Y.W. Ang, K.S. Liu y Y.-W. Huang, eds., Chapter 1: Rice Products, B.S. Luh, Technomic Publishing Co., Lancaster PA 1999, pág. 16.

52 The Joy of Japanese Cooking, K. Takahashi, Shufunomoto Col., Ltd., Japan, 1996, págs. 17-18 y 123-131.

53 Taste of Japan, D. Richie, Kodansha International, Tokyo, Japón, 1992, págs. 34-35.

54 Taste of Japan, D. Richie, Kodansha International, Tokyo, Japón, 1992, págs.141-153.

55 World Food Japan, Lonely Planet, 2002, pág. 35.

56 Taste of Japan, D. Richie, Kodansha International, Tokyo, Japón, 1992, págs. 168-169.

57 The Joy of Japanese Cooking, K. Takahashi, Shufunomoto Col., Ltd., Japón, 1996, pág. 31. 
06.8.3 Cuajada de soja (tofu):

La cuajada de soja se prepara con frijoles de soja seca que se remojan en agua, se hacen puré y se cuelan para producir leche de soja, que luego se transforma en cuajada por medio de un coagulante, y se vierte en un molde. Las cuajadas de soja pueden tener una variedad de texturas (p.ej. blanda, semisólida, sólida).52,53

06.8.4 Cuajada de soja semideshidratada:

Cuajada de soja que se ha prensado en bloques durante el moldeado de manera que se ha eliminado una parte de la humedad sin q ue el producto se deseque por completo (véase la categoría de alimentos 06.8.5). Por lo general la cuajada de soja semideshidratada contiene un 62 por ciento de agua y presenta una consistencia gomosa. ${ }^{52}$

\subsubsection{Cuajada de soja semideshidratada dura cocida en salsa espesa:}

Cuajada de soja parcialmente deshidratada que se cocina (estofado) en una salsa densa (p. ej. salsa miso). Por lo general la cuajada de soja parcialmente deshidratada absorbe la salsa, recobrando de tal manera su consistencia original. ${ }^{52}$

\subsubsection{Cuajada de soja semideshidratada frita:}

Cuajada de soja parcialmente deshidratada que se fríe en abundante aceite. Puede consumirse como tal o bien cocinarse (p.ej. estofada en salsa) después de freírla. ${ }^{52,58}$

06.8.4.3 Cuajada de soja semideshidratada distinta de las incluidas en las categorías 06.8.4.1 y 06.8.4.2:

Cuajada de soja parcialmente deshidratada preparada de maneras distintas del estofado en salsa espesa (por ej. miso) o la freidura. Comprende los productos asados a la parrilla y empastados que pueden estar combinados con otros ingredientes (p.ej. para formar una hamburguesa o un pastel). ${ }^{52}$

\subsubsection{Cuajada de soja deshidratada (kori tofu):}

Cuajada de soja de la que se ha eliminado toda la humedad a través del proceso de congelación, maduración y deshidratación. Puede reconstituirse con agua o salsa para su consumo, 0 utilizarse directamente en platos preparados. También puede freírse o cocerse a fuego lento en una salsa. ${ }^{52}$

06.8.6 Soja fermentada (por ej. natto, tempe):

El producto se prepara a partir de soja cocida al vapor y fermentada mediante ciertos hongos o bacterias (levaduras). Los frijoles enteros ablandados tienen un aroma y sabor característicos. Comprende productos como el dou chi (China), el natto (Japón), y el tempe (Indonesia).

06.8.7 Cuajada de soja fermentada:

El producto se prepara formando un pan de cuajada de soja durante el proceso de fermentación. Se trata de un producto blando, aromatizado, de color rojizo, amarillo-arroz o verde grisáceo.

06.8.8 Otros productos base de soja:

Otros productos de soja compuestos principalmente de proteína de soja, como proteína de soja extruida, texturizada, concentrada y aislada.

07.0 Productos de panadería:

Incluye las categorías relativas al pan y los productos de panadería ordinaria (07.1) y los productos de panadería fina dulces, salados y aromatizados (07.2).

07.1 Pan y productos de panadería ordinaria:

Incluye todos los tipos de productos de panadería que no son dulces y los productos derivados del pan.

\subsubsection{Panes y panecillos:}

Incluye los panes leudados con levadura, los panes especiales y el pan leudado con bicarbonato. Ejemplos de estos productos son: el pan blanco, el pan de centeno, el pan "pumpernickel", el pan con pasas, el pan de trigo entero, el pan francés, el pan de malta, los panecillos para hamburguesas, los panecillos de trigo integral y los panecillos de leche.

58 Asian Foods: Science and Technology, C.Y.W. Ang, K.S. Liu y Y.-W. Huang, Eds., Chapter 6: Oriental Soy Foods, K.S. Liu, Technomic Publishing Co., Lancaster PA 1999, págs. 162-163. 


\subsubsection{Panes leudados con levadura y panes especiales:}

Incluye todos los tipos de productos de panadería que no son dulces y los productos derivados del pan. Ejemplos de estos productos son: el pan blanco, el pan de centeno, el pan "pumpernickel", el pan con pasas, el pan de trigo entero, el pan francés, el pan de malta, los panecillos para hamburguesas, los panecillos de trigo integral y los panecillos de leche.

\subsubsection{Panes leudados con bicarbonato:}

Comprende los panes leudados con bicarbonato.

07.1.2 "Crackers", excluidos los "crackers" dulces:

El término "cracker" se refiere a una galleta fina y crujiente normalmente elaborada con una masa sin endulzar. Los "cracker" aromatizados (p. ej. con sabor a queso) que se consumen como aperitivos figuran en la categoría 15.1. Ejemplos de estos productos son: los "crackers" leudados con bicarbonato, las tostadas de centeno y "matzohs".

\subsubsection{Otros productos de panadería ordinaria (p. ej. bagels, pita, muffins ingleses, etc.):}

Comprende todos los demás productos de panadería ordinaria, como el pan de maíz y las galletas. EI término "galleta» de esta categoría se refiere a una torta pequeña de pan friable, fermentada con levadura o bicarbonato de soda. No se refiere a los "biscuit" ingleses, que son galletas o "crackers" dulces de la categoría 07.2.1.

\subsubsection{Productos similares al pan, incluidos los rellenos a base de pan y el pan rallado:}

Incluye productos a base de pan como los picatostes, los rellenos a base de pan y mezclas para rellenos, y las masas preparadas (p. ej. para galletas). Las mezclas de pan se incluyen en la categoría de alimentos 07.1.6.

\subsubsection{Panes y bollos dulces al vapor:}

Productos de trigo o arroz fermentados al estilo oriental, cocidos al vapor. Pueden tener o no relleno. En China, los productos sin relleno se llaman "pan al vapor" (mantou) y los que tienen relleno "bollos al vapor" (baozi o bao). Se pueden preparar también bollos enrollados de distintas formas (huajuan). ${ }^{59}$ Ejemplos: bolas rellenas y bollos al vapor con relleno de carne, mermelada u otros rellenos (manjyu).

\subsubsection{Mezclas para pan y productos de panadería ordinaria:}

Incluye todas las mezclas que contienen los ingredientes secos a los que se añaden ingredientes húmedos (por ejemplo, agua, leche, aceite, mantequilla, huevos) para preparar la masa de productos de panadería comprendidos en las categorías de alimentos 07.1.1 a 07.1.5. Por ejemplo, las mezclas para pan francés, pan chato, panettone o ciabatta, entre otras. Las mezclas para productos de panadería fina (p. ej. tartas, galletas, tortitas o panqueques) figuran en la categoría 07.2.3

07.2 Productos de panadería fina (dulces, salados, aromatizados) y mezclas:

Comprende subcategorías de productos listos para el consumo (07.2.1 y 07.2.2), así como mezclas (07.2.3) para preparar productos de panadería fina.

\subsubsection{Tortas, galletas y pasteles (p. ej. rellenos de fruta o crema):}

Los términos "cracker dulce" o "galleta dulce" utilizados en esta categoría se refieren a un producto tipo galleta que puede comerse como postre. Ejemplos de estos productos son los siguientes: galletas de mantequilla, tarta de queso, barritas de cereales rellenas de fruta, bizcocho sencillo (incluido kasutera), bizcocho (tipo de postre con fécula (namagash)), western cakes, moon cakes, pastelitos, pasteles rellenos de fruta ( $p$. ej. pastel de manzana), galletas de harina de avena, galletas de azúcar y "biscuits" ingleses (galletas o "crackers" dulces).

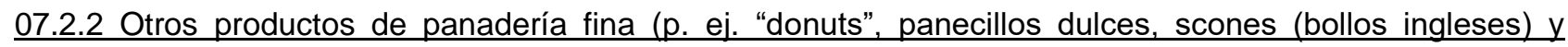
muffins):

Incluye productos que pueden consumirse como postre o desayuno. Entre ellos se incluyen los siguientes: tortitas o panqueques, gofres, bollos dulces rellenos (anpan), pastas danesas, gofres o cucuruchos para helados, pastelería a base de harina, dulce de bizcocho borracho tipo trifles.

59 Asian Foods: Science and Tecnology, C.Y.W. Ang, K.S. Liu y Y.-W. Huang, eds., Chapter 4: Wheat Products: 2. Breads, Cakes, Cookies, Pastries, and Dumplings, S. Huang, Technomic Publishing Co., Lancaster PA 1999, págs. 72 y 73. 
07.2.3 Mezclas para panadería fina (p. ej. tortas, tortitas o panqueques):

Mezclas que contienen ingredientes secos a los que se añaden ingredientes húmedos (p. ej. agua, leche, aceite, mantequilla, huevos) para preparar la masa del producto de panadería fina. Entre éstas se incluyen la mezcla para pan, mezcla para tortas, mezcla para dulces a base de harina, mezcla para tortitas o panqueques, mezcla para pasteles y mezcla para gofres. La masa preparada figura en la categoría de alimentos 07.1.4. Las mezclas para productos de panadería ordinaria (p. ej. pan) se incluyen en la categoría 07.1.6.

08.0 Carne y productos cárnicos, incluidos los de aves de corral y caza:

Esta categoría incluye todos los tipos de productos cárnicos, de aves de corral y caza, en piezas y cortados o picados, frescos (08.1) y elaborados (08.2 y 08.3).

\subsection{Carne fresca, incluida la de aves de corral y caza:}

Los productos frescos no suelen contener aditivos. Sin embargo, en algunas circunstancias los aditivos son necesarios. P. ej. en los sellos de certificación que se estampan sobre la superficie de los cortes de carne fresca se utilizan colores que se indican en el Sistema de Clasificación de los Alimentos con la anotación "para señalar o marcar". Además, antes de su comercialización para el consumo se pueden recubrir los productos de carne con glaseados o especias (p. ej. jamón glaseado y pollo para asar a la parrilla). En el Sistema de Clasificación de los Alimentos, esto se señala con la anotación "para utilizar como glaseado o recubrimiento (tratamiento de superficie)". Se debe señalar que los recubrimientos comercializados como tales se incluyen en las categorías de alimentos 04.1.2.8 (escarchados de fruta, p. ej. para jamón) y 12.2 (aderezos con especias).

\subsubsection{Carne fresca, incluida la de aves de corral y caza en piezas enteras o en cortes:}

Canales y cortes de carne, cruda no tratada incluida la de aves de corral y caza. Entre estos productos se incluyen: canales de vacuno y de cerdo; sangre fresca de vacuno; pollos frescos enteros y en partes; cortes de carne de vacuno fresca (p. ej. filetes); órganos de vacuno (p. ej. corazón, riñones); tripa fresca; y costillas de cerdo.

\subsubsection{Carne fresca picada, incluida la de aves de corral y caza:}

Carne cruda y no tratada incluida la de aves de corral y caza, picada o deshuesada mecánicamente. Ejemplos de estos productos son: carne de vacuno fresca (hamburguesas); boerewors; salchichas frescas para el desayuno; gehackt (carne picada); Ionganiza (salchicha fresca sin curar); albóndigas frescas; piezas de aves de corral deshuesadas mecánicamente, trituradas y moldeadas (empanadas o recubiertas, o sin empanar ni recubrir); y salchichas frescas (p. ej. de vacuno, italianas y de cerdo).

\subsection{Productos cárnicos, de aves de corral y caza elaborados, en piezas enteras o en cortes:}

Abarca varios tratamientos para los cortes de carne no tratados térmicamente (08.2.1) y para los cortes de carne tratados térmicamente (08.3.2).

08.2.1 Productos cárnicos, de aves de corral y caza elaborados sin tratar térmicamente, en piezas enteras 0 en cortes:

Esta categoría comprende varios métodos de tratamiento (p. ej. curado, salazón, secado y encurtido) que conservan la carne y prolongan su duración en el almacenamiento.

08.2.1.1. Productos cárnicos, de aves de corral y caza elaborados, curados (incluidos los salados) y sin tratar térmicamente, en piezas enteras o en cortes:

Los productos salados se tratan con cloruro de sodio. Los productos curados en seco (encurtidos en seco) se preparan frotando directamente la superficie de la carne con sal. Los productos curados encurtidos en líquido se preparan sumergiendo la carne en una solución de salmuera. Los productos curados por bombeo se preparan inyectando salmuera en la carne. El curado puede realizarse también agregando aditivos. Los productos ahumados se incluyen también en esta categoría. ${ }^{60}$ Ejemplos de estos productos son los siguientes: tocino (curado, curado en seco, curado por inmersión, curado por bombeo); tocino de los flancos; "corned beef"; carne de vacuno marinada; y diferentes tipos de productos encurtidos orientales: carne encurtida con miso (miso-zuke), carne encurtida con koji (koji-zuke) y carne encurtida con salsa de soja (shoyu-zuke).

60 Food Chemistry, H.-D. Belitz \& W. Grosch, Springer- Verlag, Heidelberg, 1987, págs. 439 a 445. 
8.2.1.2. Productos cárnicos, de aves de corral y caza elaborados, curados (incluidos los salados), desecados y sin tratar térmicamente, en piezas enteras o en cortes:

Los cortes de carne pueden curarse o salarse como se describe en la categoría 08.2.1.1 y, a continuación, secarse, o bien secarse solamente. El secado se realiza con aire caliente 0 al vacío. ${ }^{60}$ Entre estos productos se incluyen los siguientes: cerdo salado y desecado, carne deshidratada como relleno, jamón ibérico y jamón tipo prosciutto.

08.2.1.3 Productos cárnicos, de aves de corral y caza elaborados, fermentados y sin tratar térmicamente, en piezas enteras o en cortes:

Los productos fermentados son un tipo de producto encurtido que se obtiene mediante la acción de las bacterias del ácido láctico en presencia de sal. Ejemplos de estos productos son: carne de vacuno aderezada, manitas de cerdo encurtidas (fermentadas).

08.2.2 Productos cárnicos, de aves de corral y caza elaborados tratados térmicamente, en piezas enteras o en cortes:

Comprende los cortes de carne cocidos (incluidos los curados y cocidos, y los secados y cocidos), tratados térmicamente (incluidos los esterilizados) y enlatados. Ejemplos de estos productos son: el jamón curado y cocido; el lomo de cerdo curado y cocido; la carne de pollo en lata; y las piezas de carne hervidas en salsa de soja (tsukudani).

08.2.3 Productos cárnicos, de aves de corral y caza elaborados, congelados, en piezas enteras o en cortes: Incluye los cortes de carne crudos y cocidos que se han congelado. Ejemplos de estos productos son: los pollos enteros congelados, las piezas de pollo congeladas y los filetes de vacuno congelados.

08.3 Productos cárnicos, de aves de corral y de caza picados elaborados:

Comprende varios tratamientos para los productos no tratados térmicamente (08.3.1) y para los tratados térmicamente (08.3.2).

\subsubsection{Productos cárnicos, de aves de corral y caza picados y elaborados sin tratar térmicamente:}

Esta categoría incluye varios métodos de tratamiento (p. ej. adobar, salar, secar y encurtir) que conservan la carne y prolongan la duración en el almacenamiento de los productos en cuestión.

08.3.1.1 Productos cárnicos, de aves de corral y caza picados y elaborados, curados (incluidos los salados) y sin tratar térmicamente:

Los productos salados se tratan con cloruro de sodio. Los productos curados en seco (encurtidos en seco) se preparan frotando directamente la superficie de la carne con sal. Los productos curados encurtidos en líquido se preparan sumergiendo la carne en una solución de salmuera. Los productos curados por bombeo se preparan inyectando salmuera en la carne. El curado puede realizarse también agregando aditivos. Los productos ahumados se incluyen también en esta categoría. ${ }^{60}$ Ejemplos de estos productos son: chorizo, productos tipo salami, salchichón, tocino (salchicha fresca o curada), salchichón a la pimienta, salchicha ahumada.

08.3.1.2 Productos cárnicos, de aves de corral y caza picados y elaborados, curados (incluidos los salados) y secos y sin tratar térmicamente:

Los productos picados o deshuesados mecánicamente pueden curarse o salarse, como se describe en la categoría 08.3.1.1, y, a continuación, secarse, o bien secarse solamente. El secado se realiza con aire caliente 0 al vací ${ }^{60}$. Ejemplos de estos productos son: pasturmas, embutidos secos, embutidos curados y secados, cecina de vacuno, salchichas chinas (incluida la salchicha de cerdo tradicional curada o ahumada), sobrasada.

08.3.1.3 Productos cárnicos, de aves de corral y caza picados y elaborados, fermentados y sin tratar térmicamente:

Los productos fermentados son un tipo de producto encurtido que se obtiene mediante la acción de las bacterias del ácido láctico en presencia de sal. Algunos tipos de embutidos pueden estar fermentados. 
08.3.2 Productos cárnicos, de aves de corral y caza picados, elaborados y tratados térmicamente:

Incluye los productos picados cocidos (incluidos los curados y cocidos, y los secos y cocidos), tratados térmicamente (incluida la esterilización) y enlatados. Entre estos productos se incluyen: hamburguesas de vacuno preparadas para la parrilla; foie gras y patés; carne en gelatina; carne picada cocida y curada; carne picada hervida en salsa de soja (tsukudani); "corned beef" en lata; fiambre en conserva; pastas de carne; hamburguesas de carne cocida; productos cocidos tipo salami; albóndigas cocidas; salchichas de Estrasburgo; salchichas para desayuno; salchichas para tostar y servir; y terrinas (mezcla de carne picada y cocida).

08.3.3 Productos cárnicos, de aves de corral y caza picados, elaborados y congelados:

Esta categoría incluye los productos cárnicos picados o deshuesados mecánicamente, crudos o cocidos total o parcialmente, que se han congelado. Ejemplos de estos productos son: hamburguesas congeladas; barritas de pollo empanadas o rebozadas y congeladas.

08.4 Tripas comestibles (p. ej. para embutidos):

Tripas o tubos elaborados con colágeno, celulosa o material sintético de calidad alimentaria, o bien de origen natural (p. ej. intestinos de cerdo o de cordero) que contienen la mezcla del embutido. ${ }^{60}$

09.0 Pescado y productos pesqueros, incluidos moluscos, crustáceos, y equinodermos:

Esta amplia categoría se subdivide en categorías para el pescado fresco (09.1) y para diversos productos pesqueros elaborados (09.2-09.4). Se incluyen en ella los vertebrados acuáticos (pescado y mamíferos acuáticos (p. ej. ballenas)) y los invertebrados acuáticos (p. ej. medusas), así como los moluscos (p. ej. almejas y caracoles), los crustáceos (p. ej. camarones cangrejos, langostas) y los equinodermos (p. ej. erizos de mar, cohombros de mar). Los productos pesqueros se pueden recubrir, p. ej. con glaseados o con especias, antes de su comercialización para el consumo (p. ej. filetes de pescado congelados y glaseados). En el Sistema de Clasificación de los Alimentos, esto se indica con una anotación relativa al "uso como glaseado o recubrimiento (tratamiento de superficie)".

\subsection{Pescado y productos pesqueros frescos, incluidos moluscos, crustáceos y equinodermos:}

El término "fresco" se refiere al pescado y los productos pesqueros cuya única elaboración ha consistido en refrigerarlos, guardarlos en hielo o congelarlos una vez capturados en el mar, en lagos o en otras masas de agua para evitar su descomposición y deterioro. ${ }^{61}$

\subsubsection{Pescado fresco:}

Incluye la carne fresca de ballena, el bacalao, el salmón, la trucha, etc.; y las huevas frescas de pescado.

09.1.2 Moluscos, crustáceos, y equinodermos frescos:

Incluye camarones, almejas, cangrejos, langostas, caracoles, etc. frescos.

09.2 Pescado y productos pesqueros elaborados, incluidos moluscos, crustáceos y equinodermos:

Esta categoría se refiere a los productos pesqueros que están congelados y que pueden precisar más cocción, así como a los productos cocidos, ahumados, desecados y salados, listos para el consumo.

09.2.1 Pescado, filetes de pescado y productos pesqueros congelados, incluidos moluscos, crustáceos y equinodermos:

Pescado fresco, incluido el cocido parcialmente, sometido a congelación o congelación rápida en el mar o en tierra para su posterior elaboración. ${ }^{61}$ Ejemplos de estos productos son: almejas, filetes de bacalao, cangrejo, pez de escama, eglefino, merluza, langosta, pescado picado, camarones y gambas, congelados o congelados rápidamente; huevas congeladas de pescado; surimi congelado; y carne de ballena congelada.

09.2.2 Pescado, filetes de pescado y productos pesqueros rebozados congelados, incluidos moluscos, crustáceos y equinodermos:

Producto sin cocinar a base de pescado o porciones de pescado, con aderezo a base de huevo y migas de pan o rebozado. Ejemplos de estos productos son: camarones crudos congelados empanados o rebozados y filetes, porciones de pescado y barritas de pescado empanados o rebozados, congelados o congelados rápidamente. ${ }^{62}$

61 Food Chemistry, H.-D. Belitz \& W. Grosch, Springer- Verlag, Heidelberg, 1987, págs. 464 a 468

62 Norma para Barritas, Porciones y Filetes de Pescado Empanados o Rebozados Congelados Rápidamente (CODEX STAN 166-1989). 
09.2.3 Productos pesqueros picados, amalgamados y congelados, incluidos moluscos, crustáceos y equinodermos:

Producto sin cocinar preparado con piezas de productos pesqueros picados en una salsa cremosa.

09.2.4 Pescado y productos pesqueros cocidos y/o fritos, incluidos moluscos, crustáceos y equinodermos:

Incluye todos los productos cocidos listos para el consumo, tal como se describen en las subcategorías.

09.2.4.1 Pescado y productos pesqueros cocidos:

Los productos cocidos incluyen los elaborados al vapor, hervidos o preparados con cualquier otro método de cocción, salvo los fritos (véase 09.2.4.3). El pescado puede estar entero, en porciones o picado. Entre estos productos se incluyen los siguientes: embutidos de pescado, productos pesqueros hervidos reducidos por cocción en salsa de soja (tsukudani); los productos de surimi cocidos (kamaboko); los productos de kamaboko cocidos con aroma de cangrejo (kanikama); las huevas de pescado cocidas; el surimi cocido; los productos de surimi cocidos y modelados en forma de tubo (chikuwa); y la pasta de pescado y langosta cocidos (productos análogos al surimi). En 09.3.4 se incluyen otras pastas de pescado (de tipo oriental).

\subsubsection{Moluscos, crustáceos y equinodermos cocidos:}

Los productos cocidos incluyen los elaborados al vapor, hervidos o preparados con cualquier otro método de cocción, salvo los fritos (véase 09.2.4.3). Son ejemplos de estos productos: crangon y crangon vulgaris cocidos (camarón pardo); camarones, almejas y cangrejos cocidos.

09.2.4.3 Pescado y productos pesqueros fritos, incluidos los moluscos, crustáceos y equinodermos:

Productos listos para el consumo preparados a base de pescado o porciones de pescado, con o sin más condimentos a base de huevo, pan rallado o rebozado, que se fríen, cuecen, asan o preparan a la parrilla, y después se envasan o enlatan con o sin salsa o aceite. ${ }^{61}$ Son ejemplos de esta categoría: el surimi frito listo para el consumo, los calamares fritos y los cangrejos de caparazón blando fritos.

09.2.5 Pescado y productos pesqueros ahumados, desecados, fermentados y/o salados, incluidos moluscos. crustáceos y equinodermos:

El pescado ahumado normalmente se prepara a partir de pescado fresco congelado o congelado rápidamente que se deseca directamente o tras la ebullición, con o sin salazón, mediante la exposición del pescado a humo de serrín recién generado. El pescado desecado se prepara exponiéndolo al sol o desecándolo directamente o tras la ebullición en una instalación especial; se puede salar el pescado antes de desecarlo. El pescado salado se frota con sal o se introduce en una solución de sal. Este proceso de elaboración es diferente del que se describe en la categoría de alimentos 09.3 para el pescado marinado y escabechado. El pescado curado se prepara mediante salazón y posterior ahumado del pescado. ${ }^{61}$ Entre estos productos se incluyen: las anchoas, el camarón y el sábalo salados; el cacho, la sepia y el pulpo ahumados; el jamón de pescado; las especies de la familia Gadidae desecadas y saladas; la pasta de pescado y huevas de pescado ahumadas y saladas; el bacalao negro, el sábalo y el salmón curados y ahumados; los mariscos desecados, el bonito desecado (katsuobushi) y el pescado hervido y desecado (niboshi).

09.3 Pescado y productos pesqueros semiconservados, incluidos moluscos, crustáceos y equinodermos:

Incluye productos tratados con métodos tales como el marinado, el escabechado y la cocción parcial, que tienen un tiempo de conservación limitado.

09.3.1 Pescado y productos pesqueros marinados y/o en gelatina, incluidos moluscos, crustáceos $y$ equinodermos:

Los productos marinados se elaboran remojando el pescado en vinagre o vino con o sin sal o especias añadidas. Se envasan en tarros o latas y tienen un tiempo de conservación limitado. Los productos en gelatina se pueden elaborar ablandando los productos pesqueros mediante cocción o vapor, añadiendo vinagre o vino, sal y conservantes, y solidificándolos en una gelatina. Entre otros ejemplos cabe mencionar: el rollmops (una especie de arenque marinado), la anguila de mar (cazón) en gelatina y el áspic de pescado. ${ }^{61}$ 
09.3.2 Pescado y productos pesqueros escabechados y/o en salmuera, incluidos moluscos, crustáceos y equinodermos:

Con frecuencia los productos en escabeche se consideran un tipo de producto marinado. El escabechado es el resultado del tratamiento del pescado con una solución de sal y vinagre o alcohol (p. ej. vino) $\cdot{ }^{61}$ Entre estos productos se incluyen los siguientes: distintos tipos de productos orientales en escabeche, como el pescado escabechado en koji (koji-zuke), el pescado escabechado en poso (kasu-zuke), el pescado escabechado en miso (miso-zuke), el pescado escabechado en salsa de soja (shoyu-zuke) y el pescado escabechado en vinagre (su-zuke); la carne de ballena en escabeche; y el espadín y el arenque en escabeche.

\subsubsection{Sucedáneos de salmón, caviar y otros productos pesqueros a base de huevas:}

Normalmente las huevas se elaboran lavándolas, salándolas y dejándolas madurar hasta que estén transparentes. Después, las huevas se envasan en un recipiente de vidrio o en otro tipo de recipiente adecuado. El término "caviar" se refiere sólo a las huevas de las especies de esturión (p. ej. la beluga). Los sucedáneos del caviar consisten en huevas de distintos pescados marinos y de agua dulce (p. ej. el bacalao y el arenque) que se salan, sazonan, colorean y pueden tratarse con conservantes. ${ }^{61}$ Entre estos productos se incluyen: las huevas de salmón saladas (sujiko), las huevas de salmón elaboradas y saladas (ikura), las huevas de bacalao, las huevas de bacalao saladas (tarako) y el caviar de liebre de mar. En ocasiones, la hueva puede pasterizarse. En ese caso, se incluye en la categoría de alimentos 09.4, puesto que se trata cabalmente de un producto en conserva. Los productos a base de huevas congelados, cocidos o ahumados se incluyen en las categorías 09.2.1, 09.2.4.1 y 09.2.5, respectivamente; las huevas de pescado frescas se encuentran en la categoría 09.1.1.

09.3.4 Pescado y productos pesqueros semiconservados, incluidos moluscos, crustáceos y equinodermos (p. ej. la pasta de pescado), excluidos los productos indicados en las categorías de alimentos 09.3.1 a 09.3.3:

Entre otros ejemplos cabe mencionar la pasta de pescado o crustáceo y la pasta de pescado oriental tradicional. Esta última se elabora a base de pescado fresco o del residuo derivado de la producción de salsa de pescado, que se combina con otros ingredientes como la harina de trigo, el salvado, el arroz o la soja. El producto puede luego fermentarse. ${ }^{63}$ Las pastas de pescado o crustáceo cocidos (productos análogos al surimi) se hallan en las categorías 09.2.4.1 y 09.2.4.2, respectivamente.

09.4 Pescado y productos pesqueros (incluidos los moluscos, crustáceos y equinodermos) en conserva, con inclusión los enlatados o fermentados:

Son productos de larga conservación, elaborados mediante la pasterización o el uso de autoclaves y que se envasan herméticamente al vacío a fin de garantizar la esterilidad. Los productos pueden envasarse en su propio jugo 0 en aceite 0 salsa añadidos. ${ }^{61}$ De esta categoría se excluyen los productos cocidos completamente (véase la categoría 09.2.4). Entre otros ejemplos cabe mencionar: el atún, las almejas, el cangrejo, las huevas de pescado y las sardinas en conserva; las albóndigas de pescado sazonado; y el surimi (pasterizado térmicamente).

\subsection{Huevos y productos a base de huevo:}

Incluye los huevos frescos en su cáscara (10.1), los productos que pueden ser sucedáneos de los huevos frescos (10.2) y otros tipos de productos a base de huevo (10.3 y 10.4).

\subsection{Huevos frescos:}

Los huevos frescos en su cáscara no deben contener aditivos. Sin embargo, se pueden utilizar colores para decorar, teñir o sellar la superficie exterior de los huevos de cáscara. En el SCA se da cuenta de ello con la anotación "para decoración, sellado, marcado o marcado al fuego del producto (tratamiento de la superficie)".

\subsection{Productos a base de huevo:}

Productos que pueden utilizarse como sucedáneos de los huevos frescos en recetas o como alimento (p. ej. la tortilla). Se elaboran a base de huevos frescos, ya sea i) batiendo y purificando el huevo entero o ii) separando la clara de la yema del huevo y después batiendo y purificando cada una por separado. El huevo entero, la clara o la yema purificado se elabora luego para producir huevos líquidos, congelados o en polvo, tal como se describe más adelante. ${ }^{64}$

63 Asian Foods: Science and Tecnology, C.Y.W. Ang, K.S. Liu y Y.-W. Huang, eds., Chapter 9: Traditional Oriental Seafood Products, Y.-W. Huang, Technomic Publishing Co., Lancaster PA 1999, pág. 264.

64 Food Chemistry, H.-D. Belitz \& W. Grosch, Springer-Verlag, Heidelberg, 1987, págs. 411 a 414. 
10.2.1 Productos líquidos a base de huevo:

El huevo entero, la yema o la clara purificados se pasterizan y se conservan químicamente ( $p$. ej. añadiendo sal).

10.2.2 Productos congelados a base de huevo:

El huevo entero, la yema o la clara purificados se pasterizan y congelan.

10.2.3 Productos a base de huevo en polvo y/o cuajados por calor:

Se retiran los azúcares del huevo entero, la yema o la clara purificados, que a continuación se pasterizan y desecan.

10.3 Huevos en conserva, incluidos los huevos en álcali, salados y envasados:

Incluye los productos orientales tradicionales en conserva, tales como los huevos de pato curados en sal (Hueidan) y los "huevos milenarios" (pidan) tratados con alkali.65

10.4 Postres a base de huevo (p. ej. el flan):

Incluye productos listos para el consumo y productos que hay que preparar a partir de una mezcla en polvo. Como ejemplos cabe mencionar las tartas y los flanes. Se incluyen también los rellenos de crema para los productos de pastelería fina (p. ej. tartas).

\subsection{Edulcorantes, incluida la miel:}

Incluye todos los azúcares normalizados (11.1), los productos sin normalizar (p. ej. en 11.2, 11.3, 11.4 y 11.6) y los edulcorantes naturales (11.5 - Miel).

\subsection{Azúcares refinados y en bruto:}

Edulcorantes nutritivos, tales como la sacarosa purificada total o parcialmente (obtenida de la remolacha azucarera y la caña de azúcar), la glucosa (obtenida del almidón) o la fructosa, que se incluyen en las subcategorías 11.1.1 a 11.1.5.

\subsubsection{Azúcar blanco, dextrosa anhidra, dextrosa monohidrato y fructosa:}

El azúcar blanco es sacarosa purificada y cristalizada con una polarización no menor de $99,7^{\circ} \mathrm{Z}$. La dextrosa anhidra es D-glucosa purificada y cristalizada sin agua de cristalización. La dextrosa monohidrato es Dglucosa purificada y cristalizada con una molécula de agua de cristalización. La fructosa es D-fructosa purificada y cristalizada. ${ }^{66}$

\subsubsection{Azúcar en polvo y dextrosa en polvo:}

El azúcar en polvo (azúcar glasé) es azúcar blanco finamente pulverizado con o sin antiaglutinantes añadidos. La dextrosa en polvo (dextrosa glasé) es dextrosa anhidra o dextrosa monohidrato finamente pulverizada, o una mezcla de ambas, con o sin antiaglomerantes añadidos. ${ }^{66}$

11.1.3 Azúcar blando blanco, azúcar blando moreno, jarabe de glucosa, jarabe de glucosa deshidratado y azúcar de caña sin refinar:

El azúcar blando blanco es azúcar húmedo purificado, de grano fino, de color blanco. El azúcar blando moreno es azúcar húmedo, de grano fino, de color marrón claro a marrón oscuro. El jarabe de glucosa es una solución acuosa concentrada y purificada de sacáridos nutritivos obtenidos del almidón y/o la inulina. ${ }^{67}$ El jarabe de glucosa deshidratado es jarabe de glucosa del que se ha separado parcialmente el agua. El azúcar de caña sin refinar es sacarosa parcialmente purificada, cristalizada a partir de jugo de caña parcialmente purificado sin más purificación.66

\subsubsection{Jarabe de glucosa deshidratado utilizado para la elaboración de golosinas:}

Se trata del jarabe de glucosa deshidratado, tal como se describe en 11.1.3, utilizado para elaborar los productos de confitería que se incluyen en la categoría de alimentos 05.2 (p. ej. caramelos blandos o duros).

\subsubsection{Jarabe de glucosa utilizado para la elaboración de golosinas:}

Se trata del jarabe de glucosa, tal como se describe en 11.1.3, utilizado para elaborar los productos de confitería que se incluyen en la categoría de alimentos 05.2 (p. ej. caramelos blandos o duros).

65 Asian Foods: Science and Tecnology, C.Y.W. Ang, K.S. Liu y Y.-W. Huang, eds., Chapter 8: Traditional Poultry and Egg Products, T.C. Chen, Tecnomic Publishing Co., Lancaster PA 1999, págs. 240 a 244.

66 Norma para los Azúcares (CODEX STAN 212-1999).

67 Food Chemistry, H.D. Belitz \& W. Grosch, Springer-Verlag, Heidelberg, 1987, págs. 631 a 633. 


\subsubsection{Lactosa:}

Es un constituyente natural de la leche que se obtiene normalmente del suero. Puede ser anhidra, contener una molécula de agua de cristalización, o ser una mezcla de ambas formas. ${ }^{66}$

\subsubsection{Azúcar blanco de plantación o refinería:}

Es sacarosa purificada y cristalizada con una polarización no menor de $99,5^{\circ} Z .^{66}$

\subsection{Azúcar moreno, excluidos los productos de la categoría de alimentos 11.1.3:}

Incluye los azúcares en terrones de grano largo, de color marrón o amarillo, tales como el azúcar Demerara.

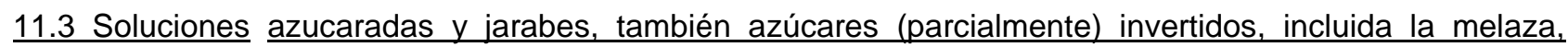
excluidos los productos indicados en la categoría de alimentos 11.1.3:

Incluye subproductos del proceso de refinación del azúcar (p. ej. la melaza), el azúcar invertido (mezcla equimolar de glucosa y fructosa obtenida de la hidrólisis de sacarosa), ${ }^{67}$ y otros edulcorantes, tales como el jarabe de maíz rico en fructosa, el jarabe de inulina rico en fructosa y azúcar de maíz.

\subsection{Otros azúcares y jarabes (p. ej. la xilosa, el jarabe de arce y los revestimientos de azúcar):}

Incluye todos los tipos de jarabe de mesa (p. ej. el jarabe de arce), los jarabes para productos de pastelería fina y helados ( $p$. ej. jarabe de caramelo, jarabes aromatizados), el azúcar de palma y los revestimientos decorativos de azúcar (p. ej. cristales de azúcar coloreados para galletas).

\subsection{Miel:}

La miel es la sustancia edulcorante natural elaborada por las abejas melíferas a partir del néctar de las flores o las secreciones de las plantas. Las abejas recogen el néctar o las secreciones, los transforman por combinación con sustancias específicas propias y lo almacenan en un panal para que madure y añeje ${ }^{68}$ Entre otros ejemplos cabe mencionar la miel de flores silvestres y la miel de trébol.

\subsection{Edulcorantes de mesa, incluidos los que contienen edulcorantes de gran intensidad:}

Incluye los productos que son mezclas de edulcorantes de gran intensidad (p. ej. el acesulfame potásico) o de polioles (p. ej. el sorbitol) con otros aditivos (p. ej. Los como carbohidratos ) que se comercializan para su utilización como sucedáneos del azúcar. Los productos pueden presentarse en polvo o en forma sólida ( $p$. ej. terrones) o líquida.

\subsection{Sales, especias, sopas, salsas, ensaladas, productos proteínicos:}

Se trata de una categoría amplia que incluye sustancias que se añaden a un alimento para acentuar su aroma y gusto (12.1 - sal y sus sucedáneos; 12.2 - hierbas aromáticas, especias, aderezos y condimentos (p. ej. el aderezo para fideos instantáneos); 12.3 - vinagres; y 12.4 - mostazas), determinados alimentos elaborados (12.5 - sopas y caldos; 12.6 - salsas y productos análogos; y 12.7 - ensaladas (p. ej. la ensalada de macarrones, la ensalada de patatas (papas)) y emulsiones para untar emparedados, excluidas las emulsiones para untar a base de cacao y nueces de las categorías de alimentos 04.2.2.5 y 05.1.3), y productos compuestos principalmente de proteínas que derivan de la soja o de otras fuentes, p. ej. leche, cereales u hortalizas (12.9 - Aderezos y condimentos a base de soja; y 12.10 - Productos proteínicos distintos a los de soja).

\subsection{Sal y sucedáneos de la sal:}

Incluye la sal (12.1.1) y los sucedáneos de la sal (12.1.2) empleados para aderezar alimentos.

\subsubsection{Sal:}

Se trata principalmente de cloruro de sodio de calidad alimentaria. Incluye la sal de mesa, la sal yodada, la sal fluorada yodada y la sal dendrítica.

\subsubsection{Sucedáneos de la sal:}

Los sucedáneos de la sal son aderezos con un contenido reducido de sodio destinados a emplearse en los alimentos en sustitución de la sal. 
12.2 Hierbas aromáticas, especias, aderezos y condimentos (p. ej. el aderezo para fideos instantáneos):

\subsubsection{Hierbas aromáticas y especias}

En esta categoría se describen los productos cuyo uso tiene por objeto acentuar el aroma y el sabor del alimento. Las hierbas aromáticas y las especias normalmente se obtienen de fuentes vegetales y pueden deshidratarse, y presentarse molidas o enteras. Ejemplos de hierbas aromáticas son la albahaca, el orégano y el tomillo. Como ejemplos de especias cabe mencionar el comino y los carvis. Las especias pueden también encontrarse en forma de mezclas, en polvo o pasta. Ejemplos de mezclas de especias son los pimentones picantes, la pasta de pimentón picante, la pasta de curry, espesantes a base de curry y salmueras o ungüentos que se aplican a las superficies externas de la carne o el pescado.

\section{$\underline{\text { 12.2.2 Aderezos y condimentos }}$}

Los condimentos incluyen aderezos tales como los ablandadores de la carne, la sal de cebolla, la sal de ajo, los preparados de aderezo oriental (dashi), los revestimientos para esparcir sobre el arroz (furikake, que contiene p. ej. trocitos de algas desecadas, semillas de sésamo y aderezos) y los aderezos para fideos. El término "condimentos" tal como se emplea en el Sistema de Clasificación de los Alimentos no incluye las salsas para condimentar (p. ej. el "ketchup", la mayonesa, la mostaza).

\subsection{Vinagres:}

Se trata de un líquido obtenido de la fermentación acética de alcohol etílico derivado de una fuente apropiada (p. ej. el vino, la sidra). Como ejemplos cabe mencionar el vinagre de sidra, el vinagre de vino, el vinagre de malta, el vinagre de licor, el vinagre de cereales, el vinagre de pasas y el vinagre de fruta (vino). ${ }^{69}$

\subsection{Mostazas:}

Es una salsa de condimento elaborada a partir de semillas de mostaza molidas y a menudo desgrasadas que se mezclan en una solución con agua, vinagre, sal, aceite y otras especias y se refina. Destacan la mostaza de Dijon y la mostaza "picante" (preparada a base de semillas con hollejo). ${ }^{70}$

\subsection{Sopas y caldos:}

Incluye las sopas y los preparados listos para el consumo. Los productos finales pueden ser a base de agua (p. ej. el consomé) o leche (p. ej. la sopa de pescado).

\subsubsection{Sopas y caldos listos para el consumo, incluidos los envasados, embotellados y congelados:}

Se trata de productos elaborados a base de agua o leche que consisten en caldos de hortalizas, carne 0 pescado con o sin otros ingredientes ( $p$. ej. hortalizas, carne, fideos). Como ejemplos cabe mencionar: cubitos, caldos, consomés, sopas a base de agua y nata (crema), sopas de pescado y sopas de marisco.

\subsubsection{Mezclas para sopas y caldos:}

Se trata de la sopa concentrada que habrá de reconstituirse con agua y/o leche, con o sin otros ingredientes optativos añadidos (p. ej. hortalizas, carne, fideos). Cabe mencionar como ejemplos: los cubitos y polvos para caldo y las sopas en polvo y condensadas (p. ej. mentsuyu).

\subsection{Salsas y productos análogos:}

Incluye las salsas, los "gravies", los aliños y las mezclas que hay que reconstituir antes de su consumo. Los productos listos para el consumo se dividen en una subcategoría de productos emulsionados (12.6.1) y otra de productos no emulsionados (12.6.2), mientras que la subcategoría de mezclas (12.6.3) abarca las mezclas de salsas emulsionadas y no emulsionadas.

12.6.1 Salsas emulsionadas y salsas para mojar (p.ej. mayonesa, aderezos para ensaladas, salsa para mojar de cebollas):

Salsas, gravies, aderezos, y salsas para mojar a base de, por lo menos en parte, una emulsión de grasa o aceite en agua. Los ejemplos incluyen: aderezos para ensaladas (p. ej. estilos francés, italiano, griego, ranchero), grasas para untar (por ejemplo, la mayonesa con la mostaza), cremas para ensaladas, salsas grasas y salsas para mojar para aperitivos ( $p$. ej. salsa para mojar de tocino y queso cheddar, salsa para mojar de cebollas). 
12.6.2 Salsas no emulsionadas (p. ej. "ketchup", salsas a base de queso, salsas a base de nata (crema) y salsa "gravy"):

Incluye las salsas, "gravies" y aderezos a base de agua, leche de coco, y leche. Entre otros ejemplos cabe mencionar: la salsa picante, la salsa de tomate, la salsa de queso, la salsa Worcestershire, la salsa Worcestershire oriental espesa (salsa tonkatsu), el ajiaco, la salsa agridulce para mojar, y la salsa bechamel (a base de nata (crema)) (se trata de una salsa que consiste principalmente en leche o nata (crema) con poca grasa (p. ej. mantequilla) y harina añadidas, con o sin aderezos o especias).

\subsubsection{Mezclas para salsas y "gravies":}

Producto concentrado, normalmente en polvo, que hay que mezclar con agua, leche, aceite u otro líquido para preparar una salsa o "gravy" acabados. Ejemplos de ese producto son las mezclas para salsa de queso, salsa holandesa, y los aliños para ensaladas (p. ej. el italiano o el tipo "ranch").

12.6.4 Salsas ligeras (p. ej. salsa de pescado):

Incluye las salsas ligeras no emulsionadas y poco espesas que pueden elaborarse a base de agua. Estas salsas se utilizan más como condimento o ingrediente que como un "gravy" acabado (para emplear, p. ej. en el rosbif). Son ejemplos de estos productos la salsa de ostra, y la salsa de pescado tailandesa (nam pla).

12.7 Ensaladas (p. ej. la ensalada de macarrones, la ensalada de patatas (papas)) y emulsiones para untar emparedados, excluidas las emulsiones para untar a base de cacao y nueces de las categorías de alimentos 04.2.2.5 y 05.1.3:

Incluye las ensaladas preparadas, las emulsiones a base de leche para untar emparedados, las emulsiones sin normalizar para untar emparedados parecidas a la mayonesa y el aliño para coleslaw (ensalada de col).

\subsection{Levadura y productos similares:}

Incluye la levadura para pastelería que se utiliza en la elaboración de productos cocidos al horno. Incluye los productos koji orientales (arroz o trigo malteado con $A$. oryzae) utilizados en la producción de bebidas alcohólicas.

\subsection{Aderezos y condimentos a base de soja:}

Comprende productos compuestos que se derivan de la soja y otros ingredientes destinados a utilizar como aderezos y condimentos, como la pasta de soja fermentada y salsas de soja.

\subsubsection{Pasta de soja fermentada ("miso"):}

El producto se prepara con soja, sal, agua y otros ingredientes, mediante un proceso de fermentación. El producto comprende el dou jiang (China), el doenjang (República de Corea) y el miso (Japón), que pueden usar para preparar sopas o aderezos, o bien como condimento. ${ }^{52,71}$

\subsubsection{Salsa de soja:}

Un aderezo líquido que se obtiene por fermentación de soja, no-fermentación (p.ej. hidrólisis) de soja, o por hidrólisis de proteína vegetal.

\subsubsection{Salsa de soja fermentada:}

Salsa diáfana no emulsionada que se prepara con soja, cereales, sal y agua mediante un proceso de fermentación.

\subsubsection{Salsa de soja no fermentada:}

Salsa de soja no fermentada, que se conoce también como salsa de soja no elaborada, puede elaborarse a partir de proteínas vegetales, como frijoles de soja desgrasados, hidrolizados por ácido (p.ej. con ácido clorhídrico), neutralizados (p.ej. con carbonato de sodio), y filtrados. ${ }^{72}$

\subsubsection{Otras salsas de soja:}

Salsa de soja no emulsionada elaborada con salsa de soja fermentada y/o salsa de soja no fermentada, con o sin azúcar. Con o sin proceso de caramelización.

71 Asian Foods: Science and Technology, C.Y.W. Ang, K.S. Liu, \& Y.-W. Huang, Eds., Chapter 6: Oriental Soy Foods, K.S. Liu, Technomic Publishing Co., Lancaster PA 1999, págs. 173-181.

72 Asian Foods: Science and Technology, C.Y.W. Ang, K.S. Liu, \& Y.-W. Huang, Eds., Chapter 6: Oriental Soy Foods, K.S. Liu, Technomic Publishing Co., Lancaster PA 1999, págs. 181-187. 


\subsection{Productos proteínicos distintos a los de soja:}

Incluye, por ejemplo, los productos de proteínas de leche, proteínas de cereales y proteínas de vegetales que se asemejan o sustituyen a productos habituales, como la carne, el pescado o la leche. Entre otros ejemplos cabe mencionar: productos análogos de proteínas vegetales, fu (una mezcla de gluten (proteína vegetal) y harina que se vende en polvo (cocido) o crudo y se utiliza como ingrediente, p.ej. en la sopa de miso), sucedáneos proteínicos de la carne y el pescado.

\subsection{Productos alimenticios para usos nutricionales especiales:}

Por alimentos para regímenes especiales se entienden los elaborados o preparados especialmente para satisfacer necesidades especiales de alimentación determinadas por unas condiciones físicas o fisiológicas particulares y/o por enfermedades o trastornos específicos. La composición de estos alimentos deberá ser fundamentalmente diferente de los alimentos ordinarios con los que se comparan, en caso de que dichos alimentos existan..$^{73}$ Los alimentos dietéticos distintos de los de esta categoría se incluyen en las categorías de los alimentos ordinarios homólogos. ${ }^{74}$

13.1 Preparados para lactantes, preparados de continuación y preparados para usos medicinales especiales destinados a los lactantes:

Alimentos destinados a lactantes y niños pequeños, tal como se definen en las subcategorías 13.1.1, 13.1.2 y 13.1.3.

\subsubsection{Preparados para lactantes:}

Un sucedáneo de la leche materna para lactantes (niños de no más de 12 meses) de formulación específica para que sirva como única fuente de nutrición en los primeros meses de vida hasta el comienzo de una alimentación complementaria adecuada. El producto se consume en forma líquida listo para el consumo o ha de reconstituirse a partir de un polvo. Los productos, fuera de los incluidos en la categoría de alimentos 13.1.3, pueden ser a base de soja, proteínas hidrolizadas y/o aminoácidos, o de leche.

\subsubsection{Preparados de continuación:}

Por preparados de continuación se entiende todo alimento destinado a ser utilizado como la parte líquida de la alimentación complementaria de los lactantes (de seis meses de edad o más) y niños pequeños (de uno a tres años). ${ }^{75}$ Pueden estar listos para el consumo o en polvo que debe reconstituirse con agua. Los productos, fuera de los incluidos en la categoría de alimentos 13.1.3, pueden ser a base de soja, proteínas hidrolizadas y/o aminoácidos, o leche.

\subsubsection{Preparados para usos medicinales especiales destinados a los lactantes:}

Alimentos para usos dietéticos especiales que se elaboran o preparan y presentan especialmente para el control dietético de los lactantes y sólo pueden consumirse bajo control médico. Están destinados a la alimentación exclusiva o parcial de lactantes con una capacidad limitada o disminuida para tomar, digerir, absorber o metabolizar preparados ordinarios para lactantes o ciertos nutrientes contenidos en ellos, o que según el diagnóstico médico tienen otras necesidades especiales de nutrientes, cuyo control dietético no puede lograrse simplemente modificando la dieta normal, tomando otros alimentos para usos dietéticos especiales o mediante una combinación de ambos medios. ${ }^{76}$

13.2 Alimentos complementarios para lactantes y niños pequeños:

Alimentos para lactantes de seis meses de edad o más, y para la adaptación progresiva de los lactantes y niños pequeños a la comida ordinaria. Los productos pueden estar listos para el consumo o en polvo que debe reconstituirse con agua, leche $u$ otro líquido adecuado. ${ }^{77}$ Estos alimentos excluyen los preparados para lactantes (13.1.1), los preparados de continuación (13.1.2) y los preparados para usos medicinales especiales $(13.13)^{78}$. Ejemplos: "alimentos" para lactantes, "para bebés" y para niños pequeños a base de cereales, frutas, hortalizas y carne; harinas lácteas y galletas y bizcochos para niños pequeños.

73 Norma General para el Etiquetado y Declaración de Propiedades de Alimentos Preenvasados para Regímenes Especiales (CODEX STAN 146-1985).

74 P. ej. los refrescos dietéticos figuran en la categoría 14.1.4.1 y la mermelada baja en calorías en la 04.1.2.5.

75 Norma para Preparados Complementarios (CODEX STAN 156-1987).

76 Norma para Etiquetado y la Declaración de Propiedades de los Alimentos para Fines Medicinales Especiales (CODEX STAN 180-1991).

77 Norma para Alimentos Elaborados a Base de Cereales para Lactantes y Niños (CODEX STAN 74-1981).

78 Norma para Alimentos Envasados para Lactantes y Niños (CODEX STAN 73-1981). 
13.3 Alimentos dietéticos para usos medicinales especiales (excluidos los productos de la categoría 13.1):

Alimentos para usos dietéticos especiales que se elaboran o preparan y presentan especialmente para el control dietético de ciertos pacientes y sólo pueden consumirse bajo control médico. Están destinados a la alimentación exclusiva o parcial de pacientes con una capacidad limitada o disminuida de tomar, digerir, absorber o metabolizar alimentos ordinarios o ciertos nutrientes contenidos en ellos, o que según el diagnóstico médico tienen otras necesidades especiales de nutrientes, cuyo control dietético no puede lograrse simplemente modificando la dieta normal, tomando otros alimentos para usos dietéticos especiales o mediante una combinación de ambos medios. ${ }^{76}$

\subsection{Preparados dietéticos para adelgazamiento y control del peso:}

Preparados que, sea que se presenten "listos para el consumo" o se preparen de conformidad con las instrucciones de uso se presentan específicamente como sustitutos de la dieta completa diaria o de parte de ella. ${ }^{79}$ La categoría comprende productos con un contenido de calorías reducido que tienen también un contenido bajo o nulo de azúcar y/o grasa, o contienen sucedáneos de azúcar y/o grasa.

13.5 Alimentos dietéticos (p. ej. los complementos alimenticios para usos dietéticos), excluidos los indicados en las categorías de alimentos 13.1 a 13.4 y 13.6 :

Productos de elevado contenido nutritivo, en forma líquida o sólida, para consumo de ciertas personas como parte de una dieta equilibrada a fin de obtener una alimentación complementaria. Estos productos no están destinados a utilizarse para perder peso o como parte de un régimen médico.

\subsection{Complementos alimenticios:}

Comprende los complementos de vitaminas y minerales o en forma de dosis unitarias, tales como cápsulas, tabletas, polvos, soluciones, etc. en los casos en los que las jurisdicciones nacionales regulen estos productos como alimentos. ${ }^{80}$

14.0 Bebidas, excluidos los productos lácteos:

Esta importante categoría se divide en las amplias categorías de bebidas no alcohólicas (14.1) y bebidas alcohólicas (14.2). Las bebidas lácteas figuran en la categoría 01.1.4.

14.1 Bebidas no alcohólicas:

Esta amplia categoría comprende aguas y aguas gaseosas (14.1.1), zumos (jugos) de frutas y hortalizas (14.1.2), néctares de frutas y hortalizas (14.1.3), bebidas a base de agua aromatizadas con gas y sin gas (14.1.4) y bebidas en infusión a base de agua como el café y el té (14.1.5).

\subsubsection{Aguas:}

Comprende las aguas naturales (14.1.1.1) y otras aguas embotelladas (14.1.1.2), cada una de las cuales puede ser sin gas o con gas.

\subsubsection{Aguas minerales naturales y aguas de manantial:}

Aguas obtenidas directamente del manantial y envasadas cerca de éste; se caracterizan por la presencia, en proporciones relativas, de determinadas sales minerales, oligoelementos $u$ otros componentes. El agua mineral natural puede tener un contenido natural de gas (anhídrido carbónico del manantial), estar carbonatada (con la adición de anhídrido carbónico), descarbonatada (contener menos anhídrido carbónico que el agua de manantial, de modo que no libera espontáneamente anhídrido carbónico en condiciones normales de temperatura y presión) o enriquecida (con anhídrido carbónico del manantial) o bien no contener gas (sin anhídrido carbónico libre). ${ }^{81}$

\subsubsection{Aguas de mesa y gaseosas:}

Comprende aguas, distintas de las aguas naturales de manantial, que pueden tener gas por la adición de anhídrido carbónico y estar tratadas mediante filtración, purificación u otros medios adecuados. Estas aguas pueden contener sales minerales. Las aguas con gas y sin gas con adición de aromatizantes figuran en la categoría 14.1.4. Ejemplos: agua de mesa, agua embotellada con o sin adición de minerales, agua purificada, agua de Seltz, soda y agua de Vichy.

\footnotetext{
79 Norma para Preparados Dietéticos para Regímenes de Control del Peso (CODEX STAN 181-1991) y Norma para Preparados Dietéticos para Regímenes muy Hipocalóricos de Adelgazamiento (CODEX STAN 203-1995).

80 Directrices para Complementos de Vitaminas y Minerales (CAC/GL 55-2005).

81 Norma para las Aguas Minerales Naturales (CODEX STAN 108-1997).
} 


\subsubsection{Zumos (jugos) de frutas y hortalizas:}

Esta categoría comprende únicamente los zumos (jugos) de frutas y hortalizas. Las bebidas que se preparan con zumos de frutas u hortalizas figuran en la categoría 14.1.4.2. Hay diferentes categorías para las mezclas de zumos (jugos) de frutas u hortalizas en función de sus componentes (a saber, zumos (jugos) de frutas (14.1.2.1) y zumos (jugos) de hortalizas (14.1.3.1)).

14.1.2.1 Zumos (jugos) de fruta:

El zumo (jugo) de fruta es el producto líquido sin fermentar pero fermentable obtenido de la parte comestible de frutas frescas sanas de madurez apropiada o de fruta que se ha mantenido sana por medios idóneos. El zumo (jugo) se prepara mediante un procedimiento adecuado que mantiene las características físicas, químicas, organolépticas y nutricionales de los zumos (jugos) de la fruta de la que procede el producto. El zumo (jugo) puede ser turbio o claro, y pueden haberse añadido (hasta reponer el nivel habitual que alcanzan en el mismo tipo de frutas) sustancias aromáticas y componentes volátiles, todos los cuales deberán haberse obtenido por medios físicos idóneos, y haberse extraído en todos los casos del mismo tipo de fruta. Podrán añadirse pulpa y células obtenidas por medios físicos idóneos del mismo tipo de fruta. Los zumos (jugos) de una sola fruta se obtienen de un solo tipo de fruta. Los zumos (jugos) mixtos se obtienen mezclando dos o más zumos o zumos y purés de distintos tipos de fruta. El zumo (jugo) de fruta puede obtenerse, p. ej. exprimiendo directamente el jugo mediante procedimientos de extracción mecánica, reconstituyendo zumo (jugo) concentrado de fruta (categoría de alimentos 14.1.2.3) con agua, o bien con sólo en algunas situaciones, mediante extracción con agua de la fruta entera ( $p$. ej. zumo de ciruelas obtenido de ciruelas secas). ${ }^{82}$ Son algunos ejemplos el zumo (jugos) de naranja, el zumo (jugo) de manzana, el zumo (jugo) de grosellas negras, el zumo (jugo) de limón el zumo (jugo) de naranja y mango y el agua de coco.

\subsubsection{Zumo (jugo) de hortalizas:}

El zumo (jugo) de hortalizas es el producto líquido sin fermentar pero fermentable destinado al consumo directo que se obtiene por extracción mecánica, prensado, molido y/o tamizado de una o más hortalizas frescas sanas u hortalizas conservadas exclusivamente por medios físicos. El zumo (jugo) puede ser claro, turbio o pulposo. Puede haberse concentrado y reconstituido con agua. Los productos pueden obtenerse de una sola hortaliza (p. ej. zanahorias) o de mezclas de las mismas (p. ej. zanahoria y apio).

\subsubsection{Concentrados para zumos (jugos) de fruta:}

El zumo (jugo) de fruta es el producto que cumple con la definición proporcional en la categoría de alimentos 14.1.2.1. Se prepara mediante eliminación física del zumo (jugo) de fruta en una cantidad que incremente el nivel Brix hasta un valor superior por lo menos en un 50 por ciento al establecido para el zumo (jugo) reconstituido de la misma fruta. En la producción del zumo (jugo) destinado a la elaboración de concentrado se aplicarán procedimientos idóneos, que podrán combinarse con la difusión simultánea de las células o la pulpa de la fruta mediante agua, siempre y cuando los sólidos solubles de fruta extraídos mediante agua se añadan al zumo (jugo) primario en la línea de producción antes del procedimiento de concentración. A los zumos (jugos) concentrados de fruta se les pueden añadir (hasta reponer el nivel que alcanzan normalmente en el mismo tipo de frutas) sustancias aromáticas y componentes volátiles, todos los cuales deben haberse obtenido por medios físicos idóneos y proceder del mismo tipo de fruta. Asimismo podrán añadirse pulpa y células obtenidas por medios físicos idóneos del mismo tipo de fruta. ${ }^{22}$ Se venden en forma líquida en jarabe y congelados para la preparación de zumos (jugos) listos para el consumo mediante la adición de agua. Ejemplos: concentrado congelado de zumo de naranja y concentrado de zumo de limón.

\subsubsection{Concentrados para zumos (jugos) de hortalizas:}

Se prepara mediante la eliminación física del agua del zumo (jugo) de hortaliza. Se vende en forma líquida, en jarabe y congelados para la preparación de un zumo (jugo) listo para el consumo mediante la adición de agua. Incluye el zumo concentrado de zanahoria.

\subsubsection{Néctares de frutas y hortalizas:}

Los néctares de frutas y hortalizas son bebidas producidas a partir de purés, zumos (jugos) o concentrados de cualquiera de ellos, mezclados con agua y azúcar, miel, jarabes y/o edulcorantes. ${ }^{82}$ Las mezclas de néctares de frutas $u$ hortalizas se clasifican en función de sus componentes (a saber, néctares de frutas (14.1.3.1) y néctares de hortalizas (14.3.1.2)).

82 Norma General para Zumos (Jugos) y Néctares de Frutas (CODEX STAN 247-2005). 


\subsubsection{Néctares de frutas:}

El néctar de fruta es el producto sin fermentar pero fermentable que se obtiene añadiendo agua, con o sin adición de azúcar, miel, jarabes y/o edulcorantes al zumo (jugo) de fruta, el zumo (jugo) de fruta concentrado, los purés de fruta o purés de fruta concentrados o una mezcla de estos productos. Se le pueden añadir sustancias aromáticas, componentes volátiles, pulpa y células, todos los cuales deben proceder del mismo tipo de fruta y haberse obtenidos por medios físicos idóneos. Los productos pueden elaborarse a base de una fruta o una mezcla de frutas. ${ }^{82}$ Ejemplos: néctar de pera y néctar de melocotón.

\subsubsection{Néctares de hortalizas:}

Producto obtenido añadiendo agua, con o sin adición de azúcar, miel, jarabes y/o edulcorantes, a zumo (jugo) de hortalizas o zumo (jugo) concentrado de hortalizas, o a una mezcla de estos productos. Los productos pueden elaborarse a base de una hortaliza o una mezcla de hortalizas.

\subsubsection{Concentrados para néctares de frutas:}

Preparados mediante la eliminación física del agua del néctar de fruta o de los materiales de los que se obtiene. ${ }^{82}$ Se venden en forma líquida, en jarabe y congelados para la preparación de néctar listo para el consumo mediante adición de agua. Ejemplos: concentrado de néctar de pera y concentrado de néctar de melocotón.

\subsubsection{Concentrados para néctar de hortalizas:}

Preparados por eliminación física del agua del néctar de hortalizas. Se venden en forma líquida, en jarabe y congelados para la preparación de néctares listos para el consumo mediante adición de agua.

14.1.4 Bebidas a base de agua aromatizadas, incluidas las bebidas para deportistas, bebidas electrolíticas y bebidas con partículas añadidas:

Comprende todas las variedades y concentrados con gas y sin gas. Comprende productos a base de zumos (jugos) de frutas y hortalizas. ${ }^{83}$ También incluye las bebidas a base de café, té y hierbas aromáticas.

\subsubsection{Bebidas a base de agua aromatizadas con gas:}

Comprende todas las bebidas aromatizadas a base de agua con adición de anhídrido carbónico y con edulcorantes nutritivos, no nutritivos o intensos y otros aditivos alimentarios permitidos. Incluye la gaseosa (bebida a base de agua con adición de anhídrido carbónico, edulcorantes y aromatizantes) y bebidas con gas como "colas", bebidas refrescantes a base de raíces y ciertos tipos de especias, lima-limón y otros tipos de cítricos, tanto los de tipo dietético o ligero como normal. Estas bebidas pueden ser transparentes, turbias o pueden contener partículas (p. ej. trozos de fruta). Incluye las así llamadas bebidas para deportistas con gas que contienen niveles elevados de nutrientes y otros ingredientes. (p. ej. cafeína, taurina, carnitina).

14.1.4.2 Bebidas a base de agua aromatizadas $\sin$ gas, incluidos los ponches de fruta $y$ las limonadas $y$ bebidas similares:

Comprende bebidas sin adición de anhídrido carbónico a base de zumos (jugos) de frutas y hortalizas (p. ej. almendras, anís, coco y ginseng), limonadas y bebidas similares con sabor a fruta ( $p$. ej. naranjadas), refrescos a base de cítricos, capilé groselha, bebidas de ácido láctico, bebidas a base de café y té listas para consumir con o sin leche o sólidos lácteos y bebidas a base de hierbas aromáticas ( $p$. ej. té frío, té frío con sabor a frutas, capuchino en lata para beber frío) y bebidas para "deportistas" que contienen electrolitos. Estas bebidas pueden ser transparentes o contener partículas ( $p$. ej. trozos de fruta) y pueden estar o no edulcoradas con azúcar o un edulcorante no nutritivo de gran intensidad. Comprende las bebidas denominadas "energéticas" sin gas que contienen niveles elevados de nutrientes y otros ingredientes ( $p$. ej. cafeína, taurina, carnitina).

\subsubsection{Concentrados (líquidos o sólidos) para bebidas a base de agua aromatizadas:}

Comprende concentrados en polvo, jarabe, líquidos y congelados para preparar refrescos a base de agua, con gas o sin gas, mediante la adición de agua o agua con gas. Ejemplos: jarabes para refrescos con soda (p. ej. el jarabe de cola), jarabes de fruta para refrescos, concentrado helado o en polvo para limonada y mezclas para té frío.

83 Zumos (jugos) de frutas y hortalizas per se se encontran en 14.1.2.1 and 14.1.2.2, respectivamente. 
14.1.5 Café, sucedáneos del café, té, infusiones de hierbas y otras bebidas calientes a base de cereales y granos, excluido el cacao:

Comprende los productos listos para consumir (p. ej. enlatados) y sus mezclas y concentrados. Ejemplos: bebidas calientes a base de achicoria (postum), té de arroz, infusión de yerba mate, y mezclas para bebidas calientes a base de café y té ( $p$. ej. café instantáneo, polvos para capuchino caliente). Se incluyen también los granos de café tratados para la elaboración de productos de café. El cacao listo para el consumo se incluye en la categoría 01.1.4, y las mezclas de cacao en la 05.1.1.

14.2 Bebidas alcohólicas, incluidas las bebidas análogas sin alcohol y con bajo contenido de alcohol:

Las bebidas semejantes a las bebidas sin alcohol y con bajo contenido de alcohol se incluyen en la misma categoría que las bebidas alcohólicas.

\subsubsection{Cerveza y bebidas a base de malta:}

Bebidas alcohólicas elaboradas con cebada germinada (malta), lúpulo, levadura y agua. Ejemplos: cerveza amarga, cerveza oscura, cerveza blanca (weiss beer), cerveza pilsner, cerveza rubia, oud bruin, Obergariges Einfachbier, cerveza ligera, cerveza de mesa, licor de malta, cerveza porter, cerveza fuerte (stout) y extrafuerte (barley wine). ${ }^{84}$

\subsubsection{Sidra y sidra de pera:}

Vinos de fruta elaborados a base de manzana (sidra) y pera (sidra de pera). Incluye también la cidre bouché. ${ }^{85}$

\subsubsection{Vinos de uva:}

Bebida alcohólica que se obtiene exclusivamente de la fermentación parcial o total del alcohol de uvas frescas, prensadas o sin prensar, o del mosto (zumo) de uva. ${ }^{86}$

\subsubsection{Vino de uva no espumoso:}

Vino de uva (blanco, tinto, rosado o de color rosáceo, seco o dulce) que puede contener hasta un máximo de $0,4 \mathrm{~g} / 100 \mathrm{ml}(4000 \mathrm{mg} / \mathrm{kg})$ de anhídrido carbónico a $20^{\circ} \mathrm{C}$.

\subsubsection{Vinos de uva espumosos y semiespumosos:}

Vinos de uva en los que se produce gasificación durante el proceso de fermentación en botella o en cuba cerrada. Comprende también vino con gas, cuyo anhídrido carbónico ha sido añadido parcial o totalmente. Ejemplos: champán, vino espumoso y vino "cold duck". 85

\subsubsection{Vino de uva enriquecido, vino de uva licoroso y vino de uva dulce:}

Vinos de uva producidos por uno de los métodos siguientes: i) fermentación del mosto (zumo) de uva con una gran concentración de azúcar; ii) mezcla de zumo (jugo) concentrado de uva con vino; iii) mezcla de mosto fermentado con alcohol. Ejemplos: vino de uva para postres, oporto, madeira, marsala, tokay y jerez. ${ }^{85}$

\subsubsection{Vinos (distintos de los de uva):}

Comprende vinos elaborados con frutas distintas de la uva, la manzana y la pera ${ }^{87}$, y de otros productos agrícolas, incluidos los granos (p. ej. el arroz). Estos vinos pueden ser espumosos o no espumosos. Ejemplos: vino de arroz (sake) y vinos de fruta espumosos y no espumosos.

\subsubsection{Aguamiel:}

Licor elaborado a base de miel, malta y especias fermentadas, o solamente miel. Incluye el vino de miel. ${ }^{85}$

84 Food Chemistry, H.-D. Belitz y W. Grosch, Springer-Verlag, Heidelberg, 1987, pág. 644.

85 Food Chemistry, H.-D. Belitz y W. Grosch, Springer-Verlag, Heidelberg, 1987, págs. 669 a 679.

86 Food Chemistry, H.-D. Belitz y W. Grosch, Springer-Verlag, Heidelberg, 1987, pág. 654. Código internacional de las prácticas enológicas de la Oficina Internacional de la Viña y el Vino (OIV).

87 Los vinos de uva se incluyen en la categoría 14.2.3; y el vino de manzana (sidra) y de pera (sidra de pera) en la 14.2.2. 


\subsubsection{Licores destilados que contengan más de un 15 por ciento de alcohol:}

Comprende todos los licores destilados derivados de granos (p. ej. maíz, cebada, centeno, trigo), tubérculos (p. ej. la patata (papa)), frutas (p. ej. uvas, bayas) o caña de azúcar que contengan más del 15 por ciento de alcohol. Ejemplos: aperitivos, coñac (vino destilado), cordiales, licores (incluidos los licores emulsionados), bagaceirea belha (grapa de Portugal; la bragaceira es una bebida destilada que se obtiene del bagaço (pieles, semillas y tallos de uva prensados)), eau de vie (un tipo de coñac), ginebra, grapa (coñac italiano destilado de los residuos del vino prensados), marc (coñac destilado de los residuos de uva o manzana), korn (licor de cereales (schnapps) de Alemania, normalmente obtenido del centeno (Roggen), a veces del trigo (Weizen) o de ambos cereales (Getreide); conocido también como Kornbrantt o Kornbranttwein) ${ }^{88}$, mistela (también mistelle (Francia) y jeropico (Sudáfrica); zumo (jugo) de uva sin fermentar enriquecido con alcohol de uva), ouzo (bebida espirituosa griega aromatizada con anís), ron, tsikoudia (bebida espirituosa de uva de Creta), tspouro (bebida espirituosa de uva de ciertas regiones de Grecia, wienbrand (un tipo de coñac a base de uva elaborado por Hugo Asbach, Rudesheim, Alemania; literalmente "vino quemado") ${ }^{88}$, cachaça (licor de Brasil elaborado a base de zumo (jugo) de azúcar de caña destilado y fermentado) ${ }^{89}$, tequila, whisky y vodka. ${ }^{85,90,91}$

14.2.7 Bebidas alcohólicas aromatizadas (p. ej. cerveza, vino y bebidas espirituosas tipo refresco, refrescos con bajo contenido de alcohol:

Comprende todos los productos de bebidas alcohólicas no normalizadas. Si bien la mayoría de estos productos contienen menos del 15 por ciento de alcohol, algunos productos aromatizados tradicionales que no están normalizados pueden contener hasta un 24 por ciento de alcohol. Ejemplos: vino, sidra y sidra de pera aromatizados; vinos de aperitivo; americano; batidas (bebidas hechas con cachaça (cachaça, zumo (jugo) de fruta o leche de coco y, facultativamente, leche condensada) ${ }^{89}$; bitter soda y bitter vino; clarea (también claré o clary); una mezcla de miel, vino blanco y especias; es muy similar al hippocras, que se elabora con vino tinto); bebidas alcohólicas de jurubeba (producto alcohólico hecho con Solanum paniculatum, una planta indígena del norte del Brasil y de otras zonas de América del Sur); negus (sangría; una bebida caliente hecha con oporto, azúcar, limón y especias); sod, saft y sodet; vermut; zurra (en el sur de España, una sangría hecha con melocotones y nectarinas; también es el término español para designar el vino de especias preparado con vino frío o tibio, azúcar, limón, naranjas o especias); amazake (bebida dulce con bajo contenido de alcohol (menos del 1 por ciento) hecho de arroz con koji; mirin (una bebida alcohólica dulce (menos del 10 por ciento de alcohol preparada mezclando shoochuu (un licor), arroz y koji); "malternatives" (bebidas a base de malta)y cócteles listos para el consumo (mezclas de bebidas alcohólicas, licores, vinos, esencias, frutas y extractos de plantas, etc. comercializadas como productos o mezclas listas para el consumo). Las bebidas tipo refresco se componen de cerveza, bebidas a base de malta, vino o licor, zumo (jugo) o zumos de fruta y soda (si contienen gas). ${ }^{85,90,92}$

\subsection{Aperitivos listos para el consumo:}

Comprende todos los tipos de alimentos para el aperitivo.

15.1 Aperitivos a base de patatas (papas), cereales, harina o almidón (derivados de raíces y tubérculos, legumbres y leguminosas):

Comprende todos los aperitivos, con o sin aromatizantes añanidos, pero excluye las galletas "cracker" sin endulzar (categoría 07.1.2). Ejemplos: patatas (papas) fritas, palomitas de maíz, galletas saladas (pretzels), galletas "cracker" de arroz (senbei), galletas "cracker" aromatizadas (p. ej. las galletas "cracker" con sabor a queso), bhujía (nankeen); aperitivo elaborado a base de una mezcla de harinas, maíz, patatas, sal, frutos secos, piñones, especias, colores, aromas y antioxidantes) y papads (elaboradas a base de harina de arroz con agua, o de harina de frijoles o de caupí, con la adición de sal y especias, y preparadas en forma de bola o torta plana).

\subsection{Nueces elaboradas, incluidas las nueces revestidas y mezclas de nueces (p. ej. con frutas secas):}

Comprende todos los tipos de nueces enteras elaboradas; $p$. ej. tostadas en seco, tostadas, marinadas o hervidas, con cáscara o sin ella, saladas o sin sal. Se clasifican aquí los aperitivos de nueces recubiertas de yogur, cereales y miel y los aperitivos secos de frutas, nueces y cereales (p. ej. las mezclas "para caminatas"). Las nueces recubiertas de chocolate se clasifican en la categoría 05.1.4 y las nueces recubiertas de sucedáneos del chocolate figuran en la categoría 05.1.5.

88 The Wordsworth Dictionary of Drink, N. Halley, Wordsworth Ltd., Hertfordshire, England, 1996.

89 Insight Guide: Río de Janeiro, APA Publications, GmBH \& Co., Verlag KG, Singapore, 2000, pág. 241.

90 Lexique de la Vigne, Oficina Internacional de la Viña y el Vino (OIV).

91 Véase también el Glosario de términos portugueses en el sitio web www.bar-do-binho.com/help.htm.

92 Alexis Lichinne's New Encyclopedia of Wine and Spirits, 3a ed. Véase también: rain-tree-com/jurubeba.htm, y www.florilegium.org/files/BEVERAGES/Clarea-d-Agua-art.html

wine.abour.com/food/wine/library/types/bl sangria.htm. 


\subsection{Aperitivos a base de pescado:}

Se refiere a las galletas "cracker" para aperitivo con pescado, productos pesqueros o sabor a pescado. EI pescado seco en sí que puede consumirse como aperitivo se clasifica en la categoría 09.2.5, y los aperitivos de fiambre (p. ej. el "charqui" de vacuno, el "pemmican") en la categoría 08.3.1.2.

\subsection{Alimentos preparados:}

Estos alimentos no están incluidos en las demás categorías de alimentos (01-15) y deberán considerarse caso por caso. Los alimentos compuestos son mezclas de varios componentes (p. ej. carne, salsas, cereales, quesos, hortalizas), estos componentes figuran en otras categorías de alimentos. Los alimentos compuestos requieren una preparación mínima por parte del consumidor (p. ej. calentamiento, descongelación, rehidratación). En esta categoría de alimentos en la NGAA figurarán disposiciones sobre aditivos sólo si el aditivo es necesario: (i) únicamente para desempeñar una función tecnológica en el alimento compuesto como se vende al consumidor, o (ii) en un nivel de uso que tenga una función tecnológica intencional en el alimento compuesto que supere el nivel de uso y se pueda explicar por transferencia desde los componentes individuales. 
ANEXO C

\section{REFERENCIAS A LAS NORMAS PARA PRODUCTOS DEL CODEX Y AL SISTEMA DE CLASIFICACIÓN DE ALIMENTOS}

Anexo C - Ordenado por Referencia de la Norma del Codex

\begin{tabular}{|c|c|c|}
\hline $\begin{array}{l}\text { Ref. de la } \\
\text { Norma }\end{array}$ & Título de la Norma del Codex & $\begin{array}{l}\text { Categoría de } \\
\text { Alimentos }\end{array}$ \\
\hline 3-1981 & Salmón en conserva & 09.4 \\
\hline $12-1981$ & Miel & 11.5 \\
\hline $13-1981$ & Tomates en conserva & 04.2 .2 .4 \\
\hline $17-1981$ & Compota de manzanas en conserva & 04.1 .2 .4 \\
\hline $19-1981$ & $\begin{array}{l}\text { Grasas y aceites comestibles no regulados por normas individuales } \\
\text { (Norma General) }\end{array}$ & 02.1 \\
\hline 33-1981 & Aceites de oliva y los aceites de orujo de aceituna & 02.1 .2 \\
\hline $36-1981$ & Pescados no eviscerados y eviscerados congelados rápidamente & 09.2 .1 \\
\hline $37-1981$ & Camarones en conserva & 09.4 \\
\hline $38-1981$ & $\begin{array}{l}\text { Hongos comestibles y sus productos (concentrados, concentrados } \\
\text { desecados o extractos) }\end{array}$ & 04.2 .2 .6 \\
\hline $38-1981$ & Hongos comestibles y sus productos (hongos comestibles) & 04.2 .1 .1 \\
\hline $38-1981$ & Hongos comestibles y sus productos (fermentados) & 04.2 .2 .7 \\
\hline $38-1981$ & Hongos comestibles y sus productos (productos de hongos) & 04.2 .2 \\
\hline $38-1981$ & $\begin{array}{l}\text { Hongos comestibles y sus productos (incluido hongos liofilizados, } \\
\text { sémola de hongos y polvo de hongos) }\end{array}$ & 04.2 .2 .2 \\
\hline $38-1981$ & Hongos comestibles y sus productos (hongos congelados rápidamente) & 04.2 .2 .1 \\
\hline $38-1981$ & $\begin{array}{l}\text { Hongos comestibles y sus productos (hongos salados, encurtidos o en } \\
\text { aceites vegetales) }\end{array}$ & 04.2 .2 .3 \\
\hline $38-1981$ & Hongos comestibles y sus productos (hongos esterilizados) & 04.2 .2 .4 \\
\hline $39-1981$ & Hongos comestibles desecados & 04.2 .2 .2 \\
\hline 40R-1981 & Hongos frescos "Cantarelos" (Norma Regional) & 04.2 .1 .1 \\
\hline $52-1981$ & Fresas congeladas rápidamente & 04.1 .2 .1 \\
\hline $53-1981$ & $\begin{array}{l}\text { Regímenes especiales pobres en sodio (incluso los sucedáneos de la } \\
\text { sal) (sucedáneos de la sal) }\end{array}$ & 12.1 .2 \\
\hline $53-1981$ & $\begin{array}{l}\text { Regímenes especiales pobres en sodio (incluso los sucedáneos de la } \\
\text { sal) (regímenes especiales pobres en sodio) }\end{array}$ & 13.0 \\
\hline $57-1981$ & Concentrados de tomate elaborados (pasta de tomate en conserva) & 04.2 .2 .4 \\
\hline $57-1981$ & Concentrados de tomate elaborados (puré de tomate) & 04.2 .2 .5 \\
\hline $57-1981$ & Concentrados de tomate elaborados (pasta de tomate) & 04.2 .2 .6 \\
\hline $60-1981$ & Frambuesas en conserva & 04.1 .2 .4 \\
\hline $62-1987$ & Fresas en conserva & 04.1 .2 .4 \\
\hline $66-1981$ & Aceitunas de mesa & 04.2 .2 .3 \\
\hline $67-1981$ & Uvas pasas & 04.1 .2 .2 \\
\hline $69-1981$ & Frambuesas congeladas rápidamente & 04.1 .2 .1 \\
\hline $70-1981$ & Atún y el bonito en conserva & 09.4 \\
\hline $72-1981$ & $\begin{array}{l}\text { Preparados para lactantes y preparados para uso medicinales } \\
\text { especiales destinados a los lactantes (preparados para lactantes) }\end{array}$ & 13.1.1 \\
\hline
\end{tabular}




\begin{tabular}{|c|c|c|}
\hline $\begin{array}{l}\text { Ref. de la } \\
\text { Norma }\end{array}$ & Título de la Norma del Codex & $\begin{array}{l}\text { Categoría de } \\
\text { Alimentos }\end{array}$ \\
\hline $72-1981$ & $\begin{array}{l}\text { Preparados para lactantes y preparados para uso medicinales } \\
\text { especiales destinados a los lactantes (preparados para uso medicinales } \\
\text { especiales destinados a los lactantes) }\end{array}$ & 13.1 .3 \\
\hline $73-1981$ & Alimentos envasados para lactantes y niños & 13.2 \\
\hline 74-1981 & Alimentos elaborados a base de cereales para lactantes y niños & 13.2 \\
\hline $75-1981$ & Melocotones (duraznos) congelados rápidamente & 04.1 .2 .1 \\
\hline $76-1981$ & Arándanos congelados rápidamente & 04.1 .2 .1 \\
\hline $78-1981$ & Cóctel de frutas en conserva & 04.1 .2 .4 \\
\hline $86-1981$ & Manteca de cacao & 05.1 .3 \\
\hline $87-2003$ & Chocolate & 05.1 .4 \\
\hline $88-1981$ & Carne tipo "Corned Beef" & 08.3 .2 \\
\hline $89-1981$ & Carne Luncheon & 08.3 .2 \\
\hline $90-1981$ & Carne de cangrejo en conserva & 09.4 \\
\hline $92-1981$ & Camarones congelados rápidamente & 09.2 .1 \\
\hline $94-1981$ & Sardinas y productos análogos en conserva & 09.4 \\
\hline $95-1981$ & Langostas congeladas rápidamente & 09.2 .1 \\
\hline $96-1981$ & Jamón curado cocido & 08.2 .2 \\
\hline $97-1981$ & Espaldilla de cerdo curada cocida & 08.2 .2 \\
\hline 98-1981 & Carne picada curada cocida & 08.3 .2 \\
\hline $99-1981$ & Ensalada de frutas tropicales en conserva & 04.1 .2 .4 \\
\hline 103-1981 & Arándanos americanos congelados rápidamente & 04.1 .2 .1 \\
\hline $105-1981$ & Cacao en polvo (cacaos) y a las mezclas de cacao y azúcares & 05.1 .1 \\
\hline $108-1981$ & Aguas minerales naturales & 14.1.1.1 \\
\hline $115-1981$ & Pepinos encurtidos (encurtido de pepinos) & 04.2 .2 .3 \\
\hline $117-1981$ & Bouillons y consomés & 12.5 \\
\hline $118-1981$ & $\begin{array}{l}\text { Alimentos para regímenes especiales destinados a personas } \\
\text { intolerantes al gluten }\end{array}$ & 13.3 \\
\hline $119-1981$ & Pescados en conserva & 09.4 \\
\hline $130-1981$ & Albaricoques secos & 04.1 .2 .2 \\
\hline $131-1981$ & Pistachos con cáscara & 04.2 .1 .1 \\
\hline $141-1983$ & Cacao en pasta (licor de cacao/chocolate) y la torta de cacao & 05.1 .1 \\
\hline $143-1985$ & Dátiles (cubiertos) & 04.1 .1 .2 \\
\hline 143-1985 & Dátiles (frescos) & 04.1 .1 .1 \\
\hline $145-1985$ & Castañas en conserva y el puré de castañas en conserva & 04.2 .2 .4 \\
\hline $150-1985$ & Sal de calidad alimentaria & 12.1 .1 \\
\hline $151-1985$ & Gari & 04.2 .2 .7 \\
\hline $152-1985$ & Harina de trigo & 06.2 .1 \\
\hline $153-1985$ & Maíz & 06.1 \\
\hline 154-1985 & Harina integral de maíz & 06.2 .1 \\
\hline $155-1985$ & Harina y la sémola de maíz sin germen & 06.2 .1 \\
\hline $156-1987$ & Preparados complementarios & 13.1 .2 \\
\hline $160-1987$ & Salsa picante de mango & 04.1 .2 .6 \\
\hline
\end{tabular}




\begin{tabular}{|c|c|c|}
\hline $\begin{array}{l}\text { Ref. de la } \\
\text { Norma }\end{array}$ & Título de la Norma del Codex & $\begin{array}{l}\text { Categoría de } \\
\text { Alimentos }\end{array}$ \\
\hline $163-1987$ & Productos de proteínas de trigo incluido el gluten de trigo & 12.10 \\
\hline $165-1989$ & $\begin{array}{l}\text { Bloques de filetes de pescado, carne de pescado picada y mezclas de } \\
\text { filetes y de carne de pescado picada congelados rápidamente }\end{array}$ & 09.2 .1 \\
\hline $166-1989$ & $\begin{array}{l}\text { Barritas, porciones y filetes de pescado empanados o rebozados } \\
\text { congelados rápidamente }\end{array}$ & 09.2 .2 \\
\hline $167-1989$ & Pescado salado y pescado seco salado de la familia Gadidae & 09.2 .5 \\
\hline $169-1989$ & Mijo perla en grano entero y decorticado & 06.1 \\
\hline $170-1989$ & Harina de mijo perla & 06.2 .1 \\
\hline $171-1989$ & Determinadas legumbres & 04.2 .1 .1 \\
\hline $172-1989$ & Sorgo en grano & 06.1 \\
\hline 173-1989 & Harina de sorgo & 06.2 .1 \\
\hline 174-1989 & Productos proteínicos vegetales (PPV) & 12.10 \\
\hline $175-1989$ & Productos proteínicos de soja (PPS) & 06.8 .8 \\
\hline $176-1989$ & Harina de yuca comestible & 06.2 .1 \\
\hline $177-1991$ & Coco rallado desecado & 04.1 .2 .2 \\
\hline $178-1991$ & Sémola y la harina de trigo duro & 06.2 .1 \\
\hline $181-1991$ & Preparados dietéticos para regímenes de control del peso & 13.4 \\
\hline $182-1993$ & Piña & 04.1 .1 .1 \\
\hline $183-1993$ & Papaya & 04.1 .1 .1 \\
\hline $184-1993$ & Mango & 04.1 .1 .1 \\
\hline $185-1993$ & Nopal & 04.2 .1 .1 \\
\hline $186-1993$ & Tuna & 04.2 .1 .1 \\
\hline $187-1993$ & Carambola & 04.1 .1 .1 \\
\hline $188-1993$ & Maíz Enano & 04.2 .1 .1 \\
\hline $189-1993$ & Aletas de tiburón secas & 09.2 .5 \\
\hline $190-1995$ & Filetes de pescado congelados rápidamente & 09.2 .1 \\
\hline $191-1995$ & Calamares congelados rápidamente & 09.1 .2 \\
\hline 196-1995 & Lichí & 04.1 .1 .1 \\
\hline 197-1995 & Aguacate & 04.2 .1 .1 \\
\hline $198-1995$ & Arroz & 06.1 \\
\hline 199-1995 & Trigo y el trigo duro & 06.1 \\
\hline $200-1995$ & Maní & 04.2 .1 .1 \\
\hline $201-1995$ & Avena & 06.1 \\
\hline $202-1995$ & Cúscus & 06.1 \\
\hline 203-1995 & $\begin{array}{l}\text { Preparados dietéticos para regímenes muy hipocalóricos de } \\
\text { adelgazamiento }\end{array}$ & 13.4 \\
\hline $204-1997$ & Mangostán & 04.1.1.1 \\
\hline $205-1997$ & Banano (plátano) & 04.1 .1 .1 \\
\hline $207-1999$ & Leches en polvo y la nata (crema) en polvo & 01.5 .1 \\
\hline $208-1999$ & Queso en salmuera & 01.6 .2 .1 \\
\hline $210-1999$ & Aceites vegetales especificados & 02.1 .2 \\
\hline $211-1999$ & Grasas animales especificadas & 02.1 .3 \\
\hline
\end{tabular}




\begin{tabular}{|c|c|c|}
\hline $\begin{array}{l}\text { Ref. de la } \\
\text { Norma }\end{array}$ & Título de la Norma del Codex & $\begin{array}{l}\text { Categoría de } \\
\text { Alimentos }\end{array}$ \\
\hline $212-1999$ & $\begin{array}{l}\text { Azúcares (jarabe de glucosa, glucosa deshidratado, azúcar blando } \\
\text { blanco, azúcar moreno, azúcar de caña sin refinar) }\end{array}$ & 11.1 .3 \\
\hline 212-1999 & Azúcares (lactosa) & 11.1 .4 \\
\hline 212-1999 & Azúcares (azúcar de plantación o refinería) & 11.1 .5 \\
\hline $212-1999$ & Azúcares (azúcar en polvo o dextrosa en polvo) & 11.1 .2 \\
\hline 212-1999 & $\begin{array}{l}\text { Azúcares (azúcar blanco, dextrosa anhidra, dextrosa monohidrato, } \\
\text { fructosa) }\end{array}$ & 11.1 .1 \\
\hline 213-1999 & Lima-limón & 04.1 .1 .1 \\
\hline 214-1999 & Pomelo (Citrus grandi) & 04.1 .1 .1 \\
\hline $215-1999$ & Guayaba & 04.1 .1 .1 \\
\hline 216-1999 & Chayote & 04.1 .1 .1 \\
\hline 217-1999 & Limas mexicanas & 04.1.1.1 \\
\hline 218-1999 & Jengibre & 04.2 .1 .1 \\
\hline 219-1999 & Toronja (Citrus paradisi) & 04.1.1.1 \\
\hline $220-1999$ & Longán & 04.1.1.1 \\
\hline $221-2001$ & Queso no madurado incluido el queso fresco & 01.6 .1 \\
\hline $222-2001$ & $\begin{array}{l}\text { Galletas de pescado marino y de agua dulce y de mariscos, crustáceos } \\
\text { y moluscos }\end{array}$ & 09.2 .5 \\
\hline 223-2001 & Kimchi & 04.2 .2 .7 \\
\hline 224-2001 & Tiquisque & 04.2 .1 .1 \\
\hline $225-2001$ & Espárrago & 04.2 .1 .1 \\
\hline $226-2001$ & Uchuva & 04.1.1.1 \\
\hline $227-2001$ & $\begin{array}{l}\text { Aguas potables embotelladas/envasadas (distintas de las aguas } \\
\text { minerales naturales) }\end{array}$ & 14.1.1.2 \\
\hline $236-2003$ & Anchoas hervidas secas saladas & 09.2 .5 \\
\hline $237-2003$ & Pitahayas & 04.1 .1 .1 \\
\hline $238-2003$ & Yuca (mandioca) dulce & 04.2 .1 .1 \\
\hline $240-2003$ & Productos acuosos de coco - leche de coco y crema de coco & 04.1 .2 .8 \\
\hline $241-2003$ & Brotes de bambú en conserva & 04.2 .2 .4 \\
\hline 242-2003 & Frutas de hueso en conserva & 04.1 .2 .4 \\
\hline $243-2003$ & $\begin{array}{l}\text { Leches fermentadas (aromatizadas, con tratamiento térmico y sin } \\
\text { tratamiento térmico) }\end{array}$ & 01.7 \\
\hline $243-2003$ & $\begin{array}{l}\text { Leches fermentadas (bebidas a base de leche fermentada, o } \\
\text { aromatizada, tratada térmicamente o sin tratamiento térmico) }\end{array}$ & 01.1 .4 \\
\hline 243-2003 & $\begin{array}{l}\text { Leches fermentadas (bebidas a base de leche fermentada (naturales / } \\
\text { simples)) }\end{array}$ & 01.2 .1 \\
\hline $243-2003$ & $\begin{array}{l}\text { Leches fermentadas (bebidas a base de leche fermentada (naturales / } \\
\text { simples, sin tratamiento térmico)) }\end{array}$ & 01.2 .1 .1 \\
\hline $243-2003$ & $\begin{array}{l}\text { Leches fermentadas (bebidas a base de leche fermentada (naturales } \\
\text { /simples, con tratamiento térmico)) }\end{array}$ & 01.2 .1 .2 \\
\hline 244-2004 & Arenque del Atlántico salado y el espadín salado & 09.2 .5 \\
\hline $245-2004$ & Naranja & 04.1 .1 .1 \\
\hline $246-2005$ & Rambután & 04.1 .1 .1 \\
\hline 247-2005 & Zumos (yugos) y néctares de frutas (zumos (yugos) de frutas) & 14.1.2.1 \\
\hline
\end{tabular}




\begin{tabular}{|c|c|c|}
\hline $\begin{array}{l}\text { Ref. de la } \\
\text { Norma }\end{array}$ & Título de la Norma del Codex & $\begin{array}{l}\text { Categoría de } \\
\text { Alimentos }\end{array}$ \\
\hline $247-2005$ & $\begin{array}{l}\text { Zumos (yugos) y néctares de frutas (concentrados para zumos (yugos) } \\
\text { de fruta) }\end{array}$ & 14.1.2.3 \\
\hline $247-2005$ & Zumos (yugos) y néctares de frutas (néctares de frutas) & 14.1.3.1 \\
\hline $247-2005$ & $\begin{array}{l}\text { Zumos (yugos) y néctares de frutas (concentrados para néctares de } \\
\text { frutas) }\end{array}$ & 14.1.3.3 \\
\hline 249-2006 & Fideos instantáneos & 06.4 .3 \\
\hline $250-2006$ & Leche evaporada desnatada (descremada) y grasa vegetal & 01.3 .2 \\
\hline $251-2006$ & Leche desnatada (descremada) y grasa vegetal en polvo & 01.5 .2 \\
\hline $252-2006$ & $\begin{array}{l}\text { Leche condensada edulcorada desnatada (descremada) y grasa } \\
\text { vegetal }\end{array}$ & 01.3 .2 \\
\hline 253-2006 & Quesos de suero & 02.2 .2 \\
\hline $254-2007$ & Algunos frutos cítricos en conserva & 04.1 .2 .4 \\
\hline $255-2007$ & Uvas de mesa & 04.1 .1 .1 \\
\hline $256-2007$ & Grasas para untar y mezclas de grasa para untar & 02.2 .2 \\
\hline 257R-2007 & Humus con tahina en conserva (Norma regional) & 04.2 .2 .4 \\
\hline 258R-2007 & Foul medames en conserva (Norma regional) & 04.2 .2 .4 \\
\hline 259R-2007 & Tahina (Norma regional) & 04.2 .2 .6 \\
\hline $260-2007$ & Frutas y hortalizas encurtidas (frutas encurtidas) & 04.1 .2 .3 \\
\hline $260-2007$ & Frutas y hortalizas encurtidas (frutas fermentadas) & 04.1 .2 .10 \\
\hline $260-2007$ & Frutas y hortalizas encurtidas (hortalizas encurtidas) & 04.2 .2 .3 \\
\hline $260-2007$ & Frutas y hortalizas encurtidas (hortalizas fermentadas) & 04.1 .2 .7 \\
\hline $262-2007$ & Mozzarella & 01.6 .1 \\
\hline $263-1966$ & Queso Cheddar & 01.6 .2 .1 \\
\hline $264-1966$ & Queso Danbo & 01.6 .2 .1 \\
\hline $265-1966$ & Queso Edam & 01.6 .2 .1 \\
\hline $266-1966$ & Queso Gouda & 01.6 .2 .1 \\
\hline $267-1966$ & Queso Havarti & 01.6 .2 .1 \\
\hline $268-1966$ & Queso Samsoe & 01.6 .2 .1 \\
\hline $269-1967$ & Queso Emmental & 01.6 .2 .1 \\
\hline $270-1968$ & Queso Tilsiter & 01.6 .2 .1 \\
\hline $271-1968$ & Queso Saint-Paulin & 01.6 .2 .1 \\
\hline $272-1968$ & Queso Provolone & 01.6 .2 .1 \\
\hline $273-1968$ & Cottage Cheese & 01.6 .1 \\
\hline $274-1969$ & Queso Coulommiers & 01.6 .2 .1 \\
\hline $275-1973$ & Queso de nata (crema) (Rahmfrischkäse) & 01.6 .1 \\
\hline $276-1973$ & Queso Camembert & 01.6 .2 .1 \\
\hline $277-1973$ & Queso Brie & 01.6 .2 .1 \\
\hline 278-1978 & Queso extra duro para rallar & 01.6 .2 .1 \\
\hline $279-1971$ & Mantequilla & 02.2 .1 .1 \\
\hline $280-1973$ & Productos a base de grasa de leche & 02.1 .1 \\
\hline $281-1971$ & Leches evaporadas & 01.3 .1 \\
\hline $282-1971$ & Leches condensadas & 01.3 .1 \\
\hline
\end{tabular}




\begin{tabular}{|c|c|c|}
\hline $\begin{array}{l}\text { Ref. de la } \\
\text { Norma }\end{array}$ & Título de la Norma del Codex & $\begin{array}{l}\text { Categoría de } \\
\text { Alimentos }\end{array}$ \\
\hline 283-1978 & Queso (queso madurado, incluido queso madurado por homos) & 01.6.2.1 \\
\hline $283-1978$ & $\begin{array}{l}\text { Queso (no madurado, incluido queso fresco) - véase también CODEX } \\
\text { STAN 221-2001 }\end{array}$ & 01.6 .1 \\
\hline 284-1971 & Quesos de suero (queso de suero) & 01.6 .3 \\
\hline 284-1971 & Quesos de suero (queso de proteínas del suero) & 01.6 .6 \\
\hline $288-1976$ & $\begin{array}{l}\text { Natas (crema) y las natas (cremas) preparadas (nata (crema) } \\
\text { fermentada y nata (crema) acidificada) }\end{array}$ & 01.4 .3 \\
\hline 288-1976 & $\begin{array}{l}\text { Natas (crema) y las natas (cremas) preparadas (nata (crema) } \\
\text { reconstituida, nata (crema) recombinada, nata (crema líquida } \\
\text { preenvasada) }\end{array}$ & 01.4 .1 \\
\hline $288-1976$ & $\begin{array}{l}\text { Natas (crema) y las natas (cremas) preparadas (nata (crema) para } \\
\text { montar o batir, nata (crema) envasada a presión, nata (crema) montada } \\
\text { o batida) }\end{array}$ & 01.4 .2 \\
\hline 289-1995 & Sueros en polvo & 01.8 .2 \\
\hline $290-1995$ & Productos a base de caseína alimentaria & 01.5 .1 \\
\hline $291-2010$ & Caviar de Esturión & 09.3 .3 \\
\hline $292-2008$ & Moluscos bivalvos vivos y crudos (vivos) & 09.1 .2 \\
\hline $292-2008$ & Moluscos bivalvos vivos y crudos (crudos, enfriados, desbullados) & 09.1 .2 \\
\hline 292-2008 & Moluscos bivalvos vivos y crudos (crudos, congelados) & 09.2 .1 \\
\hline $293-2008$ & Tomates & 04.2 .1 .1 \\
\hline 294R-2009 & Goghujang (Norma Regional) & 04.2 .2 .7 \\
\hline $296-2009$ & Confituras, jaleas y mermeladas & 04.1 .2 .5 \\
\hline $297-2009$ & Algunas hortalizas en conserva & 04.2 .2 .4 \\
\hline 298R-2009 & Pasta de Soja Fermentada (Norma Regional) & 12.9 .1 \\
\hline $299-2010$ & Manzanas & 04.1 .1 .1 \\
\hline $300-2010$ & Yuca (mandioca) amarga & 04.2 .1 .1 \\
\hline 301R-2011 & Harina de Sagú Comestible (Norma Regional) & 06.2 .1 \\
\hline $302-2011$ & Salsa de Pescado & 12.6 .4 \\
\hline $303-2011$ & Tomate de Árbol & 04.2 .1 .1 \\
\hline 304R-2011 & Culantro Coyote (Norma Regional) & 04.2 .1 .1 \\
\hline 305R-2011 & Lúcuma (Norma Regional) & 04.1.1.1 \\
\hline 306R-2011 & Salsa de Ají (Norma Regional) & 12.6 .2 \\
\hline $307-2011$ & Chile & 04.2 .1 .1 \\
\hline 308R-2011 & Harissa (Norma Regional) & 04.2 .2 .6 \\
\hline 309R-2011 & Halva com Tahina (Norma Regional) & 05.2 .2 \\
\hline $310-2013$ & Granada & 04.2 .1 .1 \\
\hline $311-2013$ & $\begin{array}{l}\text { Pescado Ahumado, Pescado con Sabor a Humo y Pescado Secado con } \\
\text { Humo }\end{array}$ & 09.2 .5 \\
\hline $312-2013$ & $\begin{array}{l}\text { Abalón Vivo y al Abalón Crudo Refrigerado o Congelado Destinado al } \\
\text { Consumo Directo o a su Elaboración Ulterior (crudo) }\end{array}$ & 09.1 .2 \\
\hline $312-2013$ & $\begin{array}{l}\text { Abalón Vivo y al Abalón Crudo Refrigerado o Congelado Destinado al } \\
\text { Consumo Directo o a su Elaboración Ulterior (congelado) }\end{array}$ & 09.2 .1 \\
\hline 313R-2013 & Tempe (Norma Regional) & 06.8 .6 \\
\hline 314R-2013 & Pasta de datíl (Norma Regional) & 04.1 .2 .8 \\
\hline
\end{tabular}




\begin{tabular}{|c|c|c|}
\hline $\begin{array}{l}\text { Ref. de la } \\
\text { Norma }\end{array}$ & Título de la Norma del Codex & $\begin{array}{l}\text { Categoría de } \\
\text { Alimentos }\end{array}$ \\
\hline $315-2014$ & $\begin{array}{l}\text { Productos de Pectínidos Frescos y Pectínidos Crudos Congelados } \\
\text { Rápidamente (crudo) }\end{array}$ & 09.1 .2 \\
\hline $315-2014$ & $\begin{array}{l}\text { Productos de Pectínidos Frescos y Pectínidos Crudos Congelados } \\
\text { Rápidamente (congelado) }\end{array}$ & 09.2 .1 \\
\hline $316-2014$ & Frutas de la Pasión & 04.1.1.1 \\
\hline $317-2014$ & Durión & 04.1 .1 .1 \\
\hline $318-2014$ & Okra & 04.2 .1 .1 \\
\hline $319-2015$ & Algunas Frutas en Conserva & 04.1 .2 .4 \\
\hline $320-2015$ & Hortalizas Congeladas Rápidamente & 04.2 .2 .1 \\
\hline $321-2015$ & $\begin{array}{l}\text { Productos a base de Ginseng (ginseng desecado, ginseng crudo } \\
\text { desecado, ginseng cocido al vapour desecado) }\end{array}$ & 04.2 .2 .2 \\
\hline $321-2015$ & $\begin{array}{l}\text { Productos a base de Ginseng (extracto de ginseng, extracto de ginseng } \\
\text { crudo, extracto de ginseng cocido al vapor) }\end{array}$ & 04.2 .2 .6 \\
\hline 322R-2015 & $\begin{array}{l}\text { Productos de soya no fermentados (bebida de soja básica, bebidas de } \\
\text { soja compuestas o aromatizadas, bebidas a base de soja) (Norma } \\
\text { Regional) }\end{array}$ & 06.8 .1 \\
\hline 322R-2015 & $\begin{array}{l}\text { Productos de soya no fermentados (película de soja deshidratada) } \\
\text { (Norma Regional) }\end{array}$ & 06.8 .2 \\
\hline 322R-2015 & $\begin{array}{l}\text { Productos de soya no fermentados (tofu semisólido, tofu) (Norma } \\
\text { Regional) }\end{array}$ & 06.8 .3 \\
\hline 322R-2015 & Productos de soya no fermentados (tofu compactado) (Norma Regional) & 06.8 .4 \\
\hline 323R-2017 & $\begin{array}{l}\text { Productos a base de alga nori (productos a base de alga nori secada y } \\
\text { productos de alga nori condimentada) (Norma regional) }\end{array}$ & 04.2 .2 .2 \\
\hline 323R-2017 & $\begin{array}{l}\text { Productos a base de alga nori (productos de alga nori tostada y } \\
\text { productos de alga nori condimentada) (Norma regional) }\end{array}$ & 04.2 .2 .8 \\
\hline 324R-2017 & Yacón (Norma regional) & 04.2 .1 .1 \\
\hline 325R-2017 & Manteca de karité sin refinar (Norma regional) & 02.1 .2 \\
\hline $326-2017$ & Pimientas negra, blanca y verde & 12.2 .1 \\
\hline $327-2017$ & Comino & 12.2 .1 \\
\hline $328-2017$ & Tomillo seco & 12.2 .1 \\
\hline $329-2017$ & Aceites de pescado & 02.1 .3 \\
\hline $330-2018$ & Berenjena (sin tratamiento) & 04.2 .1 .1 \\
\hline $330-2018$ & Berenjena (tratadas en la superficie) & 04.2 .1 .2 \\
\hline $331-2017$ & Permeados lácteos en polvo & 01.8 .2 \\
\hline 332R-2018 & Doogh (Norma regional) (simple, no sometido a tratamiento térmico) & 01.2 .1 .1 \\
\hline 332R-2018 & Doogh (Norma regional) (simple, sometido a tratamiento térmico) & 01.2 .1 .2 \\
\hline 332R-2018 & $\begin{array}{l}\text { Doogh (Norma regional) (aromatizado, sometido y no sometido a } \\
\text { tratamiento térmico) }\end{array}$ & 01.1 .4 \\
\hline 333-2019 & Quinua & 06.1 \\
\hline 334-2019 & Ajo seco & 12.2 .1 \\
\hline
\end{tabular}


Anexo C - Ordenado por Título de la Norma del Codex

\begin{tabular}{|c|c|c|}
\hline $\begin{array}{l}\text { Ref. de la } \\
\text { Norma }\end{array}$ & Título de la Norma del Codex & $\begin{array}{l}\text { Categoría de } \\
\text { Alimentos }\end{array}$ \\
\hline $312-2013$ & $\begin{array}{l}\text { Abalón Vivo y al Abalón Crudo Refrigerado o Congelado Destinado al } \\
\text { Consumo Directo o a su Elaboración Ulterior (crudo) }\end{array}$ & 09.1 .2 \\
\hline $312-2013$ & $\begin{array}{l}\text { Abalón Vivo y al Abalón Crudo Refrigerado o Congelado Destinado al } \\
\text { Consumo Directo o a su Elaboración Ulterior (congelado) }\end{array}$ & 09.2 .1 \\
\hline 33-1981 & Aceites de oliva y los aceites de orujo de aceituna & 02.1 .2 \\
\hline $329-2017$ & Aceites de pescado & 02.1 .3 \\
\hline $210-1999$ & Aceites vegetales especificados & 02.1 .2 \\
\hline $66-1981$ & Aceitunas de mesa & 04.2 .2 .3 \\
\hline 197-1995 & Aguacate & 04.2 .1 .1 \\
\hline $108-1981$ & Aguas minerales naturales & 14.1.1.1 \\
\hline $227-2001$ & $\begin{array}{l}\text { Aguas potables embotelladas/envasadas (distintas de las aguas } \\
\text { minerales naturales) }\end{array}$ & 14.1.1.2 \\
\hline 334-2019 & Ajo seco & 12.2 .1 \\
\hline $130-1981$ & Albaricoques secos & 04.1 .2 .2 \\
\hline $189-1993$ & Aletas de tiburón secas & 09.2 .5 \\
\hline $319-2015$ & Algunas Frutas en Conserva & 04.1 .2 .4 \\
\hline $297-2009$ & Algunas hortalizas en conserva & 04.2 .2 .4 \\
\hline $254-2007$ & Algunos frutos cítricos en conserva & 04.1 .2 .4 \\
\hline $74-1981$ & Alimentos elaborados a base de cereales para lactantes y niños & 13.2 \\
\hline $73-1981$ & Alimentos envasados para lactantes y niños & 13.2 \\
\hline $118-1981$ & $\begin{array}{l}\text { Alimentos para regímenes especiales destinados a personas } \\
\text { intolerantes al gluten }\end{array}$ & 13.3 \\
\hline $236-2003$ & Anchoas hervidas secas saladas & 09.2 .5 \\
\hline $103-1981$ & Arándanos americanos congelados rápidamente & 04.1 .2 .1 \\
\hline $76-1981$ & Arándanos congelados rápidamente & 04.1 .2 .1 \\
\hline 244-2004 & Arenque del Atlántico salado y el espadín salado & 09.2 .5 \\
\hline $198-1995$ & Arroz & 06.1 \\
\hline $70-1981$ & Atún y el bonito en conserva & 09.4 \\
\hline 201-1995 & Avena & 06.1 \\
\hline 212-1999 & $\begin{array}{l}\text { Azúcares (azúcar blanco, dextrosa anhidra, dextrosa monohidrato, } \\
\text { fructosa) }\end{array}$ & 11.1.1 \\
\hline 212-1999 & Azúcares (azúcar de plantación o refinería) & 11.1 .5 \\
\hline $212-1999$ & Azúcares (azúcar en polvo o dextrosa en polvo) & 11.1 .2 \\
\hline 212-1999 & $\begin{array}{l}\text { Azúcares (jarabe de glucosa, glucosa deshidratado, azúcar blando } \\
\text { blanco, azúcar moreno, azúcar de caña sin refinar) }\end{array}$ & 11.1 .3 \\
\hline 212-1999 & Azúcares (lactosa) & 11.1.4 \\
\hline $205-1997$ & Banano (plátano) & 04.1 .1 .1 \\
\hline $166-1989$ & $\begin{array}{l}\text { Barritas, porciones y filetes de pescado empanados o rebozados } \\
\text { congelados rápidamente }\end{array}$ & 09.2 .2 \\
\hline $330-2018$ & Berenjena (sin tratamiento) & 04.2 .1 .1 \\
\hline $330-2018$ & Berenjena (tratadas en la superficie) & 04.2 .1 .2 \\
\hline $165-1989$ & $\begin{array}{l}\text { Bloques de filetes de pescado, carne de pescado picada y mezclas de } \\
\text { filetes y de carne de pescado picada congelados rápidamente }\end{array}$ & 09.2 .1 \\
\hline
\end{tabular}




\begin{tabular}{|c|c|c|}
\hline $\begin{array}{l}\text { Ref. de la } \\
\text { Norma }\end{array}$ & Título de la Norma del Codex & $\begin{array}{l}\text { Categoría de } \\
\text { Alimentos }\end{array}$ \\
\hline $117-1981$ & Bouillons y consomés & 12.5 \\
\hline $241-2003$ & Brotes de bambú en conserva & 04.2 .2 .4 \\
\hline $141-1983$ & Cacao en pasta (licor de cacao/chocolate) y la torta de cacao & 05.1 .1 \\
\hline $105-1981$ & Cacao en polvo (cacaos) y a las mezclas de cacao y azúcares & 05.1 .1 \\
\hline 191-1995 & Calamares congelados rápidamente & 09.1 .2 \\
\hline $92-1981$ & Camarones congelados rápidamente & 09.2 .1 \\
\hline $37-1981$ & Camarones en conserva & 09.4 \\
\hline $187-1993$ & Carambola & 04.1.1.1 \\
\hline $90-1981$ & Carne de cangrejo en conserva & 09.4 \\
\hline $89-1981$ & Carne Luncheon & 08.3 .2 \\
\hline 98-1981 & Carne picada curada cocida & 08.3 .2 \\
\hline $88-1981$ & Carne tipo "Corned Beef" & 08.3 .2 \\
\hline $145-1985$ & Castañas en conserva y el puré de castañas en conserva & 04.2 .2 .4 \\
\hline $291-2010$ & Caviar de Esturión & 09.3 .3 \\
\hline $177-1991$ & Coco rallado desecado & 04.1 .2 .2 \\
\hline $78-1981$ & Cóctel de frutas en conserva & 04.1 .2 .4 \\
\hline $327-2017$ & Comino & 12.2 .1 \\
\hline 17-1981 & Compota de manzanas en conserva & 04.1 .2 .4 \\
\hline $57-1981$ & Concentrados de tomate elaborados (pasta de tomate en conserva) & 04.2 .2 .4 \\
\hline $57-1981$ & Concentrados de tomate elaborados (pasta de tomate) & 04.2 .2 .6 \\
\hline $57-1981$ & Concentrados de tomate elaborados (puré de tomate) & 04.2 .2 .5 \\
\hline 296-2009 & Confituras, jaleas y mermeladas & 04.1 .2 .5 \\
\hline $273-1968$ & Cottage Cheese & 01.6 .1 \\
\hline 304R-2011 & Culantro Coyote (Norma Regional) & 04.2 .1 .1 \\
\hline 202-1995 & Cúscus & 06.1 \\
\hline 216-1999 & Chayote & 04.1 .1 .1 \\
\hline $307-2011$ & Chile & 04.2 .1 .1 \\
\hline $87-2003$ & Chocolate & 05.1 .4 \\
\hline 143-1985 & Dátiles (cubiertos) & 04.1.1.2 \\
\hline $143-1985$ & Dátiles (frescos) & 04.1.1.1 \\
\hline $171-1989$ & Determinadas legumbres & 04.2 .1 .1 \\
\hline 332R-2018 & $\begin{array}{l}\text { Doogh (Norma regional) (aromatizado, sometido y no sometido a } \\
\text { tratamiento térmico) }\end{array}$ & 01.1 .4 \\
\hline 332R-2018 & Doogh (Norma regional) (simple, no sometido a tratamiento térmico) & 01.2 .1 .1 \\
\hline 332R-2018 & Doogh (Norma regional) (simple, sometido a tratamiento térmico) & 01.2 .1 .2 \\
\hline $317-2014$ & Durión & 04.1 .1 .1 \\
\hline $99-1981$ & Ensalada de frutas tropicales en conserva & 04.1 .2 .4 \\
\hline $97-1981$ & Espaldilla de cerdo curada cocida & 08.2 .2 \\
\hline $225-2001$ & Espárrago & 04.2 .1 .1 \\
\hline 249-2006 & Fideos instantáneos & 06.4 .3 \\
\hline $190-1995$ & Filetes de pescado congelados rápidamente & 09.2 .1 \\
\hline
\end{tabular}




\begin{tabular}{|c|c|c|}
\hline $\begin{array}{l}\text { Ref. de la } \\
\text { Norma }\end{array}$ & Título de la Norma del Codex & $\begin{array}{l}\text { Categoría de } \\
\text { Alimentos }\end{array}$ \\
\hline 258R-2007 & Foul medames en conserva (Norma regional) & 04.2 .2 .4 \\
\hline $69-1981$ & Frambuesas congeladas rápidamente & 04.1 .2 .1 \\
\hline $60-1981$ & Frambuesas en conserva & 04.1 .2 .4 \\
\hline $52-1981$ & Fresas congeladas rápidamente & 04.1 .2 .1 \\
\hline $62-1987$ & Fresas en conserva & 04.1 .2 .4 \\
\hline 242-2003 & Frutas de hueso en conserva & 04.1 .2 .4 \\
\hline $316-2014$ & Frutas de la Pasión & 04.1 .1 .1 \\
\hline $260-2007$ & Frutas y hortalizas encurtidas (frutas encurtidas) & 04.1 .2 .3 \\
\hline $260-2007$ & Frutas y hortalizas encurtidas (frutas fermentadas) & 04.1 .2 .10 \\
\hline $260-2007$ & Frutas y hortalizas encurtidas (hortalizas encurtidas) & 04.2 .2 .3 \\
\hline $260-2007$ & Frutas y hortalizas encurtidas (hortalizas fermentadas) & 04.1 .2 .7 \\
\hline $222-2001$ & $\begin{array}{l}\text { Galletas de pescado marino y de agua dulce y de mariscos, crustáceos } \\
\text { y moluscos }\end{array}$ & 09.2 .5 \\
\hline $151-1985$ & Gari & 04.2 .2 .7 \\
\hline 294R-2009 & Goghujang (Norma Regional) & 04.2 .2 .7 \\
\hline $310-2013$ & Granada & 04.2 .1 .1 \\
\hline 211-1999 & Grasas animales especificadas & 02.1 .3 \\
\hline $256-2007$ & Grasas para untar y mezclas de grasa para untar & 02.2 .2 \\
\hline $19-1981$ & $\begin{array}{l}\text { Grasas y aceites comestibles no regulados por normas individuales } \\
\text { (Norma General) }\end{array}$ & 02.1 \\
\hline 215-1999 & Guayaba & 04.1.1.1 \\
\hline 309R-2011 & Halva com Tahina (Norma Regional) & 05.2 .2 \\
\hline $170-1989$ & Harina de mijo perla & 06.2 .1 \\
\hline 301R-2011 & Harina de Sagú Comestible (Norma Regional) & 06.2 .1 \\
\hline 173-1989 & Harina de sorgo & 06.2 .1 \\
\hline $152-1985$ & Harina de trigo & 06.2 .1 \\
\hline $176-1989$ & Harina de yuca comestible & 06.2 .1 \\
\hline $154-1985$ & Harina integral de maíz & 06.2 .1 \\
\hline $155-1985$ & Harina y la sémola de maíz sin germen & 06.2 .1 \\
\hline 308R-2011 & Harissa (Norma Regional) & 04.2 .2 .6 \\
\hline $39-1981$ & Hongos comestibles desecados & 04.2 .2 .2 \\
\hline $38-1981$ & $\begin{array}{l}\text { Hongos comestibles y sus productos (concentrados, concentrados } \\
\text { desecados o extractos) }\end{array}$ & 04.2 .2 .6 \\
\hline $38-1981$ & Hongos comestibles y sus productos (fermentados) & 04.2 .2 .7 \\
\hline 38-1981 & Hongos comestibles y sus productos (hongos comestibles) & 04.2 .1 .1 \\
\hline 38-1981 & Hongos comestibles y sus productos (hongos congelados rápidamente) & 04.2 .2 .1 \\
\hline $38-1981$ & Hongos comestibles y sus productos (hongos esterilizados) & 04.2 .2 .4 \\
\hline $38-1981$ & $\begin{array}{l}\text { Hongos comestibles y sus productos (hongos salados, encurtidos o en } \\
\text { aceites vegetales) }\end{array}$ & 04.2 .2 .3 \\
\hline $38-1981$ & $\begin{array}{l}\text { Hongos comestibles y sus productos (incluido hongos liofilizados, } \\
\text { sémola de hongos y polvo de hongos) }\end{array}$ & 04.2 .2 .2 \\
\hline $38-1981$ & Hongos comestibles y sus productos (productos de hongos) & 04.2 .2 \\
\hline 40R-1981 & Hongos frescos "Cantarelos" (Norma Regional) & 04.2 .1 .1 \\
\hline
\end{tabular}




\begin{tabular}{|c|c|c|}
\hline $\begin{array}{l}\text { Ref. de la } \\
\text { Norma }\end{array}$ & Título de la Norma del Codex & $\begin{array}{l}\text { Categoría de } \\
\text { Alimentos }\end{array}$ \\
\hline $320-2015$ & Hortalizas Congeladas Rápidamente & 04.2 .2 .1 \\
\hline 257R-2007 & Humus con tahina en conserva (Norma regional) & 04.2 .2 .4 \\
\hline $96-1981$ & Jamón curado cocido & 08.2 .2 \\
\hline 218-1999 & Jengibre & 04.2 .1 .1 \\
\hline 223-2001 & Kimchi & 04.2 .2 .7 \\
\hline $95-1981$ & Langostas congeladas rápidamente & 09.2 .1 \\
\hline $252-2006$ & $\begin{array}{l}\text { Leche condensada edulcorada desnatada (descremada) y grasa } \\
\text { vegetal }\end{array}$ & 01.3 .2 \\
\hline $251-2006$ & Leche desnatada (descremada) y grasa vegetal en polvo & 01.5 .2 \\
\hline $250-2006$ & Leche evaporada desnatada (descremada) y grasa vegetal & 01.3 .2 \\
\hline $282-1971$ & Leches condensadas & 01.3 .1 \\
\hline 207-1999 & Leches en polvo y la nata (crema) en polvo & 01.5 .1 \\
\hline $281-1971$ & Leches evaporadas & 01.3 .1 \\
\hline $243-2003$ & $\begin{array}{l}\text { Leches fermentadas (aromatizadas, con tratamiento térmico y sin } \\
\text { tratamiento térmico) }\end{array}$ & 01.7 \\
\hline $243-2003$ & $\begin{array}{l}\text { Leches fermentadas (bebidas a base de leche fermentada (naturales / } \\
\text { simples)) }\end{array}$ & 01.2 .1 \\
\hline $243-2003$ & $\begin{array}{l}\text { Leches fermentadas (bebidas a base de leche fermentada (naturales / } \\
\text { simples, sin tratamiento térmico)) }\end{array}$ & 01.2 .1 .1 \\
\hline $243-2003$ & $\begin{array}{l}\text { Leches fermentadas (bebidas a base de leche fermentada (naturales } \\
\text { /simples, con tratamiento térmico)) }\end{array}$ & 01.2 .1 .2 \\
\hline $243-2003$ & $\begin{array}{l}\text { Leches fermentadas (bebidas a base de leche fermentada, o } \\
\text { aromatizada, tratada térmicamente o sin tratamiento térmico) }\end{array}$ & 01.1 .4 \\
\hline 196-1995 & Lichí & 04.1 .1 .1 \\
\hline 213-1999 & Lima-limón & 04.1 .1 .1 \\
\hline 217-1999 & Limas mexicanas & 04.1 .1 .1 \\
\hline 220-1999 & Longán & 04.1 .1 .1 \\
\hline 305R-2011 & Lúcuma (Norma Regional) & 04.1.1.1 \\
\hline 153-1985 & Maíz & 06.1 \\
\hline 188-1993 & Maíz Enano & 04.2 .1 .1 \\
\hline 184-1993 & Mango & 04.1 .1 .1 \\
\hline 204-1997 & Mangostán & 04.1 .1 .1 \\
\hline 200-1995 & Maní & 04.2 .1 .1 \\
\hline $86-1981$ & Manteca de cacao & 05.1 .3 \\
\hline 325R-2017 & Manteca de karité sin refinar (Norma regional) & 02.1 .2 \\
\hline $279-1971$ & Mantequilla & 02.2 .1 .1 \\
\hline $299-2010$ & Manzanas & 04.1 .1 .1 \\
\hline $75-1981$ & Melocotones (duraznos) congelados rápidamente & 04.1 .2 .1 \\
\hline $12-1981$ & Miel & 11.5 \\
\hline $169-1989$ & Mijo perla en grano entero y decorticado & 06.1 \\
\hline $292-2008$ & Moluscos bivalvos vivos y crudos (crudos, congelados) & 09.2 .1 \\
\hline $292-2008$ & Moluscos bivalvos vivos y crudos (crudos, enfriados, desbullados) & 09.1 .2 \\
\hline 292-2008 & Moluscos bivalvos vivos y crudos (vivos) & 09.1 .2 \\
\hline
\end{tabular}




\begin{tabular}{|c|c|c|}
\hline $\begin{array}{l}\text { Ref. de la } \\
\text { Norma }\end{array}$ & Título de la Norma del Codex & $\begin{array}{l}\text { Categoría de } \\
\text { Alimentos }\end{array}$ \\
\hline $262-2007$ & Mozzarella & 01.6 .1 \\
\hline $245-2004$ & Naranja & 04.1 .1 .1 \\
\hline 288-1976 & $\begin{array}{l}\text { Natas (crema) y las natas (cremas) preparadas (nata (crema) } \\
\text { fermentada y nata (crema) acidificada) }\end{array}$ & 01.4 .3 \\
\hline 288-1976 & $\begin{array}{l}\text { Natas (crema) y las natas (cremas) preparadas (nata (crema) para } \\
\text { montar o batir, nata (crema) envasada a presión, nata (crema) montada } \\
\text { o batida) }\end{array}$ & 01.4 .2 \\
\hline 288-1976 & $\begin{array}{l}\text { Natas (crema) y las natas (cremas) preparadas (nata (crema) } \\
\text { reconstituida, nata (crema) recombinada, nata (crema líquida } \\
\text { preenvasada) }\end{array}$ & 01.4 .1 \\
\hline $185-1993$ & Nopal & 04.2 .1 .1 \\
\hline $318-2014$ & Okra & 04.2 .1 .1 \\
\hline $183-1993$ & Papaya & 04.1.1.1 \\
\hline 314R-2013 & Pasta de datíl (Norma Regional) & 04.1 .2 .8 \\
\hline 298R-2009 & Pasta de Soja Fermentada (Norma Regional) & 12.9 .1 \\
\hline $115-1981$ & Pepinos encurtidos (encurtido de pepinos) & 04.2 .2 .3 \\
\hline $331-2017$ & Permeados lácteos en polvo & 01.8 .2 \\
\hline $311-2013$ & $\begin{array}{l}\text { Pescado Ahumado, Pescado con Sabor a Humo y Pescado Secado con } \\
\text { Humo }\end{array}$ & 09.2 .5 \\
\hline $167-1989$ & Pescado salado y pescado seco salado de la familia Gadidae & 09.2 .5 \\
\hline $119-1981$ & Pescados en conserva & 09.4 \\
\hline $36-1981$ & Pescados no eviscerados y eviscerados congelados rápidamente & 09.2 .1 \\
\hline $326-2017$ & Pimientas negra, blanca y verde & 12.2 .1 \\
\hline $182-1993$ & Piña & 04.1 .1 .1 \\
\hline $131-1981$ & Pistachos con cáscara & 04.2 .1 .1 \\
\hline $237-2003$ & Pitahayas & 04.1.1.1 \\
\hline 214-1999 & Pomelo (Citrus grandi) & 04.1 .1 .1 \\
\hline $156-1987$ & Preparados complementarios & 13.1 .2 \\
\hline $181-1991$ & Preparados dietéticos para regímenes de control del peso & 13.4 \\
\hline 203-1995 & $\begin{array}{l}\text { Preparados dietéticos para regímenes muy hipocalóricos de } \\
\text { adelgazamiento }\end{array}$ & 13.4 \\
\hline $72-1981$ & $\begin{array}{l}\text { Preparados para lactantes y preparados para uso medicinales } \\
\text { especiales destinados a los lactantes (preparados para lactantes) }\end{array}$ & 13.1 .1 \\
\hline $72-1981$ & $\begin{array}{l}\text { Preparados para lactantes y preparados para uso medicinales } \\
\text { especiales destinados a los lactantes (preparados para uso medicinales } \\
\text { especiales destinados a los lactantes) }\end{array}$ & 13.1 .3 \\
\hline 323R-2017 & $\begin{array}{l}\text { Productos a base de alga nori (productos a base de alga nori secada y } \\
\text { productos de alga nori condimentada) (Norma regional) }\end{array}$ & 04.2 .2 .2 \\
\hline 323R-2017 & $\begin{array}{l}\text { Productos a base de alga nori (productos de alga nori tostada y } \\
\text { productos de alga nori condimentada) (Norma regional) }\end{array}$ & 04.2 .2 .8 \\
\hline 290-1995 & Productos a base de caseína alimentaria & 01.5 .1 \\
\hline $321-2015$ & $\begin{array}{l}\text { Productos a base de Ginseng (extracto de ginseng, extracto de ginseng } \\
\text { crudo, extracto de ginseng cocido al vapor) }\end{array}$ & 04.2 .2 .6 \\
\hline $321-2015$ & $\begin{array}{l}\text { Productos a base de Ginseng (ginseng desecado, ginseng crudo } \\
\text { desecado, ginseng cocido al vapour desecado) }\end{array}$ & 04.2 .2 .2 \\
\hline $280-1973$ & Productos a base de grasa de leche & 02.1 .1 \\
\hline
\end{tabular}




\begin{tabular}{|c|c|c|}
\hline $\begin{array}{l}\text { Ref. de la } \\
\text { Norma }\end{array}$ & Título de la Norma del Codex & $\begin{array}{l}\text { Categoría de } \\
\text { Alimentos }\end{array}$ \\
\hline $240-2003$ & Productos acuosos de coco - leche de coco y crema de coco & 04.1 .2 .8 \\
\hline $315-2014$ & $\begin{array}{l}\text { Productos de Pectínidos Frescos y Pectínidos Crudos Congelados } \\
\text { Rápidamente (crudo) }\end{array}$ & 09.1 .2 \\
\hline $315-2014$ & $\begin{array}{l}\text { Productos de Pectínidos Frescos y Pectínidos Crudos Congelados } \\
\text { Rápidamente (congelado) }\end{array}$ & 09.2 .1 \\
\hline $163-1987$ & Productos de proteínas de trigo incluido el gluten de trigo & 12.10 \\
\hline 322R-2015 & $\begin{array}{l}\text { Productos de soya no fermentados (bebida de soja básica, bebidas de } \\
\text { soja compuestas o aromatizadas, bebidas a base de soja) (Norma } \\
\text { Regional) }\end{array}$ & 06.8 .1 \\
\hline 322R-2015 & $\begin{array}{l}\text { Productos de soya no fermentados (película de soja deshidratada) } \\
\text { (Norma Regional) }\end{array}$ & 06.8 .2 \\
\hline 322R-2015 & Productos de soya no fermentados (tofu compactado) (Norma Regional) & 06.8 .4 \\
\hline 322R-2015 & $\begin{array}{l}\text { Productos de soya no fermentados (tofu semisólido, tofu) (Norma } \\
\text { Regional) }\end{array}$ & 06.8 .3 \\
\hline $175-1989$ & Productos proteínicos de soja (PPS) & 06.8 .8 \\
\hline 174-1989 & Productos proteínicos vegetales (PPV) & 12.10 \\
\hline $283-1978$ & $\begin{array}{l}\text { Queso (no madurado, incluido queso fresco) - véase también CODEX } \\
\text { STAN 221-2001 }\end{array}$ & 01.6 .1 \\
\hline 283-1978 & Queso (queso madurado, incluido queso madurado por homos) & 01.6 .2 .1 \\
\hline $277-1973$ & Queso Brie & 01.6 .2 .1 \\
\hline $276-1973$ & Queso Camembert & 01.6 .2 .1 \\
\hline $274-1969$ & Queso Coulommiers & 01.6 .2 .1 \\
\hline $263-1966$ & Queso Cheddar & 01.6 .2 .1 \\
\hline $264-1966$ & Queso Danbo & 01.6 .2 .1 \\
\hline $275-1973$ & Queso de nata (crema) (Rahmfrischkäse) & 01.6 .1 \\
\hline $265-1966$ & Queso Edam & 01.6 .2 .1 \\
\hline $269-1967$ & Queso Emmental & 01.6 .2 .1 \\
\hline 208-1999 & Queso en salmuera & 01.6 .2 .1 \\
\hline $278-1978$ & Queso extra duro para rallar & 01.6 .2 .1 \\
\hline $266-1966$ & Queso Gouda & 01.6 .2 .1 \\
\hline $267-1966$ & Queso Havarti & 01.6 .2 .1 \\
\hline $221-2001$ & Queso no madurado incluido el queso fresco & 01.6 .1 \\
\hline $272-1968$ & Queso Provolone & 01.6 .2 .1 \\
\hline $271-1968$ & Queso Saint-Paulin & 01.6 .2 .1 \\
\hline 268-1966 & Queso Samsoe & 01.6 .2 .1 \\
\hline $270-1968$ & Queso Tilsiter & 01.6.2.1 \\
\hline 253-2006 & Quesos de suero & 02.2 .2 \\
\hline 284-1971 & Quesos de suero (queso de proteínas del suero) & 01.6 .6 \\
\hline 284-1971 & Quesos de suero (queso de suero) & 01.6 .3 \\
\hline 333-2019 & Quinua & 06.1 \\
\hline $246-2005$ & Rambután & 04.1 .1 .1 \\
\hline $53-1981$ & $\begin{array}{l}\text { Regímenes especiales pobres en sodio (incluso los sucedáneos de la } \\
\text { sal) (sucedáneos de la sal) }\end{array}$ & 12.1 .2 \\
\hline $53-1981$ & Regímenes especiales pobres en sodio (incluso los sucedáneos de la & 13.0 \\
\hline
\end{tabular}




\begin{tabular}{|c|c|c|}
\hline $\begin{array}{l}\text { Ref. de la } \\
\text { Norma }\end{array}$ & Título de la Norma del Codex & $\begin{array}{l}\text { Categoría de } \\
\text { Alimentos }\end{array}$ \\
\hline & sal) (regímenes especiales pobres en sodio) & \\
\hline $150-1985$ & Sal de calidad alimentaria & 12.1 .1 \\
\hline $3-1981$ & Salmón en conserva & 09.4 \\
\hline 306R-2011 & Salsa de Ají (Norma Regional) & 12.6.2 \\
\hline $302-2011$ & Salsa de Pescado & 12.6 .4 \\
\hline $160-1987$ & Salsa picante de mango & 04.1 .2 .6 \\
\hline $94-1981$ & Sardinas y productos análogos en conserva & 09.4 \\
\hline $178-1991$ & Sémola y la harina de trigo duro & 06.2 .1 \\
\hline $172-1989$ & Sorgo en grano & 06.1 \\
\hline 289-1995 & Sueros en polvo & 01.8 .2 \\
\hline 259R-2007 & Tahina (Norma regional) & 04.2 .2 .6 \\
\hline 313R-2013 & Tempe (Norma Regional) & 06.8 .6 \\
\hline $224-2001$ & Tiquisque & 04.2 .1 .1 \\
\hline $303-2011$ & Tomate de Árbol & 04.2 .1 .1 \\
\hline $293-2008$ & Tomates & 04.2 .1 .1 \\
\hline 13-1981 & Tomates en conserva & 04.2 .2 .4 \\
\hline $328-2017$ & Tomillo seco & 12.2 .1 \\
\hline 219-1999 & Toronja (Citrus paradisi) & 04.1 .1 .1 \\
\hline 199-1995 & Trigo y el trigo duro & 06.1 \\
\hline $186-1993$ & Tuna & 04.2 .1 .1 \\
\hline 226-2001 & Uchuva & 04.1.1.1 \\
\hline $255-2007$ & Uvas de mesa & 04.1 .1 .1 \\
\hline 67-1981 & Uvas pasas & 04.1 .2 .2 \\
\hline 324R-2017 & Yacón (Norma regional) & 04.2 .1 .1 \\
\hline $300-2010$ & Yuca (mandioca) amarga & 04.2 .1 .1 \\
\hline $238-2003$ & Yuca (mandioca) dulce & 04.2 .1 .1 \\
\hline 247-2005 & $\begin{array}{l}\text { Zumos (yugos) y néctares de frutas (concentrados para néctares de } \\
\text { frutas) }\end{array}$ & 14.1.3.3 \\
\hline 247-2005 & $\begin{array}{l}\text { Zumos (yugos) y néctares de frutas (concentrados para zumos (yugos) } \\
\text { de fruta) }\end{array}$ & 14.1.2.3 \\
\hline 247-2005 & Zumos (yugos) y néctares de frutas (néctares de frutas) & 14.1.3.1 \\
\hline 247-2005 & Zumos (yugos) y néctares de frutas (zumos (yugos) de frutas) & 14.1.2.1 \\
\hline
\end{tabular}


Anexo C - Ordenado por Categoría de Alimentos

\begin{tabular}{|c|c|c|}
\hline $\begin{array}{l}\text { Ref. de la } \\
\text { Norma }\end{array}$ & Título de la Norma del Codex & $\begin{array}{l}\text { Categoría de } \\
\text { Alimentos }\end{array}$ \\
\hline 243-2003 & $\begin{array}{l}\text { Leches fermentadas (bebidas a base de leche fermentada (naturales / } \\
\text { simples)) }\end{array}$ & 01.2 .1 \\
\hline $243-2003$ & $\begin{array}{l}\text { Leches fermentadas (bebidas a base de leche fermentada (naturales / } \\
\text { simples, sin tratamiento térmico)) }\end{array}$ & 01.2 .1 .1 \\
\hline $281-1971$ & Leches evaporadas & 01.3 .1 \\
\hline $282-1971$ & Leches condensadas & 01.3 .1 \\
\hline 332R-2018 & Doogh (Norma regional) (simple, no sometido a tratamiento térmico) & 01.2 .1 .1 \\
\hline $243-2003$ & $\begin{array}{l}\text { Leches fermentadas (bebidas a base de leche fermentada, o } \\
\text { aromatizada, tratada térmicamente o sin tratamiento térmico) }\end{array}$ & 01.1 .4 \\
\hline $243-2003$ & $\begin{array}{l}\text { Leches fermentadas (bebidas a base de leche fermentada (naturales } \\
\text { /simples, con tratamiento térmico)) }\end{array}$ & 01.2 .1 .2 \\
\hline $250-2006$ & Leche evaporada desnatada (descremada) y grasa vegetal & 01.3 .2 \\
\hline $252-2006$ & $\begin{array}{l}\text { Leche condensada edulcorada desnatada (descremada) y grasa } \\
\text { vegetal }\end{array}$ & 01.3 .2 \\
\hline 288-1976 & $\begin{array}{l}\text { Natas (crema) y las natas (cremas) preparadas (nata (crema) } \\
\text { reconstituida, nata (crema) recombinada, nata (crema líquida } \\
\text { preenvasada) }\end{array}$ & 01.4 .1 \\
\hline 332R-2018 & Doogh (Norma regional) (simple, sometido a tratamiento térmico) & 01.2 .1 .2 \\
\hline 332R-2018 & $\begin{array}{l}\text { Doogh (Norma regional) (aromatizado, sometido y no sometido a } \\
\text { tratamiento térmico) }\end{array}$ & 01.1 .4 \\
\hline 207-1999 & Leches en polvo y la nata (crema) en polvo & 01.5 .1 \\
\hline $288-1976$ & $\begin{array}{l}\text { Natas (crema) y las natas (cremas) preparadas (nata (crema) para } \\
\text { montar o batir, nata (crema) envasada a presión, nata (crema) montada } \\
\text { o batida) }\end{array}$ & 01.4 .2 \\
\hline 290-1995 & Productos a base de caseína alimentaria & 01.5 .1 \\
\hline $221-2001$ & Queso no madurado incluido el queso fresco & 01.6 .1 \\
\hline $243-2003$ & $\begin{array}{l}\text { Leches fermentadas (aromatizadas, con tratamiento térmico y sin } \\
\text { tratamiento térmico) }\end{array}$ & 01.7 \\
\hline 251-2006 & Leche desnatada (descremada) y grasa vegetal en polvo & 01.5 .2 \\
\hline $262-2007$ & Mozzarella & 01.6 .1 \\
\hline 273-1968 & Cottage Cheese & 01.6 .1 \\
\hline 275-1973 & Queso de nata (crema) (Rahmfrischkäse) & 01.6 .1 \\
\hline $283-1978$ & $\begin{array}{l}\text { Queso (no madurado, incluido queso fresco) - véase también CODEX } \\
\text { STAN 221-2001 }\end{array}$ & 01.6 .1 \\
\hline 288-1976 & $\begin{array}{l}\text { Natas (crema) y las natas (cremas) preparadas (nata (crema) } \\
\text { fermentada y nata (crema) acidificada) }\end{array}$ & 01.4 .3 \\
\hline 208-1999 & Queso en salmuera & 01.6 .2 .1 \\
\hline $263-1966$ & Queso Cheddar & 01.6 .2 .1 \\
\hline $264-1966$ & Queso Danbo & 01.6 .2 .1 \\
\hline $265-1966$ & Queso Edam & 01.6 .2 .1 \\
\hline $266-1966$ & Queso Gouda & 01.6 .2 .1 \\
\hline 267-1966 & Queso Havarti & 01.6 .2 .1 \\
\hline $268-1966$ & Queso Samsoe & 01.6 .2 .1 \\
\hline $269-1967$ & Queso Emmental & 01.6 .2 .1 \\
\hline
\end{tabular}




\begin{tabular}{|c|c|c|}
\hline $\begin{array}{l}\text { Ref. de la } \\
\text { Norma }\end{array}$ & Título de la Norma del Codex & $\begin{array}{l}\text { Categoría de } \\
\text { Alimentos }\end{array}$ \\
\hline $270-1968$ & Queso Tilsiter & 01.6 .2 .1 \\
\hline 271-1968 & Queso Saint-Paulin & 01.6.2.1 \\
\hline 272-1968 & Queso Provolone & 01.6 .2 .1 \\
\hline 274-1969 & Queso Coulommiers & 01.6 .2 .1 \\
\hline $276-1973$ & Queso Camembert & 01.6.2.1 \\
\hline 277-1973 & Queso Brie & 01.6.2.1 \\
\hline 278-1978 & Queso extra duro para rallar & 01.6 .2 .1 \\
\hline 283-1978 & Queso (queso madurado, incluido queso madurado por homos) & 01.6.2.1 \\
\hline 284-1971 & Quesos de suero (queso de suero) & 01.6 .3 \\
\hline $289-1995$ & Sueros en polvo & 01.8 .2 \\
\hline $331-2017$ & Permeados lácteos en polvo & 01.8 .2 \\
\hline $19-1981$ & $\begin{array}{l}\text { Grasas y aceites comestibles no regulados por normas individuales } \\
\text { (Norma General) }\end{array}$ & 02.1 \\
\hline $280-1973$ & Productos a base de grasa de leche & 02.1 .1 \\
\hline $284-1971$ & Quesos de suero (queso de proteínas del suero) & 01.6 .6 \\
\hline 33-1981 & Aceites de oliva y los aceites de orujo de aceituna & 02.1 .2 \\
\hline 210-1999 & Aceites vegetales especificados & 02.1 .2 \\
\hline 325R-2017 & Manteca de karité sin refinar (Norma regional) & 02.1 .2 \\
\hline 211-1999 & Grasas animales especificadas & 02.1 .3 \\
\hline 253-2006 & Quesos de suero & 02.2 .2 \\
\hline $256-2007$ & Grasas para untar y mezclas de grasa para untar & 02.2 .2 \\
\hline $279-1971$ & Mantequilla & 02.2 .1 .1 \\
\hline 329-2017 & Aceites de pescado & 02.1 .3 \\
\hline 143-1985 & Dátiles (frescos) & 04.1 .1 .1 \\
\hline $182-1993$ & Piña & 04.1 .1 .1 \\
\hline 183-1993 & Papaya & 04.1 .1 .1 \\
\hline 184-1993 & Mango & 04.1 .1 .1 \\
\hline $187-1993$ & Carambola & 04.1 .1 .1 \\
\hline 196-1995 & Lichí & 04.1 .1 .1 \\
\hline 204-1997 & Mangostán & 04.1 .1 .1 \\
\hline 205-1997 & Banano (plátano) & 04.1 .1 .1 \\
\hline 213-1999 & Lima-limón & 04.1 .1 .1 \\
\hline 214-1999 & Pomelo (Citrus grandi) & 04.1 .1 .1 \\
\hline 215-1999 & Guayaba & 04.1 .1 .1 \\
\hline 216-1999 & Chayote & 04.1 .1 .1 \\
\hline 217-1999 & Limas mexicanas & 04.1 .1 .1 \\
\hline 219-1999 & Toronja (Citrus paradisi) & 04.1 .1 .1 \\
\hline 220-1999 & Longán & 04.1 .1 .1 \\
\hline $226-2001$ & Uchuva & 04.1 .1 .1 \\
\hline $237-2003$ & Pitahayas & 04.1 .1 .1 \\
\hline $245-2004$ & Naranja & 04.1 .1 .1 \\
\hline
\end{tabular}




\begin{tabular}{|c|c|c|}
\hline $\begin{array}{l}\text { Ref. de la } \\
\text { Norma }\end{array}$ & Título de la Norma del Codex & $\begin{array}{l}\text { Categoría de } \\
\text { Alimentos }\end{array}$ \\
\hline $246-2005$ & Rambután & 04.1 .1 .1 \\
\hline $255-2007$ & Uvas de mesa & 04.1 .1 .1 \\
\hline $299-2010$ & Manzanas & 04.1 .1 .1 \\
\hline 305R-2011 & Lúcuma (Norma Regional) & 04.1 .1 .1 \\
\hline $316-2014$ & Frutas de la Pasión & 04.1.1.1 \\
\hline $317-2014$ & Durión & 04.1.1.1 \\
\hline 38-1981 & Hongos comestibles y sus productos (hongos comestibles) & 04.2 .1 .1 \\
\hline $38-1981$ & Hongos comestibles y sus productos (productos de hongos) & 04.2 .2 \\
\hline 40R-1981 & Hongos frescos "Cantarelos" (Norma Regional) & 04.2 .1 .1 \\
\hline $52-1981$ & Fresas congeladas rápidamente & 04.1 .2 .1 \\
\hline $69-1981$ & Frambuesas congeladas rápidamente & 04.1 .2 .1 \\
\hline $75-1981$ & Melocotones (duraznos) congelados rápidamente & 04.1 .2 .1 \\
\hline $76-1981$ & Arándanos congelados rápidamente & 04.1 .2 .1 \\
\hline $103-1981$ & Arándanos americanos congelados rápidamente & 04.1 .2 .1 \\
\hline $131-1981$ & Pistachos con cáscara & 04.2 .1 .1 \\
\hline $143-1985$ & Dátiles (cubiertos) & 04.1 .1 .2 \\
\hline $171-1989$ & Determinadas legumbres & 04.2 .1 .1 \\
\hline $185-1993$ & Nopal & 04.2 .1 .1 \\
\hline $186-1993$ & Tuna & 04.2 .1 .1 \\
\hline $188-1993$ & Maíz Enano & 04.2 .1 .1 \\
\hline $197-1995$ & Aguacate & 04.2 .1 .1 \\
\hline $200-1995$ & Maní & 04.2 .1 .1 \\
\hline 218-1999 & Jengibre & 04.2 .1 .1 \\
\hline $224-2001$ & Tiquisque & 04.2 .1 .1 \\
\hline $225-2001$ & Espárrago & 04.2 .1 .1 \\
\hline $238-2003$ & Yuca (mandioca) dulce & 04.2 .1 .1 \\
\hline $260-2007$ & Frutas y hortalizas encurtidas (frutas fermentadas) & 04.1 .2 .10 \\
\hline $293-2008$ & Tomates & 04.2 .1 .1 \\
\hline $300-2010$ & Yuca (mandioca) amarga & 04.2 .1 .1 \\
\hline $303-2011$ & Tomate de Árbol & 04.2 .1 .1 \\
\hline 304R-2011 & Culantro Coyote (Norma Regional) & 04.2 .1 .1 \\
\hline $307-2011$ & Chile & 04.2 .1 .1 \\
\hline $310-2013$ & Granada & 04.2 .1 .1 \\
\hline 318-2014 & Okra & 04.2 .1 .1 \\
\hline 324R-2017 & Yacón (Norma regional) & 04.2 .1 .1 \\
\hline $330-2018$ & Berenjena (sin tratamiento) & 04.2 .1 .1 \\
\hline $38-1981$ & Hongos comestibles y sus productos (hongos congelados rápidamente) & 04.2 .2 .1 \\
\hline $67-1981$ & Uvas pasas & 04.1 .2 .2 \\
\hline $130-1981$ & Albaricoques secos & 04.1 .2 .2 \\
\hline $177-1991$ & Coco rallado desecado & 04.1 .2 .2 \\
\hline $320-2015$ & Hortalizas Congeladas Rápidamente & 04.2 .2 .1 \\
\hline
\end{tabular}




\begin{tabular}{|c|c|c|}
\hline $\begin{array}{l}\text { Ref. de la } \\
\text { Norma }\end{array}$ & Título de la Norma del Codex & $\begin{array}{l}\text { Categoría de } \\
\text { Alimentos }\end{array}$ \\
\hline $330-2018$ & Berenjena (tratadas en la superficie) & 04.2 .1 .2 \\
\hline $38-1981$ & $\begin{array}{l}\text { Hongos comestibles y sus productos (incluido hongos liofilizados, } \\
\text { sémola de hongos y polvo de hongos) }\end{array}$ & 04.2 .2 .2 \\
\hline $39-1981$ & Hongos comestibles desecados & 04.2 .2 .2 \\
\hline $260-2007$ & Frutas y hortalizas encurtidas (frutas encurtidas) & 04.1 .2 .3 \\
\hline $321-2015$ & $\begin{array}{l}\text { Productos a base de Ginseng (ginseng desecado, ginseng crudo } \\
\text { desecado, ginseng cocido al vapour desecado) }\end{array}$ & 04.2 .2 .2 \\
\hline 323R-2017 & $\begin{array}{l}\text { Productos a base de alga nori (productos a base de alga nori secada y } \\
\text { productos de alga nori condimentada) (Norma regional) }\end{array}$ & 04.2 .2 .2 \\
\hline $17-1981$ & Compota de manzanas en conserva & 04.1 .2 .4 \\
\hline $38-1981$ & $\begin{array}{l}\text { Hongos comestibles y sus productos (hongos salados, encurtidos o en } \\
\text { aceites vegetales) }\end{array}$ & 04.2 .2 .3 \\
\hline $60-1981$ & Frambuesas en conserva & 04.1 .2 .4 \\
\hline $62-1987$ & Fresas en conserva & 04.1 .2 .4 \\
\hline $66-1981$ & Aceitunas de mesa & 04.2 .2 .3 \\
\hline $78-1981$ & Cóctel de frutas en conserva & 04.1 .2 .4 \\
\hline $99-1981$ & Ensalada de frutas tropicales en conserva & 04.1 .2 .4 \\
\hline $115-1981$ & Pepinos encurtidos (encurtido de pepinos) & 04.2 .2 .3 \\
\hline $242-2003$ & Frutas de hueso en conserva & 04.1 .2 .4 \\
\hline $254-2007$ & Algunos frutos cítricos en conserva & 04.1 .2 .4 \\
\hline $260-2007$ & Frutas y hortalizas encurtidas (hortalizas encurtidas) & 04.2 .2 .3 \\
\hline $319-2015$ & Algunas Frutas en Conserva & 04.1 .2 .4 \\
\hline 13-1981 & Tomates en conserva & 04.2 .2 .4 \\
\hline $38-1981$ & Hongos comestibles y sus productos (hongos esterilizados) & 04.2 .2 .4 \\
\hline $57-1981$ & Concentrados de tomate elaborados (pasta de tomate en conserva) & 04.2 .2 .4 \\
\hline $145-1985$ & Castañas en conserva y el puré de castañas en conserva & 04.2 .2 .4 \\
\hline $241-2003$ & Brotes de bambú en conserva & 04.2 .2 .4 \\
\hline 257R-2007 & Humus con tahina en conserva (Norma regional) & 04.2 .2 .4 \\
\hline 258R-2007 & Foul medames en conserva (Norma regional) & 04.2 .2 .4 \\
\hline 296-2009 & Confituras, jaleas y mermeladas & 04.1 .2 .5 \\
\hline 297-2009 & Algunas hortalizas en conserva & 04.2 .2 .4 \\
\hline $57-1981$ & Concentrados de tomate elaborados (puré de tomate) & 04.2 .2 .5 \\
\hline $160-1987$ & Salsa picante de mango & 04.1 .2 .6 \\
\hline $38-1981$ & $\begin{array}{l}\text { Hongos comestibles y sus productos (concentrados, concentrados } \\
\text { desecados o extractos) }\end{array}$ & 04.2 .2 .6 \\
\hline $57-1981$ & Concentrados de tomate elaborados (pasta de tomate) & 04.2 .2 .6 \\
\hline 259R-2007 & Tahina (Norma regional) & 04.2 .2 .6 \\
\hline $260-2007$ & Frutas y hortalizas encurtidas (hortalizas fermentadas) & 04.1 .2 .7 \\
\hline 308R-2011 & Harissa (Norma Regional) & 04.2 .2 .6 \\
\hline $321-2015$ & $\begin{array}{l}\text { Productos a base de Ginseng (extracto de ginseng, extracto de ginseng } \\
\text { crudo, extracto de ginseng cocido al vapor) }\end{array}$ & 04.2 .2 .6 \\
\hline $38-1981$ & Hongos comestibles y sus productos (fermentados) & 04.2 .2 .7 \\
\hline $151-1985$ & Gari & 04.2 .2 .7 \\
\hline
\end{tabular}




\begin{tabular}{|c|c|c|}
\hline $\begin{array}{l}\text { Ref. de la } \\
\text { Norma }\end{array}$ & Título de la Norma del Codex & $\begin{array}{l}\text { Categoría de } \\
\text { Alimentos }\end{array}$ \\
\hline 223-2001 & Kimchi & 04.2 .2 .7 \\
\hline $240-2003$ & Productos acuosos de coco - leche de coco y crema de coco & 04.1.2.8 \\
\hline 294R-2009 & Goghujang (Norma Regional) & 04.2 .2 .7 \\
\hline 314R-2013 & Pasta de datíl (Norma Regional) & 04.1 .2 .8 \\
\hline $105-1981$ & Cacao en polvo (cacaos) y a las mezclas de cacao y azúcares & 05.1 .1 \\
\hline $141-1983$ & Cacao en pasta (licor de cacao/chocolate) y la torta de cacao & 05.1 .1 \\
\hline 323R-2017 & $\begin{array}{l}\text { Productos a base de alga nori (productos de alga nori tostada y } \\
\text { productos de alga nori condimentada) (Norma regional) }\end{array}$ & 04.2 .2 .8 \\
\hline $86-1981$ & Manteca de cacao & 05.1 .3 \\
\hline 309R-2011 & Halva com Tahina (Norma Regional) & 05.2 .2 \\
\hline $87-2003$ & Chocolate & 05.1 .4 \\
\hline 153-1985 & Maíz & 06.1 \\
\hline 169-1989 & Mijo perla en grano entero y decorticado & 06.1 \\
\hline $172-1989$ & Sorgo en grano & 06.1 \\
\hline 198-1995 & Arroz & 06.1 \\
\hline 199-1995 & Trigo y el trigo duro & 06.1 \\
\hline 201-1995 & Avena & 06.1 \\
\hline 202-1995 & Cúscus & 06.1 \\
\hline 333-2019 & Quinua & 06.1 \\
\hline $152-1985$ & Harina de trigo & 06.2 .1 \\
\hline 154-1985 & Harina integral de maíz & 06.2 .1 \\
\hline $155-1985$ & Harina y la sémola de maíz sin germen & 06.2 .1 \\
\hline 170-1989 & Harina de mijo perla & 06.2 .1 \\
\hline 173-1989 & Harina de sorgo & 06.2 .1 \\
\hline 176-1989 & Harina de yuca comestible & 06.2 .1 \\
\hline $178-1991$ & Sémola y la harina de trigo duro & 06.2 .1 \\
\hline 301R-2011 & Harina de Sagú Comestible (Norma Regional) & 06.2 .1 \\
\hline 249-2006 & Fideos instantáneos & 06.4 .3 \\
\hline 322R-2015 & $\begin{array}{l}\text { Productos de soya no fermentados (bebida de soja básica, bebidas de } \\
\text { soja compuestas o aromatizadas, bebidas a base de soja) (Norma } \\
\text { Regional) }\end{array}$ & 06.8 .1 \\
\hline 322R-2015 & $\begin{array}{l}\text { Productos de soya no fermentados (película de soja deshidratada) } \\
\text { (Norma Regional) }\end{array}$ & 06.8 .2 \\
\hline 322R-2015 & $\begin{array}{l}\text { Productos de soya no fermentados (tofu semisólido, tofu) (Norma } \\
\text { Regional) }\end{array}$ & 06.8 .3 \\
\hline 322R-2015 & Productos de soya no fermentados (tofu compactado) (Norma Regional) & 06.8 .4 \\
\hline 313R-2013 & Tempe (Norma Regional) & 06.8 .6 \\
\hline $175-1989$ & Productos proteínicos de soja (PPS) & 06.8 .8 \\
\hline $96-1981$ & Jamón curado cocido & 08.2 .2 \\
\hline $97-1981$ & Espaldilla de cerdo curada cocida & 08.2 .2 \\
\hline 88-1981 & Carne tipo "Corned Beef" & 08.3.2 \\
\hline 89-1981 & Carne Luncheon & 08.3 .2 \\
\hline $98-1981$ & Carne picada curada cocida & 08.3 .2 \\
\hline
\end{tabular}




\begin{tabular}{|c|c|c|}
\hline $\begin{array}{l}\text { Ref. de la } \\
\text { Norma }\end{array}$ & Título de la Norma del Codex & $\begin{array}{l}\text { Categoría de } \\
\text { Alimentos }\end{array}$ \\
\hline $36-1981$ & Pescados no eviscerados y eviscerados congelados rápidamente & 09.2 .1 \\
\hline $92-1981$ & Camarones congelados rápidamente & 09.2 .1 \\
\hline $95-1981$ & Langostas congeladas rápidamente & 09.2 .1 \\
\hline $165-1989$ & $\begin{array}{l}\text { Bloques de filetes de pescado, carne de pescado picada y mezclas de } \\
\text { filetes y de carne de pescado picada congelados rápidamente }\end{array}$ & 09.2 .1 \\
\hline $190-1995$ & Filetes de pescado congelados rápidamente & 09.2 .1 \\
\hline 191-1995 & Calamares congelados rápidamente & 09.1 .2 \\
\hline $292-2008$ & Moluscos bivalvos vivos y crudos (vivos) & 09.1 .2 \\
\hline $292-2008$ & Moluscos bivalvos vivos y crudos (crudos, enfriados, desbullados) & 09.1 .2 \\
\hline $292-2008$ & Moluscos bivalvos vivos y crudos (crudos, congelados) & 09.2 .1 \\
\hline $312-2013$ & $\begin{array}{l}\text { Abalón Vivo y al Abalón Crudo Refrigerado o Congelado Destinado al } \\
\text { Consumo Directo o a su Elaboración Ulterior (crudo) }\end{array}$ & 09.1 .2 \\
\hline $312-2013$ & $\begin{array}{l}\text { Abalón Vivo y al Abalón Crudo Refrigerado o Congelado Destinado al } \\
\text { Consumo Directo o a su Elaboración Ulterior (congelado) }\end{array}$ & 09.2 .1 \\
\hline $315-2014$ & $\begin{array}{l}\text { Productos de Pectínidos Frescos y Pectínidos Crudos Congelados } \\
\text { Rápidamente (crudo) }\end{array}$ & 09.1 .2 \\
\hline $315-2014$ & $\begin{array}{l}\text { Productos de Pectínidos Frescos y Pectínidos Crudos Congelados } \\
\text { Rápidamente (congelado) }\end{array}$ & 09.2 .1 \\
\hline $3-1981$ & Salmón en conserva & 09.4 \\
\hline $37-1981$ & Camarones en conserva & 09.4 \\
\hline $70-1981$ & Atún y el bonito en conserva & 09.4 \\
\hline $90-1981$ & Carne de cangrejo en conserva & 09.4 \\
\hline $94-1981$ & Sardinas y productos análogos en conserva & 09.4 \\
\hline $119-1981$ & Pescados en conserva & 09.4 \\
\hline $166-1989$ & $\begin{array}{l}\text { Barritas, porciones y filetes de pescado empanados o rebozados } \\
\text { congelados rápidamente }\end{array}$ & 09.2 .2 \\
\hline $291-2010$ & Caviar de Esturión & 09.3 .3 \\
\hline 167-1989 & Pescado salado y pescado seco salado de la familia Gadidae & 09.2 .5 \\
\hline $189-1993$ & Aletas de tiburón secas & 09.2 .5 \\
\hline $222-2001$ & $\begin{array}{l}\text { Galletas de pescado marino y de agua dulce y de mariscos, crustáceos } \\
\text { y moluscos }\end{array}$ & 09.2 .5 \\
\hline $236-2003$ & Anchoas hervidas secas saladas & 09.2 .5 \\
\hline $244-2004$ & Arenque del Atlántico salado y el espadín salado & 09.2 .5 \\
\hline $311-2013$ & $\begin{array}{l}\text { Pescado Ahumado, Pescado con Sabor a Humo y Pescado Secado con } \\
\text { Humo }\end{array}$ & 09.2 .5 \\
\hline $212-1999$ & $\begin{array}{l}\text { Azúcares (azúcar blanco, dextrosa anhidra, dextrosa monohidrato, } \\
\text { fructosa) }\end{array}$ & 11.1 .1 \\
\hline $212-1999$ & Azúcares (azúcar en polvo o dextrosa en polvo) & 11.1 .2 \\
\hline $212-1999$ & $\begin{array}{l}\text { Azúcares (jarabe de glucosa, glucosa deshidratado, azúcar blando } \\
\text { blanco, azúcar moreno, azúcar de caña sin refinar) }\end{array}$ & 11.1 .3 \\
\hline $12-1981$ & Miel & 11.5 \\
\hline 212-1999 & Azúcares (lactosa) & 11.1 .4 \\
\hline $212-1999$ & Azúcares (azúcar de plantación o refinería) & 11.1 .5 \\
\hline $163-1987$ & Productos de proteínas de trigo incluido el gluten de trigo & 12.10 \\
\hline
\end{tabular}




\begin{tabular}{|c|c|c|}
\hline $\begin{array}{l}\text { Ref. de la } \\
\text { Norma }\end{array}$ & Título de la Norma del Codex & $\begin{array}{l}\text { Categoría de } \\
\text { Alimentos }\end{array}$ \\
\hline 174-1989 & Productos proteínicos vegetales (PPV) & 12.10 \\
\hline $150-1985$ & Sal de calidad alimentaria & 12.1 .1 \\
\hline $53-1981$ & $\begin{array}{l}\text { Regímenes especiales pobres en sodio (incluso los sucedáneos de la } \\
\text { sal) (sucedáneos de la sal) }\end{array}$ & 12.1 .2 \\
\hline $326-2017$ & Pimientas negra, blanca y verde & 12.2 .1 \\
\hline $327-2017$ & Comino & 12.2 .1 \\
\hline $328-2017$ & Tomillo seco & 12.2 .1 \\
\hline $334-2019$ & Ajo seco & 12.2 .1 \\
\hline $117-1981$ & Bouillons y consomés & 12.5 \\
\hline 306R-2011 & Salsa de Ají (Norma Regional) & 12.6 .2 \\
\hline $53-1981$ & $\begin{array}{l}\text { Regímenes especiales pobres en sodio (incluso los sucedáneos de la } \\
\text { sal) (regímenes especiales pobres en sodio) }\end{array}$ & 13.0 \\
\hline 298R-2009 & Pasta de Soja Fermentada (Norma Regional) & 12.9.1 \\
\hline $302-2011$ & Salsa de Pescado & 12.6 .4 \\
\hline $72-1981$ & $\begin{array}{l}\text { Preparados para lactantes y preparados para uso medicinales } \\
\text { especiales destinados a los lactantes (preparados para lactantes) }\end{array}$ & 13.1.1 \\
\hline $73-1981$ & Alimentos envasados para lactantes y niños & 13.2 \\
\hline 74-1981 & Alimentos elaborados a base de cereales para lactantes y niños & 13.2 \\
\hline $118-1981$ & $\begin{array}{l}\text { Alimentos para regímenes especiales destinados a personas } \\
\text { intolerantes al gluten }\end{array}$ & 13.3 \\
\hline $156-1987$ & Preparados complementarios & 13.1 .2 \\
\hline $72-1981$ & $\begin{array}{l}\text { Preparados para lactantes y preparados para uso medicinales } \\
\text { especiales destinados a los lactantes (preparados para uso medicinales } \\
\text { especiales destinados a los lactantes) }\end{array}$ & 13.1 .3 \\
\hline $181-1991$ & Preparados dietéticos para regímenes de control del peso & 13.4 \\
\hline 203-1995 & $\begin{array}{l}\text { Preparados dietéticos para regímenes muy hipocalóricos de } \\
\text { adelgazamiento }\end{array}$ & 13.4 \\
\hline $108-1981$ & Aguas minerales naturales & 14.1.1.1 \\
\hline $227-2001$ & $\begin{array}{l}\text { Aguas potables embotelladas/envasadas (distintas de las aguas } \\
\text { minerales naturales) }\end{array}$ & 14.1.1.2 \\
\hline 247-2005 & Zumos (yugos) y néctares de frutas (zumos (yugos) de frutas) & 14.1.2.1 \\
\hline $247-2005$ & Zumos (yugos) y néctares de frutas (néctares de frutas) & 14.1.3.1 \\
\hline $247-2005$ & $\begin{array}{l}\text { Zumos (yugos) y néctares de frutas (concentrados para zumos (yugos) } \\
\text { de fruta) }\end{array}$ & 14.1.2.3 \\
\hline $247-2005$ & $\begin{array}{l}\text { Zumos (yugos) y néctares de frutas (concentrados para néctares de } \\
\text { frutas) }\end{array}$ & 14.1.3.3 \\
\hline
\end{tabular}




\section{NORMA GENERAL PARA LOS ADITIVOS ALIMENTARIOS CUADRO I}

\section{Aditivos cuyo uso se permite en condiciones especificadas para ciertas categorías de alimentos o determinados productos alimenticios}

\section{ACEITE DE RICINO}

SIN 1503 Aceite de ricino

Clases Funcionales: Antiaglutinantes, Sustancias inertes, Emulsionantes, Agentes de glaseado

\begin{tabular}{|c|c|c|c|c|}
\hline 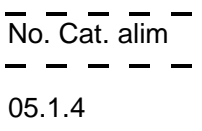 & $\begin{array}{l}\text { Ca āegoría de alimento }--------- \\
\overline{-}-\overline{-}-------- \\
\text { Productos de cacao y chocolate }\end{array}$ & $\begin{array}{l}\text { Dosis máxima } \\
----\overline{-} \\
350 \mathrm{mg} / \mathrm{kg}\end{array}$ & $\begin{array}{l}- \text { Notas }- \\
-\overline{x S 87}\end{array}$ & $-\frac{\bar{A} \tilde{n} \bar{o} \text { Adoptōada }}{2017}$ \\
\hline 05.2 & $\begin{array}{l}\text { Dulces, incluidos los caramelos duros y blandos, los } \\
\text { turrones, etc. distintos de los indicados en las categorías de } \\
\text { alimentos } 05.1,05.3 \text { y } 05.4\end{array}$ & $500 \mathrm{mg} / \mathrm{kg}$ & XS309R & 2017 \\
\hline 05.3 & Goma de mascar & $2100 \mathrm{mg} / \mathrm{kg}$ & & 2007 \\
\hline 13.6 & Complementos alimenticios & $1000 \mathrm{mg} / \mathrm{kg}$ & & 2007 \\
\hline
\end{tabular}

\section{ACEITE DE SOJA OXIDADO CON PROCEDIMIENTO}

\section{TÉRMICO INTERACCIONADO CON MONO Y} DIGLICÉRIDOS DE ÁCIDOS GRASOS

SIN $479 \quad \begin{aligned} & \text { Aceite de soja oxidado con } \\ & \text { procedimiento térmico } \\ & \text { interaccionado con } \\ & \text { monoglicéridos y diglicéridos de } \\ & \text { ácidos grasos }\end{aligned}$

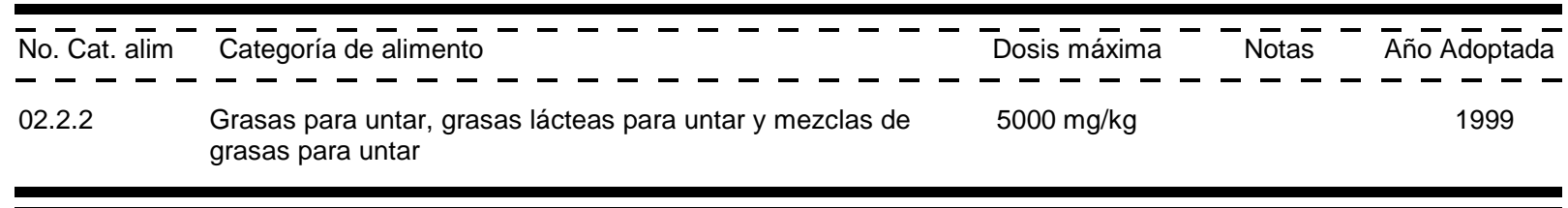

\section{ACEITE MINERAL DE ALTA VISCOSIDAD}

SIN 905d Aceite mineral de alta viscosidad Clases Funcionales: Antiespumantes, Agentes de glaseado

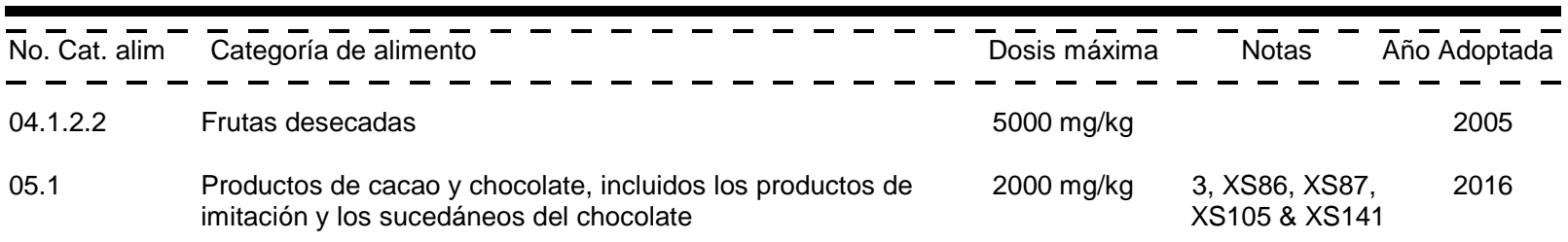


ACEITE MINERAL DE ALTA VISCOSIDAD

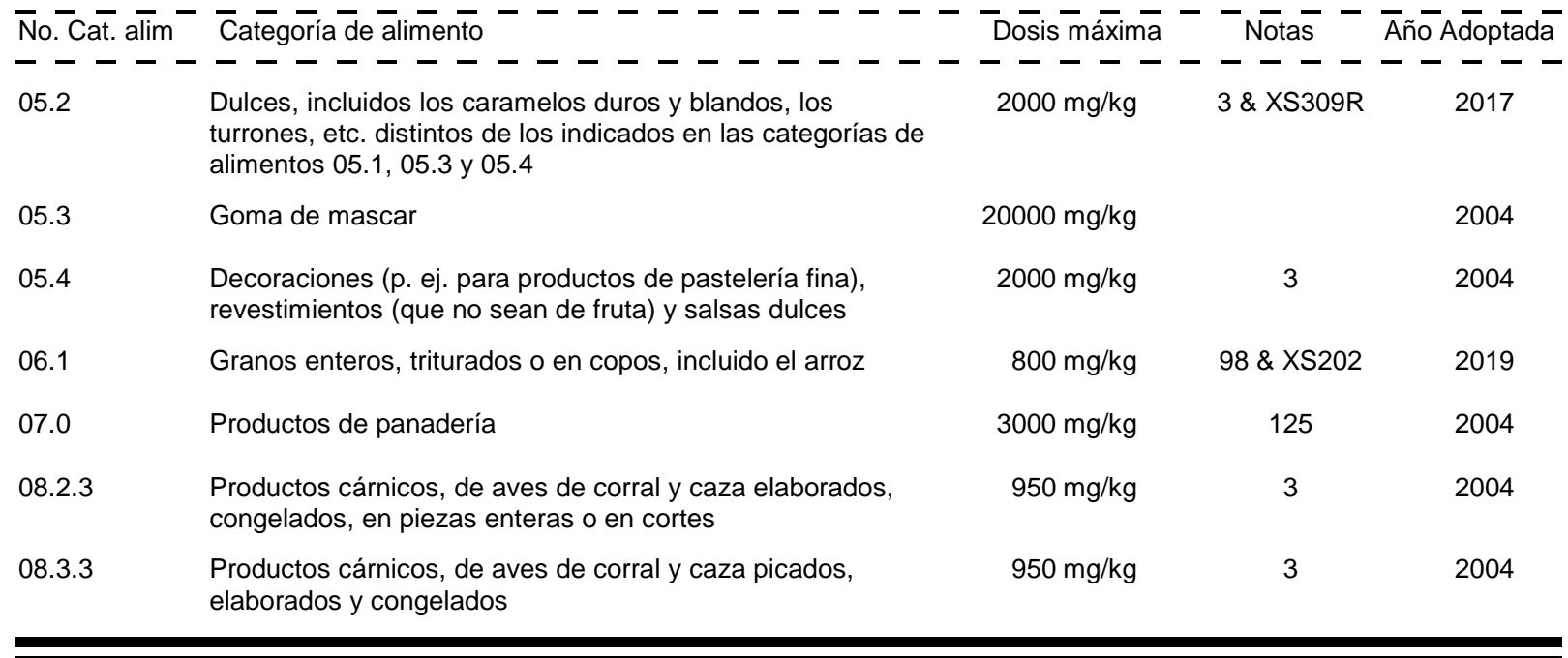

\section{ACEITE MINERAL, VISCOSIDAD MEDIA}

SIN 905e Aceite mineral, viscosidad media Clases Funcionales: Agentes de glaseado

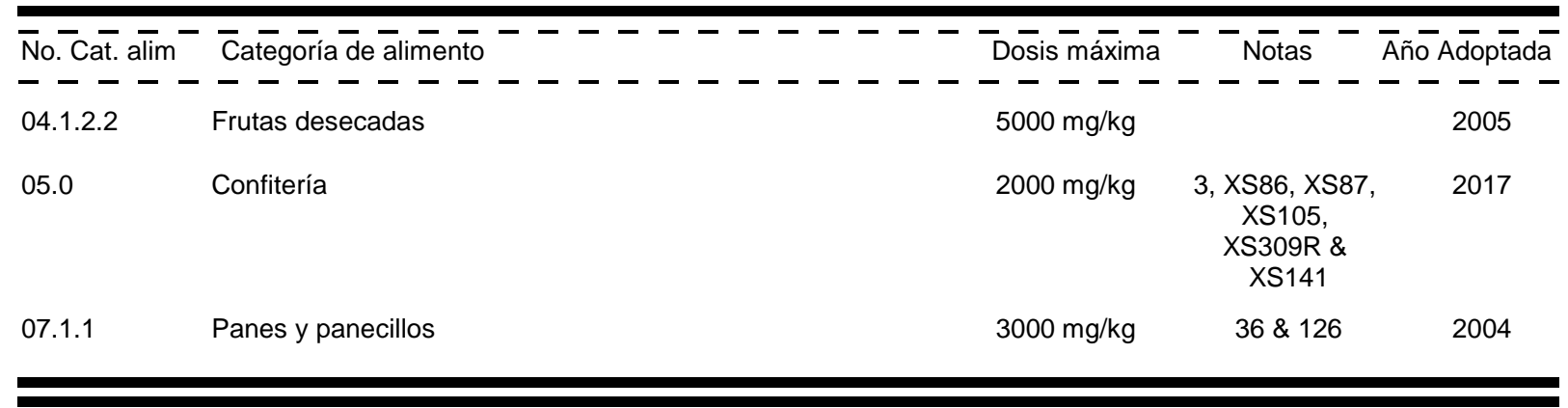

\section{ACESULFAME DE POTASIO}

SIN 950 Acesulfame de potasio Clases Funcionales: Acentuadores del sabor, Edulcorantes

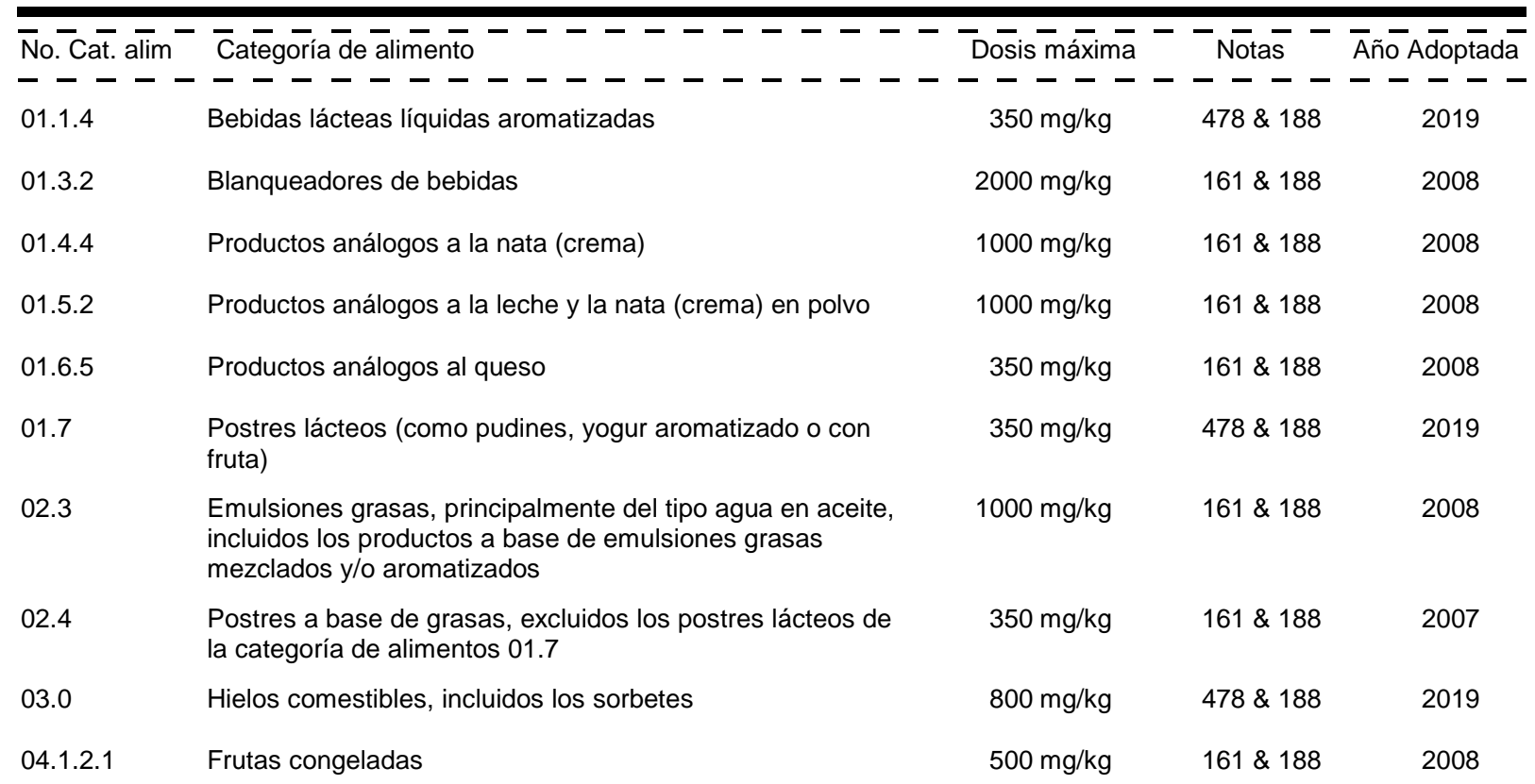


Cuadro I

ACESULFAME DE POTASIO

\begin{tabular}{|c|c|c|c|c|}
\hline 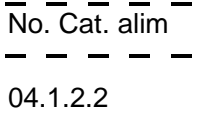 & 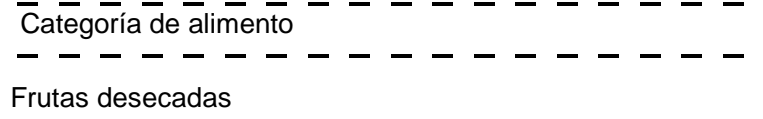 & $\begin{array}{l}\text { Dosis máxima } \\
-\quad--- \\
500 \mathrm{mg} / \mathrm{kg}\end{array}$ & $-\overline{\text { Notas }}-$ & Adopta \\
\hline 04.1 .2 .3 & Frutas en vinagre, aceite o salmuera & $200 \mathrm{mg} / \mathrm{kg}$ & $161 \& 188$ & 2007 \\
\hline 04.1 .2 .4 & Frutas en conserva, enlatadas o en frascos (pasteurizadas) & $350 \mathrm{mg} / \mathrm{kg}$ & $\begin{array}{l}161,188 \& \\
\quad \text { XS319 }\end{array}$ & 2018 \\
\hline 04.1 .2 .5 & Confituras, jaleas, mermeladas & $1000 \mathrm{mg} / \mathrm{kg}$ & $478 \& 188$ & 2019 \\
\hline 04.1 .2 .6 & $\begin{array}{l}\text { Productos para untar a base de fruta (p. ej. el "chutney"), } \\
\text { excluidos los productos de la categoría de alimentos } \\
\text { 04.1.2.5 }\end{array}$ & $1000 \mathrm{mg} / \mathrm{kg}$ & $478 \& 188$ & 2019 \\
\hline 04.1 .2 .7 & Frutas confitadas & $500 \mathrm{mg} / \mathrm{kg}$ & $161 \& 188$ & 2007 \\
\hline 04.1 .2 .8 & $\begin{array}{l}\text { Preparados a base de fruta, incluida la pulpa, los purés, los } \\
\text { revestimientos de fruta y la leche de coco }\end{array}$ & $350 \mathrm{mg} / \mathrm{kg}$ & $478 \& 188$ & 2019 \\
\hline 04.1 .2 .9 & $\begin{array}{l}\text { Postres a base de fruta, incluidos los postres a base de } \\
\text { agua con aromas de fruta }\end{array}$ & $350 \mathrm{mg} / \mathrm{kg}$ & $478 \& 188$ & 2019 \\
\hline 04.1 .2 .10 & Productos de fruta fermentada & $350 \mathrm{mg} / \mathrm{kg}$ & $478 \& 188$ & 2019 \\
\hline 04.1 .2 .11 & Rellenos de fruta para pastelería & $350 \mathrm{mg} / \mathrm{kg}$ & $161 \& 188$ & 2007 \\
\hline 04.1 .2 .12 & Frutas cocidas o fritas & $500 \mathrm{mg} / \mathrm{kg}$ & $478 \& 188$ & 2019 \\
\hline 04.2 .2 .3 & $\begin{array}{l}\text { Hortalizas (incluidos hongos y setas, raíces y tubérculos, } \\
\text { legumbres y leguminosas y áloe vera) y algas marinas en } \\
\text { vinagre, aceite, salmuera o salsa de soja }\end{array}$ & $200 \mathrm{mg} / \mathrm{kg}$ & $144 \& 188$ & 2007 \\
\hline 04.2 .2 .4 & $\begin{array}{l}\text { Hortalizas (incluidos hongos y setas, raíces y tubérculos, } \\
\text { legumbres y leguminosas y áloe vera) y algas marinas en } \\
\text { conserva, en latas o frascos (pasteurizadas) o en bolsas de } \\
\text { esterilización }\end{array}$ & $350 \mathrm{mg} / \mathrm{kg}$ & $161 \& 188$ & 2008 \\
\hline 04.2 .2 .5 & $\begin{array}{l}\text { Purés y preparados para untar elaborados con hortalizas } \\
\text { (incluidos hongos y setas, raíces y tubérculos, legumbres y } \\
\text { leguminosas y áloe vera), algas marinas y nueces y } \\
\text { semillas (p. ej., la mantequilla de maní (cacahuete)) }\end{array}$ & $1000 \mathrm{mg} / \mathrm{kg}$ & 188 & 2008 \\
\hline 04.2 .2 .6 & $\begin{array}{l}\text { Pulpas y preparados de hortalizas (incluidos hongos y } \\
\text { setas, raíces y tubérculos, legumbres y leguminosas y áloe } \\
\text { vera), algas marinas y nueces y semillas (como los postres } \\
\text { y las salsas a base de hortalizas y hortalizas confitadas) } \\
\text { distintos de los indicados en la categoría de alimentos } \\
\text { 04.2.2.5 }\end{array}$ & $350 \mathrm{mg} / \mathrm{kg}$ & $161 \& 188$ & 2007 \\
\hline 04.2 .2 .7 & $\begin{array}{l}\text { Productos a base de hortalizas (incluidos hongos y setas, } \\
\text { raíces y tubérculos, legumbres y leguminosas y áloe vera) y } \\
\text { algas marinas fermentadas, excluidos los productos } \\
\text { fermentados de soja de las categorías 06.8.6, 06.8.7, } \\
\text { 12.9.1, 12.9.2.1 y 12.9.2.3 }\end{array}$ & $1000 \mathrm{mg} / \mathrm{kg}$ & 188 & 2008 \\
\hline 05.1 .1 & $\begin{array}{l}\text { Mezclas de cacao (en polvo) y cacao en pasta/torta de } \\
\text { cacao }\end{array}$ & $350 \mathrm{mg} / \mathrm{kg}$ & $\begin{array}{l}97,188 \& \\
\quad X S 141\end{array}$ & 2016 \\
\hline 05.1 .2 & Mezclas de cacao (jarabes) & $350 \mathrm{mg} / \mathrm{kg}$ & $97,161 \& 188$ & 2007 \\
\hline 05.1 .3 & $\begin{array}{l}\text { Productos para untar a base de cacao, incluidos los } \\
\text { rellenos a base de cacao }\end{array}$ & $1000 \mathrm{mg} / \mathrm{kg}$ & $\begin{array}{l}478,188 \& \\
\quad X S 86\end{array}$ & 2019 \\
\hline 05.1 .4 & Productos de cacao y chocolate & $500 \mathrm{mg} / \mathrm{kg}$ & $478 \& 188$ & 2019 \\
\hline 05.1 .5 & Productos de imitación y sucedáneos del chocolate & $500 \mathrm{mg} / \mathrm{kg}$ & $161 \& 188$ & 2007 \\
\hline 05.2 .1 & Caramelos duros & $500 \mathrm{mg} / \mathrm{kg}$ & $156,478 \& 188$ & 2019 \\
\hline 05.2 .2 & Caramelos blandos & $1000 \mathrm{mg} / \mathrm{kg}$ & $\begin{array}{c}157,478,188 \\
\& \text { xs3 }\end{array}$ & 2019 \\
\hline
\end{tabular}


Cuadro I

ACESULFAME DE POTASIO

\begin{tabular}{|c|c|}
\hline 05.2 .3 & Turrón y mazapán \\
\hline 05.3 & Goma de mascar \\
\hline 05.4 & $\begin{array}{l}\text { Decoraciones (p. ej. para productos de pastelería fina), } \\
\text { revestimientos (que no sean de fruta) y salsas dulces }\end{array}$ \\
\hline 06.3 & Cereales para el desayuno, incluidos los copos de avena \\
\hline 06.5 & $\begin{array}{l}\text { Postres a base de cereales y almidón ( } p \text {. ej. pudines de } \\
\text { arroz, pudines de mandioca) }\end{array}$ \\
\hline 07.1 & Pan y productos de panadería ordinaria \\
\hline 07.2 & $\begin{array}{l}\text { Productos de panadería fina (dulces, salados, } \\
\text { aromatizados) y mezclas }\end{array}$ \\
\hline 09.2 & $\begin{array}{l}\text { Pescado y productos pesqueros elaborados, incluidos los } \\
\text { moluscos, crustáceos y equinodermos }\end{array}$ \\
\hline
\end{tabular}

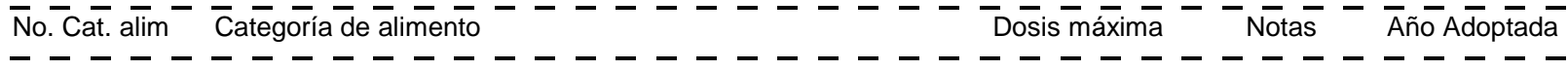

$1000 \mathrm{mg} / \mathrm{kg}$

$478 \& 188$

2019

$5000 \mathrm{mg} / \mathrm{kg}$

$478 \& 188$

2019

$500 \mathrm{mg} / \mathrm{kg}$

$478 \& 188$

2019

$1200 \mathrm{mg} / \mathrm{kg}$

$478 \& 188$

2019

$350 \mathrm{mg} / \mathrm{kg}$

$161 \& 188$

2007

$1000 \mathrm{mg} / \mathrm{kg} \quad 161 \& 188 \quad 2008$

$1000 \mathrm{mg} / \mathrm{kg} \quad 165 \& 188 \quad 2007$

$200 \mathrm{mg} / \mathrm{kg}$

144,188 ,

XS36, XS92,

XS95, XS165,

XS166, XS167,

XS189, XS190

XS191, XS222,

XS236, XS244,

XS292, XS311

XS312 \& XS315

$09.3 \quad$ Pescado y productos pesqueros semiconservados, incluidos los moluscos, crustáceos y equinodermos

$144,188 \&$ XS291

2018

$200 \mathrm{mg} / \mathrm{kg}$

$200 \mathrm{mg} / \mathrm{kg} \quad \begin{array}{r}144,188, \mathrm{XS} 3, \\ \text { XS37, XS70, }\end{array}$

XS90, XS94 \&

XS119

crustáceos y equinodermos) en conserva, con inclusión de los enlatados y fermentados

Postres a base de huevo (p. ej. flan)

$350 \mathrm{mg} / \mathrm{kg}$

$478 \& 188$

2019

$1000 \mathrm{mg} / \mathrm{kg}$

$159 \& 188$

2007 aderezos de azúcar)

$11.6 \quad$ Edulcorantes de mesa, incluidos los que contienen edulcorantes de gran intensidad

BPF

188

2007

Hierbas aromáticas, especias, aderezos y condimentos ( $p$. ej. el aderezo para fideos instantáneos)

$2000 \mathrm{mg} / \mathrm{kg}$

$161 \& 188$

2008

$2000 \mathrm{mg} / \mathrm{kg}$

$161 \& 188$

2008

$350 \mathrm{mg} / \mathrm{kg}$

188

2007

$110 \mathrm{mg} / \mathrm{kg}$

$478,188 \&$

XS117

$1000 \mathrm{mg} / \mathrm{kg}$

188

2019

Sopas y caldos

Salsas y productos análogos

$350 \mathrm{mg} / \mathrm{kg}$

$161 \& 188$

2007

Ensaladas (p. ej., la ensalada de macarrones, la ensalada de patatas (papas)) y productos para untar en

emparedados, excluidos los productos para untar a base de cacao y nueces de las categorías de alimentos 04.2.2.5 y

05.1 .3

Alimentos dietéticos para usos médicos especiales (excluidos los productos de la categoría de alimentos 13.1)

Preparados dietéticos para adelgazamiento y control del peso 
Cuadro I

ACESULFAME DE POTASIO

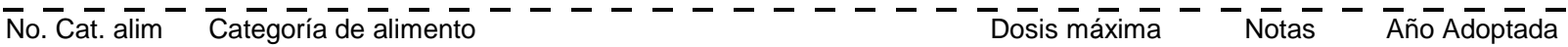

- - - - - - - - - - - - - - - - - - - - - - - - - -

$\begin{array}{llrr}\text { 14.1.3.1 Néctares de frutas } & 350 \mathrm{mg} / \mathrm{kg} & 188 & 2005\end{array}$

14.1.3.2 Néctares de hortalizas

$350 \mathrm{mg} / \mathrm{kg} \quad 161 \& 188 \quad 2008$

14.1.3.3 Concentrados para néctares de frutas

$350 \mathrm{mg} / \mathrm{kg} \quad 127 \& 188 \quad 2005$

14.1.3.4 Concentrados para néctares de hortalizas

$350 \mathrm{mg} / \mathrm{kg} \quad 127,161 \& 188 \quad 2007$

14.1.4 Bebidas a base de agua aromatizadas, incluidas las

$600 \mathrm{mg} / \mathrm{kg} \quad 161 \& 188 \quad 2007$

bebidas para deportistas, bebidas energéticas o bebidas electrolíticas y bebidas con partículas añadidas

14.1.5 Café, sucedáneos del café, té, infusiones de hierbas y otras bebidas calientes a base de cereales y granos, excluido el cacao

14.2.7 Bebidas alcohólicas aromatizadas (p. ej. cerveza, vino y bebidas con licor tipo bebida gaseosa, bebidas refrescantes con bajo contenido de alcohol)

$15.0 \quad$ Aperitivos listos para el consumo

$350 \mathrm{mg} / \mathrm{kg}$

188

2007

\section{ACETATO DE ALMIDÓN}

SIN 1420 Acetato de almidón

Clases Funcionales: Emulsionantes, Estabilizadores, Espesantes

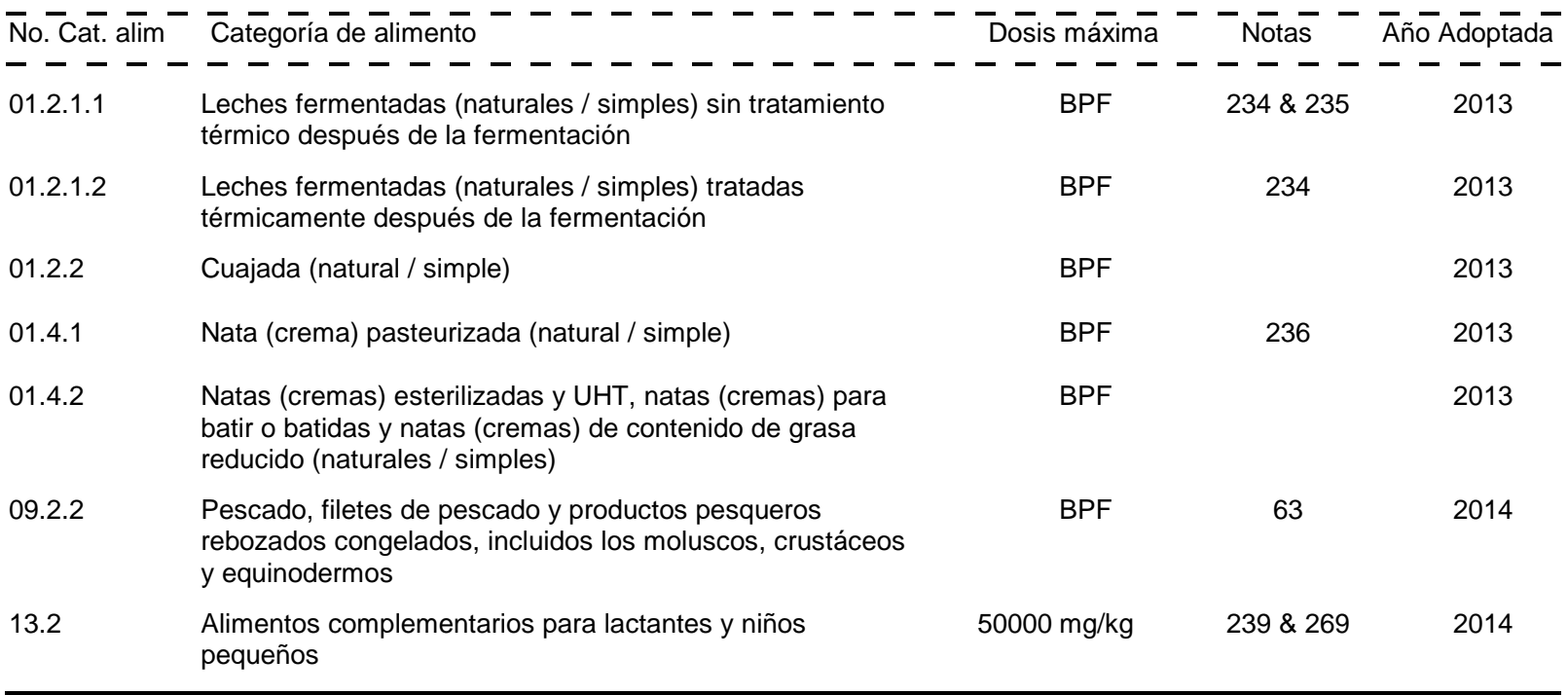

\section{ACETATO DE CALCIO}

SIN 263

Acetato de calcio

Clases Funcionales: Reguladores de la acidez, Sustancias conservadoras, Estabilizadores

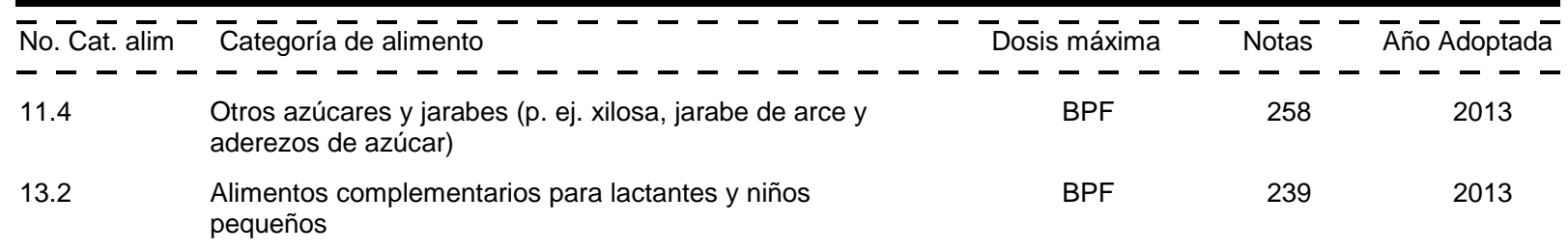




\section{ACETATO DE POTASIO}

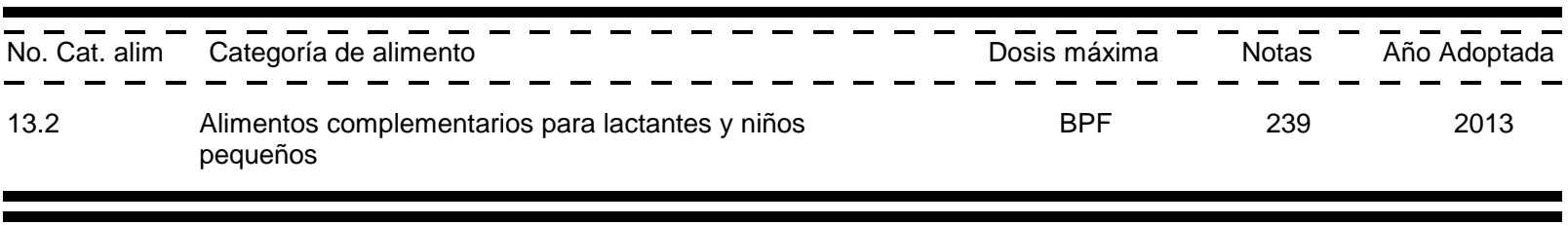

\section{ACETATO DE SODIO}

SIN 262(i) Acetato de sodio

Clases Funcionales: Reguladores de la acidez, Sustancias conservadoras, Secuestrantes

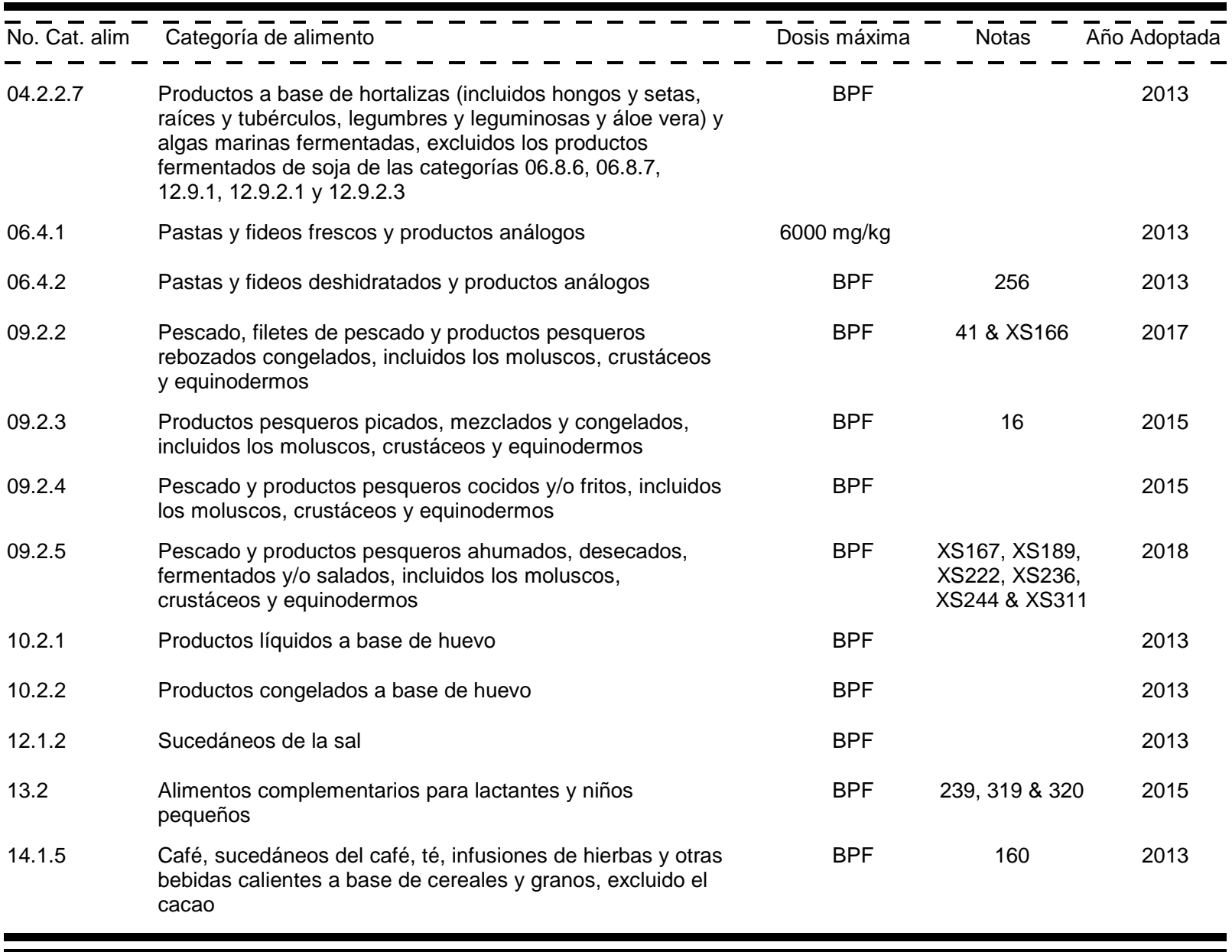

\section{ACETATO ISOBUTIRATO DE SACAROSA}

SIN 444 Acetato isobutirato de sacarosa Clases Funcionales: Emulsionantes, Estabilizadores

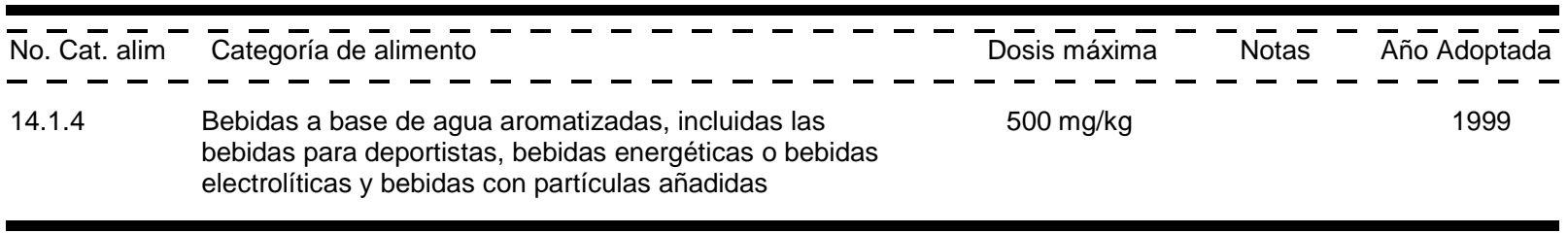




\title{
ÁCIDO ACÉTICO GLACIAL
}

\author{
SIN $260 \quad$ Ácido acético, glacial
}

Clases Funcionales: Reguladores de la acidez, Sustancias conservadoras

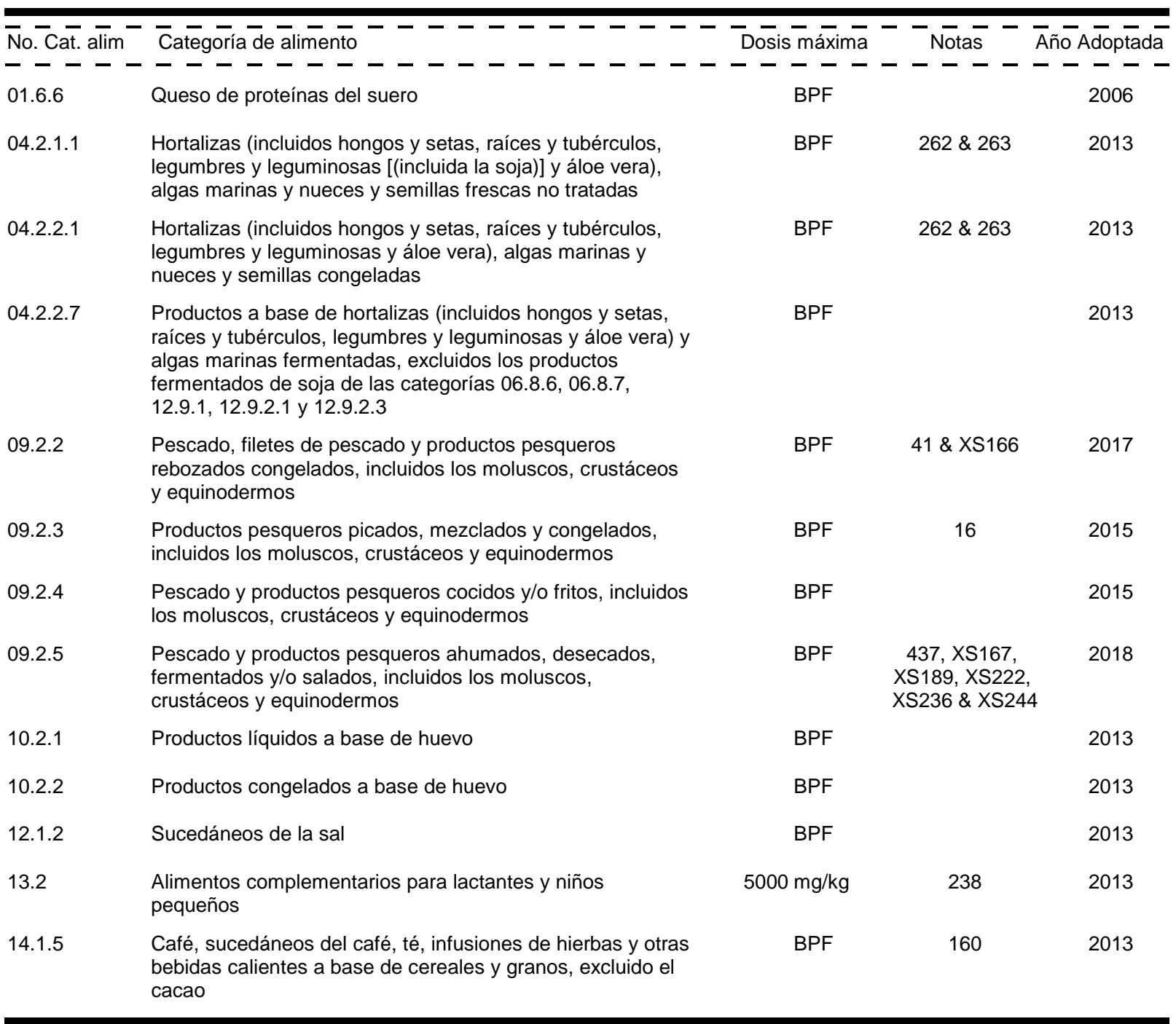

\section{ÁCIDO ALGÍNICO}

Clases Funcionales: Incrementadores del volumen, Sustancias inertes, Emulsionantes, Espumantes, Agentes gelificantes, Agentes de glaseado, Humectantes, Secuestrantes, Estabilizadores, Espesantes

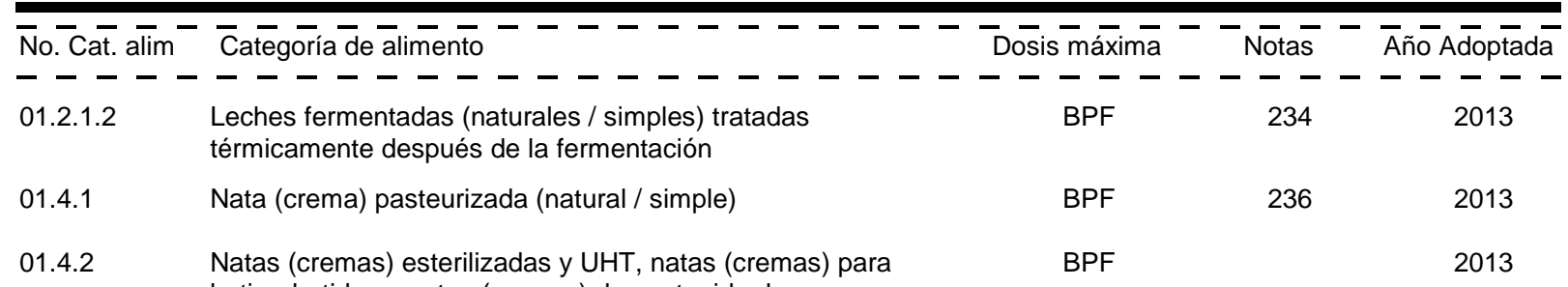
batir o batidas y natas (cremas) de contenido de grasa reducido (naturales / simples) 
ÁCIDO ALGÍNICO

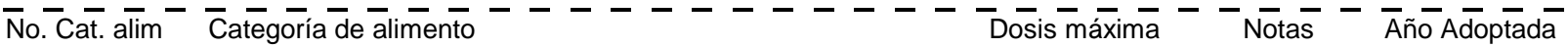

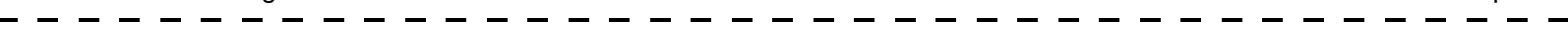

$\begin{array}{llll}\text { 04.2.2.7 } & \text { Productos a base de hortalizas (incluidos hongos y setas, } & \text { BPF } & 2013\end{array}$ raíces y tubérculos, legumbres y leguminosas y áloe vera) y algas marinas fermentadas, excluidos los productos fermentados de soja de las categorías 06.8.6, 06.8.7, 12.9.1, 12.9.2.1 y 12.9.2.3

06.4.1 Pastas y fideos frescos y productos análogos

$\begin{array}{cc}\text { BPF } & 211 \\ \text { BPF } & 256 \\ \text { BPF } & 16, \text { XS36, } \\ & \text { XS92, XS95, } \\ & \text { XS165, XS190, } \\ & \text { XS191, XS292, } \\ & \text { XS312 \& XS315 }\end{array}$

2014

06.4.2 Pastas y fideos deshidratados y productos análogos

09.2.3 Productos pesqueros picados, mezclados y congelados,

09.2.4.1 Pescado y productos pesqueros cocidos

09.2.4.2 Moluscos, crustáceos y equinodermos cocidos

09.2.4.3 Pescado y productos pesqueros fritos, incluidos los

14.1.5 Café, sucedáneos del café, té, infusiones de hierbas y otras bebidas calientes a base de cereales y granos, excluido el

\section{ÁCIDO ASCÓRBICO, L-}

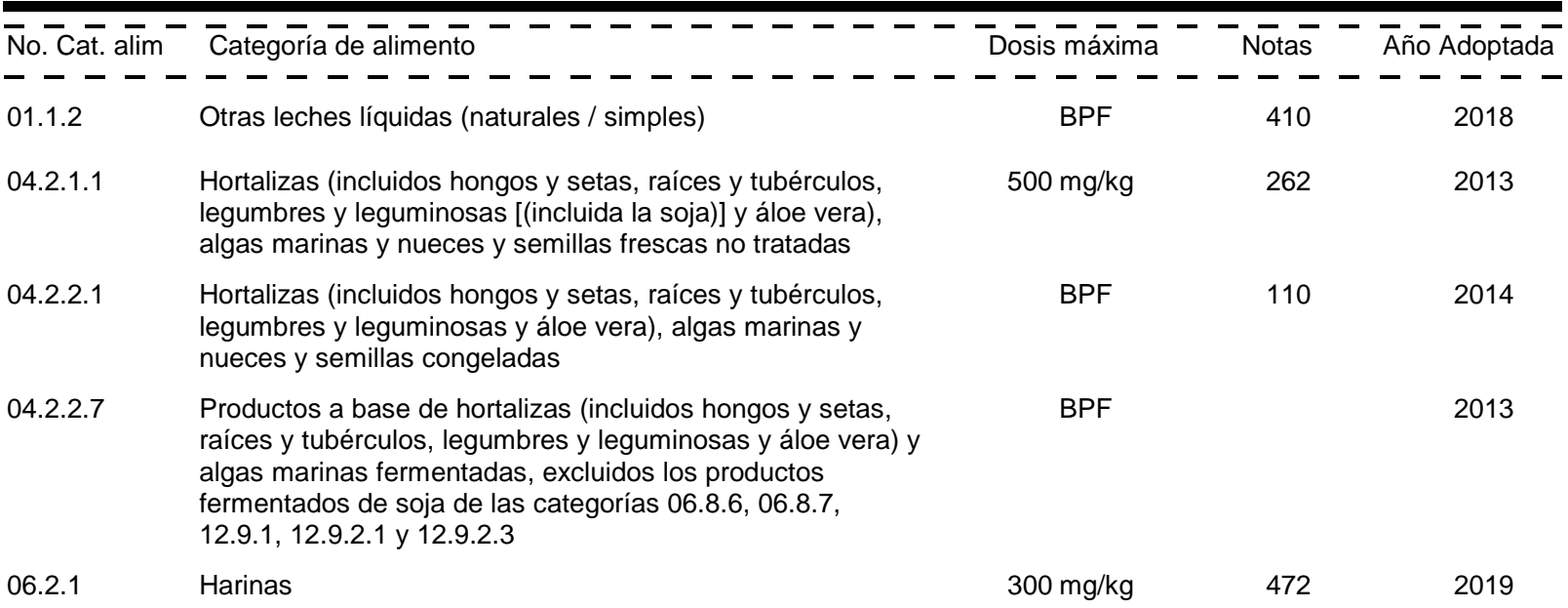


Cuadro I

ÁCIDO ASCÓRBICO, L-

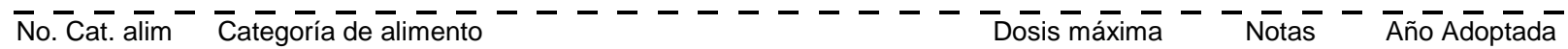
- - - - - - - - - - - - - - - - - - - - - - - - - - -

06.4.1 Pastas y fideos frescos y productos análogos $200 \mathrm{mg} / \mathrm{kg} \quad 2013$

06.4.2 Pastas y fideos deshidratados y productos análogos

BPF 256

08.1.2 Carne fresca picada, incluida la de aves de corral y caza

BPF

281

2014

09.1.2 Moluscos, crustáceos y equinodermos frescos

BPF

390, XS312 \&

2017

09.2.1 Pescado, filetes de pescado y productos pesqueros congelados, incluidos los moluscos, crustáceos y

307,392

2017 equinodermos

XS189, XS190,

XS191, XS222

XS236, XS312

\& XS315

09.2.2 Pescado, filetes de pescado y productos pesqueros

BPF

$306 \& 307$

2015

rebozados congelados, incluidos los moluscos, crustáceos y equinodermos

09.2.3 Productos pesqueros picados, mezclados y congelados, incluidos los moluscos, crustáceos y equinodermos

BPF

16

2015

09.2.4 Pescado y productos pesqueros cocidos y/o fritos, incluidos los moluscos, crustáceos y equinodermos

09.2.5 Pescado y productos pesqueros ahumados, desecados, fermentados y/o salados, incluidos los moluscos, crustáceos y equinodermos

12.1.2 Sucedáneos de la sal

BPF

BPF

XS167, XS189,

2018

$$
\text { \& XS311 }
$$

BPF

2013

13.1.2 Fórmulas (preparados) de continuación

$50 \mathrm{mg} / \mathrm{kg}$

$72,242 \& 315$

2015

13.2 Alimentos complementarios para lactantes y niños

$500 \mathrm{mg} / \mathrm{kg}$

242

2013

14.1.2.1 Zumos (jugos) de frutas

BPF

2005

14.1.2.2 Zumos (jugos) de hortalizas

BPF

2013

14.1.2.3 Concentrados para zumos (jugos) de frutas

BPF

127

2005

14.1.2.4 Concentrados para zumos (jugos) de hortalizas

BPF

2013

14.1.3.1 Néctares de frutas

BPF

2005

14.1.3.2 Néctares de hortalizas

BPF

14.1.3.3 Concentrados para néctares de frutas

BPF

127

14.1.3.4 Concentrados para néctares de hortalizas

BPF

14.1.5 Café, sucedáneos del café, té, infusiones de hierbas y otras bebidas calientes a base de cereales y granos, excluido el

BPF

160

2013 cacao

\section{ÁCIDO CÍTRICO}

SIN 330 Ácido cítrico
Clases Funcionales: Reguladores de la acidez, Antioxidantes, Agentes de retención de color, Secuestrantes

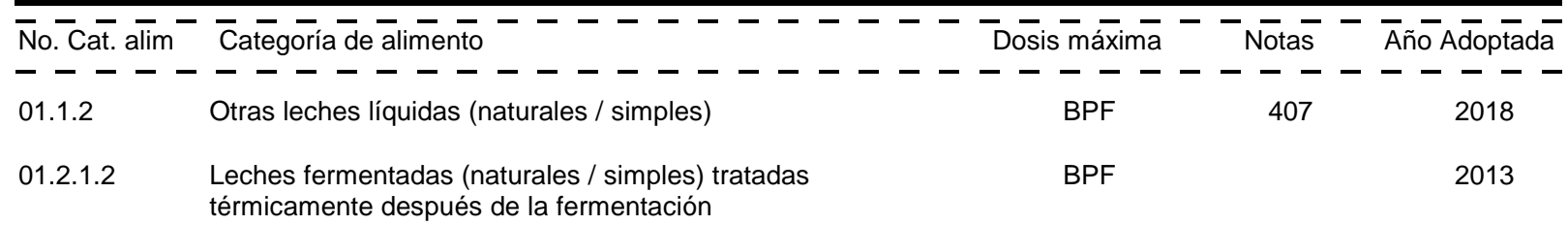


Cuadro I

ÁCIDO CÍTRICO

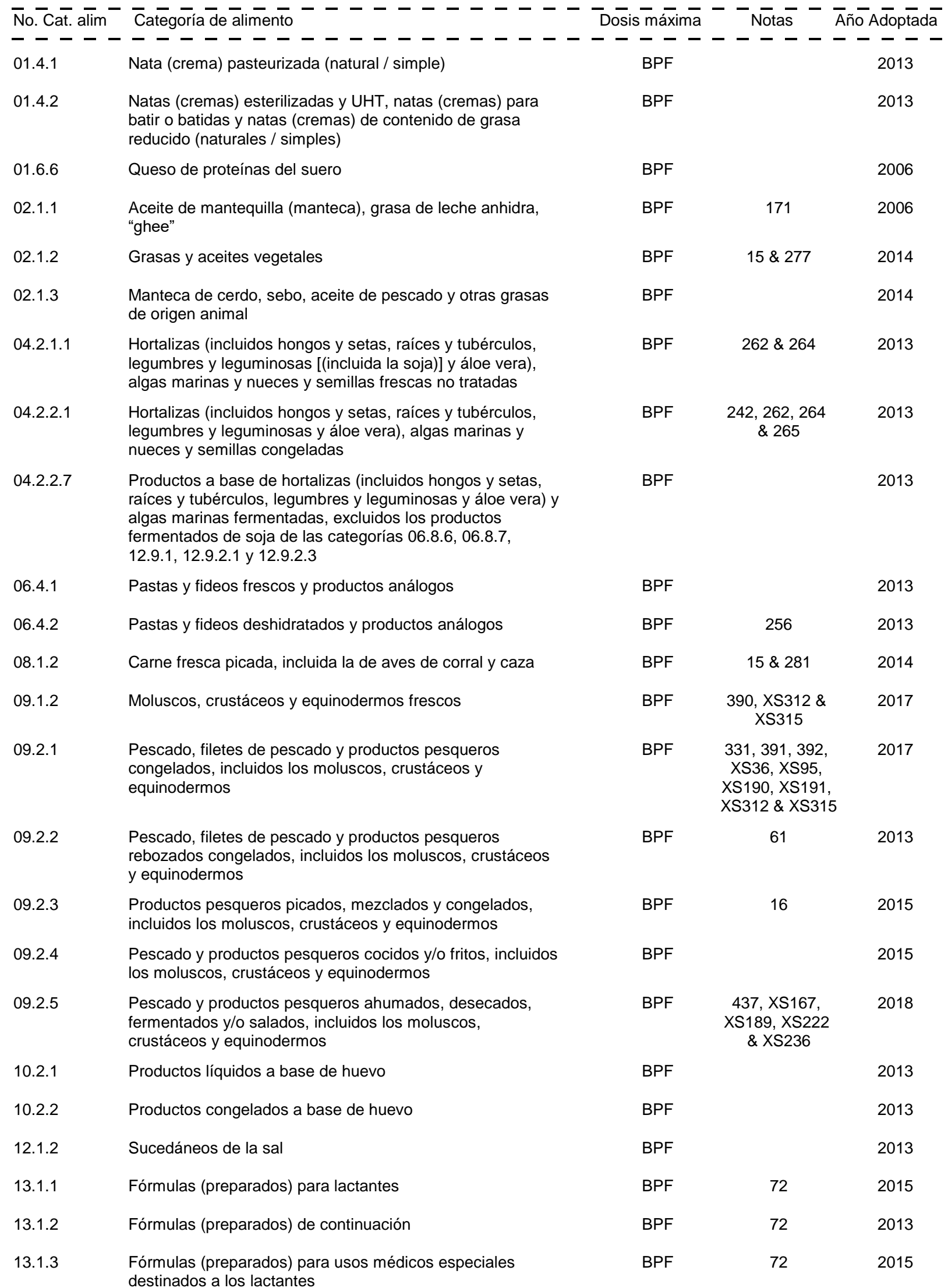


Cuadro I

ÁCIDO CÍTRICO

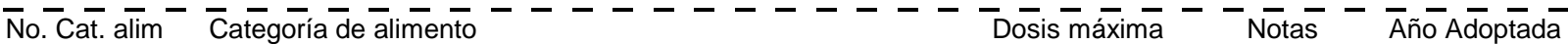

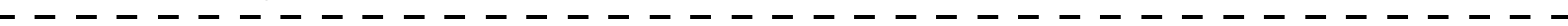
pequeños

14.1.2.1 Zumos (jugos) de frutas

$3000 \mathrm{mg} / \mathrm{kg} \quad 122 \quad 2005$

14.1.2.2 Zumos (jugos) de hortalizas

BPF

2013

14.1.2.3 Concentrados para zumos (jugos) de frutas

$3000 \mathrm{mg} / \mathrm{kg} \quad 122 \& 127 \quad 2005$

14.1.2.4 Concentrados para zumos (jugos) de hortalizas

BPF

2013

14.1.3.1 Néctares de frutas

$5000 \mathrm{mg} / \mathrm{kg}$

2005

14.1.3.2 Néctares de hortalizas

BPF

2013

14.1.3.3 Concentrados para néctares de frutas

$5000 \mathrm{mg} / \mathrm{kg}$

127

2005

14.1.3.4 Concentrados para néctares de hortalizas

BPF

2013

14.1 .5

Café, sucedáneos del café, té, infusiones de hierbas y otras bebidas calientes a base de cereales y granos, excluido el

BPF

160

2013 cacao

\section{ÁCIDO CLORHÍDRICO}

SIN $507 \quad$ Ácido clorhídrico

Clases Funcionales: Reguladores de la acidez

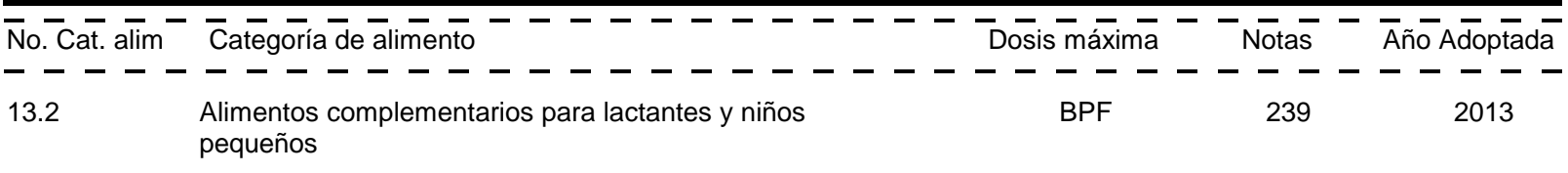

\section{ÁCIDO ERITÓRBICO (ACIDO ISOASCÓBICO)}

SIN 315

Ácido eritórbico (Ácido

Clases Funcionales: Antioxidantes

isoascóbico)

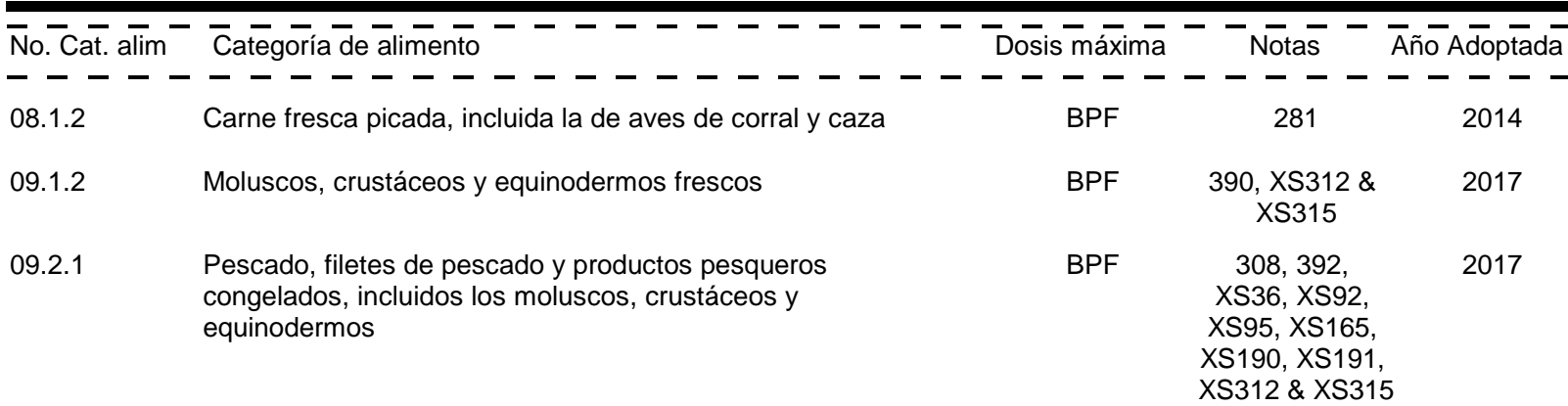

09.2.2 Pescado, filetes de pescado y productos pesqueros

BPF

139 \& XS166

2017 rebozados congelados, incluidos los moluscos, crustáceos y equinodermos

\section{ÁCIDO FUMÁRICO}

SIN $297 \quad$ Ácido fumárico

Clases Funcionales: Reguladores de la acidez

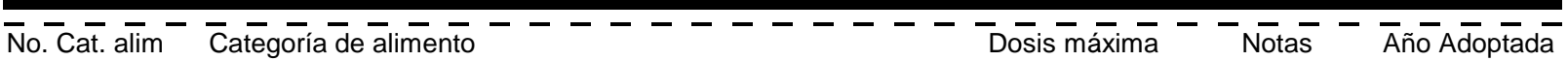


Cuadro I

ÁCIDO FUMÁRICO

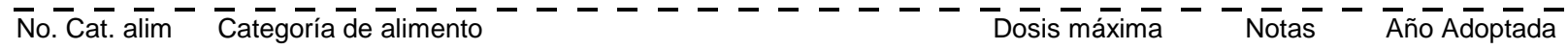

- - - - - - - - - - - - - - - - - - - - - - - raíces y tubérculos, legumbres y leguminosas y áloe vera) y algas marinas fermentadas, excluidos los productos

fermentados de soja de las categorías 06.8.6, 06.8.7, 12.9.1, 12.9.2.1 y 12.9 .2 .3

06.4.1 Pastas y fideos frescos y productos análogos

06.4.2 Pastas y fideos deshidratados y productos análogos

BPF

256

2013

09.2 .2

Pescado, filetes de pescado y productos pesqueros

BPF

$41 \& X S 166$

2017 y equinodermos

09.2.3 Productos pesqueros picados, mezclados y congelados, incluidos los moluscos, crustáceos y equinodermos

BPF

16

2013

09.2.4 Pescado y productos pesqueros cocidos $y / 0$ fritos, incluidos los moluscos, crustáceos y equinodermos

09.2.5 Pescado y productos pesqueros ahumados, desecados, fermentados y/o salados, incluidos los moluscos, crustáceos y equinodermos

12.1.2 Sucedáneos de la sal

BPF

BPF

XS167, XS189,

XS222, XS236

XS244 \& XS311

BPF

2013

BPF

160

2013 bebidas calientes a base de cereales y granos, excluido el cacao

\section{ÁCIDO GLUTÁMICO, L(+)-}

SIN 620 Ácido glutámico, L(+)-

Clases Funcionales: Acentuadores del sabor

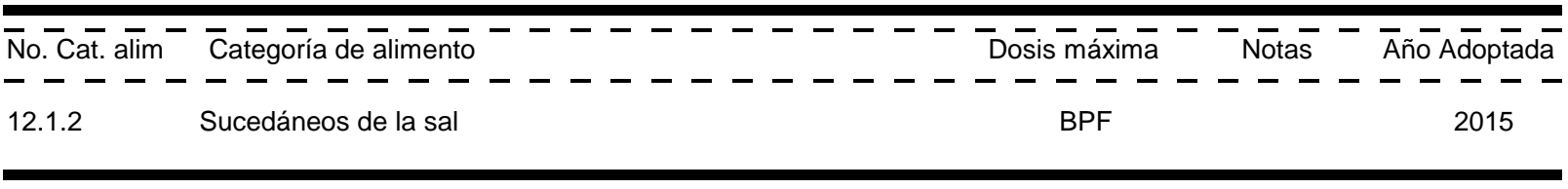

ÁCIDO GUANÍLICO, 5'-

SIN 626 Ácido guanílico, 5'-

Clases Funcionales: Acentuadores del sabor

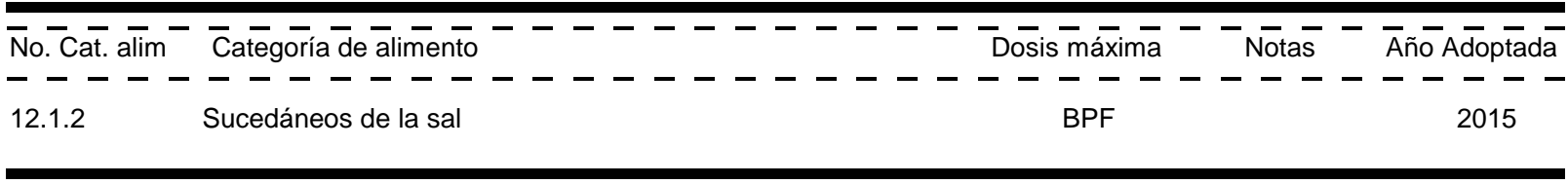

ÁCIDO INOSÍNICO, 5'-

SIN 630 Ácido inosínico, 5'-

Clases Funcionales: Acentuadores del sabor

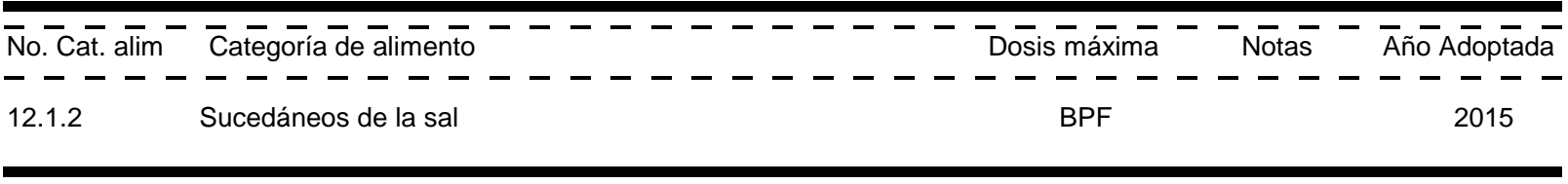

ÁCIDO LÁCTICO, L-, D- y DL-

SIN 270 Ácido láctico, L-, D- y DL-

Clases Funcionales: Reguladores de la acidez

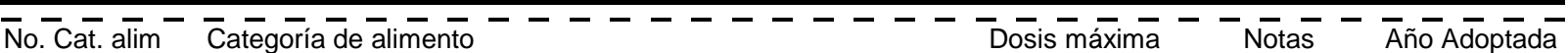

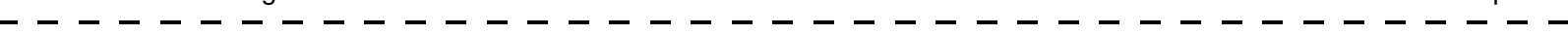


Cuadro I

ÁCIDO LÁCTICO, L-, D- y DL-

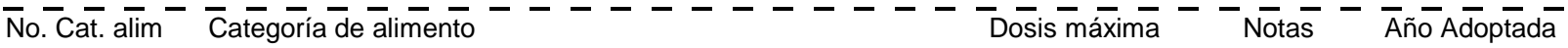

- - - - - - - - - - - - - - - - - - - - - - - - - - -

$\begin{array}{llll}\text { 01.4.1 Nata (crema) pasteurizada (natural / simple) } & \text { BPF } & 2013\end{array}$

01.4.2 Natas (cremas) esterilizadas y UHT, natas (cremas) para

BPF

2013

batir o batidas y natas (cremas) de contenido de grasa

reducido (naturales / simples)

01.6.6 Queso de proteínas del suero

BPF

2006

04.2.1.1 Hortalizas (incluidos hongos y setas, raíces y tubérculos, legumbres y leguminosas [(incluida la soja)] y áloe vera),

BPF

$262 \& 264$

2013 algas marinas y nueces y semillas frescas no tratadas

04.2.2.1 Hortalizas (incluidos hongos y setas, raíces y tubérculos, legumbres y leguminosas y áloe vera), algas marinas y nueces y semillas congeladas

04.2.2.7 Productos a base de hortalizas (incluidos hongos y setas, raíces y tubérculos, legumbres y leguminosas y áloe vera) y algas marinas fermentadas, excluidos los productos fermentados de soja de las categorías 06.8.6, 06.8.7, 12.9.1, 12.9.2.1 y 12.9.2.3

06.4.1 Pastas y fideos frescos y productos análogos

06.4.2 Pastas y fideos deshidratados y productos análogos

09.2.5 Pescado y productos pesqueros ahumados, desecados, fermentados y/o salados, incluidos los moluscos,

10.2.1 Productos líquidos a base de huevo BPF

10.2.2 Productos congelados a base de huevo

12.1.2 Sucedáneos de la sal

13.1.3 Fórmulas (preparados) para usos médicos especiales destinados a los lactantes 
Cuadro I

ÁCIDO MÁLICO, DL-

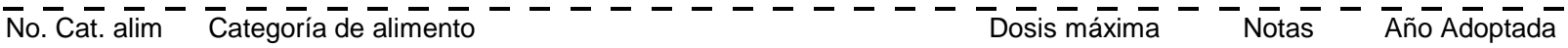

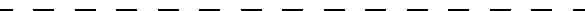
rebozados congelados, incluidos los moluscos, crustáceos

$\begin{array}{lll} & 41 \& \text { XS166 } & 2017\end{array}$ y equinodermos

09.2.3 Productos pesqueros picados, mezclados y congelados,

BPF

16

2013 incluidos los moluscos, crustáceos y equinodermos

09.2.4 Pescado y productos pesqueros cocidos $y / 0$ fritos, incluidos los moluscos, crustáceos y equinodermos

BPF

2013

09.2.5 Pescado y productos pesqueros ahumados, desecados, fermentados y/o salados, incluidos los moluscos,

BPF

XS167, XS189

XS222, XS236

crustáceos y equinodermos

XS244 \& XS311

12.1.2 Sucedáneos de la sal

BPF

2013

13.2 Alimentos complementarios para lactantes y niños

BPF

239

2013

14.1.2.1 Zumos (jugos) de frutas

BPF

115

2005

14.1.2.2 Zumos (jugos) de hortalizas

BPF

2013

14.1.2.3 Concentrados para zumos (jugos) de frutas

BPF

$115 \& 127$

2005

14.1.2.4 Concentrados para zumos (jugos) de hortalizas

BPF

2013

14.1.3.1 Néctares de frutas

BPF

14.1.3.2

Néctares de hortalizas

BPF

2013

14.1.3.3 Concentrados para néctares de frutas

BPF

2005

14.1.3.4 Concentrados para néctares de hortalizas

BPF

2013

Café, sucedáneos del café, té, infusiones de hierbas y otras bebidas calientes a base de cereales y granos, excluido el

BPF

160

2013 cacao

\section{ÁCIDO PROPIONICO}

SIN 280 Ácido propionico

Clases Funcionales: Sustancias conservadoras

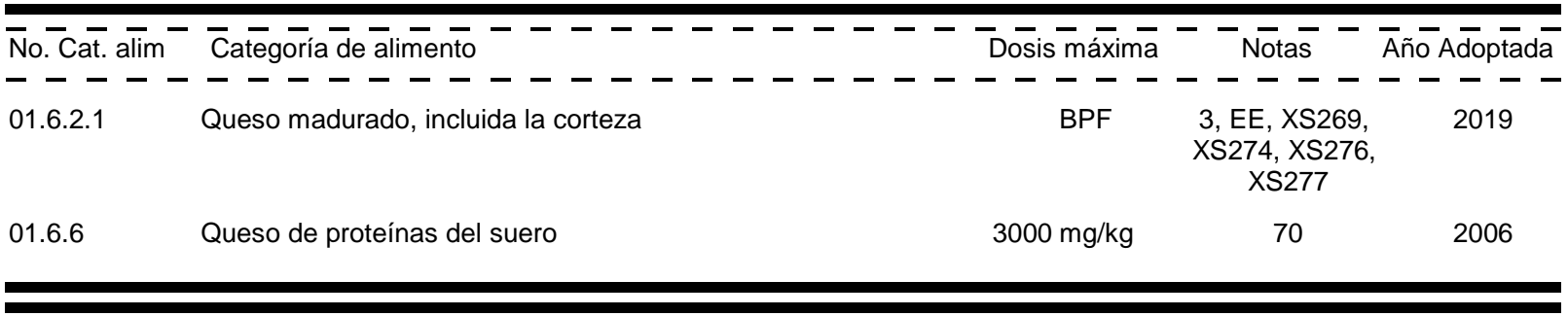

\section{ADIPATO DE DIALMIDÓN ACETILADO}

SIN 1422 Adipato de dialmidón acetilado Clases Funcionales: Emulsionantes, Estabilizadores, Espesantes

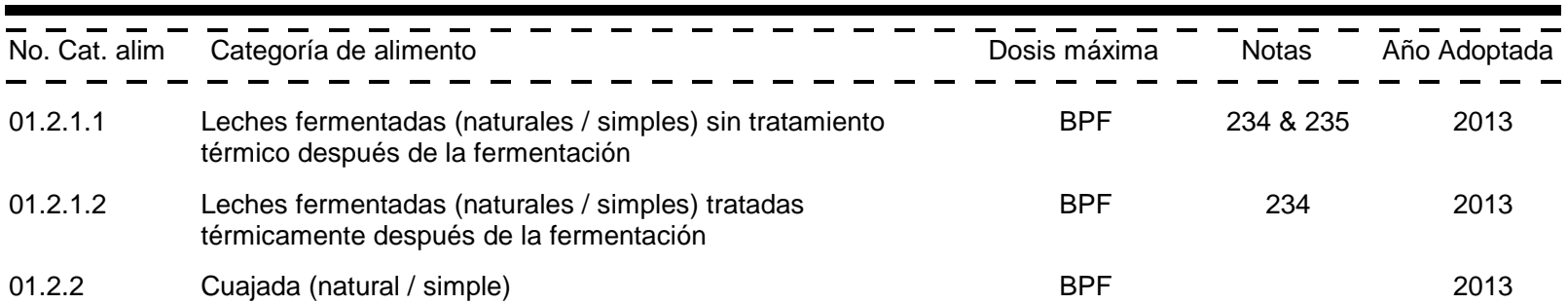


ADIPATO DE DIALMIDÓN ACETILADO

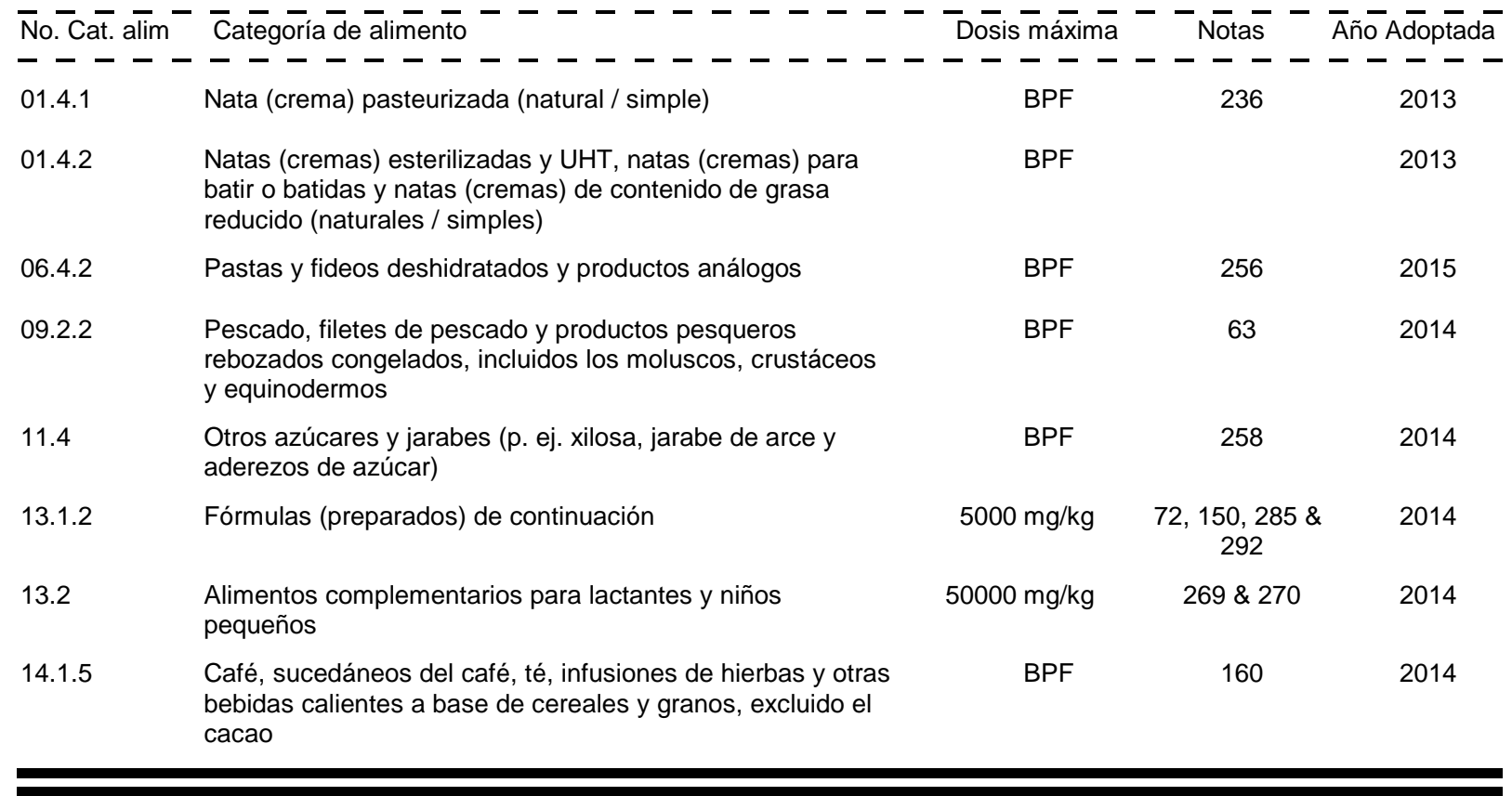

ADIPATOS

SIN 355 Ácido adípico Clases Funcionales: Reguladores de la acidez

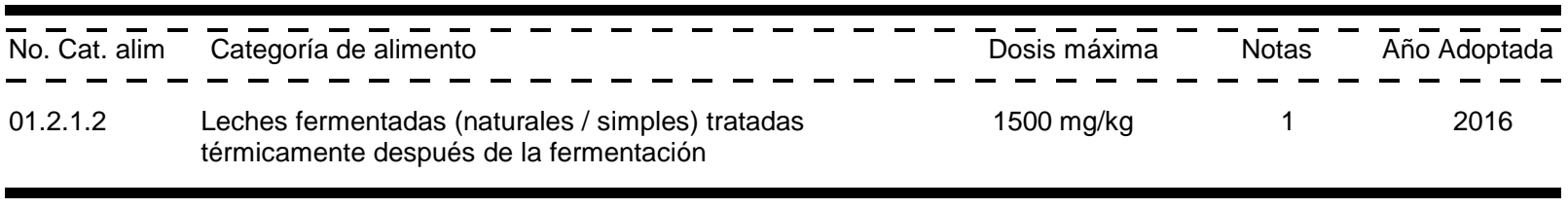

AGAR

SIN 406 Agar Clases Funcionales: Incrementadores del volumen, Sustancias inertes, Emulsionantes, Agentes gelificantes, Agentes de glaseado, Humectantes, Estabilizadores, Espesantes

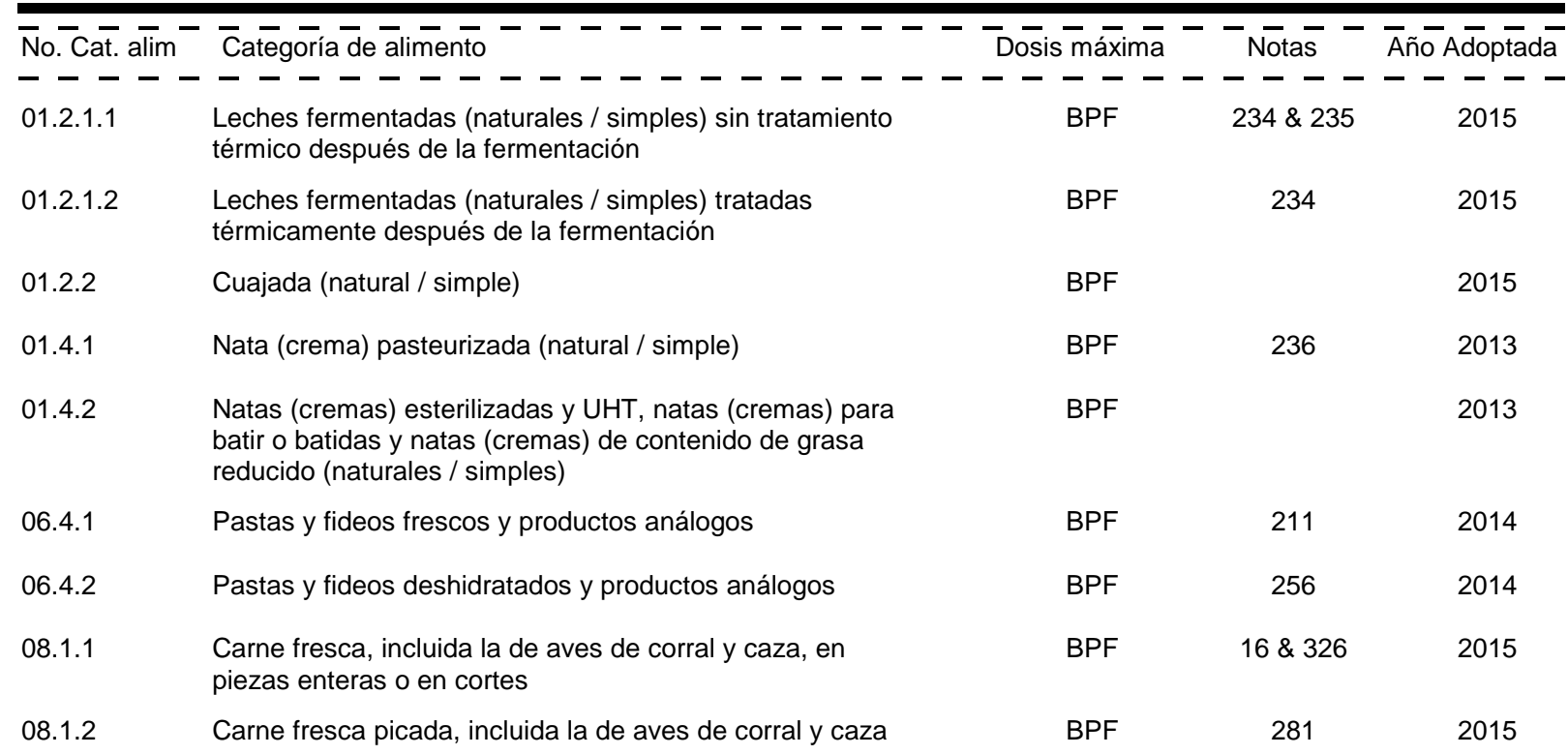


Cuadro I

AGAR

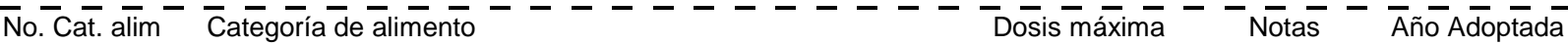

- - - - - - - - - - - - - - - - - - - -

09.2.1 Pescado, filetes de pescado y productos pesqueros

BPF congelados, incluidos los moluscos, crustáceos y equinodermos

$3,53, \mathrm{XS} 36$

XS92, XS95,

XS165, XS190

XS191, XS292,

XS312 \& XS315

09.2.2 Pescado, filetes de pescado y productos pesqueros rebozados congelados, incluidos los moluscos, crustáceos

XS166

2017 y equinodermos

09.2.3 Productos pesqueros picados, mezclados y congelados, incluidos los moluscos, crustáceos y equinodermos

09.2.4.1 Pescado y productos pesqueros cocidos

BPF

09.2.4.2 Moluscos, crustáceos y equinodermos cocidos

BPF

09.2.4.3 Pescado y productos pesqueros fritos, incluidos los moluscos, crustáceos y equinodermos

09.2.5 Pescado y productos pesqueros ahumados, desecados, fermentados y/o salados, incluidos los moluscos,

crustáceos y equinodermos

BPF

241

2015

BPF

241

2015

BPF

$41 \& 325$

2015

BPF

$300, \mathrm{XS} 167$

XS189, XS222

XS236, XS244

\& XS311

10.2.1 Productos líquidos a base de huevo

BPF

10.2.2 Productos congelados a base de huevo

BPF

11.4 Otros azúcares y jarabes (p. ej. xilosa, jarabe de arce y

BPF

2014 aderezos de azúcar)

BPF

14.1.5 Café, sucedáneos del café, té, infusiones de hierbas y otras bebidas calientes a base de cereales y granos, excluido el

BPF

160

2014 cacao

\section{ALCOHOL POLIVINÍLICO}

SIN 1203 Alcohol polivinílico Clases Funcionales: Agentes de glaseado, Espesantes

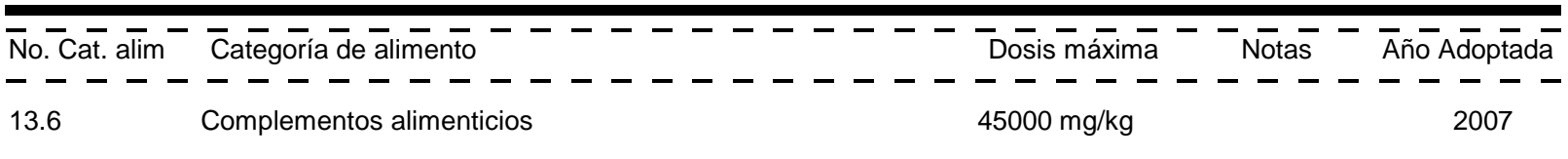

ALFA-AMILASA DE ASPERGILLUS ORYZAE VAR.

SIN 1100(i) alfa-Amilasa de Aspergillus Clases Funcionales: Agentes de tratamiento de las harinas oryzae var.

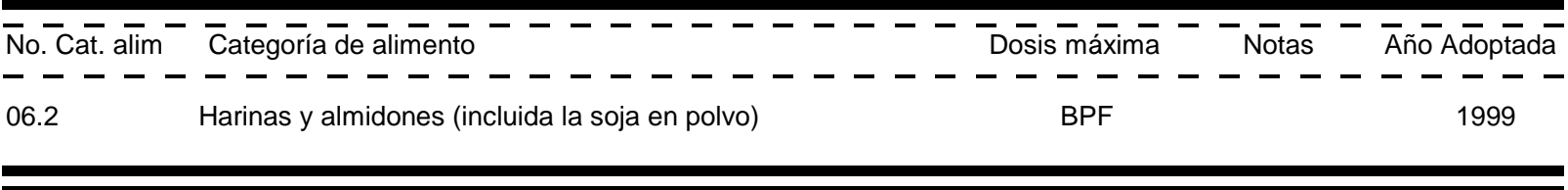

\section{ALFA-AMILASA DE BACILLUS SUBTILIS}

SIN 1100(iii) alfa-Amilasa de Bacillus subtilis Clases Funcionales: Agentes de tratamiento de las harinas

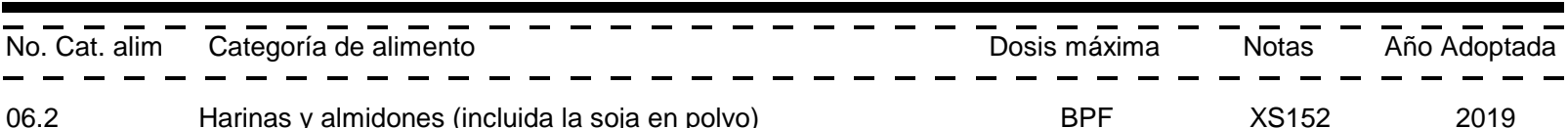




\section{ALGA EUCHEUMA ELABORADA}

SIN 407a Alga euchema elaborad

Clases Funcionales: Incrementadores del volumen, Sustancias inertes, Emulsionantes, Agentes gelificantes, Agentes de glaseado, Humectantes, Estabilizadores, Espesantes

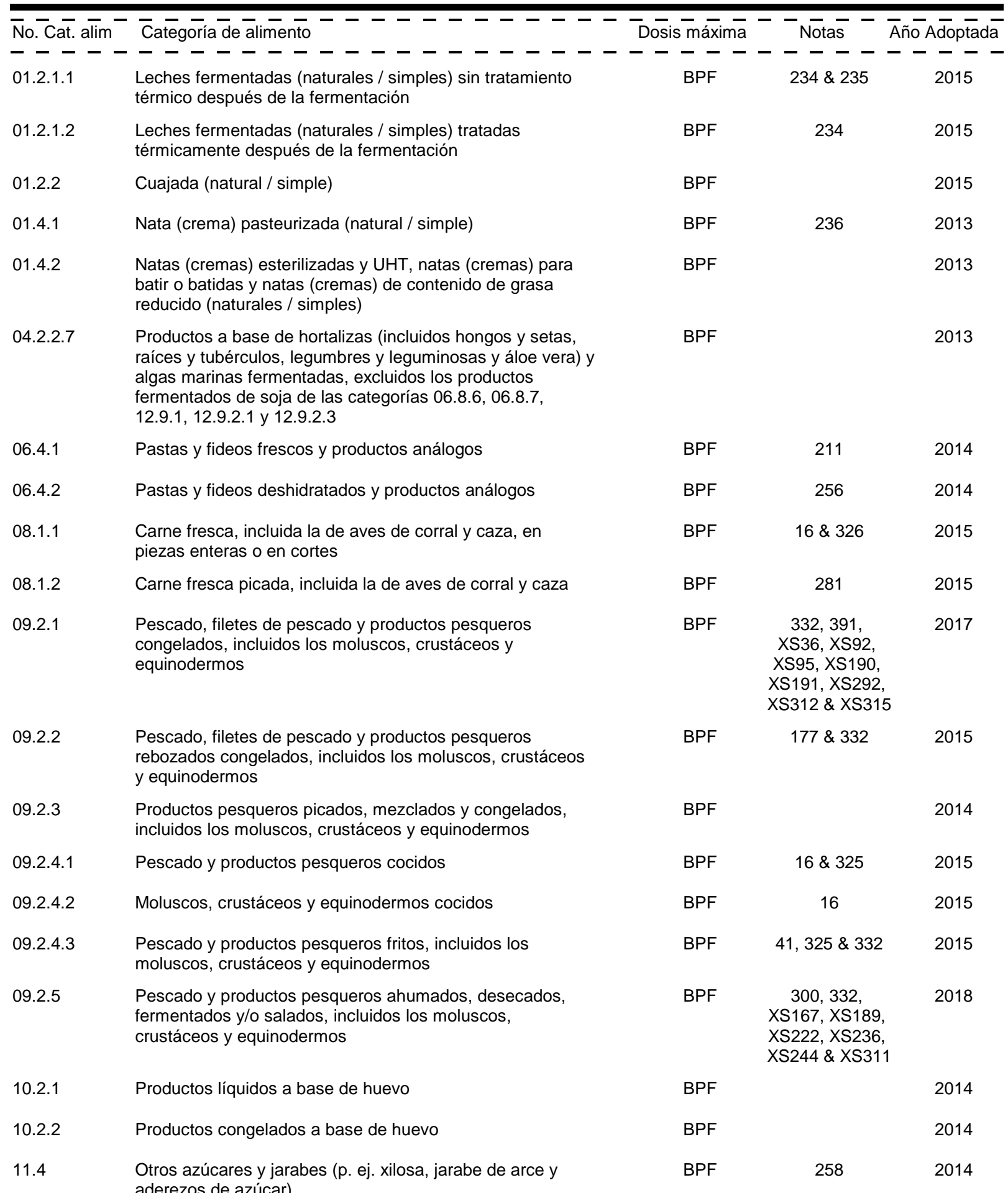


ALGA EUCHEUMA ELABORADA

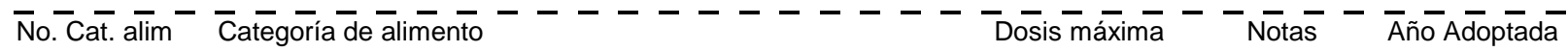

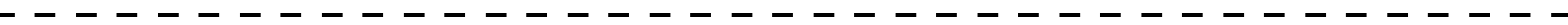

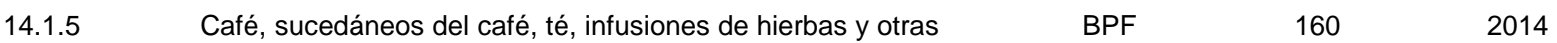
bebidas calientes a base de cereales y granos, excluido el cacao

\section{ALGINATO DE AMONIO}

SIN $403 \quad$ Alginato de amonio

Clases Funcionales: Incrementadores del volumen, Sustancias inertes, Emulsionantes, Espumantes, Agentes gelificantes, Agentes de glaseado, Humectantes, Secuestrantes, Estabilizadores, Espesantes

\begin{tabular}{|c|c|c|c|c|}
\hline 01.2.1.2 & $\begin{array}{l}\text { Leches fermentadas (naturales / simples) tratadas } \\
\text { térmicamente después de la fermentación }\end{array}$ & BPF & 234 & 2013 \\
\hline 01.4 .1 & Nata (crema) pasteurizada (natural / simple) & BPF & 236 & 2013 \\
\hline 01.4 .2 & $\begin{array}{l}\text { Natas (cremas) esterilizadas y UHT, natas (cremas) para } \\
\text { batir o batidas y natas (cremas) de contenido de grasa } \\
\text { reducido (naturales / simples) }\end{array}$ & BPF & & 2013 \\
\hline 06.4 .2 & Pastas y fideos deshidratados y productos análogos & BPF & 256 & 2014 \\
\hline 09.2 .1 & $\begin{array}{l}\text { Pescado, filetes de pescado y productos pesqueros } \\
\text { congelados, incluidos los moluscos, crustáceos y } \\
\text { equinodermos }\end{array}$ & BPF & $\begin{array}{l}\text { XS36, XS92, } \\
\text { XS95, XS165, } \\
\text { XS190, XS191, } \\
\text { XS292, XS312 } \\
\text { \& XS315 }\end{array}$ & 2017 \\
\hline 09.2 .2 & $\begin{array}{l}\text { Pescado, filetes de pescado y productos pesqueros } \\
\text { rebozados congelados, incluidos los moluscos, crustáceos } \\
\text { y equinodermos }\end{array}$ & BPF & 63 & 2017 \\
\hline 11.4 & $\begin{array}{l}\text { Otros azúcares y jarabes (p. ej. xilosa, jarabe de arce y } \\
\text { aderezos de azúcar) }\end{array}$ & BPF & 258 & 2014 \\
\hline
\end{tabular}

ALGINATO DE CALCIO

SIN $404 \quad$ Alginato de calcio

Clases Funcionales: Antiespumantes, Incrementadores del volumen, Sustancias inertes, Espumantes, Agentes gelificantes, Agentes de glaseado, Humectantes, Secuestrantes, Estabilizadores, Espesantes

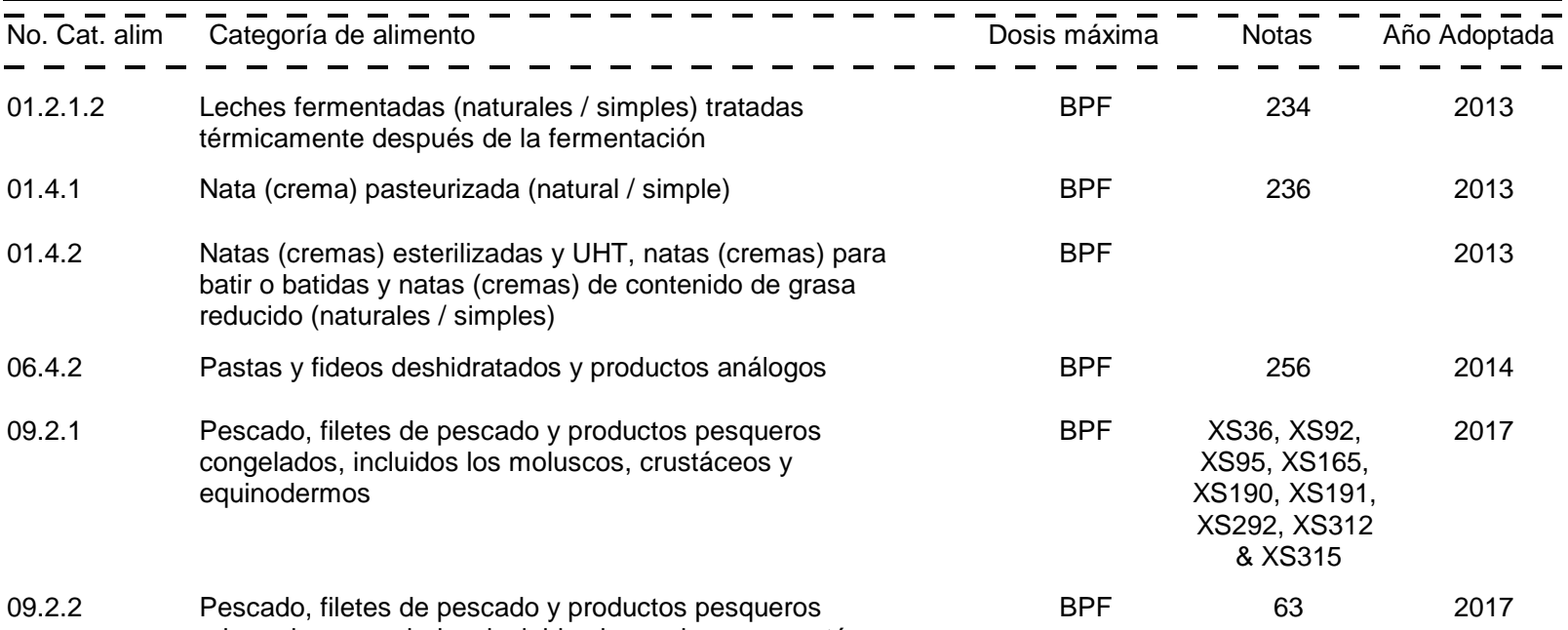
y equinodermos 
ALGINATO DE CALCIO

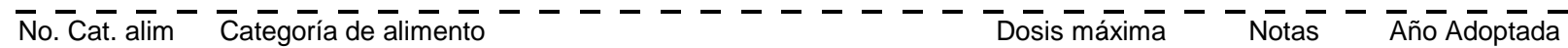

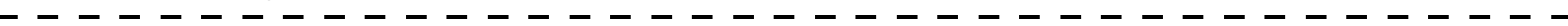

10.2.1 Productos líquidos a base de huevo $\quad$ BPF 2014

10.2.2 Productos congelados a base de huevo BPF

11.4 Otros azúcares y jarabes (p. ej. xilosa, jarabe de arce y $\quad$ BPF 2014 aderezos de azúcar)

\section{ALGINATO DE POTASIO}

SIN $402 \quad$ Alginato de potasio
Clases Funcionales: Incrementadores del volumen, Sustancias inertes, Emulsionantes, Espumantes, Agentes gelificantes, Agentes de glaseado, Humectantes, Secuestrantes, Estabilizadores, Espesantes

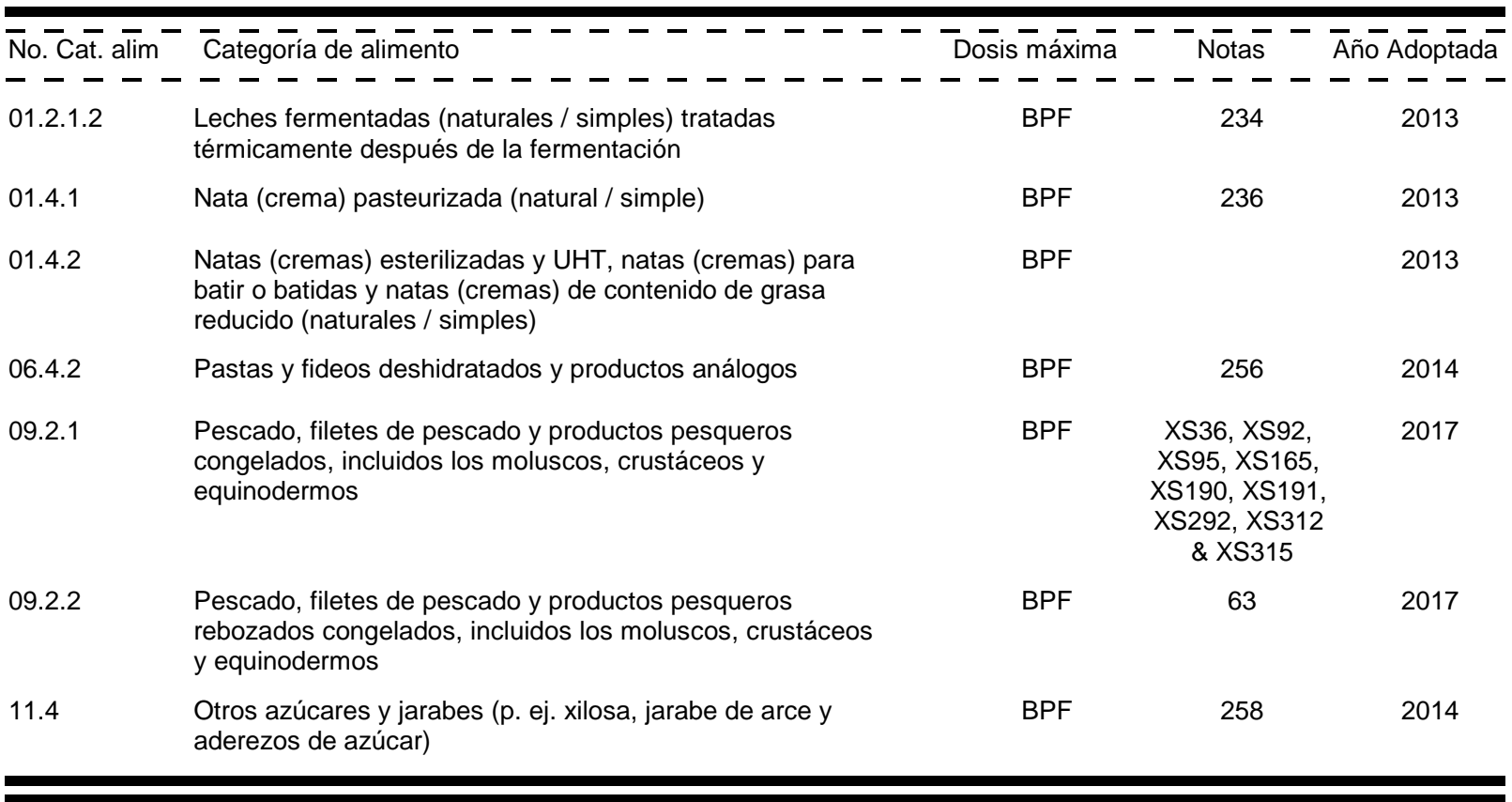

\section{ALGINATO DE PROPILENGLICOL}

Clases Funcionales: Incrementadores del volumen, Sustancias inertes, Emulsionantes, Espumantes, Agentes gelificantes, Estabilizadores, Espesantes

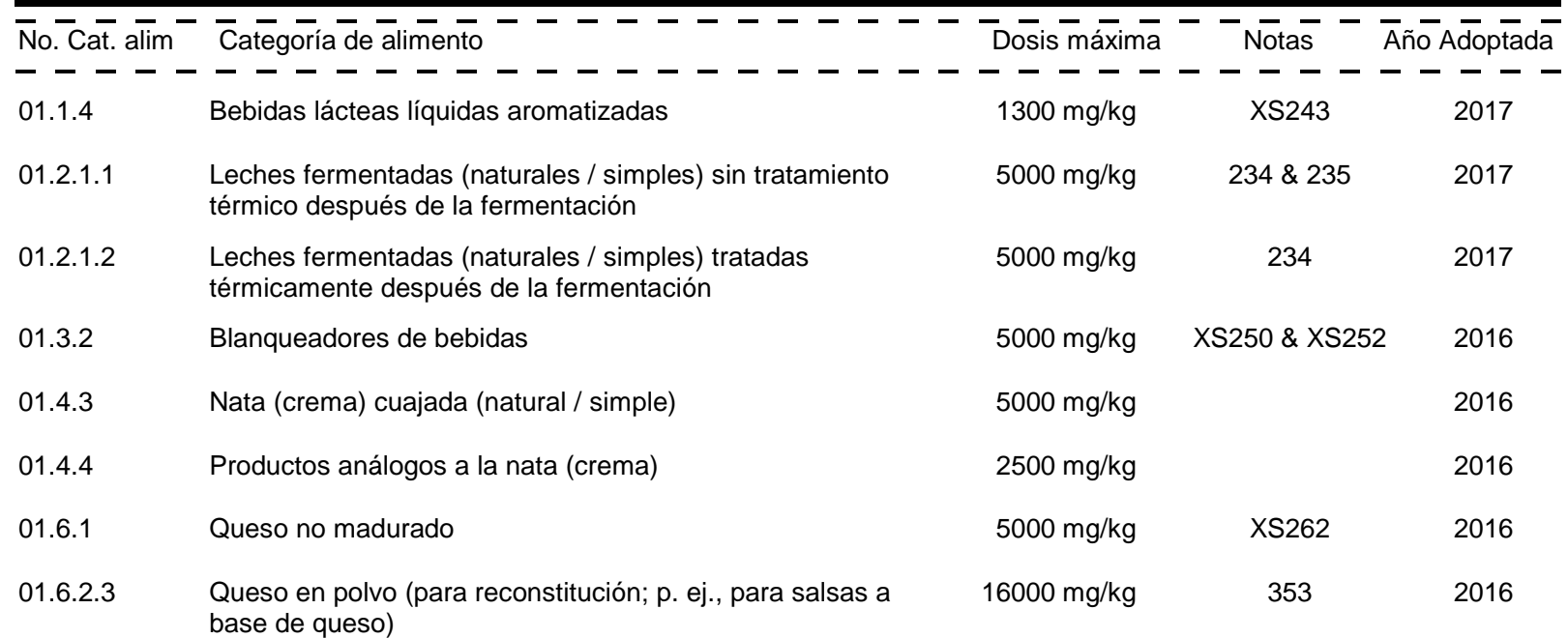


Cuadro I

ALGINATO DE PROPILENGLICOL

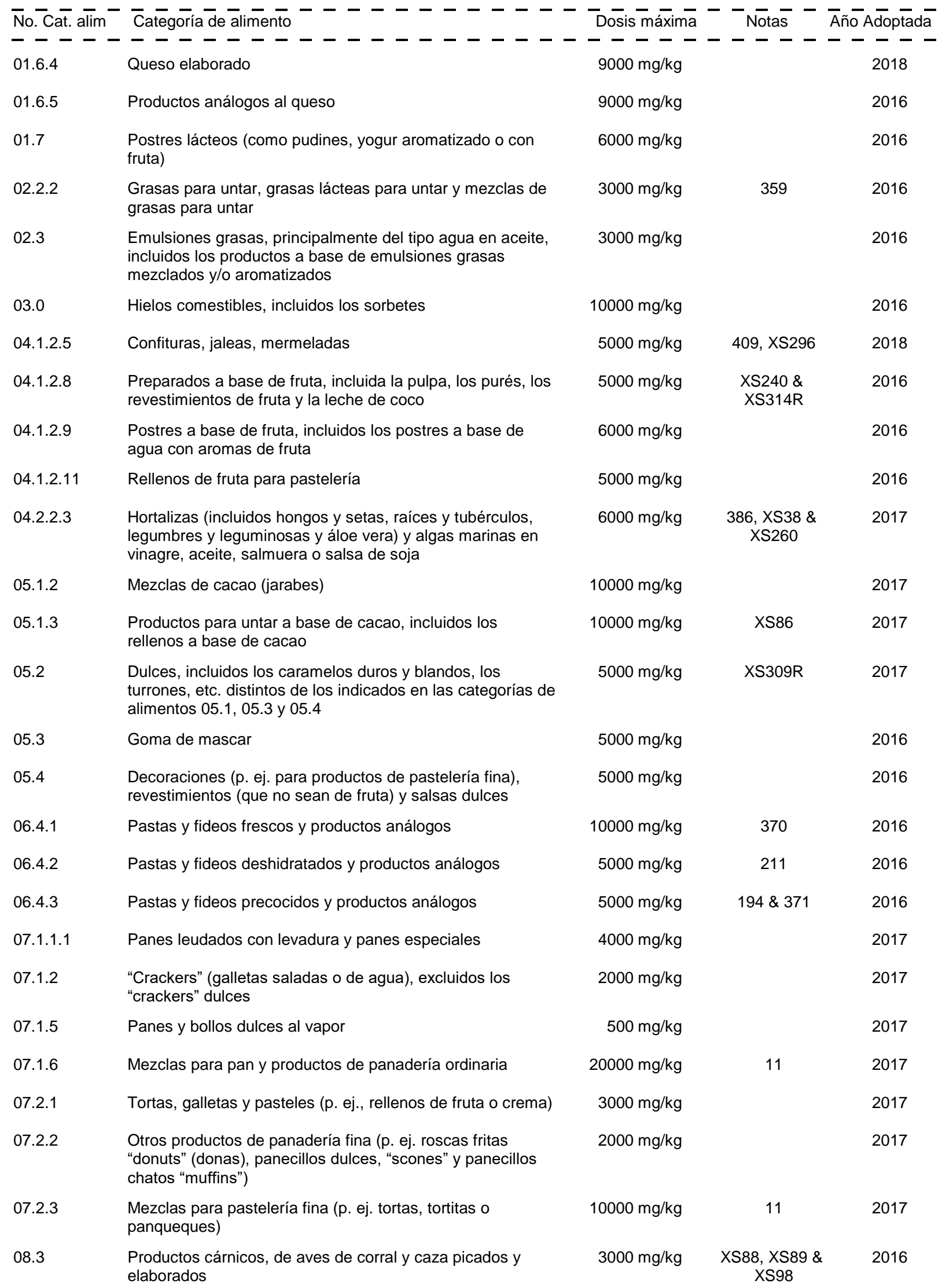


Cuadro I

ALGINATO DE PROPILENGLICOL

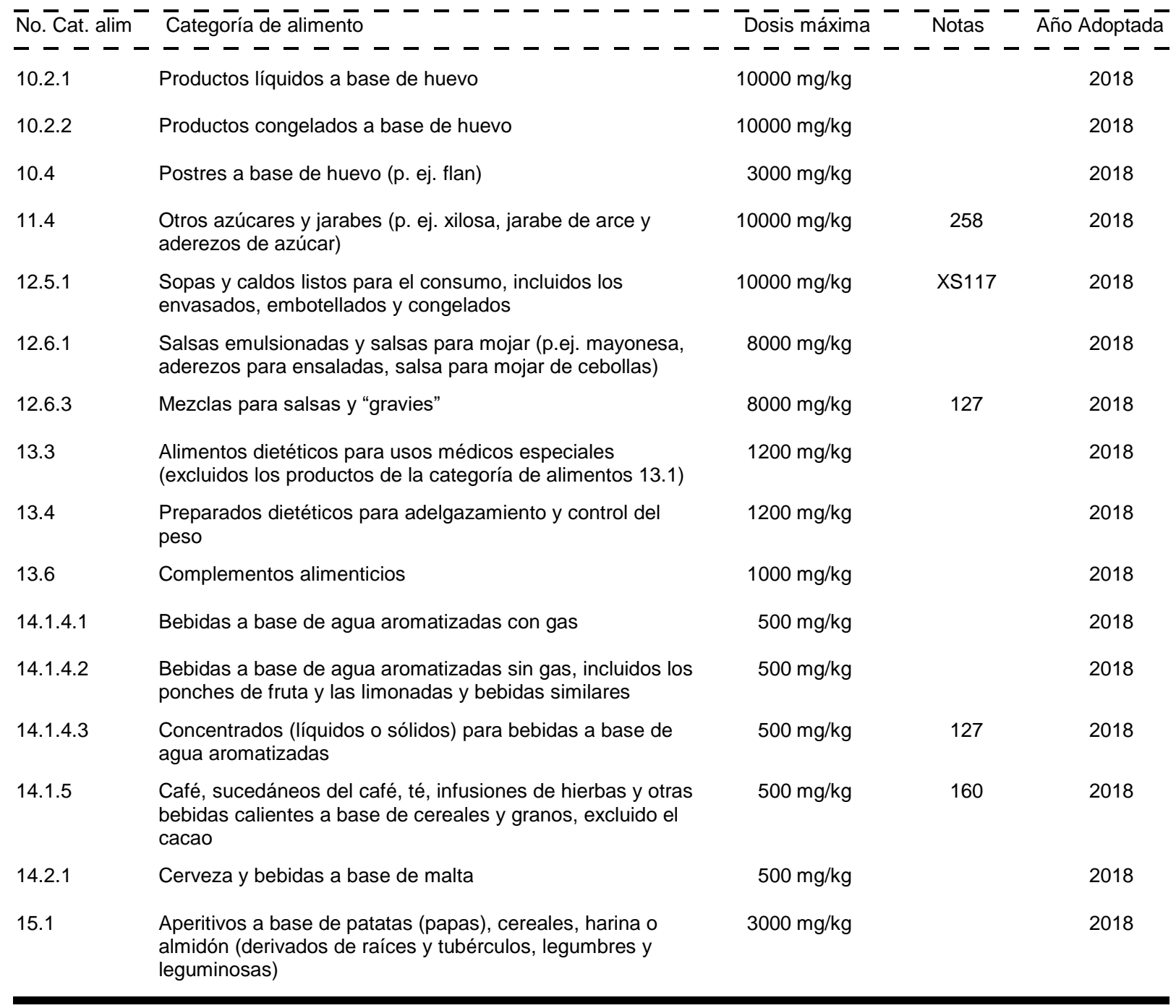

\section{ALGINATO DE SODIO}

SIN $401 \quad$ Alginato de sodio

Clases Funcionales: Incrementadores del volumen, Sustancias inertes, Emulsionantes, Espumantes, Agentes gelificantes, Agentes de glaseado, Humectantes, Secuestrantes, Estabilizadores, Espesantes

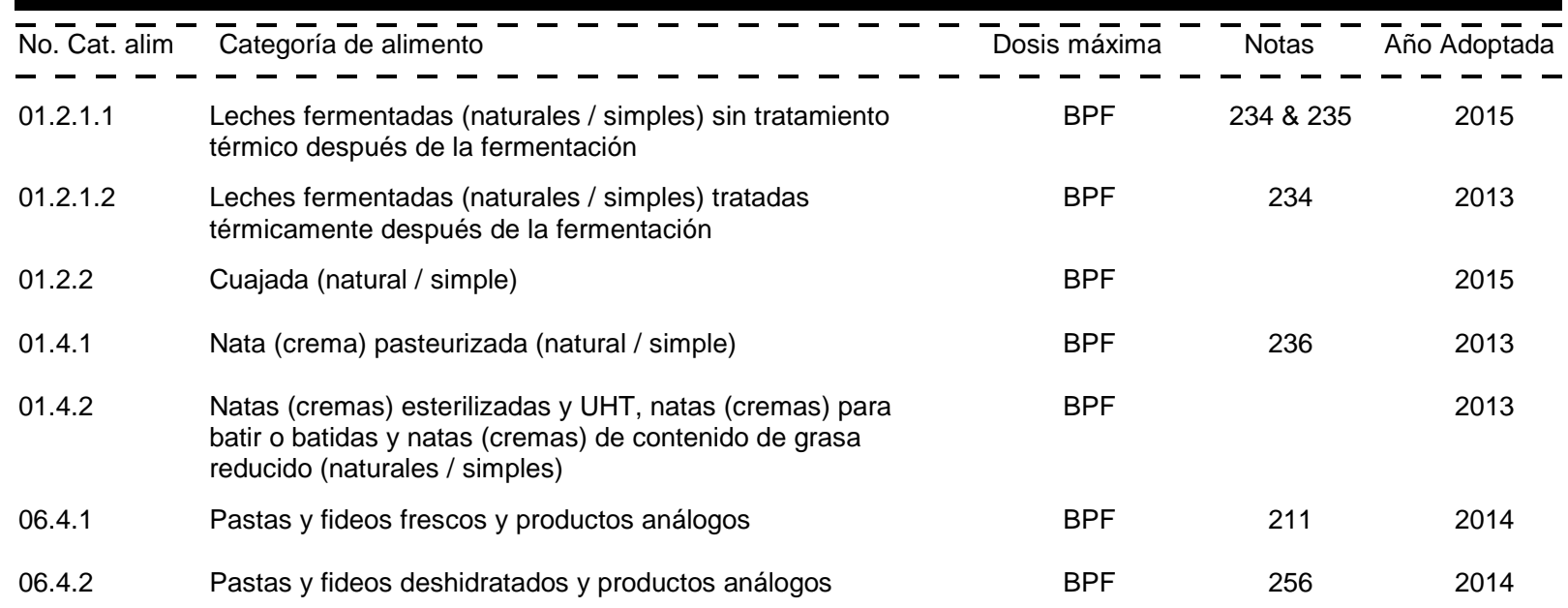


Cuadro I

ALGINATO DE SODIO

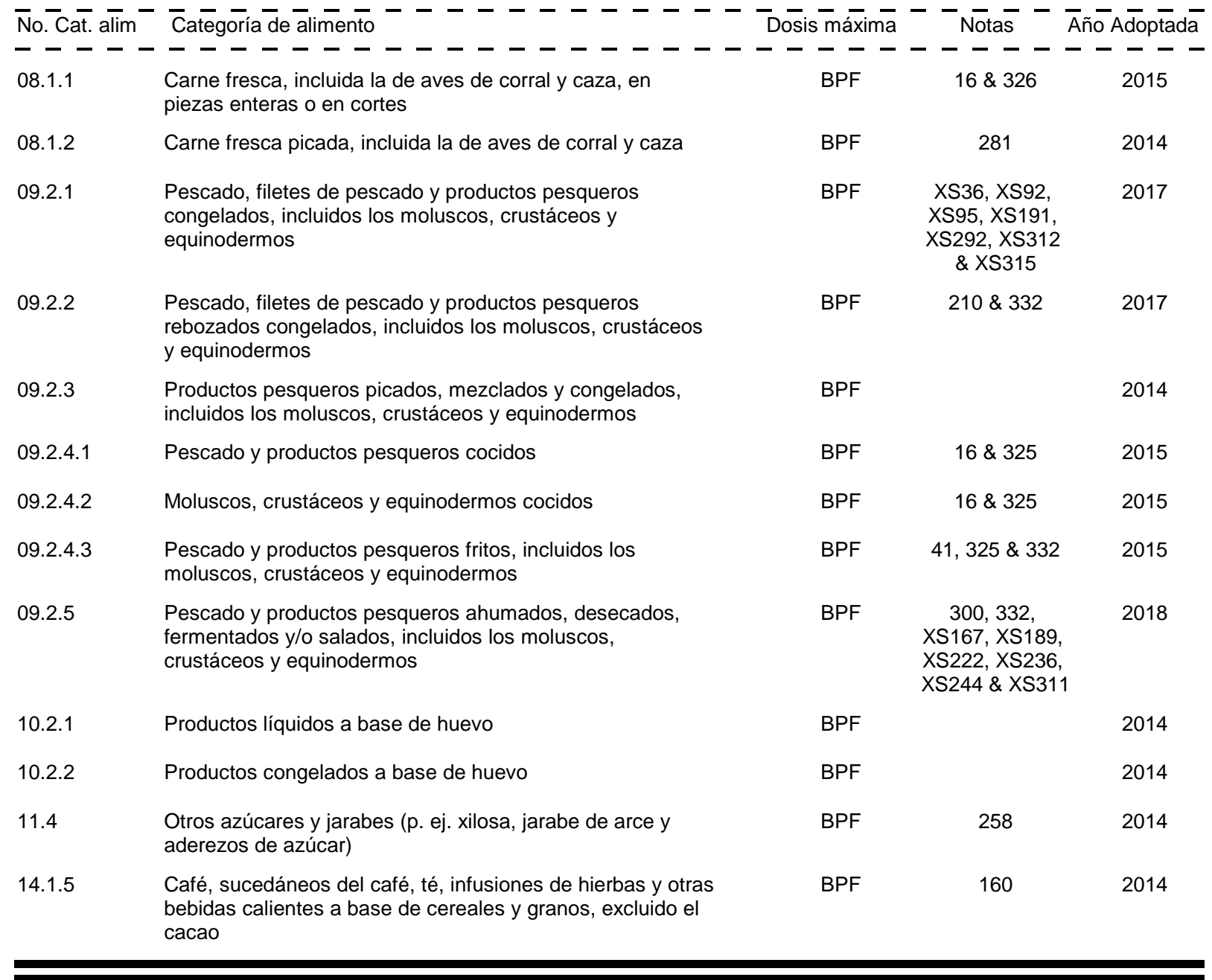

\section{ALITAME}

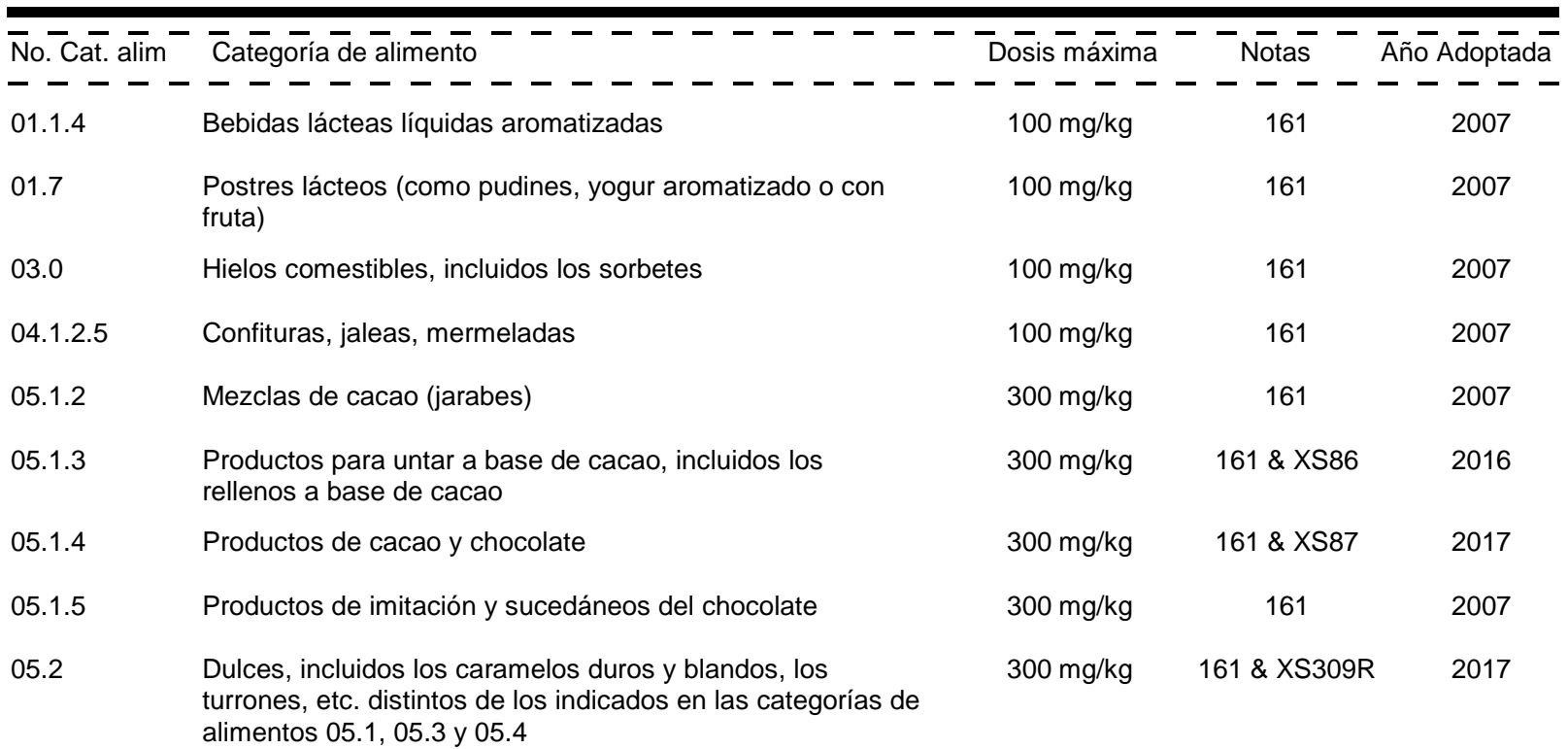


Cuadro I

ALITAME

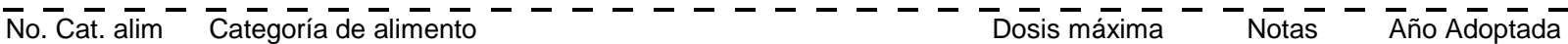
- - - - - - - - - - - - - - - - - - - - - - - - - - -

$\begin{array}{llrl}05.3 \quad \text { Goma de mascar } & 300 \mathrm{mg} / \mathrm{kg} & 161 & 2007\end{array}$

$05.4 \quad$ Decoraciones (p. ej. para productos de pastelería fina),

$300 \mathrm{mg} / \mathrm{kg} \quad 161 \quad 2007$ revestimientos (que no sean de fruta) y salsas dulces

$11.4 \quad$ Otros azúcares y jarabes (p. ej. xilosa, jarabe de arce y aderezos de azúcar)

$11.6 \quad$ Edulcorantes de mesa, incluidos los que contienen edulcorantes de gran intensidad

12.5

Sopas y caldos

$200 \mathrm{mg} / \mathrm{kg}$

159

2007

BPF

2007

13.5

Alimentos dietéticos (p. ej. los complementos alimenticios para usos dietéticos), excluidos los indicados en las categorías de alimentos 13.1 a 13.4 y 13.6

$\begin{array}{cr}\text { BPF } & 2007 \\ 40 \mathrm{mg} / \mathrm{kg} & 161 \& \mathrm{XS} 117 \\ 300 \mathrm{mg} / \mathrm{kg} & 2015 \\ & 2007\end{array}$

14.1.4 Bebidas a base de agua aromatizadas, incluidas las bebidas para deportistas, bebidas energéticas o bebidas

$40 \mathrm{mg} / \mathrm{kg}$

161

2007 electrolíticas y bebidas con partículas añadidas

\section{ALMIDÓN ACETILADO OXIDADO}

SIN 1451 Almidón acetilado oxidado Clases Funcionales: Emulsionantes, Estabilizadores, Espesantes

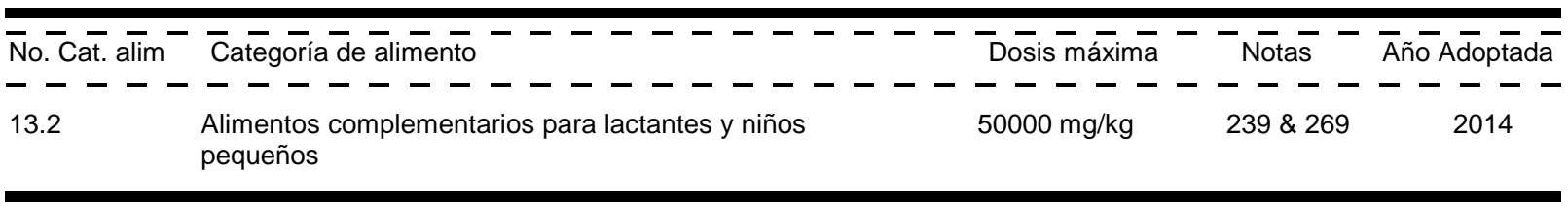

\section{ALMIDÓN BLANQUEADO}

\section{SIN 1403 Almidón blanqueado Clases Funcionales: Emulsionantes, Estabilizadores, Espesantes}

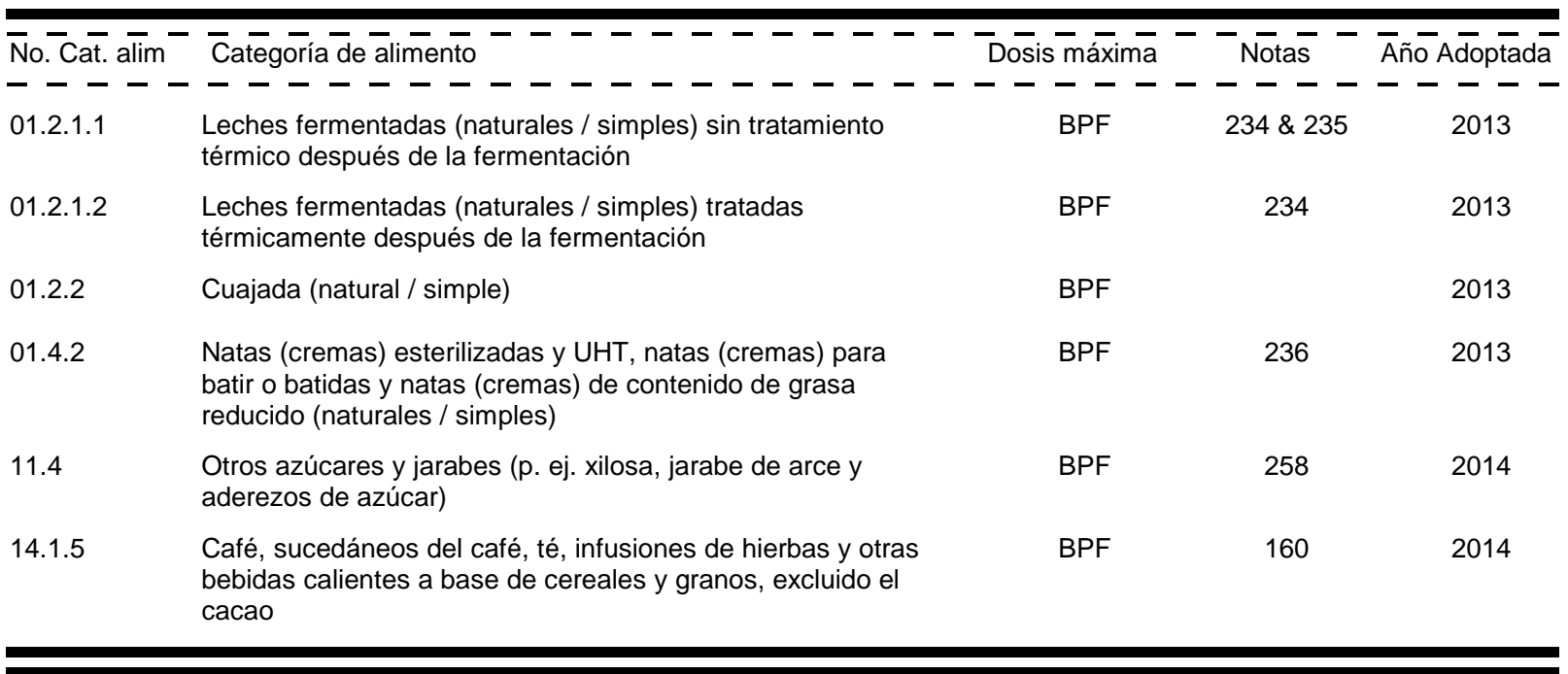

\section{ALMIDÓN HIDROXIPROPÍLICO}

SIN 1440 Almidón hidroxipropílico Clases Funcionales: Emulsionantes, Estabilizadores, Espesantes

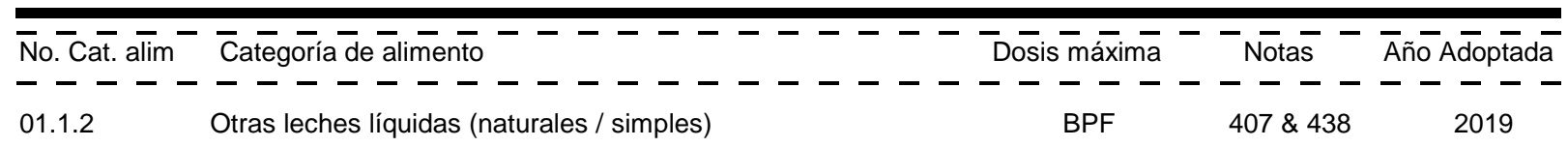


Cuadro I

ALMIDÓN HIDROXIPROPÍLICO

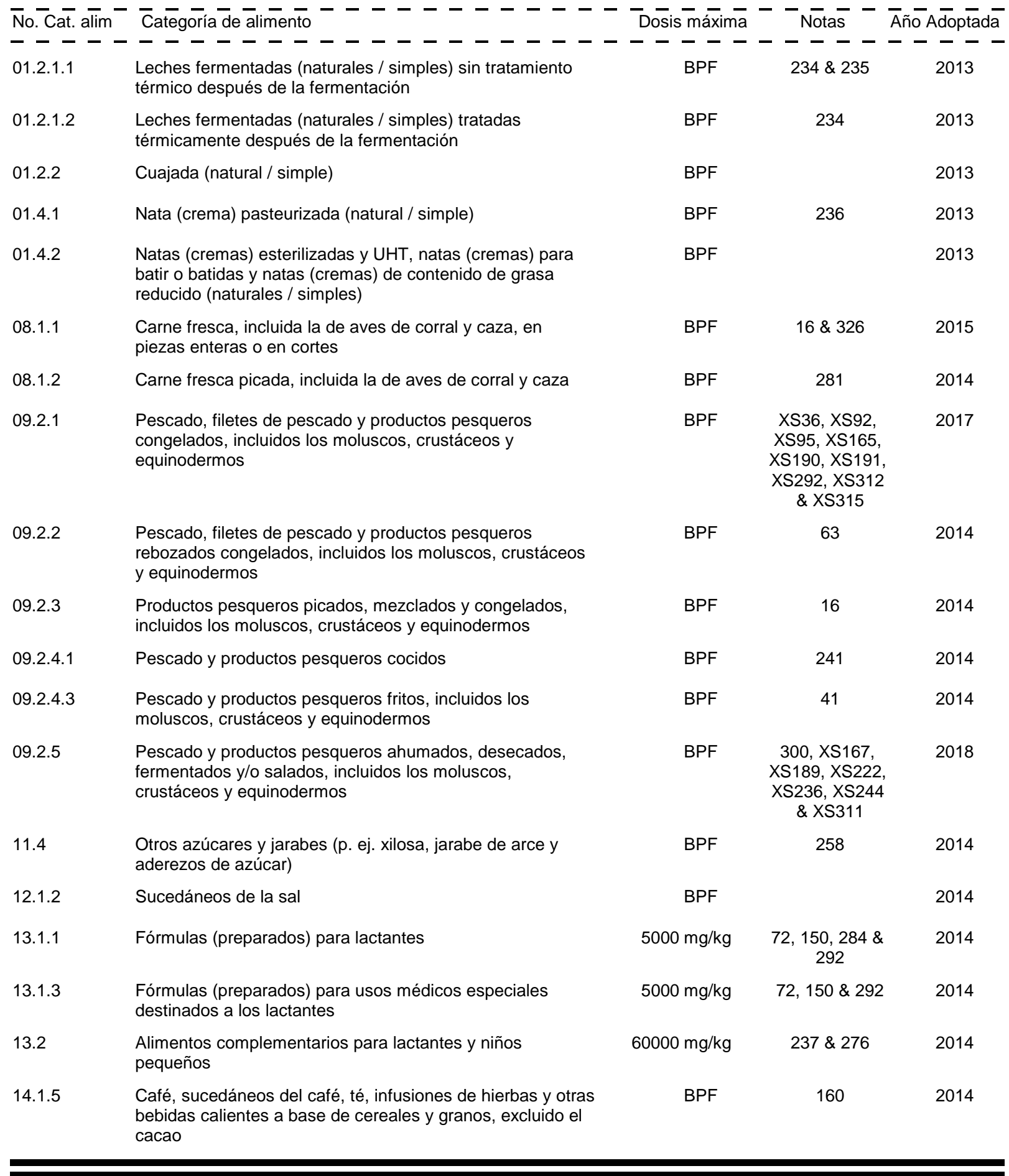

\section{ALMIDÓN OXIDADO}

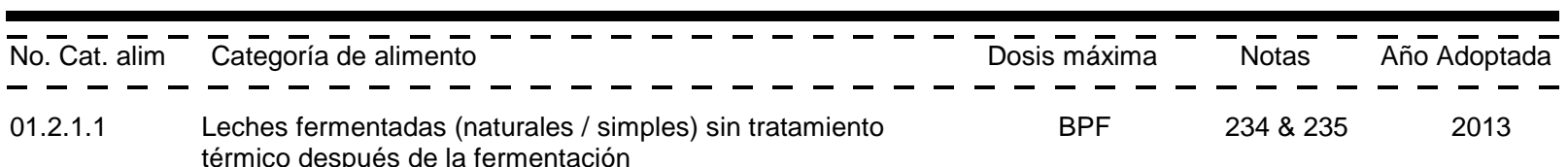




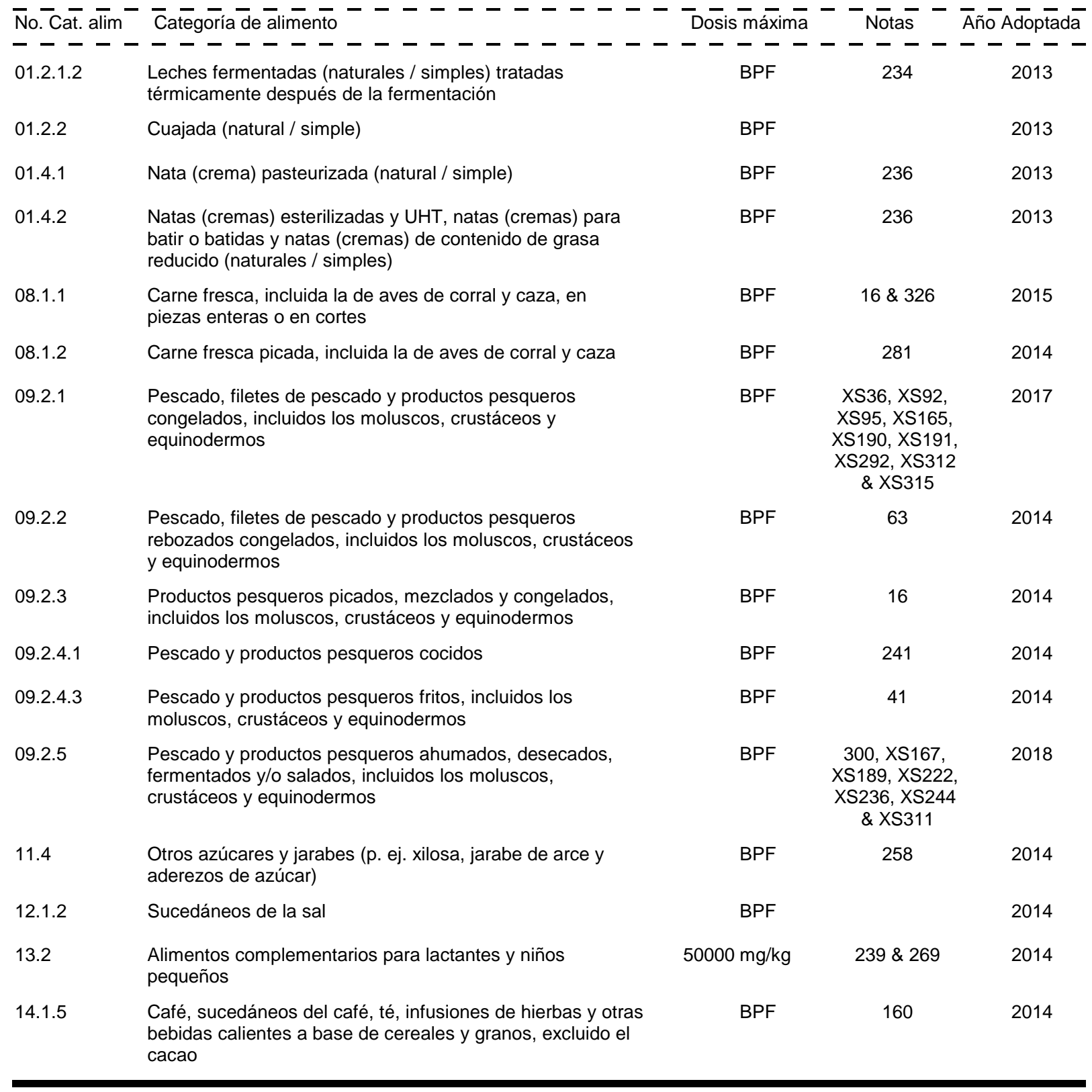

\section{ALMIDÓN TRATADO CON ÁCIDO}

SIN $1401 \quad$ Almidón tratado con ácido Clases Funcionales: Emulsionantes, Estabilizadores, Espesantes

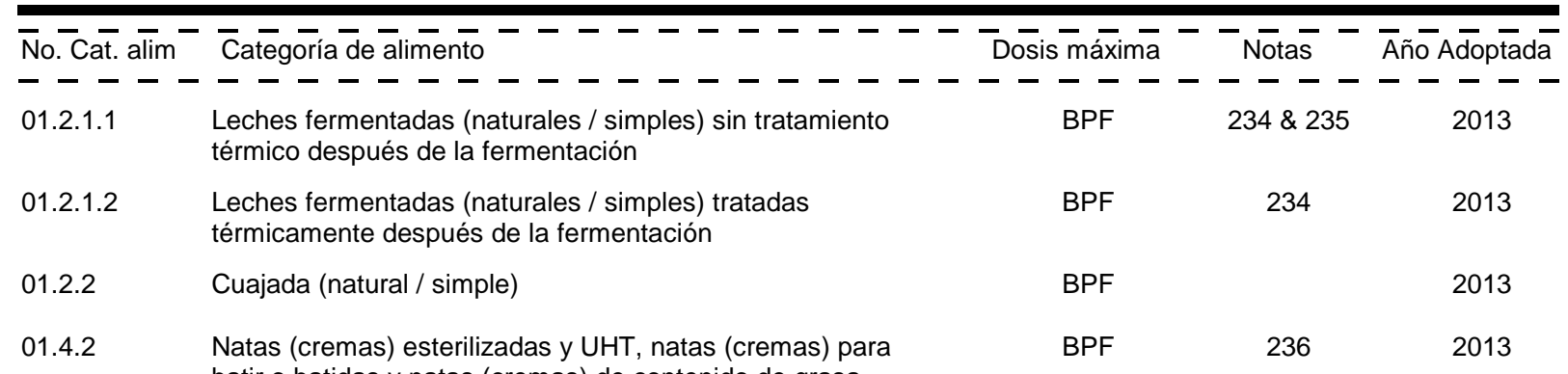
batir o batidas y natas (cremas) de contenido de grasa reducido (naturales / simples) 
Cuadro I

ALMIDÓN TRATADO CON ÁCIDO

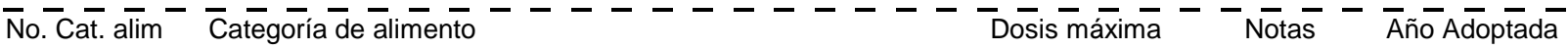

- - - - - - - - - - - - - - - - - - - - - - - - - -

$\begin{array}{llll}\text { 09.2.2 } & \text { Pescado, filetes de pescado y productos pesqueros } & \text { BPF } & 63\end{array}$ rebozados congelados, incluidos los moluscos, crustáceos y equinodermos

Otros azúcares y jarabes (p. ej. xilosa, jarabe de arce y

BPF

258

2014 aderezos de azúcar)

14.1.5 Café, sucedáneos del café, té, infusiones de hierbas y otras bebidas calientes a base de cereales y granos, excluido el

BPF

160

2014 cacao

\section{ALMIDÓN TRATADO CON ÁLCALIS}

SIN 1402 Almidón tratado con álcalis Clases Funcionales: Emulsionantes, Estabilizadores, Espesantes

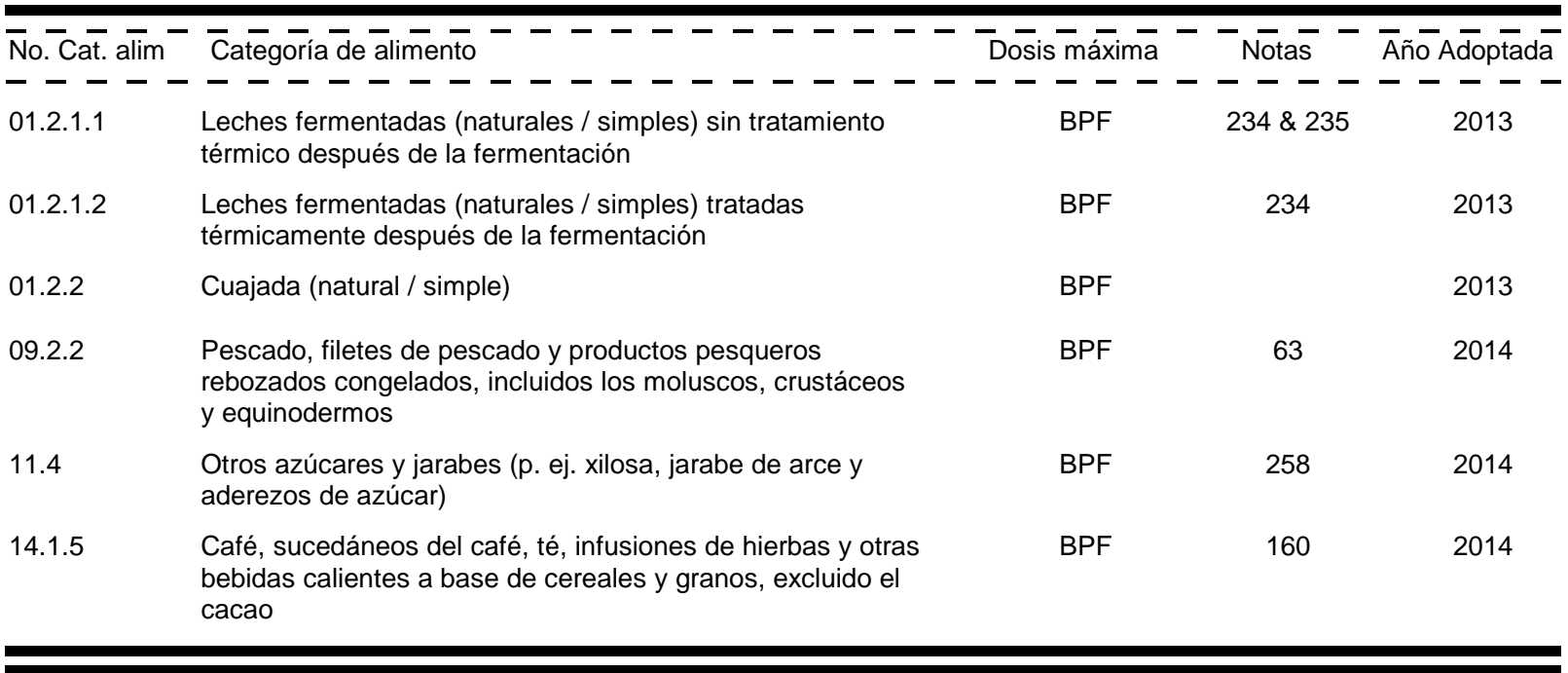

\section{ALMIDONES TRATADOS CON ENZIMAS}

SIN 1405 Almidones tratados con enzimas Clases Funcionales: Emulsionantes, Estabilizadores, Espesantes

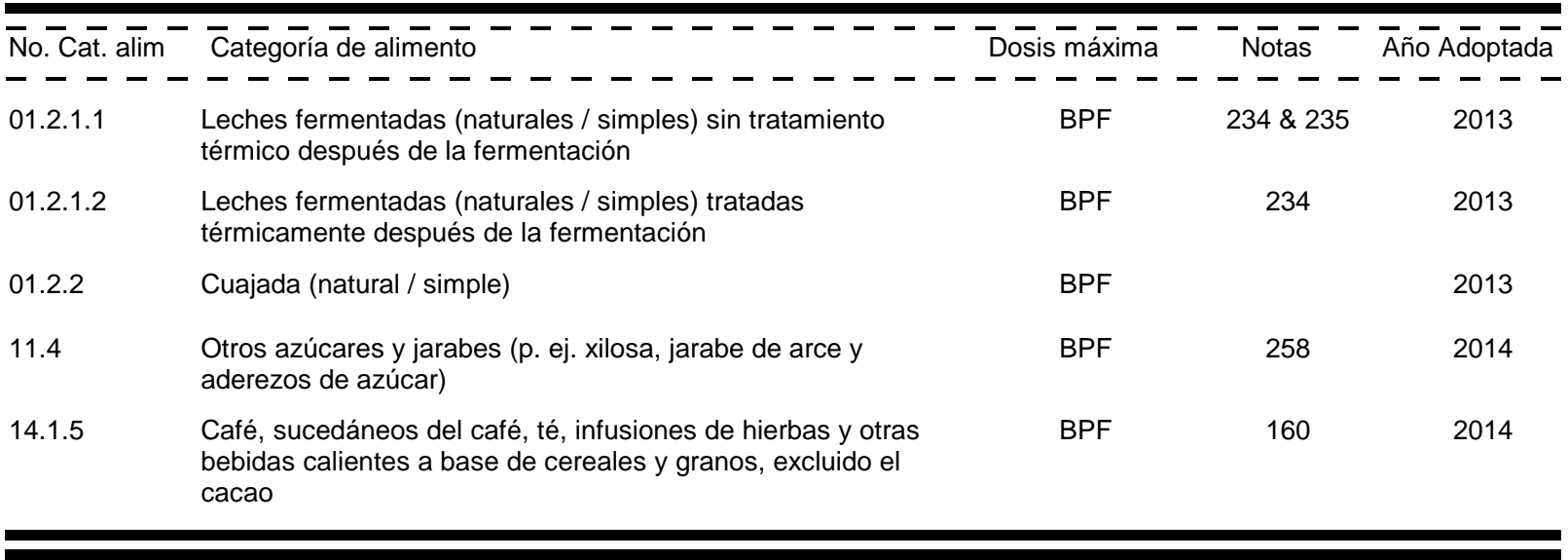

\section{AMARANTO}
SIN 123
Amaranto
Clases Funcionales: Colorantes

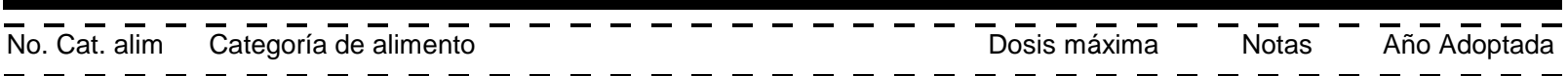


Cuadro I

AMARANTO

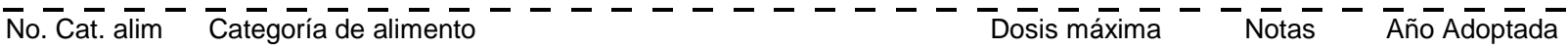
- - - - - - - - - - - - - - - - - - - - - - - - - - -

01.1.4 Bebidas lácteas líquidas aromatizadas $\quad 50 \mathrm{mg} / \mathrm{kg} \quad 52$

$05.3 \quad$ Goma de mascar $100 \mathrm{mg} / \mathrm{kg}$

$05.4 \quad$ Decoraciones (p. ej. para productos de pastelería fina), $\quad 100 \mathrm{mg} / \mathrm{kg}$

06.4.3 Pastas y fideos precocidos y productos análogos $\quad 100 \mathrm{mg} / \mathrm{kg} \quad 194 \quad 2019$

$09.4 \quad$ Pescado y productos pesqueros (incluidos los moluscos, $\quad 30 \mathrm{mg} / \mathrm{kg} \quad 435, \mathrm{XS3}, \quad 2018$ crustáceos y equinodermos) en conserva, con inclusión de XS70, XS90, los enlatados y fermentados $\quad$ XS94 \& XS119

\section{AMARILLO DE QUINOLEÍNA}

SIN 104 Amarillo de quinoleína Clases Funcionales: Colorantes

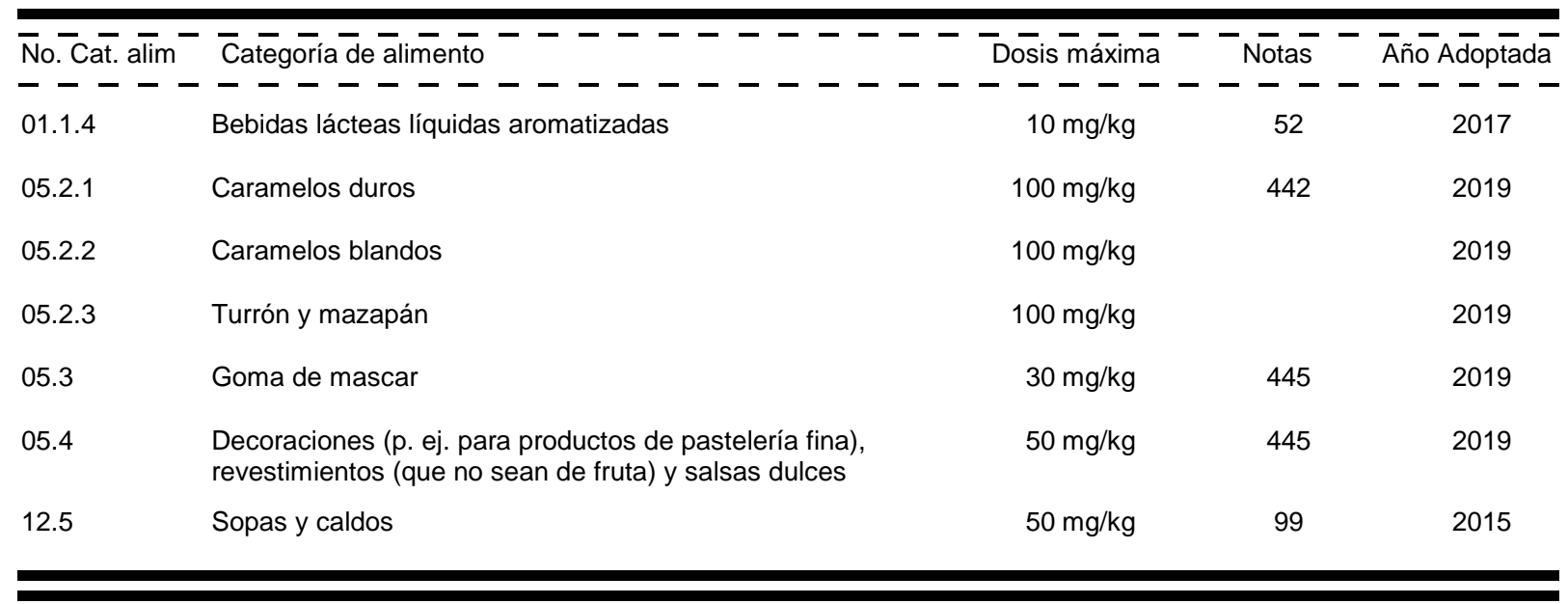

\section{AMARILLO OCASO FCF}

SIN $110 \quad$ Amarillo ocaso FCF

Clases Funcionales: Colorantes

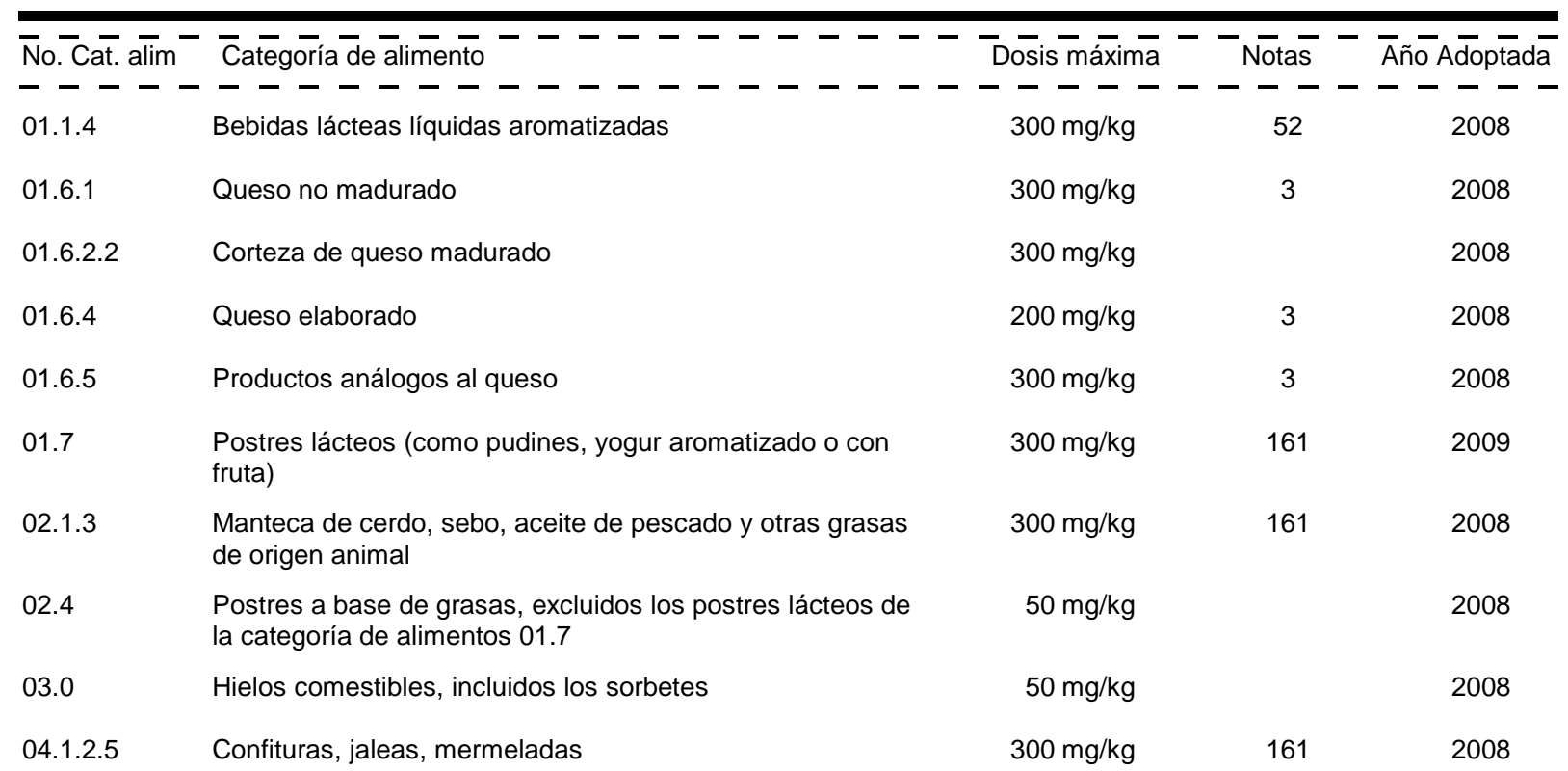


AMARILLO OCASO FCF

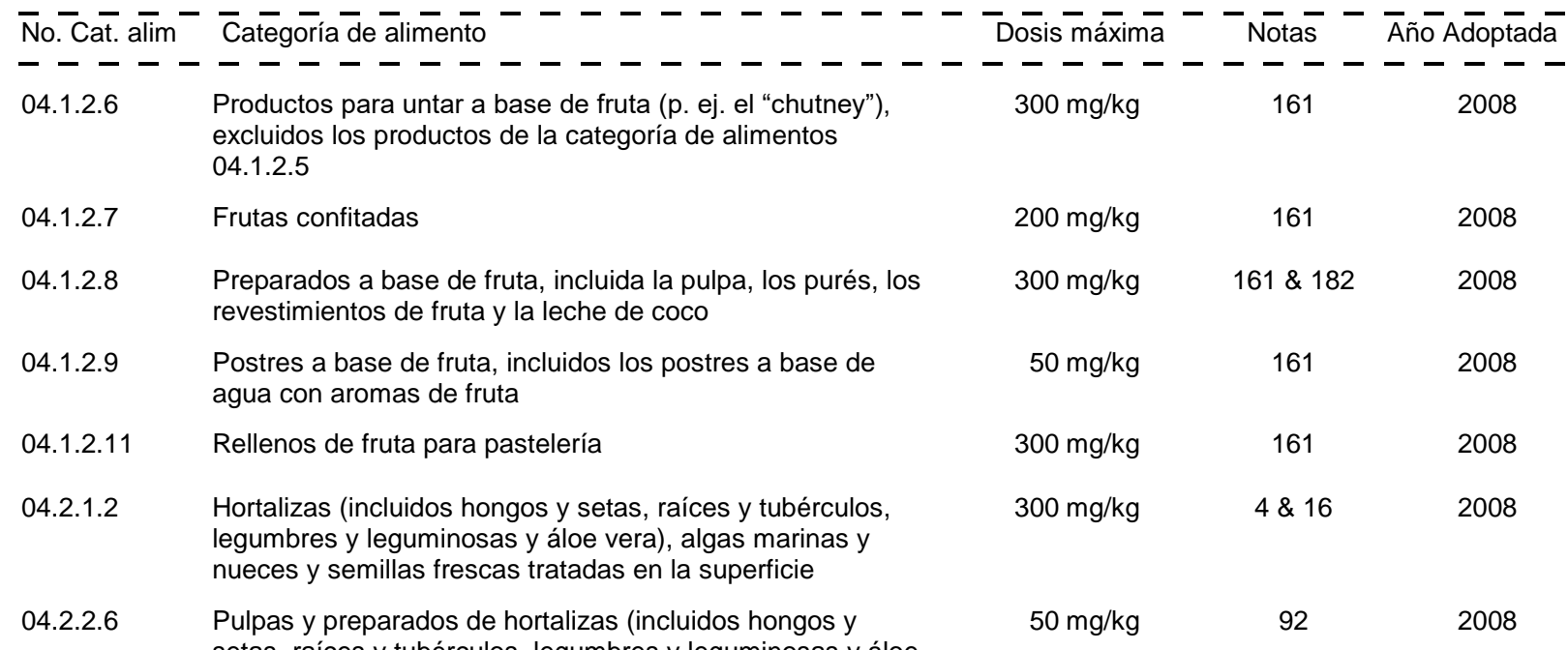

setas, raíces y tubérculos, legumbres y leguminosas y áloe vera), algas marinas y nueces y semillas (como los postres y las salsas a base de hortalizas y hortalizas confitadas) distintos de los indicados en la categoría de alimentos 04.2.2.5

04.2.2.7 Productos a base de hortalizas (incluidos hongos y setas, raíces y tubérculos, legumbres y leguminosas y áloe vera) y algas marinas fermentadas, excluidos los productos fermentados de soja de las categorías 06.8.6, 06.8.7, 12.9.1, 12.9.2.1 y 12.9.2.3

05.1.4 Productos de cacao y chocolate

05.1.5 Productos de imitación y sucedáneos del chocolate

$300 \mathrm{mg} / \mathrm{kg}$

161

2008

$05.2 \quad$ Dulces, incluidos los caramelos duros y blandos, los turrones, etc. distintos de los indicados en las categorías de $300 \mathrm{mg} / \mathrm{kg}$ alimentos $05.1,05.3$ y 05.4

05.3 Goma de mascar

$300 \mathrm{mg} / \mathrm{kg}$ revestimientos (que no sean de fruta) y salsas dulces

06.3 Cereales para el desayuno, incluidos los copos de avena

$300 \mathrm{mg} / \mathrm{kg}$

06.4 .3 Pastas y fideos precocidos y productos análogos

$08.2 \quad$ Productos cárnicos, de aves de corral y caza elaborados, en piezas enteras o en cortes

$300 \mathrm{mg} / \mathrm{kg}$
16, XS96 \& XS97

08.3.1.1 Productos cárnicos, de aves de corral y caza picados y elaborados, curados (incluidos los salados) y sin tratamiento térmico

08.3.1.2 Productos cárnicos, de aves de corral y caza picados y elaborados, curados (incluidos los salados), desecados y sin tratamiento térmico

08.3.1.3 Productos cárnicos, de aves de corral y caza picados, elaborados, fermentados y sin tratamiento térmico 
Cuadro I

AMARILLO OCASO FCF

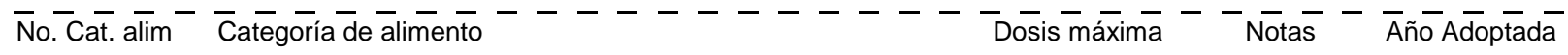

- - - - - - - - - - - - - - - - - -

Productos cárnicos, de aves de corral y caza picados, elaborados y congelados

$08.4 \quad$ Envolturas o tripas comestibles (p. ej. para embutidos)

\begin{tabular}{|c|c|}
\hline 300 mg/kg & 16 \\
\hline $300 \mathrm{mg} / \mathrm{kg}$ & 16 \\
\hline $300 \mathrm{mg} / \mathrm{kg}$ & $4,16 \& 50$ \\
\hline $300 \mathrm{mg} / \mathrm{kg}$ & $\begin{array}{c}\text { 4, 16, XS292, } \\
\text { XS312 \& XS315 }\end{array}$ \\
\hline $300 \mathrm{mg} / \mathrm{kg}$ & $\begin{array}{c}\text { 95, XS36, } \\
\text { XS92, XS95, } \\
\text { XS165, XS190, } \\
\text { XS191, XS292, } \\
\text { XS312 \& XS315 }\end{array}$ \\
\hline
\end{tabular}

09.2.2 Pescado, filetes de pescado y productos pesqueros rebozados congelados, incluidos los moluscos, crustáceos

$300 \mathrm{mg} / \mathrm{kg}$

$16 \&$ XS166 y equinodermos

09.2.3 Productos pesqueros picados, mezclados y congelados, incluidos los moluscos, crustáceos y equinodermos

$300 \mathrm{mg} / \mathrm{kg}$

$16 \& 95$

2008

09.2.4.1 Pescado y productos pesqueros cocidos

$300 \mathrm{mg} / \mathrm{kg}$

95

2008

09.2.4.2 Moluscos, crustáceos y equinodermos cocidos

$250 \mathrm{mg} / \mathrm{kg}$

2008

$300 \mathrm{mg} / \mathrm{kg}$

16

2008 moluscos, crustáceos y equinodermos

09.2.5 Pescado y productos pesqueros ahumados, desecados, fermentados y/o salados, incluidos los moluscos, crustáceos y equinodermos

$100 \mathrm{mg} / \mathrm{kg}$

$382, \mathrm{XS} 167$ XS189, XS222

XS236 \& XS244

Pescado y productos pesqueros marinados y/o en gelatina, incluidos los moluscos, crustáceos y equinodermos

$300 \mathrm{mg} / \mathrm{kg}$

16

2008

$300 \mathrm{mg} / \mathrm{kg}$

16

2008

salmuera, incluidos los moluscos, crustáceos y

equinodermos

09.3.3 Sucedáneos de salmón, caviar y otros productos pesqueros a base de huevas

$300 \mathrm{mg} / \mathrm{kg}$

XS291

2018

$300 \mathrm{mg} / \mathrm{kg}$

2008

incluidos los moluscos, crustáceos y equinodermos (p. ej.,

la pasta de pescado), excluidos los productos indicados en las categorías de alimentos 09.3.1 a 09.3.3

Pescado y productos pesqueros (incluidos los moluscos, crustáceos y equinodermos) en conserva, con inclusión de los enlatados y fermentados

$300 \mathrm{mg} / \mathrm{kg}$

$95,435, \mathrm{XS} 3$,

XS70, XS90,

2018

XS94 \& XS119

$10.1 \quad$ Huevos frescos

BPF

4

2008

$50 \mathrm{mg} / \mathrm{kg}$

2008

Postres a base de huevo (p. ej. flan)

$300 \mathrm{mg} / \mathrm{kg}$

2008

$300 \mathrm{mg} / \mathrm{kg}$

2008

$50 \mathrm{mg} / \mathrm{kg}$

2008

$300 \mathrm{mg} / \mathrm{kg}$

XS302

2018

$50 \mathrm{mg} / \mathrm{kg}$

2008

(excluidos los productos de la categoría de alimentos 13.1)

$50 \mathrm{mg} / \mathrm{kg}$

2008 peso 
Cuadro I

AMARILLO OCASO FCF

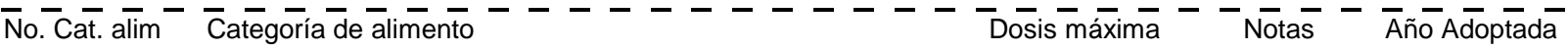

- - - - - - - - - - - - - - - - - - - - - - - - - -

$13.5 \quad$ Alimentos dietéticos (p. ej. los complementos alimenticios $\quad 300 \mathrm{mg} / \mathrm{kg} \quad 2008$ para usos dietéticos), excluidos los indicados en las categorías de alimentos 13.1 a 13.4 y 13.6

13.6 Complementos alimenticios

$300 \mathrm{mg} / \mathrm{kg}$

2008

14.1.4 Bebidas a base de agua aromatizadas, incluidas las

$100 \mathrm{mg} / \mathrm{kg} \quad 127 \& 161 \quad 2008$ bebidas para deportistas, bebidas energéticas o bebidas electrolíticas y bebidas con partículas añadidas

14.2.6 Licores destilados que contengan más de un 15 por ciento de alcohol

$200 \mathrm{mg} / \mathrm{kg}$

2008

14.2.7 Bebidas alcohólicas aromatizadas (p. ej. cerveza, vino y bebidas con licor tipo bebida gaseosa, bebidas refrescantes

$200 \mathrm{mg} / \mathrm{kg}$

2008 con bajo contenido de alcohol)

15.1 Aperitivos a base de patatas (papas), cereales, harina o almidón (derivados de raíces y tubérculos, legumbres y leguminosas)

$200 \mathrm{mg} / \mathrm{kg}$

2008

\section{ASCORBATO DE CALCIO}

SIN 302 Ascorbato de calcio Clases Funcionales: Antioxidantes

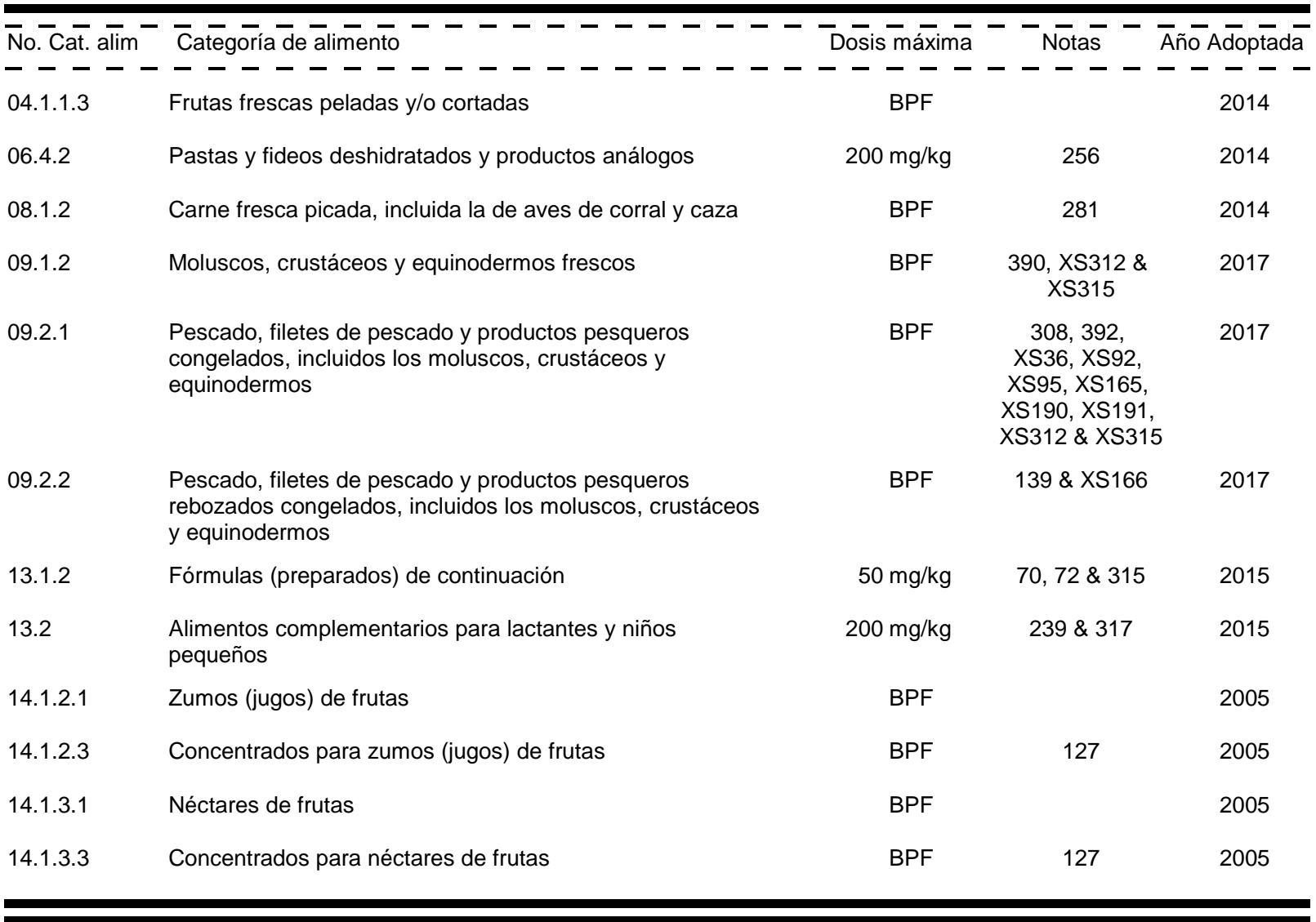

\section{ASCORBATO DE SODIO}

SIN $301 \quad$ Ascorbato de sodio Clases Funcionales: Antioxidantes

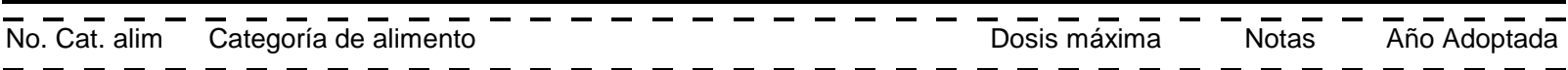


Cuadro I

ASCORBATO DE SODIO

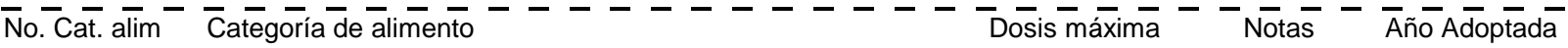

- - - - - - - - - - - - - - - - - - - - - - - - - - -

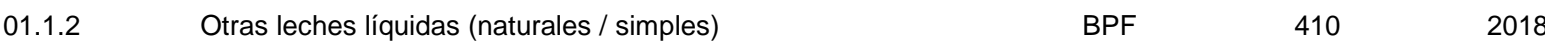

$\begin{array}{lll}\text { 04.1.1.3 Frutas frescas peladas y/o cortadas } & \text { BPF }\end{array}$

04.2.1.3 Hortalizas (incluidos hongos y setas, raíces y tubérculos,

BPF

2014

legumbres y leguminosas y aloe vera), algas marinas y

nueces y semillas frescas peladas, cortadas 0

desmenuzadas

04.2.2.7 Productos a base de hortalizas (incluidos hongos y setas, raíces y tubérculos, legumbres y leguminosas y áloe vera) y

BPF

algas marinas fermentadas, excluidos los productos

fermentados de soja de las categorías 06.8.6, 06.8.7,

12.9.1, 12.9.2.1 y 12.9 .2 .3

06.2.1 Harinas

$300 \mathrm{mg} / \mathrm{kg}$

2014

06.4.1 Pastas y fideos frescos y productos análogos

BPF

2014

06.4.2 Pastas y fideos deshidratados y productos análogos

$200 \mathrm{mg} / \mathrm{kg}$

256

2014

08.1.2 Carne fresca picada, incluida la de aves de corral y caza

BPF

281

2014

09.1 .2

Moluscos, crustáceos y equinodermos frescos

BPF

390, XS312 \&

2017

09.2

Pescado y productos pesqueros elaborados, incluidos los moluscos, crustáceos y equinodermos

XS315

BPF $\quad 437,307,392$

XS92, XS167,

XS189, XS191

XS222, XS236

XS244, XS312

\& XS315

12.1.2 Sucedáneos de la sal

BPF

314

2015

13.1.2 Fórmulas (preparados) de continuación

$50 \mathrm{mg} / \mathrm{kg}$

$70,72,315 \&$

316

13.2 Alimentos complementarios para lactantes y niños pequeños

$500 \mathrm{mg} / \mathrm{kg} \quad 317,319 \& 320$

2015

2015

14.1.2.1 Zumos (jugos) de frutas

BPF

2005

14.1.2.3 Concentrados para zumos (jugos) de frutas

BPF

127

2005

14.1.3.1 Néctares de frutas

BPF

2005

14.1.3.3 Concentrados para néctares de frutas

BPF

127

2005

14.1 .5

Café, sucedáneos del café, té, infusiones de hierbas y otras bebidas calientes a base de cereales y granos, excluido el

BPF

160

2015

\section{ASPARTAMO}

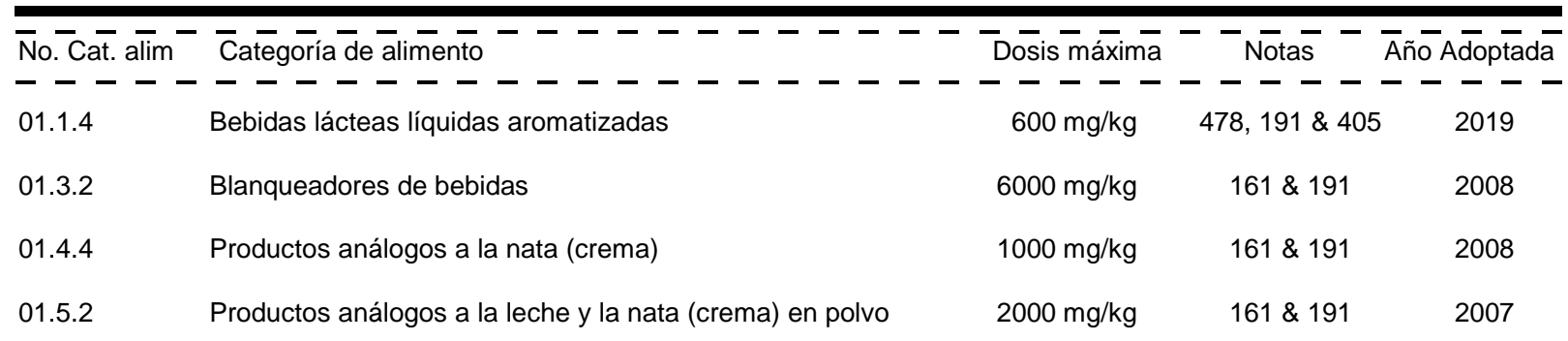


Cuadro I

\section{ASPARTAMO}

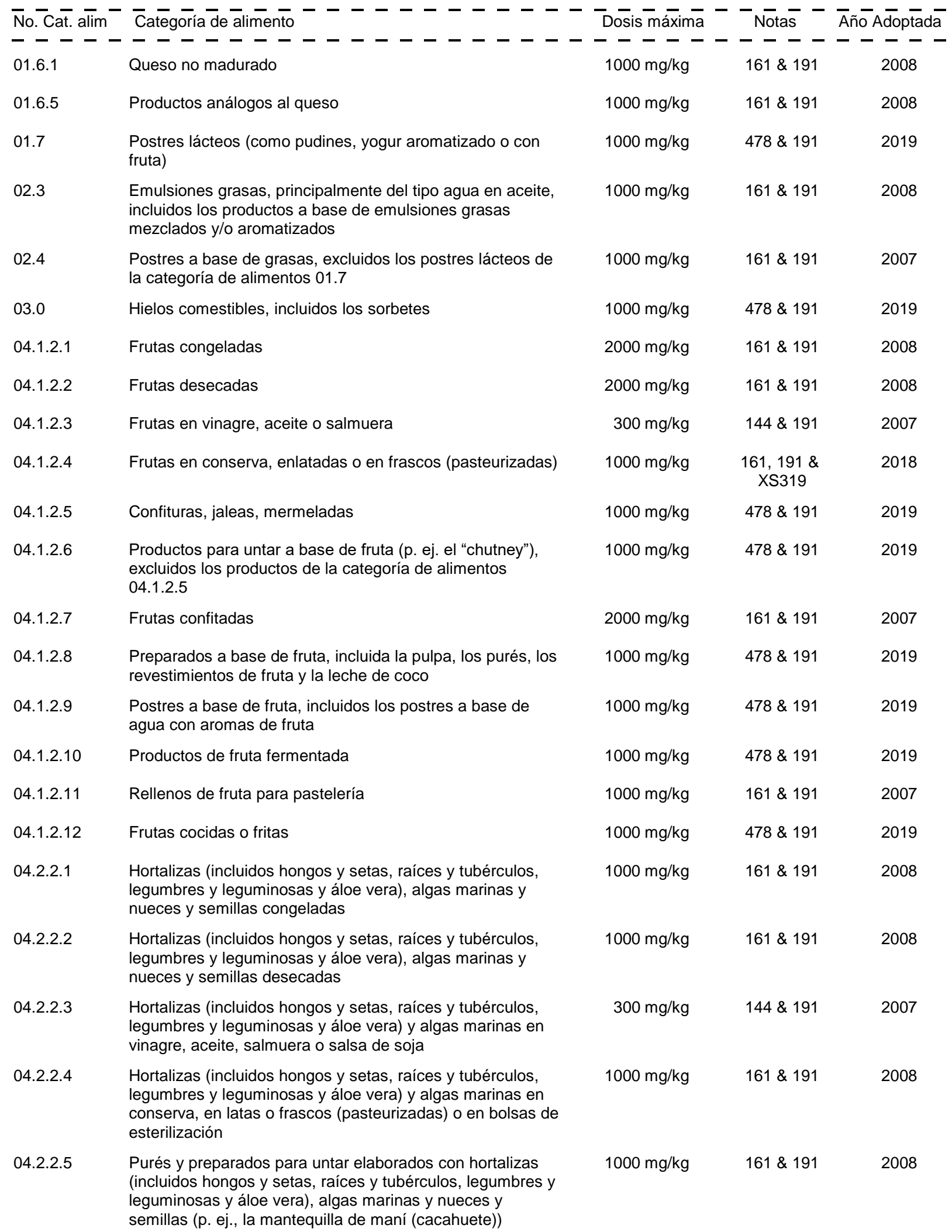


Cuadro I

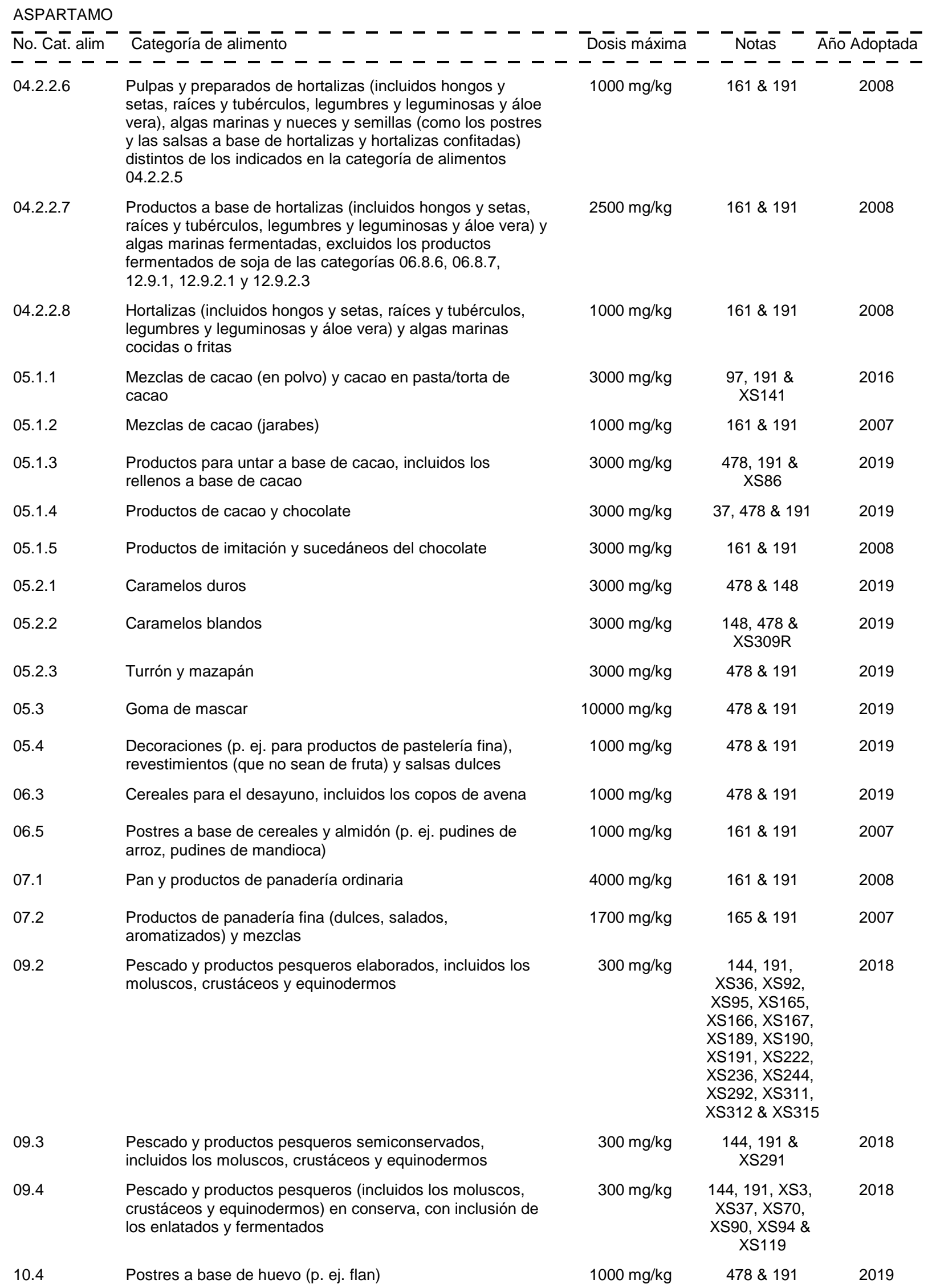


Cuadro I

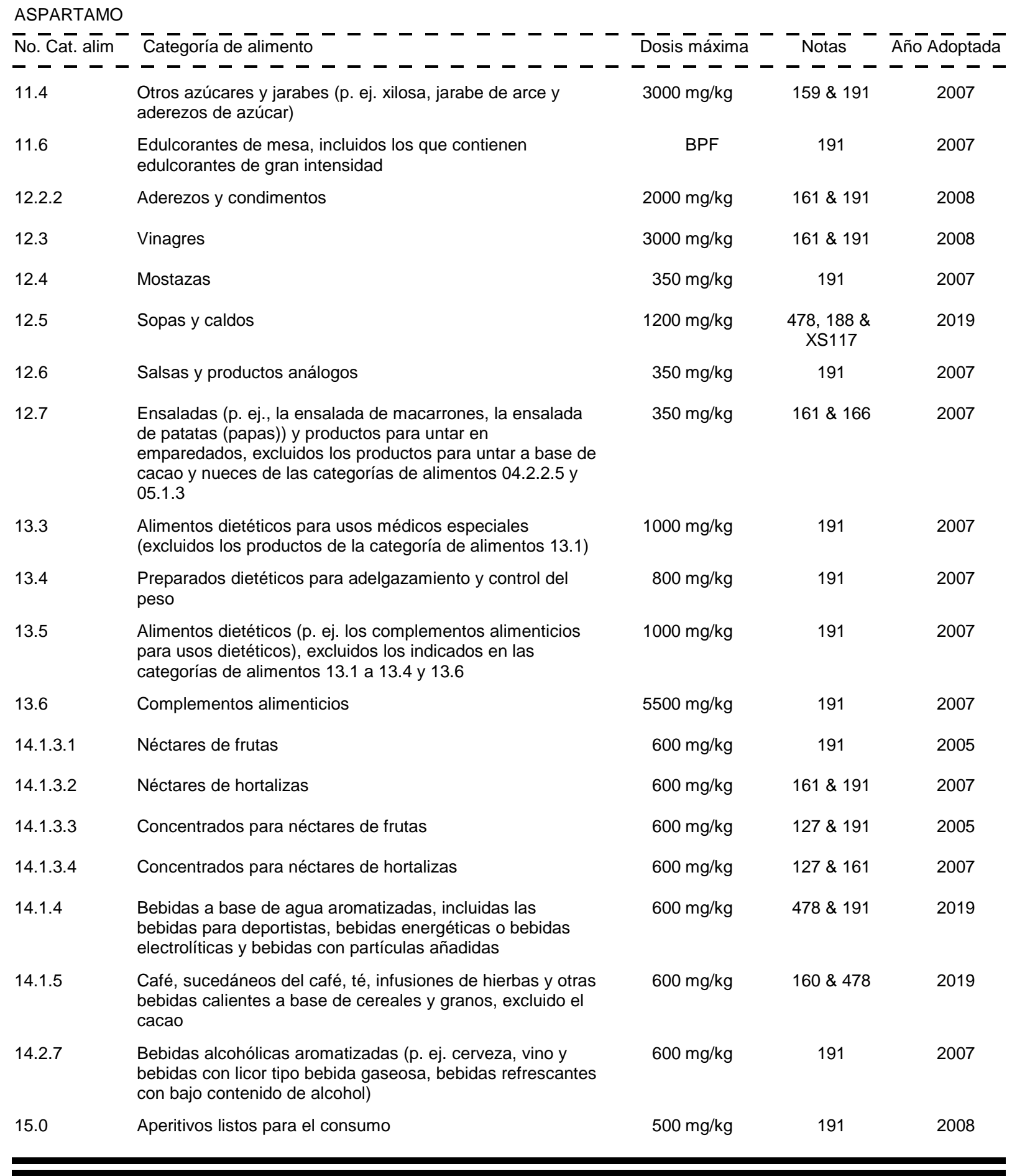

\section{AZODICARBONAMIDA}

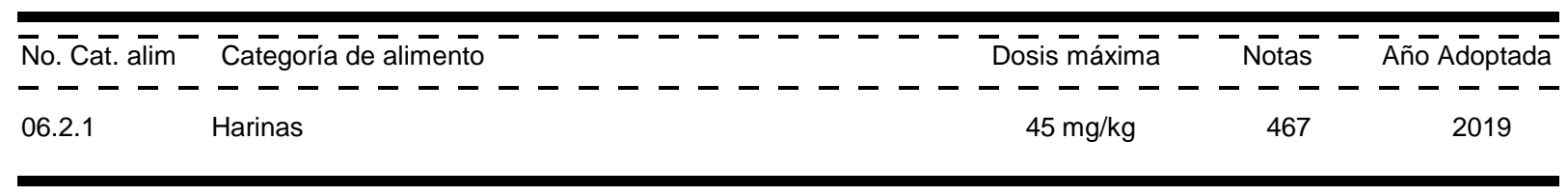


Cuadro I

AZORRUBINA (CARMOISINA)

\section{AZORRUBINA (CARMOISINA)}

SIN 122 Azorrubina (Carmoisina) Clases Funcionales: Colorantes

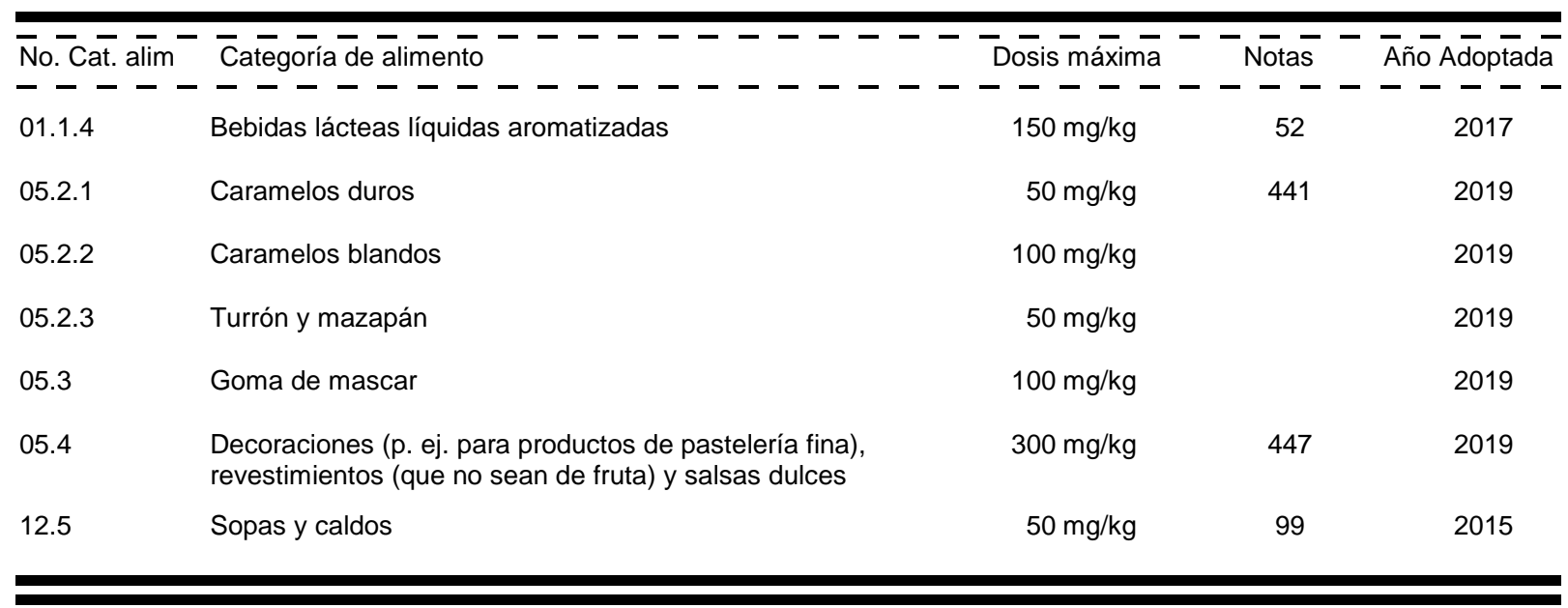

\section{AZUL BRILLANTE FCF}

SIN 133 Azul brillante FCF Clases Funcionales: Colorantes

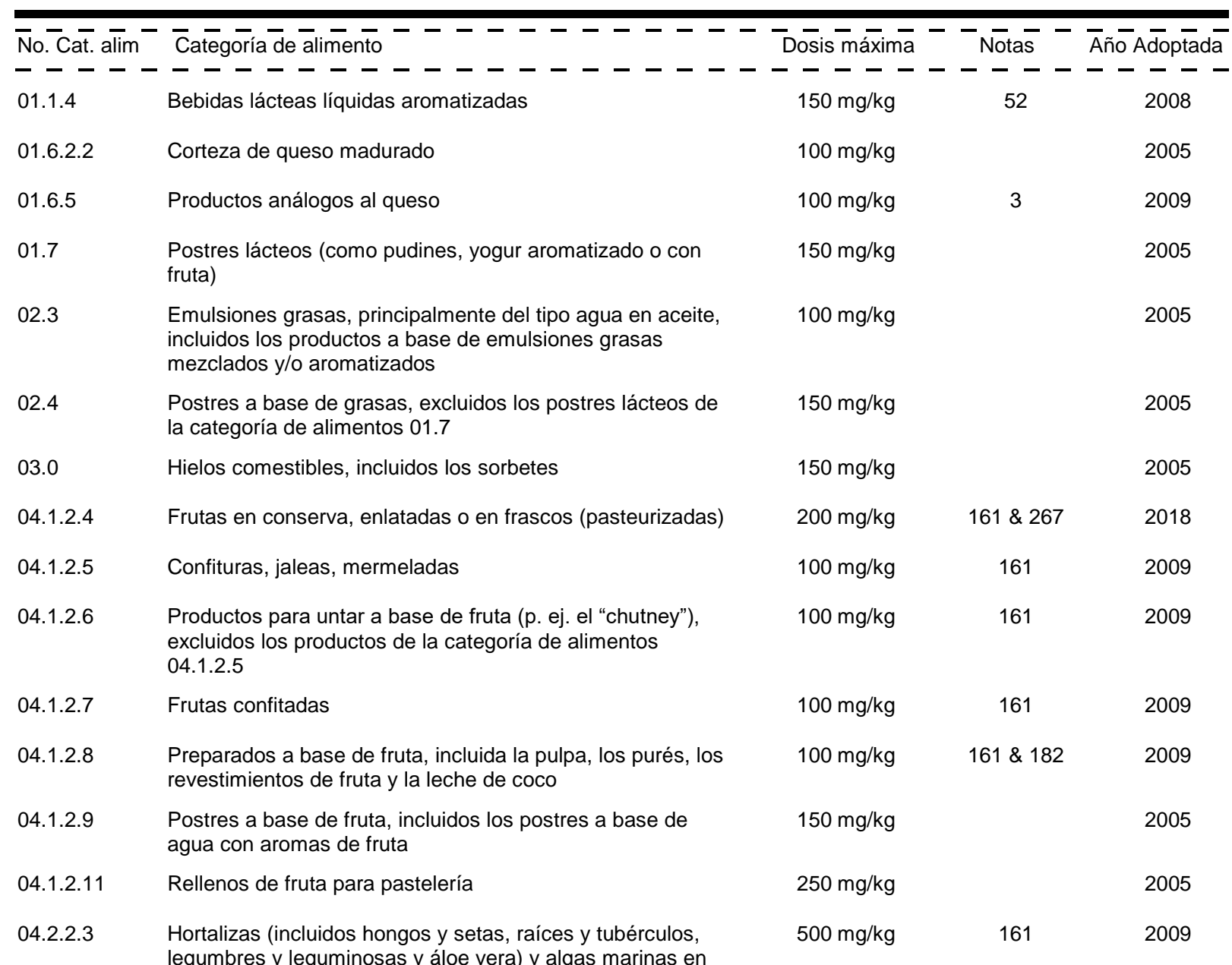


Cuadro I

AZUL BRILLANTE FCF

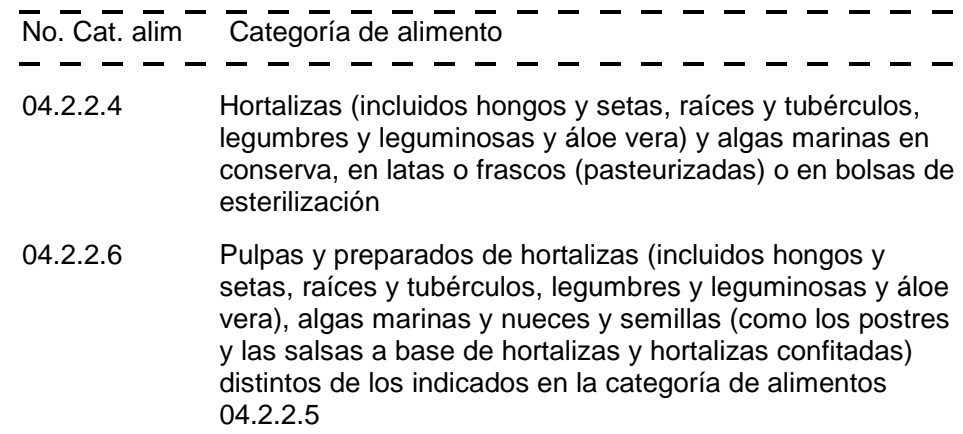

04.2.2.7 Productos a base de hortalizas (incluidos hongos y setas, raíces y tubérculos, legumbres y leguminosas y áloe vera) y algas marinas fermentadas, excluidos los productos fermentados de soja de las categorías 06.8.6, 06.8.7, 12.9.1, 12.9.2.1 y 12.9 .2 .3

05.1.3 Productos para untar a base de cacao, incluidos los rellenos a base de cacao

05.1.4 Productos de cacao y chocolate

05.1.5 Productos de imitación y sucedáneos del chocolate

$05.2 \quad$ Dulces, incluidos los caramelos duros y blandos, los turrones, etc. distintos de los indicados en las categorías de alimentos $05.1,05.3$ y 05.4

2009

$100 \mathrm{mg} / \mathrm{kg} \quad 92 \& 161$

2009

Goma de mascar

$300 \mathrm{mg} / \mathrm{kg}$

2005

$500 \mathrm{mg} / \mathrm{kg}$

2005

Decoraciones (p. ej. para productos de pastelería fina)
revestimientos (que no sean de fruta) y salsas dulces

06.3 Cereales para el desayuno, incluidos los copos de avena

$200 \mathrm{mg} / \mathrm{kg}$

2005

$150 \mathrm{mg} / \mathrm{kg}$

2005 arroz, pudines de mandioca)

$100 \mathrm{mg} / \mathrm{kg}$

161

2009

$200 \mathrm{mg} / \mathrm{kg}$

161

2009 aromatizados) y mezclas

$100 \mathrm{mg} / \mathrm{kg} \quad 4,16, \mathrm{XS} 88$, XS89, XS96, XS97 \& XS98 y caza

$4,16 \& 50$

2008

09.1.1 Pescado fresco

$300 \mathrm{mg} / \mathrm{kg}$

4, 16, XS292, XS312 \& XS315

09.2.1 Pescado, filetes de pescado y productos pesqueros congelados, incluidos los moluscos, crustáceos y equinodermos rebozados congelados, incluidos los moluscos, crustáceos y equinodermos

09.2.3 Productos pesqueros picados, mezclados y congelados, incluidos los moluscos, crustáceos y equinodermos

$500 \mathrm{mg} / \mathrm{kg}$

09.2.4.1 Pescado y productos pesqueros cocidos

$100 \mathrm{mg} / \mathrm{kg}$

09.2.4.2 Moluscos, crustáceos y equinodermos cocidos

$100 \mathrm{mg} / \mathrm{kg}$

09.2.4.3 Pescado y productos pesqueros fritos, incluidos los moluscos, crustáceos y equinodermos 
Cuadro I

AZUL BRILLANTE FCF

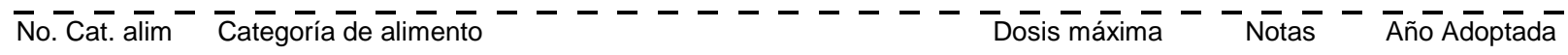

- - - - - - - - - - - - - - - - - - - - - - - - - - -

09.3.1 Pescado y productos pesqueros marinados y/o en gelatina, $\quad 500 \mathrm{mg} / \mathrm{kg} \quad 16$ incluidos los moluscos, crustáceos y equinodermos

09.3.2 Pescado y productos pesqueros escabechados y/o en salmuera, incluidos los moluscos, crustáceos y

$500 \mathrm{mg} / \mathrm{kg}$

2005 equinodermos

09.3 .3

Sucedáneos de salmón, caviar y otros productos pesqueros

$500 \mathrm{mg} / \mathrm{kg}$

XS291

2018

$09.4 \quad$ Pescado y productos pesqueros (incluidos los moluscos, crustáceos y equinodermos) en conserva, con inclusión de

$500 \mathrm{mg} / \mathrm{kg}$

XS3, XS37,

$\mathrm{XS70}, \mathrm{XS} 90$

XS94 \& XS119 los enlatados y fermentados

$10.1 \quad$ Huevos frescos

BPF

4

2005

10.4 Postres a base de huevo (p. ej. flan)

$150 \mathrm{mg} / \mathrm{kg}$

2005

$100 \mathrm{mg} / \mathrm{kg}$

2009

$100 \mathrm{mg} / \mathrm{kg}$

2009

$50 \mathrm{mg} / \mathrm{kg}$

2009

$100 \mathrm{mg} / \mathrm{kg}$

XS302

2018

$50 \mathrm{mg} / \mathrm{kg}$

2005

(excluidos los productos de la categoría de alimentos 13.1)

$50 \mathrm{mg} / \mathrm{kg}$

2005

peso

13.5 Alimentos dietéticos (p. ej. los complementos alimenticios para usos dietéticos), excluidos los indicados en las

$300 \mathrm{mg} / \mathrm{kg}$

2005 categorías de alimentos 13.1 a 13.4 y 13.6

14.1.4 Bebidas a base de agua aromatizadas, incluidas las bebidas para deportistas, bebidas energéticas o bebidas

$100 \mathrm{mg} / \mathrm{kg}$ electrolíticas y bebidas con partículas añadidas

14.2.6 Licores destilados que contengan más de un 15 por ciento de alcohol

$200 \mathrm{mg} / \mathrm{kg}$

2005

14.2.7 Bebidas alcohólicas aromatizadas (p. ej. cerveza, vino y bebidas con licor tipo bebida gaseosa, bebidas refrescantes con bajo contenido de alcohol)

15.1 Aperitivos a base de patatas (papas), cereales, harina o almidón (derivados de raíces y tubérculos, legumbres y leguminosas)

15.2 Nueces elaboradas, incluidas las nueces revestidas y las mezclas de nueces (p. ej. con frutas secas) 


\section{BENZOATOS}

$\begin{array}{llll}\text { SIN } & 210 & \text { Ácido benzoico } & \text { Clases Funcionales: Sustancias conservadoras } \\ \text { SIN } 211 & \text { Benzoato de sodio } & \text { Clases Funcionales: Sustancias conservadoras } \\ \text { SIN } 212 & \text { Benzoato de potasio } & \text { Clases Funcionales: Sustancias conservadoras } \\ \text { SIN } 213 & \text { Benzoato de calcio } & \text { Clases Funcionales: Sustancias conservadoras }\end{array}$

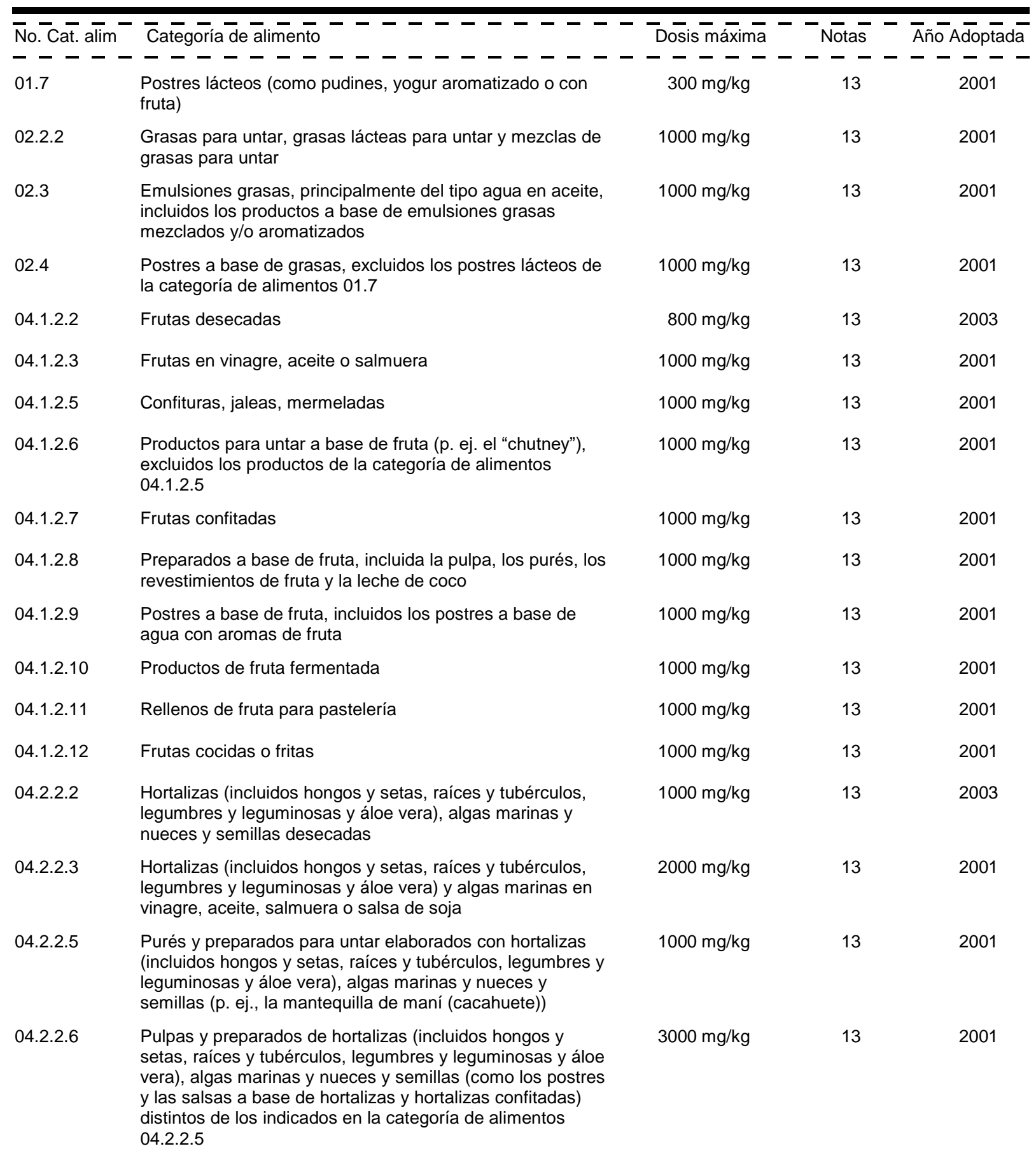


Cuadro I

BENZOATOS

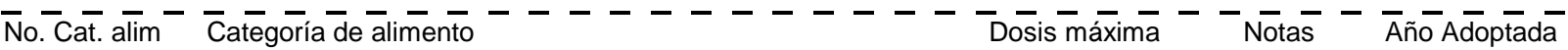

- - -

Productos a base de hortalizas (incluidos hongos y setas,

$1000 \mathrm{mg} / \mathrm{kg}$

13

2001 raíces y tubérculos, legumbres y leguminosas y áloe vera) y algas marinas fermentadas, excluidos los productos

fermentados de soja de las categorías 06.8.6, 06.8.7, 12.9.1, 12.9.2.1 y 12.9.2.3

04.2.2.8 Hortalizas (incluidos hongos y setas, raíces y tubérculos, legumbres y leguminosas y áloe vera) y algas marinas cocidas o fritas

05.1.3 Productos para untar a base de cacao, incluidos los rellenos a base de cacao

05.1.5 Productos de imitación y sucedáneos del chocolate

Dulces, incluidos los caramelos duros y blandos, los turrones, etc. distintos de los indicados en las categorías de alimentos $05.1,05.3$ y 05.4

$05.3 \quad$ Goma de mascar

$1500 \mathrm{mg} / \mathrm{kg}$

13

2005

05.4

Decoraciones (p. ej. para productos de pastelería fina),

$1500 \mathrm{mg} / \mathrm{kg}$

13

2003

06.4 .3

revestimientos (que no sean de fruta) y salsas dulces

$1000 \mathrm{mg} / \mathrm{kg}$

$13 \&$ XS249

2019

06.5

Postres a base de cereales y almidón ( $p$. ej. pudines de arroz, pudines de mandioca)

$1000 \mathrm{mg} / \mathrm{kg}$

2003

07.0

Productos de panadería

$1000 \mathrm{mg} / \mathrm{kg}$

13

2004

08.2 .1 .2

Productos cárnicos, de aves de corral y caza elaborados, curados (incluidos los salados), desecados y sin tratamiento térmico, en piezas enteras o en cortes

08.3.1.2 Productos cárnicos, de aves de corral y caza picados y elaborados, curados (incluidos los salados), desecados y sin tratamiento térmico

09.2.4.2 Moluscos, crustáceos y equinodermos cocidos

$1000 \mathrm{mg} / \mathrm{kg}$

$3 \& 13$

2005

$1000 \mathrm{mg} / \mathrm{kg}$

$3 \& 13$

2005

$2000 \mathrm{mg} / \mathrm{kg}$

$13 \& 82$

2003

$200 \mathrm{mg} / \mathrm{kg}$

$13,121,333$

2018

fermentados y/o salados, incluidos los moluscos,

XS167, XS189,

crustáceos y equinodermos

XS222 \& XS236

09.3 Pescado y productos pesqueros semiconservados, incluidos los moluscos, crustáceos y equinodermos

10.2.1 Productos líquidos a base de huevo

$2000 \mathrm{mg} / \mathrm{kg}$

$13,120 \&$

2018

$5000 \mathrm{mg} / \mathrm{kg}$ XS291

2003

$1000 \mathrm{mg} / \mathrm{kg}$

2003

$1000 \mathrm{mg} / \mathrm{kg}$

2003

Otros azúcares y jarabes (p. ej. xilosa, jarabe de arce y aderezos de azúcar)

$2000 \mathrm{mg} / \mathrm{kg}$

2003 edulcorantes de gran intensidad

12.2.2 Aderezos y condimentos

$1000 \mathrm{mg} / \mathrm{kg}$

2003

$12.3 \quad$ Vinagres

$1000 \mathrm{mg} / \mathrm{kg}$

2003

$1000 \mathrm{mg} / \mathrm{kg}$

13

2003

12.4

Mostazas

$500 \mathrm{mg} / \mathrm{kg}$

$13,338 \& 339$

2015

12.6

Sopas y caldos

$1000 \mathrm{mg} / \mathrm{kg}$ 
Cuadro I

BENZOATOS

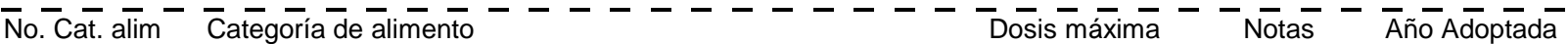

- - - - - - - - - - - - - - - - - - - - - - - - - - -

$1500 \mathrm{mg} / \mathrm{kg}$

13

2003 de patatas (papas)) y productos para untar en emparedados, excluidos los productos para untar a base de cacao y nueces de las categorías de alimentos 04.2.2.5 y 05.1 .3

13.3 Alimentos dietéticos para usos médicos especiales (excluidos los productos de la categoría de alimentos 13.1)

13.4 Preparados dietéticos para adelgazamiento y control del peso

$13.5 \quad$ Alimentos dietéticos (p. ej. los complementos alimenticios para usos dietéticos), excluidos los indicados en las categorías de alimentos 13.1 a 13.4 y 13.6

Complementos alimenticios

2003

14.1.2.1 Zumos (jugos) de frutas

14.1.2.3 Concentrados para zumos (jugos) de frutas

$1000 \mathrm{mg} / \mathrm{kg}$

$13,91 \& 122$

2004

$1000 \mathrm{mg} / \mathrm{kg}$

$13,91,122 \&$

127

14.1.3.1 Néctares de frutas

$1000 \mathrm{mg} / \mathrm{kg}$

$13,91 \& 122$

2004

14.1.3.3 Concentrados para néctares de frutas

$1000 \mathrm{mg} / \mathrm{kg}$

$13,91,122 \&$

2004

14.1.3.4

Concentrados para néctares de hortalizas

14.1 .4

Bebidas a base de agua aromatizadas, incluidas las bebidas para deportistas, bebidas energéticas o bebidas electrolíticas y bebidas con partículas añadidas

14.1.5 Café, sucedáneos del café, té, infusiones de hierbas y otras bebidas calientes a base de cereales y granos, excluido el cacao

14.2.2 Sidra y sidra de pera

$600 \mathrm{mg} / \mathrm{kg}$

127

2004

$250 \mathrm{mg} / \mathrm{kg}$

13

2004

$13 \& 301$

2016

$1000 \mathrm{mg} / \mathrm{kg}$

13

2004

14.2.4 Vinos (distintos de los de uva)

14.2.5 Aguamiel

14.2.7 Bebidas alcohólicas aromatizadas (p. ej. cerveza, vino y bebidas con licor tipo bebida gaseosa, bebidas refrescantes con bajo contenido de alcohol)

15.1 Aperitivos a base de patatas (papas), cereales, harina o almidón (derivados de raíces y tubérculos, legumbres y leguminosas)

$\begin{array}{ccc}1000 \mathrm{mg} / \mathrm{kg} & 13 \& 124 & 2004 \\ 1000 \mathrm{mg} / \mathrm{kg} & 13 & 2003 \\ 1000 \mathrm{mg} / \mathrm{kg} & 13 & 2004 \\ 1000 \mathrm{mg} / \mathrm{kg} & 13 & 2003 \\ & & \\ 1000 \mathrm{mg} / \mathrm{kg} & 13 & 2004\end{array}$

\section{BROMELINA}

SIN 1101(iii) Bromelina

Clases Funcionales: Acentuadores del sabor, Agentes de tratamiento de las harinas, Estabilizadores

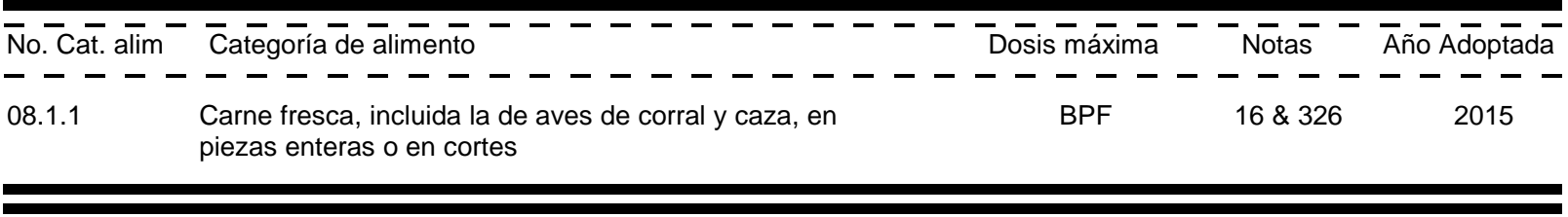

\section{BUTILHIDROXIANISOL}


Cuadro I

BUTILHIDROXIANISOL

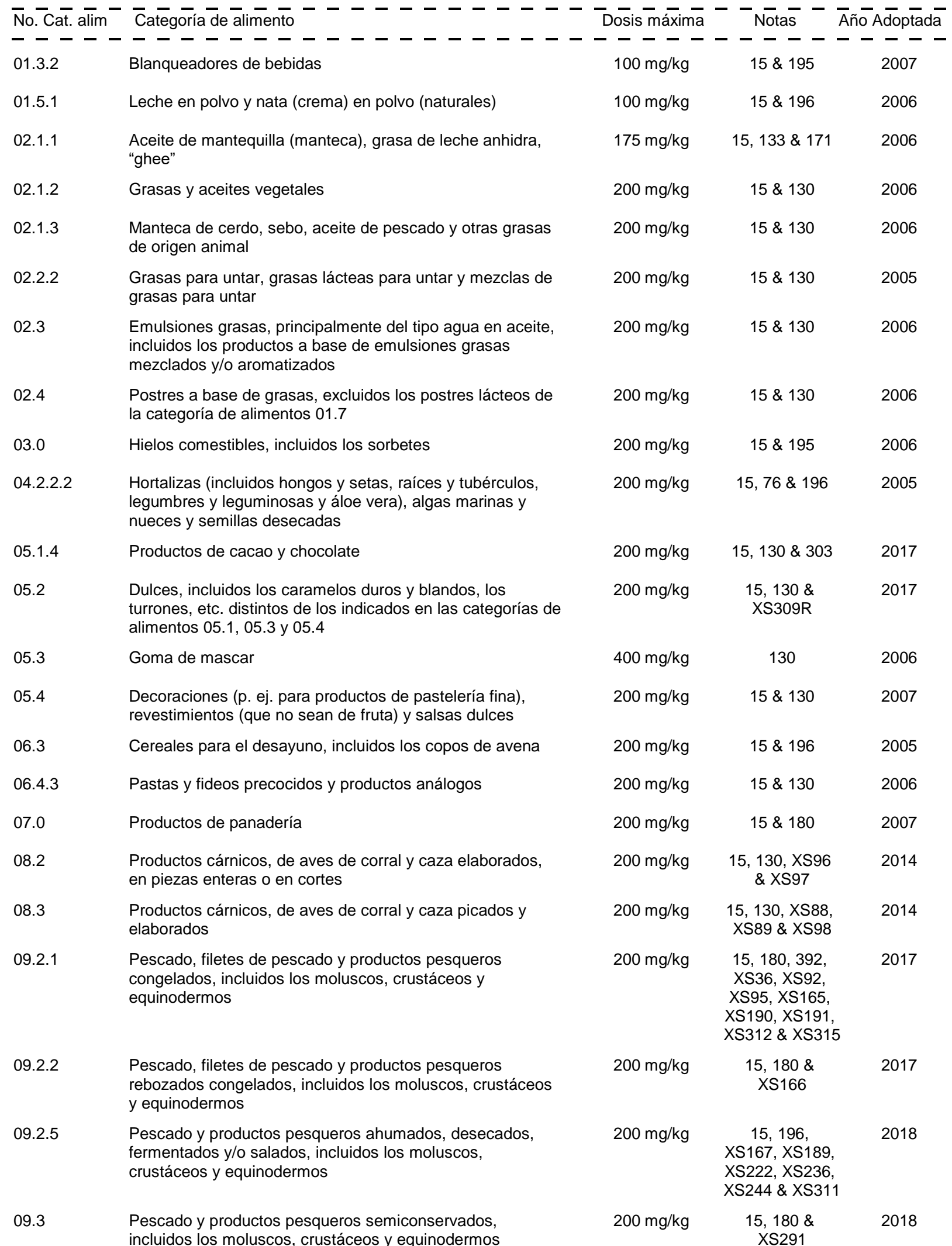


Cuadro I

BUTILHIDROXIANISOL

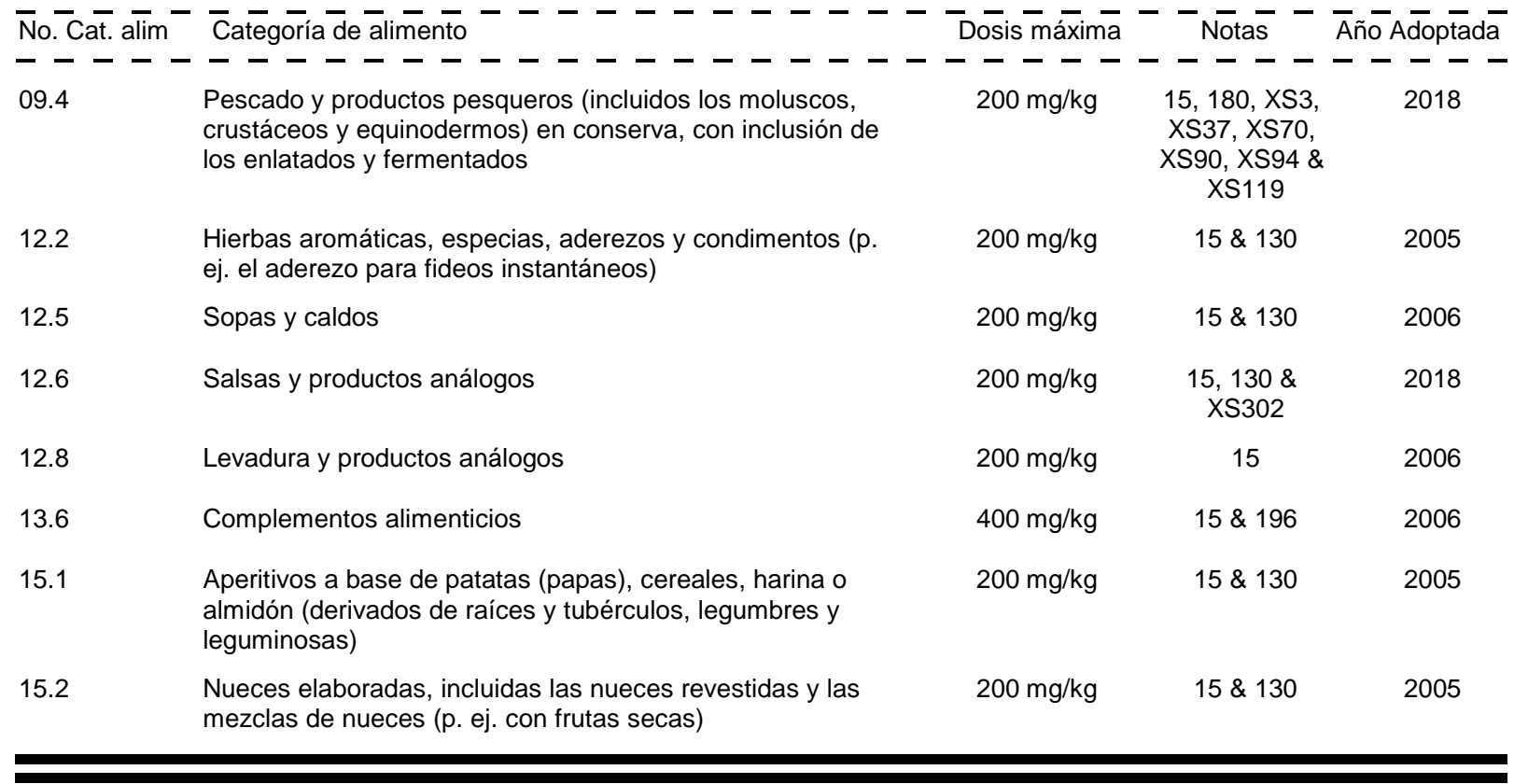

\section{BUTILHIDROXITOLUENO}

SIN $321 \quad$ Butilhidroxitolueno (BHT) Clases Funcionales: Antioxidantes

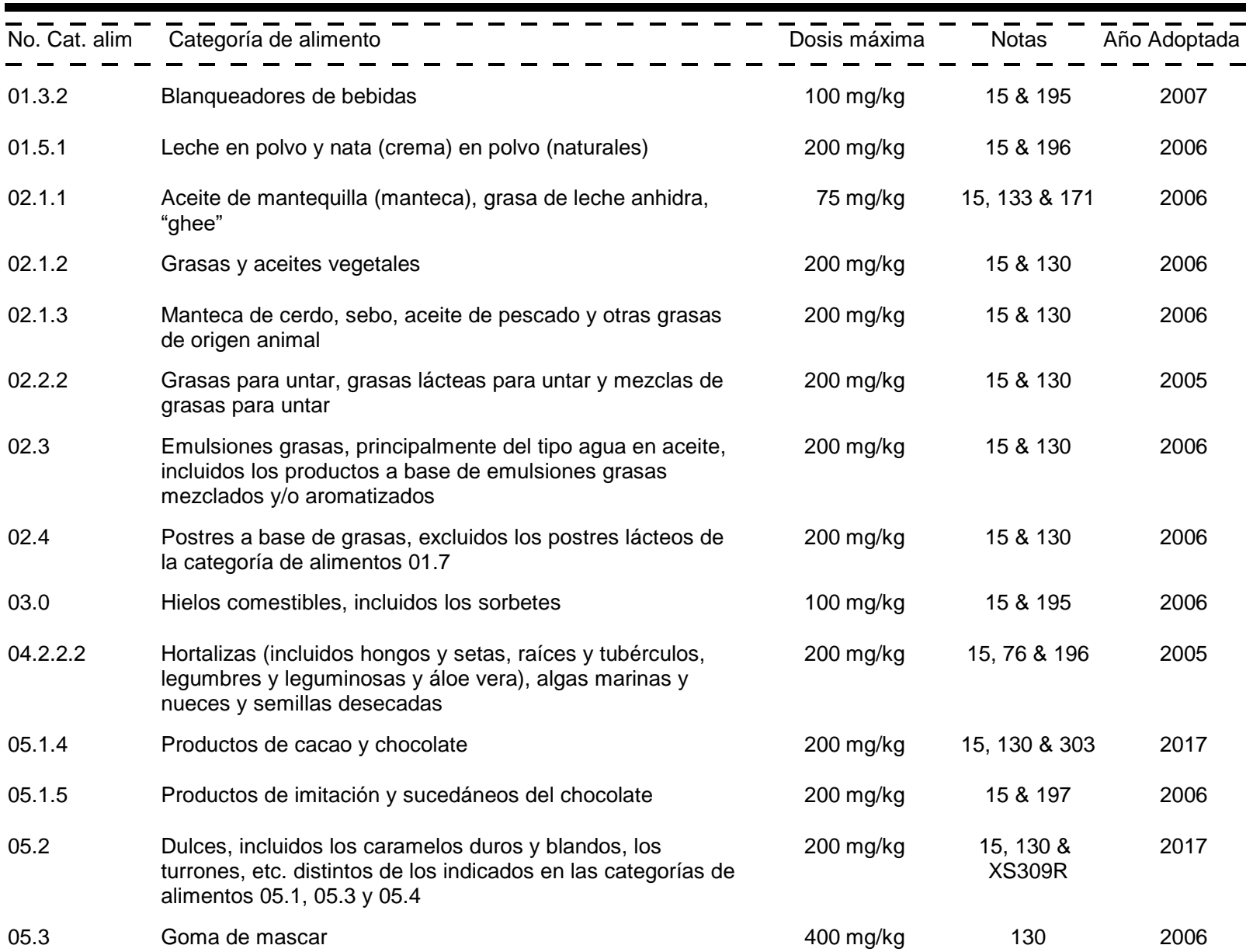


Cuadro I

BUTILHIDROXITOLUENO

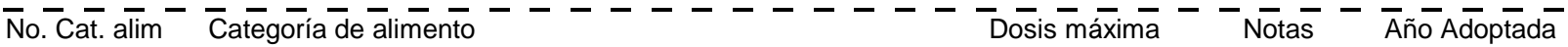

- - - - - - - - - - - - - - - - - - - - - - - - - - revestimientos (que no sean de fruta) y salsas dulces

06.3 Cereales para el desayuno, incluidos los copos de avena

$\begin{array}{ccc}100 \mathrm{mg} / \mathrm{kg} & 15 \& 196 & 2006 \\ 200 \mathrm{mg} / \mathrm{kg} & 15 \& 130 & 2006 \\ 200 \mathrm{mg} / \mathrm{kg} & 15 \& 180 & 2007 \\ 100 \mathrm{mg} / \mathrm{kg} & \begin{array}{l}15,130,167, \\ \text { XS96 \& XS97 }\end{array} & 2014 \\ 100 \mathrm{mg} / \mathrm{kg} & \begin{array}{c}15,130,162, \\ \text { XS88, XS89 \& } \\ \text { XS98 }\end{array} & 2014 \\ & \begin{array}{l}\text { X } \\ \text { X }\end{array}\end{array}$

09.2.1 Pescado, filetes de pescado y productos pesqueros congelados, incluidos los moluscos, crustáceos y

$200 \mathrm{mg} / \mathrm{kg} \quad 15,180,392$

XS36, XS92,

XS95, XS165, equinodermos

XS190, XS191

XS312 \& XS315

09.2.2 Pescado, filetes de pescado y productos pesqueros rebozados congelados, incluidos los moluscos, crustáceos y equinodermos

\section{$15,180 \&$} XS166

$200 \mathrm{mg} / \mathrm{kg} \quad \begin{gathered}15,180 \& \quad 2017 \\ X S 166\end{gathered}$

$200 \mathrm{mg} / \mathrm{kg} \quad 15,196$

09.2.5 Pescado y productos pesqueros ahumados, desecados, fermentados y/o salados, incluidos los moluscos, crustáceos y equinodermos

XS167, XS189,

XS222, XS236,

XS244 \& XS311

$09.3 \quad$ Pescado y productos pesqueros semiconservados, incluidos los moluscos, crustáceos y equinodermos

$200 \mathrm{mg} / \mathrm{kg}$

$15,180 \&$

XS291

$09.4 \quad$ Pescado y productos pesqueros (incluidos los moluscos, crustáceos y equinodermos) en conserva, con inclusión de

$200 \mathrm{mg} / \mathrm{kg}$

$15,180, \mathrm{XS} 3$,

$\mathrm{XS} 37, \mathrm{XS} 70$,

XS90, XS94 \&

XS119

$12.2 \quad$ Hierbas aromáticas, especias, aderezos y condimentos (p. ej. el aderezo para fideos instantáneos)

$200 \mathrm{mg} / \mathrm{kg}$

$15 \& 130$

2006

Sopas y caldos

$200 \mathrm{mg} / \mathrm{kg}$

$15,130 \& 340$

2015

Salsas y productos análogos

$100 \mathrm{mg} / \mathrm{kg}$

$15,130 \&$

XS302

2018

$400 \mathrm{mg} / \mathrm{kg}$

$15 \& 196$

2006

13.6

Complementos alimenticios

$200 \mathrm{mg} / \mathrm{kg}$

$15 \& 130$

2006

\section{CANTAXANTINA}

\section{SIN 1619 Cantaxantina}

Clases Funcionales: Colorantes

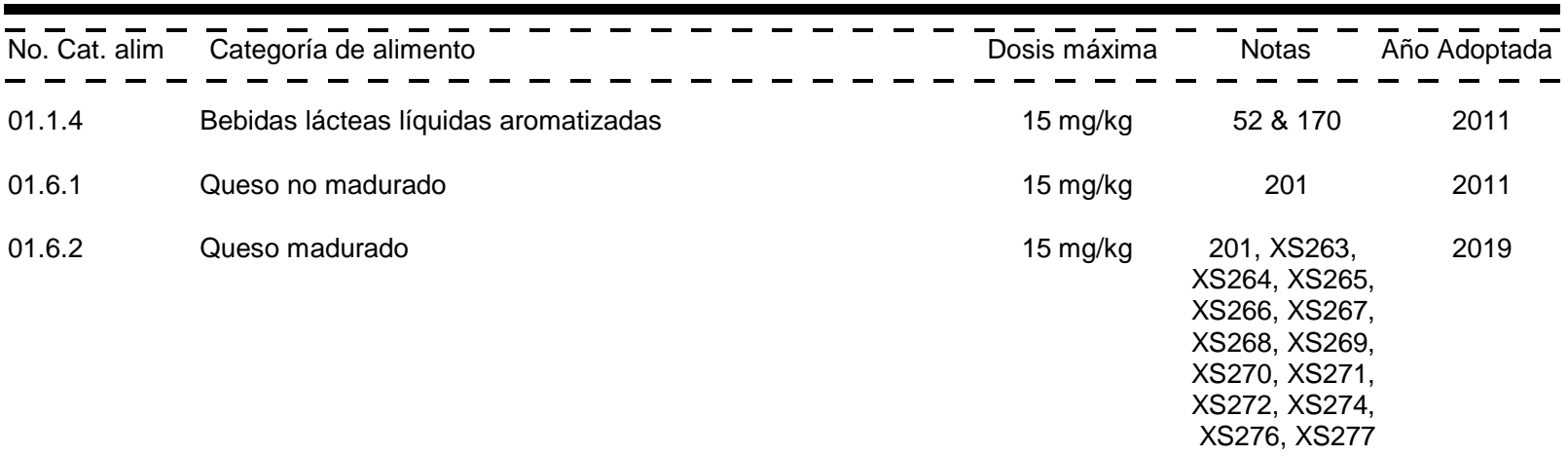


Cuadro I

CANTAXANTINA

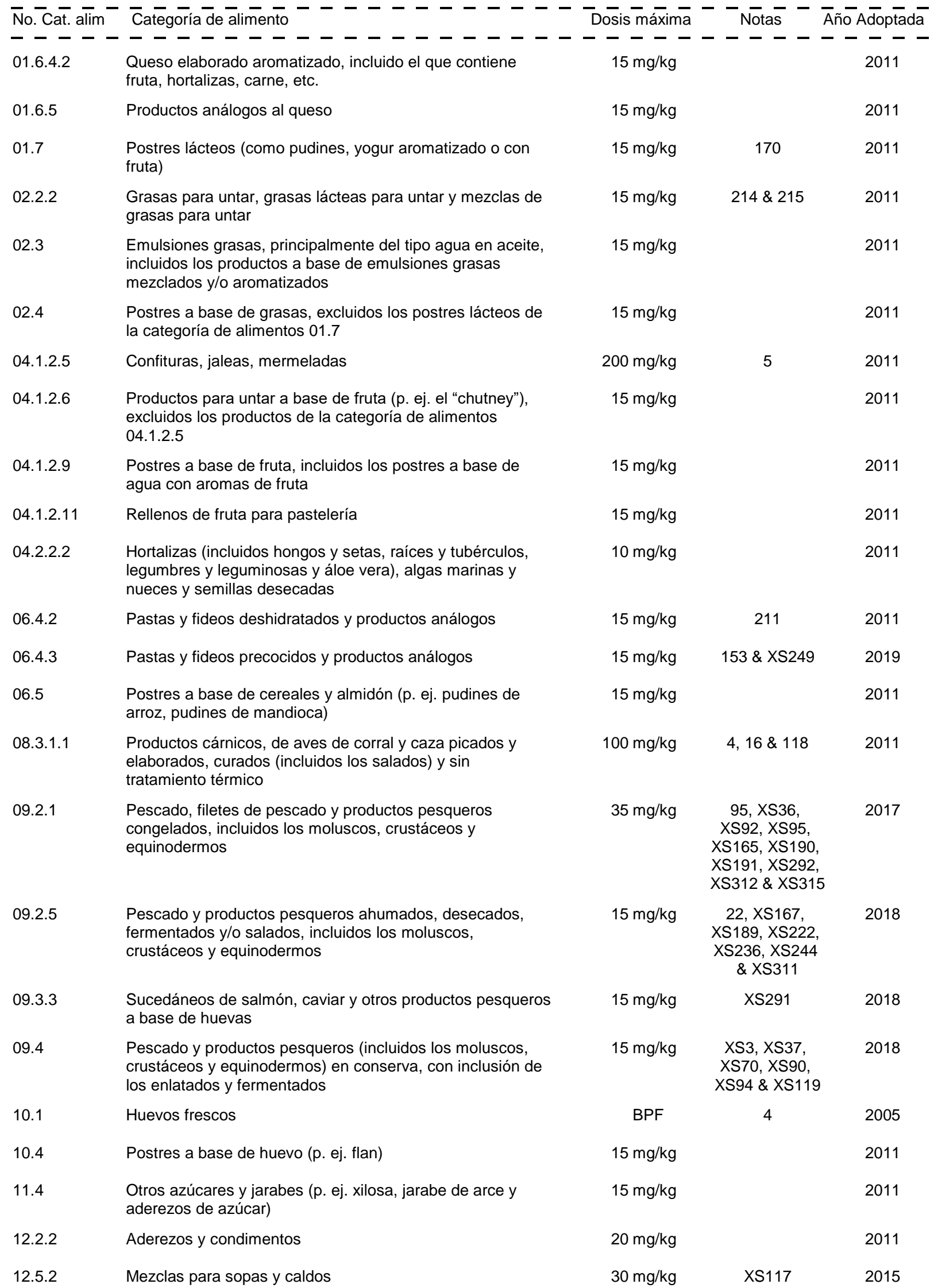


Cuadro I

CANTAXANTINA

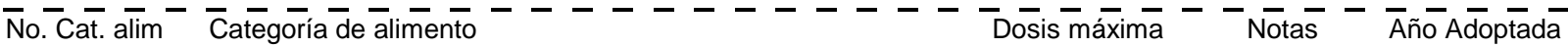

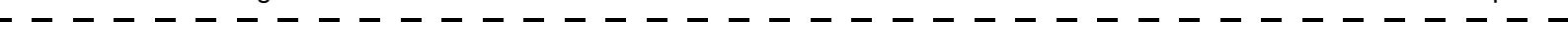

$\begin{array}{llll}12.6 & \text { Salsas y productos análogos } & 30 \mathrm{mg} / \mathrm{kg} & \text { XS302 }\end{array}$

14.1.4.1 Bebidas a base de agua aromatizadas con gas $\quad 5 \mathrm{mg} / \mathrm{kg}$

14.1.4.2 Bebidas a base de agua aromatizadas sin gas, incluidos los $\quad 5 \mathrm{mg} / \mathrm{kg}$

14.1.4.3 Concentrados (líquidos o sólidos) para bebidas a base de $\quad 5 \mathrm{mg} / \mathrm{kg} \quad 127$

14.2.6 Licores destilados que contengan más de un 15 por ciento $\quad 5 \mathrm{mg} / \mathrm{kg}$ de alcohol

14.2.7 Bebidas alcohólicas aromatizadas (p. ej. cerveza, vino y bebidas con licor tipo bebida gaseosa, bebidas refrescantes con bajo contenido de alcohol)

15.1 Aperitivos a base de patatas (papas), cereales, harina o almidón (derivados de raíces y tubérculos, legumbres y leguminosas)

\section{CARAMELO I - CARAMELO PURO}

\section{SIN 150a Caramelo I - caramelo puro Clases Funcionales: Colorantes}

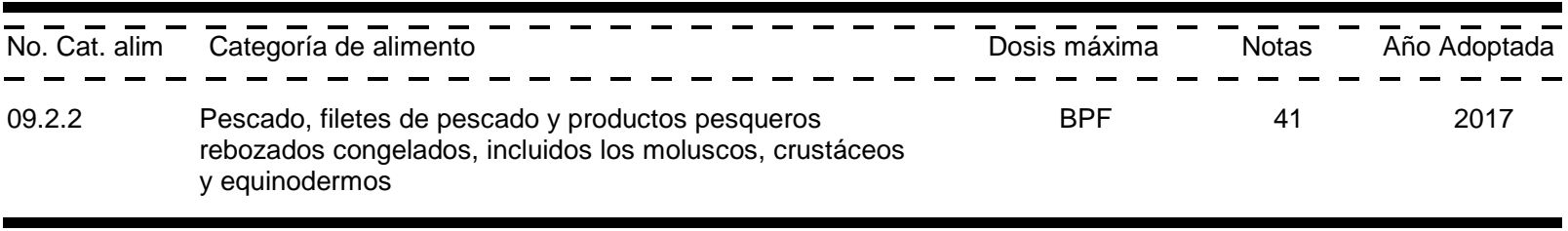

CARAMELO II - CARAMELO AL SULFITO

SIN 150b Caramelo II - caramelo al sulfito Clases Funcionales: Colorantes

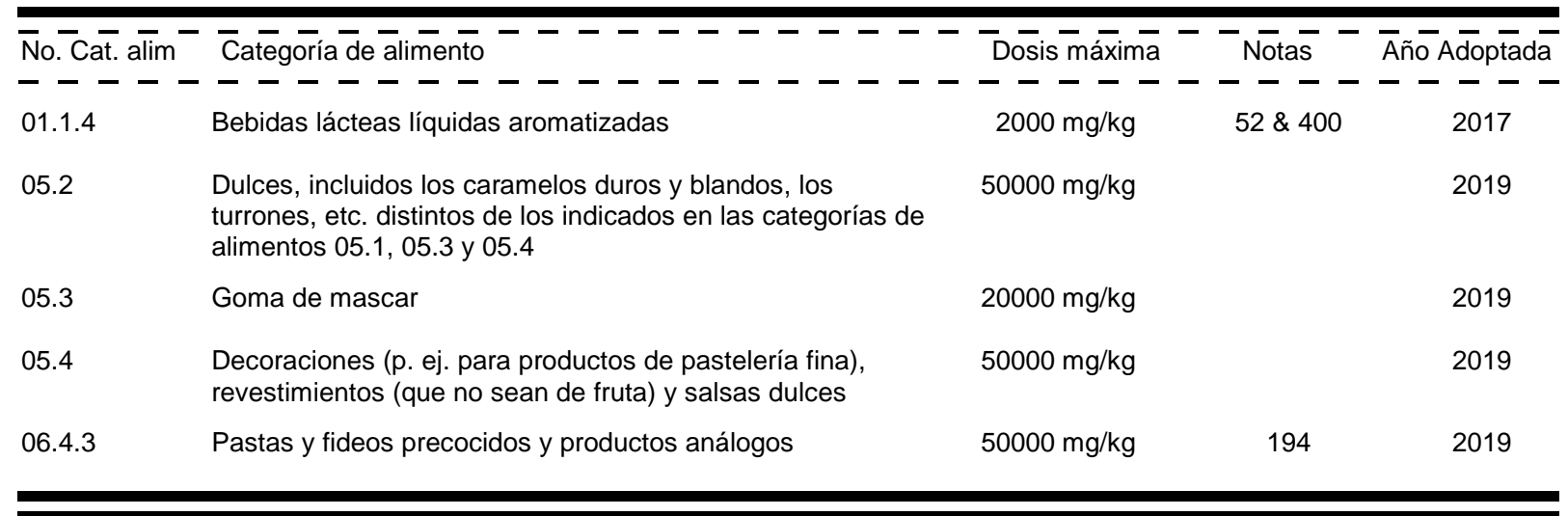

\section{CARAMELO III - CARAMELO AL AMONÍACO}

SIN 150c Caramelo III - caramelo al Clases Funcionales: Colorantes amoníaco

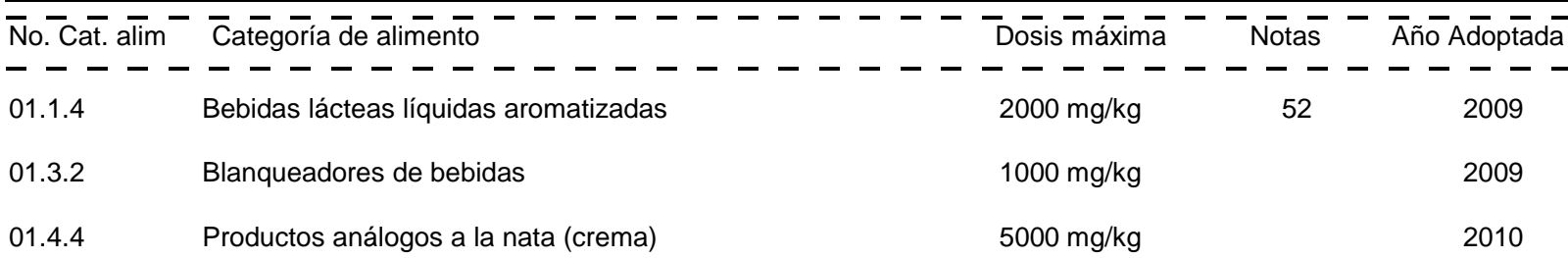


Cuadro I

CARAMELO III - CARAMELO AL AMONÍACO

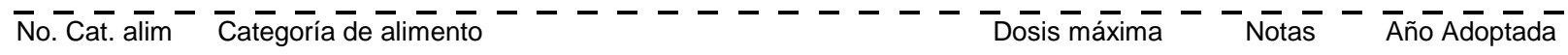

- - - - - - - - - - - - - - - - - - - - - - - - - - - -

01.5.2 Productos análogos a la leche y la nata (crema) en polvo

$5000 \mathrm{mg} / \mathrm{kg}$

01.6.1 Queso no madurado

$15000 \mathrm{mg} / \mathrm{kg} \quad 201 \quad 2012$

01.6.2.2 Corteza de queso madurado

$50000 \mathrm{mg} / \mathrm{kg} \quad 2010$

01.6.4.2 Queso elaborado aromatizado, incluido el que contiene

$50000 \mathrm{mg} / \mathrm{kg}$

2010

01.6.5 Productos análogos al queso

$50000 \mathrm{mg} / \mathrm{kg}$

01.7 Postres lácteos (como pudines, yogur aromatizado o con fruta)

$2000 \mathrm{mg} / \mathrm{kg}$

02.2.2 Grasas para untar, grasas lácteas para untar y mezclas de grasas para untar

$500 \mathrm{mg} / \mathrm{kg}$

02.3 Emulsiones grasas, principalmente del tipo agua en aceite, incluidos los productos a base de emulsiones grasas mezclados $\mathrm{y} / \mathrm{o}$ aromatizados

$02.4 \quad$ Postres a base de grasas, excluidos los postres lácteos de la categoría de alimentos 01.7

$03.0 \quad$ Hielos comestibles, incluidos los sorbetes

2010

$1000 \mathrm{mg} / \mathrm{kg}$

1999

$200 \mathrm{mg} / \mathrm{kg}$

2010

04.1.2.4 Frutas en conserva, enlatadas o en frascos (pasteurizadas)

$200 \mathrm{mg} / \mathrm{kg}$

267

2018

04.1.2.5 Confituras, jaleas, mermeladas

$200 \mathrm{mg} / \mathrm{kg}$

2010

04.1.2.6 Productos para untar a base de fruta (p. ej. el "chutney"), excluidos los productos de la categoría de alimentos

$500 \mathrm{mg} / \mathrm{kg}$

1999 04.1.2.5

04.1.2.7 Frutas confitadas

$200 \mathrm{mg} / \mathrm{kg}$

04.1.2.8 Preparados a base de fruta, incluida la pulpa, los purés, los revestimientos de fruta y la leche de coco

$7500 \mathrm{mg} / \mathrm{kg}$

182

2008

04.1.2.9

Postres a base de fruta, incluidos los postres a base de agua con aromas de fruta

$200 \mathrm{mg} / \mathrm{kg}$

2010

$7500 \mathrm{mg} / \mathrm{kg}$

1999

04.1.2.11 Rellenos de fruta para pastelería

$50000 \mathrm{mg} / \mathrm{kg}$

$76 \& 161$

2010 legumbres y leguminosas y áloe vera), algas marinas y nueces y semillas desecadas

04.2.2.3 Hortalizas (incluidos hongos y setas, raíces y tubérculos, legumbres y leguminosas y áloe vera) y algas marinas en vinagre, aceite, salmuera o salsa de soja

04.2.2.4 Hortalizas (incluidos hongos y setas, raíces y tubérculos, legumbres y leguminosas y áloe vera) y algas marinas en conserva, en latas o frascos (pasteurizadas) o en bolsas de esterilización

04.2.2.5 Purés y preparados para untar elaborados con hortalizas (incluidos hongos y setas, raíces y tubérculos, legumbres y leguminosas y áloe vera), algas marinas y nueces y semillas (p. ej., la mantequilla de maní (cacahuete))

Pulpas y preparados de hortalizas (incluidos hongos y setas, raíces y tubérculos, legumbres y leguminosas y áloe vera), algas marinas y nueces y semillas (como los postres y las salsas a base de hortalizas y hortalizas confitadas) distintos de los indicados en la categoría de alimentos 04.2.2.5 
Cuadro I

CARAMELO III - CARAMELO AL AMONÍACO

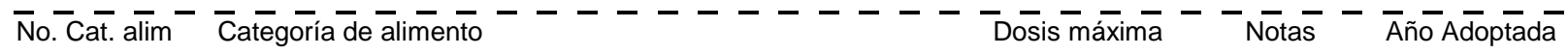

- - - - - - - - - - - - - - - - - - - - - - - - - - - - - -

04.2.2.7 Productos a base de hortalizas (incluidos hongos y setas,

$50000 \mathrm{mg} / \mathrm{kg}$

161

2010 raíces y tubérculos, legumbres y leguminosas y áloe vera) y algas marinas fermentadas, excluidos los productos

fermentados de soja de las categorías 06.8.6, 06.8.7, 12.9.1, 12.9.2.1 y 12.9.2.3

04.2.2.8 Hortalizas (incluidos hongos y setas, raíces y tubérculos, legumbres y leguminosas y áloe vera) y algas marinas cocidas o fritas

05.1.2 Mezclas de cacao (jarabes)

$50000 \mathrm{mg} / \mathrm{kg}$

05.1.3 Productos para untar a base de cacao, incluidos los rellenos a base de cacao

$50000 \mathrm{mg} / \mathrm{kg} \quad \mathrm{XS} 86 \quad 2016$

05.1.4 Productos de cacao y chocolate

$50000 \mathrm{mg} / \mathrm{kg}$

183

2016

05.1.5 Productos de imitación y sucedáneos del chocolate

$50000 \mathrm{mg} / \mathrm{kg}$

2009

05.2

Dulces, incluidos los caramelos duros y blandos, los turrones, etc. distintos de los indicados en las categorías de

$50000 \mathrm{mg} / \mathrm{kg}$

XS309R

2017 alimentos $05.1,05.3$ y 05.4

05.3

Goma de mascar

$20000 \mathrm{mg} / \mathrm{kg}$

1999

05.4

Decoraciones (p. ej. para productos de pastelería fina), revestimientos (que no sean de fruta) y salsas dulces

$50000 \mathrm{mg} / \mathrm{kg}$

2012

06.3

Cereales para el desayuno, incluidos los copos de avena

$50000 \mathrm{mg} / \mathrm{kg}$

189

2009

06.4 .3

Pastas y fideos precocidos y productos análogos

$50000 \mathrm{mg} / \mathrm{kg}$

$153 \& 173$

2010

06.5

Postres a base de cereales y almidón (p. ej. pudines de

$50000 \mathrm{mg} / \mathrm{kg}$

2009 arroz, pudines de mandioca)

06.6

Mezclas batidas para rebozar (p. ej. para empanizar o

$50000 \mathrm{mg} / \mathrm{kg}$

2009 rebozar pescado o carne de aves de corral)

$50000 \mathrm{mg} / \mathrm{kg}$

2009 incluidas las tortas de arroz (sólo del tipo oriental)

06.8.1 Bebidas a base de soja

$1500 \mathrm{mg} / \mathrm{kg}$

2010

06.8.8 Otros productos a base de proteína de soja

$20000 \mathrm{mg} / \mathrm{kg}$

XS175

2019

$50000 \mathrm{mg} / \mathrm{kg}$

161

2009 "crackers" dulces

07.1.3 Otros productos de panadería ordinaria (p. ej. panecillos tipo rosca "bagels", pan tipo mediterráneo "pita", panecillos

$50000 \mathrm{mg} / \mathrm{kg}$

161

2009 ingleses chatos "muffins", etc.)

07.1.4 Productos similares al pan, incluidos los rellenos a base de pan y el pan rallado

$50000 \mathrm{mg} / \mathrm{kg}$

161

2009

07.1 .5

Panes y bollos dulces al vapor

$50000 \mathrm{mg} / \mathrm{kg}$

161

2009

07.1 .6

Mezclas para pan y productos de panadería ordinaria

$50000 \mathrm{mg} / \mathrm{kg}$

161

2010

$50000 \mathrm{mg} / \mathrm{kg}$

161

2009 aromatizados) y mezclas

08.0

Carne y productos cárnicos, incluidos los de aves de corral y caza

BPF

$3,4,16, \mathrm{XS} 88$

XS89, XS96,

XS97 \& XS98

2014 
Cuadro I

CARAMELO III - CARAMELO AL AMONÍACO

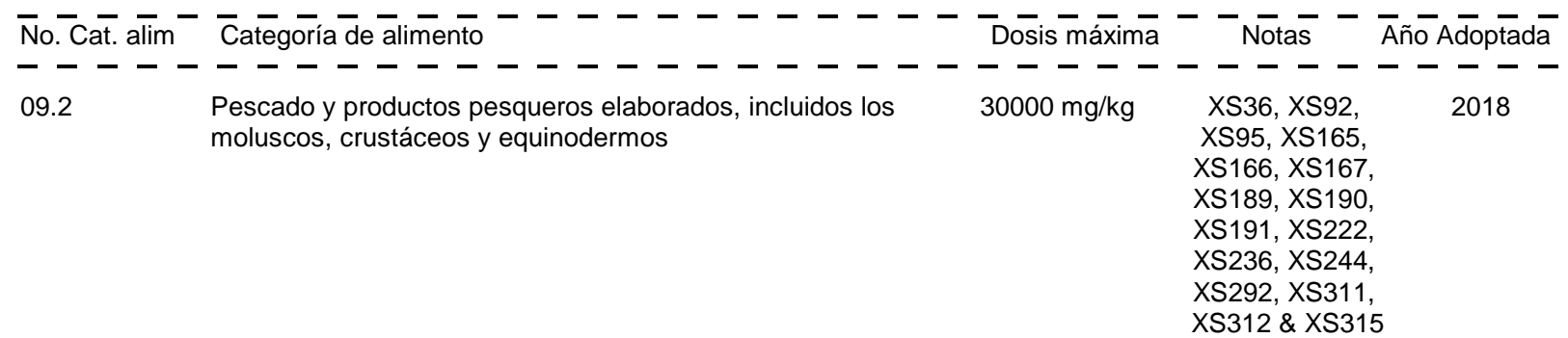

09.3 Pescado y productos pesqueros semiconservados, incluidos los moluscos, crustáceos y equinodermos

$09.4 \quad$ Pescado y productos pesqueros (incluidos los moluscos, crustáceos y equinodermos) en conserva, con inclusión de los enlatados y fermentados

$\begin{array}{rcc}500 \mathrm{mg} / \mathrm{kg} & \begin{array}{c}\text { 50, XS3, XS37, } \\ \text { XS70, XS90, } \\ \text { XS94 \& XS119 }\end{array} & 2018 \\ 20000 \mathrm{mg} / \mathrm{kg} & 4 & 2010 \\ 20000 \mathrm{mg} / \mathrm{kg} & 4 & 2010 \\ 20000 \mathrm{mg} / \mathrm{kg} & & 2010 \\ 50000 \mathrm{mg} / \mathrm{kg} & 100 & 2010 \\ 50000 \mathrm{mg} / \mathrm{kg} & & 2010 \\ 1000 \mathrm{mg} / \mathrm{kg} & 78 & 2010 \\ 50000 \mathrm{mg} / \mathrm{kg} & & 2010 \\ 25000 \mathrm{mg} / \mathrm{kg} & & 2010 \\ 50000 \mathrm{mg} / \mathrm{kg} & & 2010 \\ 50000 \mathrm{mg} / \mathrm{kg} & 89 & 2012\end{array}$

$10.1 \quad$ Huevos frescos

10.3 Huevos en conserva, incluidos los huevos en álcali, salados y envasados

10.4 Postres a base de huevo (p. ej. flan)

11.4 Otros azúcares y jarabes (p. ej. xilosa, jarabe de arce y aderezos de azúcar)

12.2.2 Aderezos y condimentos

$12.3 \quad$ Vinagres

$12.4 \quad$ Mostazas

$12.5 \quad$ Sopas y caldos

$12.6 \quad$ Salsas y productos análogos

12.7 Ensaladas (p. ej., la ensalada de macarrones, la ensalada de patatas (papas)) y productos para untar en emparedados, excluidos los productos para untar a base de cacao y nueces de las categorías de alimentos 04.2.2.5 y 05.1 .3

13.3 Alimentos dietéticos para usos médicos especiales (excluidos los productos de la categoría de alimentos 13.1)

$20000 \mathrm{mg} / \mathrm{kg}$

2010

$20000 \mathrm{mg} / \mathrm{kg}$

2010 peso

$20000 \mathrm{mg} / \mathrm{kg}$

2010

13.5 Alimentos dietéticos (p. ej. los complementos alimenticios para usos dietéticos), excluidos los indicados en las

$20000 \mathrm{mg} / \mathrm{kg}$ categorías de alimentos 13.1 a 13.4 y 13.6

14.1.4 Bebidas a base de agua aromatizadas, incluidas las bebidas para deportistas, bebidas energéticas o bebidas $5000 \mathrm{mg} / \mathrm{kg}$ electrolíticas y bebidas con partículas añadidas

14.1.5 Café, sucedáneos del café, té, infusiones de hierbas y otras bebidas calientes a base de cereales y granos, excluido el cacao 
Cuadro I

CARAMELO III - CARAMELO AL AMONÍACO

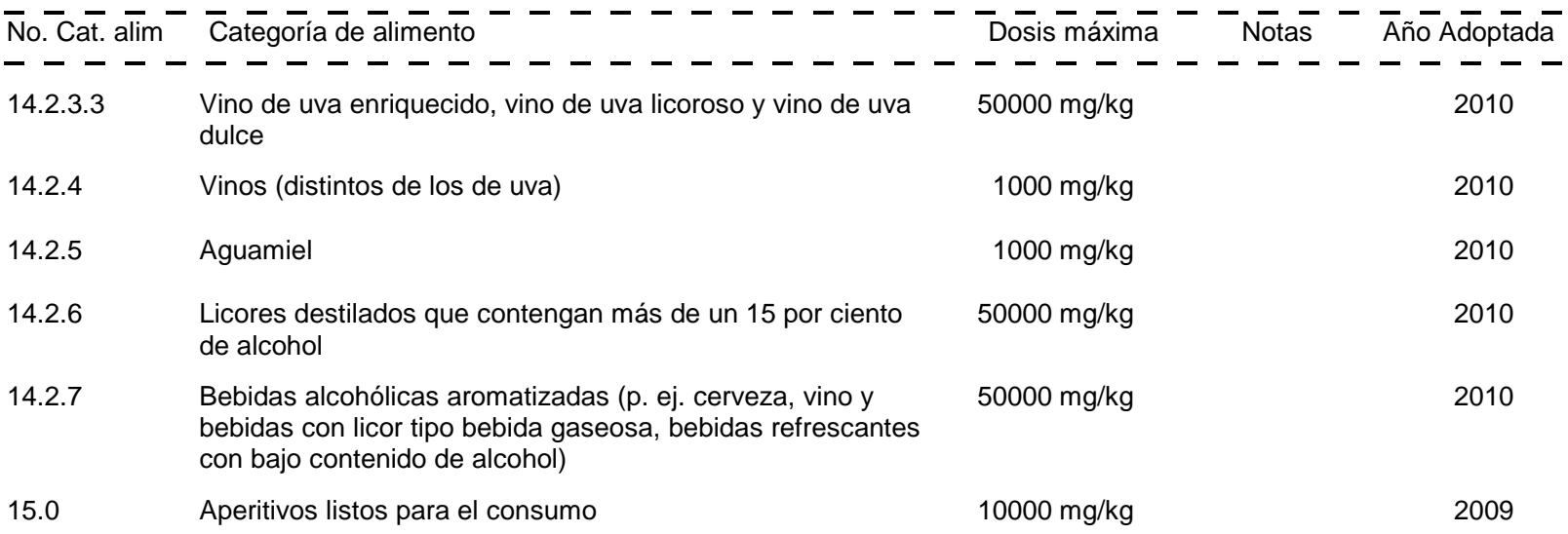

\section{CARAMELO IV - CARAMELO AL SULFITO AMÓNICO}

SIN 150d Caramelo IV - caramelo al sulfito Clases Funcionales: Colorantes amónico

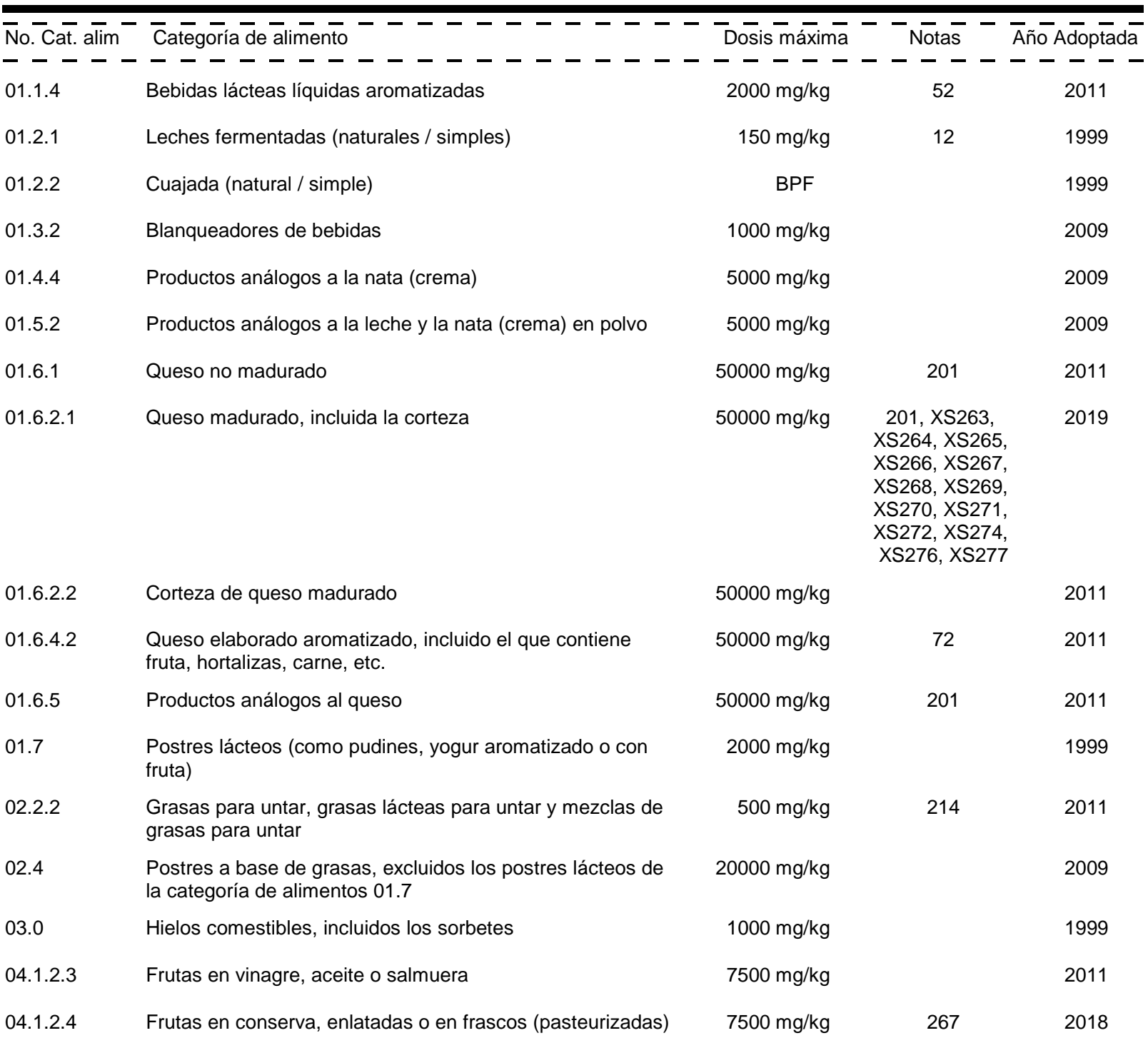


Cuadro I

CARAMELO IV - CARAMELO AL SULFITO

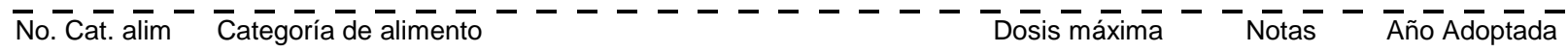

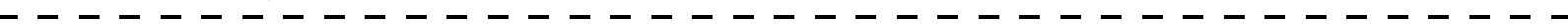

04.1.2.5 Confituras, jaleas, mermeladas $\quad 1500 \mathrm{mg} / \mathrm{kg} \quad 1999$

04.1.2.6 Productos para untar a base de fruta (p. ej. el "chutney"),

$500 \mathrm{mg} / \mathrm{kg}$

1999

excluidos los productos de la categoría de alimentos 04.1.2.5

04.1.2.7 Frutas confitadas

$7500 \mathrm{mg} / \mathrm{kg}$

2011

04.1.2.8 Preparados a base de fruta, incluida la pulpa, los purés, los

$7500 \mathrm{mg} / \mathrm{kg}$

182

2008

04.1 .2 .9 revestimientos de fruta y la leche de coco

$7500 \mathrm{mg} / \mathrm{kg}$

2011 agua con aromas de fruta

04.1.2.11 Rellenos de fruta para pastelería

$7500 \mathrm{mg} / \mathrm{kg}$

1999

04.2.2 Hortalizas (incluidos hongos y setas, raíces y tubérculos, legumbres y leguminosas y áloe vera), algas marinas y nueces y semillas elaboradas

05.1.2 Mezclas de cacao (jarabes)

$50000 \mathrm{mg} / \mathrm{kg}$

2012

05.1.3 Productos para untar a base de cacao, incluidos los rellenos a base de cacao

05.1.4 Productos de cacao y chocolate

$50000 \mathrm{mg} / \mathrm{kg}$

XS86

2016

$50000 \mathrm{mg} / \mathrm{kg}$

183

2016

05.1 .5

Productos de imitación y sucedáneos del chocolate

$50000 \mathrm{mg} / \mathrm{kg}$

2012

05.2

Dulces, incluidos los caramelos duros y blandos, los

$50000 \mathrm{mg} / \mathrm{kg}$

XS309R

2017 alimentos $05.1,05.3$ y 05.4

05.3

Goma de mascar

$20000 \mathrm{mg} / \mathrm{kg}$

$50000 \mathrm{mg} / \mathrm{kg}$

2012

revestimientos (que no sean de fruta) y salsas dulces

06.3 Cereales para el desayuno, incluidos los copos de avena

$2500 \mathrm{mg} / \mathrm{kg}$

1999

$50000 \mathrm{mg} / \mathrm{kg}$

$50000 \mathrm{mg} / \mathrm{kg}$ arroz, pudines de mandioca)

06.6

Mezclas batidas para rebozar (p. ej. para empanizar o

$2500 \mathrm{mg} / \mathrm{kg}$

2011

$2500 \mathrm{mg} / \mathrm{kg}$

2011

incluidas las tortas de arroz (sólo del tipo oriental)

06.8.8 Otros productos a base de proteína de soja

$20000 \mathrm{mg} / \mathrm{kg}$

XS175

2019

07.1 .2

"Crackers" (galletas saladas o de agua), excluidos los "crackers" dulces

$50000 \mathrm{mg} / \mathrm{kg}$

161

2010

07.1.3 Otros productos de panadería ordinaria (p. ej. panecillos tipo rosca "bagels", pan tipo mediterráneo "pita", panecillos

$50000 \mathrm{mg} / \mathrm{kg}$

161

2010 ingleses chatos "muffins", etc.) 
CARAMELO IV - CARAMELO AL SULFITO

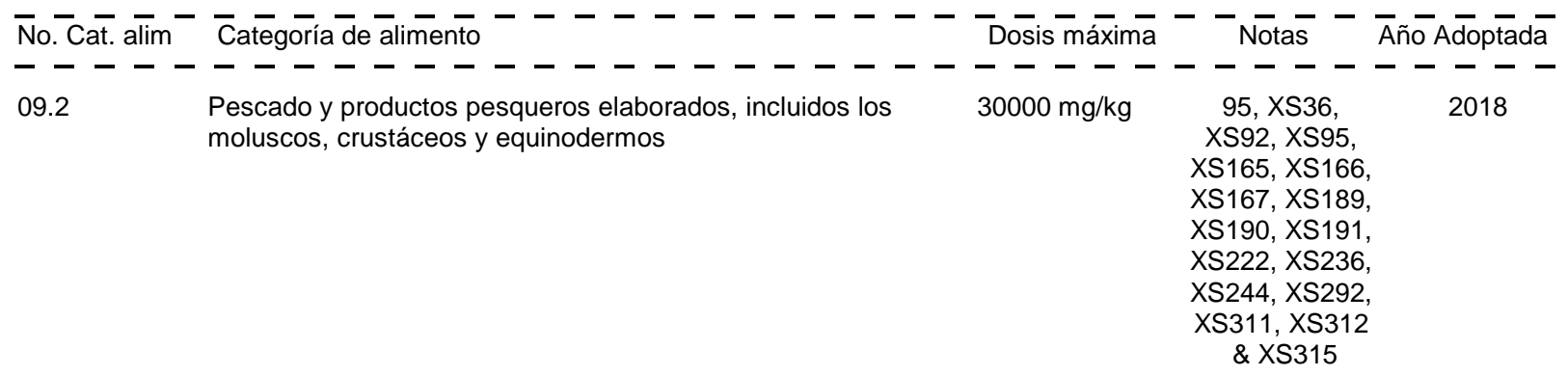

09.3

Pescado y productos pesqueros semiconservados, incluidos los moluscos, crustáceos y equinodermos

09.4 Pescado y productos pesqueros (incluidos los moluscos crustáceos y equinodermos) en conserva, con inclusión de los enlatados y fermentados

10.1

Huevos frescos

10.2

Productos a base de huevo

10.3

Huevos en conserva, incluidos los huevos en álcali, salados y envasados

10.4

Postres a base de huevo (p. ej. flan)

30000 mg/kg

$95 \&$ XS291

2018

$30000 \mathrm{mg} / \mathrm{kg} \quad 95, \mathrm{XS} 3, \mathrm{XS} 37$

XS70, XS90,

XS94 \& XS119

$20000 \mathrm{mg} / \mathrm{kg}$

161

$20000 \mathrm{mg} / \mathrm{kg}$

$20000 \mathrm{mg} / \mathrm{kg}$

$20000 \mathrm{mg} / \mathrm{kg}$

$1200 \mathrm{mg} / \mathrm{kg}$

213

edulcorantes de gran intensidad

Hierbas aromáticas, especias, aderezos y condimentos ( $p$. ej. el aderezo para fideos instantáneos)

12.3

Vinagres

$10000 \mathrm{mg} / \mathrm{kg}$

$50000 \mathrm{mg} / \mathrm{kg}$

$50000 \mathrm{mg} / \mathrm{kg}$

$25000 \mathrm{mg} / \mathrm{kg}$

$30000 \mathrm{mg} / \mathrm{kg}$

$50000 \mathrm{mg} / \mathrm{kg}$

Ensaladas (p. ej., la ensalada de macarrones, la ensalada de patatas (papas)) y productos para untar en

emparedados, excluidos los productos para untar a base de cacao y nueces de las categorías de alimentos 04.2.2.5 y

05.1 .3

12.9.2.

Salsa de soja fermentada

$60000 \mathrm{mg} / \mathrm{kg}$

2011

$20000 \mathrm{mg} / \mathrm{kg}$

2009

(excluidos los productos de la categoría de alimentos 13.1)

13.4 Preparados dietéticos para adelgazamiento y control del peso

$20000 \mathrm{mg} / \mathrm{kg}$

2009

$20000 \mathrm{mg} / \mathrm{kg}$

2009

para usos dietéticos), excluidos los indicados en las categorías de alimentos 13.1 a 13.4 y 13.6

13.6

Complementos alimenticios

$20000 \mathrm{mg} / \mathrm{kg}$

2009

$50000 \mathrm{mg} / \mathrm{kg}$

2009

bebidas para deportistas, bebidas energéticas o bebidas electrolíticas y bebidas con partículas añadidas

14.1.5 Café, sucedáneos del café, té, infusiones de hierbas y otras bebidas calientes a base de cereales y granos, excluido el cacao

$10000 \mathrm{mg} / \mathrm{kg}$

$7 \& 127$

2011

$50000 \mathrm{mg} / \mathrm{kg}$

2011

$1000 \mathrm{mg} / \mathrm{kg}$

10

009

009

011

010

011

2011

2011

2018

2011

09

Cerveza y bebidas a base de malta

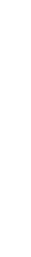

9


Cuadro I

CARAMELO IV - CARAMELO AL SULFITO

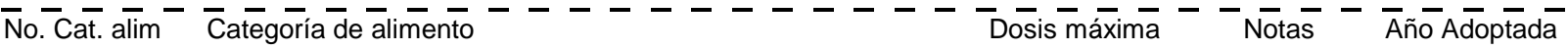

- - - - - - - - - - - - - - - - - - - - - - - - -

14.2.3.3 Vino de uva enriquecido, vino de uva licoroso y vino de uva $50000 \mathrm{mg} / \mathrm{kg} \quad 2011$ dulce

$\begin{array}{lll}\text { 14.2.4 Vinos (distintos de los de uva) } & 1000 \mathrm{mg} / \mathrm{kg} & 2009\end{array}$

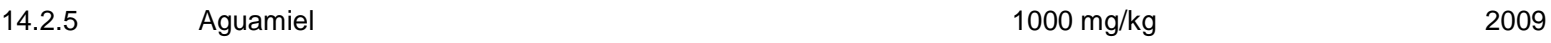

14.2.6 Licores destilados que contengan más de un 15 por ciento $\quad 50000 \mathrm{mg} / \mathrm{kg} \quad 2011$

14.2.7 Bebidas alcohólicas aromatizadas (p. ej. cerveza, vino y $\quad 50000 \mathrm{mg} / \mathrm{kg} \quad 2011$ bebidas con licor tipo bebida gaseosa, bebidas refrescantes con bajo contenido de alcohol)

\section{CARBOHIDRASA DE BACILLUS LICHENIFORMIS}

SIN 1100(vi) Carboidrasa de Bacillus Clases Funcionales: Agentes de tratamiento de las harinas licheniformi

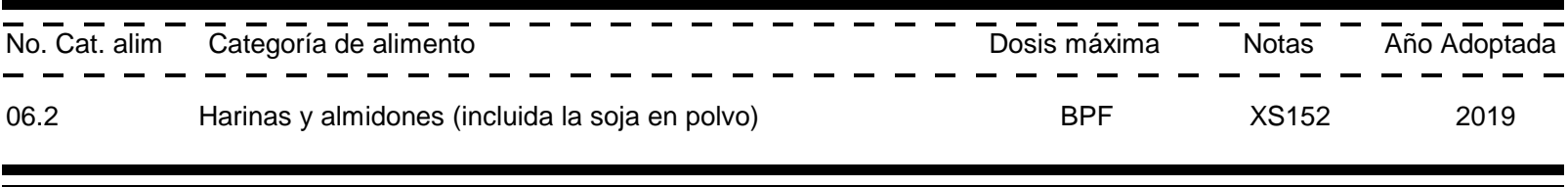

\section{CARBONATO ÁCIDO DE AMONIO}

\section{SIN 503(ii) Carbonato ácido de amonio Clases Funcionales: Reguladores de la acidez, Leudantes}

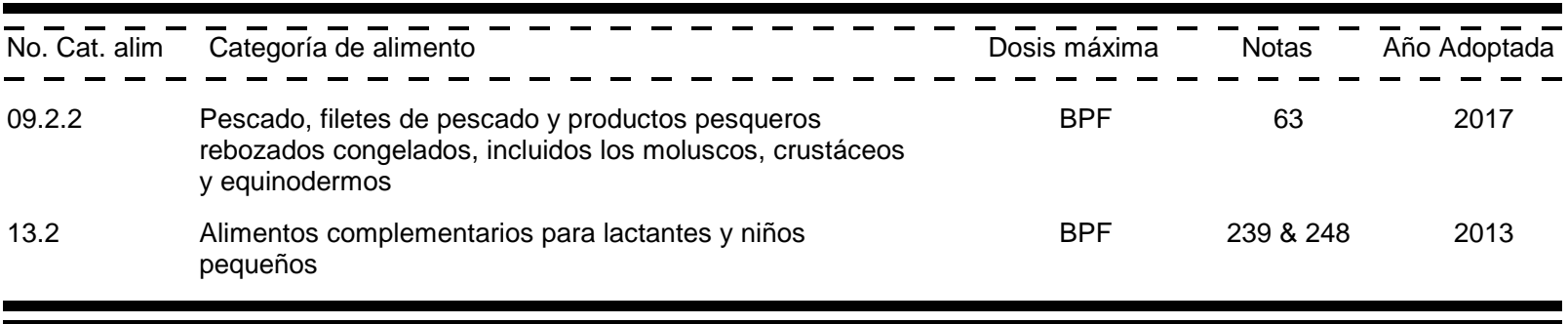

\section{CARBONATO ÁCIDO DE MAGNESIO}

SIN 504(ii) Carbonato ácido de magnesio Clases Funcionales: Reguladores de la acidez, Antiaglutinantes, Sustancias inertes, Agentes de retención de color

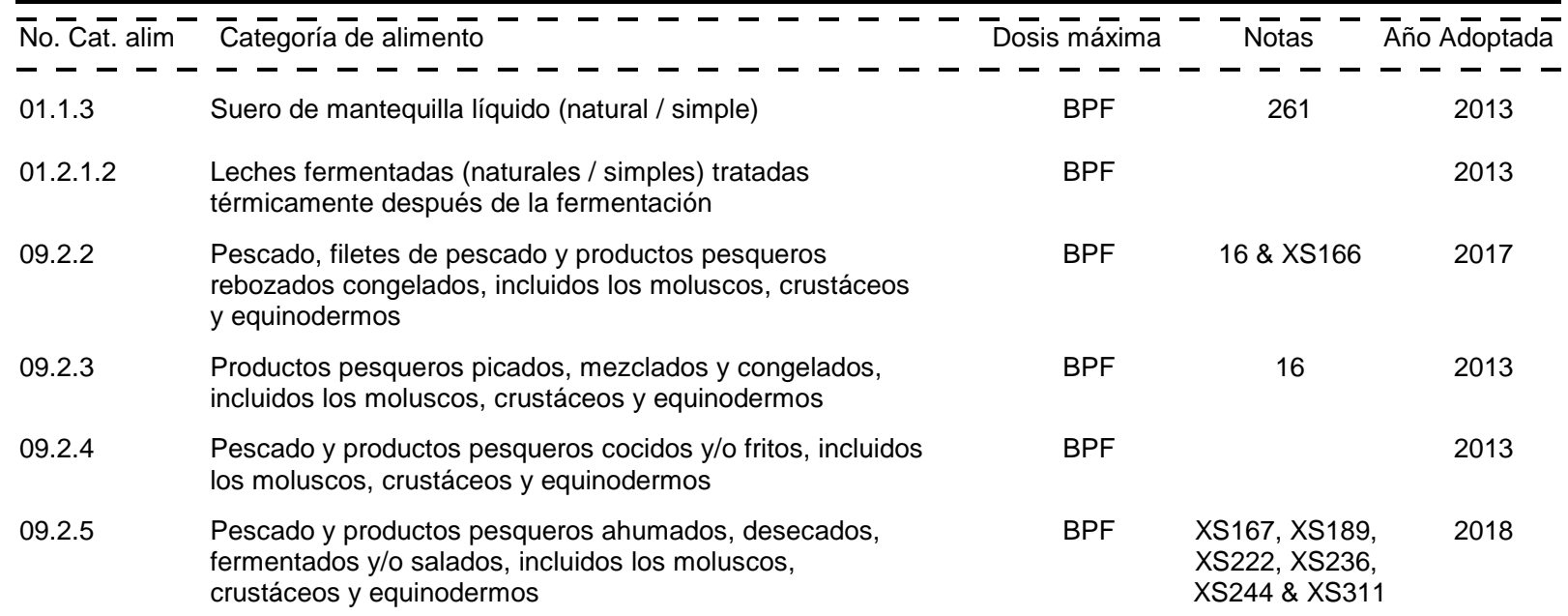


Cuadro I

CARBONATO ÁCIDO DE MAGNESIO

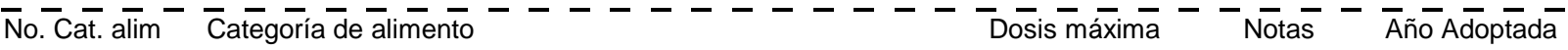

- - - - - - - - - - - - - - - - - - - - - - - - - -

11.4 Otros azúcares y jarabes (p. ej. xilosa, jarabe de arce y $\quad$ BPF $\quad 258$ aderezos de azúcar)

12.1.2 Sucedáneos de la sal

BPF

2013

14.1 .5

Café, sucedáneos del café, té, infusiones de hierbas y otras

BPF

160

2013 cacao

\section{CARBONATO ÁCIDO DE POTASIO}

SIN 501(ii) Carbonato ácido de potasio Clases Funcionales: Reguladores de la acidez, Leudantes, Estabilizadores

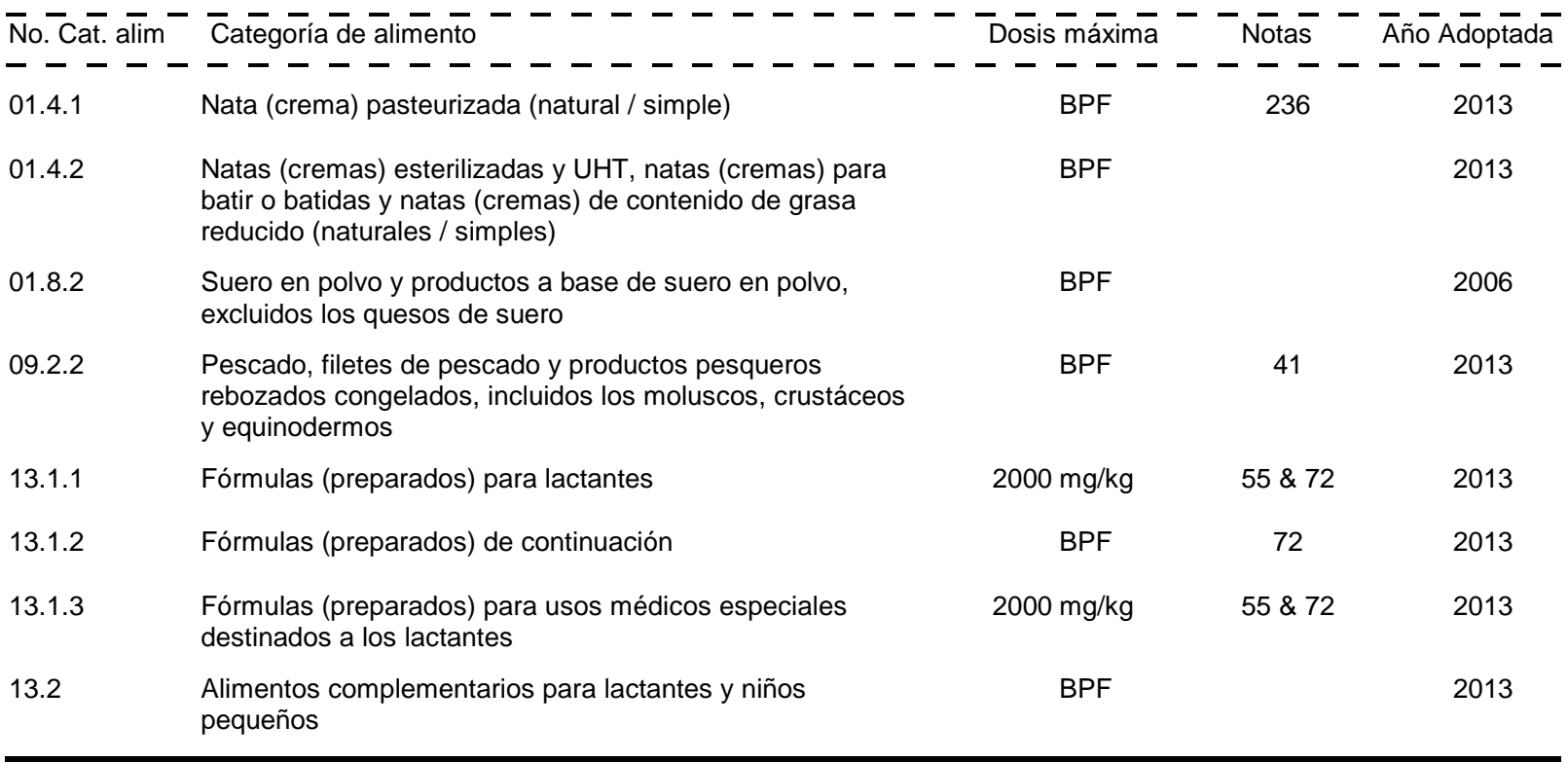

\section{CARBONATO ÁCIDO DE SODIO}

SIN 500(ii) Carbonato ácido de sodio Clases Funcionales: Reguladores de la acidez, Antiaglutinantes, Leudantes, Estabilizadores, Espesantes

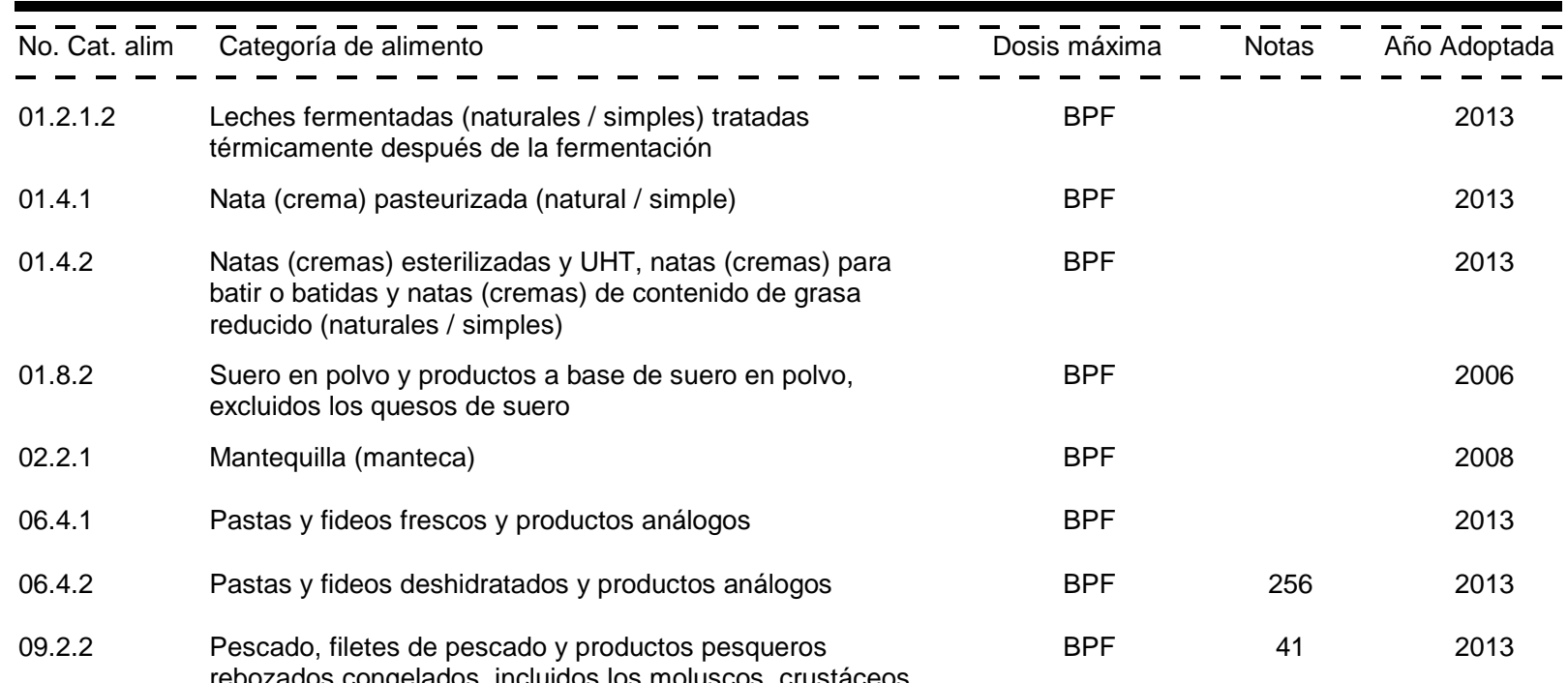


Cuadro I

CARBONATO ÁCIDO DE SODIO

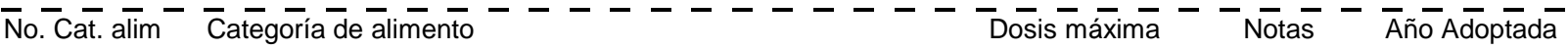

- - - - - - - - - - - - - - - - - - - - - - - - - -

13.1.1 Fórmulas (preparados) para lactantes $\quad 2000 \mathrm{mg} / \mathrm{kg} \quad 55 \& 72 \quad 2013$

13.1.2 Fórmulas (preparados) de continuación $\quad$ BPF $\quad 72 \& 316 \quad 2015$

13.1.3 Fórmulas (preparados) para usos médicos especiales $\quad 2000 \mathrm{mg} / \mathrm{kg} \quad 55 \& 72 \quad 2013$

13.2 Alimentos complementarios para lactantes y niños $\quad$ BPF $\quad 240,319 \& 320 \quad 2015$

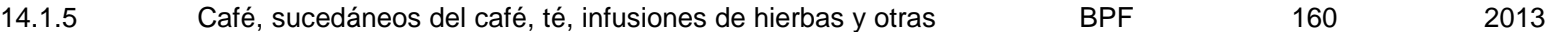
bebidas calientes a base de cereales y granos, excluido el cacao

\section{CARBONATO DE AMONIO}

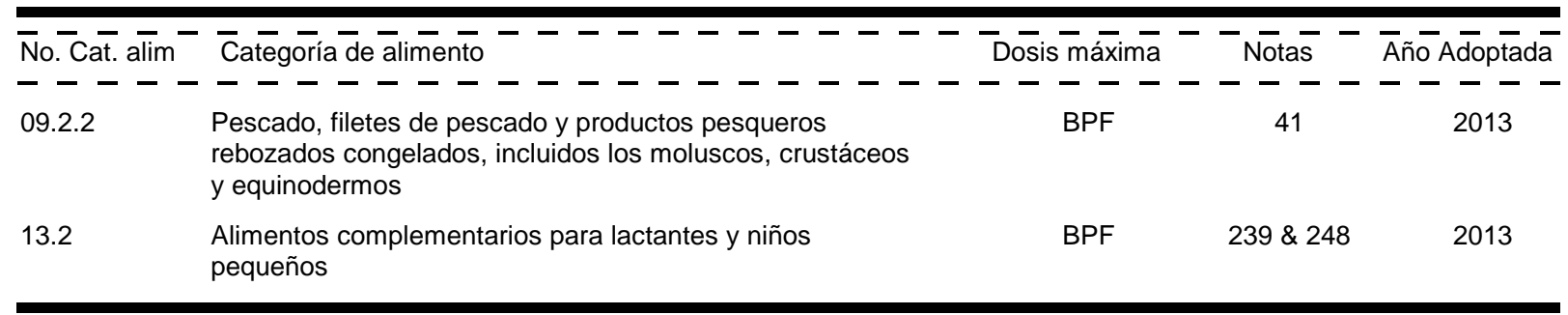

\section{CARBONATO DE CALCIO}

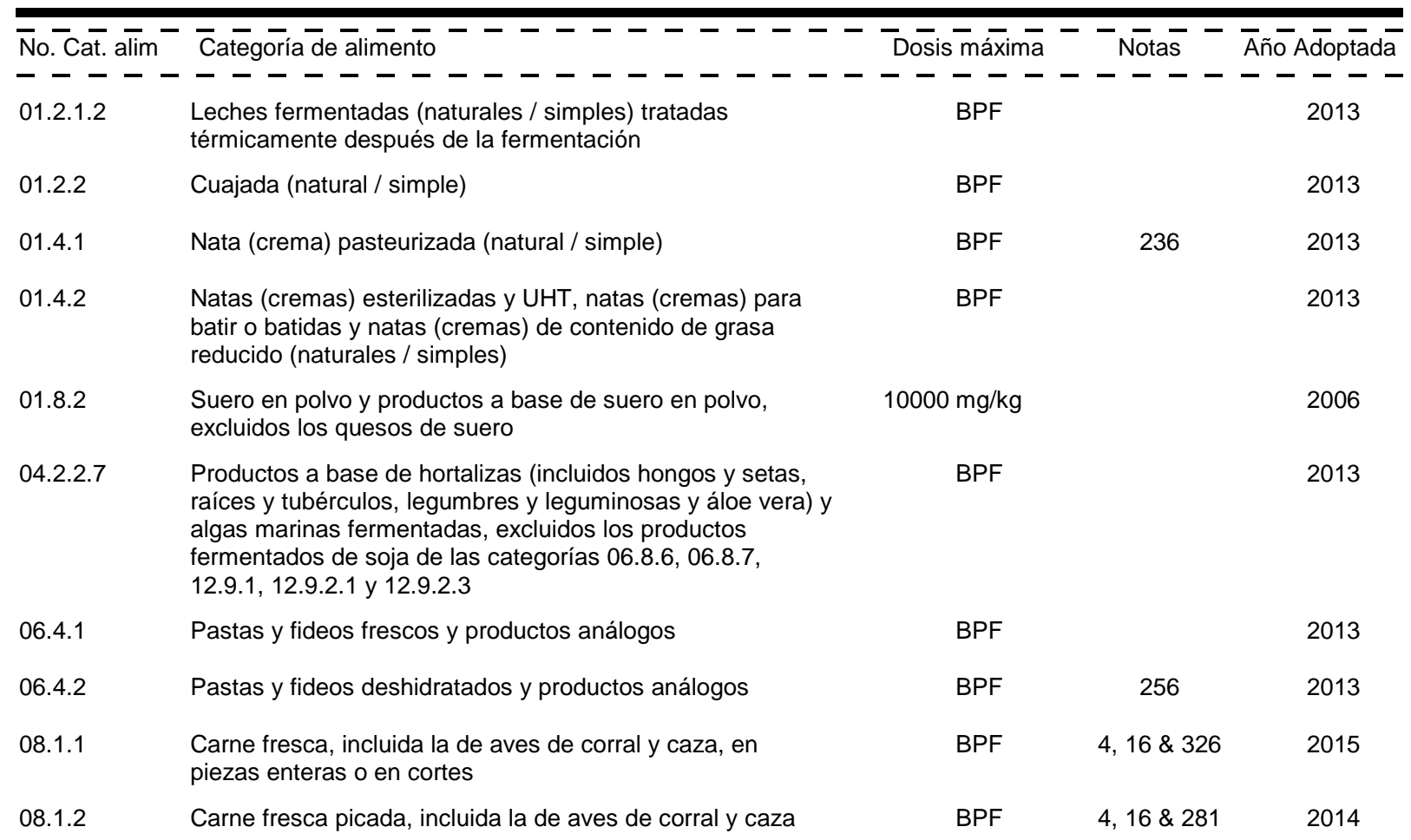


Cuadro I

CARBONATO DE CALCIO

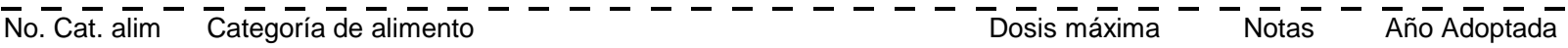

- - - - - - - - - - - - - - - - - - - - -

95, XS36

2017 congelados, incluidos los moluscos, crustáceos y

BPF

XS92, XS95,

equinodermos

XS165, XS190

XS191, XS292,

XS312 \& XS315

09.2.2 Pescado, filetes de pescado y productos pesqueros

BPF

$16 \&$ XS166

2017 rebozados congelados, incluidos los moluscos, crustáceos y equinodermos

09.2.3 Productos pesqueros picados, mezclados y congelados, incluidos los moluscos, crustáceos y equinodermos

16

09.2.4 Pescado y productos pesqueros cocidos y/o fritos, incluidos

BPF

2013 los moluscos, crustáceos y equinodermos

BPF fermentados y/o salados, incluidos los moluscos,

BPF

XS167, XS189,

XS222, XS236,

XS244 \& XS311 crustáceos y equinodermos pequeños

14.1.5 Café, sucedáneos del café, té, infusiones de hierbas y otras bebidas calientes a base de cereales y granos, excluido el cacao

\section{CARBONATO DE MAGNESIO} de retención de color

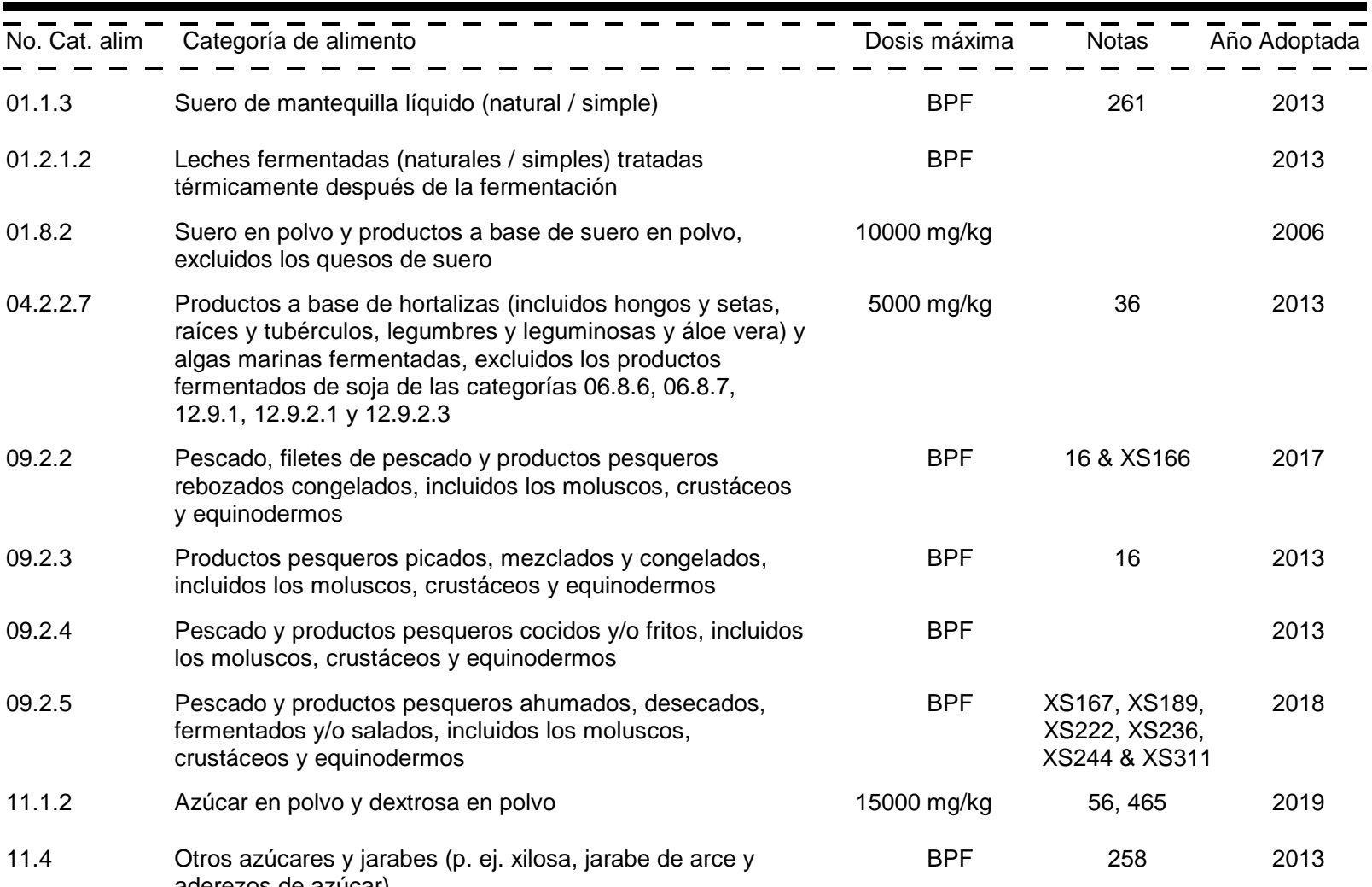


Cuadro I

CARBONATO DE MAGNESIO

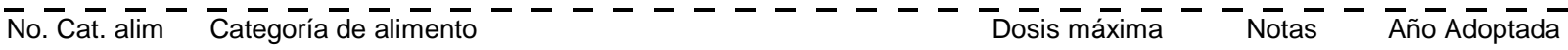

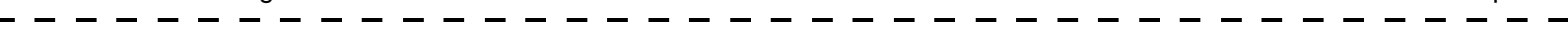

$\begin{array}{rlll}\text { 12.1.1 Sal } & \text { BPF } & 2006\end{array}$

$\begin{array}{lll}\text { 12.1.2 Sucedáneos de la sal } & \text { BPF } & 2013\end{array}$

14.1.5 Café, sucedáneos del café, té, infusiones de hierbas y otras $\quad$ BPF $\quad 160 \quad 2013$ bebidas calientes a base de cereales y granos, excluido el cacao

\section{CARBONATO DE POTASIO}

SIN 501(i) Carbonato de potasio Clases Funcionales: Reguladores de la acidez, Estabilizadores

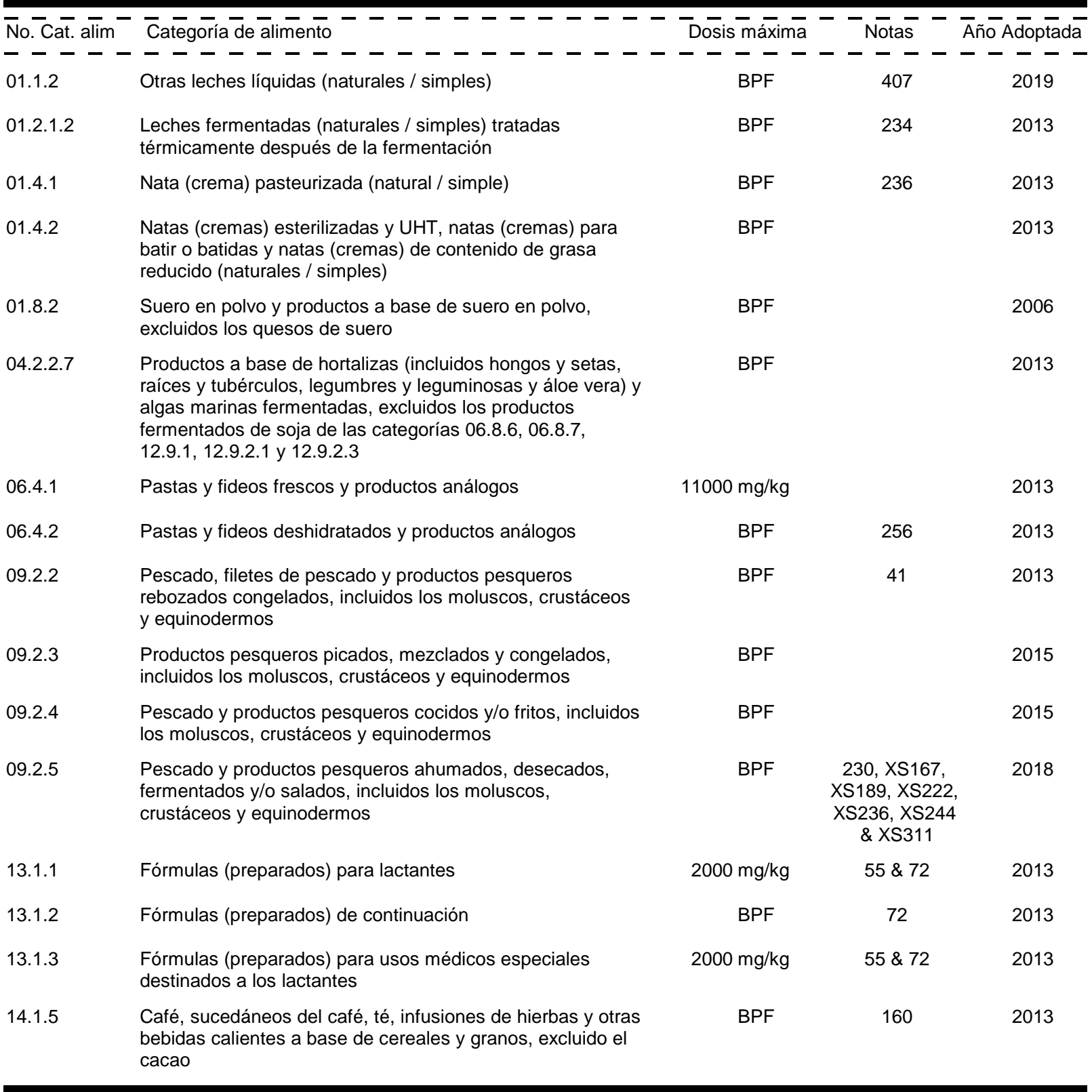




\section{CARBONATO DE SODIO}

SIN 500(i)
Clases Funcionales: Reguladores de la acidez, Antiaglutinantes, Sales emulsionantes, Leudantes, Estabilizadores, Espesantes

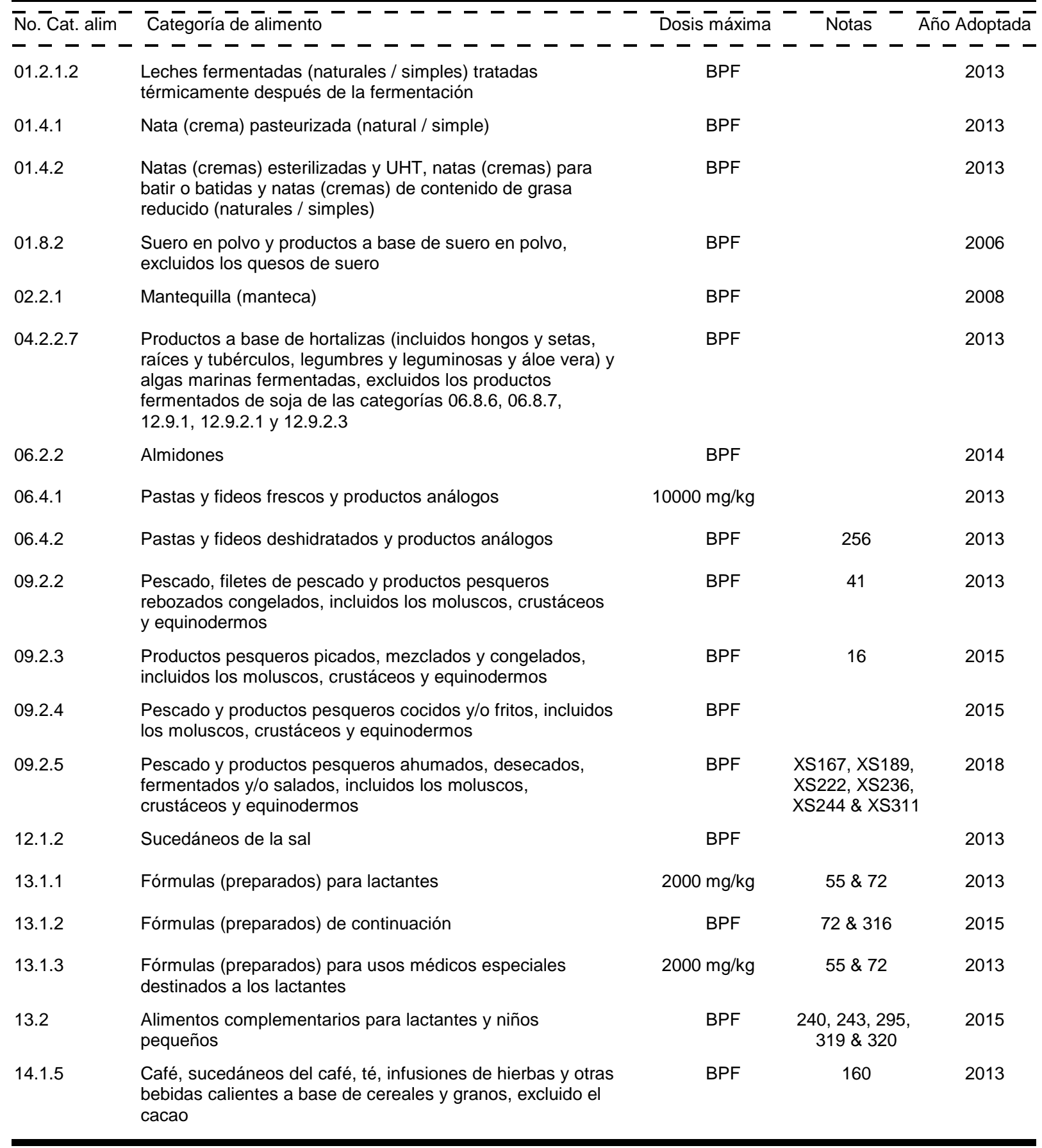


Cuadro I

CARBOXIMETILCELULOSA SÓDICA (GOMA DE

\section{CARBOXIMETILCELULOSA SÓDICA (GOMA DE}

CELULOSA)

SIN $466 \quad$ Carboximetilcelulosa sódica (Goma de celulosa)
Clases Funcionales: Incrementadores del volumen, Emulsionantes, Agentes endurecedores, Agentes gelificantes, Agentes de glaseado, Humectantes, Estabilizadores, Espesantes

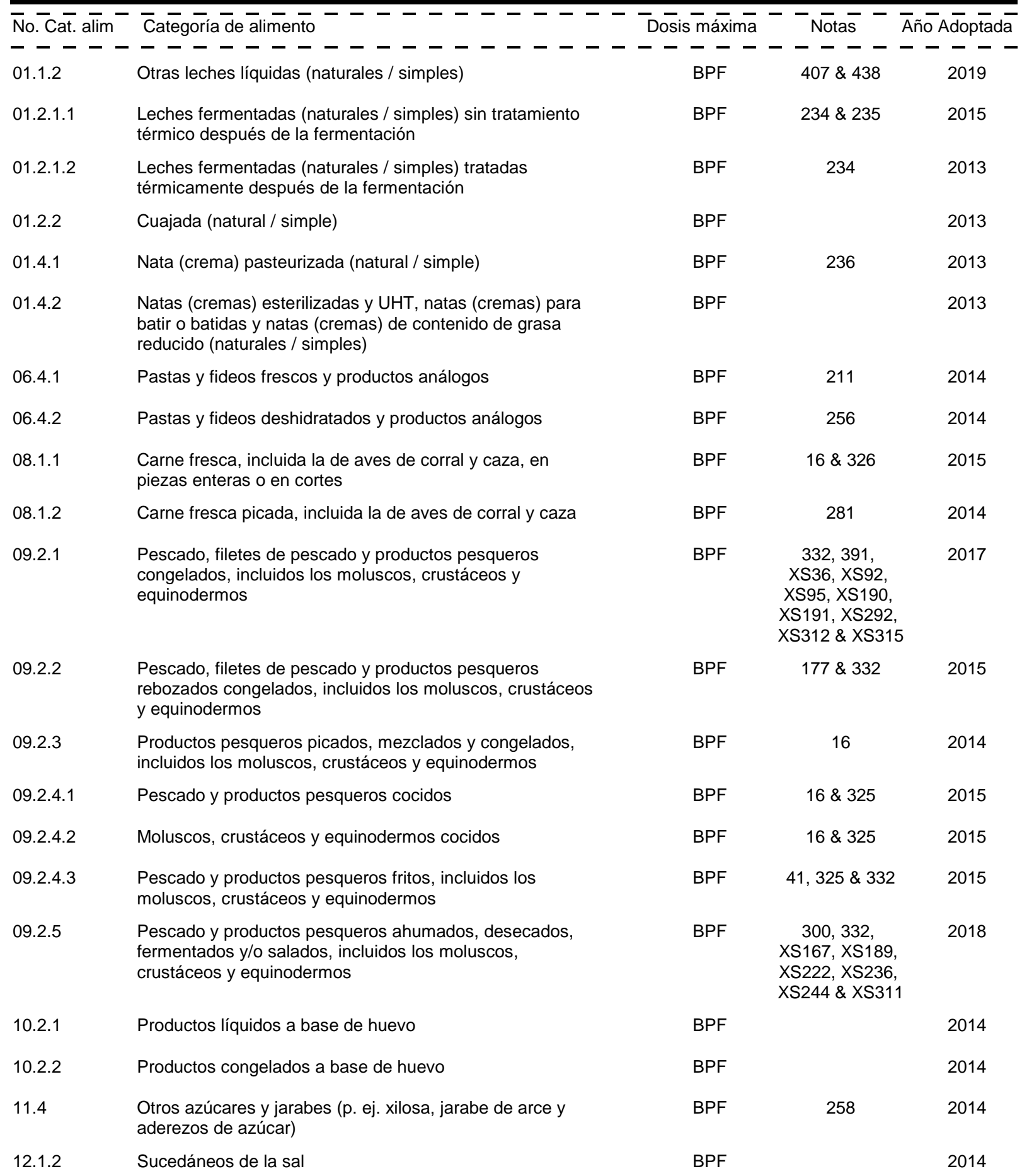


Cuadro I

CARBOXIMETILCELULOSA SÓDICA (GOMA DE

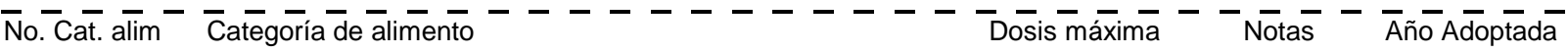

- - - - - - - - - - - - - - - - - - - - - - - - - -

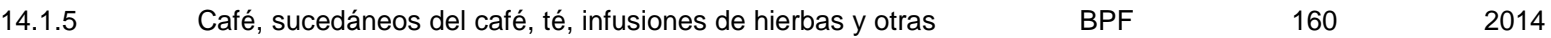
bebidas calientes a base de cereales y granos, excluido el cacao

\section{CARMINES}

SIN 120 Carmines Clases Funcionales: Colorantes

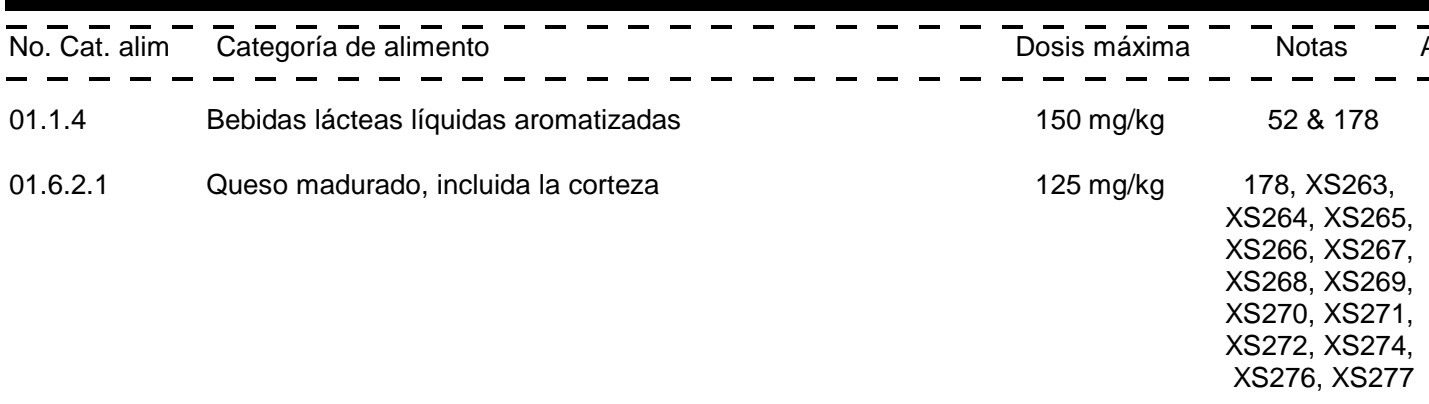

01.6.4.2 Queso elaborado aromatizado, incluido el que contiene

178

2005

ruta, hortalizas, carne, etc.

$100 \mathrm{mg} / \mathrm{kg}$

$3 \& 178$

2008

01.7

Postres lácteos (como pudines, yogur aromatizado o con fruta)

$150 \mathrm{mg} / \mathrm{kg}$

178

2005

02.2 .2

Grasas para untar, grasas lácteas para untar y mezclas de grasas para untar

$500 \mathrm{mg} / \mathrm{kg}$

$161 \& 178$

2008

02.3 Emulsiones grasas, principalmente del tipo agua en aceite, incluidos los productos a base de emulsiones grasas

$500 \mathrm{mg} / \mathrm{kg}$

$161 \& 178$

2008 mezclados y/o aromatizados

$02.4 \quad$ Postres a base de grasas, excluidos los postres lácteos de la categoría de alimentos 01.7

$150 \mathrm{mg} / \mathrm{kg}$

178

2005

$150 \mathrm{mg} / \mathrm{kg}$

178

2005

$500 \mathrm{mg} / \mathrm{kg}$

$4,16 \& 178$

2008

04.1.1.2 Frutas frescas tratadas en la superficie

$200 \mathrm{mg} / \mathrm{kg}$

$104 \& 178$

2018

$200 \mathrm{mg} / \mathrm{kg}$

178

2005

04.1.2.5 Confituras, jaleas, mermeladas

$500 \mathrm{mg} / \mathrm{kg}$

178

2005 excluidos los productos de la categoría de alimentos

04.1 .2 .5

04.1.2.7 Frutas confitadas

$200 \mathrm{mg} / \mathrm{kg}$

178

2005

04.1.2.8 Preparados a base de fruta, incluida la pulpa, los purés, los revestimientos de fruta y la leche de coco

$500 \mathrm{mg} / \mathrm{kg}$

$178 \& 182$

2008

$150 \mathrm{mg} / \mathrm{kg}$

178

2005

agua con aromas de fruta

$300 \mathrm{mg} / \mathrm{kg}$

178

2005

04.1.2.11 Rellenos de fruta para pastelería

$500 \mathrm{mg} / \mathrm{kg}$

$4,16 \& 178$

2008

04.2.1.2 Hortalizas (incluidos hongos y setas, raíces y tubérculos, legumbres y leguminosas y áloe vera), algas marinas y nueces y semillas frescas tratadas en la superficie

04.2.2.3

Hortalizas (incluidos hongos y setas, raíces y tubérculos, legumbres y leguminosas y áloe vera) y algas marinas en vinagre, aceite, salmuera o salsa de soja 
Cuadro I

CARMINES

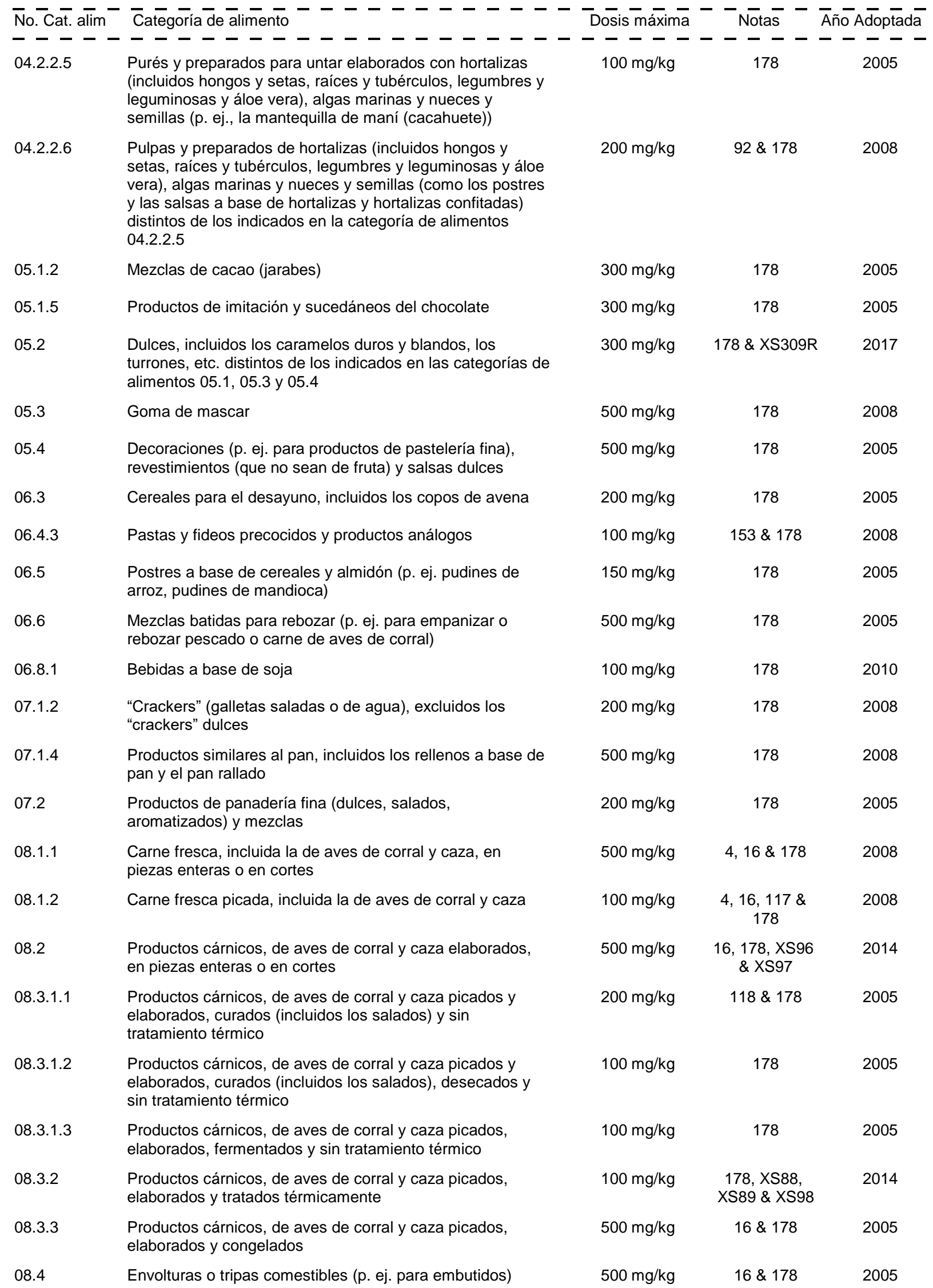


Cuadro I

CARMINES

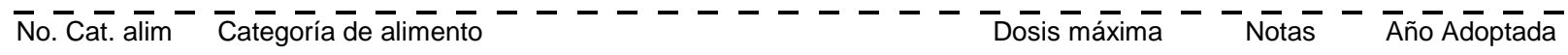

- - - - - - - - - - - - - - - - -

$300 \mathrm{mg} / \mathrm{kg}$

$4,16,50 \& 178 \quad 2008$

09.1 .2

Moluscos, crustáceos y equinodermos frescos

$500 \mathrm{mg} / \mathrm{kg}$

$4,16,178$

2017

XS292, XS312

\& XS315

09.2.1 Pescado, filetes de pescado y productos pesqueros congelados, incluidos los moluscos, crustáceos y equinodermos

$100 \mathrm{mg} / \mathrm{kg} \quad 95,178, \mathrm{XS} 36$

XS92, XS95,

XS165, XS190

XS191, XS292,

XS312 \& XS315

09.2.2 Pescado, filetes de pescado y productos pesqueros rebozados congelados, incluidos los moluscos, crustáceos

$16,95,178, \&$

XS166

2017

$500 \mathrm{mg} / \mathrm{kg}$

$x \sin 6$

2017

$500 \mathrm{mg} / \mathrm{kg}$

$16 \& 178$

2005

incluidos los moluscos, crustáceos y equinodermos

09.2.4.1 Pescado y productos pesqueros cocidos

$500 \mathrm{mg} / \mathrm{kg}$

178

2005

$250 \mathrm{mg} / \mathrm{kg}$

178

2005

$500 \mathrm{mg} / \mathrm{kg}$

$16,95 \& 178$

2008

$300 \mathrm{mg} / \mathrm{kg}$

22,178

Pescado y productos pesqueros ahumados, desecados, fermentados y/o salados, incluidos los moluscos, crustáceos y equinodermos

XS167, XS189

XS222, XS236

XS244 \& XS311

09.3.1 Pescado y productos pesqueros marinados y/o en gelatina, incluidos los moluscos, crustáceos y equinodermos

$500 \mathrm{mg} / \mathrm{kg}$

$16 \& 178$

2005

$500 \mathrm{mg} / \mathrm{kg}$

$16 \& 178$

2005

salmuera, incluidos los moluscos, crustáceos y

equinodermos

09.3.3 Sucedáneos de salmón, caviar y otros productos pesqueros a base de huevas

$500 \mathrm{mg} / \mathrm{kg}$

178 \& XS291

2018

$100 \mathrm{mg} / \mathrm{kg}$

178

2005

incluidos los moluscos, crustáceos y equinodermos (p. ej.,

la pasta de pescado), excluidos los productos indicados en las categorías de alimentos 09.3.1 a 09.3.3

Pescado y productos pesqueros (incluidos los moluscos, crustáceos y equinodermos) en conserva, con inclusión de los enlatados y fermentados

$500 \mathrm{mg} / \mathrm{kg}$

$16,178, \mathrm{XS} 3$,

XS37, XS70,

XS90, XS94 \&

XS119

Huevos frescos

$4 \& 178$

2005

10.4 Postres a base de huevo (p. ej. flan)

$150 \mathrm{mg} / \mathrm{kg}$

178

2005

$500 \mathrm{mg} / \mathrm{kg}$

178

2005

$300 \mathrm{mg} / \mathrm{kg}$

178

2005

$50 \mathrm{mg} / \mathrm{kg}$

178

2005

$500 \mathrm{mg} / \mathrm{kg}$

$178 \& X S 302$

2018

$50 \mathrm{mg} / \mathrm{kg}$

178

2005

(excluidos los productos de la categoría de alimentos 13.1)

$50 \mathrm{mg} / \mathrm{kg}$

178

2005 peso

$300 \mathrm{mg} / \mathrm{kg}$

178

2005 
Cuadro I

CARMINES

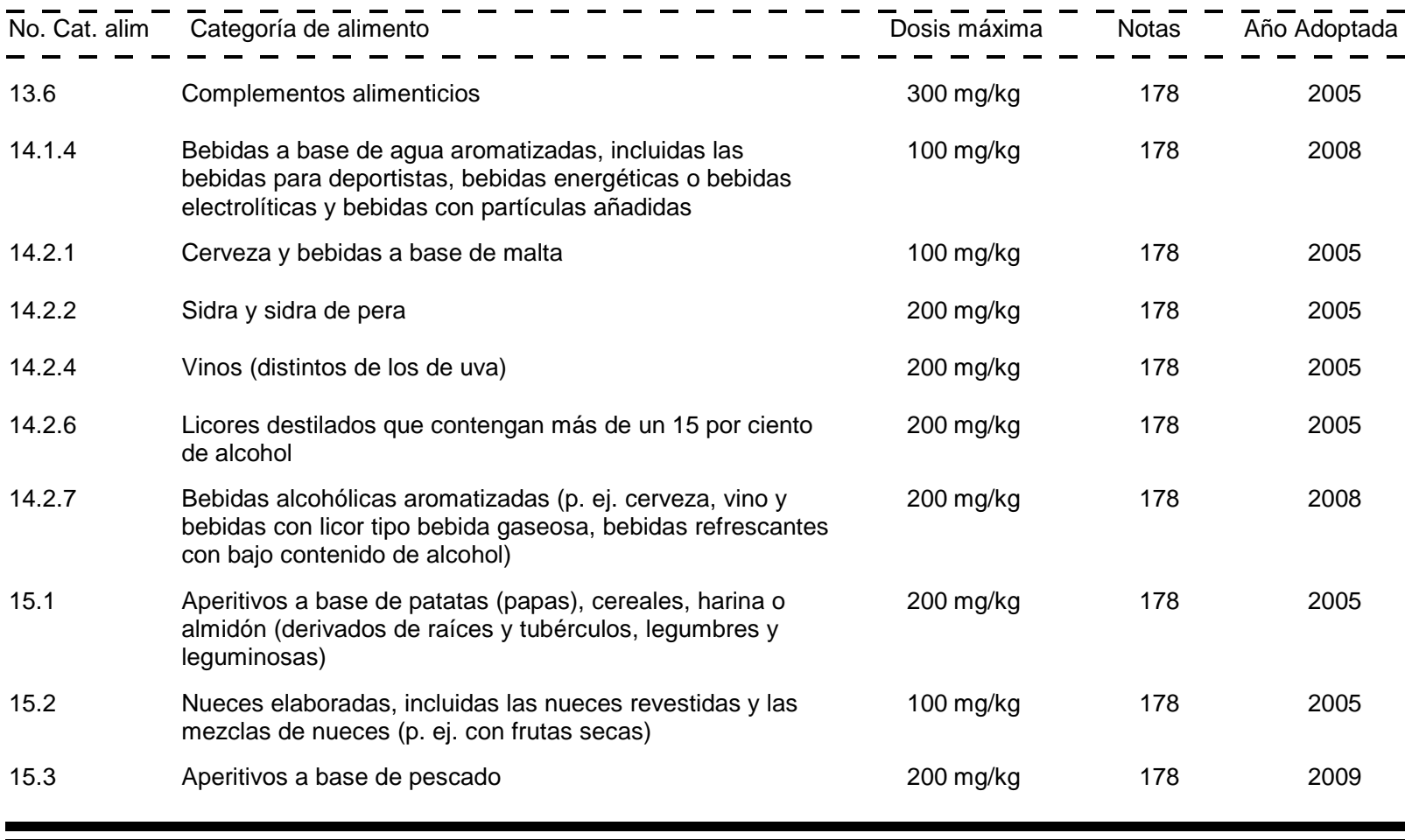

\section{CAROTENOIDES}

$\begin{array}{llll}\text { SIN } 160 \mathrm{a}(\mathrm{i}) & \text { Carotenos, beta-, sintético } & \text { Clases Funcionales: Colorantes } \\ \text { SIN } 160 \mathrm{a}(\mathrm{iii}) & \begin{array}{l}\text { Carotenos, beta-, Blakeslea } \\ \text { trispora- }\end{array} & \text { Clases Funcionales: Colorantes } \\ \text { SIN } 160 \mathrm{e} & \text { Carotenal, beta-apo-8'- } & \text { Clases Funcionales: Colorantes } \\ \text { SIN } 160 f & \begin{array}{l}\text { Éster etílico del ácido beta-apo-8'-Clases Funcionales: Colorantes } \\ \text { carotenoico }\end{array}\end{array}$

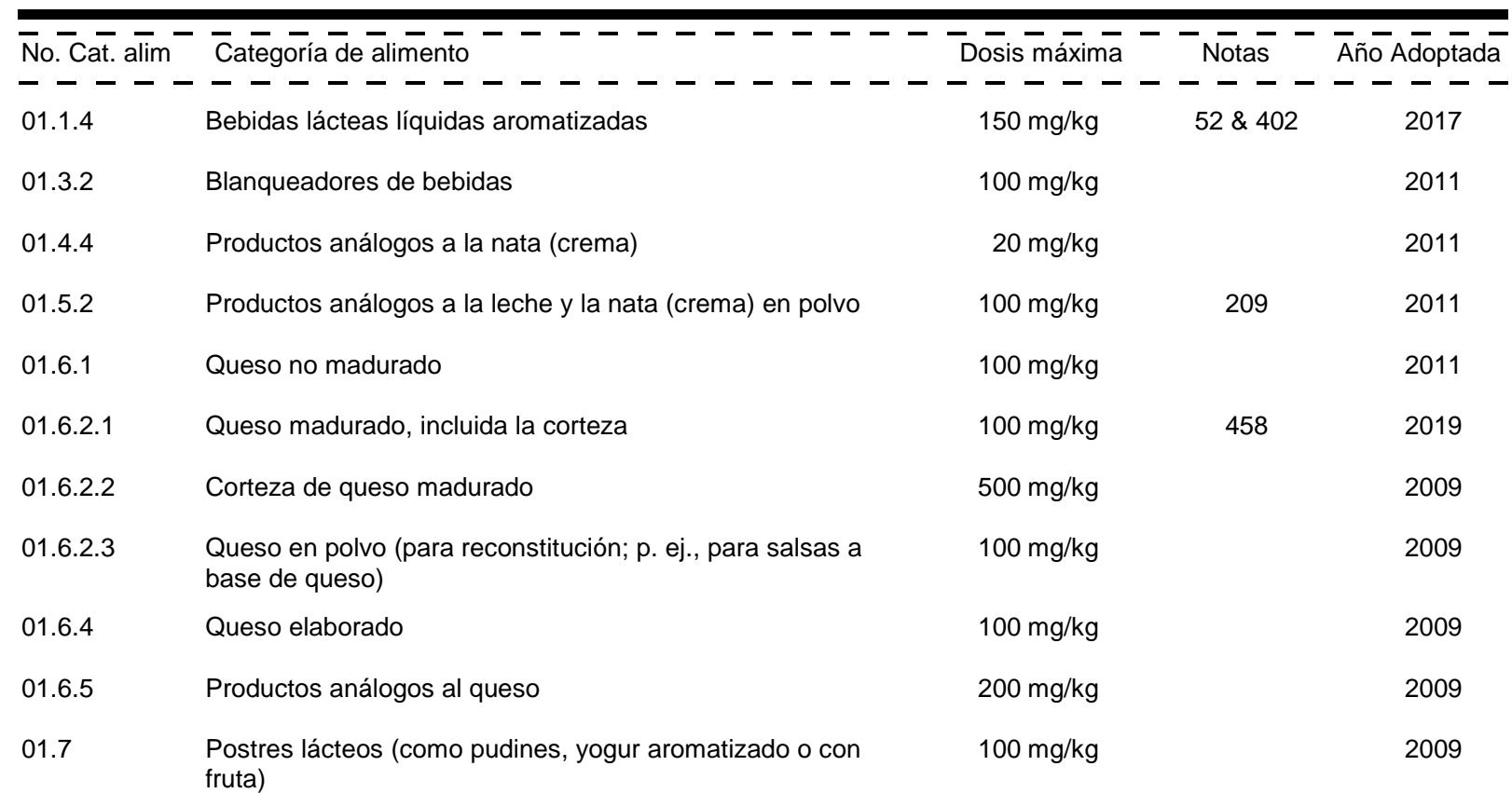


Cuadro I

CAROTENOIDES

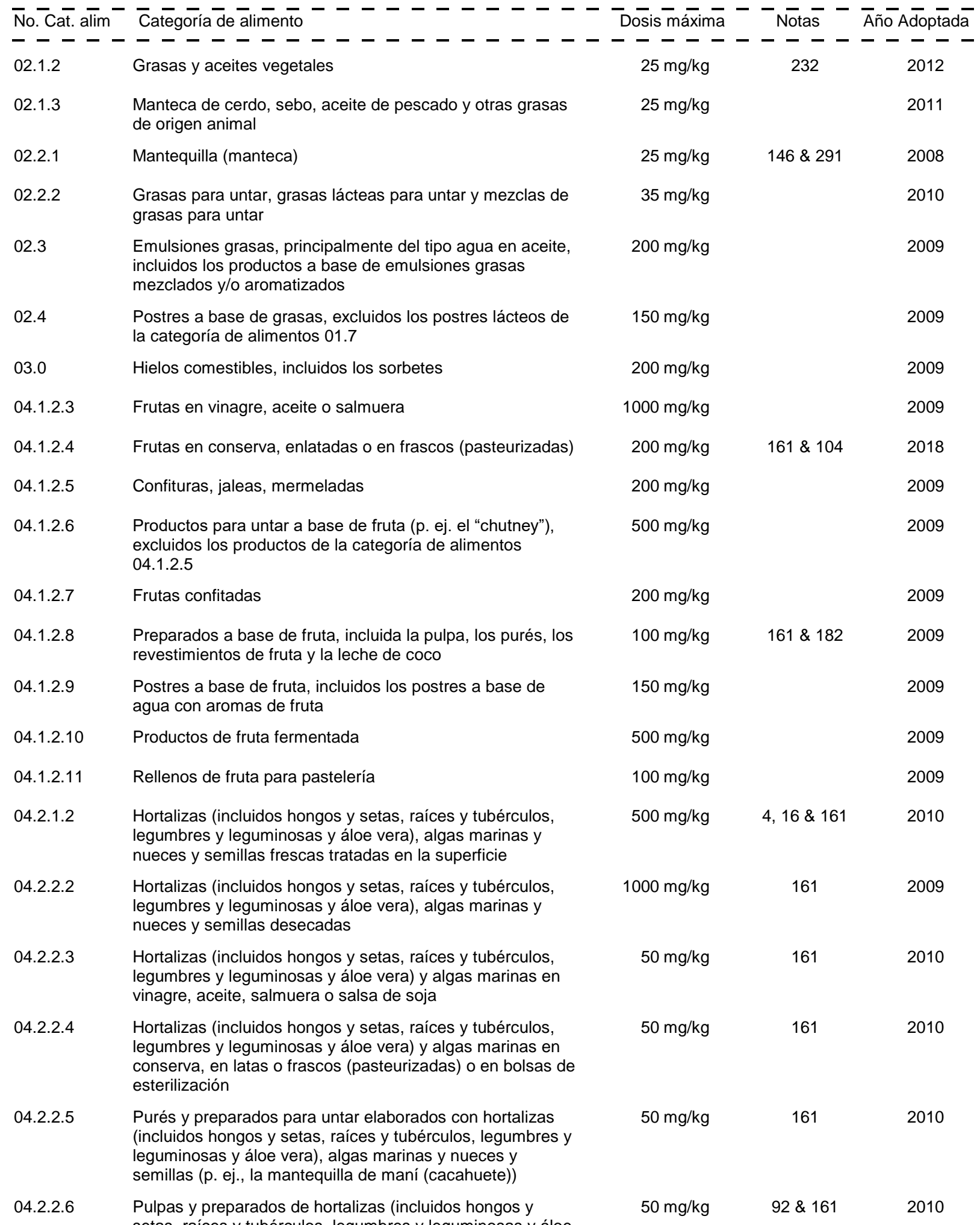
setas, raíces y tubérculos, legumbres y leguminosas y áloe vera), algas marinas y nueces y semillas (como los postres y las salsas a base de hortalizas y hortalizas confitadas) distintos de los indicados en la categoría de alimentos 04.2.2.5 
Cuadro I

CAROTENOIDES

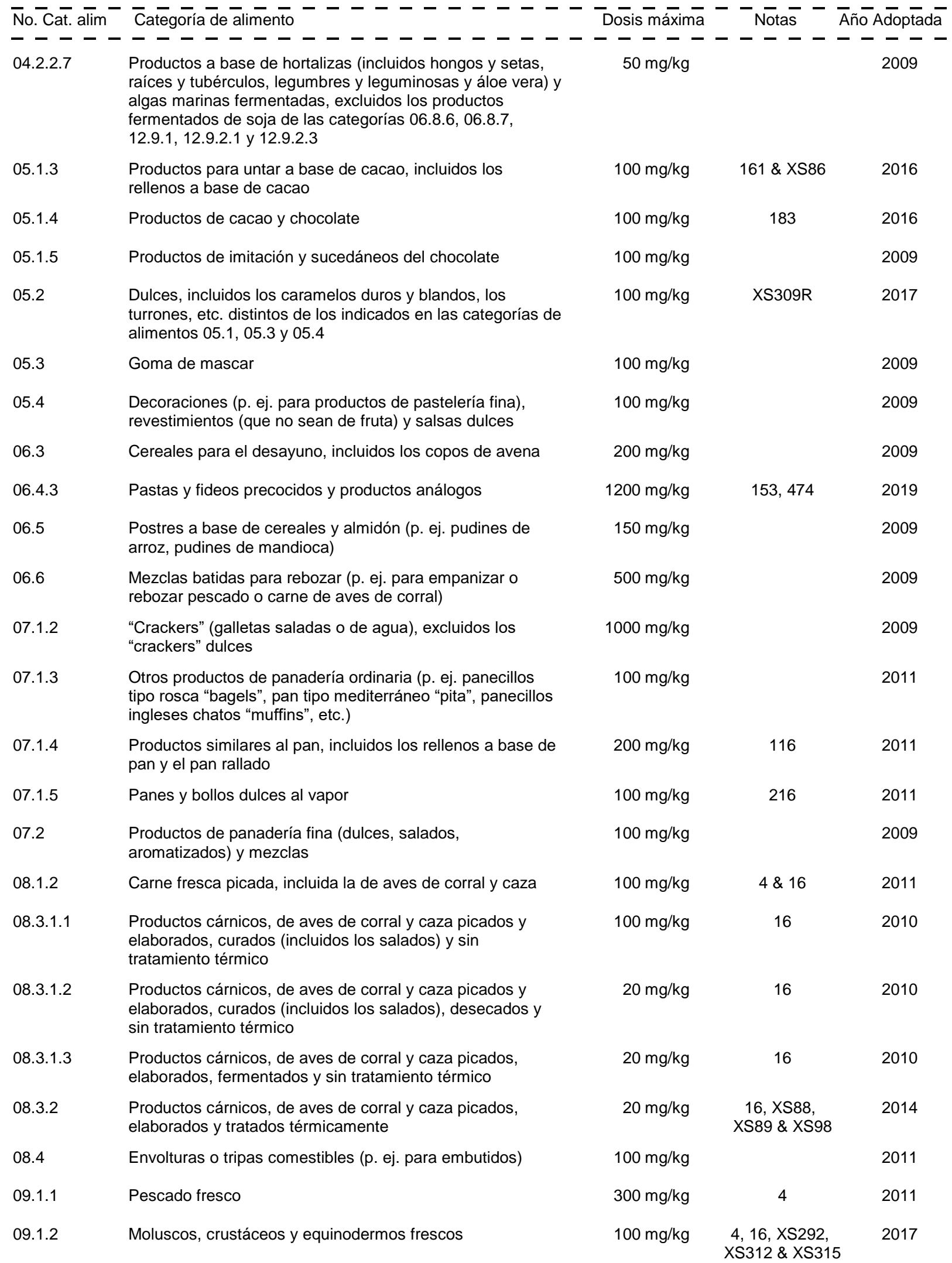




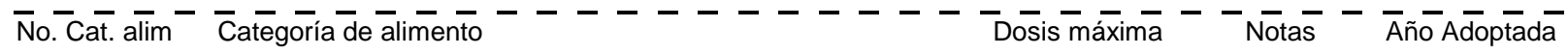

- - - - - - - - - - - - - - - - - -

Pescado y productos pesqueros elaborados, incluidos los moluscos, crustáceos y equinodermos

Pescado y productos pesqueros semiconservados, incluidos los moluscos, crustáceos y equinodermos

09.4

Pescado y productos pesqueros (incluidos los moluscos, crustáceos y equinodermos) en conserva, con inclusión de los enlatados y fermentados

10.4

Huevos frescos

Postres a base de huevo (p. ej. flan)

11.4

Otros azúcares y jarabes (p. ej. xilosa, jarabe de arce y aderezos de azúcar)

12.2.2 Aderezos y condimentos

Mostazas

Sopas y caldos

Salsas y productos análogos

Ensaladas (p. ej., la ensalada de macarrones, la ensalada de patatas (papas)) y productos para untar en emparedados, excluidos los productos para untar a base de cacao y nueces de las categorías de alimentos 04.2.2.5 y 05.1 .3 (excluidos los productos de la categoría de alimentos 13.1)

Preparados dietéticos para adelgazamiento y control del peso

Alimentos dietéticos (p. ej. los complementos alimenticios para usos dietéticos), excluidos los indicados en las categorías de alimentos 13.1 a 13.4 y 13.6

\section{Complementos alimenticios}

Bebidas a base de agua aromatizadas, incluidas las bebidas para deportistas, bebidas energéticas o bebidas electrolíticas y bebidas con partículas añadidas

Sidra y sidra de pera

Vinos (distintos de los de uva)

Licores destilados que contengan más de un 15 por ciento de alcohol

Bebidas alcohólicas aromatizadas (p. ej. cerveza, vino y bebidas con licor tipo bebida gaseosa, bebidas refrescantes con bajo contenido de alcohol)

Aperitivos a base de patatas (papas), cereales, harina o almidón (derivados de raíces y tubérculos, legumbres y leguminosas)

$\begin{array}{cc}100 \mathrm{mg} / \mathrm{kg} & 95,304, \mathrm{XS} 36, \\ & \text { XS92, XS95, } \\ & \text { XS165, XS167, } \\ & \text { XS189, XS190, } \\ & \text { XS191, XS222, } \\ & \text { XS236, XS244, } \\ & \text { XS292, XS311, } \\ & \text { XS312 \& XS315 }\end{array}$

$100 \mathrm{mg} / \mathrm{kg} \quad 95, \mathrm{XS} 3, \mathrm{XS} 37$

2018

XS70, XS90,

XS94 \& XS119

$1000 \mathrm{mg} / \mathrm{kg}$

2011

$150 \mathrm{mg} / \mathrm{kg} \quad 2009$

$50 \mathrm{mg} / \mathrm{kg} \quad 217$

2011

$500 \mathrm{mg} / \mathrm{kg}$

2009

$300 \mathrm{mg} / \mathrm{kg}$

2009

$300 \mathrm{mg} / \mathrm{kg}$

$500 \mathrm{mg} / \mathrm{kg}$

XS302

2018

$50 \mathrm{mg} / \mathrm{kg}$

2009

$50 \mathrm{mg} / \mathrm{kg}$

2009

$50 \mathrm{mg} / \mathrm{kg}$

2009

$300 \mathrm{mg} / \mathrm{kg}$

2009

$300 \mathrm{mg} / \mathrm{kg}$

2009

$100 \mathrm{mg} / \mathrm{kg}$

2009

$200 \mathrm{mg} / \mathrm{kg}$

2009

200 mg/kg

2009

$200 \mathrm{mg} / \mathrm{kg}$

2009

$200 \mathrm{mg} / \mathrm{kg}$

2009

$100 \mathrm{mg} / \mathrm{kg}$

2010

$100 \mathrm{mg} / \mathrm{kg}$ 
Cuadro I

CAROTENOS, BETA-, VEGETALES

\section{CAROTENOS, BETA-, VEGETALES}

SIN 160a(ii) Carotenos, beta-, vegetales

Clases Funcionales: Colorantes

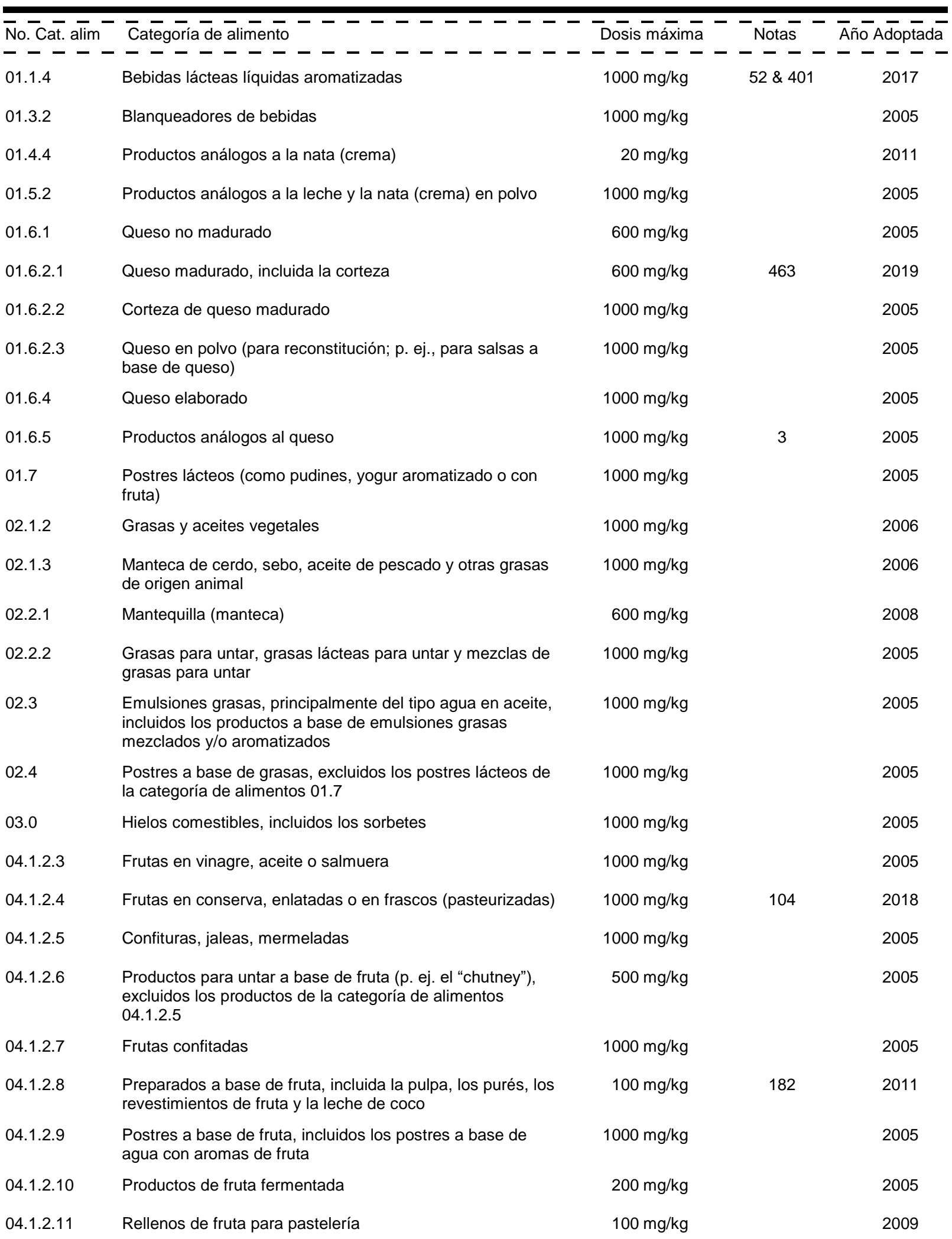


Cuadro I

CAROTENOS, BETA-, VEGETALES

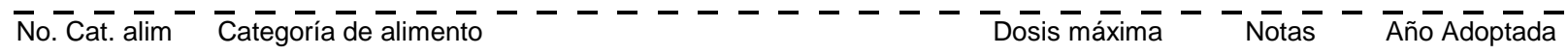

- - - - - - - - - - - - - - - - - - - - - - - - - - -

04.2.2.2 Hortalizas (incluidos hongos y setas, raíces y tubérculos,

$200 \mathrm{mg} / \mathrm{kg}$

2011

legumbres y leguminosas y áloe vera), algas marinas y

nueces y semillas desecadas

04.2.2.3 Hortalizas (incluidos hongos y setas, raíces y tubérculos, legumbres y leguminosas y áloe vera) y algas marinas en

$1320 \mathrm{mg} / \mathrm{kg}$ vinagre, aceite, salmuera o salsa de soja

04.2.2.4 Hortalizas (incluidos hongos y setas, raíces y tubérculos, legumbres y leguminosas y áloe vera) y algas marinas en conserva, en latas o frascos (pasteurizadas) o en bolsas de esterilización

04.2.2.5 Purés y preparados para untar elaborados con hortalizas (incluidos hongos y setas, raíces y tubérculos, legumbres y leguminosas y áloe vera), algas marinas y nueces y semillas (p. ej., la mantequilla de maní (cacahuete))

04.2.2.6 Pulpas y preparados de hortalizas (incluidos hongos y setas, raíces y tubérculos, legumbres y leguminosas y áloe vera), algas marinas y nueces y semillas (como los postres y las salsas a base de hortalizas y hortalizas confitadas) distintos de los indicados en la categoría de alimentos 04.2.2.5

04.2.2.7 Productos a base de hortalizas (incluidos hongos y setas, raíces y tubérculos, legumbres y leguminosas y áloe vera) y algas marinas fermentadas, excluidos los productos fermentados de soja de las categorías 06.8.6, 06.8.7 12.9.1, 12.9.2. 1 y 12.9 .2 .3

05.1.3 Productos para untar a base de cacao, incluidos los rellenos a base de cacao

05.1.4 Productos de cacao y chocolate

$100 \mathrm{mg} / \mathrm{kg}$

05.1.5 Productos de imitación y sucedáneos del chocolate

$100 \mathrm{mg} / \mathrm{kg}$

$05.2 \quad$ Dulces, incluidos los caramelos duros y blandos, los turrones, etc. distintos de los indicados en las categorías de alimentos $05.1,05.3$ y 05.4

Goma de mascar

$500 \mathrm{mg} / \mathrm{kg}$

XS309R

$500 \mathrm{mg} / \mathrm{kg}$

2005

05.4 Decoraciones (p. ej. para productos de pastelería fina) revestimientos (que no sean de fruta) y salsas dulces

06.3

Cereales para el desayuno, incluidos los copos de avena

$20000 \mathrm{mg} / \mathrm{kg}$

2005

$400 \mathrm{mg} / \mathrm{kg}$

06.4 .2

Pastas y fideos deshidratados y productos análogos

$1000 \mathrm{mg} / \mathrm{kg}$

211

2011

06.4 .3

Pastas y fideos precocidos y productos análogos

06.5 Postres a base de cereales y almidón (p. ej. pudines de arroz, pudines de mandioca)

$1000 \mathrm{mg} / \mathrm{kg}$

153

2010

$1000 \mathrm{mg} / \mathrm{kg}$

2005

$1000 \mathrm{mg} / \mathrm{kg}$

2005

rebozar pescado o carne de aves de corral)

07.1.2 "Crackers" (galletas saladas o de agua), excluidos los "crackers" dulces

07.1.4 Productos similares al pan, incluidos los rellenos a base de pan y el pan rallado

07.2 Productos de panadería fina (dulces, salados, aromatizados) y mezclas

08.1 .2

Carne fresca picada, incluida la de aves de corral y caza 
Cuadro I

CAROTENOS, BETA-, VEGETALES

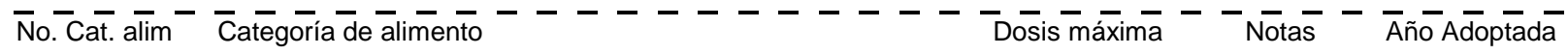

- - - - -

Productos cárnicos, de aves de corral y caza picados y

$20 \mathrm{mg} / \mathrm{kg}$

118

2005 laborados sin tratamiento térmico

08.3.2 Productos cárnicos, de aves de corral y caza picados, elaborados y tratados térmicamente

$20 \mathrm{mg} / \mathrm{kg} \quad X S 88, X S 89 \&$

2014

08.3.3 Productos cárnicos, de aves de corral y caza picados, elaborados y congelados

2005

08.4 Envolturas o tripas comestibles (p. ej. para embutidos)

$5000 \mathrm{mg} / \mathrm{kg}$

2005

09.1.1 Pescado fresco

$100 \mathrm{mg} / \mathrm{kg}$

$4,16 \& 50$

2010

09.2 .2

Pescado, filetes de pescado y productos pesqueros rebozados congelados, incluidos los moluscos, crustáceos y equinodermos

09.2.3 Productos pesqueros picados, mezclados y congelados, incluidos los moluscos, crustáceos y equinodermos

09.2.4.1 Pescado y productos pesqueros cocidos

$100 \mathrm{mg} / \mathrm{kg}$

304

2017

$1000 \mathrm{mg} / \mathrm{kg}$

16

2005

$1000 \mathrm{mg} / \mathrm{kg}$

95

2009

09.2 .4 .2

Moluscos, crustáceos y equinodermos cocidos

$1000 \mathrm{mg} / \mathrm{kg}$

2005

09.2.4.3 Pescado y productos pesqueros fritos, incluidos los moluscos, crustáceos y equinodermos

$1000 \mathrm{mg} / \mathrm{kg}$

16

2005

09.2.5 Pescado y productos pesqueros ahumados, desecados, fermentados y/o salados, incluidos los moluscos, crustáceos y equinodermos

$1000 \mathrm{mg} / \mathrm{kg} \quad \mathrm{XS167,XS189}$ XS222, XS236 XS244 \& XS311

09.3.1 Pescado y productos pesqueros marinados y/o en gelatina, incluidos los moluscos, crustáceos y equinodermos

$1000 \mathrm{mg} / \mathrm{kg}$

16

2005

$1000 \mathrm{mg} / \mathrm{kg}$

16

2005 salmuera, incluidos los moluscos, crustáceos y equinodermos

09.3.3 Sucedáneos de salmón, caviar y otros productos pesqueros a base de huevas

$1000 \mathrm{mg} / \mathrm{kg}$

XS291

2018

$1000 \mathrm{mg} / \mathrm{kg}$

16

2005

incluidos los moluscos, crustáceos y equinodermos (p. ej. la pasta de pescado), excluidos los productos indicados en las categorías de alimentos 09.3.1 a 09.3.3

09.4 Pescado y productos pesqueros (incluidos los moluscos, crustáceos y equinodermos) en conserva, con inclusión de los enlatados y fermentados

$500 \mathrm{mg} / \mathrm{kg}$

$\mathrm{XS} 3, \mathrm{XS} 37$ $\mathrm{XS70}, \mathrm{XS} 90$,

Huevos frescos

$1000 \mathrm{mg} / \mathrm{kg}$

4

2005

$1000 \mathrm{mg} / \mathrm{kg}$

2005

$150 \mathrm{mg} / \mathrm{kg}$

2005

$50 \mathrm{mg} / \mathrm{kg}$

2005 aderezos de azúcar)

12.2.2 Aderezos y condimentos

$500 \mathrm{mg} / \mathrm{kg}$

2011

$1000 \mathrm{mg} / \mathrm{kg}$

$1000 \mathrm{mg} / \mathrm{kg}$

2015

$12.5 \quad$ Sopas y caldos

$2000 \mathrm{mg} / \mathrm{kg}$

2005

Salsas emulsionadas y salsas para mojar (p.ej. mayonesa,
aderezos para ensaladas, salsa para mojar de cebollas)

12.6.2 Salsas no emulsionadas (p. ej. salsa de tomate "ketchup", salsas a base de queso, salsas a base de nata (crema) y

$2000 \mathrm{mg} / \mathrm{kg}$ 
Cuadro I

CAROTENOS, BETA-, VEGETALES

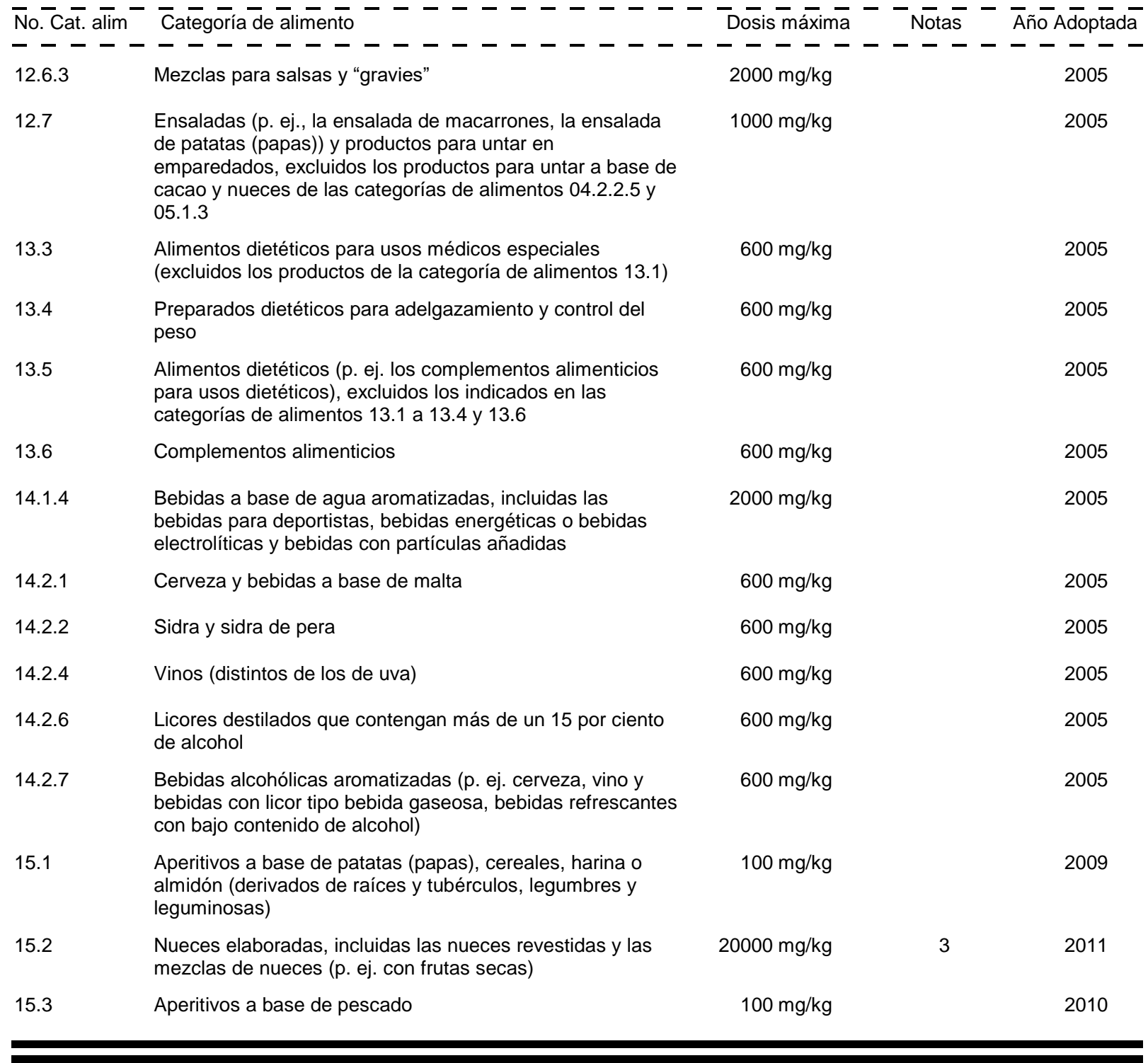

\section{CARRAGENINA}

SIN $407 \quad$ Carragenina
Clases Funcionales: Incrementadores del volumen, Sustancias inertes, Emulsionantes, Agentes gelificantes, Agentes de glaseado, Humectantes, Estabilizadores, Espesantes

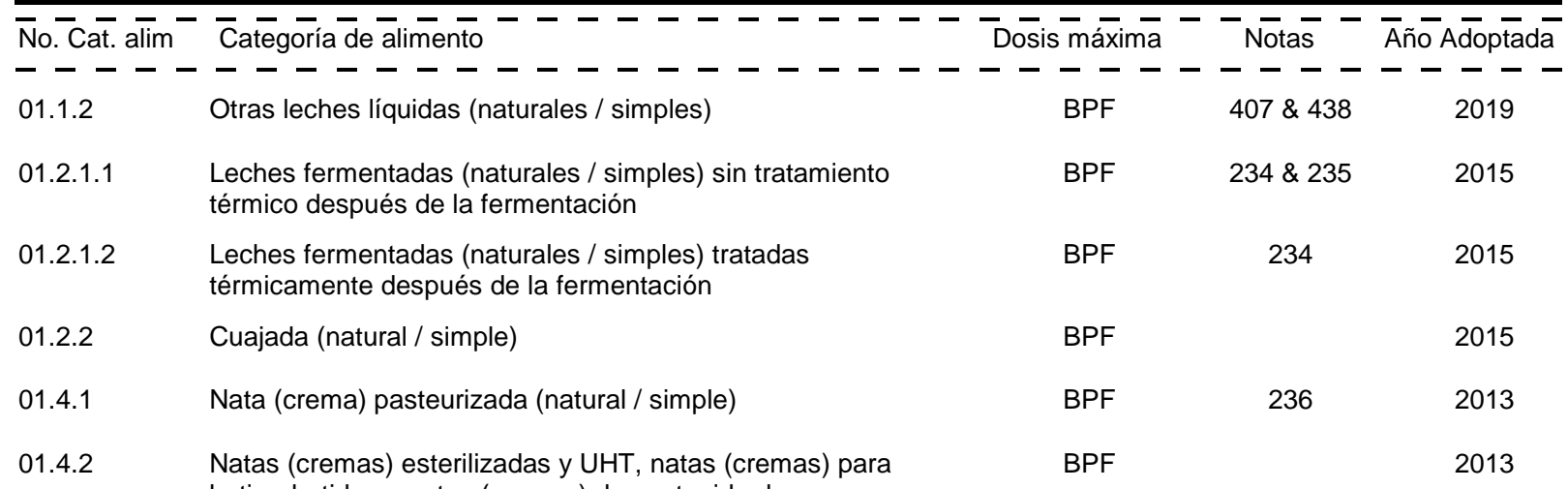
batir o batidas y natas (cremas) de contenido de grasa reducido (naturales / simples) 
Cuadro I

CARRAGENINA

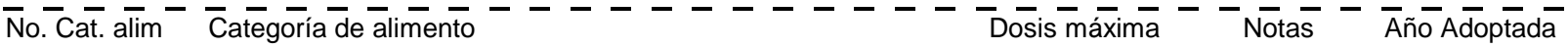

- - - - - - - - - - - - - - - - - - - - - - - - - - - - - - - $-\overline{-}$

04.2.2.7 Productos a base de hortalizas (incluidos hongos y setas,

BPF

2013 raíces y tubérculos, legumbres y leguminosas y áloe vera) y algas marinas fermentadas, excluidos los productos

fermentados de soja de las categorías 06.8.6, 06.8.7, 12.9.1, 12.9.2.1 y 12.9 .2 .3

06.4.1 Pastas y fideos frescos y productos análogos

\begin{tabular}{|c|c|c|}
\hline BPF & 211 & 2014 \\
\hline BPF & 256 & 2014 \\
\hline BPF & $16 \& 326$ & 2015 \\
\hline BPF & 281 & 2015 \\
\hline BPF & $\begin{array}{c}\text { 332, 391, } \\
\text { XS36, XS92, } \\
\text { XS95, XS190, } \\
\text { XS191, XS292, } \\
\text { XS312 \& XS315 }\end{array}$ & 2017 \\
\hline
\end{tabular}

09.2.2 Pescado, filetes de pescado y productos pesqueros

$177 \& 332$ rebozados congelados, incluidos los moluscos, crustáceos y equinodermos

09.2.3 Productos pesqueros picados, mezclados y congelados, incluidos los moluscos, crustáceos y equinodermos

09.2.4.1 Pescado y productos pesqueros cocidos

BPF

BPF

$16 \& 325$

2015

09.2.4.2 Moluscos, crustáceos y equinodermos cocidos

BPF

$16 \& 325$

2015

09.2.4.3 Pescado y productos pesqueros fritos, incluidos los moluscos, crustáceos y equinodermos

BPF

$41,325 \& 332$

2015

09.2 .5

Pescado y productos pesqueros ahumados, desecados, fermentados y/o salados, incluidos los moluscos,

300,332 ,

BPF

XS167, XS189

XS222, XS236,

XS244 \& XS311

10.2.1 Productos líquidos a base de huevo BPF

10.2.2 Productos congelados a base de huevo

BPF

11.4 Otros azúcares y jarabes (p. ej. xilosa, jarabe de arce y aderezos de azúcar)

12.1.2 Sucedáneos de la sal

BPF

258

2014

BPF

13.1.1

Fórmulas (preparados) para lactantes

$300 \mathrm{mg} / \mathrm{kg}$

$378 \& 381$

2016

13.1.2 Fórmulas (preparados) de continuación

$300 \mathrm{mg} / \mathrm{kg}$

$72,151,328 \&$ 329

13.1.3 Fórmulas (preparados) para usos médicos especiales destinados a los lactantes

$1000 \mathrm{mg} / \mathrm{kg} \quad 379 \& 381 \quad 2016$

14.1.5 Café, sucedáneos del café, té, infusiones de hierbas y otras bebidas calientes a base de cereales y granos, excluido el cacao

BPF

160

2014

\section{CELULOSA EN POLVO}

SIN 460(ii) Celulosa en polvo

Clases Funcionales: Antiaglutinantes, Incrementadores del volumen, Emulsionantes, Agentes de glaseado, Humectantes, Estabilizadores, Espesantes

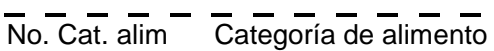

Dosis máxima Notas $\bar{A}$ ño Adoptāā 
Cuadro I

CELULOSA EN POLVO

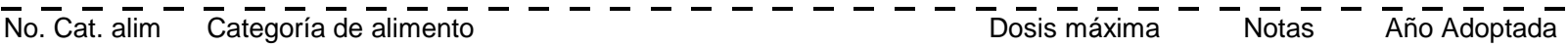

- - - - -

01.2.1.1 Leches fermentadas (naturales / simples) sin tratamier térmico después de la fermentación

01.2.1.2 Leches fermentadas (naturales / simples) tratadas térmicamente después de la fermentación

01.2.2 Cuajada (natural / simple)

$234 \& 235$

2013

BPF

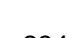

2013

01.4 .1

Nata (crema) pasteurizada (natural / simple)

BPF

2013

01.4.2 Natas (cremas) esterilizadas y UHT, natas (cremas) para

BPF

236

2013 batir o batidas y natas (cremas) de contenido de grasa

BPF reducido (naturales / simples)

01.8.2 Suero en polvo y productos a base de suero en polvo, excluidos los quesos de suero

08.1.1 Carne fresca, incluida la de aves de corral y caza, en piezas enteras o en cortes

08.1.2 Carne fresca picada, incluida la de aves de corral y caza

$\begin{array}{cc}\text { BPF } & 16 \& 326 \\ \text { BPF } & 281 \\ \text { BPF } & 16, \text { XS36, } \\ & \begin{array}{c}\text { XS92, XS95, } \\ \text { XS165, XS190, } \\ \text { XS191, XS292, } \\ \\ \end{array} \text { XS312 \& XS315 }\end{array}$

2015

09.2.1 Pescado, filetes de pescado y productos pesqueros congelados, incluidos los moluscos, crustáceos y equinodermos

XS312 \& XS315

09.2.2 Pescado, filetes de pescado y productos pesqueros rebozados congelados, incluidos los moluscos, crustáceos BPF

$16 \& X S 166$ y equinodermos

09.2.3 Productos pesqueros picados, mezclados y congelados, incluidos los moluscos, crustáceos y equinodermos

09.2.4.1 Pescado y productos pesqueros cocidos

09.2.4.2 Moluscos, crustáceos y equinodermos cocidos

09.2.4.3 Pescado y productos pesqueros fritos, incluidos los moluscos, crustáceos y equinodermos

11.4 Otros azúcares y jarabes (p. ej. xilosa, jarabe de arce y

\section{CELULOSA MICROCRISTALINA (GEL DE CELULOSA)}

SIN 460(i) Celulosa microcristalina (Gel de Clases Funcionales: Antiaglutinantes, Incrementadores del volumen, celulosa) Sustancias inertes, Emulsionantes, Espumantes, Agentes de glaseado, Estabilizadores, Espesantes

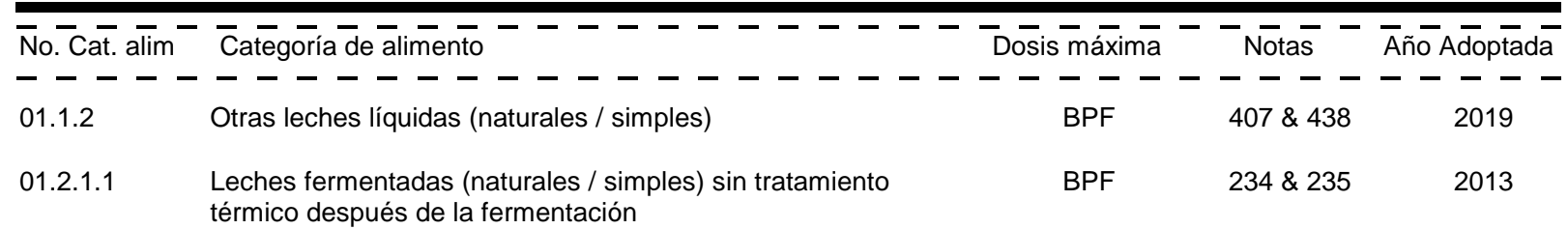


Cuadro I

CELULOSA MICROCRISTALINA (GEL DE

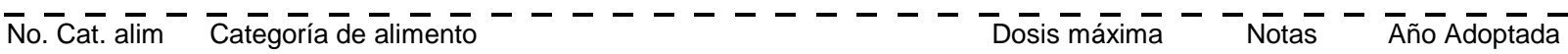

- - - - - - - - - - - - - - - - - - - - - - - - - - térmicamente después de la fermentación

01.2.2 Cuajada (natural / simple)

BPF

2013

01.4.1 Nata (crema) pasteurizada (natural / simple)

BPF

236

2013

01.4.2 Natas (cremas) esterilizadas y UHT, natas (cremas) para

BPF

2013 reducido (naturales / simples)

01.8.2 Suero en polvo y productos a base de suero en polvo, excluidos los quesos de suero

06.4.1 Pastas y fideos frescos y productos análogos

06.4.2 Pastas y fideos deshidratados y productos análogos

08.1.1 Carne fresca, incluida la de aves de corral y caza, en piezas enteras o en cortes

08.1.2 Carne fresca picada, incluida la de aves de corral y caza

$10000 \mathrm{mg} / \mathrm{kg}$

2006

09.2.1 Pescado, filetes de pescado y productos pesqueros congelados, incluidos los moluscos, crustáceos y equinodermos

09.2 .2

Pescado, filetes de pescado y productos pesqueros rebozados congelados, incluidos los moluscos, crustáceos y equinodermos

09.2.3 Productos pesqueros picados, mezclados y congelados, incluidos los moluscos, crustáceos y equinodermos

$\begin{array}{cc}\text { BPF } & 211 \\ \text { BPF } & 256 \\ \text { BPF } & 16 \& 326 \\ \text { BPF } & 281 \\ \text { BPF } & 16, \text { XS36, } \\ & \begin{array}{c}\text { XS92, XS95, } \\ \text { XS165, XS190, } \\ \text { XS191, XS292, } \\ \text { XS312 \& XS315 } \\ \text { BPF }\end{array} \\ & 41,325,332 \& \\ & \text { XS166 }\end{array}$

09.2.4.1 Pescado y productos pesqueros cocidos

09.2.4.2 Moluscos, crustáceos y equinodermos cocidos

09.2.4.3 Pescado y productos pesqueros fritos, incluidos los moluscos, crustáceos y equinodermos

11.2 Azúcar moreno, excluidos los productos de la categoría de alimentos 11.1.3

$11.4 \quad$ Otros azúcares y jarabes (p. ej. xilosa, jarabe de arce y aderezos de azúcar)

\section{CERA CANDELILLA}

SIN 902 Cera candelilla
Clases Funcionales: Sustancias inertes, Emulsionantes, Agentes de glaseado, Espesantes 
Cuadro I

CERA CANDELILLA

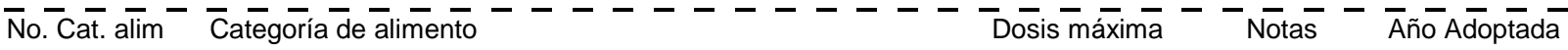

- - - - - - - - - - - - - - - - - - - - - - - - - -

$\begin{array}{llll} & \text { 04.1.1.2 } & \text { Frutas frescas tratadas en la superficie } & \text { BPF }\end{array}$

04.2.1.2 Hortalizas (incluidos hongos y setas, raíces y tubérculos,

$\begin{array}{lll}\text { BPF } & 79 & 2003\end{array}$

legumbres y leguminosas y áloe vera), algas marinas y nueces y semillas frescas tratadas en la superficie

05.1.5 Productos de imitación y sucedáneos del chocolate

BPF $\quad 3-2001$

$05.2 \quad$ Dulces, incluidos los caramelos duros y blandos, los

BPF $\quad 3001$

Durrones, etc. distintos de los indicados en las categorías de

BPF

$3 \&$ XS309R

2017 alimentos $05.1,05.3$ y 05.4

05.3

Goma de mascar

BPF

2003

05.4

Decoraciones (p. ej. para productos de pastelería fina),

BPF

2003

$07.2 \quad$ Productos de panadería fina (dulces, salados,

BPF

2001 aromatizados) y mezclas

13.6 Complementos alimenticios

$\begin{array}{ccc}\text { BPF } & 3 & 2001 \\ 200 \mathrm{mg} / \mathrm{kg} & 131 & 2006\end{array}$
bebidas para deportistas, bebidas energéticas o bebidas electrolíticas y bebidas con partículas añadidas

14.1.5 Café, sucedáneos del café, té, infusiones de hierbas y otras bebidas calientes a base de cereales y granos, excluido el cacao

\section{CERA CARNAUBA}

SIN 903 Cera carnauba

Clases Funcionales: Reguladores de la acidez, Antiaglutinantes, Incrementadores del volumen, Sustancias inertes, Agentes de glaseado

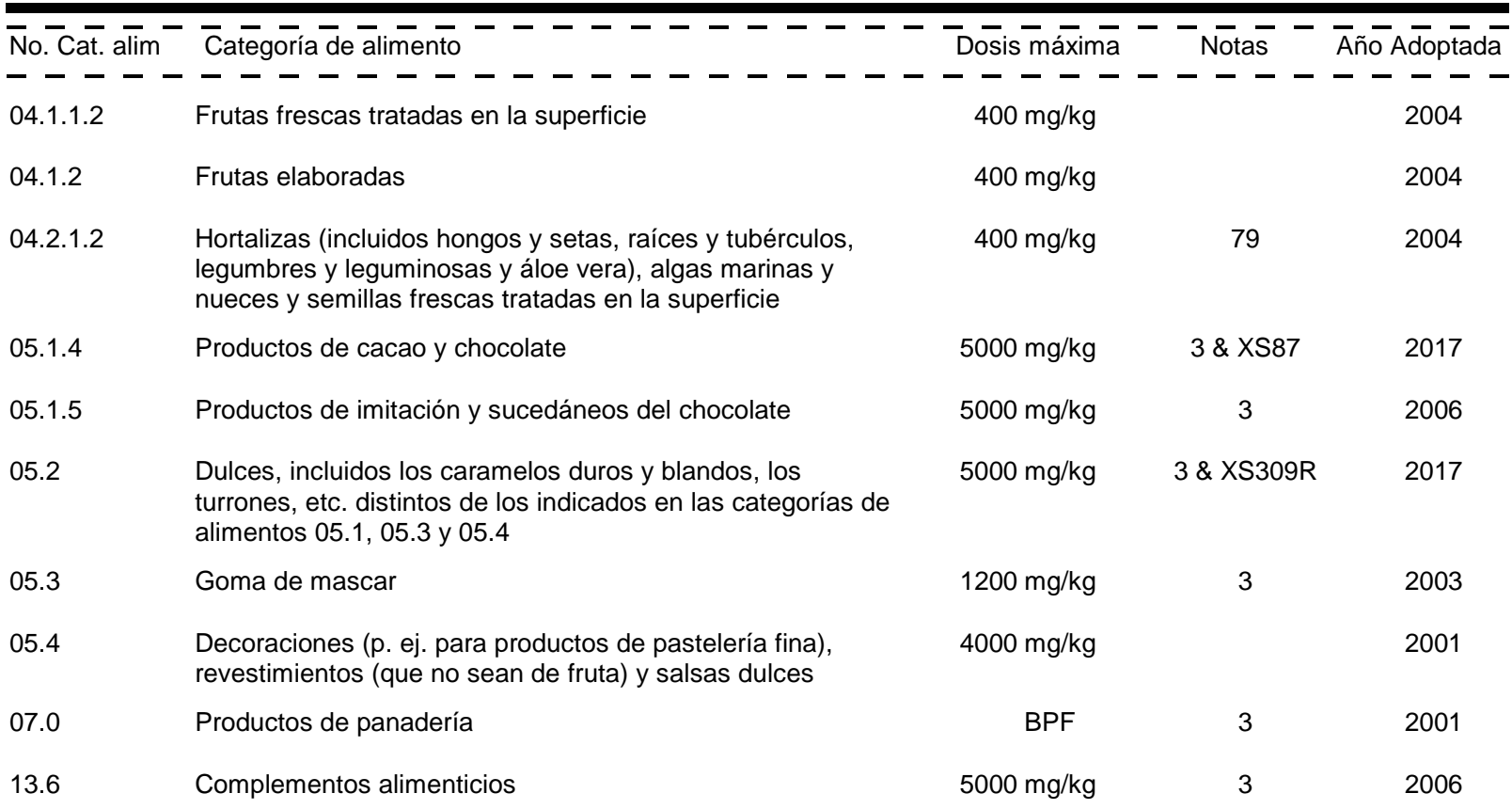


Cuadro I

CERA CARNAUBA

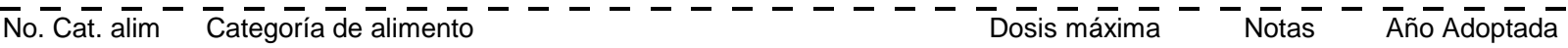

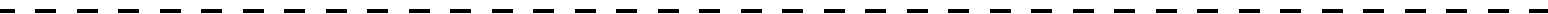

14.1.4 Bebidas a base de agua aromatizadas, incluidas las $\quad 200 \mathrm{mg} / \mathrm{kg} \quad 131 \quad 2003$ bebidas para deportistas, bebidas energéticas o bebidas electrolíticas y bebidas con partículas añadidas

14.1.5 Café, sucedáneos del café, té, infusiones de hierbas y otras $\quad 200$ mg/kg $\quad 108 \quad 2006$ bebidas calientes a base de cereales y granos, excluido el cacao

\section{CERA DE ABEJAS}

SIN $901 \quad$ Cera de abejas

Clases Funcionales: Sustancias inertes, Emulsionantes, Agentes de glaseado, Estabilizadores, Espesantes

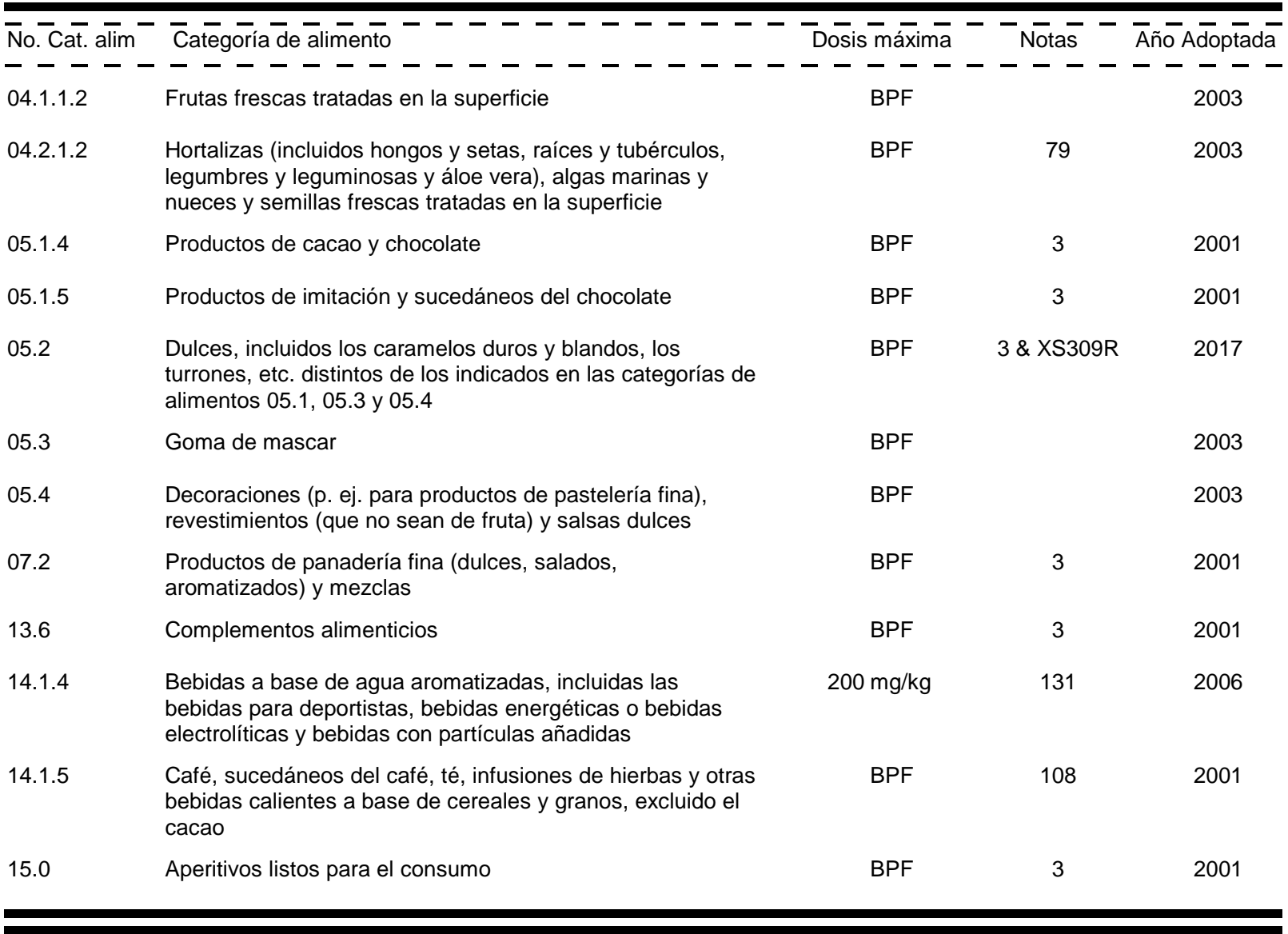

\section{CERA MICROCRISTALINA}

SIN 905c(i) Cera microcristalina Clases Funcionales: Antiespumantes, Agentes de glaseado

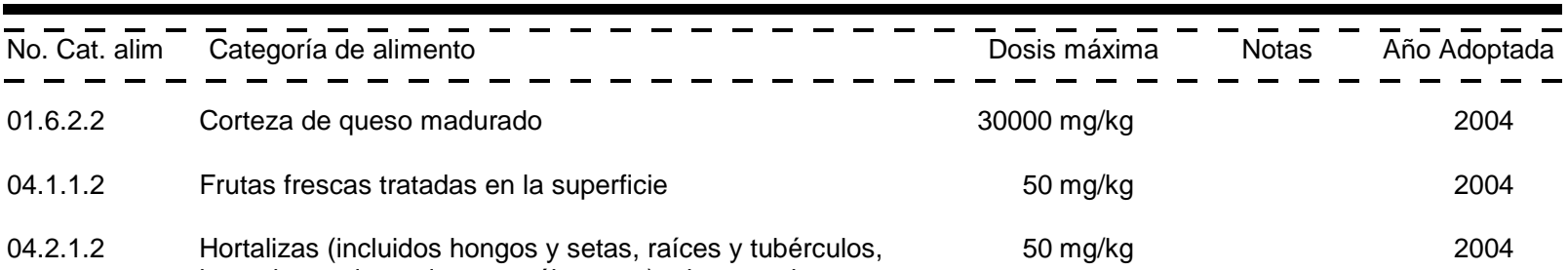

legumbres y leguminosas y áloe vera), algas marinas y

nueces y semillas frescas tratadas en la superficie 
CERA MICROCRISTALINA

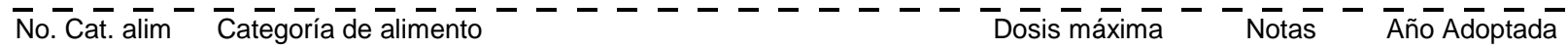

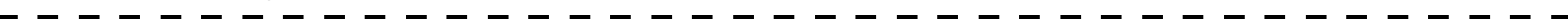

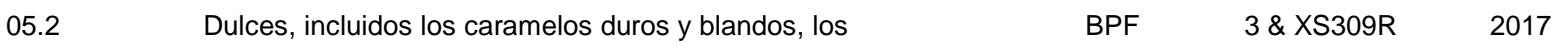
turrones, etc. distintos de los indicados en las categorías de alimentos $05.1,05.3$ y 05.4

\section{CICLAMATOS}

\begin{tabular}{|c|c|c|}
\hline 952(i) & Ácido ciclámico & Clases Funcionales: Edulcorantes \\
\hline 952(ii) & Ciclamato de calcio & Clases Funcionales: Edulcorantes \\
\hline & Ciclamato de sodio & Clases Funcionales: Edulcorantes \\
\hline
\end{tabular}

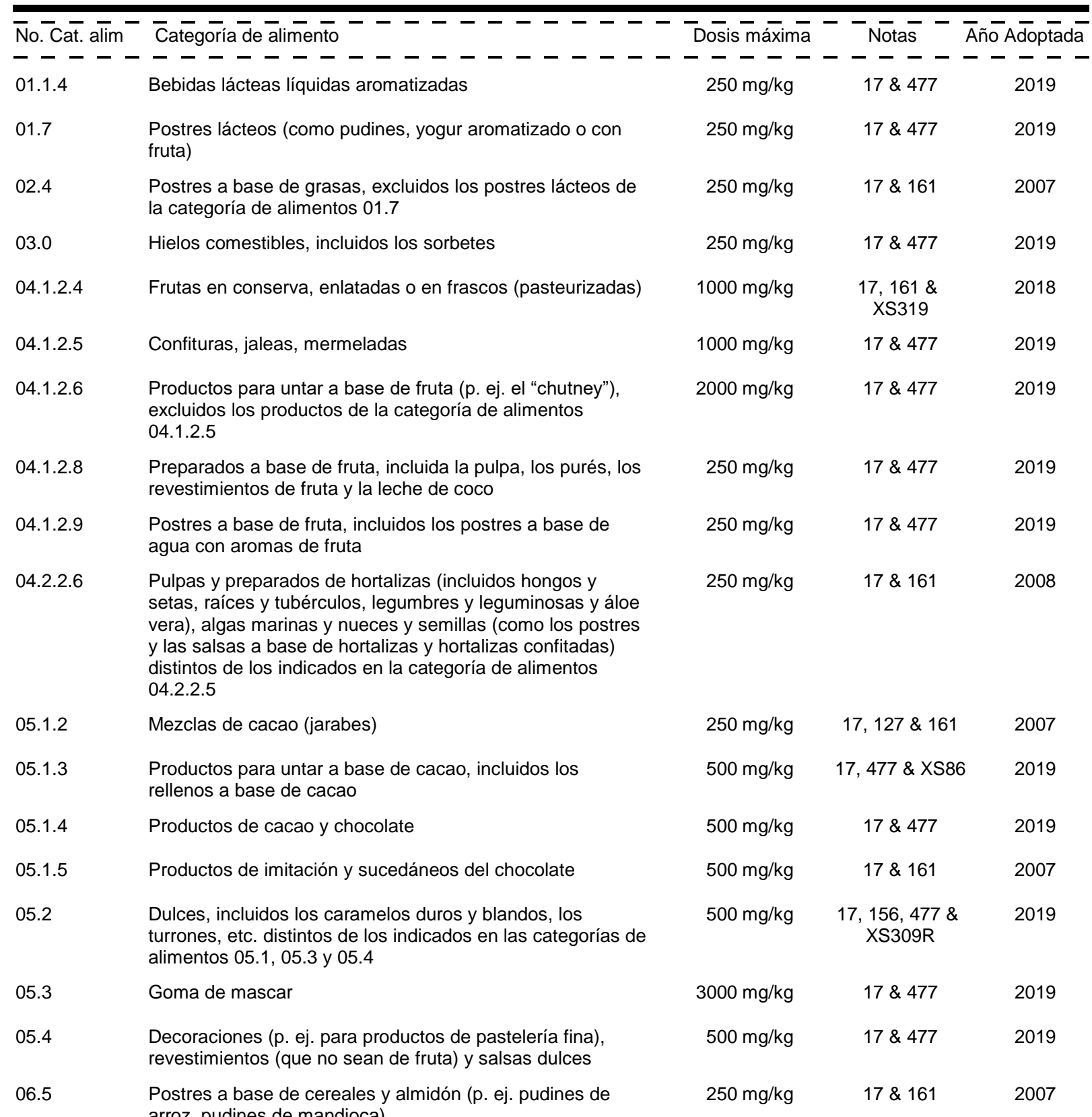


Cuadro I

\section{CICLAMATOS}

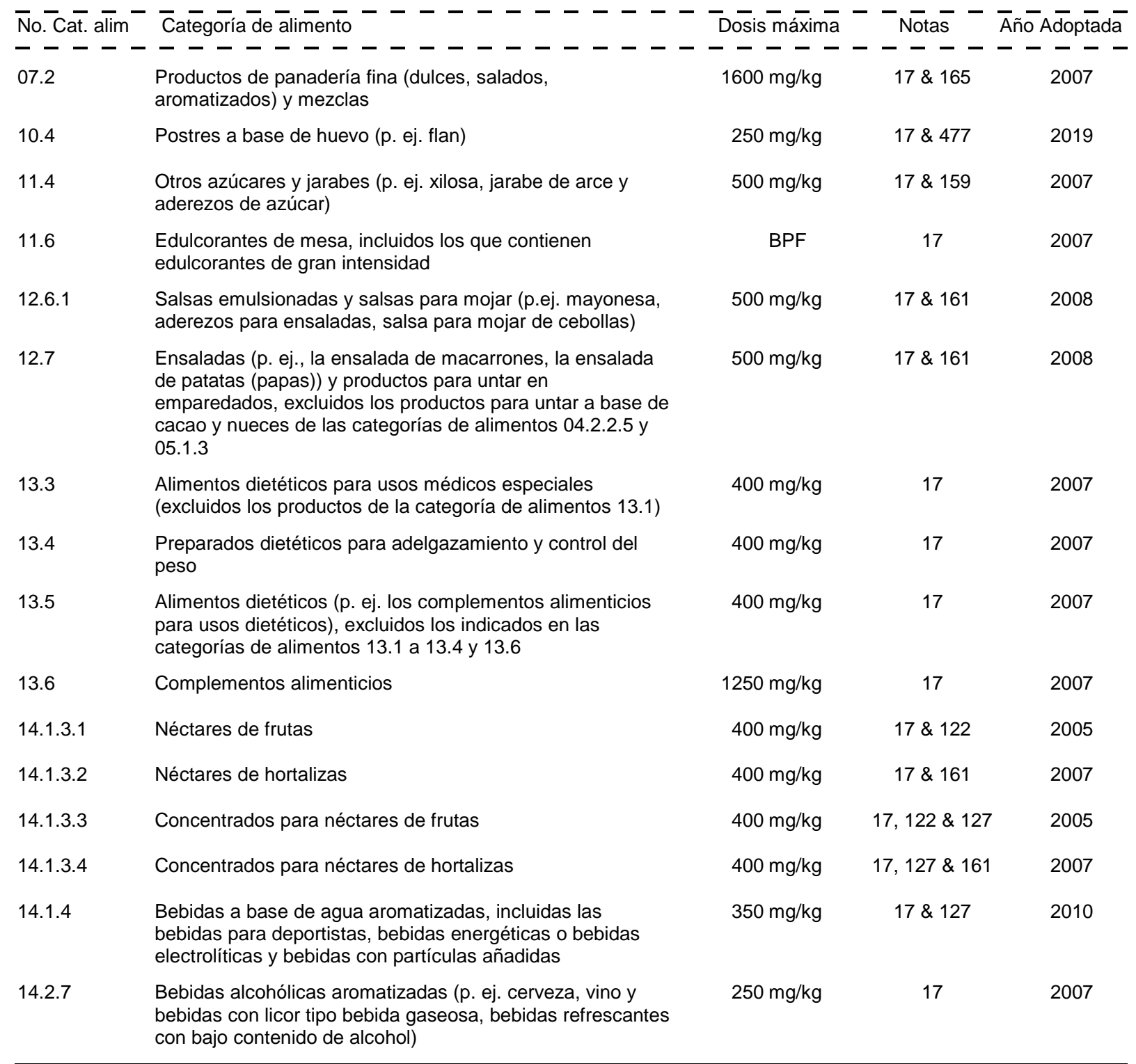

\section{CICLODEXTRINA, BETA-}

SIN 459 Ciclodextrina, beta- Clases Funcionales: Sustancias inertes, Estabilizadores, Espesantes

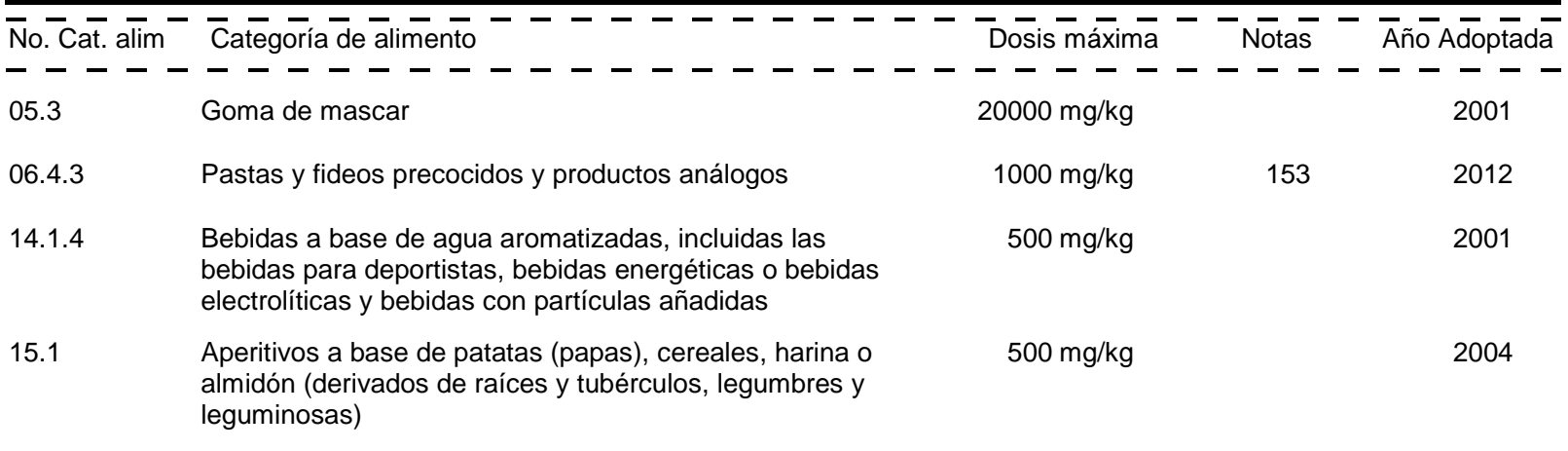


Cuadro I

CITRATO DE AMONIO FÉRRICO

\section{CITRATO DE AMONIO FÉRRICO}

SIN $381 \quad$ Citrato de amonio férrico Clases Funcionales: Antiaglutinantes

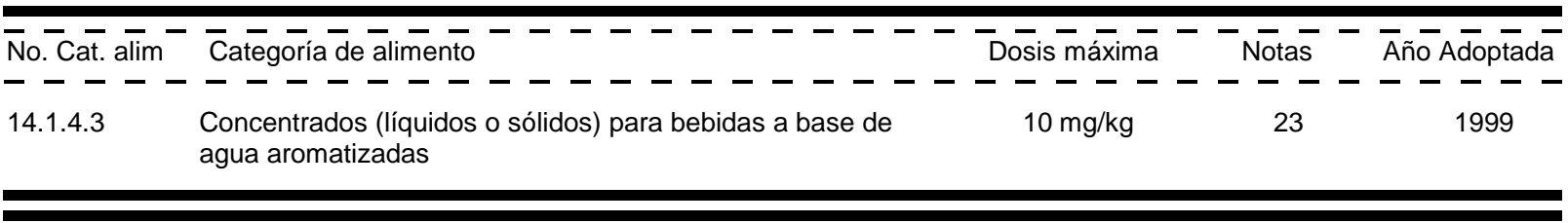

CITRATO DE ESTEARILO

Citrato de estearilo

Clases Funcionales: Antioxidantes, Emulsionantes, Secuestrantes

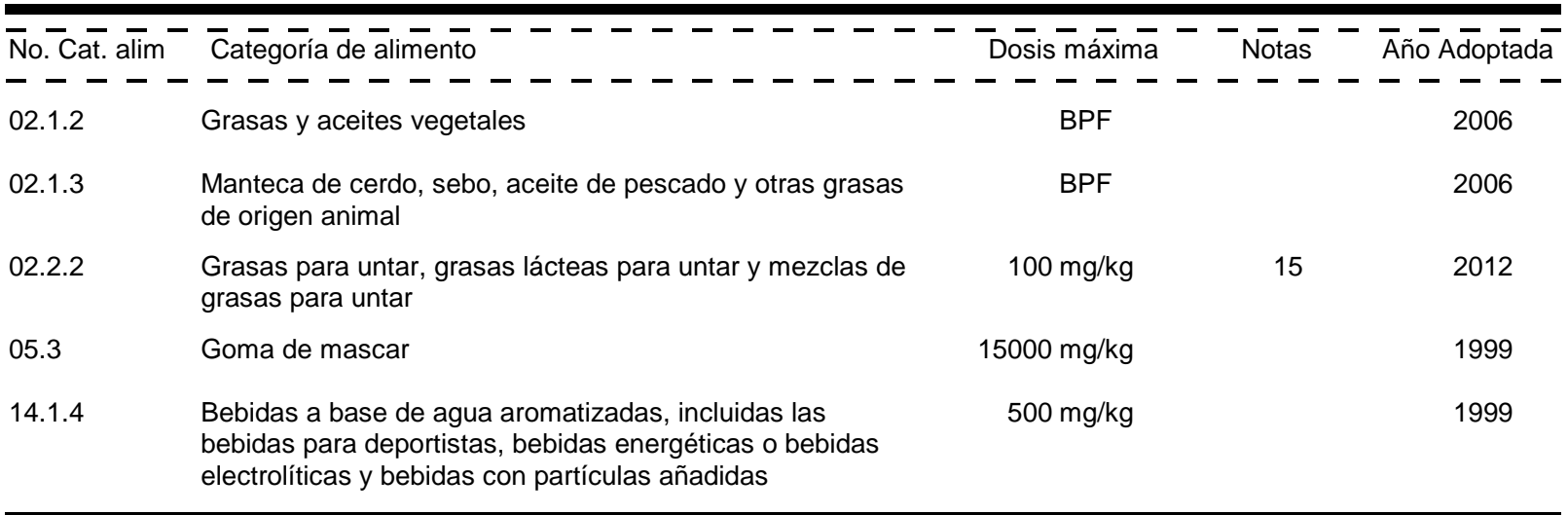

\section{CITRATO DE TRIETILO}

SIN 1505 Citrato de trietilo
Clases Funcionales: Sustancias inertes, Emulsionantes, Secuestrantes, Estabilizadores

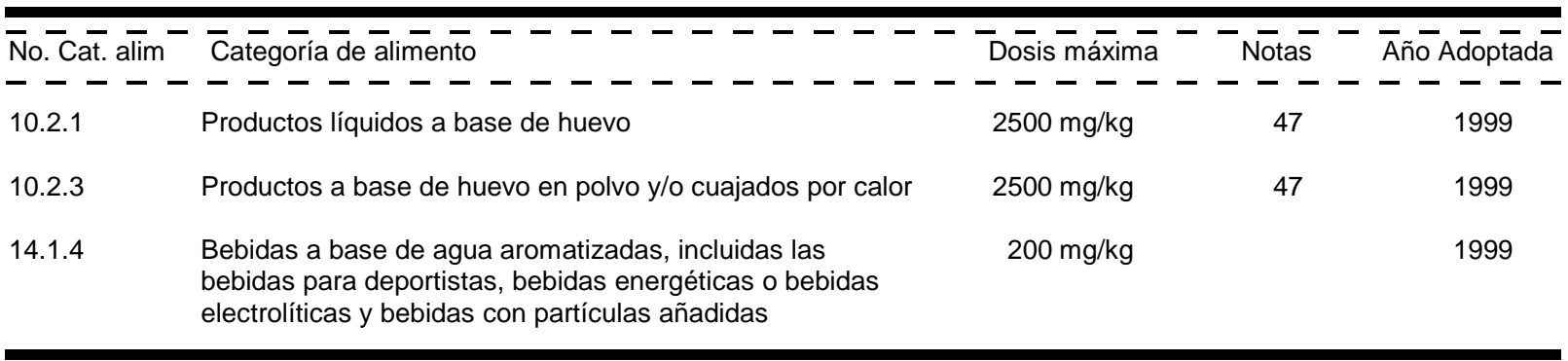

\section{CITRATO DÍACIDO DE POTASIO}

SIN 332(i) Citrato díacido de potasio Clases Funcionales: Reguladores de la acidez, Sales emulsionantes, Secuestrantes, Estabilizadores

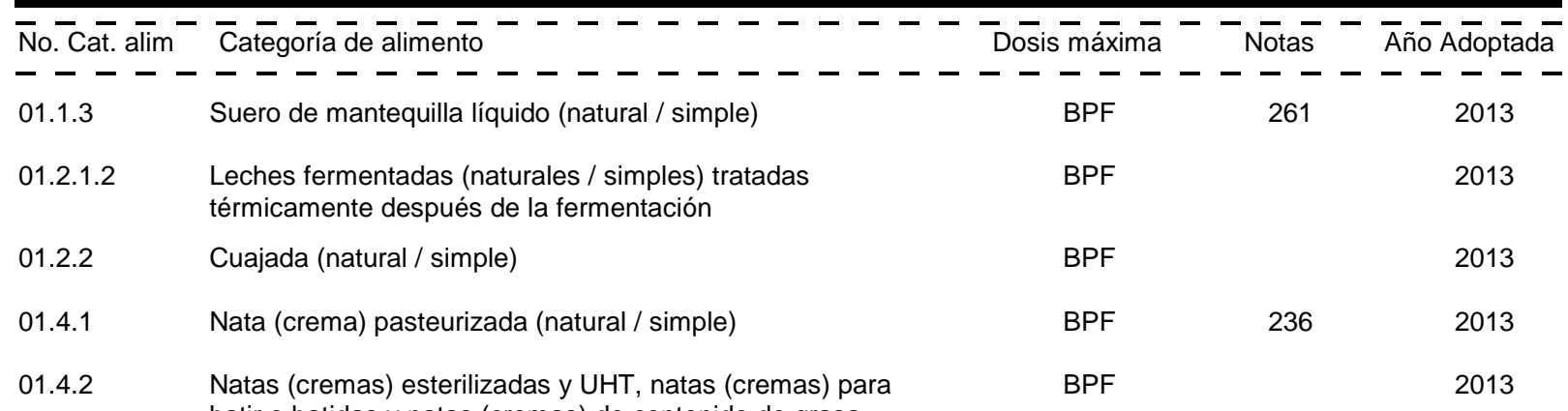


Cuadro I

CITRATO DÍACIDO DE POTASIO

\begin{tabular}{|c|c|c|c|c|}
\hline 01.8 .2 & $\begin{array}{l}\text { Suero en polvo y productos a base de suero en polvo, } \\
\text { excluidos los quesos de suero }\end{array}$ & BPF & & 2006 \\
\hline 04.2.2.1 & $\begin{array}{l}\text { Hortalizas (incluidos hongos y setas, raíces y tubérculos, } \\
\text { legumbres y leguminosas y áloe vera), algas marinas y } \\
\text { nueces y semillas congeladas }\end{array}$ & BPF & 29 & 2015 \\
\hline 08.1 .1 & $\begin{array}{l}\text { Carne fresca, incluida la de aves de corral y caza, en } \\
\text { piezas enteras o en cortes }\end{array}$ & BPF & $16 \& 326$ & 2015 \\
\hline 08.1 .2 & Carne fresca picada, incluida la de aves de corral y caza & BPF & 281 & 2014 \\
\hline 09.2 & $\begin{array}{l}\text { Pescado y productos pesqueros elaborados, incluidos los } \\
\text { moluscos, crustáceos y equinodermos }\end{array}$ & BPF & $\begin{array}{c}\text { 253, 391, } \\
\text { XS36, XS92, } \\
\text { XS95, XS167, } \\
\text { XS189, XS190, } \\
\text { XS191, XS222, } \\
\text { XS236, XS244, } \\
\text { XS292, XS311, } \\
\text { XS312 \& XS315 }\end{array}$ & 2018 \\
\hline 11.4 & $\begin{array}{l}\text { Otros azúcares y jarabes (p. ej. xilosa, jarabe de arce y } \\
\text { aderezos de azúcar) }\end{array}$ & BPF & 258 & 2013 \\
\hline 12.1 .2 & Sucedáneos de la sal & BPF & & 2013 \\
\hline 13.1.1 & Fórmulas (preparados) para lactantes & BPF & $55 \& 72$ & 2014 \\
\hline 13.1.2 & Fórmulas (preparados) de continuación & BPF & 72 & 2013 \\
\hline 13.1 .3 & $\begin{array}{l}\text { Fórmulas (preparados) para usos médicos especiales } \\
\text { destinados a los lactantes }\end{array}$ & BPF & $55 \& 72$ & 2014 \\
\hline 13.2 & $\begin{array}{l}\text { Alimentos complementarios para lactantes y niños } \\
\text { pequeños }\end{array}$ & BPF & 239 & 2013 \\
\hline 14.1.5 & $\begin{array}{l}\text { Café, sucedáneos del café, té, infusiones de hierbas y otras } \\
\text { bebidas calientes a base de cereales y granos, excluido el } \\
\text { cacao }\end{array}$ & BPF & 160 & 2013 \\
\hline
\end{tabular}

\section{CITRATO DÍACIDO DE SODIO}

SIN 331(i) Citrato díacido de sodio Clases Funcionales: Reguladores de la acidez, Emulsionantes, Sales emulsionantes, Secuestrantes, Estabilizadores

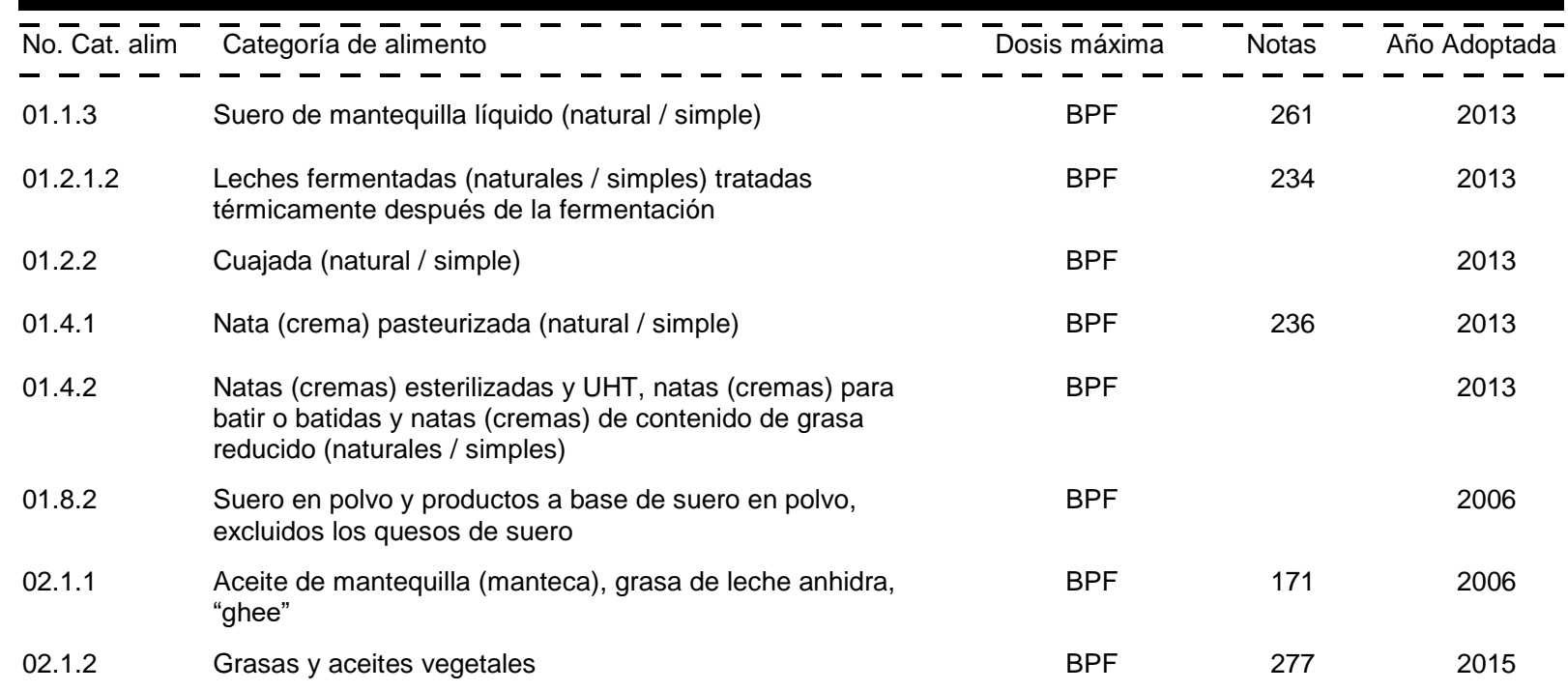


Cuadro I

CITRATO DÍACIDO DE SODIO

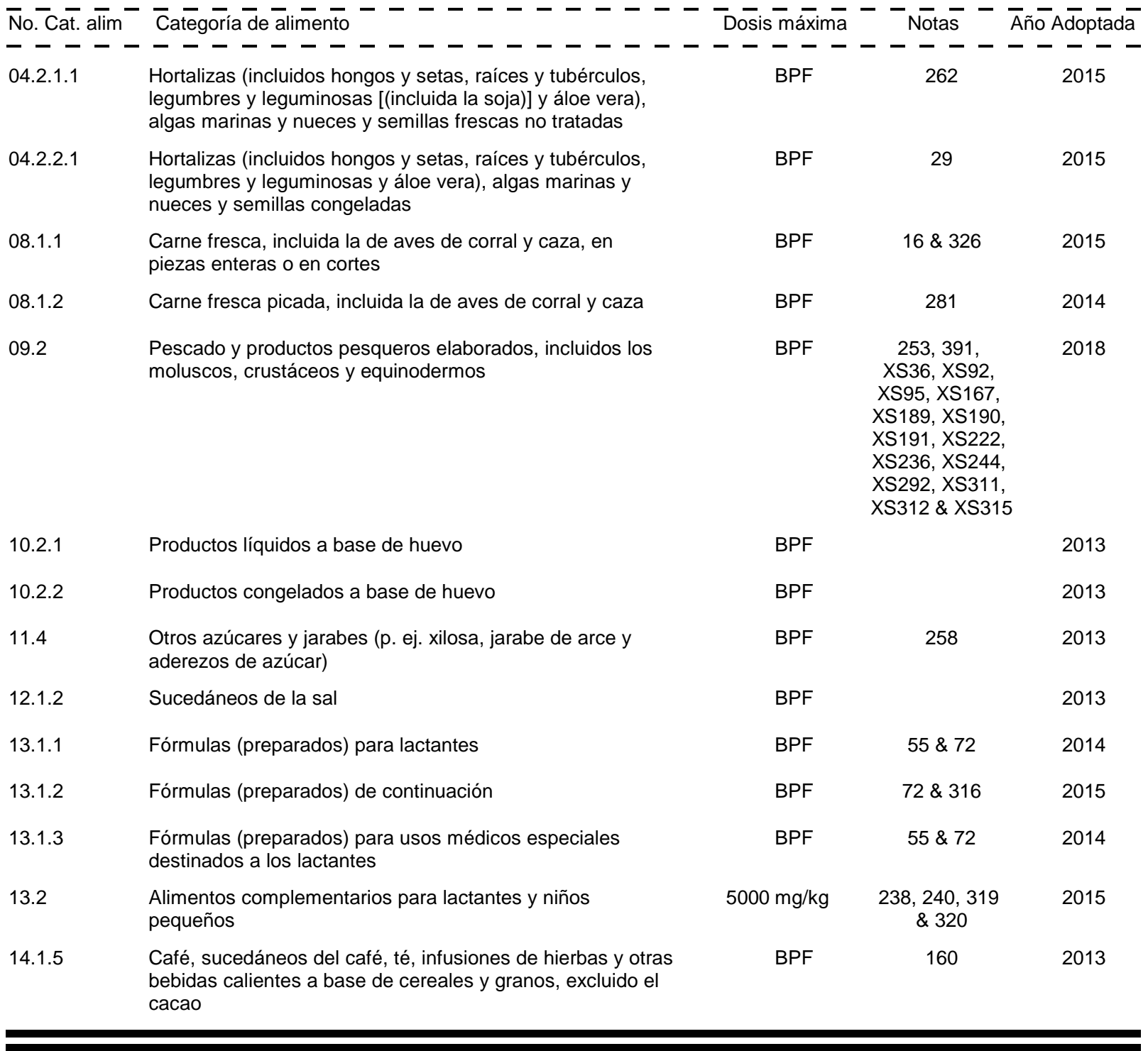

\section{CITRATO TRICÁLCICO}

SIN 333(iii) Citrato tricálcico

Clases Funcionales: Reguladores de la acidez, Sales emulsionantes, Agentes endurecedores, Secuestrantes, Estabilizadores

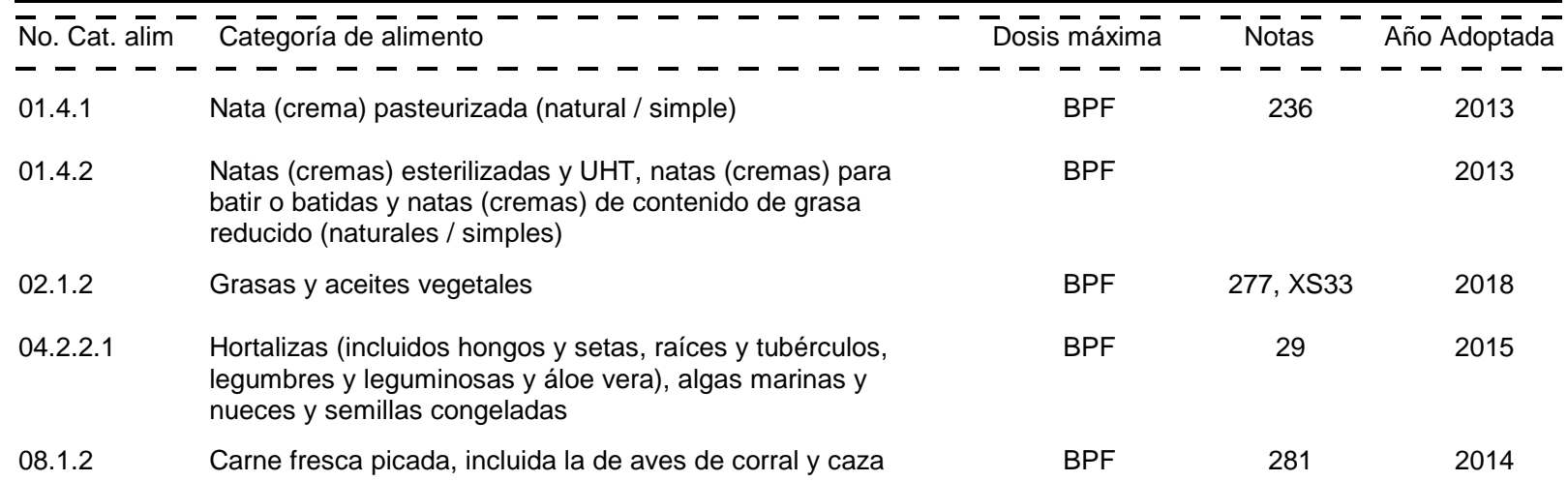


CITRATO TRICÁLCICO

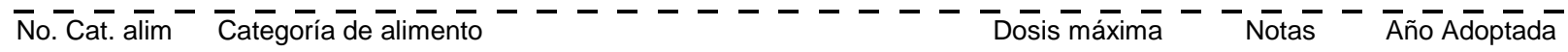

Pescado y productos pesqueros elaborados, incluidos los

BPF

XS36, XS92,

XS95, XS165,

moluscos, crustáceos y equinodermos

XS166, XS167,

XS189, XS190

XS191, XS222,

XS236, XS244

XS292, Xs311,

XS312 \& XS315

\section{CITRATO TRIPOTÁSICO}

\begin{tabular}{|c|c|c|c|c|}
\hline 01.1 .3 & Suero de mantequilla líquido (natural / simple) & BPF & 261 & 2013 \\
\hline 01.2 .1 .2 & $\begin{array}{l}\text { Leches fermentadas (naturales / simples) tratadas } \\
\text { térmicamente después de la fermentación }\end{array}$ & BPF & 234 & 2013 \\
\hline 01.2 .2 & Cuajada (natural / simple) & BPF & & 2013 \\
\hline 01.4 .1 & Nata (crema) pasteurizada (natural / simple) & BPF & 236 & 2013 \\
\hline 01.4 .2 & $\begin{array}{l}\text { Natas (cremas) esterilizadas y UHT, natas (cremas) para } \\
\text { batir o batidas y natas (cremas) de contenido de grasa } \\
\text { reducido (naturales / simples) }\end{array}$ & BPF & & 2013 \\
\hline 01.8 .2 & $\begin{array}{l}\text { Suero en polvo y productos a base de suero en polvo, } \\
\text { excluidos los quesos de suero }\end{array}$ & BPF & & 2006 \\
\hline 02.1 .2 & Grasas y aceites vegetales & BPF & 277, XS33 & 2018 \\
\hline 04.2 .2 .1 & $\begin{array}{l}\text { Hortalizas (incluidos hongos y setas, raíces y tubérculos, } \\
\text { legumbres y leguminosas y áloe vera), algas marinas y } \\
\text { nueces y semillas congeladas }\end{array}$ & BPF & 29 & 2015 \\
\hline 08.1 .1 & $\begin{array}{l}\text { Carne fresca, incluida la de aves de corral y caza, en } \\
\text { piezas enteras o en cortes }\end{array}$ & BPF & $16 \& 326$ & 2015 \\
\hline 08.1 .2 & Carne fresca picada, incluida la de aves de corral y caza & BPF & 281 & 2014 \\
\hline 09.2 & $\begin{array}{l}\text { Pescado y productos pesqueros elaborados, incluidos los } \\
\text { moluscos, crustáceos y equinodermos }\end{array}$ & BPF & $\begin{array}{c}\text { 253, 391, } \\
\text { XS36, XS92, } \\
\text { XS95, XS167, } \\
\text { XS189, XS190, } \\
\text { XS191, XS222, } \\
\text { XS236, XS244, } \\
\text { XS292, XS311, } \\
\text { XS312 \& XS315 }\end{array}$ & 2018 \\
\hline 11.4 & $\begin{array}{l}\text { Otros azúcares y jarabes (p. ej. xilosa, jarabe de arce y } \\
\text { aderezos de azúcar) }\end{array}$ & BPF & 258 & 2013 \\
\hline 12.1.2 & Sucedáneos de la sal & BPF & & 2013 \\
\hline 13.1.1 & Fórmulas (preparados) para lactantes & BPF & $55 \& 72$ & 2014 \\
\hline 13.1 .2 & Fórmulas (preparados) de continuación & BPF & 72 & 2013 \\
\hline 13.1.3 & $\begin{array}{l}\text { Fórmulas (preparados) para usos médicos especiales } \\
\text { destinados a los lactantes }\end{array}$ & BPF & $55 \& 72$ & 2014 \\
\hline 13.2 & Alimentos complementarios para lactantes y niños & BPF & 239 & 2013 \\
\hline
\end{tabular}


CITRATO TRIPOTÁSICO

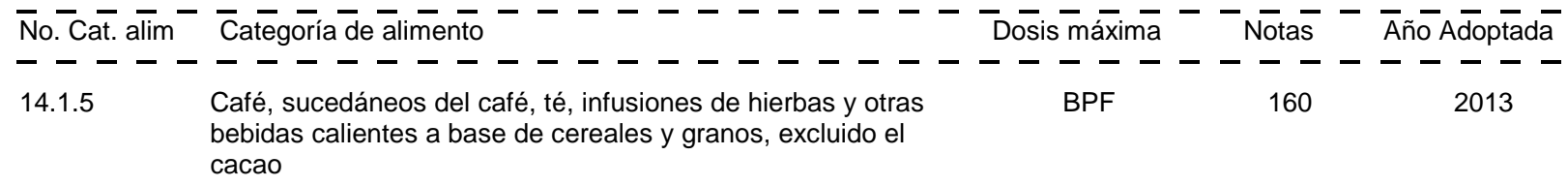

\section{CITRATO TRISÓDICO}

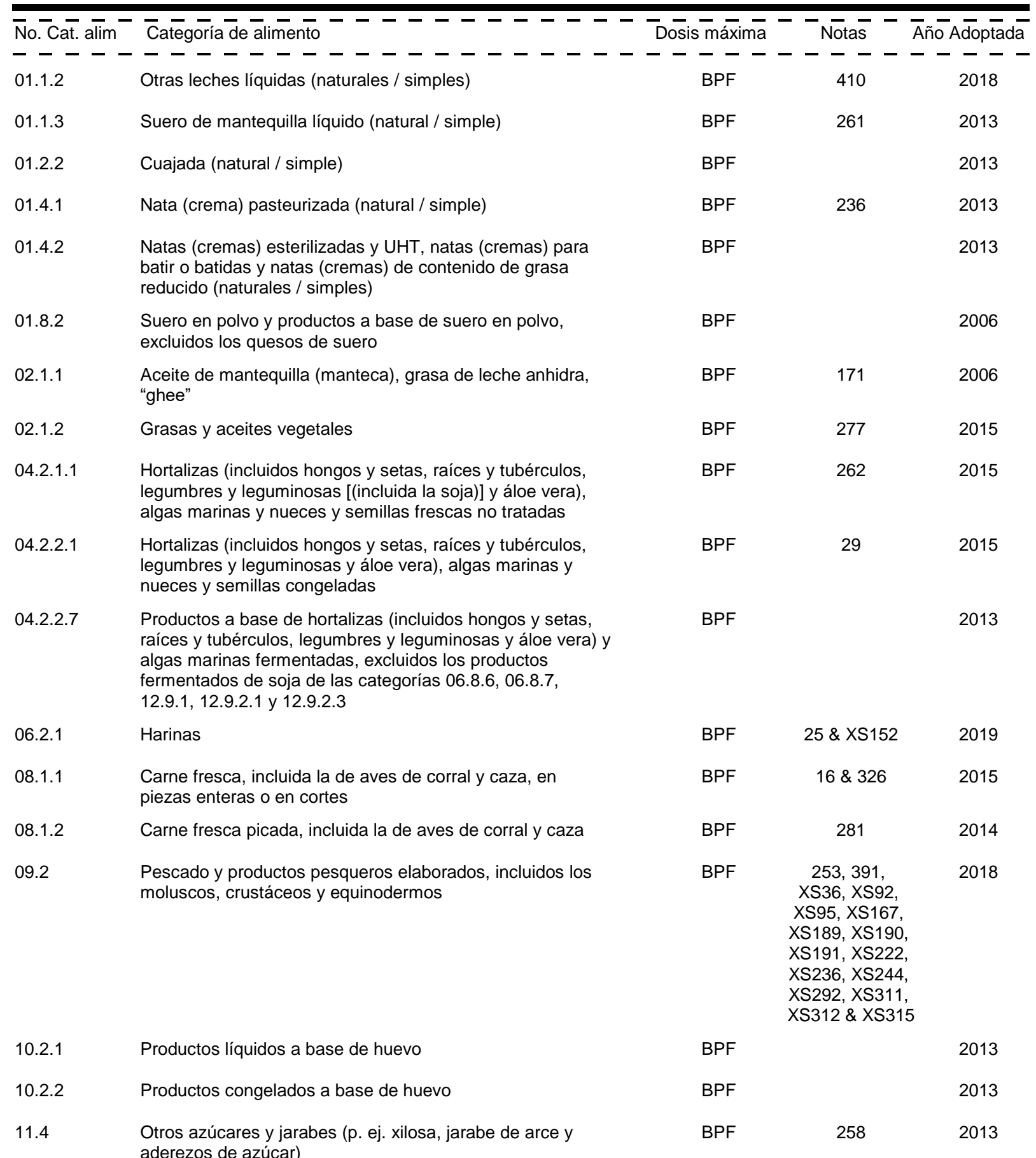


Cuadro I

CITRATO TRISÓDICO

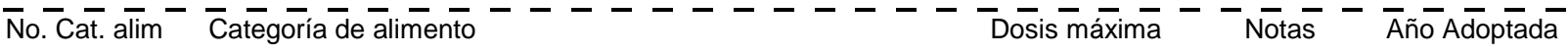

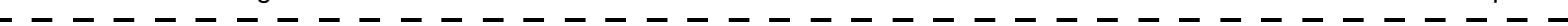

$\begin{array}{llll}\text { 12.1.2 Sucedáneos de la sal } & \text { BPF } & 2013\end{array}$

$\begin{array}{llll}\text { 13.1.1 Fórmulas (preparados) para lactantes } & \text { BPF } & 55 \& 72 \quad 2014\end{array}$

13.1.2 Fórmulas (preparados) de continuación $\quad$ BPF $\quad 72 \& 316 \quad 2015$

$\begin{array}{llll}\text { 13.1.3 } & \text { Fórmulas (preparados) para usos médicos especiales } & \text { BPF } & 55 \& 72 \quad 2014\end{array}$

$13.2 \quad$ Alimentos complementarios para lactantes y niños $\quad 5000 \mathrm{mg} / \mathrm{kg} \quad 238,240,319 \quad 2015$ pequeños

$\begin{aligned} 5000 \mathrm{mg} / \mathrm{kg} \quad 238, & 240,319 \quad 2015 \\ \& & 320\end{aligned}$

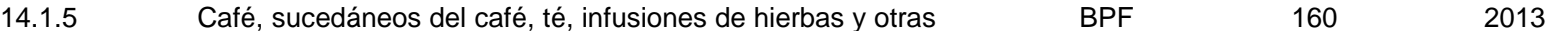
bebidas calientes a base de cereales y granos, excluido el cacao

\section{CITRATOS DE ISOPROPILO}

SIN $384 \quad$ Citratos de isopropilo

Clases Funcionales: Antioxidantes, Sustancias conservadoras, Secuestrantes

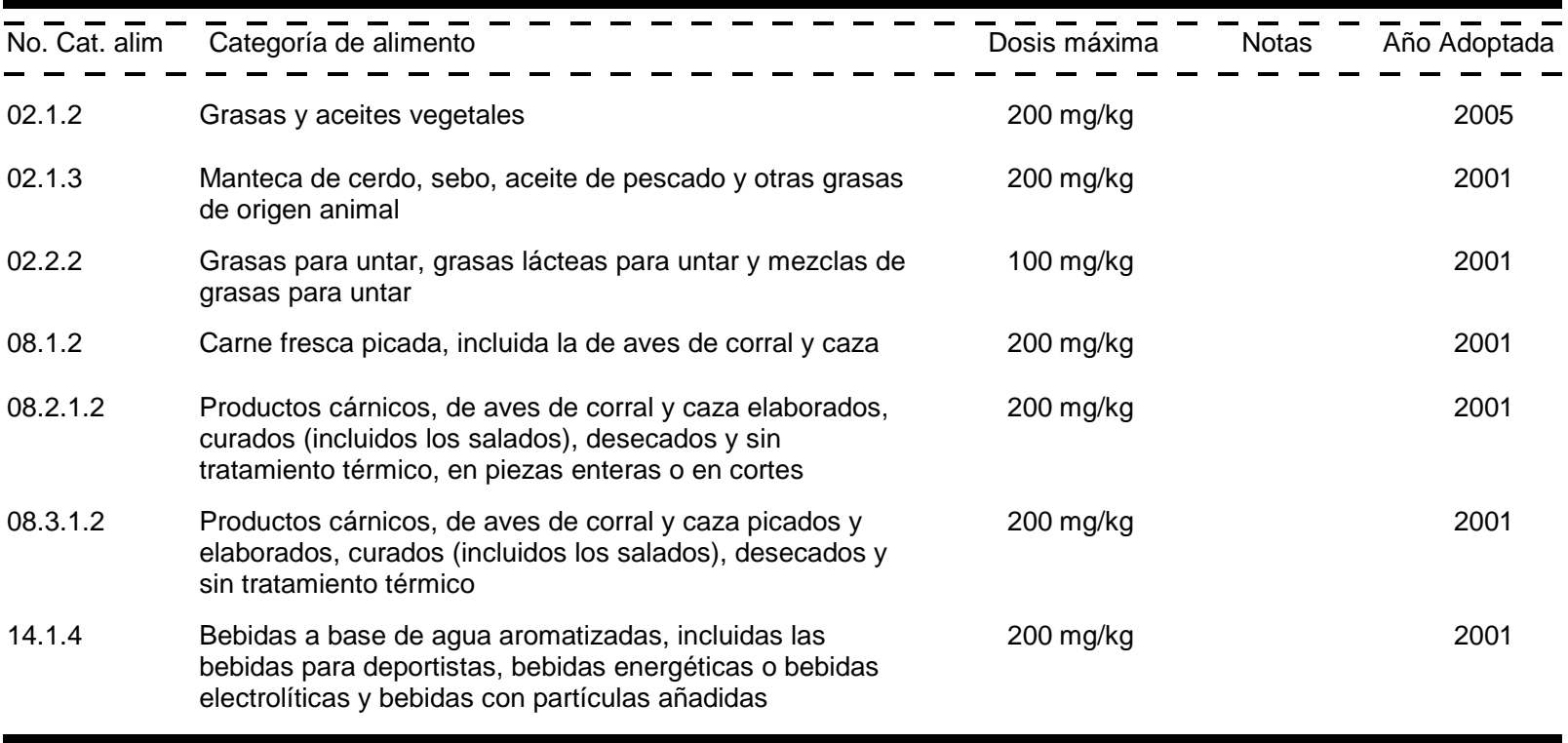

\section{CLORO}

SIN 925

Cloro

Clases Funcionales: Agentes de tratamiento de las harinas

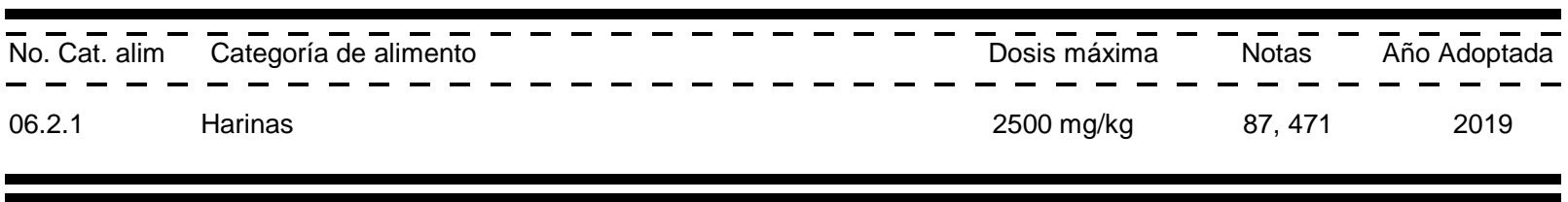

\section{CLOROFILAS Y CLOROFILINAS, COMPLEJOS CUPRICOS}

SIN 141(i) Clorofilas, complejos cúpricos Clases Funcionales: Colorantes

SIN 141(ii) Clorofilinas, complejos cúpricos, Clases Funcionales: Colorantes sales de potasio y sodio

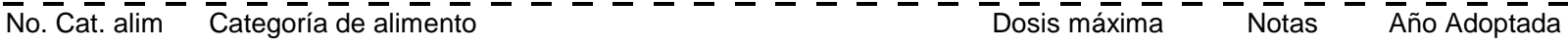


Cuadro I

CLOROFILAS Y CLOROFILINAS, COMPLEJOS

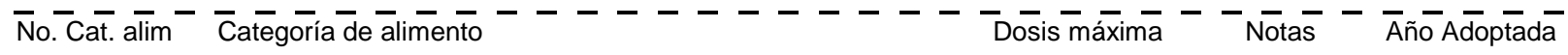

- - - - - - - - - - - - - - - - - - - - - - - - - -

01.1.4 Bebidas lácteas líquidas aromatizadas

$\begin{array}{cc}50 \mathrm{mg} / \mathrm{kg} & 52 \& 190 \\ 50 \mathrm{mg} / \mathrm{kg} & 161 \\ 15 \mathrm{mg} / \mathrm{kg} & 62, \mathrm{XS} 263, \\ & \text { XS264, XS265, } \\ & \text { XS266, XS267, } \\ & \text { XS268, XS269, } \\ & \text { XS270, XS271, } \\ & \text { XS272, XS274, } \\ & \text { XS276, XS277 }\end{array}$

2009

01.6.1 Queso no madurado

2009

01.6.2.2 Corteza de queso madurado

2009

01.6.2.3 Queso en polvo (para reconstitución; p. ej., para salsas a base de queso)

01.6.4.2 Queso elaborado aromatizado, incluido el que contiene

$50 \mathrm{mg} / \mathrm{kg}$

2009 fruta, hortalizas, carne, etc

01.6.5 Productos análogos al queso

$50 \mathrm{mg} / \mathrm{kg}$

2009

01.7

Postres lácteos (como pudines, yogur aromatizado o con fruta)

$500 \mathrm{mg} / \mathrm{kg}$

2009

02.4

Postres a base de grasas, excluidos los postres lácteos de la categoría de alimentos 01.7

$500 \mathrm{mg} / \mathrm{kg}$

2009

$500 \mathrm{mg} / \mathrm{kg}$

2009

04.1.2.3 Frutas en vinagre, aceite o salmuera

$100 \mathrm{mg} / \mathrm{kg}$

62

2005

04.1.2.4 Frutas en conserva, enlatadas o en frascos (pasteurizadas)

$100 \mathrm{mg} / \mathrm{kg}$

$62 \& 267$

2018

04.1 .2 .5

Confituras, jaleas, mermeladas

$200 \mathrm{mg} / \mathrm{kg}$

16

2009

$150 \mathrm{mg} / \mathrm{kg}$

2009

excluidos los productos de la categoría de alimentos

04.1.2.5

04.1.2.7 Frutas confitadas

$250 \mathrm{mg} / \mathrm{kg}$

2009

04.1 .2 .8

Preparados a base de fruta, incluida la pulpa, los purés, los revestimientos de fruta y la leche de coco

$100 \mathrm{mg} / \mathrm{kg}$

$62 \& 182$

2008

$150 \mathrm{mg} / \mathrm{kg}$

2009 agua con aromas de fruta

04.1.2.10 Productos de fruta fermentada

$100 \mathrm{mg} / \mathrm{kg}$

62

2005

04.1.2.11 Rellenos de fruta para pastelería

$100 \mathrm{mg} / \mathrm{kg}$

62

2005

04.1.2.12 Frutas cocidas o fritas

$100 \mathrm{mg} / \mathrm{kg}$

62

2005

04.2.2.5 Purés y preparados para untar elaborados con hortalizas (incluidos hongos y setas, raíces y tubérculos, legumbres y

$100 \mathrm{mg} / \mathrm{kg}$

62

2005

eguminosas y áloe vera), algas marinas y nueces y semillas (p. ej., la mantequilla de maní (cacahuete))

04.2.2.6 Pulpas y preparados de hortalizas (incluidos hongos y setas, raíces y tubérculos, legumbres y leguminosas y áloe vera), algas marinas y nueces y semillas (como los postres y las salsas a base de hortalizas y hortalizas confitadas) distintos de los indicados en la categoría de alimentos 04.2.2.5

Productos a base de hortalizas (incluidos hongos y setas, raíces y tubérculos, legumbres y leguminosas y áloe vera) y algas marinas fermentadas, excluidos los productos fermentados de soja de las categorías 06.8.6, 06.8.7, 12.9.1, 12.9.2.1 y 12.9 .2 .3 
Cuadro I

CLOROFILAS Y CLOROFILINAS, COMPLEJOS

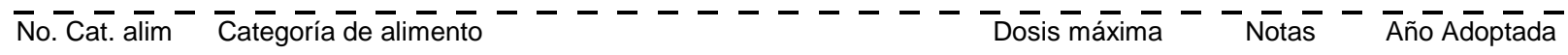

- - - - - - - - - - - - - - - - - - - - - - - - - - - -

04.2.2.8 Hortalizas (incluidos hongos y setas, raíces y tubérculos,

$100 \mathrm{mg} / \mathrm{kg}$

62

2005

egumbres y leguminosas y áloe vera) y algas marinas cocidas o fritas

05.1.2 Mezclas de cacao (jarabes)

$\begin{array}{lcc}6.4 \mathrm{mg} / \mathrm{kg} & 62 \& 161 & 2009 \\ 6.4 \mathrm{mg} / \mathrm{kg} & 62,161 \& \text { XS86 } & 2016 \\ 700 \mathrm{mg} / \mathrm{kg} & 183 & 2016 \\ 700 \mathrm{mg} / \mathrm{kg} & & 2009 \\ 700 \mathrm{mg} / \mathrm{kg} & & 2009 \\ 100 \mathrm{mg} / \mathrm{kg} & X S 309 \mathrm{R} & 2017 \\ 100 \mathrm{mg} / \mathrm{kg} & & 2009 \\ 700 \mathrm{mg} / \mathrm{kg} & & 2009 \\ 100 \mathrm{mg} / \mathrm{kg} & & 2009 \\ 100 \mathrm{mg} / \mathrm{kg} & 153 & 2009 \\ 75 \mathrm{mg} / \mathrm{kg} & & 2009 \\ 6.4 \mathrm{mg} / \mathrm{kg} & 62 \& 161 & 2009 \\ 75 \mathrm{mg} / \mathrm{kg} & & 2009\end{array}$

$\begin{array}{llll}07.2 & \text { Productos de panadería fina (dulces, salados, } & 75 \mathrm{mg} / \mathrm{kg} & 2009\end{array}$

09.2.3 Productos pesqueros picados, mezclados y congelados,

$40 \mathrm{mg} / \mathrm{kg}$

95

2009

09.2.4.1 Pescado y productos pesqueros cocidos

$30 \mathrm{mg} / \mathrm{kg}$

$62 \& 95$

2009

09.2.4.3 Pescado y productos pesqueros fritos, incluidos los moluscos, crustáceos y equinodermos

$40 \mathrm{mg} / \mathrm{kg}$

95

2009

09.2.5 Pescado y productos pesqueros ahumados, desecados, fermentados y/o salados, incluidos los moluscos,

$200 \mathrm{mg} / \mathrm{kg}$

XS167, XS189, XS222, XS236 crustáceos y equinodermos

09.3.1 Pescado y productos pesqueros marinados y/o en gelatina incluidos los moluscos, crustáceos y equinodermos

09.3.2 Pescado y productos pesqueros escabechados y/o en salmuera, incluidos los moluscos, crustáceos y equinodermos

09.3.3 Sucedáneos de salmón, caviar y otros productos pesqueros a base de huevas

$200 \mathrm{mg} / \mathrm{kg}$

XS291

2018

Pescado y productos pesqueros semiconservados,

$75 \mathrm{mg} / \mathrm{kg}$

95

2009

la pasta de pescado), excluidos los productos indicados en las categorías de alimentos 09.3.1 a 09.3.3

$09.4 \quad$ Pescado y productos pesqueros (incluidos los moluscos, crustáceos y equinodermos) en conserva, con inclusión de los enlatados y fermentados

$500 \mathrm{mg} / \mathrm{kg} \quad 95, \mathrm{XS} 3, \mathrm{XS} 37$

XS70, XS90,

XS94 \& XS119

$10.4 \quad$ Postres a base de huevo (p. ej. flan)

$300 \mathrm{mg} / \mathrm{kg}$

2

2009

$11.4 \quad$ Otros azúcares y jarabes (p. ej. xilosa, jarabe de arce y

$64 \mathrm{mg} / \mathrm{kg}$

62

2005 aderezos de azúcar) 
Cuadro I

CLOROFILAS Y CLOROFILINAS, COMPLEJOS

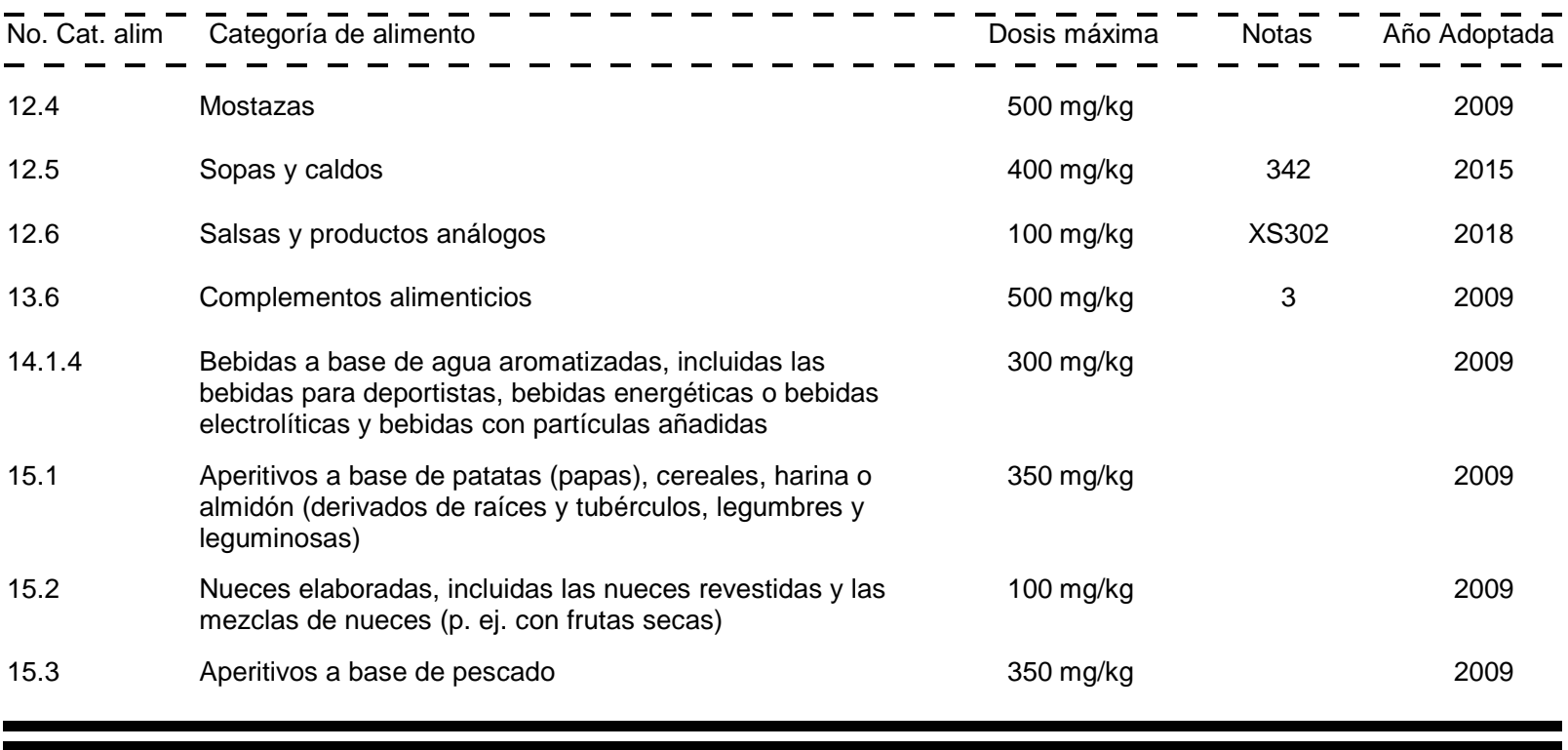

\section{CLORURO DE CALCIO}

SIN 509 Cloruro de calcio Clases Funcionales: Agentes endurecedores, Estabilizadores, Espesantes

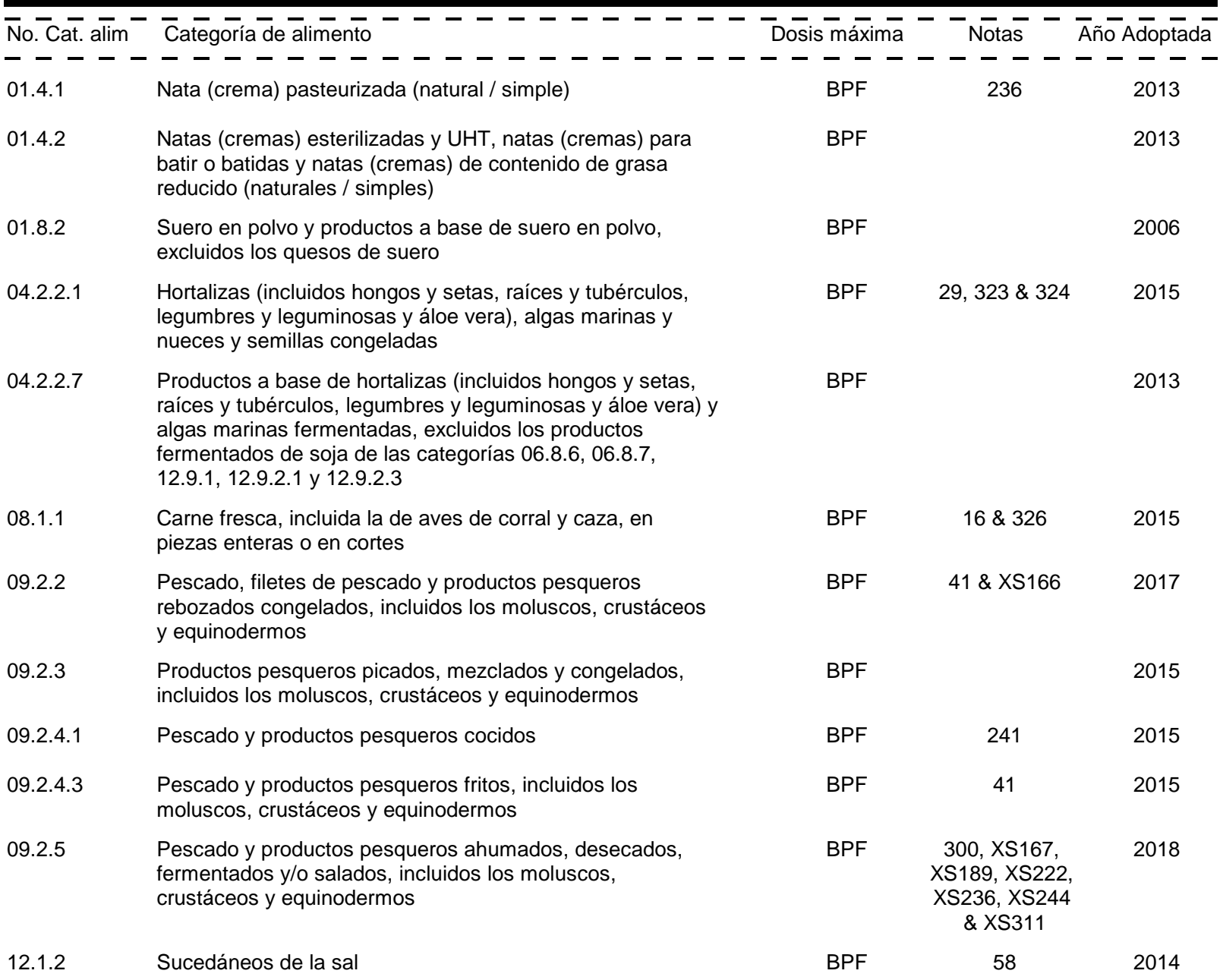


CLORURO DE CALCIO

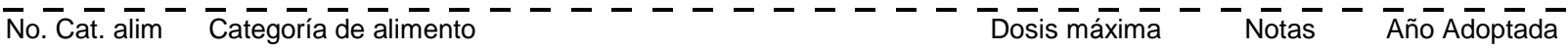
- - - - - - - - - - - - - - - - - - - - - - - - - -

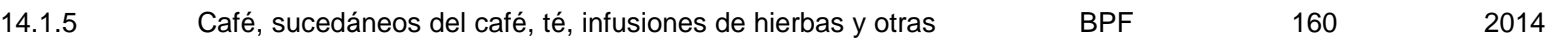
bebidas calientes a base de cereales y granos, excluido el cacao

\section{CLORURO DE MAGNESIO}

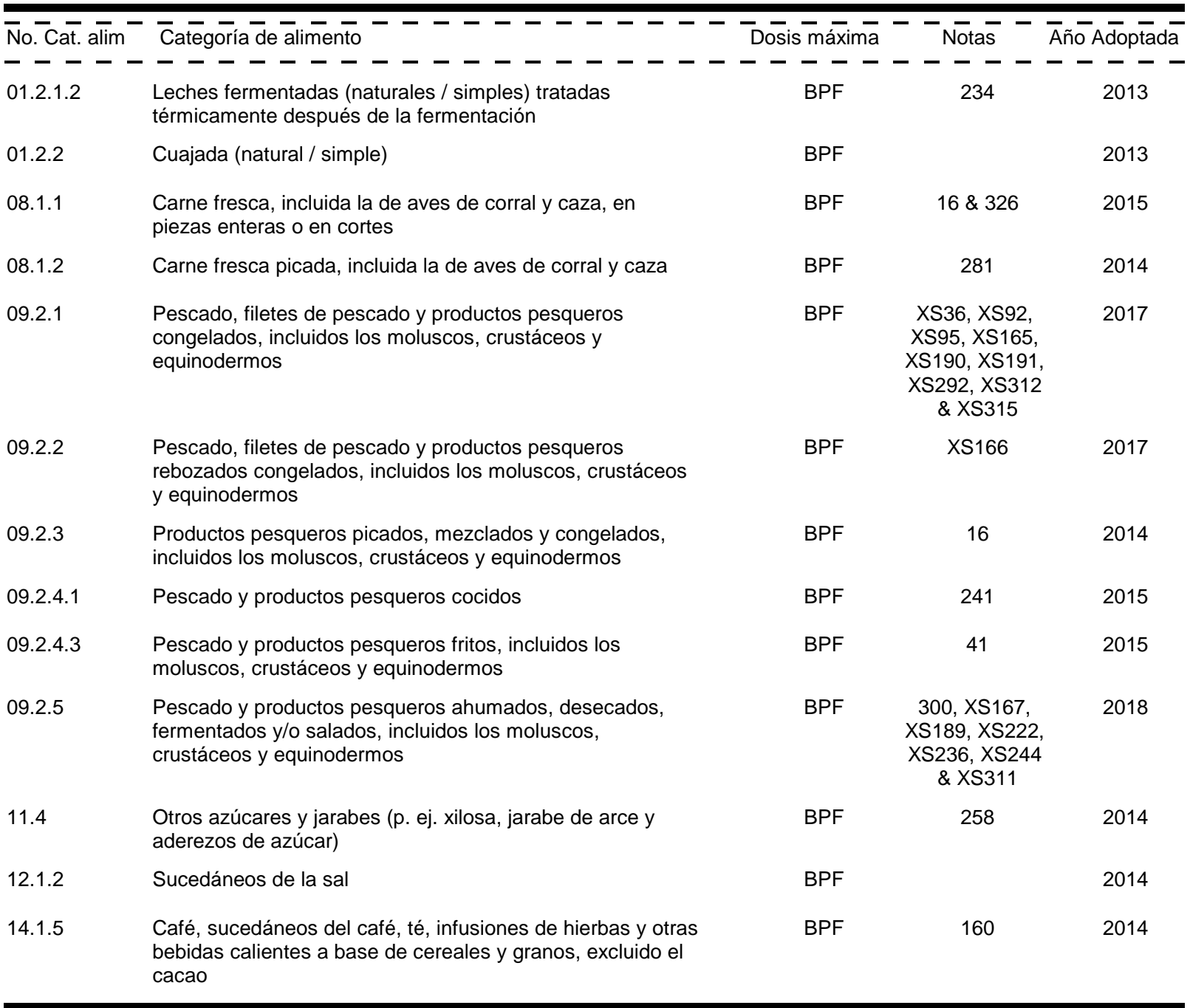

\section{CLORURO DE POTASIO}

\section{SIN $508 \quad$ Cloruro de potasio}

Clases Funcionales: Agentes endurecedores, Acentuadores del sabor, Estabilizadores, Espesantes

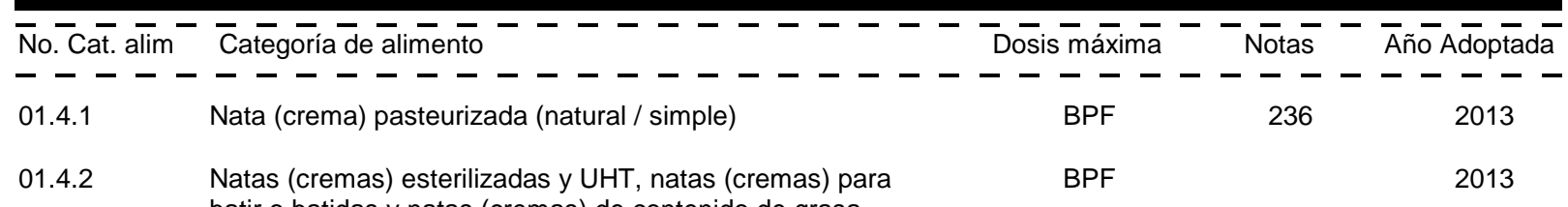
batir o batidas y natas (cremas) de contenido de grasa reducido (naturales / simples) 
Cuadro I

CLORURO DE POTASIO

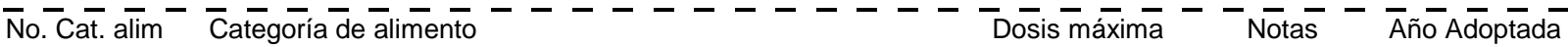

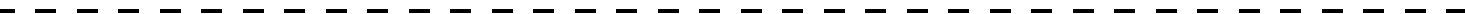

$\begin{array}{llll}\text { 01.8.2 Suero en polvo y productos a base de suero en polvo, } & \text { BPF } & 2006\end{array}$ excluidos los quesos de suero

04.2.2.7 Productos a base de hortalizas (incluidos hongos y setas,

BPF

2013

raíces y tubérculos, legumbres y leguminosas y áloe vera) y

algas marinas fermentadas, excluidos los productos

fermentados de soja de las categorías 06.8.6, 06.8.7, 12.9.1, 12.9.2.1 y 12.9 .2 .3

06.4.2 Pastas y fideos deshidratados y productos análogos

BPF

256

2014

08.1.

Carne fresca, incluida la de aves de corral y caza, en piezas enteras o en cortes

09.2.1 Pescado, filetes de pescado y productos pesqueros congelados, incluidos los moluscos, crustáceos y equinodermos

09.2.2 Pescado, filetes de pescado y productos pesqueros rebozados congelados, incluidos los moluscos, crustáceos y equinodermos

09.2.3 Productos pesqueros picados, mezclados y congelados, incluidos los moluscos, crustáceos y equinodermos

09.2.5 Pescado y productos pesqueros ahumados, desecados, fermentados y/o salados, incluidos los moluscos, crustáceos y equinodermos

BPF

BPF

XS36, XS92,

$\mathrm{XS} 95, \mathrm{XS} 165$

XS190, XS191

XS292, XS312

\& XS315

BPF

$41 \&$ XS166

BPF

BPF

$300, \mathrm{XS} 167$

XS189, XS222

XS236, XS244

\& XS311

12.1.2 Sucedáneos de la sal

BPF

BPF

160 bebidas calientes a base de cereales y granos, excluido el cacao

\section{CLORURO ESTAÑOSO}

SIN $512 \quad$ Cloruro estañoso

Clases Funcionales: Antioxidantes, Agentes de retención de color

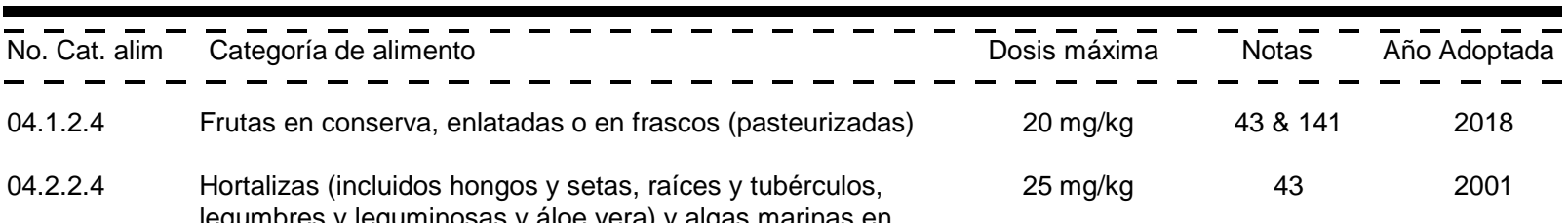

conserva, en latas o frascos (pasteurizadas) o en bolsas esterilización

14.1.4 Bebidas a base de agua aromatizadas, incluidas las bebidas para deportistas, bebidas energéticas o bebidas

$20 \mathrm{mg} / \mathrm{kg}$

43

2001 electrolíticas y bebidas con partículas añadidas

\section{COPOLÍMERO CON INJERTO DE POLIVINILALCOHOL (PVA)-POLIETILENGLICOL (PEG)}

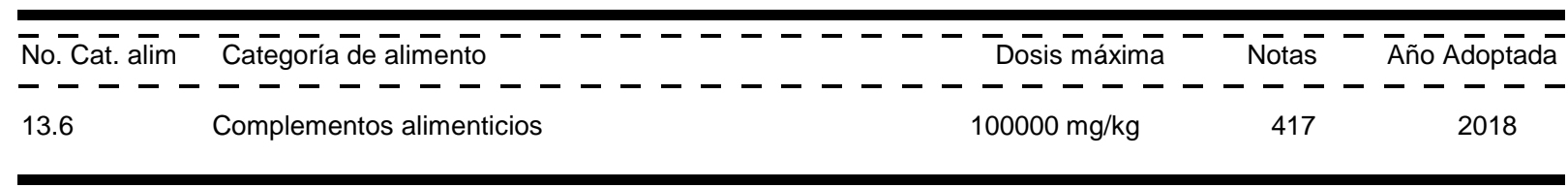


Cuadro I

CURCUMINA

\section{CURCUMINA}

Clases Funcionales: Colorantes

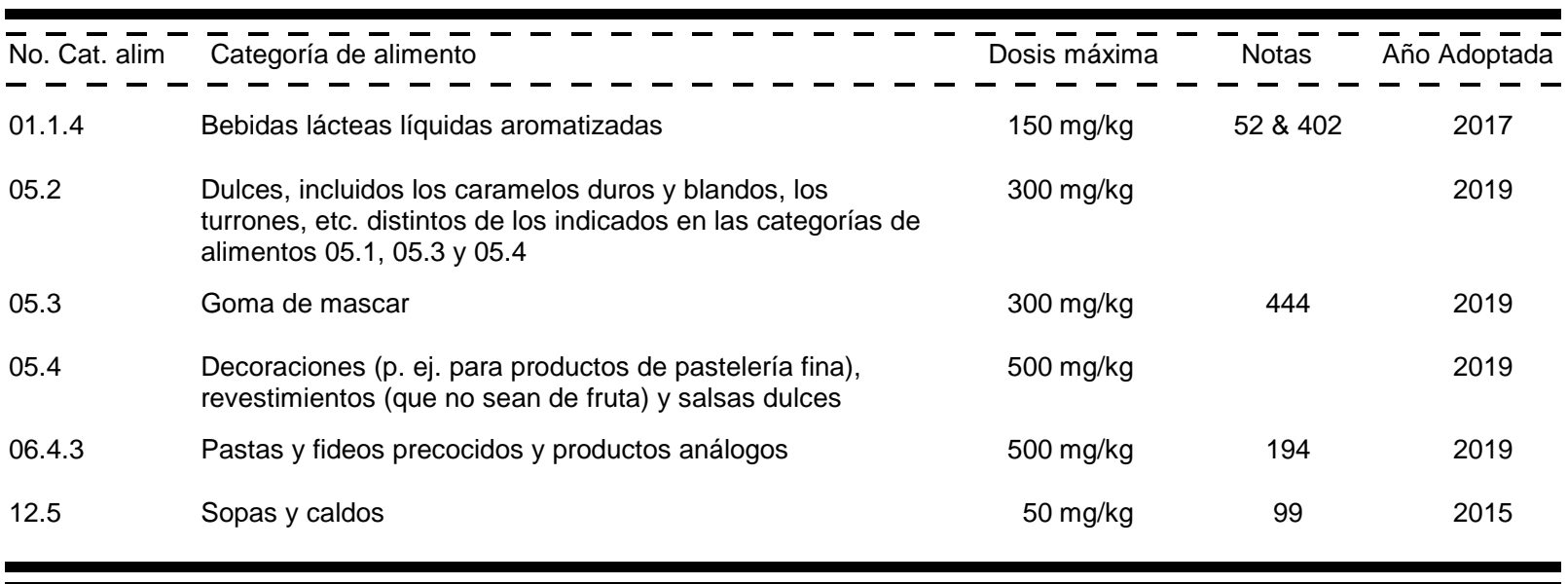

\section{CURDLAN}

SIN 424 Curdlan Clases Funcionales: Agentes endurecedores, Agentes gelificantes,
Estabilizadores, Espesantes

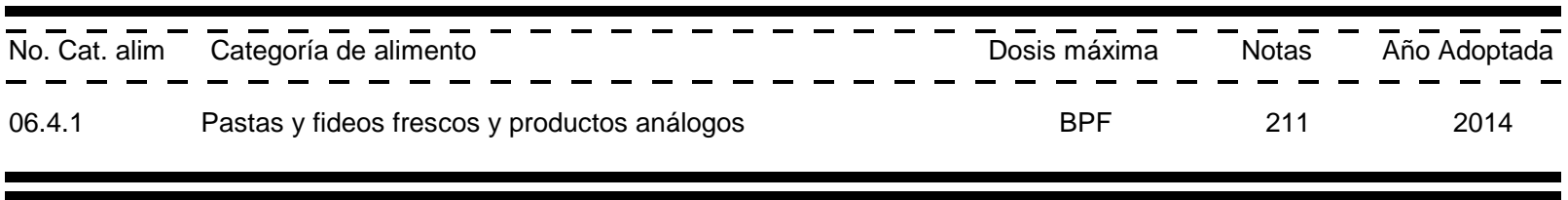

\section{DEXTRINAS, ALMIDÓN TOSTADO}

SIN 1400 Dextrinas, almidón tostado Clases Funcionales: Sustancias inertes, Emulsionantes, Estabilizadores, Espesantes

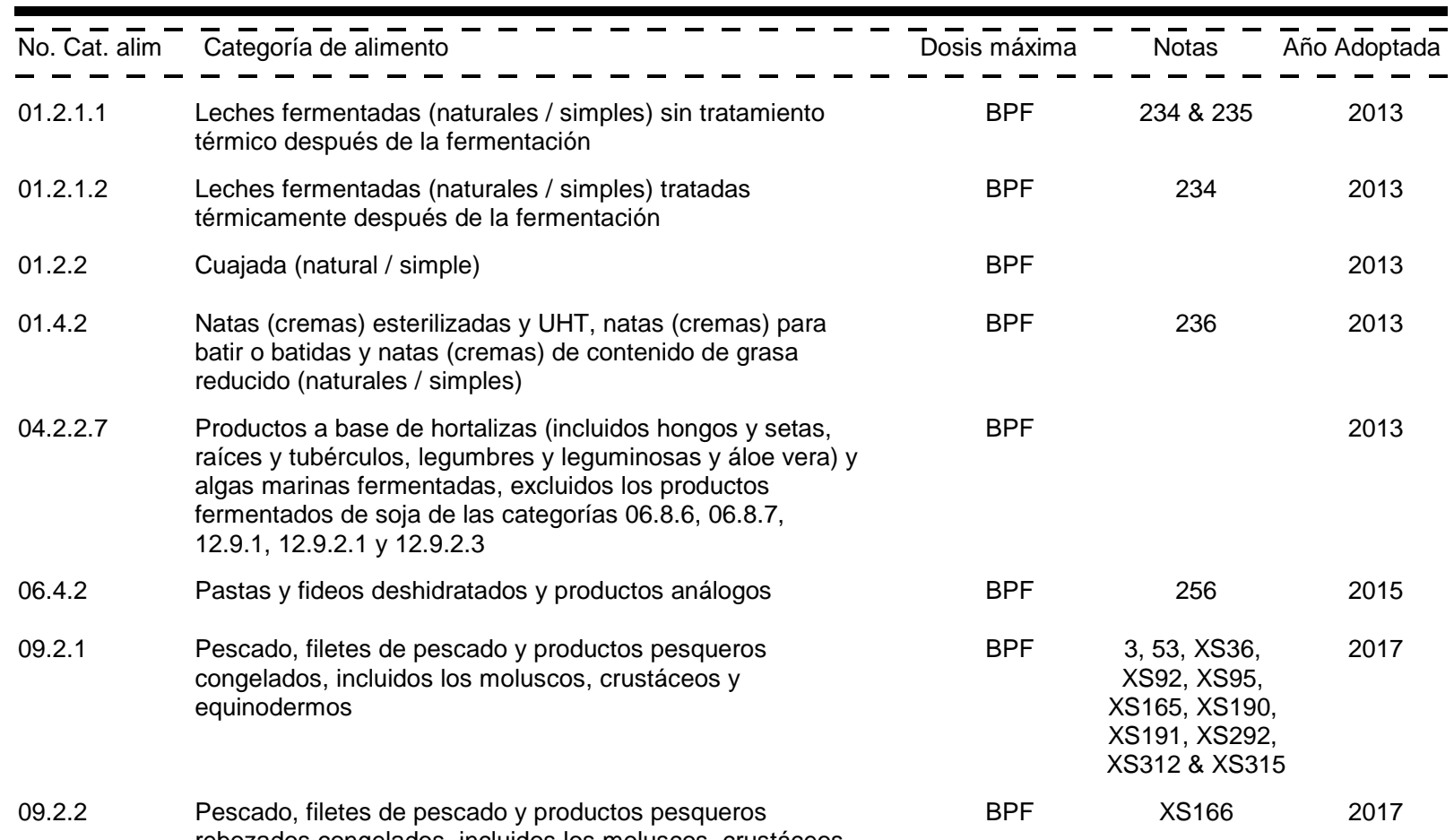
rebozados congelados, incluidos los moluscos, crustáceos y equinodermos 
Cuadro I

DEXTRINAS, ALMIDÓN TOSTADO

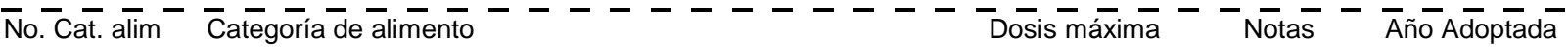

- - - - - - - - - - - - - - - - - - - - - - - - - - incluidos los moluscos, crustáceos y equinodermos

BPF $\quad 241 \quad 2014$

09.2.4.3

Pescado y productos pesqueros fritos, incluidos los

BPF

$41 \quad 2014$

10.2.1 Productos líquidos a base de huevo

BPF

2015

10.2.2 Productos congelados a base de huevo

BPF

2018

14.1.5 Café, sucedáneos del café, té, infusiones de hierbas y otras bebidas calientes a base de cereales y granos, excluido el

BPF

$90 \& 160$

2014 cacao

\section{DIACETATO DE SODIO}

SIN 262(ii) Diacetato de sodio

Clases Funcionales: Reguladores de la acidez, Sustancias conservadoras, Secuestrantes

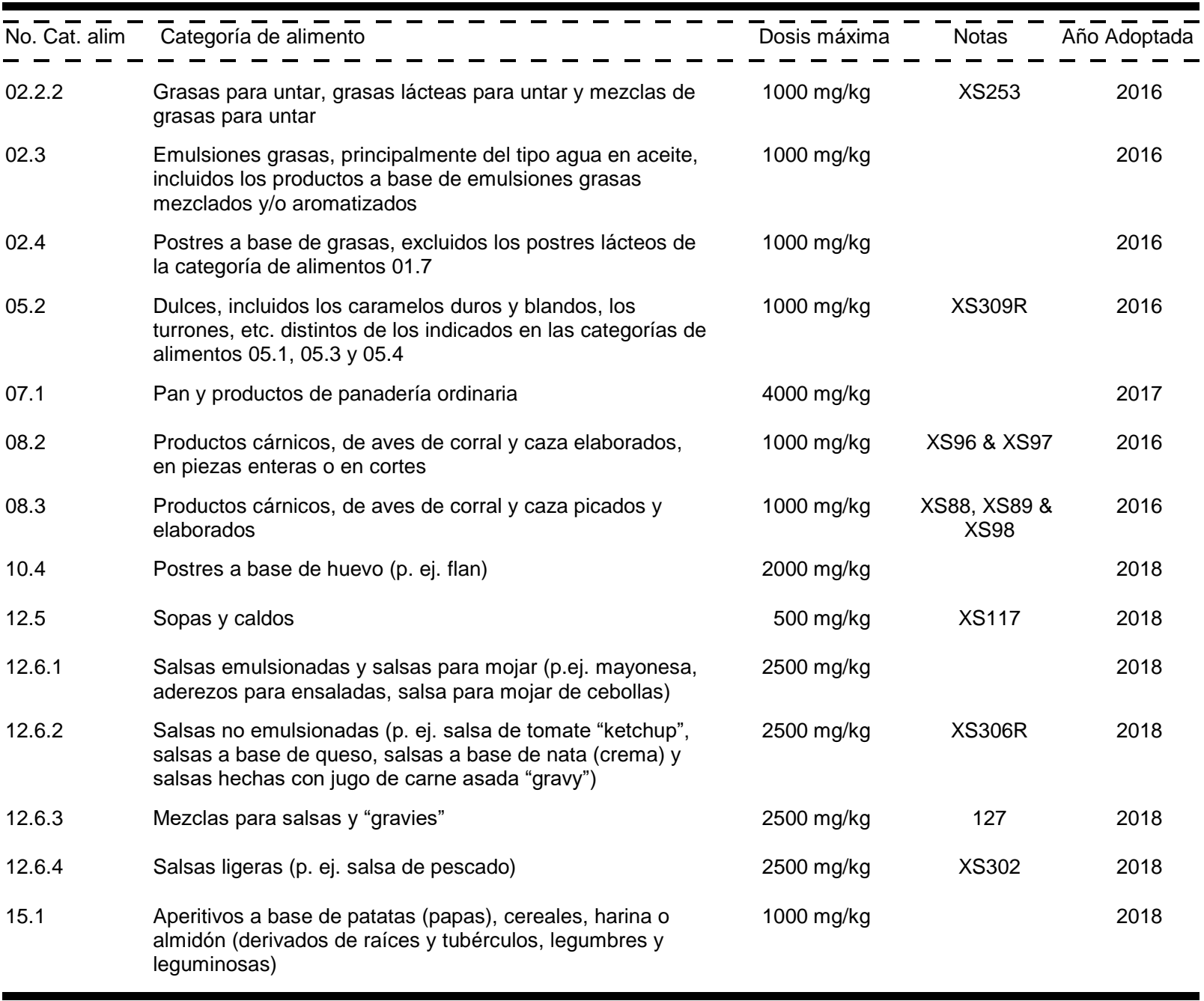

\section{DIMETIL DICARBONATO}


Cuadro I

DIMETIL DICARBONATO

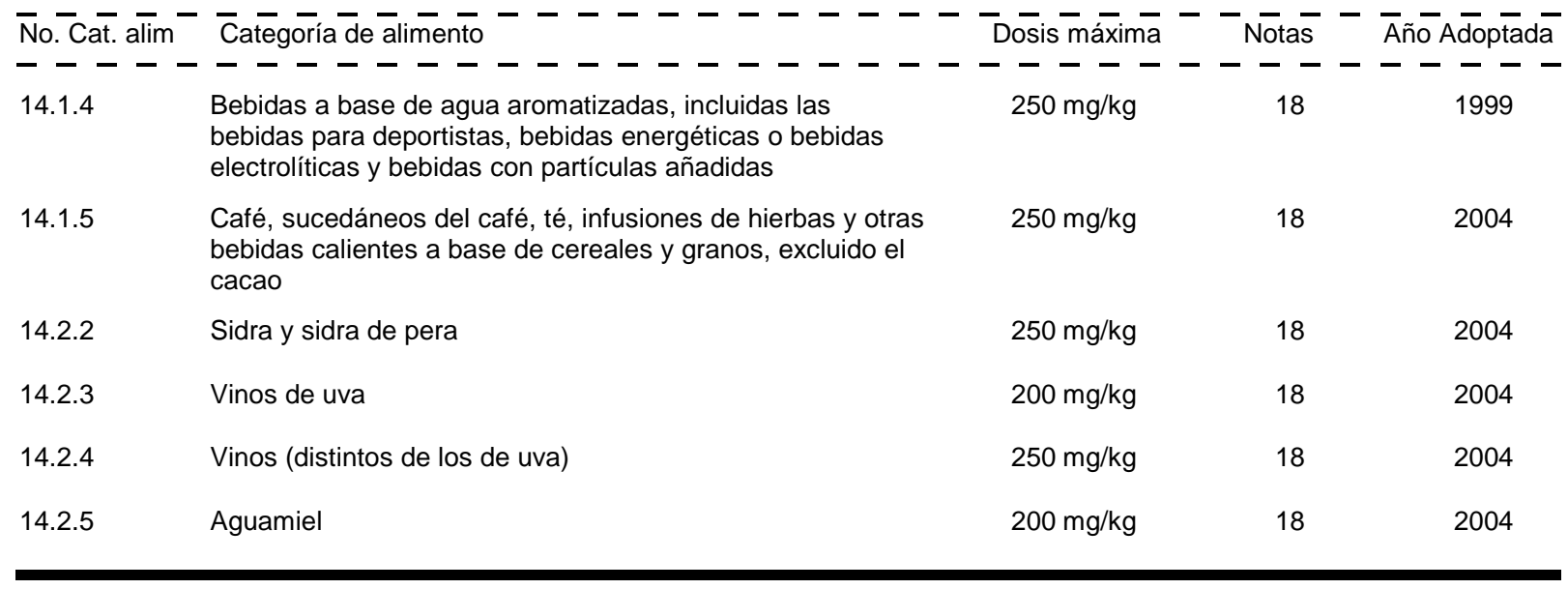

\section{DIMETILPOLISILOXANO}

SIN 900a Polidimetilsiloxano Clases Funcionales: Antiaglutinantes, Antiespumantes, Emulsionantes

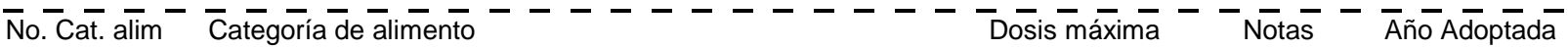

- - - - - - - - - - - - - - - - - - - - - - - - - -

$\begin{array}{llr}\text { 01.5.1 Leche en polvo y nata (crema) en polvo (naturales) } & 10 \mathrm{mg} / \mathrm{kg} & 1999\end{array}$

02.1.2 Grasas y aceites vegetales

$10 \mathrm{mg} / \mathrm{kg} \quad 2006$

02.1.3 Manteca de cerdo, sebo, aceite de pescado y otras grasas de origen animal

02.2.2 Grasas para untar, grasas lácteas para untar y mezclas de grasas para untar

2006

$10 \mathrm{mg} / \mathrm{kg} \quad 152 \quad 2007$

04.1.2.3 Frutas en vinagre, aceite o salmuera

$10 \mathrm{mg} / \mathrm{kg} \quad 1999$

04.1.2.4 Frutas en conserva, enlatadas o en frascos (pasteurizadas)

$10 \mathrm{mg} / \mathrm{kg} \quad 266 \quad 2018$

04.1.2.5 Confituras, jaleas, mermeladas

$30 \mathrm{mg} / \mathrm{kg} \quad 1999$

04.1.2.6 Productos para untar a base de fruta (p. ej. el "chutney"), excluidos los productos de la categoría de alimentos

$10 \mathrm{mg} / \mathrm{kg}$

1999 04.1.2.5

04.1.2.9 Postres a base de fruta, incluidos los postres a base de

$110 \mathrm{mg} / \mathrm{kg}$

1999 agua con aromas de fruta

04.1.2.10 Productos de fruta fermentada

$10 \mathrm{mg} / \mathrm{kg}$

2008

04.2.2.1 Hortalizas (incluidos hongos y setas, raíces y tubérculos, legumbres y leguminosas y áloe vera), algas marinas y

$10 \mathrm{mg} / \mathrm{kg}$

15

1999 nueces y semillas congeladas

04.2.2.3 Hortalizas (incluidos hongos y setas, raíces y tubérculos, legumbres y leguminosas y áloe vera) y algas marinas en vinagre, aceite, salmuera o salsa de soja

04.2.2.4 Hortalizas (incluidos hongos y setas, raíces y tubérculos, legumbres y leguminosas y áloe vera) y algas marinas en conserva, en latas o frascos (pasteurizadas) o en bolsas de esterilización

04.2.2.5 Purés y preparados para untar elaborados con hortalizas (incluidos hongos y setas, raíces y tubérculos, legumbres y semillas (p. ej. la mantequilla de maní (cacahuete) 
Cuadro I

DIMETILPOLISILOXANO

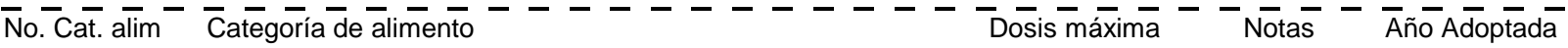

04.2.2.6 Pulpas y preparados de hortalizas (incluidos hongos y setas, raíces y tubérculos, legumbres y leguminosas y áloe

$50 \mathrm{mg} / \mathrm{kg}$

2004

vera), algas marinas y nueces y semillas (como los postres

y las salsas a base de hortalizas y hortalizas confitadas)

distintos de los indicados en la categoría de alimentos

04.2 .2 .5

04.2.2.7 Productos a base de hortalizas (incluidos hongos y setas, raíces y tubérculos, legumbres y leguminosas y áloe vera) y

algas marinas fermentadas, excluidos los productos

fermentados de soja de las categorías 06.8.6, 06.8.7.

12.9.1, 12.9.2.1 y 12.9 .2 .3

05.1.5 Productos de imitación y sucedáneos del chocolate

$10 \mathrm{mg} / \mathrm{kg}$

$05.2 \quad$ Dulces, incluidos los caramelos duros y blandos, los turrones, etc. distintos de los indicados en las categorías de alimentos $05.1,05.3$ y 05.4

$05.3 \quad$ Goma de mascar

$10 \mathrm{mg} / \mathrm{kg} \quad \mathrm{XS} 309 \mathrm{R}$

$100 \mathrm{mg} / \mathrm{kg}$

06.4.3 Pastas y fideos precocidos y productos análogos

$50 \mathrm{mg} / \mathrm{kg}$

06.6 Mezclas batidas para rebozar (p. ej. para empanizar o

$10 \mathrm{mg} / \mathrm{kg}$ rebozar pescado o carne de aves de corral)

$12.5 \quad$ Sopas y caldos

$10 \mathrm{mg} / \mathrm{kg}$

Alimentos dietéticos para usos médicos especiales

$50 \mathrm{mg} / \mathrm{kg}$

Preparados dietéticos para adelgazamiento y control del peso

$50 \mathrm{mg} / \mathrm{kg}$

Alimentos dietéticos (p. ej. los complementos alimenticios para usos dietéticos), excluidos los indicados en las categorías de alimentos 13.1 a 13.4 y 13.6

13.6 Complementos alimenticios

$50 \mathrm{mg} / \mathrm{kg}$

14.1.4 Bebidas a base de agua aromatizadas, incluidas las bebidas para deportistas, bebidas energéticas o bebidas electrolíticas y bebidas con partículas añadidas

14.2.1 Cerveza y bebidas a base de malta

14.2.7 Bebidas alcohólicas aromatizadas (p. ej. cerveza, vino y bebidas con licor tipo bebida gaseosa, bebidas refrescantes con bajo contenido de alcohol)

\section{DIOCTIL SULFOSUCCINATO DE SODIO}

SIN 480 Dioctil sulfosuccinato de sodio Clases Funcionales: Emulsionantes, Humectantes

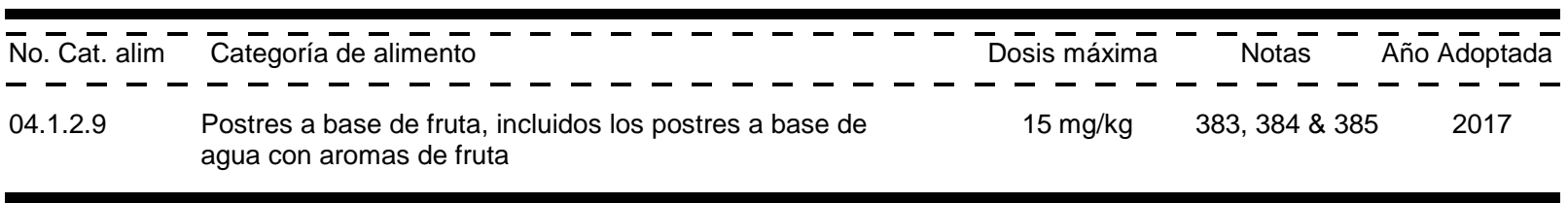

\section{DIÓXIDO DE CARBONO}

Dióxido de carbono
Clases Funcionales: Gasificantes, Espumantes, Gases de envasado, Sustancias conservadoras, Propulsores 
Cuadro I

DIÓXIDO DE CARBONO

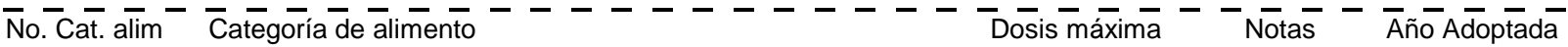

- - - - -

Leches fermentadas (naturales / simples) tratadas

BPF

2014 térmicamente después de la fermentación

01.2 .2

BPF

BPF

Natas (cremas) esterilizadas y UHT, natas (cremas) para batir o batidas y natas (cremas) de contenido de grasa reducido (naturales / simples)

04.1.1.3

Frutas frescas peladas $y / 0$ cortadas

06.4.1 Pastas y fideos frescos y productos análogos

09.2 .5

Pescado y productos pesqueros ahumados, desecados, fermentados y/o salados, incluidos los moluscos, crustáceos y equinodermos

13.1.1 Fórmulas (preparados) para lactantes

13.1.3 Fórmulas (preparados) para usos médicos especiales destinados a los lactantes

13.2 Alimentos complementarios para lactantes y niños pequeños

14.1.1.1 Aguas minerales naturales y aguas de manantial

14.1.1.2 Aguas de mesa y gaseosas

14.1.2.1 Zumos (jugos) de frutas

14.1.2.3 Concentrados para zumos (jugos) de frutas

14.1.3.1 Néctares de frutas

14.1.3.3 Concentrados para néctares de frutas

14.1 .5

Café, sucedáneos del café, té, infusiones de hierbas y otras bebidas calientes a base de cereales y granos, excluido el cacao
BPF

BPF

BPF

BPF

BPF

BPF

BPF

BPF

BPF

BPF

BPF

BPF

BPF

BPF
59

$59 \& 278$

2014

2014

59

2014

$$
59 \& 211
$$

2014

59,382

XS167, XS189

XS222, XS236

\& XS244

59

2015

59

2015

59

2015

019

019

466

2005

69

$69 \& 127$

2005

69

2005

$69 \& 127$

2005

$59 \& 160 \quad 2015$

Vinos de uva

60

2015

\section{DIÓXIDO DE SILICIO AMORFO}

SIN 551 Dióxido de silicio amorfo Clases Funcionales: Antiaglutinantes, Antiespumantes, Sustancias inertes

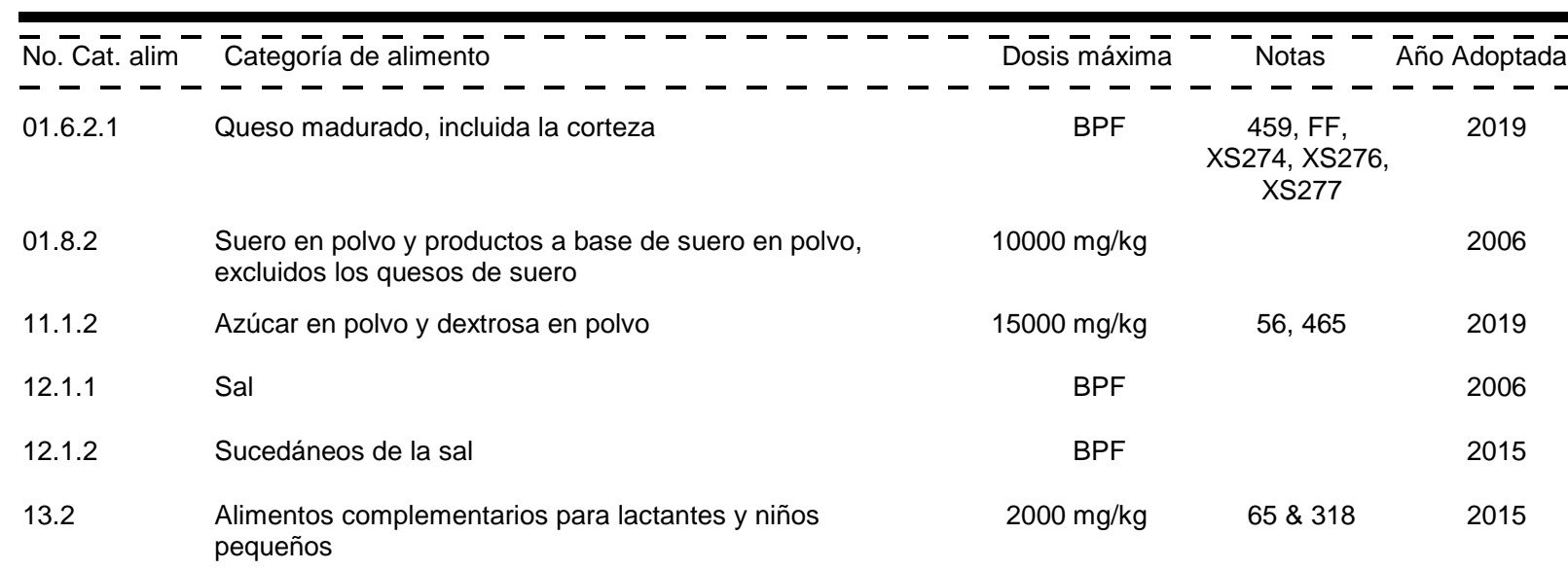


Cuadro I

DIÓXIDO DE SILICIO AMORFO

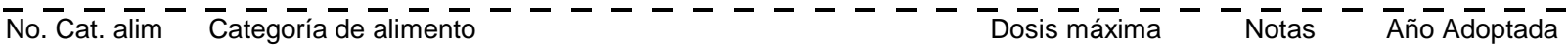
- - - - - - - - - - - - - - - - - - - - - - - - - -

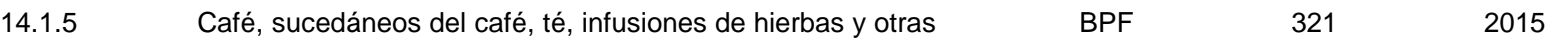
bebidas calientes a base de cereales y granos, excluido el cacao

\section{ERITORBATO DE SODIO (ISOASCORBATO DE SODIO)}

SIN 316

Eritorbato de sodio (Isoascorbato Clases Funcionales: Antioxidantes de sodio)

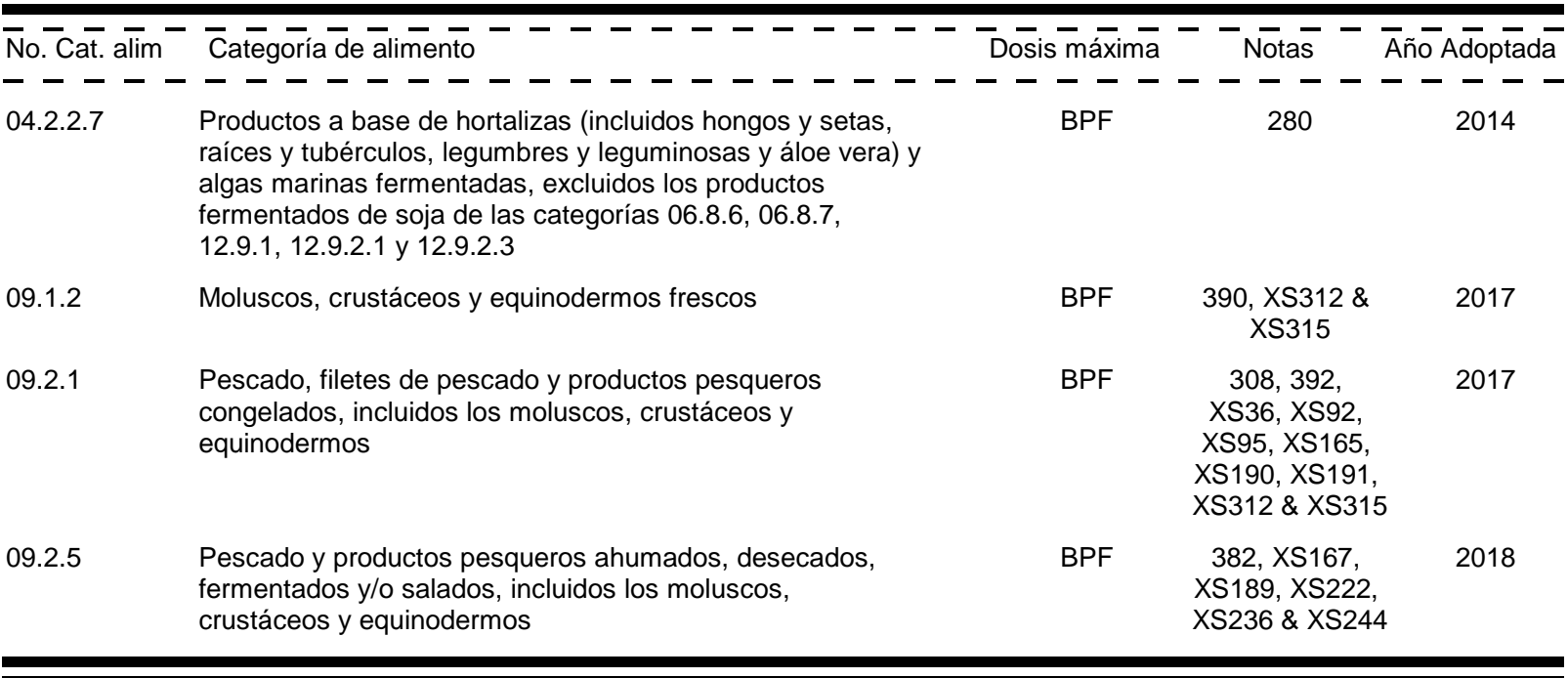

\section{ERITROSINA}

SIN 127 Eritrosina Clases Funcionales: Colorantes

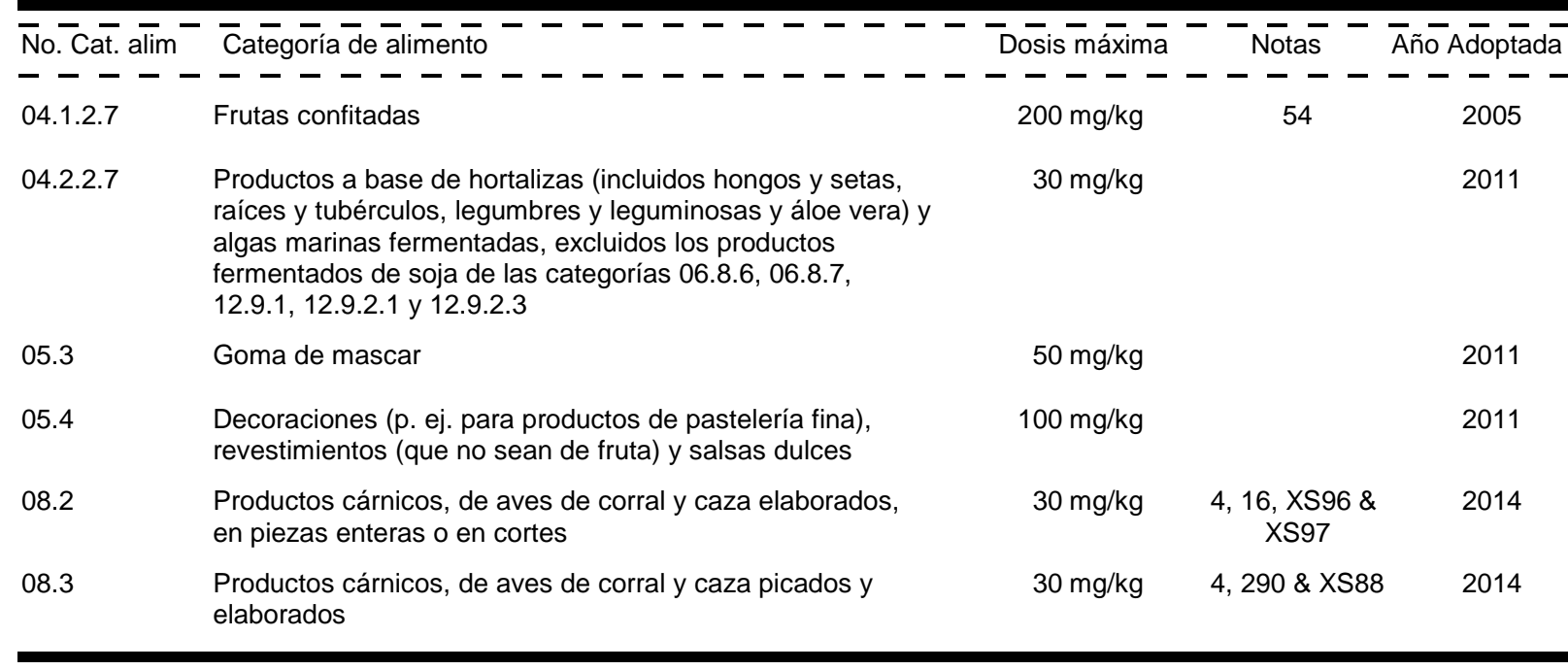

\section{ESTEARATOS DE POLIOXIETILENO}

$\begin{array}{llll}\text { SIN } 430 & \text { Estearato de polioxietileno (8) Clases Funcionales: Emulsionantes } \\ \text { SIN } 431 & \text { Estearato de polioxietileno (40) Clases Funcionales: Emulsionantes }\end{array}$

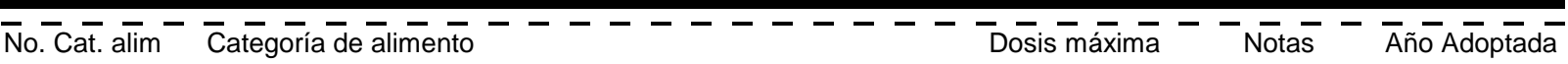


Cuadro I

ESTEARATOS DE POLIOXIETILENO

\begin{tabular}{|c|c|c|c|c|}
\hline 05.3 & Goma de mascar & $200 \mathrm{mg} / \mathrm{kg}$ & & 2017 \\
\hline 06.4 .3 & Pastas y fideos precocidos y productos análogos & $5000 \mathrm{mg} / \mathrm{kg}$ & $2 \& 194$ & 2016 \\
\hline 07.1 & Pan y productos de panadería ordinaria & $3000 \mathrm{mg} / \mathrm{kg}$ & & 2016 \\
\hline 07.2 & $\begin{array}{l}\text { Productos de panadería fina (dulces, salados, } \\
\text { aromatizados) y mezclas }\end{array}$ & $3000 \mathrm{mg} / \mathrm{kg}$ & & 2016 \\
\hline
\end{tabular}

\section{ESTEAROIL LACTILATOS}

SIN 481(i) Estearoil lactilato de sodio

SIN 482(i) Estearoil lactilato de calcio
Clases Funcionales: Emulsionantes, Agentes de tratamiento de las harinas, Espumantes, Estabilizadores

Clases Funcionales: Emulsionantes, Agentes de tratamiento de las harinas, Espumantes, Estabilizadores

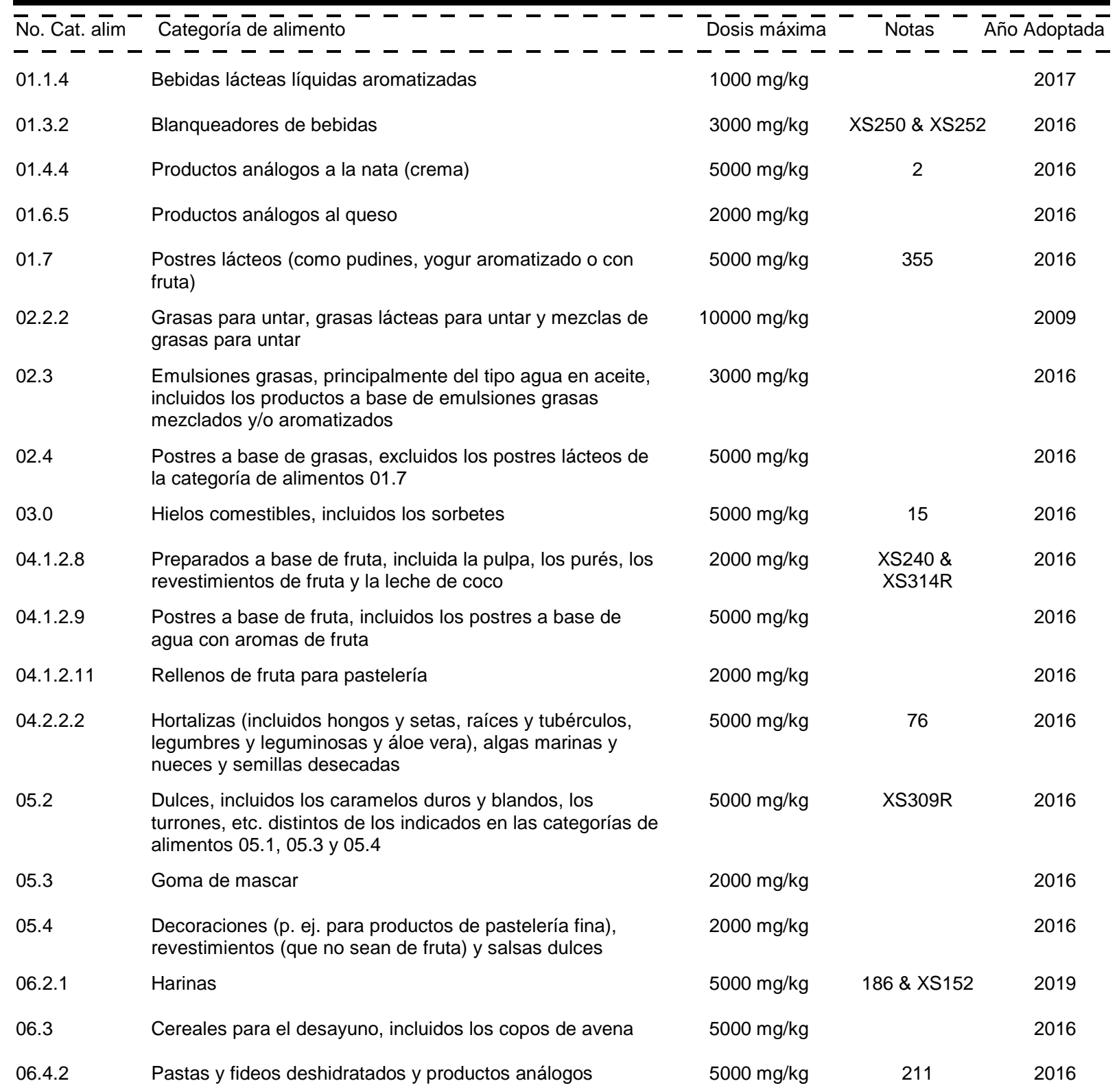


Cuadro I

ESTEAROIL LACTILATOS

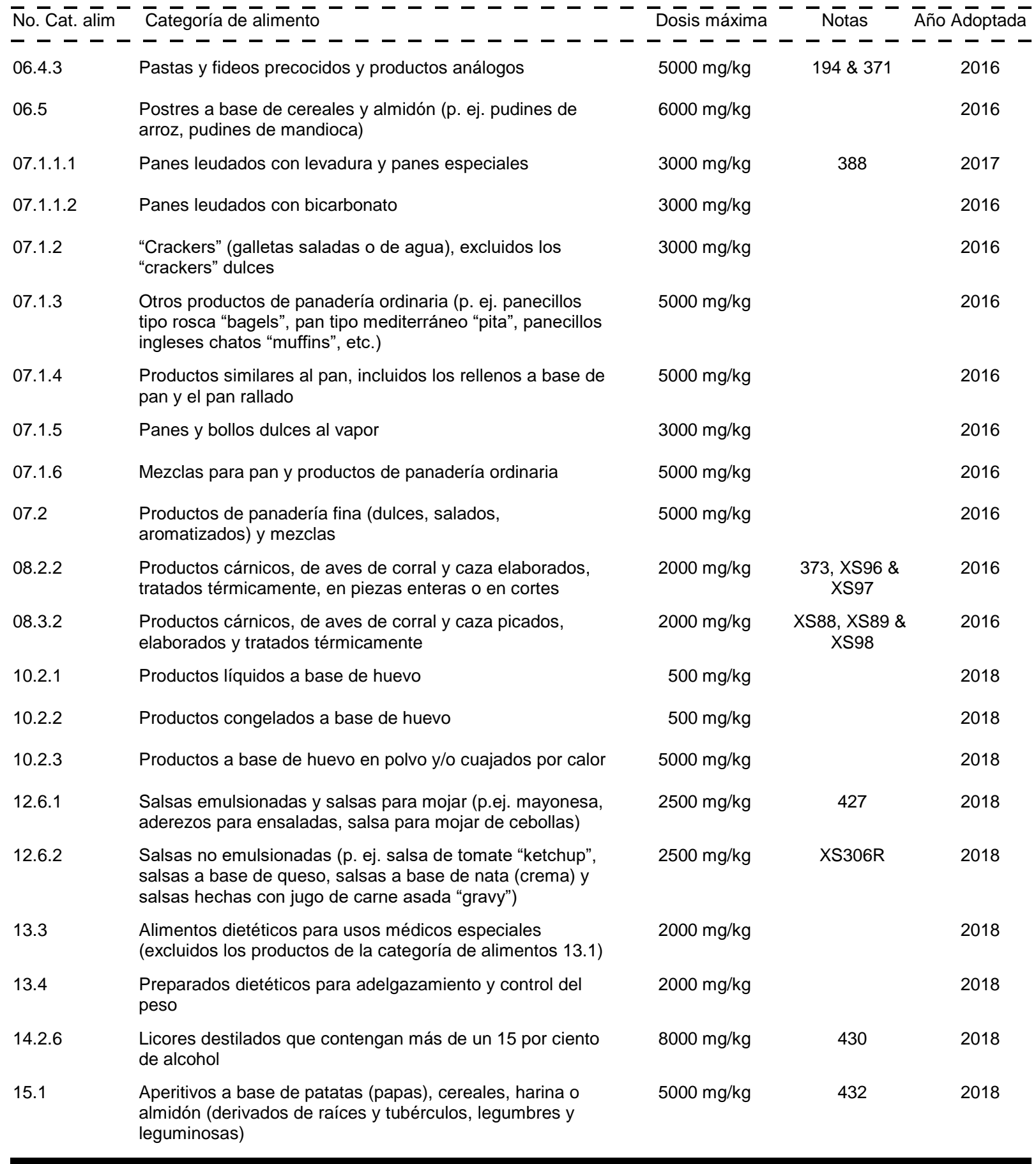

\section{ÉSTERES ACÉTICOS Y DE ÁCIDOS GRASOS DE}

\section{GLICEROL}

SIN 472a Ésteres acéticos y de ácidos Clases Funcionales: Emulsionantes, Secuestrantes, Estabilizadores grasos de glicerol

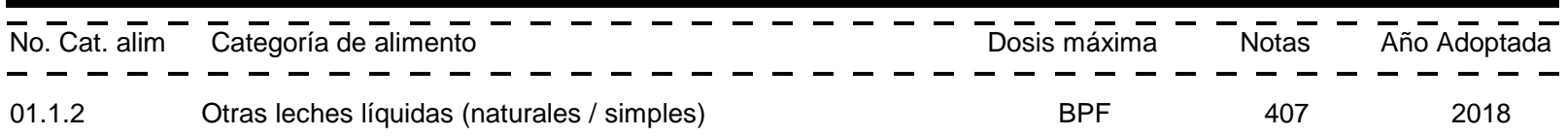


Cuadro I

ÉSTERES ACÉTICOS Y DE ÁCIDOS GRASOS DE

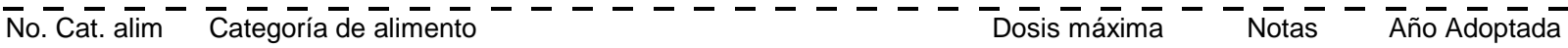

- - - - - - - - - - - - - - - - - - - - - - - - - - térmicamente después de la fermentación

01.2.2 Cuajada (natural / simple)

BPF

2013

01.4.1 Nata (crema) pasteurizada (natural / simple)

BPF

236

2013

01.4.2 Natas (cremas) esterilizadas y UHT, natas (cremas) para

BPF

2013 reducido (naturales / simples)

06.4.1 Pastas y fideos frescos y productos análogos

BPF

211

2015

08.1.1 Carne fresca, incluida la de aves de corral y caza, en piezas enteras o en cortes

BPF

$16 \& 326$

2015

08.1.2 Carne fresca picada, incluida la de aves de corral y caza

BPF

281

2014

09.2.1 Pescado, filetes de pescado y productos pesqueros congelados, incluidos los moluscos, crustáceos y equinodermos

XS36, XS92,

XS95, XS165

XS190, XS191

XS292, XS312

\& XS315

09.2.2 Pescado, filetes de pescado y productos pesqueros rebozados congelados, incluidos los moluscos, crustáceos

$16 \&$ XS166

2017 y equinodermos

09.2.3 Productos pesqueros picados, mezclados y congelados, incluidos los moluscos, crustáceos y equinodermos

09.2.4.1 Pescado y productos pesqueros cocidos

BPF

16

2014

BPF

241

2015

09.2.4.3

Pescado y productos pesqueros fritos, incluidos los moluscos, crustáceos y equinodermos

41

2015

09.2.5 Pescado y productos pesqueros ahumados, desecados, fermentados y/o salados, incluidos los moluscos,

BPF

$300, \mathrm{XS} 167$

XS189, XS222

2018 crustáceos y equinodermos

XS236, XS244

\& XS311

11.4 Otros azúcares y jarabes (p. ej. xilosa, jarabe de arce y aderezos de azúcar)

BPF

258

2014

12.1.2

Sucedáneos de la sal

BPF Alimentos complementarios para lactantes y niños
pequeños

14.1.5 Café, sucedáneos del café, té, infusiones de hierbas y otras bebidas calientes a base de cereales y granos, excluido el cacao

\section{ÉSTERES CÍTRICOS Y DE ÁCIDOS GRASOS DE GLICEROL}

SIN 472c Ésteres cítricos y de ácidos grasos de glicerol
Clases Funcionales:

Antioxidantes, Emulsionantes, Agentes de tratamiento de las harinas, Secuestrantes, Estabilizadores

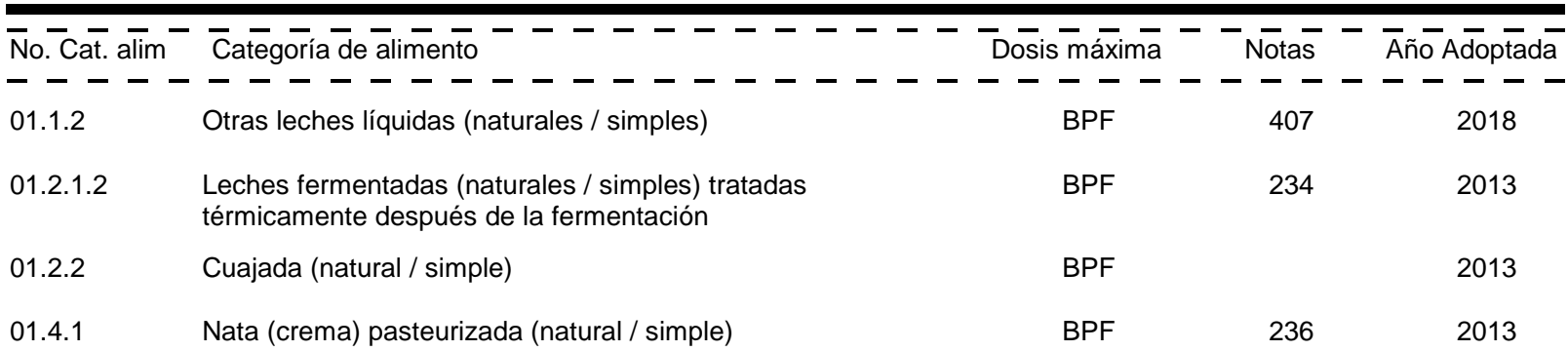


Cuadro I

ÉSTERES CÍTRICOS Y DE ÁCIDOS GRASOS DE

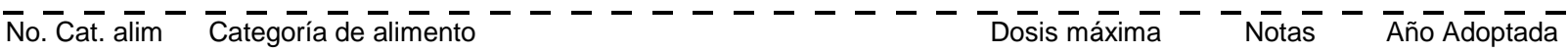

- - - - -

Natas (cremas) esterilizadas y UHT, natas (cremas) para

BPF

2013

batir o batidas y natas (cremas) de contenido de grasa

reducido (naturales / simples)

02.1 .2

Grasas y aceites vegetales

$\begin{array}{ccc}100 \mathrm{mg} / \mathrm{kg} & 277 & 2015 \\ 100 \mathrm{mg} / \mathrm{kg} & 322 & 2015 \\ \mathrm{BPF} & & 2013\end{array}$

04.2.2.7 Productos a base de hortalizas (incluidos hongos y setas, raíces y tubérculos, legumbres y leguminosas y áloe vera) y algas marinas fermentadas, excluidos los productos fermentados de soja de las categorías 06.8.6, 06.8.7, 12.9.1, 12.9.2.1 y 12.9 .2 .3

06.4.1 Pastas y fideos frescos y productos análogos

BPF

211

2015

08.1.1 Carne fresca, incluida la de aves de corral y caza, en piezas enteras o en cortes

08.1.2 Carne fresca picada, incluida la de aves de corral y caza

09.1.2 Moluscos, crustáceos y equinodermos frescos

09.2.1 Pescado, filetes de pescado y productos pesqueros congelados, incluidos los moluscos, crustáceos y equinodermos

09.2.2 Pescado, filetes de pescado y productos pesqueros rebozados congelados, incluidos los moluscos, crustáceos y equinodermos

09.2.3 Productos pesqueros picados, mezclados y congelados, incluidos los moluscos, crustáceos y equinodermos

09.2.4.1 Pescado y productos pesqueros cocidos

09.2.4.3 Pescado y productos pesqueros fritos, incluidos los moluscos, crustáceos y equinodermos

09.2.5 Pescado y productos pesqueros ahumados, desecados, fermentados y/o salados, incluidos los moluscos, crustáceos y equinodermos

11.4 Otros azúcares y jarabes (p. ej. xilosa, jarabe de arce y aderezos de azúcar)

12.1.2 Sucedáneos de la sal

13.1 Fórmulas (preparados) para lactantes, fórmulas de continuación y fórmulas para usos médicos especiales destinados a los lactantes

13.2 Alimentos complementarios para lactantes y niños pequeños

14.1.5 Café, sucedáneos del café, té, infusiones de hierbas y otras bebidas calientes a base de cereales y granos, excluido el cacao

$\begin{array}{cc}\text { BPF } & 16 \& 326 \\ \text { BPF } & 281 \\ \text { BPF } & 390, \text { XS312 \& } \\ & \text { XS315 } \\ \text { BPF } & 392, \text { XS36, } \\ & \text { XS92, XS95, } \\ & \text { XS165, XS190, } \\ & \text { XS191, XS312 } \\ & \& \text { XS315 }\end{array}$

BPF

$16 \&$ XS166

BPF

16

2014

BPF

241

2015

BPF

41

2015

BPF

300, XS167,

XS189, XS222

XS236, XS244

\& XS311

BPF

258

2014

BPF

$9000 \mathrm{mg} / \mathrm{kg}$

$380 \& 381$

2016

$5000 \mathrm{mg} / \mathrm{kg}$

$239 \& 268$

BPF

160

2014

\section{ÉSTERES DE ASCORBILO}

SIN 304

SIN 305
Palmitato de ascorbilo

Estearato de ascorbilo
Clases Funcionales: Antioxidantes

Clases Funcionales: Antioxidantes 
Cuadro I

ÉSTERES DE ASCORBILO

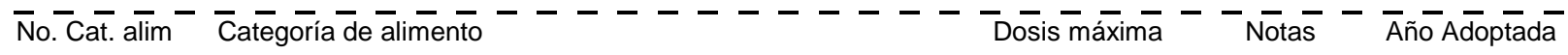

- - - - - - - - - - - - - - - - - - - - - - - - - - - -

$80 \mathrm{mg} / \mathrm{kg} \quad 10 \quad 2001$

01.5.1 Leche en polvo y nata (crema) en polvo (naturales)

$500 \mathrm{mg} / \mathrm{kg} \quad 10 \quad 2001$

01.5.2 Productos análogos a la leche y la nata (crema) en polvo

$80 \mathrm{mg} / \mathrm{kg}$

10

2001

01.6.2.1 Queso madurado, incluida la corteza

$500 \mathrm{mg} / \mathrm{kg}$

10,112

2019

XS263, XS264

XS265, XS266,

XS267, XS268

XS269, XS270

XS271, XS272,

XS274, XS276

XS277

01.7

Postres lácteos (como pudines, yogur aromatizado o con

$2 \& 10$

2001

02.1.1 Aceite de mantequilla (manteca), grasa de leche anhidra, "ghee"

$500 \mathrm{mg} / \mathrm{kg}$

$10 \& 171$

2006

02.1 .2

Grasas y aceites vegetales

$500 \mathrm{mg} / \mathrm{kg}$

10

2006

$500 \mathrm{mg} / \mathrm{kg}$

10

2006

02.1.3 Manteca de cerdo, sebo, aceite de pescado y otras grasas de origen animal

$500 \mathrm{mg} / \mathrm{kg}$

$500 \mathrm{mg} / \mathrm{kg}$

10

2006 grasas para untar

$500 \mathrm{mg} / \mathrm{kg}$

10

2001

incluidos los productos a base de emulsiones grasas mezclados $\mathrm{y} / \mathrm{o}$ aromatizados

02.4

Postres a base de grasas, excluidos los postres lácteos de la categoría de alimentos 01.7

$80 \mathrm{mg} / \mathrm{kg}$

10

2001

$200 \mathrm{mg} / \mathrm{kg}$

$10 \& 15$

2001

$80 \mathrm{mg} / \mathrm{kg}$

10

2001

$500 \mathrm{mg} / \mathrm{kg}$

$2 \& 10$

2001 agua con aromas de fruta

04.2.2.2 Hortalizas (incluidos hongos y setas, raíces y tubérculos, legumbres y leguminosas y áloe vera), algas marinas y nueces y semillas desecadas

05.0

Confitería

$80 \mathrm{mg} / \mathrm{kg}$

10

2001

$500 \mathrm{mg} / \mathrm{kg}$

$10,15,375$

XS86, XS105,

2017

$\mathrm{XS} 141$ \&

XS309R

06.3

Cereales para el desayuno, incluidos los copos de avena

$200 \mathrm{mg} / \mathrm{kg}$

10

2001

06.4 .3

Pastas y fideos precocidos y productos análogos

$500 \mathrm{mg} / \mathrm{kg}$

$10 \& 211$

2012

06.5 Postres a base de cereales y almidón (p. ej. pudines de arroz, pudines de mandioca)

$500 \mathrm{mg} / \mathrm{kg}$

$2 \& 10$

2001

$1000 \mathrm{mg} / \mathrm{kg}$

$10 \& 15$

2003

$5000 \mathrm{mg} / \mathrm{kg}$

10

2001

$1000 \mathrm{mg} / \mathrm{kg}$

10, 392, XS36,

XS92, XS95,

XS190, XS191, equinodermos

XS312 \& XS315

09.2.2 Pescado, filetes de pescado y productos pesqueros rebozados congelados, incluidos los moluscos, crustáceos

10

2001 
Cuadro I

ÉSTERES DE ASCORBILO

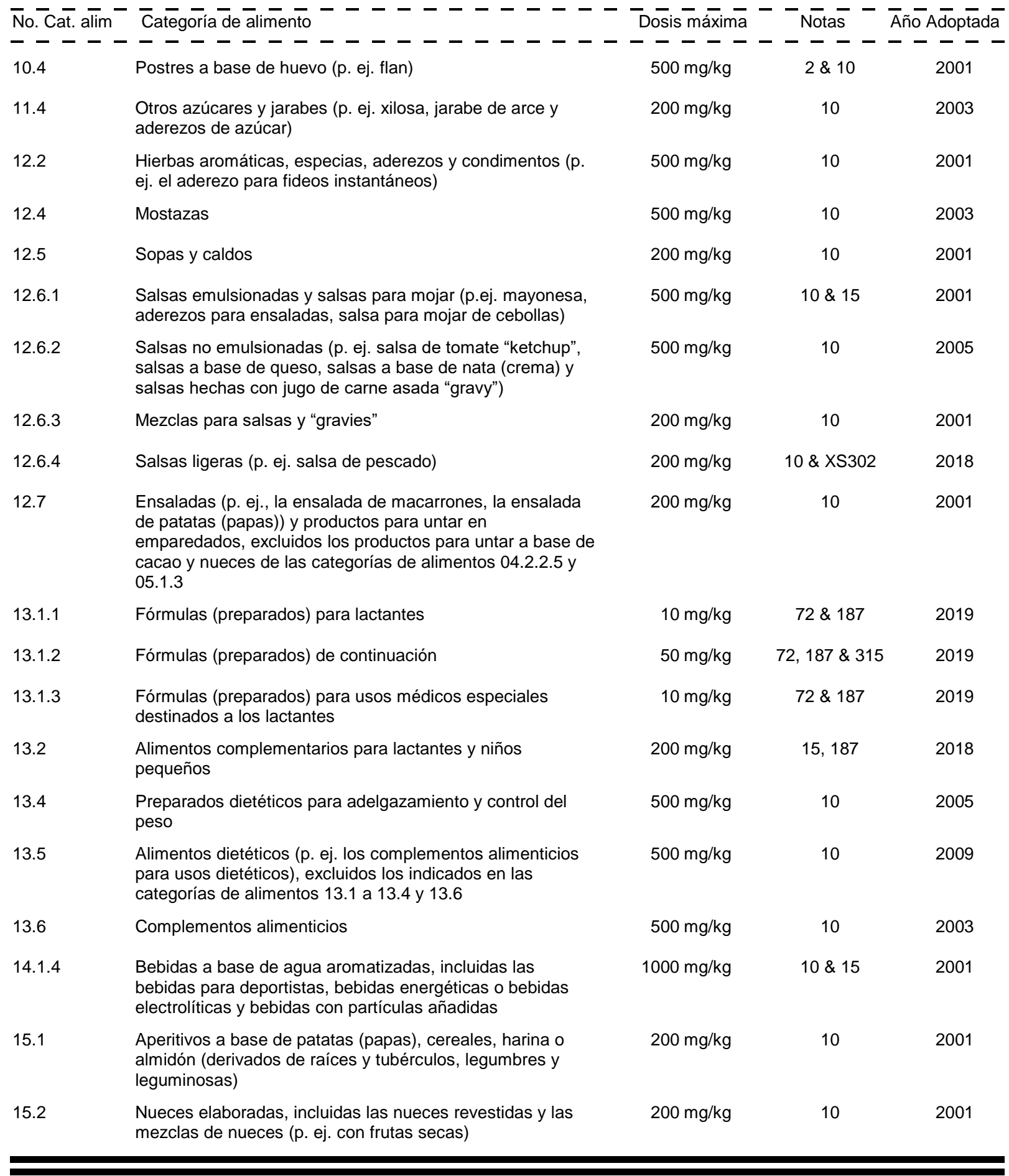

\section{ÉSTERES DE GLICEROL DE COLOFONIA}

SIN 445(iii) Ésteres de glicerol de colofonia Clases Funcionales: Emulsionantes, Estabilizadores de madera

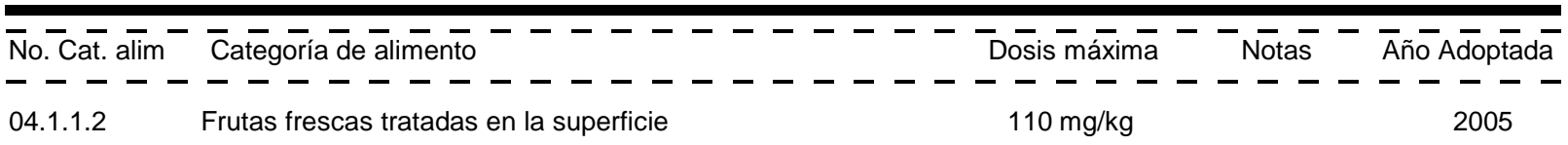


Cuadro I

ÉSTERES DE GLICEROL DE COLOFONIA

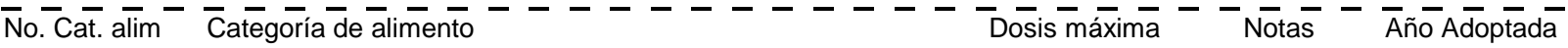

- - - - - - - - - - - - - - - - - - - - - - - - - -

04.2.1.2 Hortalizas (incluidos hongos y setas, raíces y tubérculos, $\quad 110 \mathrm{mg} / \mathrm{kg} \quad 2005$ legumbres y leguminosas y áloe vera), algas marinas y nueces y semillas frescas tratadas en la superficie

14.1.4 Bebidas a base de agua aromatizadas, incluidas las bebidas para deportistas, bebidas energéticas o bebidas electrolíticas y bebidas con partículas añadidas

\section{ÉSTERES DE PROPILENGLICOL DE ÁCIDOS GRASOS}

\section{SIN $477 \quad$ Ésteres de propilenglicol de Clases Funcionales: Emulsionantes} ácidos grasos

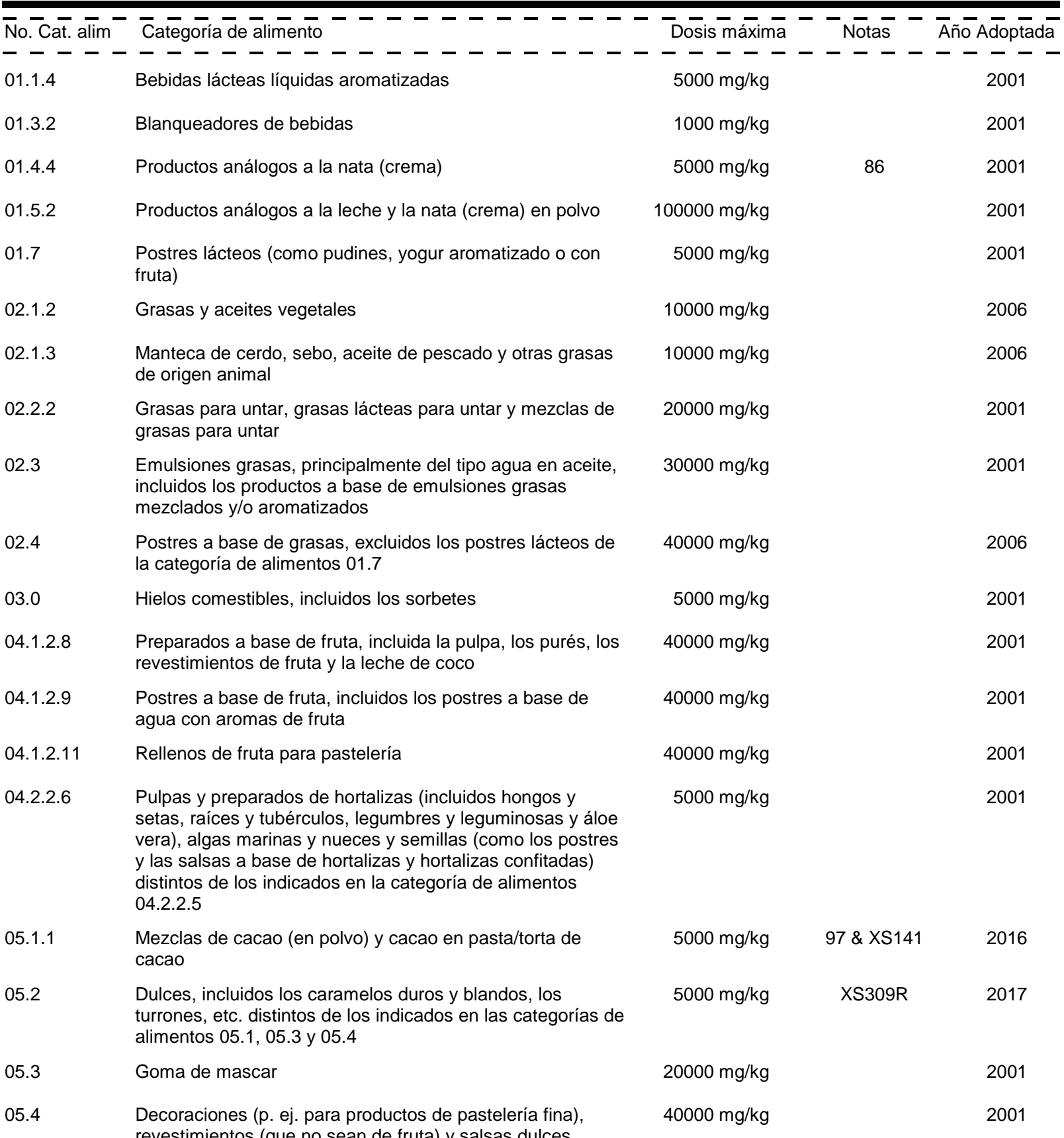


Cuadro I

ÉSTERES DE PROPILENGLICOL DE ÁCIDOS

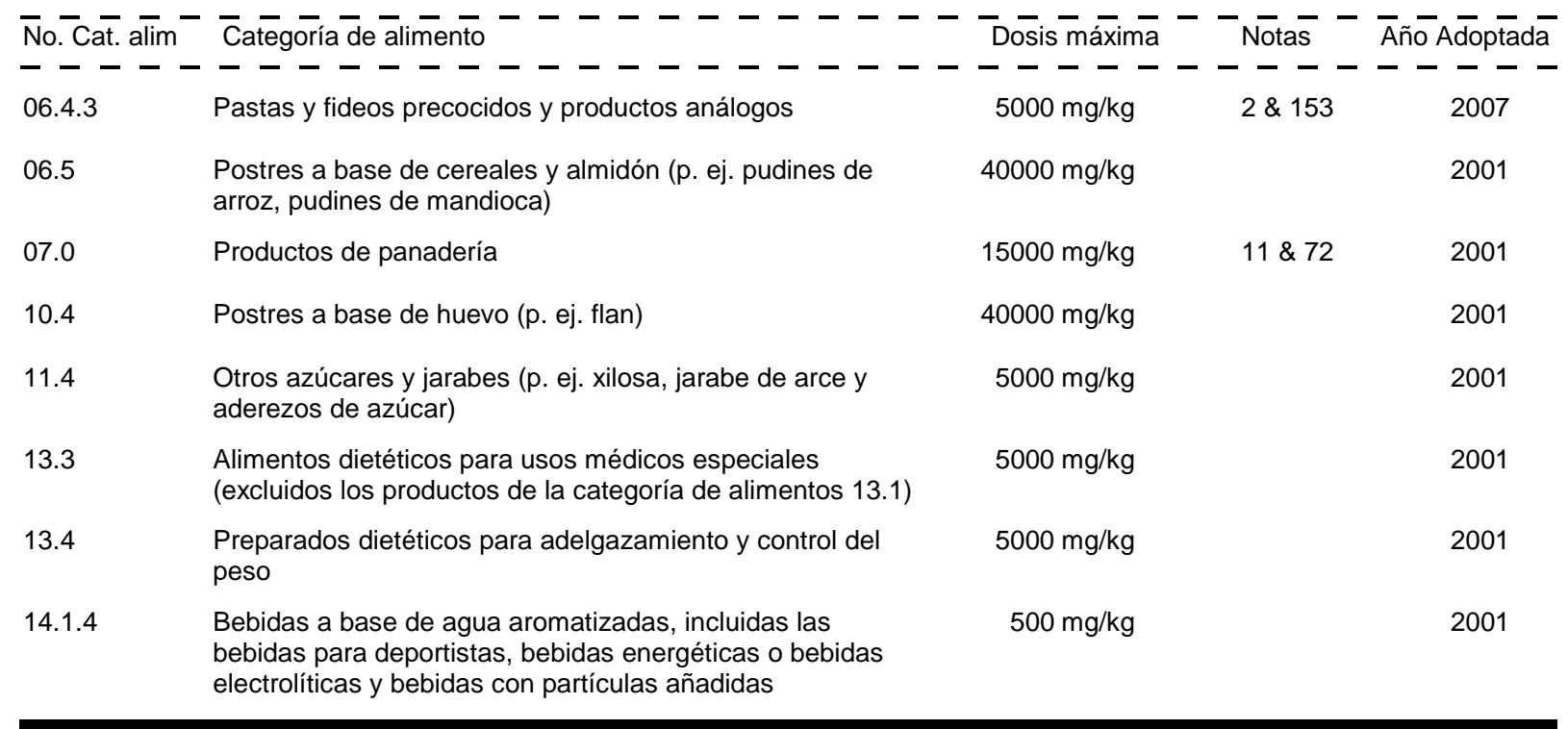

\section{ÉSTERES DE SORBITÁN DE ÁCIDOS GRASOS}

$\begin{array}{llll}\text { SIN } 491 & \text { Monoestearato de sorbitán } & \text { Clases Funcionales: Emulsionantes, Estabilizadores } \\ \text { SIN } 492 & \text { Triestearato de sorbitán } & \text { Clases Funcionales: Emulsionantes, Estabilizadores } \\ \text { SIN } 493 & \text { Monolaurato de sorbitán } & \text { Clases Funcionales: Emulsionantes, Estabilizadores } \\ \text { SIN } 494 & \text { Monooleato de sorbitán } & \text { Clases Funcionales: Emulsionantes, Estabilizadores } \\ \text { SIN } 495 & \text { Monopalmitato de sorbitán } & \text { Clases Funcionales: Emulsionantes }\end{array}$

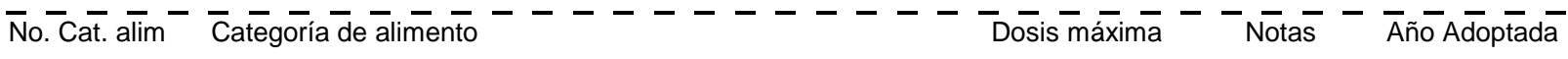

- - - - - - - - - - - - - - - - - - - - - - - - - - -

01.1.4 Bebidas lácteas líquidas aromatizadas $\quad 5000 \mathrm{mg} / \mathrm{kg} \quad 2017$

01.3.2 Blanqueadores de bebidas

$4000 \mathrm{mg} / \mathrm{kg} \quad \mathrm{XS} 250 \& \mathrm{XS} 252 \quad 2016$

01.4.4 Productos análogos a la nata (crema)

$5000 \mathrm{mg} / \mathrm{kg} \quad 349 \quad 2016$

01.5.2 Productos análogos a la leche y la nata (crema) en polvo

$4000 \mathrm{mg} / \mathrm{kg} \quad \mathrm{XS} 251 \quad 2016$

$01.7 \quad$ Postres lácteos (como pudines, yogur aromatizado o con fruta)

$5000 \mathrm{mg} / \mathrm{kg} \quad 362 \quad 2019$

02.2.2 Grasas para untar, grasas lácteas para untar y mezclas de grasas para untar

$10000 \mathrm{mg} / \mathrm{kg}$

359

2016

$02.3 \quad$ Emulsiones grasas, principalmente del tipo agua en aceite, incluidos los productos a base de emulsiones grasas

$5000 \mathrm{mg} / \mathrm{kg}$

363

2016

$02.4 \quad$ Postres a base de grasas, excluidos los postres lácteos de la categoría de alimentos 01.7

$10000 \mathrm{mg} / \mathrm{kg}$

2016

03.0

Hielos comestibles, incluidos los sorbetes

$1000 \mathrm{mg} / \mathrm{kg}$

2016

04.1 .2 .8

Preparados a base de fruta, incluida la pulpa, los purés, los revestimientos de fruta y la leche de coco

$5000 \mathrm{mg} / \mathrm{kg}$

XS240 \&

$\mathrm{XS} 314 \mathrm{R}$

2016

04.1.2.9 Postres a base de fruta, incluidos los postres a base de agua con aromas de fruta 
Cuadro I

ÉSTERES DE SORBITÁN DE ÁCIDOS GRASOS

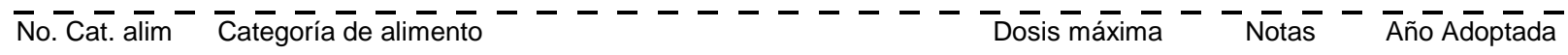

04.2.2.2 Hortalizas (incluidos hongos y setas, raíces y tubérculos, legumbres y leguminosas y áloe vera), algas marinas y nueces y semillas desecadas

05.1.1 Mezclas de cacao (en polvo) y cacao en pasta/torta de cacao

05.1.3 Productos para untar a base de cacao, incluidos los rellenos a base de cacao

05.1.4 Productos de cacao y chocolate

05.1.5 Productos de imitación y sucedáneos del chocolate

05.2.1 Caramelos duros

05.2.2 Caramelos blandos

05.2.3 Turrón y mazapán

$05.3 \quad$ Goma de mascar

05.4

Decoraciones (p. ej. para productos de pastelería fina), revestimientos (que no sean de fruta) y salsas dulces

06.4.2 Pastas y fideos deshidratados y productos análogos

06.4.3 Pastas y fideos precocidos y productos análogos

06.5 Postres a base de cereales y almidón (p. ej. pudines de arroz, pudines de mandioca)

07.1.1 Panes y panecillos

07.1.2 "Crackers" (galletas saladas o de agua), excluidos los "crackers" dulces

07.1.3 Otros productos de panadería ordinaria (p. ej. panecillos tipo rosca "bagels", pan tipo mediterráneo "pita", panecillos ingleses chatos "muffins", etc.)

07.1.4 Productos similares al pan, incluidos los rellenos a base de pan y el pan rallado

07.1.5 Panes y bollos dulces al vapor

07.1.6 Mezclas para pan y productos de panadería ordinaria

07.2 Productos de panadería fina (dulces, salados, aromatizados) y mezclas

10.2.1 Productos líquidos a base de huevo

10.2.2 Productos congelados a base de huevo

10.2 .3

10.4

12.5 .2

12.6 .3

12.8

Productos a base de huevo en polvo y/o cuajados por calor

Postres a base de huevo (p. ej. flan)

Mezclas para sopas y caldos

Salsas emulsionadas y salsas para mojar (p.ej. mayonesa, aderezos para ensaladas, salsa para mojar de cebollas)

Mezclas para salsas y "gravies"

Levadura y productos análogos
$5000 \mathrm{mg} / \mathrm{kg}$

76

2016

$\begin{array}{ccc}2000 \mathrm{mg} / \mathrm{kg} & \begin{array}{c}97,123 \& \\ \text { XS141 }\end{array} & 2016 \\ 10000 \mathrm{mg} / \mathrm{kg} & \text { XS86 } & 2017 \\ 10000 \mathrm{mg} / \mathrm{kg} & 101 & 2016 \\ 10000 \mathrm{mg} / \mathrm{kg} & & 2017 \\ 10000 \mathrm{mg} / \mathrm{kg} & & 2017 \\ 10000 \mathrm{mg} / \mathrm{kg} & \text { XS309R } & 2017 \\ 10000 \mathrm{mg} / \mathrm{kg} & & 2017 \\ 5000 \mathrm{mg} / \mathrm{kg} & & 2016 \\ 10000 \mathrm{mg} / \mathrm{kg} & & 2016 \\ 5000 \mathrm{mg} / \mathrm{kg} & 11 \& 211 & 2016 \\ 5000 \mathrm{mg} / \mathrm{kg} & 2 \& 194 & 2019 \\ 5000 \mathrm{mg} / \mathrm{kg} & & 2016 \\ 3000 \mathrm{mg} / \mathrm{kg} & & 2017\end{array}$

$10000 \mathrm{mg} / \mathrm{kg} \quad 11 \quad 2016$

$10000 \mathrm{mg} / \mathrm{kg} \quad 11 \quad 2016$

$10000 \mathrm{mg} / \mathrm{kg} \quad 11 \quad 2016$

$10000 \mathrm{mg} / \mathrm{kg} \quad 11 \quad 2016$

$10000 \mathrm{mg} / \mathrm{kg} \quad 11 \quad 2016$

$10000 \mathrm{mg} / \mathrm{kg}$

$500 \mathrm{mg} / \mathrm{kg} \quad 2019$

$500 \mathrm{mg} / \mathrm{kg} \quad 2019$

$500 \mathrm{mg} / \mathrm{kg} \quad 452 \quad 2019$

$5000 \mathrm{mg} / \mathrm{kg} \quad 2018$

$250 \mathrm{mg} / \mathrm{kg} \quad 127, \mathrm{XS} 117 \quad 2018$

$5000 \mathrm{mg} / \mathrm{kg}$

$50 \mathrm{mg} / \mathrm{kg} \quad 127 \quad 2018$

$15000 \mathrm{mg} / \mathrm{kg} \quad 2018$

$1000 \mathrm{mg} / \mathrm{kg} \quad 2018$ 
Cuadro I

ÉSTERES DE SORBITÁN DE ÁCIDOS GRASOS

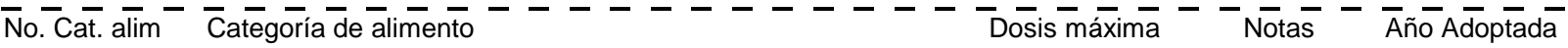

- - - - - - - - - - - - - - - - - - - - - - - - - - - -

$13.4 \quad$ Preparados dietéticos para adelgazamiento y control del $\quad 1000 \mathrm{mg} / \mathrm{kg}$ peso

13.5 Alimentos dietéticos (p. ej. los complementos alimenticios

$5000 \mathrm{mg} / \mathrm{kg}$

2018

para usos dietéticos), excluidos los indicados en las categorías de alimentos 13.1 a 13.4 y 13.6

13.6

Complementos alimenticios

$10000 \mathrm{mg} / \mathrm{kg}$

364

2018

14.1.4.1 Bebidas a base de agua aromatizadas con gas

$500 \mathrm{mg} / \mathrm{kg}$

2018

14.1.4.2

Bebidas a base de agua aromatizadas sin gas, incluidos los

$500 \mathrm{mg} / \mathrm{kg}$

2018

14.1.4.3

$500 \mathrm{mg} / \mathrm{kg}$

127

2018 agua aromatizadas

14.1.5 Café, sucedáneos del café, té, infusiones de hierbas y otras bebidas calientes a base de cereales y granos, excluido el

$500 \mathrm{mg} / \mathrm{kg}$

429

2018 cacao

15.1 Aperitivos a base de patatas (papas), cereales, harina o almidón (derivados de raíces y tubérculos, legumbres y leguminosas)

\section{ÉSTERES DIACETILTARTÁRICOS Y DE ÁCIDOS GRASOS}

\section{DE GLICEROL}

SIN 472e Ésteres diacetiltartáricos y de Clases Funcionales: Emulsionantes, Secuestrantes, Estabilizadores ácidos grasos de glicerol

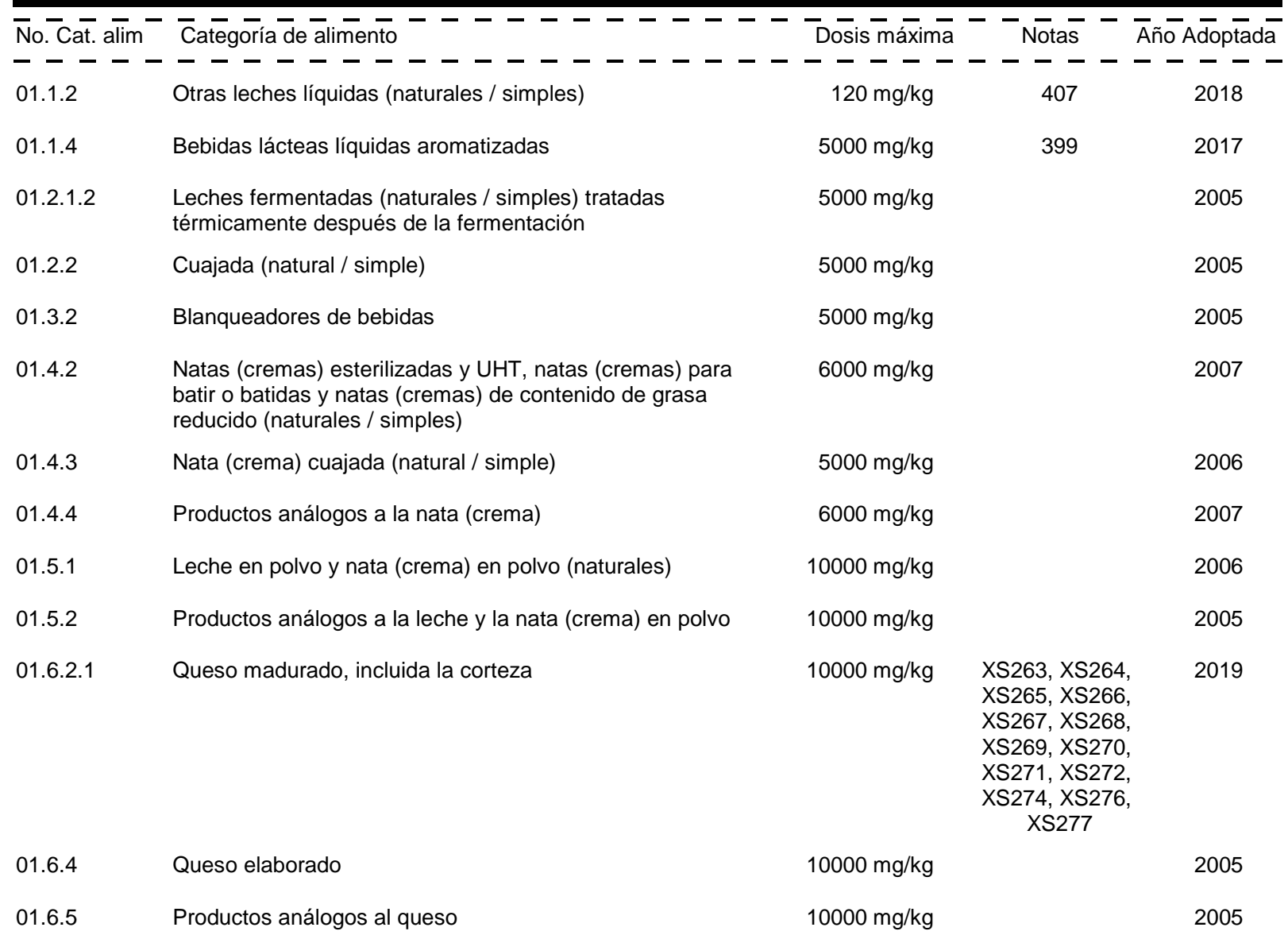


Cuadro I

ÉSTERES DIACETILTARTÁRICOS Y DE ÁCIDOS

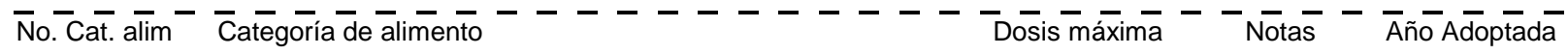

- - - - - - - - - - - - - - - - - - - - - - - - - -

$01.7 \quad$ Postres lácteos (como pudines, yogur aromatizado o con fruta)

02.1.2 Grasas y aceites vegetales

$10000 \mathrm{mg} / \mathrm{kg}$

02.1.3 Manteca de cerdo, sebo, aceite de pescado y otras grasas de origen animal

02.2.2 Grasas para untar, grasas lácteas para untar y mezclas de grasas para untar

$02.3 \quad$ Emulsiones grasas, principalmente del tipo agua en aceite, incluidos los productos a base de emulsiones grasas mezclados y/o aromatizados

$02.4 \quad$ Postres a base de grasas, excluidos los postres lácteos de la categoría de alimentos 01.7

03.0 Hielos comestibles, incluidos los sorbetes

2006

$10000 \mathrm{mg} / \mathrm{kg} \quad 2005$

$10000 \mathrm{mg} / \mathrm{kg}$

04.1.2.2 Frutas desecadas

04.1.2.3 Frutas en vinagre, aceite o salmuera

04.1.2.6 Productos para untar a base de fruta (p. ej. el "chutney"), excluidos los productos de la categoría de alimentos

04.1 .2 .5

04.1.2.7 Frutas confitadas

$000 \mathrm{mg} / \mathrm{kg}$

2005

04.1.2.8 Preparados a base de fruta, incluida la pulpa, los purés, los revestimientos de fruta y la leche de coco

2005

$1000 \mathrm{mg} / \mathrm{kg}$

$10000 \mathrm{mg} / \mathrm{kg}$

$1000 \mathrm{mg} / \mathrm{kg}$

$5000 \mathrm{mg} / \mathrm{kg} \quad 2005$

$2500 \mathrm{mg} / \mathrm{kg} \quad 2005$

04.1.2.9 Postres a base de fruta, incluidos los postres a base de agua con aromas de fruta

04.1.2.10 Productos de fruta fermentada

$2500 \mathrm{mg} / \mathrm{kg}$

$2500 \mathrm{mg} / \mathrm{kg}$

04.2.2.2 Hortalizas (incluidos hongos y setas, raíces y tubérculos, legumbres y leguminosas y áloe vera), algas marinas y nueces y semillas desecadas

04.2.2.3 Hortalizas (incluidos hongos y setas, raíces y tubérculos, legumbres y leguminosas y áloe vera) y algas marinas en vinagre, aceite, salmuera o salsa de soja

04.2.2.6 Pulpas y preparados de hortalizas (incluidos hongos y setas, raíces y tubérculos, legumbres y leguminosas y áloe vera), algas marinas y nueces y semillas (como los postres y las salsas a base de hortalizas y hortalizas confitadas) distintos de los indicados en la categoría de alimentos 04.2.2.5

04.2.2.7 Productos a base de hortalizas (incluidos hongos y setas, raíces y tubérculos, legumbres y leguminosas y áloe vera) y algas marinas fermentadas, excluidos los productos fermentados de soja de las categorías 06.8.6, 06.8.7, $12.9 .1,12.9 .2 .1$ y 12.9 .2 .3

04.2.2.8 Hortalizas (incluidos hongos y setas, raíces y tubérculos, legumbres y leguminosas y áloe vera) y algas marinas cocidas o fritas

$05.2 \quad$ Dulces, incluidos los caramelos duros y blandos, los turrones, etc. distintos de los indicados en las categorías de alimentos $05.1,05.3$ y 05.4

Decoraciones (p. ej. para productos de pastelería fina), revestimientos (que no sean de fruta) y salsas dulces

$10000 \mathrm{mg} / \mathrm{kg}$ 
Cuadro I

ÉSTERES DIACETILTARTÁRICOS Y DE ÁCIDOS

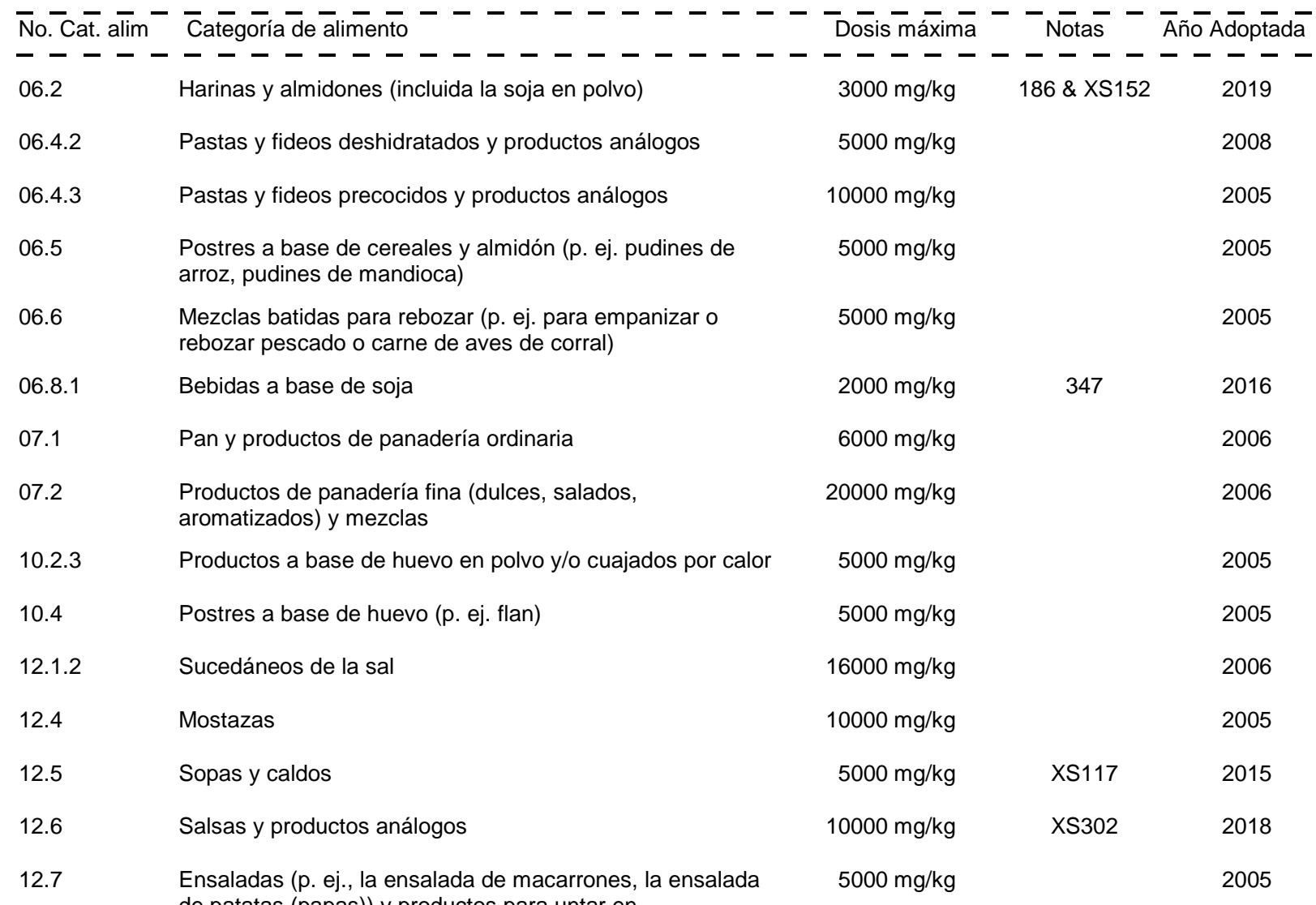

de patatas (papas)) y productos para untar en
emparedados, excluidos los productos para untar a base de cacao y nueces de las categorías de alimentos 04.2.2.5 y

05.1 .3

13.3 Alimentos dietéticos para usos médicos especiales (excluidos los productos de la categoría de alimentos 13.1)

13.4 Preparados dietéticos para adelgazamiento y control del peso

13.5 Alimentos dietéticos (p. ej. los complementos alimenticios para usos dietéticos), excluidos los indicados en las categorías de alimentos 13.1 a 13.4 y 13.6

13.6 Complementos alimenticios

$5000 \mathrm{mg} / \mathrm{kg}$

2005

$5000 \mathrm{mg} / \mathrm{kg}$

2005

$5000 \mathrm{mg} / \mathrm{kg}$

2005

$5000 \mathrm{mg} / \mathrm{kg}$

2005

14.1.4 Bebidas a base de agua aromatizadas, incluidas las bebidas para deportistas, bebidas energéticas o bebidas electrolíticas y bebidas con partículas añadidas

14.1.5 Café, sucedáneos del café, té, infusiones de hierbas y otras bebidas calientes a base de cereales y granos, excluido el cacao

14.2.6 Licores destilados que contengan más de un 15 por ciento de alcohol 
Cuadro I

ÉSTERES DIACETILTARTÁRICOS Y DE ÁCIDOS

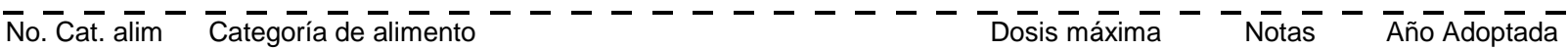
- - - - - - - - - - - - - - - - - - - - - - - - - -

$15.2 \quad$ Nueces elaboradas, incluidas las nueces revestidas y las $\quad 10000 \mathrm{mg} / \mathrm{kg} \quad 2005$ mezclas de nueces ( $p$. ej. con frutas secas)

ÉSTERES LÁCTICOS Y DE ÁCIDOS GRASOS DE GLICEROL

SIN 472b Ésteres lácticos y de ácidos Clases Funcionales: Emulsionantes, Secuestrantes, Estabilizadores grasos de glicerol

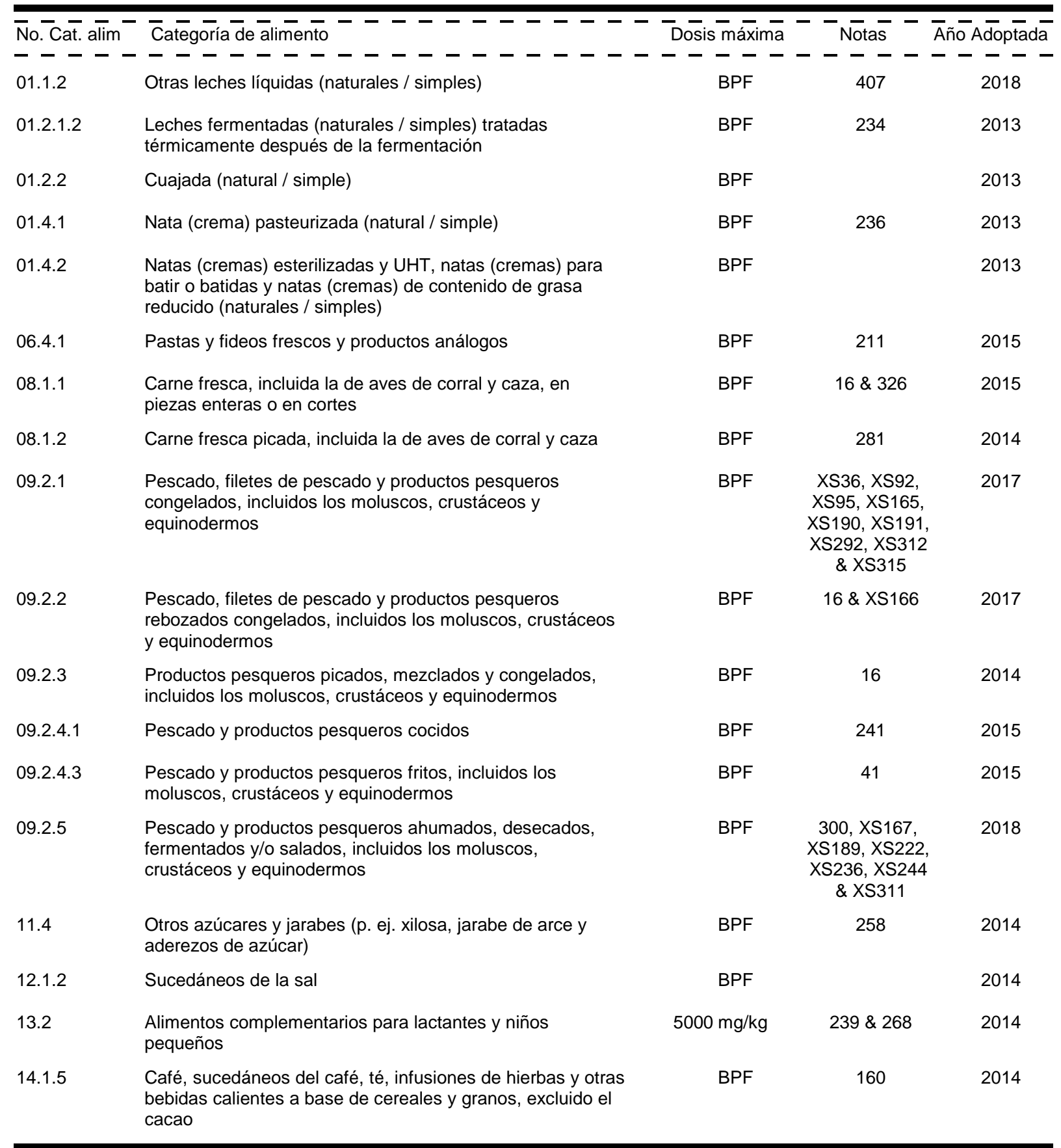




\section{ÉSTERES POLIGLICÉRIDOS DE ÁCIDO RICINOLÉICO INTERESTERIFICADO}

SIN 476 Ésteres poliglicéridos de ácido Clases Funcionales: Emulsionantes ricinoléico interesterificado

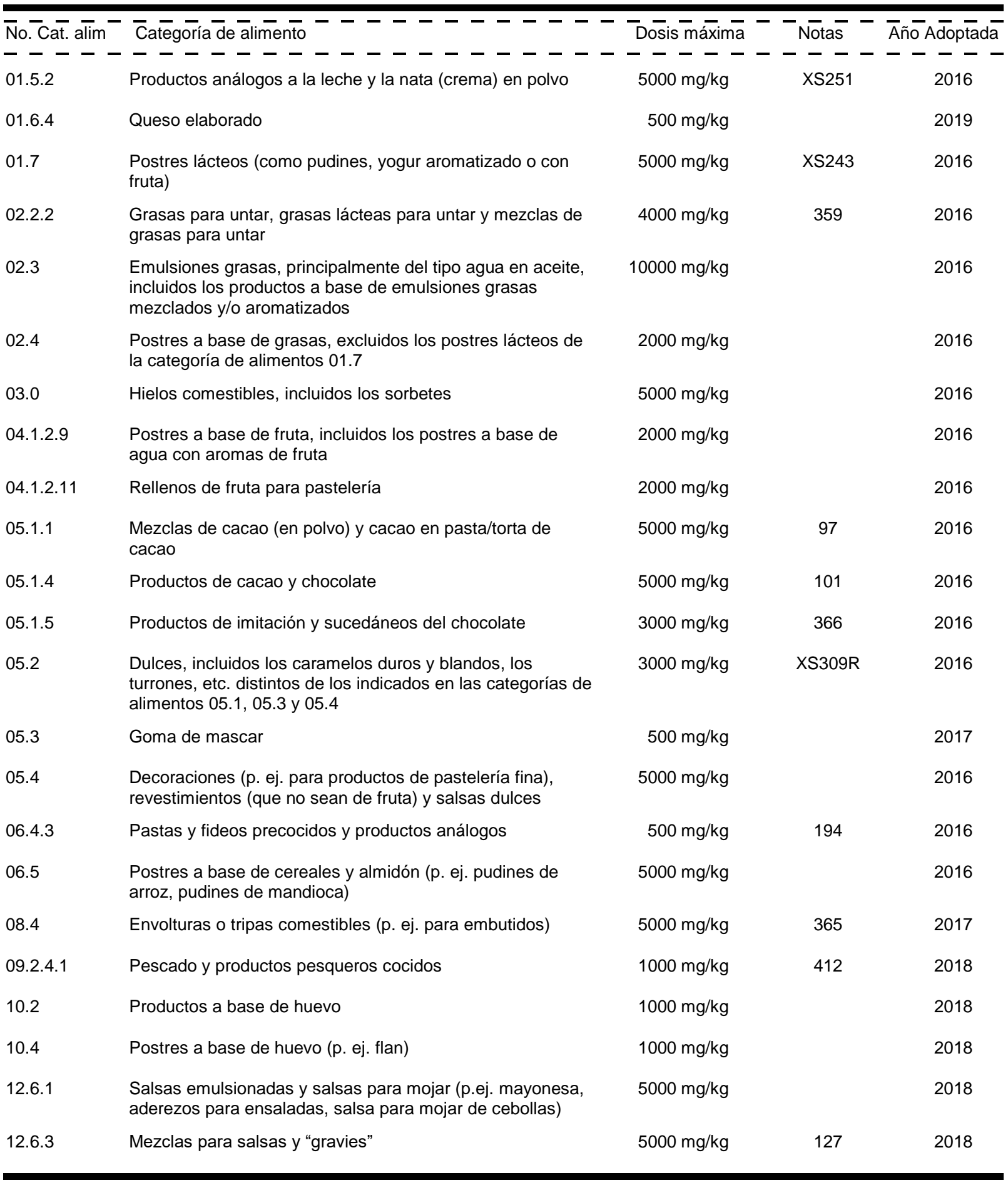




\section{ÉSTERES POLIGLICÉRIDOS DE ÁCIDOS GRASOS}

\section{SIN 475 Ésteres poliglicéridos de ácidos Clases Funcionales: Emulsionantes, Estabilizadores} grasos

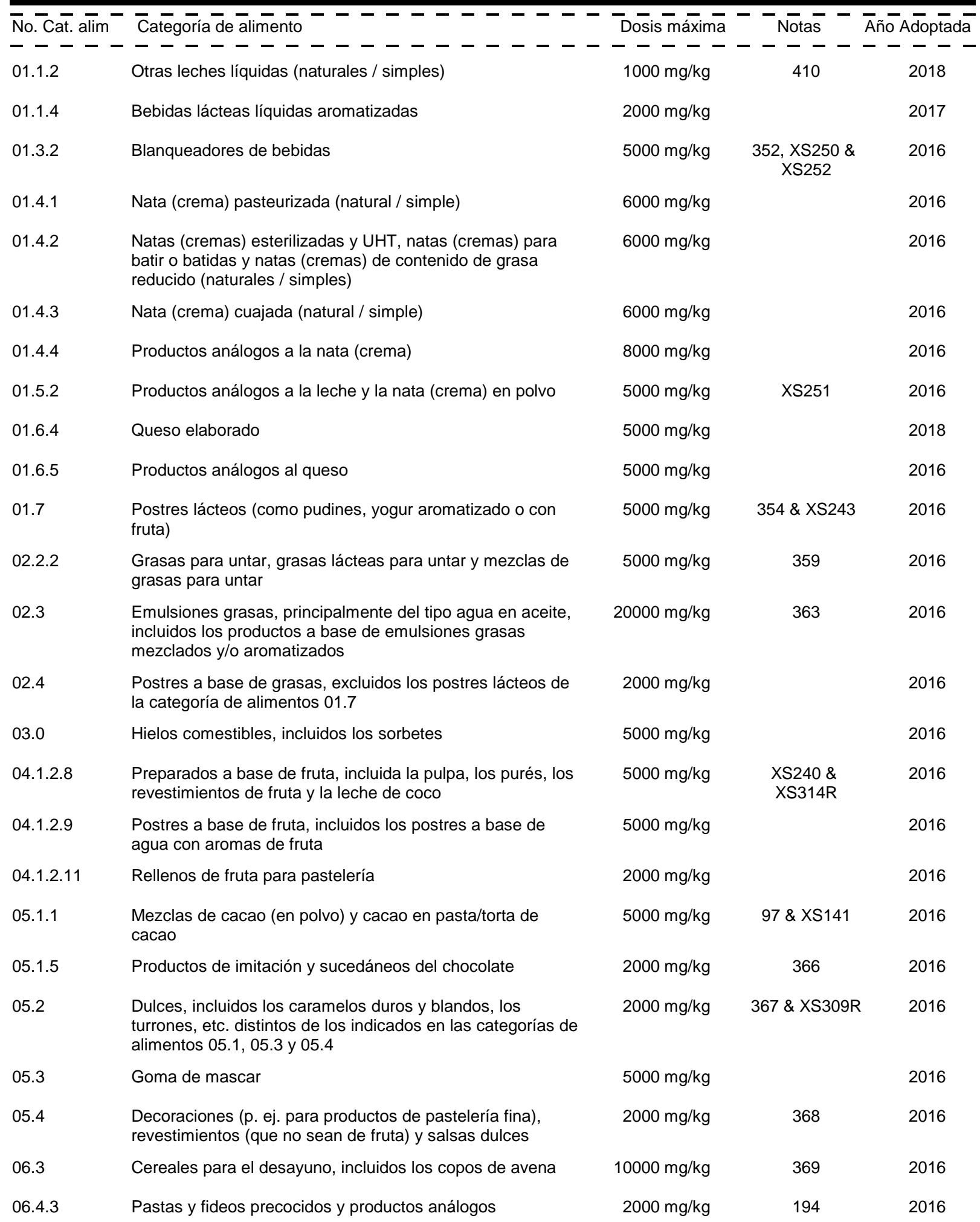




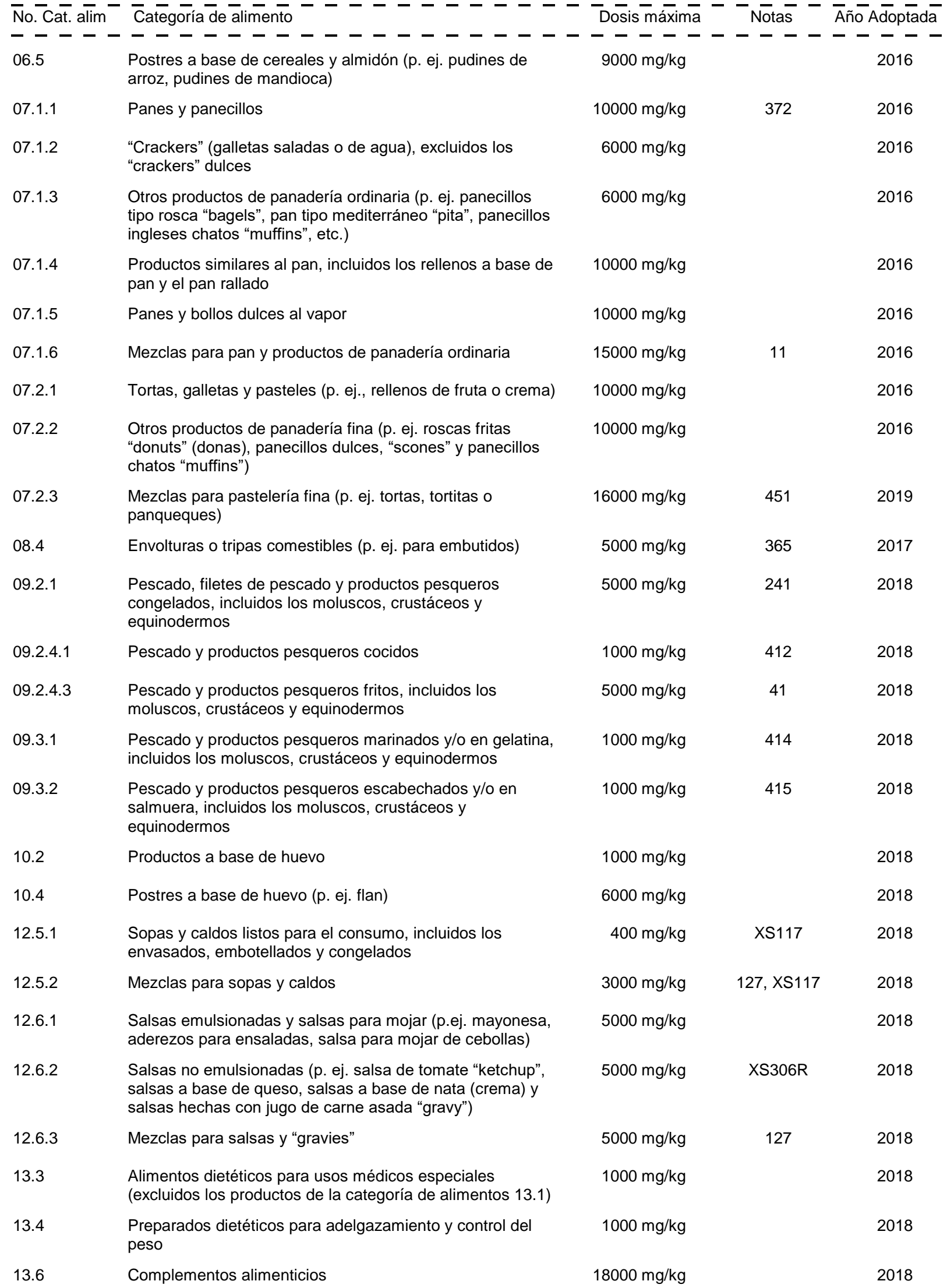




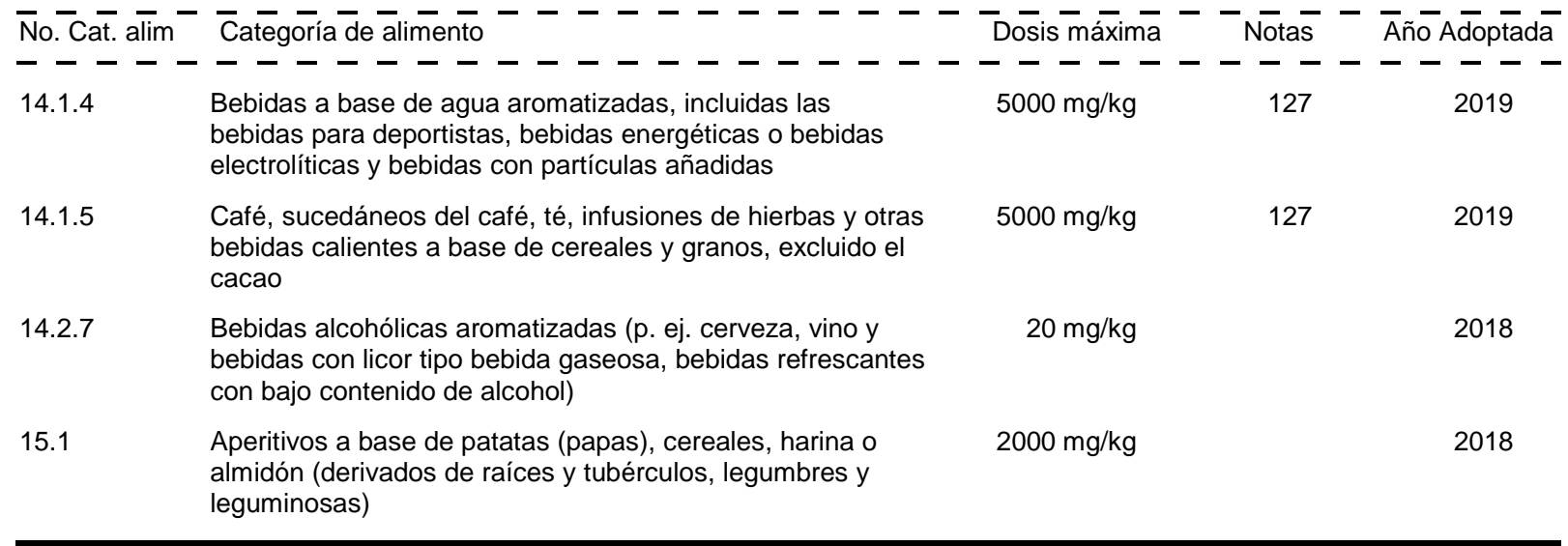

\section{ETILEN DIAMINO TETRA ACETATOS}

$\begin{array}{lll}\text { SIN } 385 & \begin{array}{l}\text { Etilendiaminotetracetato de } \\ \text { calcio disódico }\end{array} & \text { Clases Funcionales: } \\ \text { SIN } 386 & \text { Etilendiaminotetracetato disódico } & \begin{array}{l}\text { Antioxidantes, Agentes de retención de color, } \\ \text { Sustancias conservadoras, Secuestrantes }\end{array} \\ \text { Clases Funcionales: } & \begin{array}{l}\text { Antioxidantes, Agentes de retención de color, } \\ \text { Sustancias conservadoras, Secuestrantes, } \\ \text { Estabilizadores }\end{array}\end{array}$

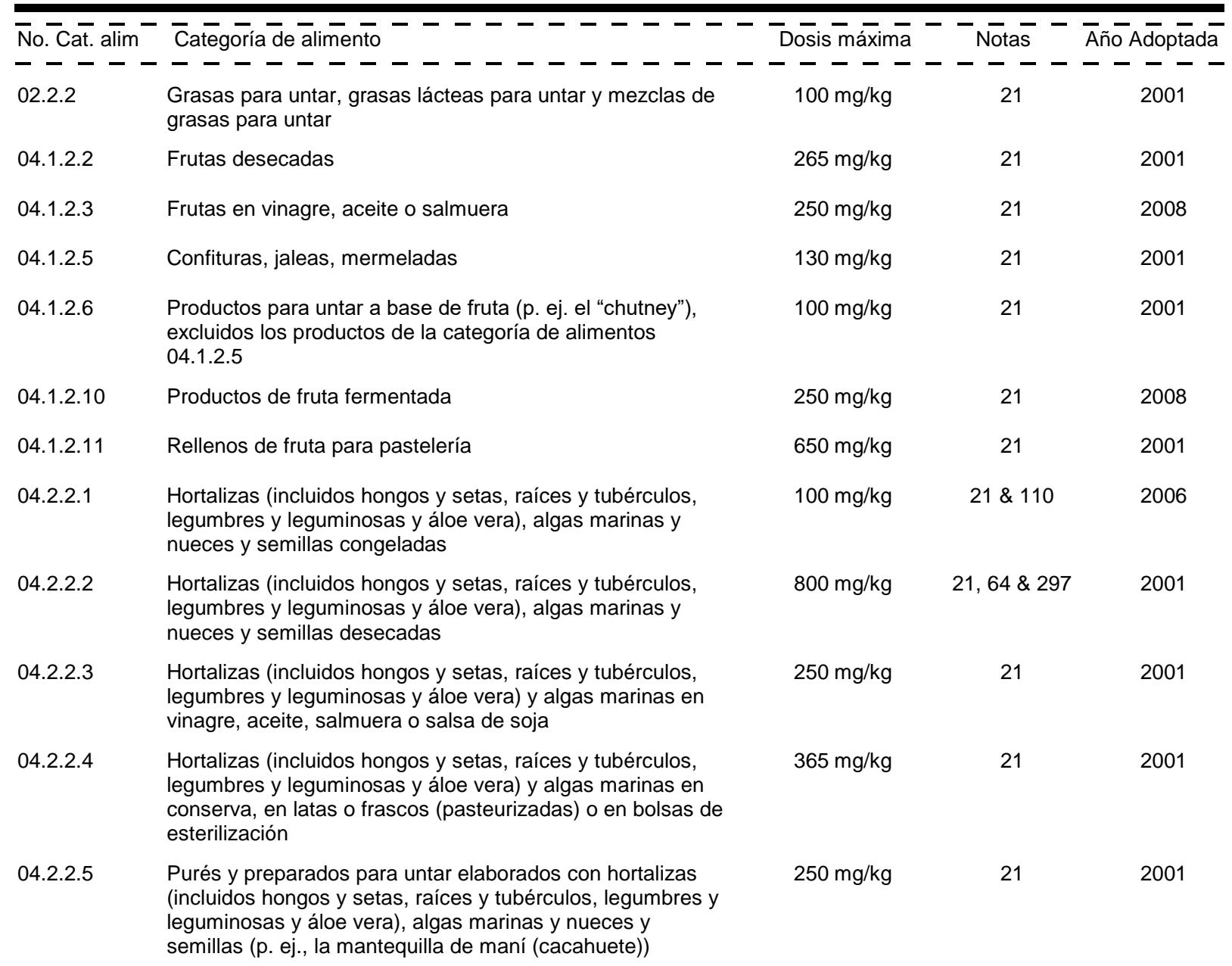




\section{- - - - - - \\ 04.2.2.6 Pulpas y preparados de hortalizas (incluidos hongos y setas, raíces y tubérculos, legumbres y leguminosas y áloe vera), algas marinas y nueces y semillas (como los postres y las salsas a base de hortalizas y hortalizas confitadas) distintos de los indicados en la categoría de alimentos 04.2.2.5}

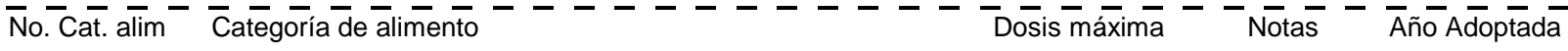

04.2 .2 .7

Productos a base de hortalizas (incluidos hongos y setas, raíces y tubérculos, legumbres y leguminosas y áloe vera) y algas marinas fermentadas, excluidos los productos fermentados de soja de las categorías 06.8.6, 06.8.7, 12.9.1, 12.9.2.1 y 12.9 .2 .3

04.2.2.8 Hortalizas (incluidos hongos y setas, raíces y tubérculos, legumbres y leguminosas y áloe vera) y algas marinas cocidas o fritas

05.1.3 Productos para untar a base de cacao, incluidos los rellenos a base de cacao

06.5 Postres a base de cereales y almidón (p. ej. pudines de arroz, pudines de mandioca)

08.3.2 Productos cárnicos, de aves de corral y caza picados, elaborados y tratados térmicamente

09.2.1 Pescado, filetes de pescado y productos pesqueros congelados, incluidos los moluscos, crustáceos y equinodermos

Pescado, filetes de pescado y productos pesqueros rebozados congelados, incluidos los moluscos, crustáceos y equinodermos

09.2.4.1 Pescado y productos pesqueros cocidos

Pescado y productos pesqueros escabechados y/o en salmuera, incluidos los moluscos, crustáceos y equinodermos

Pescado y productos pesqueros (incluidos los moluscos, crustáceos y equinodermos) en conserva, con inclusión de los enlatados y fermentados

Productos a base de huevo en polvo y/o cuajados por calor

Edulcorantes de mesa, incluidos los que contienen edulcorantes de gran intensidad

Hierbas aromáticas, especias, aderezos y condimentos ( $p$. ej. el aderezo para fideos instantáneos)

Mostazas

Salsas emulsionadas y salsas para mojar (p.ej. mayonesa aderezos para ensaladas, salsa para mojar de cebollas)

$80 \mathrm{mg} / \mathrm{kg}$

21 2001

$250 \mathrm{mg} / \mathrm{kg}$

$250 \mathrm{mg} / \mathrm{kg}$

$50 \mathrm{mg} / \mathrm{kg}$

$21 \&$ XS86

2016

$315 \mathrm{mg} / \mathrm{kg}$

21

$35 \mathrm{mg} / \mathrm{kg}$

21, XS88,

XS89 \& XS98

$75 \mathrm{mg} / \mathrm{kg} \quad 21,392, \mathrm{XS} 36$

XS92, XS95,

XS165, XS190

XS191, XS312

\& XS315

$75 \mathrm{mg} / \mathrm{kg} \quad 21 \& X S 166$

2017

$50 \mathrm{mg} / \mathrm{kg}$

21

2005

$250 \mathrm{mg} / \mathrm{kg}$

21

2001

$340 \mathrm{mg} / \mathrm{kg}$

$21,310, \mathrm{XS3}$ XS70, XS94 \&

2018 XS119

$200 \mathrm{mg} / \mathrm{kg}$

$21 \& 47$

$1000 \mathrm{mg} / \mathrm{kg}$

$21 \& 96$

2005

$70 \mathrm{mg} / \mathrm{kg}$

$75 \mathrm{mg} / \mathrm{kg}$

21

2001

$100 \mathrm{mg} / \mathrm{kg}$

21

2001

$75 \mathrm{mg} / \mathrm{kg}$

21

2001 salsas a base de queso, salsas a base de nata (crema) y salsas hechas con jugo de carne asada "gravy")

Ensaladas (p. ej., la ensalada de macarrones, la ensalada de patatas (papas)) y productos para untar en emparedados, excluidos los productos para untar a base de cacao y nueces de las categorías de alimentos 04.2.2.5 y 05.1 .3

$100 \mathrm{mg} / \mathrm{kg}$ 


\begin{tabular}{|c|c|c|c|c|}
\hline 14.1.4 & $\begin{array}{l}\text { Bebidas a base de agua aromatizadas, incluidas las } \\
\text { bebidas para deportistas, bebidas energéticas o bebidas } \\
\text { electrolíticas y bebidas con partículas añadidas }\end{array}$ & $200 \mathrm{mg} / \mathrm{kg}$ & 21 & 2001 \\
\hline 14.1.5 & $\begin{array}{l}\text { Café, sucedáneos del café, té, infusiones de hierbas y otras } \\
\text { bebidas calientes a base de cereales y granos, excluido el } \\
\text { cacao }\end{array}$ & $35 \mathrm{mg} / \mathrm{kg}$ & 21 & 2001 \\
\hline 14.2 .1 & Cerveza y bebidas a base de malta & $25 \mathrm{mg} / \mathrm{kg}$ & 21 & 2004 \\
\hline 14.2.6 & $\begin{array}{l}\text { Licores destilados que contengan más de un } 15 \text { por ciento } \\
\text { de alcohol }\end{array}$ & $25 \mathrm{mg} / \mathrm{kg}$ & 21 & 2005 \\
\hline 14.2.7 & $\begin{array}{l}\text { Bebidas alcohólicas aromatizadas ( } \mathrm{p} \text {. ej. cerveza, vino y } \\
\text { bebidas con licor tipo bebida gaseosa, bebidas refrescantes } \\
\text { con bajo contenido de alcohol) }\end{array}$ & $25 \mathrm{mg} / \mathrm{kg}$ & 21 & 2007 \\
\hline
\end{tabular}

\section{ETIL-LAUROIL ARGINATO}

\section{SIN 243 Etil-lauroil arginato Clases Funcionales: Sustancias conservadoras}

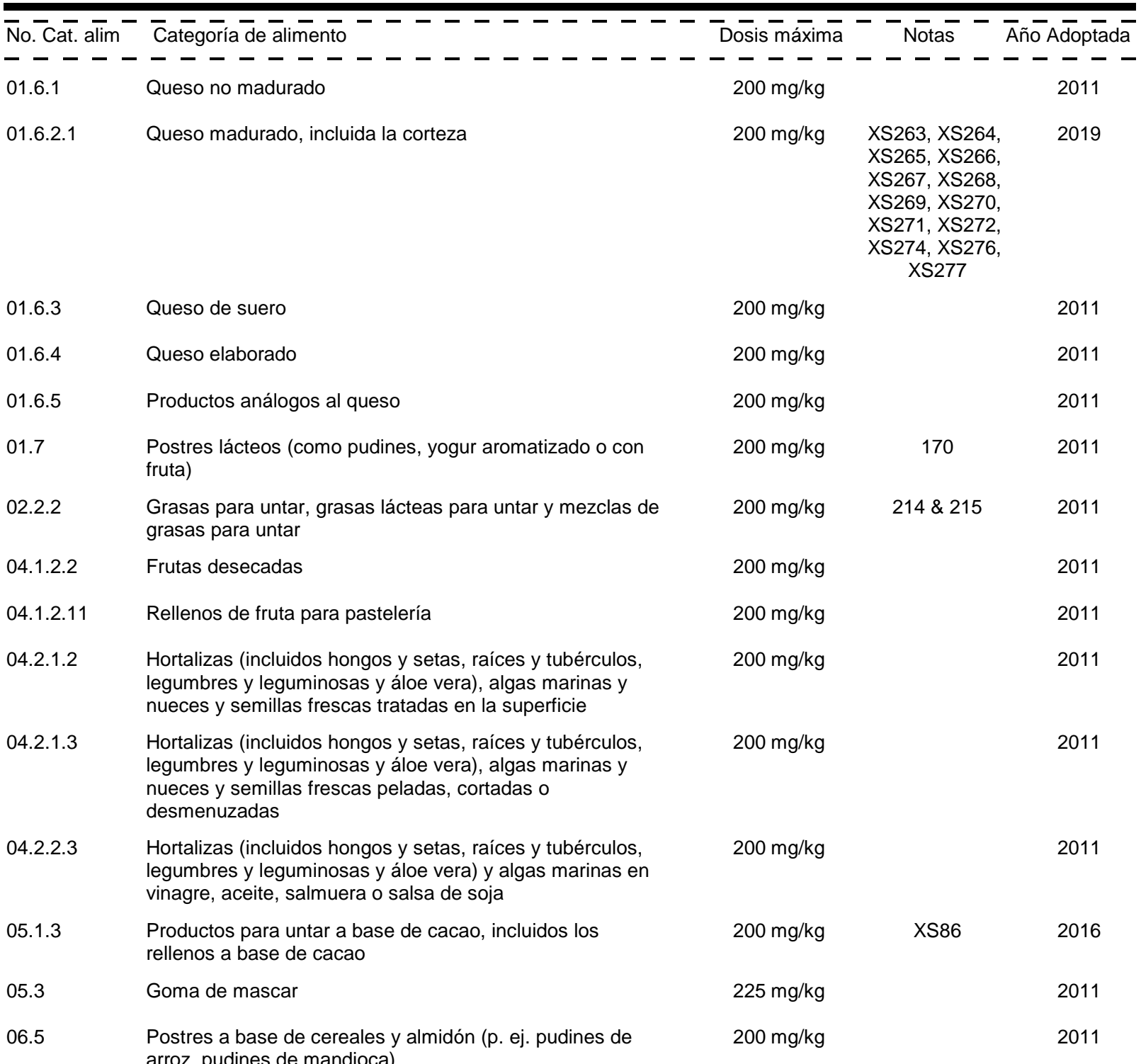




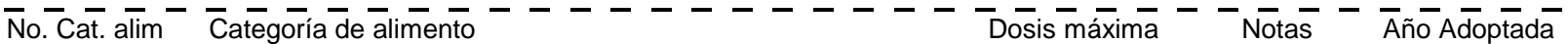

- - - - - - - - - - - - - - - - - - - - - - - - - - -

08.2.1 Productos cárnicos, de aves de corral y caza elaborados

$200 \mathrm{mg} / \mathrm{kg}$

2016 sin tratamiento térmico, en piezas enteras o en cortes

08.2.2 Productos cárnicos, de aves de corral y caza elaborados,

396

2019

08.2 .3 tratados térmicamente, en piezas enteras o en cortes

$200 \mathrm{mg} / \mathrm{kg}$

$3 \& 374$

2016

08.3.1 Productos cárnicos, de aves de corral y caza picados y elaborados sin tratamiento térmico

$315 \mathrm{mg} / \mathrm{kg}$

2016

08.3 .2

Productos cárnicos, de aves de corral y caza picados, elaborados y tratados térmicamente

$200 \mathrm{mg} / \mathrm{kg}$

377

2019

08.3.3

Productos cárnicos, de aves de corral y caza picados, elaborados y congelados

$315 \mathrm{mg} / \mathrm{kg}$

$3 \& 374$

2016

09.2 .4 .1

Pescado y productos pesqueros cocidos

$200 \mathrm{mg} / \mathrm{kg}$

2018

$200 \mathrm{mg} / \mathrm{kg}$

$200 \mathrm{mg} / \mathrm{kg}$

419

2018 moluscos, crustáceos y equinodermos

09.2.5 Pescado y productos pesqueros ahumados, desecados, fermentados y/o salados, incluidos los moluscos,

$200 \mathrm{mg} / \mathrm{kg}$

$\mathrm{XS} 167, \mathrm{XS} 189$ XS222, XS236 crustáceos y equinodermos

XS244, XS311

09.3.1 Pescado y productos pesqueros marinados y/o en gelatina, incluidos los moluscos, crustáceos y equinodermos

$200 \mathrm{mg} / \mathrm{kg}$

2018

$200 \mathrm{mg} / \mathrm{kg}$

2018 salmuera, incluidos los moluscos, crustáceos y equinodermos

09.3.3 Sucedáneos de salmón, caviar y otros productos pesqueros

$200 \mathrm{mg} / \mathrm{kg}$

XS291 a base de huevas

09.3.4 Pescado y productos pesqueros semiconservados, incluidos los moluscos, crustáceos y equinodermos ( $p$. ej., la pasta de pescado), excluidos los productos indicados en las categorías de alimentos 09.3.1 a 09.3.3

$10.2 \quad$ Productos a base de huevo

$200 \mathrm{mg} / \mathrm{kg}$

Salsas emulsionadas y salsas para mojar (p.ej. mayonesa
aderezos para ensaladas, salsa para mojar de cebollas) salsas a base de queso, salsas a base de nata (crema) y salsas hechas con jugo de carne asada "gravy")

$12.7 \quad$ Ensaladas (p. ej., la ensalada de macarrones, la ensalada de patatas (papas)) y productos para untar en emparedados, excluidos los productos para untar a base de cacao y nueces de las categorías de alimentos 04.2.2.5 y 05.1 .3

14.1.4.1 Bebidas a base de agua aromatizadas con gas

$50 \mathrm{mg} / \mathrm{kg}$

14.1.4.2 Bebidas a base de agua aromatizadas sin gas, incluidos los ponches de fruta y las limonadas y bebidas similares 


\section{ETILMALTOL}

SIN 637 Etilmaltol Clases Funcionales: Acentuadores del sabor

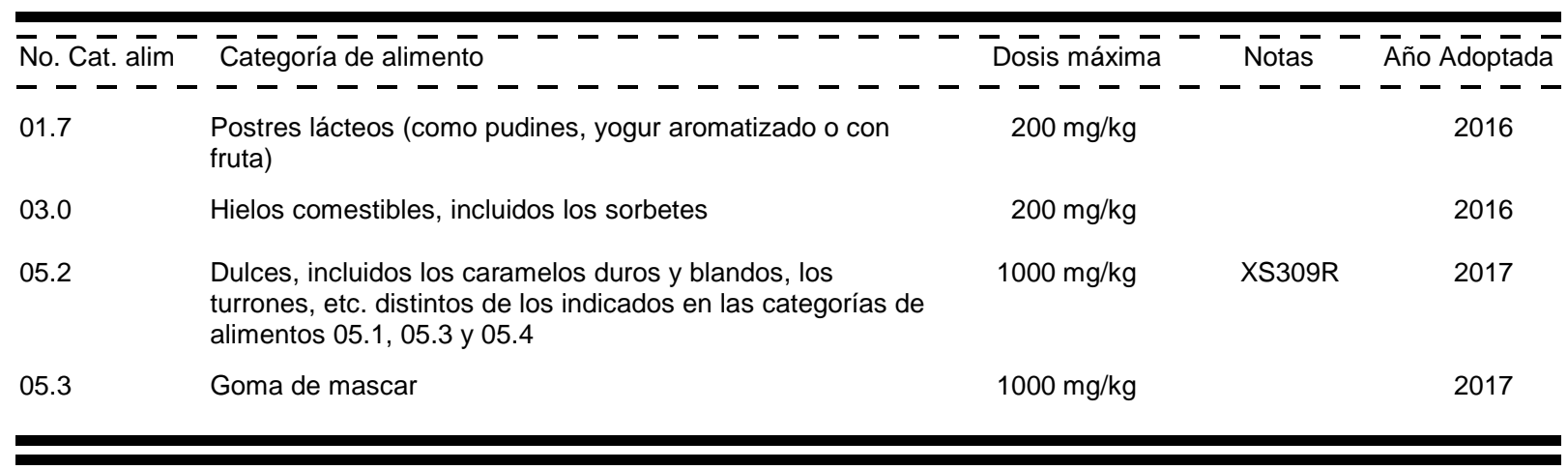

\section{EXTRACTO DE PIEL DE UVA}

\section{SIN 163(ii) Extracto de piel de uva Clases Funcionales: Colorantes}

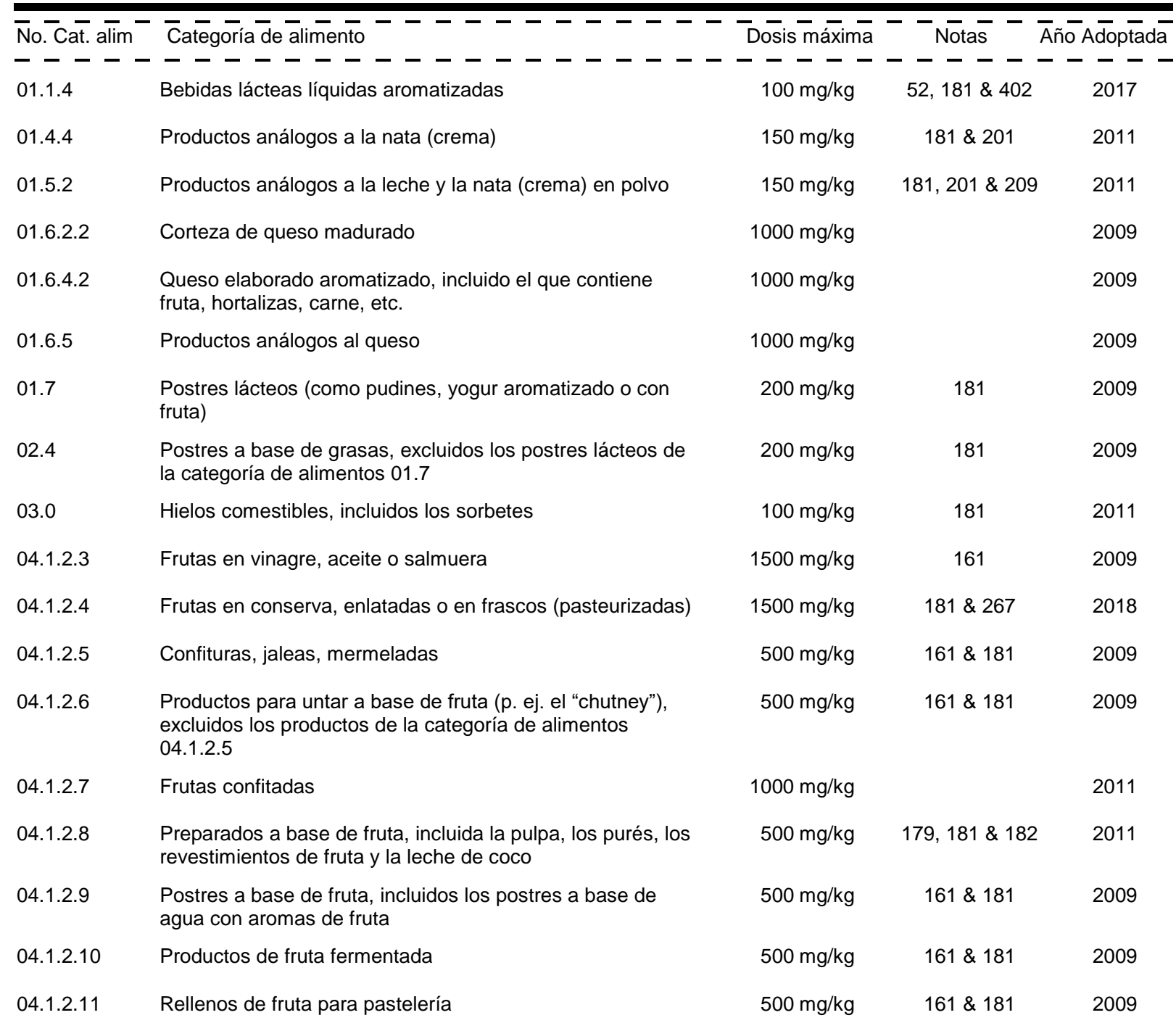



Hortalizas (incluidos hongos y setas, raíces y tubérculos, legumbres y leguminosas y áloe vera) y algas marinas en vinagre, aceite, salmuera o salsa de soja
04.2.2.5 Purés y preparados para untar elaborados con hortalizas (incluidos hongos y setas, raíces y tubérculos, legumbres y leguminosas y áloe vera), algas marinas y nueces y semillas (p. ej., la mantequilla de maní (cacahuete))
04.2 .2 .6
Pulpas y preparados de hortalizas (incluidos hongos y setas, raíces y tubérculos, legumbres y leguminosas y áloe vera), algas marinas y nueces y semillas (como los postres y las salsas a base de hortalizas y hortalizas confitadas) distintos de los indicados en la categoría de alimentos 04.2.2.5

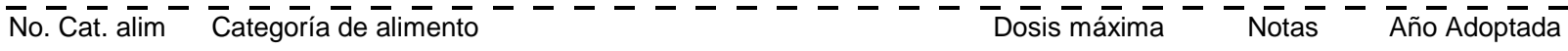

04.2.2.7 Productos a base de hortalizas (incluidos hongos y setas, raíces y tubérculos, legumbres y leguminosas y áloe vera) y algas marinas fermentadas, excluidos los productos fermentados de soja de las categorías 06.8.6, 06.8.7, 12.9.1, 12.9.2.1 y 12.9 .2 .3

05.1.3 Productos para untar a base de cacao, incluidos los rellenos a base de cacao

05.1.4 Productos de cacao y chocolate

05.1.5 Productos de imitación y sucedáneos del chocolate

05.2.2 Caramelos blandos

05.3

Goma de mascar

05.4 Decoraciones (p. ej. para productos de pastelería fina) revestimientos (que no sean de fruta) y salsas dulces

06.3 Cereales para el desayuno, incluidos los copos de avena

06.5

Postres a base de cereales y almidón ( $p$. ej. pudines de arroz, pudines de mandioca)

07.1.2 "Crackers" (galletas saladas o de agua), excluidos los "crackers" dulces

07.1.4 Productos similares al pan, incluidos los rellenos a base de pan y el pan rallado

08.1.2 Carne fresca picada, incluida la de aves de corral y caza

08.2

Productos cárnicos, de aves de corral y caza elaborados, en piezas enteras o en cortes

08.3 Productos cárnicos, de aves de corral y caza picados y elaborados

08.4 Envolturas o tripas comestibles (p. ej. para embutidos)

09.2.2 Pescado, filetes de pescado y productos pesqueros rebozados congelados, incluidos los moluscos, crustáceos y equinodermos

09.2.3 Productos pesqueros picados, mezclados y congelados incluidos los moluscos, crustáceos y equinodermos

09.2.4.1 Pescado y productos pesqueros cocidos

09.2.4.2 Moluscos, crustáceos y equinodermos cocidos

09.2 .4 .3

\section{$100 \mathrm{mg} / \mathrm{kg}$}

$179 \& 181$

2011

$100 \mathrm{mg} / \mathrm{kg}$

$179 \& 181$

2011

$100 \mathrm{mg} / \mathrm{kg}$

$92 \& 181$

2011

$100 \mathrm{mg} / \mathrm{kg} \quad 161 \& 181$

2009

\begin{tabular}{|c|c|c|}
\hline $200 \mathrm{mg} / \mathrm{kg}$ & $181 \& X S 86$ & 2016 \\
\hline $200 \mathrm{mg} / \mathrm{kg}$ & $181 \& 183$ & 2016 \\
\hline $200 \mathrm{mg} / \mathrm{kg}$ & 181 & 2009 \\
\hline $1700 \mathrm{mg} / \mathrm{kg}$ & $181 \&$ XS309R & 2017 \\
\hline $500 \mathrm{mg} / \mathrm{kg}$ & 181 & 2009 \\
\hline $500 \mathrm{mg} / \mathrm{kg}$ & 181 & 2009 \\
\hline $200 \mathrm{mg} / \mathrm{kg}$ & & 2010 \\
\hline $200 \mathrm{mg} / \mathrm{kg}$ & 181 & 2011 \\
\hline $200 \mathrm{mg} / \mathrm{kg}$ & 181 & 2011 \\
\hline $200 \mathrm{mg} / \mathrm{kg}$ & 181 & 2011 \\
\hline $1000 \mathrm{mg} / \mathrm{kg}$ & $4,16 \& 94$ & 2010 \\
\hline $5000 \mathrm{mg} / \mathrm{kg}$ & $\begin{array}{c}\text { 16, XS96 \& } \\
\text { XS97 }\end{array}$ & 2014 \\
\hline $5000 \mathrm{mg} / \mathrm{kg}$ & $\begin{array}{c}16, \text { XS88, } \\
\text { XS89 \& XS98 }\end{array}$ & 2014 \\
\hline $5000 \mathrm{mg} / \mathrm{kg}$ & & 2009 \\
\hline $500 \mathrm{mg} / \mathrm{kg}$ & $16 \& X S 166$ & 2017 \\
\hline BPF & $16 \& 95$ & 2009 \\
\hline $500 \mathrm{mg} / \mathrm{kg}$ & 95 & 2009 \\
\hline $1000 \mathrm{mg} / \mathrm{kg}$ & & 2011 \\
\hline $1000 \mathrm{mg} / \mathrm{kg}$ & $16 \& 95$ & 2009 \\
\hline
\end{tabular}




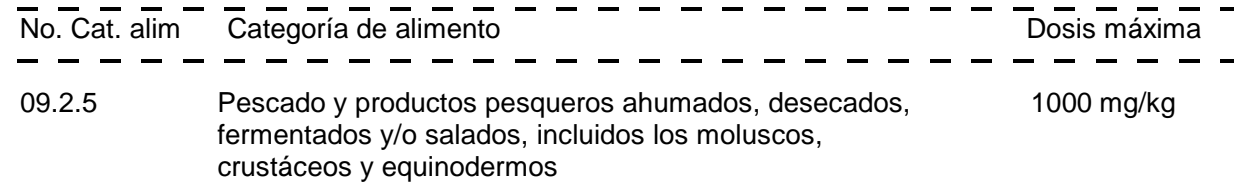

Pescado y productos pesqueros marinados y/o en gelatina, incluidos los moluscos, crustáceos y equinodermos

Pescado y productos pesqueros escabechados y/o en salmuera, incluidos los moluscos, crustáceos y equinodermos

Sucedáneos de salmón, caviar y otros productos pesqueros a base de huevas

09.3.4 Pescado y productos pesqueros semiconservados, incluidos los moluscos, crustáceos y equinodermos (p. ej., la pasta de pescado), excluidos los productos indicados en las categorías de alimentos 09.3.1 a 09.3.3

Pescado y productos pesqueros (incluidos los moluscos, crustáceos y equinodermos) en conserva, con inclusión de los enlatados y fermentados

10.1 Huevos frescos

10.4

Postres a base de huevo (p. ej. flan)

Mostazas

Sopas y caldos

Salsas emulsionadas y salsas para mojar (p.ej. mayonesa aderezos para ensaladas, salsa para mojar de cebollas)

12.6.2 Salsas no emulsionadas (p. ej. salsa de tomate "ketchup", salsas a base de queso, salsas a base de nata (crema) y salsas hechas con jugo de carne asada "gravy")

12.6.3 Mezclas para salsas y "gravies"

12.7 Ensaladas (p. ej., la ensalada de macarrones, la ensalada de patatas (papas)) y productos para untar en emparedados, excluidos los productos para untar a base de cacao y nueces de las categorías de alimentos 04.2.2.5 y 05.1 .3

13.3 Alimentos dietéticos para usos médicos especiales (excluidos los productos de la categoría de alimentos 13.1)

13.4 Preparados dietéticos para adelgazamiento y control del peso

13.5 Alimentos dietéticos (p. ej. los complementos alimenticios para usos dietéticos), excluidos los indicados en las categorías de alimentos 13.1 a 13.4 y 13.6

\section{Complementos alimenticios}

14.1.4 Bebidas a base de agua aromatizadas, incluidas las bebidas para deportistas, bebidas energéticas o bebidas electrolíticas y bebidas con partículas añadidas

$500 \mathrm{mg} / \mathrm{kg}$
$1500 \mathrm{mg} / \mathrm{kg}$

$1500 \mathrm{mg} / \mathrm{kg}$

XS291

2018

$1500 \mathrm{mg} / \mathrm{kg}$

16

2009

$1500 \mathrm{mg} / \mathrm{kg}$

16, XS3, XS37,

XS70, XS90,

XS94 \& XS119

$1500 \mathrm{mg} / \mathrm{kg}$

4

2010

$200 \mathrm{mg} / \mathrm{kg}$

181

2009

$200 \mathrm{mg} / \mathrm{kg}$

181

2009

$500 \mathrm{mg} / \mathrm{kg}$

181 \& XS117

2015

$300 \mathrm{mg} / \mathrm{kg}$

181

2009

$300 \mathrm{mg} / \mathrm{kg}$

181

2009

$300 \mathrm{mg} / \mathrm{kg}$

181

2009

$1500 \mathrm{mg} / \mathrm{kg}$

2009

$250 \mathrm{mg} / \mathrm{kg}$

181

2009

$250 \mathrm{mg} / \mathrm{kg}$

181

2009

$250 \mathrm{mg} / \mathrm{kg}$

181

2009

$500 \mathrm{mg} / \mathrm{kg}$

$300 \mathrm{mg} / \mathrm{kg}$

181

2009

$300 \mathrm{mg} / \mathrm{kg}$

181

2009

$300 \mathrm{mg} / \mathrm{kg}$

181

2009

$300 \mathrm{mg} / \mathrm{kg}$

181

2010 


\begin{tabular}{|c|c|c|c|c|}
\hline 14.2.7 & $\begin{array}{l}\text { Bebidas alcohólicas aromatizadas ( } p \text {. ej. cerveza, vino y } \\
\text { bebidas con licor tipo bebida gaseosa, bebidas refrescantes } \\
\text { con bajo contenido de alcohol) }\end{array}$ & $300 \mathrm{mg} / \mathrm{kg}$ & 181 & 2009 \\
\hline 15.1 & $\begin{array}{l}\text { Aperitivos a base de patatas (papas), cereales, harina o } \\
\text { almidón (derivados de raíces y tubérculos, legumbres y } \\
\text { leguminosas) }\end{array}$ & $500 \mathrm{mg} / \mathrm{kg}$ & 181 & 2009 \\
\hline 15.2 & $\begin{array}{l}\text { Nueces elaboradas, incluidas las nueces revestidas y las } \\
\text { mezclas de nueces (p. ej. con frutas secas) }\end{array}$ & $300 \mathrm{mg} / \mathrm{kg}$ & 181 & 2009 \\
\hline 15.3 & Aperitivos a base de pescado & $400 \mathrm{mg} / \mathrm{kg}$ & & 2011 \\
\hline
\end{tabular}

\section{EXTRACTO DE PIMENTÓN}

SIN 160c(ii) Extracto de pimentón Clases Funcionales: Colorantes

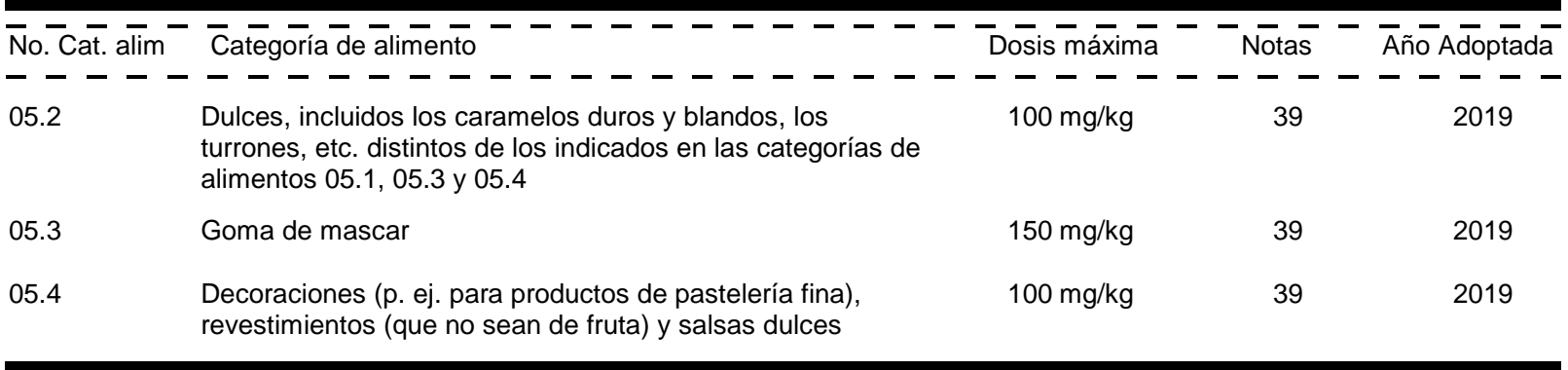

\section{EXTRACTOS DE ANNATO, BASE DE BIXINA}

SIN 160b(i) Extractos de annato, base de Clases Funcionales: Colorantes bixina

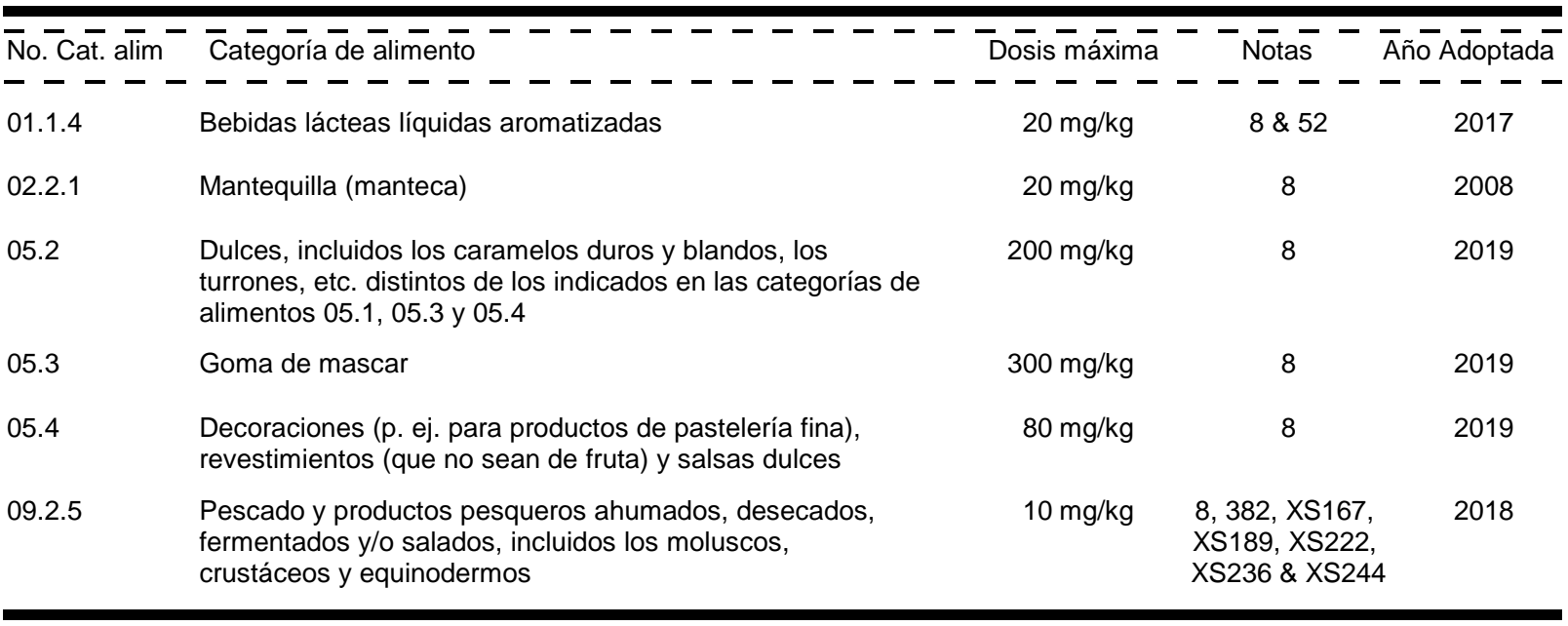

\section{EXTRACTOS DE ANNATO, BASE DE NORBIXINA}

SIN 160b(ii) Extractos de annato, base de Clases Funcionales: Colorantes norbixina

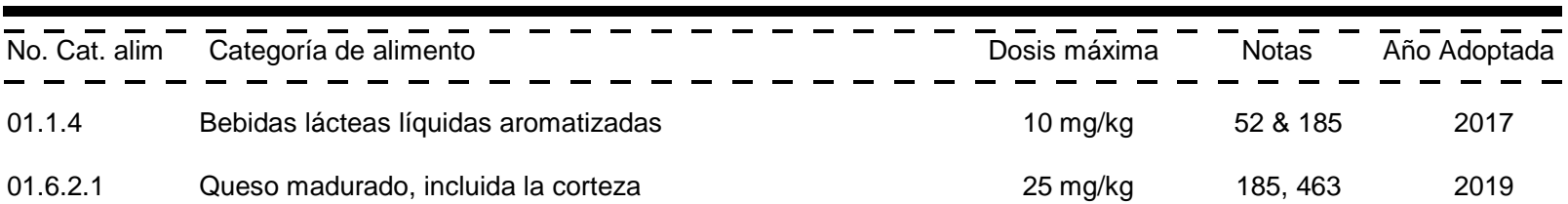




\begin{tabular}{|c|c|c|c|c|}
\hline 05.2 .1 & Caramelos duros & $30 \mathrm{mg} / \mathrm{kg}$ & 185,440 & 2019 \\
\hline 05.2 .2 & Caramelos blandos & $30 \mathrm{mg} / \mathrm{kg}$ & $185,440 \& 443$ & 2019 \\
\hline 05.2 .3 & Turrón y mazapán & $30 \mathrm{mg} / \mathrm{kg}$ & 185 & 2019 \\
\hline 05.3 & Goma de mascar & $50 \mathrm{mg} / \mathrm{kg}$ & 185 & 2019 \\
\hline 05.4 & $\begin{array}{l}\text { Decoraciones (p. ej. para productos de pastelería fina), } \\
\text { revestimientos (que no sean de fruta) y salsas dulces }\end{array}$ & $25 \mathrm{mg} / \mathrm{kg}$ & $185 \& 446$ & 2019 \\
\hline
\end{tabular}

\section{EXTRACTOS DE QUILAYA}

$\begin{array}{lll}\text { SIN } 999(\mathrm{i}) & \text { Extracto de quilaya, tipo } 1 & \text { Clases Funcionales: Emulsionantes, Espumantes } \\ \text { SIN 999(ii) } & \text { Extracto de quilaya, tipo } 2 & \text { Clases Funcionales: Emulsionantes, Espumantes }\end{array}$

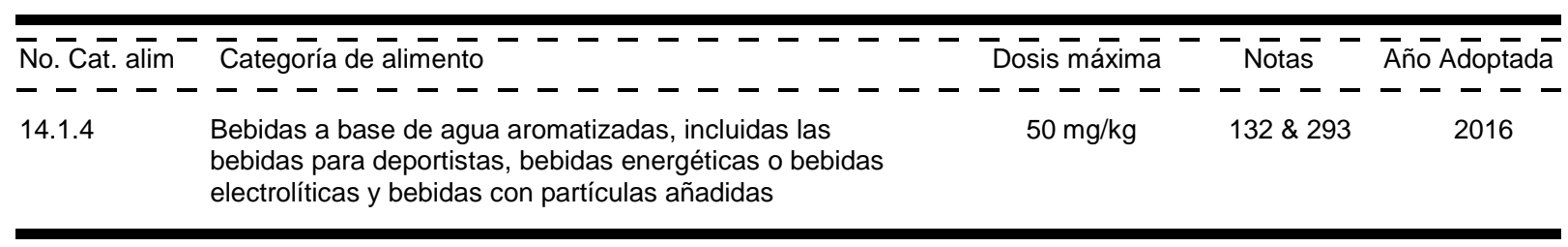

\section{FERROCIANUROS}

$\begin{array}{llll}\text { SIN } 535 & \text { Ferrocianuro de sodio } & \text { Clases Funcionales: Antiaglutinantes } \\ \text { SIN } 536 & \text { Ferrocianuro de potasio } & \text { Clases Funcionales: Antiaglutinantes } \\ \text { SIN } 538 & \text { Ferrocianuro de calcio } & \text { Clases Funcionales: Antiaglutinantes }\end{array}$

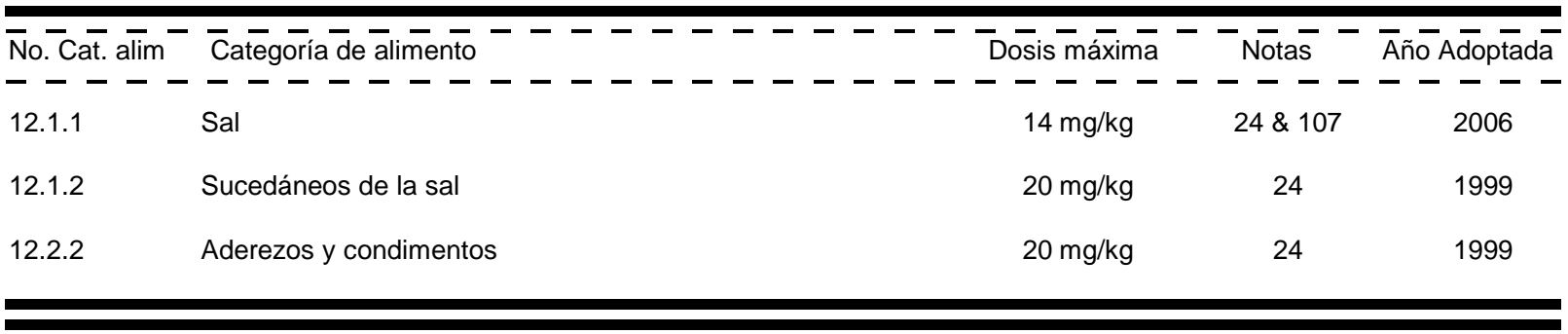

\section{FOSFATO DE DIALMIDÓN}

SIN 1412 Fosfato de dialmidón Clases Funcionales: Emulsionantes, Estabilizadores, Espesantes

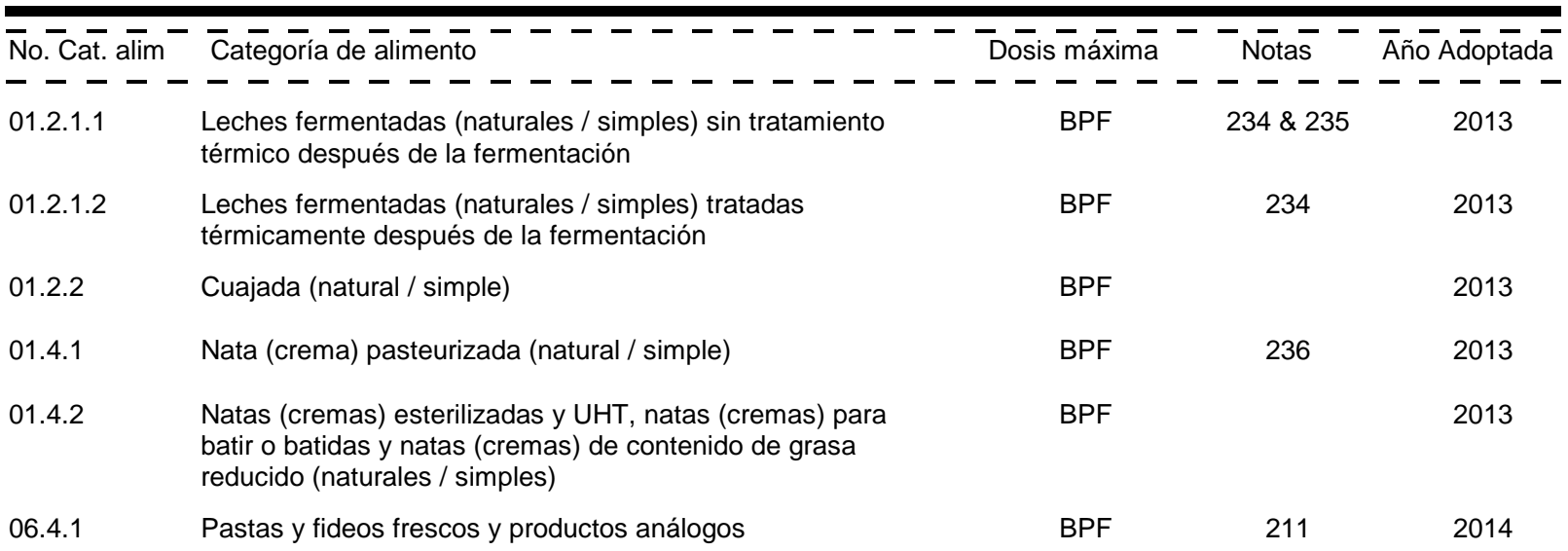




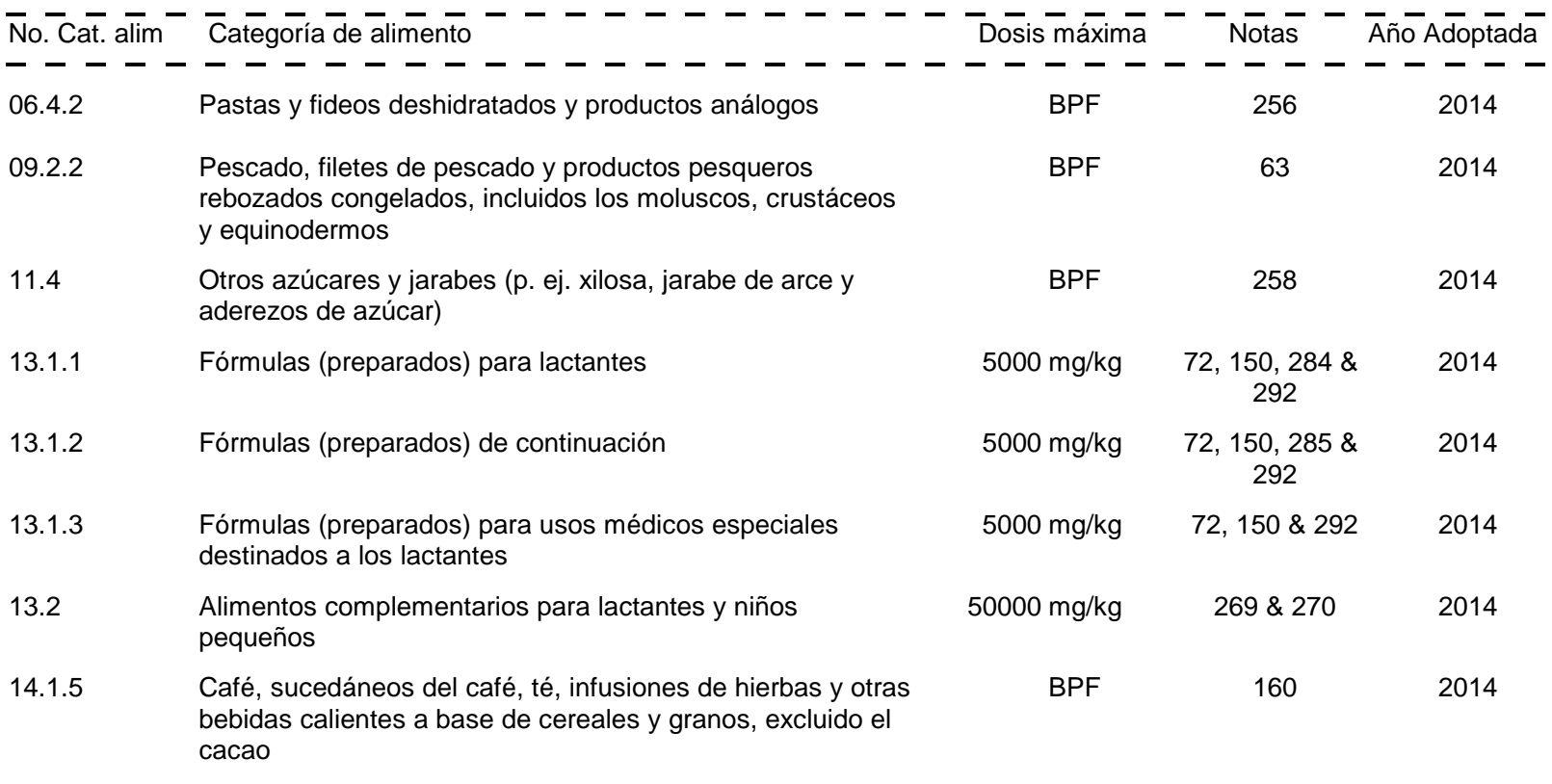

\section{FOSFATO DE DIALMIDÓN ACETILADO}

SIN 1414 Fosfato de dialmidón acetilado Clases Funcionales: Emulsionantes, Estabilizadores, Espesantes

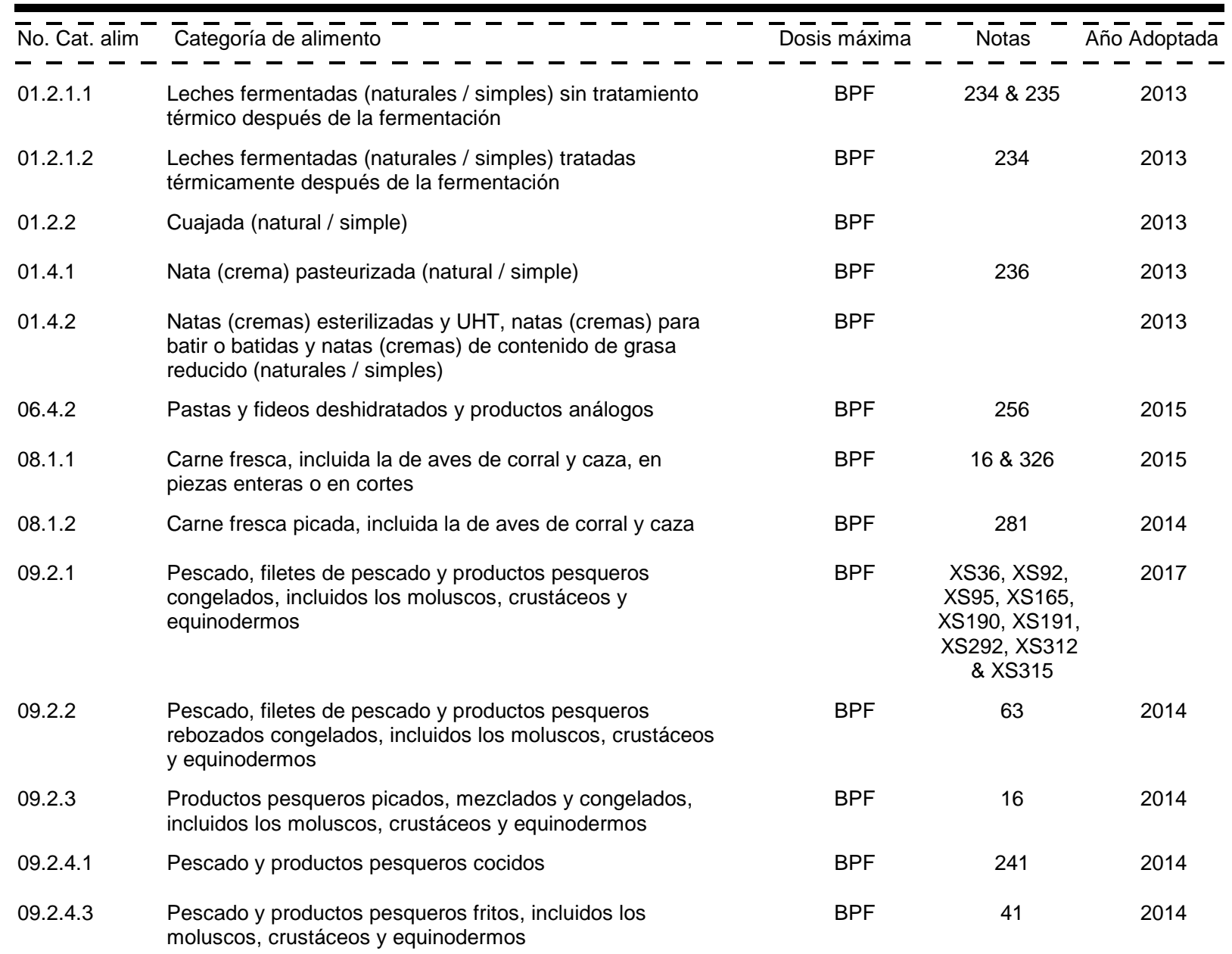




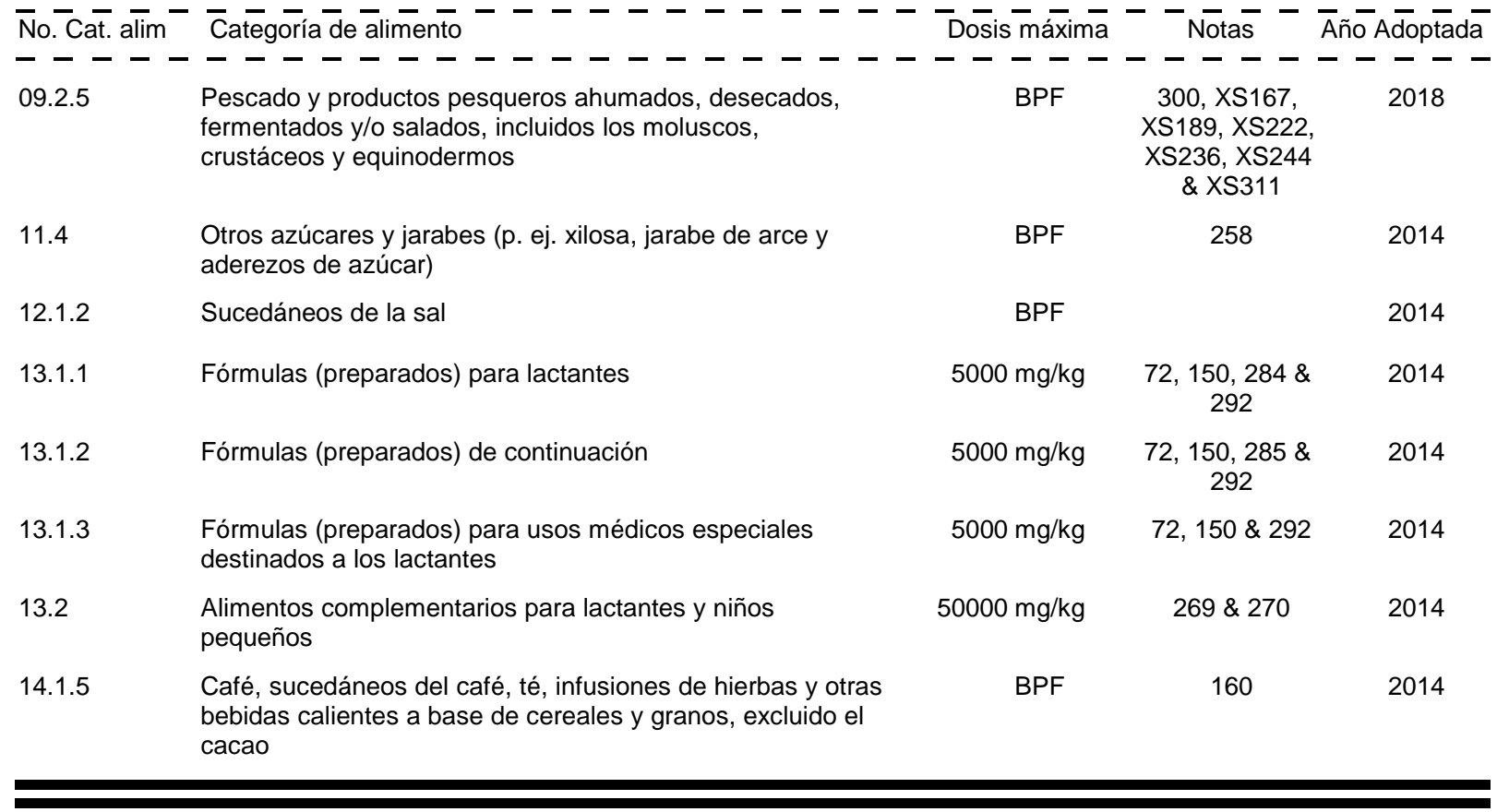

\section{FOSFATO DE DIALMIDÓN FOSFATADO}

SIN 1413 Fosfato de dialmidón fosfatado Clases Funcionales: Emulsionantes, Estabilizadores, Espesantes

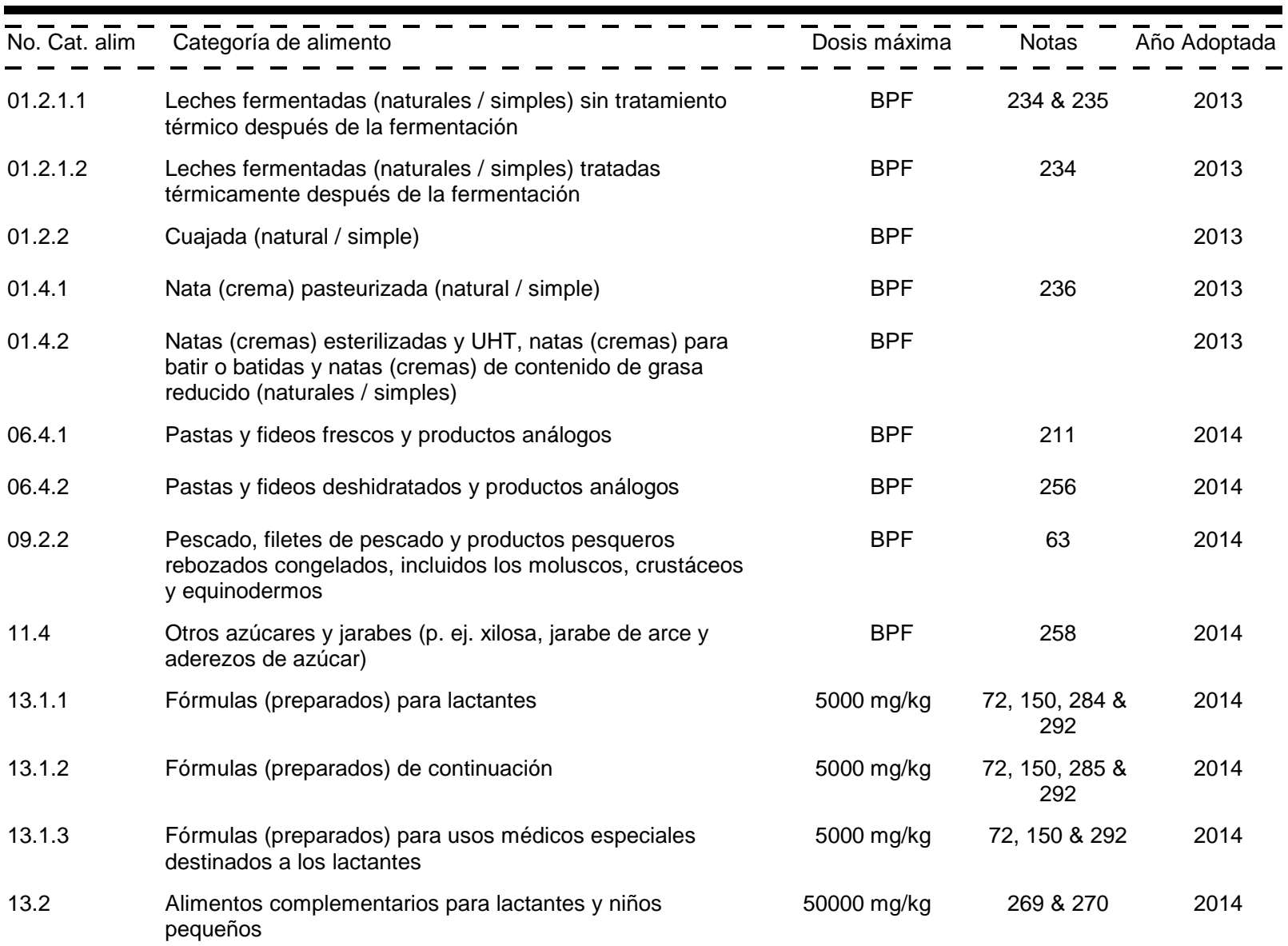




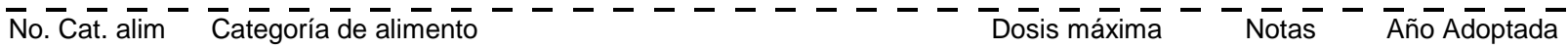
- - - - - - - - - - - - - - - - - - - - - - - - - -

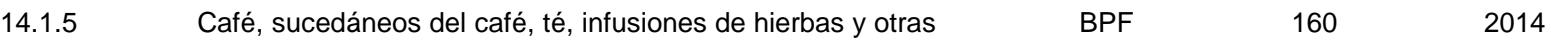
bebidas calientes a base de cereales y granos, excluido el cacao

\section{FOSFATO DE HIDROXIPROPIL DIALMIDÓN}

SIN 1442 Fosfato de hidroxipropil dialmidón Clases Funcionales: Antiaglutinantes, Emulsionantes, Estabilizadores, Espesantes

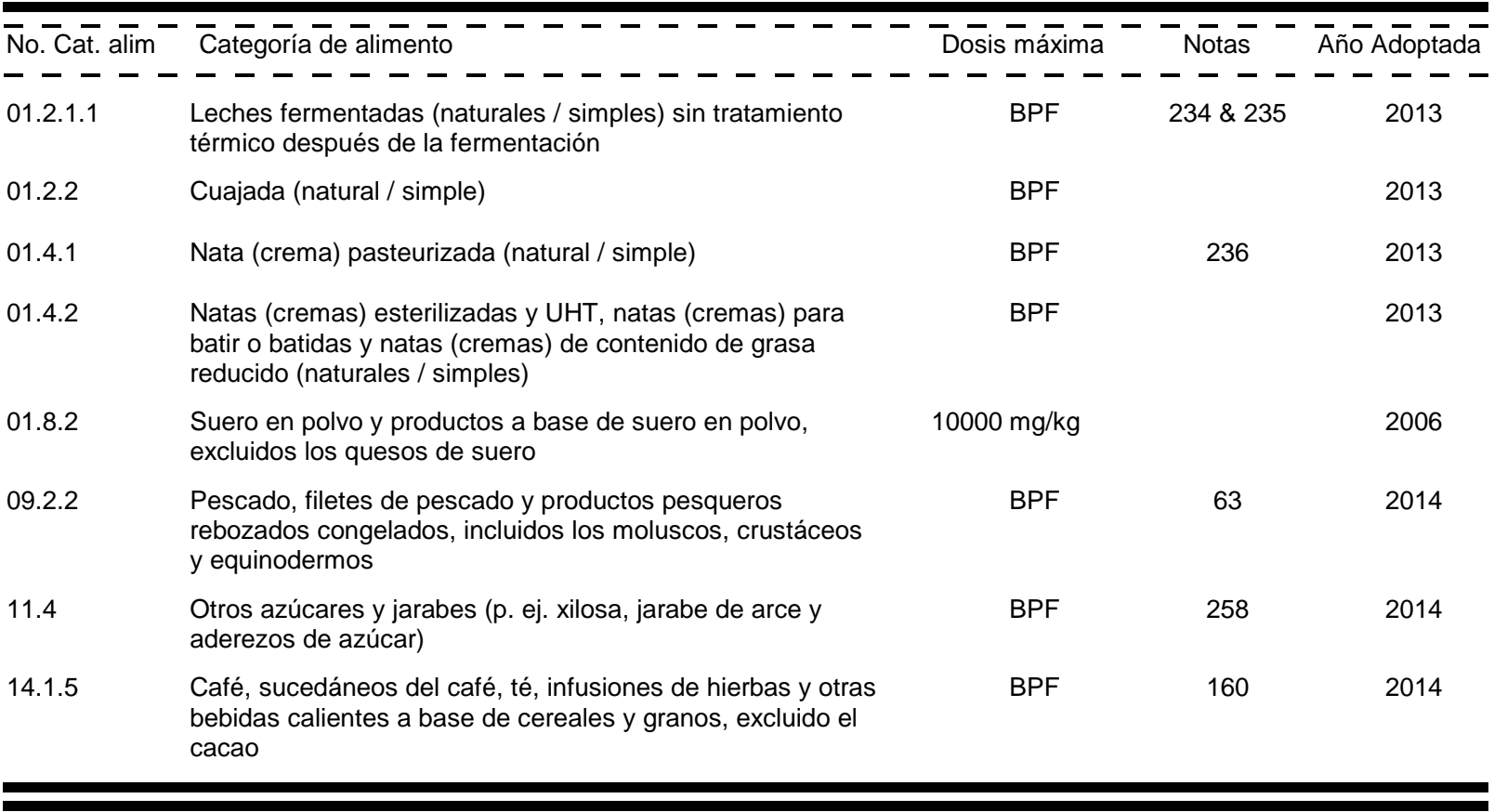

\section{FOSFATO DE MONOALMIDÓN}

SIN 1410 Fosfato de monoalmidón Clases Funcionales: Emulsionantes, Estabilizadores, Espesantes

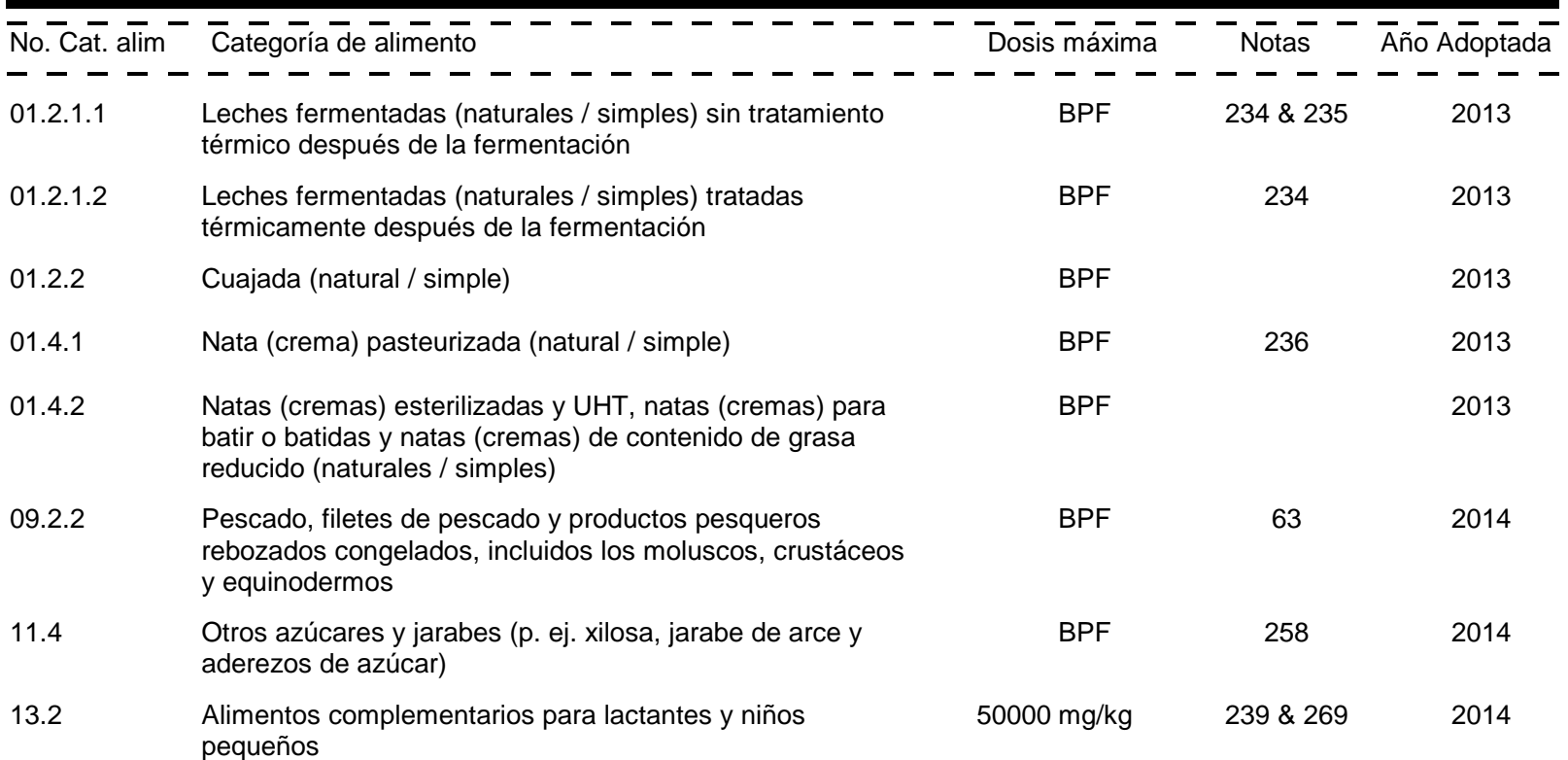


Cuadro I

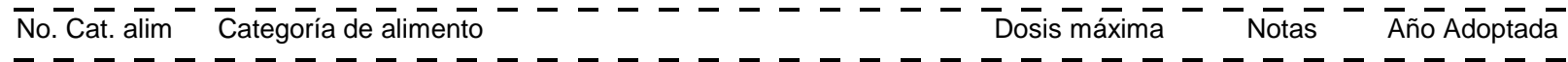

14.1.5 Café, sucedáneos del café, té, infusiones de hierbas y otras

BPF

160

2014 cacao 


\section{FOSFATOS}

$\begin{array}{lll}\text { SIN } 338 & \text { Ácido fosfórico } \\ \text { SIN } & 339(i) & \text { Ortofosfato monosódico }\end{array}$

SIN 339(ii) Hidrogenfosfato disódico

SIN 339(iii) Fosfato trisódico

SIN 340(i) Fosfato diácido de potasio

SIN 340(ii) Hidrogenfosfato dipotásico

SIN 340(iii) Fosfato tripotásico

SIN 341(i) Fosfato diácido de calcio

SIN 341(ii) Hydrogenfosfato de calcio

SIN 341(iii) Fosfato tricálcico

SIN 342(i) Fosfato diácido de amonio

SIN 342(ii) Hydrogenfosfato diamónico

SIN 343(i) Fosfato diácido de magnesio

SIN 343(ii) Hydrogenfosfato de magnesio

SIN 343(iii) Fosfato trimagnésico

SIN 450(i) Difosfato disódico

SIN 450(ii) Difosfato trisódico
Clases Funcionales: Reguladores de la acidez, Antioxidantes, Secuestrantes

Clases Funcionales: Reguladores de la acidez, Emulsionantes, Sales emulsionantes, Humectantes, Leudantes, Secuestrantes, Estabilizadores, Espesantes

Clases Funcionales: Reguladores de la acidez, Emulsionantes, Sales emulsionantes, Humectantes, Secuestrantes, Estabilizadores, Espesantes

Clases Funcionales: Reguladores de la acidez, Emulsionantes, Humectantes, Sustancias conservadoras, Secuestrantes, Estabilizadores, Espesantes

Clases Funcionales: Reguladores de la acidez, Emulsionantes, Humectantes, Secuestrantes, Estabilizadores, Espesantes

Clases Funcionales: Reguladores de la acidez, Emulsionantes, Humectantes, Secuestrantes, Estabilizadores, Espesantes

Clases Funcionales: Reguladores de la acidez, Emulsionantes, Sales emulsionantes, Humectantes, Secuestrantes, Estabilizadores, Espesantes

Clases Funcionales: Reguladores de la acidez, Antiaglutinantes, Sales emulsionantes, Agentes endurecedores, Agentes de tratamiento de las harinas, Humectantes, Leudantes, Secuestrantes, Estabilizadores, Espesantes

Clases Funcionales: Reguladores de la acidez, Antiaglutinantes, Sales emulsionantes, Agentes endurecedores, Agentes de tratamiento de las harinas, Humectantes, Leudantes, Estabilizadores, Espesantes

Clases Funcionales: Reguladores de la acidez, Antiaglutinantes, Emulsionantes, Sales emulsionantes, Agentes endurecedores, Agentes de tratamiento de las harinas, Humectantes, Leudantes, Estabilizadores, Espesantes

Clases Funcionales: Reguladores de la acidez, Agentes de tratamiento de las harinas, Leudantes, Estabilizadores, Espesantes

Clases Funcionales: Reguladores de la acidez, Agentes de tratamiento de las harinas, Leudantes, Estabilizadores, Espesantes

Clases Funcionales: Reguladores de la acidez, Antiaglutinantes, Sales emulsionantes, Estabilizadores, Espesantes

Clases Funcionales: Reguladores de la acidez, Antiaglutinantes, Sales emulsionantes, Leudantes, Estabilizadores, Espesantes

Clases Funcionales: Reguladores de la acidez, Antiaglutinantes, Estabilizadores, Espesantes

Clases Funcionales: Reguladores de la acidez, Emulsionantes, Sales emulsionantes, Humectantes, Leudantes, Secuestrantes, Estabilizadores, Espesantes

Clases Funcionales: Reguladores de la acidez, Emulsionantes, Sales emulsionantes, Humectantes, Leudantes, Secuestrantes, Estabilizadores, Espesantes 
Cuadro I

SIN 450(iii) Difosfato tetrasódico

SIN 450(ix) Difosfato diácido de magnesio

SIN 450(v) Difosfato tetrapotásico

SIN 450(vi) Difosfato dicálcico

SIN 450(vii) Difosfato diácido de calcio

SIN 451(i) Trifosfato pentasódico

SIN 451(ii) Trifosfato pentapotásico

SIN 452(i) Polifosfato de sodio

SIN 452(ii) Polifosfato de potasio

SIN 452(iii) Polifosfato de sodio y calcio

SIN 452(iv) Polifosfatos de calcio

SIN 452(v) Polifosfatos de amonio

SIN $542 \quad$ Fosfato de huesos
Clases Funcionales: Reguladores de la acidez, Emulsionantes, Sales emulsionantes, Humectantes, Leudantes, Secuestrantes, Estabilizadores, Espesantes

Clases Funcionales: Reguladores de la acidez, Leudantes, Estabilizadores

Clases Funcionales: Reguladores de la acidez, Emulsionantes, Sales emulsionantes, Humectantes, Leudantes, Secuestrantes, Estabilizadores, Espesantes

Clases Funcionales: Reguladores de la acidez, Emulsionantes, Sales emulsionantes, Agentes endurecedores, Leudantes, Secuestrantes, Estabilizadores, Espesantes

Clases Funcionales: Reguladores de la acidez, Emulsionantes, Sales emulsionantes, Humectantes, Leudantes, Secuestrantes, Estabilizadores

Clases Funcionales: Reguladores de la acidez, Emulsionantes, Sales emulsionantes, Humectantes, Secuestrantes, Estabilizadores, Espesantes

Clases Funcionales: Reguladores de la acidez, Emulsionantes, Sales emulsionantes, Humectantes, Secuestrantes, Estabilizadores, Espesantes

Clases Funcionales: Reguladores de la acidez, Emulsionantes, Sales emulsionantes, Humectantes, Leudantes, Secuestrantes, Estabilizadores, Espesantes

Clases Funcionales: Reguladores de la acidez, Emulsionantes, Sales emulsionantes, Humectantes, Leudantes, Secuestrantes, Estabilizadores, Espesantes

Clases Funcionales: Reguladores de la acidez, Emulsionantes, Humectantes, Leudantes, Secuestrantes, Estabilizadores

Clases Funcionales: Reguladores de la acidez, Emulsionantes, Sales emulsionantes, Humectantes, Leudantes, Secuestrantes, Estabilizadores, Espesantes

Clases Funcionales: Reguladores de la acidez, Emulsionantes, Sales emulsionantes, Humectantes, Secuestrantes, Estabilizadores, Espesantes

Clases Funcionales: Antiaglutinantes, Emulsionantes, Humectantes

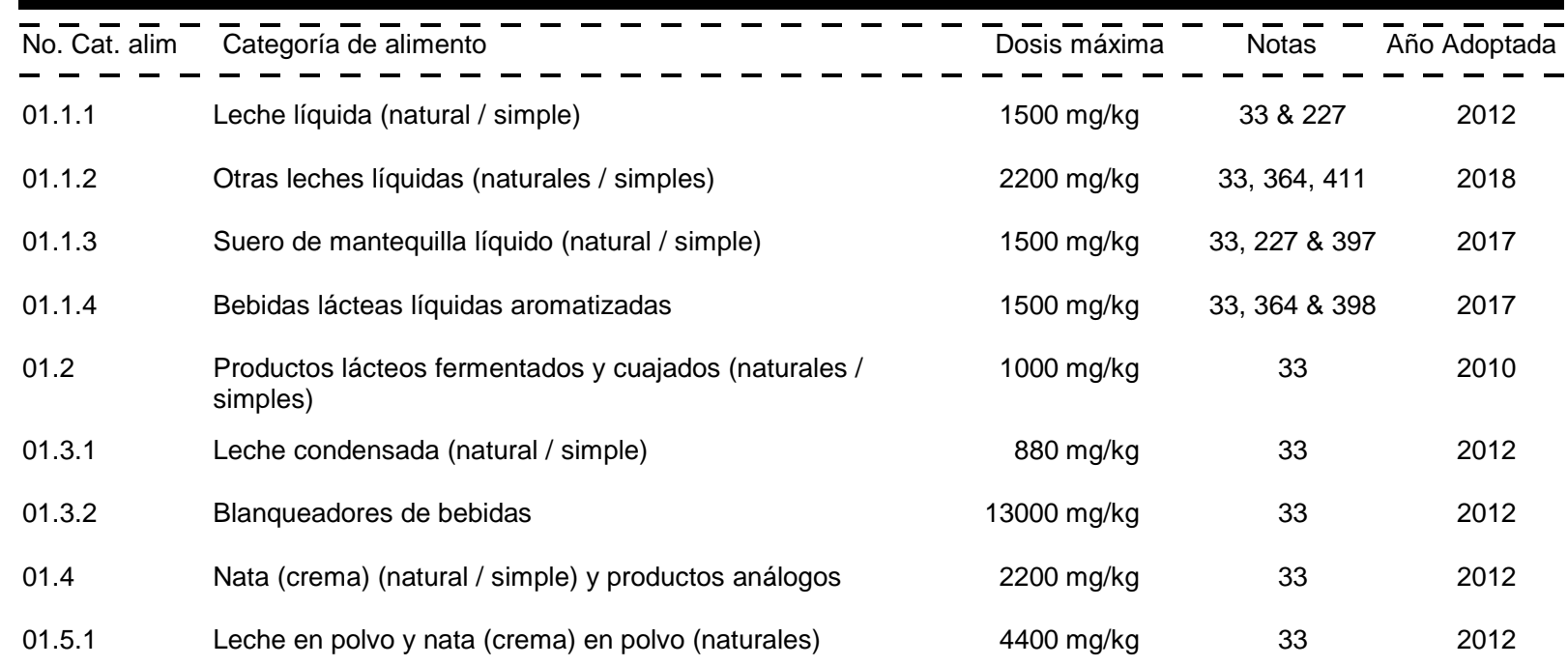




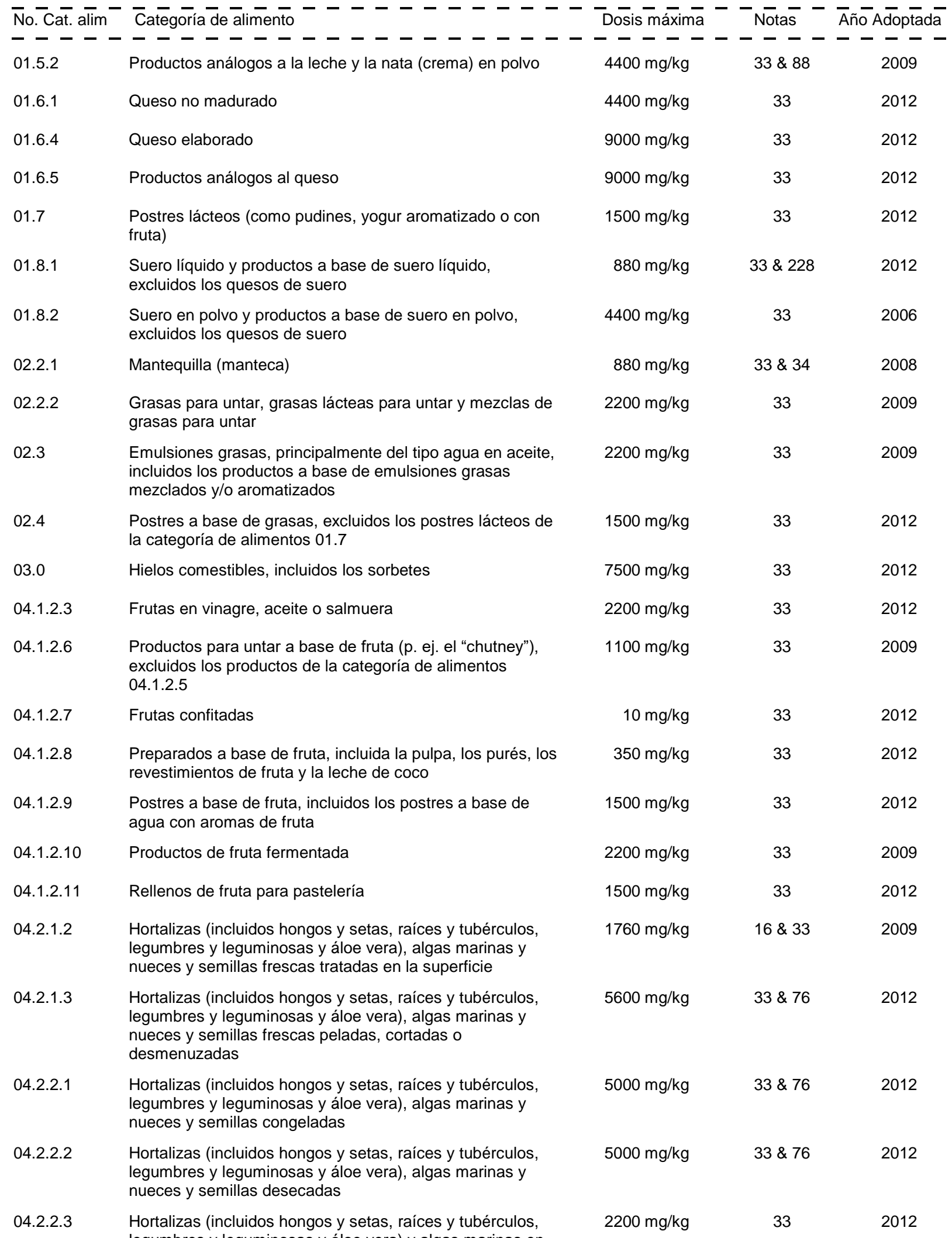




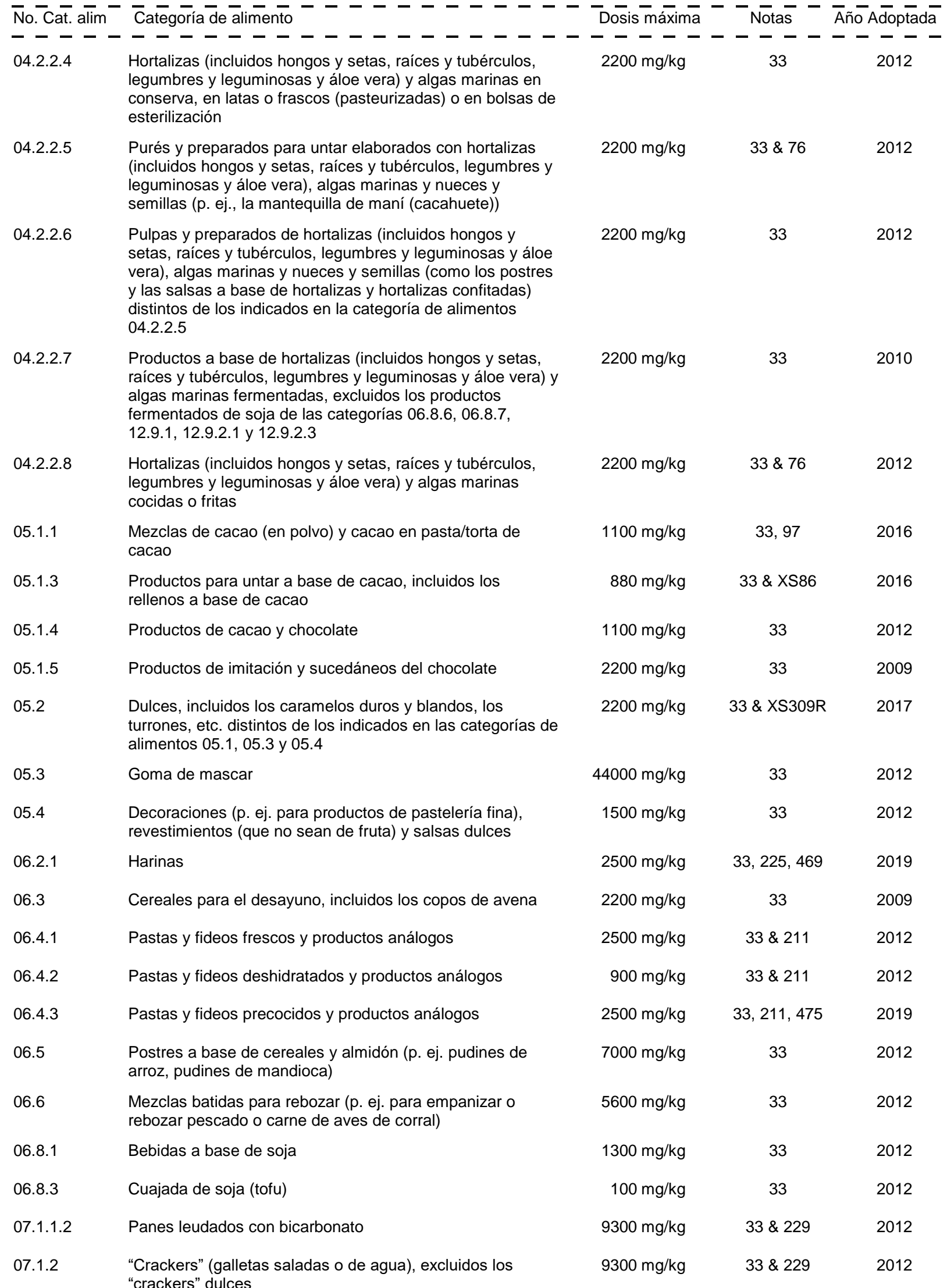




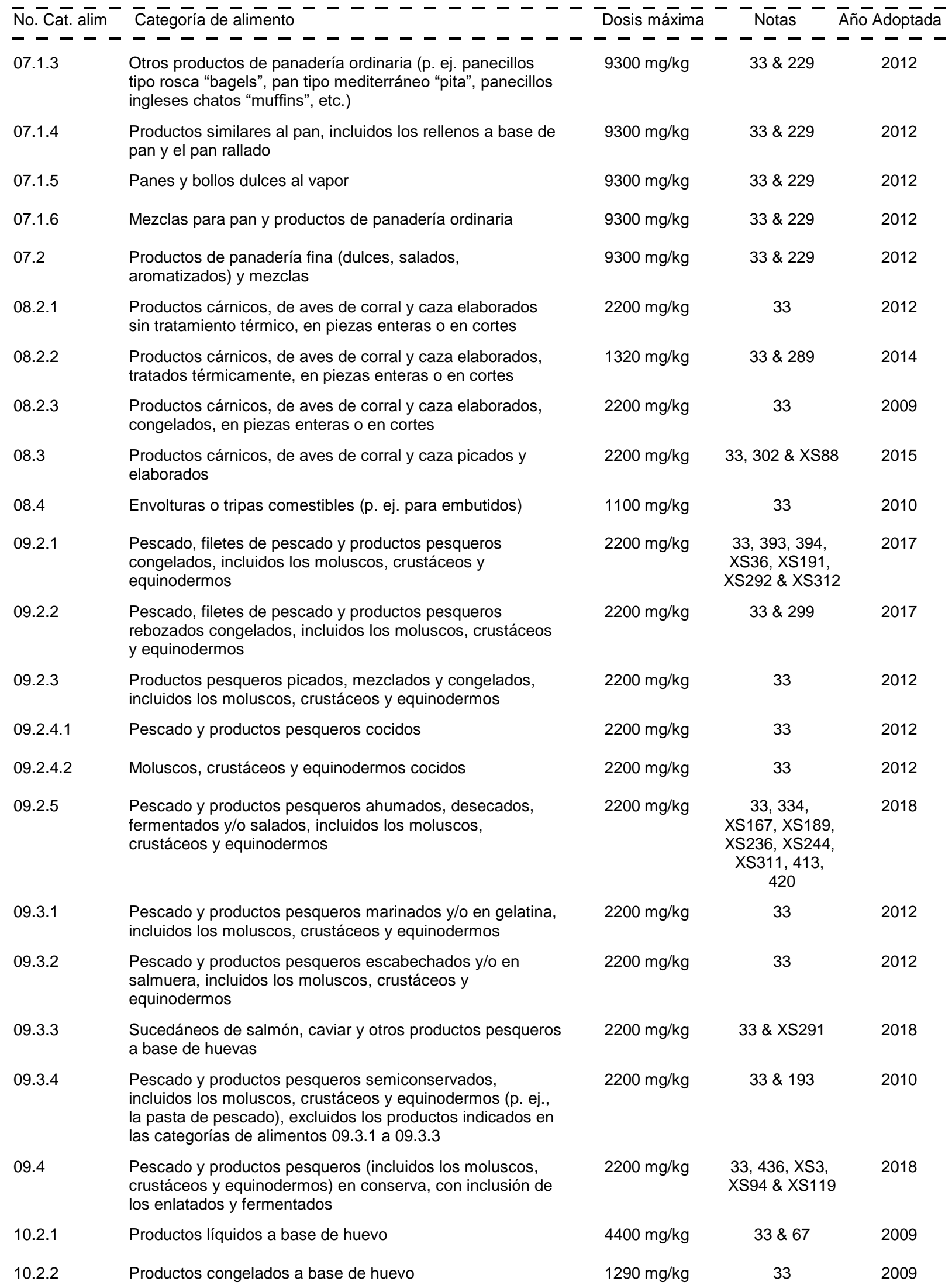




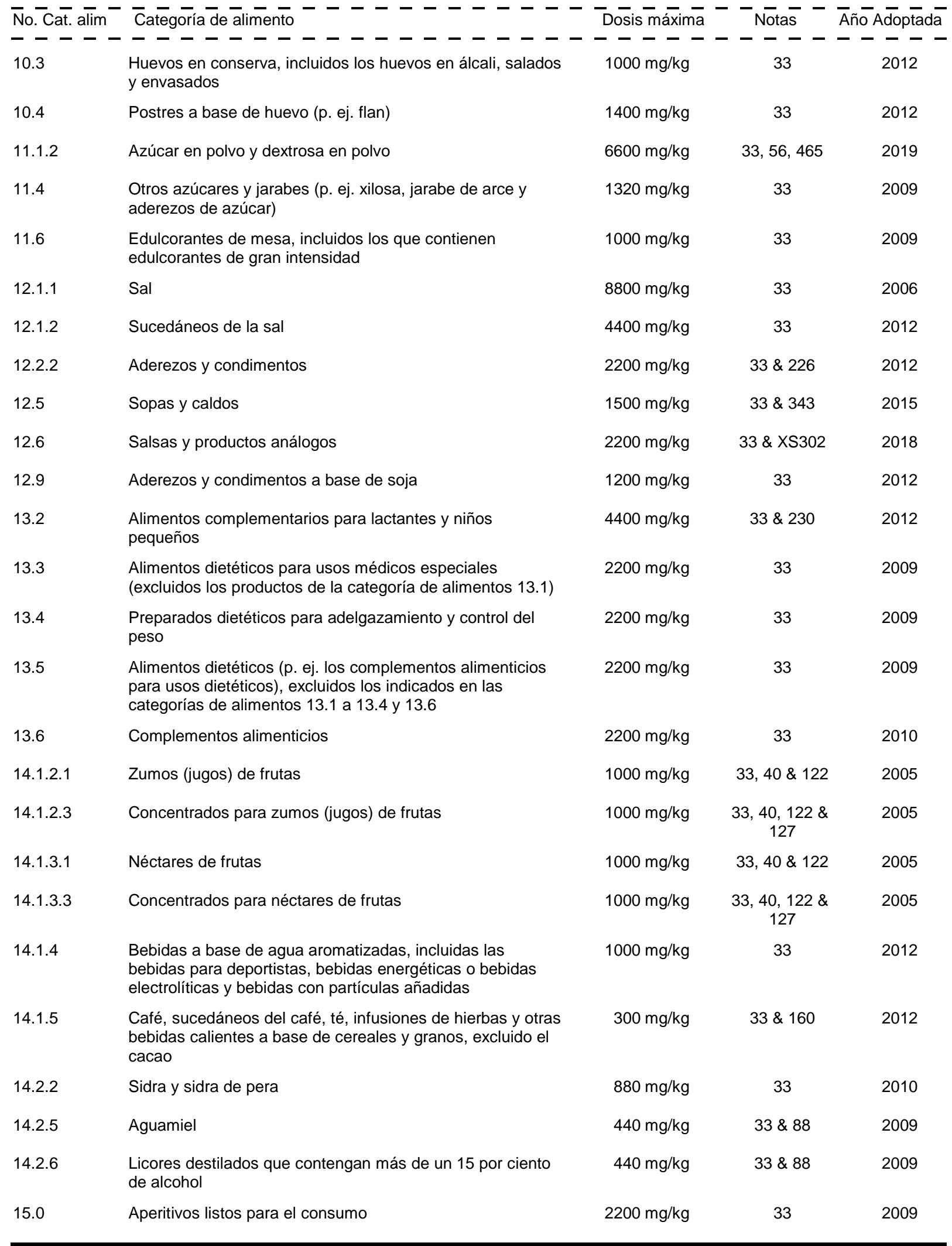




\section{FOSFATOS DE ALUMINIO Y SODIO}

SIN 541(i) Fosfato de aluminio y sodio, ácido Clases Funcionales

Reguladores de la acidez, Emulsionantes, Sales emulsionantes, Leudantes, Estabilizadores, Espesantes

SIN 541(ii) Fosfato de aluminio y sodio,

Clases Funcionales: Reguladores de la acidez, Emulsionantes, Sales básico emulsionantes, Estabilizadores, Espesantes

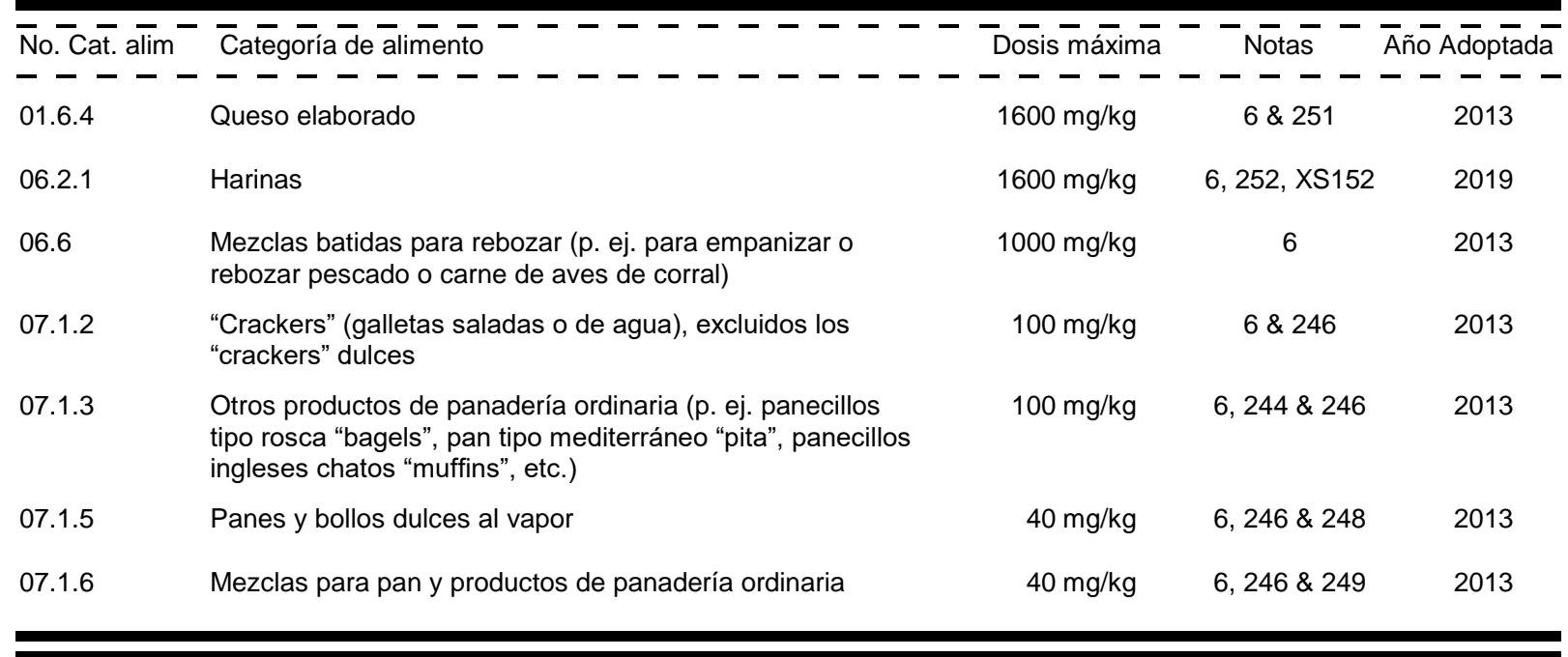

\section{FUMARATO DE SODIO}

SIN 365 Fumarato de sodio Clases Funcionales: Reguladores de la acidez

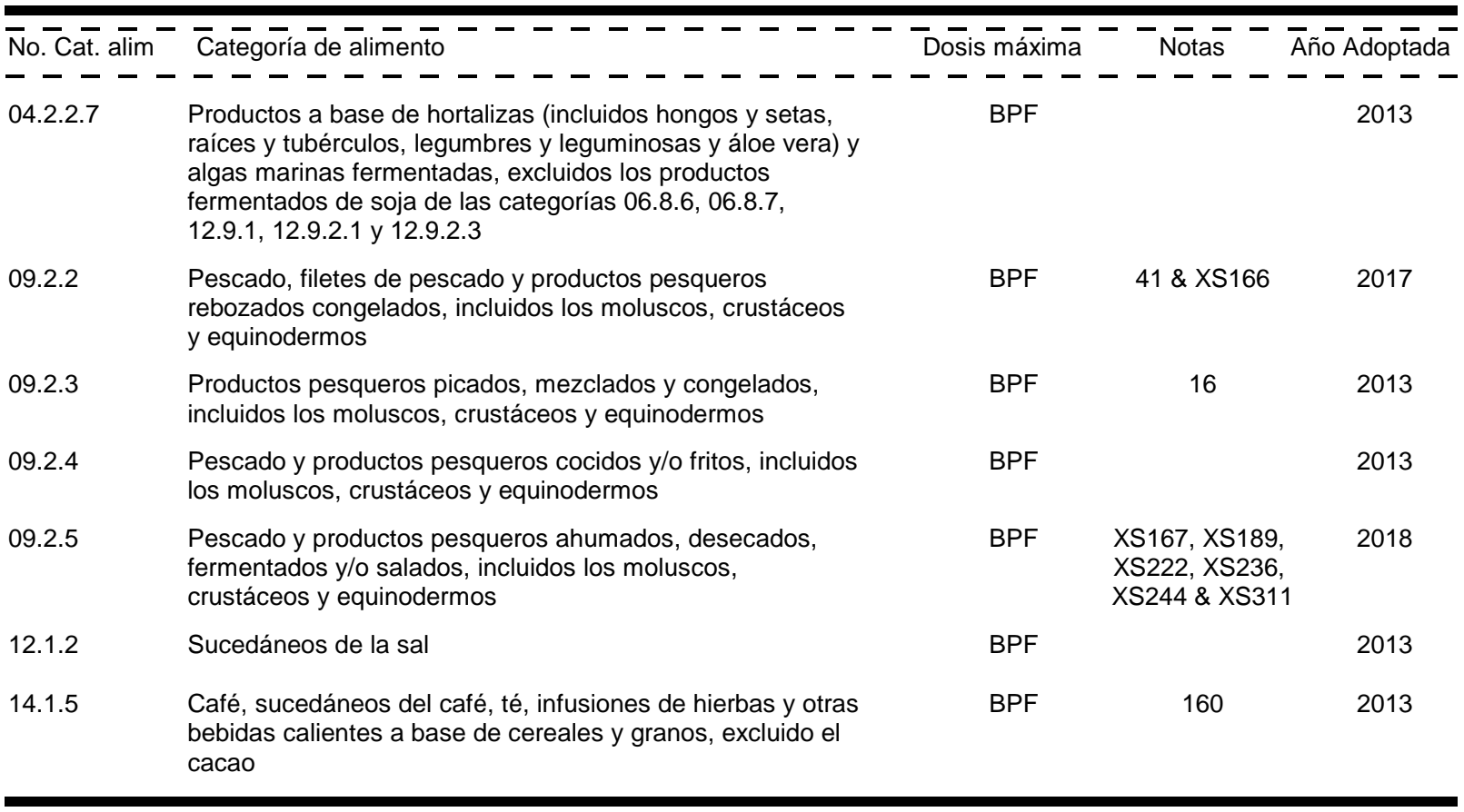

GALATO DE PROPILO

SIN $310 \quad$ Galato de propilo Clases Funcionales: Antioxidantes

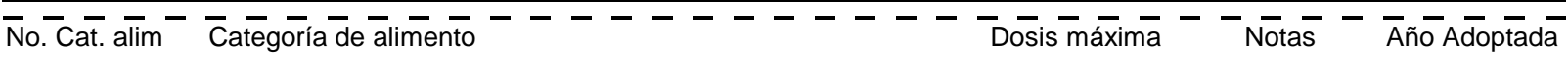

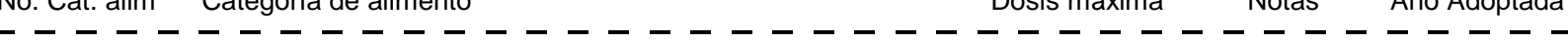




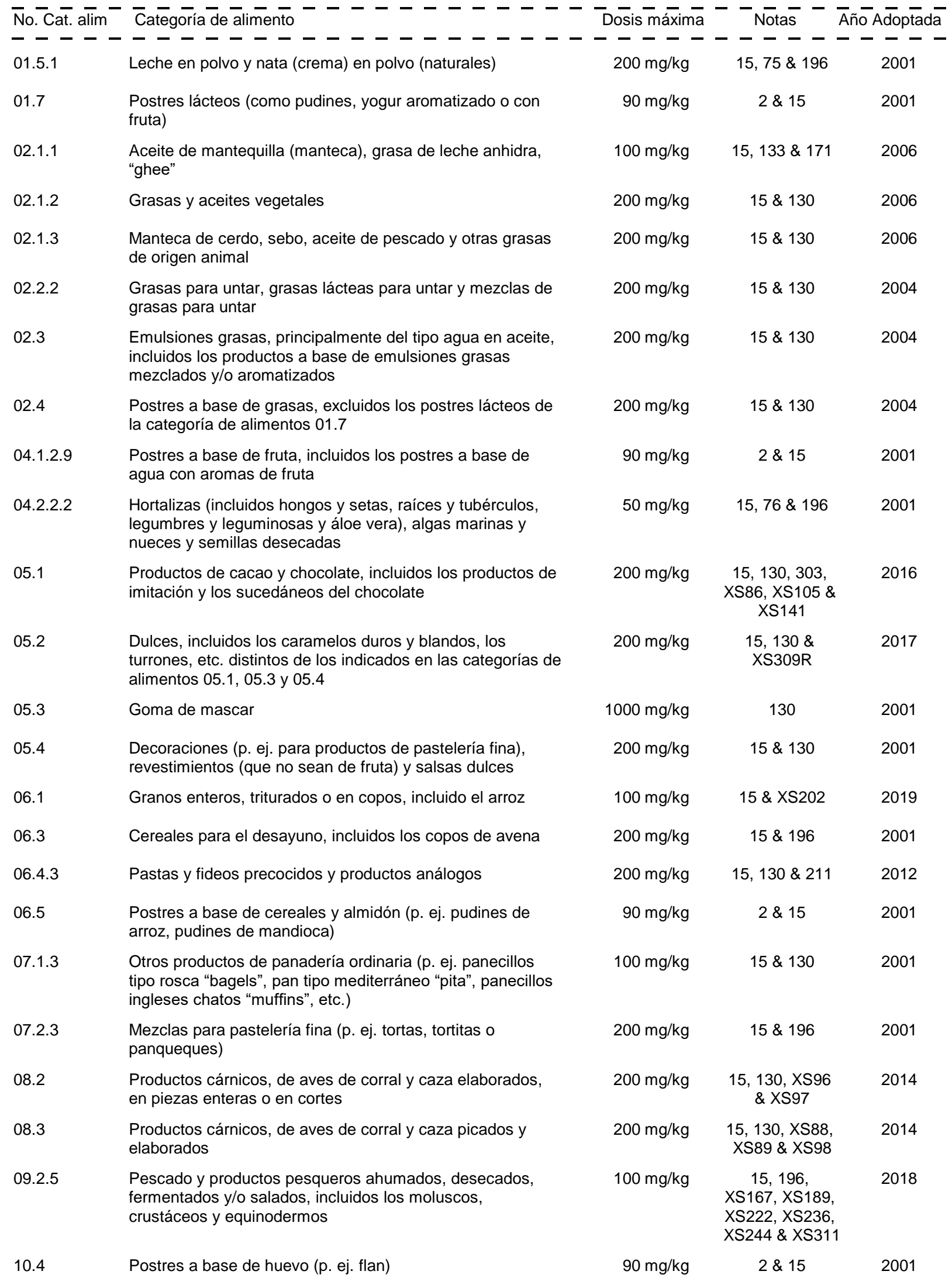




\begin{tabular}{|c|c|c|c|c|}
\hline 12.2 & $\begin{array}{l}\text { Hierbas aromáticas, especias, aderezos y condimentos ( } \mathrm{p} \text {. } \\
\text { ej. el aderezo para fideos instantáneos) }\end{array}$ & $200 \mathrm{mg} / \mathrm{kg}$ & $15 \& 130$ & 2001 \\
\hline 12.5 & Sopas y caldos & $200 \mathrm{mg} / \mathrm{kg}$ & $15,127 \& 130$ & 2012 \\
\hline 12.6 & Salsas y productos análogos & $200 \mathrm{mg} / \mathrm{kg}$ & $\begin{array}{l}15,130 \& \\
\quad \text { XS302 }\end{array}$ & 2018 \\
\hline 13.6 & Complementos alimenticios & $400 \mathrm{mg} / \mathrm{kg}$ & $15 \& 196$ & 2001 \\
\hline 14.1.4 & $\begin{array}{l}\text { Bebidas a base de agua aromatizadas, incluidas las } \\
\text { bebidas para deportistas, bebidas energéticas o bebidas } \\
\text { electrolíticas y bebidas con partículas añadidas }\end{array}$ & $1000 \mathrm{mg} / \mathrm{kg}$ & 15 & 2001 \\
\hline 15.1 & $\begin{array}{l}\text { Aperitivos a base de patatas (papas), cereales, harina o } \\
\text { almidón (derivados de raíces y tubérculos, legumbres y } \\
\text { leguminosas) }\end{array}$ & $200 \mathrm{mg} / \mathrm{kg}$ & $15 \& 130$ & 2005 \\
\hline 15.2 & $\begin{array}{l}\text { Nueces elaboradas, incluidas las nueces revestidas y las } \\
\text { mezclas de nueces (p. ej. con frutas secas) }\end{array}$ & $200 \mathrm{mg} / \mathrm{kg}$ & $15 \& 130$ & 2005 \\
\hline
\end{tabular}

\section{GLICEROL}

SIN 422 Glicerol Clases Funcionales: Humectantes, Espesantes

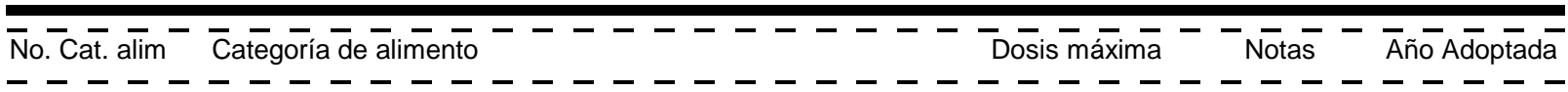

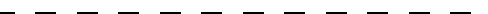

01.2 .2

Cuajada (natural / simple)

BPF

04.2.2.7 Productos a base de hortalizas (incluidos hongos y setas, raíces y tubérculos, legumbres y leguminosas y áloe vera) y algas marinas fermentadas, excluidos los productos fermentados de soja de las categorías 06.8.6, 06.8.7, 12.9.1, 12.9.2. 1 y 12.9 .2 .3

06.4.1 Pastas y fideos frescos y productos análogos

BPF

211

2014

08.1.1 Carne fresca, incluida la de aves de corral y caza, en piezas enteras o en cortes

08.1.2 Carne fresca picada, incluida la de aves de corral y caza

09.2 .2

Pescado, filetes de pescado y productos pesqueros rebozados congelados, incluidos los moluscos, crustáceos y equinodermos

09.2.3 Productos pesqueros picados, mezclados y congelados, incluidos los moluscos, crustáceos y equinodermos

09.2.4.1 Pescado y productos pesqueros cocidos

09.2.4.3 Pescado y productos pesqueros fritos, incluidos los moluscos, crustáceos y equinodermos

09.2.5 Pescado y productos pesqueros ahumados, desecados, fermentados y/o salados, incluidos los moluscos, crustáceos y equinodermos

10.2.2 Productos congelados a base de huevo

$11.4 \quad$ Otros azúcares y jarabes (p. ej. xilosa, jarabe de arce y aderezos de azúcar)

12.1.2 Sucedáneos de la sal

BPF

$16 \& 326$

2015

BPF

2014

BPF

$41 \& X S 166$

2017

BPF

2015

BPF

241

2015

BPF

41

2015

BPF

$300, \mathrm{XS} 167$,

XS189, XS222,

XS236, XS244

\& XS311

BPF

2015

BPF

258

2015

BPF

2015

14.1.5 Café, sucedáneos del café, té, infusiones de hierbas y otras bebidas calientes a base de cereales y granos, excluido el cacao
BPF

160 


\section{GLICÓSIDOS DE ESTEVIOL}

SIN 960a Glicósidos de esteviol de Stevia Clases Funcionales: Edulcorantes rebaudiana Bertoni (glicósidos de esteviol de estevia)

SIN 960b(i) Rebaudiósido A de múltiples donadores de genes expresado en Yarrowialipolytica

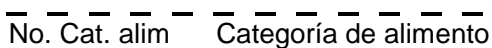

\section{- - -}

01.1 .4

Bebidas lácteas líquidas aromatizadas

Clases Funcionales: Edulcorantes

01.5.2 Productos análogos a la leche y la nata (crema) en polvo

$01.7 \quad$ Postres lácteos (como pudines, yogur aromatizado o con fruta)

02.4 Postres a base de grasas, excluidos los postres lácteos de la categoría de alimentos 01.7

$03.0 \quad$ Hielos comestibles, incluidos los sorbetes

04.1.2.3 Frutas en vinagre, aceite o salmuera

04.1.2.4 Frutas en conserva, enlatadas o en frascos (pasteurizadas)

04.1.2.5 Confituras, jaleas, mermeladas

04.1.2.6 Productos para untar a base de fruta (p. ej. el "chutney") excluidos los productos de la categoría de alimentos 04.1 .2 .5

04.1.2.7 Frutas confitadas

04.1.2.8 Preparados a base de fruta, incluida la pulpa, los purés, los revestimientos de fruta y la leche de coco

04.1.2.9 Postres a base de fruta, incluidos los postres a base de agua con aromas de fruta

04.1.2.10 Productos de fruta fermentada

04.1.2.12 Frutas cocidas o fritas

legumbres y leguminosas y áloe vera), algas marinas $y$ nueces y semillas desecadas

04.2.2.3 Hortalizas (incluidos hongos y setas, raíces y tubérculos, legumbres y leguminosas y áloe vera) y algas marinas en vinagre, aceite, salmuera o salsa de soja

04.2.2.4 Hortalizas (incluidos hongos y setas, raíces y tubérculos, legumbres y leguminosas y áloe vera) y algas marinas en conserva, en latas o frascos (pasteurizadas) o en bolsas de esterilización

Purés y preparados para untar elaborados con hortalizas (incluidos hongos y setas, raíces y tubérculos, legumbres y leguminosas y áloe vera), algas marinas y nueces y semillas (p. ej., la mantequilla de maní (cacahuete))

$40 \mathrm{mg} / \mathrm{kg} \quad 26$

2011

$330 \mathrm{mg} / \mathrm{kg}$

2011

2011

$115 \mathrm{mg} / \mathrm{kg} \quad 26$

2011

$330 \mathrm{mg} / \mathrm{kg}$

2011

$40 \mathrm{mg} / \mathrm{kg} \quad 26$

2011

$40 \mathrm{mg} / \mathrm{kg}$

26

2011

2011

2011

011

2011

2011

2018

2011

2011

11

11

011

$330 \mathrm{mg} / \mathrm{kg} \quad 26$

2011

$70 \mathrm{mg} / \mathrm{kg} \quad 26$

2011

$330 \mathrm{mg} / \mathrm{kg}$

26

2011 


\section{- - - - - - \\ Pulpas y preparados de hortalizas (incluidos hongos y setas, raíces y tubérculos, legumbres y leguminosas y áloe vera), algas marinas y nueces y semillas (como los postres y las salsas a base de hortalizas y hortalizas confitadas) distintos de los indicados en la categoría de alimentos 04.2.2.5}

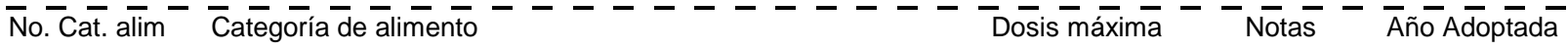

04.2 .2 .7

Productos a base de hortalizas (incluidos hongos y setas, raíces y tubérculos, legumbres y leguminosas y áloe vera) y algas marinas fermentadas, excluidos los productos fermentados de soja de las categorías 06.8.6, 06.8.7, 12.9.1, 12.9.2.1 y 12.9.2.3

04.2.2.8 Hortalizas (incluidos hongos y setas, raíces y tubérculos, legumbres y leguminosas y áloe vera) y algas marinas cocidas o fritas

05.2

Dulces, incluidos los caramelos duros y blandos, los turrones, etc. distintos de los indicados en las categorías de alimentos $05.1,05.3$ y 05.4

05.3

Goma de mascar

06.3

Cereales para el desayuno, incluidos los copos de avena

06.5

Postres a base de cereales y almidón (p. ej. pudines de arroz, pudines de mandioca)

06.8.1 Bebidas a base de soja

08.3.2 Productos cárnicos, de aves de corral y caza picados, elaborados y tratados térmicamente

09.3.1 Pescado y productos pesqueros marinados y/o en gelatina, incluidos los moluscos, crustáceos y equinodermos

09.3.2 Pescado y productos pesqueros escabechados y/o en salmuera, incluidos los moluscos, crustáceos y equinodermos

Sucedáneos de salmón, caviar y otros productos pesqueros a base de huevas

$09.4 \quad$ Pescado y productos pesqueros (incluidos los moluscos, crustáceos y equinodermos) en conserva, con inclusión de los enlatados y fermentados

$10.4 \quad$ Postres a base de huevo (p. ej. flan)

11.6 Edulcorantes de mesa, incluidos los que contienen edulcorantes de gran intensidad

12.2.2 Aderezos y condimentos

Mostazas

Sopas y caldos

12.5

12.6 .1

Salsas emulsionadas y salsas para mojar (p.ej. mayonesa, aderezos para ensaladas, salsa para mojar de cebollas)

12.6.2 Salsas no emulsionadas (p. ej. salsa de tomate "ketchup", salsas a base de queso, salsas a base de nata (crema) y salsas hechas con jugo de carne asada "gravy")

12.6 .3

Mezclas para salsas y "gravies"

$350 \mathrm{mg} / \mathrm{kg}$

$26 \& 127$

$350 \mathrm{mg} / \mathrm{kg} \quad 26 \&$ XS302

2011

$200 \mathrm{mg} / \mathrm{kg}$

26

2011

$40 \mathrm{mg} / \mathrm{kg}$

26

2011

$700 \mathrm{mg} / \mathrm{kg} \quad \begin{array}{r}26,199 \& \\ \text { XS309R }\end{array}$

2017

$3500 \mathrm{mg} / \mathrm{kg}$

26

2011

$350 \mathrm{mg} / \mathrm{kg}$

26

2011

$165 \mathrm{mg} / \mathrm{kg}$

26

2011

$200 \mathrm{mg} / \mathrm{kg}$

26

2011

$100 \mathrm{mg} / \mathrm{kg} \quad 26,202, \mathrm{XS} 88$

2014

XS89 \& XS98

2011

$165 \mathrm{mg} / \mathrm{kg}$

26

2011

$100 \mathrm{mg} / \mathrm{kg}$

26 \& XS291

2018

$100 \mathrm{mg} / \mathrm{kg} \quad 26, \mathrm{XS} 3, \mathrm{XS} 37$ XS70, XS90, XS94 \& XS119

$330 \mathrm{mg} / \mathrm{kg}$

26

BPF

26

2011

$130 \mathrm{mg} / \mathrm{kg}$

26

2011

$50 \mathrm{mg} / \mathrm{kg}$

$26 \& X S 117$

2015

$350 \mathrm{mg} / \mathrm{kg}$

26

2011

$350 \mathrm{mg} / \mathrm{kg}$

26

2011

12.6.4 Salsas ligeras (p. ej. salsa de pescado) 


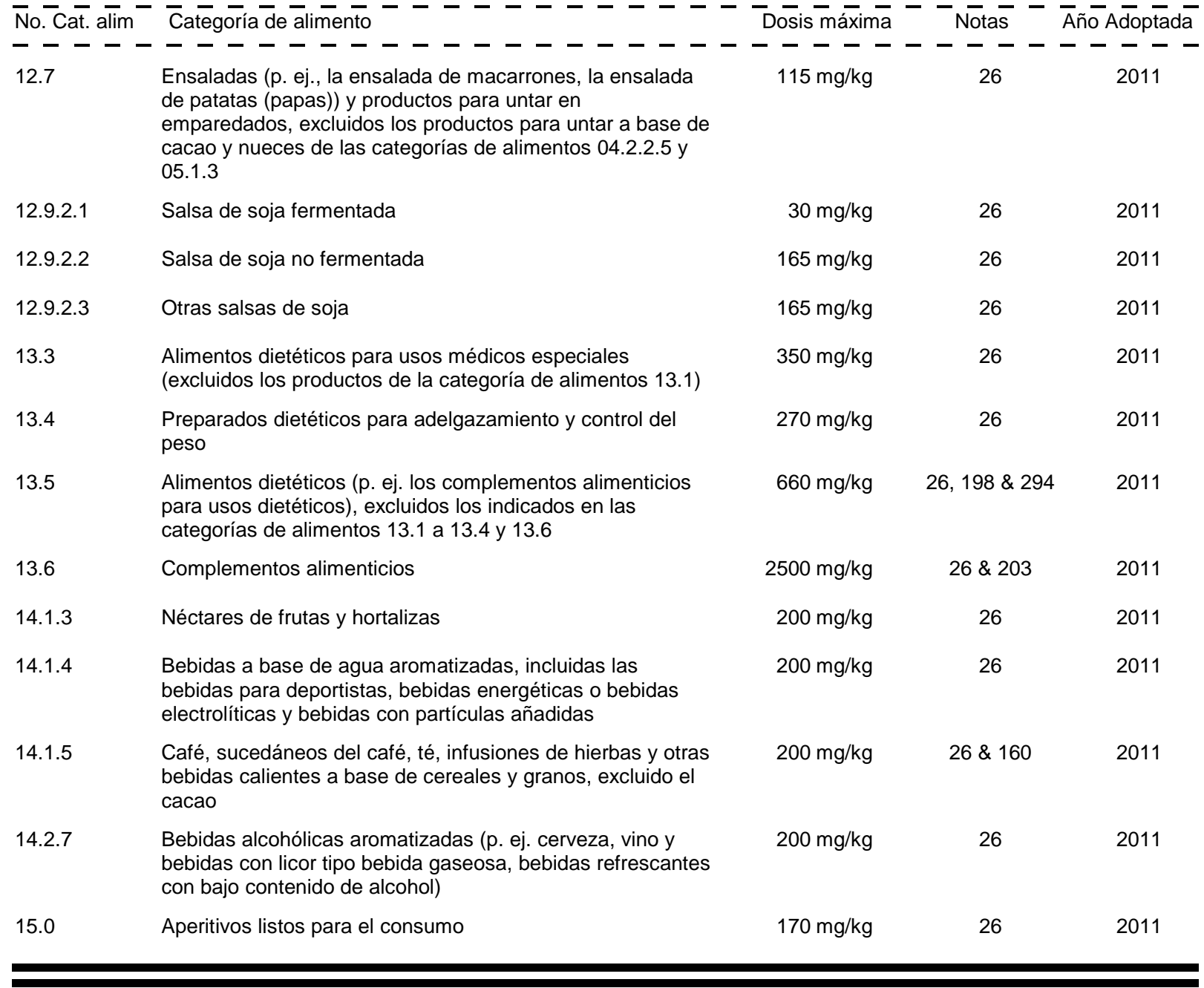

\section{GLUCONATO DE SODIO}

\section{SIN $576 \quad$ Gluconato de sodio Clases Funcionales: Secuestrantes, Estabilizadores, Espesantes}

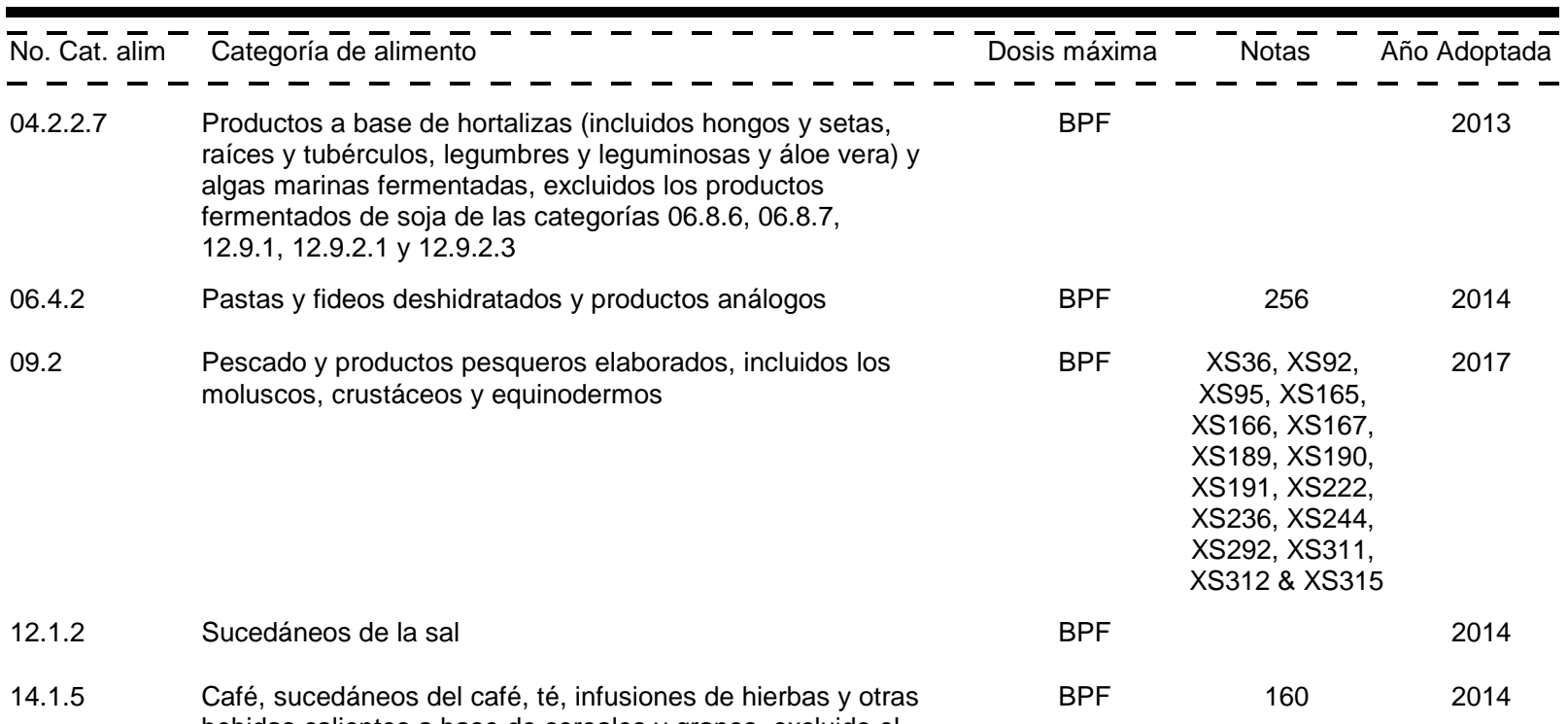
bebidas calientes a base de cereales y granos, excluido el cacao 


\section{GLUCONATO FERROSO}

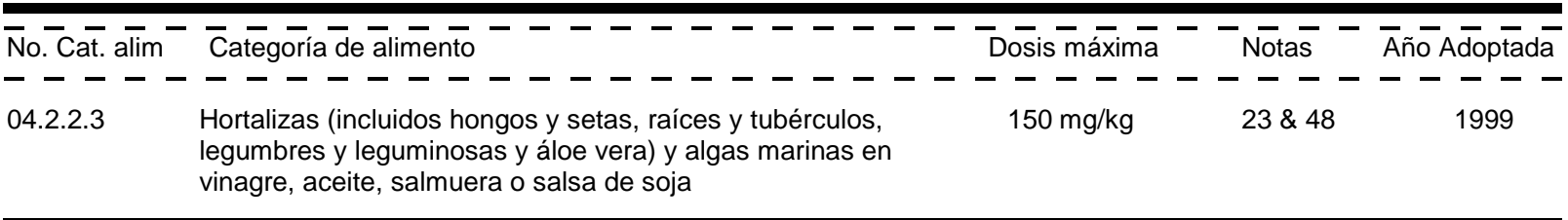

\section{GLUCONO-DELTA-LACTONA}

SIN 575 Glucono-delta-lactona Clases Funcionales: Reguladores de la acidez, Leudantes, Secuestrantes

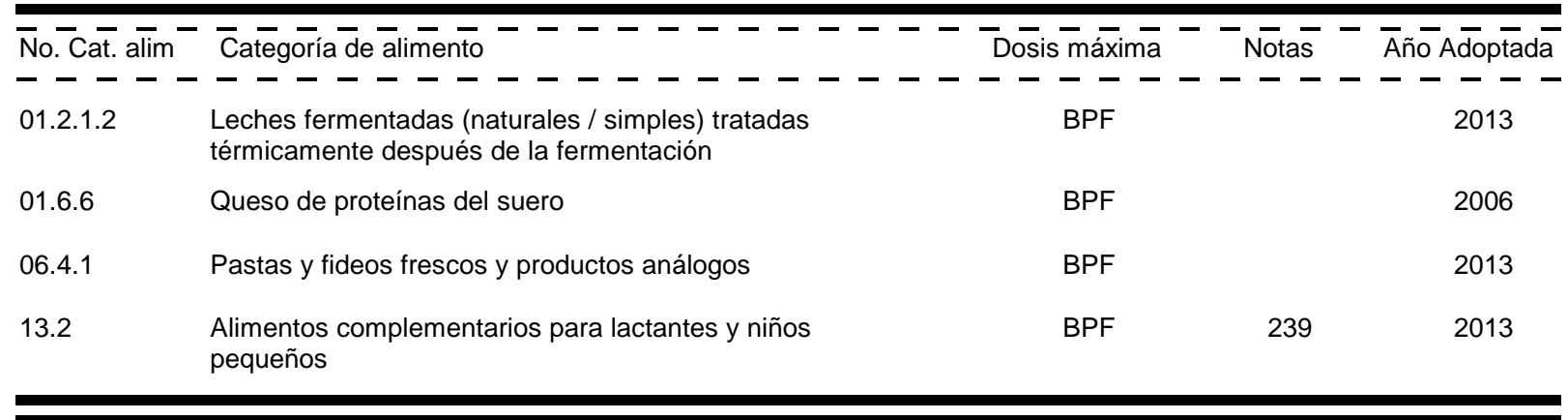

\section{GLUTAMATO DE CALCIO, DI-L-}

SIN $623 \quad$ Glutamato de calcium, di-L- Clases Funcionales: Acentuadores del sabor

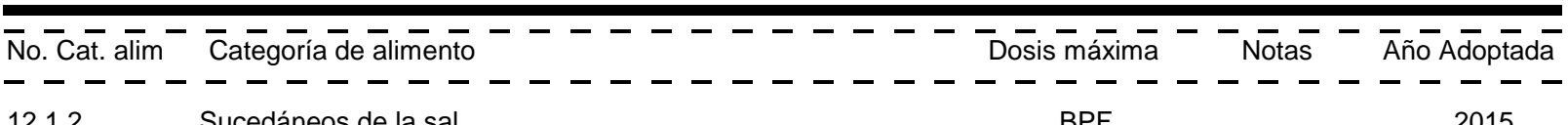
12.1 .2
Sucedáneos de la sal
BPF
2015

\section{GLUTAMATO DE MAGNÉSIO, DI-L-}

\section{SIN 625 Glutamato de magnesio, di-L- Clases Funcionales: Acentuadores del sabor}

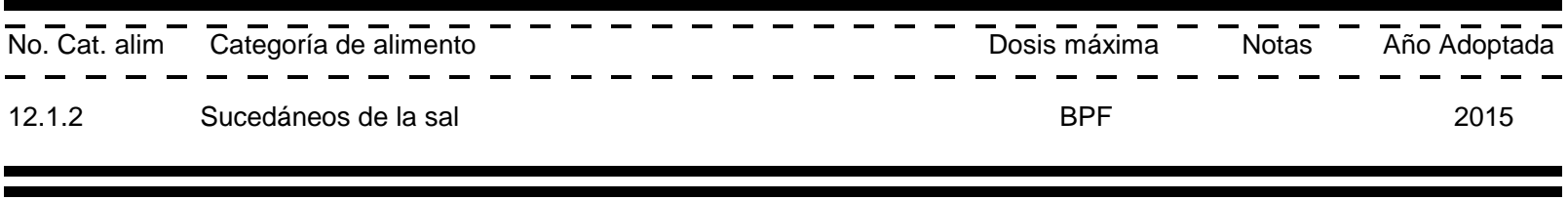

\section{GLUTAMATO MONOAMÓNICO, L-}

\section{SIN $624 \quad$ Glutamato monoamónico, L- Clases Funcionales: Acentuadores del sabor}

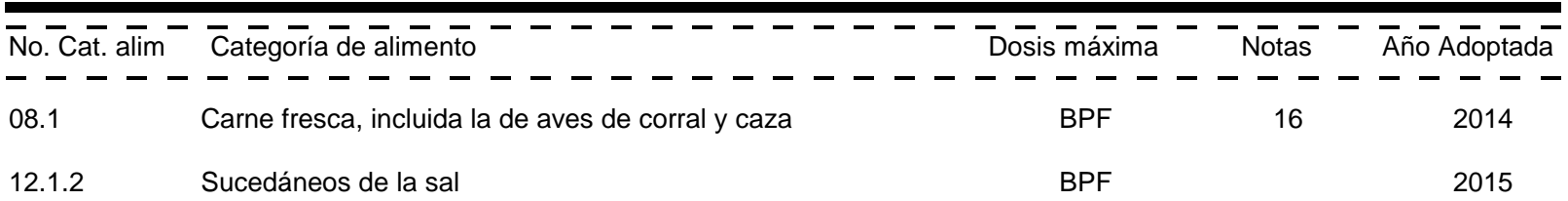

\section{GLUTAMATO MONOPOTÁSICO, L-}

SIN $622 \quad$ Glutamato monopotassium, L- Clases Funcionales: Acentuadores del sabor 


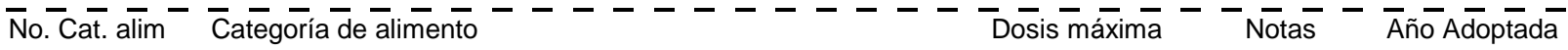

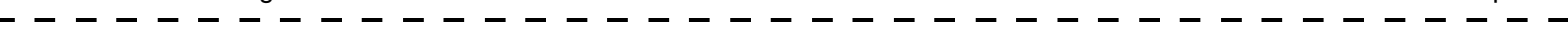

$\begin{array}{llll}\text { 09.2.2 } & \text { Pescado, filetes de pescado y productos pesqueros } & \text { BPF } & 41\end{array}$ rebozados congelados, incluidos los moluscos, crustáceos y equinodermos

\section{GLUTAMATO MONOSÓDICO, L-}

SIN $621 \quad$ Glutamato monosódico, L- Clases Funcionales: Acentuadores del sabor

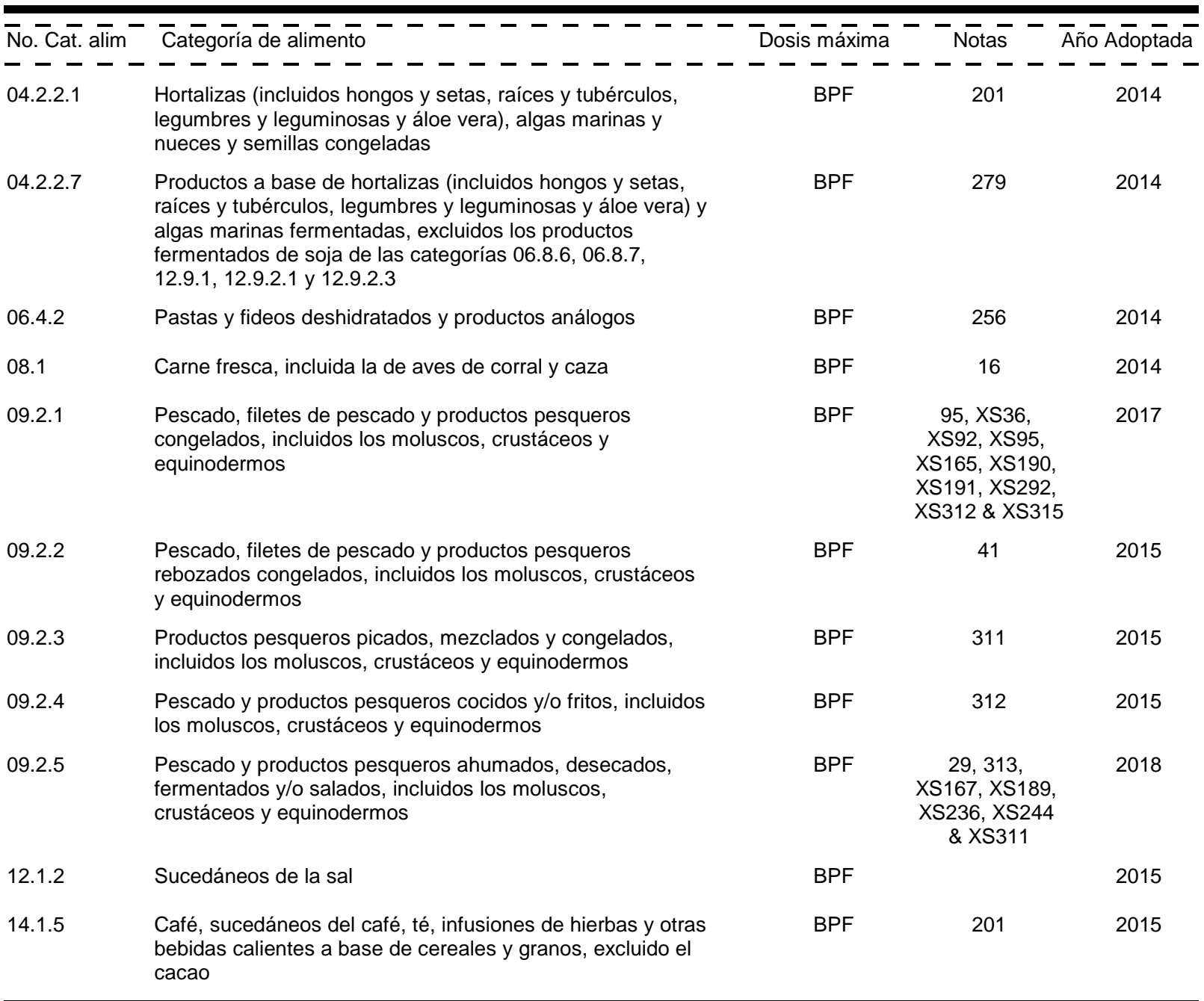

\section{GOMA ARÁBIGA (GOMA DE ACACIA)}

SIN $414 \quad$ Goma arábiga (Goma de acacia) Clases Funcionales: Incrementadores del volumen, Sustancias inertes, Emulsionantes, Agentes de glaseado, Estabilizadores, Espesantes

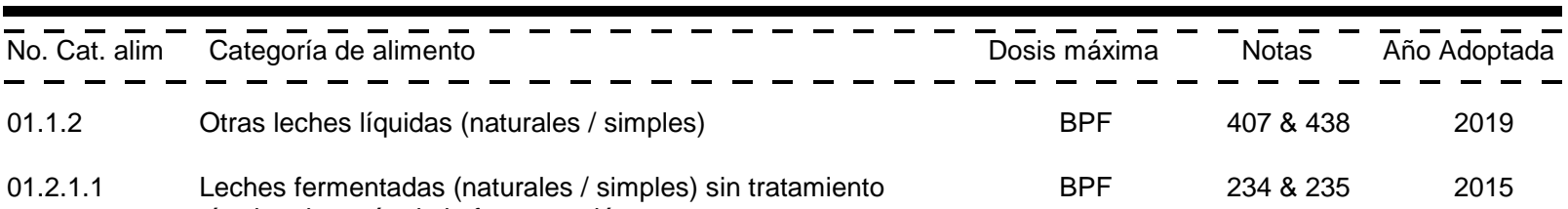
térmico después de la fermentación 


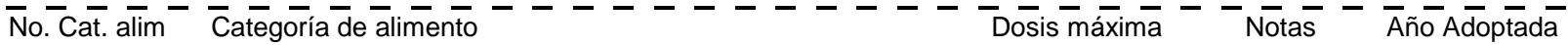

$----1$

Leches fermentadas (naturales / simples) tratadas

2013 térmicamente después de la fermentación

01.2.2 Cuajada (natural / simple)

BPF

BPF

2013

01.4.1 Nata (crema) pasteurizada (natural / simple)

BPF

236

2013

01.4.2 Natas (cremas) esterilizadas y UHT, natas (cremas) para batir o batidas y natas (cremas) de contenido de grasa reducido (naturales / simples)

06.4.1 Pastas y fideos frescos y productos análogos

06.4.2 Pastas y fideos deshidratados y productos análogos

08.1.1 Carne fresca, incluida la de aves de corral y caza, en piezas enteras o en cortes

08.1.2 Carne fresca picada, incluida la de aves de corral y caza

09.2.1 Pescado, filetes de pescado y productos pesqueros congelados, incluidos los moluscos, crustáceos y equinodermos

09.2.2 Pescado, filetes de pescado y productos pesqueros rebozados congelados, incluidos los moluscos, crustáceos y equinodermos

09.2.3 Productos pesqueros picados, mezclados y congelados, incluidos los moluscos, crustáceos y equinodermos

09.2.4.1 Pescado y productos pesqueros cocidos

09.2.4.2 Moluscos, crustáceos y equinodermos cocidos

09.2.4.3 Pescado y productos pesqueros fritos, incluidos los moluscos, crustáceos y equinodermos

09.2.5 Pescado y productos pesqueros ahumados, desecados, fermentados y/o salados, incluidos los moluscos, crustáceos y equinodermos

10.2.1 Productos líquidos a base de huevo

Productos congelados a base de huevo

10.2.2

Otros azúcares y jarabes (p. ej. xilosa, jarabe de arce y aderezos de azúcar)

12.1.2 Sucedáneos de la sal

13.2 Alimentos complementarios para lactantes y niños pequeños

14.1.5 Café, sucedáneos del café, té, infusiones de hierbas y otras bebidas calientes a base de cereales y granos, excluido el cacao
BPF

2013

BPF

211

2014

BPF

256

2014

BPF

$16 \& 326$

2015

BPF

281

2014

BPF

16, XS36,

XS92, XS95,

XS165, XS190

XS191, XS292,

XS312 \& XS315

BPF

$16 \& X S 166$

2017

BPF

16

2014

BPF

$16 \& 325$

2015

BPF

16

2015

BPF

$41,325 \& 332$

2015

BPF

300, 332 ,

XS222, XS236,

XS244 \& XS311

BPF

2014

BPF

2014

BPF

258

2014

BPF

2014

$10000 \mathrm{mg} / \mathrm{kg}$

$239 \& 273$

2014

BPF

160

2014
XS167, XS189,

\section{GOMA DE SEMILLAS DE ALGARROBO}

SIN 410 Goma de semillas de algarrobo Clases Funcionales: Emulsionantes, Estabilizadores, Espesantes

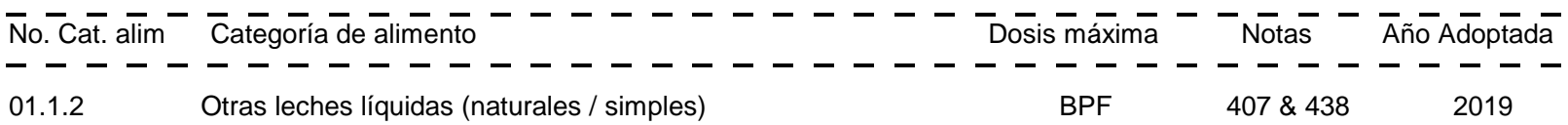




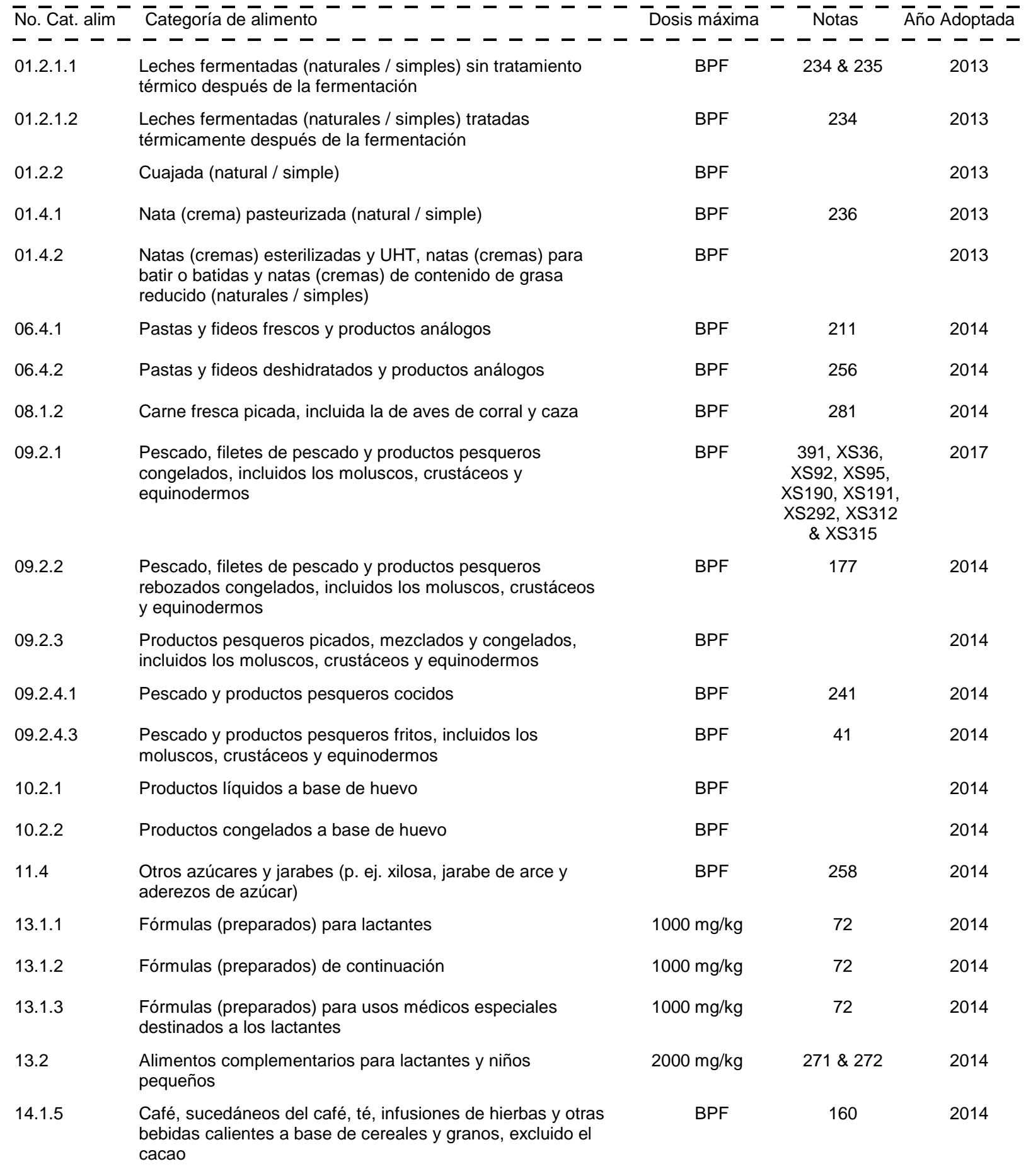

\section{GOMA GELLAN}

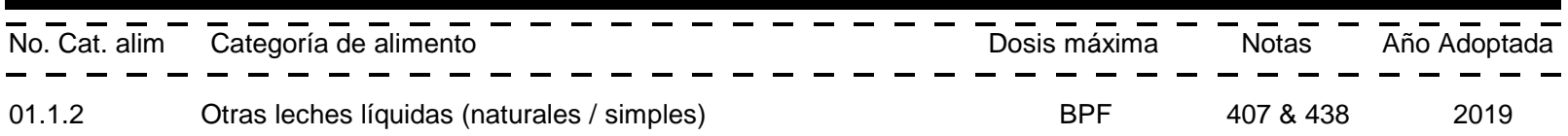




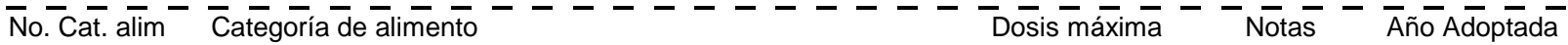

- - - térmico después de la fermentación

01.2.1.2 Leches fermentadas (naturales / simples) tratadas térmicamente después de la fermentación

01.4.1 Nata (crema) pasteurizada (natural / simple)

BPF

Natas (cremas) esterilizadas y UHT, natas (cremas) para batir o batidas y natas (cremas) de contenido de grasa reducido (naturales / simples)

06.4.1 Pastas y fideos frescos y productos análogos

06.4.2 Pastas y fideos deshidratados y productos análogos

08.1.1 Carne fresca, incluida la de aves de corral y caza, en piezas enteras o en cortes

08.1.2 Carne fresca picada, incluida la de aves de corral y caza

09.2.1 Pescado, filetes de pescado y productos pesqueros congelados, incluidos los moluscos, crustáceos y equinodermos

09.2.2 Pescado, filetes de pescado y productos pesqueros rebozados congelados, incluidos los moluscos, crustáceos y equinodermos

09.2.3 Productos pesqueros picados, mezclados y congelados, incluidos los moluscos, crustáceos y equinodermos

09.2.4.1 Pescado y productos pesqueros cocidos

09.2.4.3 Pescado y productos pesqueros fritos, incluidos los moluscos, crustáceos y equinodermos

10.2.1 Productos líquidos a base de huevo

10.2.2 Productos congelados a base de huevo

$11.4 \quad$ Otros azúcares y jarabes (p. ej. xilosa, jarabe de arce y aderezos de azúcar)

12.1.2 Sucedáneos de la sal

14.1.5 Café, sucedáneos del café, té, infusiones de hierbas y otras bebidas calientes a base de cereales y granos, excluido el cacao
BPF

BPF

BPF

\section{$234 \& 235$}

234

2013

236

2013

2013

BPF

211

2014

BPF

256

2014

BPF

$16 \& 326$

2015

BPF

281

2014

BPF

XS36, XS92,

XS95, XS165,

XS190, XS191

XS292, XS312

\& XS315

BPF

XS166

2017

BPF

2014

BPF

241

2014

BPF

41

2014

BPF

2014

BPF

2014

BPF

258

2014

BPF

2014

BPF

160

2014

\section{GOMA GUAR}

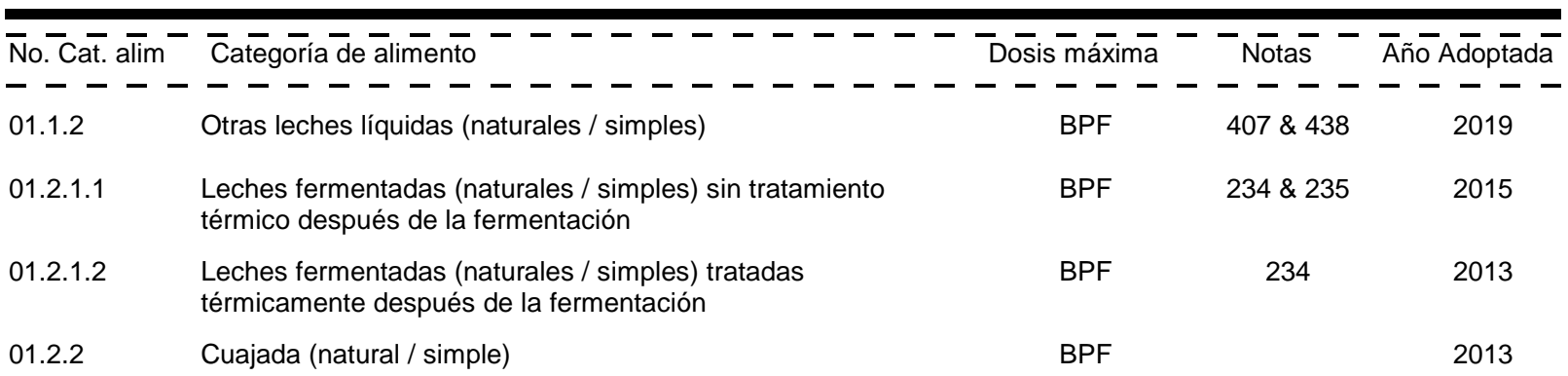




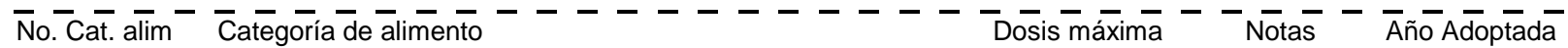
- - - - - - - - - - - - - - - - - - - - - - - - - - -

01.4.2 Natas (cremas) esterilizadas y UHT, natas (cremas) para 2013 batir o batidas y natas (cremas) de contenido de grasa reducido (naturales / simples)

04.2.2.7 Productos a base de hortalizas (incluidos hongos y setas, raíces y tubérculos, legumbres y leguminosas y áloe vera) y algas marinas fermentadas, excluidos los productos fermentados de soja de las categorías 06.8.6, 06.8.7, 12.9.1, 12.9.2.1 y 12.9 .2 .3

06.4.1 Pastas y fideos frescos y productos análogos

06.4 .2

Pastas y fideos deshidratados y productos análogos

08.1 .2

Carne fresca picada, incluida la de aves de corral y caza

09.2 .1

Pescado, filetes de pescado y productos pesqueros congelados, incluidos los moluscos, crustáceos y equinodermos

09.2 .2

Pescado, filetes de pescado y productos pesqueros y equinodermos

09.2.3 Productos pesqueros picados, mezclados y congelados, incluidos los moluscos, crustáceos y equinodermos

09.2.4.1 Pescado y productos pesqueros cocidos

09.2.4.3 Pescado y productos pesqueros fritos, incluidos los moluscos, crustáceos y equinodermos

09.2.5 Pescado y productos pesqueros ahumados, desecados, fermentados y/o salados, incluidos los moluscos, crustáceos y equinodermos

10.2.1 Productos líquidos a base de huevo

10.2.2 Productos congelados a base de huevo

$11.4 \quad$ Otros azúcares y jarabes (p. ej. xilosa, jarabe de arce y aderezos de azúcar)

12.1.2 Sucedáneos de la sal

13.1.1 Fórmulas (preparados) para lactantes

13.1.2 Fórmulas (preparados) de continuación

13.1.3 Fórmulas (preparados) para usos médicos especiales destinados a los lactantes

13.2 Alimentos complementarios para lactantes y niños pequeños

14.1.5 Café, sucedáneos del café, té, infusiones de hierbas y otras bebidas calientes a base de cereales y granos, excluido el cacao
BPF

BPF

211

256

BPF

281

2014 BPF BPF 73, 391, XS36 XS92, XS95, XS190, XS191, XS292, XS312

\& XS315

2013

2013

2014

2017

177

2014

2015

BPF

41

2018

XS236, XS244

\& XS311

BPF

BPF

BPF

258

BPF

2014

$1000 \mathrm{mg} / \mathrm{kg}$

$14 \& 72$

2014

$1000 \mathrm{mg} / \mathrm{kg}$

72

2014

$1000 \mathrm{mg} / \mathrm{kg}$

$14 \& 72$

2014

$2000 \mathrm{mg} / \mathrm{kg}$

$271 \& 272$

2014

BPF

160

2014

\section{GOMA KARAYA}




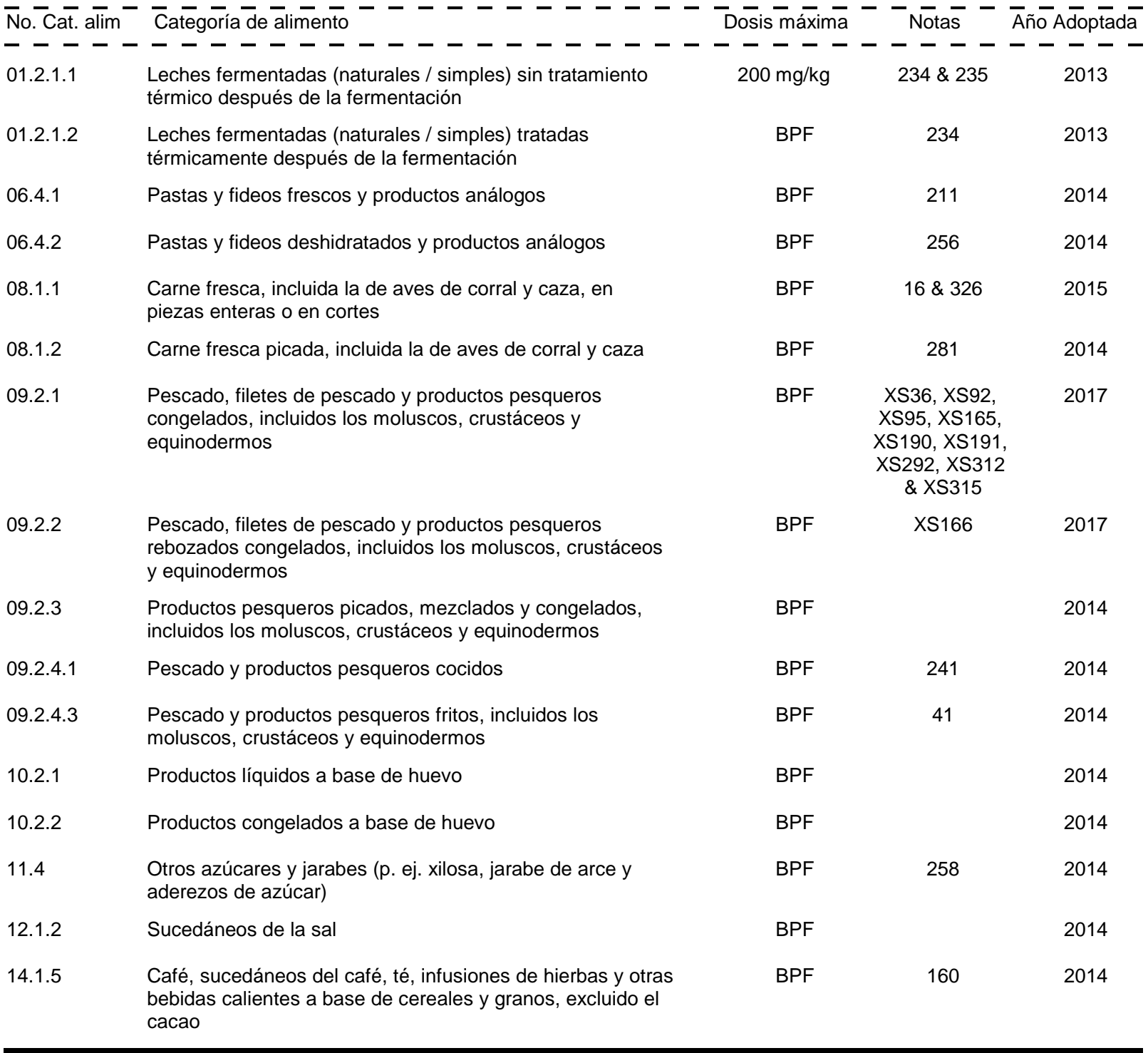

\section{GOMA LACA, BLANQUEADA}

SIN 904 Goma laca, blanqueada Clases Funcionales: Agentes de glaseado

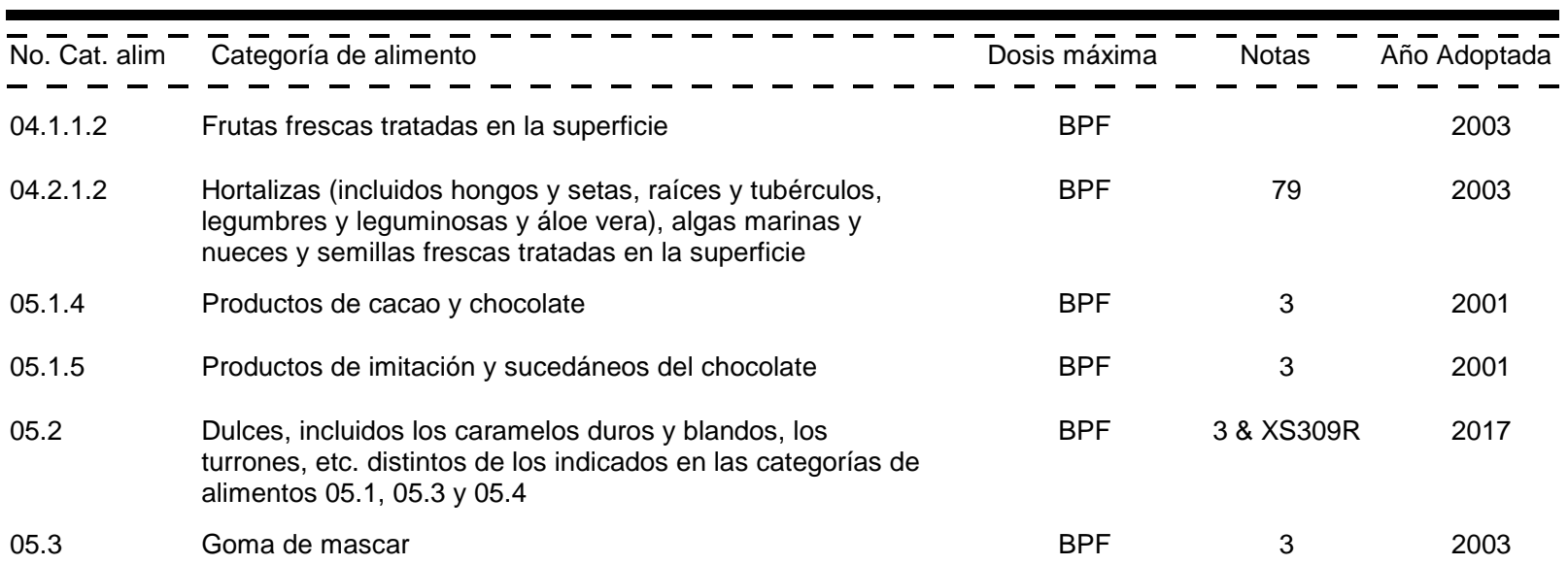




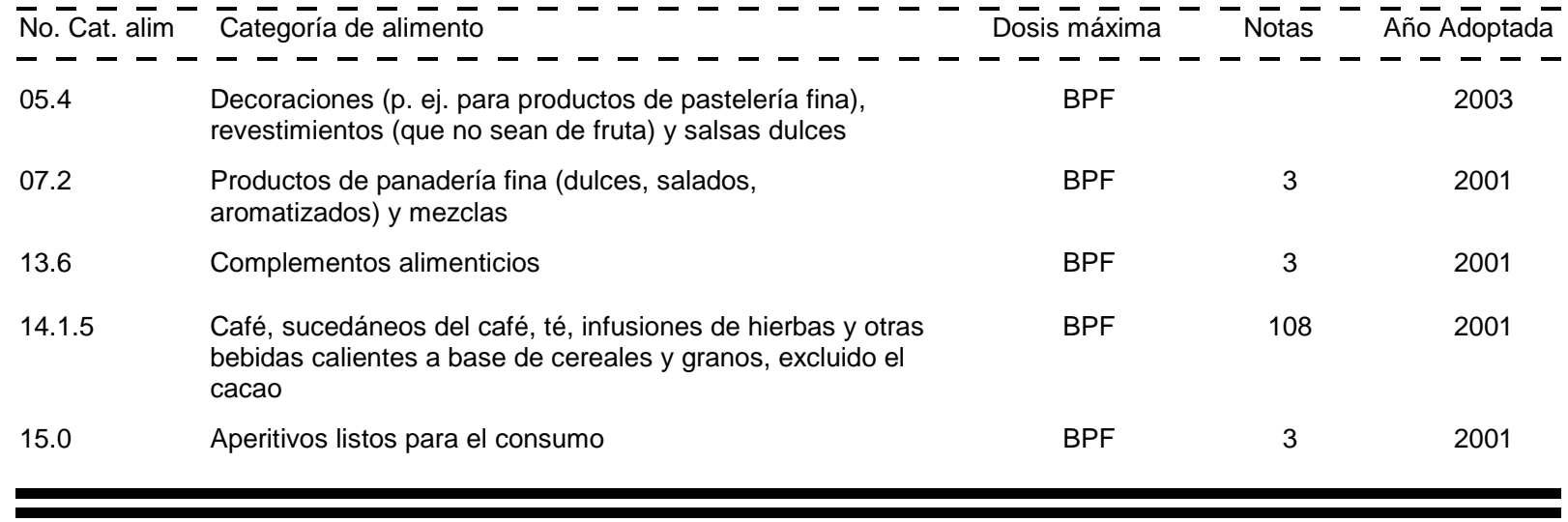

\section{GOMA TARA}

SIN $417 \quad$ Goma tara Clases Funcionales: Agentes gelificantes, Estabilizadores, Espesantes

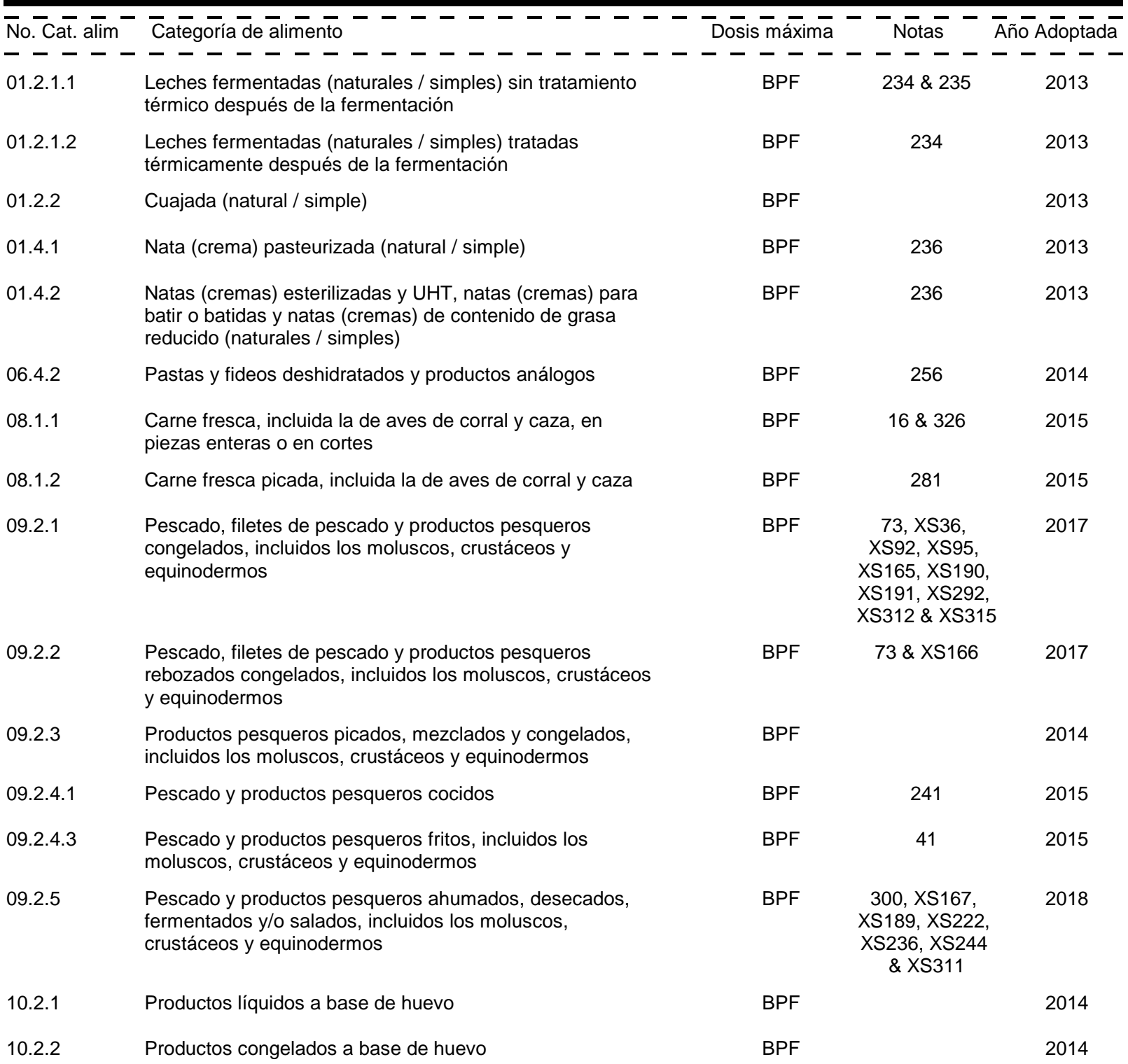




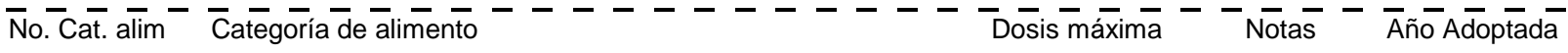
- - - - - - - - - - - - - - - - - - - - - - - - - -

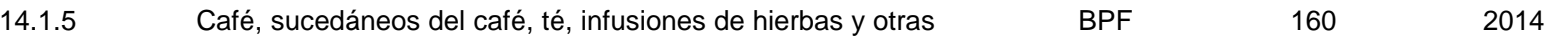
bebidas calientes a base de cereales y granos, excluido el cacao

\section{GOMA TRAGACANTO}

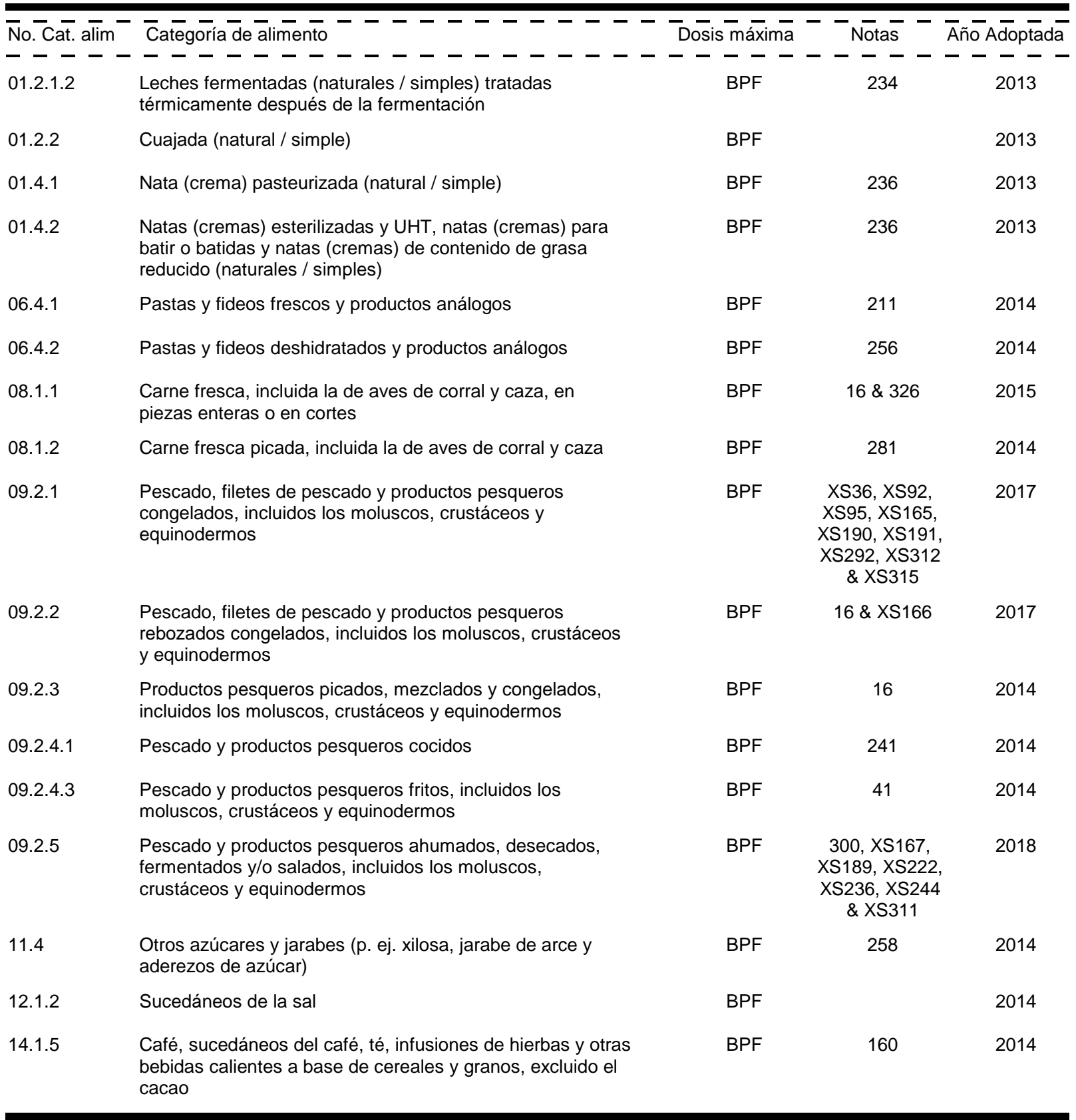

\section{GOMA XANTANA}

Goma xantana
Clases Funcionales: Emulsionantes, Espumantes, Estabilizadores, Espesantes 


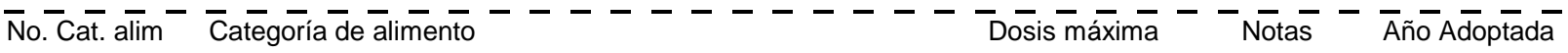
- - - - - - - - - - - - - - - - - - - - - - - - - - BPF $\quad 407 \& 438 \quad 2019$

01.2.1.1 Leches fermentadas (naturales / simples) sin tratamiento

BPF

$234 \& 235$ 2013

01.2.1.2 térmico después de la fermentación

BPF

234

2013

01.2 .2 térmicamente después de la fermentación

BPF

2015

01.4.1 Nata (crema) pasteurizada (natural / simple)

BPF

236

01.4.2 Natas (cremas) esterilizadas y UHT, natas (cremas) para

BPF batir o batidas y natas (cremas) de contenido de grasa reducido (naturales / simples)

04.2.2.7 Productos a base de hortalizas (incluidos hongos y setas, raíces y tubérculos, legumbres y leguminosas y áloe vera) y algas marinas fermentadas, excluidos los productos fermentados de soja de las categorías 06.8.6, 06.8.7, 12.9.1, 12.9.2.1 y 12.9 .2 .3

06.4.1 Pastas y fideos frescos y productos análogos

BPF

06.4.2 Pastas y fideos deshidratados y productos análogos

BPF

08.1.1 Carne fresca, incluida la de aves de corral y caza, en piezas enteras o en cortes

Pescado, filetes de pescado y productos pesqueros congelados, incluidos los moluscos, crustáceos y equinodermos

09.2.2 Pescado, filetes de pescado y productos pesqueros rebozados congelados, incluidos los moluscos, crustáceos y equinodermos

Productos pesqueros picados, mezclados y congelados, incluidos los moluscos, crustáceos y equinodermos

09.2.4.1 Pescado y productos pesqueros cocidos

09.2.4.3 Pescado y productos pesqueros fritos, incluidos los moluscos, crustáceos y equinodermos

09.2.5 Pescado y productos pesqueros ahumados, desecados, fermentados y/o salados, incluidos los moluscos, crustáceos y equinodermos

10.2.1 Productos líquidos a base de huevo

10.2.2 Productos congelados a base de huevo

11.4 Otros azúcares y jarabes (p. ej. xilosa, jarabe de arce y aderezos de azúcar)

12.1.2 Sucedáneos de la sal

13.2 Alimentos complementarios para lactantes y niños pequeños

14.1.5 Café, sucedáneos del café, té, infusiones de hierbas y otras bebidas calientes a base de cereales y granos, excluido el cacao
BPF

BPF

281

391, XS36, 2017

XS92, XS95, XS190, XS191 XS292, XS312

\& XS315 


\section{GUANILATO DE CALCIO, 5'-}

\author{
SIN $629 \quad$ Guanilato de calcio, 5'-
}

Clases Funcionales: Acentuadores del sabor

\section{GUANILATO DIPOTÁSICO, 5'-}

SIN 628

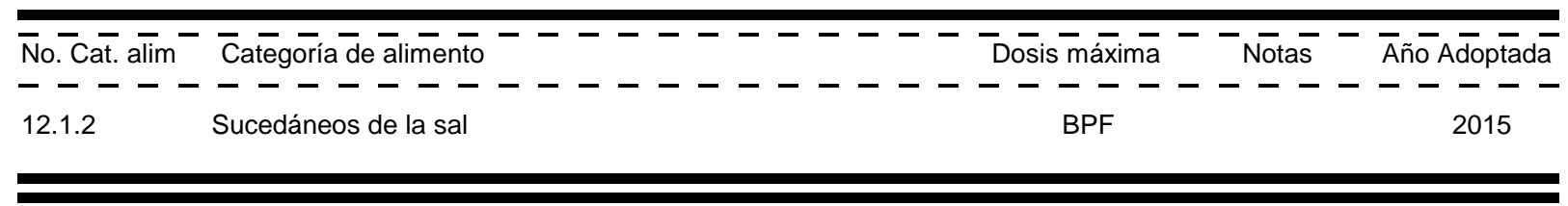

GUANILATO DISÓDICO, 5'-

SIN 627

Guanilato disódico, 5'-

Clases Funcionales: Acentuadores del sabor

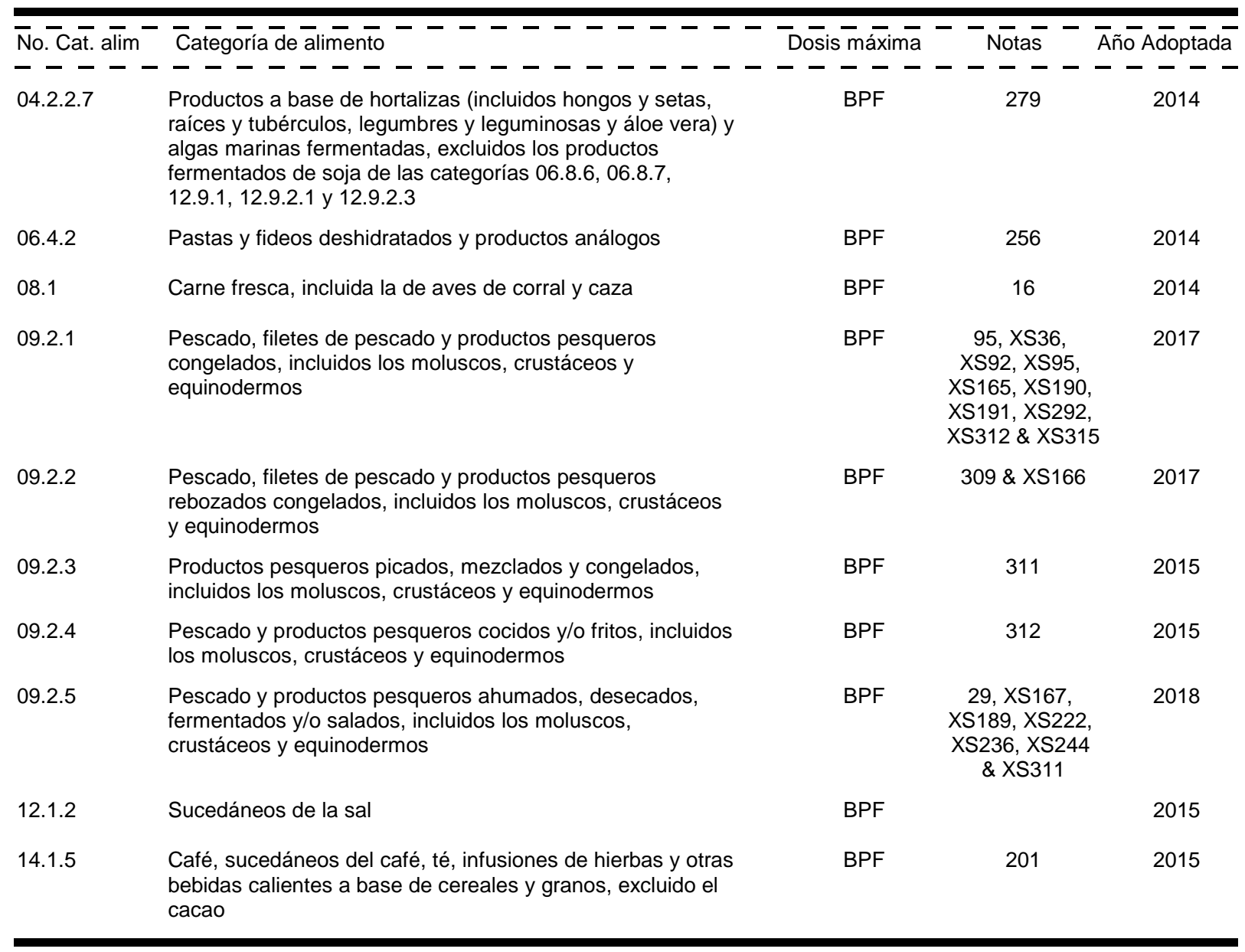


HARINA KONJAC

SIN $425 \quad$ Harina konjac
Clases Funcionales: Sustancias inertes, Emulsionantes, Agentes gelificantes, Agentes de glaseado, Humectantes, Estabilizadores, Espesantes

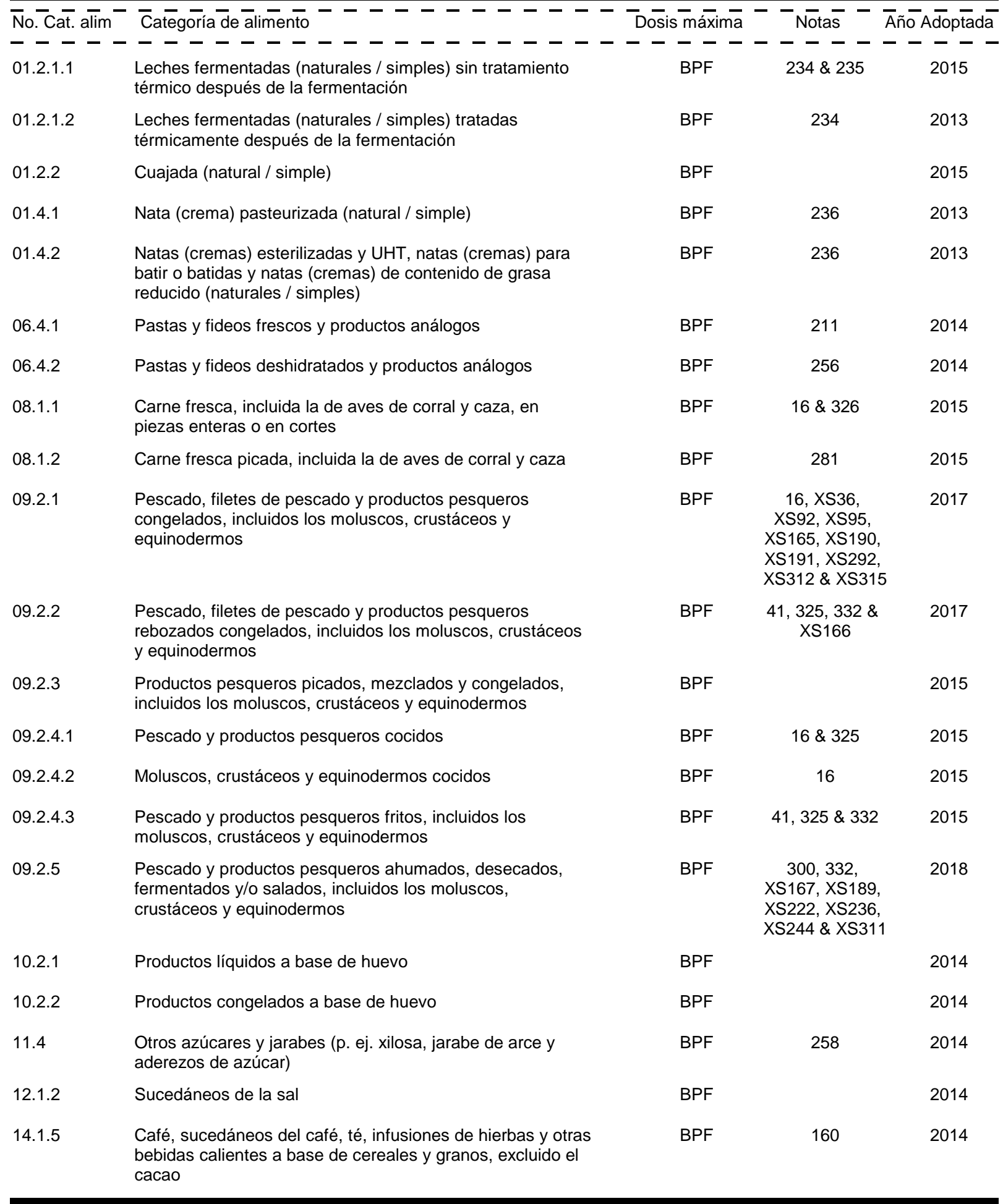




\section{HEXAMETILENTETRAMINA}

SIN 239

Hexametilentetramina
Clases Funcionales: Sustancias conservadoras

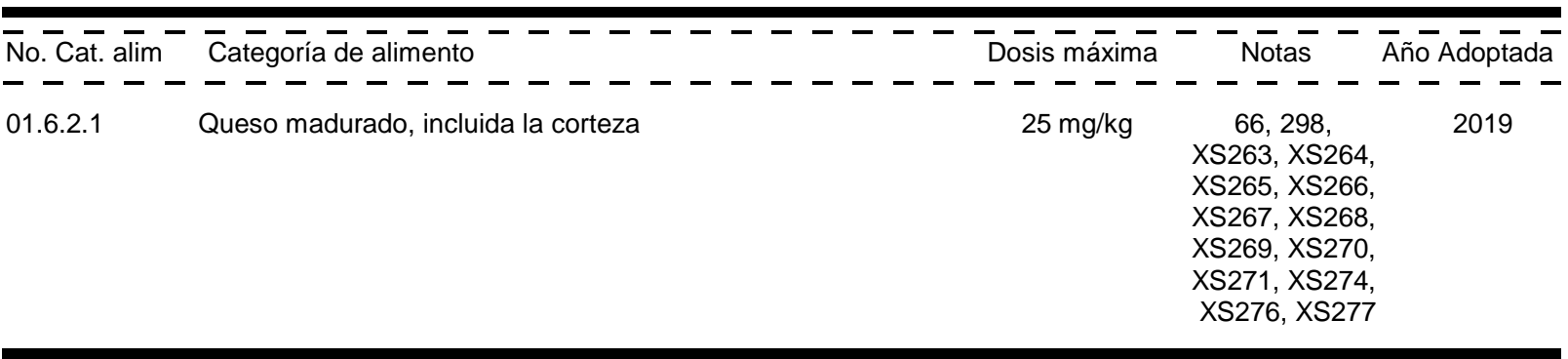

\section{HIDROXIBENZOATOS, PARA-}

$\begin{array}{lll}\text { SIN } 214 & \text { Etil para-hidroxibenzoato } & \text { Clases Funcionales: Sustancias conservadoras } \\ \text { SIN } 218 & \text { Metil para-hydroxibenzoato } & \text { Clases Funcionales: Sustancias conservadoras }\end{array}$

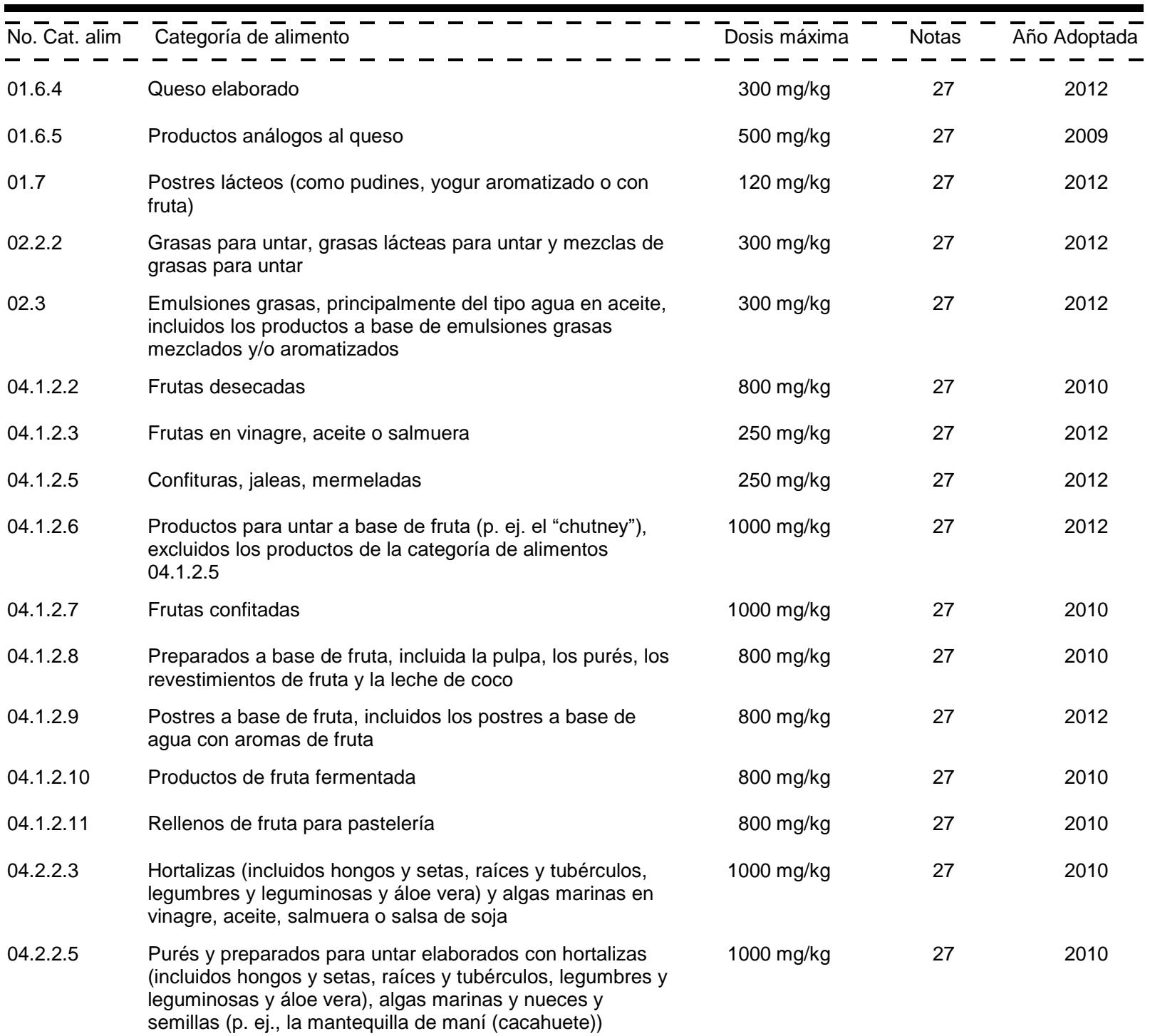



04.2.2.6 Pulpas y preparados de hortalizas (incluidos hongos y setas, raíces y tubérculos, legumbres y leguminosas y áloe vera), algas marinas y nueces y semillas (como los postres y las salsas a base de hortalizas y hortalizas confitadas) distintos de los indicados en la categoría de alimentos 04.225

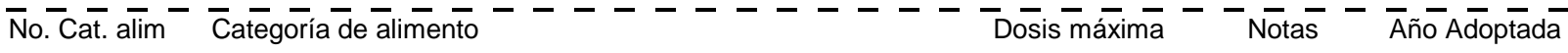

04.2 .2 .7

Productos a base de hortalizas (incluidos hongos y setas, raíces y tubérculos, legumbres y leguminosas y áloe vera) y algas marinas fermentadas, excluidos los productos fermentados de soja de las categorías 06.8.6, 06.8.7. 12.9.1, 12.9.2.1 y 12.9 .2 .3

05.1.3 Productos para untar a base de cacao, incluidos los rellenos a base de cacao

05.1.5 Productos de imitación y sucedáneos del chocolate

$05.2 \quad$ Dulces, incluidos los caramelos duros y blandos, los turrones, etc. distintos de los indicados en las categorías de alimentos $05.1,05.3$ y 05.4

05.3

Goma de mascar

05.4

Decoraciones (p. ej. para productos de pastelería fina), revestimientos (que no sean de fruta) y salsas dulces

07.2

Productos de panadería fina (dulces, salados, aromatizados) y mezclas

$08.4 \quad$ Envolturas o tripas comestibles (p. ej. para embutidos)

09.3 Pescado y productos pesqueros semiconservados, incluidos los moluscos, crustáceos y equinodermos

$11.4 \quad$ Otros azúcares y jarabes (p. ej. xilosa, jarabe de arce y aderezos de azúcar)

$12.3 \quad$ Vinagres

14.2 .2

14.2 .4

14.2 .5

\section{Mostazas}

Salsas y productos análogos

Bebidas a base de agua aromatizadas, incluidas las electrolíticas y bebidas con partículas añadidas

Café, sucedáneos del café, té, infusiones de hierbas y otras bebidas calientes a base de cereales y granos, excluido el cacao

Sidra y sidra de pera

Vinos (distintos de los de uva)

Aguamiel

Bebidas alcohólicas aromatizadas (p. ej. cerveza, vino y bebidas con licor tipo bebida gaseosa, bebidas refrescantes con bajo contenido de alcohol)

Aperitivos a base de patatas (papas), cereales, harina 0 almidón (derivados de raíces y tubérculos, legumbres y leguminosas)

Nueces elaboradas, incluidas las nueces revestidas y las mezclas de nueces (p. ej. con frutas secas) bebidas para deportistas, bebidas energéticas o bebidas
$1000 \mathrm{mg} / \mathrm{kg}$

27

2010

$300 \mathrm{mg} / \mathrm{kg}$

27

2012

$\begin{array}{rcc}300 \mathrm{mg} / \mathrm{kg} & 27 \& \text { XS86 } & 2016 \\ 300 \mathrm{mg} / \mathrm{kg} & 27 & 2009 \\ 1000 \mathrm{mg} / \mathrm{kg} & 27 \& \text { XS309R } & 2017\end{array}$

$1500 \mathrm{mg} / \mathrm{kg} \quad 27 \quad 2010$

$300 \mathrm{mg} / \mathrm{kg} \quad 27 \quad 2010$

$300 \mathrm{mg} / \mathrm{kg} \quad 27 \quad 2010$

$36 \mathrm{mg} / \mathrm{kg} \quad 27 \quad 2010$

$1000 \mathrm{mg} / \mathrm{kg} \quad 27 \& X S 291 \quad 2018$

$100 \mathrm{mg} / \mathrm{kg} \quad 27 \quad 2012$

$100 \mathrm{mg} / \mathrm{kg} \quad 27 \quad 2012$

$300 \mathrm{mg} / \mathrm{kg} \quad 27 \quad 2010$

$1000 \mathrm{mg} / \mathrm{kg} \quad 27 \&$ XS302 2018

$500 \mathrm{mg} / \mathrm{kg} \quad 27 \quad 2010$

$450 \mathrm{mg} / \mathrm{kg}$

$27 \& 160$

$200 \mathrm{mg} / \mathrm{kg}$

27

2010

$200 \mathrm{mg} / \mathrm{kg}$

2012

$200 \mathrm{mg} / \mathrm{kg}$

27

2010

$1000 \mathrm{mg} / \mathrm{kg}$

$27 \& 224$

2012

$300 \mathrm{mg} / \mathrm{kg}$

27

2009

$300 \mathrm{mg} / \mathrm{kg}$ 
HIDRÓXIDO DE AMÓNIO

SIN 527 Hidróxido de amónio Clases Funcionales: Reguladores de la acidez

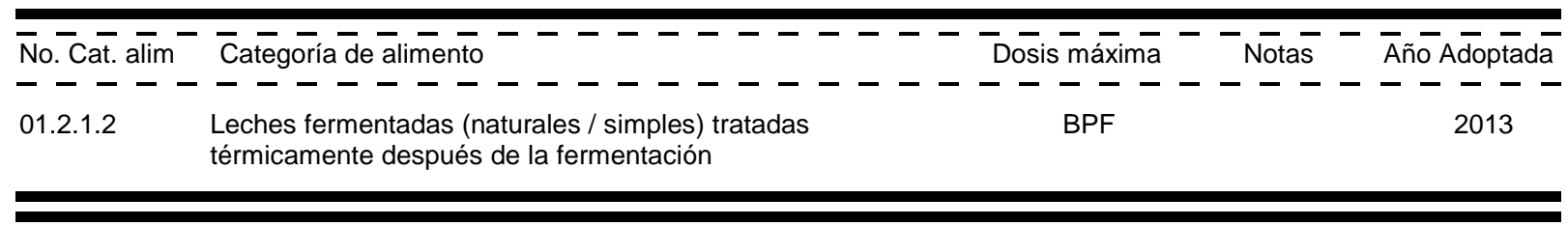

HIDRÓXIDO DE CALCIO

SIN $526 \quad$ Hidróxido de calcio

Clases Funcionales: Reguladores de la acidez, Agentes endurecedores

\begin{tabular}{|c|c|c|c|c|}
\hline 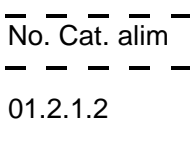 & 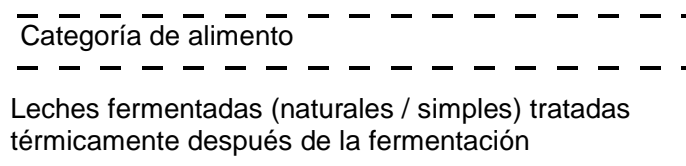 & $\begin{array}{c}\text { Dosis máxim } \\
--\overline{B P F}\end{array}$ & Notas & 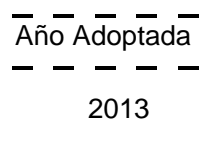 \\
\hline 01.8 .2 & $\begin{array}{l}\text { Suero en polvo y productos a base de suero en polvo, } \\
\text { excluidos los quesos de suero }\end{array}$ & BPF & & 2006 \\
\hline 02.2 .1 & Mantequilla (manteca) & BPF & & 2008 \\
\hline 13.1 .1 & Fórmulas (preparados) para lactantes & $2000 \mathrm{mg} / \mathrm{kg}$ & $55 \& 72$ & 2013 \\
\hline 13.1 .2 & Fórmulas (preparados) de continuación & BPF & 72 & 2013 \\
\hline 13.1.3 & $\begin{array}{l}\text { Fórmulas (preparados) para usos médicos especiales } \\
\text { destinados a los lactantes }\end{array}$ & $2000 \mathrm{mg} / \mathrm{kg}$ & $55 \& 72$ & 2013 \\
\hline 13.2 & $\begin{array}{l}\text { Alimentos complementarios para lactantes y niños } \\
\text { pequeños }\end{array}$ & BPF & 239 & 2013 \\
\hline
\end{tabular}

\section{HIDRÓXIDO DE MAGNESIO}

SIN $528 \quad$ Hidróxido de magnesio
Clases Funcionales: Reguladores de la acidez, Agentes de retención de color

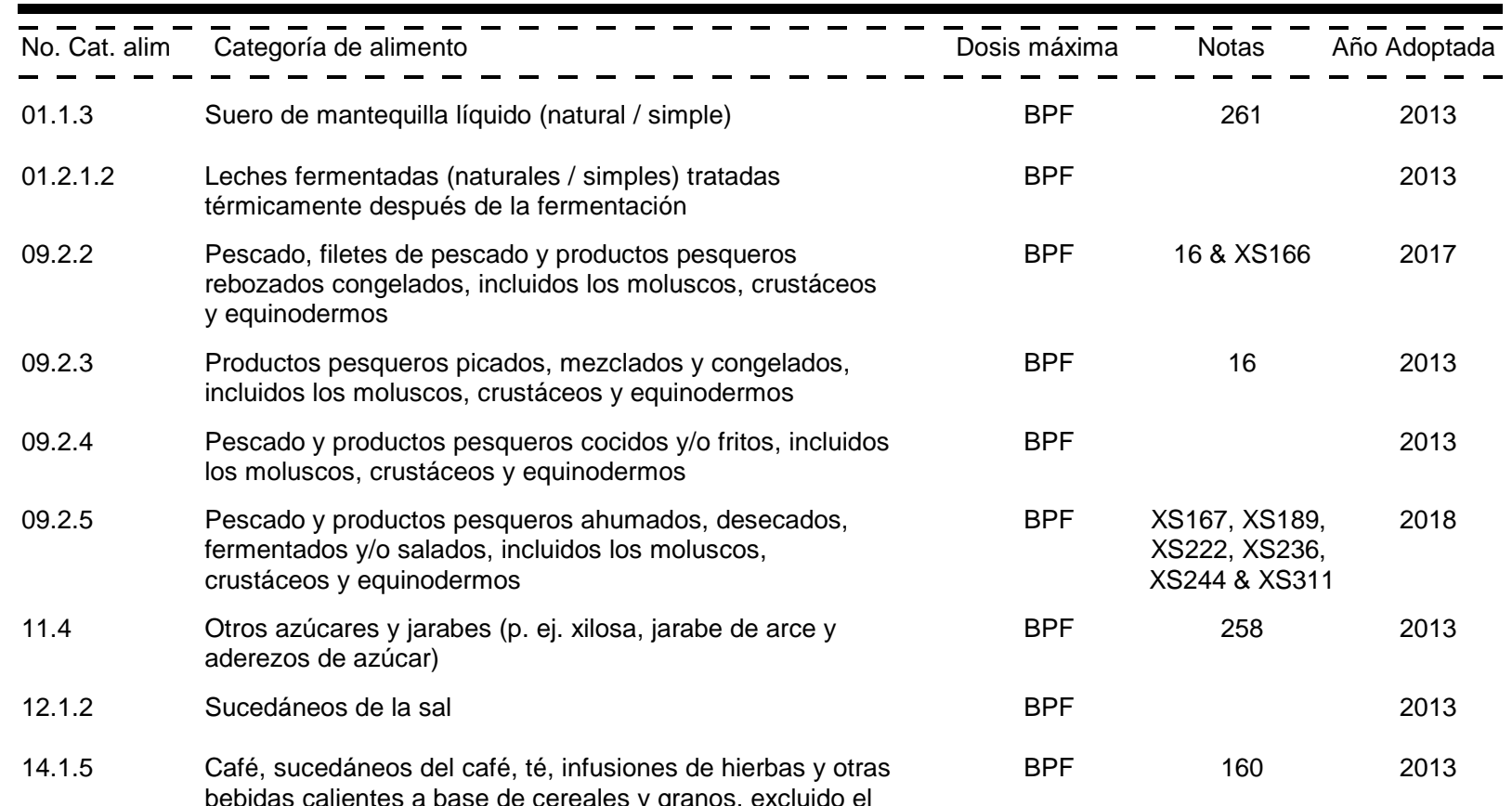
cacao 


\section{HIDRÓXIDO DE POTASIO}

\author{
SIN $525 \quad$ Hidróxido de potasio
}

Clases Funcionales: Reguladores de la acidez

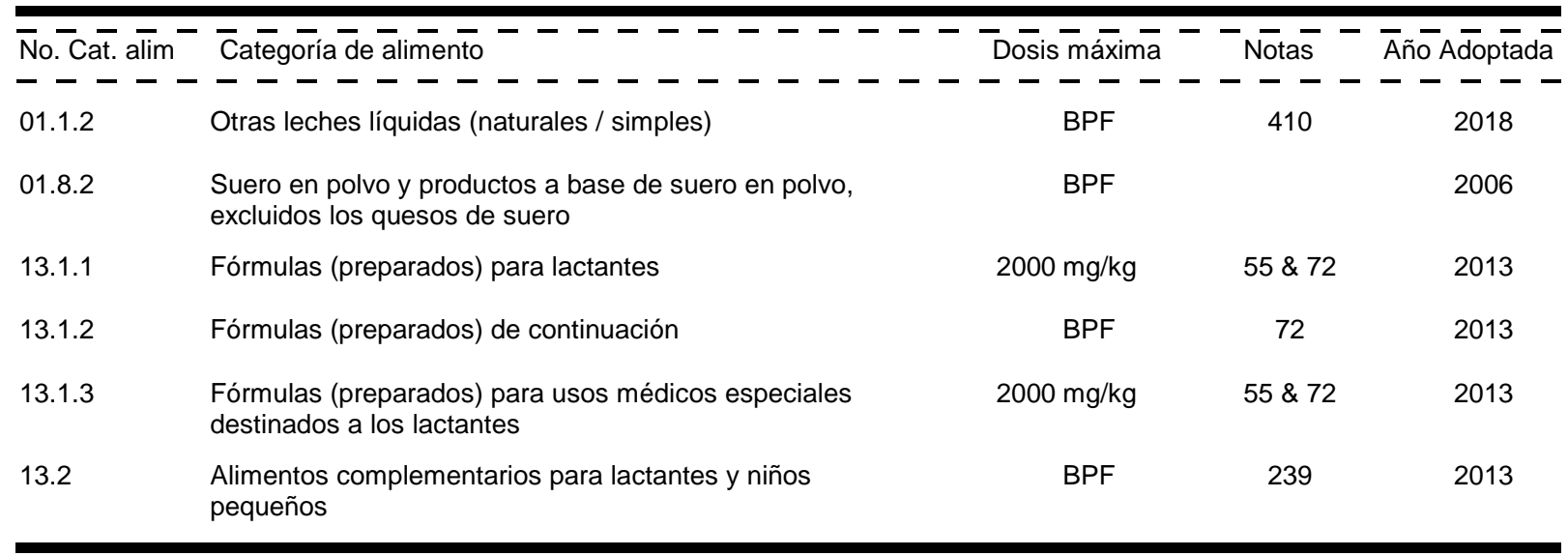

\section{HIDRÓXIDO DE SODIO}

SIN 524 Hidróxido de sodio Clases Funcionales: Reguladores de la acidez

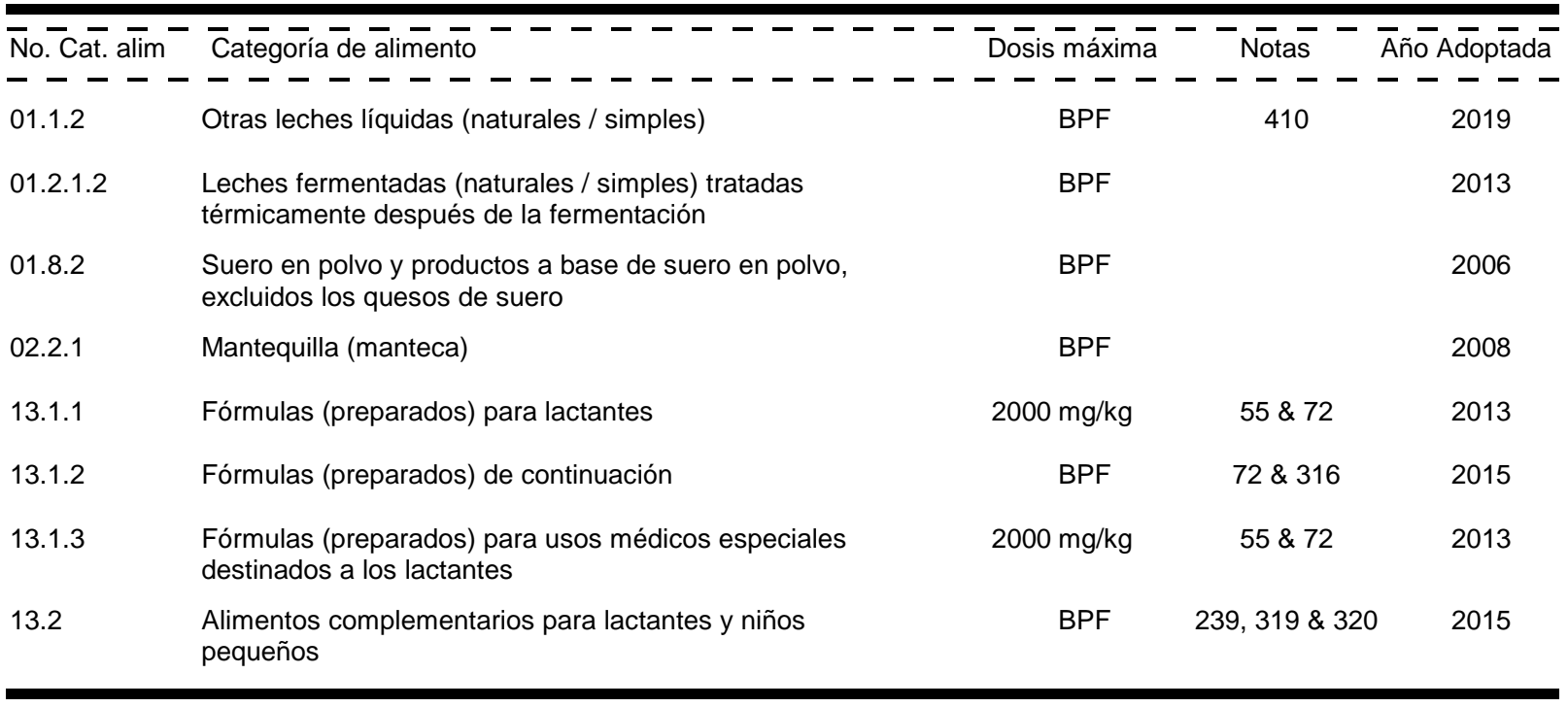

\section{HIDROXIPROPILCELULOSA}

SIN $463 \quad$ Hidroxipropilcelulosa
Clases Funcionales: Emulsionantes, Espumantes, Agentes de glaseado, Estabilizadores, Espesantes

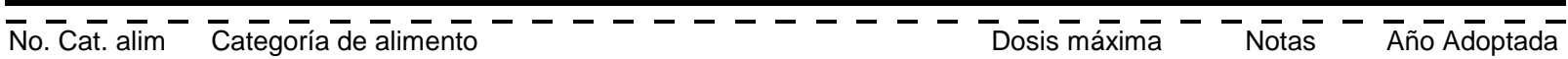

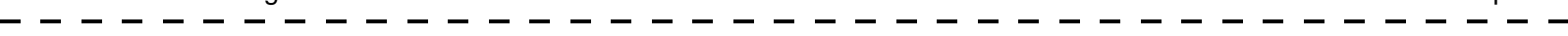
01.2.1.2
Leches fermentadas (naturales / simples) tratadas
BPF
234
2013

01.2 .2

Cuajada (natural / simple)

BPF

2013

01.4 .1

Nata (crema) pasteurizada (natural / simple)

BPF

236

2013

01.4.2 Natas (cremas) esterilizadas y UHT, natas (cremas) para

BPF

2013 batir o batidas y natas (cremas) de contenido de grasa reducido (naturales / simples)
} 


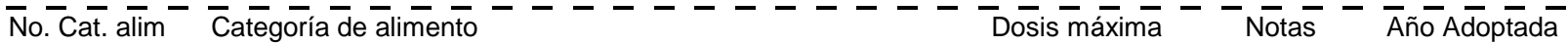
- - - - - - - - - - - - - - - - - - - - - - - - - - piezas enteras o en cortes

08.1.2 Carne fresca picada, incluida la de aves de corral y caza

BPF

281

2014

09.2.1

Pescado, filetes de pescado y productos pesqueros congelados, incluidos los moluscos, crustáceos y

BPF equinodermos

09.2 .2

Pescado, filetes de pescado y productos pesqueros rebozados congelados, incluidos los moluscos, crustáceos y equinodermos

09.2.3 Productos pesqueros picados, mezclados y congelados, incluidos los moluscos, crustáceos y equinodermos

09.2.4.1 Pescado y productos pesqueros cocidos

09.2.4.2 Moluscos, crustáceos y equinodermos cocidos

09.2.4.3 Pescado y productos pesqueros fritos, incluidos los moluscos, crustáceos y equinodermos

09.2.5 Pescado y productos pesqueros ahumados, desecados, fermentados y/o salados, incluidos los moluscos, crustáceos y equinodermos

$11.4 \quad$ Otros azúcares y jarabes (p. ej. xilosa, jarabe de arce y aderezos de azúcar)

12.1.2 Sucedáneos de la sal

14.1.5 Café, sucedáneos del café, té, infusiones de hierbas y otras bebidas calientes a base de cereales y granos, excluido el cacao
16, XS36,

XS92, XS95,

XS165, XS190

XS191, XS292

XS312 \& XS315

BPF

$63 \& 332$

2015

BPF

16

2014

BPF

$16 \& 325$

2015

BPF

16

BPF

$41,325 \& 332$

BPF

300, 332,

XS167, XS189,

XS222, XS236

XS244 \& XS311

BPF

258

BPF

BPF

160

2014

\section{HIDROXIPROPILMETILCELULOSA}

SIN $464 \quad$ Hidroxipropilmetilcelulosa

Clases Funcionales: Incrementadores del volumen, Emulsionantes, Agentes de glaseado, Estabilizadores, Espesantes

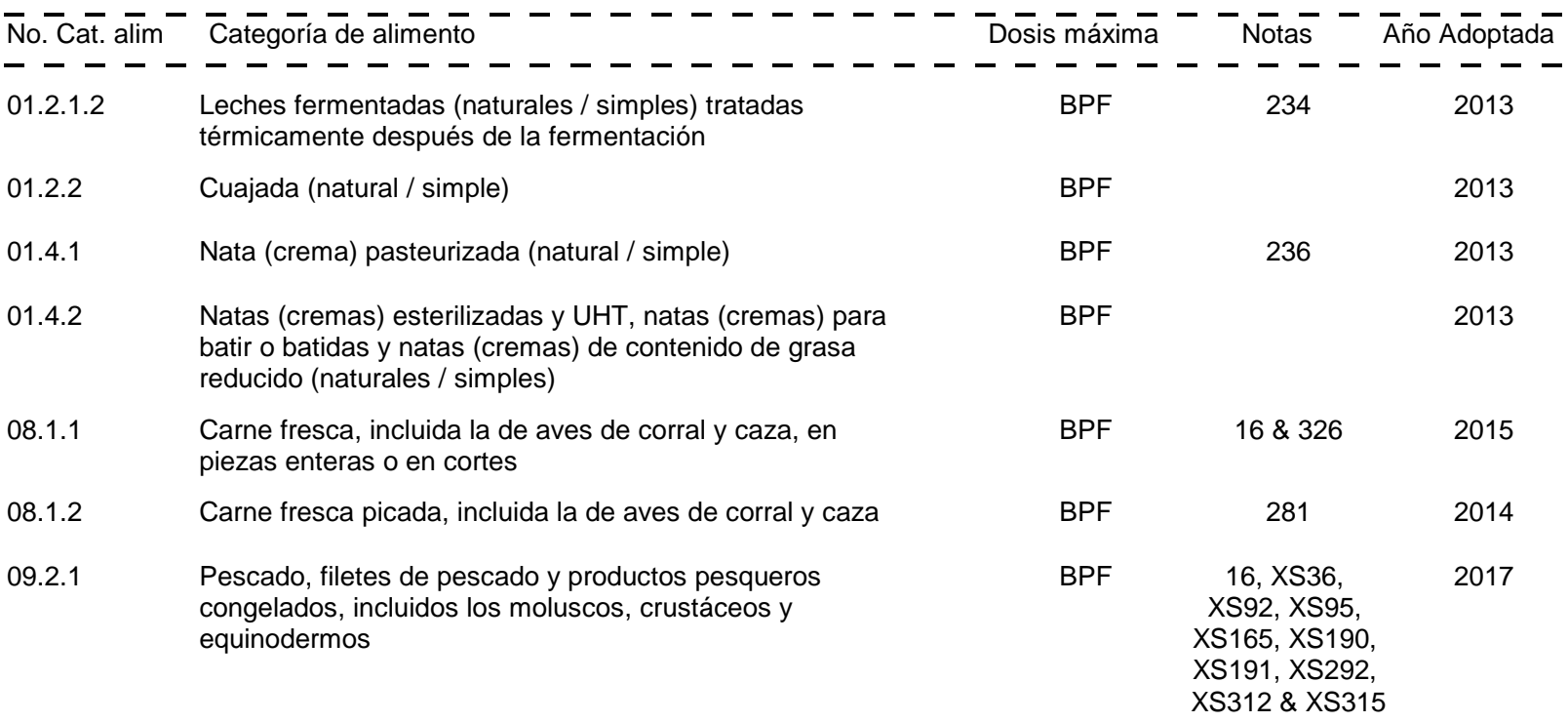




\begin{tabular}{|c|c|c|c|c|}
\hline 09.2 .2 & $\begin{array}{l}\text { Pescado, filetes de pescado y productos pesqueros } \\
\text { rebozados congelados, incluidos los moluscos, crustáceos } \\
\text { y equinodermos }\end{array}$ & BPF & $63 \& 332$ & 2015 \\
\hline 09.2 .3 & $\begin{array}{l}\text { Productos pesqueros picados, mezclados y congelados, } \\
\text { incluidos los moluscos, crustáceos y equinodermos }\end{array}$ & BPF & 16 & 2014 \\
\hline 09.2.4.1 & Pescado y productos pesqueros cocidos & BPF & $16 \& 325$ & 2015 \\
\hline 09.2.4.2 & Moluscos, crustáceos y equinodermos cocidos & BPF & 16 & 2015 \\
\hline 09.2 .4 .3 & $\begin{array}{l}\text { Pescado y productos pesqueros fritos, incluidos los } \\
\text { moluscos, crustáceos y equinodermos }\end{array}$ & BPF & $41,325 \& 332$ & 2015 \\
\hline 09.2 .5 & $\begin{array}{l}\text { Pescado y productos pesqueros ahumados, desecados, } \\
\text { fermentados y/o salados, incluidos los moluscos, } \\
\text { crustáceos y equinodermos }\end{array}$ & BPF & $\begin{array}{c}\text { 300, 332, } \\
\text { XS167, XS189, } \\
\text { XS222, XS236, } \\
\text { XS244 \& XS311 }\end{array}$ & 2018 \\
\hline 11.4 & $\begin{array}{l}\text { Otros azúcares y jarabes (p. ej. xilosa, jarabe de arce y } \\
\text { aderezos de azúcar) }\end{array}$ & BPF & 258 & 2014 \\
\hline 12.1 .2 & Sucedáneos de la sal & BPF & & 2014 \\
\hline 14.1.5 & $\begin{array}{l}\text { Café, sucedáneos del café, té, infusiones de hierbas y otras } \\
\text { bebidas calientes a base de cereales y granos, excluido el } \\
\text { cacao }\end{array}$ & BPF & 160 & 2014 \\
\hline
\end{tabular}

\section{INDIGOTINA (CARMÍN DE ÍNDIGO)}

SIN 132 Indigotina (Carmín de índigo) Clases Funcionales: Colorantes

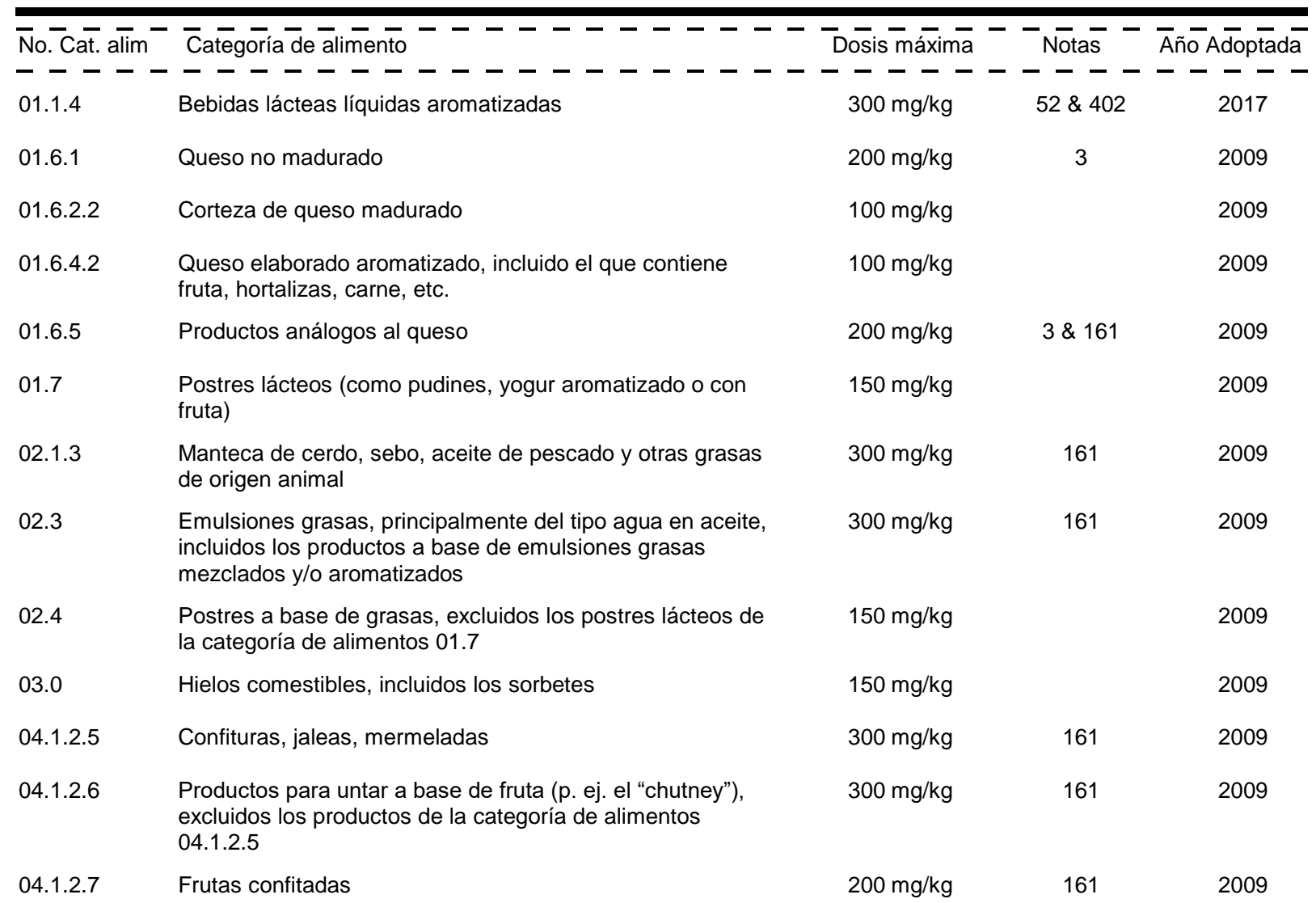


 \\ Preparados a base de fruta, incluida la pulpa, los purés, los revestimientos de fruta y la leche de coco \\ 04.1.2.9 Postres a base de fruta, incluidos los postres a base de agua con aromas de fruta \\ 04.1.2.11 Rellenos de fruta para pastelería \\ 04.2.2.3 Hortalizas (incluidos hongos y setas, raíces y tubérculos, legumbres y leguminosas y áloe vera) y algas marinas en vinagre, aceite, salmuera o salsa de soja \\ 04.2.2.6 \\ Pulpas y preparados de hortalizas (incluidos hongos y setas, raíces y tubérculos, legumbres y leguminosas y áloe vera), algas marinas y nueces y semillas (como los postres y las salsas a base de hortalizas y hortalizas confitadas) distintos de los indicados en la categoría de alimentos 04.2.2.5}

04.2.2.7 Productos a base de hortalizas (incluidos hongos y setas, raíces y tubérculos, legumbres y leguminosas y áloe vera) y algas marinas fermentadas, excluidos los productos fermentados de soja de las categorías 06.8.6, 06.8.7, 12.9.1, 12.9.2.1 y 12.9 .2 .3

05.1.4 Productos de cacao y chocolate

05.1.5 Productos de imitación y sucedáneos del chocolate

$05.2 \quad$ Dulces, incluidos los caramelos duros y blandos, los turrones, etc. distintos de los indicados en las categorías de alimentos $05.1,05.3$ y 05.4

05.3

Goma de mascar

05.4

07.2

09.1 .1

09.2 .1

Decoraciones (p. ej. para productos de pastelería fina), revestimientos (que no sean de fruta) y salsas dulces

Postres a base de cereales y almidón (p. ej. pudines de arroz, pudines de mandioca)

Productos de panadería fina (dulces, salados, aromatizados) y mezclas

Pescado fresco

Pescado, filetes de pescado y productos pesqueros congelados, incluidos los moluscos, crustáceos y equinodermos

09.2.4.1 Pescado y productos pesqueros cocidos

09.2.4.2 Moluscos, crustáceos y equinodermos cocidos

09.3.3 Sucedáneos de salmón, caviar y otros productos pesqueros a base de huevas

09.3 .4

Pescado y productos pesqueros semiconservados, incluidos los moluscos, crustáceos y equinodermos (p. ej., la pasta de pescado), excluidos los productos indicados en las categorías de alimentos 09.3.1 a 09.3.3

Pescado y productos pesqueros (incluidos los moluscos, crustáceos y equinodermos) en conserva, con inclusión de los enlatados y fermentados

\begin{tabular}{|c|c|c|}
\hline $150 \mathrm{mg} / \mathrm{kg}$ & $161 \& 182$ & 2009 \\
\hline $150 \mathrm{mg} / \mathrm{kg}$ & 161 & 2009 \\
\hline 150 mg/kg & 161 & 2009 \\
\hline $150 \mathrm{mg} / \mathrm{kg}$ & 161 & 2009 \\
\hline $200 \mathrm{mg} / \mathrm{kg}$ & $92 \& 161$ & 2009 \\
\hline
\end{tabular}

$300 \mathrm{mg} / \mathrm{kg}$ 161 2009

\begin{tabular}{|c|c|c|}
\hline $450 \mathrm{mg} / \mathrm{kg}$ & 183 & 2016 \\
\hline $300 \mathrm{mg} / \mathrm{kg}$ & & 2009 \\
\hline $300 \mathrm{mg} / \mathrm{kg}$ & XS309R & 2017 \\
\hline $300 \mathrm{mg} / \mathrm{kg}$ & & 2009 \\
\hline $300 \mathrm{mg} / \mathrm{kg}$ & & 2009 \\
\hline $150 \mathrm{mg} / \mathrm{kg}$ & & 2009 \\
\hline $200 \mathrm{mg} / \mathrm{kg}$ & 161 & 2009 \\
\hline $300 \mathrm{mg} / \mathrm{kg}$ & $4,16 \& 50$ & 2009 \\
\hline $300 \mathrm{mg} / \mathrm{kg}$ & $\begin{array}{c}\text { 95, XS36, } \\
\text { XS92, XS95, } \\
\text { XS165, XS190, } \\
\text { XS191, XS292, } \\
\text { XS312 \& XS315 }\end{array}$ & 2017 \\
\hline $300 \mathrm{mg} / \mathrm{kg}$ & 95 & 2009 \\
\hline $250 \mathrm{mg} / \mathrm{kg}$ & 16 & 2009 \\
\hline $300 \mathrm{mg} / \mathrm{kg}$ & XS291 & 2018 \\
\hline $300 \mathrm{mg} / \mathrm{kg}$ & 161 & 2009 \\
\hline 300 mg/kg & $\begin{array}{c}\text { XS3, XS37, } \\
\text { XS70, XS90, } \\
\text { XS94 \& XS119 }\end{array}$ & 2018 \\
\hline $300 \mathrm{mg} / \mathrm{kg}$ & $4 \& 161$ & 2009 \\
\hline $300 \mathrm{mg} / \mathrm{kg}$ & 161 & 2009 \\
\hline
\end{tabular}




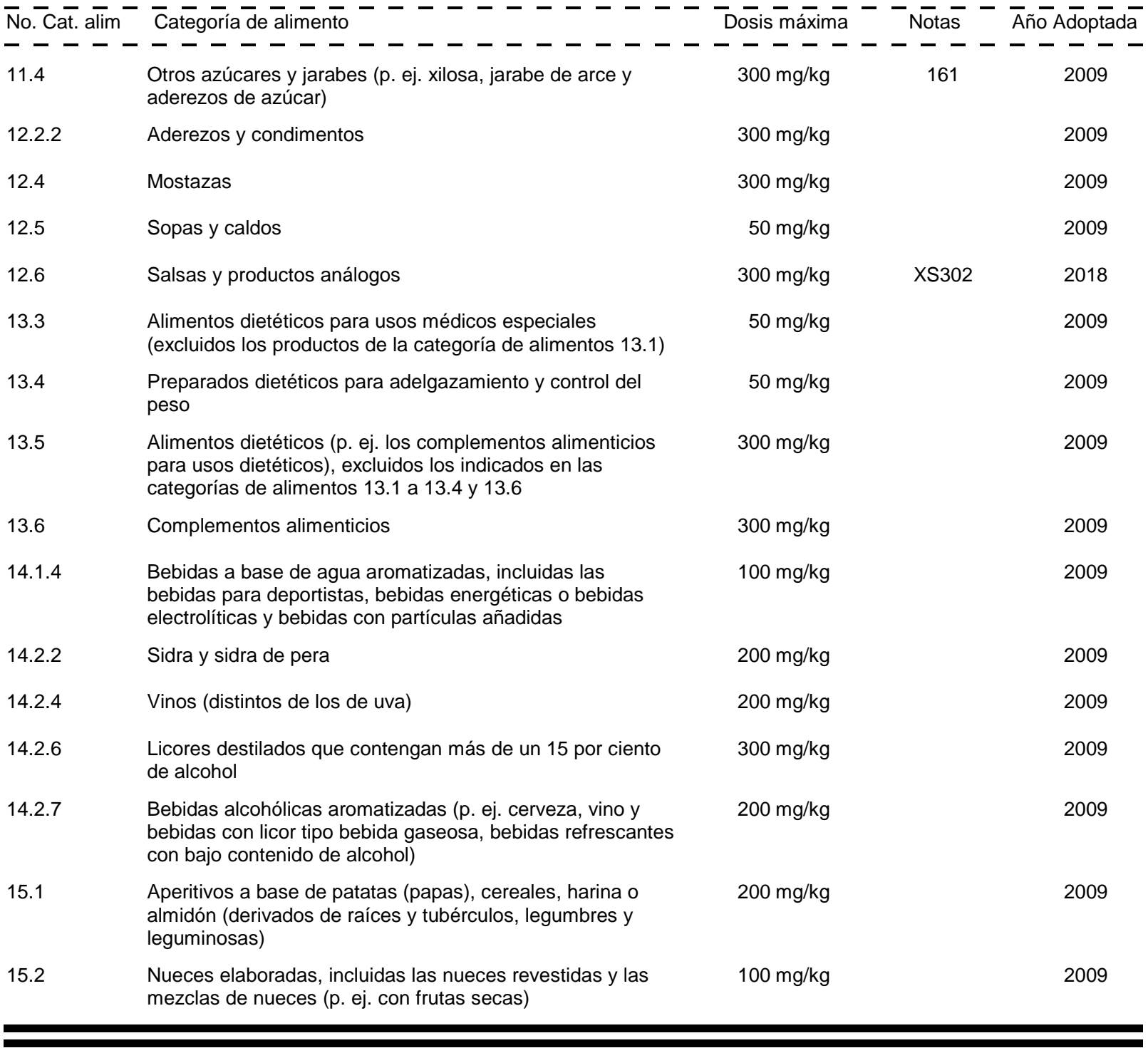

\section{INOSINATO DE CALCIO, 5'-}

\section{SIN $633 \quad$ Inosinato de calcio, 5'- Clases Funcionales: Acentuadores del sabor}

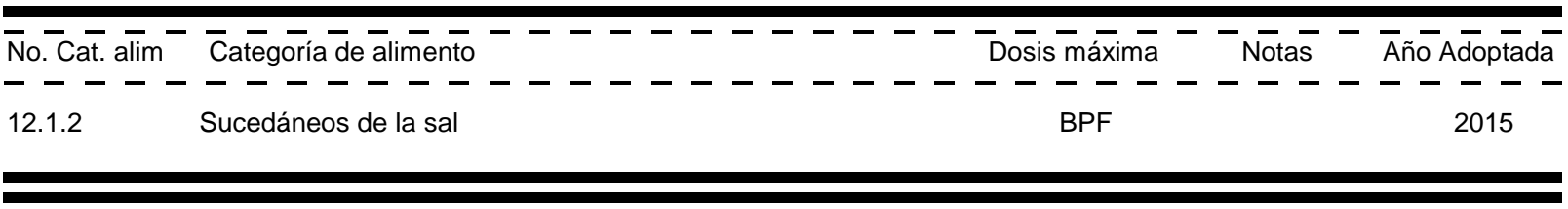

INOSINATO DE POTASIO, 5'-

SIN 632 Inosinato de potasio, 5'- Clases Funcionales: Acentuadores del sabor

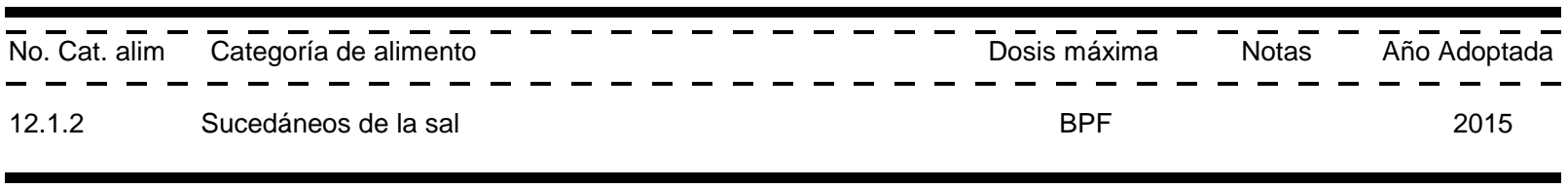




\section{INOSINATO DISÓDICO, 5'-}

\author{
SIN $631 \quad$ Inosinato disódico, 5'-
}

Clases Funcionales: Acentuadores del sabor

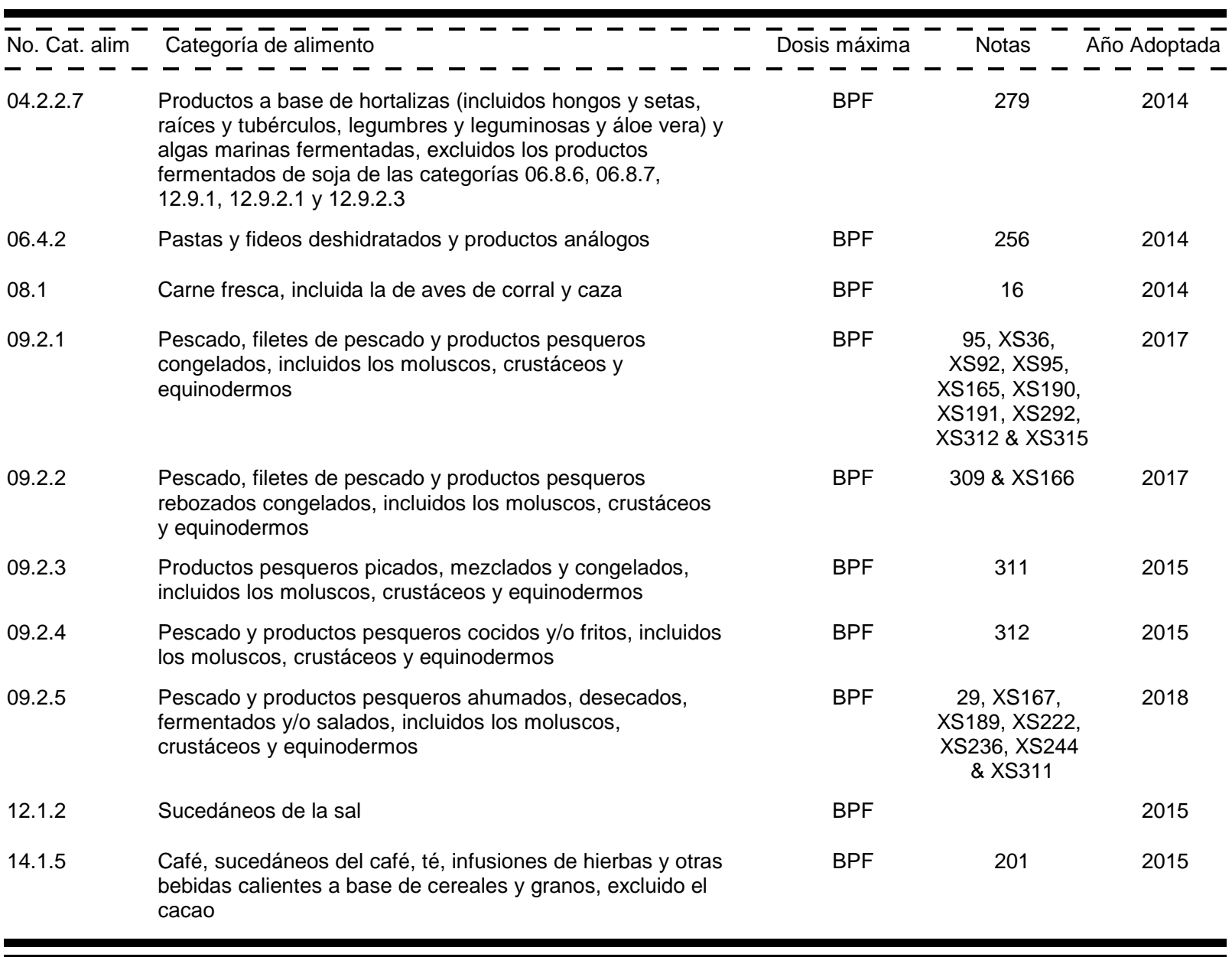

\section{LACTATO DE CALCIO}

SIN $327 \quad$ Lactato de calcio
Clases Funcionales: Reguladores de la acidez, Sales emulsionantes, Agentes endurecedores, Agentes de tratamiento de las harinas, Espesantes

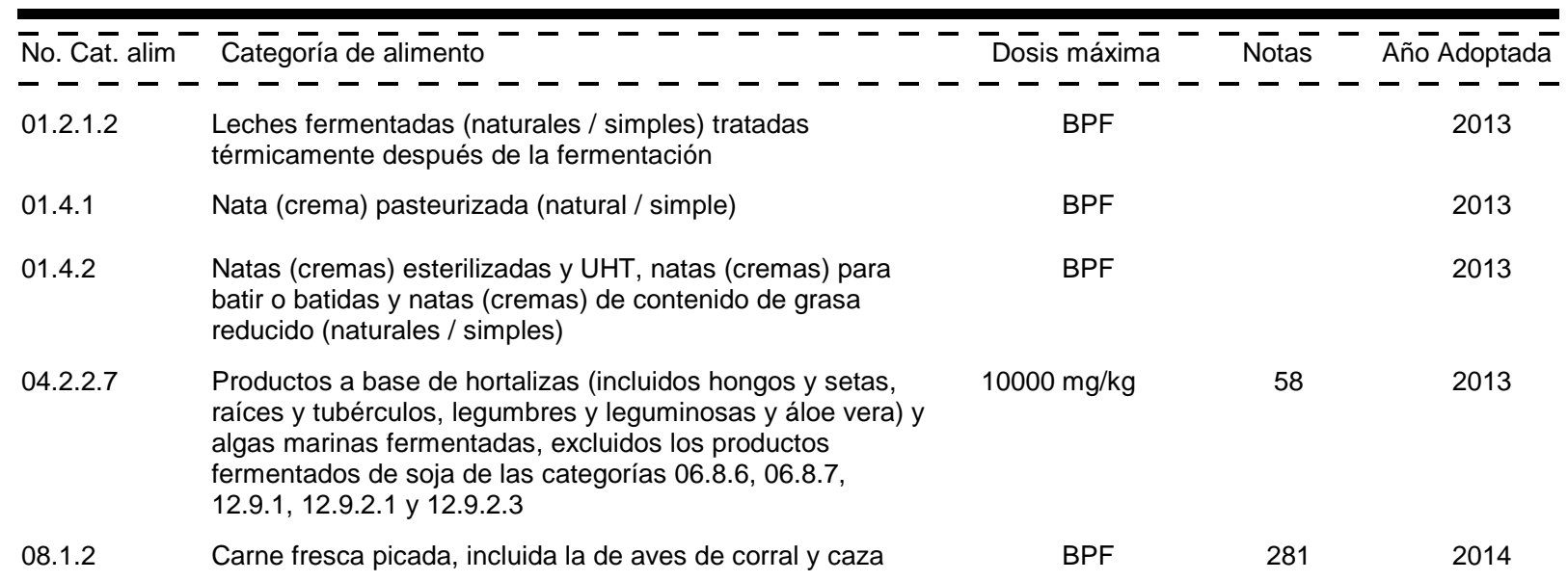




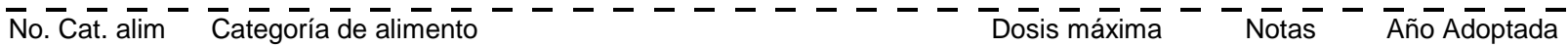

- - - - - - - - - - - - - - - - - - - - - - -

09.2.2 Pescado, filetes de pescado y productos pesqueros $\quad$ BPF $41 \&$ XS166 rebozados congelados, incluidos los moluscos, crustáceos y equinodermos

09.2.3 Productos pesqueros picados, mezclados y congelados,

BPF

16 incluidos los moluscos, crustáceos y equinodermos

09.2 .4

Pescado y productos pesqueros cocidos y/o fritos, incluidos los moluscos, crustáceos y equinodermos

09.2.5 Pescado y productos pesqueros ahumados, desecados, fermentados y/o salados, incluidos los moluscos, crustáceos y equinodermos

BPF

BPF

437, XS167 XS189, XS222

$\mathrm{XS} 236$, \&

XS244

12.1.2 Sucedáneos de la sal

BPF

13.2 Alimentos complementarios para lactantes y niños pequeños

BPF

$83 \& 239$

2013

14.1 .5

Café, sucedáneos del café, té, infusiones de hierbas y otras bebidas calientes a base de cereales y granos, excluido el cacao
BPF

160

2013

\section{LACTATO DE POTASIO}

SIN 326

Lactato de potasio

Clases Funcionales: Reguladores de la acidez, Antioxidantes, Emulsionantes, Humectantes

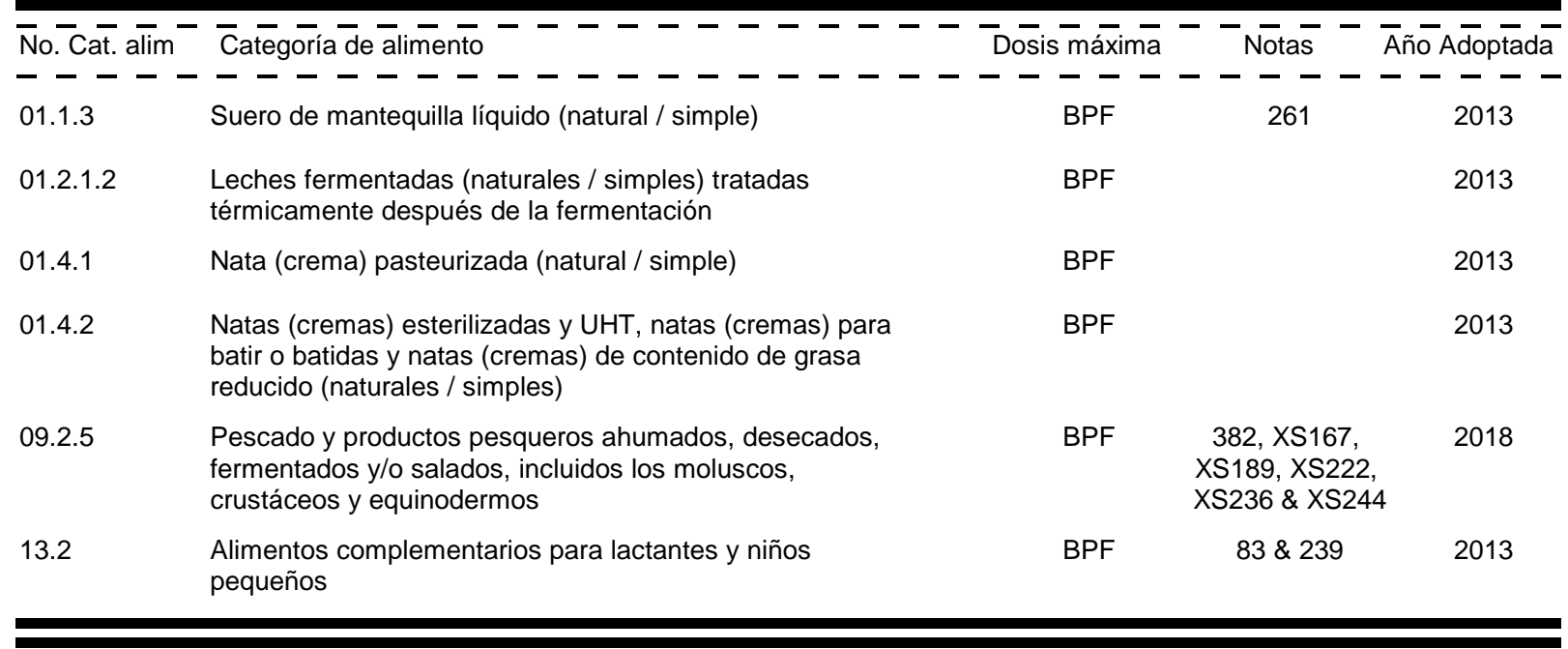

\section{LACTATO DE SODIO}

Clases Funcionales: Reguladores de la acidez, Antioxidantes, Incrementadores del volumen, Emulsionantes, Sales emulsionantes, Humectantes, Espesantes

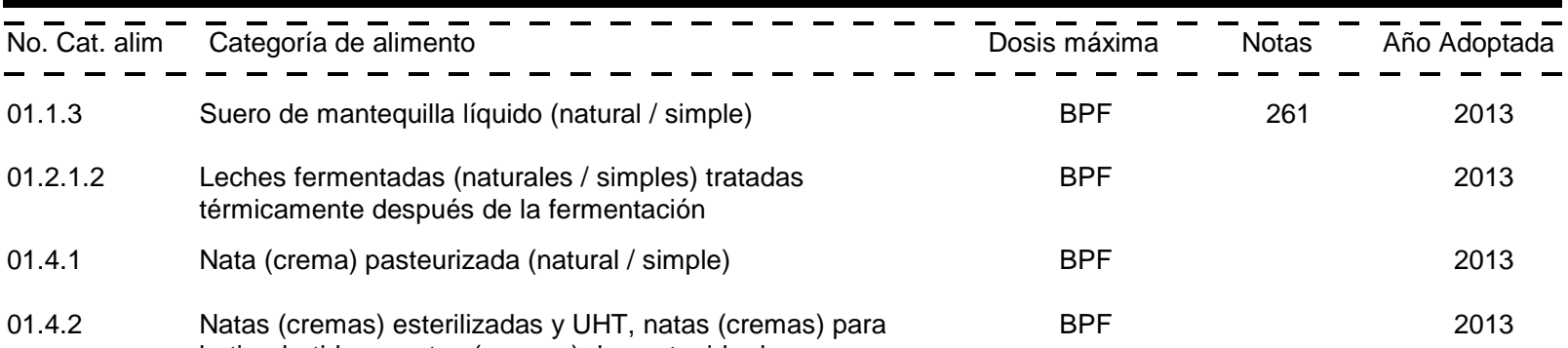
batir o batidas y natas (cremas) de contenido de grasa reducido (naturales / simples) 


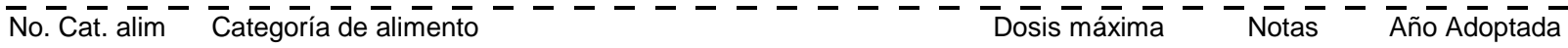

- - - - - - - - - - - - - - - - - - - - - - -

$\begin{array}{llll}\text { 04.2.2.7 } & \text { Productos a base de hortalizas (incluidos hongos y setas, } & \text { BPF } & 2013\end{array}$ raíces y tubérculos, legumbres y leguminosas y áloe vera) y algas marinas fermentadas, excluidos los productos

fermentados de soja de las categorías 06.8.6, 06.8.7 12.9.1, 12.9.2.1 y 12.9.2.3

06.4.1 Pastas y fideos frescos y productos análogo

BPF

06.4.2 Pastas y fideos deshidratados y productos análogos

09.2 .2

Pescado, filetes de pescado y productos pesqueros rebozados congelados, incluidos los moluscos, crustáceos y equinodermos

09.2.3 Productos pesqueros picados, mezclados y congelados, incluidos los moluscos, crustáceos y equinodermos

09.2.4 Pescado y productos pesqueros cocidos $\mathrm{y} / \mathrm{o}$ fritos, incluidos los moluscos, crustáceos y equinodermos

09.2.5 Pescado y productos pesqueros ahumados, desecados, fermentados y/o salados, incluidos los moluscos, crustáceos y equinodermos

10.2.1 Productos líquidos a base de huevo

10.2.2 Productos congelados a base de huevo

13.2 Alimentos complementarios para lactantes y niños pequeños

Café, sucedáneos del café, té, infusiones de hierbas y otras
bebidas calientes a base de cereales y granos, excluido el

Café, sucedáneos del café, té, infusiones de hierbas y otras
bebidas calientes a base de cereales y granos, excluido el cacao
BPF

256

2013

BPF

$41 \&$ XS166

2017

BPF

16

2015

BPF

BPF

437, XS167, XS189, XS222 XS236 \& XS244

BPF

BPF

BPF

$83,239,319$ \&

320

BPF

160

2013 


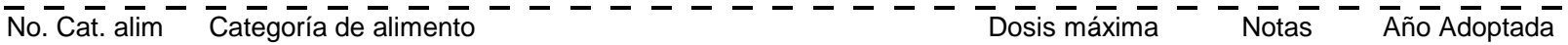
- - - - - - - - - - - - - - - - - - - - - - - - - - - -

02.1.3 Manteca de cerdo, sebo, aceite de pescado y otras grasas BPF 2018 de origen animal races y tubérculos, legumbres y leguminosas y áloe vera) y algas marinas fermentadas, excluidos los productos fermentados de soja de las categorías 06.8.6, 06.8.7, 12.9.1, 12.9.2.1 y 12.9 .2 .3

06.2.1 Harinas

BPF

$25 \& 28$

2014

06.4.1 Pastas y fideos frescos y productos análogos

06.4.2 Pastas y fideos deshidratados y productos análogos

08.1.1 Carne fresca, incluida la de aves de corral y caza, en piezas enteras o en cortes

08.1.2 Carne fresca picada, incluida la de aves de corral y caza

09.1.2 Moluscos, crustáceos y equinodermos frescos

09.2.1 Pescado, filetes de pescado y productos pesqueros congelados, incluidos los moluscos, crustáceos y equinodermos

09.2 .2

Pescado, filetes de pescado y productos pesqueros rebozados congelados, incluidos los moluscos, crustáceos y equinodermos

09.2.3 Productos pesqueros picados, mezclados y congelados, incluidos los moluscos, crustáceos y equinodermos

09.2.4.1 Pescado y productos pesqueros cocidos

09.2.4.3 Pescado y productos pesqueros fritos, incluidos los moluscos, crustáceos y equinodermos

09.2.5 Pescado y productos pesqueros ahumados, desecados, fermentados y/o salados, incluidos los moluscos, crustáceos y equinodermos

Productos líquidos a base de huevo

Productos congelados a base de huevo

$11.4 \quad$ Otros azúcares y jarabes (p. ej. xilosa, jarabe de arce y aderezos de azúcar)

12.1.2 Sucedáneos de la sa

13.1.1 Fórmulas (preparados) para lactantes

13.1.2 Fórmulas (preparados) de continuación

Fórmulas (preparados) para usos médicos especiales destinados a los lactantes

13.2 Alimentos complementarios para lactantes y niños pequeños

14.1.5 Café, sucedáneos del café, té, infusiones de hierbas y otras bebidas calientes a base de cereales y granos, excluido el cacao

\section{BPF}

BPF

BPF

BPF

BPF

BPF

BPF

BPF

BPF

BPF

$300, \mathrm{XS} 167$

XS189, XS222

XS236, XS244

\& XS311

BPF

BPF

BPF

258

BPF

2014

$5000 \mathrm{mg} / \mathrm{kg}$

72

2014

$5000 \mathrm{mg} / \mathrm{kg}$

72

2014

$5000 \mathrm{mg} / \mathrm{kg}$

72

2014

$5000 \mathrm{mg} / \mathrm{kg}$

$271 \& 274$

2014

BPF

160

2014

2014

2014

2015

2014

17

017

14

14




\section{LUTEIN DE TAGETES ERECTA}

SIN 161b(i) Lutein de Tagetes erecta Clases Funcionales: Colorantes

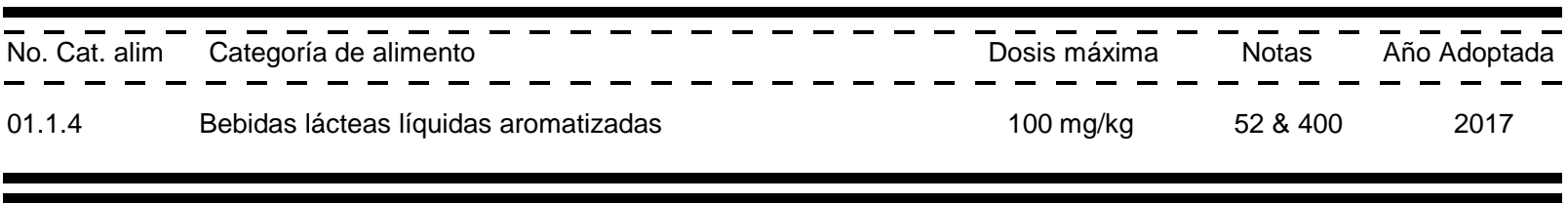

\section{LYSOZYME}

SIN 1105 Hidrocloruro de lisozima Clases Funcionales: Sustancias conservadoras

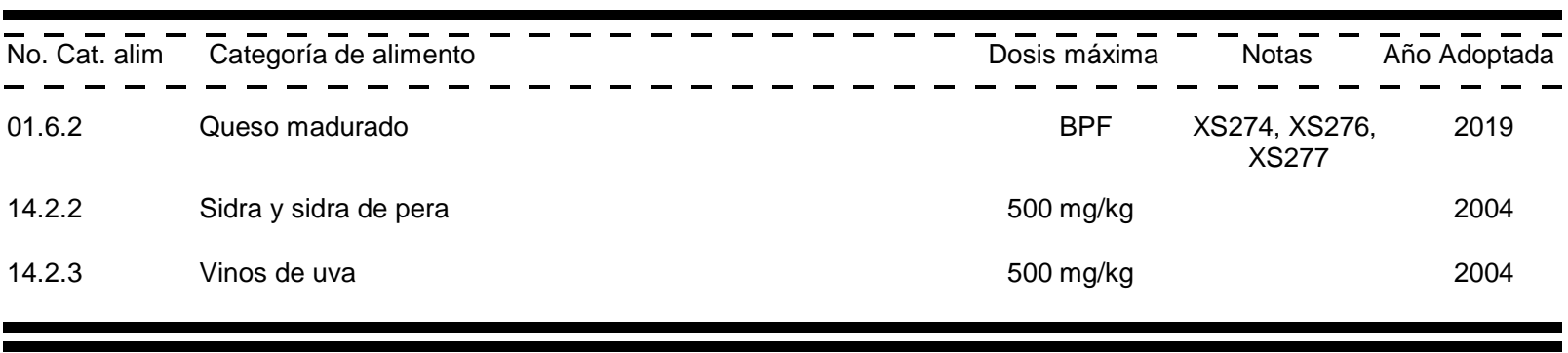

\section{MALATO DE SODIO, DL-}

SIN 350(ii) Malato de sodio, DL- Clases Funcionales: Reguladores de la acidez, Humectantes

\begin{tabular}{|c|c|c|c|c|}
\hline $\begin{array}{l}\overline{\text { No. }} \text { Cat. alim } \\
--- \\
04.2 .2 .7\end{array}$ & 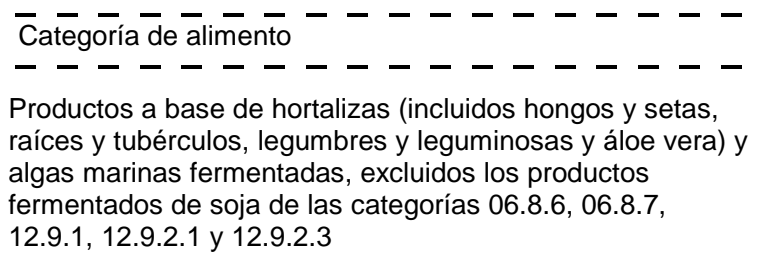 & $\begin{array}{l}\overline{\text { máxi }} \\
\overline{\text { BPF }}\end{array}$ & $\begin{array}{l}-\overline{N o t a s}- \\
----\end{array}$ & $\begin{array}{l}\text { Adopta } \\
-\overline{2013}\end{array}$ \\
\hline 06.4 .1 & Pastas y fideos frescos y productos análogos & BPF & & 2013 \\
\hline 09.2 .2 & $\begin{array}{l}\text { Pescado, filetes de pescado y productos pesqueros } \\
\text { rebozados congelados, incluidos los moluscos, crustáceos } \\
\text { y equinodermos }\end{array}$ & BPF & $41 \& X S 166$ & 2017 \\
\hline 09.2 .3 & $\begin{array}{l}\text { Productos pesqueros picados, mezclados y congelados, } \\
\text { incluidos los moluscos, crustáceos y equinodermos }\end{array}$ & BPF & 16 & 2015 \\
\hline 09.2 .4 & $\begin{array}{l}\text { Pescado y productos pesqueros cocidos y/o fritos, incluidos } \\
\text { los moluscos, crustáceos y equinodermos }\end{array}$ & BPF & & 2015 \\
\hline 09.2 .5 & $\begin{array}{l}\text { Pescado y productos pesqueros ahumados, desecados, } \\
\text { fermentados y/o salados, incluidos los moluscos, } \\
\text { crustáceos y equinodermos }\end{array}$ & BPF & $\begin{array}{l}\text { XS167, XS189, } \\
\text { XS222, XS236, } \\
\text { XS244 \& XS311 }\end{array}$ & 2018 \\
\hline 14.1 .5 & $\begin{array}{l}\text { Café, sucedáneos del café, té, infusiones de hierbas y otras } \\
\text { bebidas calientes a base de cereales y granos, excluido el } \\
\text { cacao }\end{array}$ & BPF & 160 & 2013 \\
\hline
\end{tabular}

MALTOL

SIN 636 Maltol Clases Funcionales: Acentuadores del sabor

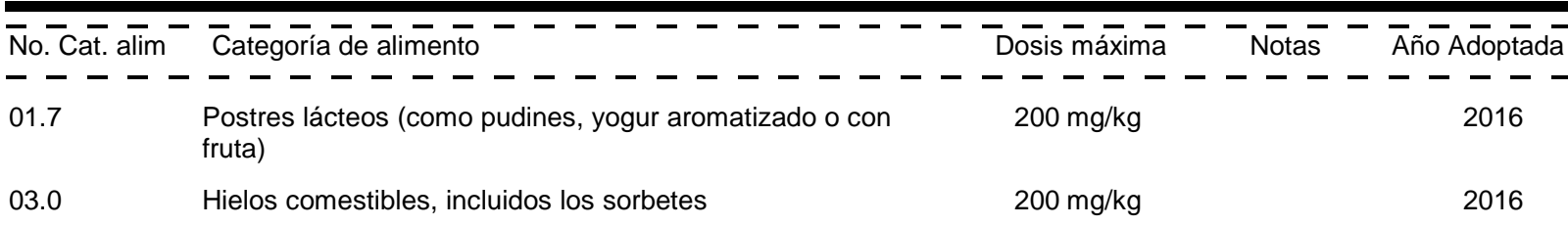




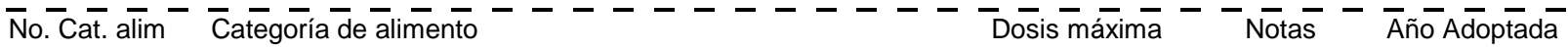

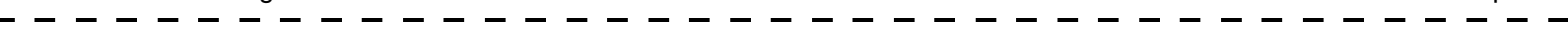

05.2 Dulces, incluidos los caramelos duros y blandos, los $\quad 200 \mathrm{mg} / \mathrm{kg} \quad$ XS309R $\quad 2017$ turrones, etc. distintos de los indicados en las categorías de alimentos $05.1,05.3$ y 05.4

\section{MANITOL}

Clases Funcionales: Antiaglutinantes, Incrementadores del volumen, Humectantes, Estabilizadores, Edulcorantes, Espesantes

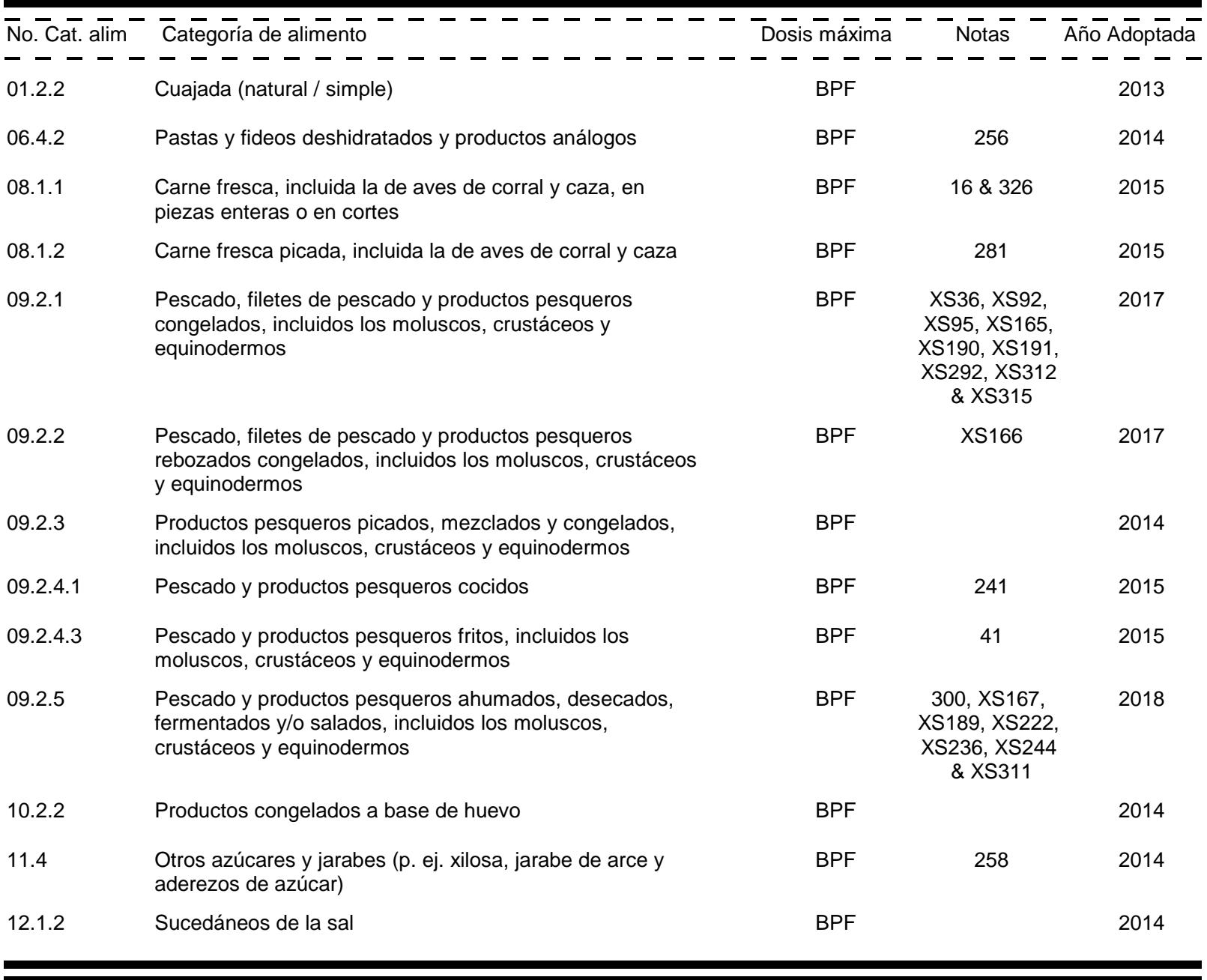

\section{MARRÓN HT}

SIN 155 Marrón HT Clases Funcionales: Colorantes

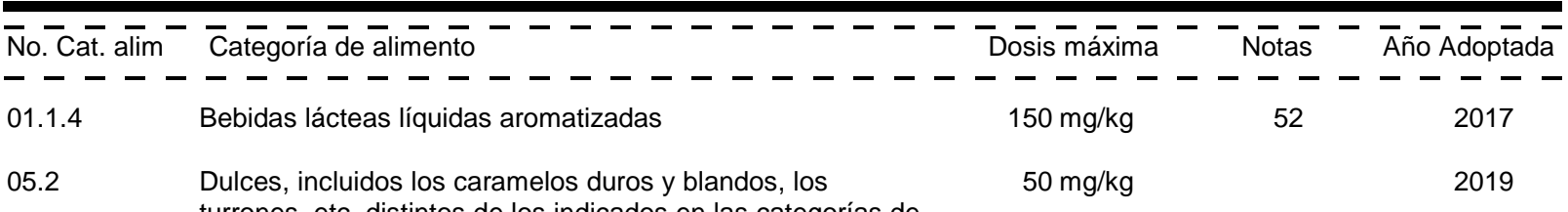




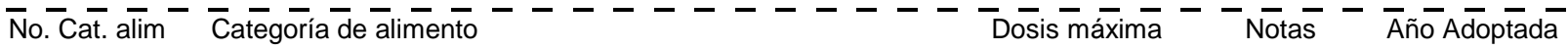
- - - - - - - - - - - - - - - - - - - - - - - - - - $\begin{array}{llr}05.3 \quad \text { Goma de mascar } & 300 \mathrm{mg} / \mathrm{kg} & 2019\end{array}$

$05.4 \quad$ Decoraciones (p. ej. para productos de pastelería fina), revestimientos (que no sean de fruta) y salsas dulces

$50 \mathrm{mg} / \mathrm{kg}$

2019

\section{METILCELULOSA}

SIN $461 \quad$ Metilcelulosa
Clases Funcionales: Incrementadores del volumen, Emulsionantes, Agentes de glaseado, Estabilizadores, Espesantes

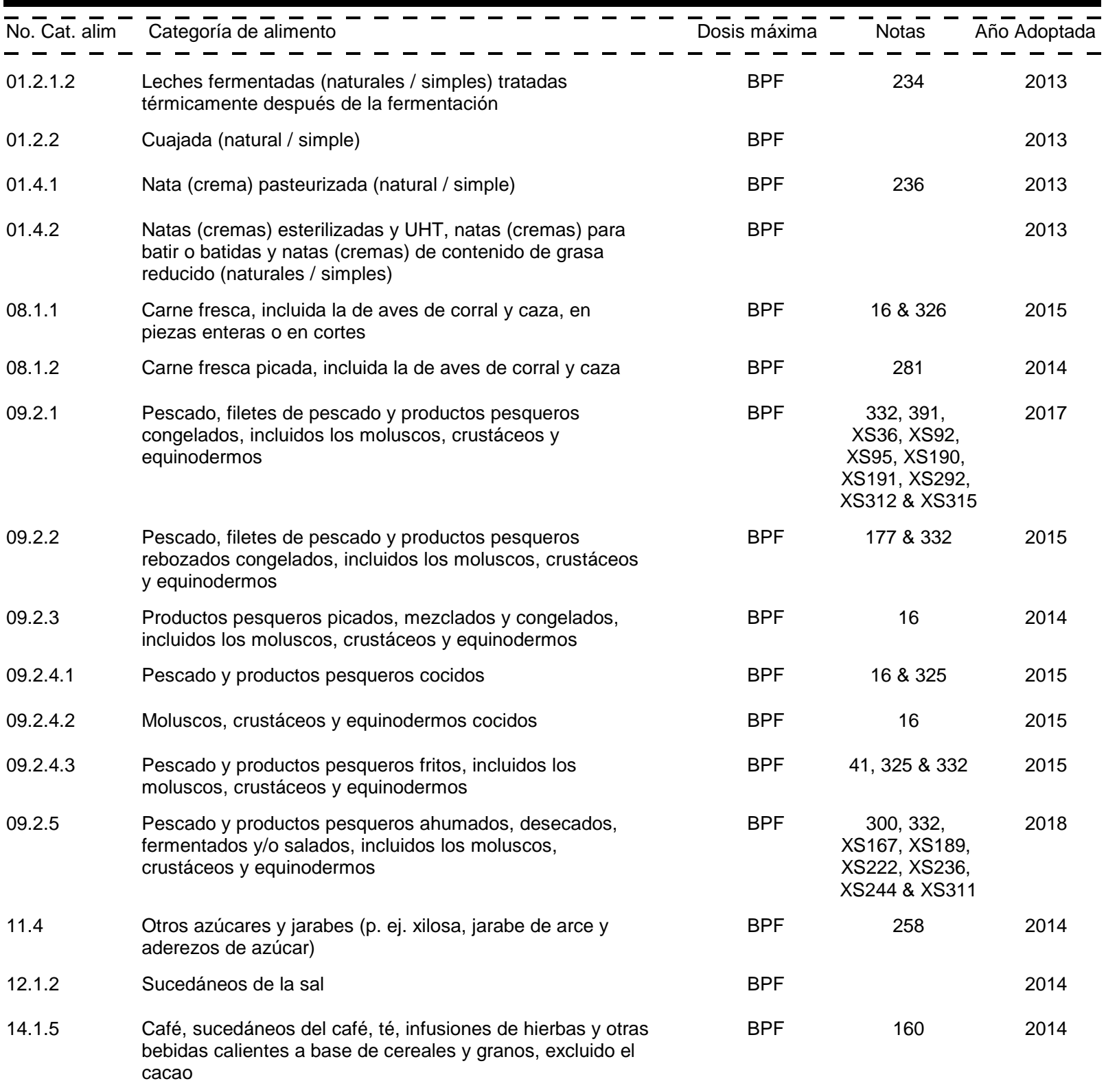

\section{METILETILCELULOSA}

SIN 465
Metiletilcelulosa
Clases Funcionales: Emulsionantes, Espumantes, Estabilizadores, Espesantes 


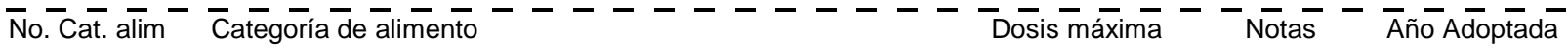
- - - - - - - - - - - - - - - - - - - - - - - - - - - - térmicamente después de la fermentación

01.2.2 Cuajada (natural / simple)

BPF

01.4.1 Nata (crema) pasteurizada (natural / simple)

BPF

236

2013

01.4.2 Natas (cremas) esterilizadas y UHT, natas (cremas) para

BPF

2013 reducido (naturales / simples)

08.1.1 Carne fresca, incluida la de aves de corral y caza, en piezas enteras o en cortes

08.1.2 Carne fresca picada, incluida la de aves de corral y caza

09.2.1 Pescado, filetes de pescado y productos pesqueros congelados, incluidos los moluscos, crustáceos y equinodermos

BPF

BPF

BPF

09.2.2 Pescado, filetes de pescado y productos pesqueros rebozados congelados, incluidos los moluscos, crustáceos y equinodermos

09.2.3 Productos pesqueros picados, mezclados y congelados, incluidos los moluscos, crustáceos y equinodermos

09.2.4.1 Pescado y productos pesqueros cocidos

09.2.4.3 Pescado y productos pesqueros fritos, incluidos los moluscos, crustáceos y equinodermos

Pescado y productos pesqueros ahumados, desecados, fermentados y/o salados, incluidos los moluscos, crustáceos y equinodermos

$11.4 \quad$ Otros azúcares y jarabes (p. ej. xilosa, jarabe de arce y aderezos de azúcar)

12.1.2 Sucedáneos de la sal

Café, sucedáneos del café, té, infusiones de hierbas y otras bebidas calientes a base de cereales y granos, excluido el cacao

\section{$16 \& 326 \quad 2015$}

281

XS36, XS92, XS95, XS165, XS190, XS191, XS292, XS312

\& XS315

BPF

BPF

16

BPF

241

2015

BPF

41

2015

BPF

300, XS167, XS189, XS222,

XS236, XS244

\& XS311

BPF

258

BPF
BPF

160

\section{MONOGLICÉRIDOS Y DIGLICÉRIDOS DE ÁCIDOS GRASOS}

\section{SIN 471}

Monoglicéridos y diglicéridos de Clases Funcionales: Antiespumantes, Emulsionantes, Agentes de ácidos grasos

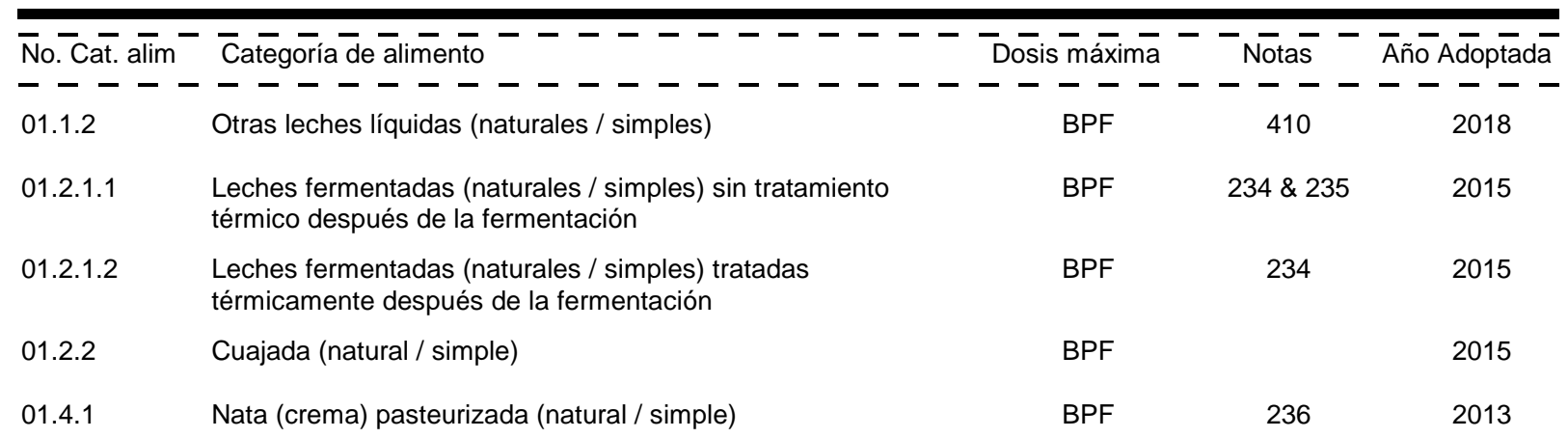




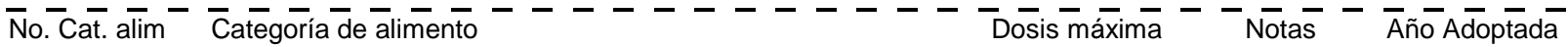

- - - -

Natas (cremas) esterilizadas y UHT, natas (cremas) para

BPF

2013 batir o batidas y natas (cremas) de contenido de grasa reducido (naturales / simples)

02.1.3 Manteca de cerdo, sebo, aceite de pescado y otras grasas de origen animal

04.1.1.2 Frutas frescas tratadas en la superficie

BPF

408, XS211

2018

legumbres y leguminosas y áloe vera), algas marinas y nueces y semillas frescas tratadas en la superficie

06.4.1 Pastas y fideos frescos y productos análogos

06.4.2 Pastas y fideos deshidratados y productos análogos

08.1.1 Carne fresca, incluida la de aves de corral y caza, en piezas enteras o en cortes

08.1.2 Carne fresca picada, incluida la de aves de corral y caza

09.2.2 Pescado, filetes de pescado y productos pesqueros rebozados congelados, incluidos los moluscos, crustáceos y equinodermos

09.2.3 Productos pesqueros picados, mezclados y congelados, incluidos los moluscos, crustáceos y equinodermos

09.2.4.1 Pescado y productos pesqueros cocidos

09.2.4.3 Pescado y productos pesqueros fritos, incluidos los moluscos, crustáceos y equinodermos

09.2.5 Pescado y productos pesqueros ahumados, desecados, fermentados y/o salados, incluidos los moluscos, crustáceos y equinodermos

10.2.1 Productos líquidos a base de huevo

10.2.2 Productos congelados a base de huevo

11.4 Otros azúcares y jarabes (p. ej. xilosa, jarabe de arce y aderezos de azúcar)

12.1.2 Sucedáneos de la sal

13.1.1 Fórmulas (preparados) para lactantes

13.1.2 Fórmulas (preparados) de continuación

13.1.3 Fórmulas (preparados) para usos médicos especiales destinados a los lactantes

13.2 Alimentos complementarios para lactantes y niños pequeños

14.1.5 Café, sucedáneos del café, té, infusiones de hierbas y otras bebidas calientes a base de cereales y granos, excluido el cacao
BPF

453

2019

BPF

455

2019

BPF

2014

BPF

256

2014

BPF

$16 \& 326$

2015

BPF

281

2014

BPF

41

2015

BPF

2015

BPF

241

2015

BPF

41

2015

BPF

300, XS167

XS189, XS222

XS236, XS244

\& XS311

BPF

2015

BPF

2014

BPF

258

2014

BPF

2014

$4000 \mathrm{mg} / \mathrm{kg}$

72

2014

$4000 \mathrm{mg} / \mathrm{kg}$

72

2014

$4000 \mathrm{mg} / \mathrm{kg}$

72

2014

$5000 \mathrm{mg} / \mathrm{kg}$

$268 \& 275$

2014

BPF

160

2014

\section{NATAMICINA (PIMARICINA)}

SIN $235 \quad$ Natamicina (Pimaricina) Clases Funcionales: Sustancias conservadoras 


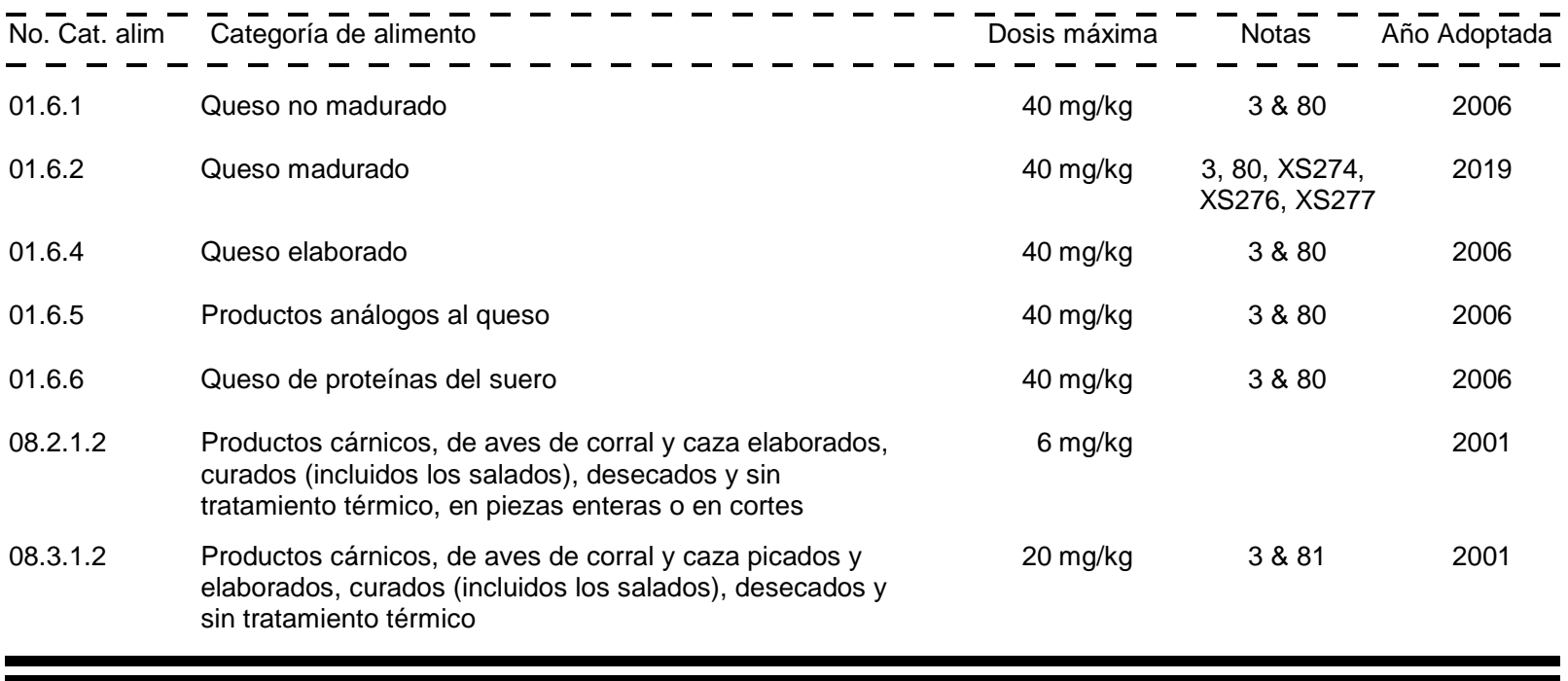

NEGRO BRILLANTE (NEGRO PN)

SIN $151 \quad$ Negro brillante (Negro PN) Clases Funcionales: Colorantes

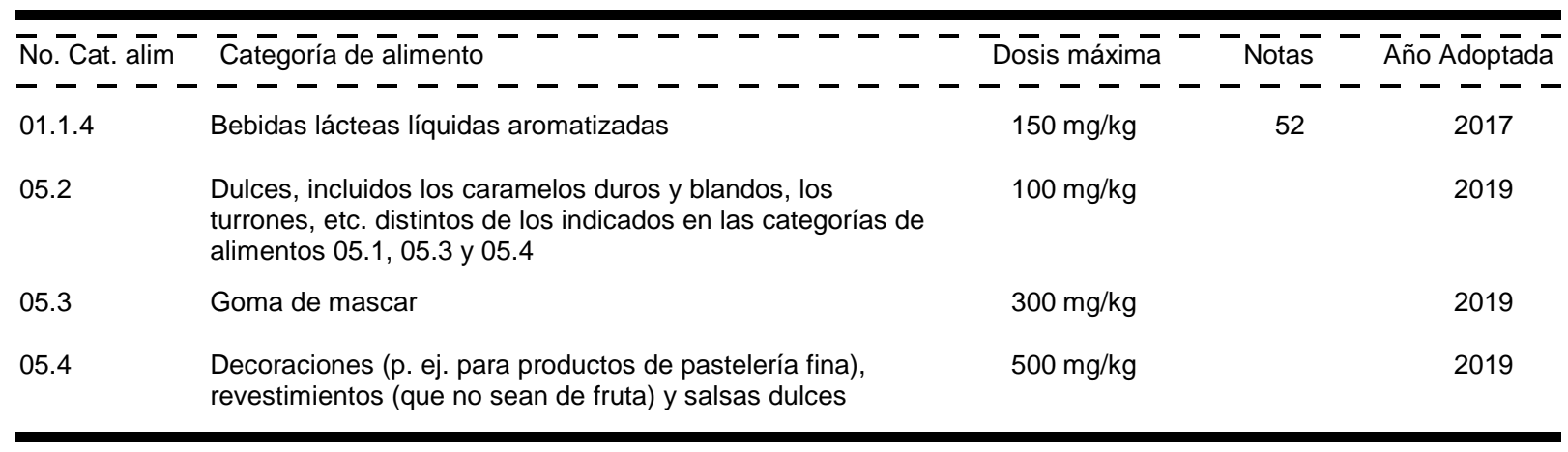

NEOTAMO

SIN $961 \quad$ Neotamo Clases Funcionales: Acentuadores del sabor, Edulcorantes

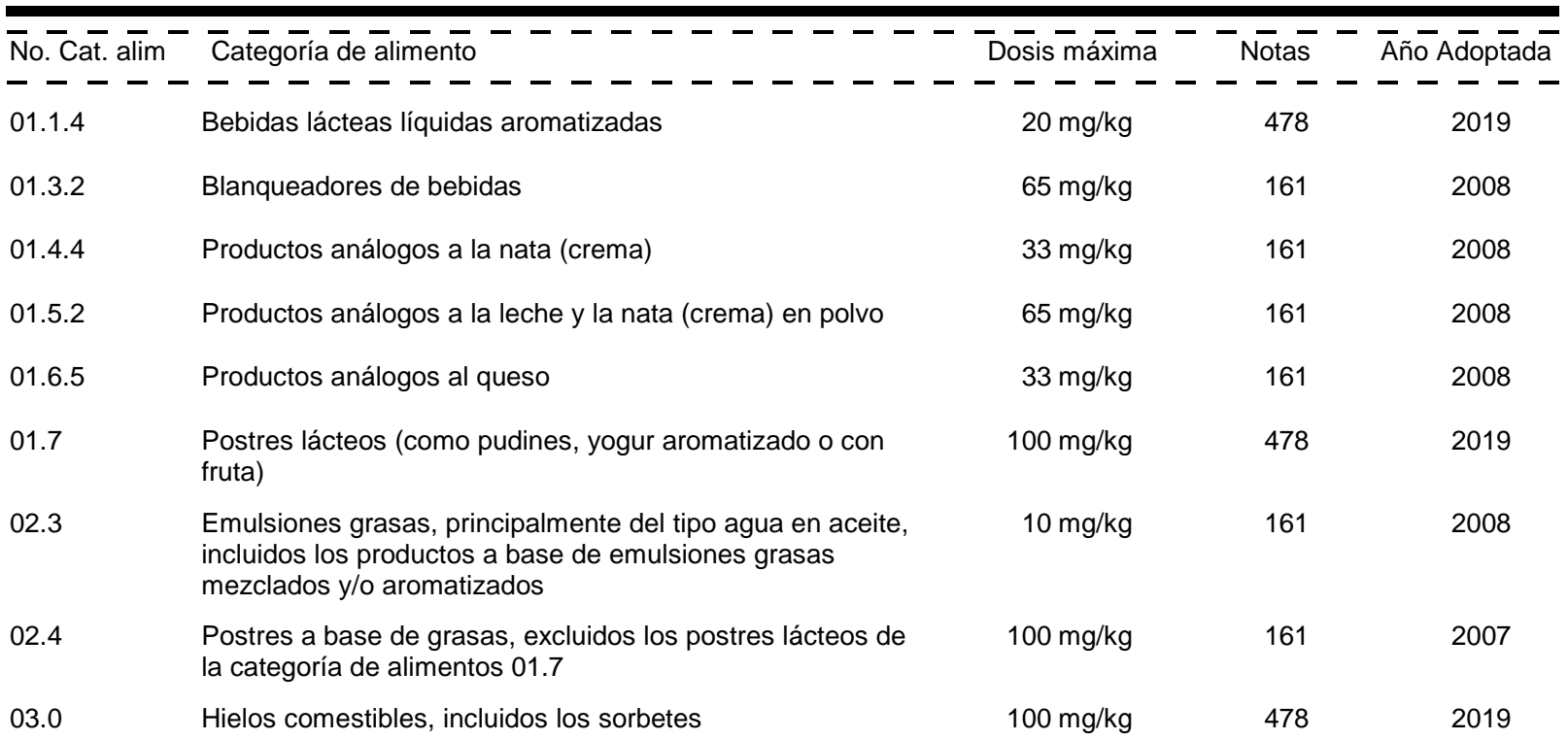




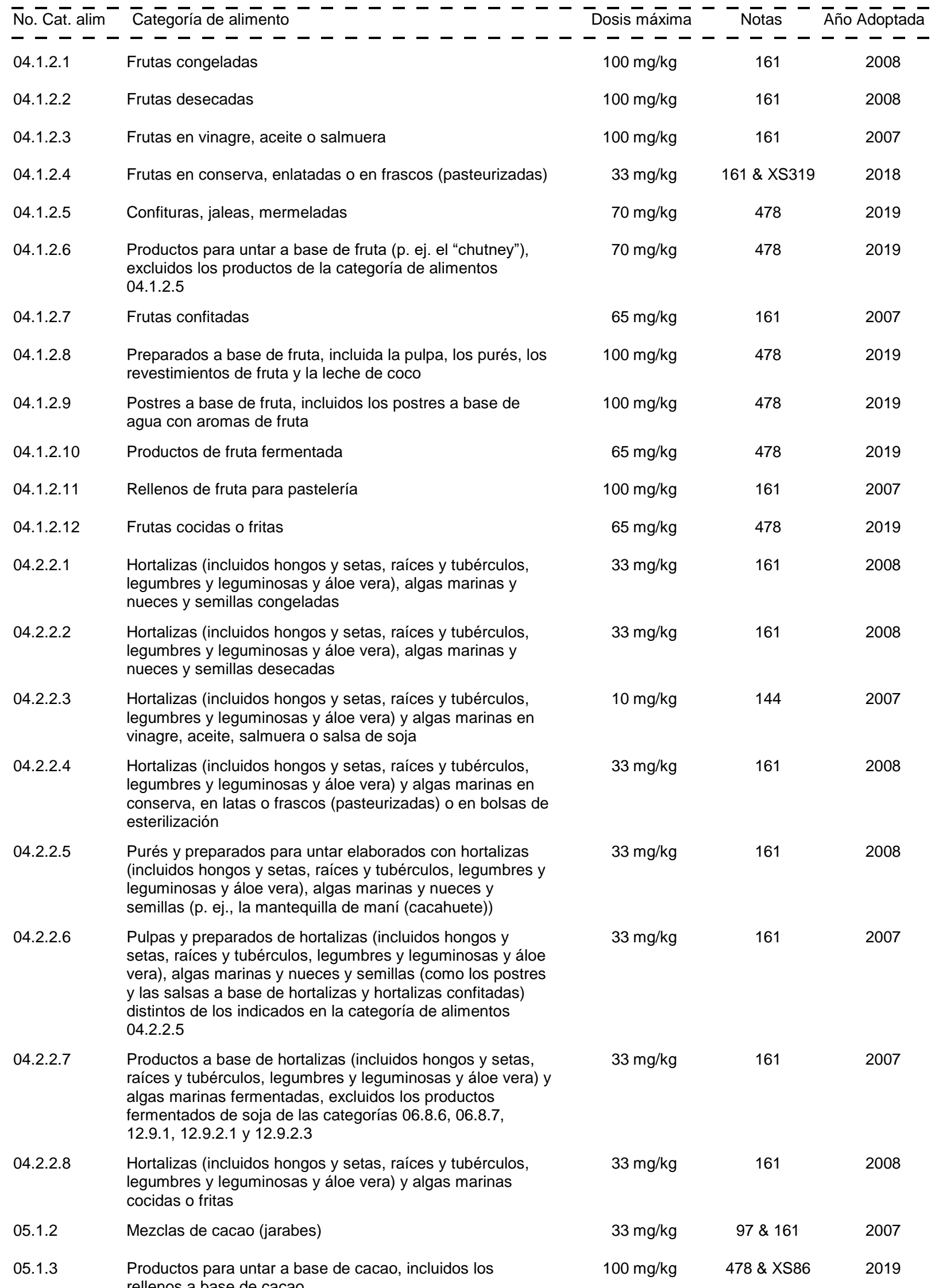




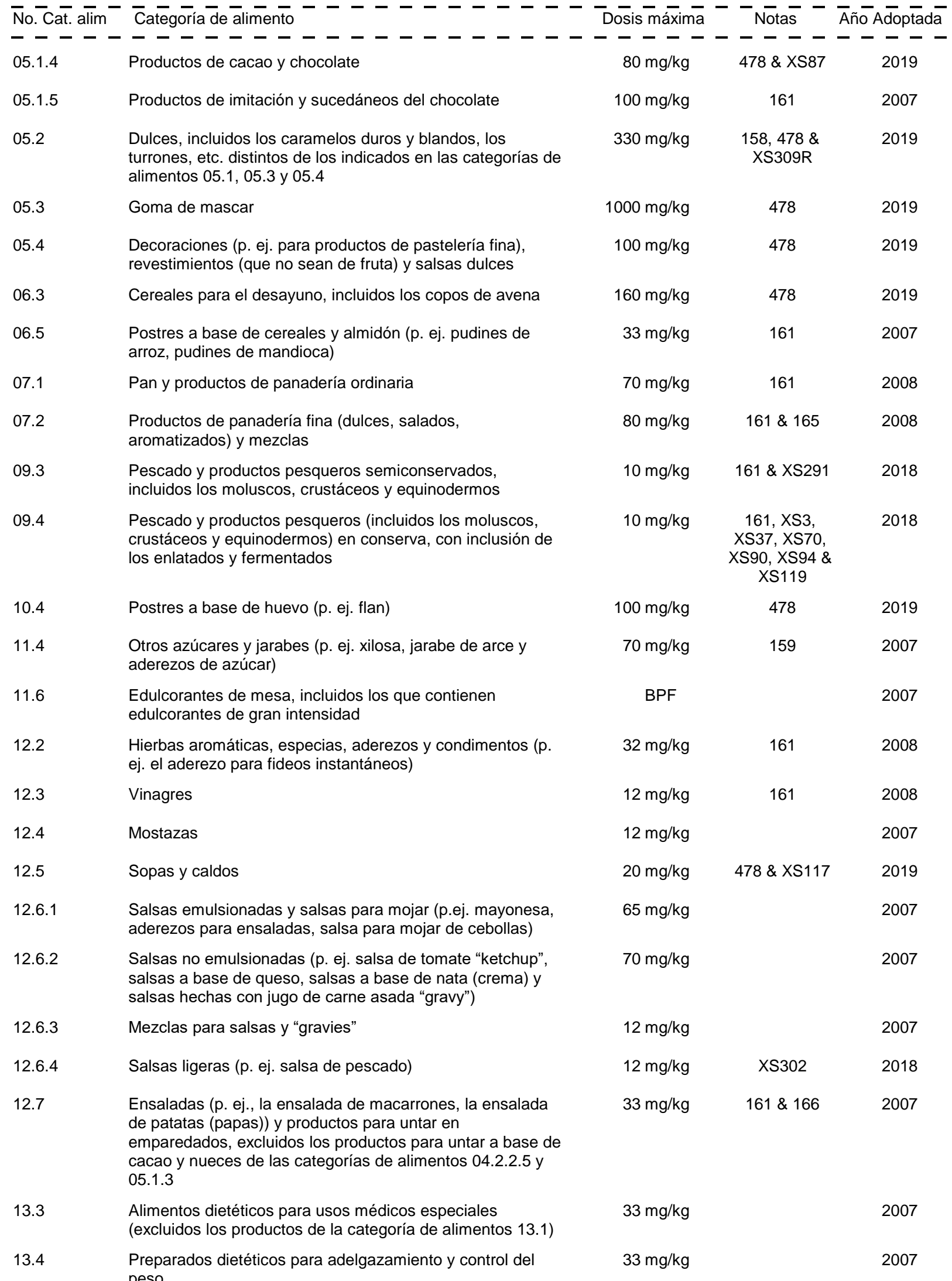




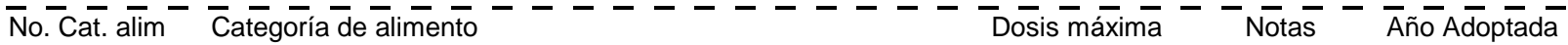

- - - - - - - - - - - - - - - - - - - - - - - - - - - -

$13.5 \quad$ Alimentos dietéticos (p. ej. los complementos alimenticios $\quad 65 \mathrm{mg} / \mathrm{kg} \quad 2007$ para usos dietéticos), excluidos los indicados en las categorías de alimentos 13.1 a 13.4 y 13.6

13.6

Complementos alimenticios

$90 \mathrm{mg} / \mathrm{kg}$

14.1.3.2 Néctares de hortalizas

$65 \mathrm{mg} / \mathrm{kg} \quad 161 \quad 2007$

14.1.3.4 Concentrados para néctares de hortalizas

$65 \mathrm{mg} / \mathrm{kg} \quad 127 \& 161 \quad 2007$

14.1.4 Bebidas a base de agua aromatizadas, incluidas las $33 \mathrm{mg} / \mathrm{kg}$ bebidas para deportistas, bebidas energéticas o bebidas bebidas calientes a base de cereales y granos, excluido el bebidas con licor tipo bebida gaseosa, bebidas refrescantes con bajo contenido de alcohol)

\section{NISINA}

\begin{tabular}{|c|c|c|c|c|}
\hline 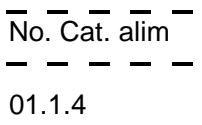 & 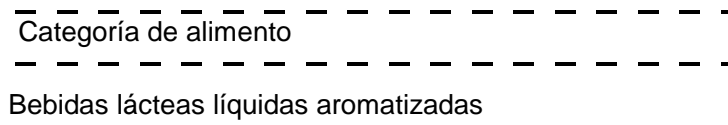 & $\begin{array}{l}\text { Dosis máximà } \\
-\overline{-}-\overline{-} \\
12.5 \mathrm{mg} / \mathrm{kg}\end{array}$ & $\begin{array}{l}- \text { Notas }- \\
---- \\
233 \& 403\end{array}$ & $\begin{array}{l}\text { Āopta } \\
\overline{-}-\overline{-} \\
2017\end{array}$ \\
\hline 01.4 .3 & Nata (crema) cuajada (natural / simple) & $10 \mathrm{mg} / \mathrm{kg}$ & & 2009 \\
\hline 01.6 .1 & Queso no madurado & $12.5 \mathrm{mg} / \mathrm{kg}$ & 233 & 2016 \\
\hline 01.6 .2 & Queso madurado & $12.5 \mathrm{mg} / \mathrm{kg}$ & $\begin{array}{l}233, \mathrm{XS} 274 \\
\mathrm{XS} 276, \mathrm{XS} 277\end{array}$ & 2019 \\
\hline 01.6 .4 & Queso elaborado & $12.5 \mathrm{mg} / \mathrm{kg}$ & 233 & 2018 \\
\hline 01.6 .5 & Productos análogos al queso & $12.5 \mathrm{mg} / \mathrm{kg}$ & & 2010 \\
\hline 01.6 .6 & Queso de proteínas del suero & $12.5 \mathrm{mg} / \mathrm{kg}$ & & 2006 \\
\hline 01.7 & $\begin{array}{l}\text { Postres lácteos (como pudines, yogur aromatizado o con } \\
\text { fruta) }\end{array}$ & $12.5 \mathrm{mg} / \mathrm{kg}$ & $233 \& 362$ & 2016 \\
\hline 06.5 & $\begin{array}{l}\text { Postres a base de cereales y almidón (p. ej. pudines de } \\
\text { arroz, pudines de mandioca) }\end{array}$ & $3 \mathrm{mg} / \mathrm{kg}$ & & 2010 \\
\hline 07.2 & $\begin{array}{l}\text { Productos de panadería fina (dulces, salados, } \\
\text { aromatizados) y mezclas }\end{array}$ & $6.25 \mathrm{mg} / \mathrm{kg}$ & 233 & 2016 \\
\hline 08.2 .2 & $\begin{array}{l}\text { Productos cárnicos, de aves de corral y caza elaborados, } \\
\text { tratados térmicamente, en piezas enteras o en cortes }\end{array}$ & $25 \mathrm{mg} / \mathrm{kg}$ & $\begin{array}{l}233,330, \text { XS96 } \\
\quad \& \text { XS97 }\end{array}$ & 2015 \\
\hline 08.3 .2 & $\begin{array}{l}\text { Productos cárnicos, de aves de corral y caza picados, } \\
\text { elaborados y tratados térmicamente }\end{array}$ & $25 \mathrm{mg} / \mathrm{kg}$ & $233 \& 377$ & 2016 \\
\hline 08.4 & Envolturas o tripas comestibles (p. ej. para embutidos) & $7 \mathrm{mg} / \mathrm{kg}$ & 233 & 2015 \\
\hline 10.2 .1 & Productos líquidos a base de huevo & $6.25 \mathrm{mg} / \mathrm{kg}$ & 233 & 2018 \\
\hline 12.5 .1 & $\begin{array}{l}\text { Sopas y caldos listos para el consumo, incluidos los } \\
\text { envasados, embotellados y congelados }\end{array}$ & $5 \mathrm{mg} / \mathrm{kg}$ & 233,339 & 2018 \\
\hline
\end{tabular}




\section{NITRATOS}

\begin{tabular}{|c|c|c|c|}
\hline 251 & Nitrato de sodio & Clases Funcionales: & $\begin{array}{l}\text { Agentes de retención de color, Sustancias } \\
\text { conservadoras }\end{array}$ \\
\hline 252 & Nitrato de potasio & Clases Funcionales: & $\begin{array}{l}\text { Agentes de retención de color, Sustancias } \\
\text { conservadoras }\end{array}$ \\
\hline
\end{tabular}

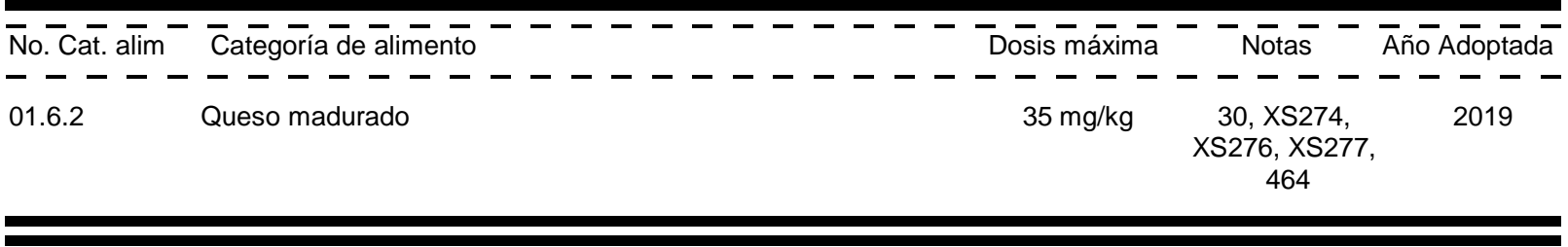

\section{NITRITOS}

$\begin{array}{lll}\text { SIN } 249 & \text { Nitrito de potasio } & \text { Clases Funcionales: } \\ \text { SIN } 250 & \text { Nitrito de sodio } & \begin{array}{l}\text { Agentes de retención de color, Sustancias } \\ \text { conservadoras }\end{array} \\ \text { Clases Funcionales: } & \begin{array}{l}\text { Agentes de retención de color, Sustancias } \\ \text { conservadoras }\end{array}\end{array}$

\section{NITRÓGENO}

SIN $941 \quad$ Nitrógeno Clases Funcionales: Espumantes, Gases de envasado, Propulsores

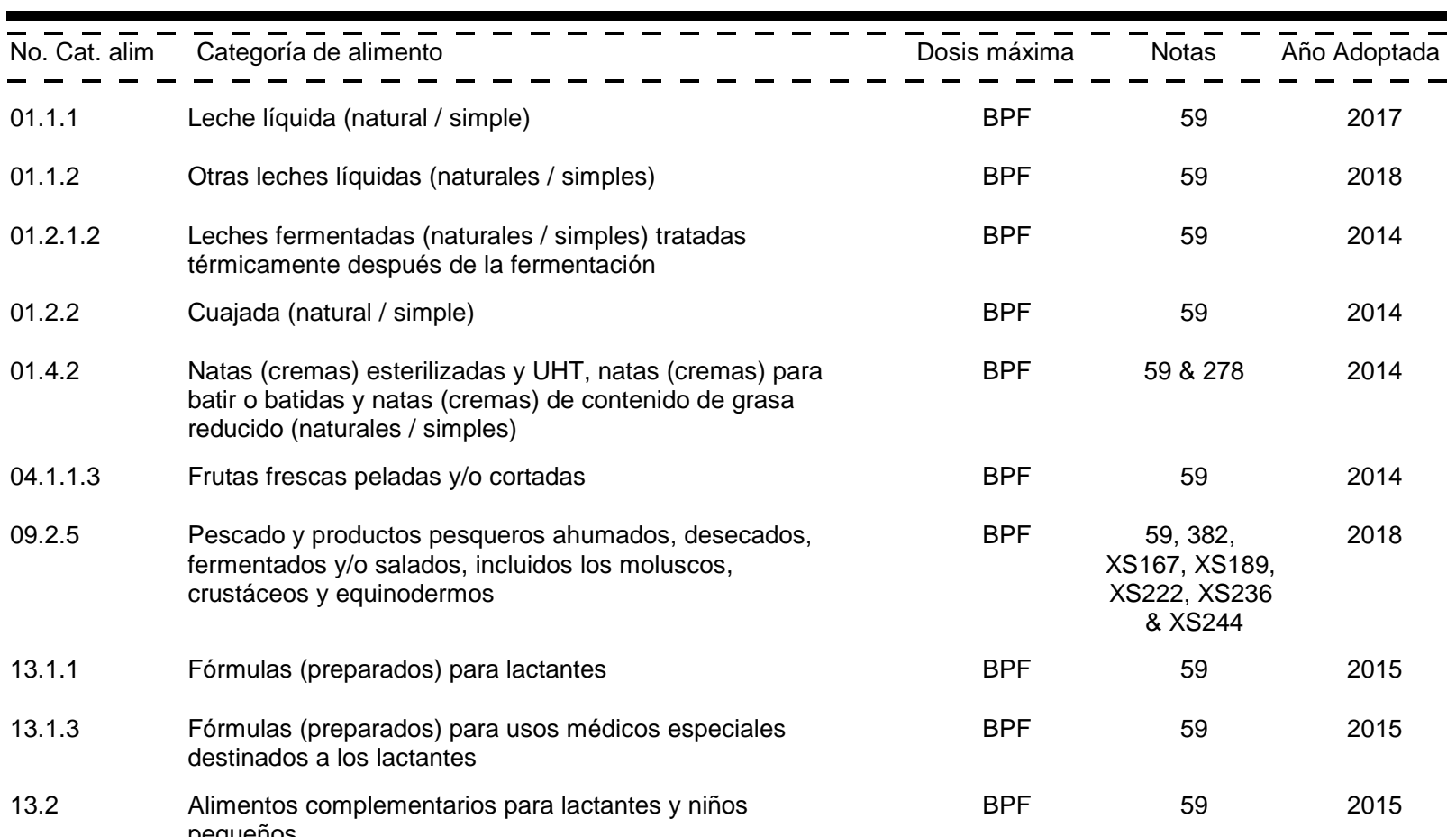




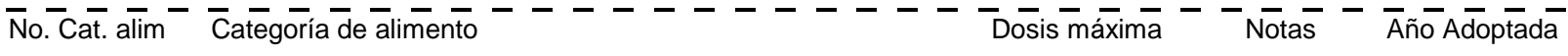
- - - - - - - - - - - - - - - - - - - - - - - - - -

14.1.5 Café, sucedáneos del café, té, infusiones de hierbas y otras $\quad$ BPF $\quad 59$ \& $160 \quad 2015$ bebidas calientes a base de cereales y granos, excluido el cacao

\section{OCTENILSUCCIONATO SÓDICO DE ALMIDÓN}

SIN 1450 Octenilsuccionato sódico de Clases Funcionales: Emulsionantes, Estabilizadores, Espesantes almidón

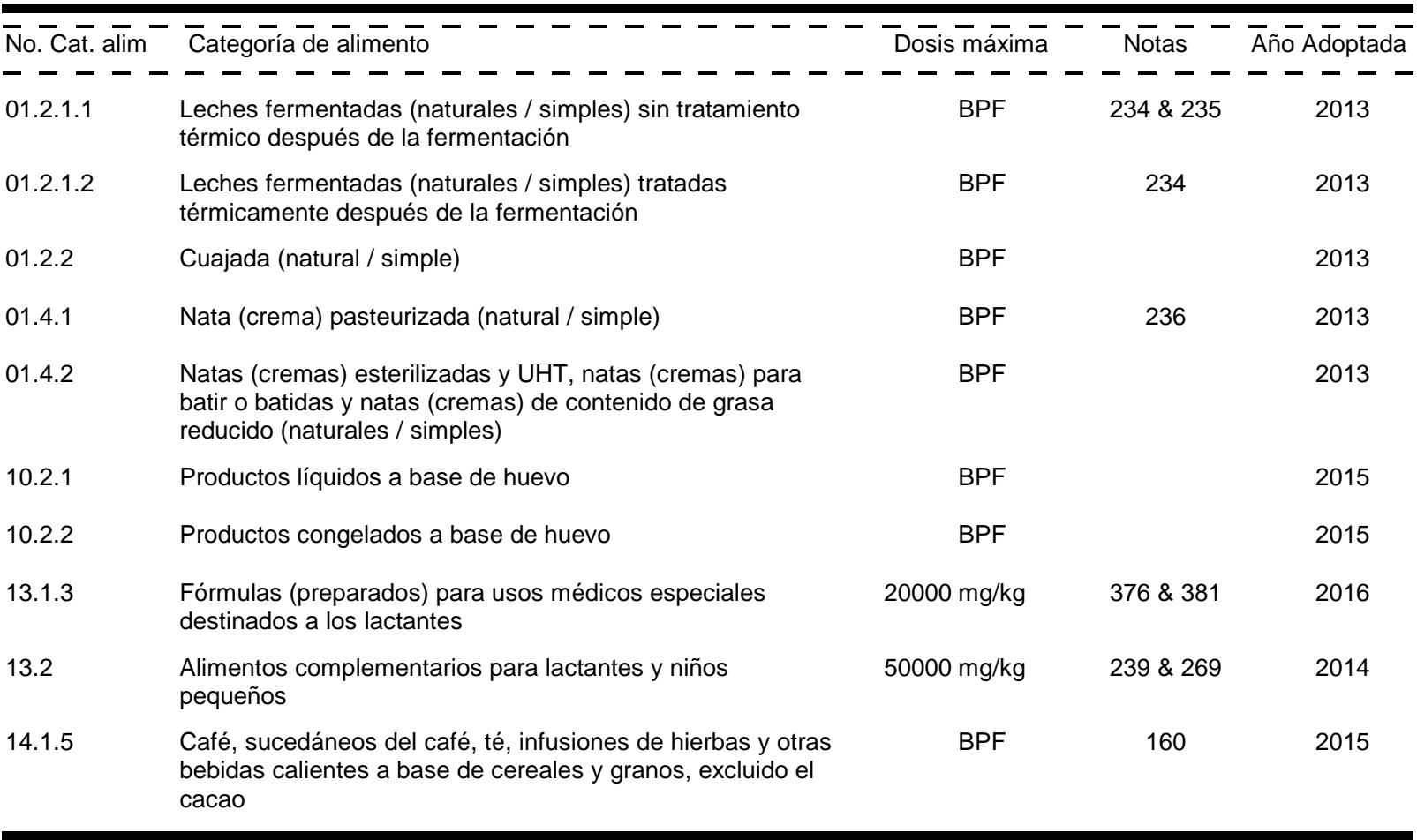

\section{ORTO-FENILFENOLES}

$\begin{array}{lll}\text { SIN } 231 & \text { Ortofenilfenol } & \text { Clases Funcionales: Sustancias conservadoras } \\ \text { SIN } 232 & \text { Ortofenilfenol de sodio } & \text { Clases Funcionales: Sustancias conservadoras }\end{array}$

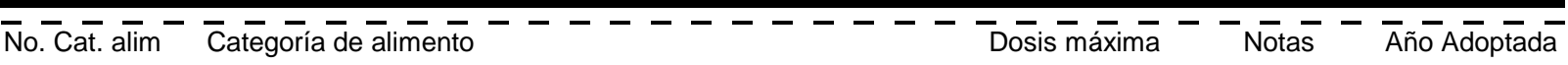
- - - - - - - - - - - - - - - - - - - - - - - - - -
04.1 .1 .2
Frutas frescas tratadas en la superficie
$12 \mathrm{mg} / \mathrm{kg}$
49
1999

\section{ÓXIDO DE CALCIO}

SIN 529 Óxido de calcio Clases Funcionales: $\begin{gathered}\text { Reguladores de la acidez, Agentes de tratamiento de } \\ \text { las harinas }\end{gathered}$

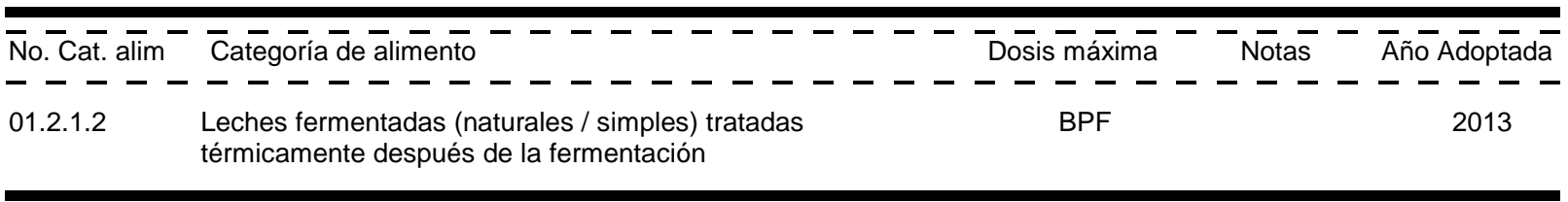




\title{
ÓXIDO DE MAGNESIO
}

\author{
SIN $530 \quad$ Óxido de magnesio
}

Clases Funcionales: Reguladores de la acidez, Antiaglutinantes

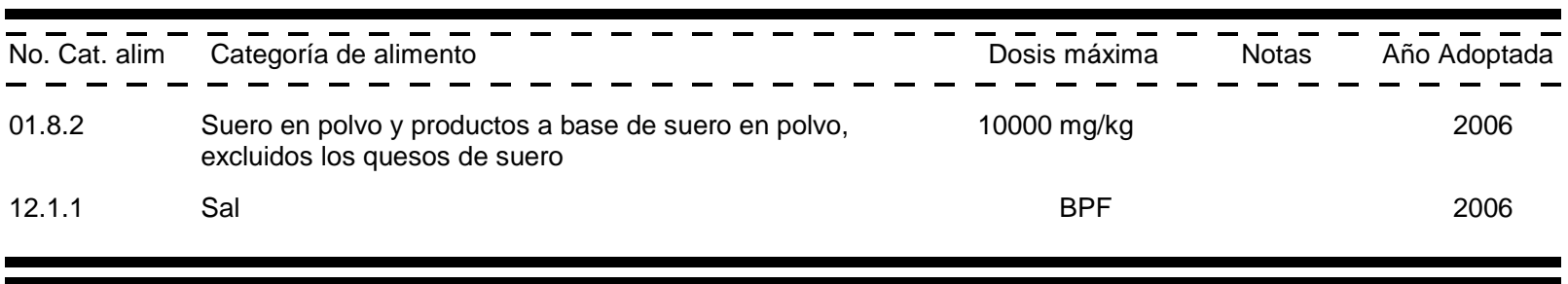

\section{ÓXIDO NITROSO}

SIN 942 Óxido nitroso Clases Funcionales: $\begin{gathered}\text { Antioxidantes, Espumantes, Gases de envasado, } \\ \text { Propulsores }\end{gathered}$

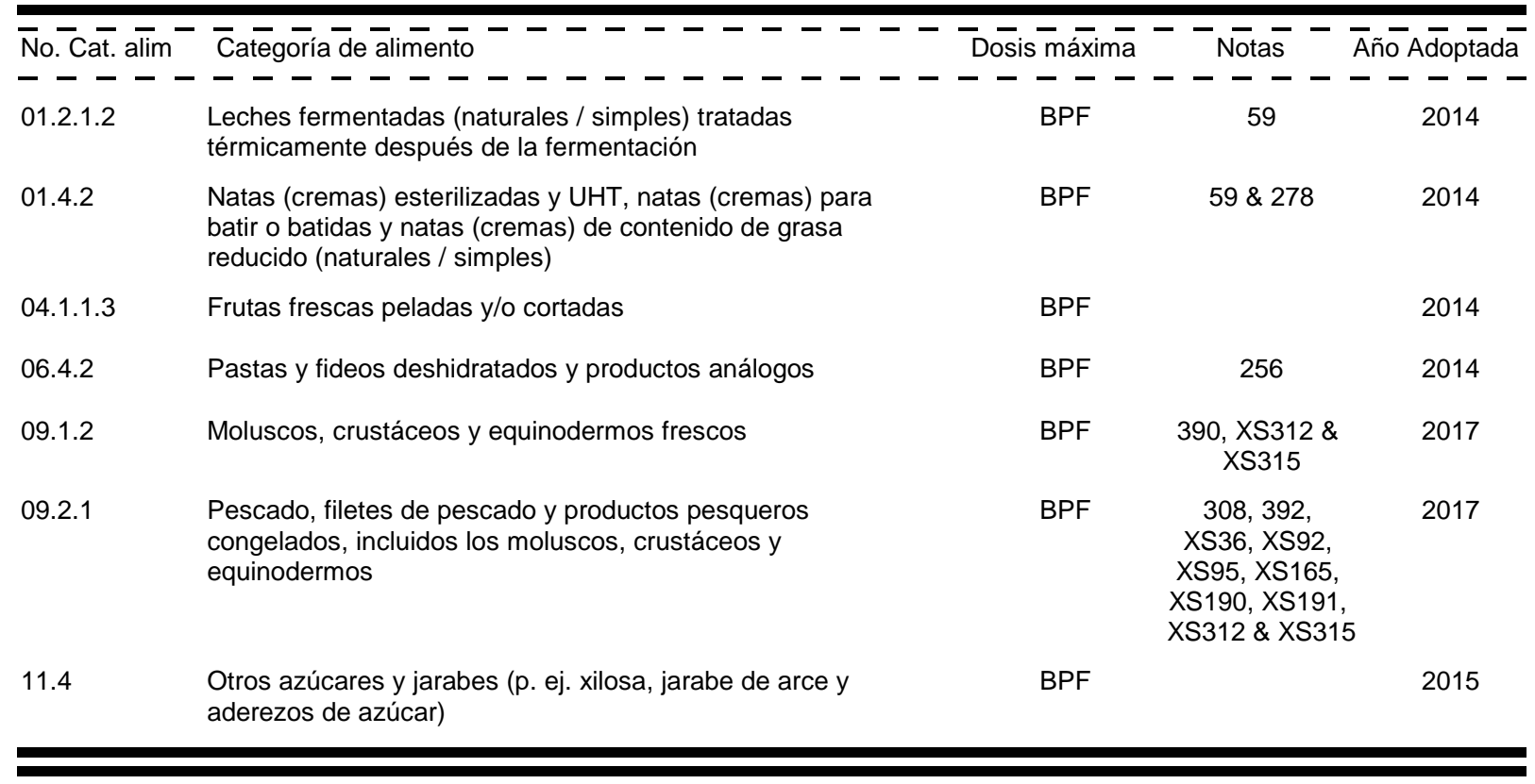

\section{ÓXIDOS DE HIERRO}

$\begin{array}{llll}\text { SIN } & 172(\text { i) } & \text { Óxido de hierro, negro } & \text { Clases Funcionales: Colorantes } \\ \text { SIN } & 172(\text { ii) } & \text { Óxido de hierro, rojo } & \text { Clases Funcionales: Colorantes } \\ \text { SIN } & 172 \text { (iii) } & \text { Óxido de hierro, amarillo } & \text { Clases Funcionales: Colorantes }\end{array}$

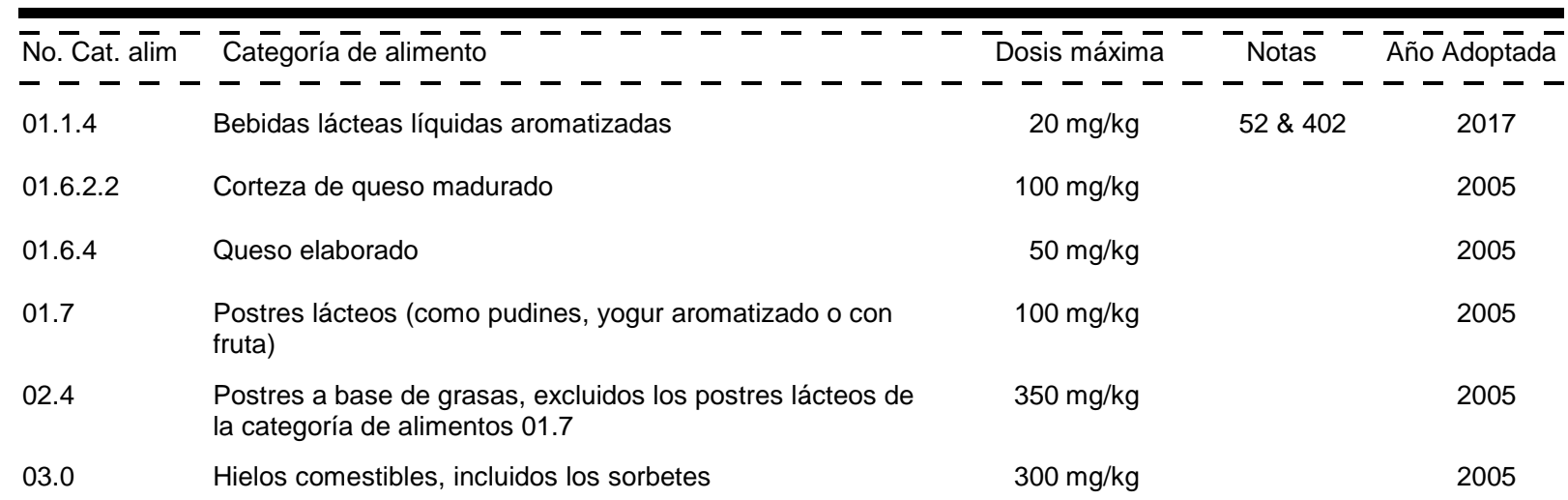




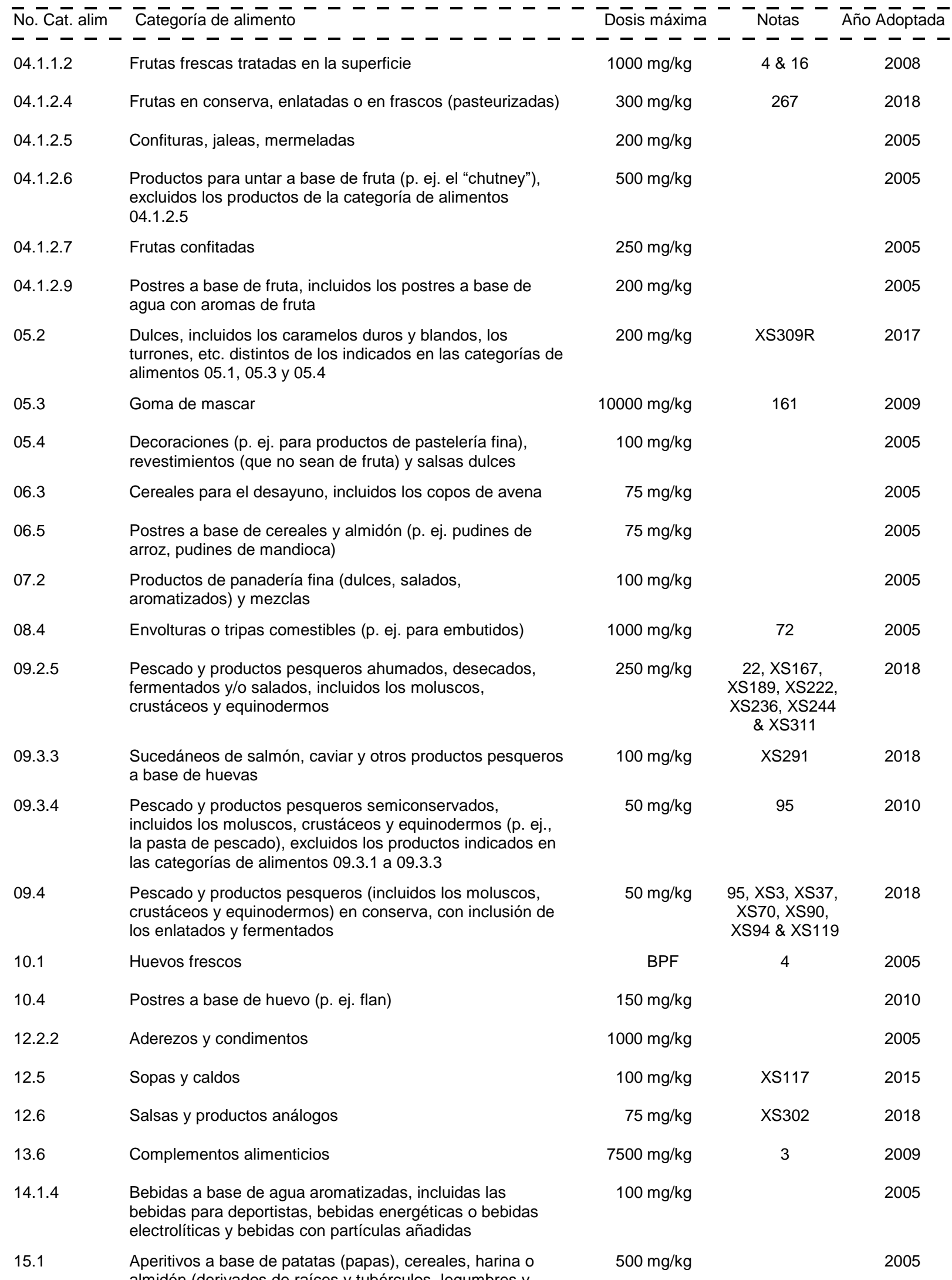




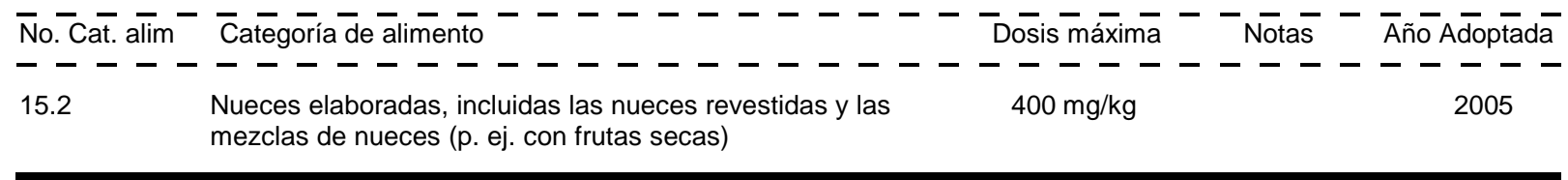

\section{PECTINAS}

SIN $440 \quad$ Pectinas
Clases Funcionales: Emulsionantes, Agentes gelificantes, Agentes de glaseado, Estabilizadores, Espesantes

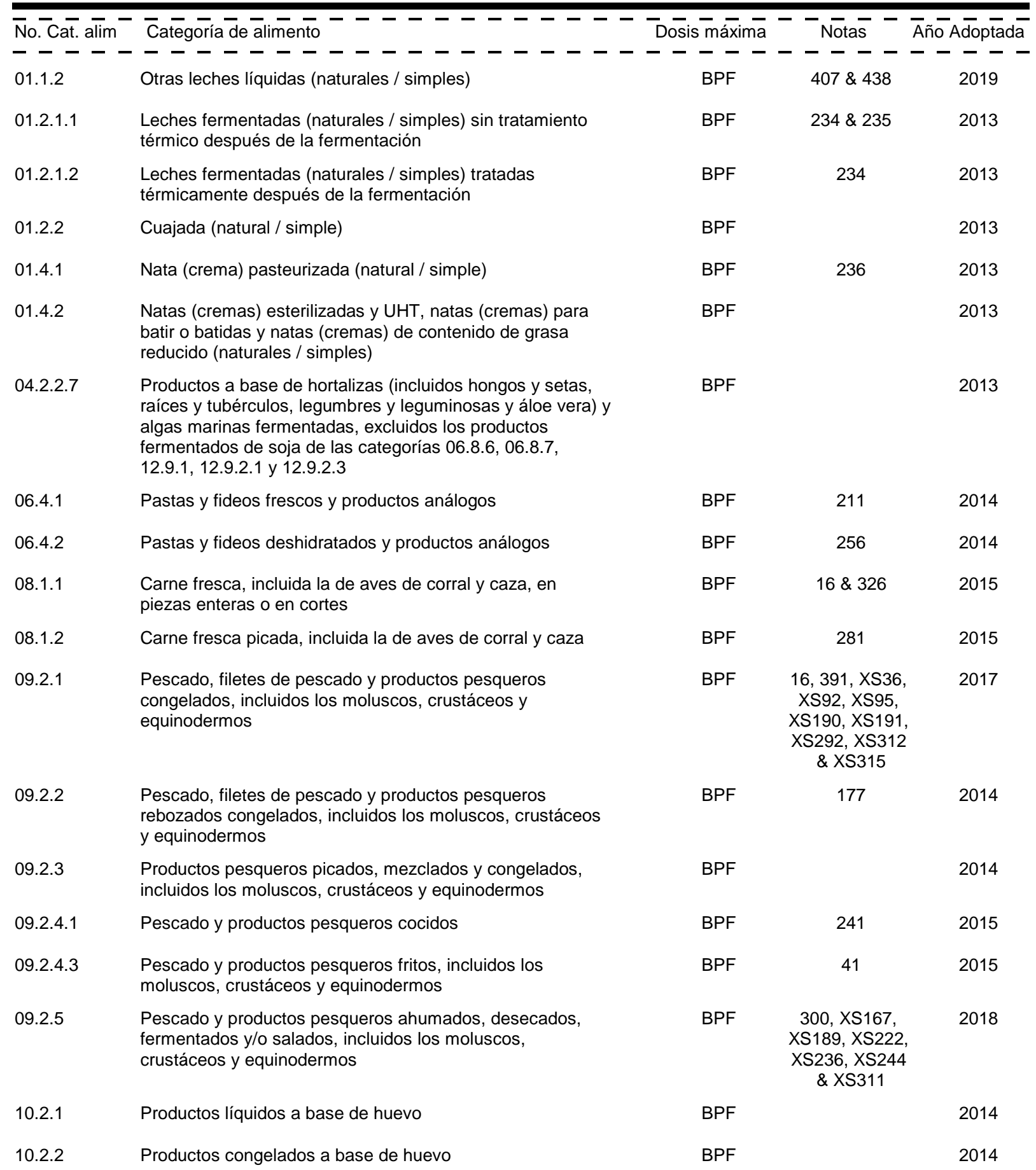




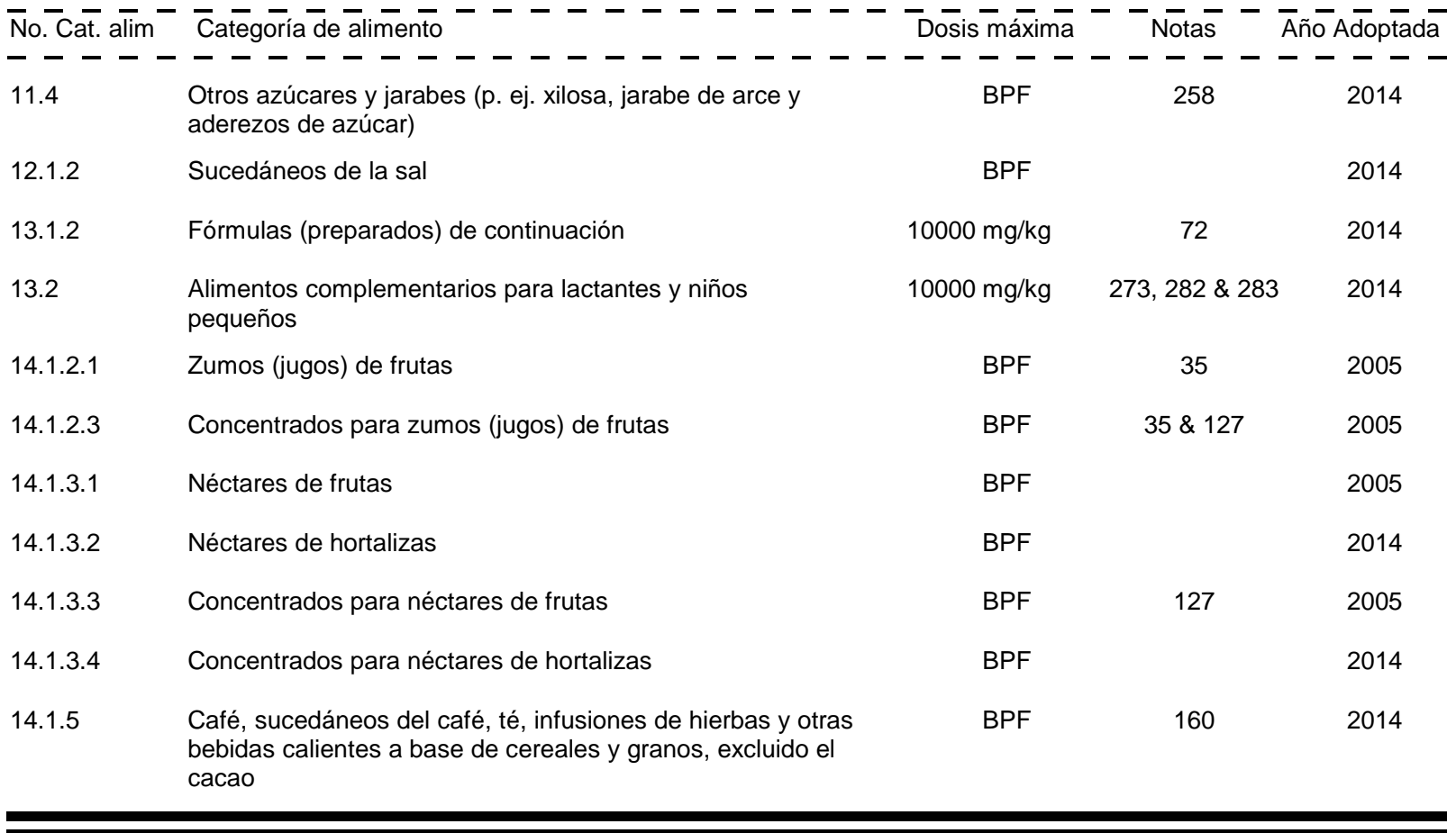

\section{PERÓXIDO DE BENZOÍLO}

SIN 928
Peróxido de benzoílo
Clases Funcionales: Decolorantes, Agentes de tratamiento de las harinas, Sustancias conservadoras

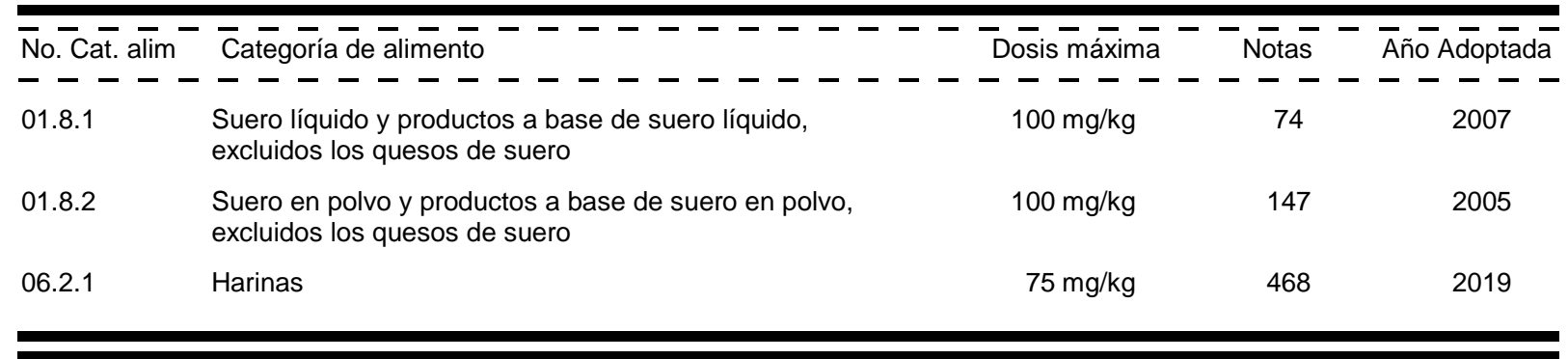

\section{POLI-1-DECENOS HIDROGENADOS}

SIN 907 Poli-1-deceno hidrogenado Clases Funcionales: Agentes de glaseado

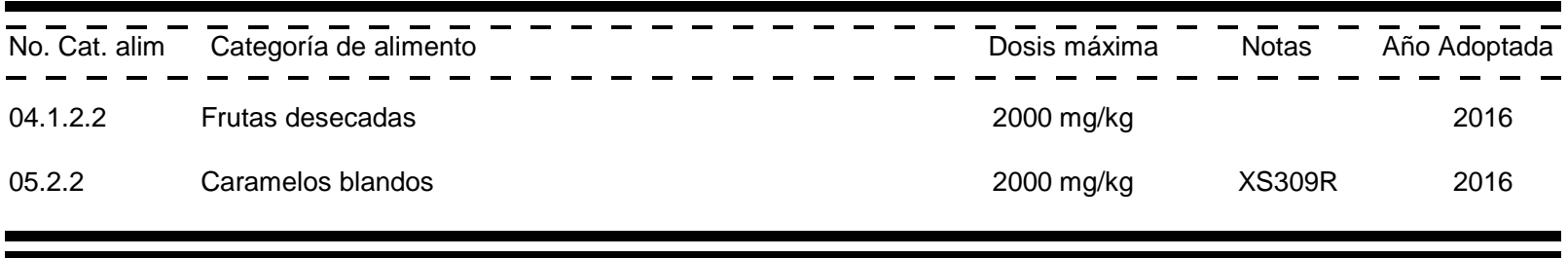

\section{POLIDEXTROSA}

SIN $1200 \quad$ Polidextrosa
Clases Funcionales: Incrementadores del volumen, Agentes de glaseado, Humectantes, Estabilizadores, Espesantes

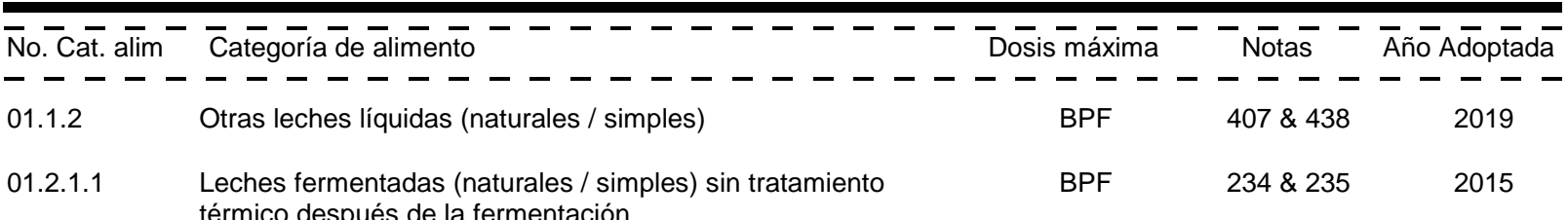




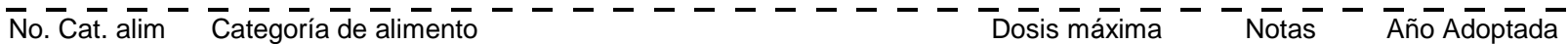

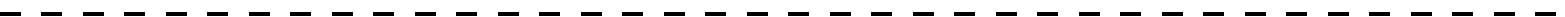

01.2.1.2 Leches fermentadas (naturales / simples) tratadas $\quad$ BPF $\quad 234 \quad 2015$ térmicamente después de la fermentación

01.2.2 Cuajada (natural / simple)

BPF

2015

01.4 .2

Natas (cremas) esterilizadas y UHT, natas (cremas) para batir o batidas y natas (cremas) de contenido de grasa reducido (naturales / simples)

09.2 .1

Pescado, filetes de pescado y productos pesqueros congelados, incluidos los moluscos, crustáceos y equinodermos

09.2.4.1 Pescado y productos pesqueros cocidos

BPF

BPF

236

2013

BPF

XS36, XS92,

XS95, XS165

XS190, XS191

XS292, XS312

\& XS315

09.2.4.3 Pescado y productos pesqueros fritos, incluidos los moluscos, crustáceos y equinodermos

241

2015

BPF

41

2015

10.2.1 Productos líquidos a base de huevo

BPF

2014

10.2 .2

Productos congelados a base de huevo

BPF

$11.4 \quad$ Otros azúcares y jarabes (p. ej. xilosa, jarabe de arce y aderezos de azúcar)

BPF

\section{POLIETILENGLICOL}

SIN $1521 \quad$ Polietilenglicol
Clases Funcionales: Antiespumantes, Sustancias inertes, Emulsionantes, Agentes de glaseado, Espesantes

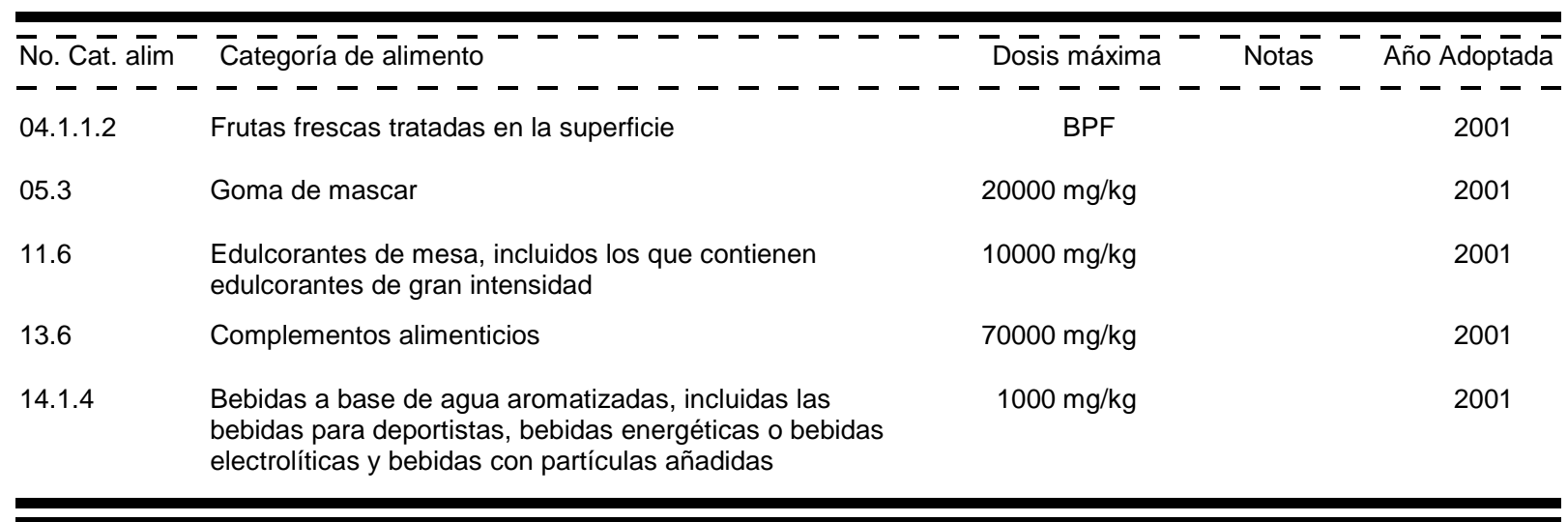

\section{POLISORBATOS}

$\begin{array}{llll}\text { SIN } 432 & \begin{array}{l}\text { Monalaurato de sorbitán } \\ \text { polioxietinelado (20) }\end{array} & \text { Clases Funcionales: Emulsionantes, Estabilizadores } \\ \text { SIN } 433 & \begin{array}{l}\text { Monooleato de sorbitán } \\ \text { polioxietinelado (20) }\end{array} & \text { Clases Funcionales: Emulsionantes, Estabilizadores } \\ \text { SIN } 434 & \begin{array}{l}\text { Monopalmitato de sorbitán } \\ \text { polioxietinelado (20) }\end{array} & \text { Clases Funcionales: Emulsionantes } \\ \text { SIN } 435 & \begin{array}{l}\text { Monoesterato de sorbitán } \\ \text { polioxietinelado (20) }\end{array} & \text { Clases Funcionales: Emulsionantes, Estabilizadores } \\ \text { SIN } 436 & \begin{array}{l}\text { Triestearato de sorbitán } \\ \text { polioxietinelado (20) }\end{array} & \text { Clases Funcionales: Emulsionantes, Estabilizadores }\end{array}$

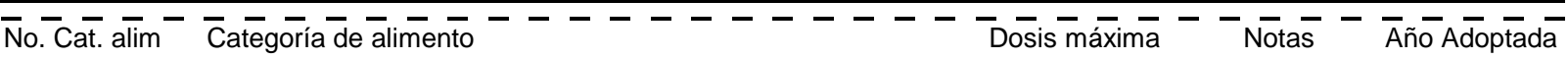




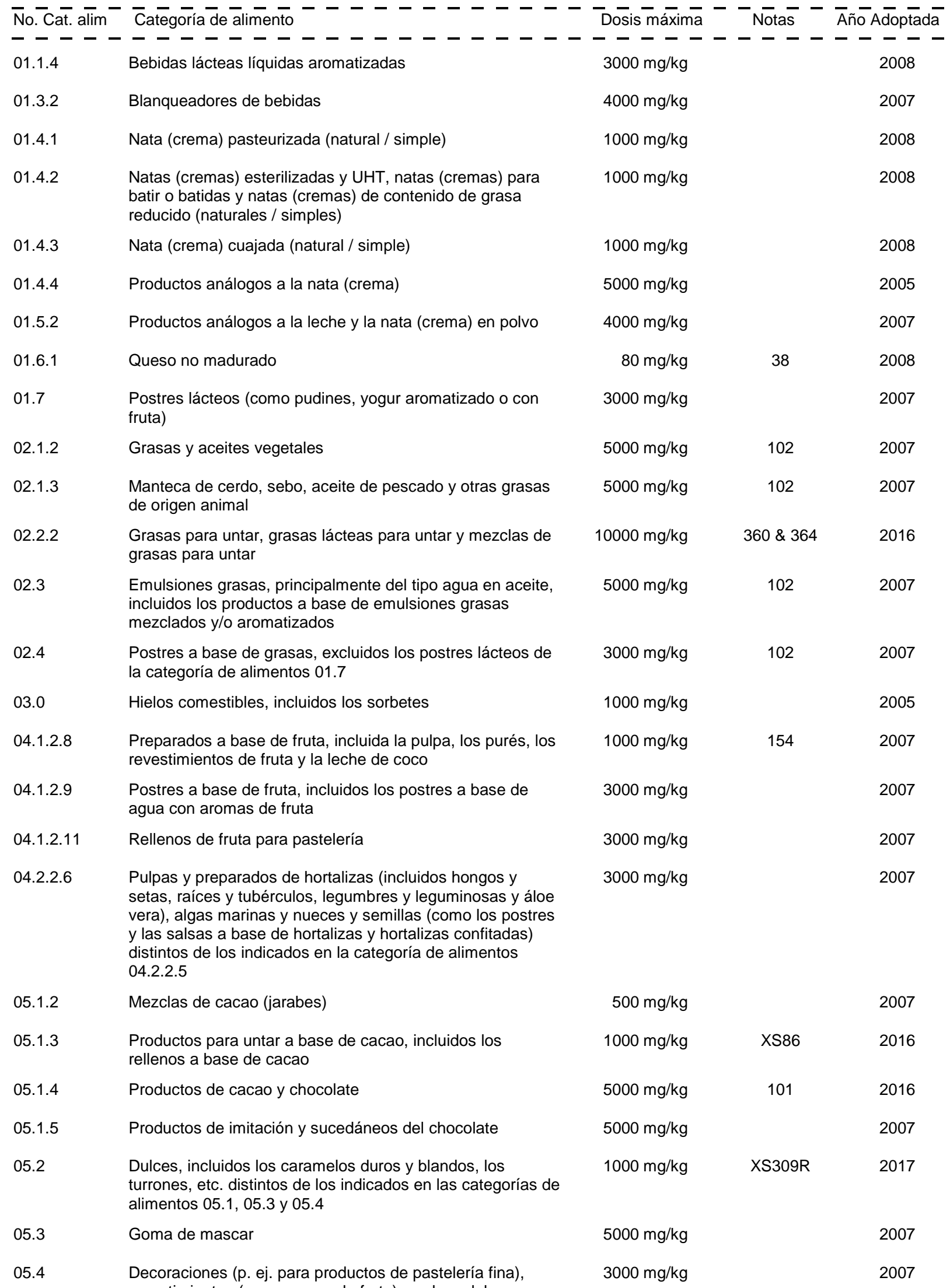




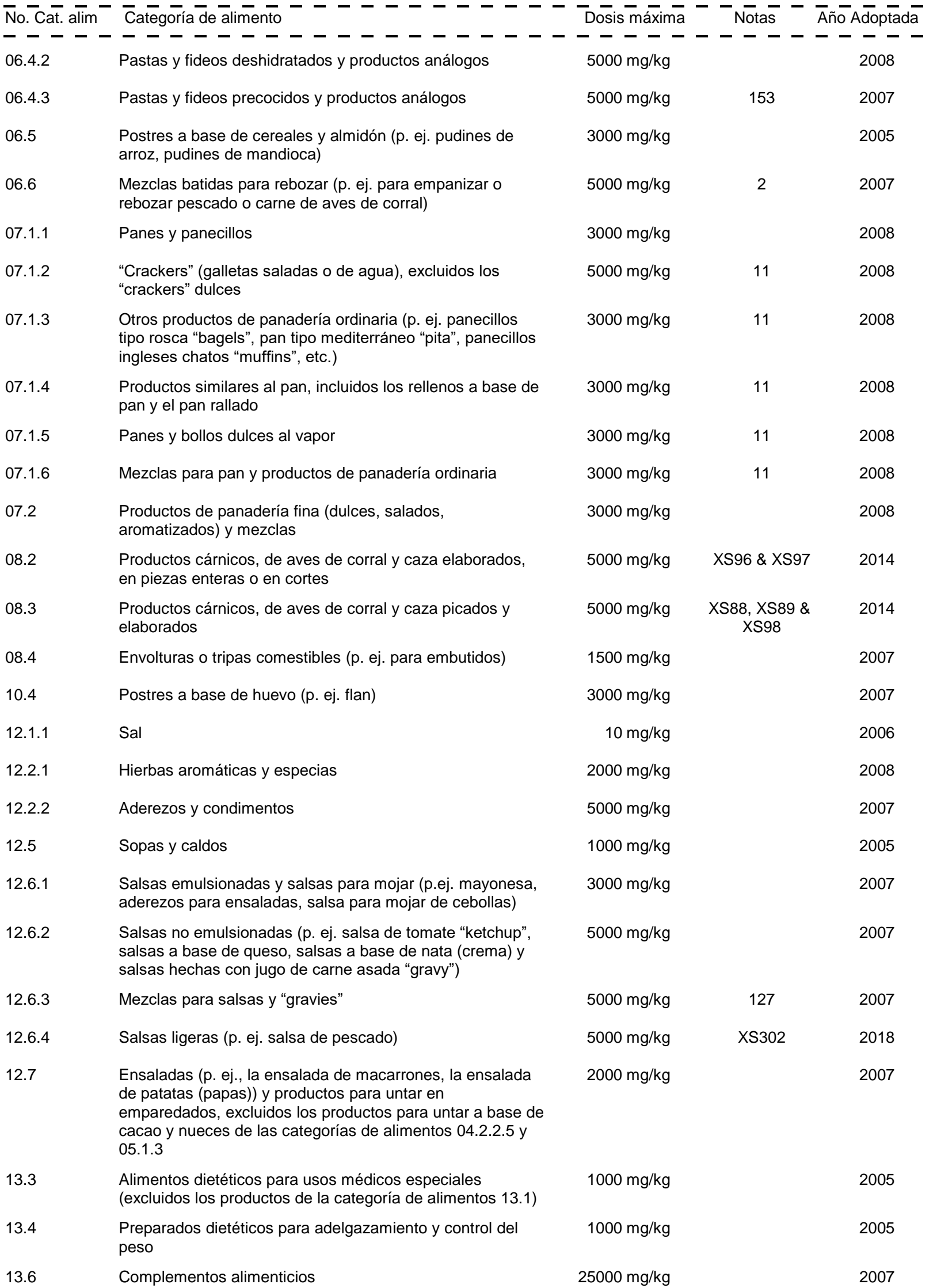




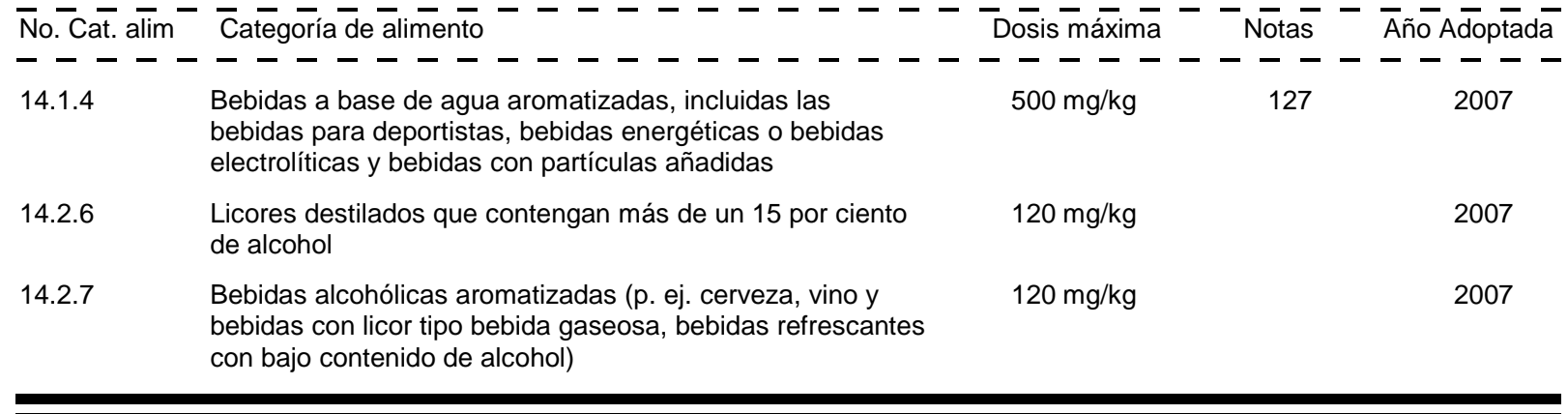

\section{POLIVINILPIRROLIDONA}

\section{SIN $1201 \quad$ Polivinilpirrolidona}

Clases Funcionales: Emulsionantes, Agentes de glaseado, Estabilizadores, Espesantes

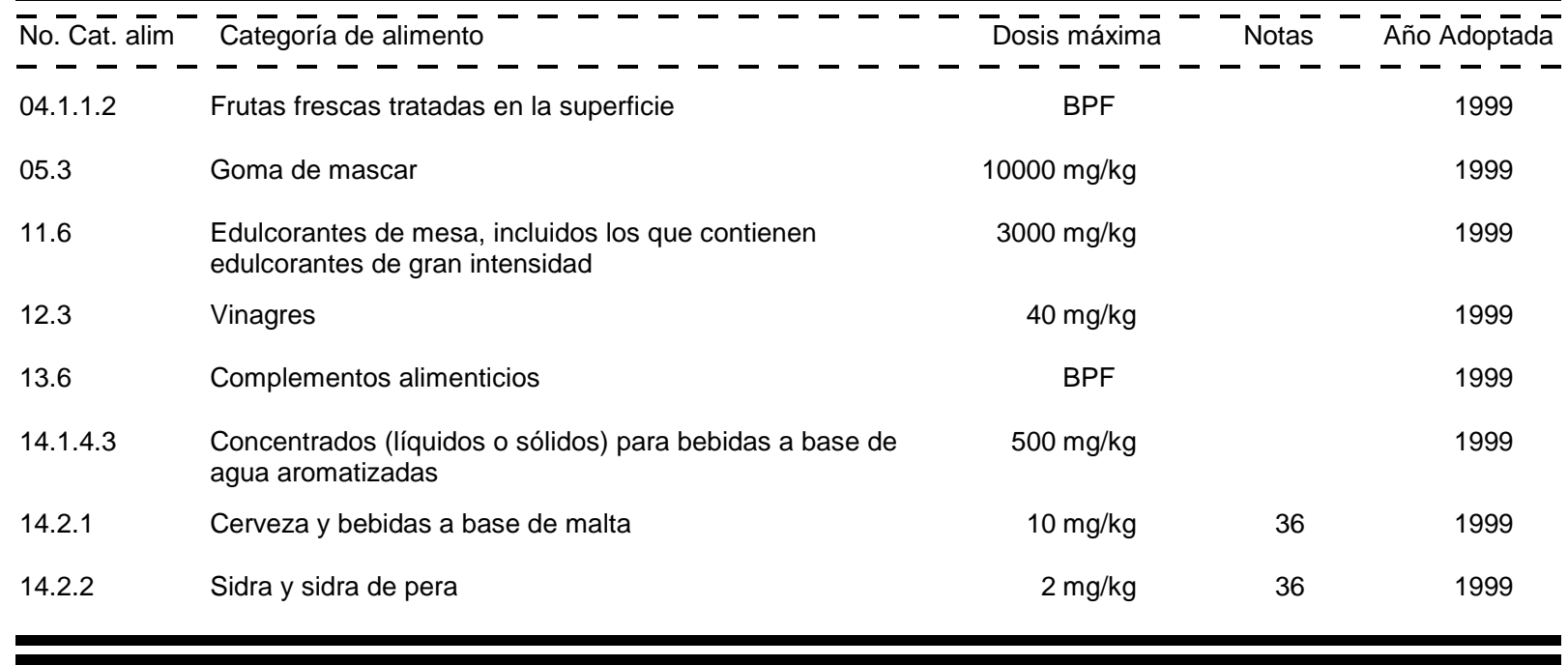

PONCEAU 4R (ROJO DE COCHINILLA A)

SIN 124 Ponceau 4R (Rojo de cochinilla Clases Funcionales: Colorantes A)

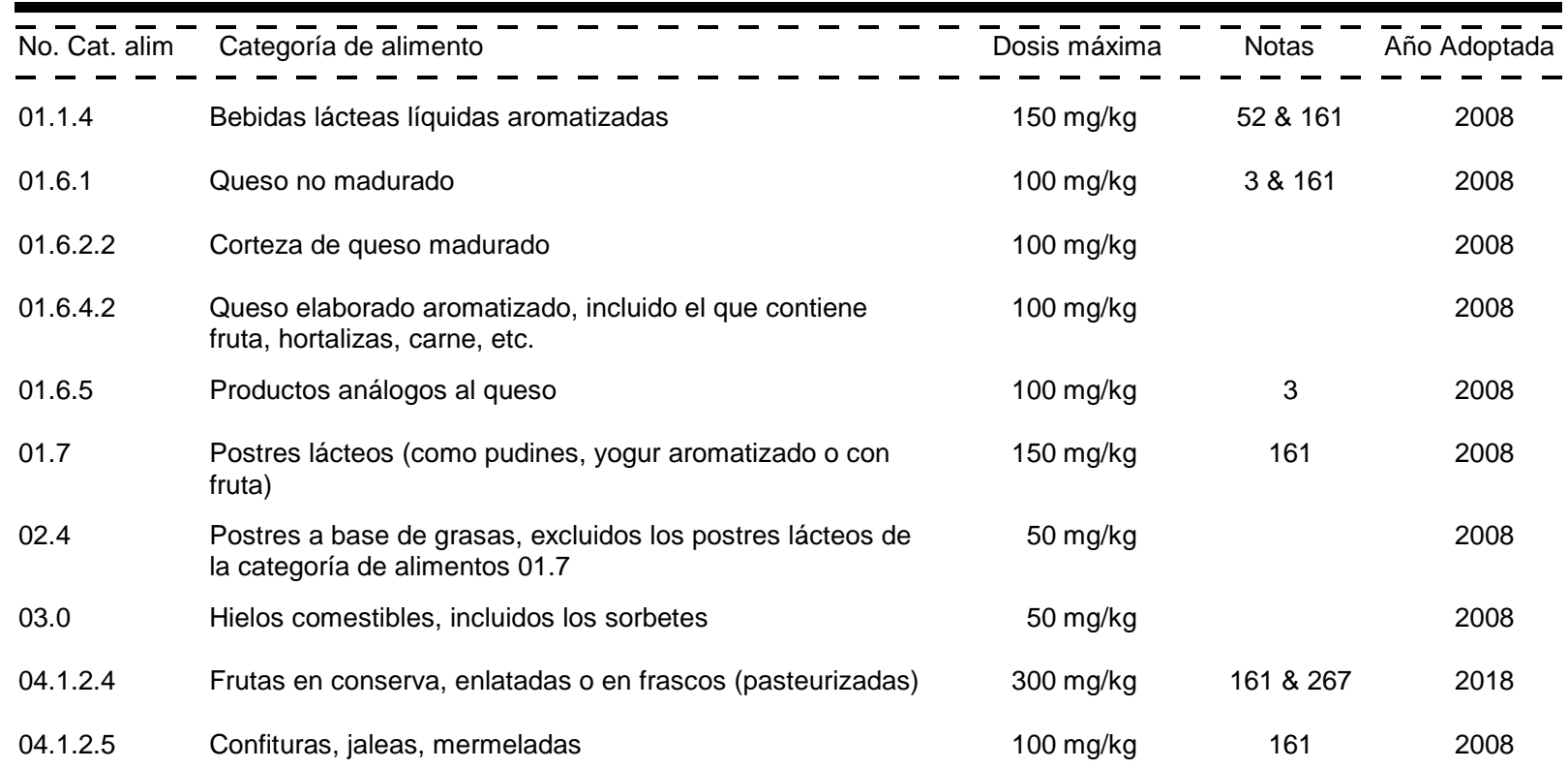




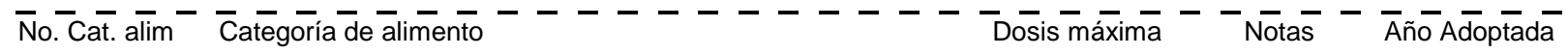

- - - - - - - - - - - - - - - - - - - - - - - - - - -

04.1.2.6 Productos para untar a base de fruta (p. ej. el "chutney"), $\quad 500$ mg/kg $\quad 161 \quad 2008$ excluidos los productos de la categoría de alimentos 04.1.2.5

04.1.2.7 Frutas confitadas

$200 \mathrm{mg} / \mathrm{kg}$

161

2008

04.1.2.8 Preparados a base de fruta, incluida la pulpa, los purés, los revestimientos de fruta y la leche de coco

$50 \mathrm{mg} / \mathrm{kg}$

$161 \& 182$

2008

$50 \mathrm{mg} / \mathrm{kg}$

161

2008

agua con aromas de fruta

04.1.2.11 Rellenos de fruta para pastelería

04.2.2.7 Productos a base de hortalizas (incluidos hongos y setas, raíces y tubérculos, legumbres y leguminosas y áloe vera) y algas marinas fermentadas, excluidos los productos fermentados de soja de las categorías 06.8.6, 06.8.7, 12.9.1, 12.9.2.1 y 12.9.2.3

05.1.4 Productos de cacao y chocolate

$300 \mathrm{mg} / \mathrm{kg}$

183

2016

$50 \mathrm{mg} / \mathrm{kg}$

2008

05.1.5 Productos de imitación y sucedáneos del chocolate

$05.2 \quad$ Dulces, incluidos los caramelos duros y blandos, los turrones, etc. distintos de los indicados en las categorías de alimentos $05.1,05.3$ y 05.4

05.3

Goma de mascar

$300 \mathrm{mg} / \mathrm{kg}$

$161 \&$ XS309R

2017

$300 \mathrm{mg} / \mathrm{kg}$

2008

$50 \mathrm{mg} / \mathrm{kg}$

2008 revestimientos (que no sean de fruta) y salsas dulces

06.5

Postres a base de cereales y almidón (p. ej. pudines de arroz, pudines de mandioca)

07.2 Productos de panadería fina (dulces, salados, aromatizados) y mezclas

08.4 Envolturas o tripas comestibles (p. ej. para embutidos)

09.2.1 Pescado, filetes de pescado y productos pesqueros congelados, incluidos los moluscos, crustáceos y equinodermos

09.2.2 Pescado, filetes de pescado y productos pesqueros rebozados congelados, incluidos los moluscos, crustáceos y equinodermos

09.2.3 Productos pesqueros picados, mezclados y congelados, incluidos los moluscos, crustáceos y equinodermos

09.2.4.1 Pescado y productos pesqueros cocidos

09.2.4.2 Moluscos, crustáceos y equinodermos cocidos

09.2.5 Pescado y productos pesqueros ahumados, desecados, fermentados y/o salados, incluidos los moluscos, crustáceos y equinodermos

Sucedáneos de salmón, caviar y otros productos pesqueros a base de huevas

09.3 .4

Pescado y productos pesqueros semiconservados, incluidos los moluscos, crustáceos y equinodermos (p. ej., la pasta de pescado), excluidos los productos indicados en las categorías de alimentos 09.3.1 a 09.3.3

$\begin{array}{ccc}50 \mathrm{mg} / \mathrm{kg} & & 2008 \\ 50 \mathrm{mg} / \mathrm{kg} & & 2008 \\ 500 \mathrm{mg} / \mathrm{kg} & 16 & 2008 \\ 30 \mathrm{mg} / \mathrm{kg} & \begin{array}{c}395, \mathrm{XS} 36, \\ \text { XS95, XS165, } \\ \text { XS190, XS191, } \\ \text { XS292, XS312 } \\ \text { \& XS315 }\end{array} & 2017 \\ & & \end{array}$

$500 \mathrm{mg} / \mathrm{kg} \quad 16,95 \&$ XS166 2017

$500 \mathrm{mg} / \mathrm{kg} \quad 16 \& 95 \quad 2008$

$500 \mathrm{mg} / \mathrm{kg} \quad 2008$

$250 \mathrm{mg} / \mathrm{kg} \quad 2008$

$100 \mathrm{mg} / \mathrm{kg} \quad 22, \mathrm{XS167}, \quad 2018$ XS189, XS222

XS236, XS244

\& XS311

$500 \mathrm{mg} / \mathrm{kg} \quad \mathrm{XS} 291 \quad 2018$

$100 \mathrm{mg} / \mathrm{kg} \quad 2008$ 


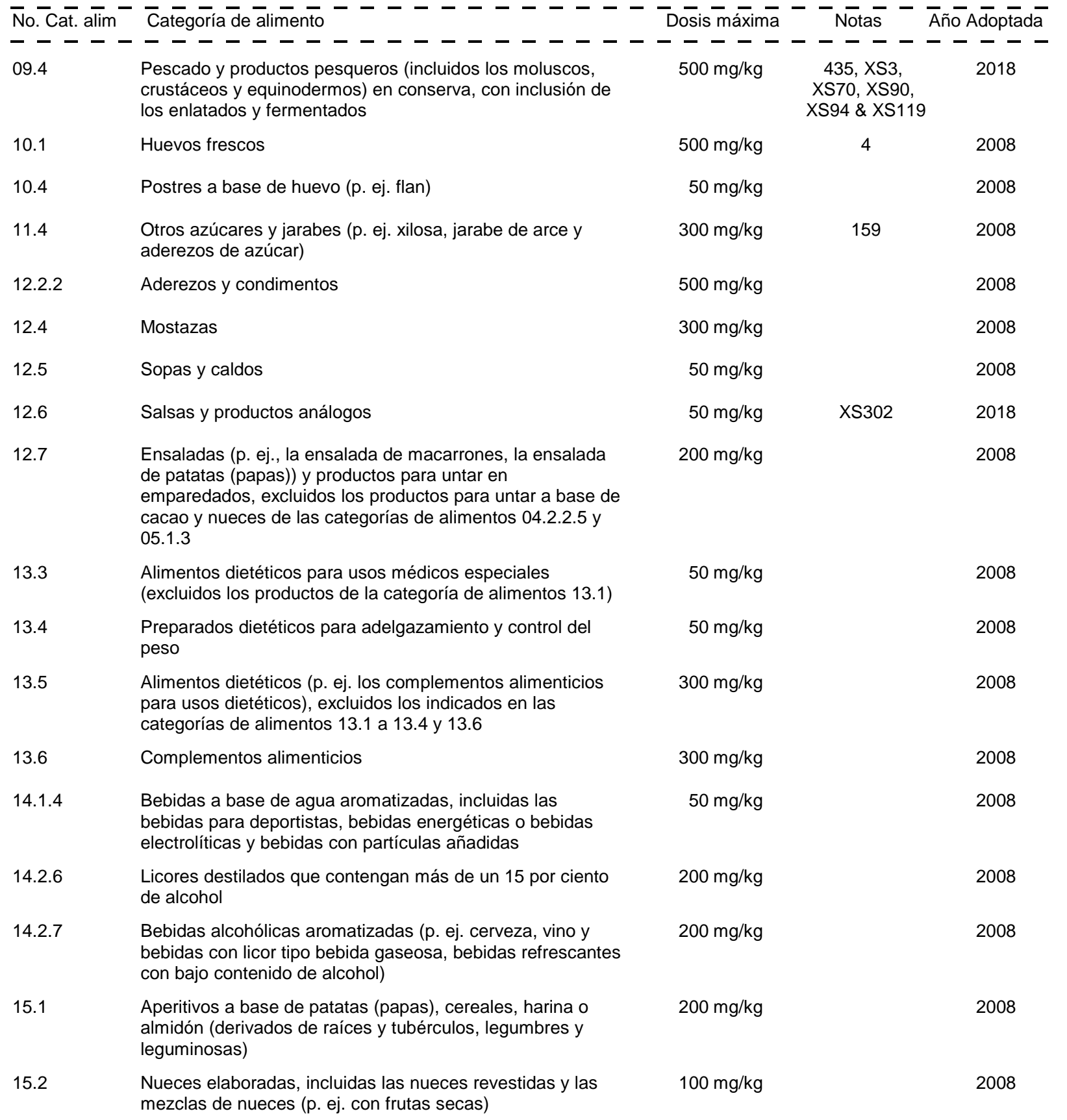

\section{PROPILENGLICOL} glaseado, Humectantes

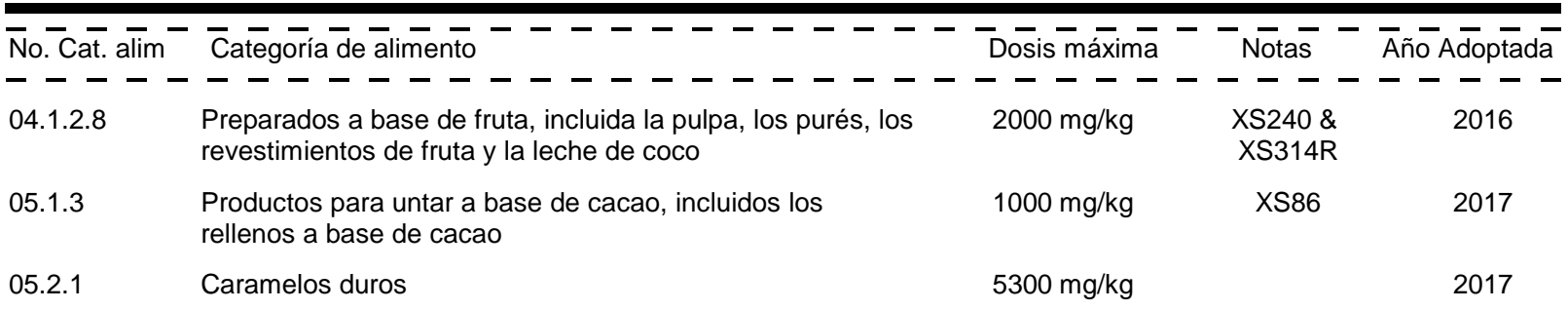




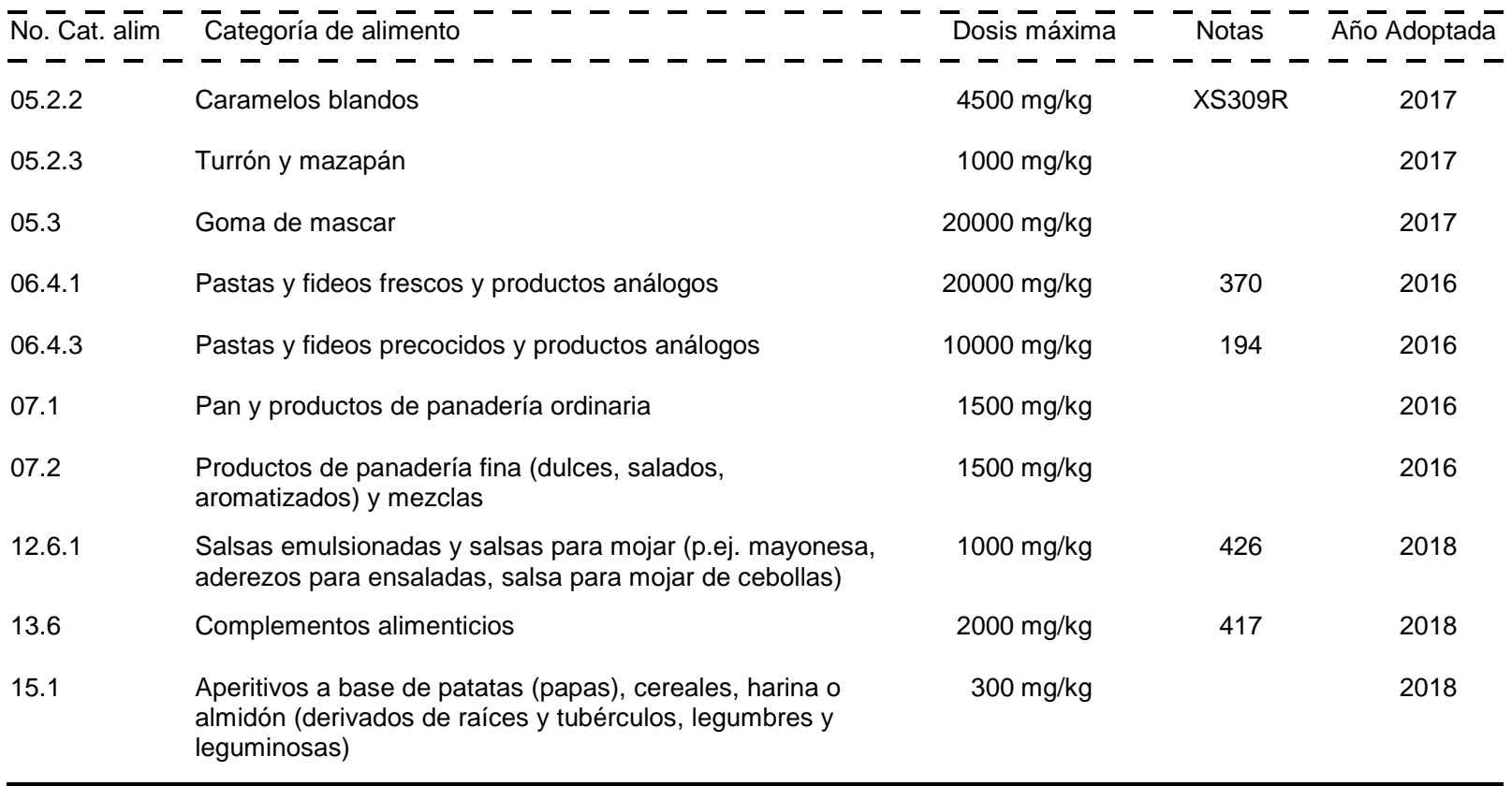

\section{PROPIONATO DE CALCIO}

SIN 282 Propionato de calcio Clases Funcionales: Sustancias conservadoras

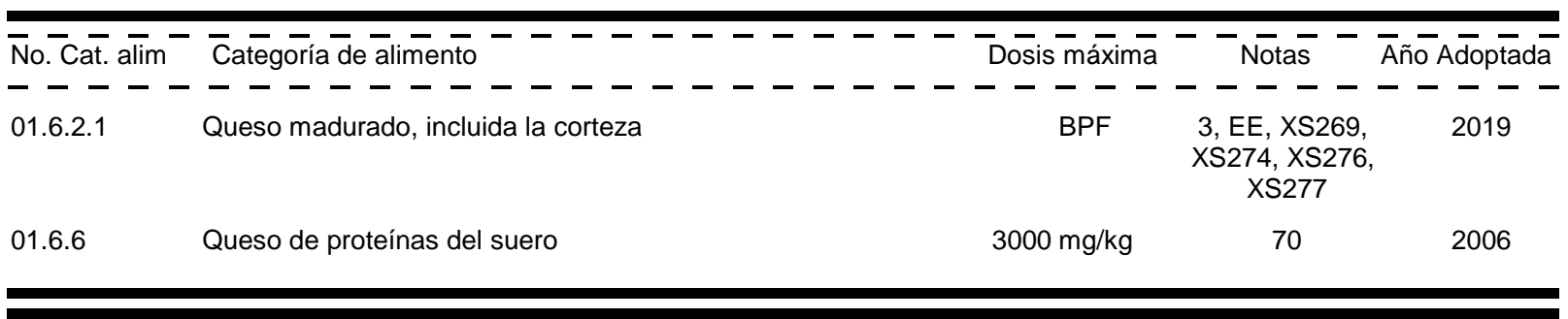

\section{PROPIONATO DE SODIO}

SIN 281 Propionato de sodio Clases Funcionales: Sustancias conservadoras

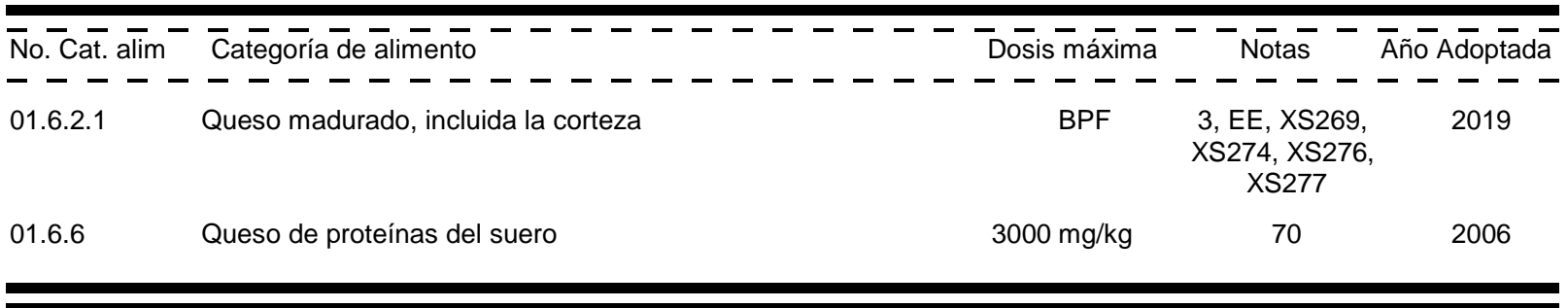

\section{PROTEASA DE ASPERGILLUS ORYZAE. VAR}

SIN 1101(i) Proteasa de Aspergillus orizae Clases Funcionales: Acentuadores del sabor, Agentes de tratamiento de var. las harinas, Estabilizadores

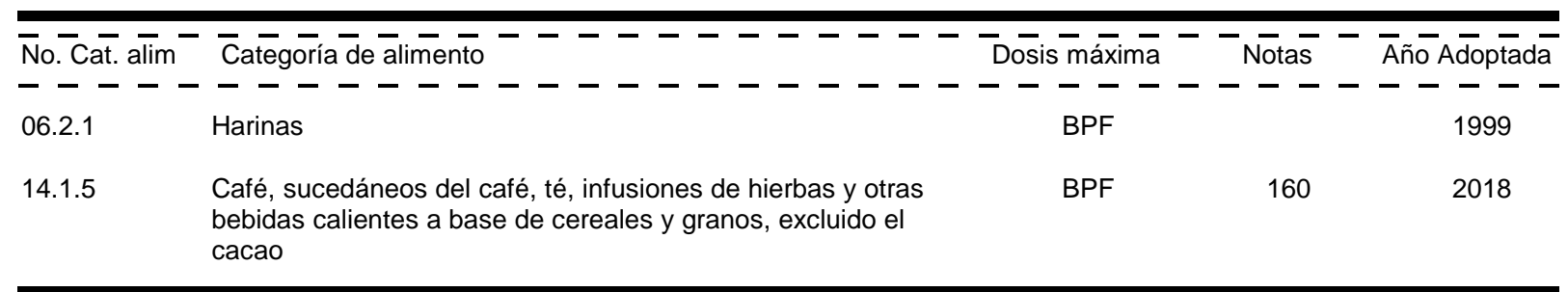




\section{PULLULAN}

SIN 1204 Pullulan Clases Funcionales: Agentes de glaseado, Espesantes

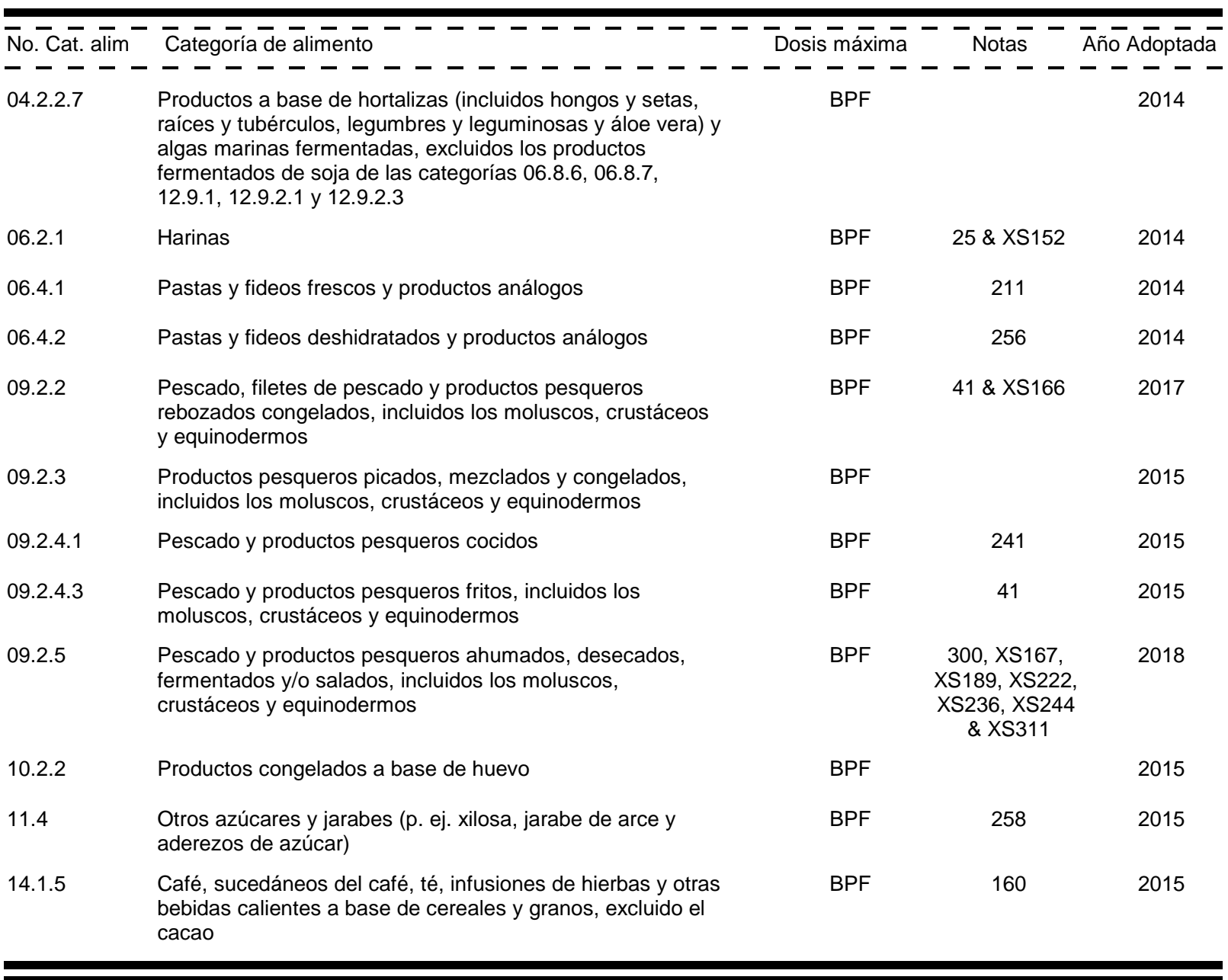

\section{RESINA DE GUAYACO}

SIN 314 Resina de guayaco Clases Funcionales: Antioxidantes

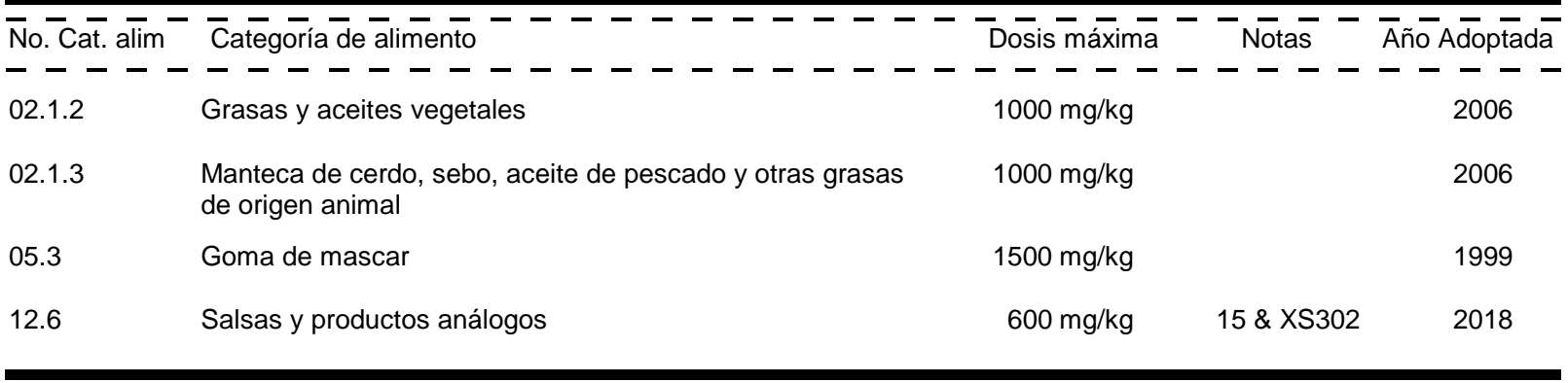




\section{RIBOFLAVINAS}
SIN 101(i)
Riboflavina, sintéticas
Clases Funcionales: Colorantes
SIN 101(ii) Riboflavina 5', fosfato de sodio
Clases Funcionales: Colorantes
SIN 101(iii) Riboflavina de Bacillus subtilis
Clases Funcionales: Colorantes

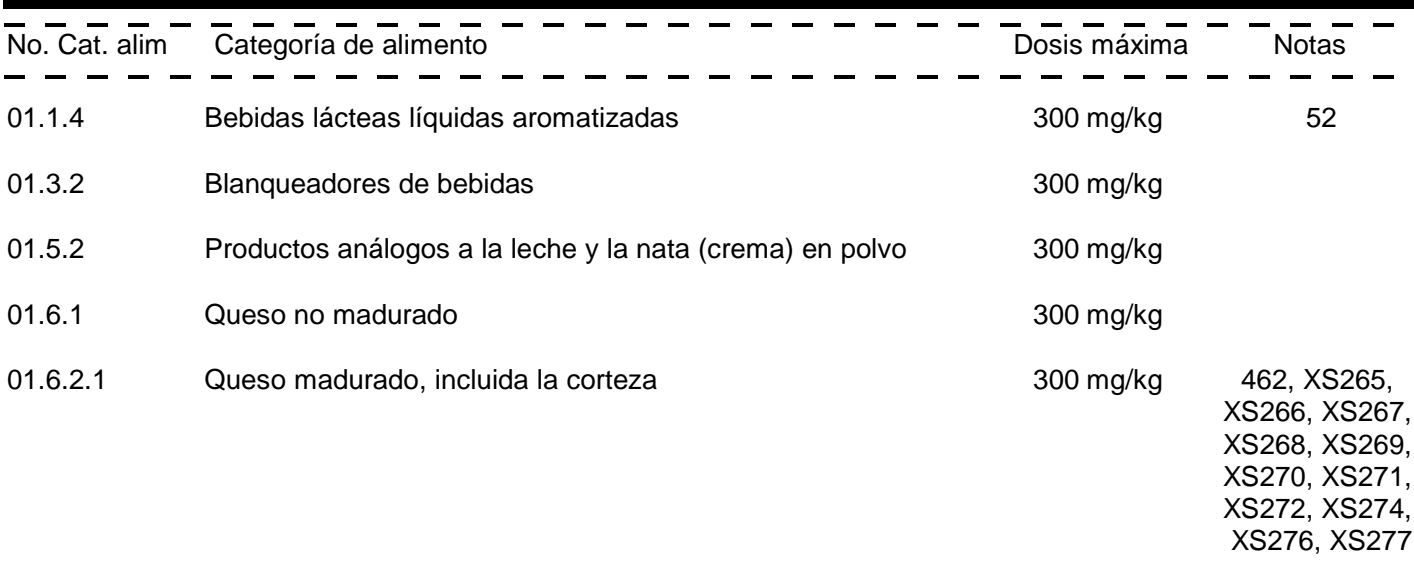

Āño Āōoptadā

01.6.2.2 Corteza de queso madurado

$300 \mathrm{mg} / \mathrm{kg}$

2005

01.6.4 Queso elaborado

$300 \mathrm{mg} / \mathrm{kg}$

2005

01.6.5 Productos análogos al queso

$300 \mathrm{mg} / \mathrm{kg}$

2005

01.7

Postres lácteos (como pudines, yogur aromatizado o con fruta)

$300 \mathrm{mg} / \mathrm{kg}$

2005

02.2 .2

Grasas para untar, grasas lácteas para untar y mezclas de

$300 \mathrm{mg} / \mathrm{kg}$

2005

02.3 Emulsiones grasas, principalmente del tipo agua en aceite, incluidos los productos a base de emulsiones grasas

$300 \mathrm{mg} / \mathrm{kg}$

2008 mezclados $\mathrm{y} / \mathrm{o}$ aromatizados

$02.4 \quad$ Postres a base de grasas, excluidos los postres lácteos de la categoría de alimentos 01.7

03.0 Hielos comestibles, incluidos los sorbetes

$300 \mathrm{mg} / \mathrm{kg}$

2005

$500 \mathrm{mg} / \mathrm{kg}$

2005

04.1.1.2 Frutas frescas tratadas en la superficie

$300 \mathrm{mg} / \mathrm{kg}$

$4 \& 16$

2008

04.1.2.4 Frutas en conserva, enlatadas o en frascos (pasteurizadas)

$300 \mathrm{mg} / \mathrm{kg}$

267

2018

04.1 .2 .5

Confituras, jaleas, mermeladas

$200 \mathrm{mg} / \mathrm{kg}$

2005

04.1 .2 .6

Productos para untar a base de fruta (p. ej. el "chutney"), excluidos los productos de la categoría de alimentos

$500 \mathrm{mg} / \mathrm{kg}$

2005 04.1.2.5

04.1.2.7 Frutas confitadas

$300 \mathrm{mg} / \mathrm{kg}$

2005

04.1.2.8 Preparados a base de fruta, incluida la pulpa, los purés, los

$300 \mathrm{mg} / \mathrm{kg}$

182

2008 revestimientos de fruta y la leche de coco

$300 \mathrm{mg} / \mathrm{kg}$

2005 agua con aromas de fruta

04.1.2.10

Productos de fruta fermentada

$500 \mathrm{mg} / \mathrm{kg}$

2008

04.1.2.11

Rellenos de fruta para pastelería

$300 \mathrm{mg} / \mathrm{kg}$ 


\section{2 .1 .2 \\ Hortalizas (incluidos hongos y setas, raíces y tubérculos, legumbres y leguminosas y áloe vera), algas marinas y nueces y semillas frescas tratadas en la superficie \\ 04.2.2.3 Hortalizas (incluidos hongos y setas, raíces y tubérculos, legumbres y leguminosas y áloe vera) y algas marinas en vinagre, aceite, salmuera o salsa de soja \\ 04.2.2.6 Pulpas y preparados de hortalizas (incluidos hongos y setas, raíces y tubérculos, legumbres y leguminosas y áloe vera), algas marinas y nueces y semillas (como los postres y las salsas a base de hortalizas y hortalizas confitadas) distintos de los indicados en la categoría de alimentos 04.2.2.5}

04.2.2.7

Productos a base de hortalizas (incluidos hongos y setas, raíces y tubérculos, legumbres y leguminosas y áloe vera) y algas marinas fermentadas, excluidos los productos fermentados de soja de las categorías 06.8.6, 06.8.7 12.9.1, 12.9.2.1 y 12.9 .2 .3

05.1.5 Productos de imitación y sucedáneos del chocolate

$05.2 \quad$ Dulces, incluidos los caramelos duros y blandos, los turrones, etc. distintos de los indicados en las categorías de alimentos $05.1,05.3$ y 05.4

05.3

Goma de mascar

05.4

Decoraciones (p. ej. para productos de pastelería fina) revestimientos (que no sean de fruta) y salsas dulces

Cereales para el desayuno, incluidos los copos de avena

06.4.3

Pastas y fideos precocidos y productos análogos

$06.5 \quad$ Postres a base de cereales y almidón (p. ej. pudines de arroz, pudines de mandioca)

06.6

Mezclas batidas para rebozar (p. ej. para empanizar o rebozar pescado o carne de aves de corral)

06.8 .1

Bebidas a base de soja

$07.2 \quad$ Productos de panadería fina (dulces, salados, aromatizados) y mezclas

08.2

Productos cárnicos, de aves de corral y caza elaborados, en piezas enteras o en cortes

08.3 Productos cárnicos, de aves de corral y caza picados y elaborados

08.4

Envolturas o tripas comestibles (p. ej. para embutidos)

09.2.1 Pescado, filetes de pescado y productos pesqueros congelados, incluidos los moluscos, crustáceos y equinodermos

09.2.2 Pescado, filetes de pescado y productos pesqueros rebozados congelados, incluidos los moluscos, crustáceos y equinodermos

09.2.3 Productos pesqueros picados, mezclados y congelados, incluidos los moluscos, crustáceos y equinodermos

09.2.4.1 Pescado y productos pesqueros cocidos

09.2.4.2 Moluscos, crustáceos y equinodermos cocidos
Dosis máximā - Notas $-\overline{\text { Año Adoptada }}$

$300 \mathrm{mg} / \mathrm{kg}$

$4 \& 16$

2008

$500 \mathrm{mg} / \mathrm{kg}$

2005

$300 \mathrm{mg} / \mathrm{kg}$

92

2008

$500 \mathrm{mg} / \mathrm{kg}$

2008

$1000 \mathrm{mg} / \mathrm{kg}$

2005

1000 mg/kg

XS309R

2017

$1000 \mathrm{mg} / \mathrm{kg}$

2005

$1000 \mathrm{mg} / \mathrm{kg}$

2005

$300 \mathrm{mg} / \mathrm{kg}$

2005

$300 \mathrm{mg} / \mathrm{kg}$

153,473

2019

$300 \mathrm{mg} / \mathrm{kg}$

2005

$300 \mathrm{mg} / \mathrm{kg}$

2005

$50 \mathrm{mg} / \mathrm{kg}$

2010

$300 \mathrm{mg} / \mathrm{kg}$

2005

$1000 \mathrm{mg} / \mathrm{kg}$

16, XS96 \&

2014

$1000 \mathrm{mg} / \mathrm{kg}$

16, XS88,

XS89 \& XS98

2014

1000 mg/kg

16

2008

1000 mg/kg

95, XS36,

XS92, XS95,

XS165, XS190

XS191, XS292,

XS312 \& XS315

$300 \mathrm{mg} / \mathrm{kg} \quad 16 \& \mathrm{XS} 166$

2017

$300 \mathrm{mg} / \mathrm{kg}$

16

2005

$300 \mathrm{mg} / \mathrm{kg}$

95

2008

300 mg/kg 


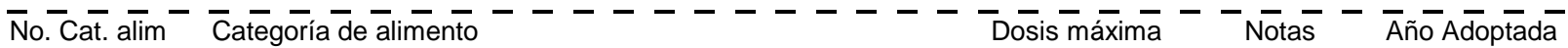

- - - - - - - - - - - - - - - - - - - - - - - - - - - moluscos, crustáceos y equinodermos

09.2.5 Pescado y productos pesqueros ahumados, desecados, fermentados y/o salados, incluidos los moluscos, crustáceos y equinodermos

09.3.1 Pescado y productos pesqueros marinados y/o en gelatina, incluidos los moluscos, crustáceos y equinodermos

$300 \mathrm{mg} / \mathrm{kg}$

(20)

$300 \mathrm{mg} / \mathrm{kg}$

$300 \mathrm{mg} / \mathrm{kg}$ salmuera, incluidos los moluscos, crustáceos y equinodermos

09.3.3 Sucedáneos de salmón, caviar y otros productos pesqueros a base de huevas

09.3.4 Pescado y productos pesqueros semiconservados, incluidos los moluscos, crustáceos y equinodermos (p. ej.. la pasta de pescado), excluidos los productos indicados en las categorías de alimentos 09.3.1 a 09.3.3

09.4 Pescado y productos pesqueros (incluidos los moluscos, crustáceos y equinodermos) en conserva, con inclusión de los enlatados y fermentados

Huevos frescos

Postres a base de huevo (p. ej. flan)

$11.3 \quad$ Soluciones azucaradas y jarabes, también azúcares (parcialmente) invertidos, incluida la melaza, excluidos los productos de la categoría de alimentos 11.1.3

11.4 Otros azúcares y jarabes (p. ej. xilosa, jarabe de arce y aderezos de azúcar)

12.2.2 Aderezos y condimentos

$12.4 \quad$ Mostazas

12.5

Sopas y caldos

Salsas y productos análogos

Ensaladas (p. ej., la ensalada de macarrones, la ensalada de patatas (papas)) y productos para untar en

emparedados, excluidos los productos para untar a base de cacao y nueces de las categorías de alimentos 04.2.2.5 y 05.1 .3

Pasta de soja fermentada (por ej. miso)

$30 \mathrm{mg} / \mathrm{kg}$

2010

$300 \mathrm{mg} / \mathrm{kg}$

2005

(excluidos los productos de la categoría de alimentos 13.1)

Preparados dietéticos para adelgazamiento y control del peso

Alimentos dietéticos (p. ej. los complementos alimenticios para usos dietéticos), excluidos los indicados en las categorías de alimentos 13.1 a 13.4 y 13.6 bebidas para deportistas, bebidas energéticas o bebidas electrolíticas y bebidas con partículas añadidas 


\begin{tabular}{|c|c|c|c|}
\hline 14.2.4 & Vinos (distintos de los de uva) & $300 \mathrm{mg} / \mathrm{kg}$ & 2005 \\
\hline 14.2.7 & $\begin{array}{l}\text { Bebidas alcohólicas aromatizadas ( } \mathrm{p} \text {. ej. cerveza, vino y } \\
\text { bebidas con licor tipo bebida gaseosa, bebidas refrescantes } \\
\text { con bajo contenido de alcohol) }\end{array}$ & $100 \mathrm{mg} / \mathrm{kg}$ & 2005 \\
\hline 15.1 & $\begin{array}{l}\text { Aperitivos a base de patatas (papas), cereales, harina o } \\
\text { almidón (derivados de raíces y tubérculos, legumbres y } \\
\text { leguminosas) }\end{array}$ & $1000 \mathrm{mg} / \mathrm{kg}$ & 2005 \\
\hline 15.2 & $\begin{array}{l}\text { Nueces elaboradas, incluidas las nueces revestidas y las } \\
\text { mezclas de nueces ( } p . \text { ej. con frutas secas) }\end{array}$ & $1000 \mathrm{mg} / \mathrm{kg}$ & 2005 \\
\hline
\end{tabular}

\section{RIBONUCLEÓTIDOS DE CALCIO, 5'-}

SIN 634 Ribonucleótidos de calcio, 5'- Clases Funcionales: Acentuadores del sabor

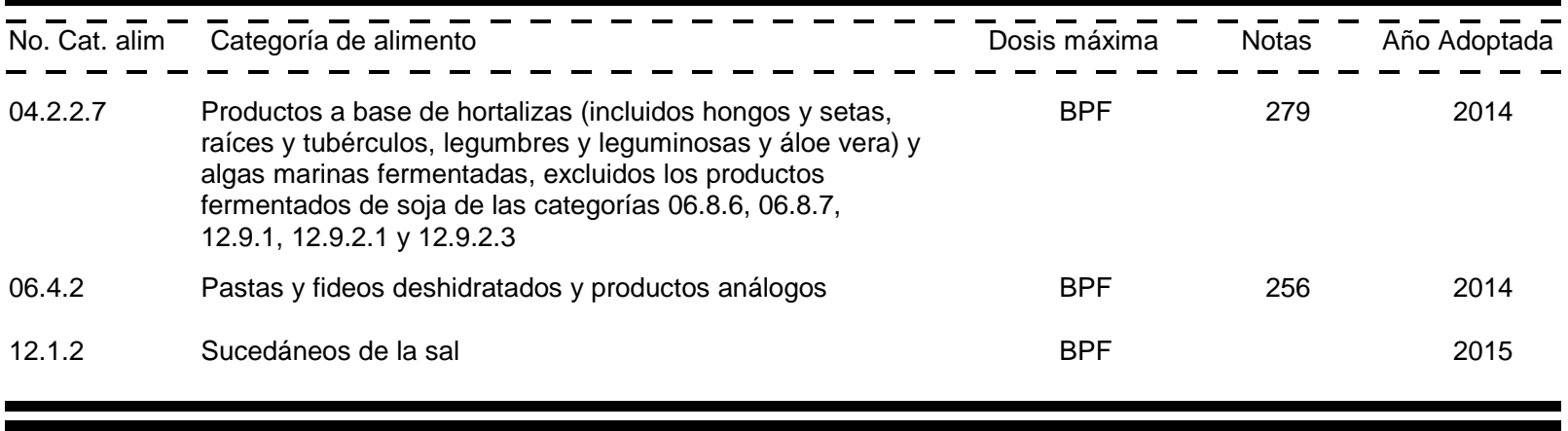

\section{RIBONUCLEÓTIDOS DE SODIO, 5'-}

SIN 635 Ribonucleótidos de sodio, 5'- Clases Funcionales: Acentuadores del sabor

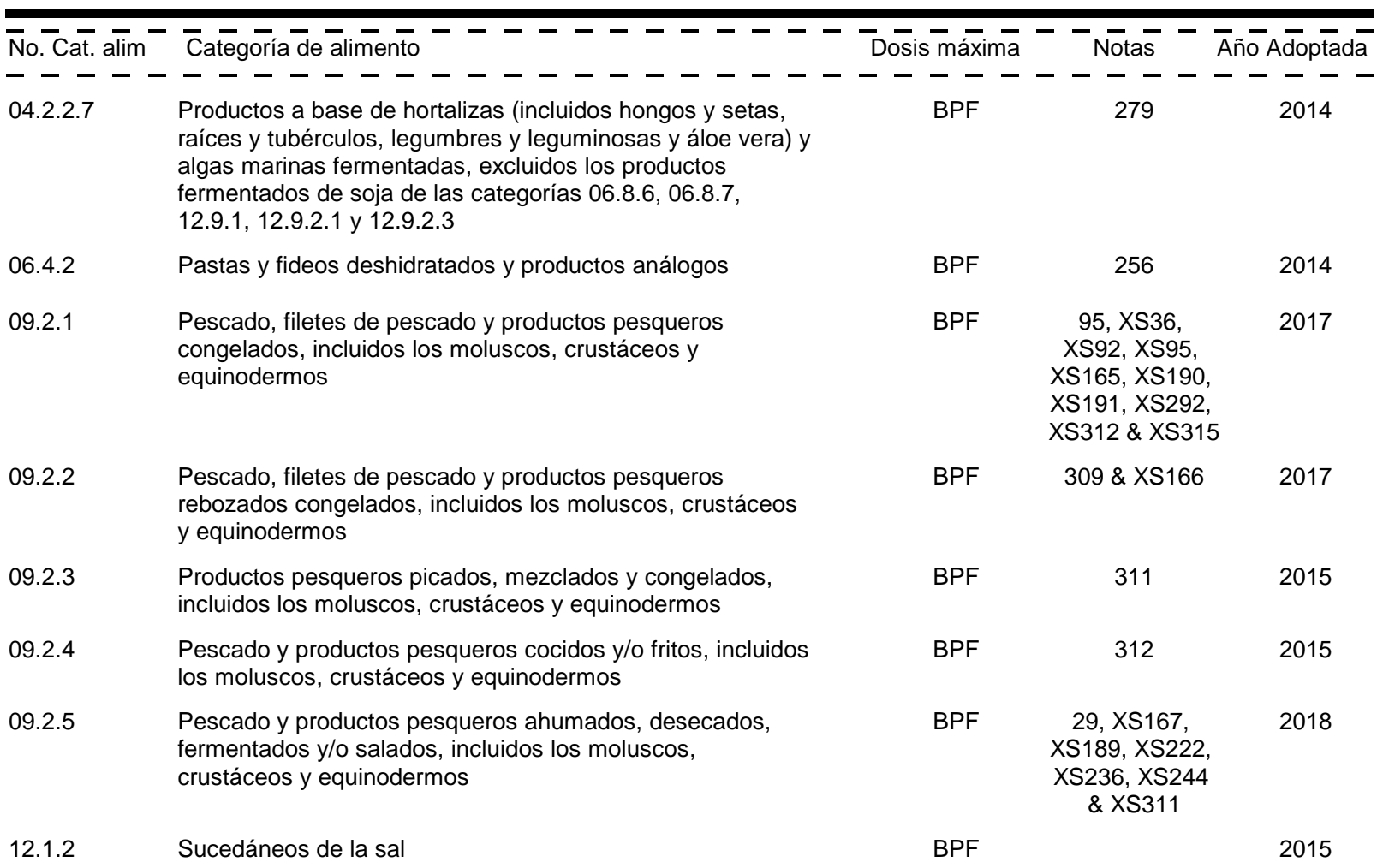




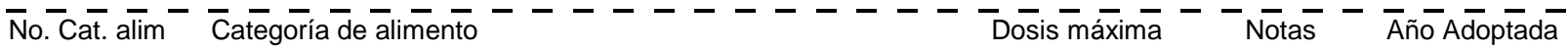
- - - - - - - - - - - - - - - - - - - - - - - - - -

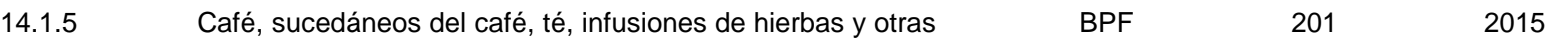
bebidas calientes a base de cereales y granos, excluido el cacao

\section{ROJO ALLURA AC}

SIN 129 Rojo allura AC Clases Funcionales: Colorantes

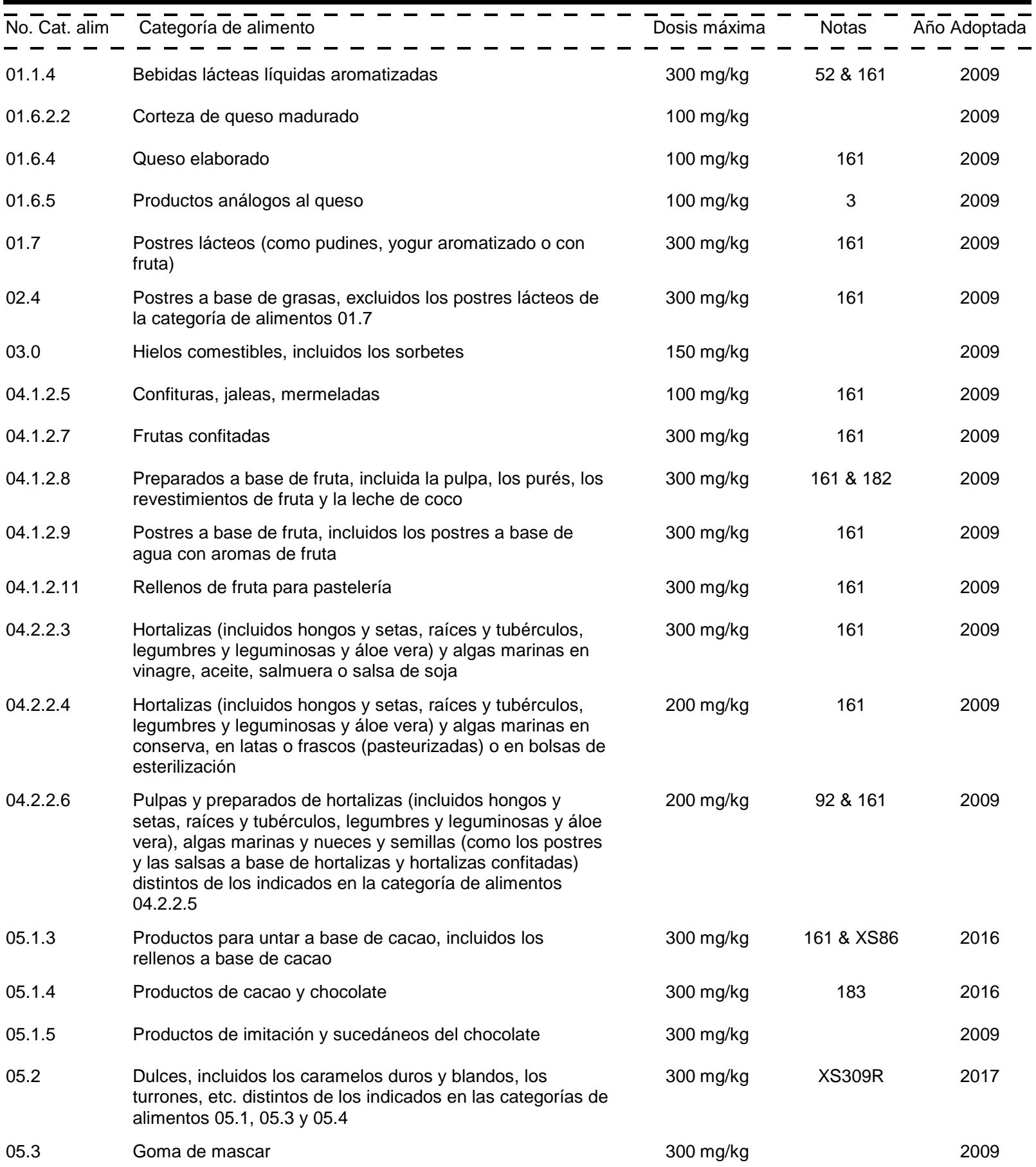




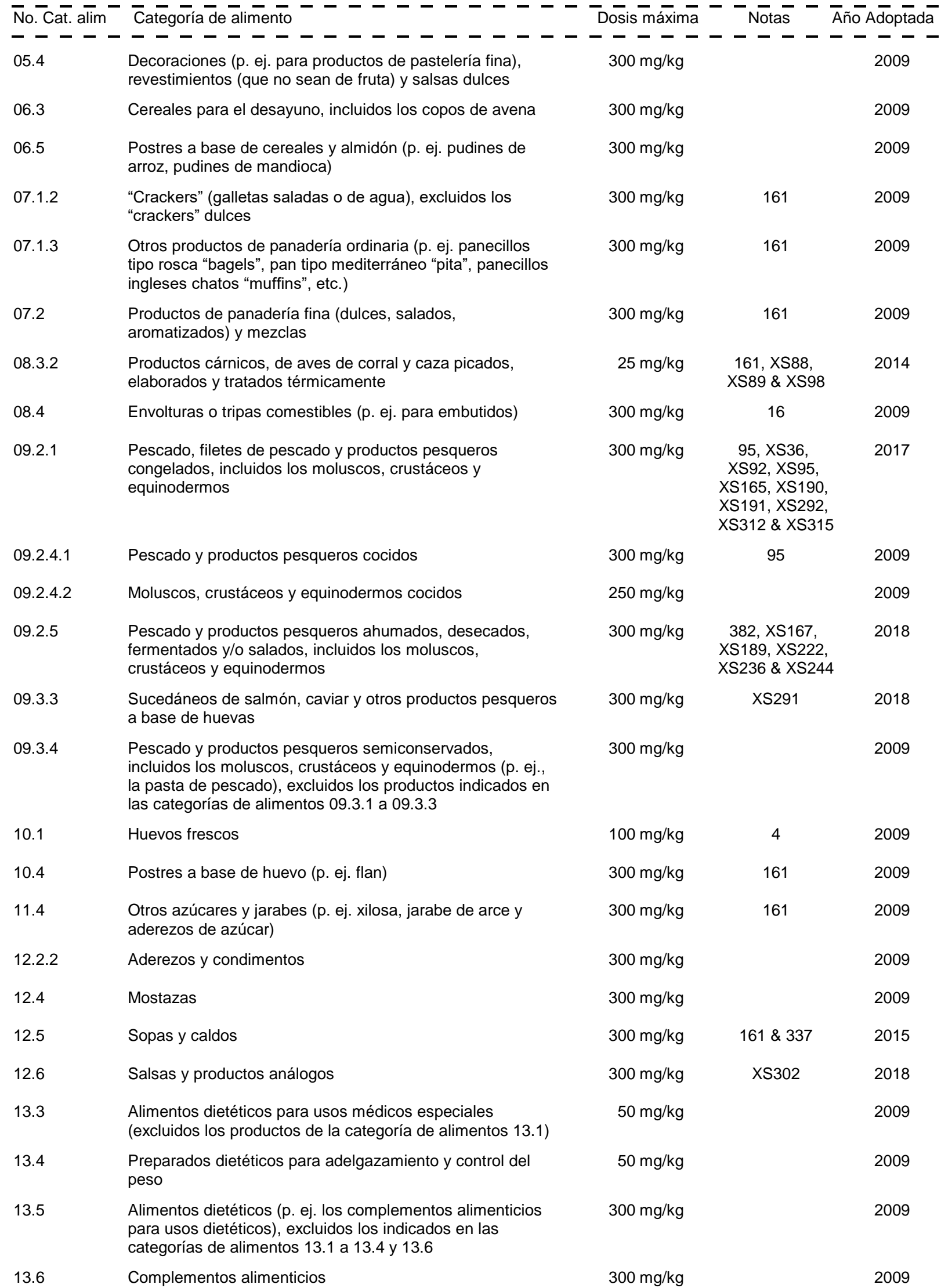




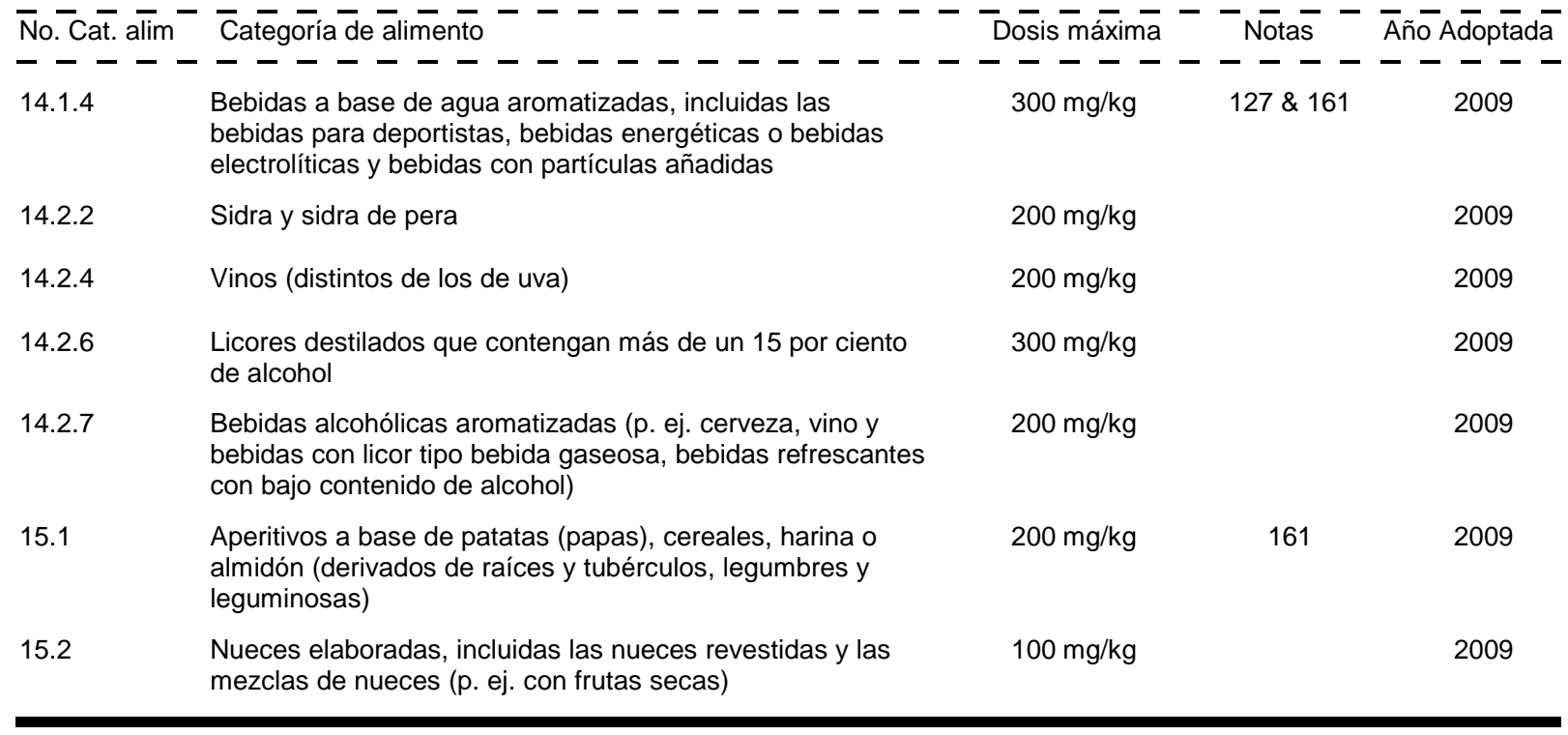

\section{SACARINAS}

$\begin{array}{llll}\text { SIN } & 954(\mathrm{i}) & \text { Sacarina } & \text { Clases Funcionales: Edulcorantes } \\ \text { SIN } & 954(\mathrm{ii}) & \text { Sacarina de calcio } & \text { Clases Funcionales: Edulcorantes } \\ \text { SIN } & 954(\mathrm{iii}) & \text { Sacarina de potasio } & \text { Clases Funcionales: Edulcorantes } \\ \text { SIN } & 954(\mathrm{iv}) & \text { Sacarina de sodio } & \text { Clases Funcionales: Edulcorantes }\end{array}$

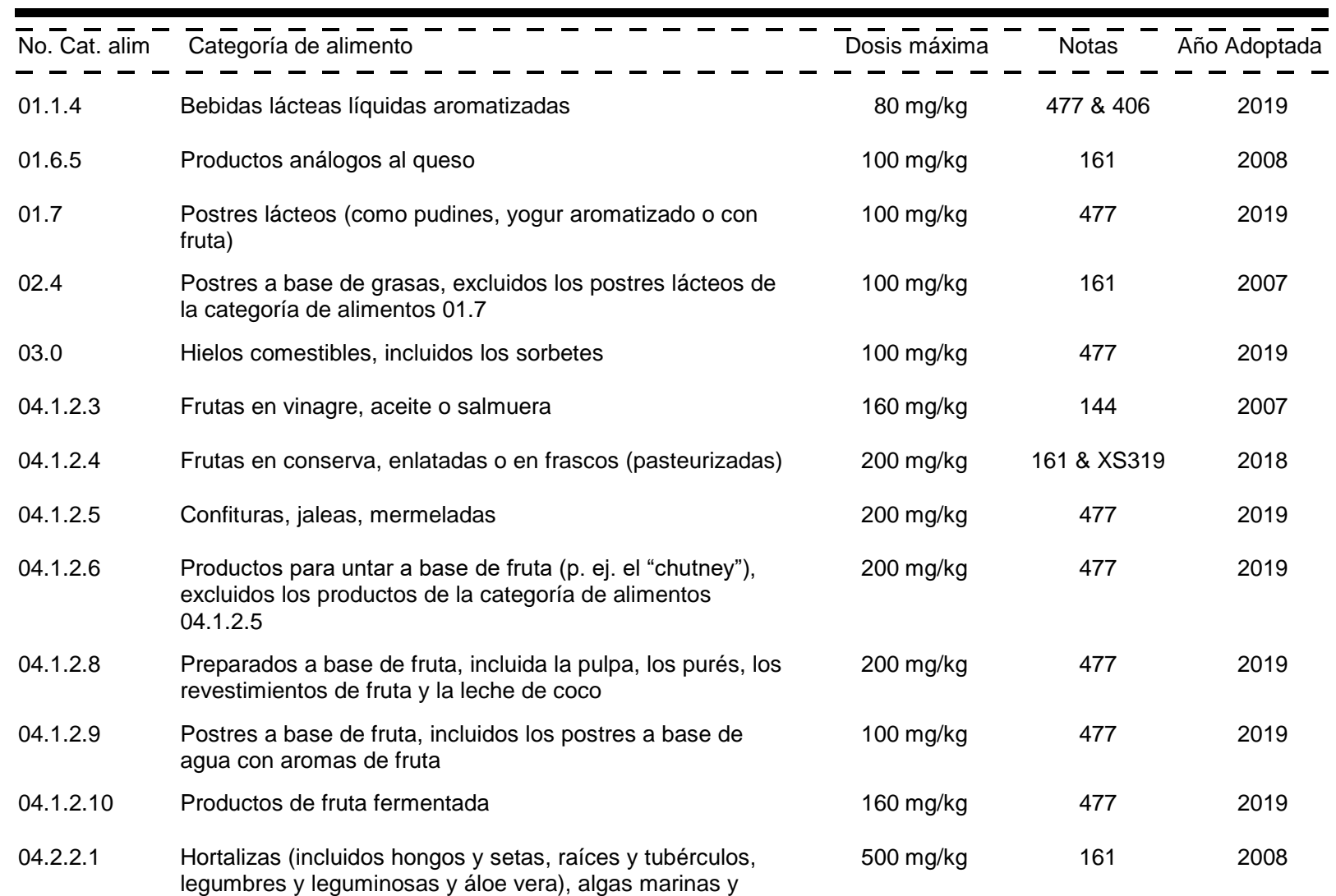


 \\ 04.2 .2 .2 \\ Hortalizas (incluidos hongos y setas, raíces y tubérculos, legumbres y leguminosas y áloe vera), algas marinas y nueces y semillas desecadas \\ 04.2.2.3 Hortalizas (incluidos hongos y setas, raíces y tubérculos, legumbres y leguminosas y áloe vera) y algas marinas en vinagre, aceite, salmuera o salsa de soja \\ 04.2.2.4 Hortalizas (incluidos hongos y setas, raíces y tubérculos, legumbres y leguminosas y áloe vera) y algas marinas en conserva, en latas o frascos (pasteurizadas) o en bolsas de esterilización}

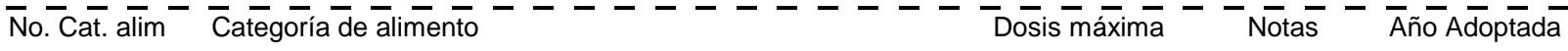

04.2.2.5 Purés y preparados para untar elaborados con hortalizas (incluidos hongos y setas, raíces y tubérculos, legumbres y leguminosas y áloe vera), algas marinas y nueces y semillas (p. ej., la mantequilla de maní (cacahuete))

04.2.2.6 Pulpas y preparados de hortalizas (incluidos hongos y setas, raíces y tubérculos, legumbres y leguminosas y áloe vera), algas marinas y nueces y semillas (como los postres y las salsas a base de hortalizas y hortalizas confitadas) distintos de los indicados en la categoría de alimentos 04.2.2.5

04.2.2.7

Productos a base de hortalizas (incluidos hongos y setas, raíces y tubérculos, legumbres y leguminosas y áloe vera) y algas marinas fermentadas, excluidos los productos fermentados de soja de las categorías 06.8.6, 06.8.7, 12.9.1, 12.9.2.1 y 12.9.2.3

04.2.2.8 Hortalizas (incluidos hongos y setas, raíces y tubérculos, legumbres y leguminosas y áloe vera) y algas marinas cocidas o fritas

05.1.1 Mezclas de cacao (en polvo) y cacao en pasta/torta de cacao

05.1.2 Mezclas de cacao (jarabes)

05.1.3 Productos para untar a base de cacao, incluidos los rellenos a base de cacao

05.1.4 Productos de cacao y chocolate

05.1.5 Productos de imitación y sucedáneos del chocolate

$05.2 \quad$ Dulces, incluidos los caramelos duros y blandos, los turrones, etc. distintos de los indicados en las categorías de alimentos $05.1,05.3$ y 05.4

05.3

Goma de mascar

Decoraciones (p. ej. para productos de pastelería fina) revestimientos (que no sean de fruta) y salsas dulces

06.3 Cereales para el desayuno, incluidos los copos de avena

$06.5 \quad$ Postres a base de cereales y almidón (p. ej. pudines de arroz, pudines de mandioca)

07.2 Productos de panadería fina (dulces, salados aromatizados) y mezclas

08.2 .2

Productos cárnicos, de aves de corral y caza elaborados, tratados térmicamente, en piezas enteras o en cortes

08.3.2 Productos cárnicos, de aves de corral y caza picados, elaborados y tratados térmicamente

09.2.4.1 Pescado y productos pesqueros cocidos
$500 \mathrm{mg} / \mathrm{kg}$

161

2008

$160 \mathrm{mg} / \mathrm{kg}$

144

2007

$160 \mathrm{mg} / \mathrm{kg}$

$144 \& 161$

2008

$160 \mathrm{mg} / \mathrm{kg}$

161

2008

$200 \mathrm{mg} / \mathrm{kg}$

161

2008

$200 \mathrm{mg} / \mathrm{kg}$

161

2008

$160 \mathrm{mg} / \mathrm{kg}$

$144 \& 161$

2008

$100 \mathrm{mg} / \mathrm{kg}$

97, 161 \&

2016

$80 \mathrm{mg} / \mathrm{kg}$

161

2007

$200 \mathrm{mg} / \mathrm{kg}$

477 \& XS86

2019

$500 \mathrm{mg} / \mathrm{kg}$

477

2019

$500 \mathrm{mg} / \mathrm{kg}$

161

2007

$500 \mathrm{mg} / \mathrm{kg}$

477,163 \&

XS309R

2019

$2500 \mathrm{mg} / \mathrm{kg}$

477

2019

500 mg/kg

477

2019

$100 \mathrm{mg} / \mathrm{kg}$

477

2019

$100 \mathrm{mg} / \mathrm{kg}$

161

2007

$170 \mathrm{mg} / \mathrm{kg}$

165

2007

$500 \mathrm{mg} / \mathrm{kg}$

161, XS96 \&

XS97

$500 \mathrm{mg} / \mathrm{kg}$

161, XS88

XS89 \& XS98

2014

2014

$500 \mathrm{mg} / \mathrm{kg}$
161

2008 


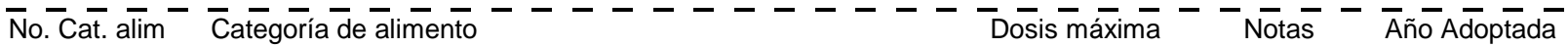

- - - - - - - - - - - - - - - - - - - - - - - - - incluidos los moluscos, crustáceos y equinodermos

09.3.2 Pescado y productos pesqueros escabechados $\mathrm{y} / \mathrm{o}$ en

$160 \mathrm{mg} / \mathrm{kg}$

144

2007

salmuera, incluidos los moluscos, crustáceos y equinodermos

09.3 .4

Pescado y productos pesqueros semiconservados, incluidos los moluscos, crustáceos y equinodermos (p. ej., la pasta de pescado), excluidos los productos indicados en las categorías de alimentos 09.3.1 a 09.3.3

09.4

Pescado y productos pesqueros (incluidos los moluscos, crustáceos y equinodermos) en conserva, con inclusión de los enlatados y fermentados

10.4 Postres a base de huevo (p. ej. flan)

$11.4 \quad$ Otros azúcares y jarabes (p. ej. xilosa, jarabe de arce y aderezos de azúcar)

11.6 Edulcorantes de mesa, incluidos los que contienen edulcorantes de gran intensidad

12.2.2 Aderezos y condimentos

$160 \mathrm{mg} / \mathrm{kg}$

144

2007

$200 \mathrm{mg} / \mathrm{kg}$

$144, \mathrm{XS3}$,

XS37, XS70,

XS90, XS94 \&

XS119

$100 \mathrm{mg} / \mathrm{kg}$

144

2007

$300 \mathrm{mg} / \mathrm{kg}$

159

2008

BPF

2007

$1500 \mathrm{mg} / \mathrm{kg}$

161

2008

$300 \mathrm{mg} / \mathrm{kg}$

2008

$320 \mathrm{mg} / \mathrm{kg}$

2007

$110 \mathrm{mg} / \mathrm{kg}$

$477 \&$ XS117

2019

$160 \mathrm{mg} / \mathrm{kg}$

XS302

2018

$200 \mathrm{mg} / \mathrm{kg}$

$161 \& 166$

2010

de patatas (papas)) y productos para untar en

emparedados, excluidos los productos para untar a base de cacao y nueces de las categorías de alimentos 04.2.2.5 y 05.1 .3

12.9.1 Pasta de soja fermentada (por ej. miso)

$200 \mathrm{mg} / \mathrm{kg}$

2012

$500 \mathrm{mg} / \mathrm{kg}$

2012

$200 \mathrm{mg} / \mathrm{kg}$

2007 (excluidos los productos de la categoría de alimentos 13.1)

$13.4 \quad$ Preparados dietéticos para adelgazamiento y control del peso

$300 \mathrm{mg} / \mathrm{kg}$

2007

$200 \mathrm{mg} / \mathrm{kg}$

2007

para usos dietéticos), excluidos los indicados en las categorías de alimentos 13.1 a 13.4 y 13.6

$13.6 \quad$ Complementos alimenticios

$1200 \mathrm{mg} / \mathrm{kg}$

$80 \mathrm{mg} / \mathrm{kg}$

2005

$80 \mathrm{mg} / \mathrm{kg}$

161

2008

$80 \mathrm{mg} / \mathrm{kg}$

127

2005

$300 \mathrm{mg} / \mathrm{kg}$

161

2008

$300 \mathrm{mg} / \mathrm{kg}$

161

2008

$300 \mathrm{mg} / \mathrm{kg}$

$127 \& 161$

2008

14.1.4.3 Concentrados (líquidos o sólidos) para bebidas a base de agua aromatizadas 


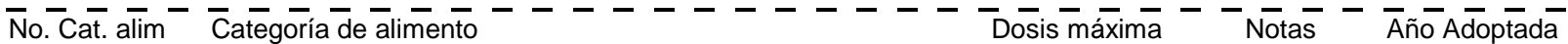
- - - - - - - - - - - - - - - - - - - - - - - - - -

14.1.5 Café, sucedáneos del café, té, infusiones de hierbas y otras $\quad 200 \mathrm{mg} / \mathrm{kg} \quad 160 \quad 2007$ bebidas calientes a base de cereales y granos, excluido el cacao

14.2.7 Bebidas alcohólicas aromatizadas (p. ej. cerveza, vino y bebidas con licor tipo bebida gaseosa, bebidas refrescantes

$80 \mathrm{mg} / \mathrm{kg}$ con bajo contenido de alcohol)

\section{SAL DE ÁCIDO OLEICO CON CALCIO, POTASIO Y SODIO}

SIN 470(ii) Sal de ácido oleico con calcio, Clases Funcionales: Antiaglutinantes, Emulsionantes, Estabilizadores potasio y sodio

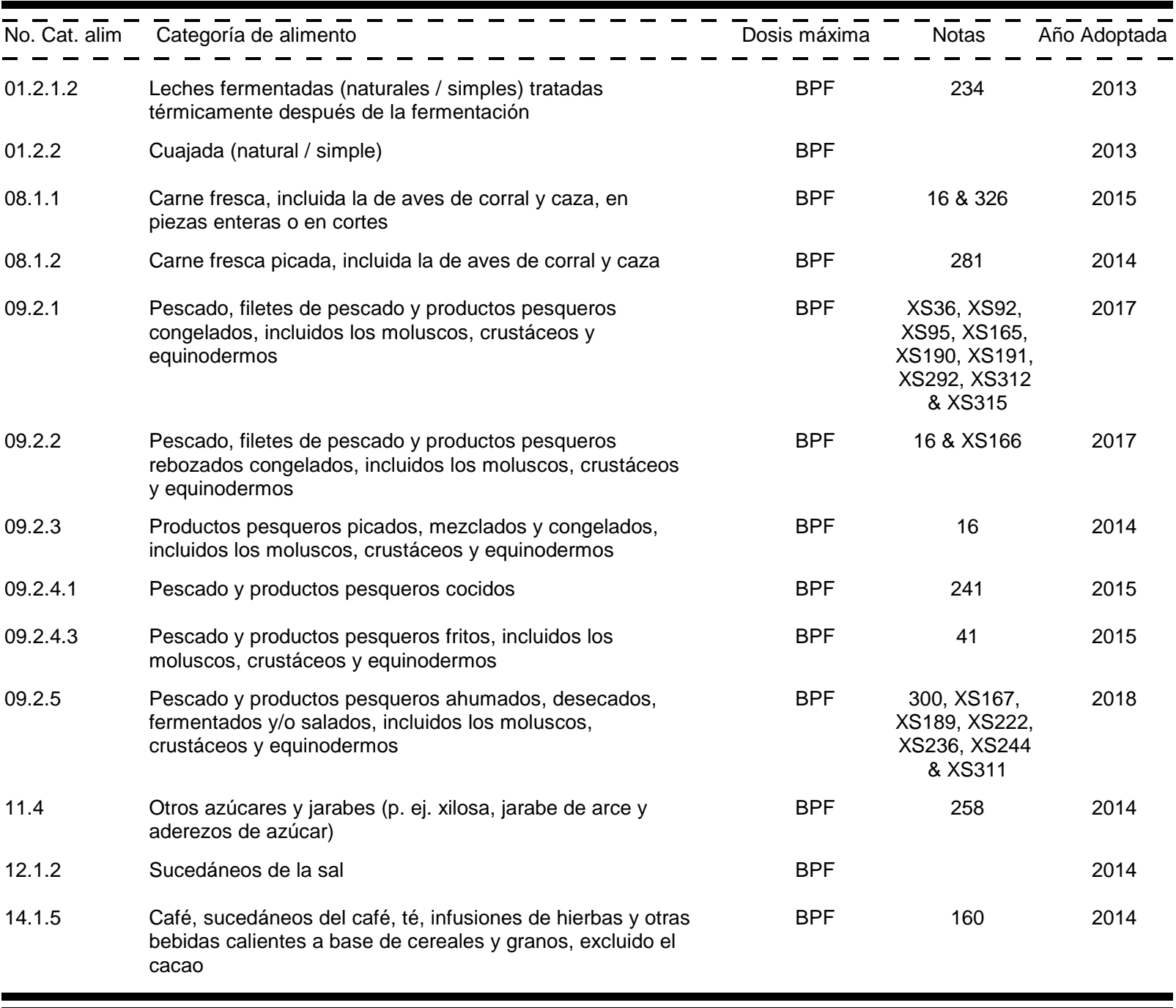

\section{SAL DE ASPARTAMO Y ACESULFAMO}

SIN 962 Sal de aspartamo y acesulfamo Clases Funcionales: Edulcorantes

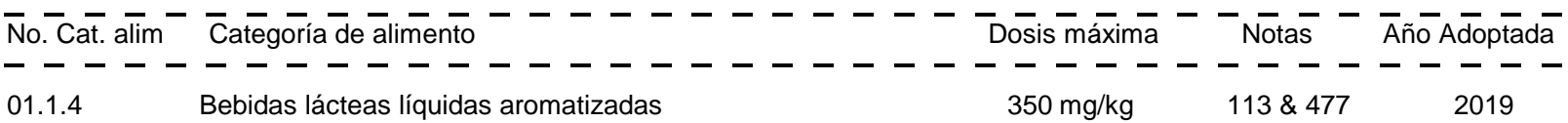




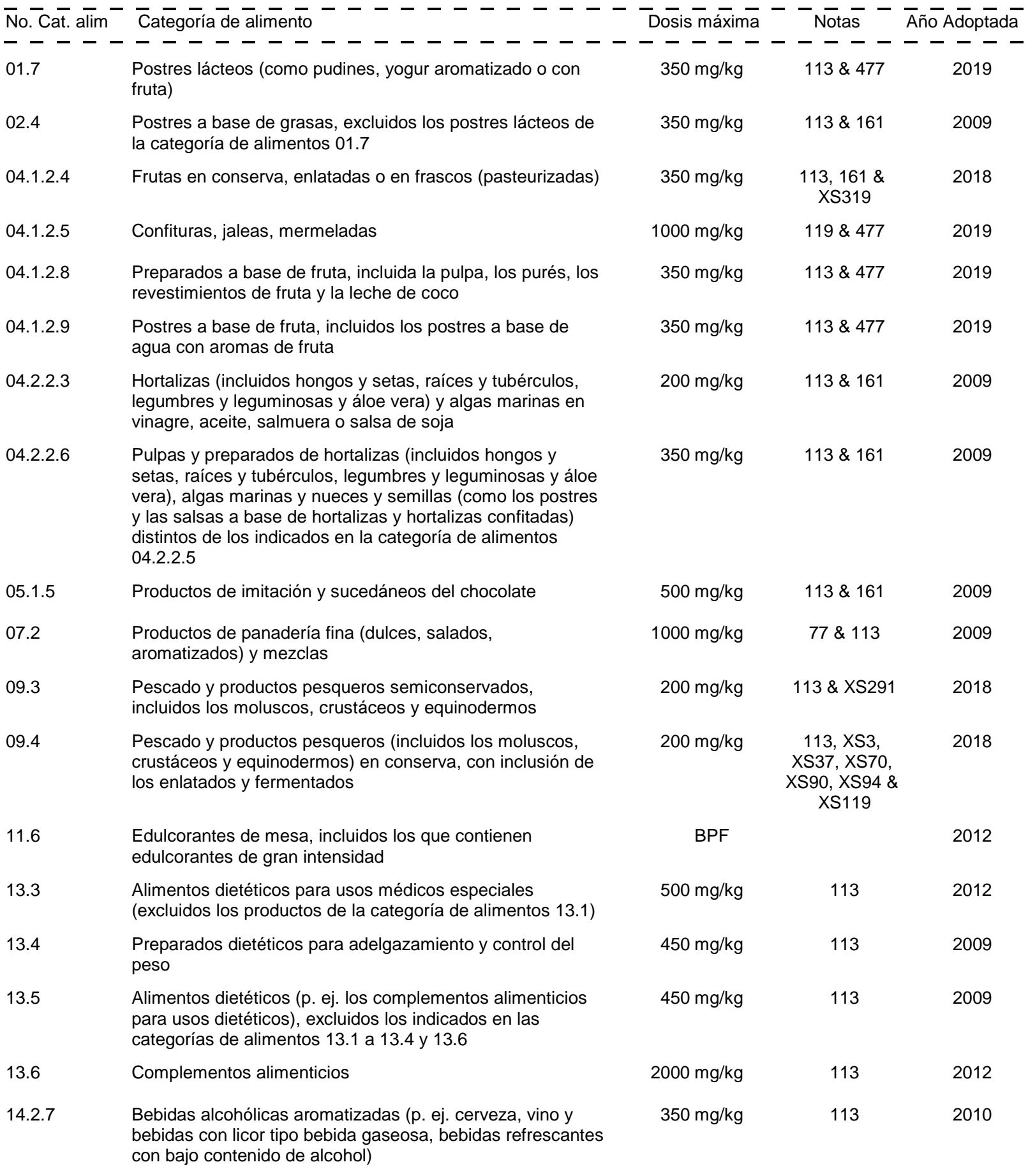

\section{SAL MIRÍSTICA, PALMÍTICA Y ÁCIDOS ESTEÁRICOS CON AMONIO, CALCIO, POTASIO Y SODIO}

SIN 470(i) Sal mirística, palmítica y ácidos Clases Funcionales: Antiaglutinantes, Emulsionantes, Estabilizadores esteáricos con amonio, calcio, potasio y sodio 


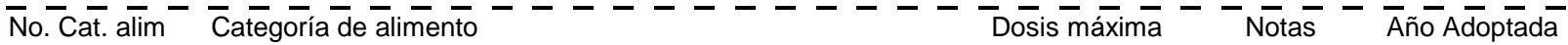

- - - - -

Leches fermentadas (naturales / simples) tratadas

2013

01.2 .2 térmicamente después de la fermentación

BPF

BPF

2013

04.1 .1 .2

Frutas frescas tratadas en la superficie

04.2 .1 .2

Hortalizas (incluidos hongos y setas, raíces y tubérculos, legumbres y leguminosas y áloe vera), algas marinas y nueces y semillas frescas tratadas en la superficie

06.4.2 Pastas y fideos deshidratados y productos análogos

08.1 .1

Carne fresca, incluida la de aves de corral y caza, en piezas enteras o en cortes

08.1.2 Carne fresca picada, incluida la de aves de corral y caza

09.2.1 Pescado, filetes de pescado y productos pesqueros congelados, incluidos los moluscos, crustáceos y equinodermos

09.2.2 Pescado, filetes de pescado y productos pesqueros rebozados congelados, incluidos los moluscos, crustáceos y equinodermos

09.2.3 Productos pesqueros picados, mezclados y congelados, incluidos los moluscos, crustáceos y equinodermos

09.2.4.1 Pescado y productos pesqueros cocidos

09.2.4.3 Pescado y productos pesqueros fritos, incluidos los moluscos, crustáceos y equinodermos

09.2 .5

Pescado y productos pesqueros ahumados, desecados, fermentados y/o salados, incluidos los moluscos, crustáceos y equinodermos

10.2.1 Productos líquidos a base de huevo

BPF

BPF

2019

$71 \& 456$

2019

BPF

256

2014

BPF

$16,71 \& 326$

2015

BPF

$71 \& 281$

2014

BPF

71, XS36,

XS92, XS95,

XS165, XS190

XS191, XS292,

XS312 \& XS315

BPF

$16,71 \&$ XS166

2017

BPF

16

2014

BPF

241

2015

BPF

41

2015

BPF

300, XS167

XS189, XS222,

XS236, XS244

\& XS311

BPF

2014

BPF

2014

BPF

$71 \& 258$

2014 aderezos de azúcar)

BPF

71

2006

BPF

2014

12.1.2 Sucedáneos de la sal

BPF

160

2014

14.1.5 Café, sucedáneos del café, té, infusiones de hierbas y otras bebidas calientes a base de cereales y granos, excluido el cacao

\section{SALES AMÓNICAS DEL ÁCIDO FOSFATÍDICO}

SIN $442 \quad \begin{aligned} & \text { Sales amónicas del ácido Clases Funcionales: Emulsionantes } \\ & \text { fosfatídico }\end{aligned}$

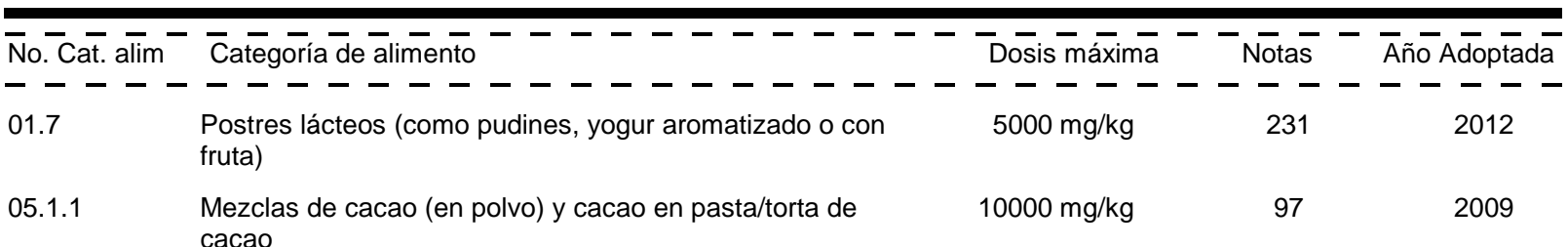




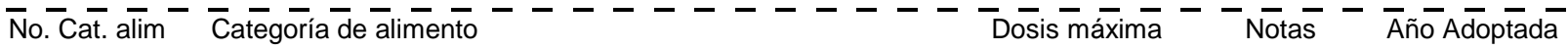
- - - - - - - - - - - - - - - - - - - - - - - - - -

$\begin{array}{llrr}05.1 .4 & \text { Productos de cacao y chocolate } & 10000 \mathrm{mg} / \mathrm{kg} & 101\end{array}$

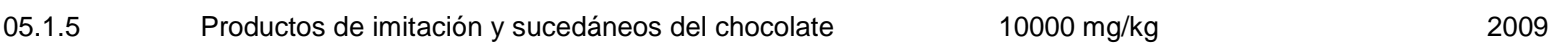

\section{SESQUICARBONATO DE SODIO}

SIN 500(iii) Sesquicarbonato de sodio Clases Funcionales: Reguladores de la acidez, Antiaglutinantes, Leudantes

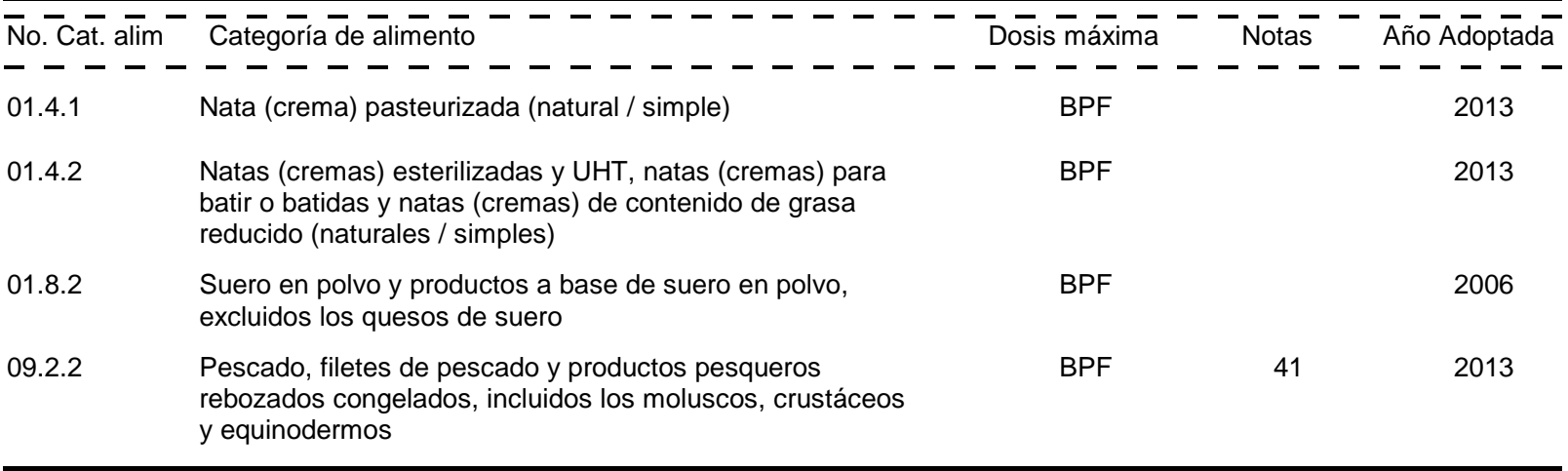

\section{SILICATO DE CALCIO}

SIN 552 Silicato de calcio Clases Funcionales: Antiaglutinantes

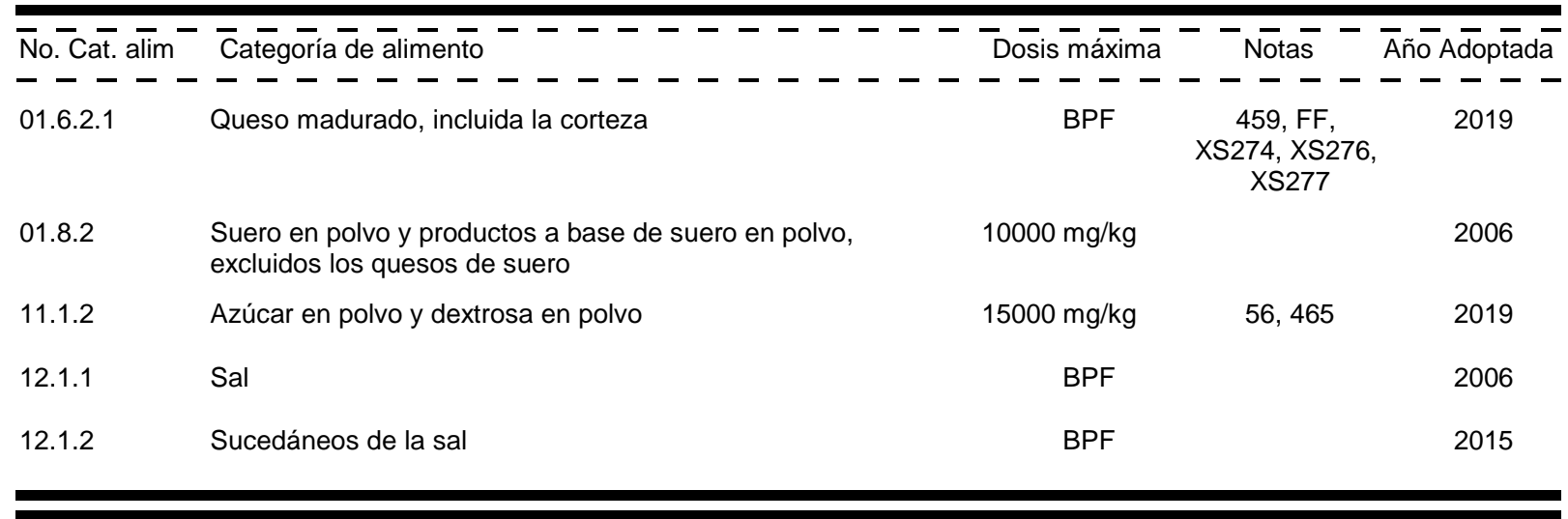

\section{SILICATO DE MAGNESIO, SINTÉTICO}

SIN 553(i) Silicato de magnesio, sintético Clases Funcionales: Antiaglutinantes

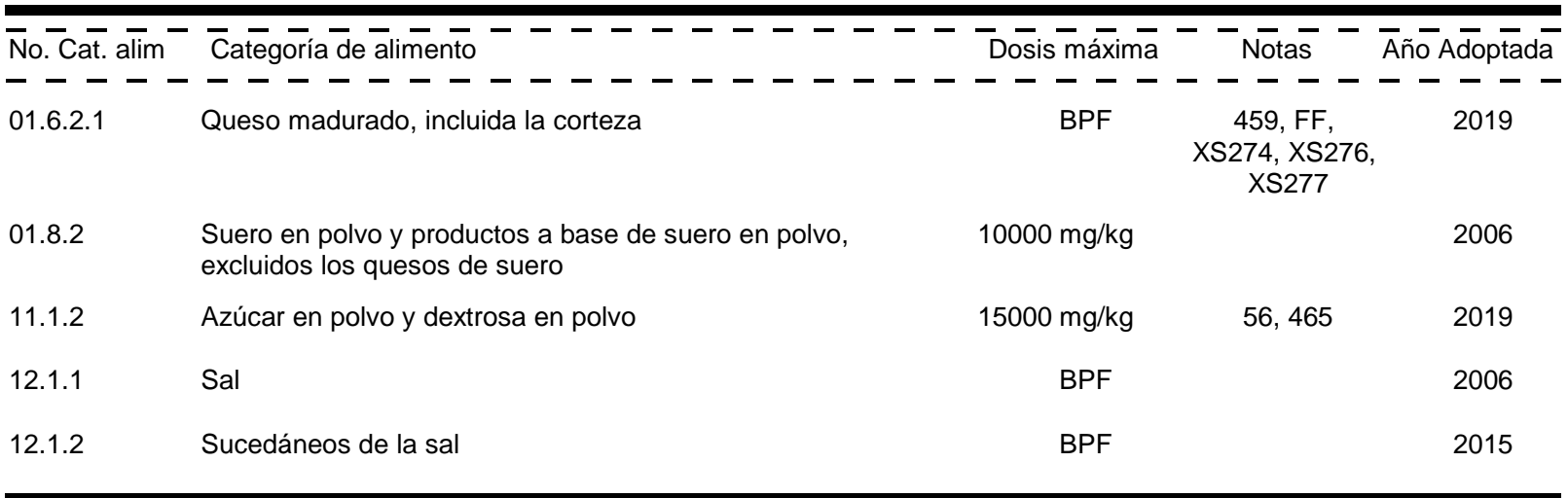




\section{SILICATO DE SODIO Y ALUMINIO}

SIN 554 Silicato de sodio y aluminio Clases Funcionales: Antiaglutinantes

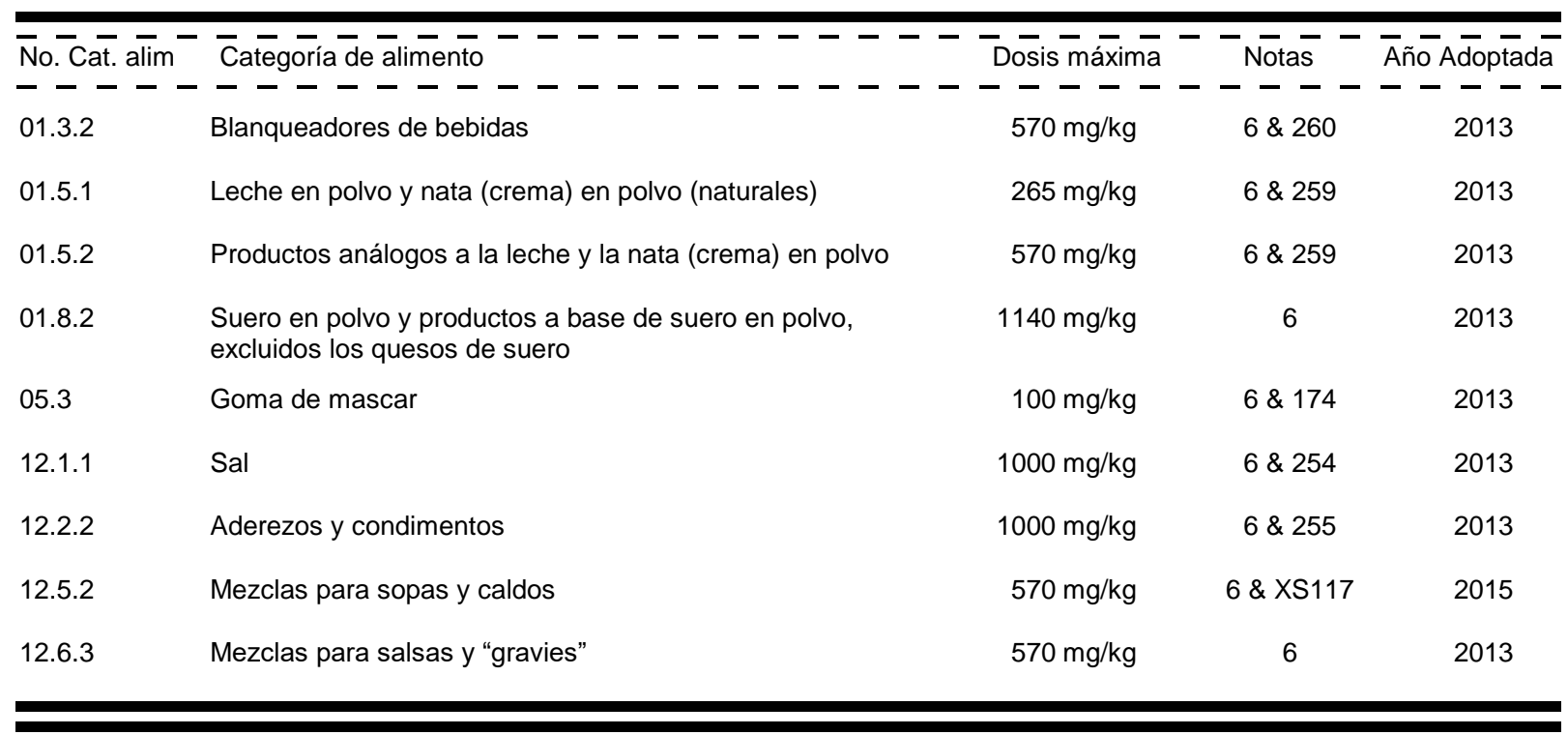

\section{SORBATOS}

$\begin{array}{llll}\text { SIN } 200 & \text { Ácido sórbico } & \text { Clases Funcionales: Sustancias conservadoras } \\ \text { SIN } 202 & \text { Sorbato de potasio } & \text { Clases Funcionales: Sustancias conservadoras } \\ \text { SIN } 203 & \text { Sorbato de calcio } & \text { Clases Funcionales: Sustancias conservadoras }\end{array}$

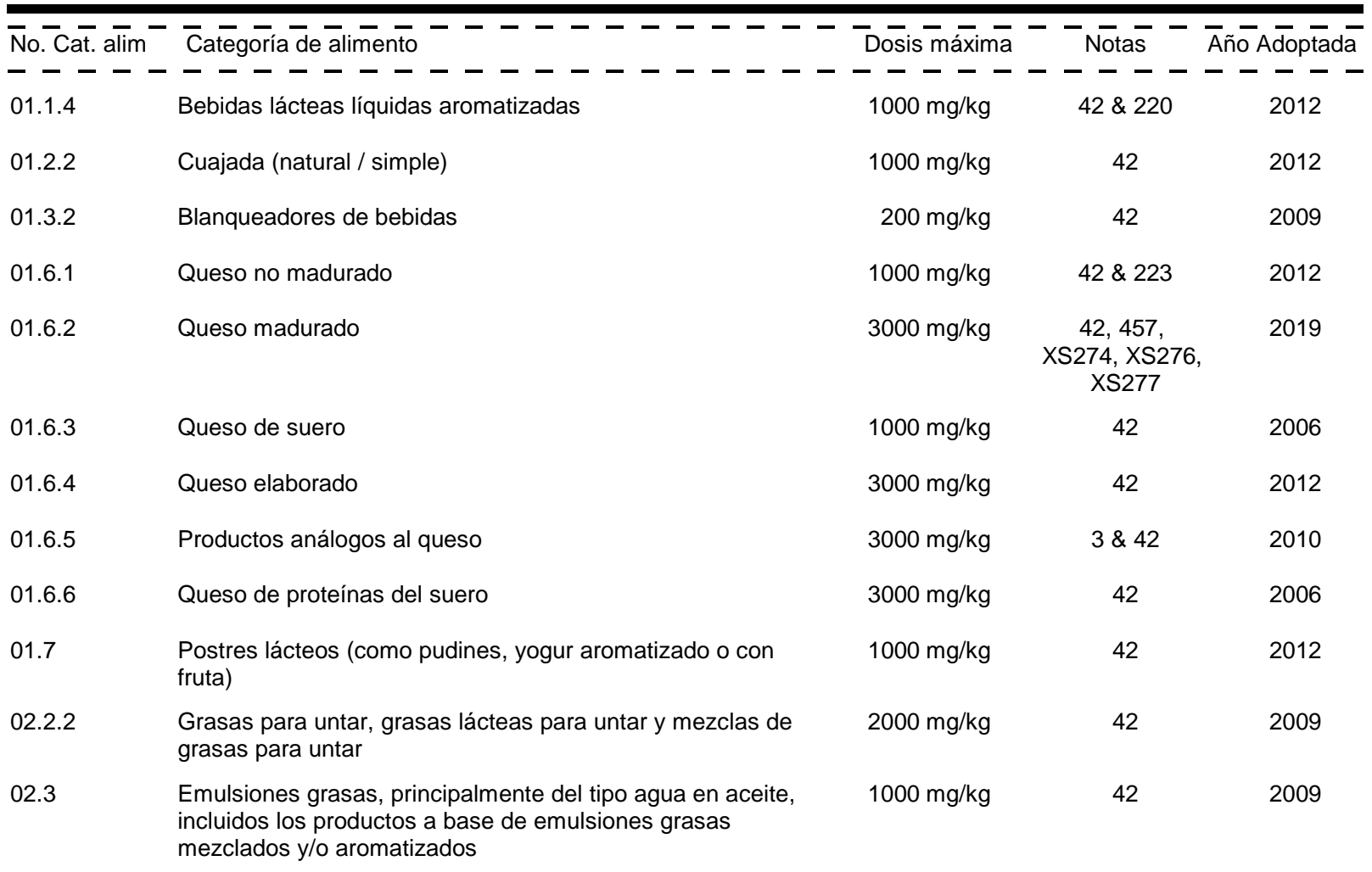




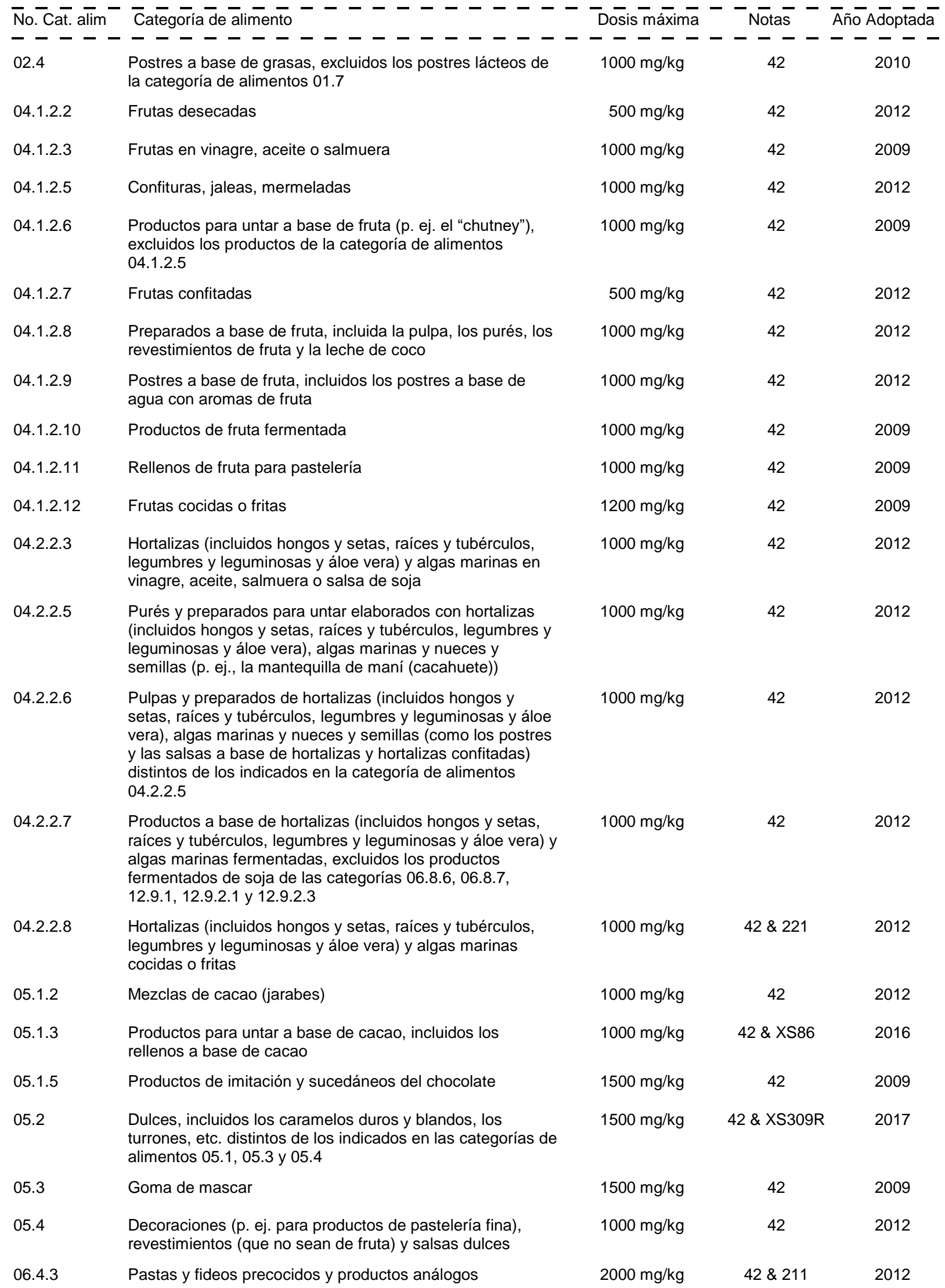




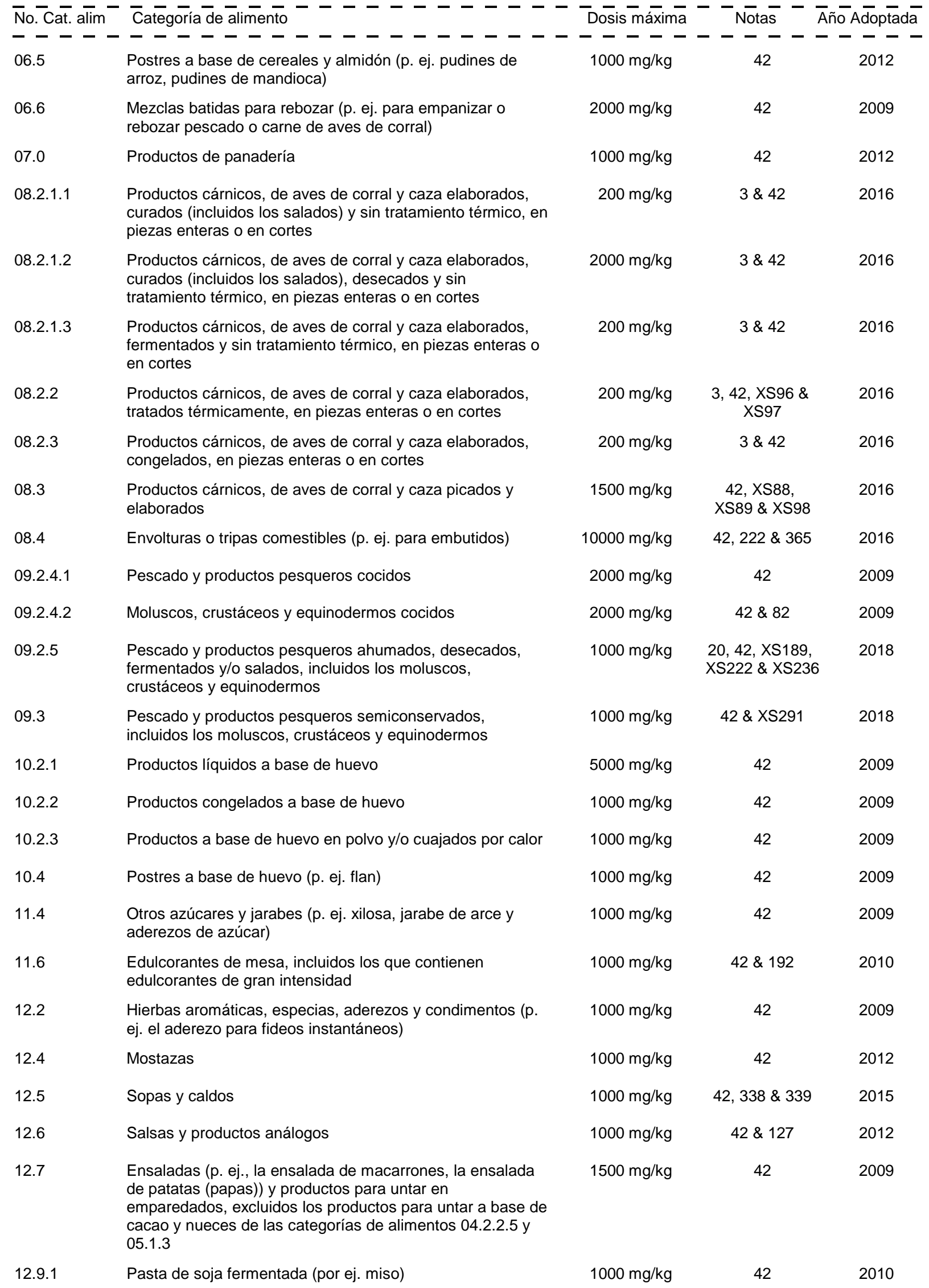




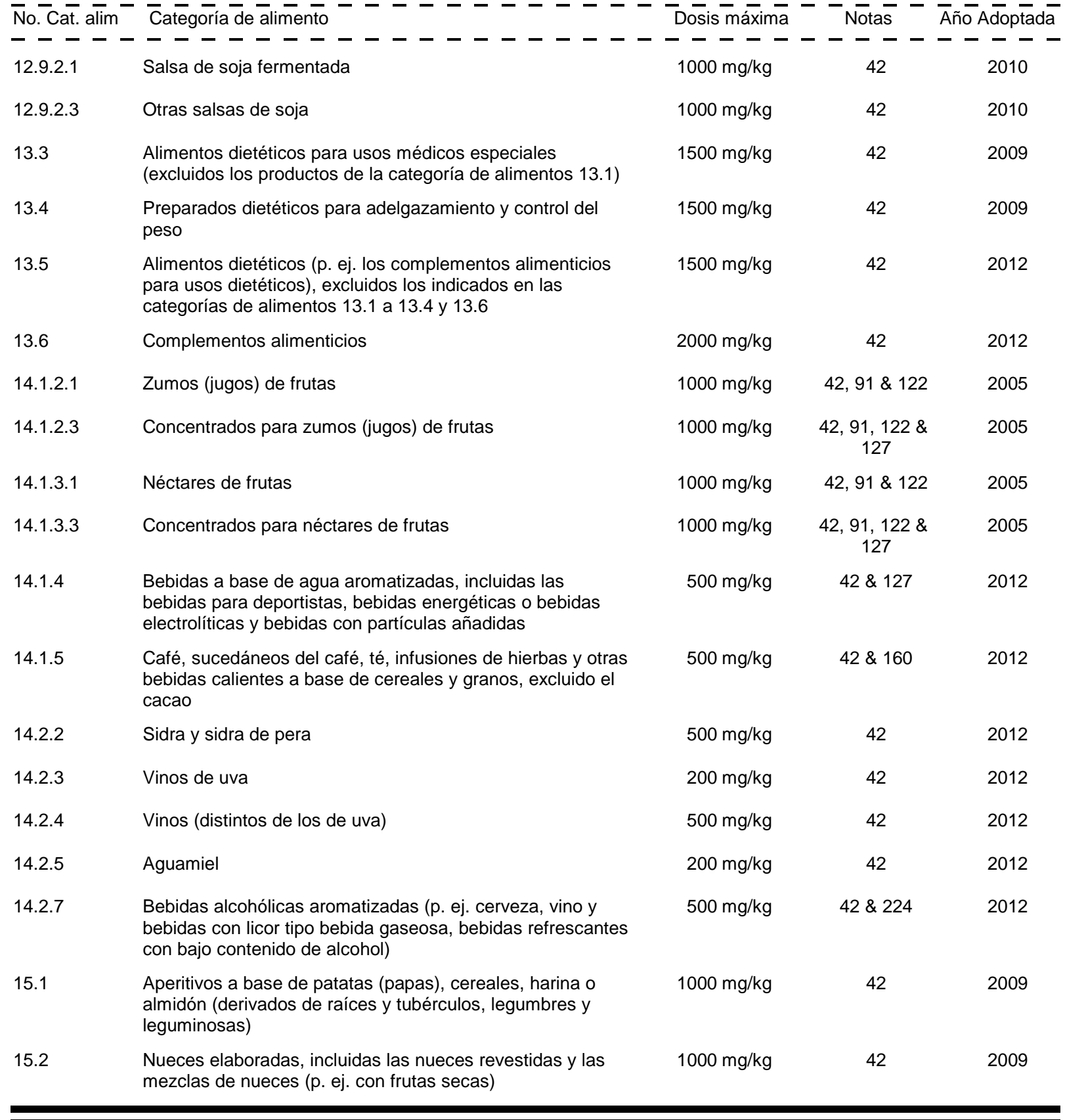

\section{SUCRALOSA (TRICLOROGALACTOSACAROSA)}

SIN 955 Sucralosa Clases Funcionales: Acentuadores del sabor, Edulcorantes

(Triclorogalactosacarosa)

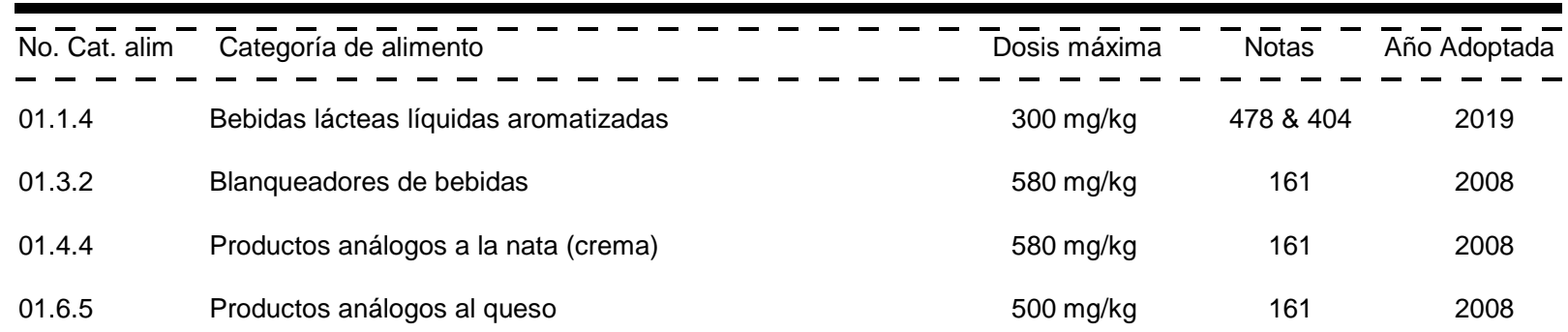




\begin{tabular}{|c|c|c|c|c|}
\hline 01.7 & $\begin{array}{l}\text { Postres lácteos (como pudines, yogur aromatizado o con } \\
\text { fruta) }\end{array}$ & $400 \mathrm{mg} / \mathrm{kg}$ & 478 & 2019 \\
\hline 02.4 & $\begin{array}{l}\text { Postres a base de grasas, excluidos los postres lácteos de } \\
\text { la categoría de alimentos } 01.7\end{array}$ & $400 \mathrm{mg} / \mathrm{kg}$ & 161 & 2007 \\
\hline 03.0 & Hielos comestibles, incluidos los sorbetes & $320 \mathrm{mg} / \mathrm{kg}$ & 478 & 2019 \\
\hline 04.1 .2 .1 & Frutas congeladas & $400 \mathrm{mg} / \mathrm{kg}$ & 161 & 2008 \\
\hline 04.1 .2 .2 & Frutas desecadas & $1500 \mathrm{mg} / \mathrm{kg}$ & 161 & 2008 \\
\hline 04.1 .2 .3 & Frutas en vinagre, aceite o salmuera & $180 \mathrm{mg} / \mathrm{kg}$ & 144 & 2007 \\
\hline 04.1 .2 .4 & Frutas en conserva, enlatadas o en frascos (pasteurizadas) & $400 \mathrm{mg} / \mathrm{kg}$ & $161 \&$ XS319 & 2018 \\
\hline 04.1 .2 .5 & Confituras, jaleas, mermeladas & $400 \mathrm{mg} / \mathrm{kg}$ & 478 & 2019 \\
\hline 04.1 .2 .6 & $\begin{array}{l}\text { Productos para untar a base de fruta (p. ej. el "chutney"), } \\
\text { excluidos los productos de la categoría de alimentos } \\
\text { 04.1.2.5 }\end{array}$ & $400 \mathrm{mg} / \mathrm{kg}$ & 478 & 2019 \\
\hline 04.1 .2 .7 & Frutas confitadas & $800 \mathrm{mg} / \mathrm{kg}$ & 161 & 2007 \\
\hline 04.1 .2 .8 & $\begin{array}{l}\text { Preparados a base de fruta, incluida la pulpa, los purés, los } \\
\text { revestimientos de fruta y la leche de coco }\end{array}$ & $400 \mathrm{mg} / \mathrm{kg}$ & 478 & 2019 \\
\hline 04.1 .2 .9 & $\begin{array}{l}\text { Postres a base de fruta, incluidos los postres a base de } \\
\text { agua con aromas de fruta }\end{array}$ & $400 \mathrm{mg} / \mathrm{kg}$ & 478 & 2019 \\
\hline 04.1 .2 .10 & Productos de fruta fermentada & $150 \mathrm{mg} / \mathrm{kg}$ & 478 & 2019 \\
\hline 04.1 .2 .11 & Rellenos de fruta para pastelería & $400 \mathrm{mg} / \mathrm{kg}$ & 161 & 2007 \\
\hline 04.1 .2 .12 & Frutas cocidas o fritas & $150 \mathrm{mg} / \mathrm{kg}$ & 478 & 2019 \\
\hline 04.2 .2 .1 & $\begin{array}{l}\text { Hortalizas (incluidos hongos y setas, raíces y tubérculos, } \\
\text { legumbres y leguminosas y áloe vera), algas marinas y } \\
\text { nueces y semillas congeladas }\end{array}$ & $150 \mathrm{mg} / \mathrm{kg}$ & 161 & 2008 \\
\hline 04.2 .2 .2 & $\begin{array}{l}\text { Hortalizas (incluidos hongos y setas, raíces y tubérculos, } \\
\text { legumbres y leguminosas y áloe vera), algas marinas y } \\
\text { nueces y semillas desecadas }\end{array}$ & $580 \mathrm{mg} / \mathrm{kg}$ & 161 & 2008 \\
\hline 04.2 .2 .3 & $\begin{array}{l}\text { Hortalizas (incluidos hongos y setas, raíces y tubérculos, } \\
\text { legumbres y leguminosas y áloe vera) y algas marinas en } \\
\text { vinagre, aceite, salmuera o salsa de soja }\end{array}$ & $400 \mathrm{mg} / \mathrm{kg}$ & & 2007 \\
\hline 04.2 .2 .4 & $\begin{array}{l}\text { Hortalizas (incluidos hongos y setas, raíces y tubérculos, } \\
\text { legumbres y leguminosas y áloe vera) y algas marinas en } \\
\text { conserva, en latas o frascos (pasteurizadas) o en bolsas de } \\
\text { esterilización }\end{array}$ & $580 \mathrm{mg} / \mathrm{kg}$ & 161 & 2008 \\
\hline 04.2 .2 .5 & $\begin{array}{l}\text { Purés y preparados para untar elaborados con hortalizas } \\
\text { (incluidos hongos y setas, raíces y tubérculos, legumbres y } \\
\text { leguminosas y áloe vera), algas marinas y nueces y } \\
\text { semillas (p. ej., la mantequilla de maní (cacahuete)) }\end{array}$ & $400 \mathrm{mg} / \mathrm{kg}$ & $161 \& 169$ & 2007 \\
\hline 04.2 .2 .6 & $\begin{array}{l}\text { Pulpas y preparados de hortalizas (incluidos hongos y } \\
\text { setas, raíces y tubérculos, legumbres y leguminosas y áloe } \\
\text { vera), algas marinas y nueces y semillas (como los postres } \\
\text { y las salsas a base de hortalizas y hortalizas confitadas) } \\
\text { distintos de los indicados en la categoría de alimentos } \\
\text { 04.2.2.5 }\end{array}$ & $400 \mathrm{mg} / \mathrm{kg}$ & 161 & 2007 \\
\hline 04.2 .2 .7 & $\begin{array}{l}\text { Productos a base de hortalizas (incluidos hongos y setas, } \\
\text { raíces y tubérculos, legumbres y leguminosas y áloe vera) y } \\
\text { algas marinas fermentadas, excluidos los productos } \\
\text { fermentados de soja de las categorías } 06.8 .6,06.8 .7 \text {, }\end{array}$ & $580 \mathrm{mg} / \mathrm{kg}$ & 161 & 2008 \\
\hline
\end{tabular}




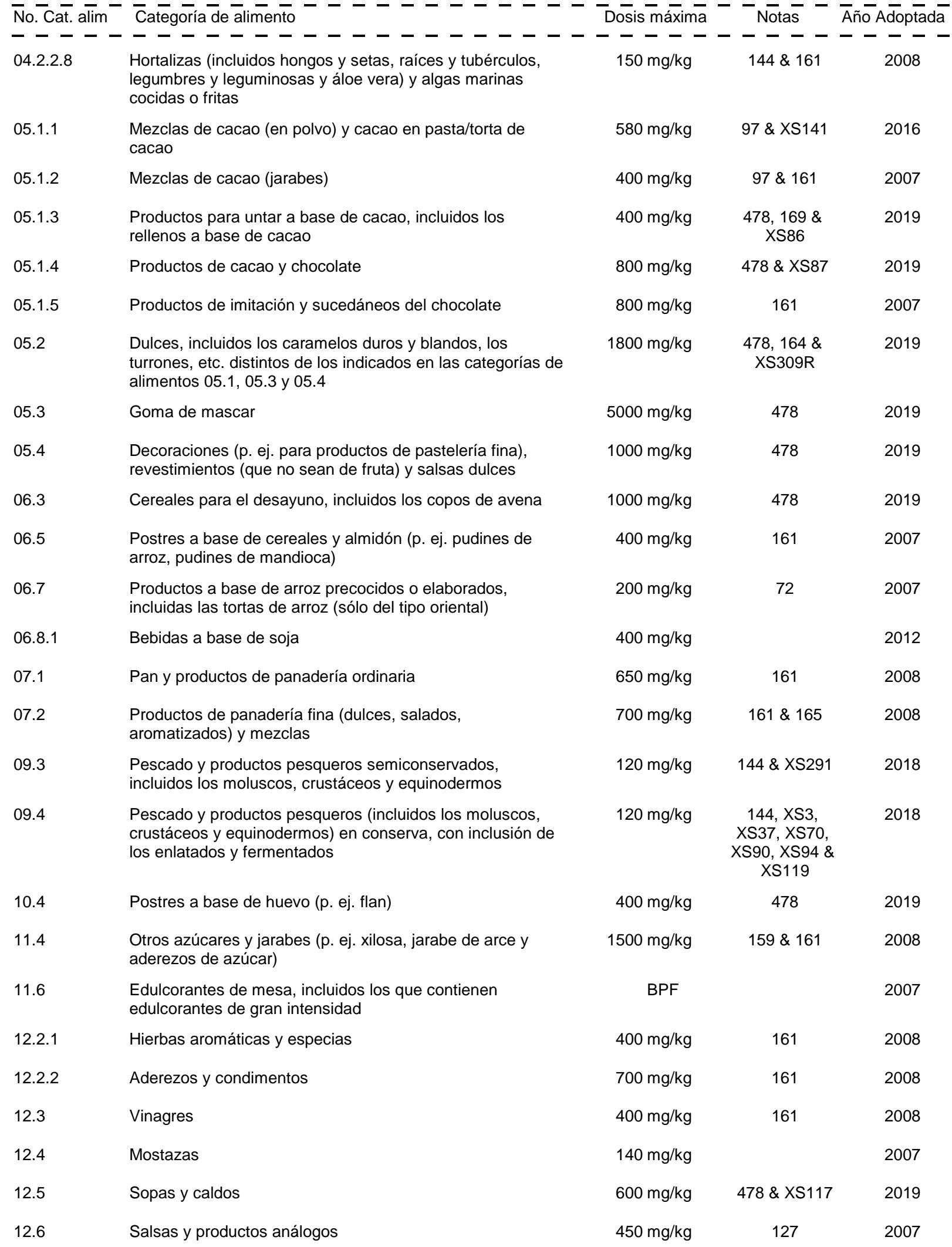




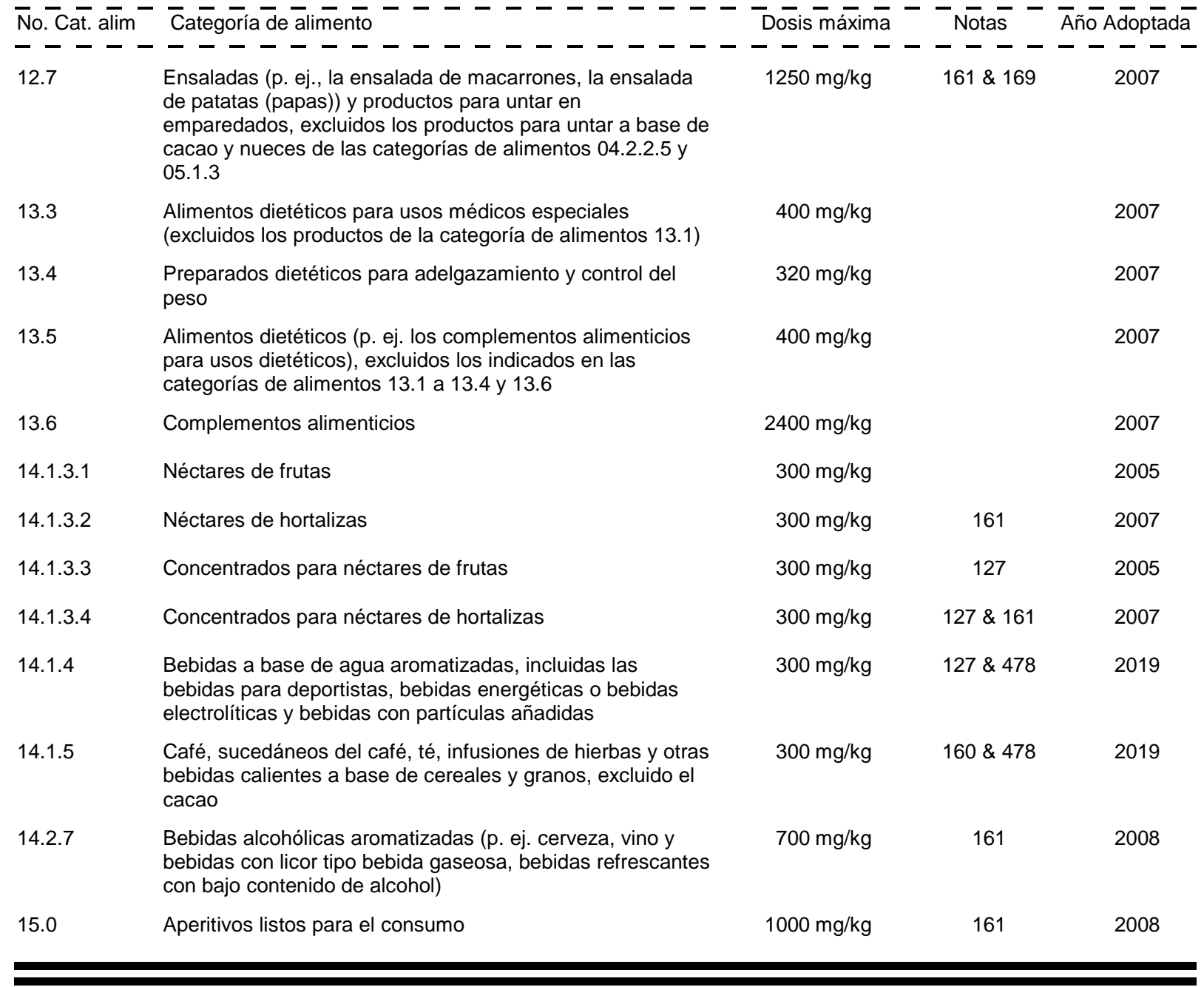

\section{SUCROÉSTERES DE ÁCIDOS GRASOS}

SIN 473 Sucroésteres de ácidos grasos Clases Funcionales: Emulsionantes, Espumantes, Agentes de glaseado, Estabilizadores

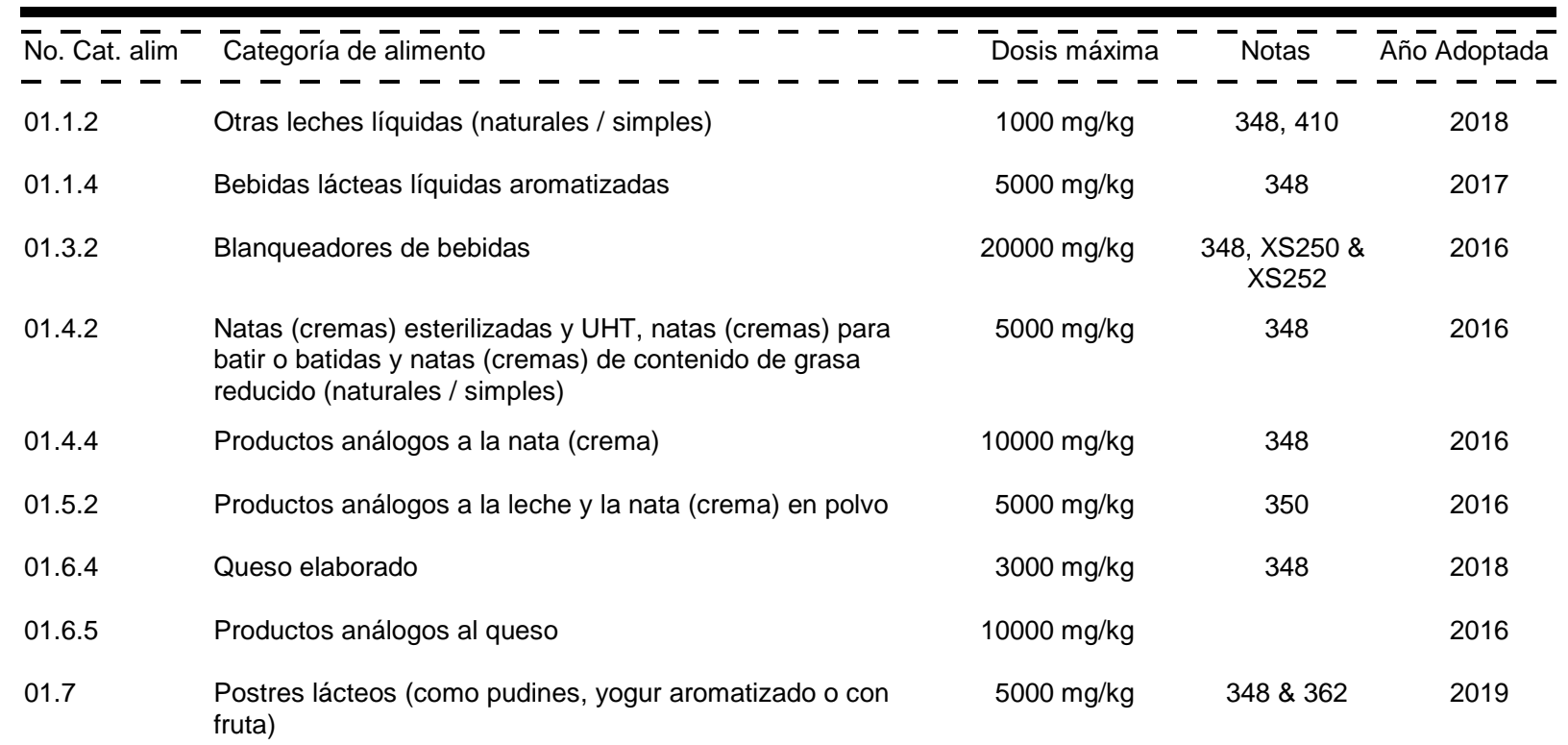




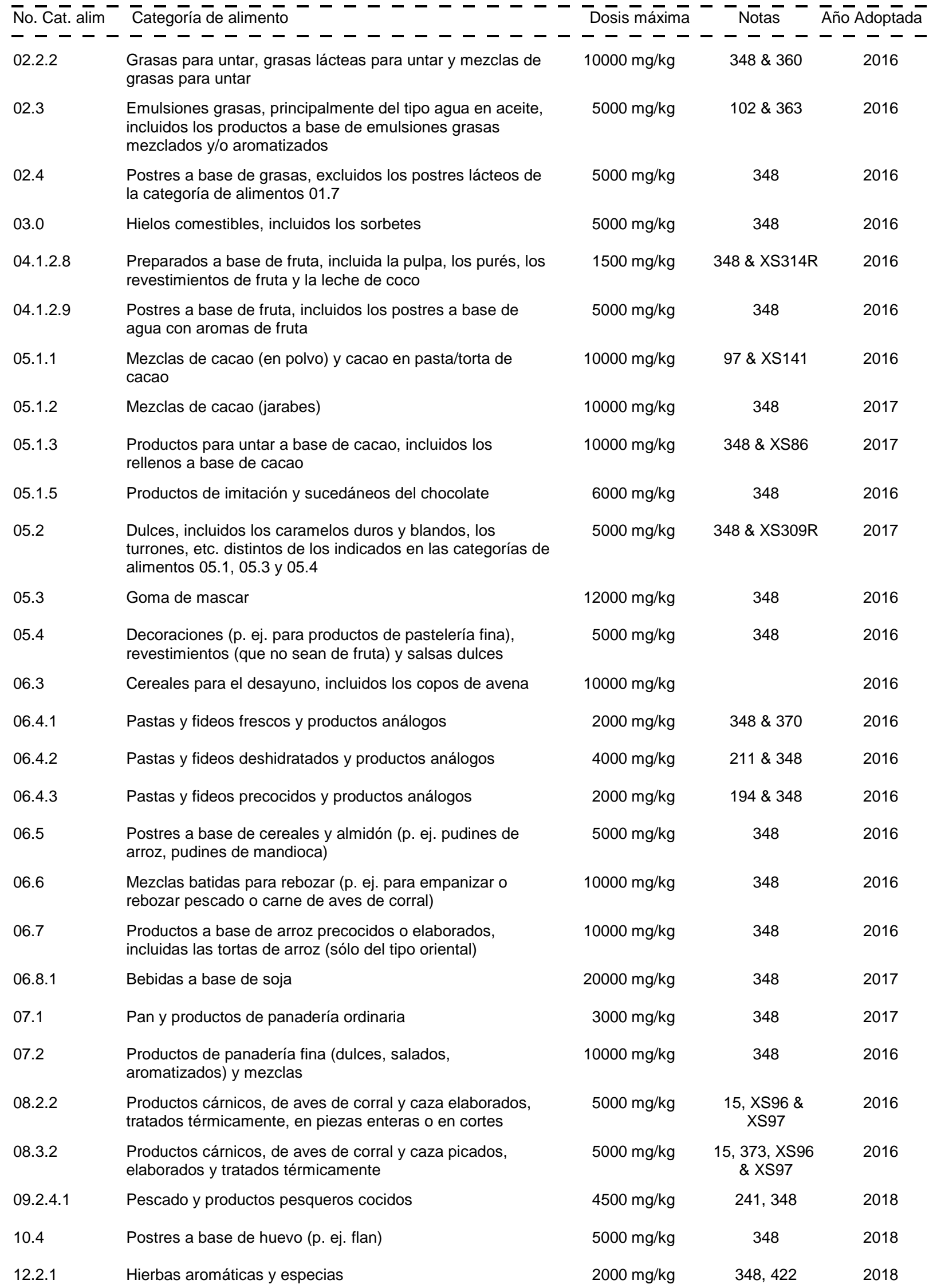




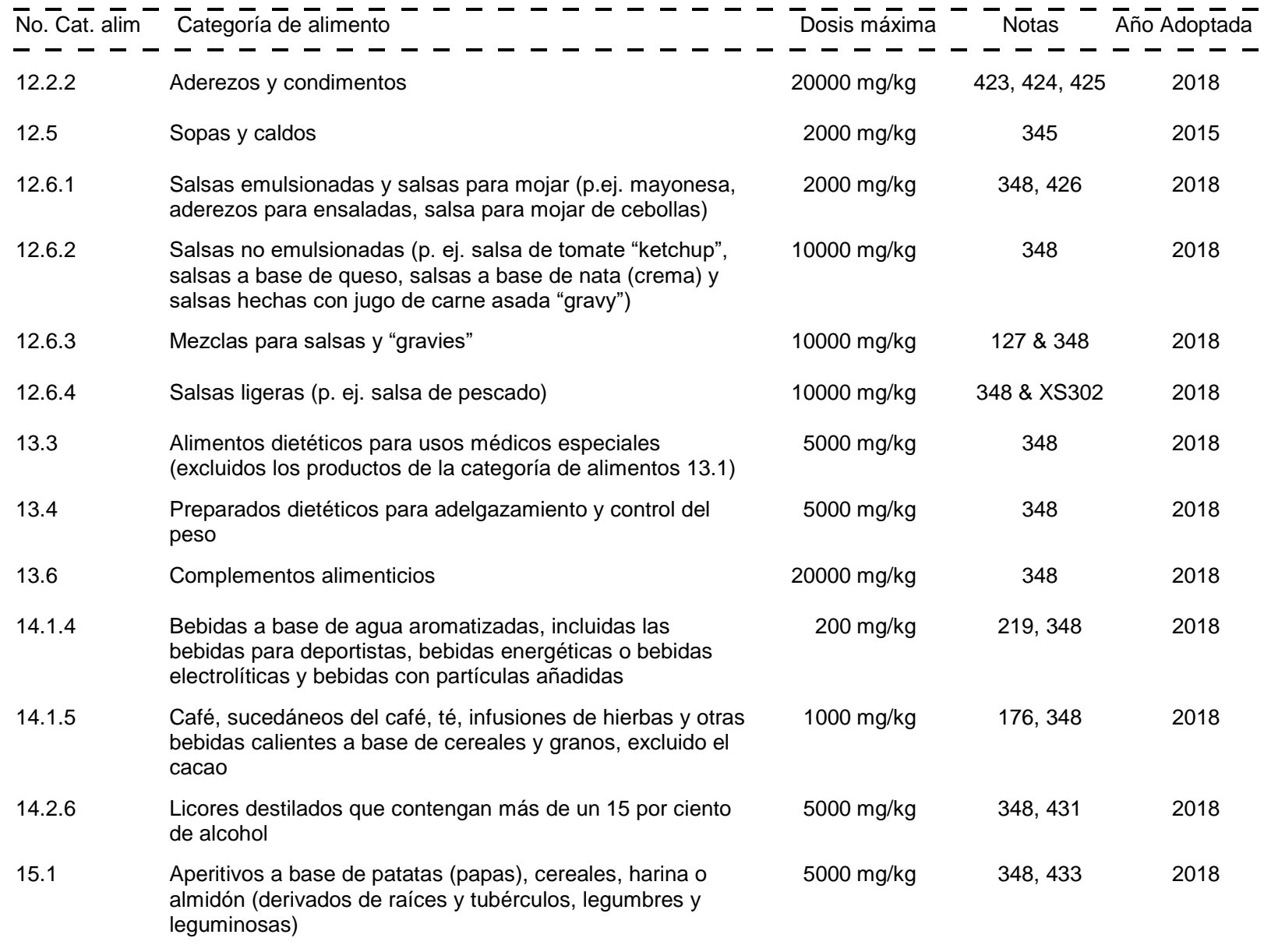

\title{
SUCROGLICÉRIDOS
}

\author{
SIN $474 \quad$ Sucroglicéridos
}

Clases Funcionales: Emulsionantes

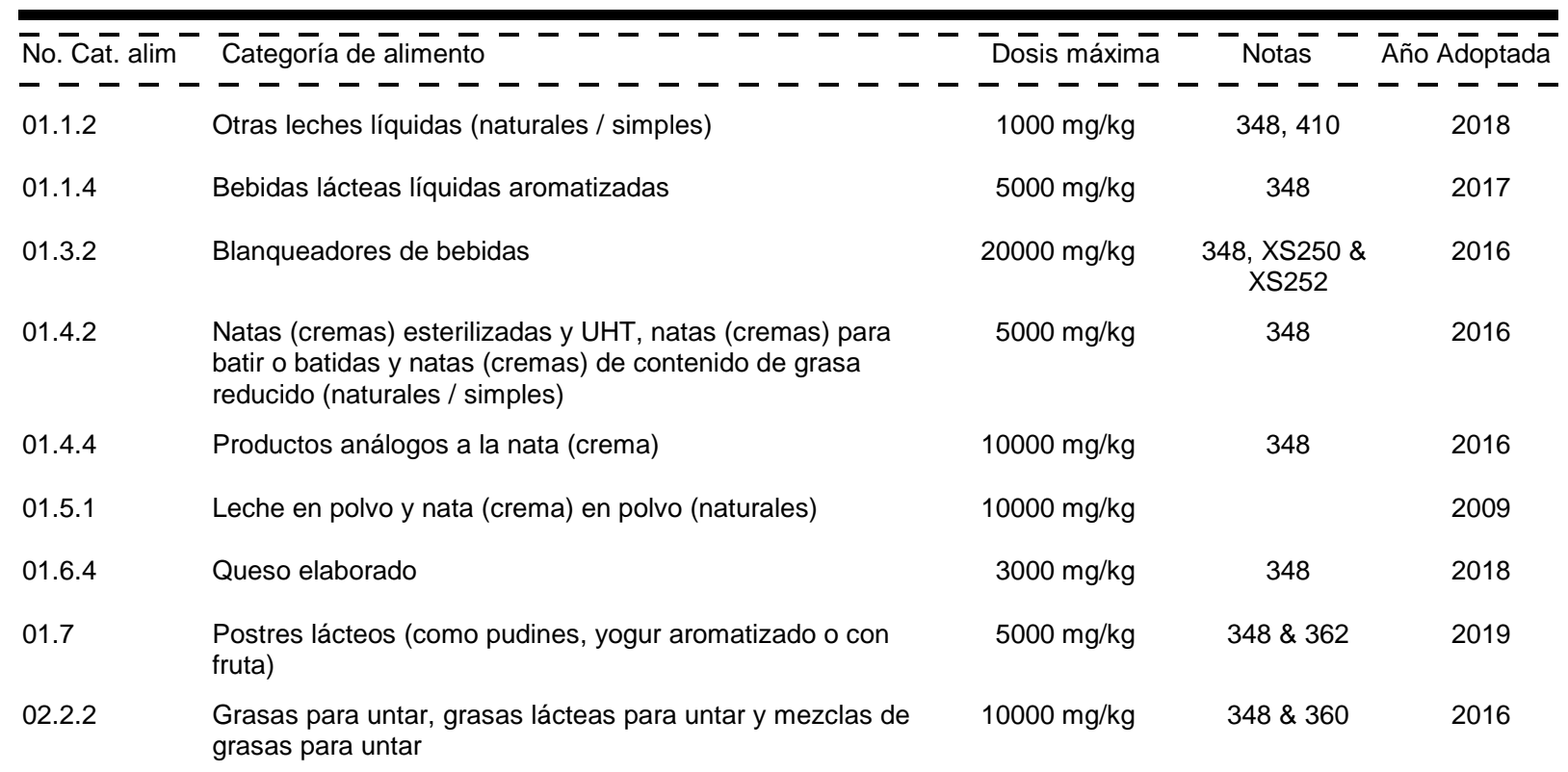




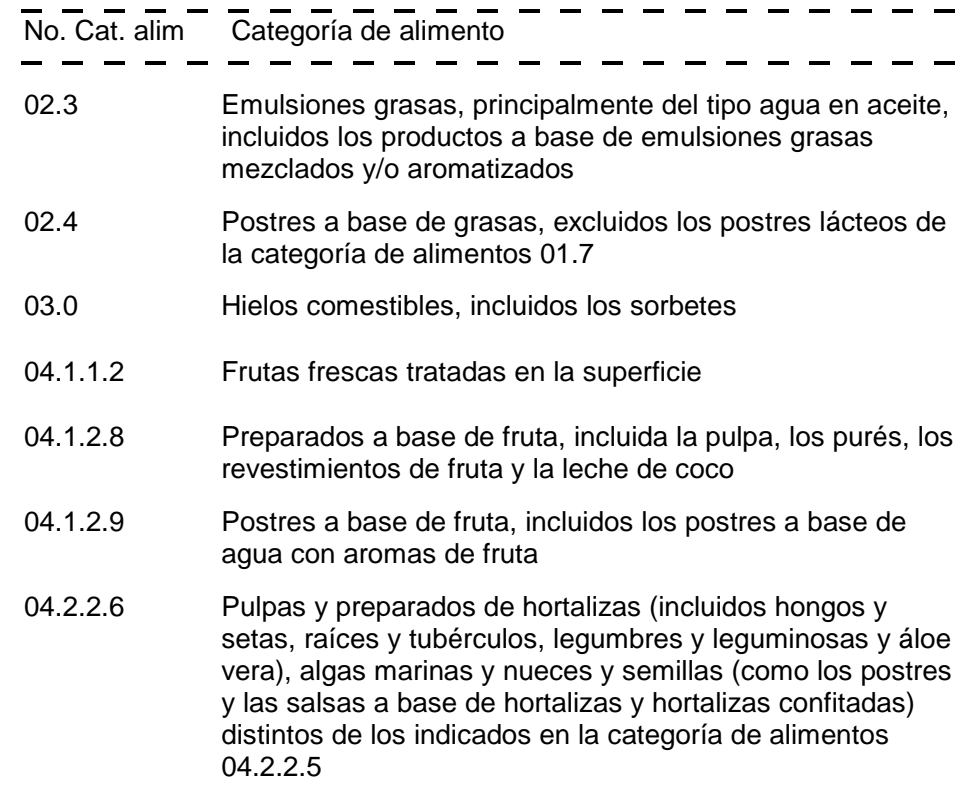

05.1.2 Mezclas de cacao (jarabes)

$\begin{array}{rcc}10000 \mathrm{mg} / \mathrm{kg} & 348 & 2017 \\ 10000 \mathrm{mg} / \mathrm{kg} & 348 & 2017 \\ 6000 \mathrm{mg} / \mathrm{kg} & 348 & 2016 \\ 5000 \mathrm{mg} / \mathrm{kg} & 348 \& \text { XS309R } & 2017\end{array}$
alimentos $05.1,05.3$ y 05.4

turrones, etc. distintos de los indicados en las categorías de

05.3

Goma de mascar

$$
500
$$

$12000 \mathrm{mg} / \mathrm{kg}$

$5000 \mathrm{mg} / \mathrm{kg}$

06.4.2 Pastas y fideos deshidratados y productos análogos

06.4.3 Pastas y fideos precocidos y productos análogos

$06.5 \quad$ Postres a base de cereales y almidón (p. ej. pudines de arroz, pudines de mandioca)

06.6

Mezclas batidas para rebozar (p. ej. para empanizar o rebozar pescado o carne de aves de corral)

$2000 \mathrm{mg} / \mathrm{k}$
$4000 \mathrm{mg} / \mathrm{kg}$
$2000 \mathrm{mg} / \mathrm{kg}$
$5000 \mathrm{mg} / \mathrm{kg}$

$10000 \mathrm{mg} / \mathrm{kg}$

$10000 \mathrm{mg} / \mathrm{kg}$

$20000 \mathrm{mg} / \mathrm{kg}$

$3000 \mathrm{mg} / \mathrm{kg}$

$10000 \mathrm{mg} / \mathrm{kg}$

Productos de panadería fina (dulces, salados, aromatizados) y mezclas

08.2 .2

08.3 .2

09.2.4.1

Productos cárnicos, de aves de corral y caza elaborados, tratados térmicamente, en piezas enteras o en cortes
Productos cárnicos, de aves de corral y caza picados, elaborados y tratados térmicamente

Pescado y productos pesqueros cocidos

Postres a base de huevo (p. ej. flan)
$5000 \mathrm{mg} / \mathrm{kg}$

$5000 \mathrm{mg} / \mathrm{kg}$

$4500 \mathrm{mg} / \mathrm{kg}$

$5000 \mathrm{mg} / \mathrm{kg}$

\section{$348 \& 370$}

$211 \& 348$

$194 \& 348$

348

348

348

348

348

348

2016

2016

2016

2016

2016

2016

2017

2017

2016

15, XS96 \&
XS97

2014

15, XS88, XS89 \& XS98

241,348

2018

348 


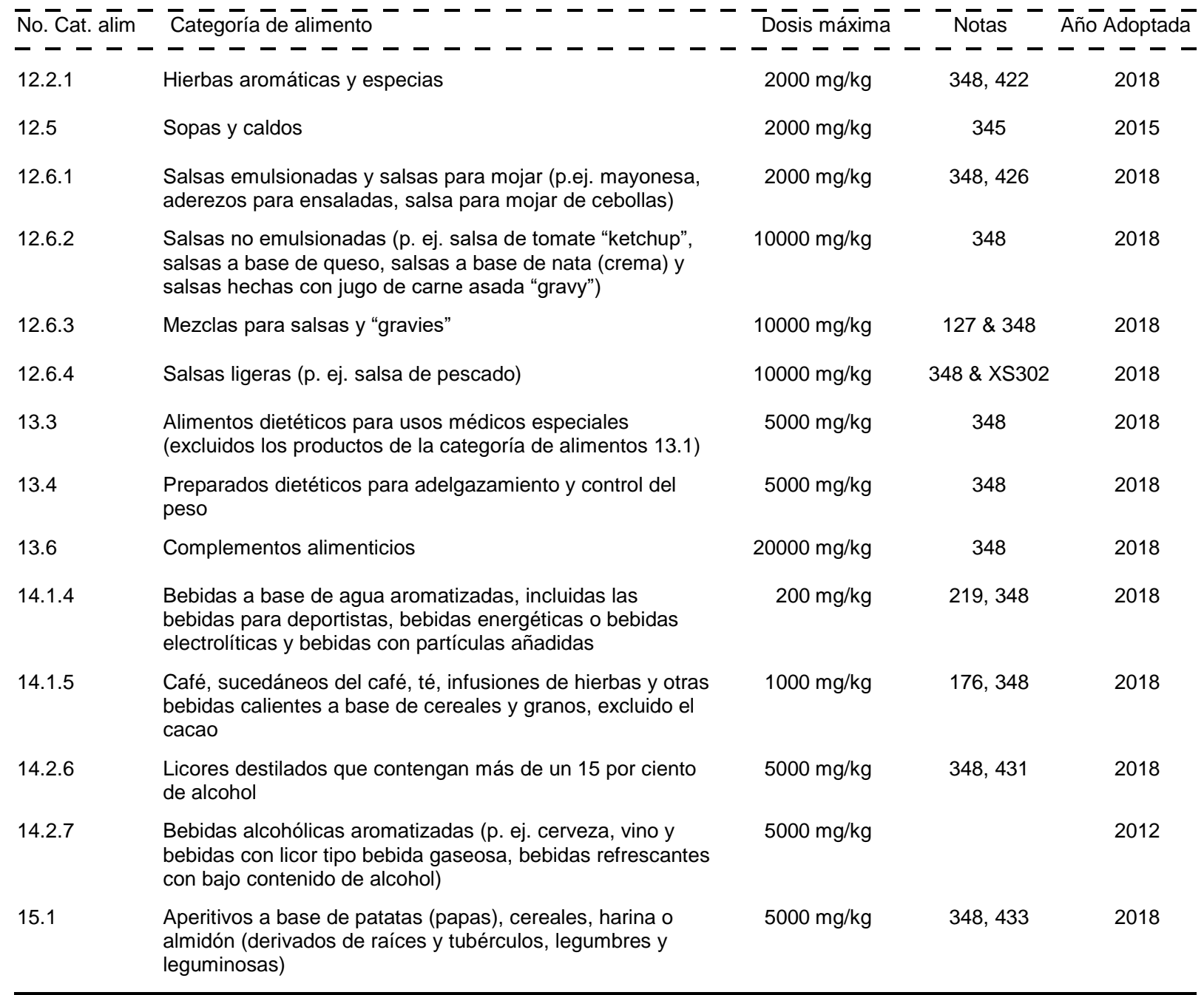

\section{SUCROSE OLIGOESTERS, TYPE I AND TYPE II}

SIN 473a Oligoésteres de sucrosa tipo I y II Clases Funcionales: Emulsionantes, Agentes de glaseado, Estabilizadores

\begin{tabular}{|c|c|c|c|c|}
\hline 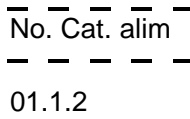 & 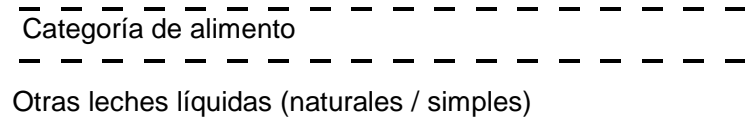 & $\begin{array}{l}\text { Dosis máxima } \\
--\overline{-}-\overline{\mathrm{mg}} \mathrm{kg}\end{array}$ & $-\frac{\text { Notas }}{348,410}-$ & Adopta \\
\hline 01.1 .4 & Bebidas lácteas líquidas aromatizadas & $5000 \mathrm{mg} / \mathrm{kg}$ & 348 & 2017 \\
\hline 01.3 .2 & Blanqueadores de bebidas & $20000 \mathrm{mg} / \mathrm{kg}$ & $\begin{array}{c}\text { 348, XS250 \& } \\
\text { XS252 }\end{array}$ & 2016 \\
\hline 01.4 .2 & $\begin{array}{l}\text { Natas (cremas) esterilizadas y UHT, natas (cremas) para } \\
\text { batir o batidas y natas (cremas) de contenido de grasa } \\
\text { reducido (naturales / simples) }\end{array}$ & $5000 \mathrm{mg} / \mathrm{kg}$ & 348 & 2016 \\
\hline 01.4 .4 & Productos análogos a la nata (crema) & $10000 \mathrm{mg} / \mathrm{kg}$ & 348 & 2016 \\
\hline 01.6 .4 & Queso elaborado & $3000 \mathrm{mg} / \mathrm{kg}$ & 348 & 2018 \\
\hline 01.7 & $\begin{array}{l}\text { Postres lácteos (como pudines, yogur aromatizado o con } \\
\text { fruta) }\end{array}$ & $5000 \mathrm{mg} / \mathrm{kg}$ & $348 \& 362$ & 2019 \\
\hline 02.2 .2 & $\begin{array}{l}\text { Grasas para untar, grasas lácteas para untar y mezclas de } \\
\text { grasas para untar }\end{array}$ & $10000 \mathrm{mg} / \mathrm{kg}$ & $348 \& 360$ & 2016 \\
\hline
\end{tabular}




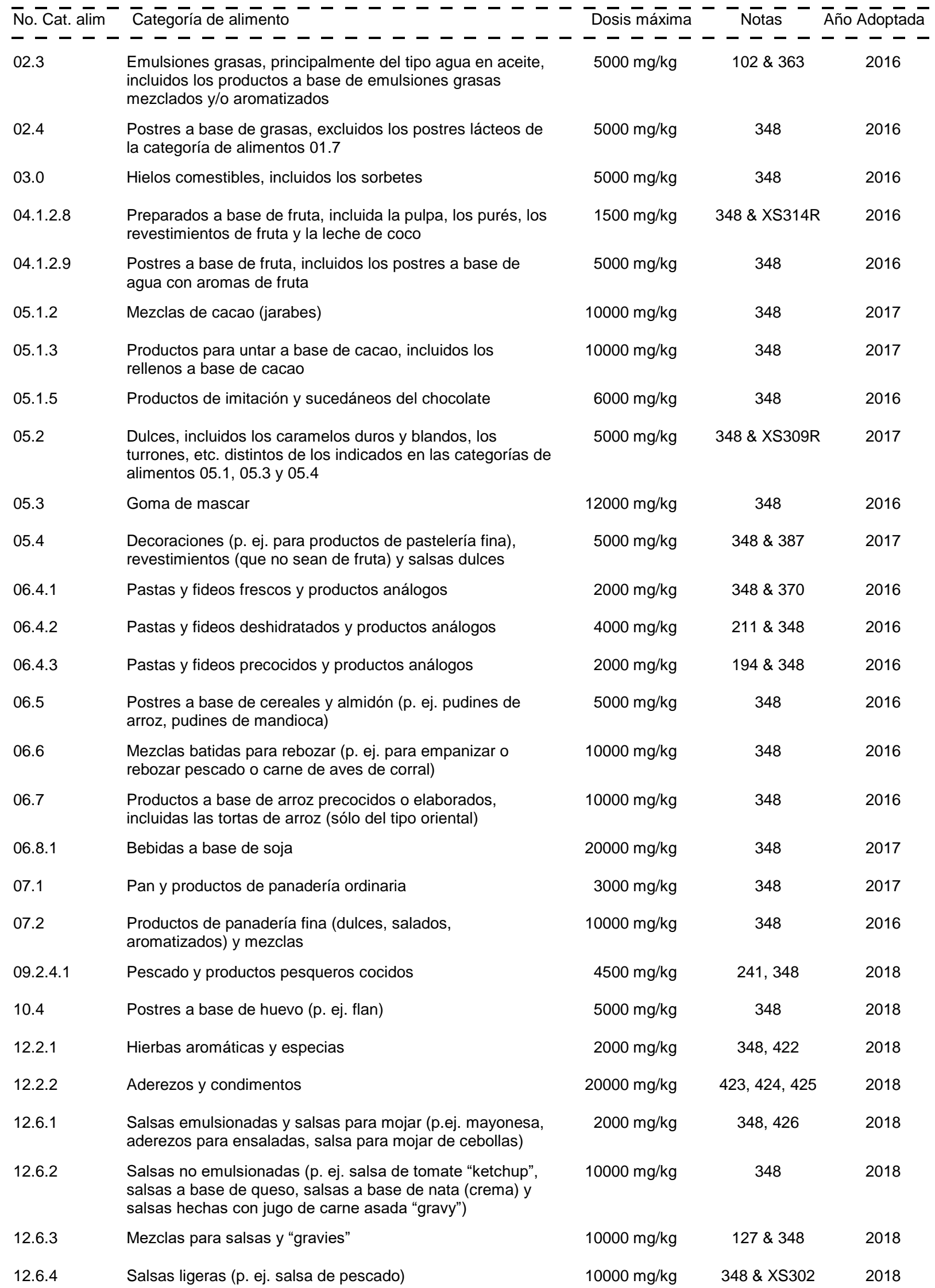




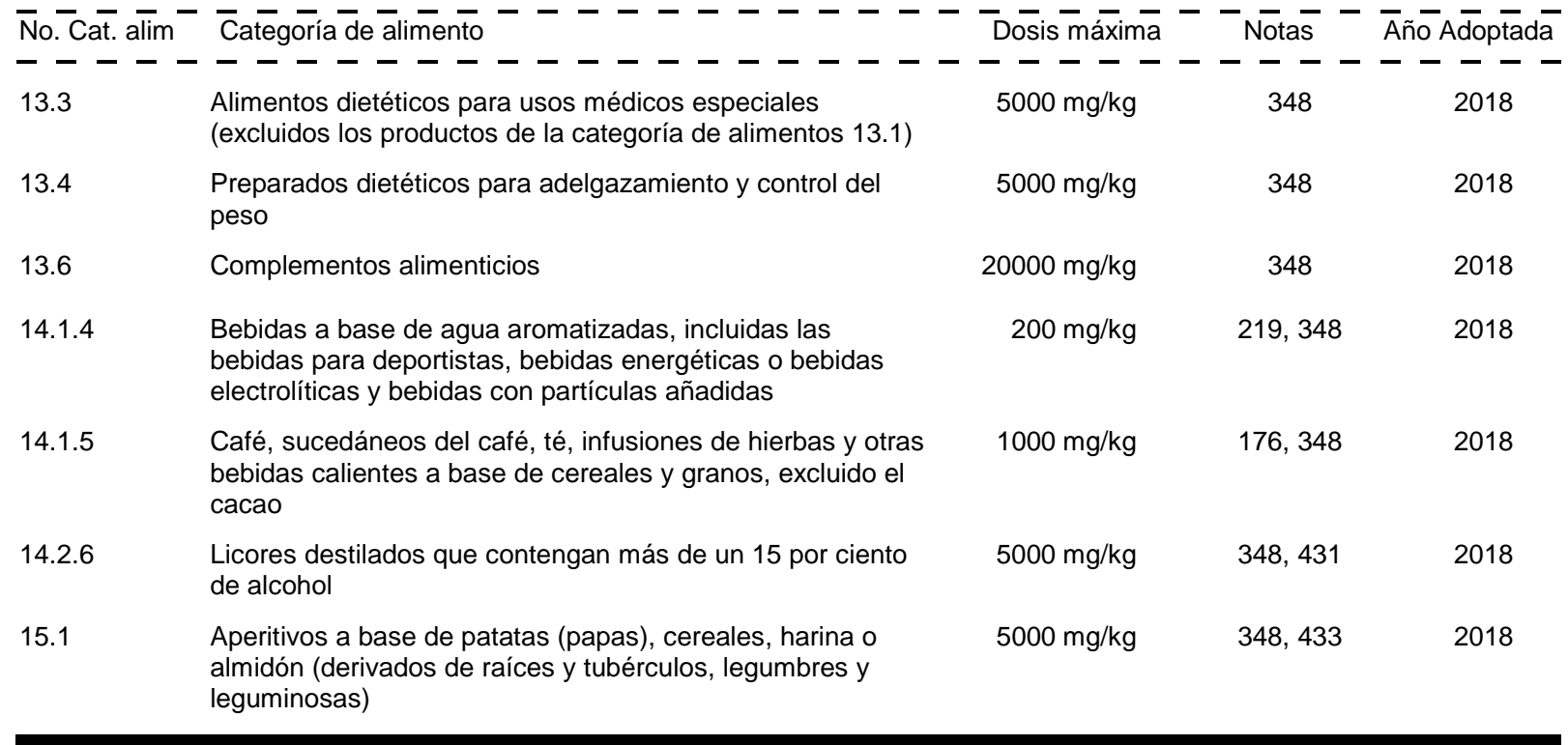

\section{SULFATO DE ALUMINIO Y AMONIO}

SIN 523 Sulfato de aluminio y amonio Clases Funcionales: $\begin{aligned} \text { Reguladores de la acidez, Agentes de retención de } \\ \text { color, Agentes endurecedores, Leudantes, }\end{aligned}$ Estabilizadores

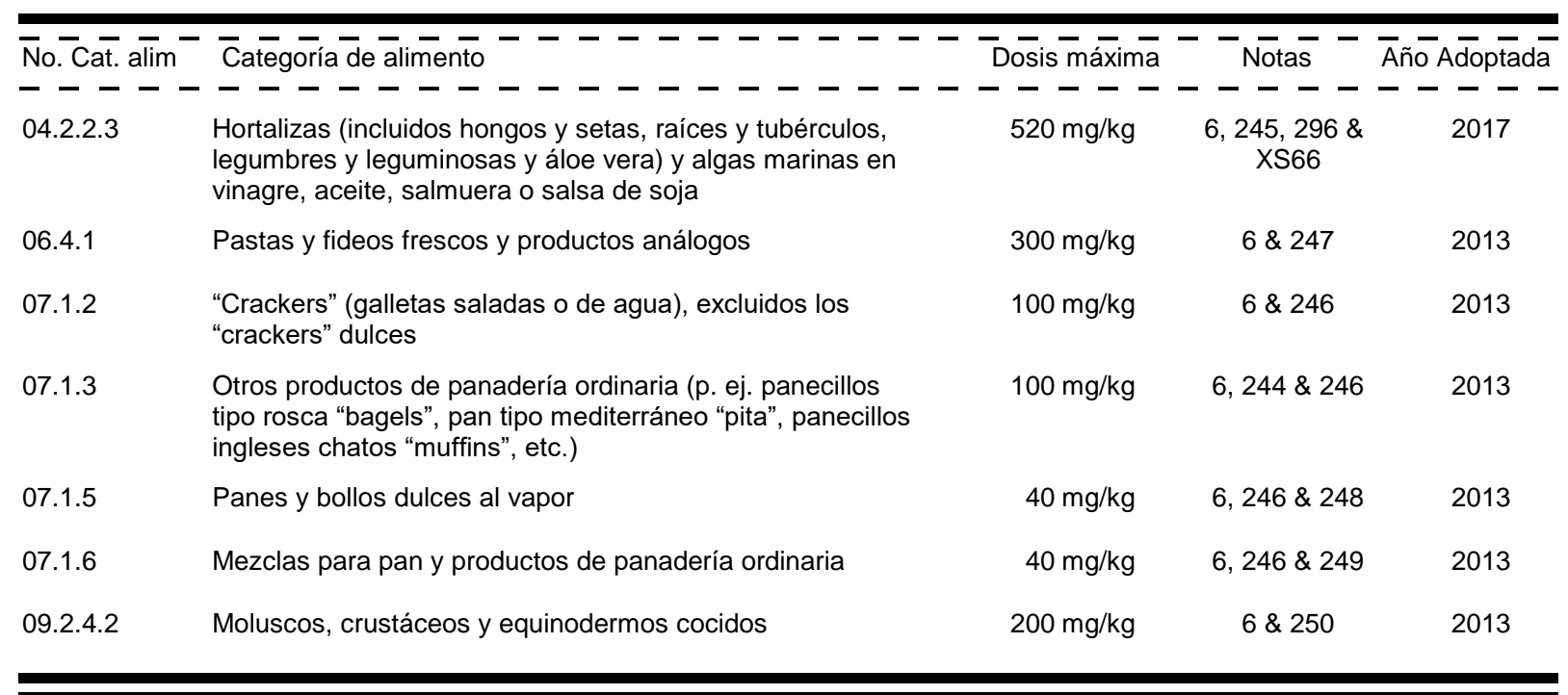

\section{SULFATO DE CALCIO}

SIN 516
Sulfato de calcio
Clases Funcionales: Reguladores de la acidez, Agentes endurecedores, Agentes de tratamiento de las harinas, Secuestrantes, Estabilizadores

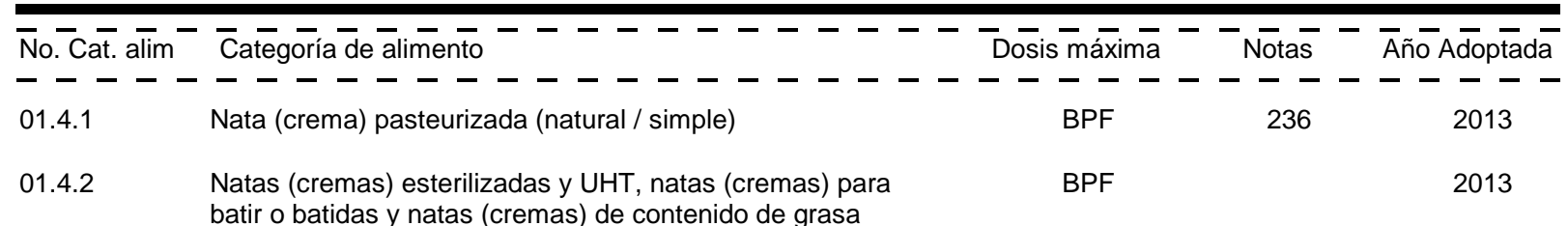
reducido (naturales / simples) 


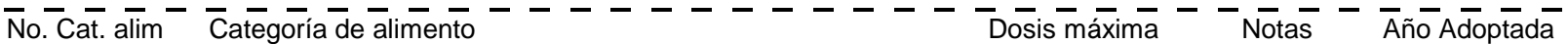
- - - - - - - - - - - - - - - - - - - - - - - - - -

04.2.2.1 Hortalizas (incluidos hongos y setas, raíces y tubérculos, $\quad$ BPF $\quad 29,323 \& 324 \quad 2015$ legumbres y leguminosas y áloe vera), algas marinas y nueces y semillas congeladas Harinas

BPF

BPF

BPF
Clases Funcionales: Agentes endurecedores, Acentuadores del sabor

\section{SULFATO DE MAGNESIO}

SIN $518 \quad$ Sulfato de magnesio

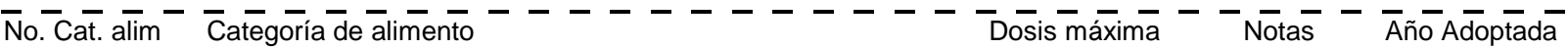
- - - - - - - - - - - - - - - - - - - - - - - - - -
12.1.2
Sucedáneos de la sal
BPF
2015

\section{SULFITOS}

\begin{tabular}{|c|c|c|c|}
\hline 220 & Dióxido de azufre & Clases Funcionales: & $\begin{array}{l}\text { Antioxidantes, Decolorantes, Agentes de tratamiento } \\
\text { de las harinas, Sustancias conservadoras }\end{array}$ \\
\hline 221 & Sulfito de sodio & Clases Funcionales: & $\begin{array}{l}\text { Antioxidantes, Decolorantes, Agentes de tratamiento } \\
\text { de las harinas, Sustancias conservadoras }\end{array}$ \\
\hline 222 & Sulfito ácido de sodio & Clases Funcionales: & Antioxidantes, Sustancias conservadoras \\
\hline 224 & Metabisulfito de potasio & Clases Funcionales: & $\begin{array}{l}\text { Antioxidantes, Decolorantes, Agentes de tratamiento } \\
\text { de las harinas, Sustancias conservadoras }\end{array}$ \\
\hline 225 & Sulfito de potasio & Clases Funcionales: & Antioxidantes, Sustancias conservadoras \\
\hline
\end{tabular}

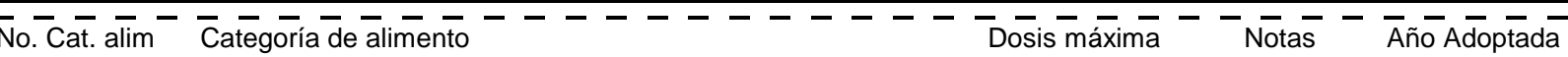

\begin{tabular}{|c|c|}
\hline $30 \mathrm{mg} / \mathrm{kg}$ & $44 \& 204$ \\
\hline
\end{tabular}

04.1.2.1 Frutas congeladas

$500 \mathrm{mg} / \mathrm{kg} \quad 44 \& 155 \quad 2007$

04.1.2.2 Frutas desecadas

$1000 \mathrm{mg} / \mathrm{kg} \quad 44,135 \& 218 \quad 2011$

04.1.2.3 Frutas en vinagre, aceite o salmuera

$100 \mathrm{mg} / \mathrm{kg} \quad 44 \quad 2006$

04.1.2.5 Confituras, jaleas, mermeladas

$100 \mathrm{mg} / \mathrm{kg} \quad 44 \quad 2008$

04.1.2.7 Frutas confitadas

$100 \mathrm{mg} / \mathrm{kg} \quad 44 \quad 2006$

04.1.2.8 Preparados a base de fruta, incluida la pulpa, los purés, los $100 \mathrm{mg} / \mathrm{kg} \quad 44 \& 206 \quad 2012$ revestimientos de fruta y la leche de coco

04.1.2.9 Postres a base de fruta, incluidos los postres a base de agua con aromas de fruta

$100 \mathrm{mg} / \mathrm{kg} \quad 44 \quad 2008$

04.1.2.10 Productos de fruta fermentada

$100 \mathrm{mg} / \mathrm{kg} \quad 44 \quad 2008$

04.1.2.11 Rellenos de fruta para pastelería

$100 \mathrm{mg} / \mathrm{kg}$

44 


\section{- - - \\ 04.2 .1 .3 \\ Hortalizas (incluidos hongos y setas, raíces y tubérculos, legumbres y leguminosas y áloe vera), algas marinas y nueces y semillas frescas peladas, cortadas o desmenuzadas}

04.2 .2 .1

Hortalizas (incluidos hongos y setas, raíces y tubérculos, legumbres y leguminosas y áloe vera), algas marinas y nueces y semillas congeladas

04.2.2.2 Hortalizas (incluidos hongos y setas, raíces y tubérculos, legumbres y leguminosas y áloe vera), algas marinas y nueces y semillas desecadas

04.2.2.3 Hortalizas (incluidos hongos y setas, raíces y tubérculos, legumbres y leguminosas y áloe vera) y algas marinas en vinagre, aceite, salmuera o salsa de soja

04.2.2.4 Hortalizas (incluidos hongos y setas, raíces y tubérculos, legumbres y leguminosas y áloe vera) y algas marinas en conserva, en latas o frascos (pasteurizadas) o en bolsas de esterilización

04.2 .2 .5

Purés y preparados para untar elaborados con hortalizas (incluidos hongos y setas, raíces y tubérculos, legumbres y leguminosas y áloe vera), algas marinas y nueces y semillas (p. ej., la mantequilla de maní (cacahuete))

04.2.2.6 Pulpas y preparados de hortalizas (incluidos hongos y setas, raíces y tubérculos, legumbres y leguminosas y áloe vera), algas marinas y nueces y semillas (como los postres y las salsas a base de hortalizas y hortalizas confitadas) distintos de los indicados en la categoría de alimentos 04.2 .2 .5

04.2.2.7 Productos a base de hortalizas (incluidos hongos y setas, raíces y tubérculos, legumbres y leguminosas y áloe vera) y algas marinas fermentadas, excluidos los productos fermentados de soja de las categorías 06.8.6, 06.8.7, 12.9.1, 12.9.2.1 y 12.9 .2 .3

06.2.1 Harinas

06.2.2 Almidones

06.4.3 Pastas y fideos precocidos y productos análogos

$07.2 \quad$ Productos de panadería fina (dulces, salados aromatizados) y mezclas

09.1.2 Moluscos, crustáceos y equinodermos frescos

09.2.1 Pescado, filetes de pescado y productos pesqueros congelados, incluidos los moluscos, crustáceos y equinodermos

09.2.4.2 Moluscos, crustáceos y equinodermos cocidos

09.2.5 Pescado y productos pesqueros ahumados, desecados fermentados y/o salados, incluidos los moluscos, crustáceos y equinodermos

Pescado y productos pesqueros (incluidos los moluscos, crustáceos y equinodermos) en conserva, con inclusión de los enlatados y fermentados

11.1.1 Azúcar blanco, dextrosa anhidra, dextrosa monohidrato y fructosa

$\begin{array}{ccc}50 \mathrm{mg} / \mathrm{kg} & \begin{array}{c}44,76,136 \& \\ 137\end{array} & 2006 \\ & & \\ 500 \mathrm{mg} / \mathrm{kg} & 44 \& 105 & 2006\end{array}$

$50 \mathrm{mg} / \mathrm{kg} \quad 44$

2006

$500 \mathrm{mg} / \mathrm{kg} \quad 44 \& 138 \quad 2006$

$300 \mathrm{mg} / \mathrm{kg} \quad 44 \& 205 \quad 2011$

$500 \mathrm{mg} / \mathrm{kg}$

2006

$200 \mathrm{mg} / \mathrm{kg}$

44,470

2019

$50 \mathrm{mg} / \mathrm{kg} \quad 44 \quad 2006$

$20 \mathrm{mg} / \mathrm{kg} \quad 44,476 \quad 2019$

$50 \mathrm{mg} / \mathrm{kg} \quad 44 \quad 2006$

$100 \mathrm{mg} / \mathrm{kg} \quad 44,390, \mathrm{XS} 312 \quad 2017$

\& XS315

$100 \mathrm{mg} / \mathrm{kg} \quad 19,44,139$

$392, \mathrm{XS} 36$

XS165, XS190,

XS191, XS312

\& XS315

$150 \mathrm{mg} / \mathrm{kg}$

2007

$30 \mathrm{mg} / \mathrm{kg} \quad 44, \mathrm{XS} 167$

XS189, XS222

XS236, XS244

\& XS311

$150 \mathrm{mg} / \mathrm{kg}$

44, 140, XS3,

XS37, XS70,

XS90, XS94 \&

XS119

$15 \mathrm{mg} / \mathrm{kg}$ 


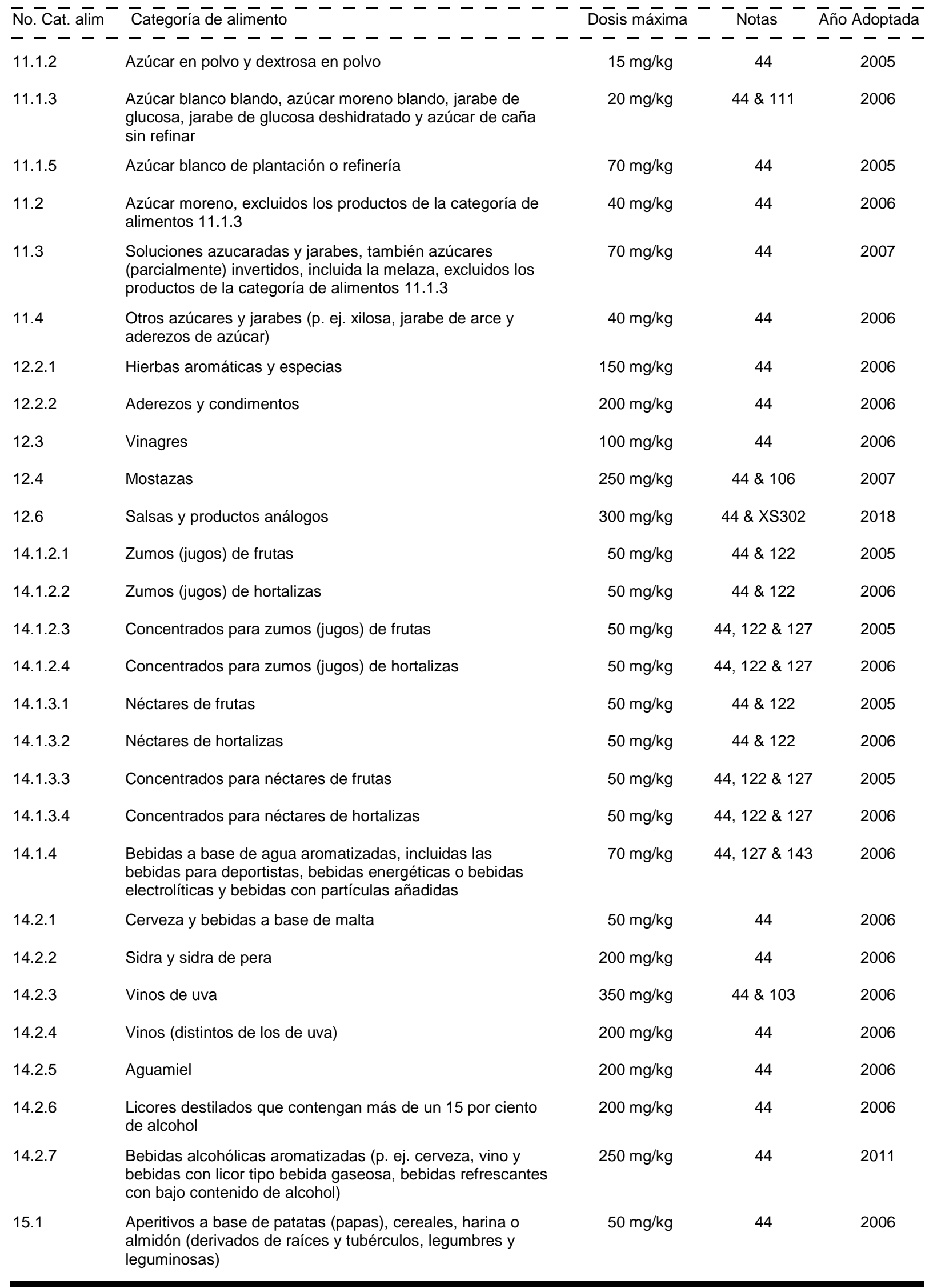




\section{TALCO}

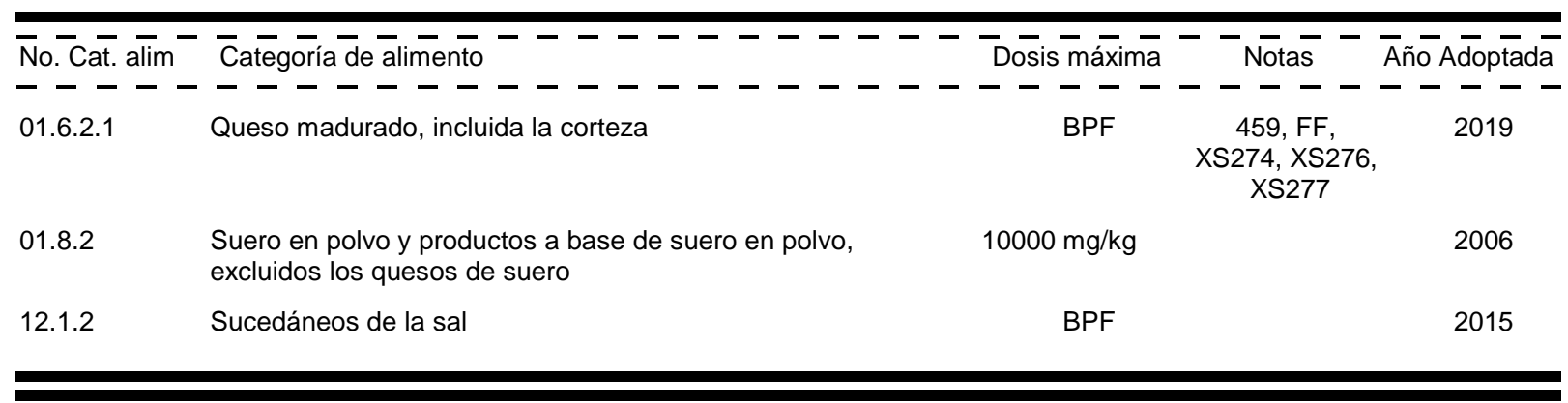

\section{TARTRATOS}

$\begin{array}{llll}\text { SIN } 334 & \text { Ácido tartárico, L(+)- } & \text { Clases Funcionales: } \begin{array}{l}\text { Reguladores de la acidez, Antioxidantes, } \\ \text { Acentuadores del sabor, Secuestrantes }\end{array} \\ \text { SIN } 335(\mathrm{ii}) & \text { Tartrato de sodio, L(+)- } & \begin{array}{l}\text { Clases Funcionales: } \\ \text { Reguladores de la acidez, Sales emulsionantes, } \\ \text { Secuestrantes, Estabilizadores }\end{array} \\ \text { SIN } 337 & \text { Tartrato de potasio y sodio, L(+)- } & \text { Clases Funcionales: } \\ & & \end{array}$

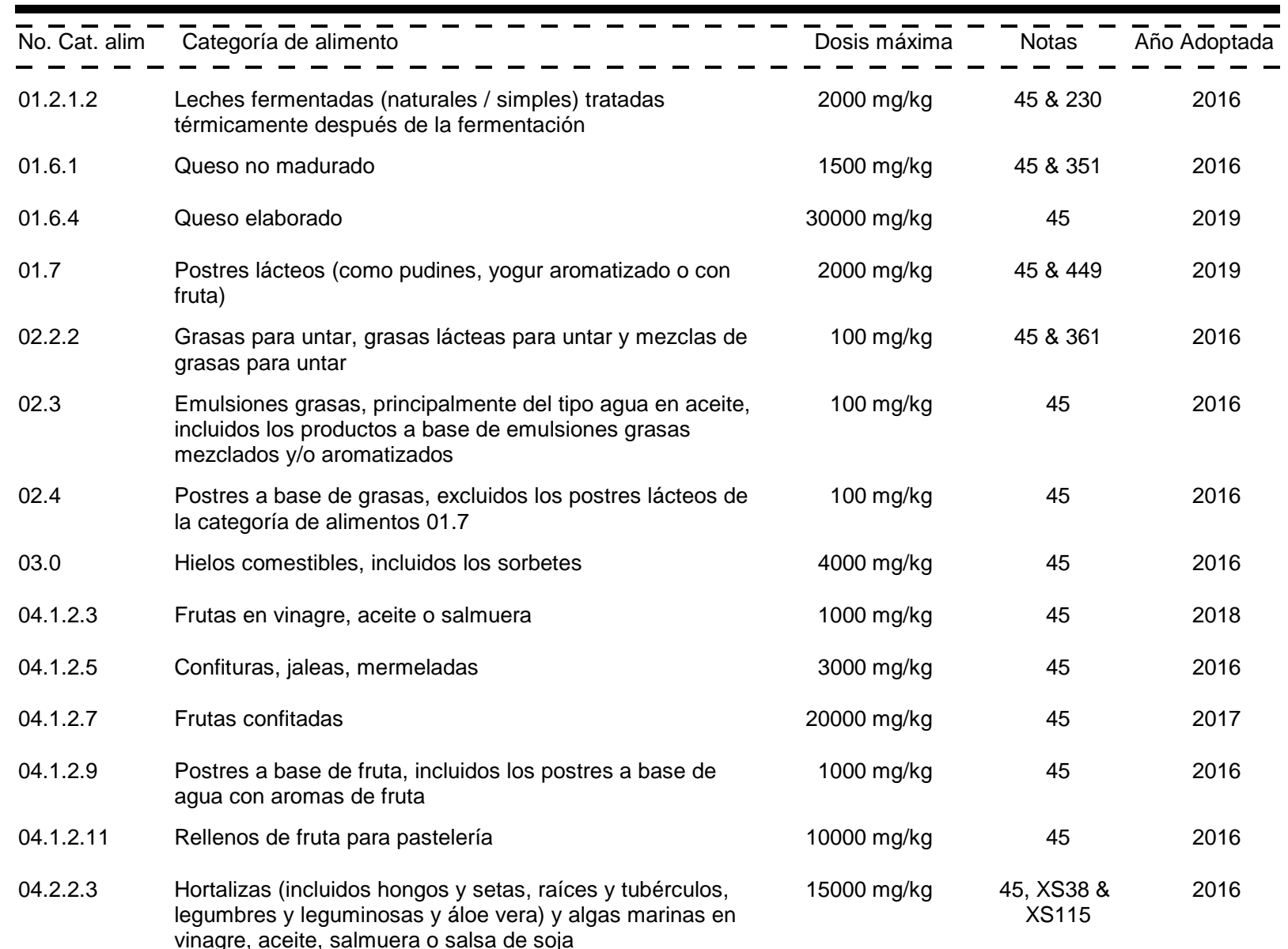




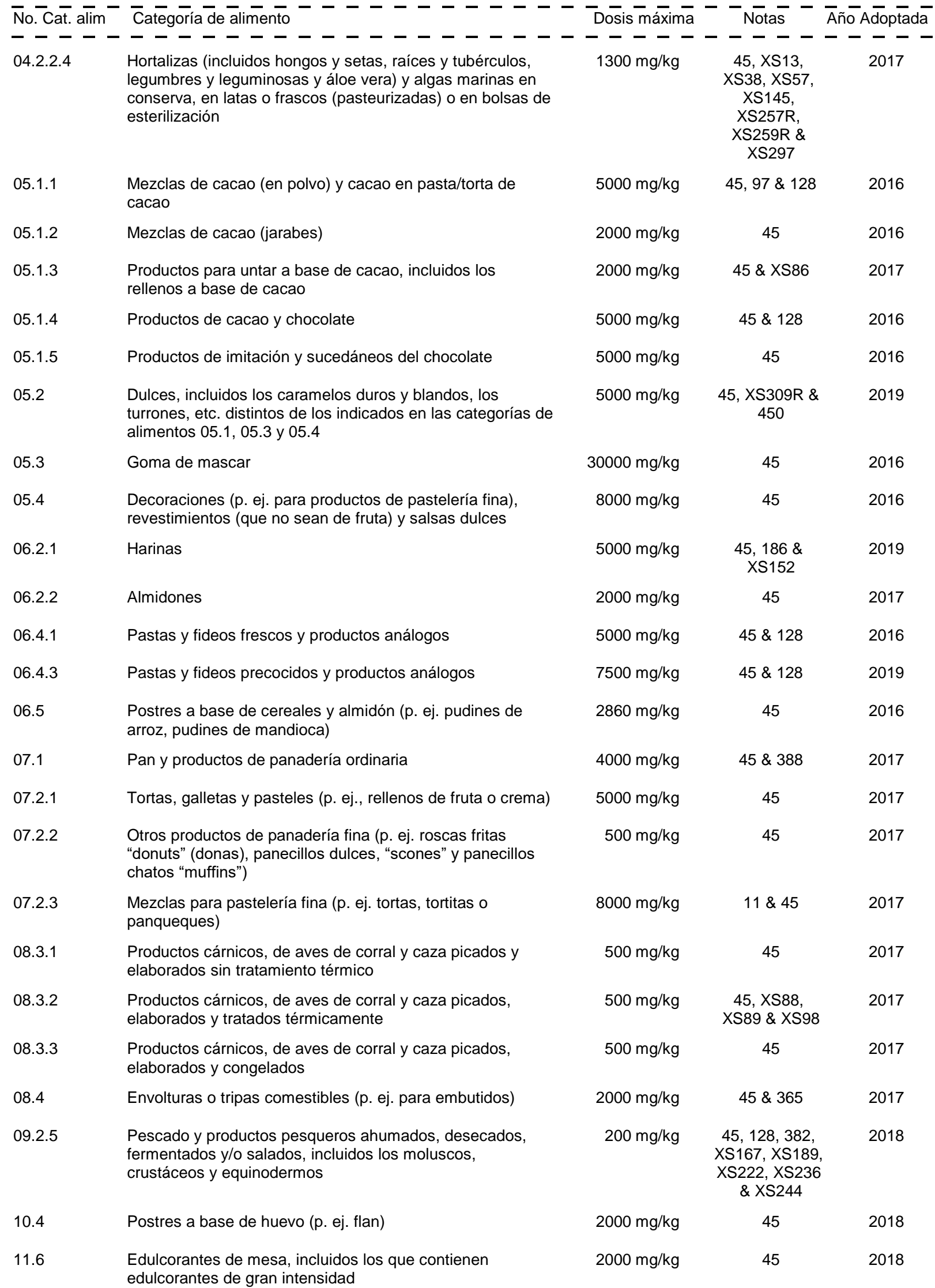




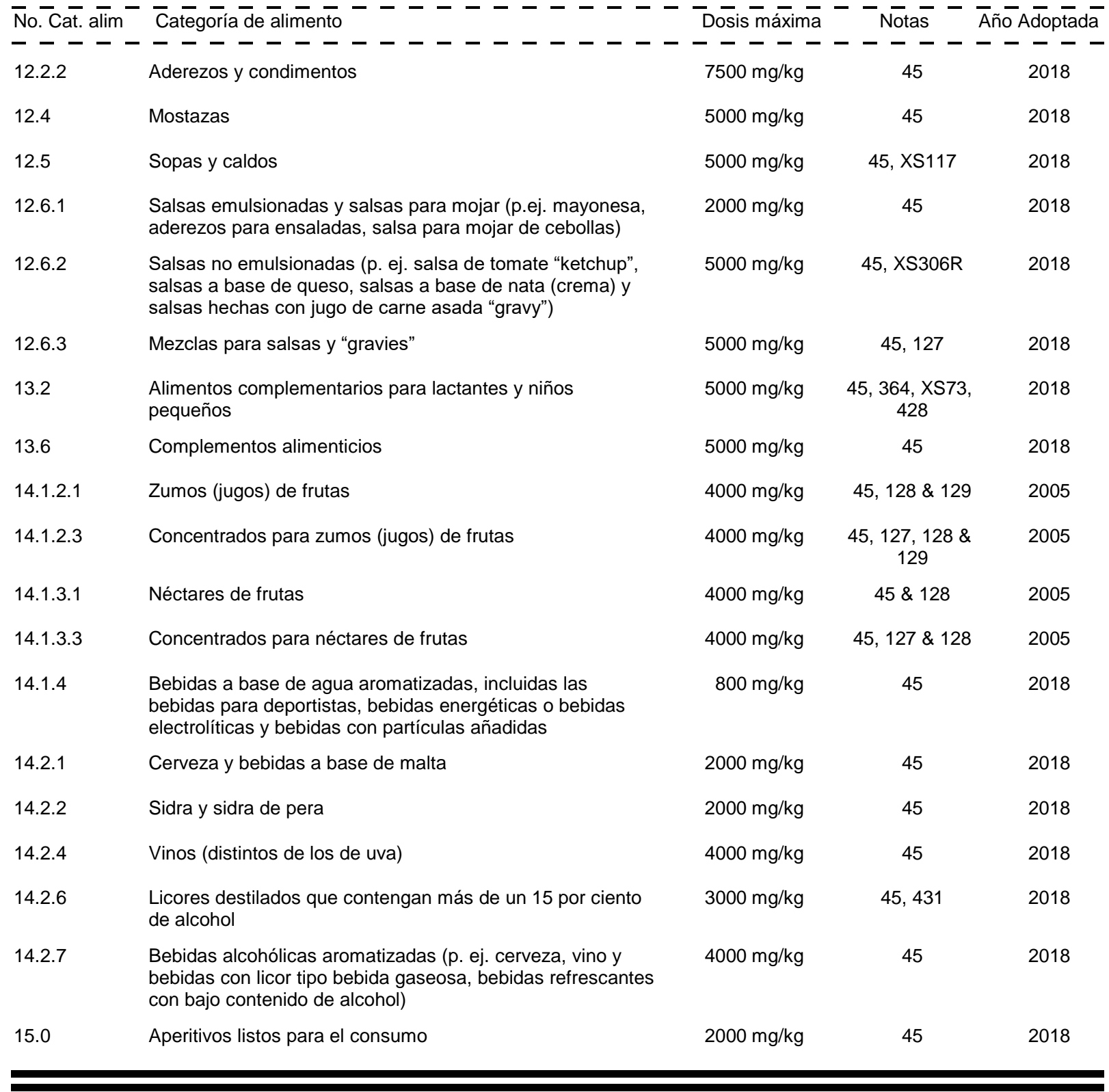

\section{TARTRAZINA}
SIN 102
Tartrazina
Clases Funcionales: Colorantes

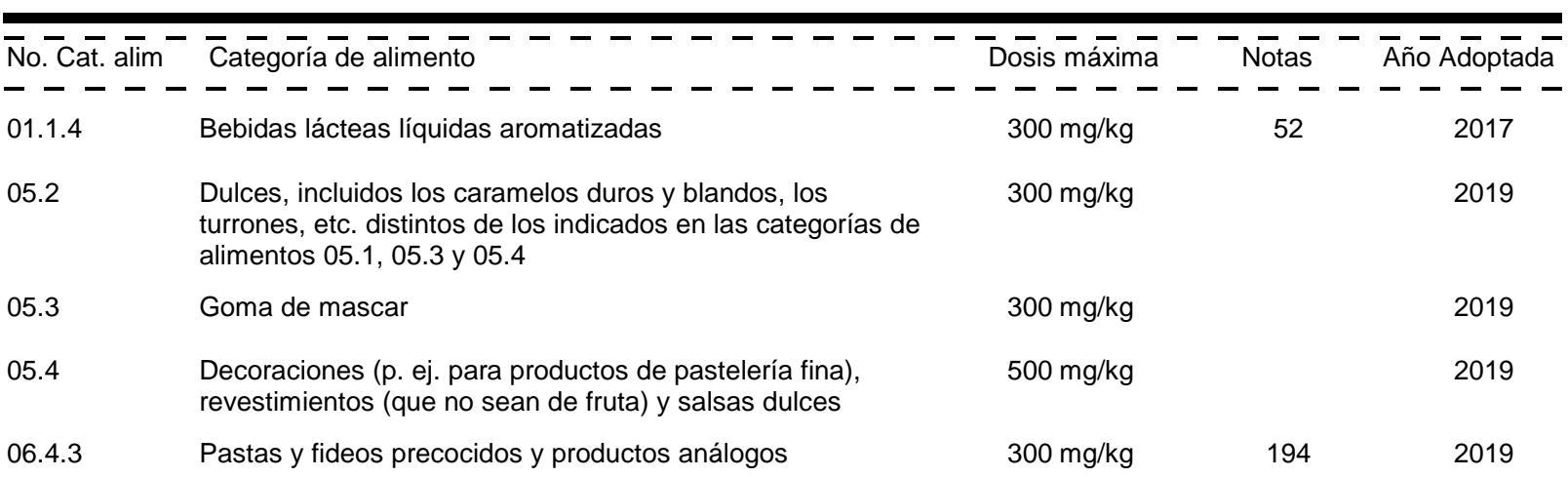




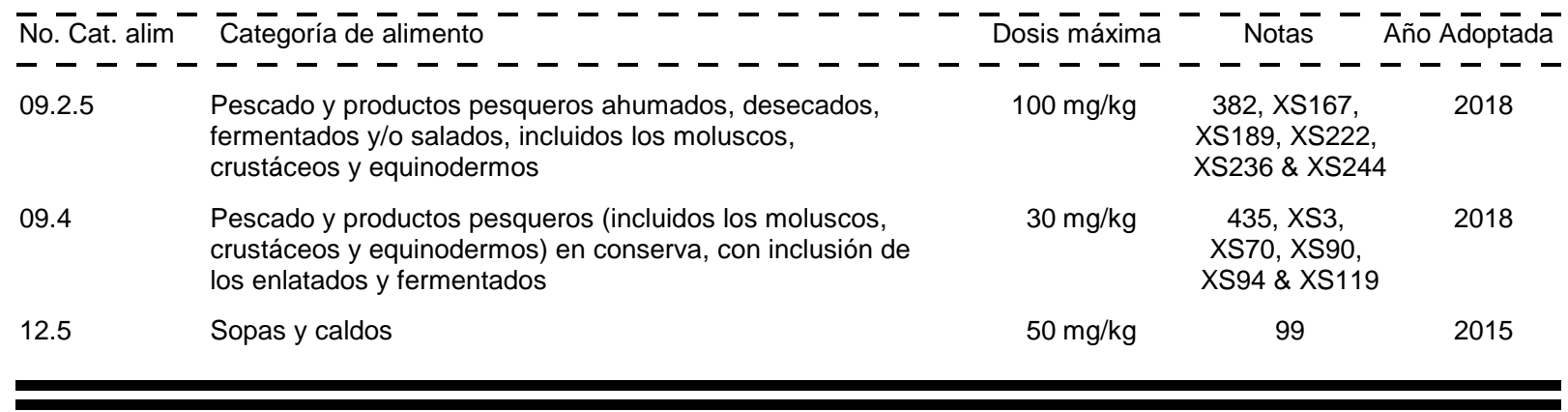

\section{TERBUTILHIDROQUINONA}

SIN 319 Terbutilhidroquinona (TBHQ) Clases Funcionales: Antioxidantes

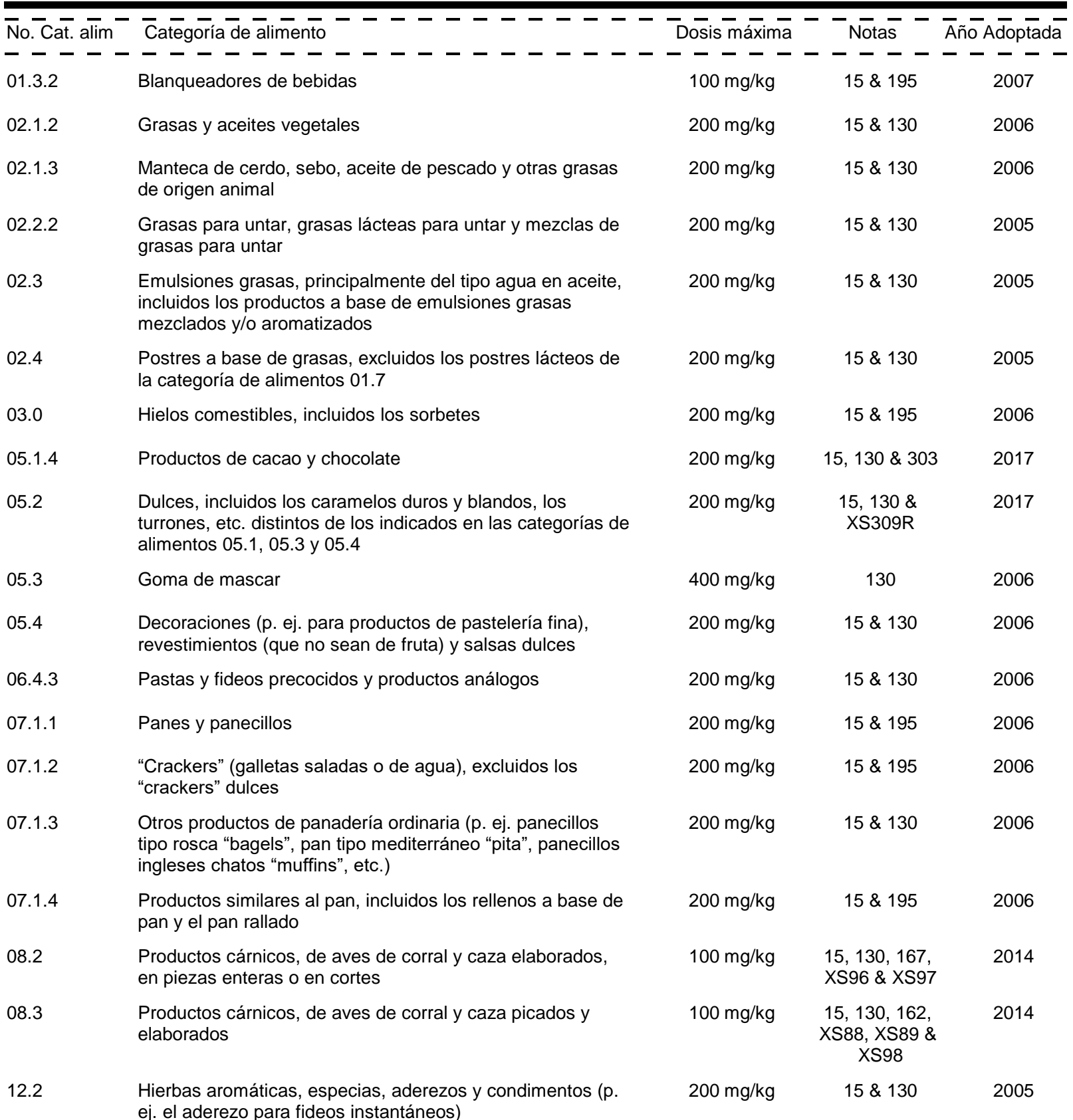




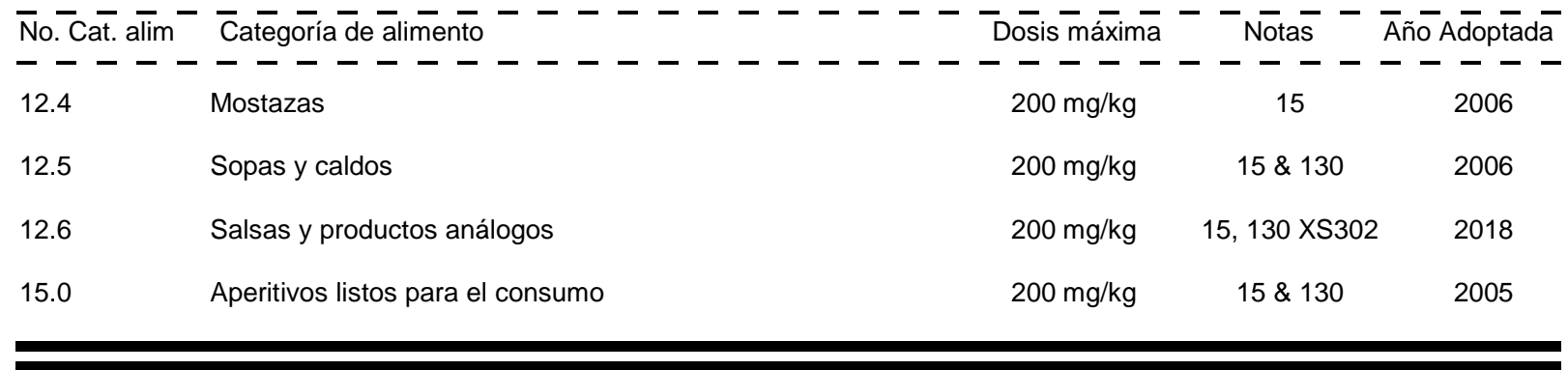

\section{TIODIPROPIONATOS}

$\begin{array}{llll}\text { SIN } 388 & \text { Ácido tiodipropiónico } & \text { Clases Funcionales: Antioxidantes } \\ \text { SIN } 389 & \text { Tiodipropionato de dilaurilo } & \text { Clases Funcionales: Antioxidantes }\end{array}$

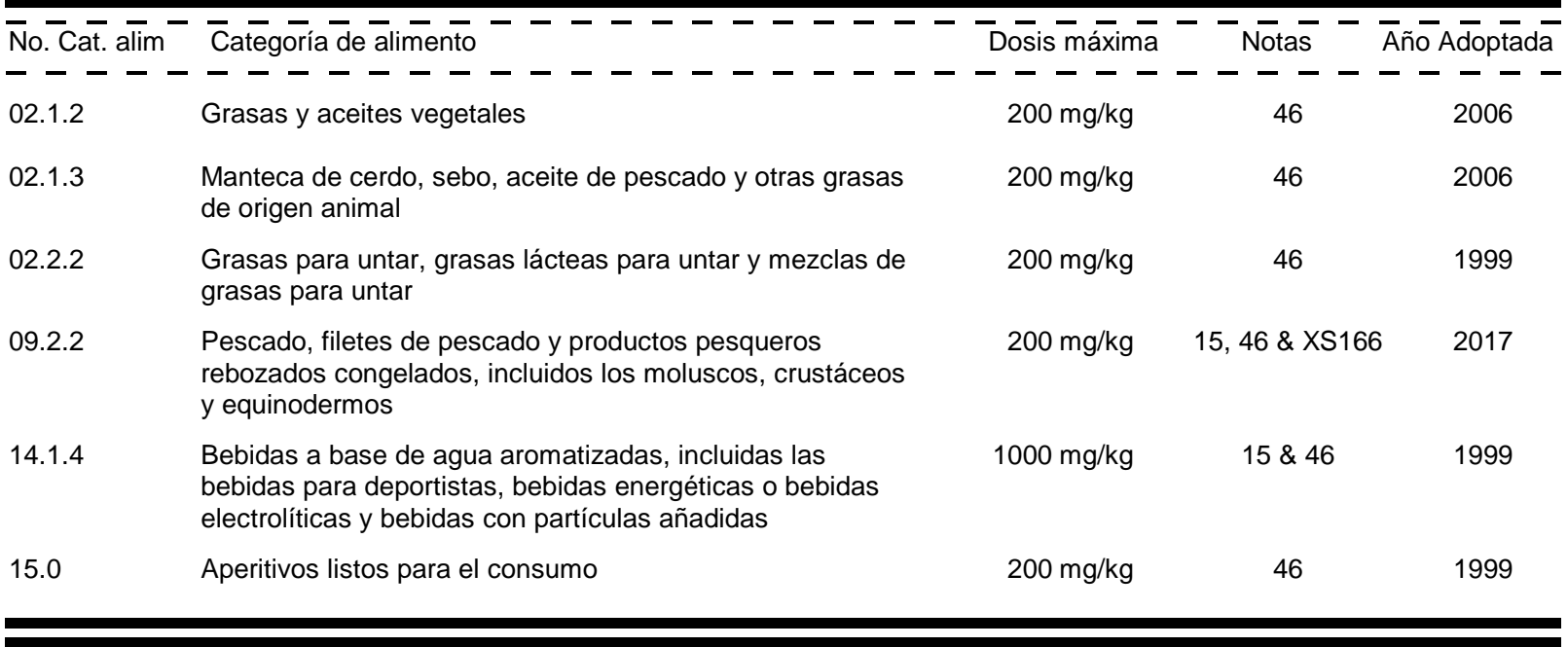

\section{TOCOFEROLES}

$\begin{array}{llll}\text { SIN } & 307 a & \text { Tocoferol, d-alfa- } & \text { Clases Funcionales: Antioxidantes } \\ \text { SIN } & 307 b & \text { Tocoférol concentrado, mexcla } & \text { Clases Funcionales: Antioxidantes } \\ \text { SIN } & 307 \mathrm{c} & \text { Tocoferol, dl-alfa- } & \text { Clases Funcionales: Antioxidantes }\end{array}$

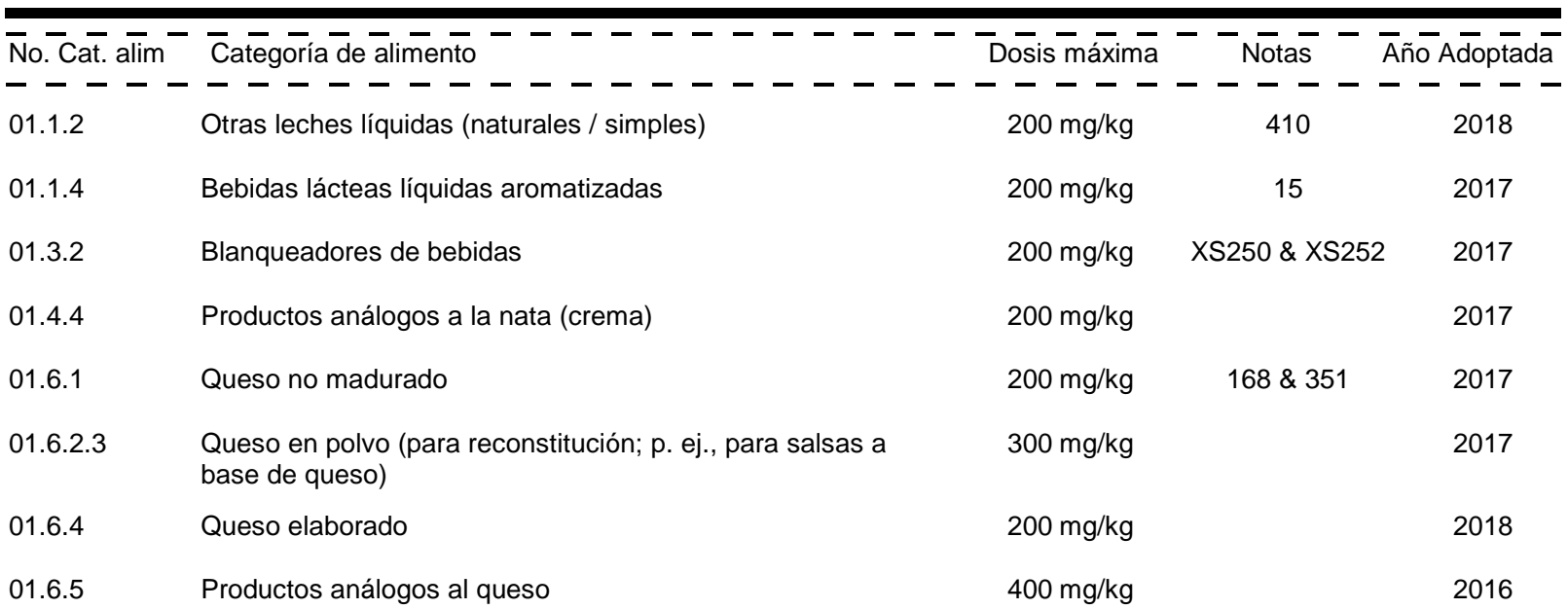




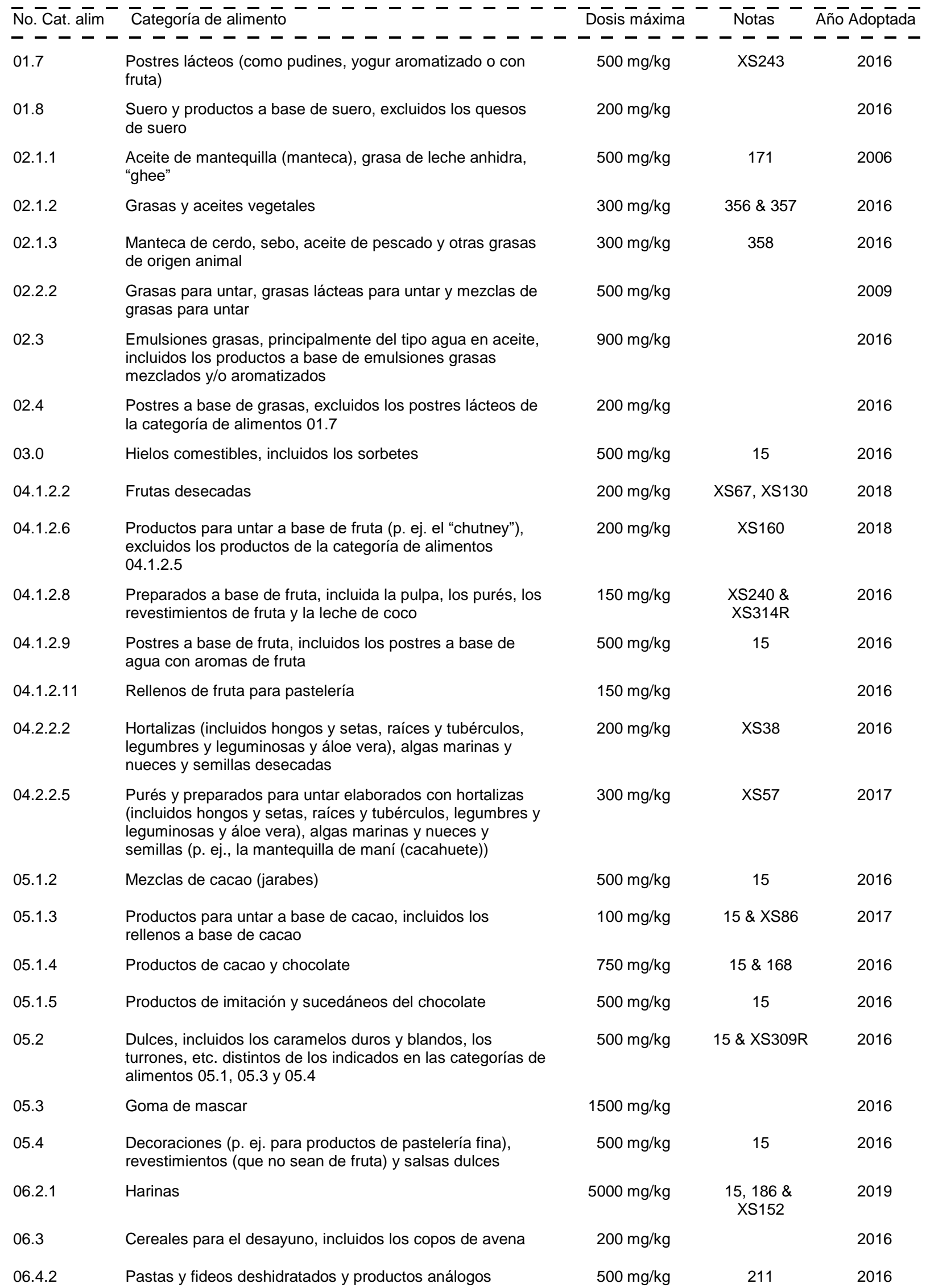




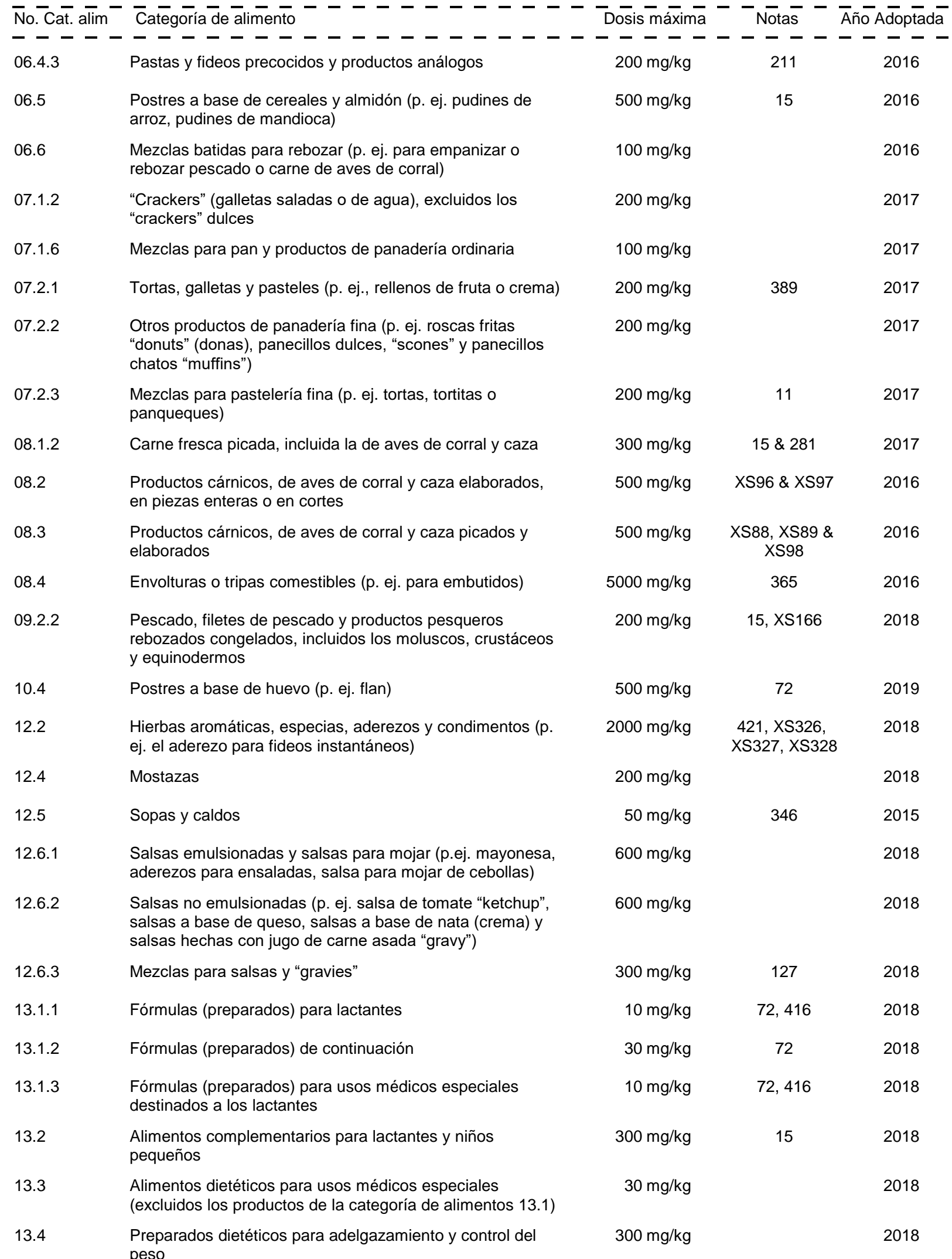




\begin{tabular}{|c|c|c|c|c|}
\hline 13.5 & $\begin{array}{l}\text { Alimentos dietéticos (p. ej. los complementos alimenticios } \\
\text { para usos dietéticos), excluidos los indicados en las } \\
\text { categorías de alimentos } 13.1 \text { a } 13.4 \text { y } 13.6\end{array}$ & $300 \mathrm{mg} / \mathrm{kg}$ & & 2018 \\
\hline 13.6 & Complementos alimenticios & $2000 \mathrm{mg} / \mathrm{kg}$ & 418 & 2018 \\
\hline 14.1 .4 & $\begin{array}{l}\text { Bebidas a base de agua aromatizadas, incluidas las } \\
\text { bebidas para deportistas, bebidas energéticas o bebidas } \\
\text { electrolíticas y bebidas con partículas añadidas }\end{array}$ & $200 \mathrm{mg} / \mathrm{kg}$ & 434 & 2018 \\
\hline 14.2 .7 & $\begin{array}{l}\text { Bebidas alcohólicas aromatizadas ( } p \text {. ej. cerveza, vino y } \\
\text { bebidas con licor tipo bebida gaseosa, bebidas refrescantes } \\
\text { con bajo contenido de alcohol) }\end{array}$ & $5 \mathrm{mg} / \mathrm{kg}$ & & 2018 \\
\hline 15.1 & $\begin{array}{l}\text { Aperitivos a base de patatas (papas), cereales, harina o } \\
\text { almidón (derivados de raíces y tubérculos, legumbres y } \\
\text { leguminosas) }\end{array}$ & $200 \mathrm{mg} / \mathrm{kg}$ & & 2018 \\
\hline 15.2 & $\begin{array}{l}\text { Nueces elaboradas, incluidas las nueces revestidas y las } \\
\text { mezclas de nueces (p. ej. con frutas secas) }\end{array}$ & $200 \mathrm{mg} / \mathrm{kg}$ & & 2018 \\
\hline
\end{tabular}

\section{VERDE SÓLIDO FCF}

SIN 143 Verde sólido FCF Clases Funcionales: Colorantes

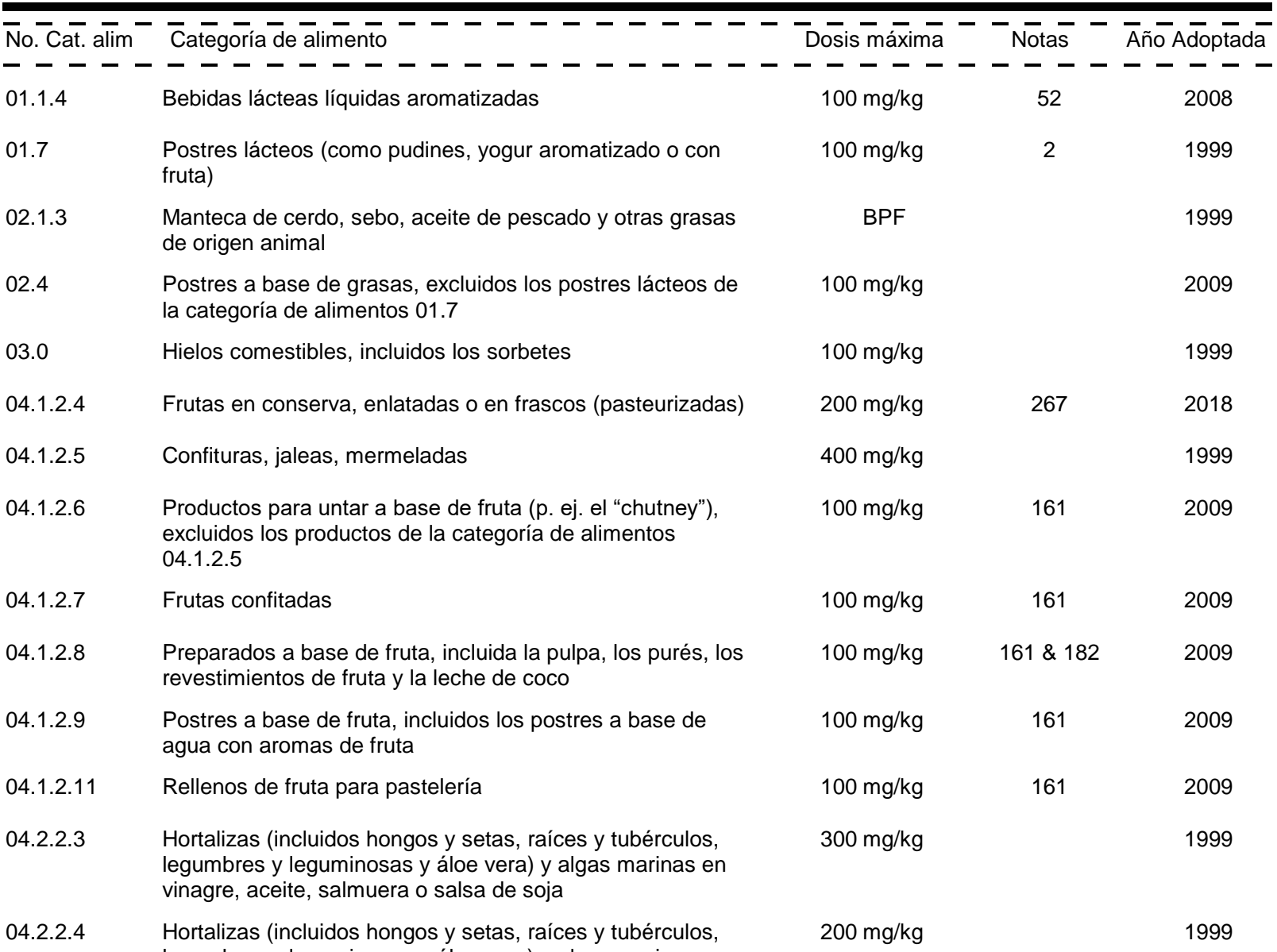
legumbres y leguminosas y áloe vera) y algas marinas en conserva, en latas o frascos (pasteurizadas) o en bolsas de esterilización 


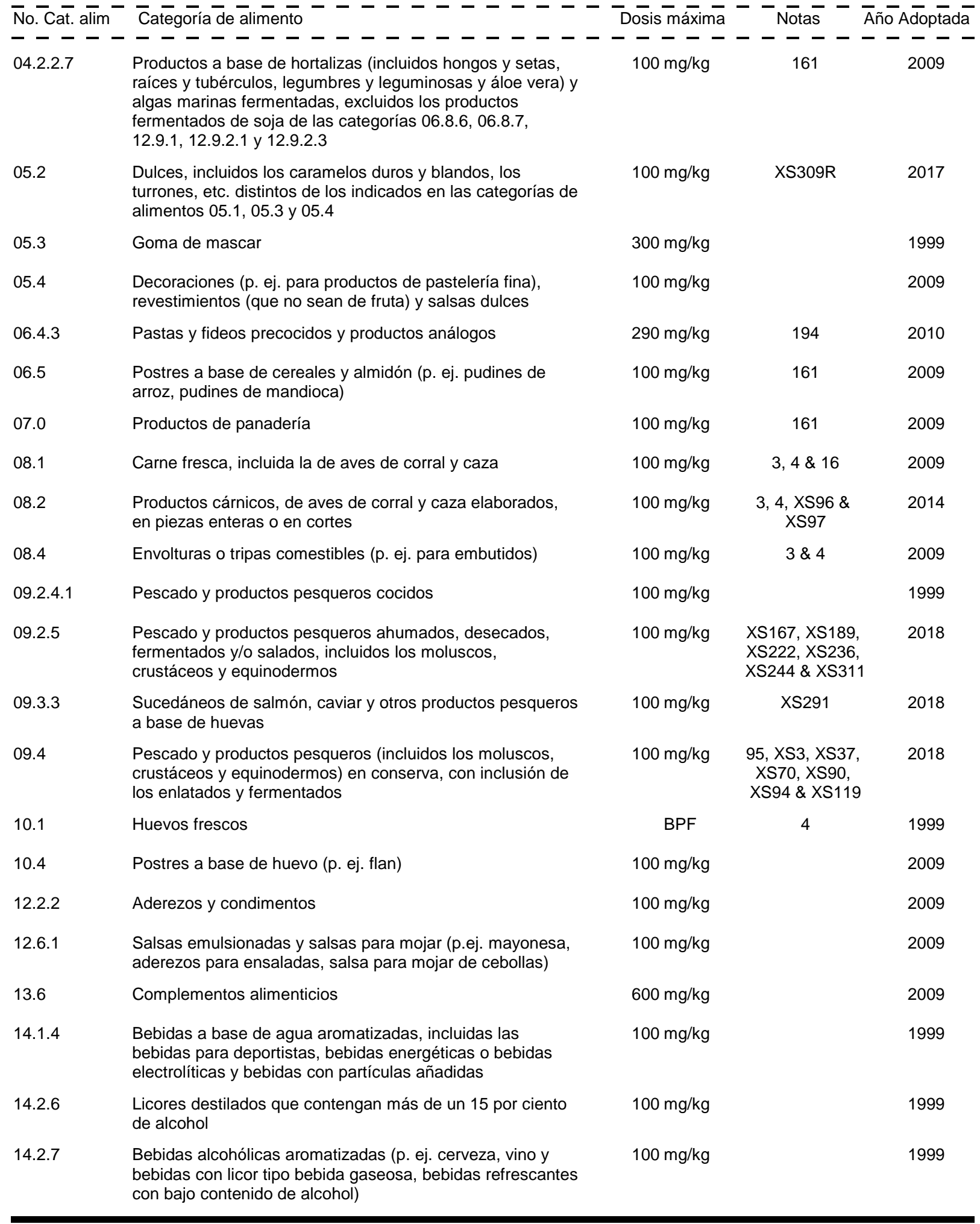

\section{ZEAXANTHIN, SINTÉTICO}


Cuadro I

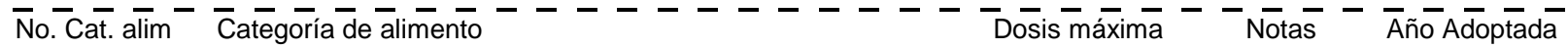

$-1--$

01.1 .4

Bebidas lácteas líquidas aromatizadas

$100 \mathrm{mg} / \mathrm{kg}$

$52 \& 400$

2017 


\section{Notas a la Norma general para los aditivos alimentarios}

$\begin{array}{ll}\text { Nota } & 1 \\ \text { Nota } & 2 \\ \text { Nota } & 3 \\ \text { Nota } & 4 \\ \text { Nota } & 5 \\ & \\ \text { Nota } & 6 \\ \text { Nota } & 7 \\ \text { Nota } & 8 \\ \text { Nota } & 9 \\ \text { Nota } & 10 \\ \text { Nota } & 11 \\ \text { Nota } & 12 \\ \text { Nota } & 13 \\ \text { Nota } & 14 \\ \text { Nota } & 15 \\ \text { Nota } & 16 \\ & \\ \text { Nota } & 17 \\ \text { Nota } & 18 \\ & \\ \text { Nota } & 19\end{array}$

Nota 21

Nota 22

Nota 23

Nota 24

Nota 25

Nota 26

Nota 27

Nota 28

Nota 29

Nota 30

Nota 31

Nota 32

Nota 33

Nota 34

Nota 35
Como ácido adípico.

Sobre la base del ingrediente seco, peso en seco, mezcla seca, o concentrado.

Para uso en tratamiento superficial solamente.

Para uso en decoración, sellado, marcado o marcado a fuego del producto solamente.

Quedan excluidos los productos que corresponden a la Norma para las confituras, jaleas y mermeladas (CODEX STAN 296-2009).

Como aluminio.

Para uso en sucedáneos del café solamente.

Como bixina.

Excepto para uso en productos de café listos para el consumo a $10000 \mathrm{mg} / \mathrm{kg}$.

Como estearato de ascorbilo.

Sobre la base de la harina.

Como resultado de transferencia procedente de sustancias aromatizantes.

Como ácido benzoico.

Sólo para su uso en preparados líquidos a base de proteína hidrolizada.

Sobre la base de las grasas o los aceites.

Para uso en el glaseado, rebozado o decoración de frutas, hortalizas, carnes o pescados solamente.

Como ácido ciclámico.

Como dosis añadida; residuos no detectados en los alimentos listos para el consumo.

Para uso en productos que corresponden a la Norma para los camarones congelados rápidamente (CODEX STAN 92-1981) y a la Norma para las langostas congeladas rápidamente (CODEX STAN 95-1981): dióxido de azufre (SIN 220), sulfito de sodio (SIN 221), hidrogensulfito de sodio (SIN 222), metabisulfito de sodio (SIN 223), pirosulfito potásico (INS 224), y sulfito de potasio (SIN 225) como conservantes en dosis de $100 \mathrm{mg} / \mathrm{kg}$ en la parte comestible del producto crudo, o $30 \mathrm{mg} / \mathrm{kg}$ en la parte comestible del producto cocido.

Excepto para uso en los productos regulados por la Norma para pescado salado y pescado seco salado de la familia Gadidae (CODEX STAN 167-1989), la Norma para el arenque del Atlántico salado y el espadín salado ( CODEX STAN 244-2004) a $200 \mathrm{mg} / \mathrm{kg}$, y en el pescado ahumado y pescado con sabor a humo en los productos regulados por la Norma para el pescado ahumado, pescado con sabor a humo y pescado secado con humo (CODEX STAN 311-2013) a $2000 \mathrm{mg} / \mathrm{kg}$ para productos envasados con oxígeno reducido solamente.

Como etilendiamitetraacetato de cálcio disódico.

Sólo para uso en productos pesqueros ahumados.

Como hierro.

Como ferrocianuro de sodio anhidro.

Para uso a BPF únicamente en harinas de soya con toda su grasa.

Como equivalentes de esteviol.

Como ácido para-hidroxibenzoico.

Excepto para uso en harinas de trigo que correspondan a la Norma para la harina de trigo (CODEX STAN 152-1985) a 2000 mg/kg.

Para alimentos no normalizados únicamente.

Como ion residual de NO3.

Sobre la base del puré que se use.

Como ion residual de $\mathrm{NO} 2$.

Como fósforo.

Sobre la base el anhidro.

Sólo para uso en los zumos (jugos) turbios. 
$\begin{array}{ll}\text { Nota } & 36 \\ \text { Nota } & 37 \\ & \\ \text { Nota } & 38 \\ \text { Nota } & 39 \\ \text { Nota } & 40 \\ & \\ \text { Nota } & 41 \\ \text { Nota } & 42 \\ \text { Nota } & 43 \\ \text { Nota } & 44 \\ \text { Nota } & 45 \\ \text { Nota } & 46 \\ \text { Nota } & 47 \\ \text { Nota } & 48 \\ \text { Nota } & 49 \\ \text { Nota } & 50 \\ \text { Nota } & 51 \\ \text { Nota } & 52 \\ \text { Nota } & 53 \\ \text { Nota } & 54 \\ \text { Nota } & 55\end{array}$

Nota 56

Nota 57

Nota 58

Nota 59

Nota 60

Nota 61

Nota 62

Nota 63

Nota 64

Nota 65

Nota 66

Nota 67

Nota 68

Nota 69

Nota 70

Nota 71

Nota 72

Nota 73

Nota 74

Nota 75

Nota 76

Nota 77

Nota 78
Sobre la base de la dosis residual.

Excepto para los productos que se ajusten a la Norma para el chocolate y los productos de chocolate (CODEX STAN 87-1981) a $2000 \mathrm{mg} / \mathrm{kg}$.

Sobre la base de la mezcla que se ha de descremar.

Sobre la base total de carotenoids.

Trifosfato pentasódico (SIN 451(i)) solamente, para mejorar la eficacia de los benzoatos y sorbatos.

Solo para uso en empanizados o albardillas, rebozados.

Como ácido sórbico.

Como estaño.

Como SO2 residual.

Como ácido tartárico.

Como ácido tiodipropiónico.

Sobre la base del peso de la yema del huevo.

Para uso en las aceitunas solamente.

Sólo para uso en los frutos cítricos.

Sólo para uso en las huevas de pescado.

Sólo para uso en las hierbas.

Excepto la leche chocolatada.

Sólo para uso en rebozados.

Sólo para uso en cócteles de cereza y cerezas caramelos.

Dentro de los límites para el sodio, calcio y potasio especificados en la Norma para preparados para lactantes y preparados para usos medicinales especiales destinados a los lactantes (CODEX STAN 72-1981): individualmente o en combinación con otras sales de sodio, calcio y/o potasio.

Excluidos los productos donde haya almidón presente.

Las BPF indican 1 parte de peróxido de benzoílo y no más de 6 partes del aditivo en cuestión, en peso.

Como calcio.

Para uso como gas de envasado solamente.

El contenido de $\mathrm{CO} 2$ en los vinos no espumantes terminados no deberá superar los $4000 \mathrm{mg} / \mathrm{kg}$ a $20^{\circ} \mathrm{C}$

Sólo para uso en pescado picado.

Como cobre.

Para alimentos no normalizados y para revestimientos para empanar o rebozar en alimentos que correspondan a la Norma para barritas, porciones y filetes empanados o rebozados congelados rápidamente (CODEX STAN 166-1989).

Para uso en frijoles secos solamente.

Como resultado de transferencia procedente de las preparaciones nutritivas.

Como formaldehido.

Excepto para uso en claras de huevo líquidas a $8800 \mathrm{mg} / \mathrm{kg}$ como fósforo, y en huevos enteros líquidos a $14700 \mathrm{mg} / \mathrm{kg}$ como fósforo.

Sólo para su uso en productos sin azúcar añadido.

Para uso como gasificante solamente.

Como ácido.

Sólo sales de calcio, potasio y sodio.

Sobre la base del producto listo para el consumo.

Excluido el pescado entero.

Excepto el suero líquido y los productos de suero que se utilizan como ingrediente en preparados para lactantes.

Para uso en leche en polvo para máquinas expendedoras solamente.

Para uso en las patatas (papas) solamente.

Sólo para usos nutricionales especiales.

Excepto para encurtir y vinagres balsámicos a $50000 \mathrm{mg} / \mathrm{kg}$. 


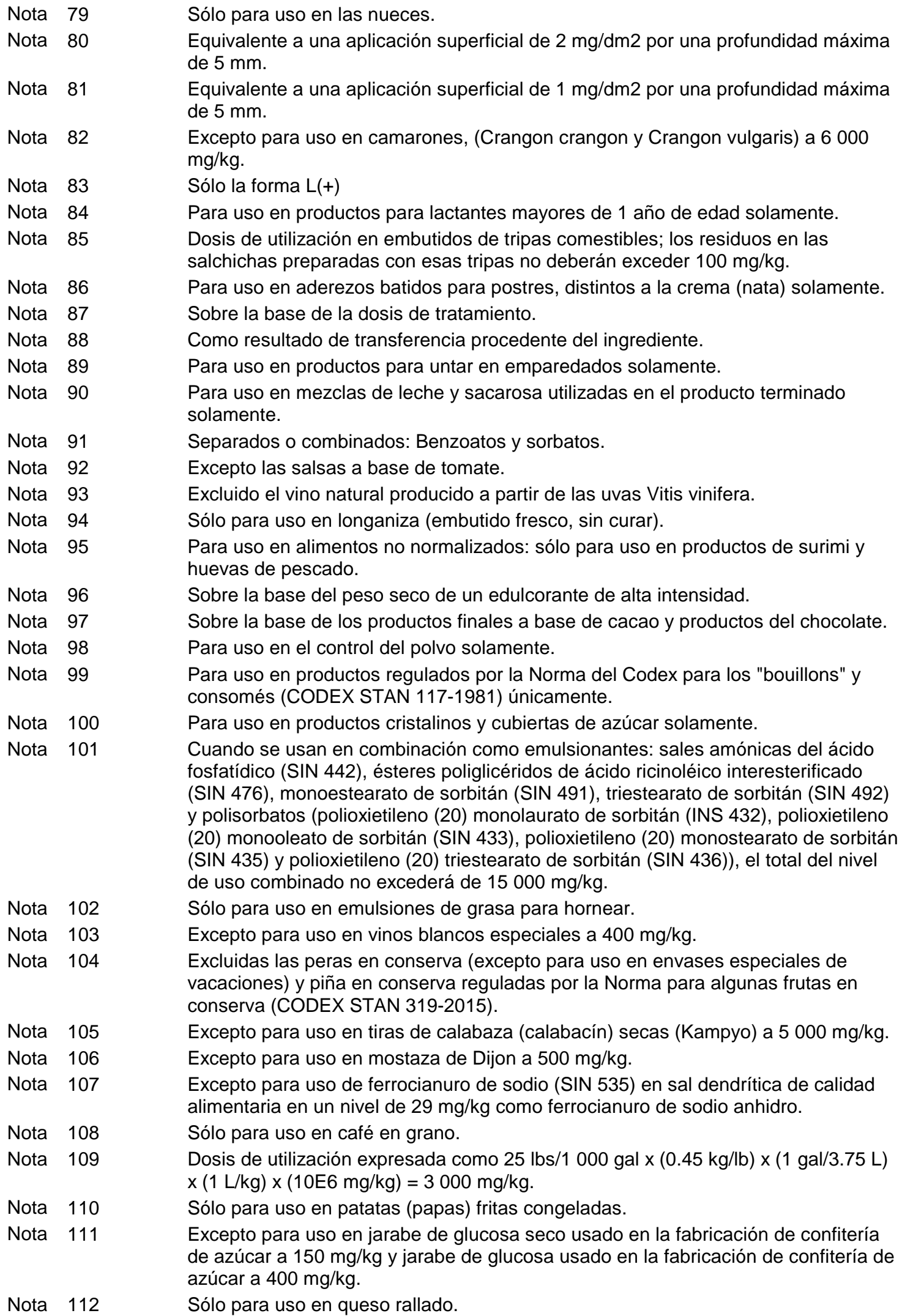


Nota 113

$\begin{array}{ll}\text { Nota } & 114 \\ \text { Nota } & 115 \\ \text { Nota } & 116 \\ \text { Nota } & 117 \\ \text { Nota } & 118 \\ \text { Nota } & 119\end{array}$

Nota 120

Nota 121

Nota 122

Nota 123

Nota 124

Nota 125

Nota 126

Nota 127

Nota 128

Nota 129

Nota 130

Nota 131

Nota 132

Nota 133

Nota 134

Nota 135

Nota 136

Nota 137

Nota 138

Nota 139

Nota 140

Nota 141

Nota 142

Nota 143

Nota 144
Como equivalentes de acesulfame potásico (la dosis máxima registrada puede convertirse a una base de sal de aspartamo y acesulfame dividiéndola por 0,44). El uso combinado de la sal de aspartamo y acesulfame con acesulfame potásico o aspartamo individual no debe ser superior a las dosis máximas individuales para acesulfame potásico o aspartamo (la dosis máxima de uso registrada puede convertirse al equivalente de aspartamo dividiéndola por 0,68 ).

Excepto para uso en micropastillas y pastillas de menta para refrescar el aliento en dosis de $100 \mathrm{mg} / \mathrm{kg}$.

Sólo para uso en el zumo (jugo) de piña.

Sólo para el uso en masas.

Excepto para uso en longaniza (embutido fresco, sin curar) a $1000 \mathrm{mg} / \mathrm{kg}$.

Excepto para uso en tocino (embutido fresco, curado) a $1000 \mathrm{mg} / \mathrm{kg}$.

Como equivalentes de aspartamo (la dosis máxima registrada puede convertirse a una base de sal de aspartamo y acesulfame dividiéndola por 0,64). El uso combinado de la sal de aspartamo y acesulfame con aspartamo o acesulfame potásico individual no debe ser superior a las dosis máximas individuales para aspartamo o acesulfame potásico (la dosis máxima de uso registrada puede convertirse a equivalentes de acesulfame potásico dividiéndola por 0,68 ).

Excepto para uso en sucedáneos de caviar a $2500 \mathrm{mg} / \mathrm{kg}$.

Excepto para uso en productos pesqueros fermentados a $1000 \mathrm{mg} / \mathrm{kg}$.

Sujeto a las leyes nacionales del país importador.

Para el uso de monoestearato de sorbitán (SIN 491), triestearato de sorbitán (SIN 492), monolaurato de sorbitán (SIN 493), monooleato de sorbitán (SIN 494) y monopalmitato de sorbitán (SIN 495) en combinación hasta un nivel máximo dea $2000 \mathrm{mg} / \mathrm{kg}$ en la base final de cacao y de chocolate como emulsionantes en productos que correspondan a la Norma para el cacao en polvo (cacaos) y las mezclas de cacao y azúcares (CODEX STAN 105-1981).

Para uso en productos que contienen menos de $7 \%$ de etanol solamente.

Para uso en una mezcla con aceite vegetal solo, como agente antiadherente para moldes para hornear.

Para uso en efectos antiadherentes en la masa, al dividirla y hornearla solamente. Sobre la base que se sirve al consumidor.

Ácido tartárico (SIN 334) solamente.

Para uso como un regulador de la acidez en el zumo (jugo) de uva solamente. Individualmente o en combinación: butilhidroxianisol (INS 320), butilhidroxitolueno (INS 321), terbutilhidroquinona (INS 319), y galato de propilo (INS 310).

Para uso como sustancia inerte aromatizante solamente.

Excepto para uso en bebidas semicongeladas a $130 \mathrm{mg} / \mathrm{kg}$ sobre una base seca. Toda combinación de butilhidroxianisol (SIN 320), butilhidroxitolueno (SIN 321) y galato de propilo (SIN 310) en una dosis de $200 \mathrm{mg} / \mathrm{kg}$, siempre que no se superen las doses individuales de uso.

Excepto para uso en pudines a base de cereales a $500 \mathrm{mg} / \mathrm{kg}$.

Excepto para uso en albaricoques secos con un nivel de $2000 \mathrm{mg} / \mathrm{kg}$, uvas pasas blanqueadas en un nivel de $1500 \mathrm{mg} / \mathrm{kg}$, coco desecado en un nivel de $200 \mathrm{mg} / \mathrm{kg}$, y coco del que se ha extraído parcialmente el aceite en un nivel de $50 \mathrm{mg} / \mathrm{kg}$.

Para uso para prevenir el pardeamiento de ciertas hortalizas de color claro solamente.

Excepto para uso en aguacate congelado en un nivel de $300 \mathrm{mg} / \mathrm{kg}$.

Para uso en productos de contenido energético reducido únicamente.

Sólo para uso en productos de contenido energético reducido.

Sólo para uso en moluscos, crustáceos y equinodermos.

Excluidas las peras en conserva y piña en conserva reguladas por la Norma para algunas frutas en conserva (CODEX STAN 319-2015).

Excepto el café y el té.

Sólo para uso en bebidas a base de zumo (jugo) de frutas y dry ginger ale.

Sólo para uso en productos agridulces. 


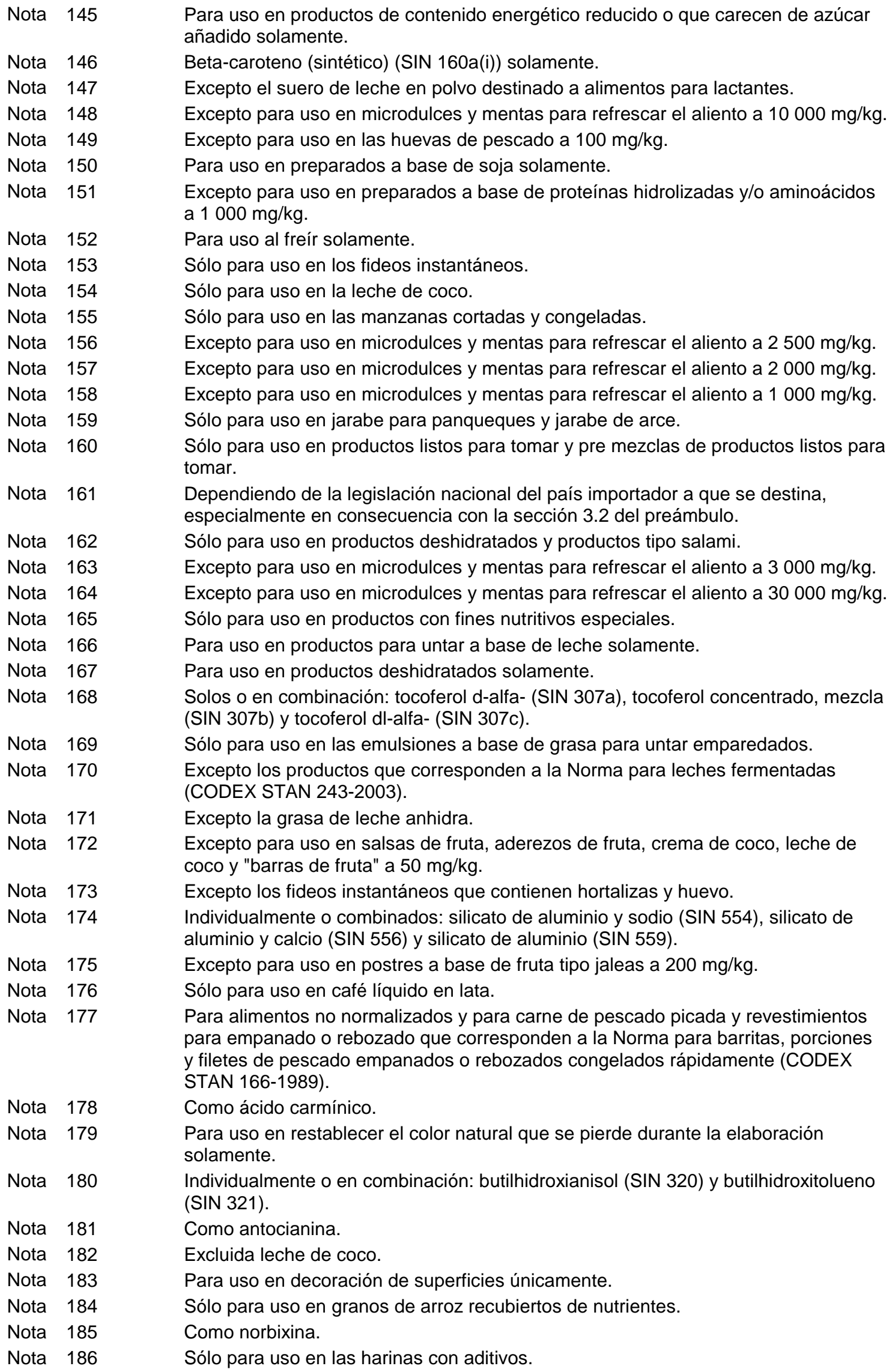




\begin{tabular}{|c|c|}
\hline Nota & 187 \\
\hline Nota & 188 \\
\hline Nota & 189 \\
\hline Nota & 190 \\
\hline Nota & 191 \\
\hline Nota & 192 \\
\hline Nota & 193 \\
\hline Nota & 194 \\
\hline Nota & 195 \\
\hline Nota & 196 \\
\hline Nota & 197 \\
\hline Nota & 198 \\
\hline Nota & 199 \\
\hline Nota & 200 \\
\hline Nota & 201 \\
\hline Nota & 202 \\
\hline Nota & 203 \\
\hline Nota & 204 \\
\hline Nota & 205 \\
\hline Nota & 206 \\
\hline Nota & 207 \\
\hline Nota & 208 \\
\hline Nota & 209 \\
\hline & \\
\hline
\end{tabular}

Nota 211

Nota 212

Nota 213

Nota 214

Nota 215

Nota 216

Nota 217

Nota 218
Sólo para SIN 304 (palmitato de ascorbilo).

Si se utiliza en combinación con la sal de aspartamo y acesulfamo (SIN 962), la dosis máxima de uso combinada, expresada como acesulfame de potasio, no será superior a esta dosis.

Excepto los copos de avena.

Excepto para uso en bebidas a base de leche fermentada a $500 \mathrm{mg} / \mathrm{kg}$.

Si se utiliza en combinación con la sal de aspartamo y acesulfamo (SIN 962), la dosis máxima de uso combinada, expresada como aspartamo, no será superior a esta dosis.

Para uso en productos líquidos solamente.

Sólo para uso en pastas de crustáceos o de pescado.

Para uso en fideos instantáneos de conformidad con la Norma para fideos instantáneos (CODEX STAN 249-2006) solamente.

Individualmente o en combinación: butilhidroxianisol (SIN 320), butilhidroxitolueno (SIN 321) y terbutilhidroquinona (SIN 319).

Individualmente o en combinación: butilhidroxianisol (SIN 320), butilhidroxitolueno (SIN 321) y galato de propilo (SIN 310).

Individualmente o en combinación: butilhidroxitolueno (SIN 321) y galato de propilo (SIN 310).

Para uso en productos sólidos (p.ej., barras energéticas, sustituyentes de comidas o enriquecidas) solamente.

Excepto para uso en microdulces y mentas para refrescar el aliento a $6000 \mathrm{mg} / \mathrm{kg}$ como equivalentes de esteviol.

Excepto para uso en el "jamón asalmonado" o filete de cerdo (curado y sin haber recibido tratamiento térmico) en dosis de $120 \mathrm{mg} / \mathrm{kg}$ como equivalentes de esteviol. Sólo para uso en productos aromatizados.

Sólo para uso en la salmuera para la producción de embutidos.

Sólo para uso en complementos masticables.

Excepto para en longans y lichis a $50 \mathrm{mg} / \mathrm{kg}$.

Excepto para uso para prevenir la coloración café de algunas hortalizas de color claro a $50 \mathrm{mg} / \mathrm{kg}$.

Excepto para uso como blanqueador en productos que corresponden a la Norma para los productos acuosos de coco (CODEX STAN 240-2003) a $30 \mathrm{mg} / \mathrm{kg}$.

Excepto para uso en la salsa de soja destinada a ulterior elaboración a 50000 $\mathrm{mg} / \mathrm{kg}$.

Sólo para uso en productos secos y deshidratados.

Quedan excluidos los productos que corresponden a la Norma para mezclas de leche desnatada (descremada) y grasa vegetal en polvo (CODEX STAN 251 2006). Para alimentos no normalizados y para uso como humectante en productos que corresponden a la Norma para barritas, porciones y filetes de pescado empanados o rebozados congelados rápidamente (CODEX STAN 166-1989); y para uso como espesante en empanados o rebozados para productos que correspondan a la Norma para barritas, porciones y filetes de pescado empanados o rebozados congelados rápidamente (CODEX STAN 166-1989).

Sólo para uso en los fideos.

Excepto para uso en los productos que corresponden a la Norma para los "bouillons" y consomés (CODEX STAN 117-1981) a dosis de $3000 \mathrm{mg} / \mathrm{kg}$.

Sólo para uso en productos líquidos que contengan edulcorantes de alta intensidad. Excepto los productos que corresponden a la Norma para materias grasas lácteas para untar (CODEX STAN 253-2006).

Excepto los productos que corresponden a la Norma para grasas para untar y mezclas de grasas para untar (CODEX STAN 256-2007).

Sólo para uso en productos a base de maíz.

Excepto para uso en cubiertas a $300 \mathrm{mg} / \mathrm{kg}$.

En los productos regulados por la Norma para el Coco Rallado Desecado solamente pueden utilizarse sulfitos como conservantes y antioxidantes (CODEX STAN 177-1991). 


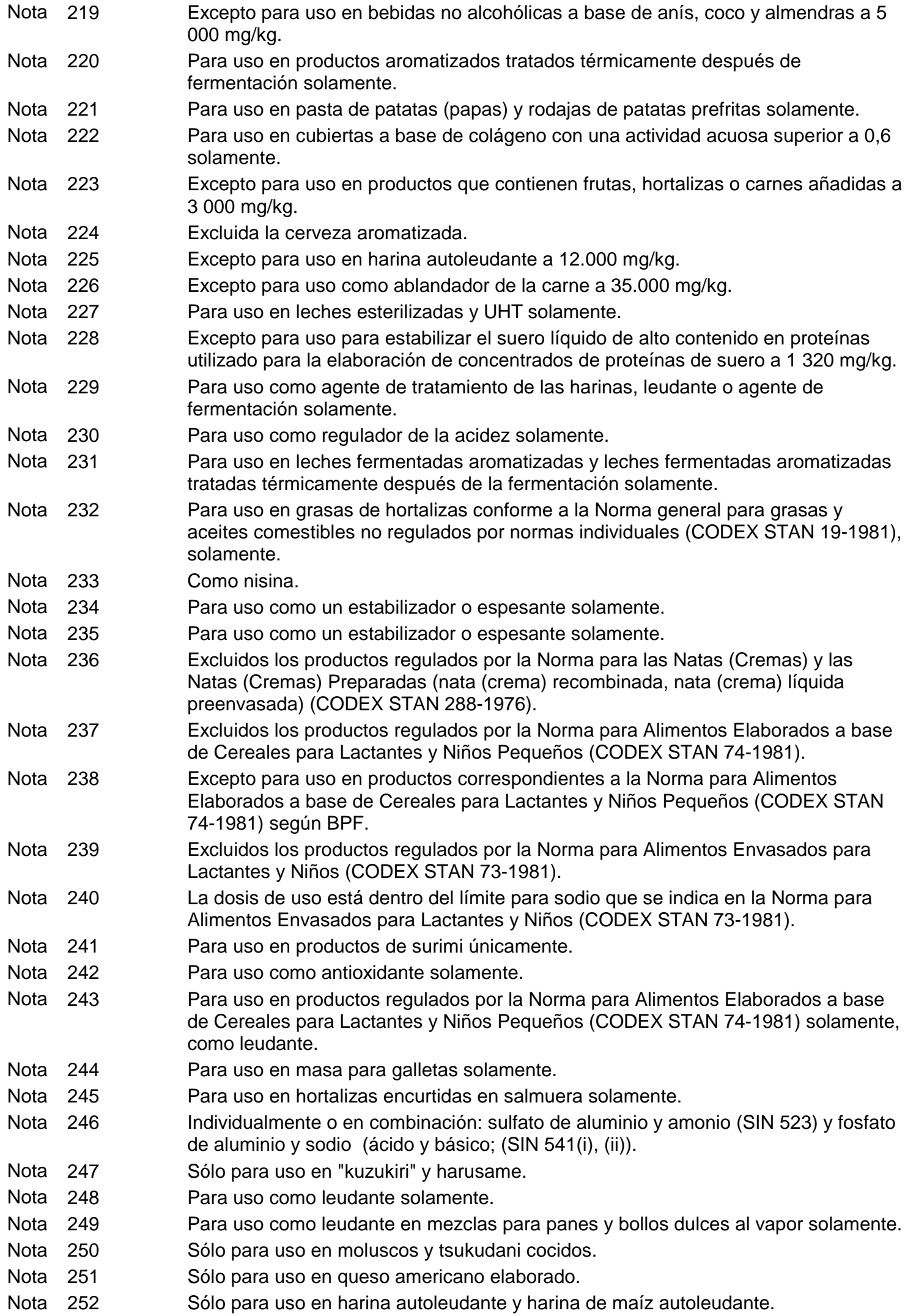


Nota 253

Nota 254

Nota 255

Nota 256

Nota 257

Nota 258

Nota 259

Nota 260

Nota 261

Nota 262

Nota 263

Nota 264

Nota 265

Nota 266

Nota 267

Nota 268

Nota 269

Nota 270

Nota 271

Nota 272

Nota 273

Nota 274

Nota 275

Nota 276

Nota 277
Para alimentos no normalizados y para uso en carne picada de pescado, únicamente en productos que corresponden a la Norma para barritas, porciones y filetes de pescado empanados o rebozados congelados rápidamente (CODEX STAN 166-1989).

Para uso en sal aplicada a quesos secos salados durante la fabricación solamente. Excepto para uso en aderezos aplicados a alimentos de la categoría de alimentos 15.1 a $1700 \mathrm{mg} / \mathrm{kg}$.

Sólo para uso en fideos, pasta sin gluten y pasta destinada a dietas hipoproteicas.

Excepto para uso en empanados o rebozados en los productos que corresponden a la Norma para barritas, porciones y filetes de pescado empanados o rebozados congelados rápidamente (CODEX STAN 166-1989), sólo en dosis de 25 mg(kg como bixina.

Excluido jarabe de arce.

Individualmente o en combinación: silicato de aluminio y sodio (SIN 554) y silicato de aluminio y calcio (SIN 556).

Sólo para uso en blanqueadores de bebidas en polvo.

Sólo para uso en suero de mantequilla sometido a tratamiento térmico.

Para uso en hongos comestibles y productos de hongos solamente.

Excepto para uso en hongos encurtidos en salmuera a $20000 \mathrm{mg} / \mathrm{kg}$.

Excepto para uso en hongos esterilizados a 5000 mg/kg: ácido cítrico (SIN 330) y ácido láctico (SIN 270), individualmente o en combinación.

Para uso en patatas (papas) fritas francesas congeladas rápidamente solamente, como secuestrante.

Excluidos los mangos en conserva y las peras en conserva regulados por la Norma para algunas frutas en conserva (CODEX STAN 319-2015).

Excluidos los productos regulados por la Norma para algunas frutas en conserva (CODEX STAN 319-2015), excepto para uso en envases especiales de vacaciones para peras en conserva reguladas por la norma.

Separados o combinados: SIN 471, 472a, 472b y 472c en productos que correspondan a la Norma para alimentos elaborados a base de cereales para lactantes y niños pequeños (CODEX STAN 74-1981).

Separados o combinados con otros almidones modificados utilizados como espesantes en productos que corresponden a la Norma para alimentos elaborados a base de cereales para lactantes y niños pequeños (CODEX STAN 74-1981).

Para uso a $60000 \mathrm{mg} / \mathrm{kg}$, separados o combinados con otros almidones espesantes en productos que corresponden a la Norma para alimentos envasados para lactantes y niños (CODEX STAN 73-1981).

Para uso en productos que corresponden a la Norma para alimentos envasados para lactantes y niños (CODEX STAN 73-1981).

Separados o combinados: SIN 410, 412, 414, 415 y 440 a 20000 mg/kg en alimentos sin gluten a base de cereales, y $10000 \mathrm{mg} / \mathrm{kg}$ en otros productos que correspondan a la Norma para alimentos elaborados a base de cereales para lactantes y niños pequeños (CODEX STAN 74-1981).

Separados o combinados: SIN 410, 412, 414, 415 y 440 excepto para uso a 20000 $\mathrm{mg} / \mathrm{kg}$ en alimentos sin gluten a base de cereales que correspondan a la Norma para alimentos elaborados a base de cereales para lactantes y niños pequeños (CODEX STAN 74-1981).

Para uso a $15000 \mathrm{mg} / \mathrm{kg}$ en productos que correspondan a la Norma para alimentos elaborados a base de cereales para lactantes y niños pequeños (CODEX STAN 74-1981).

Para uso a $1500 \mathrm{mg} / \mathrm{kg}$ en productos que corresponden a la Norma para alimentos envasados para lactantes y niños (CODEX STAN 73-1981).

Separados o combinados con otros almidones espesantes en productos que corresponden a la Norma para alimentos envasados para lactantes y niños (CODEX STAN 73-1981).

Excluidos los aceites vírgenes y los aceites prensados en frío, así como los productos que corresponden a la Norma para los aceites de oliva y aceites de orujo de oliva (CODEX STAN 33-1981). 
Nota 278

Nota 279

Nota 280

Nota 281

Nota 282

Nota 283

Nota 284

Nota 285

Nota 286

Nota 287

Nota 288

Nota 289

Nota 290

Nota 291

Nota 292

Nota 293

Nota 294

Nota 295

Nota 296

Nota 297

Nota 298
Para uso en nata (crema) batida y en nata envasada a presión solamente. Excepto para los productos que corresponden a la Norma para los hongos comestibles y sus productos (CODEX STAN 38-1981).

Para uso en rábanos encurtidos solamente.

Para uso en carne fresca picada que contenga otros ingredientes aparte de la carne molida solamente.

Únicamente pectinas no amidadas se pueden utilizar en la Norma para alimentos envasados para lactantes y niños (CODEX STAN 73-1981).

Para uso en alimentos envasados a base de fruta para lactantes, que correspondan a la Norma para alimentos envasados para lactantes y niños (CODEX STAN 731981) solamente.

Separados o combinados: SIN 1412, 1413, 1414 y 1440 en productos que correspondan a la Norma para preparados para lactantes y preparados para usos medicinales especiales destinados a los lactantes (CODEX STAN 72-1981).

Separados o combinados: SIN 1412, 1413, 1414 y 1422 en productos que correspondan a la Norma para preparados complementarios (CODEX STAN 1561987).

Para uso en productos que corresponden a la Norma para la "carne luncheon" (CODEX STAN 89-1981) y la Norma para la carne picada curada cocida (CODEX STAN 98-1981).

Excepto para uso en productos que corresponden a la Norma para la carne tipo "corned beef" (CODEX STAN 88-1981) a 30 mg/kg como ion NO2 residuo.

Para uso en productos que corresponden a la Norma para el jamón curado cocido (CODEX STAN 96-1981) y la Norma para la espaldilla de cerdo curada cocida (CODEX STAN 97-1981).

Para uso de fosfato diácido de sodio (SIN 339(i)), hidrogenofosfato disódico (SIN 339(ii)), fosfato trisódico (SIN 339(iii)), fosfato diácido de potasio (SIN 340(i)), hidrogenofosfato dipotásico (SIN 340(ii)), fosfato tripotásico (SIN 340(iii)), fosfato diácido de calcio (SIN 341(i)), hidrogenofosfato de calcio (SIN 341(ii)), fosfato tricálcico (SIN 341(iii), difosfato disódico (SIN 450(i)), difosfato trisódico (SIN 450(ii)), difosfato tetrasódico (SIN 450(iii)), difosfato tetrapotásico (SIN 450(v)), difosfato diácido cálcico (SIN 450(vii)), trifosfato pentasódico (SIN 451(i)), trifosfato pentapotásico (SIN 451(ii)), polifosfato de sodio (SIN 452(i)), polifosfato de potasio (SIN 452(ii)), polifosfato de sodio y calcio (SIN 452(iii)), polifosfato de calcio (SIN 452(iv)), polifosfato de amonio (SIN 452(v)) y fosfato de huesos (SIN 542) como humectantes en los productos que correspondan a la Norma para el jamón curado cocido (CODEX STAN 96-1981) y la Norma para la espaldilla de cerdo curada cocida (CODEX STAN 97-1981). La cantidad del total de fosfatos (naturalmente presentes y añadidos) no excederá $3520 \mathrm{mg} / \mathrm{kg}$ como fósforo.

Para uso en productos que corresponden a la Norma para la "carne luncheon" (CODEX STAN 89-1981) y la Norma para la carne picada curada cocida (CODEX STAN 98-1981) a $15 \mathrm{mg} / \mathrm{kg}$ para sustituir la pérdida de color en el producto únicamente con aglutinantes.

Excepto para uso de beta-apo-8'-carotenal (SIN 160e) y el éster metílico o etílico del ácido beta-apo-8'-carotenoico (SIN 160f) a 35 mg/kg.

Excepto para uso en preparados a base de proteínas hidrolizadas y/o aminoácidos a $25000 \mathrm{mg} / \mathrm{kg}$.

Sobre la base de saponina.

Excepto para uso en productos líquidos a $600 \mathrm{mg} / \mathrm{kg}$ como equivalentes de esteviol. Para uso en productos regulados por la Norma para Alimentos Envasados para Lactantes y Niños (CODEX STAN 73-1981) solamente, como regulador de la acidez.

Excepto para uso en perilla en salmuera a $780 \mathrm{mg} / \mathrm{kg}$.

La dosis en el alimento listo para el consumo no excederá de $200 \mathrm{mg} / \mathrm{kg}$ tomando como base el anhidro.

Para uso solamente en los productos que corresponden a la Norma para Provolone (CXS 272-1968). 
Nota 300

Nota 301

Nota 302

Nota 303

Nota 304

Nota 305

Nota 307

Nota 308

Nota 309

Nota 310

Nota 311

Nota 312

Nota 313

Nota 314
Para uso en alimentos no normalizados; y en productos que correspondan a la Norma del Codex para barritas, porciones y filetes de pescado empanados o rebozados congelados rápidamente (CODEX STAN 166-1989): los siguientes fosfatos para uso como humectantes en dosis de $2200 \mathrm{mg} / \mathrm{kg}$ como fósforo, SIN 339(i), 339(ii), 339(iii), 340(i), 340(ii), 340(iii), 341(i), 341(ii), 341(iii), 450(i), 450(ii), 450(iii), 450(v), 450(vii), 451(i), 451(ii), 452(i), 452(ii), 452(iii), 452(iv), 452(v), y 542; y los siguientes fosfatos para uco como leudantest en empanados y rebozados sólo en dosis de $440 \mathrm{mg} / \mathrm{kg}$ como fósforo, SIN 339(i), 340(iii), 341(i), 341(ii), 341(iii), 450(i), 450(ii), 450(iii), 450(v), 450(vi), 450(vii), 450(ix), 452(i), 452(ii), 452(iii) y 452(iv).

Para uso en calamar salado solamente.

Dosis máxima provisional hasta la CCFA53.

Para uso de fosfato diácido de sodio (SIN 339(i)), hidrogenofosfato disódico (SIN 339(ii)), fosfato trisódico (SIN 339(iii)), fosfato diácido de potasio (SIN 340(i)), hidrogenofosfato dipotásico (SIN 340(ii)), fosfato tripotásico (SIN 340(iii)), fosfato diácido de calcio (SIN 341(i)), hidrogenofosfato de calcio (SIN 341(ii)), fosfato tricálcico (SIN 341 (iii), difosfato disódico (SIN 450(i)), difosfato trisódico (SIN 450(ii)), difosfato tetrasódico (SIN 450(iii)), difosfato tetrapotásico (SIN 450(v)), difosfato diácido cálcico (SIN 450(vii)), trifosfato pentasódico (SIN 451(i)), trifosfato pentapotásico (SIN 451(ii)), polifosfato de sodio (SIN 452(i)), polifosfato de potasio (SIN 452(ii)), polifosfato de sodio y calcio (SIN 452(iii)), polifosfato de calcio (SIN 452(iv)), polifosfato de amonio (SIN 452(v)) y fosfato de huesos (SIN 542) como humectantes en los productos que correspondan a la Norma para la "carne luncheon" (CODEX STAN 89-1981) y Norma para la carne picada curada cocida (CODEX STAN 98-1981). La cantidad del total de fosfatos (naturalmente presentes y añadidos) no excederá $3520 \mathrm{mg} / \mathrm{kg}$ como fósforo.

Excluidos los productos (distintos del chocolate blanco) que corresponden a la Norma para el chocolate y los productos de chocolate (CODEX STAN 87-1981). Solo para uso en empanados o rebozados en productos que correspondan a la Norma para barritas, porciones y filetes de pescado empanados o rebozados congelados rápidamente (CODEX STAN 166-1989), solo o en combinación: carotenos (carotenos, beta-, sintéticos (SIN 160a(i)), carotenos beta-, Blakeslea trispora (SIN 160a(iii)), carotenal, beta-apo-8' (SIN 160e) y éster etílico del ácido beta-apo-8'-carotenoico (SIN 160f) y carotenos beta-, vegetales (SIN 160a(ii)).

Excepto para uso en empanados o rebozados en los productos que corresponden a la Norma del Codex para barritas, porciones y filetes de pescado empanados 0 rebozados congelados rápidamente (CODEX STAN 166-1989), únicamente en dosis de $25 \mathrm{mg} / \mathrm{kg}$ como norbixina.

Excluidos los productos correspondientes a la Norma para las aletas de tiburón secas (CODEX STAN 189-1993), la Norma para galletas de pescado marino y de agua dulce y de mariscos, crustáceos y moluscos (CODEX STAN 222-2001), la Norma para las anchoas hervidas secas saladas (CODEX STAN 236-2003), la Norma relativa al abalón vivo y al abalón crudo, fresco, refrigerado o congelado destinado al consumo directo o a su procesamiento ulterior (CODEX STAN 3122013), y la Norma para los productos de pectínidos frescos y pectínidos crudos congelados rápidamente (CODEX STAN 315-2014).

Excluidos los calamares crudos.

Sólo para uso en moluscos crudos.

Sólo para uso en alimentos empanados o rebozados aplicado únicamente a los alimentos no normalizados.

Excepto para uso en productos regulados por la Norma para los camarones en conserva (CODEX STAN 37-1981) y la Norma para la carne de cangrejo en conserva (CODEX STAN 90-1981) a $250 \mathrm{mg} / \mathrm{kg}$.

Sólo para uso en terrinas.

Sólo para uso en productos de tsukudani y de surimi.

Para uso en productos correspondientes a la Norma para galletas de pescado marino y de agua dulce y de mariscos, crustáceos y moluscos (CODEX STAN 2222001).

Para uso en extractos de levadura. 
Nota 315

Nota 316

Nota 317

Nota 318

Nota 319

Nota 320

Nota 321

Nota 322

Nota 323

Nota 324

Nota 325

Nota 326

Nota 327

Nota 328

Nota 329

Nota 330

Nota 331

Nota 332

Nota 333

Nota 334

Nota 335

Nota 336

Nota 337

Nota 338

Nota 339

Nota 340

Nota 341

Nota 342
Separado o combinado: ácido ascórbico (SIN 300), ascorbato de sodio (SIN 301), ascorbato cálcico (SIN 302) y palmitato de ascorbilo (SIN 304).

Dentro de los límites para el sodio especificados en la Norma para preparados complementarios (Codex Stan 156-1987): por separado o en combinación con otros aditivos que contengan sodio.

Como ácido ascórbico.

Sólo en cereal seco.

Dentro de los límites para el sodio especificados en la Norma para alimentos envasados para lactantes y niños (Codex Stan 73-1981): por separado o en combinación con otros aditivos que contengan sodio.

Dentro de los límites para el sodio especificados en la Norma para alimentos elaborados a base de cereales para lactantes y niños pequeños (Codex Stan 741981): por separado o en combinación con otros aditivos que contengan sodio.

Sólo para uso en mezclas en polvo.

Para uso en productos regulados por la Norma general para grasas y aceites comestibles no regulados por normas individuales (CODEX STAN 19-1981) y la Norma para grasas animales no especificadas (CODEX STAN 211-1999).

Para uso como agente endurecedor.

Sólo para uso en áloe vera.

Para uso general en productos de surimi.

Sólo para uso en productos de carne, de aves de corral y carne de caza frescas.

Para uso en productos de pescado cocido en salsa de soja.

Separados o combinados con otros espesantes.

La dosis de uso en los productos de leche y productos a base de soya.

Excepto para uso en productos envasados.

Para productos no normalizados: para uso en carne picada de pescado, camarones y langostinos únicamente.

Para uso general como agente de glaseado.

En los alimentos regulados por la Norma para el pescado ahumado, pescado con sabor a humo y pescado secado con humo (CODEX STAN 311-2013), para uso en los productos envasados con oxígeno reducido en pescado ahumado y productos de pescado con sabor a humo solamente.

Para pescado salado con un contenido de sal mayor o igual al 18 por ciento durante la elaboración.

Para uso en productos que contengan proteínas vegetales únicamente.

Para uso en los zumos de ciruelas chinas únicamente.

Para uso en productos regulados por la Norma del Codex para los "bouillons" y consomés (CODEX STAN 117-1981) a $50 \mathrm{mg} / \mathrm{kg}$.

Para uso en productos regulados por la Norma del Codex para los "bouillons" y consomés (CODEX STAN 117-1981) por separado o en combinación: ácido sórbico (SIN 200), sorbato de potasio (SIN 202), sorbato de calcio (SIN 203), ácido benzoico (SIN 210), benzoato de sodio (SIN 211), benzoato de potasio (SIN 212) y benzoato de calcio (SIN 213) a $500 \mathrm{mg} / \mathrm{kg}$ como ácido sórbico (SIN 200-203) o como ácido benzoico (SIN 210-213).

Excluidos los bouillons y consomés en conserva.

Excepto para los productos que no correspondan a la Norma del Codex para los "bouillons" y consomés (CODEX STAN 117-1981) a 100 mg/kg.

Para uso en productos que se ajusten a la Norma del Codex para los "bouillons" y consomés (CODEX STAN 117-1981) por separado o en combinación: carotenos, beta-, vegetales (SIN 160a(ii)), -carotenal, beta-apo-8 '- (SIN 160e) y éster etílico del ácido beta-apo-8'-carotenoico (SIN 160f) a $50 \mathrm{mg} / \mathrm{kg}$.

Para el uso de las clorofilas, complejos cúpricos (SIN 141 (i) sólo en los productos que se ajustan a la Norma del Codex para los "bouillons" y consomés (CODEX STAN 117-1981). 
Para uso en productos regulados por la Norma del Codex para los "bouillons" y consomés (CODEX STAN 117-1981): fosfato diácido de sodio (SIN 339 (i)), hidrogenfosfato disódico(SIN 339ii), fosfato trisódico (SIN 339iii), fosfato diácido de potasio (SIN 340 (i)), hidrogenfosfato dipotásico (SIN 340ii), fosfato tripotásico (SIN 340 (iii)), difosfato disódico (SIN 450 (i)), difosfato trisódico (SIN 450ii), difosfato tetrasódico (SIN 450iii), difosfato tetrapotásico (SIN 450(v)), trifosfato pentasódico (SIN 451(i)), trifosfato pentapotásico (SIN 451(ii)), polifosfato de sodio (SIN 452(i)) y polifosfato de potasio (SIN 452(ii) como reguladores de la acidez a $440 \mathrm{mg} / \mathrm{kg}$ como fósforo; fosfato diácido de calcio (SIN 341 (i)), hidrogenfosfato de calcio (SIN 341 (ii)) y fosfato tricálcico (SIN 341 (iii)) como aglutinantes a $800 \mathrm{mg} / \mathrm{kg}$ como fósforo en materia seca sólo en productos deshidratados; y difosfato dicálcico (SIN 450 (vi)) y polifosfato de calcio (SIN 452(iv) como emulsionantes, estabilizadores y espesantes a $1320 \mathrm{mg} / \mathrm{kg}$ como fósforo.

Para el uso de riboflavina, sintética (SIN 101(i)) sólo en productos regulados por la Norma del Codex para los "bouillons" y consomés (CODEX STAN 117-1981).

Para uso en productos regulados por la Norma del Codex para los "bouillons" y consomés (CODEX STAN 117-1981): ésteres de ácidos grasos y sacarosa (SIN 473), sucroglicéridos (SIN 474) individualmente o en combinación a $2000 \mathrm{mg} / \mathrm{kg}$. Para uso en productos regulados por la Norma del Codex para los "bouillons" y consomés (CODEX STAN 117-1981), solos o en combinación: tocoferol d-alfa- (SIN 307a), tocoferol concentrado, mezcla (SIN 307b), y tocoferol dl-alfa- (SIN 307c) a $50 \mathrm{mg} / \mathrm{kg}$.

Excluidos los productos naturales.

Sólo o en combinación: sucroésteres de ácidos grasos (SIN 473), oligoésteres de sucrosa tipo I y II (SIN 473a) y sucroglicéridos (SIN 474).

Para uso en dosis de $7000 \mathrm{mg} / \mathrm{kg}$ únicamente en rellenos de nata para panadería. Para uso en dosis de $10000 \mathrm{mg} / \mathrm{kg}$ únicamente en productos análogos a la crema en polvo.

Para uso en productos que correspondan a la Norma para el queso crema (CODEX STAN 275-1973).

Excepto para uso en dosis de $6000 \mathrm{mg} / \mathrm{kg}$ en productos con $>20 \%$ de contenido de grasa.

En seco.

Para uso en dosis de $2000 \mathrm{mg} / \mathrm{kg}$ en productos aromatizados que correspondan a la Norma para las leches fermentadas (CODEX STAN 243-2003) únicamente.

Para uso en dosis de $10000 \mathrm{mg} / \mathrm{kg}$ en productos aromatizados que correspondan a la Norma para las leches fermentadas (CODEX STAN 243-2003) únicamente.

Excluidos los aceites vírgenes o prensados en frío.

Excepto para uso en aceite de oliva refinado, aceite de oliva, aceite de orujo de oliva refinado y aceite de orujo de oliva en dosis de $200 \mathrm{mg} / \mathrm{kg}$ para restablecer los tocoferoles naturales perdidos en la producción.

Excepto para uso en aceites de pescado a $6000 \mathrm{mg} / \mathrm{kg}$, individualmente o en combinación.

Excepto las grasas lácteas para untar con $\geq 70 \%$ de contenido de materias grasas de la leche.

En grasas lácteas para untar limitado a productos con $<70 \%$ de materia grasa 0 para el horno.

Para uso en dosis de $5000 \mathrm{mg} / \mathrm{kg}$ como ácido tartárico en productos que correspondan a la Norma para materias lácteas grasas para untar (CODEX STAN 253-2006).

Excluidos los productos naturales que correspondan a la Norma para las leches fermentadas (CODEX STAN 243-2003).

Para uso en dosis de $50000 \mathrm{mg} / \mathrm{kg}$ para los aceites emulsionados utilizados en la producción de fideos o productos de panadería.

Individualmente o en combinación.

En las tripas para embutido.

Para uso en dosis de $10000 \mathrm{mg} / \mathrm{kg}$ en sucedáneos del chocolate con $>5 \%$ de contenido de agua. 
$\begin{array}{ll}\text { Nota } & 367 \\ & \\ \text { Nota } & 368 \\ \text { Nota } & 369 \\ \text { Nota } & 370 \\ & \\ \text { Nota } & 371 \\ \text { Nota } & 372 \\ \text { Nota } & 373 \\ \text { Nota } & 374 \\ \text { Nota } & 375\end{array}$

Nota 376

Nota 377

Nota 378

Nota 379

Nota 380

Nota 381

Nota 382

Nota 383

Nota 384

Nota 385

Nota 386

Nota 387

Nota 388

Nota 389

Nota 390

Nota 391

Nota 392
Para uso en dosis de $10000 \mathrm{mg} / \mathrm{kg}$ en los dulces que contengan no menos del $10 \%$ de aceite.

Para uso en dosis de $10000 \mathrm{mg} / \mathrm{kg}$ en decoraciones batidas.

Para uso en cereales de desayuno tipo granola únicamente.

Para uso en fideos, cubiertas o envolturas para rollitos de primavera, wontons y shou mai únicamente.

Para uso en dosis de $10000 \mathrm{mg} / \mathrm{kg}$ en fideos hervidos únicamente.

Para uso en bollos únicamente.

Para uso en salchichas únicamente.

Para su uso en productos cárnicos cocidos congelados únicamente.

Excluidos los productos que corresponden a la Norma para el chocolate y los productos de chocolate (CODEX STAN 87-1981), excepto para el chocolate blanco, en que se puede usar el palmitato de ascorbilo (SIN 304) únicamente como antioxidante en dosis de $200 \mathrm{mg} / \mathrm{kg}$, calculada sobre la base del contenido de grasa. Para uso únicamente en preparados líquidos a base de proteínas hidrolizadas y/o aminoácidos para lactantes.

Para los productos que correspondan a la Norma para la "carne luncheon" (CODEX STAN 89-1981), Norma para la carne picada curada cocida (CODEX STAN 981981), y Norma para la carne tipo "corned beef" (CODEX STAN 88-1981) el uso está limitado a los productos listos para el consumo que requieren refrigeración. Para aceites y grasas para freír.

Para uso únicamente en preparados líquidos a base de proteínas hidrolizadas y/o aminoácidos para lactantes.

Excepto para uso en preparados en polvo para lactantes en dosis de $7500 \mathrm{mg} / \mathrm{kg}$. Según se consumen.

Para uso solamente en el pescado ahumado y productos de pescado con sabor a humo que correspondan a la Norma para para el pescado ahumado, pescado con sabor a humo y pescado secado con humo (CODEX STAN 311-2013).

Para uso en gelatina en polvo solamente.

Sobre la base de la gelatina en polvo.

Como humectante para la humectación de ácido fumárico (SIN 297).

Excepto para su uso en la Norma para pepinos encurtidos (encurtido de pepinos) (CODEX STAN 115-1981) en dosis de $500 \mathrm{mg} / \mathrm{kg}$, solo o en combinación con otros emulsionantes.

Excepto para uso en dosis de $20000 \mathrm{mg} / \mathrm{kg}$ en azúcar en polvo para productos de panadería fina.

Excluido el pan preparado únicamente con harina de trigo, agua, levadura o leudante y sal.

Excepto para su uso en dosis de $500 \mathrm{mg} / \mathrm{kg}$ en productos que contengan pasta de nueces.

Para su uso como antioxidante para alimentos no normalizados y para moluscos crudos sin concha refrigerados que corresponden a la Norma para los moluscos bivalvos vivos y los moluscos bivalvos crudos (CODEX STAN 292-2008).

Para alimentos no normalizados y para carne de pescado picada en los productos que corresponden a la Norma para bloques de filetes de pescado, carne de pescado picada y mezclas de filetes y de carne de pescado picada congelados rápidamente (CODEX STAN 165-1989).

Para alimentos no normalizados y para productos que corresponden a la Norma para los moluscos bivalvos vivos y los moluscos bivalvos crudos (CODEX STAN 292-2008): para uso como antioxidante para los moluscos crudos congelados. 
Para uso en carne de pectínidos congelada rápidamente y carne de pectínidos con huevas congeladas rápidamente elaborada con fosfatos conforme a la Norma para los productos de pectínidos frescos y pectínidos crudos congelados rápidamente (CODEX STAN 315-2014) como sigue: los siguientes fosfatos a $2200 \mathrm{mg} / \mathrm{kg}$ como fósforo para usar como reguladores de la acidez: SIN 338, 339(i,ii,iii), 340(i,ii,iii), 341(i,ii,iii), 342(i,ii), 343(i,ii,iii), 450(i,ii,iii,v,vi,vii,ix), 451(i,ii), 452(i,ii,iii,iv,v); los siguientes para uso como humectantes:SIN 339(i,ii,iii), 340(i,ii,iii), 341(i,ii,iii), 450(i,ii,iii,v,vii), 451(i,ii), INS 452(i,ii,iii,iv,v), y 542; los siguientes para uso como secuestrantes: SIN 338, 339(i,ii,iii), 340(i,ii,iii), 341(i), 450(i,ii,iii,v,vi,vii), 451 (i,ii,), 452(i,ii,iii,iv,v); y los siguientes para uso como estabilizadores: SIN 339(i,ii,ii), 340(i,ii,iii), 341(i,ii,iii), 342(i,ii), 343(i,ii,iii), I450(i), INS 450(ii), INS 450(iii,v,vi,vii,ix), $451(\mathrm{i}, \mathrm{ii}), 452(\mathrm{i}, \mathrm{ii}, \mathrm{iii}, \mathrm{iv}, \mathrm{v})$ y 542.

$\begin{array}{ll}\text { Nota } 394 & \text { Para uso en alimentos no normalizados; y en los productos que corresponden a la } \\ & \text { Norma para los camarones congelados rápidamente (CODEX STAN 92-1981); } \\ & \text { Norma para langostas congeladas rápidamente (CODEX STAN 95-1981); Norma } \\ & \text { para bloques de filetes de pescado, carne de pescado picada y mezclas de filetes y } \\ & \text { de carne de pescado picada congelados rápidamente (CODEX STAN 165-1989); y } \\ & \text { Norma para filetes de pescado congelados rápidamente (CODEX STAN 190-1995) } \\ & \text { como humectantes en dosis de } 2200 \mathrm{mg} / \mathrm{kg} \text { como fósforo: SIN 339(i), SIN 339(ii), } \\ & \text { SIN 339(iii), SIN 340(i), SIN 340(ii), SIN 340(iii), SIN 341(i), SIN 341(ii), SIN 450(iii), } \\ & \text { SIN 450(v), SIN 450(vii), SIN 451(i), SIN 451(ii), SIN 452(i), SIN 452(ii), SIN 452(iii), } \\ & \text { SIN 452(iv), SIN 452(v) y SIN 542. }\end{array}$

Para uso en productos con tratamiento térmico que corresponden a la Norma para los camarones congelados rápidamente (CODEX STAN 92-1981).

Para productos regulados por la Norma para el jamón curado cocido (CXS 96 1981) y la Norma para la espaldilla de cerdo curada cocida (CXS 97 -1981), el uso está limitado a productos listos para el consumo que requieren refrigeración.

Nota 397

Nota 398

Nota 399

Nota 400

Nota 401

Nota 402

Nota 403

Nota 404

Nota 405

Nota 406

Nota 407

Nota 408

Nota 409
Para uso en dosis de $1000 \mathrm{mg} / \mathrm{kg}$ en sueros de leche no UHT y no esterilizados. Para uso en productos que se ajustan a la Norma para Leche Fermentada (CODEX STAN 243-2003) a $1000 \mathrm{mg} / \mathrm{kg}$.

Para uso en productos que se ajustan a la Norma para Leche Fermentada (CODEX STAN 243-2003) a $10.000 \mathrm{mg} / \mathrm{kg}$.

Para uso en productos que se ajustan a la Norma para Leche Fermentada (CODEX STAN 243-2003) a $150 \mathrm{mg} / \mathrm{kg}$.

Para uso en productos que se ajustan a la Norma para Leche Fermentada (CODEX STAN 243-2003) a $600 \mathrm{mg} / \mathrm{kg}$.

Para uso en productos que se ajustan a la Norma para Leche Fermentada (CODEX STAN 243-2003) a $100 \mathrm{mg} / \mathrm{kg}$.

Excluyendo las leches fermentadas y las bebidas no tratadas térmicamente después de la fermentación.

Para uso en los productos de valor energético reducido o sin azúcares añadidos correspondientes a la Norma para leches fermentadas (CODEX STAN 243-2003), en dosis de $400 \mathrm{mg} / \mathrm{kg}$.

Para uso en los productos de valor energético reducido o sin azúcares añadidos correspondientes a la Norma para leches fermentadas (CODEX STAN 243-2003), en dosis de $1000 \mathrm{mg} / \mathrm{kg}$.

Para uso en los productos de valor energético reducido o sin azúcares añadidos correspondientes a la Norma para leches fermentadas (CODEX STAN 243-2003), en dosis de $100 \mathrm{mg} / \mathrm{kg}$.

Excluidas todas las leches líquidas que no estén enriquecidas con minerales o vitaminas.

Solo para uso como emulsionante en los productos regulados por la Norma para aceites de pescado (CODEX STAN 329-2017), o como antiespumante en aceites y grasas para freír regulados para la Norma para grasas y aceites comestibles no regulados por normas individuales (CODEX STAN 19-1981).

Solo para uso en productos destinados a elaboración ulterior o usos dietéticos especiales, de contenido de azúcar bajo o reducido, o donde las propiedades edulcorantes han sido sustituidas entera o parcialmente por edulcorantes aditivos alimentarios. 
$\begin{array}{ll}\text { Nota } & 410 \\ \text { Nota } & 411 \\ \text { Nota } & 412 \\ \text { Nota } & 413 \\ & \\ \text { Nota } & 414 \\ \text { Nota } & 415 \\ \text { Nota } & 416 \\ \text { Nota } & 417 \\ \text { Nota } & 418 \\ & \\ \text { Nota } & 419 \\ \text { Nota } & 420 \\ \text { Nota } & 421 \\ & \\ \text { Nota } & 422 \\ \text { Nota } & 423 \\ \text { Nota } & 424 \\ \text { Nota } & 425 \\ & \\ \text { Nota } & 426 \\ \text { Nota } & 427 \\ \text { Nota } & 428 \\ \text { Nota } & 429 \\ \text { Nota } & 430 \\ \text { Nota } & 431 \\ \text { Nota } & 432 \\ \text { Nota } & 433 \\ \text { Nota } & 434 \\ & \\ & 435 \\ & \\ & \\ & \\ & \\ & \end{array}$

Nota 436

Nota 437

Nota 438

Nota 439

Nota 440

Nota 441

Nota 442

Nota 443
Excluidas leches con contenido reducido en lactosa.

Excepto para uso en leches con contenido reducido en lactosa a $500 \mathrm{mg} / \mathrm{kg}$.

Solo para uso en salsas de pescado.

SIN 452(i-v) solo para uso en los productos regulados por la Norma para galletas de pescado marino y de agua dulce y de mariscos, crustáceos y moluscos (CODEX STAN 222-2001).

Solo para uso en productos marinados.

Solo para uso en encurtidos.

Tocoferol concentrado, mezcla (SIN 307b) solo.

Para uso en forma de cápsulas y tabletas.

Excepto para uso a $6000 \mathrm{mg} / \mathrm{kg}$, solo o en combinación, sobre la base de aceites de pescado.

Solo para uso en productos listos para el consumo que requieren refrigeración.

Excepto para uso a $700 \mathrm{mg} / \mathrm{kg}$ en moluscos ahumados y moluscos salados.

Solo para uso en pastas y productos condimentados que contienen aceites vegetales.

Solo para uso en roux de curry.

Solo para uso en dashi y furikake.

Para uso como agente de glaseado.

Solos o en combinación: sucroésteres de ácidos grasos (SIN 473), y oligoésteres de sucrosa, tipo I y tipo II (SIN 473a).

Excepto para uso en marinadas concentradas aplicadas a alimentos a $20000 \mathrm{mg} / \mathrm{kg}$.

Excepto para uso en marinadas concentradas aplicadas a alimentos a $10000 \mathrm{mg} / \mathrm{kg}$.

Como residuo en bizcochos y galletas.

Excepto para uso en café con leche envasado a $2000 \mathrm{mg} / \mathrm{kg}$.

Solo para uso en licores emulsionados.

Excluido el uso en whiskey.

Solo para uso en masas utilizadas en aperitivos salados a base de cereals.

Solo para uso en galletas de arroz y aperitivos de patatas (papas).

Transferencia del uso como antioxidante en aromatizantes, colorantes, ingredientes de zumos (jugos) y preparados nutritivos.

Para uso de tartrazina (SIN 102), amarillo ocaso FCF (SIN 110), amaranto (SIN 123) y ponceau $4 R$ (rojo de cochinilla $A$ ) (SIN 124) solos o en combinación, hasta una dosis máxima de $30 \mathrm{mg} / \mathrm{kg}$ en el producto final como colorantes solamente para restaurar el color perdido en el procesado de los productos regulados por la Norma para los camarones en conserva (CODEX STAN 37-1991).

Solo para uso como reguladores de la acidez: en los productos regulados por la Norma para los camarones en conserva (CODEX STAN 37-1991) solo está permitido ácido fosfórico (SIN 338) hasta un máximo de $540 \mathrm{mg} / \mathrm{kg}$ como fósforo; en los productos regulados por la Norma para el atún y el bonito en conserva (CODEX STAN 70-1981) solo está permitido el difosfato disódico (SIN 450(i)) hasta un máximo de $4400 \mathrm{mg} / \mathrm{kg}$ como fósforo (incluyendo fosfatos naturales); en los productos regulados por la Norma para la carne de cangrejo en conserva (CODEX STAN 90-1981) solo está permitido ácido fosfórico (SIN 338) y difosfato disódico (SIN 450(i)) hasta un máximo de $4400 \mathrm{mg} / \mathrm{kg}$, solos o en combinación, como fósforo (incluyendo fosfatos naturales).

Excluido el uso en el pescado secado con humo regulado por la Norma para el pescado ahumado, pescado con sabor a humo y pescado secado con humo (CODEX STAN 311-2013).

Para uso como emulsionante o estabilizador solamente.

Para la leche UHT de especies no bovinas únicamente.

Excepto para uso a $200 \mathrm{mg} / \mathrm{kg}$ en caramelos con revestimiento duro de azúcar.

Excepto para uso a $300 \mathrm{mg} / \mathrm{kg}$ en caramelos con sabor a frutas rojas.

Excepto para uso a $300 \mathrm{mg} / \mathrm{kg}$ en caramelos con sabor a limón.

Excepto para uso a $200 \mathrm{mg} / \mathrm{kg}$ en tofes de leche. 
$\begin{array}{ll}\text { Nota } & 444 \\ \text { Nota } & 445 \\ \text { Nota } & 446 \\ \text { Nota } & 447 \\ \text { Nota } & 448 \\ & \\ \text { Nota } & 449 \\ & \\ \text { Nota } & 450 \\ \text { Nota } & 451 \\ \text { Nota } & 452 \\ \text { Nota } & 453 \\ & \\ \text { Nota } & 454 \\ \text { Nota } & 455 \\ \text { Nota } & 456\end{array}$

Nota 457

Nota 458

Nota 459

Nota 460

Nota 461

Nota 462

Excepto para uso a $700 \mathrm{mg} / \mathrm{kg}$ en fruta amarilla o goma de mascar con sabor a especias.

Excepto para uso a $300 \mathrm{mg} / \mathrm{kg}$ en productos aromatizados con limón y cítricos.

Excepto para uso a $100 \mathrm{mg} / \mathrm{kg}$ en glaseados a base de azúcar.

Excepto para uso a $500 \mathrm{mg} / \mathrm{kg}$ en productos a base de grasa o gaseados.

Para uso en la leche UHT de especies bovinas para compensar el contenido de citrato o de calcio para evitar la sedimentación debido a las condiciones climáticas solamente.

Excluidas las leches fermentadas naturales/simples a base de leches fermentadas sin tratamiento térmico después de la fermentación contempladas por CXS 2432003.

Excepto para uso a $20000 \mathrm{mg} / \mathrm{kg}$ en productos dulces afrutados.

Sobre la base de la mezcla en seco.

Excepto para uso a $5200 \mathrm{mg} / \mathrm{kg}$ en claras de huevo secas utilizadas para elaboración posterior solamente.

Para uso como glaseado cuando ese tratamiento de superficie está permitido para la aplicación a la superficie de la fruta fresca.

Para uso en ceras, revestimientos o glaseados cuando esos tratamientos de superficie están permitidos para la aplicación a la superficie de la fruta fresca.

Para uso como glaseado cuando ese tratamiento de superficie está permitido para la aplicación a la superficie de hortalizas frescas, algas o nueces y semillas.

Para uso en ceras, revestimientos o glaseados cuando esos tratamientos de superficie están permitidos para la aplicación a la superficie de hortalizas frescas, algas o nueces y semillas.

Excepto para uso en los productos correspondientes a las normas para el Cheddar (CXS 263-1966), Danbo (CXS 264-1966), Edam (CXS 265-1966), Gouda (CXS 2661966), Havarti (CXS 267-1966), Samsø (CXS 268-1966), Emmental (CXS 2691967), Tilsiter (CXS 270-1968), Saint-Paulin (CXS 271-1968) y Provolone (CXS 2721968): a una dosis máxima de $1000 \mathrm{mg} / \mathrm{kg}$ para el tratamiento de la superficie solamente.

Excepto para uso en pasta de queso solo para los productos correspondientes a las normas para el Cheddar (CXS 263-1966), Danbo (CXS 264-1966), Edam (CXS 2651966), Gouda (CXS 266-1966), Havarti (CXS 267-1966), Samsø (CXS 268-1966), Emmental (CXS 269-1967), Tilsiter (CXS 270-1968), Saint-Paulin (CXS 271-1968), Provolone (CXS 272-1968), Coulommiers (CXS 274-1969), Camembert (CXS 2761973) y Brie (CXS 277-1973); solos o en combinación a $35 \mathrm{mg} / \mathrm{kg}$.

Excepto para uso a $10000 \mathrm{mg} / \mathrm{kg}$, solo o en combinación: dióxido de silicio, amorfo (SIN 551), silicato de calcio (SIN 552), silicato de magnesio, sintético (SIN 553(i)) y talco (SIN 553(iii)) en los productos correspondientes a las Normas para el Cheddar (CXS 263-1966), Danbo (CXS 264-1966), Edam (CXS 265-1966), Gouda (CXS 2661966), Havarti (CXS 267-1966), Samsø (CXS 268-1966), Emmental (CXS 2691967), Tilsiter (CXS 270-1968), Saint-Paulin (CXS 271-1968) y Provolone (CXS 2721968), como antiaglutinante solamente: silicatos calculados como dióxido de silicio. Excepto para uso a $3000 \mathrm{mg} / \mathrm{kg}$, solo o en combinación: ácido propiónico (SIN 280 ), propionato de sodio (SIN 281) y propionato de calcio (SIN 282) en los productos correspondientes a las normas para el Cheddar (CXS 263-1966), Danbo (CXS 264-1966), Edam (CXS 265-1966), Gouda (CXS 266-1966), Havarti (CXS 267-1966), Samsø (CXS 268-1966), Tilsiter (CXS 270-1968), Saint-Paulin (CXS 271-1968) y Provolone (CXS 272-1968).

Para el tratamiento de superficie del queso en lonchas, cortado, desmenuzado o rallado en los productos correspondientes a las normas para el Cheddar (CXS 2631966), Danbo (CXS 264-1966), Edam (CXS 265-1966), Gouda (CXS 266-1966), Havarti (CXS 267-1966), Samsø (CXS 268-1966), Emmental (CXS 269-1967), Tilsiter (CXS 270-1968), Saint-Paulin (CXS 271-1968) y Provolone (CXS 272-1968) solo como antiaglutinantes.

Para uso en la pasta de queso solo para los productos correspondientes a las normas para el Cheddar (CXS 263-1966) y Danbo (CXS 264-1966). 
Nota 463

Nota 464

Nota 465

Nota 466

Nota 467

Nota 468

Nota 469

Nota 470

Nota 471

Nota 472

Nota 473

Nota 474

Nota 475
Para uso en la pasta de queso solo para los productos correspondientes a las normas para el Cheddar (CXS 263-1966), Danbo (CXS 264-1966), Edam (CXS 2651966), Gouda (CXS 266-1966), Havarti (CXS 267-1966), Samsø (CXS 268-1966), Emmental (CXS 269-1967), Tilsiter (CXS 270-1968), Saint-Paulin (CXS 271-1968), Provolone (CXS 272-1968), Coulommiers (CXS 274-1969), Camembert (CXS 2761973) y Brie (CXS 277-1973).

Para uso en los productos correspondientes a las normas para el Cheddar (CXS 263-1966), Danbo (CXS 264-1966), Edam (CXS 265-1966), Gouda (CXS 2661966), Havarti (CXS 267-1966), Samsø (CXS 268-1966), Emmental (CXS 2691967), Tilsiter (CXS 270-1968), Saint-Paulin (CXS 271-1968) y Provolone (CXS 2721968) como conservante solamente.

Para los productos correspondientes a la Norma para los azúcares (CXS 212-1999) como antiaglutinantes solamente: dihidrógeno fosfato de calcio (SIN 341(i)), hidrógeno fosfato de calcio (SIN 341(ii)), fosfato tricálcico (SIN 341(iii)), dihidrógeno fosfato de magnesio (SIN 343(i)), hidrógeno fosfato de magnesio (SIN 343(ii)), fosfato de trimagnesio (SIN 343(iii)), carbonato de magnesio (SIN 504(i)), fosfato de huesos (SIN 542), dióxido de silicio, amorfo (SIN 551), silicato de calcio (SIN 552) y silicato de magnesio, sintético (SIN 553(i)) solos o en combinación, pero todavía dentro de las distintas dosis máximas separadas prescritas.

Solo para uso para elaborar productos con gas.

Para las harinas para el pan leudado solo en los productos correspondientes a la Norma para la harina de trigo (CXS 152-1985).

Excepto para uso en los productos correspondientes a la Norma para la harina de trigo (CXS 152-1985) como agente de tratamiento de la harina solamente, a una dosis máxima de $60 \mathrm{mg} / \mathrm{kg}$.

Para uso en los productos correspondientes a la Norma para la harina de trigo (CXS 152-1985) como agente de tratamiento de la harina: dihidrógeno fosfato de calcio (SIN 341(i)), hidrógeno fosfato de calcio (SIN 341(ii)), fosfato tricálcico (SIN 341 (iii)), dihidrógeno fosfato de amonio (SIN 342(i)) e hidrógeno fosfato diamónico (SIN 342(ii)) solamente.

En los productos correspondientes a la Norma para la harina de trigo (CXS 1521985), solo para uso como agente de tratamiento de la harina en las harinas para la fabricación de galletas y pasteles: dióxido de azufre (SIN 220), sulfito de sodio (SIN 221), metabisulfito de sodio (SIN 223) y metabisulfito de potasio (SIN 224) solamente.

En los productos correspondientes a la Norma para la harina de trigo (CXS 1521985), solo para uso en las harinas para pasteles que contienen más agua y azúcar que harina.

Para uso en los productos correspondientes a la Norma para la harina de trigo (CXS 152-1985) como agente de tratamiento de la harina solamente.

Excepto para uso en los productos correspondientes a la Norma para los fideos instantáneos (CXS 249-2006) a $200 \mathrm{mg} / \mathrm{kg}$.

Excepto para uso de beta-carotenos, Blakeslea trispora (SIN 160a(iii)) a 1000 $\mathrm{mg} / \mathrm{kg}$, carotenal, beta-apo-8' (SIN 160e) a $200 \mathrm{mg} / \mathrm{kg}$, y éster etílico del ácidobetaapo-8'-carotenoico (SIN 160f) a $1000 \mathrm{mg} / \mathrm{kg}$ en los productos correspondientes a la Norma para los fideos instantáneos (CXS 249-2006).

Excepto en los productos correspondientes a la Norma para los fideos instantáneos (CXS 249-2006): dihidrógeno fosfato de sodio (SIN 339(i)), hidrógeno fosfato de sodio (SIN 339(ii)), fosfato trisódico (SIN 339(iii)), dihidrógeno fosfato de potasio (SIN 340(i)), hidrógeno fosfato dipotásico (SIN 340(ii)), fosfato tripotásico (SIN 340(iii)), dihidrógeno fosfato de calcio (SIN 341(i)), hidrógeno fosfato de calcio (SIN 341 (ii)), fosfato tricálcico (SIN 341 (iii)), difosfato disódico (SIN 450(i)), fosfato trisódico (SIN 450(ii)), difosfato tetrasódico (SIN 450(iii)), difosfato dipotásico (SIN 450(iv)), difosfato tetrapotásico (SIN 450(v)), dihidrógeno fosfato de calcio (SIN 450(vii)), trifosfato pentapotásico (SIN 451(i)), trifosfato pentapotásico(SIN 451(ii)), polifosfato de sodio (SIN 452(i)), polifosfato de potasio (SIN 452(ii)), polifosfato de sodio y calcio (SIN 452(iii)), polifosfato de calcio (SIN 452(iv)), y polifosfato de amonio (SIN 452(v)) solo para uso como humectantes a $2000 \mathrm{mg} / \mathrm{kg}$, solos o en combinación, como fósforo. 
Nota 476

Nota 477

Nota 478

Nota XS13

Nota XS36

Nota XS38

Nota XS57

Nota XS66

Nota XS86

Nota XS87

Nota XS88

Nota XS89

Nota XS92

Nota XS95

Nota XS96

Nota XS97

Nota XS98

Nota XS105

Nota XS115

Nota XS117

Nota XS141

Nota XS145

Nota XS165

Nota XS166
Para los productos correspondientes a la Norma para los fideos instantáneos (CXS 249-2006): dióxido de azufre (SIN 220), sulfito de sodio (SIN 221), metabisulfito de sodio (SIN 223) y metabisulfito de potasio (SIN 224) para uso como agentes de tratamiento de la harina solo.

Algunos miembros del Codex permiten el uso de aditivos con función de edulcorante en todos los alimentos de esta categoría de alimentos mientras que otros limitan los aditivos con función de edulcorante a los alimentos con reducción significativa del contenido de energía o sin azúcares añadidos.

Algunos miembros del Codex permiten el uso de aditivos con función de edulcorante en todos los alimentos de esta categoría de alimentos mientras que otros limitan los aditivos con función de edulcorante a los alimentos con reducción significativa del contenido de energía o sin azúcares añadidos. Esta limitación puede no ser aplicable al uso conveniente como potenciador del sabor.

Excluidos los productos que corresponden a la Norma para los tomates en conserva (CODEX STAN 13 1981).

Excluidos los productos que corresponden a la Norma para pescados no eviscerados y eviscerados congelados rápidamente (CODEX STAN 36-1981).

Excluidos los productos que correspondan a la Norma general para los hongos comestibles y sus productos (CODEX STAN 38-1981).

Excluidos los productos que corresponden a la Norma para los concentrados de tomate elaborados (CODEX STAN 57-1981).

Excluidos los productos que corresponden a la Norma para las aceitunas de mesa (CODEX STAN 66-1981).

Excluidos los productos que correspondan a la Norma para la manteca de cacao (CODEX STAN 86-1981).

Excluidos los productos que corresponden a la Norma para el chocolate y los productos de chocolate (CODEX STAN 87-1981).

Excluidos los productos que corresponden a la Norma para la carne tipo "corned beef" (CODEX STAN 88-1981).

Excluidos los productos que corresponden a la Norma para la "carne luncheon" (CODEX STAN 89-1981).

Excluidos los productos que corresponden a la Norma para los camarones congelados rápidamente (CODEX STAN 92-1981).

Excluidos los productos que corresponden a la Norma para para langostas congeladas rápidamente (CODEX STAN 95-1981).

Excluidos los productos que corresponden a la Norma para el jamón curado cocido (CODEX STAN 96-1981).

Excluidos los productos que corresponden a la Norma para la espaldilla de cerdo curada cocida (CODEX STAN 97-1981).

Excluidos los productos que corresponden a y la Norma para la carne picada curada cocida (CODEX STAN 98-1981)

Excluidos los productos que corresponden a la Norma para el cacao en polvo (cacaos) y las mezclas secas de cacao y azúcares (CODEX STAN 105-1981).

Excluidos los productos que correspondan a la Norma para pepinos encurtidos (encurtidos de pepinos) (CODEX STAN 115-1981).

Excluidos los productos regulados por la Norma del Codex para los "bouillons" y consomés (CODEX STAN 117-1981).

Excluidos los productos que corresponden a la Norma para el cacao en pasta (licor de cacao/chocolate) y la torta de cacao (CODEX STAN 141-1983).

Excluidos los productos que corresponden a la Norma para las castañas en conserva y el puré de castañas en conserva (CODEX STAN 145-1985).

Excluidos los productos que corresponden a la Norma para bloques de filetes de pescado, carne de pescado picada y mezclas de filetes y de carne de pescado picada congelados rápidamente (CODEX STAN 165-1989).

Excluidos los productos que corresponden a la Norma para barritas, porciones y filetes de pescado empanados o rebozados congelados rápidamente (CODEX STAN 166-1989). 


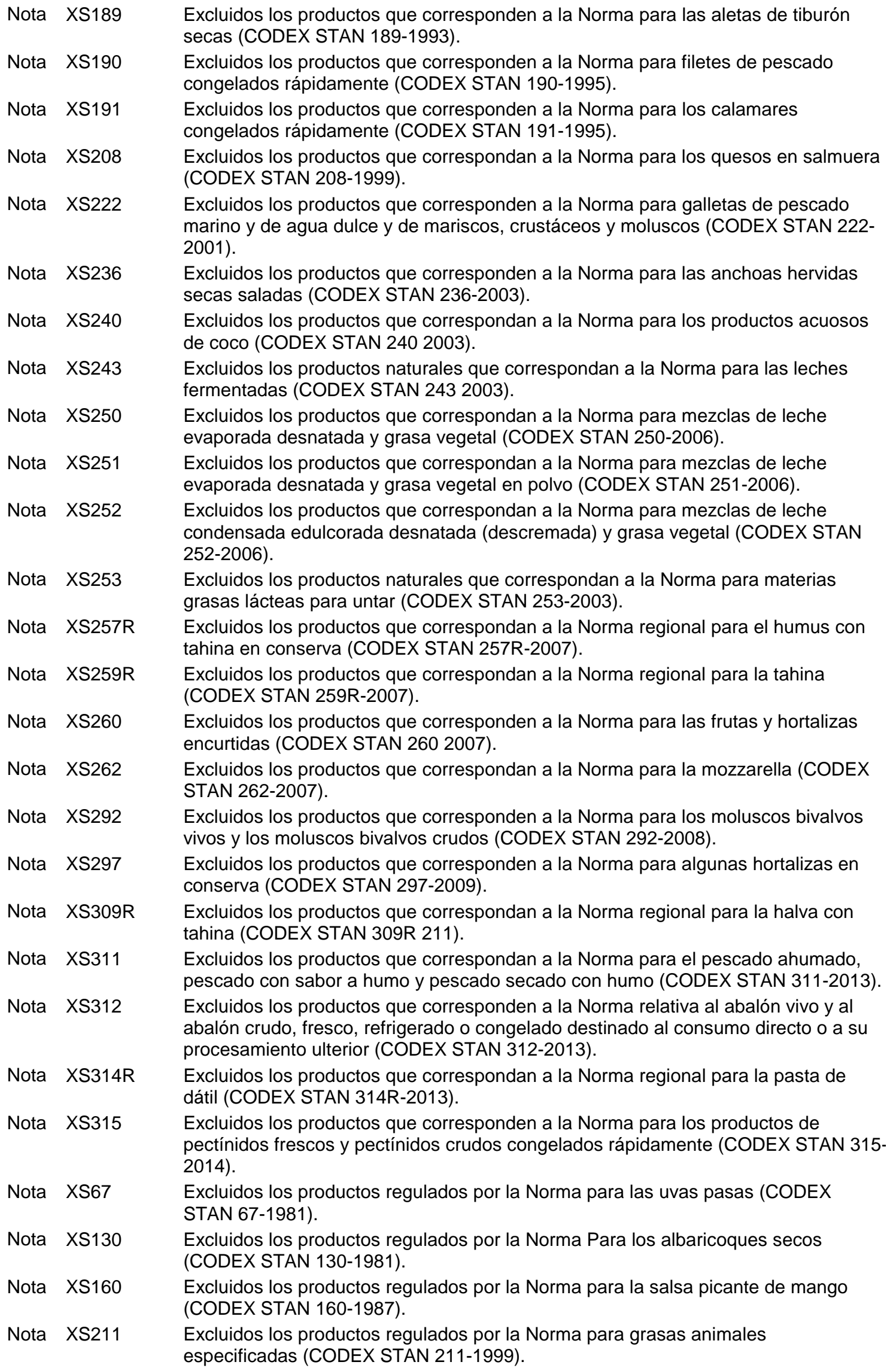




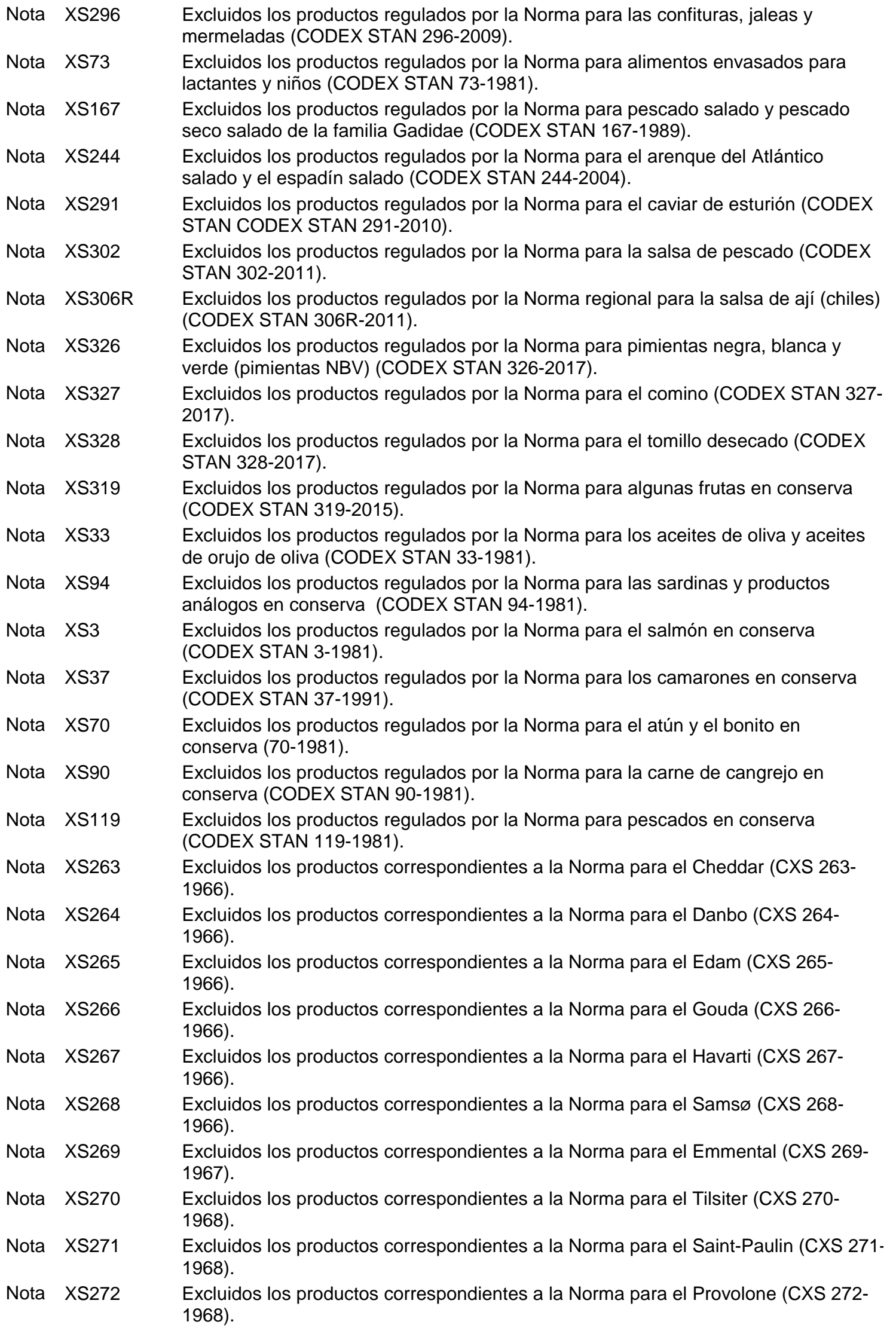




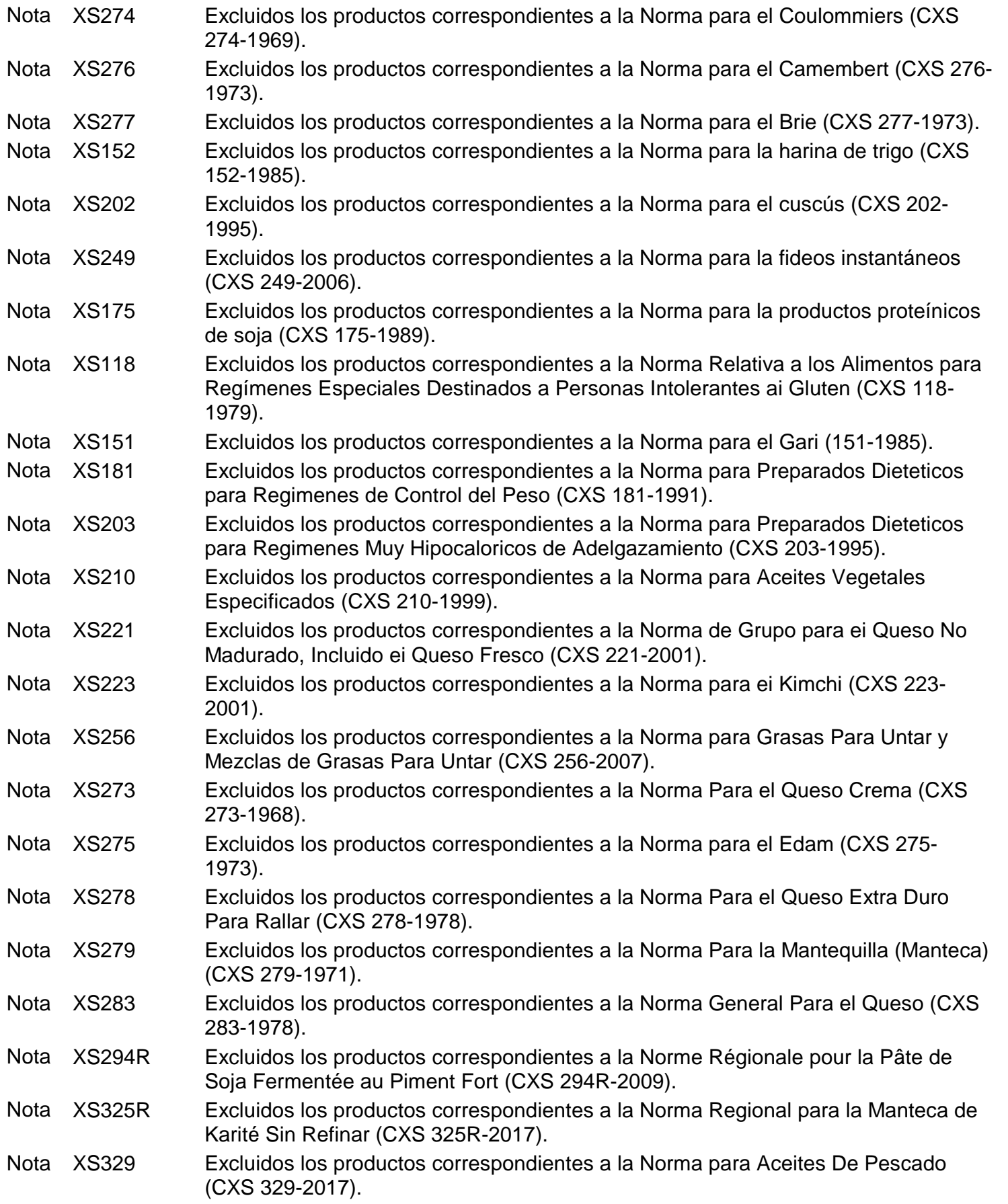




\section{NORMA GENERAL PARA LOS ADITIVOS} ALIMENTARIOS

CUADRO II

\section{Alimentos o categorías de alimentos en los que se permite el uso de aditivos}

\begin{tabular}{|c|c|c|c|c|}
\hline \multicolumn{2}{|c|}{ No. de Categoría de alimento 01.1.1 } & \multicolumn{3}{|c|}{ Leche líquida (natural / simple) } \\
\hline Aditivo & SIN & Año Adoptada & Dosis máxima & Notas \\
\hline FOSFATOS & $\begin{array}{l}\text { 338; 339(i)-(iii); } \\
\text { 340(i)-(iii); 341(i)- } \\
\text { (iii); 342(i)-(ii); } \\
\text { 343(i)-(iii); 450(i)- } \\
\text { (iii),(v)-(vii), (ix); } \\
\text { 451(i),(ii); 452(i)- } \\
\text { (v); } 542\end{array}$ & 2012 & $1500 \mathrm{mg} / \mathrm{kg}$ & $33 \& 227$ \\
\hline NITRÓGENO & 941 & 2017 & BPF & 59 \\
\hline
\end{tabular}

\begin{tabular}{|c|c|c|c|c|}
\hline \multicolumn{2}{|c|}{ No. de Categoría de alimento 01.1.2 } & \multicolumn{3}{|c|}{$\begin{array}{l}\text { Otras leches líquidas (naturales / } \\
\text { simples) }\end{array}$} \\
\hline Aditivo & SIN & Año Adoptada & Dosis máxima & Notas \\
\hline ÁCIDO ASCÓRBICO, L- & 300 & 2018 & BPF & 410 \\
\hline ÁCIDO CÍTRICO & 330 & 2018 & BPF & 407 \\
\hline ALMIDÓN HIDROXIPROPÍLICO & 1440 & 2019 & BPF & $407 \& 438$ \\
\hline ASCORBATO DE SODIO & 301 & 2018 & BPF & 410 \\
\hline CARBONATO DE POTASIO & 501 (i) & 2019 & BPF & 407 \\
\hline $\begin{array}{l}\text { CARBOXIMETILCELULOSA SÓDICA } \\
\text { (GOMA DE CELULOSA) }\end{array}$ & 466 & 2019 & BPF & $407 \& 438$ \\
\hline CARRAGENINA & 407 & 2019 & BPF & $407 \& 438$ \\
\hline $\begin{array}{l}\text { CELULOSA MICROCRISTALINA (GEL DE } \\
\text { CELULOSA) }\end{array}$ & 460 (i) & 2019 & BPF & $407 \& 438$ \\
\hline CITRATO TRISÓDICO & 331(iii) & 2018 & BPF & 410 \\
\hline $\begin{array}{l}\text { ÉSTERES ACÉTICOS Y DE ÁCIDOS } \\
\text { GRASOS DE GLICEROL }\end{array}$ & $472 a$ & 2018 & BPF & 407 \\
\hline $\begin{array}{l}\text { ÉSTERES CÍTRICOS Y DE ÁCIDOS } \\
\text { GRASOS DE GLICEROL }\end{array}$ & $472 c$ & 2018 & BPF & 407 \\
\hline $\begin{array}{l}\text { ÉSTERES DIACETILTARTÁRICOS Y DE } \\
\text { ÁCIDOS GRASOS DE GLICEROL }\end{array}$ & $472 e$ & 2018 & $120 \mathrm{mg} / \mathrm{kg}$ & 407 \\
\hline $\begin{array}{l}\text { ÉSTERES LÁCTICOS Y DE ÁCIDOS } \\
\text { GRASOS DE GLICEROL }\end{array}$ & $472 b$ & 2018 & BPF & 407 \\
\hline $\begin{array}{l}\text { ÉSTERES POLIGLICÉRIDOS DE ÁCIDOS } \\
\text { GRASOS }\end{array}$ & 475 & 2018 & $1000 \mathrm{mg} / \mathrm{kg}$ & 410 \\
\hline
\end{tabular}




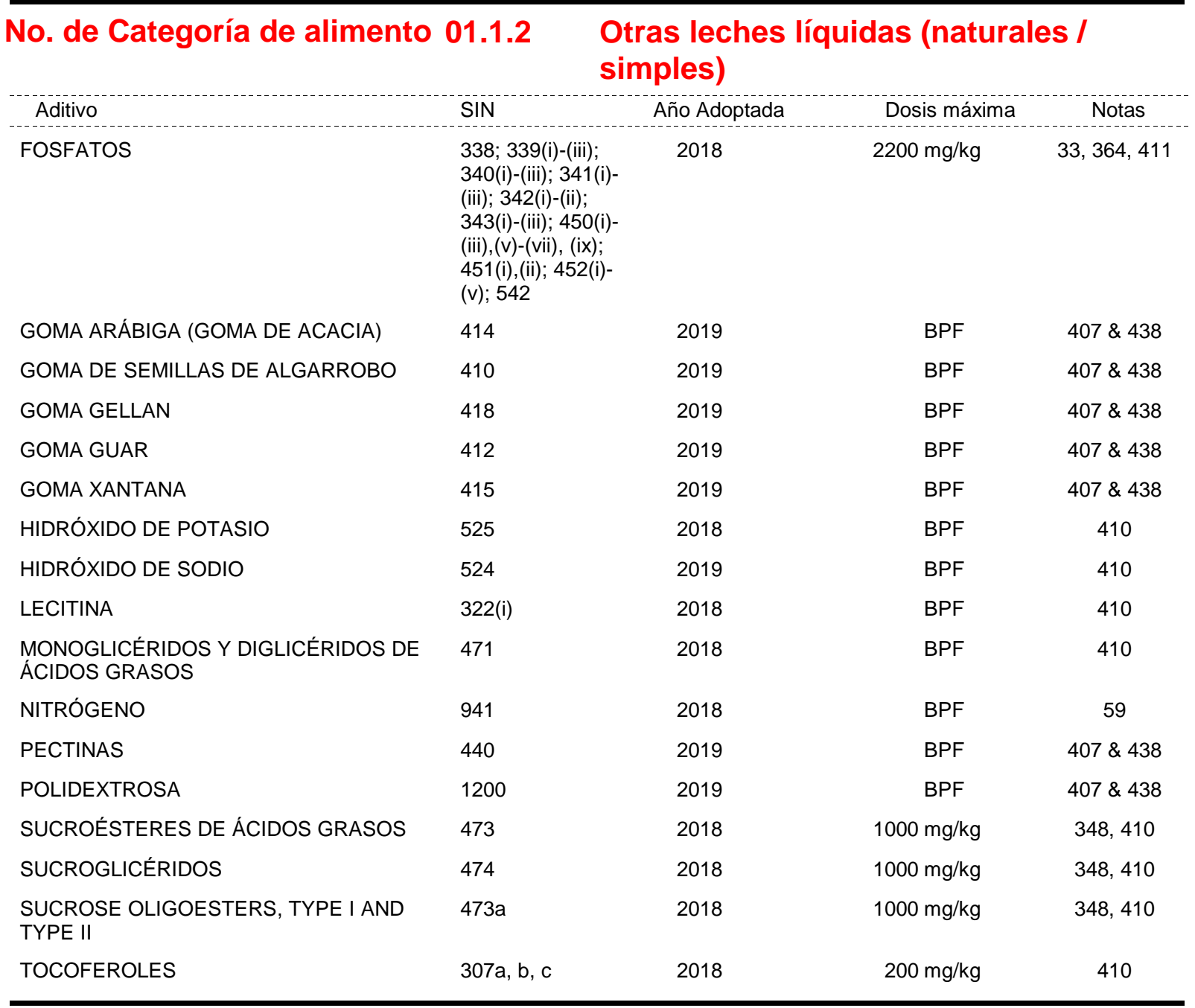

No. de Categoría de alimento 01.1.3 Suero de mantequilla líquido (natural / simple)

\begin{tabular}{|c|c|c|c|c|}
\hline Aditivo & $\operatorname{SIN}$ & Año Adoptada & Dosis máxima & Notas \\
\hline CARBONATO ÁCIDO DE MAGNESIO & 504(ii) & 2013 & BPF & 261 \\
\hline CARBONATO DE MAGNESIO & $504(i)$ & 2013 & BPF & 261 \\
\hline CITRATO DÍACIDO DE POTASIO & 332(i) & 2013 & BPF & 261 \\
\hline CITRATO DÍACIDO DE SODIO & $331(\mathrm{i})$ & 2013 & BPF & 261 \\
\hline CITRATO TRIPOTÁSICO & 332(ii) & 2013 & BPF & 261 \\
\hline CITRATO TRISÓDICO & 331 (iii) & 2013 & BPF & 261 \\
\hline FOSFATOS & $\begin{array}{l}\text { 338; 339(i)-(iii); } \\
340 \text { (i)-(iii); 341(i)- } \\
\text { (iii); 342(i)-(ii); } \\
343(\text { i)-(iii); } 450 \text { (i)- } \\
\text { (iii),(v)-(vii), (ix); } \\
\text { 451(i),(ii); 452(i)- } \\
\text { (v); } 542\end{array}$ & 2017 & $1500 \mathrm{mg} / \mathrm{kg}$ & $33,227 \& 397$ \\
\hline HIDRÓXIDO DE MAGNESIO & 528 & 2013 & BPF & 261 \\
\hline LACTATO DE POTASIO & 326 & 2013 & BPF & 261 \\
\hline LACTATO DE SODIO & 325 & 2013 & BPF & 261 \\
\hline
\end{tabular}


No. de Categoría de alimento 01.1.4 Bebidas lácteas líquidas aromatizadas

\begin{tabular}{|c|c|c|c|c|}
\hline Aditivo & SIN & Año Adoptada & Dosis máxima & Notas \\
\hline ACESULFAME DE POTASIO & 950 & 2019 & $350 \mathrm{mg} / \mathrm{kg}$ & $478 \& 188$ \\
\hline ALGINATO DE PROPILENGLICOL & 405 & 2017 & $1300 \mathrm{mg} / \mathrm{kg}$ & XS243 \\
\hline ALITAME & 956 & 2007 & $100 \mathrm{mg} / \mathrm{kg}$ & 161 \\
\hline AMARANTO & 123 & 2017 & $50 \mathrm{mg} / \mathrm{kg}$ & 52 \\
\hline AMARILLO DE QUINOLEÍNA & 104 & 2017 & $10 \mathrm{mg} / \mathrm{kg}$ & 52 \\
\hline AMARILLO OCASO FCF & 110 & 2008 & $300 \mathrm{mg} / \mathrm{kg}$ & 52 \\
\hline ASPARTAMO & 951 & 2019 & $600 \mathrm{mg} / \mathrm{kg}$ & $478,191 \& 405$ \\
\hline AZORRUBINA (CARMOISINA) & 122 & 2017 & $150 \mathrm{mg} / \mathrm{kg}$ & 52 \\
\hline AZUL BRILLANTE FCF & 133 & 2008 & $150 \mathrm{mg} / \mathrm{kg}$ & 52 \\
\hline CANTAXANTINA & $161 \mathrm{~g}$ & 2011 & $15 \mathrm{mg} / \mathrm{kg}$ & $52 \& 170$ \\
\hline CARAMELO II - CARAMELO AL SULFITO & $150 \mathrm{~b}$ & 2017 & $2000 \mathrm{mg} / \mathrm{kg}$ & $52 \& 400$ \\
\hline $\begin{array}{l}\text { CARAMELO III - CARAMELO AL } \\
\text { AMONÍACO }\end{array}$ & $150 c$ & 2009 & $2000 \mathrm{mg} / \mathrm{kg}$ & 52 \\
\hline $\begin{array}{l}\text { CARAMELO IV - CARAMELO AL SULFITO } \\
\text { AMÓNICO }\end{array}$ & $150 d$ & 2011 & $2000 \mathrm{mg} / \mathrm{kg}$ & 52 \\
\hline CARMINES & 120 & 2008 & $150 \mathrm{mg} / \mathrm{kg}$ & $52 \& 178$ \\
\hline CAROTENOIDES & $160 a(i), a(i i i), e, f$ & 2017 & $150 \mathrm{mg} / \mathrm{kg}$ & $52 \& 402$ \\
\hline CAROTENOS, BETA-, VEGETALES & $160 a(i i)$ & 2017 & $1000 \mathrm{mg} / \mathrm{kg}$ & $52 \& 401$ \\
\hline CICLAMATOS & 952(i), (ii), (iv) & 2019 & $250 \mathrm{mg} / \mathrm{kg}$ & $17 \& 477$ \\
\hline $\begin{array}{l}\text { CLOROFILAS Y CLOROFILINAS, } \\
\text { COMPLEJOS CUPRICOS }\end{array}$ & 141 (i),(ii) & 2009 & $50 \mathrm{mg} / \mathrm{kg}$ & $52 \& 190$ \\
\hline CURCUMINA & $100(\mathrm{i})$ & 2017 & $150 \mathrm{mg} / \mathrm{kg}$ & $52 \& 402$ \\
\hline ESTEAROIL LACTILATOS & 481(i), 482(i) & 2017 & $1000 \mathrm{mg} / \mathrm{kg}$ & \\
\hline $\begin{array}{l}\text { ÉSTERES DE PROPILENGLICOL DE } \\
\text { ÁCIDOS GRASOS }\end{array}$ & 477 & 2001 & $5000 \mathrm{mg} / \mathrm{kg}$ & \\
\hline $\begin{array}{l}\text { ÉSTERES DE SORBITÁN DE ÁCIDOS } \\
\text { GRASOS }\end{array}$ & $491-495$ & 2017 & $5000 \mathrm{mg} / \mathrm{kg}$ & \\
\hline $\begin{array}{l}\text { ÉSTERES DIACETILTARTÁRICOS Y DE } \\
\text { ÁCIDOS GRASOS DE GLICEROL }\end{array}$ & $472 e$ & 2017 & $5000 \mathrm{mg} / \mathrm{kg}$ & 399 \\
\hline $\begin{array}{l}\text { ÉSTERES POLIGLICÉRIDOS DE ÁCIDOS } \\
\text { GRASOS }\end{array}$ & 475 & 2017 & $2000 \mathrm{mg} / \mathrm{kg}$ & \\
\hline EXTRACTO DE PIEL DE UVA & 163(ii) & 2017 & $100 \mathrm{mg} / \mathrm{kg}$ & $52,181 \& 402$ \\
\hline $\begin{array}{l}\text { EXTRACTOS DE ANNATO, BASE DE } \\
\text { BIXINA }\end{array}$ & $160 \mathrm{~b}(\mathrm{i})$ & 2017 & $20 \mathrm{mg} / \mathrm{kg}$ & $8 \& 52$ \\
\hline $\begin{array}{l}\text { EXTRACTOS DE ANNATO, BASE DE } \\
\text { NORBIXINA }\end{array}$ & $160 b(i i)$ & 2017 & $10 \mathrm{mg} / \mathrm{kg}$ & $52 \& 185$ \\
\hline FOSFATOS & $\begin{array}{l}\text { 338; 339(i)-(iii); } \\
340 \text { (i)-(iii); } 341 \text { (i)- } \\
\text { (iii); 342(i)-(ii); } \\
343(\text { i)-(iii); } 450 \text { (i)- } \\
\text { (iii),(v)-(vii), (ix); } \\
451 \text { (i),(ii); 452(i)- } \\
\text { (v); } 542\end{array}$ & 2017 & $1500 \mathrm{mg} / \mathrm{kg}$ & $33,364 \& 398$ \\
\hline GLICÓSIDOS DE ESTEVIOL & $960 \mathrm{a}, 960 \mathrm{~b}(\mathrm{i})$ & 2017 & $200 \mathrm{mg} / \mathrm{kg}$ & $26 \&$ XS243 \\
\hline INDIGOTINA (CARMÍN DE ÍNDIGO) & 132 & 2017 & $300 \mathrm{mg} / \mathrm{kg}$ & $52 \& 402$ \\
\hline LUTEIN DE TAGETES ERECTA & $161 \mathrm{~b}(\mathrm{i})$ & 2017 & $100 \mathrm{mg} / \mathrm{kg}$ & $52 \& 400$ \\
\hline MARRÓN HT & 155 & 2017 & $150 \mathrm{mg} / \mathrm{kg}$ & 52 \\
\hline
\end{tabular}




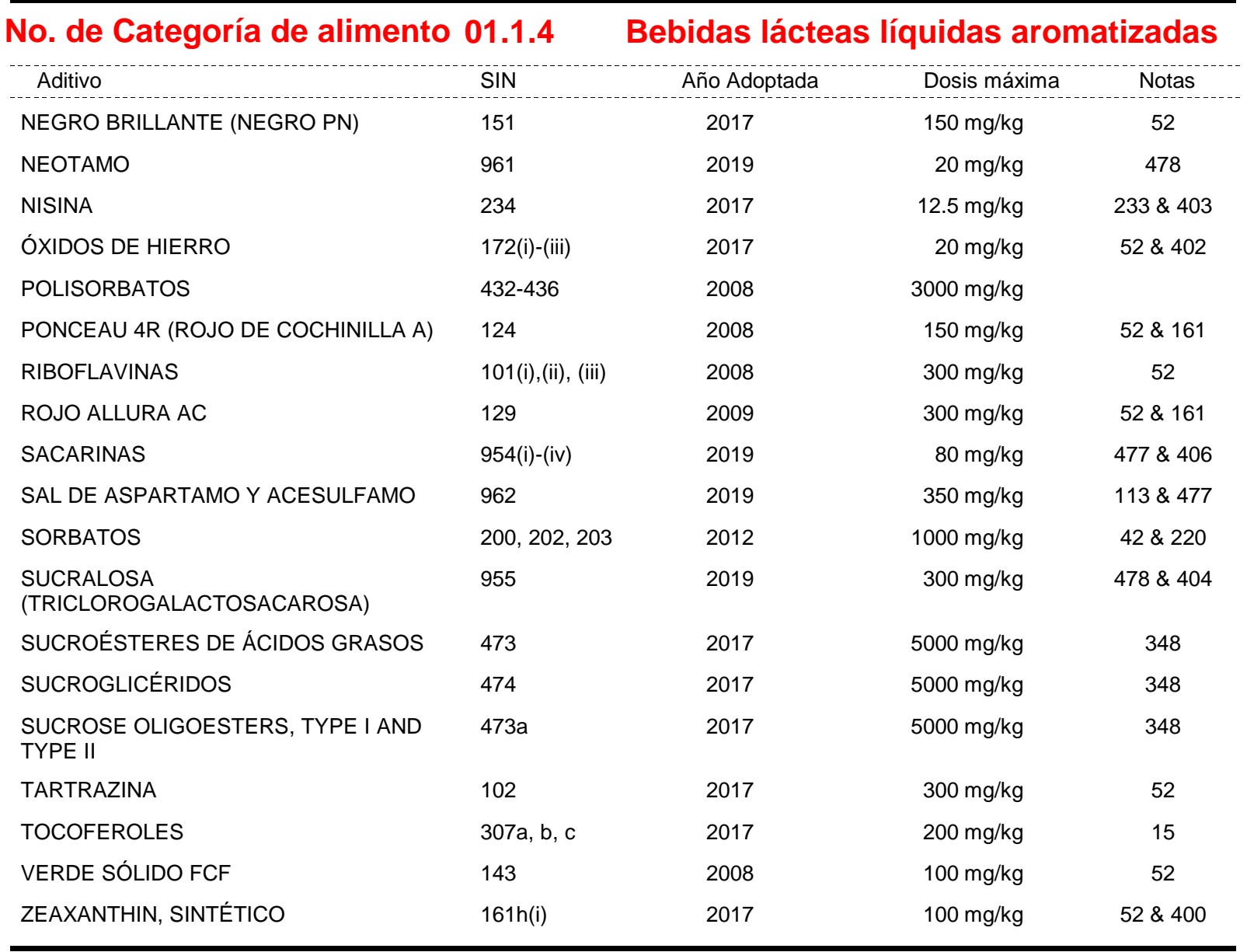

No. de Categoría de alimento 01.2

\section{Productos lácteos fermentados y} cuajados (naturales / simples)

\begin{tabular}{|c|c|c|c|c|}
\hline Aditivo & SIN & Año Adoptada & Dosis máxima & Notas \\
\hline FOSFATOS & $\begin{array}{l}338 ; 339(i)-(i i i) ; \\
340(\mathrm{i})-(\mathrm{iii}) ; 341(\mathrm{i})- \\
\text { (iii); 342(i)-(ii); } \\
\text { 343(i)-(iii); 450(i)- } \\
\text { (iii),(v)-(vii), (ix); } \\
\text { 451(i),(ii); 452(i)- } \\
\text { (v); } 542\end{array}$ & 2010 & $1000 \mathrm{mg} / \mathrm{kg}$ & 33 \\
\hline
\end{tabular}

Leches fermentadas (naturales / simples)

\begin{tabular}{|c|c|c|c|c|}
\hline Aditivo & SIN & Año Adoptada & Dosis máxima & Notas \\
\hline $\begin{array}{l}\text { CARAMELO IV - CARAMELO AL SULFITO } \\
\text { AMÓNICO }\end{array}$ & $150 d$ & 1999 & $150 \mathrm{mg} / \mathrm{kg}$ & 12 \\
\hline
\end{tabular}

No. de Categoría de alimento 01.2.1.1 Leches fermentadas (naturales / simples) sin tratamiento térmico después de la fermentación

\begin{tabular}{|c|c|c|c|c|}
\hline Aditivo & SIN & Año Adoptada & Dosis máxima & Notas \\
\hline ACETATO DE ALMIDÓN & 1420 & 2013 & BPF & $234 \& 235$ \\
\hline ADIPATO DE DIALMIDÓN ACETILADO & 1422 & 2013 & BPF & $234 \& 235$ \\
\hline
\end{tabular}




\section{No. de Categoría de alimento 01.2.1.1 Leches fermentadas (naturales / simples) sin tratamiento térmico después de la fermentación}

\begin{tabular}{|c|c|c|c|c|}
\hline Aditivo & SIN & Año Adoptada & Dosis máxima & Notas \\
\hline AGAR & 406 & 2015 & BPF & $234 \& 235$ \\
\hline ALGA EUCHEUMA ELABORADA & $407 a$ & 2015 & BPF & $234 \& 235$ \\
\hline ALGINATO DE PROPILENGLICOL & 405 & 2017 & $5000 \mathrm{mg} / \mathrm{kg}$ & $234 \& 235$ \\
\hline ALGINATO DE SODIO & 401 & 2015 & BPF & $234 \& 235$ \\
\hline ALMIDÓN BLANQUEADO & 1403 & 2013 & BPF & $234 \& 235$ \\
\hline ALMIDÓN HIDROXIPROPÍLICO & 1440 & 2013 & BPF & $234 \& 235$ \\
\hline ALMIDÓN OXIDADO & 1404 & 2013 & BPF & $234 \& 235$ \\
\hline ALMIDÓN TRATADO CON ÁCIDO & 1401 & 2013 & BPF & $234 \& 235$ \\
\hline ALMIDÓN TRATADO CON ÁLCALIS & 1402 & 2013 & BPF & $234 \& 235$ \\
\hline ALMIDONES TRATADOS CON ENZIMAS & 1405 & 2013 & BPF & $234 \& 235$ \\
\hline $\begin{array}{l}\text { CARBOXIMETILCELULOSA SÓDICA } \\
\text { (GOMA DE CELULOSA) }\end{array}$ & 466 & 2015 & BPF & $234 \& 235$ \\
\hline CARRAGENINA & 407 & 2015 & BPF & $234 \& 235$ \\
\hline CELULOSA EN POLVO & 460(ii) & 2013 & BPF & $234 \& 235$ \\
\hline $\begin{array}{l}\text { CELULOSA MICROCRISTALINA (GEL DE } \\
\text { CELULOSA) }\end{array}$ & $460(i)$ & 2013 & BPF & $234 \& 235$ \\
\hline DEXTRINAS, ALMIDÓN TOSTADO & 1400 & 2013 & BPF & $234 \& 235$ \\
\hline FOSFATO DE DIALMIDÓN & 1412 & 2013 & BPF & $234 \& 235$ \\
\hline FOSFATO DE DIALMIDÓN ACETILADO & 1414 & 2013 & BPF & $234 \& 235$ \\
\hline FOSFATO DE DIALMIDÓN FOSFATADO & 1413 & 2013 & BPF & $234 \& 235$ \\
\hline FOSFATO DE HIDROXIPROPIL DIALMIDÓN & 1442 & 2013 & BPF & $234 \& 235$ \\
\hline FOSFATO DE MONOALMIDÓN & 1410 & 2013 & BPF & $234 \& 235$ \\
\hline GOMA ARÁBIGA (GOMA DE ACACIA) & 414 & 2015 & BPF & $234 \& 235$ \\
\hline GOMA DE SEMILLAS DE ALGARROBO & 410 & 2013 & BPF & $234 \& 235$ \\
\hline GOMA GELLAN & 418 & 2013 & BPF & $234 \& 235$ \\
\hline GOMA GUAR & 412 & 2015 & BPF & $234 \& 235$ \\
\hline GOMA KARAYA & 416 & 2013 & 200 mg/kg & $234 \& 235$ \\
\hline GOMA TARA & 417 & 2013 & BPF & $234 \& 235$ \\
\hline GOMA XANTANA & 415 & 2013 & BPF & $234 \& 235$ \\
\hline HARINA KONJAC & 425 & 2015 & BPF & $234 \& 235$ \\
\hline $\begin{array}{l}\text { MONOGLICÉRIDOS Y DIGLICÉRIDOS DE } \\
\text { ÁCIDOS GRASOS }\end{array}$ & 471 & 2015 & BPF & $234 \& 235$ \\
\hline $\begin{array}{l}\text { OCTENILSUCCIONATO SÓDICO DE } \\
\text { ALMIDÓN }\end{array}$ & 1450 & 2013 & BPF & $234 \& 235$ \\
\hline PECTINAS & 440 & 2013 & BPF & $234 \& 235$ \\
\hline POLIDEXTROSA & 1200 & 2015 & BPF & $234 \& 235$ \\
\hline
\end{tabular}

No. de Categoría de alimento 01.2.1.2 Leches fermentadas (naturales / simples) tratadas térmicamente después de la fermentación 
No. de Categoría de alimento 01.2.1.2 Leches fermentadas (naturales / simples) tratadas térmicamente después de la fermentación

\begin{tabular}{|c|c|c|c|c|}
\hline Aditivo & SIN & Año Adoptada & Dosis máxima & Notas \\
\hline ACETATO DE ALMIDÓN & 1420 & 2013 & BPF & 234 \\
\hline ÁCIDO ALGÍNICO & 400 & 2013 & BPF & 234 \\
\hline ÁCIDO CÍTRICO & 330 & 2013 & BPF & \\
\hline ÁCIDO MÁLICO, DL- & 296 & 2013 & BPF & \\
\hline ADIPATO DE DIALMIDÓN ACETILADO & 1422 & 2013 & BPF & 234 \\
\hline ADIPATOS & 355 & 2016 & $1500 \mathrm{mg} / \mathrm{kg}$ & 1 \\
\hline AGAR & 406 & 2015 & BPF & 234 \\
\hline ALGA EUCHEUMA ELABORADA & $407 a$ & 2015 & BPF & 234 \\
\hline ALGINATO DE AMONIO & 403 & 2013 & BPF & 234 \\
\hline ALGINATO DE CALCIO & 404 & 2013 & BPF & 234 \\
\hline ALGINATO DE POTASIO & 402 & 2013 & BPF & 234 \\
\hline ALGINATO DE PROPILENGLICOL & 405 & 2017 & $5000 \mathrm{mg} / \mathrm{kg}$ & 234 \\
\hline ALGINATO DE SODIO & 401 & 2013 & BPF & 234 \\
\hline ALMIDÓN BLANQUEADO & 1403 & 2013 & BPF & 234 \\
\hline ALMIDÓN HIDROXIPROPÍLICO & 1440 & 2013 & BPF & 234 \\
\hline ALMIDÓN OXIDADO & 1404 & 2013 & BPF & 234 \\
\hline ALMIDÓN TRATADO CON ÁCIDO & 1401 & 2013 & BPF & 234 \\
\hline ALMIDÓN TRATADO CON ÁLCALIS & 1402 & 2013 & BPF & 234 \\
\hline ALMIDONES TRATADOS CON ENZIMAS & 1405 & 2013 & BPF & 234 \\
\hline CARBONATO ÁCIDO DE MAGNESIO & 504(ii) & 2013 & BPF & \\
\hline CARBONATO ÁCIDO DE SODIO & 500 (ii) & 2013 & BPF & \\
\hline CARBONATO DE CALCIO & $170(\mathrm{i})$ & 2013 & BPF & \\
\hline CARBONATO DE MAGNESIO & $504(i)$ & 2013 & BPF & \\
\hline CARBONATO DE POTASIO & $501(i)$ & 2013 & BPF & 234 \\
\hline CARBONATO DE SODIO & $500(\mathrm{i})$ & 2013 & BPF & \\
\hline $\begin{array}{l}\text { CARBOXIMETILCELULOSA SÓDICA } \\
\text { (GOMA DE CELULOSA) }\end{array}$ & 466 & 2013 & BPF & 234 \\
\hline CARRAGENINA & 407 & 2015 & BPF & 234 \\
\hline CELULOSA EN POLVO & 460(ii) & 2013 & BPF & 234 \\
\hline $\begin{array}{l}\text { CELULOSA MICROCRISTALINA (GEL DE } \\
\text { CELULOSA) }\end{array}$ & 460 (i) & 2013 & BPF & 234 \\
\hline CITRATO DÍACIDO DE POTASIO & 332(i) & 2013 & BPF & \\
\hline CITRATO DÍACIDO DE SODIO & $331(\mathrm{i})$ & 2013 & BPF & 234 \\
\hline CITRATO TRIPOTÁSICO & 332(ii) & 2013 & BPF & 234 \\
\hline CLORURO DE MAGNESIO & 511 & 2013 & BPF & 234 \\
\hline DEXTRINAS, ALMIDÓN TOSTADO & 1400 & 2013 & BPF & 234 \\
\hline DIÓXIDO DE CARBONO & 290 & 2014 & BPF & 59 \\
\hline $\begin{array}{l}\text { ÉSTERES ACÉTICOS Y DE ÁCIDOS } \\
\text { GRASOS DE GLICEROL }\end{array}$ & $472 a$ & 2013 & BPF & 234 \\
\hline
\end{tabular}




\section{No. de Categoría de alimento 01.2.1.2 Leches fermentadas (naturales / simples) tratadas térmicamente después de la fermentación}

\begin{tabular}{|c|c|c|c|c|}
\hline Aditivo & SIN & Año Adoptada & Dosis máxima & Notas \\
\hline $\begin{array}{l}\text { ÉSTERES CÍTRICOS Y DE ÁCIDOS } \\
\text { GRASOS DE GLICEROL }\end{array}$ & $472 c$ & 2013 & BPF & 234 \\
\hline $\begin{array}{l}\text { ÉSTERES DIACETILTARTÁRICOS Y DE } \\
\text { ÁCIDOS GRASOS DE GLICEROL }\end{array}$ & $472 e$ & 2005 & $5000 \mathrm{mg} / \mathrm{kg}$ & \\
\hline $\begin{array}{l}\text { ÉSTERES LÁCTICOS Y DE ÁCIDOS } \\
\text { GRASOS DE GLICEROL }\end{array}$ & $472 b$ & 2013 & BPF & 234 \\
\hline FOSFATO DE DIALMIDÓN & 1412 & 2013 & BPF & 234 \\
\hline FOSFATO DE DIALMIDÓN ACETILADO & 1414 & 2013 & BPF & 234 \\
\hline FOSFATO DE DIALMIDÓN FOSFATADO & 1413 & 2013 & BPF & 234 \\
\hline FOSFATO DE MONOALMIDÓN & 1410 & 2013 & BPF & 234 \\
\hline GLUCONO-DELTA-LACTONA & 575 & 2013 & BPF & \\
\hline GOMA ARÁBIGA (GOMA DE ACACIA) & 414 & 2013 & BPF & 234 \\
\hline GOMA DE SEMILLAS DE ALGARROBO & 410 & 2013 & BPF & 234 \\
\hline GOMA GELLAN & 418 & 2013 & BPF & 234 \\
\hline GOMA GUAR & 412 & 2013 & BPF & 234 \\
\hline GOMA KARAYA & 416 & 2013 & BPF & 234 \\
\hline GOMA TARA & 417 & 2013 & BPF & 234 \\
\hline GOMA TRAGACANTO & 413 & 2013 & BPF & 234 \\
\hline GOMA XANTANA & 415 & 2013 & BPF & 234 \\
\hline HARINA KONJAC & 425 & 2013 & BPF & 234 \\
\hline HIDRÓXIDO DE AMÓNIO & 527 & 2013 & BPF & \\
\hline HIDRÓXIDO DE CALCIO & 526 & 2013 & BPF & \\
\hline HIDRÓXIDO DE MAGNESIO & 528 & 2013 & BPF & \\
\hline HIDRÓXIDO DE SODIO & 524 & 2013 & BPF & \\
\hline HIDROXIPROPILCELULOSA & 463 & 2013 & BPF & 234 \\
\hline HIDROXIPROPILMETILCELULOSA & 464 & 2013 & BPF & 234 \\
\hline LACTATO DE CALCIO & 327 & 2013 & BPF & \\
\hline LACTATO DE POTASIO & 326 & 2013 & BPF & \\
\hline LACTATO DE SODIO & 325 & 2013 & BPF & \\
\hline METILCELULOSA & 461 & 2013 & BPF & 234 \\
\hline METILETILCELULOSA & 465 & 2013 & BPF & 234 \\
\hline $\begin{array}{l}\text { MONOGLICÉRIDOS Y DIGLICÉRIDOS DE } \\
\text { ÁCIDOS GRASOS }\end{array}$ & 471 & 2015 & BPF & 234 \\
\hline NITRÓGENO & 941 & 2014 & BPF & 59 \\
\hline $\begin{array}{l}\text { OCTENILSUCCIONATO SÓDICO DE } \\
\text { ALMIDÓN }\end{array}$ & 1450 & 2013 & BPF & 234 \\
\hline ÓXIDO DE CALCIO & 529 & 2013 & BPF & \\
\hline ÓXIDO NITROSO & 942 & 2014 & BPF & 59 \\
\hline PECTINAS & 440 & 2013 & BPF & 234 \\
\hline POLIDEXTROSA & 1200 & 2015 & BPF & 234 \\
\hline
\end{tabular}


No. de Categoría de alimento 01.2.1.2 Leches fermentadas (naturales / simples) tratadas térmicamente después de la fermentación

\begin{tabular}{|c|c|c|c|c|}
\hline Aditivo & SIN & Año Adoptada & Dosis máxima & Notas \\
\hline $\begin{array}{l}\text { SAL DE ÁCIDO OLEICO CON CALCIO, } \\
\text { POTASIO Y SODIO }\end{array}$ & 470(ii) & 2013 & BPF & 234 \\
\hline $\begin{array}{l}\text { SAL MIRÍSTICA, PALMÍTICA Y ÁCIDOS } \\
\text { ESTEÁRICOS CON AMONIO, CALCIO, } \\
\text { POTASIO Y SODIO }\end{array}$ & 470(i) & 2013 & BPF & 234 \\
\hline TARTRATOS & 334, 335(ii), 337 & 2016 & $2000 \mathrm{mg} / \mathrm{kg}$ & $45 \& 230$ \\
\hline
\end{tabular}

No. de Categoría de alimento 01.2.2 Cuajada (natural / simple)

\begin{tabular}{|c|c|c|c|c|}
\hline Aditivo & SIN & Año Adoptada & Dosis máxima & Notas \\
\hline ACETATO DE ALMIDÓN & 1420 & 2013 & BPF & \\
\hline ADIPATO DE DIALMIDÓN ACETILADO & 1422 & 2013 & BPF & \\
\hline AGAR & 406 & 2015 & BPF & \\
\hline ALGA EUCHEUMA ELABORADA & $407 a$ & 2015 & BPF & \\
\hline ALGINATO DE SODIO & 401 & 2015 & BPF & \\
\hline ALMIDÓN BLANQUEADO & 1403 & 2013 & BPF & \\
\hline ALMIDÓN HIDROXIPROPÍLICO & 1440 & 2013 & BPF & \\
\hline ALMIDÓN OXIDADO & 1404 & 2013 & BPF & \\
\hline ALMIDÓN TRATADO CON ÁCIDO & 1401 & 2013 & BPF & \\
\hline ALMIDÓN TRATADO CON ÁLCALIS & 1402 & 2013 & BPF & \\
\hline ALMIDONES TRATADOS CON ENZIMAS & 1405 & 2013 & BPF & \\
\hline $\begin{array}{l}\text { CARAMELO IV - CARAMELO AL SULFITO } \\
\text { AMÓNICO }\end{array}$ & $150 d$ & 1999 & BPF & \\
\hline CARBONATO DE CALCIO & 170 (i) & 2013 & BPF & \\
\hline $\begin{array}{l}\text { CARBOXIMETILCELULOSA SÓDICA } \\
\text { (GOMA DE CELULOSA) }\end{array}$ & 466 & 2013 & BPF & \\
\hline CARRAGENINA & 407 & 2015 & BPF & \\
\hline CELULOSA EN POLVO & 460 (ii) & 2013 & BPF & \\
\hline $\begin{array}{l}\text { CELULOSA MICROCRISTALINA (GEL DE } \\
\text { CELULOSA) }\end{array}$ & 460 (i) & 2013 & BPF & \\
\hline CITRATO DÍACIDO DE POTASIO & 332(i) & 2013 & BPF & \\
\hline CITRATO DÍACIDO DE SODIO & $331(\mathrm{i})$ & 2013 & BPF & \\
\hline CITRATO TRIPOTÁSICO & 332(ii) & 2013 & BPF & \\
\hline CITRATO TRISÓDICO & 331 (iii) & 2013 & BPF & \\
\hline CLORURO DE MAGNESIO & 511 & 2013 & BPF & \\
\hline DEXTRINAS, ALMIDÓN TOSTADO & 1400 & 2013 & BPF & \\
\hline DIÓXIDO DE CARBONO & 290 & 2014 & BPF & 59 \\
\hline $\begin{array}{l}\text { ÉSTERES ACÉTICOS Y DE ÁCIDOS } \\
\text { GRASOS DE GLICEROL }\end{array}$ & $472 a$ & 2013 & BPF & \\
\hline $\begin{array}{l}\text { ÉSTERES CÍTRICOS Y DE ÁCIDOS } \\
\text { GRASOS DE GLICEROL }\end{array}$ & $472 c$ & 2013 & BPF & \\
\hline $\begin{array}{l}\text { ÉSTERES DIACETILTARTÁRICOS Y DE } \\
\text { ÁCIDOS GRASOS DE GLICEROL }\end{array}$ & $472 \mathrm{e}$ & 2005 & $5000 \mathrm{mg} / \mathrm{kg}$ & \\
\hline
\end{tabular}




\begin{tabular}{|c|c|c|c|c|}
\hline \multicolumn{2}{|c|}{ No. de Categoría de alimento 01.2.2 } & \multicolumn{2}{|c|}{ Cuajada (natural / simple) } & \multirow[b]{2}{*}{ Notas } \\
\hline Aditivo & SIN & Año Adoptada & Dosis máxima & \\
\hline $\begin{array}{l}\text { ÉSTERES LÁCTICOS Y DE ÁCIDOS } \\
\text { GRASOS DE GLICEROL }\end{array}$ & $472 b$ & 2013 & BPF & \\
\hline FOSFATO DE DIALMIDÓN & 1412 & 2013 & BPF & \\
\hline FOSFATO DE DIALMIDÓN ACETILADO & 1414 & 2013 & BPF & \\
\hline FOSFATO DE DIALMIDÓN FOSFATADO & 1413 & 2013 & BPF & \\
\hline FOSFATO DE HIDROXIPROPIL DIALMIDÓN & 1442 & 2013 & BPF & \\
\hline FOSFATO DE MONOALMIDÓN & 1410 & 2013 & BPF & \\
\hline GLICEROL & 422 & 2014 & BPF & \\
\hline GOMA ARÁBIGA (GOMA DE ACACIA) & 414 & 2013 & BPF & \\
\hline GOMA DE SEMILLAS DE ALGARROBO & 410 & 2013 & BPF & \\
\hline GOMA GUAR & 412 & 2013 & BPF & \\
\hline GOMA TARA & 417 & 2013 & BPF & \\
\hline GOMA TRAGACANTO & 413 & 2013 & BPF & \\
\hline GOMA XANTANA & 415 & 2015 & BPF & \\
\hline HARINA KONJAC & 425 & 2015 & BPF & \\
\hline HIDROXIPROPILCELULOSA & 463 & 2013 & BPF & \\
\hline HIDROXIPROPILMETILCELULOSA & 464 & 2013 & BPF & \\
\hline LECITINA & 322(i) & 2013 & BPF & \\
\hline MANITOL & 421 & 2013 & BPF & \\
\hline METILCELULOSA & 461 & 2013 & BPF & \\
\hline METILETILCELULOSA & 465 & 2013 & BPF & \\
\hline $\begin{array}{l}\text { MONOGLICÉRIDOS Y DIGLICÉRIDOS DE } \\
\text { ÁCIDOS GRASOS }\end{array}$ & 471 & 2015 & BPF & \\
\hline NITRÓGENO & 941 & 2014 & BPF & 59 \\
\hline $\begin{array}{l}\text { OCTENILSUCCIONATO SÓDICO DE } \\
\text { ALMIDÓN }\end{array}$ & 1450 & 2013 & BPF & \\
\hline PECTINAS & 440 & 2013 & BPF & \\
\hline POLIDEXTROSA & 1200 & 2015 & BPF & \\
\hline $\begin{array}{l}\text { SAL DE ÁCIDO OLEICO CON CALCIO, } \\
\text { POTASIO Y SODIO }\end{array}$ & 470(ii) & 2013 & BPF & \\
\hline $\begin{array}{l}\text { SAL MIRÍSTICA, PALMÍTICA Y ÁCIDOS } \\
\text { ESTEÁRICOS CON AMONIO, CALCIO, } \\
\text { POTASIO Y SODIO }\end{array}$ & $470(\mathrm{i})$ & 2013 & BPF & \\
\hline SORBATOS & $200,202,203$ & 2012 & $1000 \mathrm{mg} / \mathrm{kg}$ & 42 \\
\hline
\end{tabular}

\section{No. de Categoría de alimento 01.3.1 Leche condensada (natural / simple)}

\begin{tabular}{|c|c|c|c|c|}
\hline Aditivo & SIN & Año Adoptada & Dosis máxima & Notas \\
\hline FOSFATOS & $\begin{array}{l}\text { 338; 339(i)-(iii); } \\
\text { 340(i)-(iii); 341(i)- } \\
\text { (iii); 342(i)-(ii); } \\
343(\mathrm{i}) \text {-(iii); } 450 \text { (i)- } \\
\text { (iii),(v)-(vii), (ix); } \\
\text { 451(i),(ii); 452(i)- } \\
\text { (v); } 542\end{array}$ & 2012 & $880 \mathrm{mg} / \mathrm{kg}$ & 33 \\
\hline
\end{tabular}




\begin{tabular}{|c|c|c|c|c|}
\hline \multicolumn{2}{|c|}{ No. de Categoría de alimento 01.3.2 } & \multicolumn{2}{|c|}{ Blanqueadores de bebidas } & \multirow[b]{2}{*}{ Notas } \\
\hline Aditivo & SIN & Año Adoptada & Dosis máxima & \\
\hline ACESULFAME DE POTASIO & 950 & 2008 & $2000 \mathrm{mg} / \mathrm{kg}$ & $161 \& 188$ \\
\hline ALGINATO DE PROPILENGLICOL & 405 & 2016 & $5000 \mathrm{mg} / \mathrm{kg}$ & XS250 \& XS252 \\
\hline ASPARTAMO & 951 & 2008 & $6000 \mathrm{mg} / \mathrm{kg}$ & $161 \& 191$ \\
\hline BUTILHIDROXIANISOL & 320 & 2007 & $100 \mathrm{mg} / \mathrm{kg}$ & $15 \& 195$ \\
\hline BUTILHIDROXITOLUENO & 321 & 2007 & $100 \mathrm{mg} / \mathrm{kg}$ & $15 \& 195$ \\
\hline $\begin{array}{l}\text { CARAMELO III - CARAMELO AL } \\
\text { AMONÍACO }\end{array}$ & $150 c$ & 2009 & $1000 \mathrm{mg} / \mathrm{kg}$ & \\
\hline $\begin{array}{l}\text { CARAMELO IV - CARAMELO AL SULFITO } \\
\text { AMÓNICO }\end{array}$ & $150 d$ & 2009 & $1000 \mathrm{mg} / \mathrm{kg}$ & \\
\hline CAROTENOIDES & $160 a(i), a(i i i), e, f$ & 2011 & $100 \mathrm{mg} / \mathrm{kg}$ & \\
\hline CAROTENOS, BETA-, VEGETALES & $160 a(i i)$ & 2005 & $1000 \mathrm{mg} / \mathrm{kg}$ & \\
\hline ESTEAROIL LACTILATOS & $481(\mathrm{i}), 482(\mathrm{i})$ & 2016 & $3000 \mathrm{mg} / \mathrm{kg}$ & XS250 \& XS252 \\
\hline ÉSTERES DE ASCORBILO & 304,305 & 2001 & $80 \mathrm{mg} / \mathrm{kg}$ & 10 \\
\hline $\begin{array}{l}\text { ÉSTERES DE PROPILENGLICOL DE } \\
\text { ÁCIDOS GRASOS }\end{array}$ & 477 & 2001 & $1000 \mathrm{mg} / \mathrm{kg}$ & \\
\hline $\begin{array}{l}\text { ÉSTERES DE SORBITÁN DE ÁCIDOS } \\
\text { GRASOS }\end{array}$ & $491-495$ & 2016 & $4000 \mathrm{mg} / \mathrm{kg}$ & XS250 \& XS252 \\
\hline $\begin{array}{l}\text { ÉSTERES DIACETILTARTÁRICOS Y DE } \\
\text { ÁCIDOS GRASOS DE GLICEROL }\end{array}$ & $472 \mathrm{e}$ & 2005 & $5000 \mathrm{mg} / \mathrm{kg}$ & \\
\hline $\begin{array}{l}\text { ÉSTERES POLIGLICÉRIDOS DE ÁCIDOS } \\
\text { GRASOS }\end{array}$ & 475 & 2016 & $5000 \mathrm{mg} / \mathrm{kg}$ & $\begin{array}{l}\text { 352, XS250 \& } \\
\text { XS252 }\end{array}$ \\
\hline FOSFATOS & $\begin{array}{l}\text { 338; 339(i)-(iii); } \\
340(\mathrm{i})-(\mathrm{iii}) ; 341 \text { (i)-- } \\
\text { (iii); 342(i)-(ii); } \\
343(\mathrm{i})-(\mathrm{iii}) ; 450(\mathrm{i})- \\
\text { (iii),(v)-(vii), (ix); } \\
\text { 451(i),(ii); } 452(\mathrm{i})- \\
\text { (v); } 542\end{array}$ & 2012 & $13000 \mathrm{mg} / \mathrm{kg}$ & 33 \\
\hline NEOTAMO & 961 & 2008 & $65 \mathrm{mg} / \mathrm{kg}$ & 161 \\
\hline POLISORBATOS & $432-436$ & 2007 & $4000 \mathrm{mg} / \mathrm{kg}$ & \\
\hline RIBOFLAVINAS & 101(i),(ii), (iii) & 2005 & $300 \mathrm{mg} / \mathrm{kg}$ & \\
\hline SILICATO DE SODIO Y ALUMINIO & 554 & 2013 & $570 \mathrm{mg} / \mathrm{kg}$ & $6 \& 260$ \\
\hline SORBATOS & $200,202,203$ & 2009 & $200 \mathrm{mg} / \mathrm{kg}$ & 42 \\
\hline $\begin{array}{l}\text { SUCRALOSA } \\
\text { (TRICLOROGALACTOSACAROSA) }\end{array}$ & 955 & 2008 & $580 \mathrm{mg} / \mathrm{kg}$ & 161 \\
\hline SUCROÉSTERES DE ÁCIDOS GRASOS & 473 & 2016 & $20000 \mathrm{mg} / \mathrm{kg}$ & $\begin{array}{l}\text { 348, XS250 \& } \\
\text { XS252 }\end{array}$ \\
\hline SUCROGLICÉRIDOS & 474 & 2016 & $20000 \mathrm{mg} / \mathrm{kg}$ & $\begin{array}{l}\text { 348, XS250 \& } \\
\quad \text { XS252 }\end{array}$ \\
\hline $\begin{array}{l}\text { SUCROSE OLIGOESTERS, TYPE I AND } \\
\text { TYPE II }\end{array}$ & $473 a$ & 2016 & $20000 \mathrm{mg} / \mathrm{kg}$ & $\begin{array}{l}\text { 348, XS250 \& } \\
\quad \text { XS252 }\end{array}$ \\
\hline TERBUTILHIDROQUINONA & 319 & 2007 & $100 \mathrm{mg} / \mathrm{kg}$ & $15 \& 195$ \\
\hline TOCOFEROLES & $307 a, b, c$ & 2017 & $200 \mathrm{mg} / \mathrm{kg}$ & XS250 \& XS252 \\
\hline
\end{tabular}

\section{No. de Categoría de alimento $01.4 \quad$ Nata (crema) (natural / simple) y productos análogos}

Aditivo




\begin{tabular}{|c|c|c|c|c|}
\hline \multicolumn{2}{|c|}{ No. de Categoría de alimento 01.4} & \multicolumn{3}{|c|}{$\begin{array}{l}\text { Nata (crema) (natural / simple) y } \\
\text { productos análogos }\end{array}$} \\
\hline Aditivo & SIN & Año Adoptada & Dosis máxima & Notas \\
\hline FOSFATOS & $\begin{array}{l}\text { 338; 339(i)-(iii); } \\
340 \text { (i)-(iii); 341(i)- } \\
\text { (iii); 342(i)-(ii); } \\
343(\text { i)-(iii); 450(i)- } \\
\text { (iii),(v)-(vii), (ix); } \\
\text { 451(i),(ii); 452(i)- } \\
\text { (v); } 542\end{array}$ & 2012 & $2200 \mathrm{mg} / \mathrm{kg}$ & 33 \\
\hline
\end{tabular}

\begin{tabular}{|c|c|c|c|c|}
\hline \multicolumn{2}{|c|}{ No. de Categoría de alimento 01.4.1 } & \multicolumn{3}{|c|}{$\begin{array}{l}\text { Nata (crema) pasteurizada (natural / } \\
\text { simple) }\end{array}$} \\
\hline Aditivo & $\sin$ & Año Adoptada & Dosis máxima & Notas \\
\hline ACETATO DE ALMIDÓN & 1420 & 2013 & BPF & 236 \\
\hline ÁCIDO ALGÍNICO & 400 & 2013 & BPF & 236 \\
\hline ÁCIDO CÍTRICO & 330 & 2013 & BPF & \\
\hline ÁCIDO LÁCTICO, L-, D- y DL- & 270 & 2013 & BPF & \\
\hline ADIPATO DE DIALMIDÓN ACETILADO & 1422 & 2013 & BPF & 236 \\
\hline AGAR & 406 & 2013 & BPF & 236 \\
\hline ALGA EUCHEUMA ELABORADA & $407 a$ & 2013 & BPF & 236 \\
\hline ALGINATO DE AMONIO & 403 & 2013 & BPF & 236 \\
\hline ALGINATO DE CALCIO & 404 & 2013 & BPF & 236 \\
\hline ALGINATO DE POTASIO & 402 & 2013 & BPF & 236 \\
\hline ALGINATO DE SODIO & 401 & 2013 & BPF & 236 \\
\hline ALMIDÓN HIDROXIPROPÍLICO & 1440 & 2013 & BPF & 236 \\
\hline ALMIDÓN OXIDADO & 1404 & 2013 & BPF & 236 \\
\hline CARBONATO ÁCIDO DE POTASIO & 501 (ii) & 2013 & BPF & 236 \\
\hline CARBONATO ÁCIDO DE SODIO & 500 (ii) & 2013 & BPF & \\
\hline CARBONATO DE CALCIO & $170(\mathrm{i})$ & 2013 & BPF & 236 \\
\hline CARBONATO DE POTASIO & $501(i)$ & 2013 & BPF & 236 \\
\hline CARBONATO DE SODIO & 500 (i) & 2013 & BPF & \\
\hline $\begin{array}{l}\text { CARBOXIMETILCELULOSA SÓDICA } \\
\text { (GOMA DE CELULOSA) }\end{array}$ & 466 & 2013 & BPF & 236 \\
\hline CARRAGENINA & 407 & 2013 & BPF & 236 \\
\hline CELULOSA EN POLVO & 460 (ii) & 2013 & BPF & 236 \\
\hline $\begin{array}{l}\text { CELULOSA MICROCRISTALINA (GEL DE } \\
\text { CELULOSA) }\end{array}$ & $460(i)$ & 2013 & BPF & 236 \\
\hline CITRATO DÍACIDO DE POTASIO & $332(i)$ & 2013 & BPF & 236 \\
\hline CITRATO DÍACIDO DE SODIO & $331(\mathrm{i})$ & 2013 & BPF & 236 \\
\hline CITRATO TRICÁLCICO & 333(iii) & 2013 & BPF & 236 \\
\hline CITRATO TRIPOTÁSICO & 332(ii) & 2013 & BPF & 236 \\
\hline CITRATO TRISÓDICO & 331 (iii) & 2013 & BPF & 236 \\
\hline CLORURO DE CALCIO & 509 & 2013 & BPF & 236 \\
\hline CLORURO DE POTASIO & 508 & 2013 & BPF & 236 \\
\hline ÉSTERES ACÉTICOS Y DE ÁCIDOS & $472 a$ & 2013 & BPF & 236 \\
\hline
\end{tabular}




\begin{tabular}{|c|c|c|c|c|}
\hline \multicolumn{2}{|c|}{ No. de Categoría de alimento 01.4.1 } & \multicolumn{3}{|c|}{$\begin{array}{l}\text { Nata (crema) pasteurizada (natural / } \\
\text { simple) }\end{array}$} \\
\hline Aditivo & SIN & Año Adoptada & Dosis máxima & Notas \\
\hline $\begin{array}{l}\text { ÉSTERES CÍTRICOS Y DE ÁCIDOS } \\
\text { GRASOS DE GLICEROL }\end{array}$ & $472 \mathrm{c}$ & 2013 & BPF & 236 \\
\hline $\begin{array}{l}\text { ÉSTERES LÁCTICOS Y DE ÁCIDOS } \\
\text { GRASOS DE GLICEROL }\end{array}$ & $472 b$ & 2013 & BPF & 236 \\
\hline $\begin{array}{l}\text { ÉSTERES POLIGLICÉRIDOS DE ÁCIDOS } \\
\text { GRASOS }\end{array}$ & 475 & 2016 & $6000 \mathrm{mg} / \mathrm{kg}$ & \\
\hline FOSFATO DE DIALMIDÓN & 1412 & 2013 & BPF & 236 \\
\hline FOSFATO DE DIALMIDÓN ACETILADO & 1414 & 2013 & BPF & 236 \\
\hline FOSFATO DE DIALMIDÓN FOSFATADO & 1413 & 2013 & BPF & 236 \\
\hline FOSFATO DE HIDROXIPROPIL DIALMIDÓN & 1442 & 2013 & BPF & 236 \\
\hline FOSFATO DE MONOALMIDÓN & 1410 & 2013 & BPF & 236 \\
\hline GOMA ARÁBIGA (GOMA DE ACACIA) & 414 & 2013 & BPF & 236 \\
\hline GOMA DE SEMILLAS DE ALGARROBO & 410 & 2013 & BPF & 236 \\
\hline GOMA GELLAN & 418 & 2013 & BPF & 236 \\
\hline GOMA GUAR & 412 & 2013 & BPF & 236 \\
\hline GOMA TARA & 417 & 2013 & BPF & 236 \\
\hline GOMA TRAGACANTO & 413 & 2013 & BPF & 236 \\
\hline GOMA XANTANA & 415 & 2013 & BPF & 236 \\
\hline HARINA KONJAC & 425 & 2013 & BPF & 236 \\
\hline HIDROXIPROPILCELULOSA & 463 & 2013 & BPF & 236 \\
\hline HIDROXIPROPILMETILCELULOSA & 464 & 2013 & BPF & 236 \\
\hline LACTATO DE CALCIO & 327 & 2013 & BPF & \\
\hline LACTATO DE POTASIO & 326 & 2013 & BPF & \\
\hline LACTATO DE SODIO & 325 & 2013 & BPF & \\
\hline LECITINA & $322(i)$ & 2013 & BPF & 236 \\
\hline METILCELULOSA & 461 & 2013 & BPF & 236 \\
\hline METILETILCELULOSA & 465 & 2013 & BPF & 236 \\
\hline $\begin{array}{l}\text { MONOGLICÉRIDOS Y DIGLICÉRIDOS DE } \\
\text { ÁCIDOS GRASOS }\end{array}$ & 471 & 2013 & BPF & 236 \\
\hline $\begin{array}{l}\text { OCTENILSUCCIONATO SÓDICO DE } \\
\text { ALMIDÓN }\end{array}$ & 1450 & 2013 & BPF & 236 \\
\hline PECTINAS & 440 & 2013 & BPF & 236 \\
\hline POLISORBATOS & $432-436$ & 2008 & $1000 \mathrm{mg} / \mathrm{kg}$ & \\
\hline SESQUICARBONATO DE SODIO & 500(iii) & 2013 & BPF & \\
\hline SULFATO DE CALCIO & 516 & 2013 & BPF & 236 \\
\hline
\end{tabular}

No. de Categoría de alimento 01.4.2 Natas (cremas) esterilizadas y UHT, natas (cremas) para batir o batidas y natas (cremas) de contenido de grasa reducido (naturales / simples)

\begin{tabular}{|c|c|c|c|c|}
\hline Aditivo & SIN & Año Adoptada & Dosis máxima & Notas \\
\hline ACETATO DE ALMIDÓN & 1420 & 2013 & BPF & \\
\hline
\end{tabular}



No. de Categoría de alimento 01.4.2 Natas (cremas) esterilizadas y UHT, natas (cremas) para batir o batidas y natas (cremas) de contenido de grasa reducido (naturales / simples)

\begin{tabular}{|c|c|c|c|c|}
\hline Aditivo & $\sin$ & Año Adoptada & Dosis máxima & Notas \\
\hline ÁCIDO ALGÍNICO & 400 & 2013 & BPF & \\
\hline ÁCIDO CÍTRICO & 330 & 2013 & BPF & \\
\hline ÁCIDO LÁCTICO, L-, D- y DL- & 270 & 2013 & BPF & \\
\hline ADIPATO DE DIALMIDÓN ACETILADO & 1422 & 2013 & BPF & \\
\hline AGAR & 406 & 2013 & BPF & \\
\hline ALGA EUCHEUMA ELABORADA & $407 a$ & 2013 & BPF & \\
\hline ALGINATO DE AMONIO & 403 & 2013 & BPF & \\
\hline ALGINATO DE CALCIO & 404 & 2013 & BPF & \\
\hline ALGINATO DE POTASIO & 402 & 2013 & BPF & \\
\hline ALGINATO DE SODIO & 401 & 2013 & BPF & \\
\hline ALMIDÓN BLANQUEADO & 1403 & 2013 & BPF & 236 \\
\hline ALMIDÓN HIDROXIPROPÍLICO & 1440 & 2013 & BPF & \\
\hline ALMIDÓN OXIDADO & 1404 & 2013 & BPF & 236 \\
\hline ALMIDÓN TRATADO CON ÁCIDO & 1401 & 2013 & BPF & 236 \\
\hline CARBONATO ÁCIDO DE POTASIO & 501 (ii) & 2013 & BPF & \\
\hline CARBONATO ÁCIDO DE SODIO & 500 (ii) & 2013 & BPF & \\
\hline CARBONATO DE CALCIO & $170(\mathrm{i})$ & 2013 & BPF & \\
\hline CARBONATO DE POTASIO & $501(i)$ & 2013 & BPF & \\
\hline CARBONATO DE SODIO & $500(i)$ & 2013 & BPF & \\
\hline $\begin{array}{l}\text { CARBOXIMETILCELULOSA SÓDICA } \\
\text { (GOMA DE CELULOSA) }\end{array}$ & 466 & 2013 & BPF & \\
\hline CARRAGENINA & 407 & 2013 & BPF & \\
\hline CELULOSA EN POLVO & 460 (ii) & 2013 & BPF & \\
\hline $\begin{array}{l}\text { CELULOSA MICROCRISTALINA (GEL DE } \\
\text { CELULOSA) }\end{array}$ & $460(i)$ & 2013 & BPF & \\
\hline CITRATO DÍACIDO DE POTASIO & 332(i) & 2013 & BPF & \\
\hline CITRATO DÍACIDO DE SODIO & 331 (i) & 2013 & BPF & \\
\hline CITRATO TRICÁLCICO & 333(iii) & 2013 & BPF & \\
\hline CITRATO TRIPOTÁSICO & 332(ii) & 2013 & BPF & \\
\hline CITRATO TRISÓDICO & 331(iii) & 2013 & BPF & \\
\hline CLORURO DE CALCIO & 509 & 2013 & BPF & \\
\hline CLORURO DE POTASIO & 508 & 2013 & BPF & \\
\hline DEXTRINAS, ALMIDÓN TOSTADO & 1400 & 2013 & BPF & 236 \\
\hline DIÓXIDO DE CARBONO & 290 & 2014 & BPF & $59 \& 278$ \\
\hline $\begin{array}{l}\text { ÉSTERES ACÉTICOS Y DE ÁCIDOS } \\
\text { GRASOS DE GLICEROL }\end{array}$ & $472 a$ & 2013 & BPF & \\
\hline $\begin{array}{l}\text { ÉSTERES CÍTRICOS Y DE ÁCIDOS } \\
\text { GRASOS DE GLICEROL }\end{array}$ & $472 c$ & 2013 & BPF & \\
\hline $\begin{array}{l}\text { ÉSTERES DIACETILTARTÁRICOS Y DE } \\
\text { ÁCIDOS GRASOS DE GLICEROL }\end{array}$ & $472 \mathrm{e}$ & 2007 & $6000 \mathrm{mg} / \mathrm{kg}$ & \\
\hline
\end{tabular}



No. de Categoría de alimento 01.4.2 Natas (cremas) esterilizadas y UHT, natas (cremas) para batir o batidas y natas (cremas) de contenido de grasa reducido (naturales / simples)

\begin{tabular}{|c|c|c|c|c|}
\hline Aditivo & $\operatorname{SiN}$ & Año Adoptada & Dosis máxima & Notas \\
\hline $\begin{array}{l}\text { ÉSTERES LÁCTICOS Y DE ÁCIDOS } \\
\text { GRASOS DE GLICEROL }\end{array}$ & $472 b$ & 2013 & BPF & \\
\hline $\begin{array}{l}\text { ÉSTERES POLIGLICÉRIDOS DE ÁCIDOS } \\
\text { GRASOS }\end{array}$ & 475 & 2016 & $6000 \mathrm{mg} / \mathrm{kg}$ & \\
\hline FOSFATO DE DIALMIDÓN & 1412 & 2013 & BPF & \\
\hline FOSFATO DE DIALMIDÓN ACETILADO & 1414 & 2013 & BPF & \\
\hline FOSFATO DE DIALMIDÓN FOSFATADO & 1413 & 2013 & BPF & \\
\hline FOSFATO DE HIDROXIPROPIL DIALMIDÓN & 1442 & 2013 & BPF & \\
\hline FOSFATO DE MONOALMIDÓN & 1410 & 2013 & BPF & \\
\hline GOMA ARÁBIGA (GOMA DE ACACIA) & 414 & 2013 & BPF & \\
\hline GOMA DE SEMILLAS DE ALGARROBO & 410 & 2013 & BPF & \\
\hline GOMA GELLAN & 418 & 2013 & BPF & \\
\hline GOMA GUAR & 412 & 2013 & BPF & \\
\hline GOMA TARA & 417 & 2013 & BPF & 236 \\
\hline GOMA TRAGACANTO & 413 & 2013 & BPF & 236 \\
\hline GOMA XANTANA & 415 & 2013 & BPF & \\
\hline HARINA KONJAC & 425 & 2013 & BPF & 236 \\
\hline HIDROXIPROPILCELULOSA & 463 & 2013 & BPF & \\
\hline HIDROXIPROPILMETILCELULOSA & 464 & 2013 & BPF & \\
\hline LACTATO DE CALCIO & 327 & 2013 & BPF & \\
\hline LACTATO DE POTASIO & 326 & 2013 & BPF & \\
\hline LACTATO DE SODIO & 325 & 2013 & BPF & \\
\hline LECITINA & 322(i) & 2013 & BPF & \\
\hline METILCELULOSA & 461 & 2013 & BPF & \\
\hline METILETILCELULOSA & 465 & 2013 & BPF & \\
\hline $\begin{array}{l}\text { MONOGLICÉRIDOS Y DIGLICÉRIDOS DE } \\
\text { ÁCIDOS GRASOS }\end{array}$ & 471 & 2013 & BPF & \\
\hline NITRÓGENO & 941 & 2014 & BPF & $59 \& 278$ \\
\hline $\begin{array}{l}\text { OCTENILSUCCIONATO SÓDICO DE } \\
\text { ALMIDÓN }\end{array}$ & 1450 & 2013 & BPF & \\
\hline ÓXIDO NITROSO & 942 & 2014 & BPF & $59 \& 278$ \\
\hline PECTINAS & 440 & 2013 & BPF & \\
\hline POLIDEXTROSA & 1200 & 2013 & BPF & 236 \\
\hline POLISORBATOS & $432-436$ & 2008 & $1000 \mathrm{mg} / \mathrm{kg}$ & \\
\hline SESQUICARBONATO DE SODIO & 500 (iii) & 2013 & BPF & \\
\hline SUCROÉSTERES DE ÁCIDOS GRASOS & 473 & 2016 & $5000 \mathrm{mg} / \mathrm{kg}$ & 348 \\
\hline SUCROGLICÉRIDOS & 474 & 2016 & $5000 \mathrm{mg} / \mathrm{kg}$ & 348 \\
\hline $\begin{array}{l}\text { SUCROSE OLIGOESTERS, TYPE I AND } \\
\text { TYPE II }\end{array}$ & $473 a$ & 2016 & $5000 \mathrm{mg} / \mathrm{kg}$ & 348 \\
\hline SULFATO DE CALCIO & 516 & 2013 & BPF & \\
\hline
\end{tabular}




\begin{tabular}{|c|c|c|c|c|}
\hline \multicolumn{2}{|c|}{ No. de Categoría de alimento 01.4.3 } & \multicolumn{3}{|c|}{ Nata (crema) cuajada (natural / simple) } \\
\hline Aditivo & SIN & Año Adoptada & Dosis máxima & Notas \\
\hline ALGINATO DE PROPILENGLICOL & 405 & 2016 & $5000 \mathrm{mg} / \mathrm{kg}$ & \\
\hline $\begin{array}{l}\text { ÉSTERES DIACETILTARTÁRICOS Y DE } \\
\text { ÁCIDOS GRASOS DE GLICEROL }\end{array}$ & $472 e$ & 2006 & $5000 \mathrm{mg} / \mathrm{kg}$ & \\
\hline $\begin{array}{l}\text { ÉSTERES POLIGLICÉRIDOS DE ÁCIDOS } \\
\text { GRASOS }\end{array}$ & 475 & 2016 & $6000 \mathrm{mg} / \mathrm{kg}$ & \\
\hline NISINA & 234 & 2009 & $10 \mathrm{mg} / \mathrm{kg}$ & \\
\hline POLISORBATOS & $432-436$ & 2008 & $1000 \mathrm{mg} / \mathrm{kg}$ & \\
\hline
\end{tabular}

\begin{tabular}{|c|c|c|c|c|}
\hline \multicolumn{2}{|c|}{ No. de Categoría de alimento 01.4.4 } & \multicolumn{3}{|c|}{ Productos análogos a la nata (crema) } \\
\hline Aditivo & SIN & Año Adoptada & Dosis máxima & Notas \\
\hline ACESULFAME DE POTASIO & 950 & 2008 & $1000 \mathrm{mg} / \mathrm{kg}$ & $161 \& 188$ \\
\hline ALGINATO DE PROPILENGLICOL & 405 & 2016 & $2500 \mathrm{mg} / \mathrm{kg}$ & \\
\hline ASPARTAMO & 951 & 2008 & $1000 \mathrm{mg} / \mathrm{kg}$ & $161 \& 191$ \\
\hline $\begin{array}{l}\text { CARAMELO III - CARAMELO AL } \\
\text { AMONÍACO }\end{array}$ & $150 c$ & 2010 & $5000 \mathrm{mg} / \mathrm{kg}$ & \\
\hline $\begin{array}{l}\text { CARAMELO IV - CARAMELO AL SULFITO } \\
\text { AMÓNICO }\end{array}$ & $150 d$ & 2009 & $5000 \mathrm{mg} / \mathrm{kg}$ & \\
\hline CAROTENOIDES & $160 a(i), a(i i i), e, f$ & 2011 & $20 \mathrm{mg} / \mathrm{kg}$ & \\
\hline CAROTENOS, BETA-, VEGETALES & $160 a(i i)$ & 2011 & $20 \mathrm{mg} / \mathrm{kg}$ & \\
\hline ESTEAROIL LACTILATOS & 481(i), 482(i) & 2016 & $5000 \mathrm{mg} / \mathrm{kg}$ & 2 \\
\hline $\begin{array}{l}\text { ÉSTERES DE PROPILENGLICOL DE } \\
\text { ÁCIDOS GRASOS }\end{array}$ & 477 & 2001 & $5000 \mathrm{mg} / \mathrm{kg}$ & 86 \\
\hline $\begin{array}{l}\text { ÉSTERES DE SORBITÁN DE ÁCIDOS } \\
\text { GRASOS }\end{array}$ & 491-495 & 2016 & $5000 \mathrm{mg} / \mathrm{kg}$ & 349 \\
\hline $\begin{array}{l}\text { ÉSTERES DIACETILTARTÁRICOS Y DE } \\
\text { ÁCIDOS GRASOS DE GLICEROL }\end{array}$ & $472 e$ & 2007 & $6000 \mathrm{mg} / \mathrm{kg}$ & \\
\hline $\begin{array}{l}\text { ÉSTERES POLIGLICÉRIDOS DE ÁCIDOS } \\
\text { GRASOS }\end{array}$ & 475 & 2016 & $8000 \mathrm{mg} / \mathrm{kg}$ & \\
\hline EXTRACTO DE PIEL DE UVA & 163(ii) & 2011 & $150 \mathrm{mg} / \mathrm{kg}$ & $181 \& 201$ \\
\hline NEOTAMO & 961 & 2008 & $33 \mathrm{mg} / \mathrm{kg}$ & 161 \\
\hline POLISORBATOS & $432-436$ & 2005 & $5000 \mathrm{mg} / \mathrm{kg}$ & \\
\hline $\begin{array}{l}\text { SUCRALOSA } \\
\text { (TRICLOROGALACTOSACAROSA) }\end{array}$ & 955 & 2008 & $580 \mathrm{mg} / \mathrm{kg}$ & 161 \\
\hline SUCROÉSTERES DE ÁCIDOS GRASOS & 473 & 2016 & $10000 \mathrm{mg} / \mathrm{kg}$ & 348 \\
\hline SUCROGLICÉRIDOS & 474 & 2016 & $10000 \mathrm{mg} / \mathrm{kg}$ & 348 \\
\hline $\begin{array}{l}\text { SUCROSE OLIGOESTERS, TYPE I AND } \\
\text { TYPE II }\end{array}$ & $473 a$ & 2016 & $10000 \mathrm{mg} / \mathrm{kg}$ & 348 \\
\hline TOCOFEROLES & $307 a, b, c$ & 2017 & $200 \mathrm{mg} / \mathrm{kg}$ & \\
\hline
\end{tabular}

\begin{tabular}{ccccc}
\hline No. de Categoría de alimento & $\mathbf{0 1 . 5 . 1}$ & $\begin{array}{l}\text { Leche en polvo y nata (crema) en polvo } \\
\text { (naturales) }\end{array}$ \\
\hline Aditivo & SIN & Año Adoptada & Dosis máxima & Notas \\
\hline BUTILHIDROXIANISOL & 320 & 2006 & $100 \mathrm{mg} / \mathrm{kg}$ & $15 \& 196$ \\
BUTILHIDROXITOLUENO & 321 & 2006 & $200 \mathrm{mg} / \mathrm{kg}$ & $15 \& 196$ \\
DIMETILPOLISILOXANO & $900 \mathrm{a}$ & 1999 & $10 \mathrm{mg} / \mathrm{kg}$ &
\end{tabular}




\begin{tabular}{|c|c|c|c|c|}
\hline No. de Categoría de aliment & 01.5 .1 & $\begin{array}{l}\text { he en pol } \\
\text { turales) }\end{array}$ & nata (crem & en polvo \\
\hline Aditivo & SIN & Año Adoptada & Dosis máxima & Notas \\
\hline ÉSTERES DE ASCORBILO & 304,305 & 2001 & $500 \mathrm{mg} / \mathrm{kg}$ & 10 \\
\hline $\begin{array}{l}\text { ÉSTERES DIACETILTARTÁRICOS Y DE } \\
\text { ÁCIDOS GRASOS DE GLICEROL }\end{array}$ & $472 e$ & 2006 & $10000 \mathrm{mg} / \mathrm{kg}$ & \\
\hline FOSFATOS & $\begin{array}{l}\text { 338; 339(i)-(iii); } \\
340(\mathrm{i})-(\mathrm{iii)} ; 341 \text { (i)- } \\
\text { (iii); 342(i)-(ii); } \\
343(\mathrm{i})-(\mathrm{iii)} ; 450(\mathrm{i})- \\
\text { (iii),(v)-(vii), (ix); } \\
451 \text { (i),(ii); } 452(\mathrm{i})- \\
\text { (v); } 542\end{array}$ & 2012 & $4400 \mathrm{mg} / \mathrm{kg}$ & 33 \\
\hline GALATO DE PROPILO & 310 & 2001 & $200 \mathrm{mg} / \mathrm{kg}$ & $15,75 \& 196$ \\
\hline SILICATO DE SODIO Y ALUMINIO & 554 & 2013 & $265 \mathrm{mg} / \mathrm{kg}$ & $6 \& 259$ \\
\hline SUCROGLICÉRIDOS & 474 & 2009 & $10000 \mathrm{mg} / \mathrm{kg}$ & \\
\hline
\end{tabular}

\begin{tabular}{|c|c|c|c|c|}
\hline No. de Categoría de alimento & 1.5 .2 & $\begin{array}{l}\text { ductos ar } \\
\text { ema) en p }\end{array}$ & gos a la lec & y la nata \\
\hline Aditivo & SIN & Año Adoptada & Dosis máxima & Notas \\
\hline ACESULFAME DE POTASIO & 950 & 2008 & $1000 \mathrm{mg} / \mathrm{kg}$ & $161 \& 188$ \\
\hline ASPARTAMO & 951 & 2007 & $2000 \mathrm{mg} / \mathrm{kg}$ & $161 \& 191$ \\
\hline $\begin{array}{l}\text { CARAMELO III - CARAMELO AL } \\
\text { AMONÍACO }\end{array}$ & $150 \mathrm{c}$ & 2010 & $5000 \mathrm{mg} / \mathrm{kg}$ & \\
\hline $\begin{array}{l}\text { CARAMELO IV - CARAMELO AL SULFITO } \\
\text { AMÓNICO }\end{array}$ & $150 d$ & 2009 & $5000 \mathrm{mg} / \mathrm{kg}$ & \\
\hline CAROTENOIDES & $160 a(i), a(i i i), e, f$ & 2011 & $100 \mathrm{mg} / \mathrm{kg}$ & 209 \\
\hline CAROTENOS, BETA-, VEGETALES & $160 a(i i)$ & 2005 & $1000 \mathrm{mg} / \mathrm{kg}$ & \\
\hline ÉSTERES DE ASCORBILO & 304,305 & 2001 & $80 \mathrm{mg} / \mathrm{kg}$ & 10 \\
\hline $\begin{array}{l}\text { ÉSTERES DE PROPILENGLICOL DE } \\
\text { ÁCIDOS GRASOS }\end{array}$ & 477 & 2001 & $100000 \mathrm{mg} / \mathrm{kg}$ & \\
\hline $\begin{array}{l}\text { ÉSTERES DE SORBITÁN DE ÁCIDOS } \\
\text { GRASOS }\end{array}$ & $491-495$ & 2016 & $4000 \mathrm{mg} / \mathrm{kg}$ & XS251 \\
\hline $\begin{array}{l}\text { ÉSTERES DIACETILTARTÁRICOS Y DE } \\
\text { ÁCIDOS GRASOS DE GLICEROL }\end{array}$ & $472 \mathrm{e}$ & 2005 & $10000 \mathrm{mg} / \mathrm{kg}$ & \\
\hline $\begin{array}{l}\text { ÉSTERES POLIGLICÉRIDOS DE ÁCIDO } \\
\text { RICINOLÉICO INTERESTERIFICADO }\end{array}$ & 476 & 2016 & $5000 \mathrm{mg} / \mathrm{kg}$ & XS251 \\
\hline $\begin{array}{l}\text { ÉSTERES POLIGLICÉRIDOS DE ÁCIDOS } \\
\text { GRASOS }\end{array}$ & 475 & 2016 & $5000 \mathrm{mg} / \mathrm{kg}$ & XS251 \\
\hline EXTRACTO DE PIEL DE UVA & 163(ii) & 2011 & $150 \mathrm{mg} / \mathrm{kg}$ & $181,201 \& 209$ \\
\hline FOSFATOS & $\begin{array}{l}\text { 338; 339(i)-(iii); } \\
340 \text { (i)-(iii); 341(i)- } \\
\text { (iii); 342(i)-(ii); } \\
343 \text { (i)-(iii); 450(i)- } \\
\text { (iii),(v)-(vii), (ix); } \\
\text { 451(i),(ii); 452(i)- } \\
\text { (v); } 542\end{array}$ & 2009 & $4400 \mathrm{mg} / \mathrm{kg}$ & $33 \& 88$ \\
\hline GLICÓSIDOS DE ESTEVIOL & $960 a, 960 b(i)$ & 2011 & $330 \mathrm{mg} / \mathrm{kg}$ & $26 \& 201$ \\
\hline NEOTAMO & 961 & 2008 & $65 \mathrm{mg} / \mathrm{kg}$ & 161 \\
\hline POLISORBATOS & $432-436$ & 2007 & $4000 \mathrm{mg} / \mathrm{kg}$ & \\
\hline RIBOFLAVINAS & 101(i),(ii), (iii) & 2005 & $300 \mathrm{mg} / \mathrm{kg}$ & \\
\hline
\end{tabular}




\begin{tabular}{ccccc}
\hline No. de Categoría de alimento & $\mathbf{0 1 . 5 . 2}$ & \multicolumn{2}{c}{$\begin{array}{l}\text { Productos análogos a la leche y la nata } \\
\text { (crema) en polvo }\end{array}$} \\
\hline Aditivo & SIN & Año Adoptada & Dosis máxima & Notas \\
\hline SILICATO DE SODIO Y ALUMINIO & 554 & 2013 & $570 \mathrm{mg} / \mathrm{kg}$ & $6 \& 259$ \\
SUCROÉSTERES DE ÁCIDOS GRASOS & 473 & 2016 & $5000 \mathrm{mg} / \mathrm{kg}$ & 350 \\
\hline
\end{tabular}

\begin{tabular}{|c|c|c|c|c|}
\hline \multicolumn{2}{|c|}{ No. de Categoría de alimento 01.6.1 } & \multicolumn{2}{|c|}{ ueso no madurado } & \multirow[b]{2}{*}{ Notas } \\
\hline Aditivo & SIN & Año Adoptada & Dosis máxima & \\
\hline ALGINATO DE PROPILENGLICOL & 405 & 2016 & $5000 \mathrm{mg} / \mathrm{kg}$ & XS262 \\
\hline AMARILLO OCASO FCF & 110 & 2008 & $300 \mathrm{mg} / \mathrm{kg}$ & 3 \\
\hline ASPARTAMO & 951 & 2008 & $1000 \mathrm{mg} / \mathrm{kg}$ & $161 \& 191$ \\
\hline CANTAXANTINA & $161 \mathrm{~g}$ & 2011 & $15 \mathrm{mg} / \mathrm{kg}$ & 201 \\
\hline $\begin{array}{l}\text { CARAMELO III - CARAMELO AL } \\
\text { AMONÍACO }\end{array}$ & $150 c$ & 2012 & $15000 \mathrm{mg} / \mathrm{kg}$ & 201 \\
\hline $\begin{array}{l}\text { CARAMELO IV - CARAMELO AL SULFITO } \\
\text { AMÓNICO }\end{array}$ & $150 d$ & 2011 & $50000 \mathrm{mg} / \mathrm{kg}$ & 201 \\
\hline CAROTENOIDES & $160 a(i), a(i i i), e, f$ & 2011 & $100 \mathrm{mg} / \mathrm{kg}$ & \\
\hline CAROTENOS, BETA-, VEGETALES & $160 a(i i)$ & 2005 & $600 \mathrm{mg} / \mathrm{kg}$ & \\
\hline $\begin{array}{l}\text { CLOROFILAS Y CLOROFILINAS, } \\
\text { COMPLEJOS CUPRICOS }\end{array}$ & 141 (i),(ii) & 2009 & $50 \mathrm{mg} / \mathrm{kg}$ & 161 \\
\hline ETIL-LAUROIL ARGINATO & 243 & 2011 & $200 \mathrm{mg} / \mathrm{kg}$ & \\
\hline FOSFATOS & $\begin{array}{l}\text { 338; 339(i)-(iii); } \\
340 \text { (i)-(iii); 341(i)- } \\
\text { (iii); 342(i)-(ii); } \\
343(\text { i)-(iii); 450(i)- } \\
\text { (iii),(v)-(vii), (ix); } \\
451 \text { (i),(ii); 452(i)- } \\
\text { (v); } 542\end{array}$ & 2012 & $4400 \mathrm{mg} / \mathrm{kg}$ & 33 \\
\hline INDIGOTINA (CARMÍN DE ÍNDIGO) & 132 & 2009 & $200 \mathrm{mg} / \mathrm{kg}$ & 3 \\
\hline NATAMICINA (PIMARICINA) & 235 & 2006 & $40 \mathrm{mg} / \mathrm{kg}$ & $3 \& 80$ \\
\hline NISINA & 234 & 2016 & $12.5 \mathrm{mg} / \mathrm{kg}$ & 233 \\
\hline POLISORBATOS & $432-436$ & 2008 & $80 \mathrm{mg} / \mathrm{kg}$ & 38 \\
\hline PONCEAU 4R (ROJO DE COCHINILLA A) & 124 & 2008 & $100 \mathrm{mg} / \mathrm{kg}$ & $3 \& 161$ \\
\hline RIBOFLAVINAS & 101 (i),(ii), (iii) & 2005 & $300 \mathrm{mg} / \mathrm{kg}$ & \\
\hline SORBATOS & $200,202,203$ & 2012 & $1000 \mathrm{mg} / \mathrm{kg}$ & $42 \& 223$ \\
\hline TARTRATOS & 334, 335(ii), 337 & 2016 & $1500 \mathrm{mg} / \mathrm{kg}$ & $45 \& 351$ \\
\hline TOCOFEROLES & $307 a, b, c$ & 2017 & $200 \mathrm{mg} / \mathrm{kg}$ & $168 \& 351$ \\
\hline
\end{tabular}

\section{No. de Categoría de alimento 01.6.2 Queso madurado}

\begin{tabular}{|c|c|c|c|c|}
\hline Aditivo & SIN & Año Adoptada & Dosis máxima & Notas \\
\hline CANTAXANTINA & $161 \mathrm{~g}$ & 2019 & $15 \mathrm{mg} / \mathrm{kg}$ & $\begin{array}{c}\text { 201, XS263, } \\
\text { XS264, XS265, } \\
\text { XS266, XS267, } \\
\text { XS268, XS269, } \\
\text { XS270, XS271, } \\
\text { XS272, XS274, } \\
\text { XS276, XS277 }\end{array}$ \\
\hline LYSOZYME & 1105 & 2019 & BPF & XS274, XS276, \\
\hline
\end{tabular}




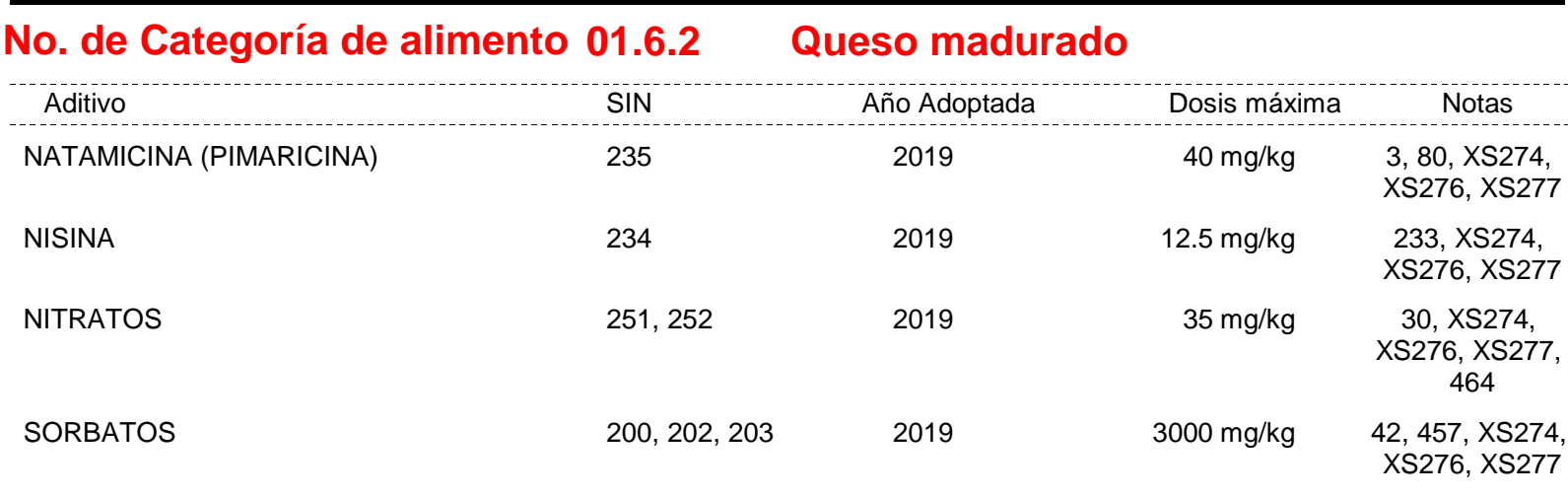

No. de Categoría de alimento 01.6.2.1 Queso madurado, incluida la corteza

\begin{tabular}{|c|c|c|c|c|}
\hline Aditivo & SIN & Año Adoptada & Dosis máxima & Notas \\
\hline ÁCIDO PROPIONICO & 280 & 2019 & BPF & $\begin{array}{c}\text { 3, EE, XS269, } \\
\text { XS274, XS276, } \\
\text { XS277 }\end{array}$ \\
\hline $\begin{array}{l}\text { CARAMELO IV - CARAMELO AL SULFITO } \\
\text { AMÓNICO }\end{array}$ & $150 d$ & 2019 & $50000 \mathrm{mg} / \mathrm{kg}$ & $\begin{array}{c}\text { 201, XS263, } \\
\text { XS264, XS265, } \\
\text { XS266, XS267, } \\
\text { XS268, XS269, } \\
\text { XS270, XS271, } \\
\text { XS272, XS274, } \\
\text { XS276, XS277 }\end{array}$ \\
\hline CARMINES & 120 & 2019 & $125 \mathrm{mg} / \mathrm{kg}$ & $\begin{array}{c}\text { 178, XS263, } \\
\text { XS264, XS265, } \\
\text { XS266, XS267, } \\
\text { XS268, XS269, } \\
\text { XS270, XS271, } \\
\text { XS272, XS274, } \\
\text { XS276, XS277 }\end{array}$ \\
\hline CAROTENOIDES & $160 a(i), a(i i i), e, f$ & 2019 & $100 \mathrm{mg} / \mathrm{kg}$ & 458 \\
\hline CAROTENOS, BETA-, VEGETALES & $160 \mathrm{a}(\mathrm{ii})$ & 2019 & $600 \mathrm{mg} / \mathrm{kg}$ & 463 \\
\hline $\begin{array}{l}\text { CLOROFILAS Y CLOROFILINAS, } \\
\text { COMPLEJOS CUPRICOS }\end{array}$ & $141(\mathrm{i}),(\mathrm{ii})$ & 2019 & $15 \mathrm{mg} / \mathrm{kg}$ & $\begin{array}{c}\text { 62, XS263, } \\
\text { XS264, XS265, } \\
\text { XS266, XS267, } \\
\text { XS268, XS269, } \\
\text { XS270, XS271, } \\
\text { XS272, XS274, } \\
\text { XS276, XS277 }\end{array}$ \\
\hline DIÓXIDO DE SILICIO AMORFO & 551 & 2019 & BPF & $\begin{array}{l}\text { 459, FF, XS274, } \\
\text { XS276, XS277 }\end{array}$ \\
\hline ÉSTERES DE ASCORBILO & 304,305 & 2019 & $500 \mathrm{mg} / \mathrm{kg}$ & $\begin{array}{l}10,112, X S 263, \\
\text { XS264, XS265, } \\
\text { XS266, XS267, } \\
\text { XS268, XS269, } \\
\text { XS270, XS271, } \\
\text { XS272, XS274, } \\
\text { XS276, XS277 }\end{array}$ \\
\hline $\begin{array}{l}\text { ÉSTERES DIACETILTARTÁRICOS Y DE } \\
\text { ÁCIDOS GRASOS DE GLICEROL }\end{array}$ & $472 \mathrm{e}$ & 2019 & $10000 \mathrm{mg} / \mathrm{kg}$ & $\begin{array}{c}\text { XS263, XS264, } \\
\text { XS265, XS266, } \\
\text { XS267, XS268, } \\
\text { XS269, XS270, } \\
\text { XS271, XS272, } \\
\text { XS274, XS276, } \\
\text { XS277 }\end{array}$ \\
\hline
\end{tabular}




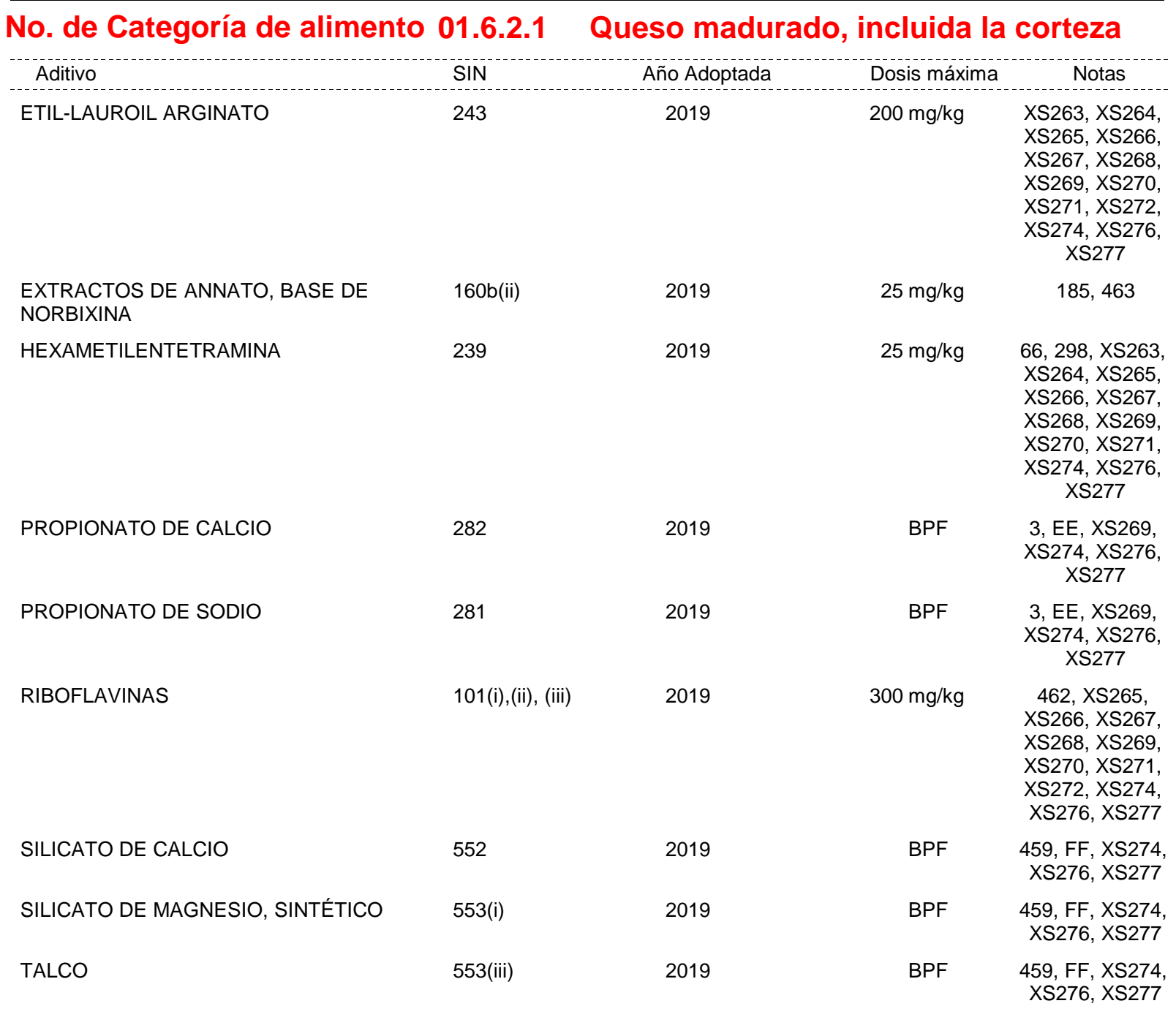

No. de Categoría de alimento 01.6.2.2 Corteza de queso madurado

\begin{tabular}{|c|c|c|c|c|}
\hline Aditivo & SIN & Año Adoptada & Dosis máxima & Notas \\
\hline AMARILLO OCASO FCF & 110 & 2008 & 300 mg/kg & \\
\hline AZUL BRILLANTE FCF & 133 & 2005 & $100 \mathrm{mg} / \mathrm{kg}$ & \\
\hline $\begin{array}{l}\text { CARAMELO III - CARAMELO AL } \\
\text { AMONÍACO }\end{array}$ & $150 c$ & 2010 & $50000 \mathrm{mg} / \mathrm{kg}$ & \\
\hline $\begin{array}{l}\text { CARAMELO IV - CARAMELO AL SULFITO } \\
\text { AMÓNICO }\end{array}$ & $150 d$ & 2011 & $50000 \mathrm{mg} / \mathrm{kg}$ & \\
\hline CAROTENOIDES & $160 a(i), a(i i i), e, f$ & 2009 & $500 \mathrm{mg} / \mathrm{kg}$ & \\
\hline CAROTENOS, BETA-, VEGETALES & $160 \mathrm{a}(\mathrm{ii})$ & 2005 & $1000 \mathrm{mg} / \mathrm{kg}$ & \\
\hline CERA MICROCRISTALINA & $905 c(i)$ & 2004 & $30000 \mathrm{mg} / \mathrm{kg}$ & \\
\hline $\begin{array}{l}\text { CLOROFILAS Y CLOROFILINAS, } \\
\text { COMPLEJOS CUPRICOS }\end{array}$ & 141 (i),(ii) & 2009 & $75 \mathrm{mg} / \mathrm{kg}$ & \\
\hline EXTRACTO DE PIEL DE UVA & 163(ii) & 2009 & $1000 \mathrm{mg} / \mathrm{kg}$ & \\
\hline INDIGOTINA (CARMIIN DE ÍNDIGO) & 132 & 2009 & $100 \mathrm{mg} / \mathrm{kg}$ & \\
\hline ÓXIDOS DE HIERRO & 172(i)-(iii) & 2005 & $100 \mathrm{mg} / \mathrm{kg}$ & \\
\hline PONCEAU 4R (ROJO DE COCHINILLA A) & 124 & 2008 & $100 \mathrm{mg} / \mathrm{kg}$ & \\
\hline
\end{tabular}




\section{No. de Categoría de alimento 01.6.2.2 Corteza de queso madurado}

\begin{tabular}{|c|c|c|c|c|}
\hline Aditivo & SIN & Año Adoptada & Dosis máxima & Notas \\
\hline RIBOFLAVINAS & 101(i),(ii), (iii) & 2005 & $300 \mathrm{mg} / \mathrm{kg}$ & \\
\hline ROJO ALLURA AC & 129 & 2009 & $100 \mathrm{mg} / \mathrm{kg}$ & \\
\hline
\end{tabular}

No. de Categoría de alimento 01.6.2.3 Queso en polvo (para reconstitución; p. ej., para salsas a base de queso)

\begin{tabular}{|c|c|c|c|c|}
\hline Aditivo & SIN & Año Adoptada & Dosis máxima & Notas \\
\hline ALGINATO DE PROPILENGLICOL & 405 & 2016 & $16000 \mathrm{mg} / \mathrm{kg}$ & 353 \\
\hline CAROTENOIDES & $160 a(i), a(i i i), e, f$ & 2009 & $100 \mathrm{mg} / \mathrm{kg}$ & \\
\hline CAROTENOS, BETA-, VEGETALES & $160 a(i i)$ & 2005 & $1000 \mathrm{mg} / \mathrm{kg}$ & \\
\hline $\begin{array}{l}\text { CLOROFILAS Y CLOROFILINAS, } \\
\text { COMPLEJOS CUPRICOS }\end{array}$ & 141(i),(ii) & 2009 & $50 \mathrm{mg} / \mathrm{kg}$ & \\
\hline TOCOFEROLES & $307 a, b, c$ & 2017 & $300 \mathrm{mg} / \mathrm{kg}$ & \\
\hline
\end{tabular}

\section{No. de Categoría de alimento 01.6.3 Queso de suero}

\begin{tabular}{|c|c|c|c|c|}
\hline Aditivo & SIN & Año Adoptada & Dosis máxima & Notas \\
\hline ETIL-LAUROIL ARGINATO & 243 & 2011 & $200 \mathrm{mg} / \mathrm{kg}$ & \\
\hline SORBATOS & $200,202,203$ & 2006 & $1000 \mathrm{mg} / \mathrm{kg}$ & 42 \\
\hline
\end{tabular}

\section{No. de Categoría de alimento 01.6.4 Queso elaborado}

\begin{tabular}{|c|c|c|c|c|}
\hline Aditivo & SIN & Año Adoptada & Dosis máxima & Notas \\
\hline ALGINATO DE PROPILENGLICOL & 405 & 2018 & $9000 \mathrm{mg} / \mathrm{kg}$ & \\
\hline AMARILLO OCASO FCF & 110 & 2008 & $200 \mathrm{mg} / \mathrm{kg}$ & 3 \\
\hline CAROTENOIDES & $160 a(i), a(i i i), e, f$ & 2009 & $100 \mathrm{mg} / \mathrm{kg}$ & \\
\hline CAROTENOS, BETA-, VEGETALES & $160 a(i i)$ & 2005 & $1000 \mathrm{mg} / \mathrm{kg}$ & \\
\hline $\begin{array}{l}\text { ÉSTERES DIACETILTARTÁRICOS Y DE } \\
\text { ÁCIDOS GRASOS DE GLICEROL }\end{array}$ & $472 e$ & 2005 & $10000 \mathrm{mg} / \mathrm{kg}$ & \\
\hline $\begin{array}{l}\text { ÉSTERES POLIGLICÉRIDOS DE ÁCIDO } \\
\text { RICINOLÉICO INTERESTERIFICADO }\end{array}$ & 476 & 2019 & $500 \mathrm{mg} / \mathrm{kg}$ & \\
\hline $\begin{array}{l}\text { ÉSTERES POLIGLICÉRIDOS DE ÁCIDOS } \\
\text { GRASOS }\end{array}$ & 475 & 2018 & $5000 \mathrm{mg} / \mathrm{kg}$ & \\
\hline ETIL-LAUROIL ARGINATO & 243 & 2011 & $200 \mathrm{mg} / \mathrm{kg}$ & \\
\hline FOSFATOS & $\begin{array}{l}\text { 338; 339(i)-(iii); } \\
\text { 340(i)-(iii); 341(i)- } \\
\text { (iii); 342(i)-(ii); } \\
\text { 343(i)-(iii); 450(i)- } \\
\text { (iii),(v)-(vii), (ix); } \\
\text { 451(i),(ii); 452(i)- } \\
\text { (v); } 542\end{array}$ & 2012 & $9000 \mathrm{mg} / \mathrm{kg}$ & 33 \\
\hline FOSFATOS DE ALUMINIO Y SODIO & 541 (i),(ii) & 2013 & $1600 \mathrm{mg} / \mathrm{kg}$ & $6 \& 251$ \\
\hline HIDROXIBENZOATOS, PARA- & 214,218 & 2012 & $300 \mathrm{mg} / \mathrm{kg}$ & 27 \\
\hline NATAMICINA (PIMARICINA) & 235 & 2006 & $40 \mathrm{mg} / \mathrm{kg}$ & $3 \& 80$ \\
\hline NISINA & 234 & 2018 & $12.5 \mathrm{mg} / \mathrm{kg}$ & 233 \\
\hline ÓXIDOS DE HIERRO & 172(i)-(iii) & 2005 & $50 \mathrm{mg} / \mathrm{kg}$ & \\
\hline RIBOFLAVINAS & 101(i),(ii), (iii) & 2005 & $300 \mathrm{mg} / \mathrm{kg}$ & \\
\hline ROJO ALLURA AC & 129 & 2009 & $100 \mathrm{mg} / \mathrm{kg}$ & 161 \\
\hline
\end{tabular}




\begin{tabular}{|c|c|c|c|c|}
\hline \multicolumn{2}{|c|}{ No. de Categoría de alimento 01.6.4 } & \multicolumn{3}{|c|}{ Queso elaborado } \\
\hline Aditivo & $\operatorname{SIN}$ & Año Adoptada & Dosis máxima & Notas \\
\hline SORBATOS & $200,202,203$ & 2012 & $3000 \mathrm{mg} / \mathrm{kg}$ & 42 \\
\hline SUCROÉSTERES DE ÁCIDOS GRASOS & 473 & 2018 & $3000 \mathrm{mg} / \mathrm{kg}$ & 348 \\
\hline SUCROGLICÉRIDOS & 474 & 2018 & $3000 \mathrm{mg} / \mathrm{kg}$ & 348 \\
\hline $\begin{array}{l}\text { SUCROSE OLIGOESTERS, TYPE I AND } \\
\text { TYPE II }\end{array}$ & $473 a$ & 2018 & $3000 \mathrm{mg} / \mathrm{kg}$ & 348 \\
\hline TARTRATOS & 334, 335(ii), 337 & 2019 & $30000 \mathrm{mg} / \mathrm{kg}$ & 45 \\
\hline TOCOFEROLES & $307 a, b, c$ & 2018 & $200 \mathrm{mg} / \mathrm{kg}$ & \\
\hline
\end{tabular}

No. de Categoría de alimento 01.6.4.2 Queso elaborado aromatizado, incluido el que contiene fruta, hortalizas, carne, etc.

\begin{tabular}{|c|c|c|c|c|}
\hline Aditivo & SIN & Año Adoptada & Dosis máxima & Notas \\
\hline CANTAXANTINA & $161 \mathrm{~g}$ & 2011 & $15 \mathrm{mg} / \mathrm{kg}$ & \\
\hline $\begin{array}{l}\text { CARAMELO III - CARAMELO AL } \\
\text { AMONÍACO }\end{array}$ & $150 c$ & 2010 & $50000 \mathrm{mg} / \mathrm{kg}$ & \\
\hline $\begin{array}{l}\text { CARAMELO IV - CARAMELO AL SULFITO } \\
\text { AMÓNICO }\end{array}$ & $150 d$ & 2011 & $50000 \mathrm{mg} / \mathrm{kg}$ & 72 \\
\hline CARMINES & 120 & 2005 & $100 \mathrm{mg} / \mathrm{kg}$ & 178 \\
\hline $\begin{array}{l}\text { CLOROFILAS Y CLOROFILINAS, } \\
\text { COMPLEJOS CUPRICOS }\end{array}$ & 141 (i),(ii) & 2009 & $50 \mathrm{mg} / \mathrm{kg}$ & \\
\hline EXTRACTO DE PIEL DE UVA & 163(ii) & 2009 & $1000 \mathrm{mg} / \mathrm{kg}$ & \\
\hline INDIGOTINA (CARMÍN DE ÍNDIGO) & 132 & 2009 & $100 \mathrm{mg} / \mathrm{kg}$ & \\
\hline PONCEAU 4R (ROJO DE COCHINILLA A) & 124 & 2008 & $100 \mathrm{mg} / \mathrm{kg}$ & \\
\hline
\end{tabular}

\begin{tabular}{|c|c|c|c|c|}
\hline \multicolumn{2}{|c|}{ No. de Categoría de alimento 01.6.5 } & \multicolumn{2}{|c|}{ Productos análogos al queso } & \multirow[b]{2}{*}{ Notas } \\
\hline Aditivo & SIN & Año Adoptada & Dosis máxima & \\
\hline ACESULFAME DE POTASIO & 950 & 2008 & $350 \mathrm{mg} / \mathrm{kg}$ & $161 \& 188$ \\
\hline ALGINATO DE PROPILENGLICOL & 405 & 2016 & $9000 \mathrm{mg} / \mathrm{kg}$ & \\
\hline AMARILLO OCASO FCF & 110 & 2008 & $300 \mathrm{mg} / \mathrm{kg}$ & 3 \\
\hline ASPARTAMO & 951 & 2008 & $1000 \mathrm{mg} / \mathrm{kg}$ & $161 \& 191$ \\
\hline AZUL BRILLANTE FCF & 133 & 2009 & $100 \mathrm{mg} / \mathrm{kg}$ & 3 \\
\hline CANTAXANTINA & $161 \mathrm{~g}$ & 2011 & $15 \mathrm{mg} / \mathrm{kg}$ & \\
\hline $\begin{array}{l}\text { CARAMELO III - CARAMELO AL } \\
\text { AMONÍACO }\end{array}$ & $150 c$ & 2010 & $50000 \mathrm{mg} / \mathrm{kg}$ & \\
\hline $\begin{array}{l}\text { CARAMELO IV - CARAMELO AL SULFITO } \\
\text { AMÓNICO }\end{array}$ & $150 d$ & 2011 & $50000 \mathrm{mg} / \mathrm{kg}$ & 201 \\
\hline CARMINES & 120 & 2008 & $100 \mathrm{mg} / \mathrm{kg}$ & $3 \& 178$ \\
\hline CAROTENOIDES & $160 a(i), a(i i i), e, f$ & 2009 & $200 \mathrm{mg} / \mathrm{kg}$ & \\
\hline CAROTENOS, BETA-, VEGETALES & $160 \mathrm{a}(\mathrm{ii})$ & 2005 & $1000 \mathrm{mg} / \mathrm{kg}$ & 3 \\
\hline $\begin{array}{l}\text { CLOROFILAS Y CLOROFILINAS, } \\
\text { COMPLEJOS CUPRICOS }\end{array}$ & 141 (i),(ii) & 2009 & $50 \mathrm{mg} / \mathrm{kg}$ & \\
\hline ESTEAROIL LACTILATOS & 481(i), 482(i) & 2016 & $2000 \mathrm{mg} / \mathrm{kg}$ & \\
\hline $\begin{array}{l}\text { ÉSTERES DIACETILTARTÁRICOS Y DE } \\
\text { ÁCIDOS GRASOS DE GLICEROL }\end{array}$ & $472 e$ & 2005 & $10000 \mathrm{mg} / \mathrm{kg}$ & \\
\hline
\end{tabular}




\begin{tabular}{|c|c|c|c|c|}
\hline \multicolumn{2}{|c|}{ No. de Categoría de alimento 01.6.5 } & \multicolumn{2}{|c|}{ roductos análogos al queso } & \multirow[b]{2}{*}{ Notas } \\
\hline Aditivo & SIN & Año Adoptada & Dosis máxima & \\
\hline $\begin{array}{l}\text { ÉSTERES POLIGLICÉRIDOS DE ÁCIDOS } \\
\text { GRASOS }\end{array}$ & 475 & 2016 & $5000 \mathrm{mg} / \mathrm{kg}$ & \\
\hline ETIL-LAUROIL ARGINATO & 243 & 2011 & $200 \mathrm{mg} / \mathrm{kg}$ & \\
\hline EXTRACTO DE PIEL DE UVA & 163(ii) & 2009 & $1000 \mathrm{mg} / \mathrm{kg}$ & \\
\hline FOSFATOS & $\begin{array}{l}\text { 338; 339(i)-(iii); } \\
340 \text { (i)-(iii); 341(i)- } \\
\text { (iii); 342(i)-(ii); } \\
343 \text { (i)-(iii); 450(i)- } \\
\text { (iii),(v)-(vii), (ix); } \\
\text { 451(i),(ii); 452(i)- } \\
\text { (v); } 542\end{array}$ & 2012 & $9000 \mathrm{mg} / \mathrm{kg}$ & 33 \\
\hline HIDROXIBENZOATOS, PARA- & 214,218 & 2009 & $500 \mathrm{mg} / \mathrm{kg}$ & 27 \\
\hline INDIGOTINA (CARMÍN DE ÍNDIGO) & 132 & 2009 & $200 \mathrm{mg} / \mathrm{kg}$ & $3 \& 161$ \\
\hline NATAMICINA (PIMARICINA) & 235 & 2006 & $40 \mathrm{mg} / \mathrm{kg}$ & $3 \& 80$ \\
\hline NEOTAMO & 961 & 2008 & $33 \mathrm{mg} / \mathrm{kg}$ & 161 \\
\hline NISINA & 234 & 2010 & $12.5 \mathrm{mg} / \mathrm{kg}$ & \\
\hline PONCEAU 4R (ROJO DE COCHINILLA A) & 124 & 2008 & $100 \mathrm{mg} / \mathrm{kg}$ & 3 \\
\hline RIBOFLAVINAS & 101(i),(ii), (iii) & 2005 & $300 \mathrm{mg} / \mathrm{kg}$ & \\
\hline ROJO ALLURA AC & 129 & 2009 & $100 \mathrm{mg} / \mathrm{kg}$ & 3 \\
\hline SACARINAS & 954(i)-(iv) & 2008 & $100 \mathrm{mg} / \mathrm{kg}$ & 161 \\
\hline SORBATOS & $200,202,203$ & 2010 & $3000 \mathrm{mg} / \mathrm{kg}$ & $3 \& 42$ \\
\hline $\begin{array}{l}\text { SUCRALOSA } \\
\text { (TRICLOROGALACTOSACAROSA) }\end{array}$ & 955 & 2008 & $500 \mathrm{mg} / \mathrm{kg}$ & 161 \\
\hline SUCROÉSTERES DE ÁCIDOS GRASOS & 473 & 2016 & $10000 \mathrm{mg} / \mathrm{kg}$ & \\
\hline TOCOFEROLES & $307 a, b, c$ & 2016 & $400 \mathrm{mg} / \mathrm{kg}$ & \\
\hline
\end{tabular}

\section{No. de Categoría de alimento 01.6.6 Queso de proteínas del suero}

\begin{tabular}{|c|c|c|c|c|}
\hline Aditivo & SIN & Año Adoptada & Dosis máxima & Notas \\
\hline ÁCIDO ACÉTICO GLACIAL & 260 & 2006 & BPF & \\
\hline ÁCIDO CÍTRICO & 330 & 2006 & BPF & \\
\hline ÁCIDO LÁCTICO, L-, D- y DL- & 270 & 2006 & BPF & \\
\hline ÁCIDO MÁLICO, DL- & 296 & 2006 & BPF & \\
\hline ÁCIDO PROPIONICO & 280 & 2006 & $3000 \mathrm{mg} / \mathrm{kg}$ & 70 \\
\hline GLUCONO-DELTA-LACTONA & 575 & 2006 & BPF & \\
\hline NATAMICINA (PIMARICINA) & 235 & 2006 & $40 \mathrm{mg} / \mathrm{kg}$ & $3 \& 80$ \\
\hline NISINA & 234 & 2006 & $12.5 \mathrm{mg} / \mathrm{kg}$ & \\
\hline PROPIONATO DE CALCIO & 282 & 2006 & $3000 \mathrm{mg} / \mathrm{kg}$ & 70 \\
\hline PROPIONATO DE SODIO & 281 & 2006 & $3000 \mathrm{mg} / \mathrm{kg}$ & 70 \\
\hline SORBATOS & 200, 202, 203 & 2006 & $3000 \mathrm{mg} / \mathrm{kg}$ & 42 \\
\hline
\end{tabular}

No. de Categoría de alimento 01.7
Postres lácteos (como pudines, yogur aromatizado o con fruta)

\begin{tabular}{|c|c|c|c|c|}
\hline Aditivo & SIN & Año Adoptada & Dosis máxima & Notas \\
\hline ACESULFAME DE POTASIO & 950 & 2019 & $350 \mathrm{mg} / \mathrm{kg}$ & $478 \& 188$ \\
\hline
\end{tabular}


No. de Categoría de alimento 01.7
ALGINATO DE PROPILENGLICOL

ALITAME

AMARILLO OCASO FCF

ASPARTAMO

AZUL BRILLANTE FCF

BENZOATOS

CANTAXANTINA

CARAMELO III - CARAMELO AL AMONÍACO

CARAMELO IV - CARAMELO AL SULFITO AMÓNICO

CARMINES

CAROTENOIDES

CAROTENOS, BETA-, VEGETALES

CICLAMATOS

CLOROFILAS Y CLOROFILINAS, COMPLEJOS CUPRICOS

ESTEAROIL LACTILATOS

ÉSTERES DE ASCORBILO

ÉSTERES DE PROPILENGLICOL DE ÁCIDOS GRASOS

ÉSTERES DE SORBITÁN DE ÁCIDOS GRASOS

ÉSTERES DIACETILTARTÁRICOS Y DE ÁCIDOS GRASOS DE GLICEROL

ÉSTERES POLIGLICÉRIDOS DE ÁCIDO RICINOLÉICO INTERESTERIFICADO

ÉSTERES POLIGLICÉRIDOS DE ÁCIDOS GRASOS

ETIL-LAUROIL ARGINATO

ETILMALTOL

EXTRACTO DE PIEL DE UVA

FOSFATOS

GALATO DE PROPILO

GLICÓSIDOS DE ESTEVIOL

HIDROXIBENZOATOS, PARA-

INDIGOTINA (CARMÍN DE ÍNDIGO)

MALTOL

NEOTAMO

NISINA

SIN

405

956

110

951

133

210-213

$161 \mathrm{~g}$

$150 \mathrm{c}$

150d

120

160a(i),a(iii),e,f

160 a(ii)

952(i), (ii), (iv)

141(i),(ii)

481(i), 482(i)

304, 305

477

491-495

$472 e$

476

475

243

637

163(ii)

338; 339(i)-(iii); 340(i)-(iii); 341(i)(iii); $342(\mathrm{i})$-(ii) 343(i)-(iii); 450(i)(iii),(v)-(vii), (ix); 451(i),(ii); 452(i)(v); 542

310

960a, 960b(i)

214, 218

132

636

961

234
Postres lácteos (como pudines, yogur aromatizado o con fruta)

\begin{tabular}{|c|c|c|}
\hline Año Adoptada & Dosis máxima & Notas \\
\hline 2016 & $6000 \mathrm{mg} / \mathrm{kg}$ & \\
\hline 2007 & $100 \mathrm{mg} / \mathrm{kg}$ & 161 \\
\hline 2009 & $300 \mathrm{mg} / \mathrm{kg}$ & 161 \\
\hline 2019 & $1000 \mathrm{mg} / \mathrm{kg}$ & $478 \& 191$ \\
\hline 2005 & $150 \mathrm{mg} / \mathrm{kg}$ & \\
\hline 2001 & $300 \mathrm{mg} / \mathrm{kg}$ & 13 \\
\hline 2011 & $15 \mathrm{mg} / \mathrm{kg}$ & 170 \\
\hline 1999 & $2000 \mathrm{mg} / \mathrm{kg}$ & \\
\hline 1999 & $2000 \mathrm{mg} / \mathrm{kg}$ & \\
\hline 2005 & $150 \mathrm{mg} / \mathrm{kg}$ & 178 \\
\hline 2009 & $100 \mathrm{mg} / \mathrm{kg}$ & \\
\hline 2005 & $1000 \mathrm{mg} / \mathrm{kg}$ & \\
\hline 2019 & $250 \mathrm{mg} / \mathrm{kg}$ & $17 \& 477$ \\
\hline 2009 & $500 \mathrm{mg} / \mathrm{kg}$ & \\
\hline 2016 & $5000 \mathrm{mg} / \mathrm{kg}$ & 355 \\
\hline 2001 & $500 \mathrm{mg} / \mathrm{kg}$ & $2 \& 10$ \\
\hline 2001 & $5000 \mathrm{mg} / \mathrm{kg}$ & \\
\hline 2019 & $5000 \mathrm{mg} / \mathrm{kg}$ & 362 \\
\hline 2005 & $10000 \mathrm{mg} / \mathrm{kg}$ & \\
\hline 2016 & $5000 \mathrm{mg} / \mathrm{kg}$ & XS243 \\
\hline 2016 & $5000 \mathrm{mg} / \mathrm{kg}$ & 354 \& XS243 \\
\hline 2011 & $200 \mathrm{mg} / \mathrm{kg}$ & 170 \\
\hline 2016 & $200 \mathrm{mg} / \mathrm{kg}$ & \\
\hline 2009 & $200 \mathrm{mg} / \mathrm{kg}$ & 181 \\
\hline 2012 & $1500 \mathrm{mg} / \mathrm{kg}$ & 33 \\
\hline 2001 & 90 mg/kg & $2 \& 15$ \\
\hline 2011 & $330 \mathrm{mg} / \mathrm{kg}$ & 26 \\
\hline 2012 & $120 \mathrm{mg} / \mathrm{kg}$ & 27 \\
\hline 2009 & $150 \mathrm{mg} / \mathrm{kg}$ & \\
\hline 2016 & $200 \mathrm{mg} / \mathrm{kg}$ & \\
\hline 2019 & $100 \mathrm{mg} / \mathrm{kg}$ & 478 \\
\hline 2016 & $12.5 \mathrm{mg} / \mathrm{kg}$ & $233 \& 362$ \\
\hline
\end{tabular}




\begin{tabular}{|c|c|c|c|c|}
\hline \multicolumn{2}{|c|}{ No. de Categoría de alimento 01.7} & \multicolumn{3}{|c|}{$\begin{array}{l}\text { Postres lácteos (como pudines, yogur } \\
\text { aromatizado o con fruta) }\end{array}$} \\
\hline Aditivo & SIN & Año Adoptada & Dosis máxima & Notas \\
\hline ÓXIDOS DE HIERRO & 172(i)-(iii) & 2005 & $100 \mathrm{mg} / \mathrm{kg}$ & \\
\hline POLISORBATOS & $432-436$ & 2007 & $3000 \mathrm{mg} / \mathrm{kg}$ & \\
\hline PONCEAU 4R (ROJO DE COCHINILLA A) & 124 & 2008 & $150 \mathrm{mg} / \mathrm{kg}$ & 161 \\
\hline RIBOFLAVINAS & 101(i),(ii), (iii) & 2005 & $300 \mathrm{mg} / \mathrm{kg}$ & \\
\hline ROJO ALLURA AC & 129 & 2009 & $300 \mathrm{mg} / \mathrm{kg}$ & 161 \\
\hline SACARINAS & 954(i)-(iv) & 2019 & $100 \mathrm{mg} / \mathrm{kg}$ & 477 \\
\hline SAL DE ASPARTAMO Y ACESULFAMO & 962 & 2019 & $350 \mathrm{mg} / \mathrm{kg}$ & $113 \& 477$ \\
\hline $\begin{array}{l}\text { SALES AMÓNICAS DEL ÁCIDO } \\
\text { FOSFATÍDICO }\end{array}$ & 442 & 2012 & $5000 \mathrm{mg} / \mathrm{kg}$ & 231 \\
\hline SORBATOS & $200,202,203$ & 2012 & $1000 \mathrm{mg} / \mathrm{kg}$ & 42 \\
\hline $\begin{array}{l}\text { SUCRALOSA } \\
\text { (TRICLOROGALACTOSACAROSA) }\end{array}$ & 955 & 2019 & $400 \mathrm{mg} / \mathrm{kg}$ & 478 \\
\hline SUCROÉSTERES DE ÁCIDOS GRASOS & 473 & 2019 & $5000 \mathrm{mg} / \mathrm{kg}$ & $348 \& 362$ \\
\hline SUCROGLICÉRIDOS & 474 & 2019 & $5000 \mathrm{mg} / \mathrm{kg}$ & $348 \& 362$ \\
\hline $\begin{array}{l}\text { SUCROSE OLIGOESTERS, TYPE I AND } \\
\text { TYPE II }\end{array}$ & $473 a$ & 2019 & $5000 \mathrm{mg} / \mathrm{kg}$ & $348 \& 362$ \\
\hline TARTRATOS & 334, 335(ii), 337 & 2019 & $2000 \mathrm{mg} / \mathrm{kg}$ & $45 \& 449$ \\
\hline TOCOFEROLES & $307 a, b, c$ & 2016 & $500 \mathrm{mg} / \mathrm{kg}$ & XS243 \\
\hline VERDE SÓLIDO FCF & 143 & 1999 & $100 \mathrm{mg} / \mathrm{kg}$ & 2 \\
\hline
\end{tabular}

No. de Categoría de alimento $01.8 \quad$ Suero y productos a base de suero, excluidos los quesos de suero

\begin{tabular}{|c|c|c|c|c|}
\hline Aditivo & SIN & Año Adoptada & Dosis máxima & Notas \\
\hline TOCOFEROLES & $307 a, b, c$ & 2016 & 200 mg/kg & \\
\hline
\end{tabular}

No. de Categoría de alimento 01.8.1 Suero líquido y productos a base de suero líquido, excluidos los quesos de suero

\begin{tabular}{|c|c|c|c|c|}
\hline Aditivo & SIN & Año Adoptada & Dosis máxima & Notas \\
\hline FOSFATOS & $\begin{array}{l}\text { 338; 339(i)-(iii); } \\
340 \text { (i)-(iii); } 341 \text { (i)- } \\
\text { (iii); 342(i)-(ii); } \\
343(\text { (i)-(iii); } 450(\mathrm{i})- \\
\text { (iii),(v)-(vii), (ix); } \\
451 \text { (i),(ii); 452(i)- } \\
\text { (v); } 542\end{array}$ & 2012 & 880 mg/kg & $33 \& 228$ \\
\hline PERÓXIDO DE BENZOÍLO & 928 & 2007 & $100 \mathrm{mg} / \mathrm{kg}$ & 74 \\
\hline
\end{tabular}

\begin{tabular}{lccc} 
No. de Categoría de alimento & 01.8 .2 & $\begin{array}{l}\text { Suero en polvo y productos a base de } \\
\text { suero en polvo, excluidos los quesos } \\
\text { de suero }\end{array}$ \\
\hline Aditivo & SIN & Año Adoptada & Dosis máxima \\
\hline CARBONATO ÁCIDO DE POTASIO & 501 (ii) & 2006 & BPF \\
CARBONATO ÁCIDO DE SODIO & 500 (ii) & 2006 & BPF \\
CARBONATO DE CALCIO & 170 (i) & 2006 & $10000 \mathrm{mg} / \mathrm{kg}$
\end{tabular}




\begin{tabular}{|c|c|c|c|c|}
\hline lo. de Categoría de alimento & $\begin{array}{l}\text { St } \\
\text { su } \\
\text { de }\end{array}$ & $\begin{array}{l}\text { ero en pol } \\
\text { ero en pol } \\
\text { suero }\end{array}$ & $\begin{array}{l}\text { productos } \\
\text { xcluidos los }\end{array}$ & $\begin{array}{l}\text { se de } \\
\text { esos }\end{array}$ \\
\hline Aditivo & SIN & Año Adoptada & Dosis máxima & Notas \\
\hline CARBONATO DE MAGNESIO & $504(i)$ & 2006 & $10000 \mathrm{mg} / \mathrm{kg}$ & \\
\hline CARBONATO DE POTASIO & $501(\mathrm{i})$ & 2006 & BPF & \\
\hline CARBONATO DE SODIO & 500 (i) & 2006 & BPF & \\
\hline CELULOSA EN POLVO & 460 (ii) & 2006 & $10000 \mathrm{mg} / \mathrm{kg}$ & \\
\hline $\begin{array}{l}\text { CELULOSA MICROCRISTALINA (GEL DE } \\
\text { CELULOSA) }\end{array}$ & $460(i)$ & 2006 & $10000 \mathrm{mg} / \mathrm{kg}$ & \\
\hline CITRATO DÍACIDO DE POTASIO & 332(i) & 2006 & BPF & \\
\hline CITRATO DÍACIDO DE SODIO & 331 (i) & 2006 & BPF & \\
\hline CITRATO TRIPOTÁSICO & 332(ii) & 2006 & BPF & \\
\hline CITRATO TRISÓDICO & 331 (iii) & 2006 & BPF & \\
\hline CLORURO DE CALCIO & 509 & 2006 & BPF & \\
\hline CLORURO DE POTASIO & 508 & 2006 & BPF & \\
\hline DIÓXIDO DE SILICIO AMORFO & 551 & 2006 & $10000 \mathrm{mg} / \mathrm{kg}$ & \\
\hline FOSFATO DE HIDROXIPROPIL DIALMIDÓN & 1442 & 2006 & $10000 \mathrm{mg} / \mathrm{kg}$ & \\
\hline FOSFATOS & $\begin{array}{l}\text { 338; 339(i)-(iii); } \\
\text { 340(i)-(iii); 341(i)- } \\
\text { (iii); 342(i)-(ii); } \\
\text { 343(i)-(iii); 450(i)- } \\
\text { (iii),(v)-(vii), (ix); } \\
\text { 451(i),(ii); 452(i)- } \\
\text { (v); } 542\end{array}$ & 2006 & $4400 \mathrm{mg} / \mathrm{kg}$ & 33 \\
\hline HIDRÓXIDO DE CALCIO & 526 & 2006 & BPF & \\
\hline HIDRÓXIDO DE POTASIO & 525 & 2006 & BPF & \\
\hline HIDRÓXIDO DE SODIO & 524 & 2006 & BPF & \\
\hline LECITINA & $322(i)$ & 2015 & BPF & \\
\hline ÓXIDO DE MAGNESIO & 530 & 2006 & $10000 \mathrm{mg} / \mathrm{kg}$ & \\
\hline PERÓXIDO DE BENZOÍLO & 928 & 2005 & $100 \mathrm{mg} / \mathrm{kg}$ & 147 \\
\hline SESQUICARBONATO DE SODIO & 500 (iii) & 2006 & BPF & \\
\hline SILICATO DE CALCIO & 552 & 2006 & $10000 \mathrm{mg} / \mathrm{kg}$ & \\
\hline SILICATO DE MAGNESIO, SINTÉTICO & $553(i)$ & 2006 & $10000 \mathrm{mg} / \mathrm{kg}$ & \\
\hline SILICATO DE SODIO Y ALUMINIO & 554 & 2013 & $1140 \mathrm{mg} / \mathrm{kg}$ & 6 \\
\hline TALCO & 553(iii) & 2006 & $10000 \mathrm{mg} / \mathrm{kg}$ & \\
\hline
\end{tabular}

No. de Categoría de alimento 02.1.1 Aceite de mantequilla (manteca), grasa de leche anhidra, "ghee"

\begin{tabular}{llccc}
\hline Aditivo & SiN & Año Adoptada & Dosis máxima & Notas \\
\hline ÁCIDO CÍTRICO & 330 & 2006 & BPF & 171 \\
BUTILHIDROXIANISOL & 320 & 2006 & $175 \mathrm{mg} / \mathrm{kg}$ & $15,133 \& 171$ \\
BUTILHIDROXITOLUENO & 321 & 2006 & $75 \mathrm{mg} / \mathrm{kg}$ & $15,133 \& 171$ \\
CITRATO DÍACIDO DE SODIO & 331 (i) & 2006 & BPF & 171 \\
CITRATO TRISÓDICO & 331 (iii) & 2006 & BPF & 171 \\
ÉSTERES DE ASCORBILO & 304,305 & 2006 & $500 \mathrm{mg} / \mathrm{kg}$ & $10 \& 171$
\end{tabular}




\begin{tabular}{lcccc}
\hline No. de Categoría de alimento 02.1.1 & \multicolumn{2}{c}{$\begin{array}{c}\text { Aceite de mantequilla (manteca), grasa } \\
\text { de leche anhidra, "ghee" }\end{array}$} \\
\hline Aditivo & Sin & Año Adoptada & Dosis máxima & Notas \\
\hline GALATO DE PROPILO & 310 & 2006 & $100 \mathrm{mg} / \mathrm{kg}$ & 15,133 \& 171 \\
TOCOFEROLES & $307 \mathrm{a}, \mathrm{b}, \mathrm{c}$ & 2006 & $500 \mathrm{mg} / \mathrm{kg}$ & 171 \\
\hline
\end{tabular}

\begin{tabular}{|c|c|c|c|c|}
\hline \multicolumn{2}{|c|}{ No. de Categoría de alimento 02.1.2 } & \multicolumn{2}{|c|}{ Grasas y aceites vegetales } & \multirow[b]{2}{*}{ Notas } \\
\hline Aditivo & SIN & Año Adoptada & Dosis máxima & \\
\hline ÁCIDO CÍTRICO & 330 & 2014 & BPF & $15 \& 277$ \\
\hline BUTILHIDROXIANISOL & 320 & 2006 & $200 \mathrm{mg} / \mathrm{kg}$ & $15 \& 130$ \\
\hline BUTILHIDROXITOLUENO & 321 & 2006 & $200 \mathrm{mg} / \mathrm{kg}$ & $15 \& 130$ \\
\hline CAROTENOIDES & 160a(i),a(iii),e,f & 2012 & $25 \mathrm{mg} / \mathrm{kg}$ & 232 \\
\hline CAROTENOS, BETA-, VEGETALES & $160 a(i i)$ & 2006 & $1000 \mathrm{mg} / \mathrm{kg}$ & \\
\hline CITRATO DE ESTEARILO & 484 & 2006 & BPF & \\
\hline CITRATO DÍACIDO DE SODIO & $331(\mathrm{i})$ & 2015 & BPF & 277 \\
\hline CITRATO TRICÁLCICO & 333(iii) & 2018 & BPF & $277, \mathrm{XS} 33$ \\
\hline CITRATO TRIPOTÁSICO & 332(ii) & 2018 & BPF & $277, \mathrm{XS} 33$ \\
\hline CITRATO TRISÓDICO & 331 (iii) & 2015 & BPF & 277 \\
\hline CITRATOS DE ISOPROPILO & 384 & 2005 & $200 \mathrm{mg} / \mathrm{kg}$ & \\
\hline DIMETILPOLISILOXANO & $900 a$ & 2006 & $10 \mathrm{mg} / \mathrm{kg}$ & \\
\hline $\begin{array}{l}\text { ÉSTERES CÍTRICOS Y DE ÁCIDOS } \\
\text { GRASOS DE GLICEROL }\end{array}$ & $472 \mathrm{c}$ & 2015 & $100 \mathrm{mg} / \mathrm{kg}$ & 277 \\
\hline ÉSTERES DE ASCORBILO & 304,305 & 2006 & $500 \mathrm{mg} / \mathrm{kg}$ & 10 \\
\hline $\begin{array}{l}\text { ÉSTERES DE PROPILENGLICOL DE } \\
\text { ÁCIDOS GRASOS }\end{array}$ & 477 & 2006 & $10000 \mathrm{mg} / \mathrm{kg}$ & \\
\hline $\begin{array}{l}\text { ÉSTERES DIACETILTARTÁRICOS Y DE } \\
\text { ÁCIDOS GRASOS DE GLICEROL }\end{array}$ & $472 e$ & 2006 & $10000 \mathrm{mg} / \mathrm{kg}$ & \\
\hline GALATO DE PROPILO & 310 & 2006 & $200 \mathrm{mg} / \mathrm{kg}$ & $15 \& 130$ \\
\hline LECITINA & $322(\mathrm{i})$ & 2018 & BPF & 277 \\
\hline POLISORBATOS & $432-436$ & 2007 & $5000 \mathrm{mg} / \mathrm{kg}$ & 102 \\
\hline RESINA DE GUAYACO & 314 & 2006 & $1000 \mathrm{mg} / \mathrm{kg}$ & \\
\hline TERBUTILHIDROQUINONA & 319 & 2006 & $200 \mathrm{mg} / \mathrm{kg}$ & $15 \& 130$ \\
\hline TIODIPROPIONATOS & 388,389 & 2006 & $200 \mathrm{mg} / \mathrm{kg}$ & 46 \\
\hline TOCOFEROLES & $307 a, b, c$ & 2016 & $300 \mathrm{mg} / \mathrm{kg}$ & $356 \& 357$ \\
\hline
\end{tabular}

No. de Categoría de alimento 02.1.3 Manteca de cerdo, sebo, aceite de pescado y otras grasas de origen animal

\begin{tabular}{llccc} 
Aditivo & SIN & Año Adoptada & Dosis máxima & Notas \\
\hline ÁCIDO CÍTRICO & 330 & 2014 & BPF & \\
AMARILLO OCASO FCF & 110 & 2008 & $300 \mathrm{mg} / \mathrm{kg}$ & 161 \\
BUTILHIDROXIANISOL & 320 & 2006 & $200 \mathrm{mg} / \mathrm{kg}$ & $15 \& 130$ \\
BUTILHIDROXITOLUENO & 321 & 2006 & $200 \mathrm{mg} / \mathrm{kg}$ & $15 \& 130$ \\
CAROTENOIDES & $160 \mathrm{a}(\mathrm{i}), \mathrm{a}(\mathrm{iii}), \mathrm{e}, \mathrm{f}$ & 2011 & $25 \mathrm{mg} / \mathrm{kg}$ & \\
CAROTENOS, BETA-, VEGETALES & $160 \mathrm{a}(\mathrm{ii})$ & 2006 & $1000 \mathrm{mg} / \mathrm{kg}$ & \\
CITRATO DE ESTEARILO & 484 & 2006 & BPF &
\end{tabular}




\begin{tabular}{|c|c|c|c|c|}
\hline \multicolumn{2}{|c|}{ No. de Categoría de alimento 02.1.3 } & \multicolumn{3}{|c|}{$\begin{array}{l}\text { Manteca de cerdo, sebo, aceite de } \\
\text { pescado y otras grasas de origen animal }\end{array}$} \\
\hline Aditivo & SIN & Año Adoptada & Dosis máxima & Notas \\
\hline CITRATOS DE ISOPROPILO & 384 & 2001 & 200 mg/kg & \\
\hline DIMETILPOLISILOXANO & $900 a$ & 2006 & $10 \mathrm{mg} / \mathrm{kg}$ & \\
\hline $\begin{array}{l}\text { ÉSTERES CÍTRICOS Y DE ÁCIDOS } \\
\text { GRASOS DE GLICEROL }\end{array}$ & $472 c$ & 2015 & $100 \mathrm{mg} / \mathrm{kg}$ & 322 \\
\hline ÉSTERES DE ASCORBILO & 304,305 & 2006 & $500 \mathrm{mg} / \mathrm{kg}$ & 10 \\
\hline $\begin{array}{l}\text { ÉSTERES DE PROPILENGLICOL DE } \\
\text { ÁCIDOS GRASOS }\end{array}$ & 477 & 2006 & $10000 \mathrm{mg} / \mathrm{kg}$ & \\
\hline $\begin{array}{l}\text { ÉSTERES DIACETILTARTÁRICOS Y DE } \\
\text { ÁCIDOS GRASOS DE GLICEROL }\end{array}$ & $472 e$ & 2006 & 10000 mg/kg & \\
\hline GALATO DE PROPILO & 310 & 2006 & 200 mg/kg & $15 \& 130$ \\
\hline INDIGOTINA (CARMÍN DE ÍNDIGO) & 132 & 2009 & $300 \mathrm{mg} / \mathrm{kg}$ & 161 \\
\hline LECITINA & $322(i)$ & 2018 & BPF & \\
\hline $\begin{array}{l}\text { MONOGLICÉRIDOS Y DIGLICÉRIDOS DE } \\
\text { ÁCIDOS GRASOS }\end{array}$ & 471 & 2018 & BPF & $408, X S 211$ \\
\hline POLISORBATOS & $432-436$ & 2007 & $5000 \mathrm{mg} / \mathrm{kg}$ & 102 \\
\hline RESINA DE GUAYACO & 314 & 2006 & $1000 \mathrm{mg} / \mathrm{kg}$ & \\
\hline TERBUTILHIDROQUINONA & 319 & 2006 & $200 \mathrm{mg} / \mathrm{kg}$ & $15 \& 130$ \\
\hline TIODIPROPIONATOS & 388,389 & 2006 & 200 mg/kg & 46 \\
\hline TOCOFEROLES & $307 a, b, c$ & 2016 & 300 mg/kg & 358 \\
\hline VERDE SÓLIDO FCF & 143 & 1999 & BPF & \\
\hline
\end{tabular}

\begin{tabular}{|c|c|c|c|c|}
\hline \multicolumn{2}{|c|}{ No. de Categoría de alimento 02.2.1 } & \multicolumn{2}{|c|}{ antequilla (manteca) } & \multirow[b]{2}{*}{ Notas } \\
\hline Aditivo & SIN & Año Adoptada & Dosis máxima & \\
\hline CARBONATO ÁCIDO DE SODIO & 500 (ii) & 2008 & BPF & \\
\hline CARBONATO DE SODIO & $500(\mathrm{i})$ & 2008 & BPF & \\
\hline CAROTENOIDES & 160a(i),a(iii),e,f & 2008 & $25 \mathrm{mg} / \mathrm{kg}$ & $146 \& 291$ \\
\hline CAROTENOS, BETA-, VEGETALES & 160 a(ii) & 2008 & $600 \mathrm{mg} / \mathrm{kg}$ & \\
\hline $\begin{array}{l}\text { EXTRACTOS DE ANNATO, BASE DE } \\
\text { BIXINA }\end{array}$ & $160 \mathrm{~b}(\mathrm{i})$ & 2008 & $20 \mathrm{mg} / \mathrm{kg}$ & 8 \\
\hline FOSFATOS & $\begin{array}{l}\text { 338; 339(i)-(iii); } \\
340(\mathrm{i})-(\mathrm{iii}) ; 341 \text { (i)- } \\
\text { (iii); 342(i)-(ii); } \\
343(\mathrm{i}) \text {-(iii); 450(i)- } \\
\text { (iii),(v)-(vii), (ix); } \\
451(\mathrm{i}),(\mathrm{ii}) ; 452(\mathrm{i})- \\
\text { (v); } 542\end{array}$ & 2008 & $880 \mathrm{mg} / \mathrm{kg}$ & $33 \& 34$ \\
\hline HIDRÓXIDO DE CALCIO & 526 & 2008 & BPF & \\
\hline HIDRÓXIDO DE SODIO & 524 & 2008 & BPF & \\
\hline
\end{tabular}

No. de Categoría de alimento 02.2.2 Grasas para untar, grasas lácteas para untar y mezclas de grasas para untar

\begin{tabular}{|c|c|c|c|c|}
\hline Aditivo & SIN & Año Adoptada & Dosis máxima & Notas \\
\hline $\begin{array}{l}\text { ACEITE DE SOJA OXIDADO CON } \\
\text { PROCEDIMIENTO TÉRMICO }\end{array}$ & 479 & 1999 & $5000 \mathrm{mg} / \mathrm{kg}$ & \\
\hline
\end{tabular}




\section{No. de Categoría de alimento 02.2.2}

Grasas para untar, grasas lácteas para untar y mezclas de grasas para untar

\begin{tabular}{|c|c|c|c|c|}
\hline Aditivo & SIN & Año Adoptada & Dosis máxima & Notas \\
\hline ALGINATO DE PROPILENGLICOL & 405 & 2016 & $3000 \mathrm{mg} / \mathrm{kg}$ & 359 \\
\hline BENZOATOS & $210-213$ & 2001 & $1000 \mathrm{mg} / \mathrm{kg}$ & 13 \\
\hline BUTILHIDROXIANISOL & 320 & 2005 & $200 \mathrm{mg} / \mathrm{kg}$ & $15 \& 130$ \\
\hline BUTILHIDROXITOLUENO & 321 & 2005 & $200 \mathrm{mg} / \mathrm{kg}$ & $15 \& 130$ \\
\hline CANTAXANTINA & $161 \mathrm{~g}$ & 2011 & $15 \mathrm{mg} / \mathrm{kg}$ & $214 \& 215$ \\
\hline $\begin{array}{l}\text { CARAMELO III - CARAMELO AL } \\
\text { AMONÍACO }\end{array}$ & $150 c$ & 2010 & $500 \mathrm{mg} / \mathrm{kg}$ & \\
\hline $\begin{array}{l}\text { CARAMELO IV - CARAMELO AL SULFITO } \\
\text { AMÓNICO }\end{array}$ & $150 d$ & 2011 & $500 \mathrm{mg} / \mathrm{kg}$ & 214 \\
\hline CARMINES & 120 & 2008 & $500 \mathrm{mg} / \mathrm{kg}$ & $161 \& 178$ \\
\hline CAROTENOIDES & $160 a(i), a(i i i), e, f$ & 2010 & $35 \mathrm{mg} / \mathrm{kg}$ & \\
\hline CAROTENOS, BETA-, VEGETALES & $160 a(i i)$ & 2005 & $1000 \mathrm{mg} / \mathrm{kg}$ & \\
\hline CITRATO DE ESTEARILO & 484 & 2012 & $100 \mathrm{mg} / \mathrm{kg}$ & 15 \\
\hline CITRATOS DE ISOPROPILO & 384 & 2001 & $100 \mathrm{mg} / \mathrm{kg}$ & \\
\hline DIACETATO DE SODIO & 262(ii) & 2016 & $1000 \mathrm{mg} / \mathrm{kg}$ & XS253 \\
\hline DIMETILPOLISILOXANO & $900 a$ & 2007 & $10 \mathrm{mg} / \mathrm{kg}$ & 152 \\
\hline ESTEAROIL LACTILATOS & 481(i), 482(i) & 2009 & $10000 \mathrm{mg} / \mathrm{kg}$ & \\
\hline ÉSTERES DE ASCORBILO & 304,305 & 2006 & $500 \mathrm{mg} / \mathrm{kg}$ & 10 \\
\hline $\begin{array}{l}\text { ÉSTERES DE PROPILENGLICOL DE } \\
\text { ÁCIDOS GRASOS }\end{array}$ & 477 & 2001 & $20000 \mathrm{mg} / \mathrm{kg}$ & \\
\hline $\begin{array}{l}\text { ÉSTERES DE SORBITÁN DE ÁCIDOS } \\
\text { GRASOS }\end{array}$ & $491-495$ & 2016 & $10000 \mathrm{mg} / \mathrm{kg}$ & 359 \\
\hline $\begin{array}{l}\text { ÉSTERES DIACETILTARTÁRICOS Y DE } \\
\text { ÁCIDOS GRASOS DE GLICEROL }\end{array}$ & $472 e$ & 2005 & $10000 \mathrm{mg} / \mathrm{kg}$ & \\
\hline $\begin{array}{l}\text { ÉSTERES POLIGLICÉRIDOS DE ÁCIDO } \\
\text { RICINOLÉICO INTERESTERIFICADO }\end{array}$ & 476 & 2016 & $4000 \mathrm{mg} / \mathrm{kg}$ & 359 \\
\hline $\begin{array}{l}\text { ÉSTERES POLIGLICÉRIDOS DE ÁCIDOS } \\
\text { GRASOS }\end{array}$ & 475 & 2016 & $5000 \mathrm{mg} / \mathrm{kg}$ & 359 \\
\hline ETILEN DIAMINO TETRA ACETATOS & 385,386 & 2001 & $100 \mathrm{mg} / \mathrm{kg}$ & 21 \\
\hline ETIL-LAUROIL ARGINATO & 243 & 2011 & $200 \mathrm{mg} / \mathrm{kg}$ & $214 \& 215$ \\
\hline FOSFATOS & $\begin{array}{l}338 ; 339(\mathrm{i})-(\mathrm{iii}) ; \\
340(\mathrm{i})-(\mathrm{iii}) ; 341 \text { (i)- } \\
\text { (iii); } 342(\mathrm{i})-(\mathrm{ii)} ; \\
343 \text { (i)-(iii); } 450 \text { (i)- } \\
\text { (iii),(v)-(vii), (ix); } \\
451 \text { (i),(ii); 452(i)- } \\
\text { (v); } 542\end{array}$ & 2009 & $2200 \mathrm{mg} / \mathrm{kg}$ & 33 \\
\hline GALATO DE PROPILO & 310 & 2004 & $200 \mathrm{mg} / \mathrm{kg}$ & $15 \& 130$ \\
\hline HIDROXIBENZOATOS, PARA- & 214,218 & 2012 & $300 \mathrm{mg} / \mathrm{kg}$ & 27 \\
\hline POLISORBATOS & $432-436$ & 2016 & $10000 \mathrm{mg} / \mathrm{kg}$ & $360 \& 364$ \\
\hline RIBOFLAVINAS & 101(i),(ii), (iii) & 2005 & $300 \mathrm{mg} / \mathrm{kg}$ & \\
\hline SORBATOS & $200,202,203$ & 2009 & $2000 \mathrm{mg} / \mathrm{kg}$ & 42 \\
\hline SUCROÉSTERES DE ÁCIDOS GRASOS & 473 & 2016 & $10000 \mathrm{mg} / \mathrm{kg}$ & $348 \& 360$ \\
\hline SUCROGLICÉRIDOS & 474 & 2016 & $10000 \mathrm{mg} / \mathrm{kg}$ & $348 \& 360$ \\
\hline SUCROSE OLIGOESTERS, TYPE I AND & $473 a$ & 2016 & $10000 \mathrm{mg} / \mathrm{kg}$ & $348 \& 360$ \\
\hline
\end{tabular}




\begin{tabular}{|c|c|c|c|c|}
\hline \multicolumn{2}{|c|}{ No. de Categoría de alimento 02.2.2 } & \multicolumn{3}{|c|}{$\begin{array}{l}\text { Grasas para untar, grasas lácteas para } \\
\text { untar y mezclas de grasas para untar }\end{array}$} \\
\hline Aditivo & $\sin$ & Año Adoptada & Dosis máxima & Notas \\
\hline TARTRATOS & 334, 335(ii), 337 & 2016 & 100 mg/kg & $45 \& 361$ \\
\hline TERBUTILHIDROQUINONA & 319 & 2005 & $200 \mathrm{mg} / \mathrm{kg}$ & $15 \& 130$ \\
\hline TIODIPROPIONATOS & 388, 389 & 1999 & $200 \mathrm{mg} / \mathrm{kg}$ & 46 \\
\hline TOCOFEROLES & $307 a, b, c$ & 2009 & $500 \mathrm{mg} / \mathrm{kg}$ & \\
\hline
\end{tabular}

No. de Categoría de alimento 02.3

Emulsiones grasas, principalmente del tipo agua en aceite, incluidos los productos a base de emulsiones grasas mezclados y/o aromatizados

\begin{tabular}{|c|c|c|c|c|}
\hline Aditivo & SIN & Año Adoptada & Dosis máxima & Notas \\
\hline ACESULFAME DE POTASIO & 950 & 2008 & $1000 \mathrm{mg} / \mathrm{kg}$ & $161 \& 188$ \\
\hline ALGINATO DE PROPILENGLICOL & 405 & 2016 & $3000 \mathrm{mg} / \mathrm{kg}$ & \\
\hline ASPARTAMO & 951 & 2008 & $1000 \mathrm{mg} / \mathrm{kg}$ & $161 \& 191$ \\
\hline AZUL BRILLANTE FCF & 133 & 2005 & $100 \mathrm{mg} / \mathrm{kg}$ & \\
\hline BENZOATOS & $210-213$ & 2001 & $1000 \mathrm{mg} / \mathrm{kg}$ & 13 \\
\hline BUTILHIDROXIANISOL & 320 & 2006 & $200 \mathrm{mg} / \mathrm{kg}$ & $15 \& 130$ \\
\hline BUTILHIDROXITOLUENO & 321 & 2006 & $200 \mathrm{mg} / \mathrm{kg}$ & $15 \& 130$ \\
\hline CANTAXANTINA & $161 \mathrm{~g}$ & 2011 & $15 \mathrm{mg} / \mathrm{kg}$ & \\
\hline $\begin{array}{l}\text { CARAMELO III - CARAMELO AL } \\
\text { AMONÍACO }\end{array}$ & $150 \mathrm{c}$ & 2010 & $20000 \mathrm{mg} / \mathrm{kg}$ & \\
\hline CARMINES & 120 & 2008 & $500 \mathrm{mg} / \mathrm{kg}$ & $161 \& 178$ \\
\hline CAROTENOIDES & 160a(i),a(iii),e,f & 2009 & $200 \mathrm{mg} / \mathrm{kg}$ & \\
\hline CAROTENOS, BETA-, VEGETALES & 160a(ii) & 2005 & $1000 \mathrm{mg} / \mathrm{kg}$ & \\
\hline DIACETATO DE SODIO & 262(ii) & 2016 & $1000 \mathrm{mg} / \mathrm{kg}$ & \\
\hline ESTEAROIL LACTILATOS & 481(i), 482(i) & 2016 & $3000 \mathrm{mg} / \mathrm{kg}$ & \\
\hline ÉSTERES DE ASCORBILO & 304,305 & 2001 & $500 \mathrm{mg} / \mathrm{kg}$ & 10 \\
\hline $\begin{array}{l}\text { ÉSTERES DE PROPILENGLICOL DE } \\
\text { ÁCIDOS GRASOS }\end{array}$ & 477 & 2001 & $30000 \mathrm{mg} / \mathrm{kg}$ & \\
\hline $\begin{array}{l}\text { ÉSTERES DE SORBITÁN DE ÁCIDOS } \\
\text { GRASOS }\end{array}$ & 491-495 & 2016 & $5000 \mathrm{mg} / \mathrm{kg}$ & 363 \\
\hline $\begin{array}{l}\text { ÉSTERES DIACETILTARTÁRICOS Y DE } \\
\text { ÁCIDOS GRASOS DE GLICEROL }\end{array}$ & $472 e$ & 2005 & $10000 \mathrm{mg} / \mathrm{kg}$ & \\
\hline $\begin{array}{l}\text { ÉSTERES POLIGLICÉRIDOS DE ÁCIDO } \\
\text { RICINOLÉICO INTERESTERIFICADO }\end{array}$ & 476 & 2016 & $10000 \mathrm{mg} / \mathrm{kg}$ & \\
\hline $\begin{array}{l}\text { ÉSTERES POLIGLICÉRIDOS DE ÁCIDOS } \\
\text { GRASOS }\end{array}$ & 475 & 2016 & $20000 \mathrm{mg} / \mathrm{kg}$ & 363 \\
\hline FOSFATOS & $\begin{array}{l}338 ; 339(\mathrm{i})-(\mathrm{iii}) ; \\
340(\mathrm{i})-(\mathrm{iii}) ; 341 \text { (i)- } \\
\text { (iii); 342(i)-(ii); } \\
343(\mathrm{i})-(\mathrm{iii}) ; 450(\mathrm{i})- \\
\text { (iii),(v)-(vii), (ix); } \\
451 \text { (i),(ii); 452(i)- } \\
\text { (v); } 542\end{array}$ & 2009 & $2200 \mathrm{mg} / \mathrm{kg}$ & 33 \\
\hline GALATO DE PROPILO & 310 & 2004 & $200 \mathrm{mg} / \mathrm{kg}$ & $15 \& 130$ \\
\hline HIDROXIBENZOATOS, PARA- & 214,218 & 2012 & $300 \mathrm{mg} / \mathrm{kg}$ & 27 \\
\hline
\end{tabular}


Emulsiones grasas, principalmente del tipo agua en aceite, incluidos los productos a base de emulsiones grasas mezclados y/o aromatizados

\begin{tabular}{|c|c|c|c|c|}
\hline Aditivo & $\operatorname{SIN}$ & Año Adoptada & Dosis máxima & Notas \\
\hline INDIGOTINA (CARMÍN DE ÍNDIGO) & 132 & 2009 & 300 mg/kg & 161 \\
\hline NEOTAMO & 961 & 2008 & $10 \mathrm{mg} / \mathrm{kg}$ & 161 \\
\hline POLISORBATOS & $432-436$ & 2007 & $5000 \mathrm{mg} / \mathrm{kg}$ & 102 \\
\hline RIBOFLAVINAS & 101(i),(ii), (iii) & 2008 & $300 \mathrm{mg} / \mathrm{kg}$ & \\
\hline SORBATOS & $200,202,203$ & 2009 & $1000 \mathrm{mg} / \mathrm{kg}$ & 42 \\
\hline SUCROÉSTERES DE ÁCIDOS GRASOS & 473 & 2016 & $5000 \mathrm{mg} / \mathrm{kg}$ & $102 \& 363$ \\
\hline SUCROGLICÉRIDOS & 474 & 2016 & $5000 \mathrm{mg} / \mathrm{kg}$ & $102 \& 363$ \\
\hline $\begin{array}{l}\text { SUCROSE OLIGOESTERS, TYPE I AND } \\
\text { TYPE II }\end{array}$ & $473 a$ & 2016 & $5000 \mathrm{mg} / \mathrm{kg}$ & $102 \& 363$ \\
\hline TARTRATOS & 334, 335(ii), 337 & 2016 & $100 \mathrm{mg} / \mathrm{kg}$ & 45 \\
\hline TERBUTILHIDROQUINONA & 319 & 2005 & $200 \mathrm{mg} / \mathrm{kg}$ & $15 \& 130$ \\
\hline TOCOFEROLES & $307 a, b, c$ & 2016 & $900 \mathrm{mg} / \mathrm{kg}$ & \\
\hline
\end{tabular}

No. de Categoría de alimento 02.4

Postres a base de grasas, excluidos los postres lácteos de la categoría de alimentos 01.7

\begin{tabular}{|c|c|c|c|c|}
\hline Aditivo & SIN & Año Adoptada & Dosis máxima & Notas \\
\hline ACESULFAME DE POTASIO & 950 & 2007 & $350 \mathrm{mg} / \mathrm{kg}$ & $161 \& 188$ \\
\hline AMARILLO OCASO FCF & 110 & 2008 & $50 \mathrm{mg} / \mathrm{kg}$ & \\
\hline ASPARTAMO & 951 & 2007 & $1000 \mathrm{mg} / \mathrm{kg}$ & $161 \& 191$ \\
\hline AZUL BRILLANTE FCF & 133 & 2005 & $150 \mathrm{mg} / \mathrm{kg}$ & \\
\hline BENZOATOS & $210-213$ & 2001 & $1000 \mathrm{mg} / \mathrm{kg}$ & 13 \\
\hline BUTILHIDROXIANISOL & 320 & 2006 & $200 \mathrm{mg} / \mathrm{kg}$ & $15 \& 130$ \\
\hline BUTILHIDROXITOLUENO & 321 & 2006 & $200 \mathrm{mg} / \mathrm{kg}$ & $15 \& 130$ \\
\hline CANTAXANTINA & $161 \mathrm{~g}$ & 2011 & $15 \mathrm{mg} / \mathrm{kg}$ & \\
\hline $\begin{array}{l}\text { CARAMELO III - CARAMELO AL } \\
\text { AMONÍACO }\end{array}$ & $150 \mathrm{c}$ & 2010 & $20000 \mathrm{mg} / \mathrm{kg}$ & \\
\hline $\begin{array}{l}\text { CARAMELO IV - CARAMELO AL SULFITO } \\
\text { AMÓNICO }\end{array}$ & $150 d$ & 2009 & $20000 \mathrm{mg} / \mathrm{kg}$ & \\
\hline CARMINES & 120 & 2005 & $150 \mathrm{mg} / \mathrm{kg}$ & 178 \\
\hline CAROTENOIDES & $160 a(i), a(i i i), e, f$ & 2009 & $150 \mathrm{mg} / \mathrm{kg}$ & \\
\hline CAROTENOS, BETA-, VEGETALES & $160 a(i i)$ & 2005 & $1000 \mathrm{mg} / \mathrm{kg}$ & \\
\hline CICLAMATOS & 952(i), (ii), (iv) & 2007 & $250 \mathrm{mg} / \mathrm{kg}$ & $17 \& 161$ \\
\hline $\begin{array}{l}\text { CLOROFILAS Y CLOROFILINAS, } \\
\text { COMPLEJOS CUPRICOS }\end{array}$ & 141(i),(ii) & 2009 & $500 \mathrm{mg} / \mathrm{kg}$ & \\
\hline DIACETATO DE SODIO & 262(ii) & 2016 & $1000 \mathrm{mg} / \mathrm{kg}$ & \\
\hline ESTEAROIL LACTILATOS & $481(\mathrm{i}), 482(\mathrm{i})$ & 2016 & $5000 \mathrm{mg} / \mathrm{kg}$ & \\
\hline ÉSTERES DE ASCORBILO & 304,305 & 2001 & $80 \mathrm{mg} / \mathrm{kg}$ & 10 \\
\hline $\begin{array}{l}\text { ÉSTERES DE PROPILENGLICOL DE } \\
\text { ÁCIDOS GRASOS }\end{array}$ & 477 & 2006 & $40000 \mathrm{mg} / \mathrm{kg}$ & \\
\hline
\end{tabular}




\begin{tabular}{|c|c|c|c|c|}
\hline No. de Categoría de alimento & \multicolumn{4}{|c|}{$\begin{array}{l}\text { Postres a base de grasas, excluidos los } \\
\text { postres lácteos de la categoría de } \\
\text { alimentos } 01.7\end{array}$} \\
\hline Aditivo & SIN & Año Adoptada & Dosis máxima & Notas \\
\hline $\begin{array}{l}\text { ÉSTERES DE SORBITÁN DE ÁCIDOS } \\
\text { GRASOS }\end{array}$ & 491-495 & 2016 & $10000 \mathrm{mg} / \mathrm{kg}$ & \\
\hline $\begin{array}{l}\text { ÉSTERES DIACETILTARTÁRICOS Y DE } \\
\text { ÁCIDOS GRASOS DE GLICEROL }\end{array}$ & $472 \mathrm{e}$ & 2005 & $5000 \mathrm{mg} / \mathrm{kg}$ & \\
\hline $\begin{array}{l}\text { ÉSTERES POLIGLICÉRIDOS DE ÁCIDO } \\
\text { RICINOLÉICO INTERESTERIFICADO }\end{array}$ & 476 & 2016 & $2000 \mathrm{mg} / \mathrm{kg}$ & \\
\hline $\begin{array}{l}\text { ÉSTERES POLIGLICÉRIDOS DE ÁCIDOS } \\
\text { GRASOS }\end{array}$ & 475 & 2016 & $2000 \mathrm{mg} / \mathrm{kg}$ & \\
\hline EXTRACTO DE PIEL DE UVA & 163(ii) & 2009 & $200 \mathrm{mg} / \mathrm{kg}$ & 181 \\
\hline FOSFATOS & $\begin{array}{l}\text { 338; 339(i)-(iii); } \\
\text { 340(i)-(iii); 341(i)- } \\
\text { (iii); 342(i)-(ii); } \\
343(\mathrm{i}) \text {-(iii); 450(i)- } \\
\text { (iii),(v)-(vii), (ix); } \\
\text { 451(i),(ii); 452(i)- } \\
\text { (v); } 542\end{array}$ & 2012 & $1500 \mathrm{mg} / \mathrm{kg}$ & 33 \\
\hline GALATO DE PROPILO & 310 & 2004 & $200 \mathrm{mg} / \mathrm{kg}$ & $15 \& 130$ \\
\hline GLICÓSIDOS DE ESTEVIOL & 960a, 960b(i) & 2011 & $330 \mathrm{mg} / \mathrm{kg}$ & 26 \\
\hline INDIGOTINA (CARMÍN DE ÍNDIGO) & 132 & 2009 & $150 \mathrm{mg} / \mathrm{kg}$ & \\
\hline NEOTAMO & 961 & 2007 & $100 \mathrm{mg} / \mathrm{kg}$ & 161 \\
\hline ÓXIDOS DE HIERRO & 172(i)-(iii) & 2005 & $350 \mathrm{mg} / \mathrm{kg}$ & \\
\hline POLISORBATOS & $432-436$ & 2007 & $3000 \mathrm{mg} / \mathrm{kg}$ & 102 \\
\hline PONCEAU 4R (ROJO DE COCHINILLA A) & 124 & 2008 & $50 \mathrm{mg} / \mathrm{kg}$ & \\
\hline RIBOFLAVINAS & 101(i),(ii), (iii) & 2005 & $300 \mathrm{mg} / \mathrm{kg}$ & \\
\hline ROJO ALLURA AC & 129 & 2009 & $300 \mathrm{mg} / \mathrm{kg}$ & 161 \\
\hline SACARINAS & 954(i)-(iv) & 2007 & $100 \mathrm{mg} / \mathrm{kg}$ & 161 \\
\hline SAL DE ASPARTAMO Y ACESULFAMO & 962 & 2009 & $350 \mathrm{mg} / \mathrm{kg}$ & $113 \& 161$ \\
\hline SORBATOS & $200,202,203$ & 2010 & $1000 \mathrm{mg} / \mathrm{kg}$ & 42 \\
\hline $\begin{array}{l}\text { SUCRALOSA } \\
\text { (TRICLOROGALACTOSACAROSA) }\end{array}$ & 955 & 2007 & $400 \mathrm{mg} / \mathrm{kg}$ & 161 \\
\hline SUCROÉSTERES DE ÁCIDOS GRASOS & 473 & 2016 & $5000 \mathrm{mg} / \mathrm{kg}$ & 348 \\
\hline SUCROGLICÉRIDOS & 474 & 2016 & $5000 \mathrm{mg} / \mathrm{kg}$ & 348 \\
\hline $\begin{array}{l}\text { SUCROSE OLIGOESTERS, TYPE I AND } \\
\text { TYPE II }\end{array}$ & $473 a$ & 2016 & $5000 \mathrm{mg} / \mathrm{kg}$ & 348 \\
\hline TARTRATOS & 334, 335(ii), 337 & 2016 & $100 \mathrm{mg} / \mathrm{kg}$ & 45 \\
\hline TERBUTILHIDROQUINONA & 319 & 2005 & $200 \mathrm{mg} / \mathrm{kg}$ & $15 \& 130$ \\
\hline TOCOFEROLES & $307 a, b, c$ & 2016 & $200 \mathrm{mg} / \mathrm{kg}$ & \\
\hline VERDE SÓLIDO FCF & 143 & 2009 & $100 \mathrm{mg} / \mathrm{kg}$ & \\
\hline
\end{tabular}

No. de Categoría de alimento 03.0

Hielos comestibles, incluidos los sorbetes

\begin{tabular}{|c|c|c|c|c|}
\hline Aditivo & SIN & Año Adoptada & Dosis máxima & Notas \\
\hline ACESULFAME DE POTASIO & 950 & 2019 & $800 \mathrm{mg} / \mathrm{kg}$ & $478 \& 188$ \\
\hline ALGINATO DE PROPILENGLICOL & 405 & 2016 & $10000 \mathrm{mg} / \mathrm{kg}$ & \\
\hline
\end{tabular}




\section{No. de Categoría de alimento 03.0}

Hielos comestibles, incluidos los sorbetes

\begin{tabular}{|c|c|c|c|c|}
\hline Aditivo & SIN & Año Adoptada & Dosis máxima & Notas \\
\hline ALITAME & 956 & 2007 & $100 \mathrm{mg} / \mathrm{kg}$ & 161 \\
\hline AMARILLO OCASO FCF & 110 & 2008 & $50 \mathrm{mg} / \mathrm{kg}$ & \\
\hline ASPARTAMO & 951 & 2019 & $1000 \mathrm{mg} / \mathrm{kg}$ & $478 \& 191$ \\
\hline AZUL BRILLANTE FCF & 133 & 2005 & $150 \mathrm{mg} / \mathrm{kg}$ & \\
\hline BUTILHIDROXIANISOL & 320 & 2006 & $200 \mathrm{mg} / \mathrm{kg}$ & $15 \& 195$ \\
\hline BUTILHIDROXITOLUENO & 321 & 2006 & $100 \mathrm{mg} / \mathrm{kg}$ & $15 \& 195$ \\
\hline $\begin{array}{l}\text { CARAMELO III - CARAMELO AL } \\
\text { AMONÍACO }\end{array}$ & $150 c$ & 1999 & $1000 \mathrm{mg} / \mathrm{kg}$ & \\
\hline $\begin{array}{l}\text { CARAMELO IV - CARAMELO AL SULFITO } \\
\text { AMÓNICO }\end{array}$ & $150 d$ & 1999 & $1000 \mathrm{mg} / \mathrm{kg}$ & \\
\hline CARMINES & 120 & 2005 & $150 \mathrm{mg} / \mathrm{kg}$ & 178 \\
\hline CAROTENOIDES & $160 a(i), a(i i i), e, f$ & 2009 & $200 \mathrm{mg} / \mathrm{kg}$ & \\
\hline CAROTENOS, BETA-, VEGETALES & $160 a(i i)$ & 2005 & $1000 \mathrm{mg} / \mathrm{kg}$ & \\
\hline CICLAMATOS & 952(i), (ii), (iv) & 2019 & $250 \mathrm{mg} / \mathrm{kg}$ & $17 \& 477$ \\
\hline $\begin{array}{l}\text { CLOROFILAS Y CLOROFILINAS, } \\
\text { COMPLEJOS CUPRICOS }\end{array}$ & 141(i),(ii) & 2009 & $500 \mathrm{mg} / \mathrm{kg}$ & \\
\hline ESTEAROIL LACTILATOS & $481(\mathrm{i}), 482(\mathrm{i})$ & 2016 & $5000 \mathrm{mg} / \mathrm{kg}$ & 15 \\
\hline ÉSTERES DE ASCORBILO & 304,305 & 2001 & $200 \mathrm{mg} / \mathrm{kg}$ & $10 \& 15$ \\
\hline $\begin{array}{l}\text { ÉSTERES DE PROPILENGLICOL DE } \\
\text { ÁCIDOS GRASOS }\end{array}$ & 477 & 2001 & $5000 \mathrm{mg} / \mathrm{kg}$ & \\
\hline $\begin{array}{l}\text { ÉSTERES DE SORBITÁN DE ÁCIDOS } \\
\text { GRASOS }\end{array}$ & 491-495 & 2016 & $1000 \mathrm{mg} / \mathrm{kg}$ & \\
\hline $\begin{array}{l}\text { ÉSTERES DIACETILTARTÁRICOS Y DE } \\
\text { ÁCIDOS GRASOS DE GLICEROL }\end{array}$ & $472 e$ & 2006 & $1000 \mathrm{mg} / \mathrm{kg}$ & \\
\hline $\begin{array}{l}\text { ÉSTERES POLIGLICÉRIDOS DE ÁCIDO } \\
\text { RICINOLÉICO INTERESTERIFICADO }\end{array}$ & 476 & 2016 & $5000 \mathrm{mg} / \mathrm{kg}$ & \\
\hline $\begin{array}{l}\text { ÉSTERES POLIGLICÉRIDOS DE ÁCIDOS } \\
\text { GRASOS }\end{array}$ & 475 & 2016 & $5000 \mathrm{mg} / \mathrm{kg}$ & \\
\hline ETILMALTOL & 637 & 2016 & $200 \mathrm{mg} / \mathrm{kg}$ & \\
\hline EXTRACTO DE PIEL DE UVA & 163(ii) & 2011 & $100 \mathrm{mg} / \mathrm{kg}$ & 181 \\
\hline FOSFATOS & $\begin{array}{l}338 ; 339(\mathrm{i})-(\mathrm{iii}) ; \\
340(\mathrm{i})-(\mathrm{iii}) ; 341 \text { (i)- } \\
\text { (iii); 342(i)-(ii); } \\
343(\mathrm{i}) \text {-(iii); } 450 \text { (i)- } \\
\text { (iii),(v)-(vii), (ix); } \\
451 \text { (i),(ii); 452(i)- } \\
\text { (v); } 542\end{array}$ & 2012 & $7500 \mathrm{mg} / \mathrm{kg}$ & 33 \\
\hline GLICÓSIDOS DE ESTEVIOL & $960 a, 960 b(i)$ & 2011 & $270 \mathrm{mg} / \mathrm{kg}$ & 26 \\
\hline INDIGOTINA (CARMIIN DE ÍNDIGO) & 132 & 2009 & $150 \mathrm{mg} / \mathrm{kg}$ & \\
\hline MALTOL & 636 & 2016 & $200 \mathrm{mg} / \mathrm{kg}$ & \\
\hline NEOTAMO & 961 & 2019 & $100 \mathrm{mg} / \mathrm{kg}$ & 478 \\
\hline ÓXIDOS DE HIERRO & 172(i)-(iii) & 2005 & $300 \mathrm{mg} / \mathrm{kg}$ & \\
\hline POLISORBATOS & $432-436$ & 2005 & $1000 \mathrm{mg} / \mathrm{kg}$ & \\
\hline PONCEAU 4R (ROJO DE COCHINILLA A) & 124 & 2008 & $50 \mathrm{mg} / \mathrm{kg}$ & \\
\hline RIBOFLAVINAS & 101(i),(ii), (iii) & 2005 & $500 \mathrm{mg} / \mathrm{kg}$ & \\
\hline ROJO ALLURA AC & 129 & 2009 & $150 \mathrm{mg} / \mathrm{kg}$ & \\
\hline
\end{tabular}




\begin{tabular}{|c|c|c|c|c|}
\hline \multicolumn{2}{|c|}{ No. de Categoría de alimento 03.0} & \multicolumn{3}{|c|}{$\begin{array}{l}\text { Hielos comestibles, incluidos los } \\
\text { sorbetes }\end{array}$} \\
\hline Aditivo & $\operatorname{SIN}$ & Año Adoptada & Dosis máxima & Notas \\
\hline SACARINAS & 954(i)-(iv) & 2019 & $100 \mathrm{mg} / \mathrm{kg}$ & 477 \\
\hline $\begin{array}{l}\text { SUCRALOSA } \\
\text { (TRICLOROGALACTOSACAROSA) }\end{array}$ & 955 & 2019 & $320 \mathrm{mg} / \mathrm{kg}$ & 478 \\
\hline SUCROÉSTERES DE ÁCIDOS GRASOS & 473 & 2016 & $5000 \mathrm{mg} / \mathrm{kg}$ & 348 \\
\hline SUCROGLICÉRIDOS & 474 & 2016 & $5000 \mathrm{mg} / \mathrm{kg}$ & 348 \\
\hline $\begin{array}{l}\text { SUCROSE OLIGOESTERS, TYPE I AND } \\
\text { TYPE II }\end{array}$ & $473 a$ & 2016 & $5000 \mathrm{mg} / \mathrm{kg}$ & 348 \\
\hline TARTRATOS & 334, 335(ii), 337 & 2016 & $4000 \mathrm{mg} / \mathrm{kg}$ & 45 \\
\hline TERBUTILHIDROQUINONA & 319 & 2006 & $200 \mathrm{mg} / \mathrm{kg}$ & $15 \& 195$ \\
\hline TOCOFEROLES & $307 a, b, c$ & 2016 & $500 \mathrm{mg} / \mathrm{kg}$ & 15 \\
\hline VERDE SÓLIDO FCF & 143 & 1999 & $100 \mathrm{mg} / \mathrm{kg}$ & \\
\hline
\end{tabular}

No. de Categoría de alimento 04.1.1.2 Frutas frescas tratadas en la superficie

\begin{tabular}{|c|c|c|c|c|}
\hline Aditivo & SIN & Año Adoptada & Dosis máxima & Notas \\
\hline CARMINES & 120 & 2008 & $500 \mathrm{mg} / \mathrm{kg}$ & $4,16 \& 178$ \\
\hline CERA CANDELILLA & 902 & 2003 & BPF & \\
\hline CERA CARNAUBA & 903 & 2004 & $400 \mathrm{mg} / \mathrm{kg}$ & \\
\hline CERA DE ABEJAS & 901 & 2003 & BPF & \\
\hline CERA MICROCRISTALINA & $905 c(i)$ & 2004 & $50 \mathrm{mg} / \mathrm{kg}$ & \\
\hline ÉSTERES DE GLICEROL DE COLOFONIA & 445(iii) & 2005 & $110 \mathrm{mg} / \mathrm{kg}$ & \\
\hline GOMA LACA, BLANQUEADA & 904 & 2003 & BPF & \\
\hline $\begin{array}{l}\text { MONOGLICÉRIDOS Y DIGLICÉRIDOS DE } \\
\text { ÁCIDOS GRASOS }\end{array}$ & 471 & 2019 & BPF & 453 \\
\hline ORTO-FENILFENOLES & 231,232 & 1999 & $12 \mathrm{mg} / \mathrm{kg}$ & 49 \\
\hline ÓXIDOS DE HIERRO & 172(i)-(iii) & 2008 & $1000 \mathrm{mg} / \mathrm{kg}$ & $4 \& 16$ \\
\hline POLIETILENGLICOL & 1521 & 2001 & BPF & \\
\hline POLIVINILPIRROLIDONA & 1201 & 1999 & BPF & \\
\hline RIBOFLAVINAS & 101(i),(ii), (iii) & 2008 & $300 \mathrm{mg} / \mathrm{kg}$ & $4 \& 16$ \\
\hline $\begin{array}{l}\text { SAL MIRÍSTICA, PALMÍTICA Y ÁCIDOS } \\
\text { ESTEÁRICOS CON AMONIO, CALCIO, } \\
\text { POTASIO Y SODIO }\end{array}$ & 470 (i) & 2019 & BPF & $71 \& 454$ \\
\hline SUCROGLICÉRIDOS & 474 & 2009 & BPF & \\
\hline SULFITOS & $220-225,539$ & 2011 & $30 \mathrm{mg} / \mathrm{kg}$ & $44 \& 204$ \\
\hline
\end{tabular}

\section{No. de Categoría de alimento 04.1.1.3 Frutas frescas peladas y/o cortadas}

\begin{tabular}{|c|c|c|c|c|}
\hline Aditivo & SIN & Año Adoptada & Dosis máxima & Notas \\
\hline ASCORBATO DE CALCIO & 302 & 2014 & BPF & \\
\hline ASCORBATO DE SODIO & 301 & 2014 & BPF & \\
\hline DIÓXIDO DE CARBONO & 290 & 2014 & BPF & 59 \\
\hline NITRÓGENO & 941 & 2014 & BPF & 59 \\
\hline ÓXIDO NITROSO & 942 & 2014 & BPF & \\
\hline
\end{tabular}


No. de Categoría de alimento 04.1.2 Frutas elaboradas

\begin{tabular}{|c|c|c|c|c|}
\hline Aditivo & SIN & Año Adoptada & Dosis máxima & Notas \\
\hline CERA CARNAUBA & 903 & 2004 & $400 \mathrm{mg} / \mathrm{kg}$ & \\
\hline
\end{tabular}

\section{No. de Categoría de alimento 04.1.2.1 Frutas congeladas}

\begin{tabular}{|c|c|c|c|c|}
\hline Aditivo & SIN & Año Adoptada & Dosis máxima & Notas \\
\hline ACESULFAME DE POTASIO & 950 & 2008 & $500 \mathrm{mg} / \mathrm{kg}$ & $161 \& 188$ \\
\hline ASPARTAMO & 951 & 2008 & $2000 \mathrm{mg} / \mathrm{kg}$ & $161 \& 191$ \\
\hline NEOTAMO & 961 & 2008 & $100 \mathrm{mg} / \mathrm{kg}$ & 161 \\
\hline $\begin{array}{l}\text { SUCRALOSA } \\
\text { (TRICLOROGALACTOSACAROSA) }\end{array}$ & 955 & 2008 & $400 \mathrm{mg} / \mathrm{kg}$ & 161 \\
\hline SULFITOS & 220-225, 539 & 2007 & $500 \mathrm{mg} / \mathrm{kg}$ & $44 \& 155$ \\
\hline
\end{tabular}

\section{No. de Categoría de alimento 04.1.2.2 Frutas desecadas}

\begin{tabular}{|c|c|c|c|c|}
\hline Aditivo & SIN & Año Adoptada & Dosis máxima & Notas \\
\hline ACEITE MINERAL DE ALTA VISCOSIDAD & $905 d$ & 2005 & $5000 \mathrm{mg} / \mathrm{kg}$ & \\
\hline ACEITE MINERAL, VISCOSIDAD MEDIA & $905 e$ & 2005 & $5000 \mathrm{mg} / \mathrm{kg}$ & \\
\hline ACESULFAME DE POTASIO & 950 & 2008 & $500 \mathrm{mg} / \mathrm{kg}$ & $161 \& 188$ \\
\hline ASPARTAMO & 951 & 2008 & $2000 \mathrm{mg} / \mathrm{kg}$ & $161 \& 191$ \\
\hline BENZOATOS & $210-213$ & 2003 & $800 \mathrm{mg} / \mathrm{kg}$ & 13 \\
\hline ÉSTERES DE ASCORBILO & 304,305 & 2001 & $80 \mathrm{mg} / \mathrm{kg}$ & 10 \\
\hline $\begin{array}{l}\text { ÉSTERES DIACETILTARTÁRICOS Y DE } \\
\text { ÁCIDOS GRASOS DE GLICEROL }\end{array}$ & $472 \mathrm{e}$ & 2005 & $10000 \mathrm{mg} / \mathrm{kg}$ & \\
\hline ETILEN DIAMINO TETRA ACETATOS & 385,386 & 2001 & $265 \mathrm{mg} / \mathrm{kg}$ & 21 \\
\hline ETIL-LAUROIL ARGINATO & 243 & 2011 & $200 \mathrm{mg} / \mathrm{kg}$ & \\
\hline HIDROXIBENZOATOS, PARA- & 214,218 & 2010 & $800 \mathrm{mg} / \mathrm{kg}$ & 27 \\
\hline NEOTAMO & 961 & 2008 & $100 \mathrm{mg} / \mathrm{kg}$ & 161 \\
\hline POLI-1-DECENOS HIDROGENADOS & 907 & 2016 & $2000 \mathrm{mg} / \mathrm{kg}$ & \\
\hline SORBATOS & $200,202,203$ & 2012 & $500 \mathrm{mg} / \mathrm{kg}$ & 42 \\
\hline $\begin{array}{l}\text { SUCRALOSA } \\
\text { (TRICLOROGALACTOSACAROSA) }\end{array}$ & 955 & 2008 & $1500 \mathrm{mg} / \mathrm{kg}$ & 161 \\
\hline SULFITOS & 220-225, 539 & 2011 & $1000 \mathrm{mg} / \mathrm{kg}$ & $44,135 \& 218$ \\
\hline TOCOFEROLES & $307 a, b, c$ & 2018 & $200 \mathrm{mg} / \mathrm{kg}$ & XS67, XS130 \\
\hline
\end{tabular}

\section{No. de Categoría de alimento 04.1.2.3 Frutas en vinagre, aceite o salmuera}

\begin{tabular}{|c|c|c|c|c|}
\hline Aditivo & SIN & Año Adoptada & Dosis máxima & Notas \\
\hline ACESULFAME DE POTASIO & 950 & 2007 & $200 \mathrm{mg} / \mathrm{kg}$ & $161 \& 188$ \\
\hline ASPARTAMO & 951 & 2007 & $300 \mathrm{mg} / \mathrm{kg}$ & $144 \& 191$ \\
\hline BENZOATOS & $210-213$ & 2001 & $1000 \mathrm{mg} / \mathrm{kg}$ & 13 \\
\hline $\begin{array}{l}\text { CARAMELO III - CARAMELO AL } \\
\text { AMONÍACO }\end{array}$ & $150 c$ & 2010 & $200 \mathrm{mg} / \mathrm{kg}$ & \\
\hline $\begin{array}{l}\text { CARAMELO IV - CARAMELO AL SULFITO } \\
\text { AMÓNICO }\end{array}$ & $150 d$ & 2011 & $7500 \mathrm{mg} / \mathrm{kg}$ & \\
\hline CAROTENOIDES & $160 a(i), a(i i i), e, f$ & 2009 & $1000 \mathrm{mg} / \mathrm{kg}$ & \\
\hline CAROTENOS, BETA-, VEGETALES & $160 \mathrm{a}(\mathrm{ii})$ & 2005 & $1000 \mathrm{mg} / \mathrm{kg}$ & \\
\hline
\end{tabular}


No. de Categoría de alimento 04.1.2.3 Frutas en vinagre, aceite o salmuera

\begin{tabular}{|c|c|c|c|c|}
\hline Aditivo & SIN & Año Adoptada & Dosis máxima & Notas \\
\hline $\begin{array}{l}\text { CLOROFILAS Y CLOROFILINAS, } \\
\text { COMPLEJOS CUPRICOS }\end{array}$ & 141(i),(ii) & 2005 & $100 \mathrm{mg} / \mathrm{kg}$ & 62 \\
\hline DIMETILPOLISILOXANO & $900 a$ & 1999 & $10 \mathrm{mg} / \mathrm{kg}$ & \\
\hline $\begin{array}{l}\text { ÉSTERES DIACETILTARTÁRICOS Y DE } \\
\text { ÁCIDOS GRASOS DE GLICEROL }\end{array}$ & $472 \mathrm{e}$ & 2005 & $1000 \mathrm{mg} / \mathrm{kg}$ & \\
\hline ETILEN DIAMINO TETRA ACETATOS & 385,386 & 2008 & $250 \mathrm{mg} / \mathrm{kg}$ & 21 \\
\hline EXTRACTO DE PIEL DE UVA & 163(ii) & 2009 & $1500 \mathrm{mg} / \mathrm{kg}$ & 161 \\
\hline FOSFATOS & $\begin{array}{l}\text { 338; 339(i)-(iii); } \\
340(\mathrm{i})-(\mathrm{iii}) ; 341 \text { (i)- } \\
\text { (iii); 342(i)-(ii); } \\
343(\mathrm{i})-(\mathrm{iii}) ; 450(\mathrm{i})- \\
\text { (iii),(v)-(vii), (ix); } \\
451 \text { (i),(ii); 452(i)- } \\
\text { (v); } 542\end{array}$ & 2012 & $2200 \mathrm{mg} / \mathrm{kg}$ & 33 \\
\hline GLICÓSIDOS DE ESTEVIOL & $960 a, 960 b(i)$ & 2011 & $100 \mathrm{mg} / \mathrm{kg}$ & 26 \\
\hline HIDROXIBENZOATOS, PARA- & 214,218 & 2012 & $250 \mathrm{mg} / \mathrm{kg}$ & 27 \\
\hline NEOTAMO & 961 & 2007 & $100 \mathrm{mg} / \mathrm{kg}$ & 161 \\
\hline SACARINAS & 954(i)-(iv) & 2007 & $160 \mathrm{mg} / \mathrm{kg}$ & 144 \\
\hline SORBATOS & $200,202,203$ & 2009 & $1000 \mathrm{mg} / \mathrm{kg}$ & 42 \\
\hline $\begin{array}{l}\text { SUCRALOSA } \\
\text { (TRICLOROGALACTOSACAROSA) }\end{array}$ & 955 & 2007 & $180 \mathrm{mg} / \mathrm{kg}$ & 144 \\
\hline SULFITOS & $220-225,539$ & 2006 & $100 \mathrm{mg} / \mathrm{kg}$ & 44 \\
\hline TARTRATOS & 334, 335(ii), 337 & 2018 & 1000 mg/kg & 45 \\
\hline
\end{tabular}

No. de Categoría de alimento 04.1.2.4 Frutas en conserva, enlatadas o en frascos (pasteurizadas)

\begin{tabular}{|c|c|c|c|c|}
\hline Aditivo & $\operatorname{SIN}$ & Año Adoptada & Dosis máxima & Notas \\
\hline ACESULFAME DE POTASIO & 950 & 2018 & $350 \mathrm{mg} / \mathrm{kg}$ & 161,188 \& XS319 \\
\hline ASPARTAMO & 951 & 2018 & $1000 \mathrm{mg} / \mathrm{kg}$ & $161,191 \&$ XS319 \\
\hline AZUL BRILLANTE FCF & 133 & 2018 & $200 \mathrm{mg} / \mathrm{kg}$ & $161 \& 267$ \\
\hline $\begin{array}{l}\text { CARAMELO III - CARAMELO AL } \\
\text { AMONÍACO }\end{array}$ & $150 c$ & 2018 & $200 \mathrm{mg} / \mathrm{kg}$ & 267 \\
\hline $\begin{array}{l}\text { CARAMELO IV - CARAMELO AL SULFITO } \\
\text { AMÓNICO }\end{array}$ & $150 d$ & 2018 & $7500 \mathrm{mg} / \mathrm{kg}$ & 267 \\
\hline CARMINES & 120 & 2018 & $200 \mathrm{mg} / \mathrm{kg}$ & $104 \& 178$ \\
\hline CAROTENOIDES & $160 a(i), a(i i i), e, f$ & 2018 & $200 \mathrm{mg} / \mathrm{kg}$ & $161 \& 104$ \\
\hline CAROTENOS, BETA-, VEGETALES & $160 \mathrm{a}(\mathrm{ii})$ & 2018 & $1000 \mathrm{mg} / \mathrm{kg}$ & 104 \\
\hline CICLAMATOS & 952(i), (ii), (iv) & 2018 & $1000 \mathrm{mg} / \mathrm{kg}$ & $17,161 \&$ XS319 \\
\hline $\begin{array}{l}\text { CLOROFILAS Y CLOROFILINAS, } \\
\text { COMPLEJOS CUPRICOS }\end{array}$ & $141(\mathrm{i}),(\mathrm{ii})$ & 2018 & $100 \mathrm{mg} / \mathrm{kg}$ & $62 \& 267$ \\
\hline CLORURO ESTAÑOSO & 512 & 2018 & $20 \mathrm{mg} / \mathrm{kg}$ & $43 \& 141$ \\
\hline DIMETILPOLISILOXANO & $900 a$ & 2018 & $10 \mathrm{mg} / \mathrm{kg}$ & 266 \\
\hline EXTRACTO DE PIEL DE UVA & 163(ii) & 2018 & $1500 \mathrm{mg} / \mathrm{kg}$ & $181 \& 267$ \\
\hline GLICÓSIDOS DE ESTEVIOL & $960 a, 960 b(i)$ & 2018 & $330 \mathrm{mg} / \mathrm{kg}$ & $26 \& X S 319$ \\
\hline NEOTAMO & 961 & 2018 & $33 \mathrm{mg} / \mathrm{kg}$ & $161 \&$ XS319 \\
\hline ÓXIDOS DE HIERRO & 172(i)-(iii) & 2018 & $300 \mathrm{mg} / \mathrm{kg}$ & 267 \\
\hline
\end{tabular}


No. de Categoría de alimento 04.1.2.4 Frutas en conserva, enlatadas o en frascos (pasteurizadas)

\begin{tabular}{llllc} 
Aditivo & SIN & Año Adoptada & Dosis máxima & Notas \\
\hline PONCEAU 4R (ROJO DE COCHINILLA A) & 124 & 2018 & $300 \mathrm{mg} / \mathrm{kg}$ & $161 \& 267$ \\
RIBOFLAVINAS & 101 (i),(ii), (iii) & 2018 & $300 \mathrm{mg} / \mathrm{kg}$ & 267 \\
SACARINAS & $954(\mathrm{i})$-(iv) & 2018 & $200 \mathrm{mg} / \mathrm{kg}$ & $161 \&$ XS319 \\
SAL DE ASPARTAMO Y ACESULFAMO & 962 & 2018 & $350 \mathrm{mg} / \mathrm{kg}$ & $113,161 \&$ XS319 \\
SUCRALOSA & 955 & 2018 & $400 \mathrm{mg} / \mathrm{kg}$ & $161 \&$ XS319 \\
(TRICLOROGALACTOSACAROSA) & 143 & 2018 & & $200 \mathrm{mg} / \mathrm{kg}$ \\
VERDE SÓLIDO FCF & & & 267 \\
\hline
\end{tabular}

No. de Categoría de alimento 04.1.2.5 Confituras, jaleas, mermeladas

\begin{tabular}{|c|c|c|c|c|}
\hline Aditivo & SIN & Año Adoptada & Dosis máxima & Notas \\
\hline ACESULFAME DE POTASIO & 950 & 2019 & $1000 \mathrm{mg} / \mathrm{kg}$ & $478 \& 188$ \\
\hline ALGINATO DE PROPILENGLICOL & 405 & 2018 & $5000 \mathrm{mg} / \mathrm{kg}$ & 409, XS296 \\
\hline ALITAME & 956 & 2007 & $100 \mathrm{mg} / \mathrm{kg}$ & 161 \\
\hline AMARILLO OCASO FCF & 110 & 2008 & $300 \mathrm{mg} / \mathrm{kg}$ & 161 \\
\hline ASPARTAMO & 951 & 2019 & $1000 \mathrm{mg} / \mathrm{kg}$ & $478 \& 191$ \\
\hline AZUL BRILLANTE FCF & 133 & 2009 & $100 \mathrm{mg} / \mathrm{kg}$ & 161 \\
\hline BENZOATOS & $210-213$ & 2001 & $1000 \mathrm{mg} / \mathrm{kg}$ & 13 \\
\hline CANTAXANTINA & $161 \mathrm{~g}$ & 2011 & $200 \mathrm{mg} / \mathrm{kg}$ & 5 \\
\hline $\begin{array}{l}\text { CARAMELO III - CARAMELO AL } \\
\text { AMONÍACO }\end{array}$ & $150 c$ & 2010 & $200 \mathrm{mg} / \mathrm{kg}$ & \\
\hline $\begin{array}{l}\text { CARAMELO IV - CARAMELO AL SULFITO } \\
\text { AMÓNICO }\end{array}$ & $150 d$ & 1999 & $1500 \mathrm{mg} / \mathrm{kg}$ & \\
\hline CARMINES & 120 & 2005 & $200 \mathrm{mg} / \mathrm{kg}$ & 178 \\
\hline CAROTENOIDES & $160 a(i), a(i i i), e, f$ & 2009 & $200 \mathrm{mg} / \mathrm{kg}$ & \\
\hline CAROTENOS, BETA-, VEGETALES & $160 a(i i)$ & 2005 & $1000 \mathrm{mg} / \mathrm{kg}$ & \\
\hline CICLAMATOS & 952(i), (ii), (iv) & 2019 & $1000 \mathrm{mg} / \mathrm{kg}$ & $17 \& 477$ \\
\hline $\begin{array}{l}\text { CLOROFILAS Y CLOROFILINAS, } \\
\text { COMPLEJOS CUPRICOS }\end{array}$ & 141(i),(ii) & 2009 & $200 \mathrm{mg} / \mathrm{kg}$ & 161 \\
\hline DIMETILPOLISILOXANO & $900 a$ & 1999 & $30 \mathrm{mg} / \mathrm{kg}$ & \\
\hline ETILEN DIAMINO TETRA ACETATOS & 385,386 & 2001 & $130 \mathrm{mg} / \mathrm{kg}$ & 21 \\
\hline EXTRACTO DE PIEL DE UVA & 163(ii) & 2009 & $500 \mathrm{mg} / \mathrm{kg}$ & $161 \& 181$ \\
\hline GLICÓSIDOS DE ESTEVIOL & $960 a, 960 b(i)$ & 2011 & $360 \mathrm{mg} / \mathrm{kg}$ & 26 \\
\hline HIDROXIBENZOATOS, PARA- & 214,218 & 2012 & $250 \mathrm{mg} / \mathrm{kg}$ & 27 \\
\hline INDIGOTINA (CARMÍN DE ÍNDIGO) & 132 & 2009 & $300 \mathrm{mg} / \mathrm{kg}$ & 161 \\
\hline NEOTAMO & 961 & 2019 & $70 \mathrm{mg} / \mathrm{kg}$ & 478 \\
\hline ÓXIDOS DE HIERRO & 172(i)-(iii) & 2005 & $200 \mathrm{mg} / \mathrm{kg}$ & \\
\hline PONCEAU 4R (ROJO DE COCHINILLA A) & 124 & 2008 & $100 \mathrm{mg} / \mathrm{kg}$ & 161 \\
\hline RIBOFLAVINAS & 101(i),(ii), (iii) & 2005 & $200 \mathrm{mg} / \mathrm{kg}$ & \\
\hline ROJO ALLURA AC & 129 & 2009 & $100 \mathrm{mg} / \mathrm{kg}$ & 161 \\
\hline SACARINAS & 954(i)-(iv) & 2019 & $200 \mathrm{mg} / \mathrm{kg}$ & 477 \\
\hline SAL DE ASPARTAMO Y ACESULFAMO & 962 & 2019 & $1000 \mathrm{mg} / \mathrm{kg}$ & $119 \& 477$ \\
\hline SORBATOS & 200, 202, 203 & 2012 & $1000 \mathrm{mg} / \mathrm{kg}$ & 42 \\
\hline
\end{tabular}




\begin{tabular}{|c|c|c|c|c|}
\hline Aditivo & SIN & Año Adoptada & Dosis máxima & Notas \\
\hline $\begin{array}{l}\text { SUCRALOSA } \\
\text { (TRICLOROGALACTOSACAROSA) }\end{array}$ & 955 & 2019 & 400 mg/kg & 478 \\
\hline SULFITOS & 220-225, 539 & 2008 & 100 mg/kg & 44 \\
\hline TARTRATOS & 334, 335(ii), 337 & 2016 & $3000 \mathrm{mg} / \mathrm{kg}$ & 45 \\
\hline VERDE SÓLIDO FCF & 143 & 1999 & 400 mg/kg & \\
\hline
\end{tabular}

No. de Categoría de alimento 04.1.2.6 Productos para untar a base de fruta ( $\mathrm{p}$. ej. el "chutney"), excluidos los productos de la categoría de alimentos 04.1.2.5

\begin{tabular}{|c|c|c|c|c|}
\hline Aditivo & SIN & Año Adoptada & Dosis máxima & Notas \\
\hline ACESULFAME DE POTASIO & 950 & 2019 & $1000 \mathrm{mg} / \mathrm{kg}$ & $478 \& 188$ \\
\hline AMARILLO OCASO FCF & 110 & 2008 & $300 \mathrm{mg} / \mathrm{kg}$ & 161 \\
\hline ASPARTAMO & 951 & 2019 & $1000 \mathrm{mg} / \mathrm{kg}$ & $478 \& 191$ \\
\hline AZUL BRILLANTE FCF & 133 & 2009 & $100 \mathrm{mg} / \mathrm{kg}$ & 161 \\
\hline BENZOATOS & $210-213$ & 2001 & $1000 \mathrm{mg} / \mathrm{kg}$ & 13 \\
\hline CANTAXANTINA & $161 \mathrm{~g}$ & 2011 & $15 \mathrm{mg} / \mathrm{kg}$ & \\
\hline $\begin{array}{l}\text { CARAMELO III - CARAMELO AL } \\
\text { AMONÍACO }\end{array}$ & $150 \mathrm{c}$ & 1999 & $500 \mathrm{mg} / \mathrm{kg}$ & \\
\hline $\begin{array}{l}\text { CARAMELO IV - CARAMELO AL SULFITO } \\
\text { AMÓNICO }\end{array}$ & $150 d$ & 1999 & $500 \mathrm{mg} / \mathrm{kg}$ & \\
\hline CARMINES & 120 & 2005 & $500 \mathrm{mg} / \mathrm{kg}$ & 178 \\
\hline CAROTENOIDES & $160 a(i), a(i i i), e, f$ & 2009 & $500 \mathrm{mg} / \mathrm{kg}$ & \\
\hline CAROTENOS, BETA-, VEGETALES & $160 \mathrm{a}(\mathrm{ii})$ & 2005 & $500 \mathrm{mg} / \mathrm{kg}$ & \\
\hline CICLAMATOS & 952(i), (ii), (iv) & 2019 & $2000 \mathrm{mg} / \mathrm{kg}$ & $17 \& 477$ \\
\hline $\begin{array}{l}\text { CLOROFILAS Y CLOROFILINAS, } \\
\text { COMPLEJOS CUPRICOS }\end{array}$ & 141(i),(ii) & 2009 & $150 \mathrm{mg} / \mathrm{kg}$ & \\
\hline DIMETILPOLISILOXANO & $900 a$ & 1999 & $10 \mathrm{mg} / \mathrm{kg}$ & \\
\hline $\begin{array}{l}\text { ÉSTERES DIACETILTARTÁRICOS Y DE } \\
\text { ÁCIDOS GRASOS DE GLICEROL }\end{array}$ & $472 e$ & 2005 & $5000 \mathrm{mg} / \mathrm{kg}$ & \\
\hline ETILEN DIAMINO TETRA ACETATOS & 385,386 & 2001 & $100 \mathrm{mg} / \mathrm{kg}$ & 21 \\
\hline EXTRACTO DE PIEL DE UVA & 163(ii) & 2009 & $500 \mathrm{mg} / \mathrm{kg}$ & $161 \& 181$ \\
\hline FOSFATOS & $\begin{array}{l}\text { 338; 339(i)-(iii); } \\
340 \text { (i)-(iii); 341(i)- } \\
\text { (iii); 342(i)-(ii); } \\
343 \text { (i)-(iii); 450(i)- } \\
\text { (iii),(v)-(vii), (ix); } \\
451 \text { (i),(ii); 452(i)- } \\
\text { (v); } 542\end{array}$ & 2009 & $1100 \mathrm{mg} / \mathrm{kg}$ & 33 \\
\hline GLICÓSIDOS DE ESTEVIOL & $960 a, 960 b(i)$ & 2011 & $330 \mathrm{mg} / \mathrm{kg}$ & 26 \\
\hline HIDROXIBENZOATOS, PARA- & 214,218 & 2012 & $1000 \mathrm{mg} / \mathrm{kg}$ & 27 \\
\hline INDIGOTINA (CARMÍN DE ÍNDIGO) & 132 & 2009 & 300 mg/kg & 161 \\
\hline NEOTAMO & 961 & 2019 & $70 \mathrm{mg} / \mathrm{kg}$ & 478 \\
\hline ÓXIDOS DE HIERRO & 172(i)-(iii) & 2005 & $500 \mathrm{mg} / \mathrm{kg}$ & \\
\hline PONCEAU 4R (ROJO DE COCHINILLA A) & 124 & 2008 & $500 \mathrm{mg} / \mathrm{kg}$ & 161 \\
\hline RIBOFLAVINAS & 101(i),(ii), (iii) & 2005 & 500 mg/kg & \\
\hline
\end{tabular}


No. de Categoría de alimento 04.1.2.6 Productos para untar a base de fruta ( $\mathrm{p}$. ej. el "chutney"), excluidos los productos de la categoría de alimentos 04.1.2.5

\begin{tabular}{|c|c|c|c|c|}
\hline Aditivo & SIN & Año Adoptada & Dosis máxima & Notas \\
\hline SACARINAS & 954(i)-(iv) & 2019 & 200 mg/kg & 477 \\
\hline SORBATOS & $200,202,203$ & 2009 & $1000 \mathrm{mg} / \mathrm{kg}$ & 42 \\
\hline $\begin{array}{l}\text { SUCRALOSA } \\
\text { (TRICLOROGALACTOSACAROSA) }\end{array}$ & 955 & 2019 & $400 \mathrm{mg} / \mathrm{kg}$ & 478 \\
\hline TOCOFEROLES & $307 a, b, c$ & 2018 & 200 mg/kg & XS160 \\
\hline VERDE SÓLIDO FCF & 143 & 2009 & $100 \mathrm{mg} / \mathrm{kg}$ & 161 \\
\hline
\end{tabular}

\section{No. de Categoría de alimento 04.1.2.7 Frutas confitadas}

\begin{tabular}{|c|c|c|c|c|}
\hline Aditivo & SIN & Año Adoptada & Dosis máxima & Notas \\
\hline ACESULFAME DE POTASIO & 950 & 2007 & $500 \mathrm{mg} / \mathrm{kg}$ & $161 \& 188$ \\
\hline AMARILLO OCASO FCF & 110 & 2008 & $200 \mathrm{mg} / \mathrm{kg}$ & 161 \\
\hline ASPARTAMO & 951 & 2007 & $2000 \mathrm{mg} / \mathrm{kg}$ & $161 \& 191$ \\
\hline AZUL BRILLANTE FCF & 133 & 2009 & $100 \mathrm{mg} / \mathrm{kg}$ & 161 \\
\hline BENZOATOS & $210-213$ & 2001 & $1000 \mathrm{mg} / \mathrm{kg}$ & 13 \\
\hline $\begin{array}{l}\text { CARAMELO III - CARAMELO AL } \\
\text { AMONÍACO }\end{array}$ & $150 \mathrm{c}$ & 2010 & $200 \mathrm{mg} / \mathrm{kg}$ & \\
\hline $\begin{array}{l}\text { CARAMELO IV - CARAMELO AL SULFITO } \\
\text { AMÓNICO }\end{array}$ & $150 d$ & 2011 & $7500 \mathrm{mg} / \mathrm{kg}$ & \\
\hline CARMINES & 120 & 2005 & $200 \mathrm{mg} / \mathrm{kg}$ & 178 \\
\hline CAROTENOIDES & $160 a(i), a(i i i), e, f$ & 2009 & $200 \mathrm{mg} / \mathrm{kg}$ & \\
\hline CAROTENOS, BETA-, VEGETALES & $160 a(i i)$ & 2005 & $1000 \mathrm{mg} / \mathrm{kg}$ & \\
\hline $\begin{array}{l}\text { CLOROFILAS Y CLOROFILINAS, } \\
\text { COMPLEJOS CUPRICOS }\end{array}$ & 141(i),(ii) & 2009 & $250 \mathrm{mg} / \mathrm{kg}$ & \\
\hline ERITROSINA & 127 & 2005 & $200 \mathrm{mg} / \mathrm{kg}$ & 54 \\
\hline $\begin{array}{l}\text { ÉSTERES DIACETILTARTÁRICOS Y DE } \\
\text { ÁCIDOS GRASOS DE GLICEROL }\end{array}$ & $472 \mathrm{e}$ & 2005 & $1000 \mathrm{mg} / \mathrm{kg}$ & \\
\hline EXTRACTO DE PIEL DE UVA & 163(ii) & 2011 & $1000 \mathrm{mg} / \mathrm{kg}$ & \\
\hline FOSFATOS & $\begin{array}{l}\text { 338; 339(i)-(iii); } \\
\text { 340(i)-(iii); 341(i)- } \\
\text { (iii); 342(i)-(ii); } \\
\text { 343(i)-(iii); 450(i)- } \\
\text { (iii),(v)-(vii), (ix); } \\
\text { 451(i),(ii); 452(i)- } \\
\text { (v); } 542\end{array}$ & 2012 & $10 \mathrm{mg} / \mathrm{kg}$ & 33 \\
\hline GLICÓSIDOS DE ESTEVIOL & $960 a, 960 b(i)$ & 2011 & $40 \mathrm{mg} / \mathrm{kg}$ & 26 \\
\hline HIDROXIBENZOATOS, PARA- & 214,218 & 2010 & $1000 \mathrm{mg} / \mathrm{kg}$ & 27 \\
\hline INDIGOTINA (CARMIIN DE ÍNDIGO) & 132 & 2009 & $200 \mathrm{mg} / \mathrm{kg}$ & 161 \\
\hline NEOTAMO & 961 & 2007 & $65 \mathrm{mg} / \mathrm{kg}$ & 161 \\
\hline ÓXIDOS DE HIERRO & 172(i)-(iii) & 2005 & $250 \mathrm{mg} / \mathrm{kg}$ & \\
\hline PONCEAU 4R (ROJO DE COCHINILLA A) & 124 & 2008 & $200 \mathrm{mg} / \mathrm{kg}$ & 161 \\
\hline RIBOFLAVINAS & 101(i),(ii), (iii) & 2005 & $300 \mathrm{mg} / \mathrm{kg}$ & \\
\hline ROJO ALLURA AC & 129 & 2009 & $300 \mathrm{mg} / \mathrm{kg}$ & 161 \\
\hline SORBATOS & $200,202,203$ & 2012 & $500 \mathrm{mg} / \mathrm{kg}$ & 42 \\
\hline
\end{tabular}




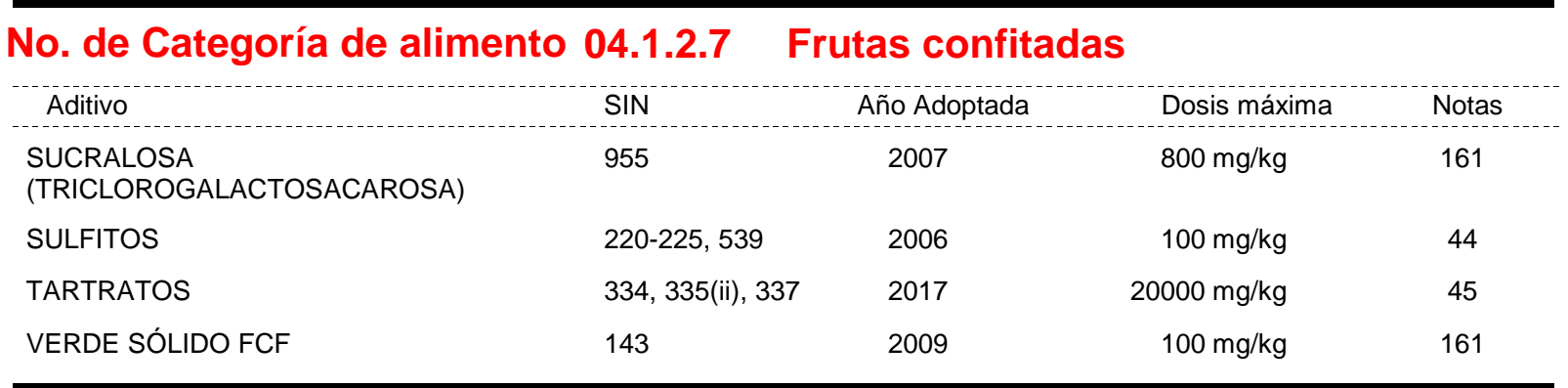

No. de Categoría de alimento 04.1.2.8 Preparados a base de fruta, incluida la pulpa, los purés, los revestimientos de fruta y la leche de coco

\begin{tabular}{|c|c|c|c|c|}
\hline Aditivo & SIN & Año Adoptada & Dosis máxima & Notas \\
\hline ACESULFAME DE POTASIO & 950 & 2019 & $350 \mathrm{mg} / \mathrm{kg}$ & $478 \& 188$ \\
\hline ALGINATO DE PROPILENGLICOL & 405 & 2016 & $5000 \mathrm{mg} / \mathrm{kg}$ & XS240 \& XS314R \\
\hline AMARILLO OCASO FCF & 110 & 2008 & $300 \mathrm{mg} / \mathrm{kg}$ & $161 \& 182$ \\
\hline ASPARTAMO & 951 & 2019 & $1000 \mathrm{mg} / \mathrm{kg}$ & $478 \& 191$ \\
\hline AZUL BRILLANTE FCF & 133 & 2009 & $100 \mathrm{mg} / \mathrm{kg}$ & $161 \& 182$ \\
\hline BENZOATOS & $210-213$ & 2001 & $1000 \mathrm{mg} / \mathrm{kg}$ & 13 \\
\hline $\begin{array}{l}\text { CARAMELO III - CARAMELO AL } \\
\text { AMONÍACO }\end{array}$ & $150 c$ & 2008 & $7500 \mathrm{mg} / \mathrm{kg}$ & 182 \\
\hline $\begin{array}{l}\text { CARAMELO IV - CARAMELO AL SULFITO } \\
\text { AMÓNICO }\end{array}$ & $150 d$ & 2008 & $7500 \mathrm{mg} / \mathrm{kg}$ & 182 \\
\hline CARMINES & 120 & 2008 & $500 \mathrm{mg} / \mathrm{kg}$ & $178 \& 182$ \\
\hline CAROTENOIDES & $160 a(i), a(i i i), e, f$ & 2009 & $100 \mathrm{mg} / \mathrm{kg}$ & $161 \& 182$ \\
\hline CAROTENOS, BETA-, VEGETALES & $160 a(i i)$ & 2011 & $100 \mathrm{mg} / \mathrm{kg}$ & 182 \\
\hline CICLAMATOS & 952(i), (ii), (iv) & 2019 & $250 \mathrm{mg} / \mathrm{kg}$ & $17 \& 477$ \\
\hline $\begin{array}{l}\text { CLOROFILAS Y CLOROFILINAS, } \\
\text { COMPLEJOS CUPRICOS }\end{array}$ & 141(i),(ii) & 2008 & $100 \mathrm{mg} / \mathrm{kg}$ & $62 \& 182$ \\
\hline ESTEAROIL LACTILATOS & $481(\mathrm{i}), 482(\mathrm{i})$ & 2016 & $2000 \mathrm{mg} / \mathrm{kg}$ & XS240 \& XS314R \\
\hline $\begin{array}{l}\text { ÉSTERES DE PROPILENGLICOL DE } \\
\text { ÁCIDOS GRASOS }\end{array}$ & 477 & 2001 & $40000 \mathrm{mg} / \mathrm{kg}$ & \\
\hline $\begin{array}{l}\text { ÉSTERES DE SORBITÁN DE ÁCIDOS } \\
\text { GRASOS }\end{array}$ & $491-495$ & 2016 & $5000 \mathrm{mg} / \mathrm{kg}$ & XS240 \& XS314R \\
\hline $\begin{array}{l}\text { ÉSTERES DIACETILTARTÁRICOS Y DE } \\
\text { ÁCIDOS GRASOS DE GLICEROL }\end{array}$ & $472 e$ & 2005 & $2500 \mathrm{mg} / \mathrm{kg}$ & \\
\hline $\begin{array}{l}\text { ÉSTERES POLIGLICÉRIDOS DE ÁCIDOS } \\
\text { GRASOS }\end{array}$ & 475 & 2016 & $5000 \mathrm{mg} / \mathrm{kg}$ & XS240 \& XS314R \\
\hline EXTRACTO DE PIEL DE UVA & 163(ii) & 2011 & $500 \mathrm{mg} / \mathrm{kg}$ & $179,181 \& 182$ \\
\hline FOSFATOS & $\begin{array}{l}\text { 338; 339(i)-(iii); } \\
\text { 340(i)-(iii); 341(i)- } \\
\text { (iii); 342(i)-(ii); } \\
\text { 343(i)-(iii); 450(i)- } \\
\text { (iii),(v)-(vii), (ix); } \\
\text { 451(i),(ii); 452(i)- } \\
\text { (v); } 542\end{array}$ & 2012 & $350 \mathrm{mg} / \mathrm{kg}$ & 33 \\
\hline GLICÓSIDOS DE ESTEVIOL & $960 a, 960 b(i)$ & 2011 & $330 \mathrm{mg} / \mathrm{kg}$ & 26 \\
\hline HIDROXIBENZOATOS, PARA- & 214,218 & 2010 & $800 \mathrm{mg} / \mathrm{kg}$ & 27 \\
\hline INDIGOTINA (CARMÍN DE ÍNDIGO) & 132 & 2009 & $150 \mathrm{mg} / \mathrm{kg}$ & $161 \& 182$ \\
\hline NEOTAMO & 961 & 2019 & $100 \mathrm{mg} / \mathrm{kg}$ & 478 \\
\hline
\end{tabular}


No. de Categoría de alimento 04.1.2.8 Preparados a base de fruta, incluida la pulpa, los purés, los revestimientos de fruta y la leche de coco

\begin{tabular}{|c|c|c|c|c|}
\hline Aditivo & SIN & Año Adoptada & Dosis máxima & Notas \\
\hline POLISORBATOS & $432-436$ & 2007 & $1000 \mathrm{mg} / \mathrm{kg}$ & 154 \\
\hline PONCEAU 4R (ROJO DE COCHINILLA A) & 124 & 2008 & $50 \mathrm{mg} / \mathrm{kg}$ & $161 \& 182$ \\
\hline PROPILENGLICOL & 1520 & 2016 & $2000 \mathrm{mg} / \mathrm{kg}$ & XS240 \& XS314R \\
\hline RIBOFLAVINAS & 101(i),(ii), (iii) & 2008 & $300 \mathrm{mg} / \mathrm{kg}$ & 182 \\
\hline ROJO ALLURA AC & 129 & 2009 & $300 \mathrm{mg} / \mathrm{kg}$ & $161 \& 182$ \\
\hline SACARINAS & 954(i)-(iv) & 2019 & $200 \mathrm{mg} / \mathrm{kg}$ & 477 \\
\hline SAL DE ASPARTAMO Y ACESULFAMO & 962 & 2019 & $350 \mathrm{mg} / \mathrm{kg}$ & $113 \& 477$ \\
\hline SORBATOS & $200,202,203$ & 2012 & $1000 \mathrm{mg} / \mathrm{kg}$ & 42 \\
\hline $\begin{array}{l}\text { SUCRALOSA } \\
\text { (TRICLOROGALACTOSACAROSA) }\end{array}$ & 955 & 2019 & $400 \mathrm{mg} / \mathrm{kg}$ & 478 \\
\hline SUCROÉSTERES DE ÁCIDOS GRASOS & 473 & 2016 & $1500 \mathrm{mg} / \mathrm{kg}$ & 348 \& XS314R \\
\hline SUCROGLICÉRIDOS & 474 & 2016 & $1500 \mathrm{mg} / \mathrm{kg}$ & 348 \& XS314R \\
\hline $\begin{array}{l}\text { SUCROSE OLIGOESTERS, TYPE I AND } \\
\text { TYPE II }\end{array}$ & $473 a$ & 2016 & $1500 \mathrm{mg} / \mathrm{kg}$ & 348 \& XS314R \\
\hline SULFITOS & $220-225,539$ & 2012 & $100 \mathrm{mg} / \mathrm{kg}$ & $44 \& 206$ \\
\hline TOCOFEROLES & $307 a, b, c$ & 2016 & $150 \mathrm{mg} / \mathrm{kg}$ & XS240 \& XS314R \\
\hline VERDE SÓLIDO FCF & 143 & 2009 & $100 \mathrm{mg} / \mathrm{kg}$ & $161 \& 182$ \\
\hline
\end{tabular}

No. de Categoría de alimento 04.1.2.9 Postres a base de fruta, incluidos los postres a base de agua con aromas de fruta

\begin{tabular}{|c|c|c|c|c|}
\hline Aditivo & SIN & Año Adoptada & Dosis máxima & Notas \\
\hline ACESULFAME DE POTASIO & 950 & 2019 & $350 \mathrm{mg} / \mathrm{kg}$ & $478 \& 188$ \\
\hline ALGINATO DE PROPILENGLICOL & 405 & 2016 & $6000 \mathrm{mg} / \mathrm{kg}$ & \\
\hline AMARILLO OCASO FCF & 110 & 2008 & $50 \mathrm{mg} / \mathrm{kg}$ & 161 \\
\hline ASPARTAMO & 951 & 2019 & $1000 \mathrm{mg} / \mathrm{kg}$ & $478 \& 191$ \\
\hline AZUL BRILLANTE FCF & 133 & 2005 & $150 \mathrm{mg} / \mathrm{kg}$ & \\
\hline BENZOATOS & $210-213$ & 2001 & $1000 \mathrm{mg} / \mathrm{kg}$ & 13 \\
\hline CANTAXANTINA & $161 \mathrm{~g}$ & 2011 & $15 \mathrm{mg} / \mathrm{kg}$ & \\
\hline $\begin{array}{l}\text { CARAMELO III - CARAMELO AL } \\
\text { AMONÍACO }\end{array}$ & $150 \mathrm{c}$ & 2010 & $200 \mathrm{mg} / \mathrm{kg}$ & \\
\hline $\begin{array}{l}\text { CARAMELO IV - CARAMELO AL SULFITO } \\
\text { AMÓNICO }\end{array}$ & $150 d$ & 2011 & $7500 \mathrm{mg} / \mathrm{kg}$ & \\
\hline CARMINES & 120 & 2005 & $150 \mathrm{mg} / \mathrm{kg}$ & 178 \\
\hline CAROTENOIDES & 160a(i),a(iii),e,f & 2009 & $150 \mathrm{mg} / \mathrm{kg}$ & \\
\hline CAROTENOS, BETA-, VEGETALES & 160a(ii) & 2005 & $1000 \mathrm{mg} / \mathrm{kg}$ & \\
\hline CICLAMATOS & 952(i), (ii), (iv) & 2019 & $250 \mathrm{mg} / \mathrm{kg}$ & $17 \& 477$ \\
\hline $\begin{array}{l}\text { CLOROFILAS Y CLOROFILINAS, } \\
\text { COMPLEJOS CUPRICOS }\end{array}$ & 141 (i),(ii) & 2009 & $150 \mathrm{mg} / \mathrm{kg}$ & \\
\hline DIMETILPOLISILOXANO & $900 a$ & 1999 & $110 \mathrm{mg} / \mathrm{kg}$ & \\
\hline DIOCTIL SULFOSUCCINATO DE SODIO & 480 & 2017 & $15 \mathrm{mg} / \mathrm{kg}$ & $83,384 \& 38$ \\
\hline
\end{tabular}


$\begin{aligned} \text { No. de Categoría de alimento 04.1.2.9 } & \begin{array}{l}\text { Postres a base de fruta, incluidos los } \\ \text { postres a base de agua con aromas de }\end{array}\end{aligned}$ fruta

\begin{tabular}{|c|c|c|c|c|}
\hline Aditivo & SIN & Año Adoptada & Dosis máxima & Notas \\
\hline ESTEAROIL LACTILATOS & 481(i), 482(i) & 2016 & $5000 \mathrm{mg} / \mathrm{kg}$ & \\
\hline ÉSTERES DE ASCORBILO & 304,305 & 2001 & $500 \mathrm{mg} / \mathrm{kg}$ & $2 \& 10$ \\
\hline $\begin{array}{l}\text { ÉSTERES DE PROPILENGLICOL DE } \\
\text { ÁCIDOS GRASOS }\end{array}$ & 477 & 2001 & $40000 \mathrm{mg} / \mathrm{kg}$ & \\
\hline $\begin{array}{l}\text { ÉSTERES DE SORBITÁN DE ÁCIDOS } \\
\text { GRASOS }\end{array}$ & $491-495$ & 2016 & $5000 \mathrm{mg} / \mathrm{kg}$ & \\
\hline $\begin{array}{l}\text { ÉSTERES DIACETILTARTÁRICOS Y DE } \\
\text { ÁCIDOS GRASOS DE GLICEROL }\end{array}$ & $472 \mathrm{e}$ & 2005 & $2500 \mathrm{mg} / \mathrm{kg}$ & \\
\hline $\begin{array}{l}\text { ÉSTERES POLIGLICÉRIDOS DE ÁCIDO } \\
\text { RICINOLÉICO INTERESTERIFICADO }\end{array}$ & 476 & 2016 & $2000 \mathrm{mg} / \mathrm{kg}$ & \\
\hline $\begin{array}{l}\text { ÉSTERES POLIGLICÉRIDOS DE ÁCIDOS } \\
\text { GRASOS }\end{array}$ & 475 & 2016 & $5000 \mathrm{mg} / \mathrm{kg}$ & \\
\hline EXTRACTO DE PIEL DE UVA & 163(ii) & 2009 & $500 \mathrm{mg} / \mathrm{kg}$ & $161 \& 181$ \\
\hline FOSFATOS & $\begin{array}{l}\text { 338; 339(i)-(iii); } \\
340 \text { (i)-(iii); 341(i)- } \\
\text { (iii); 342(i)-(ii); } \\
343 \text { (i)-(iii); } 450(\mathrm{i})- \\
\text { (iii),(v)-(vii), (ix); } \\
451 \text { (i),(ii); } 452(\mathrm{i})- \\
\text { (v); } 542\end{array}$ & 2012 & $1500 \mathrm{mg} / \mathrm{kg}$ & 33 \\
\hline GALATO DE PROPILO & 310 & 2001 & $90 \mathrm{mg} / \mathrm{kg}$ & $2 \& 15$ \\
\hline GLICÓSIDOS DE ESTEVIOL & $960 a, 960 b(i)$ & 2011 & $350 \mathrm{mg} / \mathrm{kg}$ & 26 \\
\hline HIDROXIBENZOATOS, PARA- & 214,218 & 2012 & $800 \mathrm{mg} / \mathrm{kg}$ & 27 \\
\hline INDIGOTINA (CARMÍN DE ÍNDIGO) & 132 & 2009 & $150 \mathrm{mg} / \mathrm{kg}$ & 161 \\
\hline NEOTAMO & 961 & 2019 & $100 \mathrm{mg} / \mathrm{kg}$ & 478 \\
\hline ÓXIDOS DE HIERRO & 172(i)-(iii) & 2005 & 200 mg/kg & \\
\hline POLISORBATOS & $432-436$ & 2007 & $3000 \mathrm{mg} / \mathrm{kg}$ & \\
\hline PONCEAU 4R (ROJO DE COCHINILLA A) & 124 & 2008 & $50 \mathrm{mg} / \mathrm{kg}$ & 161 \\
\hline RIBOFLAVINAS & 101(i),(ii), (iii) & 2005 & $300 \mathrm{mg} / \mathrm{kg}$ & \\
\hline ROJO ALLURA AC & 129 & 2009 & $300 \mathrm{mg} / \mathrm{kg}$ & 161 \\
\hline SACARINAS & 954(i)-(iv) & 2019 & $100 \mathrm{mg} / \mathrm{kg}$ & 477 \\
\hline SAL DE ASPARTAMO Y ACESULFAMO & 962 & 2019 & $350 \mathrm{mg} / \mathrm{kg}$ & $113 \& 477$ \\
\hline SORBATOS & $200,202,203$ & 2012 & $1000 \mathrm{mg} / \mathrm{kg}$ & 42 \\
\hline $\begin{array}{l}\text { SUCRALOSA } \\
\text { (TRICLOROGALACTOSACAROSA) }\end{array}$ & 955 & 2019 & $400 \mathrm{mg} / \mathrm{kg}$ & 478 \\
\hline SUCROÉSTERES DE ÁCIDOS GRASOS & 473 & 2016 & $5000 \mathrm{mg} / \mathrm{kg}$ & 348 \\
\hline SUCROGLICÉRIDOS & 474 & 2016 & $5000 \mathrm{mg} / \mathrm{kg}$ & 348 \\
\hline $\begin{array}{l}\text { SUCROSE OLIGOESTERS, TYPE I AND } \\
\text { TYPE II }\end{array}$ & $473 a$ & 2016 & $5000 \mathrm{mg} / \mathrm{kg}$ & 348 \\
\hline SULFITOS & 220-225, 539 & 2008 & $100 \mathrm{mg} / \mathrm{kg}$ & 44 \\
\hline TARTRATOS & 334, 335(ii), 337 & 2016 & $1000 \mathrm{mg} / \mathrm{kg}$ & 45 \\
\hline TOCOFEROLES & $307 a, b, c$ & 2016 & $500 \mathrm{mg} / \mathrm{kg}$ & 15 \\
\hline VERDE SÓLIDO FCF & 143 & 2009 & $100 \mathrm{mg} / \mathrm{kg}$ & 161 \\
\hline
\end{tabular}




\begin{tabular}{|c|c|c|c|c|}
\hline Aditivo & SIN & Año Adoptada & Dosis máxima & Notas \\
\hline ACESULFAME DE POTASIO & 950 & 2019 & $350 \mathrm{mg} / \mathrm{kg}$ & $478 \& 188$ \\
\hline ASPARTAMO & 951 & 2019 & $1000 \mathrm{mg} / \mathrm{kg}$ & $478 \& 191$ \\
\hline BENZOATOS & $210-213$ & 2001 & $1000 \mathrm{mg} / \mathrm{kg}$ & 13 \\
\hline CAROTENOIDES & $160 a(i), a(i i i), e, f$ & 2009 & $500 \mathrm{mg} / \mathrm{kg}$ & \\
\hline CAROTENOS, BETA-, VEGETALES & 160a(ii) & 2005 & $200 \mathrm{mg} / \mathrm{kg}$ & \\
\hline $\begin{array}{l}\text { CLOROFILAS Y CLOROFILINAS, } \\
\text { COMPLEJOS CUPRICOS }\end{array}$ & $141(\mathrm{i}),(\mathrm{ii})$ & 2005 & $100 \mathrm{mg} / \mathrm{kg}$ & 62 \\
\hline DIMETILPOLISILOXANO & $900 a$ & 2008 & $10 \mathrm{mg} / \mathrm{kg}$ & \\
\hline $\begin{array}{l}\text { ÉSTERES DIACETILTARTÁRICOS Y DE } \\
\text { ÁCIDOS GRASOS DE GLICEROL }\end{array}$ & $472 e$ & 2005 & $2500 \mathrm{mg} / \mathrm{kg}$ & \\
\hline ETILEN DIAMINO TETRA ACETATOS & 385,386 & 2008 & $250 \mathrm{mg} / \mathrm{kg}$ & 21 \\
\hline EXTRACTO DE PIEL DE UVA & 163(ii) & 2009 & $500 \mathrm{mg} / \mathrm{kg}$ & $161 \& 181$ \\
\hline FOSFATOS & $\begin{array}{l}\text { 338; 339(i)-(iii); } \\
\text { 340(i)-(iii); 341(i)- } \\
\text { (iii); 342(i)-(ii); } \\
343 \text { (i)-(iii); 450(i)- } \\
\text { (iii),(v)-(vii), (ix); } \\
\text { 451(i),(ii); 452(i)- } \\
\text { (v); } 542\end{array}$ & 2009 & $2200 \mathrm{mg} / \mathrm{kg}$ & 33 \\
\hline GLICÓSIDOS DE ESTEVIOL & $960 a, 960 b(i)$ & 2011 & $115 \mathrm{mg} / \mathrm{kg}$ & 26 \\
\hline HIDROXIBENZOATOS, PARA- & 214,218 & 2010 & $800 \mathrm{mg} / \mathrm{kg}$ & 27 \\
\hline NEOTAMO & 961 & 2019 & $65 \mathrm{mg} / \mathrm{kg}$ & 478 \\
\hline RIBOFLAVINAS & 101(i),(ii), (iii) & 2008 & $500 \mathrm{mg} / \mathrm{kg}$ & \\
\hline SACARINAS & 954(i)-(iv) & 2019 & $160 \mathrm{mg} / \mathrm{kg}$ & 477 \\
\hline SORBATOS & $200,202,203$ & 2009 & $1000 \mathrm{mg} / \mathrm{kg}$ & 42 \\
\hline $\begin{array}{l}\text { SUCRALOSA } \\
\text { (TRICLOROGALACTOSACAROSA) }\end{array}$ & 955 & 2019 & $150 \mathrm{mg} / \mathrm{kg}$ & 478 \\
\hline SULFITOS & 220-225, 539 & 2008 & $100 \mathrm{mg} / \mathrm{kg}$ & 44 \\
\hline
\end{tabular}

No. de Categoría de alimento 04.1.2.11 Rellenos de fruta para pastelería

\begin{tabular}{|c|c|c|c|c|}
\hline Aditivo & SIN & Año Adoptada & Dosis máxima & Notas \\
\hline ACESULFAME DE POTASIO & 950 & 2007 & $350 \mathrm{mg} / \mathrm{kg}$ & $161 \& 188$ \\
\hline ALGINATO DE PROPILENGLICOL & 405 & 2016 & $5000 \mathrm{mg} / \mathrm{kg}$ & \\
\hline AMARILLO OCASO FCF & 110 & 2008 & $300 \mathrm{mg} / \mathrm{kg}$ & 161 \\
\hline ASPARTAMO & 951 & 2007 & $1000 \mathrm{mg} / \mathrm{kg}$ & $161 \& 191$ \\
\hline AZUL BRILLANTE FCF & 133 & 2005 & $250 \mathrm{mg} / \mathrm{kg}$ & \\
\hline BENZOATOS & $210-213$ & 2001 & $1000 \mathrm{mg} / \mathrm{kg}$ & 13 \\
\hline CANTAXANTINA & $161 \mathrm{~g}$ & 2011 & $15 \mathrm{mg} / \mathrm{kg}$ & \\
\hline $\begin{array}{l}\text { CARAMELO III - CARAMELO AL } \\
\text { AMONÍACO }\end{array}$ & $150 c$ & 1999 & $7500 \mathrm{mg} / \mathrm{kg}$ & \\
\hline $\begin{array}{l}\text { CARAMELO IV - CARAMELO AL SULFITO } \\
\text { AMÓNICO }\end{array}$ & $150 d$ & 1999 & $7500 \mathrm{mg} / \mathrm{kg}$ & \\
\hline CARMINES & 120 & 2005 & $300 \mathrm{mg} / \mathrm{kg}$ & 178 \\
\hline CAROTENOIDES & $160 a(i), a(i i i), e, f$ & 2009 & $100 \mathrm{mg} / \mathrm{kg}$ & \\
\hline CAROTENOS, BETA-, VEGETALES & $160 a(i i)$ & 2009 & $100 \mathrm{mg} / \mathrm{kg}$ & \\
\hline
\end{tabular}


No. de Categoría de alimento 04.1.2.11 Rellenos de fruta para pastelería

\begin{tabular}{|c|c|c|c|c|}
\hline Aditivo & $\operatorname{SIN}$ & Año Adoptada & Dosis máxima & Notas \\
\hline $\begin{array}{l}\text { CLOROFILAS Y CLOROFILINAS, } \\
\text { COMPLEJOS CUPRICOS }\end{array}$ & $141(\mathrm{i}),(\mathrm{ii})$ & 2005 & $100 \mathrm{mg} / \mathrm{kg}$ & 62 \\
\hline ESTEAROIL LACTILATOS & 481(i), 482(i) & 2016 & $2000 \mathrm{mg} / \mathrm{kg}$ & \\
\hline $\begin{array}{l}\text { ÉSTERES DE PROPILENGLICOL DE } \\
\text { ÁCIDOS GRASOS }\end{array}$ & 477 & 2001 & $40000 \mathrm{mg} / \mathrm{kg}$ & \\
\hline $\begin{array}{l}\text { ÉSTERES DE SORBITÁN DE ÁCIDOS } \\
\text { GRASOS }\end{array}$ & $491-495$ & 2016 & $5000 \mathrm{mg} / \mathrm{kg}$ & \\
\hline $\begin{array}{l}\text { ÉSTERES POLIGLICÉRIDOS DE ÁCIDO } \\
\text { RICINOLÉICO INTERESTERIFICADO }\end{array}$ & 476 & 2016 & $2000 \mathrm{mg} / \mathrm{kg}$ & \\
\hline $\begin{array}{l}\text { ÉSTERES POLIGLICÉRIDOS DE ÁCIDOS } \\
\text { GRASOS }\end{array}$ & 475 & 2016 & $2000 \mathrm{mg} / \mathrm{kg}$ & \\
\hline ETILEN DIAMINO TETRA ACETATOS & 385,386 & 2001 & $650 \mathrm{mg} / \mathrm{kg}$ & 21 \\
\hline ETIL-LAUROIL ARGINATO & 243 & 2011 & $200 \mathrm{mg} / \mathrm{kg}$ & \\
\hline EXTRACTO DE PIEL DE UVA & 163(ii) & 2009 & $500 \mathrm{mg} / \mathrm{kg}$ & $161 \& 181$ \\
\hline FOSFATOS & $\begin{array}{l}\text { 338; 339(i)-(iii); } \\
\text { 340(i)-(iii); 341(i)- } \\
\text { (iii); 342(i)-(ii); } \\
343(\text { i)-(iii); 450(i)- } \\
\text { (iii),(v)-(vii), (ix); } \\
\text { 451(i),(ii); 452(i)- } \\
\text { (v); } 542\end{array}$ & 2012 & $1500 \mathrm{mg} / \mathrm{kg}$ & 33 \\
\hline GLICÓSIDOS DE ESTEVIOL & $960 a, 960 b(i)$ & 2011 & $330 \mathrm{mg} / \mathrm{kg}$ & 26 \\
\hline HIDROXIBENZOATOS, PARA- & 214,218 & 2010 & $800 \mathrm{mg} / \mathrm{kg}$ & 27 \\
\hline INDIGOTINA (CARMÍN DE ÍNDIGO) & 132 & 2009 & $150 \mathrm{mg} / \mathrm{kg}$ & 161 \\
\hline NEOTAMO & 961 & 2007 & $100 \mathrm{mg} / \mathrm{kg}$ & 161 \\
\hline POLISORBATOS & $432-436$ & 2007 & $3000 \mathrm{mg} / \mathrm{kg}$ & \\
\hline PONCEAU 4R (ROJO DE COCHINILLA A) & 124 & 2008 & $50 \mathrm{mg} / \mathrm{kg}$ & 161 \\
\hline RIBOFLAVINAS & 101(i),(ii), (iii) & 2005 & $300 \mathrm{mg} / \mathrm{kg}$ & \\
\hline ROJO ALLURA AC & 129 & 2009 & $300 \mathrm{mg} / \mathrm{kg}$ & 161 \\
\hline SORBATOS & $200,202,203$ & 2009 & $1000 \mathrm{mg} / \mathrm{kg}$ & 42 \\
\hline $\begin{array}{l}\text { SUCRALOSA } \\
\text { (TRICLOROGALACTOSACAROSA) }\end{array}$ & 955 & 2007 & $400 \mathrm{mg} / \mathrm{kg}$ & 161 \\
\hline SULFITOS & $220-225,539$ & 2006 & $100 \mathrm{mg} / \mathrm{kg}$ & 44 \\
\hline TARTRATOS & 334, 335(ii), 337 & 2016 & $10000 \mathrm{mg} / \mathrm{kg}$ & 45 \\
\hline TOCOFEROLES & $307 a, b, c$ & 2016 & $150 \mathrm{mg} / \mathrm{kg}$ & \\
\hline VERDE SÓLIDO FCF & 143 & 2009 & 100 mg/kg & 161 \\
\hline
\end{tabular}

No. de Categoría de alimento 04.1.2.12 Frutas cocidas o fritas

\begin{tabular}{|c|c|c|c|c|}
\hline Aditivo & SIN & Año Adoptada & Dosis máxima & Notas \\
\hline ACESULFAME DE POTASIO & 950 & 2019 & $500 \mathrm{mg} / \mathrm{kg}$ & $478 \& 188$ \\
\hline ASPARTAMO & 951 & 2019 & $1000 \mathrm{mg} / \mathrm{kg}$ & $478 \& 191$ \\
\hline BENZOATOS & $210-213$ & 2001 & $1000 \mathrm{mg} / \mathrm{kg}$ & 13 \\
\hline $\begin{array}{l}\text { CLOROFILAS Y CLOROFILINAS, } \\
\text { COMPLEJOS CUPRICOS }\end{array}$ & 141(i),(ii) & 2005 & $100 \mathrm{mg} / \mathrm{kg}$ & 62 \\
\hline GLICÓSIDOS DE ESTEVIOL & $960 a, 960 b(i)$ & 2011 & $40 \mathrm{mg} / \mathrm{kg}$ & 26 \\
\hline NEOTAMO & 961 & 2019 & $65 \mathrm{mg} / \mathrm{kg}$ & 478 \\
\hline
\end{tabular}


No. de Categoría de alimento 04.1.2.12 Frutas cocidas o fritas

\begin{tabular}{llccc} 
Aditivo & SIN & Año Adoptada & Dosis máxima & Notas \\
SORBATOS & $200,202,203$ & 2009 & $1200 \mathrm{mg} / \mathrm{kg}$ & 42 \\
$\begin{array}{l}\text { SUCRALOSA } \\
\text { (TRICLOROGALACTOSACAROSA) }\end{array}$ & 955 & 2019 & $150 \mathrm{mg} / \mathrm{kg}$ & 478 \\
\hline
\end{tabular}

\begin{tabular}{lllcl}
\hline No. de Categoría de alimento 04.2.1.1 & $\begin{array}{l}\text { Hortalizas (incluidos hongos y setas, } \\
\text { raíces y tubérculos, legumbres y } \\
\text { leguminosas [(incluida la soja)] y áloe } \\
\text { vera), algas marinas y nueces y } \\
\text { semillas frescas no tratadas }\end{array}$ \\
\hline Aditivo & & Año Adoptada & Dosis máxima & Notas \\
\hline ÁCIDO ACÉTICO GLACIAL & 260 & 2013 & BPF & $262 \& 263$ \\
ÁCIDO ASCÓRBICO, L- & 300 & 2013 & $500 \mathrm{mg} / \mathrm{kg}$ & 262 \\
ÁCIDO CíTRICO & 330 & 2013 & BPF & $262 \& 264$ \\
ÁCIDO LÁCTICO, L-, D- y DL- & 270 & 2013 & BPF & $262 \& 264$ \\
CITRATO DíACIDO DE SODIO & 331 (i) & 2015 & BPF & 262 \\
CITRATO TRISÓDICO & 331 (iii) & 2015 & BPF & 262 \\
\hline
\end{tabular}

No. de Categoría de alimento 04.2.1.2 Hortalizas (incluidos hongos y setas, raíces y tubérculos, legumbres y leguminosas y áloe vera), algas marinas y nueces y semillas frescas tratadas en la superficie

\begin{tabular}{|c|c|c|c|c|}
\hline Aditivo & SIN & Año Adoptada & Dosis máxima & Notas \\
\hline AMARILLO OCASO FCF & 110 & 2008 & $300 \mathrm{mg} / \mathrm{kg}$ & $4 \& 16$ \\
\hline CARMINES & 120 & 2008 & $500 \mathrm{mg} / \mathrm{kg}$ & $4,16 \& 178$ \\
\hline CAROTENOIDES & $160 a(i), a(i i i), e, f$ & 2010 & $500 \mathrm{mg} / \mathrm{kg}$ & $4,16 \& 161$ \\
\hline CERA CANDELILLA & 902 & 2003 & BPF & 79 \\
\hline CERA CARNAUBA & 903 & 2004 & $400 \mathrm{mg} / \mathrm{kg}$ & 79 \\
\hline CERA DE ABEJAS & 901 & 2003 & BPF & 79 \\
\hline CERA MICROCRISTALINA & $905 c(i)$ & 2004 & $50 \mathrm{mg} / \mathrm{kg}$ & \\
\hline ÉSTERES DE GLICEROL DE COLOFONIA & 445(iii) & 2005 & $110 \mathrm{mg} / \mathrm{kg}$ & \\
\hline ETIL-LAUROIL ARGINATO & 243 & 2011 & $200 \mathrm{mg} / \mathrm{kg}$ & \\
\hline FOSFATOS & $\begin{array}{l}\text { 338; 339(i)-(iii); } \\
340 \text { (i)-(iii); 341(i)- } \\
\text { (iii); 342(i)-(ii); } \\
343(\text { i)-(iii); 450(i)- } \\
\text { (iii),(v)-(vii), (ix); } \\
451 \text { (i),(ii); 452(i)- } \\
\text { (v); } 542\end{array}$ & 2009 & $1760 \mathrm{mg} / \mathrm{kg}$ & $16 \& 33$ \\
\hline GOMA LACA, BLANQUEADA & 904 & 2003 & BPF & 79 \\
\hline $\begin{array}{l}\text { MONOGLICÉRIDOS Y DIGLICÉRIDOS DE } \\
\text { ÁCIDOS GRASOS }\end{array}$ & 471 & 2019 & BPF & 455 \\
\hline RIBOFLAVINAS & 101(i),(ii), (iii) & 2008 & $300 \mathrm{mg} / \mathrm{kg}$ & $4 \& 16$ \\
\hline $\begin{array}{l}\text { SAL MIRÍSTICA, PALMÍTICA Y ÁCIDOS } \\
\text { ESTEÁRICOS CON AMONIO, CALCIO, } \\
\text { POTASIO Y SODIO }\end{array}$ & $470(i)$ & 2019 & BPF & $71 \& 456$ \\
\hline
\end{tabular}




\begin{tabular}{|c|c|c|c|c|}
\hline No. de Categoría de & 04.2 .1 .3 & \multicolumn{3}{|c|}{$\begin{array}{l}\text { Hortalizas (incluidos hongos y setas, } \\
\text { raíces y tubérculos, legumbres y } \\
\text { leguminosas y áloe vera), algas } \\
\text { marinas y nueces y semillas frescas } \\
\text { peladas, cortadas o desmenuzadas }\end{array}$} \\
\hline Aditivo & $\operatorname{SiN}$ & Año Adoptada & Dosis máxima & Notas \\
\hline ASCORBATO DE SODIO & 301 & 2014 & BPF & \\
\hline ETIL-LAUROIL ARGINATO & 243 & 2011 & 200 mg/kg & \\
\hline FOSFATOS & $\begin{array}{l}\text { 338; 339(i)-(iii); } \\
340 \text { (i)-(iii); } 341 \text { (i)- } \\
\text { (iii); 342(i)-(ii); } \\
343(\text { i)-(iii); } 450(\text { i)-- } \\
\text { (iii),(v)-(vii), (ix); } \\
\text { 451(i),(ii); } 452 \text { (i)- } \\
\text { (v); } 542\end{array}$ & 2012 & $5600 \mathrm{mg} / \mathrm{kg}$ & $33 \& 76$ \\
\hline SULFITOS & $220-225,539$ & 2006 & $50 \mathrm{mg} / \mathrm{kg}$ & $44,76 \& 136$ \\
\hline
\end{tabular}

No. de Categoría de alimento 04.2.2

Hortalizas (incluidos hongos y setas, raíces y tubérculos, legumbres y leguminosas y áloe vera), algas marinas y nueces y semillas elaboradas

\begin{tabular}{|c|c|c|c|c|}
\hline Aditivo & SIN & Año Adoptada & Dosis máxima & Notas \\
\hline $\begin{array}{l}\text { CARAMELO IV - CARAMELO AL SULFITO } \\
\text { AMÓNICO }\end{array}$ & $150 d$ & 2009 & $50000 \mathrm{mg} / \mathrm{kg}$ & $92 \& 161$ \\
\hline
\end{tabular}

No. de Categoría de alimento 04.2.2.1 Hortalizas (incluidos hongos y setas, raíces y tubérculos, legumbres y leguminosas y áloe vera), algas marinas y nueces y semillas congeladas

\begin{tabular}{|c|c|c|c|c|}
\hline Aditivo & SIN & Año Adoptada & Dosis máxima & Notas \\
\hline ÁCIDO ACÉTICO GLACIAL & 260 & 2013 & BPF & $262 \& 263$ \\
\hline ÁCIDO ASCÓRBICO, L- & 300 & 2014 & BPF & 110 \\
\hline ÁCIDO CÍTRICO & 330 & 2013 & BPF & $\begin{array}{c}242,262,264 \& \\
265\end{array}$ \\
\hline ÁCIDO LÁCTICO, L-, D- y DL- & 270 & 2013 & BPF & $262 \& 264$ \\
\hline ÁCIDO MÁLICO, DL- & 296 & 2013 & BPF & 265 \\
\hline ASPARTAMO & 951 & 2008 & $1000 \mathrm{mg} / \mathrm{kg}$ & $161 \& 191$ \\
\hline CITRATO DÍACIDO DE POTASIO & 332(i) & 2015 & BPF & 29 \\
\hline CITRATO DÍACIDO DE SODIO & 331 (i) & 2015 & BPF & 29 \\
\hline CITRATO TRICÁLCICO & 333(iii) & 2015 & BPF & 29 \\
\hline CITRATO TRIPOTÁSICO & 332(ii) & 2015 & BPF & 29 \\
\hline CITRATO TRISÓDICO & 331 (iii) & 2015 & BPF & 29 \\
\hline CLORURO DE CALCIO & 509 & 2015 & BPF & $29,323 \& 324$ \\
\hline DIMETILPOLISILOXANO & $900 a$ & 1999 & $10 \mathrm{mg} / \mathrm{kg}$ & 15 \\
\hline ETILEN DIAMINO TETRA ACETATOS & 385,386 & 2006 & $100 \mathrm{mg} / \mathrm{kg}$ & $21 \& 110$ \\
\hline
\end{tabular}




\begin{tabular}{|c|c|c|c|c|}
\hline No. de Categoría de alim & $\begin{array}{l}\mathrm{H} \\
\mathrm{re} \\
\mathrm{le}\end{array}$ & \multicolumn{3}{|c|}{$\begin{array}{l}\text { Hortalizas (incluidos hongos y setas, } \\
\text { raíces y tubérculos, legumbres y } \\
\text { leguminosas y áloe vera), algas } \\
\text { marinas y nueces y semillas congeladas }\end{array}$} \\
\hline Aditivo & $\operatorname{SIN}$ & Año Adoptada & Dosis máxima & Notas \\
\hline FOSFATOS & $\begin{array}{l}\text { 338; 339(i)-(iii); } \\
\text { 340(i)-(iii); 341(i)-- } \\
\text { (iii); 342(i)-(ii); } \\
343(\text { i)-(iii); 450(i)-- } \\
\text { (iii),(v)-(vii), (ix); } \\
\text { 451(i),(ii); 452(i)- } \\
\text { (v); } 542\end{array}$ & 2012 & $5000 \mathrm{mg} / \mathrm{kg}$ & $33 \& 76$ \\
\hline GLUTAMATO MONOSÓDICO, L- & 621 & 2014 & BPF & 201 \\
\hline NEOTAMO & 961 & 2008 & $33 \mathrm{mg} / \mathrm{kg}$ & 161 \\
\hline SACARINAS & 954(i)-(iv) & 2008 & $500 \mathrm{mg} / \mathrm{kg}$ & 161 \\
\hline $\begin{array}{l}\text { SUCRALOSA } \\
\text { (TRICLOROGALACTOSACAROSA) }\end{array}$ & 955 & 2008 & $150 \mathrm{mg} / \mathrm{kg}$ & 161 \\
\hline SULFATO DE CALCIO & 516 & 2015 & BPF & $29,323 \& 324$ \\
\hline SULFITOS & $220-225,539$ & 2006 & $50 \mathrm{mg} / \mathrm{kg}$ & $44,76,136 \& 137$ \\
\hline
\end{tabular}

\begin{tabular}{|c|c|c|c|c|}
\hline \multicolumn{2}{|c|}{ No. de Categoría de alimento 04.2.2.2 } & \multicolumn{3}{|c|}{$\begin{array}{l}\text { Hortalizas (incluidos hongos y setas, } \\
\text { raíces y tubérculos, legumbres y } \\
\text { leguminosas y áloe vera), algas } \\
\text { marinas y nueces y semillas desecadas }\end{array}$} \\
\hline Aditivo & SIN & Año Adoptada & Dosis máxima & Notas \\
\hline ASPARTAMO & 951 & 2008 & $1000 \mathrm{mg} / \mathrm{kg}$ & $161 \& 191$ \\
\hline BENZOATOS & $210-213$ & 2003 & $1000 \mathrm{mg} / \mathrm{kg}$ & 13 \\
\hline BUTILHIDROXIANISOL & 320 & 2005 & $200 \mathrm{mg} / \mathrm{kg}$ & $15,76 \& 196$ \\
\hline BUTILHIDROXITOLUENO & 321 & 2005 & $200 \mathrm{mg} / \mathrm{kg}$ & $15,76 \& 196$ \\
\hline CANTAXANTINA & $161 \mathrm{~g}$ & 2011 & $10 \mathrm{mg} / \mathrm{kg}$ & \\
\hline $\begin{array}{l}\text { CARAMELO III - CARAMELO AL } \\
\text { AMONÍACO }\end{array}$ & $150 \mathrm{c}$ & 2010 & $50000 \mathrm{mg} / \mathrm{kg}$ & $76 \& 161$ \\
\hline CAROTENOIDES & 160a(i),a(iii),e,f & 2009 & $1000 \mathrm{mg} / \mathrm{kg}$ & 161 \\
\hline CAROTENOS, BETA-, VEGETALES & 160a(ii) & 2011 & $200 \mathrm{mg} / \mathrm{kg}$ & \\
\hline ESTEAROIL LACTILATOS & $481(\mathrm{i}), 482(\mathrm{i})$ & 2016 & $5000 \mathrm{mg} / \mathrm{kg}$ & 76 \\
\hline ÉSTERES DE ASCORBILO & 304, 305 & 2001 & $80 \mathrm{mg} / \mathrm{kg}$ & 10 \\
\hline $\begin{array}{l}\text { ÉSTERES DE SORBITÁN DE ÁCIDOS } \\
\text { GRASOS }\end{array}$ & 491-495 & 2016 & $5000 \mathrm{mg} / \mathrm{kg}$ & 76 \\
\hline $\begin{array}{l}\text { ÉSTERES DIACETILTARTÁRICOS Y DE } \\
\text { ÁCIDOS GRASOS DE GLICEROL }\end{array}$ & $472 e$ & 2005 & $10000 \mathrm{mg} / \mathrm{kg}$ & \\
\hline ETILEN DIAMINO TETRA ACETATOS & 385,386 & 2001 & $800 \mathrm{mg} / \mathrm{kg}$ & $21,64 \& 297$ \\
\hline FOSFATOS & $\begin{array}{l}338 ; 339(\mathrm{i})-(\mathrm{iii}) ; \\
340(\mathrm{i})-(\mathrm{iii)} ; 341(\mathrm{i})- \\
\text { (iii); 342(i)-(ii); } \\
343(\mathrm{i})-(\mathrm{iii}) ; 450(\mathrm{i})- \\
\text { (iii),(v)-(vii), (ix); } \\
\text { 451(i),(ii); } 452(\mathrm{i})- \\
\text { (v); } 542\end{array}$ & 2012 & $5000 \mathrm{mg} / \mathrm{kg}$ & $33 \& 76$ \\
\hline GALATO DE PROPILO & 310 & 2001 & $50 \mathrm{mg} / \mathrm{kg}$ & $15,76 \& 196$ \\
\hline GLICÓSIDOS DE ESTEVIOL & $960 \mathrm{a}, 960 \mathrm{~b}(\mathrm{i})$ & 2011 & $40 \mathrm{mg} / \mathrm{kg}$ & 26 \\
\hline
\end{tabular}


No. de Categoría de alimento 04.2.2.2 Hortalizas (incluidos hongos y setas, raíces y tubérculos, legumbres y leguminosas y áloe vera), algas marinas y nueces y semillas desecadas

\begin{tabular}{llllc} 
Aditivo & SIN & Año Adoptada & Dosis máxima & Notas \\
\hline NEOTAMO & 961 & 2008 & $33 \mathrm{mg} / \mathrm{kg}$ & 161 \\
SACARINAS & 954 (i)-(iv) & 2008 & $500 \mathrm{mg} / \mathrm{kg}$ & 161 \\
$\begin{array}{l}\text { SUCRALOSA } \\
\text { (TRICLOROGALACTOSACAROSA) }\end{array}$ & 955 & 2008 & $580 \mathrm{mg} / \mathrm{kg}$ & 161 \\
SULFITOS & $220-225,539$ & 2006 & $500 \mathrm{mg} / \mathrm{kg}$ & $44 \& 105$ \\
TOCOFEROLES & $307 \mathrm{a}, \mathrm{b}, \mathrm{c}$ & 2016 & $200 \mathrm{mg} / \mathrm{kg}$ & XS38 \\
\hline
\end{tabular}

No. de Categoría de alimento 04.2.2.3 Hortalizas (incluidos hongos y setas, raíces y tubérculos, legumbres y leguminosas y áloe vera) y algas marinas en vinagre, aceite, salmuera o salsa de soja

\begin{tabular}{|c|c|c|c|c|}
\hline Aditivo & $\operatorname{SiN}$ & Año Adoptada & Dosis máxima & Notas \\
\hline ACESULFAME DE POTASIO & 950 & 2007 & $200 \mathrm{mg} / \mathrm{kg}$ & $144 \& 188$ \\
\hline ALGINATO DE PROPILENGLICOL & 405 & 2017 & $6000 \mathrm{mg} / \mathrm{kg}$ & $\begin{array}{l}\text { 386, XS38 \& } \\
\quad \text { XS260 }\end{array}$ \\
\hline ASPARTAMO & 951 & 2007 & $300 \mathrm{mg} / \mathrm{kg}$ & $144 \& 191$ \\
\hline AZUL BRILLANTE FCF & 133 & 2009 & $500 \mathrm{mg} / \mathrm{kg}$ & 161 \\
\hline BENZOATOS & $210-213$ & 2001 & $2000 \mathrm{mg} / \mathrm{kg}$ & 13 \\
\hline $\begin{array}{l}\text { CARAMELO III - CARAMELO AL } \\
\text { AMONÍACO }\end{array}$ & $150 \mathrm{c}$ & 1999 & $500 \mathrm{mg} / \mathrm{kg}$ & \\
\hline CARMINES & 120 & 2008 & $500 \mathrm{mg} / \mathrm{kg}$ & $161 \& 178$ \\
\hline CAROTENOIDES & $160 a(i), a(i i i), e, f$ & 2010 & $50 \mathrm{mg} / \mathrm{kg}$ & 161 \\
\hline CAROTENOS, BETA-, VEGETALES & $160 a(i i)$ & 2011 & $1320 \mathrm{mg} / \mathrm{kg}$ & \\
\hline DIMETILPOLISILOXANO & $900 a$ & 1999 & $10 \mathrm{mg} / \mathrm{kg}$ & \\
\hline $\begin{array}{l}\text { ÉSTERES DIACETILTARTÁRICOS Y DE } \\
\text { ÁCIDOS GRASOS DE GLICEROL }\end{array}$ & $472 e$ & 2005 & $2500 \mathrm{mg} / \mathrm{kg}$ & \\
\hline ETILEN DIAMINO TETRA ACETATOS & 385,386 & 2001 & $250 \mathrm{mg} / \mathrm{kg}$ & 21 \\
\hline ETIL-LAUROIL ARGINATO & 243 & 2011 & $200 \mathrm{mg} / \mathrm{kg}$ & \\
\hline EXTRACTO DE PIEL DE UVA & 163(ii) & 2011 & $100 \mathrm{mg} / \mathrm{kg}$ & $179 \& 181$ \\
\hline FOSFATOS & $\begin{array}{l}\text { 338; 339(i)-(iii); } \\
340 \text { (i)-(iii); } 341 \text { (i)- } \\
\text { (iii); 342(i)-(ii); } \\
343(\text { i)-(iii); } 450 \text { (i)- } \\
\text { (iii),(v)-(vii), (ix); } \\
451 \text { (i),(ii); 452(i)- } \\
\text { (v); } 542\end{array}$ & 2012 & $2200 \mathrm{mg} / \mathrm{kg}$ & 33 \\
\hline GLICÓSIDOS DE ESTEVIOL & $960 a, 960 b(i)$ & 2011 & $330 \mathrm{mg} / \mathrm{kg}$ & 26 \\
\hline GLUCONATO FERROSO & 579 & 1999 & $150 \mathrm{mg} / \mathrm{kg}$ & $23 \& 48$ \\
\hline HIDROXIBENZOATOS, PARA- & 214,218 & 2010 & $1000 \mathrm{mg} / \mathrm{kg}$ & 27 \\
\hline INDIGOTINA (CARMÍN DE ÍNDIGO) & 132 & 2009 & $150 \mathrm{mg} / \mathrm{kg}$ & 161 \\
\hline LACTATO FERROSO & 585 & 1999 & $150 \mathrm{mg} / \mathrm{kg}$ & $23 \& 48$ \\
\hline NEOTAMO & 961 & 2007 & $10 \mathrm{mg} / \mathrm{kg}$ & 144 \\
\hline
\end{tabular}




\begin{tabular}{|c|c|c|c|c|}
\hline No. de Categoría de alimen & 4.2.2.3 & $\begin{array}{l}\text { rtalizas (in } \\
\text { ees y tubé } \\
\text { uminosas } \\
\text { rinas en ví } \\
\text { sa de soja }\end{array}$ & $\begin{array}{l}\text { dos hongos } \\
\text { s, legumbr } \\
\text { re vera) y a } \\
\text { aceite, s }\end{array}$ & $\begin{array}{l}\text { y setas, } \\
\text { es y } \\
\text { lgas } \\
\text { almuera o }\end{array}$ \\
\hline Aditivo & SIN & Año Adoptada & Dosis máxima & Notas \\
\hline RIBOFLAVINAS & 101(i),(ii), (iii) & 2005 & $500 \mathrm{mg} / \mathrm{kg}$ & \\
\hline ROJO ALLURA AC & 129 & 2009 & $300 \mathrm{mg} / \mathrm{kg}$ & 161 \\
\hline SACARINAS & 954(i)-(iv) & 2007 & $160 \mathrm{mg} / \mathrm{kg}$ & 144 \\
\hline SAL DE ASPARTAMO Y ACESULFAMO & 962 & 2009 & $200 \mathrm{mg} / \mathrm{kg}$ & $113 \& 161$ \\
\hline SORBATOS & $200,202,203$ & 2012 & $1000 \mathrm{mg} / \mathrm{kg}$ & 42 \\
\hline $\begin{array}{l}\text { SUCRALOSA } \\
\text { (TRICLOROGALACTOSACAROSA) }\end{array}$ & 955 & 2007 & $400 \mathrm{mg} / \mathrm{kg}$ & \\
\hline SULFATO DE ALUMINIO Y AMONIO & 523 & 2017 & $520 \mathrm{mg} / \mathrm{kg}$ & $6,245,296 \& X S 66$ \\
\hline SULFITOS & $220-225,539$ & 2006 & $100 \mathrm{mg} / \mathrm{kg}$ & 44 \\
\hline TARTRATOS & 334, 335(ii), 337 & 2016 & $15000 \mathrm{mg} / \mathrm{kg}$ & $45, X S 38 \&$ XS115 \\
\hline VERDE SÓLIDO FCF & 143 & 1999 & $300 \mathrm{mg} / \mathrm{kg}$ & \\
\hline
\end{tabular}

No. de Categoría de alimento 04.2.2.4 Hortalizas (incluidos hongos y setas, raíces y tubérculos, legumbres y leguminosas y áloe vera) y algas marinas en conserva, en latas o frascos (pasteurizadas) 0 en bolsas de esterilización

\begin{tabular}{|c|c|c|c|c|}
\hline Aditivo & SIN & Año Adoptada & Dosis máxima & Notas \\
\hline ACESULFAME DE POTASIO & 950 & 2008 & $350 \mathrm{mg} / \mathrm{kg}$ & $161 \& 188$ \\
\hline ASPARTAMO & 951 & 2008 & $1000 \mathrm{mg} / \mathrm{kg}$ & $161 \& 191$ \\
\hline AZUL BRILLANTE FCF & 133 & 2009 & $200 \mathrm{mg} / \mathrm{kg}$ & 161 \\
\hline $\begin{array}{l}\text { CARAMELO III - CARAMELO AL } \\
\text { AMONÍACO }\end{array}$ & $150 \mathrm{c}$ & 2010 & $50000 \mathrm{mg} / \mathrm{kg}$ & 161 \\
\hline CAROTENOIDES & 160a(i),a(iii),e,f & 2010 & $50 \mathrm{mg} / \mathrm{kg}$ & 161 \\
\hline CAROTENOS, BETA-, VEGETALES & $160 a(i i)$ & 2011 & $200 \mathrm{mg} / \mathrm{kg}$ & \\
\hline CLORURO ESTAÑOSO & 512 & 2001 & $25 \mathrm{mg} / \mathrm{kg}$ & 43 \\
\hline DIMETILPOLISILOXANO & $900 a$ & 1999 & $10 \mathrm{mg} / \mathrm{kg}$ & \\
\hline ETILEN DIAMINO TETRA ACETATOS & 385,386 & 2001 & $365 \mathrm{mg} / \mathrm{kg}$ & 21 \\
\hline FOSFATOS & $\begin{array}{l}338 ; 339(\mathrm{i})-(\mathrm{iii}) ; \\
340(\mathrm{i})-(\mathrm{iii}) ; 341(\mathrm{i})- \\
\text { (iii); } 342(\mathrm{i})-(\mathrm{ii}) ; \\
343(\mathrm{i})-(\mathrm{iii}) ; 450(\mathrm{i})- \\
\text { (iii),(v)-(vii), (ix); } \\
451 \text { (i),(ii); 452(i)- } \\
\text { (v); } 542\end{array}$ & 2012 & $2200 \mathrm{mg} / \mathrm{kg}$ & 33 \\
\hline GLICÓSIDOS DE ESTEVIOL & $960 \mathrm{a}, 960 \mathrm{~b}(\mathrm{i})$ & 2011 & $70 \mathrm{mg} / \mathrm{kg}$ & 26 \\
\hline NEOTAMO & 961 & 2008 & $33 \mathrm{mg} / \mathrm{kg}$ & 161 \\
\hline ROJO ALLURA AC & 129 & 2009 & $200 \mathrm{mg} / \mathrm{kg}$ & 161 \\
\hline SACARINAS & 954(i)-(iv) & 2008 & $160 \mathrm{mg} / \mathrm{kg}$ & $144 \& 161$ \\
\hline
\end{tabular}




\begin{tabular}{|c|c|c|c|c|}
\hline No. de Categoría de alim & 04.2 .2 .4 & $\begin{array}{l}\text { rtalizas (ir } \\
\text { ces y tubé } \\
\text { uminosas } \\
\text { rinas en c } \\
\text { steurizad } \\
\text { erilizaciór }\end{array}$ & $\begin{array}{l}\text { los hongos } \\
\text { s, legumbr } \\
\text { e vera) y al } \\
\text { rva, en lata } \\
\text { en bolsas c }\end{array}$ & $\begin{array}{l}\text { y setas, } \\
\text { es y } \\
\text { lgas } \\
\text { s o frascos } \\
\text { de }\end{array}$ \\
\hline Aditivo & SIN & Año Adoptada & Dosis máxima & Notas \\
\hline $\begin{array}{l}\text { SUCRALOSA } \\
\text { (TRICLOROGALACTOSACAROSA) }\end{array}$ & 955 & 2008 & $580 \mathrm{mg} / \mathrm{kg}$ & 161 \\
\hline SULFITOS & $220-225,539$ & 2006 & $50 \mathrm{mg} / \mathrm{kg}$ & 44 \\
\hline TARTRATOS & 334, 335(ii), 337 & 2017 & $1300 \mathrm{mg} / \mathrm{kg}$ & $\begin{array}{c}\text { 45, XS13, XS38, } \\
\text { XS57, XS145, } \\
\text { XS257R, XS259R } \\
\text { \& XS297 }\end{array}$ \\
\hline VERDE SÓLIDO FCF & 143 & 1999 & $200 \mathrm{mg} / \mathrm{kg}$ & \\
\hline
\end{tabular}

\begin{tabular}{|c|c|c|c|c|}
\hline \multicolumn{2}{|c|}{ No. de Categoría de alimento 04.2.2.5 } & \multicolumn{3}{|c|}{$\begin{array}{l}\text { Purés y preparados para untar } \\
\text { elaborados con hortalizas (incluidos } \\
\text { hongos y setas, raíces y tubérculos, } \\
\text { legumbres y leguminosas y áloe vera), } \\
\text { algas marinas y nueces y semillas ( } p \text {. } \\
\text { ej., la mantequilla de maní (cacahuete)) }\end{array}$} \\
\hline Aditivo & SIN & Año Adoptada & Dosis máxima & Notas \\
\hline ACESULFAME DE POTASIO & 950 & 2008 & $1000 \mathrm{mg} / \mathrm{kg}$ & 188 \\
\hline ASPARTAMO & 951 & 2008 & $1000 \mathrm{mg} / \mathrm{kg}$ & $161 \& 191$ \\
\hline BENZOATOS & $210-213$ & 2001 & $1000 \mathrm{mg} / \mathrm{kg}$ & 13 \\
\hline $\begin{array}{l}\text { CARAMELO III - CARAMELO AL } \\
\text { AMONÍACO }\end{array}$ & $150 c$ & 2010 & $50000 \mathrm{mg} / \mathrm{kg}$ & \\
\hline CARMINES & 120 & 2005 & $100 \mathrm{mg} / \mathrm{kg}$ & 178 \\
\hline CAROTENOIDES & 160a(i),a(iii),e,f & 2010 & $50 \mathrm{mg} / \mathrm{kg}$ & 161 \\
\hline CAROTENOS, BETA-, VEGETALES & 160a(ii) & 2005 & $1000 \mathrm{mg} / \mathrm{kg}$ & \\
\hline $\begin{array}{l}\text { CLOROFILAS Y CLOROFILINAS, } \\
\text { COMPLEJOS CUPRICOS }\end{array}$ & 141 (i),(ii) & 2005 & $100 \mathrm{mg} / \mathrm{kg}$ & 62 \\
\hline DIMETILPOLISILOXANO & $900 a$ & 1999 & $10 \mathrm{mg} / \mathrm{kg}$ & \\
\hline ETILEN DIAMINO TETRA ACETATOS & 385,386 & 2001 & $250 \mathrm{mg} / \mathrm{kg}$ & 21 \\
\hline EXTRACTO DE PIEL DE UVA & 163(ii) & 2011 & $100 \mathrm{mg} / \mathrm{kg}$ & $179 \& 181$ \\
\hline FOSFATOS & $\begin{array}{l}\text { 338; 339(i)-(iii); } \\
340 \text { (i)-(iii); 341(i)- } \\
\text { (iii); 342(ii)-(ii); } \\
343(\mathrm{i}) \text {-(iii); 450(i)- } \\
\text { (iii),(v)-(vii), (ix); } \\
451 \text { (i),(ii); 452(i)- } \\
\text { (v); } 542\end{array}$ & 2012 & $2200 \mathrm{mg} / \mathrm{kg}$ & $33 \& 76$ \\
\hline GLICÓSIDOS DE ESTEVIOL & $960 a, 960 b(i)$ & 2011 & 330 mg/kg & 26 \\
\hline HIDROXIBENZOATOS, PARA- & 214,218 & 2010 & $1000 \mathrm{mg} / \mathrm{kg}$ & 27 \\
\hline NEOTAMO & 961 & 2008 & $33 \mathrm{mg} / \mathrm{kg}$ & 161 \\
\hline SACARINAS & $954(\mathrm{i})$-(iv) & 2008 & $160 \mathrm{mg} / \mathrm{kg}$ & 161 \\
\hline SORBATOS & $200,202,203$ & 2012 & $1000 \mathrm{mg} / \mathrm{kg}$ & 42 \\
\hline
\end{tabular}




\begin{tabular}{|c|c|c|c|c|}
\hline No. de Categoría de alim & 04.2 .2 .5 & \multicolumn{3}{|c|}{$\begin{array}{l}\text { Purés y preparados para untar } \\
\text { elaborados con hortalizas (incluidos } \\
\text { hongos y setas, raíces y tubérculos, } \\
\text { legumbres y leguminosas y áloe vera), } \\
\text { algas marinas y nueces y semillas (p. } \\
\text { ej., la mantequilla de maní (cacahuete)) }\end{array}$} \\
\hline Aditivo & SIN & Año Adoptada & Dosis máxima & Notas \\
\hline $\begin{array}{l}\text { SUCRALOSA } \\
\text { (TRICLOROGALACTOSACAROSA) }\end{array}$ & 955 & 2007 & $400 \mathrm{mg} / \mathrm{kg}$ & $161 \& 169$ \\
\hline SULFITOS & $220-225,539$ & 2006 & $500 \mathrm{mg} / \mathrm{kg}$ & $44 \& 138$ \\
\hline TOCOFEROLES & $307 a, b, c$ & 2017 & $300 \mathrm{mg} / \mathrm{kg}$ & XS57 \\
\hline
\end{tabular}

No. de Categoría de alimento 04.2.2.6 Pulpas y preparados de hortalizas (incluidos hongos y setas, raíces y tubérculos, legumbres y leguminosas y áloe vera), algas marinas y nueces y semillas (como los postres y las salsas a base de hortalizas y hortalizas confitadas) distintos de los indicados en la categoría de alimentos 04.2.2.5

\begin{tabular}{|c|c|c|c|c|}
\hline Aditivo & $\operatorname{SIN}$ & Año Adoptada & Dosis máxima & Notas \\
\hline ACESULFAME DE POTASIO & 950 & 2007 & $350 \mathrm{mg} / \mathrm{kg}$ & $161 \& 188$ \\
\hline AMARILLO OCASO FCF & 110 & 2008 & $50 \mathrm{mg} / \mathrm{kg}$ & 92 \\
\hline ASPARTAMO & 951 & 2008 & $1000 \mathrm{mg} / \mathrm{kg}$ & $161 \& 191$ \\
\hline AZUL BRILLANTE FCF & 133 & 2009 & $100 \mathrm{mg} / \mathrm{kg}$ & $92 \& 161$ \\
\hline BENZOATOS & $210-213$ & 2001 & $3000 \mathrm{mg} / \mathrm{kg}$ & 13 \\
\hline $\begin{array}{l}\text { CARAMELO III - CARAMELO AL } \\
\text { AMONÍACO }\end{array}$ & $150 c$ & 2010 & $50000 \mathrm{mg} / \mathrm{kg}$ & 161 \\
\hline CARMINES & 120 & 2008 & 200 mg/kg & $92 \& 178$ \\
\hline CAROTENOIDES & $160 a(i), a(i i i), e, f$ & 2010 & $50 \mathrm{mg} / \mathrm{kg}$ & $92 \& 161$ \\
\hline CAROTENOS, BETA-, VEGETALES & $160 a(i i)$ & 2008 & $1000 \mathrm{mg} / \mathrm{kg}$ & 92 \\
\hline CICLAMATOS & 952(i), (ii), (iv) & 2008 & $250 \mathrm{mg} / \mathrm{kg}$ & $17 \& 161$ \\
\hline $\begin{array}{l}\text { CLOROFILAS Y CLOROFILINAS, } \\
\text { COMPLEJOS CUPRICOS }\end{array}$ & $141(\mathrm{i}),(\mathrm{ii})$ & 2008 & $100 \mathrm{mg} / \mathrm{kg}$ & $62 \& 92$ \\
\hline DIMETILPOLISILOXANO & $900 a$ & 2004 & $50 \mathrm{mg} / \mathrm{kg}$ & \\
\hline $\begin{array}{l}\text { ÉSTERES DE PROPILENGLICOL DE } \\
\text { ÁCIDOS GRASOS }\end{array}$ & 477 & 2001 & $5000 \mathrm{mg} / \mathrm{kg}$ & \\
\hline $\begin{array}{l}\text { ÉSTERES DIACETILTARTÁRICOS Y DE } \\
\text { ÁCIDOS GRASOS DE GLICEROL }\end{array}$ & $472 e$ & 2005 & $2500 \mathrm{mg} / \mathrm{kg}$ & \\
\hline ETILEN DIAMINO TETRA ACETATOS & 385,386 & 2001 & $80 \mathrm{mg} / \mathrm{kg}$ & 21 \\
\hline EXTRACTO DE PIEL DE UVA & 163(ii) & 2011 & $100 \mathrm{mg} / \mathrm{kg}$ & $92 \& 181$ \\
\hline FOSFATOS & $\begin{array}{l}\text { 338; 339(i)-(iii); } \\
340(\text { i)-(iii); 341(i)- } \\
\text { (iii); 342(i)-(ii); } \\
\text { 343(i)-(iii); 450(i)- } \\
\text { (iii),(v)-(vii), (ix); } \\
451 \text { (i),(ii); 452(i)- } \\
\text { (v); } 542\end{array}$ & 2012 & $2200 \mathrm{mg} / \mathrm{kg}$ & 33 \\
\hline
\end{tabular}




\begin{tabular}{|c|c|c|c|c|}
\hline \multicolumn{2}{|c|}{ No. de Categoría de alimento 04.2.2.6 } & \multicolumn{3}{|c|}{$\begin{array}{l}\text { Pulpas y preparados de hortalizas } \\
\text { (incluidos hongos y setas, raíces y } \\
\text { tubérculos, legumbres y leguminosas y } \\
\text { áloe vera), algas marinas y nueces y } \\
\text { semillas (como los postres y las salsas } \\
\text { a base de hortalizas y hortalizas } \\
\text { confitadas) distintos de los indicados } \\
\text { en la categoría de alimentos } 04.2 .2 .5\end{array}$} \\
\hline Aditivo & $\operatorname{SIN}$ & Año Adoptada & Dosis máxima & Notas \\
\hline GLICÓSIDOS DE ESTEVIOL & $960 a, 960 b(i)$ & 2011 & $165 \mathrm{mg} / \mathrm{kg}$ & 26 \\
\hline HIDROXIBENZOATOS, PARA- & 214,218 & 2010 & $1000 \mathrm{mg} / \mathrm{kg}$ & 27 \\
\hline INDIGOTINA (CARMÍN DE ÍNDIGO) & 132 & 2009 & $200 \mathrm{mg} / \mathrm{kg}$ & $92 \& 161$ \\
\hline NEOTAMO & 961 & 2007 & $33 \mathrm{mg} / \mathrm{kg}$ & 161 \\
\hline POLISORBATOS & $432-436$ & 2007 & $3000 \mathrm{mg} / \mathrm{kg}$ & \\
\hline RIBOFLAVINAS & 101(i),(ii), (iii) & 2008 & $300 \mathrm{mg} / \mathrm{kg}$ & 92 \\
\hline ROJO ALLURA AC & 129 & 2009 & $200 \mathrm{mg} / \mathrm{kg}$ & $92 \& 161$ \\
\hline SACARINAS & 954(i)-(iv) & 2008 & $200 \mathrm{mg} / \mathrm{kg}$ & 161 \\
\hline SAL DE ASPARTAMO Y ACESULFAMO & 962 & 2009 & $350 \mathrm{mg} / \mathrm{kg}$ & $113 \& 161$ \\
\hline SORBATOS & $200,202,203$ & 2012 & $1000 \mathrm{mg} / \mathrm{kg}$ & 42 \\
\hline $\begin{array}{l}\text { SUCRALOSA } \\
\text { (TRICLOROGALACTOSACAROSA) }\end{array}$ & 955 & 2007 & $400 \mathrm{mg} / \mathrm{kg}$ & 161 \\
\hline SUCROGLICÉRIDOS & 474 & 2009 & $5000 \mathrm{mg} / \mathrm{kg}$ & \\
\hline SULFITOS & 220-225, 539 & 2011 & 300 mg/kg & $44 \& 205$ \\
\hline
\end{tabular}

No. de Categoría de alimento 04.2.2.7 Productos a base de hortalizas (incluidos hongos y setas, raíces y tubérculos, legumbres y leguminosas y áloe vera) y algas marinas fermentadas, excluidos los productos fermentados de soja de las categorías 06.8.6, 06.8.7, 12.9.1, 12.9.2.1 y 12.9.2.3

\begin{tabular}{|c|c|c|c|c|}
\hline Aditivo & $\operatorname{SiN}$ & Año Adoptada & Dosis máxima & Notas \\
\hline ACESULFAME DE POTASIO & 950 & 2008 & $1000 \mathrm{mg} / \mathrm{kg}$ & 188 \\
\hline ACETATO DE SODIO & 262(i) & 2013 & BPF & \\
\hline ÁCIDO ACÉTICO GLACIAL & 260 & 2013 & BPF & \\
\hline ÁCIDO ALGÍNICO & 400 & 2013 & BPF & \\
\hline ÁCIDO ASCÓRBICO, L- & 300 & 2013 & BPF & \\
\hline ÁCIDO CÍTRICO & 330 & 2013 & BPF & \\
\hline ÁCIDO FUMÁRICO & 297 & 2013 & BPF & \\
\hline ÁCIDO LÁCTICO, L-, D- y DL- & 270 & 2013 & BPF & \\
\hline ÁCIDO MÁLICO, DL- & 296 & 2013 & BPF & \\
\hline ALGA EUCHEUMA ELABORADA & $407 a$ & 2013 & BPF & \\
\hline AMARILLO OCASO FCF & 110 & 2008 & 200 mg/kg & 92 \\
\hline ASCORBATO DE SODIO & 301 & 2014 & BPF & \\
\hline
\end{tabular}




\begin{tabular}{|c|c|c|c|c|}
\hline No. de Categoría de alimentc & $\begin{array}{l}\text { Pr } \\
\text { (ir } \\
\text { tu } \\
\text { ál } \\
\text { ex } \\
\text { de } \\
12\end{array}$ & $\begin{array}{l}\text { ductos a } \\
\text { luidos ho } \\
\text { érculos, le } \\
\text { vera) y a } \\
\text { luidos los } \\
\text { soja de las } \\
.1,12.9 .2\end{array}$ & $\begin{array}{l}\text { de hortaliz } \\
\text { s y setas, ra } \\
\text { nbres y legu } \\
\text { marinas fe } \\
\text { ductos ferm } \\
\text { egorías } 06.8 \\
12.9 .2 .3\end{array}$ & $\begin{array}{l}\text { s y } \\
\text { inosas y } \\
\text { entadas, } \\
\text { itados } \\
06.8 .7\end{array}$ \\
\hline Aditivo & SIN & Año Adoptada & Dosis máxima & Notas \\
\hline ASPARTAMO & 951 & 2008 & $2500 \mathrm{mg} / \mathrm{kg}$ & $161 \& 191$ \\
\hline AZUL BRILLANTE FCF & 133 & 2009 & $100 \mathrm{mg} / \mathrm{kg}$ & $92 \& 161$ \\
\hline BENZOATOS & $210-213$ & 2001 & $1000 \mathrm{mg} / \mathrm{kg}$ & 13 \\
\hline $\begin{array}{l}\text { CARAMELO III - CARAMELO AL } \\
\text { AMONÍACO }\end{array}$ & $150 c$ & 2010 & $50000 \mathrm{mg} / \mathrm{kg}$ & 161 \\
\hline CARBONATO DE CALCIO & $170(\mathrm{i})$ & 2013 & BPF & \\
\hline CARBONATO DE MAGNESIO & $504(i)$ & 2013 & $5000 \mathrm{mg} / \mathrm{kg}$ & 36 \\
\hline CARBONATO DE POTASIO & $501(\mathrm{i})$ & 2013 & BPF & \\
\hline CARBONATO DE SODIO & $500(i)$ & 2013 & BPF & \\
\hline CAROTENOIDES & $160 a(i), a(i i i), e, f$ & 2009 & $50 \mathrm{mg} / \mathrm{kg}$ & \\
\hline CAROTENOS, BETA-, VEGETALES & $160 a(i i)$ & 2005 & $1000 \mathrm{mg} / \mathrm{kg}$ & \\
\hline CARRAGENINA & 407 & 2013 & BPF & \\
\hline CITRATO TRISÓDICO & 331 (iii) & 2013 & BPF & \\
\hline $\begin{array}{l}\text { CLOROFILAS Y CLOROFILINAS, } \\
\text { COMPLEJOS CUPRICOS }\end{array}$ & $141(\mathrm{i}),(\mathrm{ii})$ & 2005 & $100 \mathrm{mg} / \mathrm{kg}$ & 62 \\
\hline CLORURO DE CALCIO & 509 & 2013 & BPF & \\
\hline CLORURO DE POTASIO & 508 & 2013 & BPF & \\
\hline DEXTRINAS, ALMIDÓN TOSTADO & 1400 & 2013 & BPF & \\
\hline DIMETILPOLISILOXANO & $900 a$ & 2008 & $10 \mathrm{mg} / \mathrm{kg}$ & \\
\hline $\begin{array}{l}\text { ERITORBATO DE SODIO } \\
\text { (ISOASCORBATO DE SODIO) }\end{array}$ & 316 & 2014 & BPF & 280 \\
\hline ERITROSINA & 127 & 2011 & $30 \mathrm{mg} / \mathrm{kg}$ & \\
\hline $\begin{array}{l}\text { ÉSTERES CÍTRICOS Y DE ÁCIDOS } \\
\text { GRASOS DE GLICEROL }\end{array}$ & $472 c$ & 2013 & BPF & \\
\hline $\begin{array}{l}\text { ÉSTERES DIACETILTARTÁRICOS Y DE } \\
\text { ÁCIDOS GRASOS DE GLICEROL }\end{array}$ & $472 e$ & 2005 & $2500 \mathrm{mg} / \mathrm{kg}$ & \\
\hline ETILEN DIAMINO TETRA ACETATOS & 385,386 & 2001 & $250 \mathrm{mg} / \mathrm{kg}$ & 21 \\
\hline EXTRACTO DE PIEL DE UVA & 163(ii) & 2009 & $100 \mathrm{mg} / \mathrm{kg}$ & $161 \& 181$ \\
\hline FOSFATOS & $\begin{array}{l}\text { 338; 339(i)-(iii); } \\
\text { 340(i)-(iii); 341(i)- } \\
\text { (iii); 342(i)-(ii); } \\
343(\text { i)-(iii); 450(i)- } \\
\text { (iii),(v)-(vii), (ix); } \\
\text { 451(i),(ii); 452(i)- } \\
\text { (v); } 542\end{array}$ & 2010 & $2200 \mathrm{mg} / \mathrm{kg}$ & 33 \\
\hline FUMARATO DE SODIO & 365 & 2013 & BPF & \\
\hline GLICEROL & 422 & 2014 & BPF & \\
\hline GLICÓSIDOS DE ESTEVIOL & $960 a, 960 b(i)$ & 2011 & $200 \mathrm{mg} / \mathrm{kg}$ & 26 \\
\hline GLUCONATO DE SODIO & 576 & 2013 & BPF & \\
\hline GLUTAMATO MONOSÓDICO, L- & 621 & 2014 & BPF & 279 \\
\hline
\end{tabular}




\begin{tabular}{|c|c|c|c|c|}
\hline \multicolumn{2}{|c|}{ No. de Categoría de alimento 04.2.2.7 } & \multicolumn{3}{|c|}{$\begin{array}{l}\text { Productos a base de hortalizas } \\
\text { (incluidos hongos y setas, raíces y } \\
\text { tubérculos, legumbres y leguminosas y } \\
\text { áloe vera) y algas marinas fermentadas, } \\
\text { excluidos los productos fermentados } \\
\text { de soja de las categorías } 06.8 .6,06.8 .7 \text {, } \\
12.9 .1,12.9 .2 .1 \text { y } 12.9 .2 .3\end{array}$} \\
\hline Aditivo & $\operatorname{SIN}$ & Año Adoptada & Dosis máxima & Notas \\
\hline GOMA GUAR & 412 & 2013 & BPF & \\
\hline GOMA XANTANA & 415 & 2013 & BPF & \\
\hline GUANILATO DISÓDICO, 5'- & 627 & 2014 & BPF & 279 \\
\hline HIDROXIBENZOATOS, PARA- & 214,218 & 2012 & $300 \mathrm{mg} / \mathrm{kg}$ & 27 \\
\hline INDIGOTINA (CARMÍN DE ÍNDIGO) & 132 & 2009 & $300 \mathrm{mg} / \mathrm{kg}$ & 161 \\
\hline INOSINATO DISÓDICO, 5'- & 631 & 2014 & BPF & 279 \\
\hline LACTATO DE CALCIO & 327 & 2013 & $10000 \mathrm{mg} / \mathrm{kg}$ & 58 \\
\hline LACTATO DE SODIO & 325 & 2013 & BPF & \\
\hline LECITINA & $322(i)$ & 2013 & BPF & \\
\hline MALATO DE SODIO, DL- & 350(ii) & 2013 & BPF & \\
\hline NEOTAMO & 961 & 2007 & $33 \mathrm{mg} / \mathrm{kg}$ & 161 \\
\hline PECTINAS & 440 & 2013 & BPF & \\
\hline PONCEAU 4R (ROJO DE COCHINILLA A) & 124 & 2008 & $500 \mathrm{mg} / \mathrm{kg}$ & 161 \\
\hline PULLULAN & 1204 & 2014 & BPF & \\
\hline RIBOFLAVINAS & 101(i),(ii), (iii) & 2008 & $500 \mathrm{mg} / \mathrm{kg}$ & \\
\hline RIBONUCLEÓTIDOS DE CALCIO, 5'- & 634 & 2014 & BPF & 279 \\
\hline RIBONUCLEÓTIDOS DE SODIO, 5'- & 635 & 2014 & BPF & 279 \\
\hline SACARINAS & 954(i)-(iv) & 2008 & $200 \mathrm{mg} / \mathrm{kg}$ & 161 \\
\hline SORBATOS & $200,202,203$ & 2012 & $1000 \mathrm{mg} / \mathrm{kg}$ & 42 \\
\hline $\begin{array}{l}\text { SUCRALOSA } \\
\text { (TRICLOROGALACTOSACAROSA) }\end{array}$ & 955 & 2008 & $580 \mathrm{mg} / \mathrm{kg}$ & 161 \\
\hline SULFITOS & $220-225,539$ & 2006 & $500 \mathrm{mg} / \mathrm{kg}$ & 44 \\
\hline VERDE SÓLIDO FCF & 143 & 2009 & $100 \mathrm{mg} / \mathrm{kg}$ & 161 \\
\hline
\end{tabular}

No. de Categoría de alimento 04.2.2.8 Hortalizas (incluidos hongos y setas, raíces y tubérculos, legumbres y leguminosas y áloe vera) y algas marinas cocidas o fritas

\begin{tabular}{|c|c|c|c|c|}
\hline Aditivo & SIN & Año Adoptada & Dosis máxima & Notas \\
\hline ASPARTAMO & 951 & 2008 & $1000 \mathrm{mg} / \mathrm{kg}$ & $161 \& 191$ \\
\hline BENZOATOS & $210-213$ & 2001 & $1000 \mathrm{mg} / \mathrm{kg}$ & 13 \\
\hline $\begin{array}{l}\text { CARAMELO III - CARAMELO AL } \\
\text { AMONÍACO }\end{array}$ & $150 c$ & 2010 & $50000 \mathrm{mg} / \mathrm{kg}$ & 161 \\
\hline $\begin{array}{l}\text { CLOROFILAS Y CLOROFILINAS, } \\
\text { COMPLEJOS CUPRICOS }\end{array}$ & 141 (i),(ii) & 2005 & $100 \mathrm{mg} / \mathrm{kg}$ & 62 \\
\hline $\begin{array}{l}\text { ÉSTERES DIACETILTARTÁRICOS Y DE } \\
\text { ÁCIDOS GRASOS DE GLICEROL }\end{array}$ & $472 e$ & 2005 & $2500 \mathrm{mg} / \mathrm{kg}$ & \\
\hline
\end{tabular}




\begin{tabular}{|c|c|c|c|c|}
\hline \multirow[t]{2}{*}{ No. de Categoría de alime } & $\begin{array}{l}\mathrm{H} \\
\mathrm{ra} \\
\mathrm{le} \\
\mathrm{m}\end{array}$ & \multicolumn{3}{|c|}{$\begin{array}{l}\text { Hortalizas (incluidos hongos y setas, } \\
\text { raíces y tubérculos, legumbres y } \\
\text { leguminosas y áloe vera) y algas } \\
\text { marinas cocidas o fritas }\end{array}$} \\
\hline & SIN & Año Adoptada & Dosis máxima & Notas \\
\hline ETILEN DIAMINO TETRA ACETATOS & 385,386 & 2001 & $250 \mathrm{mg} / \mathrm{kg}$ & 21 \\
\hline FOSFATOS & $\begin{array}{l}338 ; 339(i)-(i i i) ; \\
340(\text { (i)-(iii); } 341 \text { (i)-- } \\
\text { (iii); 342(i)-(ii); } \\
343(\text { i)-(iii); } 450(\text { i)- } \\
\text { (iii),(v)-(vii), (ix); } \\
451 \text { (i),(ii); } 452 \text { (i)- } \\
\text { (v); } 542\end{array}$ & 2012 & $2200 \mathrm{mg} / \mathrm{kg}$ & $33 \& 76$ \\
\hline GLICÓSIDOS DE ESTEVIOL & $960 a, 960 b(i)$ & 2011 & $40 \mathrm{mg} / \mathrm{kg}$ & 26 \\
\hline NEOTAMO & 961 & 2008 & $33 \mathrm{mg} / \mathrm{kg}$ & 161 \\
\hline SACARINAS & 954(i)-(iv) & 2008 & $160 \mathrm{mg} / \mathrm{kg}$ & $144 \& 161$ \\
\hline SORBATOS & $200,202,203$ & 2012 & $1000 \mathrm{mg} / \mathrm{kg}$ & $42 \& 221$ \\
\hline $\begin{array}{l}\text { SUCRALOSA } \\
\text { (TRICLOROGALACTOSACAROSA) }\end{array}$ & 955 & 2008 & $150 \mathrm{mg} / \mathrm{kg}$ & $144 \& 161$ \\
\hline
\end{tabular}

No. de Categoría de alimento 05.0

\begin{tabular}{|c|c|c|c|c|}
\hline Aditivo & SIN & Año Adoptada & Dosis máxima & Notas \\
\hline ACEITE MINERAL, VISCOSIDAD MEDIA & $905 \mathrm{e}$ & 2017 & $2000 \mathrm{mg} / \mathrm{kg}$ & $\begin{array}{c}\text { 3, XS86, XS87, } \\
\text { XS105, XS309R \& } \\
\text { XS141 }\end{array}$ \\
\hline ÉSTERES DE ASCORBILO & 304,305 & 2017 & $500 \mathrm{mg} / \mathrm{kg}$ & $\begin{array}{c}10,15,375, \text { XS86, } \\
\text { XS105, XS141 \& } \\
\text { XS309R }\end{array}$ \\
\hline
\end{tabular}

\begin{tabular}{|c|c|c|c|c|}
\hline \multicolumn{2}{|c|}{ No. de Categoría de alimento 05.1} & \multicolumn{3}{|c|}{$\begin{array}{l}\text { Productos de cacao y chocolate, } \\
\text { incluidos los productos de imitación y } \\
\text { los sucedáneos del chocolate }\end{array}$} \\
\hline Aditivo & SIN & Año Adoptada & Dosis máxima & Notas \\
\hline ACEITE MINERAL DE ALTA VISCOSIDAD & $905 d$ & 2016 & $2000 \mathrm{mg} / \mathrm{kg}$ & $\begin{array}{l}\text { 3, XS86, XS87, } \\
\text { XS105 \& XS141 }\end{array}$ \\
\hline GALATO DE PROPILO & 310 & 2016 & $200 \mathrm{mg} / \mathrm{kg}$ & $\begin{array}{c}15,130,303 \\
\text { XS } 86, \text { XS105 \& } \\
\text { XS141 }\end{array}$ \\
\hline
\end{tabular}

\section{No. de Categoría de alimento 05.1.1 Mezclas de cacao (en polvo) y cacao en pasta/torta de cacao}

$\begin{array}{lllrr}\text { Aditivo } & \text { SIN } & \text { Año Adoptada } & \text { Dosis máxima } & \text { Notas } \\ \text { ACESULFAME DE POTASIO } & 950 & 2016 & 350 \mathrm{mg} / \mathrm{kg} & 97,188 \text { \& XS141 } \\ \begin{array}{l}\text { ASPARTAMO } \\ \text { ÉSTERES DE PROPILENGLICOL DE }\end{array} & 951 & 2016 & 3000 \mathrm{mg} / \mathrm{kg} & 97,191 \& \text { XS141 } \\ \begin{array}{l}\text { ÁCIDOS GRASOS } \\ \text { ÉSTERES DE SORBITÁN DE ÁCIDOS }\end{array} & 491-495 & 2016 & 5000 \mathrm{mg} / \mathrm{kg} & 97 \& \text { XS141 } \\ \begin{array}{l}\text { GRASOS } \\ \text { ÉSTERES POLIGLICÉRIDOS DE ÁCIDO }\end{array} & 476 & 2016 & 2000 \mathrm{mg} / \mathrm{kg} & 97,123 \& \text { XS141 } \\ \begin{array}{l}\text { RICINOLÉICO INTERESTERIFICADO } \\ \text { ÉSTERES POLIGLICÉRIDOS DE ÁCIDOS } \\ \text { GRASOS }\end{array} & 475 & 2016 & 5000 \mathrm{mg} / \mathrm{kg} & 97 \\ \end{array}$




\begin{tabular}{|c|c|c|c|c|}
\hline \multicolumn{2}{|c|}{ No. de Categoría de alimento 05.1.1 } & \multicolumn{3}{|c|}{$\begin{array}{l}\text { Mezclas de cacao (en polvo) y cacao en } \\
\text { pasta/torta de cacao }\end{array}$} \\
\hline Aditivo & SIN & Año Adoptada & Dosis máxima & Notas \\
\hline FOSFATOS & 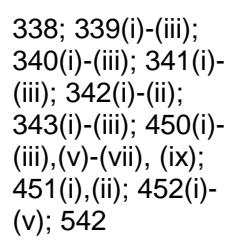 & 2016 & $1100 \mathrm{mg} / \mathrm{kg}$ & 33,97 \\
\hline SACARINAS & 954(i)-(iv) & 2016 & $100 \mathrm{mg} / \mathrm{kg}$ & $97,161 \& X S 141$ \\
\hline $\begin{array}{l}\text { SALES AMÓNICAS DEL ÁCIDO } \\
\text { FOSFATÍDICO }\end{array}$ & 442 & 2009 & $10000 \mathrm{mg} / \mathrm{kg}$ & 97 \\
\hline $\begin{array}{l}\text { SUCRALOSA } \\
\text { (TRICLOROGALACTOSACAROSA) }\end{array}$ & 955 & 2016 & $580 \mathrm{mg} / \mathrm{kg}$ & $97 \& X S 141$ \\
\hline SUCROÉSTERES DE ÁCIDOS GRASOS & 473 & 2016 & $10000 \mathrm{mg} / \mathrm{kg}$ & $97 \& X S 141$ \\
\hline TARTRATOS & 334, 335(ii), 337 & 2016 & $5000 \mathrm{mg} / \mathrm{kg}$ & $45,97 \& 128$ \\
\hline
\end{tabular}

\begin{tabular}{|c|c|c|c|c|}
\hline \multicolumn{2}{|c|}{ No. de Categoría de alimento 05.1.2 } & \multicolumn{2}{|c|}{ Mezclas de cacao (jarabes) } & \\
\hline Aditivo & $\operatorname{SIN}$ & Año Adoptada & Dosis máxima & Notas \\
\hline ACESULFAME DE POTASIO & 950 & 2007 & $350 \mathrm{mg} / \mathrm{kg}$ & $97,161 \& 188$ \\
\hline ALGINATO DE PROPILENGLICOL & 405 & 2017 & $10000 \mathrm{mg} / \mathrm{kg}$ & \\
\hline ALITAME & 956 & 2007 & $300 \mathrm{mg} / \mathrm{kg}$ & 161 \\
\hline ASPARTAMO & 951 & 2007 & $1000 \mathrm{mg} / \mathrm{kg}$ & $161 \& 191$ \\
\hline $\begin{array}{l}\text { CARAMELO III - CARAMELO AL } \\
\text { AMONÍACO }\end{array}$ & $150 \mathrm{c}$ & 2010 & $50000 \mathrm{mg} / \mathrm{kg}$ & \\
\hline $\begin{array}{l}\text { CARAMELO IV - CARAMELO AL SULFITO } \\
\text { AMÓNICO }\end{array}$ & $150 d$ & 2012 & $50000 \mathrm{mg} / \mathrm{kg}$ & \\
\hline CARMINES & 120 & 2005 & $300 \mathrm{mg} / \mathrm{kg}$ & 178 \\
\hline CICLAMATOS & 952(i), (ii), (iv) & 2007 & $250 \mathrm{mg} / \mathrm{kg}$ & $17,127 \& 161$ \\
\hline $\begin{array}{l}\text { CLOROFILAS Y CLOROFILINAS, } \\
\text { COMPLEJOS CUPRICOS }\end{array}$ & 141 (i),(ii) & 2009 & $6.4 \mathrm{mg} / \mathrm{kg}$ & $62 \& 161$ \\
\hline NEOTAMO & 961 & 2007 & 33 mg/kg & $97 \& 161$ \\
\hline POLISORBATOS & $432-436$ & 2007 & $500 \mathrm{mg} / \mathrm{kg}$ & \\
\hline SACARINAS & 954(i)-(iv) & 2007 & $80 \mathrm{mg} / \mathrm{kg}$ & 161 \\
\hline SORBATOS & $200,202,203$ & 2012 & $1000 \mathrm{mg} / \mathrm{kg}$ & 42 \\
\hline $\begin{array}{l}\text { SUCRALOSA } \\
\text { (TRICLOROGALACTOSACAROSA) }\end{array}$ & 955 & 2007 & $400 \mathrm{mg} / \mathrm{kg}$ & $97 \& 161$ \\
\hline SUCROÉSTERES DE ÁCIDOS GRASOS & 473 & 2017 & $10000 \mathrm{mg} / \mathrm{kg}$ & 348 \\
\hline SUCROGLICÉRIDOS & 474 & 2017 & $10000 \mathrm{mg} / \mathrm{kg}$ & 348 \\
\hline $\begin{array}{l}\text { SUCROSE OLIGOESTERS, TYPE I AND } \\
\text { TYPE II }\end{array}$ & $473 a$ & 2017 & $10000 \mathrm{mg} / \mathrm{kg}$ & 348 \\
\hline TARTRATOS & 334, 335(ii), 337 & 2016 & $2000 \mathrm{mg} / \mathrm{kg}$ & 45 \\
\hline TOCOFEROLES & $307 a, b, c$ & 2016 & $500 \mathrm{mg} / \mathrm{kg}$ & 15 \\
\hline
\end{tabular}

No. de Categoría de alimento 05.1.3 Productos para untar a base de cacao, incluidos los rellenos a base de cacao

\begin{tabular}{ccccc} 
Aditivo & SIN & Año Adoptada & Dosis máxima & Notas \\
\hline ACESULFAME DE POTASIO & 950 & 2019 & $1000 \mathrm{mg} / \mathrm{kg}$ & $478,188 \&$ XS86
\end{tabular}


No. de Categoría de alimento 05.1.3 Productos para untar a base de cacao, incluidos los rellenos a base de cacao

\begin{tabular}{|c|c|c|c|c|}
\hline Aditivo & SIN & Año Adoptada & Dosis máxima & Notas \\
\hline ALGINATO DE PROPILENGLICOL & 405 & 2017 & $10000 \mathrm{mg} / \mathrm{kg}$ & XS86 \\
\hline ALITAME & 956 & 2016 & $300 \mathrm{mg} / \mathrm{kg}$ & $161 \& X S 86$ \\
\hline ASPARTAMO & 951 & 2019 & $3000 \mathrm{mg} / \mathrm{kg}$ & $478,191 \&$ XS86 \\
\hline AZUL BRILLANTE FCF & 133 & 2016 & $100 \mathrm{mg} / \mathrm{kg}$ & $161 \&$ XS86 \\
\hline BENZOATOS & $210-213$ & 2016 & $1500 \mathrm{mg} / \mathrm{kg}$ & $13 \& X S 86$ \\
\hline $\begin{array}{l}\text { CARAMELO III - CARAMELO AL } \\
\text { AMONÍACO }\end{array}$ & $150 c$ & 2016 & $50000 \mathrm{mg} / \mathrm{kg}$ & XS86 \\
\hline $\begin{array}{l}\text { CARAMELO IV - CARAMELO AL SULFITO } \\
\text { AMÓNICO }\end{array}$ & $150 d$ & 2016 & $50000 \mathrm{mg} / \mathrm{kg}$ & XS86 \\
\hline CAROTENOIDES & 160a(i),a(iii),e,f & 2016 & $100 \mathrm{mg} / \mathrm{kg}$ & $161 \& X S 86$ \\
\hline CAROTENOS, BETA-, VEGETALES & 160a(ii) & 2016 & $100 \mathrm{mg} / \mathrm{kg}$ & XS86 \\
\hline CICLAMATOS & 952(i), (ii), (iv) & 2019 & $500 \mathrm{mg} / \mathrm{kg}$ & $17,477 \&$ XS86 \\
\hline $\begin{array}{l}\text { CLOROFILAS Y CLOROFILINAS, } \\
\text { COMPLEJOS CUPRICOS }\end{array}$ & 141(i),(ii) & 2016 & $6.4 \mathrm{mg} / \mathrm{kg}$ & $62,161 \& X S 86$ \\
\hline $\begin{array}{l}\text { ÉSTERES DE SORBITÁN DE ÁCIDOS } \\
\text { GRASOS }\end{array}$ & $491-495$ & 2017 & $10000 \mathrm{mg} / \mathrm{kg}$ & XS86 \\
\hline ETILEN DIAMINO TETRA ACETATOS & 385,386 & 2016 & $50 \mathrm{mg} / \mathrm{kg}$ & $21 \& X S 86$ \\
\hline ETIL-LAUROIL ARGINATO & 243 & 2016 & $200 \mathrm{mg} / \mathrm{kg}$ & XS86 \\
\hline EXTRACTO DE PIEL DE UVA & 163(ii) & 2016 & $200 \mathrm{mg} / \mathrm{kg}$ & $181 \& X S 86$ \\
\hline FOSFATOS & $\begin{array}{l}\text { 338; 339(i)-(iii); } \\
340 \text { (i)-(iii); 341(i)- } \\
\text { (iii); 342(i)-(ii); } \\
343(\text { i)-(iii); 450(i)- } \\
\text { (iii),(v)-(vii), (ix); } \\
\text { 451(i),(ii); 452(i)- } \\
\text { (v); } 542\end{array}$ & 2016 & $880 \mathrm{mg} / \mathrm{kg}$ & $33 \&$ XS86 \\
\hline HIDROXIBENZOATOS, PARA- & 214,218 & 2016 & $300 \mathrm{mg} / \mathrm{kg}$ & $27 \& X S 86$ \\
\hline NEOTAMO & 961 & 2019 & $100 \mathrm{mg} / \mathrm{kg}$ & $478 \&$ XS86 \\
\hline POLISORBATOS & $432-436$ & 2016 & $1000 \mathrm{mg} / \mathrm{kg}$ & XS86 \\
\hline PROPILENGLICOL & 1520 & 2017 & $1000 \mathrm{mg} / \mathrm{kg}$ & XS86 \\
\hline ROJO ALLURA AC & 129 & 2016 & $300 \mathrm{mg} / \mathrm{kg}$ & $161 \& X S 86$ \\
\hline SACARINAS & 954(i)-(iv) & 2019 & $200 \mathrm{mg} / \mathrm{kg}$ & $477 \&$ XS86 \\
\hline SORBATOS & $200,202,203$ & 2016 & $1000 \mathrm{mg} / \mathrm{kg}$ & $42 \& X S 86$ \\
\hline $\begin{array}{l}\text { SUCRALOSA } \\
\text { (TRICLOROGALACTOSACAROSA) }\end{array}$ & 955 & 2019 & $400 \mathrm{mg} / \mathrm{kg}$ & $478,169 \&$ XS 86 \\
\hline SUCROÉSTERES DE ÁCIDOS GRASOS & 473 & 2017 & $10000 \mathrm{mg} / \mathrm{kg}$ & $348 \&$ XS86 \\
\hline SUCROGLICÉRIDOS & 474 & 2017 & $10000 \mathrm{mg} / \mathrm{kg}$ & 348 \\
\hline $\begin{array}{l}\text { SUCROSE OLIGOESTERS, TYPE I AND } \\
\text { TYPE II }\end{array}$ & $473 a$ & 2017 & $10000 \mathrm{mg} / \mathrm{kg}$ & 348 \\
\hline TARTRATOS & 334, 335(ii), 337 & 2017 & $2000 \mathrm{mg} / \mathrm{kg}$ & $45 \&$ XS86 \\
\hline TOCOFEROLES & $307 a, b, c$ & 2017 & $100 \mathrm{mg} / \mathrm{kg}$ & $15 \& X S 86$ \\
\hline
\end{tabular}

\section{No. de Categoría de alimento 05.1.4 Productos de cacao y chocolate}

\begin{tabular}{|c|c|c|c|c|}
\hline Aditivo & SIN & Año Adoptada & Dosis máxima & Notas \\
\hline ACEITE DE RICINO & 1503 & 2017 & $350 \mathrm{mg} / \mathrm{kg}$ & XS87 \\
\hline
\end{tabular}




\section{No. de Categoría de alimento 05.1.4 Productos de cacao y chocolate}

\begin{tabular}{|c|c|c|c|c|}
\hline Aditivo & SIN & Año Adoptada & Dosis máxima & Notas \\
\hline ACESULFAME DE POTASIO & 950 & 2019 & $500 \mathrm{mg} / \mathrm{kg}$ & $478 \& 188$ \\
\hline ALITAME & 956 & 2017 & $300 \mathrm{mg} / \mathrm{kg}$ & $161 \&$ XS87 \\
\hline AMARILLO OCASO FCF & 110 & 2016 & $400 \mathrm{mg} / \mathrm{kg}$ & 183 \\
\hline ASPARTAMO & 951 & 2019 & $3000 \mathrm{mg} / \mathrm{kg}$ & $37,478 \& 191$ \\
\hline AZUL BRILLANTE FCF & 133 & 2016 & $100 \mathrm{mg} / \mathrm{kg}$ & 183 \\
\hline BUTILHIDROXIANISOL & 320 & 2017 & 200 mg/kg & $15,130 \& 303$ \\
\hline BUTILHIDROXITOLUENO & 321 & 2017 & 200 mg/kg & $15,130 \& 303$ \\
\hline $\begin{array}{l}\text { CARAMELO III - CARAMELO AL } \\
\text { AMONÍACO }\end{array}$ & $150 \mathrm{c}$ & 2016 & $50000 \mathrm{mg} / \mathrm{kg}$ & 183 \\
\hline $\begin{array}{l}\text { CARAMELO IV - CARAMELO AL SULFITO } \\
\text { AMÓNICO }\end{array}$ & $150 d$ & 2016 & $50000 \mathrm{mg} / \mathrm{kg}$ & 183 \\
\hline CAROTENOIDES & 160a(i),a(iii),e,f & 2016 & $100 \mathrm{mg} / \mathrm{kg}$ & 183 \\
\hline CAROTENOS, BETA-, VEGETALES & $160 a(i i)$ & 2016 & $100 \mathrm{mg} / \mathrm{kg}$ & 183 \\
\hline CERA CANDELILLA & 902 & 2001 & BPF & 3 \\
\hline CERA CARNAUBA & 903 & 2017 & $5000 \mathrm{mg} / \mathrm{kg}$ & $3 \&$ XS87 \\
\hline CERA DE ABEJAS & 901 & 2001 & BPF & 3 \\
\hline CICLAMATOS & 952(i), (ii), (iv) & 2019 & $500 \mathrm{mg} / \mathrm{kg}$ & $17 \& 477$ \\
\hline $\begin{array}{l}\text { CLOROFILAS Y CLOROFILINAS, } \\
\text { COMPLEJOS CUPRICOS }\end{array}$ & $141(\mathrm{i}),(\mathrm{ii})$ & 2016 & $700 \mathrm{mg} / \mathrm{kg}$ & 183 \\
\hline $\begin{array}{l}\text { ÉSTERES DE SORBITÁN DE ÁCIDOS } \\
\text { GRASOS }\end{array}$ & $491-495$ & 2016 & $10000 \mathrm{mg} / \mathrm{kg}$ & 101 \\
\hline $\begin{array}{l}\text { ÉSTERES POLIGLICÉRIDOS DE ÁCIDO } \\
\text { RICINOLÉICO INTERESTERIFICADO }\end{array}$ & 476 & 2016 & $5000 \mathrm{mg} / \mathrm{kg}$ & 101 \\
\hline EXTRACTO DE PIEL DE UVA & 163(ii) & 2016 & 200 mg/kg & $181 \& 183$ \\
\hline FOSFATOS & $\begin{array}{l}\text { 338; 339(i)-(iii); } \\
340 \text { (i)-(iii); } 341 \text { (i)- } \\
\text { (iii); 342(i)-(ii); } \\
343 \text { (i)-(iii); 450(i)- } \\
\text { (iii),(v)-(vii), (ix); } \\
\text { 451(i),(ii); 452(i)- } \\
\text { (v); } 542\end{array}$ & 2012 & $1100 \mathrm{mg} / \mathrm{kg}$ & 33 \\
\hline GOMA LACA, BLANQUEADA & 904 & 2001 & BPF & 3 \\
\hline INDIGOTINA (CARMÍN DE ÍNDIGO) & 132 & 2016 & $450 \mathrm{mg} / \mathrm{kg}$ & 183 \\
\hline NEOTAMO & 961 & 2019 & $80 \mathrm{mg} / \mathrm{kg}$ & $478 \&$ XS87 \\
\hline POLISORBATOS & $432-436$ & 2016 & $5000 \mathrm{mg} / \mathrm{kg}$ & 101 \\
\hline PONCEAU 4R (ROJO DE COCHINILLA A) & 124 & 2016 & $300 \mathrm{mg} / \mathrm{kg}$ & 183 \\
\hline ROJO ALLURA AC & 129 & 2016 & $300 \mathrm{mg} / \mathrm{kg}$ & 183 \\
\hline SACARINAS & 954(i)-(iv) & 2019 & $500 \mathrm{mg} / \mathrm{kg}$ & 477 \\
\hline $\begin{array}{l}\text { SALES AMÓNICAS DEL ÁCIDO } \\
\text { FOSFATÍDICO }\end{array}$ & 442 & 2016 & $10000 \mathrm{mg} / \mathrm{kg}$ & 101 \\
\hline $\begin{array}{l}\text { SUCRALOSA } \\
\text { (TRICLOROGALACTOSACAROSA) }\end{array}$ & 955 & 2019 & $800 \mathrm{mg} / \mathrm{kg}$ & $478 \&$ XS87 \\
\hline TARTRATOS & 334, 335(ii), 337 & 2016 & $5000 \mathrm{mg} / \mathrm{kg}$ & $45 \& 128$ \\
\hline TERBUTILHIDROQUINONA & 319 & 2017 & $200 \mathrm{mg} / \mathrm{kg}$ & $15,130 \& 303$ \\
\hline TOCOFEROLES & $307 a, b, c$ & 2016 & $750 \mathrm{mg} / \mathrm{kg}$ & $15 \& 168$ \\
\hline
\end{tabular}




\section{No. de Categoría de alimento 05.1.5}

Productos de imitación y sucedáneos del chocolate

\begin{tabular}{|c|c|c|c|c|}
\hline Aditivo & $\sin$ & Año Adoptada & Dosis máxima & Notas \\
\hline ACESULFAME DE POTASIO & 950 & 2007 & $500 \mathrm{mg} / \mathrm{kg}$ & $161 \& 188$ \\
\hline ALITAME & 956 & 2007 & $300 \mathrm{mg} / \mathrm{kg}$ & 161 \\
\hline AMARILLO OCASO FCF & 110 & 2008 & $300 \mathrm{mg} / \mathrm{kg}$ & 161 \\
\hline ASPARTAMO & 951 & 2008 & $3000 \mathrm{mg} / \mathrm{kg}$ & $161 \& 191$ \\
\hline AZUL BRILLANTE FCF & 133 & 2009 & $100 \mathrm{mg} / \mathrm{kg}$ & \\
\hline BENZOATOS & $210-213$ & 2003 & $1500 \mathrm{mg} / \mathrm{kg}$ & 13 \\
\hline BUTILHIDROXITOLUENO & 321 & 2006 & $200 \mathrm{mg} / \mathrm{kg}$ & $15 \& 197$ \\
\hline $\begin{array}{l}\text { CARAMELO III - CARAMELO AL } \\
\text { AMONÍACO }\end{array}$ & $150 c$ & 2009 & $50000 \mathrm{mg} / \mathrm{kg}$ & \\
\hline $\begin{array}{l}\text { CARAMELO IV - CARAMELO AL SULFITO } \\
\text { AMÓNICO }\end{array}$ & $150 d$ & 2012 & $50000 \mathrm{mg} / \mathrm{kg}$ & \\
\hline CARMINES & 120 & 2005 & $300 \mathrm{mg} / \mathrm{kg}$ & 178 \\
\hline CAROTENOIDES & $160 a(i), a(i i i), e, f$ & 2009 & $100 \mathrm{mg} / \mathrm{kg}$ & \\
\hline CAROTENOS, BETA-, VEGETALES & $160 a($ ii) & 2010 & $100 \mathrm{mg} / \mathrm{kg}$ & \\
\hline CERA CANDELILLA & 902 & 2001 & BPF & 3 \\
\hline CERA CARNAUBA & 903 & 2006 & $5000 \mathrm{mg} / \mathrm{kg}$ & 3 \\
\hline CERA DE ABEJAS & 901 & 2001 & BPF & 3 \\
\hline CICLAMATOS & 952(i), (ii), (iv) & 2007 & $500 \mathrm{mg} / \mathrm{kg}$ & $17 \& 161$ \\
\hline $\begin{array}{l}\text { CLOROFILAS Y CLOROFILINAS, } \\
\text { COMPLEJOS CUPRICOS }\end{array}$ & 141 (i),(ii) & 2009 & $700 \mathrm{mg} / \mathrm{kg}$ & \\
\hline DIMETILPOLISILOXANO & $900 a$ & 1999 & $10 \mathrm{mg} / \mathrm{kg}$ & \\
\hline $\begin{array}{l}\text { ÉSTERES DE SORBITÁN DE ÁCIDOS } \\
\text { GRASOS }\end{array}$ & 491-495 & 2017 & $10000 \mathrm{mg} / \mathrm{kg}$ & \\
\hline $\begin{array}{l}\text { ÉSTERES POLIGLICÉRIDOS DE ÁCIDO } \\
\text { RICINOLÉICO INTERESTERIFICADO }\end{array}$ & 476 & 2016 & $3000 \mathrm{mg} / \mathrm{kg}$ & 366 \\
\hline $\begin{array}{l}\text { ÉSTERES POLIGLICÉRIDOS DE ÁCIDOS } \\
\text { GRASOS }\end{array}$ & 475 & 2016 & $2000 \mathrm{mg} / \mathrm{kg}$ & 366 \\
\hline EXTRACTO DE PIEL DE UVA & 163(ii) & 2009 & $200 \mathrm{mg} / \mathrm{kg}$ & 181 \\
\hline FOSFATOS & $\begin{array}{l}\text { 338; 339(i)-(iii); } \\
\text { 340(i)-(iii); 341(i)- } \\
\text { (iii); 342(i)-(ii); } \\
\text { 343(i)-(iii); 450(i)- } \\
\text { (iii),(v)-(vii), (ix); } \\
\text { 451(i),(ii); 452(i)- } \\
\text { (v); } 542\end{array}$ & 2009 & $2200 \mathrm{mg} / \mathrm{kg}$ & 33 \\
\hline GOMA LACA, BLANQUEADA & 904 & 2001 & BPF & 3 \\
\hline HIDROXIBENZOATOS, PARA- & 214,218 & 2009 & $300 \mathrm{mg} / \mathrm{kg}$ & 27 \\
\hline INDIGOTINA (CARMÍN DE ÍNDIGO) & 132 & 2009 & $300 \mathrm{mg} / \mathrm{kg}$ & \\
\hline NEOTAMO & 961 & 2007 & $100 \mathrm{mg} / \mathrm{kg}$ & 161 \\
\hline POLISORBATOS & $432-436$ & 2007 & $5000 \mathrm{mg} / \mathrm{kg}$ & \\
\hline PONCEAU 4R (ROJO DE COCHINILLA A) & 124 & 2008 & $50 \mathrm{mg} / \mathrm{kg}$ & \\
\hline RIBOFLAVINAS & 101 (i),(ii), (iii) & 2005 & $1000 \mathrm{mg} / \mathrm{kg}$ & \\
\hline ROJO ALLURA AC & 129 & 2009 & $300 \mathrm{mg} / \mathrm{kg}$ & \\
\hline SACARINAS & 954(i)-(iv) & 2007 & $500 \mathrm{mg} / \mathrm{kg}$ & 161 \\
\hline SAL DE ASPARTAMO Y ACESULFAMO & 962 & 2009 & $500 \mathrm{mg} / \mathrm{kg}$ & $113 \& 161$ \\
\hline
\end{tabular}




\begin{tabular}{|c|c|c|c|c|}
\hline \multicolumn{2}{|c|}{ No. de Categoría de alimento 05.1.5 } & \multicolumn{3}{|c|}{$\begin{array}{l}\text { Productos de imitación y sucedáneos } \\
\text { del chocolate }\end{array}$} \\
\hline Aditivo & SIN & Año Adoptada & Dosis máxima & Notas \\
\hline $\begin{array}{l}\text { SALES AMÓNICAS DEL ÁCIDO } \\
\text { FOSFATÍDICO }\end{array}$ & 442 & 2009 & $10000 \mathrm{mg} / \mathrm{kg}$ & \\
\hline SORBATOS & $200,202,203$ & 2009 & $1500 \mathrm{mg} / \mathrm{kg}$ & 42 \\
\hline $\begin{array}{l}\text { SUCRALOSA } \\
\text { (TRICLOROGALACTOSACAROSA) }\end{array}$ & 955 & 2007 & $800 \mathrm{mg} / \mathrm{kg}$ & 161 \\
\hline SUCROÉSTERES DE ÁCIDOS GRASOS & 473 & 2016 & $6000 \mathrm{mg} / \mathrm{kg}$ & 348 \\
\hline SUCROGLICÉRIDOS & 474 & 2016 & $6000 \mathrm{mg} / \mathrm{kg}$ & 348 \\
\hline $\begin{array}{l}\text { SUCROSE OLIGOESTERS, TYPE I AND } \\
\text { TYPE II }\end{array}$ & $473 a$ & 2016 & $6000 \mathrm{mg} / \mathrm{kg}$ & 348 \\
\hline TARTRATOS & 334, 335(ii), 337 & 2016 & $5000 \mathrm{mg} / \mathrm{kg}$ & 45 \\
\hline TOCOFEROLES & $307 a, b, c$ & 2016 & $500 \mathrm{mg} / \mathrm{kg}$ & 15 \\
\hline
\end{tabular}

No. de Categoría de alimento 05.2

Dulces, incluidos los caramelos duros y blandos, los turrones, etc. distintos de los indicados en las categorías de alimentos $05.1,05.3$ y 05.4

\begin{tabular}{|c|c|c|c|c|}
\hline Aditivo & $\operatorname{SIN}$ & Año Adoptada & Dosis máxima & Notas \\
\hline ACEITE DE RICINO & 1503 & 2017 & $500 \mathrm{mg} / \mathrm{kg}$ & XS309R \\
\hline ACEITE MINERAL DE ALTA VISCOSIDAD & $905 d$ & 2017 & $2000 \mathrm{mg} / \mathrm{kg}$ & $3 \&$ XS309R \\
\hline ALGINATO DE PROPILENGLICOL & 405 & 2017 & $5000 \mathrm{mg} / \mathrm{kg}$ & XS309R \\
\hline ALITAME & 956 & 2017 & $300 \mathrm{mg} / \mathrm{kg}$ & $161 \& X S 309 R$ \\
\hline AMARILLO OCASO FCF & 110 & 2017 & $300 \mathrm{mg} / \mathrm{kg}$ & $161 \& X S 309 R$ \\
\hline AZUL BRILLANTE FCF & 133 & 2017 & $300 \mathrm{mg} / \mathrm{kg}$ & XS309R \\
\hline BENZOATOS & $210-213$ & 2017 & $1500 \mathrm{mg} / \mathrm{kg}$ & $13 \&$ XS309R \\
\hline BUTILHIDROXIANISOL & 320 & 2017 & 200 mg/kg & $15,130 \& X S 309 R$ \\
\hline BUTILHIDROXITOLUENO & 321 & 2017 & $200 \mathrm{mg} / \mathrm{kg}$ & $15,130 \& X S 309 R$ \\
\hline CARAMELO II - CARAMELO AL SULFITO & $150 \mathrm{~b}$ & 2019 & $50000 \mathrm{mg} / \mathrm{kg}$ & \\
\hline $\begin{array}{l}\text { CARAMELO III - CARAMELO AL } \\
\text { AMONÍACO }\end{array}$ & $150 \mathrm{c}$ & 2017 & $50000 \mathrm{mg} / \mathrm{kg}$ & XS309R \\
\hline $\begin{array}{l}\text { CARAMELO IV - CARAMELO AL SULFITO } \\
\text { AMÓNICO }\end{array}$ & $150 d$ & 2017 & $50000 \mathrm{mg} / \mathrm{kg}$ & XS309R \\
\hline CARMINES & 120 & 2017 & $300 \mathrm{mg} / \mathrm{kg}$ & $178 \& X S 309 R$ \\
\hline CAROTENOIDES & $160 a(i), a(i i i), e, f$ & 2017 & $100 \mathrm{mg} / \mathrm{kg}$ & XS309R \\
\hline CAROTENOS, BETA-, VEGETALES & $160 a(i i)$ & 2017 & $500 \mathrm{mg} / \mathrm{kg}$ & XS309R \\
\hline CERA CANDELILLA & 902 & 2017 & BPF & $3 \&$ XS309R \\
\hline CERA CARNAUBA & 903 & 2017 & $5000 \mathrm{mg} / \mathrm{kg}$ & $3 \&$ XS309R \\
\hline CERA DE ABEJAS & 901 & 2017 & BPF & $3 \&$ XS309R \\
\hline CERA MICROCRISTALINA & $905 c(i)$ & 2017 & BPF & $3 \&$ XS309R \\
\hline CICLAMATOS & 952(i), (ii), (iv) & 2019 & $500 \mathrm{mg} / \mathrm{kg}$ & $\begin{array}{l}17,156,477 \& \\
\quad \text { XS309R }\end{array}$ \\
\hline CURCUMINA & 100 (i) & 2019 & $300 \mathrm{mg} / \mathrm{kg}$ & \\
\hline DIACETATO DE SODIO & 262(ii) & 2016 & $1000 \mathrm{mg} / \mathrm{kg}$ & XS309R \\
\hline DIMETILPOLISILOXANO & $900 a$ & 2017 & $10 \mathrm{mg} / \mathrm{kg}$ & XS309R \\
\hline
\end{tabular}


Dulces, incluidos los caramelos duros y blandos, los turrones, etc. distintos de los indicados en las categorías de alimentos 05.1, 05.3 y 05.4

\begin{tabular}{|c|c|c|c|c|}
\hline Aditivo & SIN & Año Adoptada & Dosis máxima & Notas \\
\hline ESTEAROIL LACTILATOS & 481(i), 482(i) & 2016 & $5000 \mathrm{mg} / \mathrm{kg}$ & XS309R \\
\hline $\begin{array}{l}\text { ÉSTERES DE PROPILENGLICOL DE } \\
\text { ÁCIDOS GRASOS }\end{array}$ & 477 & 2017 & $5000 \mathrm{mg} / \mathrm{kg}$ & XS309R \\
\hline $\begin{array}{l}\text { ÉSTERES DIACETILTARTÁRICOS Y DE } \\
\text { ÁCIDOS GRASOS DE GLICEROL }\end{array}$ & $472 e$ & 2017 & $10000 \mathrm{mg} / \mathrm{kg}$ & XS309R \\
\hline $\begin{array}{l}\text { ÉSTERES POLIGLICÉRIDOS DE ÁCIDO } \\
\text { RICINOLÉICO INTERESTERIFICADO }\end{array}$ & 476 & 2016 & $3000 \mathrm{mg} / \mathrm{kg}$ & XS309R \\
\hline $\begin{array}{l}\text { ÉSTERES POLIGLICÉRIDOS DE ÁCIDOS } \\
\text { GRASOS }\end{array}$ & 475 & 2016 & $2000 \mathrm{mg} / \mathrm{kg}$ & $367 \&$ XS309R \\
\hline ETILMALTOL & 637 & 2017 & $1000 \mathrm{mg} / \mathrm{kg}$ & XS309R \\
\hline EXTRACTO DE PIMENTÓN & $160 c(i i)$ & 2019 & $100 \mathrm{mg} / \mathrm{kg}$ & 39 \\
\hline $\begin{array}{l}\text { EXTRACTOS DE ANNATO, BASE DE } \\
\text { BIXINA }\end{array}$ & $160 b(i)$ & 2019 & $200 \mathrm{mg} / \mathrm{kg}$ & 8 \\
\hline FOSFATOS & $\begin{array}{l}\text { 338; 339(i)-(iii); } \\
340 \text { (i)-(iii); 341(i)- } \\
\text { (iii); 342(i)-(ii); } \\
343(\text { i)-(iii); } 450 \text { (i)- } \\
\text { (iii),(v)-(vii), (ix); } \\
\text { 451(i),(ii); 452(i)- } \\
\text { (v); } 542\end{array}$ & 2017 & $2200 \mathrm{mg} / \mathrm{kg}$ & 33 \& XS309R \\
\hline GALATO DE PROPILO & 310 & 2017 & 200 mg/kg & $15,130 \& X S 309 R$ \\
\hline GLICÓSIDOS DE ESTEVIOL & $960 a, 960 b(i)$ & 2017 & $700 \mathrm{mg} / \mathrm{kg}$ & $26,199 \&$ XS309R \\
\hline GOMA LACA, BLANQUEADA & 904 & 2017 & BPF & $3 \&$ XS309R \\
\hline HIDROXIBENZOATOS, PARA- & 214,218 & 2017 & $1000 \mathrm{mg} / \mathrm{kg}$ & $27 \& X S 309 R$ \\
\hline INDIGOTINA (CARMÍN DE ÍNDIGO) & 132 & 2017 & $300 \mathrm{mg} / \mathrm{kg}$ & XS309R \\
\hline MALTOL & 636 & 2017 & $200 \mathrm{mg} / \mathrm{kg}$ & XS309R \\
\hline MARRÓN HT & 155 & 2019 & $50 \mathrm{mg} / \mathrm{kg}$ & \\
\hline NEGRO BRILLANTE (NEGRO PN) & 151 & 2019 & $100 \mathrm{mg} / \mathrm{kg}$ & \\
\hline NEOTAMO & 961 & 2019 & $330 \mathrm{mg} / \mathrm{kg}$ & $\begin{array}{l}158,478 \& \\
\text { XS309R }\end{array}$ \\
\hline ÓXIDOS DE HIERRO & 172(i)-(iii) & 2017 & $200 \mathrm{mg} / \mathrm{kg}$ & XS309R \\
\hline POLISORBATOS & $432-436$ & 2017 & $1000 \mathrm{mg} / \mathrm{kg}$ & XS309R \\
\hline PONCEAU 4R (ROJO DE COCHINILLA A) & 124 & 2017 & $300 \mathrm{mg} / \mathrm{kg}$ & $161 \& X S 309 R$ \\
\hline RIBOFLAVINAS & 101(i),(ii), (iii) & 2017 & $1000 \mathrm{mg} / \mathrm{kg}$ & XS309R \\
\hline ROJO ALLURA AC & 129 & 2017 & $300 \mathrm{mg} / \mathrm{kg}$ & XS309R \\
\hline SACARINAS & 954(i)-(iv) & 2019 & $500 \mathrm{mg} / \mathrm{kg}$ & $\begin{array}{l}477,163 \& \\
\quad X S 309 R\end{array}$ \\
\hline SORBATOS & $200,202,203$ & 2017 & $1500 \mathrm{mg} / \mathrm{kg}$ & $42 \&$ XS309R \\
\hline $\begin{array}{l}\text { SUCRALOSA } \\
\text { (TRICLOROGALACTOSACAROSA) }\end{array}$ & 955 & 2019 & $1800 \mathrm{mg} / \mathrm{kg}$ & $\begin{array}{l}478,164 \& \\
\text { XS309R }\end{array}$ \\
\hline SUCROÉSTERES DE ÁCIDOS GRASOS & 473 & 2017 & $5000 \mathrm{mg} / \mathrm{kg}$ & 348 \& XS309R \\
\hline SUCROGLICÉRIDOS & 474 & 2017 & $5000 \mathrm{mg} / \mathrm{kg}$ & 348 \& XS309R \\
\hline SUCROSE OLIGOESTERS, TYPE I AND & $473 a$ & 2017 & $5000 \mathrm{mg} / \mathrm{kg}$ & 348 \& XS309R \\
\hline
\end{tabular}


Dulces, incluidos los caramelos duros y blandos, los turrones, etc. distintos de los indicados en las categorías de alimentos $05.1,05.3$ y 05.4

$\begin{array}{llllc}\text { Aditivo } & \text { SIN } & \text { Año Adotada } & \text { Dosis máxima } & \text { Notas } \\ \text { TARTRATOS } & 334,335 \text { (ii), } 337 & 2019 & 5000 \mathrm{mg} / \mathrm{kg} & 45, \text { XS } 309 \mathrm{R} \& 450 \\ \text { TARTRAZINA } & 102 & 2019 & 300 \mathrm{mg} / \mathrm{kg} & \\ \text { TERBUTILHIDROQUINONA } & 319 & 2017 & 200 \mathrm{mg} / \mathrm{kg} & 15,130 \& \text { XS } 309 \mathrm{R} \\ \text { TOCOFEROLES } & 307 \mathrm{a}, \mathrm{b}, \mathrm{c} & 2016 & 500 \mathrm{mg} / \mathrm{kg} & 15 \& \text { XS } 309 \mathrm{R} \\ \text { VERDE SÓLIDO FCF } & 143 & 2017 & 100 \mathrm{mg} / \mathrm{kg} & \text { XS309R }\end{array}$

\section{No. de Categoría de alimento 05.2.1 Caramelos duros}

\begin{tabular}{|c|c|c|c|c|}
\hline Aditivo & SIN & Año Adoptada & Dosis máxima & Notas \\
\hline ACESULFAME DE POTASIO & 950 & 2019 & $500 \mathrm{mg} / \mathrm{kg}$ & $156,478 \& 188$ \\
\hline AMARILLO DE QUINOLEÍNA & 104 & 2019 & $100 \mathrm{mg} / \mathrm{kg}$ & 442 \\
\hline ASPARTAMO & 951 & 2019 & $3000 \mathrm{mg} / \mathrm{kg}$ & $478 \& 148$ \\
\hline AZORRUBINA (CARMOISINA) & 122 & 2019 & $50 \mathrm{mg} / \mathrm{kg}$ & 441 \\
\hline $\begin{array}{l}\text { CLOROFILAS Y CLOROFILINAS, } \\
\text { COMPLEJOS CUPRICOS }\end{array}$ & 141 (i),(ii) & 2009 & $700 \mathrm{mg} / \mathrm{kg}$ & \\
\hline $\begin{array}{l}\text { ÉSTERES DE SORBITÁN DE ÁCIDOS } \\
\text { GRASOS }\end{array}$ & $491-495$ & 2017 & $10000 \mathrm{mg} / \mathrm{kg}$ & \\
\hline $\begin{array}{l}\text { EXTRACTOS DE ANNATO, BASE DE } \\
\text { NORBIXINA }\end{array}$ & $160 b(i i)$ & 2019 & $30 \mathrm{mg} / \mathrm{kg}$ & 185,440 \\
\hline PROPILENGLICOL & 1520 & 2017 & $5300 \mathrm{mg} / \mathrm{kg}$ & \\
\hline
\end{tabular}

\section{No. de Categoría de alimento 05.2.2 Caramelos blandos}

\begin{tabular}{|c|c|c|c|c|}
\hline Aditivo & $\operatorname{SiN}$ & Año Adoptada & Dosis máxima & Notas \\
\hline ACESULFAME DE POTASIO & 950 & 2019 & $1000 \mathrm{mg} / \mathrm{kg}$ & $\begin{array}{c}157,478,188 \& \\
\text { XS309R }\end{array}$ \\
\hline AMARILLO DE QUINOLEÍNA & 104 & 2019 & $100 \mathrm{mg} / \mathrm{kg}$ & \\
\hline ASPARTAMO & 951 & 2019 & $3000 \mathrm{mg} / \mathrm{kg}$ & $\begin{array}{l}148,478 \& \\
\text { XS309R }\end{array}$ \\
\hline AZORRUBINA (CARMOISINA) & 122 & 2019 & $100 \mathrm{mg} / \mathrm{kg}$ & \\
\hline $\begin{array}{l}\text { CLOROFILAS Y CLOROFILINAS, } \\
\text { COMPLEJOS CUPRICOS }\end{array}$ & 141 (i),(ii) & 2017 & $100 \mathrm{mg} / \mathrm{kg}$ & XS309R \\
\hline $\begin{array}{l}\text { ÉSTERES DE SORBITÁN DE ÁCIDOS } \\
\text { GRASOS }\end{array}$ & $491-495$ & 2017 & $10000 \mathrm{mg} / \mathrm{kg}$ & XS309R \\
\hline EXTRACTO DE PIEL DE UVA & 163(ii) & 2017 & $1700 \mathrm{mg} / \mathrm{kg}$ & $181 \&$ XS309R \\
\hline $\begin{array}{l}\text { EXTRACTOS DE ANNATO, BASE DE } \\
\text { NORBIXINA }\end{array}$ & 160b(ii) & 2019 & $30 \mathrm{mg} / \mathrm{kg}$ & $185,440 \& 443$ \\
\hline POLI-1-DECENOS HIDROGENADOS & 907 & 2016 & $2000 \mathrm{mg} / \mathrm{kg}$ & XS309R \\
\hline PROPILENGLICOL & 1520 & 2017 & $4500 \mathrm{mg} / \mathrm{kg}$ & XS309R \\
\hline
\end{tabular}

\section{No. de Categoría de alimento 05.2.3 Turrón y mazapán}

\begin{tabular}{|c|c|c|c|c|}
\hline Aditivo & SIN & Año Adoptada & Dosis máxima & Notas \\
\hline ACESULFAME DE POTASIO & 950 & 2019 & $1000 \mathrm{mg} / \mathrm{kg}$ & $478 \& 188$ \\
\hline AMARILLO DE QUINOLEÍNA & 104 & 2019 & $100 \mathrm{mg} / \mathrm{kg}$ & \\
\hline
\end{tabular}




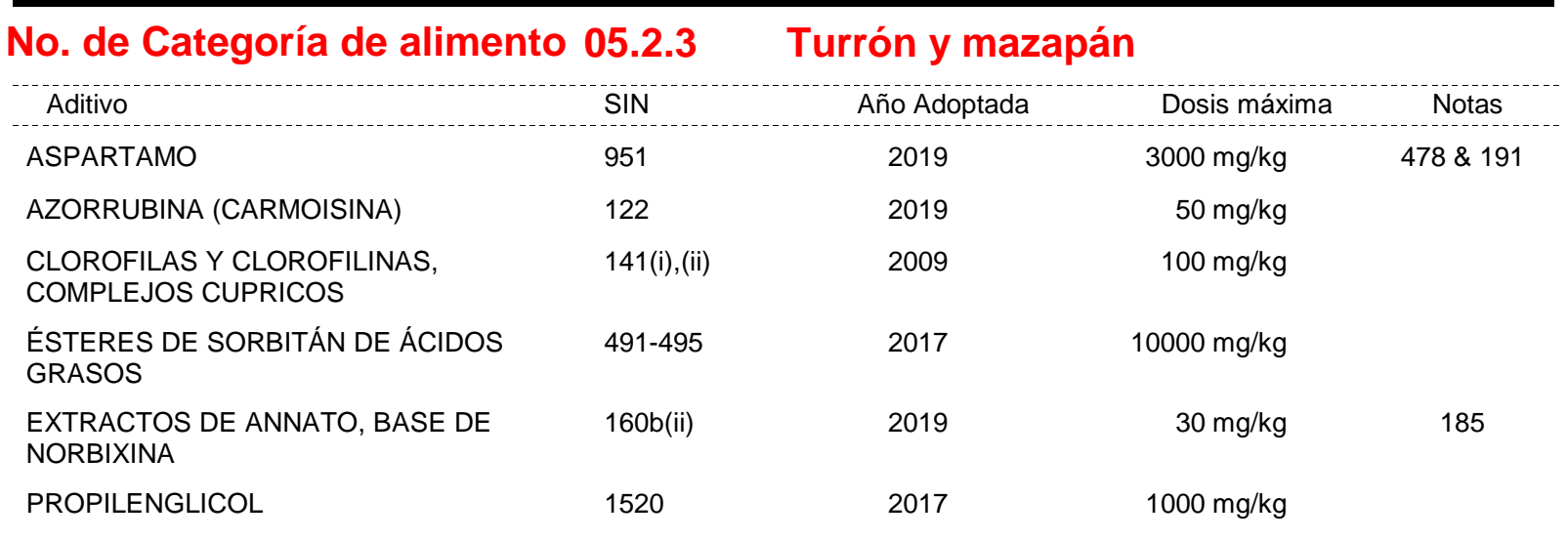

\section{No. de Categoría de alimento 05.3 Goma de mascar}

\begin{tabular}{|c|c|c|c|c|}
\hline Aditivo & SIN & Año Adoptada & Dosis máxima & Notas \\
\hline ACEITE DE RICINO & 1503 & 2007 & $2100 \mathrm{mg} / \mathrm{kg}$ & \\
\hline ACEITE MINERAL DE ALTA VISCOSIDAD & $905 d$ & 2004 & $20000 \mathrm{mg} / \mathrm{kg}$ & \\
\hline ACESULFAME DE POTASIO & 950 & 2019 & $5000 \mathrm{mg} / \mathrm{kg}$ & $478 \& 188$ \\
\hline ALGINATO DE PROPILENGLICOL & 405 & 2016 & $5000 \mathrm{mg} / \mathrm{kg}$ & \\
\hline ALITAME & 956 & 2007 & $300 \mathrm{mg} / \mathrm{kg}$ & 161 \\
\hline AMARANTO & 123 & 2019 & $100 \mathrm{mg} / \mathrm{kg}$ & \\
\hline AMARILLO DE QUINOLEÍNA & 104 & 2019 & $30 \mathrm{mg} / \mathrm{kg}$ & 445 \\
\hline AMARILLO OCASO FCF & 110 & 2008 & $300 \mathrm{mg} / \mathrm{kg}$ & \\
\hline ASPARTAMO & 951 & 2019 & $10000 \mathrm{mg} / \mathrm{kg}$ & $478 \& 191$ \\
\hline AZORRUBINA (CARMOISINA) & 122 & 2019 & $100 \mathrm{mg} / \mathrm{kg}$ & \\
\hline AZUL BRILLANTE FCF & 133 & 2005 & $300 \mathrm{mg} / \mathrm{kg}$ & \\
\hline BENZOATOS & $210-213$ & 2005 & $1500 \mathrm{mg} / \mathrm{kg}$ & 13 \\
\hline BUTILHIDROXIANISOL & 320 & 2006 & $400 \mathrm{mg} / \mathrm{kg}$ & 130 \\
\hline BUTILHIDROXITOLUENO & 321 & 2006 & $400 \mathrm{mg} / \mathrm{kg}$ & 130 \\
\hline CARAMELO II - CARAMELO AL SULFITO & $150 b$ & 2019 & $20000 \mathrm{mg} / \mathrm{kg}$ & \\
\hline $\begin{array}{l}\text { CARAMELO III - CARAMELO AL } \\
\text { AMONÍACO }\end{array}$ & $150 c$ & 1999 & $20000 \mathrm{mg} / \mathrm{kg}$ & \\
\hline $\begin{array}{l}\text { CARAMELO IV - CARAMELO AL SULFITO } \\
\text { AMÓNICO }\end{array}$ & $150 d$ & 1999 & $20000 \mathrm{mg} / \mathrm{kg}$ & \\
\hline CARMINES & 120 & 2008 & $500 \mathrm{mg} / \mathrm{kg}$ & 178 \\
\hline CAROTENOIDES & $160 a(i), a(i i i), e, f$ & 2009 & $100 \mathrm{mg} / \mathrm{kg}$ & \\
\hline CAROTENOS, BETA-, VEGETALES & $160 a(i i)$ & 2005 & $500 \mathrm{mg} / \mathrm{kg}$ & \\
\hline CERA CANDELILLA & 902 & 2003 & BPF & \\
\hline CERA CARNAUBA & 903 & 2003 & $1200 \mathrm{mg} / \mathrm{kg}$ & 3 \\
\hline CERA DE ABEJAS & 901 & 2003 & BPF & \\
\hline CERA MICROCRISTALINA & $905 c(i)$ & 2001 & $20000 \mathrm{mg} / \mathrm{kg}$ & 3 \\
\hline CICLAMATOS & 952(i), (ii), (iv) & 2019 & $3000 \mathrm{mg} / \mathrm{kg}$ & $17 \& 477$ \\
\hline CICLODEXTRINA, BETA- & 459 & 2001 & $20000 \mathrm{mg} / \mathrm{kg}$ & \\
\hline CITRATO DE ESTEARILO & 484 & 1999 & $15000 \mathrm{mg} / \mathrm{kg}$ & \\
\hline $\begin{array}{l}\text { CLOROFILAS Y CLOROFILINAS, } \\
\text { COMPLEJOS CUPRICOS }\end{array}$ & 141 (i),(ii) & 2009 & $700 \mathrm{mg} / \mathrm{kg}$ & \\
\hline
\end{tabular}




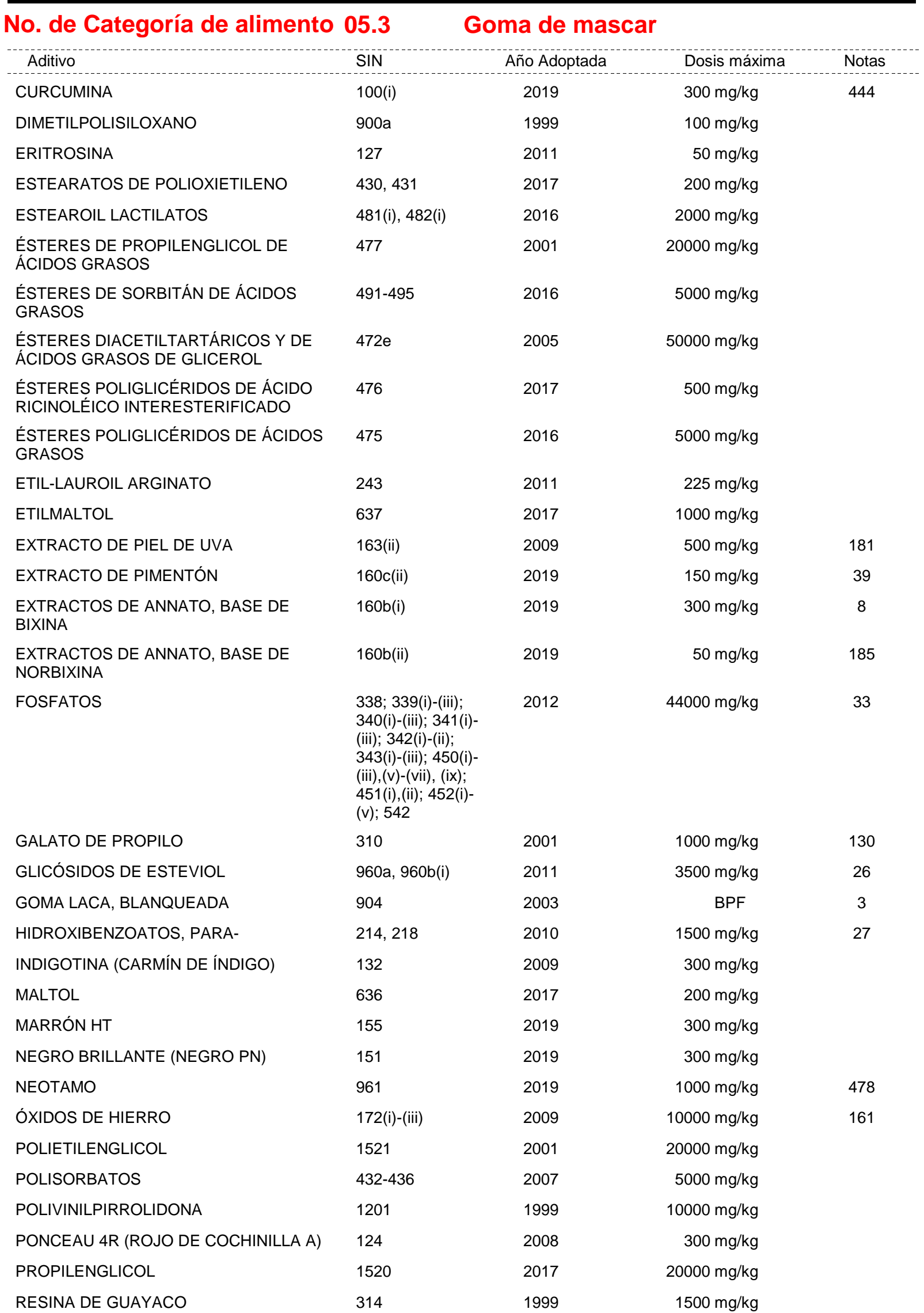




\begin{tabular}{|c|c|c|c|c|}
\hline \multicolumn{2}{|c|}{ No. de Categoría de alimento 05.3} & \multicolumn{2}{|c|}{ Goma de mascar } & \multirow[b]{2}{*}{ Notas } \\
\hline Aditivo & SIN & Año Adoptada & Dosis máxima & \\
\hline RIBOFLAVINAS & 101(i),(ii), (iii) & 2005 & $1000 \mathrm{mg} / \mathrm{kg}$ & \\
\hline ROJO ALLURA AC & 129 & 2009 & $300 \mathrm{mg} / \mathrm{kg}$ & \\
\hline SACARINAS & 954(i)-(iv) & 2019 & $2500 \mathrm{mg} / \mathrm{kg}$ & 477 \\
\hline SILICATO DE SODIO Y ALUMINIO & 554 & 2013 & $100 \mathrm{mg} / \mathrm{kg}$ & $6 \& 174$ \\
\hline SORBATOS & $200,202,203$ & 2009 & $1500 \mathrm{mg} / \mathrm{kg}$ & 42 \\
\hline $\begin{array}{l}\text { SUCRALOSA } \\
\text { (TRICLOROGALACTOSACAROSA) }\end{array}$ & 955 & 2019 & $5000 \mathrm{mg} / \mathrm{kg}$ & 478 \\
\hline SUCROÉSTERES DE ÁCIDOS GRASOS & 473 & 2016 & $12000 \mathrm{mg} / \mathrm{kg}$ & 348 \\
\hline SUCROGLICÉRIDOS & 474 & 2016 & $12000 \mathrm{mg} / \mathrm{kg}$ & 348 \\
\hline $\begin{array}{l}\text { SUCROSE OLIGOESTERS, TYPE I AND } \\
\text { TYPE II }\end{array}$ & $473 a$ & 2016 & $12000 \mathrm{mg} / \mathrm{kg}$ & 348 \\
\hline TARTRATOS & 334, 335(ii), 337 & 2016 & $30000 \mathrm{mg} / \mathrm{kg}$ & 45 \\
\hline TARTRAZINA & 102 & 2019 & $300 \mathrm{mg} / \mathrm{kg}$ & \\
\hline TERBUTILHIDROQUINONA & 319 & 2006 & $400 \mathrm{mg} / \mathrm{kg}$ & 130 \\
\hline TOCOFEROLES & $307 a, b, c$ & 2016 & $1500 \mathrm{mg} / \mathrm{kg}$ & \\
\hline VERDE SÓLIDO FCF & 143 & 1999 & 300 mg/kg & \\
\hline
\end{tabular}

No. de Categoría de alimento 05.4

Decoraciones (p. ej. para productos de pastelería fina), revestimientos (que no sean de fruta) y salsas dulces

\begin{tabular}{|c|c|c|c|c|}
\hline Aditivo & $\sin$ & Año Adoptada & Dosis máxima & Notas \\
\hline ACEITE MINERAL DE ALTA VISCOSIDAD & $905 d$ & 2004 & $2000 \mathrm{mg} / \mathrm{kg}$ & 3 \\
\hline ACESULFAME DE POTASIO & 950 & 2019 & $500 \mathrm{mg} / \mathrm{kg}$ & $478 \& 188$ \\
\hline ALGINATO DE PROPILENGLICOL & 405 & 2016 & $5000 \mathrm{mg} / \mathrm{kg}$ & \\
\hline ALITAME & 956 & 2007 & $300 \mathrm{mg} / \mathrm{kg}$ & 161 \\
\hline AMARANTO & 123 & 2019 & $100 \mathrm{mg} / \mathrm{kg}$ & \\
\hline AMARILLO DE QUINOLEÍNA & 104 & 2019 & $50 \mathrm{mg} / \mathrm{kg}$ & 445 \\
\hline AMARILLO OCASO FCF & 110 & 2008 & $300 \mathrm{mg} / \mathrm{kg}$ & \\
\hline ASPARTAMO & 951 & 2019 & $1000 \mathrm{mg} / \mathrm{kg}$ & $478 \& 191$ \\
\hline AZORRUBINA (CARMOISINA) & 122 & 2019 & $300 \mathrm{mg} / \mathrm{kg}$ & 447 \\
\hline AZUL BRILLANTE FCF & 133 & 2005 & $500 \mathrm{mg} / \mathrm{kg}$ & \\
\hline BENZOATOS & $210-213$ & 2003 & $1500 \mathrm{mg} / \mathrm{kg}$ & 13 \\
\hline BUTILHIDROXIANISOL & 320 & 2007 & $200 \mathrm{mg} / \mathrm{kg}$ & $15 \& 130$ \\
\hline BUTILHIDROXITOLUENO & 321 & 2007 & $200 \mathrm{mg} / \mathrm{kg}$ & $15 \& 130$ \\
\hline CARAMELO II - CARAMELO AL SULFITO & $150 \mathrm{~b}$ & 2019 & $50000 \mathrm{mg} / \mathrm{kg}$ & \\
\hline $\begin{array}{l}\text { CARAMELO III - CARAMELO AL } \\
\text { AMONÍACO }\end{array}$ & $150 \mathrm{c}$ & 2012 & $50000 \mathrm{mg} / \mathrm{kg}$ & \\
\hline $\begin{array}{l}\text { CARAMELO IV - CARAMELO AL SULFITO } \\
\text { AMÓNICO }\end{array}$ & $150 d$ & 2012 & $50000 \mathrm{mg} / \mathrm{kg}$ & \\
\hline CARMINES & 120 & 2005 & $500 \mathrm{mg} / \mathrm{kg}$ & 178 \\
\hline CAROTENOIDES & $160 a(i), a(i i i), e, f$ & 2009 & $100 \mathrm{mg} / \mathrm{kg}$ & \\
\hline CAROTENOS, BETA-, VEGETALES & $160 a(i i)$ & 2005 & $20000 \mathrm{mg} / \mathrm{kg}$ & \\
\hline CERA CANDELILLA & 902 & 2003 & BPF & \\
\hline
\end{tabular}


No. de Categoría de alimento 05.4

Decoraciones (p. ej. para productos de pastelería fina), revestimientos (que no sean de fruta) y salsas dulces

\begin{tabular}{|c|c|c|c|c|}
\hline Aditivo & SIN & Año Adoptada & Dosis máxima & Notas \\
\hline CERA CARNAUBA & 903 & 2001 & $4000 \mathrm{mg} / \mathrm{kg}$ & \\
\hline CERA DE ABEJAS & 901 & 2003 & BPF & \\
\hline CICLAMATOS & 952(i), (ii), (iv) & 2019 & $500 \mathrm{mg} / \mathrm{kg}$ & $17 \& 477$ \\
\hline $\begin{array}{l}\text { CLOROFILAS Y CLOROFILINAS, } \\
\text { COMPLEJOS CUPRICOS }\end{array}$ & 141 (i),(ii) & 2009 & $100 \mathrm{mg} / \mathrm{kg}$ & \\
\hline CURCUMINA & 100 (i) & 2019 & $500 \mathrm{mg} / \mathrm{kg}$ & \\
\hline ERITROSINA & 127 & 2011 & $100 \mathrm{mg} / \mathrm{kg}$ & \\
\hline ESTEAROIL LACTILATOS & 481(i), 482(i) & 2016 & $2000 \mathrm{mg} / \mathrm{kg}$ & \\
\hline $\begin{array}{l}\text { ÉSTERES DE PROPILENGLICOL DE } \\
\text { ÁCIDOS GRASOS }\end{array}$ & 477 & 2001 & $40000 \mathrm{mg} / \mathrm{kg}$ & \\
\hline $\begin{array}{l}\text { ÉSTERES DE SORBITÁN DE ÁCIDOS } \\
\text { GRASOS }\end{array}$ & $491-495$ & 2016 & $10000 \mathrm{mg} / \mathrm{kg}$ & \\
\hline $\begin{array}{l}\text { ÉSTERES DIACETILTARTÁRICOS Y DE } \\
\text { ÁCIDOS GRASOS DE GLICEROL }\end{array}$ & $472 \mathrm{e}$ & 2005 & $10000 \mathrm{mg} / \mathrm{kg}$ & \\
\hline $\begin{array}{l}\text { ÉSTERES POLIGLICÉRIDOS DE ÁCIDO } \\
\text { RICINOLÉICO INTERESTERIFICADO }\end{array}$ & 476 & 2016 & $5000 \mathrm{mg} / \mathrm{kg}$ & \\
\hline $\begin{array}{l}\text { ÉSTERES POLIGLICÉRIDOS DE ÁCIDOS } \\
\text { GRASOS }\end{array}$ & 475 & 2016 & $2000 \mathrm{mg} / \mathrm{kg}$ & 368 \\
\hline EXTRACTO DE PIEL DE UVA & 163(ii) & 2009 & $500 \mathrm{mg} / \mathrm{kg}$ & 181 \\
\hline EXTRACTO DE PIMENTÓN & 160c(ii) & 2019 & $100 \mathrm{mg} / \mathrm{kg}$ & 39 \\
\hline $\begin{array}{l}\text { EXTRACTOS DE ANNATO, BASE DE } \\
\text { BIXINA }\end{array}$ & $160 \mathrm{~b}(\mathrm{i})$ & 2019 & $80 \mathrm{mg} / \mathrm{kg}$ & 8 \\
\hline $\begin{array}{l}\text { EXTRACTOS DE ANNATO, BASE DE } \\
\text { NORBIXINA }\end{array}$ & $160 \mathrm{~b}(\mathrm{ii})$ & 2019 & $25 \mathrm{mg} / \mathrm{kg}$ & $185 \& 446$ \\
\hline FOSFATOS & $\begin{array}{l}\text { 338; 339(i)-(iii); } \\
340 \text { (i)-(iii); } 341 \text { (i)- } \\
\text { (iii); 342(i)-(ii); } \\
343 \text { (i)-(iii); 450(i)- } \\
\text { (iii),(v)-(vii), (ix); } \\
451 \text { (i),(ii); 452(i)- } \\
\text { (v); } 542\end{array}$ & 2012 & $1500 \mathrm{mg} / \mathrm{kg}$ & 33 \\
\hline GALATO DE PROPILO & 310 & 2001 & $200 \mathrm{mg} / \mathrm{kg}$ & $15 \& 130$ \\
\hline GOMA LACA, BLANQUEADA & 904 & 2003 & BPF & \\
\hline HIDROXIBENZOATOS, PARA- & 214,218 & 2010 & $300 \mathrm{mg} / \mathrm{kg}$ & 27 \\
\hline INDIGOTINA (CARMÍN DE ÍNDIGO) & 132 & 2009 & $300 \mathrm{mg} / \mathrm{kg}$ & \\
\hline MARRÓN HT & 155 & 2019 & $50 \mathrm{mg} / \mathrm{kg}$ & \\
\hline NEGRO BRILLANTE (NEGRO PN) & 151 & 2019 & $500 \mathrm{mg} / \mathrm{kg}$ & \\
\hline NEOTAMO & 961 & 2019 & 100 mg/kg & 478 \\
\hline ÓXIDOS DE HIERRO & 172(i)-(iii) & 2005 & $100 \mathrm{mg} / \mathrm{kg}$ & \\
\hline POLISORBATOS & $432-436$ & 2007 & $3000 \mathrm{mg} / \mathrm{kg}$ & \\
\hline PONCEAU 4R (ROJO DE COCHINILLA A) & 124 & 2008 & $50 \mathrm{mg} / \mathrm{kg}$ & \\
\hline RIBOFLAVINAS & 101(i),(ii), (iii) & 2005 & $1000 \mathrm{mg} / \mathrm{kg}$ & \\
\hline ROJO ALLURA AC & 129 & 2009 & 300 mg/kg & \\
\hline SACARINAS & 954(i)-(iv) & 2019 & 500 mg/kg & 477 \\
\hline SORBATOS & $200,202,203$ & 2012 & $1000 \mathrm{mg} / \mathrm{kg}$ & 42 \\
\hline
\end{tabular}




\begin{tabular}{|c|c|c|c|c|}
\hline \multicolumn{2}{|c|}{ No. de Categoría de alimento 05.4} & \multicolumn{3}{|c|}{$\begin{array}{l}\text { Decoraciones (p. ej. para productos de } \\
\text { pastelería fina), revestimientos (que no } \\
\text { sean de fruta) y salsas dulces }\end{array}$} \\
\hline Aditivo & SIN & Año Adoptada & Dosis máxima & Notas \\
\hline $\begin{array}{l}\text { SUCRALOSA } \\
\text { (TRICLOROGALACTOSACAROSA) }\end{array}$ & 955 & 2019 & $1000 \mathrm{mg} / \mathrm{kg}$ & 478 \\
\hline SUCROÉSTERES DE ÁCIDOS GRASOS & 473 & 2016 & $5000 \mathrm{mg} / \mathrm{kg}$ & 348 \\
\hline SUCROGLICÉRIDOS & 474 & 2016 & $5000 \mathrm{mg} / \mathrm{kg}$ & 348 \\
\hline $\begin{array}{l}\text { SUCROSE OLIGOESTERS, TYPE I AND } \\
\text { TYPE II }\end{array}$ & $473 a$ & 2017 & $5000 \mathrm{mg} / \mathrm{kg}$ & $348 \& 387$ \\
\hline TARTRATOS & 334, 335(ii), 337 & 2016 & $8000 \mathrm{mg} / \mathrm{kg}$ & 45 \\
\hline TARTRAZINA & 102 & 2019 & $500 \mathrm{mg} / \mathrm{kg}$ & \\
\hline TERBUTILHIDROQUINONA & 319 & 2006 & $200 \mathrm{mg} / \mathrm{kg}$ & $15 \& 130$ \\
\hline TOCOFEROLES & $307 a, b, c$ & 2016 & $500 \mathrm{mg} / \mathrm{kg}$ & 15 \\
\hline VERDE SÓLIDO FCF & 143 & 2009 & $100 \mathrm{mg} / \mathrm{kg}$ & \\
\hline
\end{tabular}

\begin{tabular}{llllc}
\hline No. de Categoría de alimento & 06.1 & $\begin{array}{l}\text { Granos enteros, triturados o en copos, } \\
\text { incluido el arroz }\end{array}$ & \\
\hline Aditivo & SIN & Año Adoptada & Dosis máxima & Notas \\
\hline ACEITE MINERAL DE ALTA VISCOSIDAD & $905 \mathrm{~d}$ & 2019 & $800 \mathrm{mg} / \mathrm{kg}$ & 98 \& XS202 \\
GALATO DE PROPILO & 310 & 2019 & $100 \mathrm{mg} / \mathrm{kg}$ & 15 \& XS202 \\
\hline
\end{tabular}

\begin{tabular}{|c|c|c|c|c|}
\hline \multicolumn{2}{|c|}{ No. de Categoría de alimento 06.2} & \multicolumn{3}{|c|}{$\begin{array}{l}\text { Harinas y almidones (incluida la soja en } \\
\text { polvo) }\end{array}$} \\
\hline Aditivo & SIN & Año Adoptada & Dosis máxima & Notas \\
\hline $\begin{array}{l}\text { ALFA-AMILASA DE ASPERGILLUS } \\
\text { ORYZAE VAR. }\end{array}$ & $1100(i)$ & 1999 & BPF & \\
\hline ALFA-AMILASA DE BACILLUS SUBTILIS & 1100(iii) & 2019 & BPF & XS152 \\
\hline $\begin{array}{l}\text { CARBOHIDRASA DE BACILLUS } \\
\text { LICHENIFORMIS }\end{array}$ & 1100 (vi) & 2019 & BPF & XS152 \\
\hline $\begin{array}{l}\text { ÉSTERES DIACETILTARTÁRICOS Y DE } \\
\text { ÁCIDOS GRASOS DE GLICEROL }\end{array}$ & $472 \mathrm{e}$ & 2019 & $3000 \mathrm{mg} / \mathrm{kg}$ & $186 \&$ XS152 \\
\hline
\end{tabular}

\begin{tabular}{|c|c|c|c|c|}
\hline \multicolumn{2}{|c|}{ No. de Categoría de alimento 06.2.1 } & arinas & & \multirow[b]{2}{*}{ Notas } \\
\hline Aditivo & SIN & Año Adoptada & Dosis máxima & \\
\hline ÁCIDO ASCÓRBICO, L- & 300 & 2019 & $300 \mathrm{mg} / \mathrm{kg}$ & 472 \\
\hline ASCORBATO DE SODIO & 301 & 2014 & $300 \mathrm{mg} / \mathrm{kg}$ & \\
\hline AZODICARBONAMIDA & $927 a$ & 2019 & $45 \mathrm{mg} / \mathrm{kg}$ & 467 \\
\hline CITRATO TRISÓDICO & 331 (iii) & 2019 & BPF & $25 \& X S 152$ \\
\hline CLORO & 925 & 2019 & $2500 \mathrm{mg} / \mathrm{kg}$ & 87,471 \\
\hline ESTEAROIL LACTILATOS & 481(i), 482(i) & 2019 & $5000 \mathrm{mg} / \mathrm{kg}$ & $186 \& X S 152$ \\
\hline FOSFATOS & $\begin{array}{l}338 ; 339(\mathrm{i})-(\mathrm{iii}) ; \\
340(\mathrm{i})-(\mathrm{iii}) ; 341(\mathrm{i})- \\
\text { (iii); } 342(\mathrm{i}) \text {-(ii); } \\
343(\mathrm{i})-(\mathrm{iii}) ; 450(\mathrm{i})- \\
\text { (iii),(v)-(vii), (ix); } \\
451(\mathrm{i}),(\mathrm{ii}) ; 452(\mathrm{i})- \\
\text { (v); } 542\end{array}$ & 2019 & $2500 \mathrm{mg} / \mathrm{kg}$ & $33,225,469$ \\
\hline
\end{tabular}




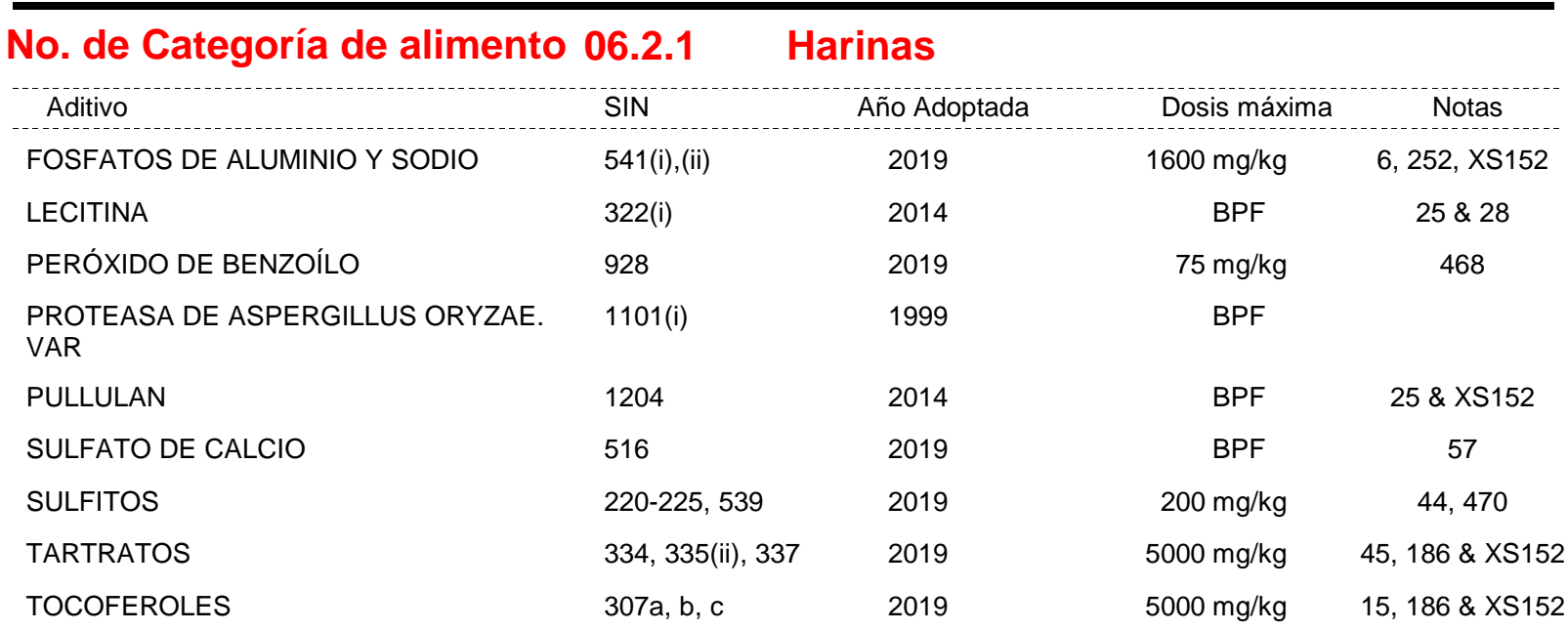

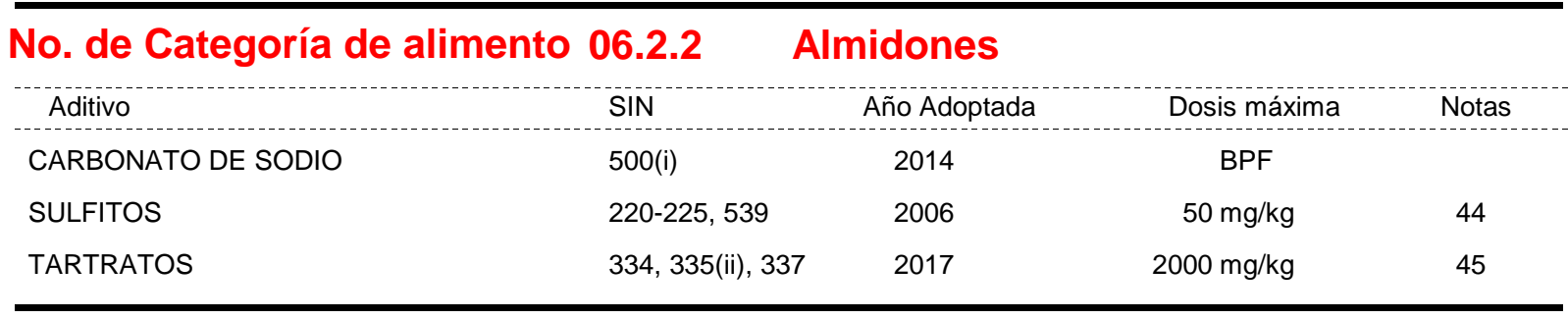

No. de Categoría de alimento 06.3

Cereales para el desayuno, incluidos los copos de avena

\begin{tabular}{|c|c|c|c|c|}
\hline Aditivo & SIN & Año Adoptada & Dosis máxima & Notas \\
\hline ACESULFAME DE POTASIO & 950 & 2019 & $1200 \mathrm{mg} / \mathrm{kg}$ & $478 \& 188$ \\
\hline AMARILLO OCASO FCF & 110 & 2008 & $300 \mathrm{mg} / \mathrm{kg}$ & 161 \\
\hline ASPARTAMO & 951 & 2019 & $1000 \mathrm{mg} / \mathrm{kg}$ & $478 \& 191$ \\
\hline AZUL BRILLANTE FCF & 133 & 2005 & $200 \mathrm{mg} / \mathrm{kg}$ & \\
\hline BUTILHIDROXIANISOL & 320 & 2005 & $200 \mathrm{mg} / \mathrm{kg}$ & $15 \& 196$ \\
\hline BUTILHIDROXITOLUENO & 321 & 2006 & $100 \mathrm{mg} / \mathrm{kg}$ & $15 \& 196$ \\
\hline $\begin{array}{l}\text { CARAMELO III - CARAMELO AL } \\
\text { AMONÍACO }\end{array}$ & $150 c$ & 2009 & $50000 \mathrm{mg} / \mathrm{kg}$ & 189 \\
\hline $\begin{array}{l}\text { CARAMELO IV - CARAMELO AL SULFITO } \\
\text { AMÓNICO }\end{array}$ & $150 d$ & 1999 & $2500 \mathrm{mg} / \mathrm{kg}$ & \\
\hline CARMINES & 120 & 2005 & $200 \mathrm{mg} / \mathrm{kg}$ & 178 \\
\hline CAROTENOIDES & $160 a(i), a(i i i), e, f$ & 2009 & $200 \mathrm{mg} / \mathrm{kg}$ & \\
\hline CAROTENOS, BETA-, VEGETALES & $160 a(i i)$ & 2005 & $400 \mathrm{mg} / \mathrm{kg}$ & \\
\hline ESTEAROIL LACTILATOS & $481(\mathrm{i}), 482(\mathrm{i})$ & 2016 & $5000 \mathrm{mg} / \mathrm{kg}$ & \\
\hline ÉSTERES DE ASCORBILO & 304,305 & 2001 & $200 \mathrm{mg} / \mathrm{kg}$ & 10 \\
\hline $\begin{array}{l}\text { ÉSTERES POLIGLICÉRIDOS DE ÁCIDOS } \\
\text { GRASOS }\end{array}$ & 475 & 2016 & $10000 \mathrm{mg} / \mathrm{kg}$ & 369 \\
\hline EXTRACTO DE PIEL DE UVA & 163(ii) & 2010 & $200 \mathrm{mg} / \mathrm{kg}$ & \\
\hline FOSFATOS & $\begin{array}{l}\text { 338; 339(i)-(iii); } \\
\text { 340(i)-(iii); 341(i)- } \\
\text { (iii); 342(i)-(ii); } \\
\text { 343(i)-(iii); 450(i)- } \\
\text { (iii),(v)-(vii), (ix); } \\
\text { 451(i),(ii); 452(i)- } \\
\text { (v); } 542\end{array}$ & 2009 & $2200 \mathrm{mg} / \mathrm{kg}$ & 33 \\
\hline
\end{tabular}


No. de Categoría de alimento 06.3

Cereales para el desayuno, incluidos los copos de avena

\begin{tabular}{lllcc} 
Aditivo & SIN & Año Adoptada & Dosis máxima & Notas \\
\hline GALATO DE PROPILO & 310 & 2001 & $200 \mathrm{mg} / \mathrm{kg}$ & 15 \& 196 \\
GLICÓSIDOS DE ESTEVIOL & $960 \mathrm{a}, 960 \mathrm{~b}$ (i) & 2011 & $350 \mathrm{mg} / \mathrm{kg}$ & 26 \\
NEOTAMO & 961 & 2019 & $160 \mathrm{mg} / \mathrm{kg}$ & 478 \\
ÓXIDOS DE HIERRO & 172 (i)-(iii) & 2005 & $75 \mathrm{mg} / \mathrm{kg}$ & \\
RIBOFLAVINAS & 101 (i),(ii), (iii) & 2005 & $300 \mathrm{mg} / \mathrm{kg}$ & \\
ROJO ALLURA AC & 129 & 2009 & $300 \mathrm{mg} / \mathrm{kg}$ & \\
SACARINAS & 954 (i)-(iv) & 2019 & $100 \mathrm{mg} / \mathrm{kg}$ & 477 \\
SUCRALOSA & 955 & 2019 & $1000 \mathrm{mg} / \mathrm{kg}$ & 478 \\
(TRICLOROGALACTOSACAROSA) & & 2016 & $10000 \mathrm{mg} / \mathrm{kg}$ & \\
SUCROÉSTERES DE ÁCIDOS GRASOS & 473 & 2016 & $200 \mathrm{mg} / \mathrm{kg}$ & \\
TOCOFEROLES & $307 \mathrm{a}, \mathrm{b}, \mathrm{c}$ & & \\
\hline
\end{tabular}

No. de Categoría de alimento 06.4.1

Pastas y fideos frescos y productos análogos

\begin{tabular}{|c|c|c|c|c|}
\hline Aditivo & SIN & Año Adoptada & Dosis máxima & Notas \\
\hline ACETATO DE SODIO & 262(i) & 2013 & $6000 \mathrm{mg} / \mathrm{kg}$ & \\
\hline ÁCIDO ALGÍNICO & 400 & 2014 & BPF & 211 \\
\hline ÁCIDO ASCÓRBICO, L- & 300 & 2013 & $200 \mathrm{mg} / \mathrm{kg}$ & \\
\hline ÁCIDO CÍTRICO & 330 & 2013 & BPF & \\
\hline ÁCIDO FUMÁRICO & 297 & 2013 & $700 \mathrm{mg} / \mathrm{kg}$ & \\
\hline ÁCIDO LÁCTICO, L-, D- y DL- & 270 & 2013 & BPF & \\
\hline AGAR & 406 & 2014 & BPF & 211 \\
\hline ALGA EUCHEUMA ELABORADA & $407 a$ & 2014 & BPF & 211 \\
\hline ALGINATO DE PROPILENGLICOL & 405 & 2016 & $10000 \mathrm{mg} / \mathrm{kg}$ & 370 \\
\hline ALGINATO DE SODIO & 401 & 2014 & BPF & 211 \\
\hline ASCORBATO DE SODIO & 301 & 2014 & BPF & \\
\hline CARBONATO ÁCIDO DE SODIO & 500(ii) & 2013 & BPF & \\
\hline CARBONATO DE CALCIO & 170(i) & 2013 & BPF & \\
\hline CARBONATO DE POTASIO & 501(i) & 2013 & $11000 \mathrm{mg} / \mathrm{kg}$ & \\
\hline CARBONATO DE SODIO & $500(\mathrm{i})$ & 2013 & $10000 \mathrm{mg} / \mathrm{kg}$ & \\
\hline $\begin{array}{l}\text { CARBOXIMETILCELULOSA SÓDICA } \\
\text { (GOMA DE CELULOSA) }\end{array}$ & 466 & 2014 & BPF & 211 \\
\hline CARRAGENINA & 407 & 2014 & BPF & 211 \\
\hline $\begin{array}{l}\text { CELULOSA MICROCRISTALINA (GEL DE } \\
\text { CELULOSA) }\end{array}$ & 460(i) & 2014 & BPF & 211 \\
\hline CURDLAN & 424 & 2014 & BPF & 211 \\
\hline DIÓXIDO DE CARBONO & 290 & 2014 & BPF & $59 \& 211$ \\
\hline $\begin{array}{l}\text { ÉSTERES ACÉTICOS Y DE ÁCIDOS } \\
\text { GRASOS DE GLICEROL }\end{array}$ & $472 a$ & 2015 & BPF & 211 \\
\hline $\begin{array}{l}\text { ÉSTERES CÍTRICOS Y DE ÁCIDOS } \\
\text { GRASOS DE GLICEROL }\end{array}$ & $472 c$ & 2015 & BPF & 211 \\
\hline $\begin{array}{l}\text { ÉSTERES LÁCTICOS Y DE ÁCIDOS } \\
\text { GRASOS DE GLICEROL }\end{array}$ & $472 b$ & 2015 & BPF & 211 \\
\hline
\end{tabular}


Pastas y fideos frescos y productos análogos

\begin{tabular}{|c|c|c|c|c|}
\hline Aditivo & SIN & Año Adoptada & Dosis máxima & Notas \\
\hline FOSFATO DE DIALMIDÓN & 1412 & 2014 & BPF & 211 \\
\hline FOSFATO DE DIALMIDÓN FOSFATADO & 1413 & 2014 & BPF & 211 \\
\hline FOSFATOS & $\begin{array}{l}\text { 338; 339(i)-(iii); } \\
\text { 340(i)-(iii); 341(i)- } \\
\text { (iii); 342(i)-(ii); } \\
\text { 343(i)-(iii); 450(i)- } \\
\text { (iii),(v)-(vii), (ix); } \\
\text { 451(i),(ii); 452(i)- } \\
\text { (v); } 542\end{array}$ & 2012 & $2500 \mathrm{mg} / \mathrm{kg}$ & $33 \& 211$ \\
\hline GLICEROL & 422 & 2014 & BPF & 211 \\
\hline GLUCONO-DELTA-LACTONA & 575 & 2013 & BPF & \\
\hline GOMA ARÁBIGA (GOMA DE ACACIA) & 414 & 2014 & BPF & 211 \\
\hline GOMA DE SEMILLAS DE ALGARROBO & 410 & 2014 & BPF & 211 \\
\hline GOMA GELLAN & 418 & 2014 & BPF & 211 \\
\hline GOMA GUAR & 412 & 2014 & BPF & 211 \\
\hline GOMA KARAYA & 416 & 2014 & BPF & 211 \\
\hline GOMA TRAGACANTO & 413 & 2014 & BPF & 211 \\
\hline GOMA XANTANA & 415 & 2014 & BPF & 211 \\
\hline HARINA KONJAC & 425 & 2014 & BPF & 211 \\
\hline LACTATO DE SODIO & 325 & 2013 & BPF & \\
\hline LECITINA & $322(i)$ & 2014 & BPF & \\
\hline MALATO DE SODIO, DL- & 350(ii) & 2013 & BPF & \\
\hline $\begin{array}{l}\text { MONOGLICÉRIDOS Y DIGLICÉRIDOS DE } \\
\text { ÁCIDOS GRASOS }\end{array}$ & 471 & 2014 & BPF & \\
\hline PECTINAS & 440 & 2014 & BPF & 211 \\
\hline PROPILENGLICOL & 1520 & 2016 & $20000 \mathrm{mg} / \mathrm{kg}$ & 370 \\
\hline PULLULAN & 1204 & 2014 & BPF & 211 \\
\hline SUCROÉSTERES DE ÁCIDOS GRASOS & 473 & 2016 & $2000 \mathrm{mg} / \mathrm{kg}$ & $348 \& 370$ \\
\hline SUCROGLICÉRIDOS & 474 & 2016 & $2000 \mathrm{mg} / \mathrm{kg}$ & $348 \& 370$ \\
\hline $\begin{array}{l}\text { SUCROSE OLIGOESTERS, TYPE I AND } \\
\text { TYPE II }\end{array}$ & $473 a$ & 2016 & $2000 \mathrm{mg} / \mathrm{kg}$ & $348 \& 370$ \\
\hline SULFATO DE ALUMINIO Y AMONIO & 523 & 2013 & $300 \mathrm{mg} / \mathrm{kg}$ & $6 \& 247$ \\
\hline TARTRATOS & 334, 335(ii), 337 & 2016 & $5000 \mathrm{mg} / \mathrm{kg}$ & $45 \& 128$ \\
\hline
\end{tabular}

\section{No. de Categoría de alimento 06.4.2 Pastas y fideos deshidratados y} productos análogos

\begin{tabular}{lllll} 
Aditivo & SIN & Año Adoptada & Dosis máxima & Notas \\
\hline ACETATO DE SODIO & $262($ i) & 2013 & BPF & 256 \\
ÁCIDO ALGÍNICO & 400 & 2014 & BPF & 256 \\
ÁCIDO ASCÓRBICO, L- & 300 & 2013 & BPF & 256 \\
ÁCIDO CÍTRICO & 330 & 2013 & BPF & 256 \\
ÁCIDO FUMÁRICO & 297 & 2013 & BPF & 256 \\
ÁCIDO LÁCTICO, L-, D- y DL- & 270 & 2013 & BPF & 256
\end{tabular}




\section{No. de Categoría de alimento 06.4.2 Pastas y fideos deshidratados y} productos análogos

\begin{tabular}{|c|c|c|c|c|}
\hline Aditivo & SIN & Año Adoptada & Dosis máxima & Notas \\
\hline ÁCIDO MÁLICO, DL- & 296 & 2013 & BPF & 256 \\
\hline ADIPATO DE DIALMIDÓN ACETILADO & 1422 & 2015 & BPF & 256 \\
\hline AGAR & 406 & 2014 & BPF & 256 \\
\hline ALGA EUCHEUMA ELABORADA & $407 a$ & 2014 & BPF & 256 \\
\hline ALGINATO DE AMONIO & 403 & 2014 & BPF & 256 \\
\hline ALGINATO DE CALCIO & 404 & 2014 & BPF & 256 \\
\hline ALGINATO DE POTASIO & 402 & 2014 & BPF & 256 \\
\hline ALGINATO DE PROPILENGLICOL & 405 & 2016 & $5000 \mathrm{mg} / \mathrm{kg}$ & 211 \\
\hline ALGINATO DE SODIO & 401 & 2014 & BPF & 256 \\
\hline ASCORBATO DE CALCIO & 302 & 2014 & $200 \mathrm{mg} / \mathrm{kg}$ & 256 \\
\hline ASCORBATO DE SODIO & 301 & 2014 & $200 \mathrm{mg} / \mathrm{kg}$ & 256 \\
\hline CANTAXANTINA & $161 \mathrm{~g}$ & 2011 & $15 \mathrm{mg} / \mathrm{kg}$ & 211 \\
\hline $\begin{array}{l}\text { CARAMELO IV - CARAMELO AL SULFITO } \\
\text { AMÓNICO }\end{array}$ & $150 d$ & 2011 & $50000 \mathrm{mg} / \mathrm{kg}$ & 211 \\
\hline CARBONATO ÁCIDO DE SODIO & 500 (ii) & 2013 & BPF & 256 \\
\hline CARBONATO DE CALCIO & $170(\mathrm{i})$ & 2013 & BPF & 256 \\
\hline CARBONATO DE POTASIO & $501(\mathrm{i})$ & 2013 & BPF & 256 \\
\hline CARBONATO DE SODIO & 500 (i) & 2013 & BPF & 256 \\
\hline $\begin{array}{l}\text { CARBOXIMETILCELULOSA SÓDICA } \\
\text { (GOMA DE CELULOSA) }\end{array}$ & 466 & 2014 & BPF & 256 \\
\hline CAROTENOS, BETA-, VEGETALES & $160 a(i i)$ & 2011 & $1000 \mathrm{mg} / \mathrm{kg}$ & 211 \\
\hline CARRAGENINA & 407 & 2014 & BPF & 256 \\
\hline $\begin{array}{l}\text { CELULOSA MICROCRISTALINA (GEL DE } \\
\text { CELULOSA) }\end{array}$ & 460 (i) & 2014 & BPF & 256 \\
\hline CLORURO DE POTASIO & 508 & 2014 & BPF & 256 \\
\hline DEXTRINAS, ALMIDÓN TOSTADO & 1400 & 2015 & BPF & 256 \\
\hline ESTEAROIL LACTILATOS & 481(i), 482(i) & 2016 & $5000 \mathrm{mg} / \mathrm{kg}$ & 211 \\
\hline $\begin{array}{l}\text { ÉSTERES DE SORBITÁN DE ÁCIDOS } \\
\text { GRASOS }\end{array}$ & 491-495 & 2016 & $5000 \mathrm{mg} / \mathrm{kg}$ & $11 \& 211$ \\
\hline $\begin{array}{l}\text { ÉSTERES DIACETILTARTÁRICOS Y DE } \\
\text { ÁCIDOS GRASOS DE GLICEROL }\end{array}$ & $472 e$ & 2008 & $5000 \mathrm{mg} / \mathrm{kg}$ & \\
\hline FOSFATO DE DIALMIDÓN & 1412 & 2014 & BPF & 256 \\
\hline FOSFATO DE DIALMIDÓN ACETILADO & 1414 & 2015 & BPF & 256 \\
\hline FOSFATO DE DIALMIDÓN FOSFATADO & 1413 & 2014 & BPF & 256 \\
\hline FOSFATOS & $\begin{array}{l}\text { 338; 339(i)-(iii); } \\
340(\mathrm{i})-(\mathrm{iii}) ; 341 \text { (i)- } \\
\text { (iii); 342(i)-(ii); } \\
343 \text { (i)-(iii); 450(i)- } \\
\text { (iii),(v)-(vii), (ix); } \\
451 \text { (i),(ii); 452(i)- } \\
\text { (v); } 542\end{array}$ & 2012 & $900 \mathrm{mg} / \mathrm{kg}$ & $33 \& 211$ \\
\hline GLUCONATO DE SODIO & 576 & 2014 & BPF & 256 \\
\hline GLUTAMATO MONOSÓDICO, L- & 621 & 2014 & BPF & 256 \\
\hline GOMA ARÁBIGA (GOMA DE ACACIA) & 414 & 2014 & BPF & 256 \\
\hline
\end{tabular}




\begin{tabular}{|c|c|c|c|c|}
\hline \multicolumn{2}{|c|}{ No. de Categoría de alimento 06.4.2 } & \multicolumn{3}{|c|}{$\begin{array}{l}\text { Pastas y fideos deshidratados y } \\
\text { productos análogos }\end{array}$} \\
\hline Aditivo & SIN & Año Adoptada & Dosis máxima & Notas \\
\hline GOMA DE SEMILLAS DE ALGARROBO & 410 & 2014 & BPF & 256 \\
\hline GOMA GELLAN & 418 & 2014 & BPF & 256 \\
\hline GOMA GUAR & 412 & 2014 & BPF & 256 \\
\hline GOMA KARAYA & 416 & 2014 & BPF & 256 \\
\hline GOMA TARA & 417 & 2014 & BPF & 256 \\
\hline GOMA TRAGACANTO & 413 & 2014 & BPF & 256 \\
\hline GOMA XANTANA & 415 & 2014 & BPF & 256 \\
\hline GUANILATO DISÓDICO, 5'- & 627 & 2014 & BPF & 256 \\
\hline HARINA KONJAC & 425 & 2014 & BPF & 256 \\
\hline INOSINATO DISÓDICO, 5'- & 631 & 2014 & BPF & 256 \\
\hline LACTATO DE SODIO & 325 & 2013 & BPF & 256 \\
\hline LECITINA & 322(i) & 2014 & BPF & 256 \\
\hline MANITOL & 421 & 2014 & BPF & 256 \\
\hline $\begin{array}{l}\text { MONOGLICÉRIDOS Y DIGLICÉRIDOS DE } \\
\text { ÁCIDOS GRASOS }\end{array}$ & 471 & 2014 & BPF & 256 \\
\hline ÓXIDO NITROSO & 942 & 2014 & BPF & 256 \\
\hline PECTINAS & 440 & 2014 & BPF & 256 \\
\hline POLISORBATOS & $432-436$ & 2008 & $5000 \mathrm{mg} / \mathrm{kg}$ & \\
\hline PULLULAN & 1204 & 2014 & BPF & 256 \\
\hline RIBONUCLEÓTIDOS DE CALCIO, 5'- & 634 & 2014 & BPF & 256 \\
\hline RIBONUCLEÓTIDOS DE SODIO, 5'- & 635 & 2014 & BPF & 256 \\
\hline $\begin{array}{l}\text { SAL MIRÍSTICA, PALMÍTICA Y ÁCIDOS } \\
\text { ESTEÁRICOS CON AMONIO, CALCIO, } \\
\text { POTASIO Y SODIO }\end{array}$ & 470 (i) & 2014 & BPF & 256 \\
\hline SUCROÉSTERES DE ÁCIDOS GRASOS & 473 & 2016 & $4000 \mathrm{mg} / \mathrm{kg}$ & $211 \& 348$ \\
\hline SUCROGLICÉRIDOS & 474 & 2016 & $4000 \mathrm{mg} / \mathrm{kg}$ & $211 \& 348$ \\
\hline $\begin{array}{l}\text { SUCROSE OLIGOESTERS, TYPE I AND } \\
\text { TYPE II }\end{array}$ & $473 a$ & 2016 & $4000 \mathrm{mg} / \mathrm{kg}$ & $211 \& 348$ \\
\hline SULFATO DE CALCIO & 516 & 2014 & BPF & 256 \\
\hline TOCOFEROLES & $307 a, b, c$ & 2016 & $500 \mathrm{mg} / \mathrm{kg}$ & 211 \\
\hline
\end{tabular}

No. de Categoría de alimento 06.4.3

Pastas y fideos precocidos y productos análogos

\begin{tabular}{llrcc}
\hline Aditivo & SIN & Año Adoptada & Dosis máxima & Notas \\
ALGINATO DE PROPILENGLICOL & 405 & 2016 & $5000 \mathrm{mg} / \mathrm{kg}$ & $194 \& 371$ \\
AMARANTO & 123 & 2019 & $100 \mathrm{mg} / \mathrm{kg}$ & 194 \\
AMARILLO OCASO FCF & 110 & 2008 & $300 \mathrm{mg} / \mathrm{kg}$ & 153 \\
BENZOATOS & $210-213$ & 2019 & $1000 \mathrm{mg} / \mathrm{kg}$ & $13 \&$ XS249 \\
BUTILHIDROXIANISOL & 320 & 2006 & $200 \mathrm{mg} / \mathrm{kg}$ & $15 \& 130$ \\
BUTILHIDROXITOLUENO & 321 & 2006 & $200 \mathrm{mg} / \mathrm{kg}$ & $15 \& 130$ \\
CANTAXANTINA & $161 \mathrm{~g}$ & 2019 & $15 \mathrm{mg} / \mathrm{kg}$ & $153 \&$ XS 249 \\
CARAMELO II - CARAMELO AL SULFITO & $150 \mathrm{~b}$ & 2019 & $50000 \mathrm{mg} / \mathrm{kg}$ & 194
\end{tabular}


No. de Categoría de alimento 06.4.3 Pastas y fideos precocidos y productos análogos

\begin{tabular}{|c|c|c|c|c|}
\hline Aditivo & $\operatorname{SIN}$ & Año Adoptada & Dosis máxima & Notas \\
\hline $\begin{array}{l}\text { CARAMELO III - CARAMELO AL } \\
\text { AMONÍACO }\end{array}$ & $150 c$ & 2010 & $50000 \mathrm{mg} / \mathrm{kg}$ & $153 \& 173$ \\
\hline $\begin{array}{l}\text { CARAMELO IV - CARAMELO AL SULFITO } \\
\text { AMÓNICO }\end{array}$ & $150 d$ & 2011 & $50000 \mathrm{mg} / \mathrm{kg}$ & 153 \\
\hline CARMINES & 120 & 2008 & $100 \mathrm{mg} / \mathrm{kg}$ & $153 \& 178$ \\
\hline CAROTENOIDES & $160 a(i), a(i i i), e, f$ & 2019 & $1200 \mathrm{mg} / \mathrm{kg}$ & 153,474 \\
\hline CAROTENOS, BETA-, VEGETALES & $160 a(i i)$ & 2010 & $1000 \mathrm{mg} / \mathrm{kg}$ & 153 \\
\hline CICLODEXTRINA, BETA- & 459 & 2012 & $1000 \mathrm{mg} / \mathrm{kg}$ & 153 \\
\hline $\begin{array}{l}\text { CLOROFILAS Y CLOROFILINAS, } \\
\text { COMPLEJOS CUPRICOS }\end{array}$ & 141(i),(ii) & 2009 & $100 \mathrm{mg} / \mathrm{kg}$ & 153 \\
\hline CURCUMINA & $100(\mathrm{i})$ & 2019 & $500 \mathrm{mg} / \mathrm{kg}$ & 194 \\
\hline DIMETILPOLISILOXANO & $900 a$ & 2007 & $50 \mathrm{mg} / \mathrm{kg}$ & 153 \\
\hline ESTEARATOS DE POLIOXIETILENO & 430,431 & 2016 & $5000 \mathrm{mg} / \mathrm{kg}$ & $2 \& 194$ \\
\hline ESTEAROIL LACTILATOS & 481(i), 482(i) & 2016 & $5000 \mathrm{mg} / \mathrm{kg}$ & $194 \& 371$ \\
\hline ÉSTERES DE ASCORBILO & 304,305 & 2012 & $500 \mathrm{mg} / \mathrm{kg}$ & $10 \& 211$ \\
\hline $\begin{array}{l}\text { ÉSTERES DE PROPILENGLICOL DE } \\
\text { ÁCIDOS GRASOS }\end{array}$ & 477 & 2007 & $5000 \mathrm{mg} / \mathrm{kg}$ & $2 \& 153$ \\
\hline $\begin{array}{l}\text { ÉSTERES DE SORBITÁN DE ÁCIDOS } \\
\text { GRASOS }\end{array}$ & $491-495$ & 2019 & $5000 \mathrm{mg} / \mathrm{kg}$ & $2 \& 194$ \\
\hline $\begin{array}{l}\text { ÉSTERES DIACETILTARTÁRICOS Y DE } \\
\text { ÁCIDOS GRASOS DE GLICEROL }\end{array}$ & $472 \mathrm{e}$ & 2005 & $10000 \mathrm{mg} / \mathrm{kg}$ & \\
\hline $\begin{array}{l}\text { ÉSTERES POLIGLICÉRIDOS DE ÁCIDO } \\
\text { RICINOLÉICO INTERESTERIFICADO }\end{array}$ & 476 & 2016 & $500 \mathrm{mg} / \mathrm{kg}$ & 194 \\
\hline $\begin{array}{l}\text { ÉSTERES POLIGLICÉRIDOS DE ÁCIDOS } \\
\text { GRASOS }\end{array}$ & 475 & 2016 & $2000 \mathrm{mg} / \mathrm{kg}$ & 194 \\
\hline FOSFATOS & $\begin{array}{l}\text { 338; 339(i)-(iii); } \\
\text { 340(i)-(iii); 341(i)- } \\
\text { (iii); 342(i)-(ii); } \\
343(\text { i)-(iii); 450(i)- } \\
\text { (iii),(v)-(vii), (ix); } \\
\text { 451(i),(ii); 452(i)- } \\
\text { (v); } 542\end{array}$ & 2019 & $2500 \mathrm{mg} / \mathrm{kg}$ & $33,211,475$ \\
\hline GALATO DE PROPILO & 310 & 2012 & $200 \mathrm{mg} / \mathrm{kg}$ & $15,130 \& 211$ \\
\hline POLISORBATOS & $432-436$ & 2007 & $5000 \mathrm{mg} / \mathrm{kg}$ & 153 \\
\hline PROPILENGLICOL & 1520 & 2016 & $10000 \mathrm{mg} / \mathrm{kg}$ & 194 \\
\hline RIBOFLAVINAS & 101(i),(ii), (iii) & 2019 & $300 \mathrm{mg} / \mathrm{kg}$ & 153,473 \\
\hline SORBATOS & 200, 202, 203 & 2012 & $2000 \mathrm{mg} / \mathrm{kg}$ & $42 \& 211$ \\
\hline SUCROÉSTERES DE ÁCIDOS GRASOS & 473 & 2016 & $2000 \mathrm{mg} / \mathrm{kg}$ & $194 \& 348$ \\
\hline SUCROGLICÉRIDOS & 474 & 2016 & $2000 \mathrm{mg} / \mathrm{kg}$ & $194 \& 348$ \\
\hline $\begin{array}{l}\text { SUCROSE OLIGOESTERS, TYPE I AND } \\
\text { TYPE II }\end{array}$ & $473 a$ & 2016 & $2000 \mathrm{mg} / \mathrm{kg}$ & $194 \& 348$ \\
\hline SULFITOS & $220-225,539$ & 2019 & $20 \mathrm{mg} / \mathrm{kg}$ & 44,476 \\
\hline TARTRATOS & 334, 335(ii), 337 & 2019 & $7500 \mathrm{mg} / \mathrm{kg}$ & $45 \& 128$ \\
\hline TARTRAZINA & 102 & 2019 & $300 \mathrm{mg} / \mathrm{kg}$ & 194 \\
\hline TERBUTILHIDROQUINONA & 319 & 2006 & $200 \mathrm{mg} / \mathrm{kg}$ & $15 \& 130$ \\
\hline TOCOFEROLES & $307 a, b, c$ & 2016 & $200 \mathrm{mg} / \mathrm{kg}$ & 211 \\
\hline
\end{tabular}


No. de Categoría de alimento 06.4.3 Pastas y fideos precocidos y productos análogos

\begin{tabular}{|c|c|c|c|c|}
\hline Aditivo & SIN & Año Adoptada & Dosis máxima & Notas \\
\hline VERDE SÓLIDO FCF & 143 & 2010 & $290 \mathrm{mg} / \mathrm{kg}$ & 194 \\
\hline
\end{tabular}

\section{No. de Categoría de alimento 06.5}

Postres a base de cereales y almidón (p. ej. pudines de arroz, pudines de mandioca)

\begin{tabular}{|c|c|c|c|c|}
\hline Aditivo & SIN & Año Adoptada & Dosis máxima & Notas \\
\hline ACESULFAME DE POTASIO & 950 & 2007 & $350 \mathrm{mg} / \mathrm{kg}$ & $161 \& 188$ \\
\hline AMARILLO OCASO FCF & 110 & 2008 & $50 \mathrm{mg} / \mathrm{kg}$ & \\
\hline ASPARTAMO & 951 & 2007 & $1000 \mathrm{mg} / \mathrm{kg}$ & $161 \& 191$ \\
\hline AZUL BRILLANTE FCF & 133 & 2005 & $150 \mathrm{mg} / \mathrm{kg}$ & \\
\hline BENZOATOS & $210-213$ & 2003 & $1000 \mathrm{mg} / \mathrm{kg}$ & 13 \\
\hline CANTAXANTINA & $161 \mathrm{~g}$ & 2011 & $15 \mathrm{mg} / \mathrm{kg}$ & \\
\hline $\begin{array}{l}\text { CARAMELO III - CARAMELO AL } \\
\text { AMONÍACO }\end{array}$ & $150 \mathrm{c}$ & 2009 & $50000 \mathrm{mg} / \mathrm{kg}$ & \\
\hline $\begin{array}{l}\text { CARAMELO IV - CARAMELO AL SULFITO } \\
\text { AMÓNICO }\end{array}$ & $150 d$ & 2011 & $2500 \mathrm{mg} / \mathrm{kg}$ & \\
\hline CARMINES & 120 & 2005 & $150 \mathrm{mg} / \mathrm{kg}$ & 178 \\
\hline CAROTENOIDES & $160 a(i), a(i i i), e, f$ & 2009 & $150 \mathrm{mg} / \mathrm{kg}$ & \\
\hline CAROTENOS, BETA-, VEGETALES & 160a(ii) & 2005 & $1000 \mathrm{mg} / \mathrm{kg}$ & \\
\hline CICLAMATOS & 952(i), (ii), (iv) & 2007 & $250 \mathrm{mg} / \mathrm{kg}$ & $17 \& 161$ \\
\hline $\begin{array}{l}\text { CLOROFILAS Y CLOROFILINAS, } \\
\text { COMPLEJOS CUPRICOS }\end{array}$ & $141(\mathrm{i}),(\mathrm{ii})$ & 2009 & $75 \mathrm{mg} / \mathrm{kg}$ & \\
\hline ESTEAROIL LACTILATOS & 481(i), 482(i) & 2016 & $6000 \mathrm{mg} / \mathrm{kg}$ & \\
\hline ÉSTERES DE ASCORBILO & 304,305 & 2001 & $500 \mathrm{mg} / \mathrm{kg}$ & $2 \& 10$ \\
\hline $\begin{array}{l}\text { ÉSTERES DE PROPILENGLICOL DE } \\
\text { ÁCIDOS GRASOS }\end{array}$ & 477 & 2001 & $40000 \mathrm{mg} / \mathrm{kg}$ & \\
\hline $\begin{array}{l}\text { ÉSTERES DE SORBITÁN DE ÁCIDOS } \\
\text { GRASOS }\end{array}$ & 491-495 & 2016 & $5000 \mathrm{mg} / \mathrm{kg}$ & \\
\hline $\begin{array}{l}\text { ÉSTERES DIACETILTARTÁRICOS Y DE } \\
\text { ÁCIDOS GRASOS DE GLICEROL }\end{array}$ & $472 e$ & 2005 & $5000 \mathrm{mg} / \mathrm{kg}$ & \\
\hline $\begin{array}{l}\text { ÉSTERES POLIGLICÉRIDOS DE ÁCIDO } \\
\text { RICINOLÉICO INTERESTERIFICADO }\end{array}$ & 476 & 2016 & $5000 \mathrm{mg} / \mathrm{kg}$ & \\
\hline $\begin{array}{l}\text { ÉSTERES POLIGLICÉRIDOS DE ÁCIDOS } \\
\text { GRASOS }\end{array}$ & 475 & 2016 & $9000 \mathrm{mg} / \mathrm{kg}$ & \\
\hline ETILEN DIAMINO TETRA ACETATOS & 385,386 & 2001 & $315 \mathrm{mg} / \mathrm{kg}$ & 21 \\
\hline ETIL-LAUROIL ARGINATO & 243 & 2011 & $200 \mathrm{mg} / \mathrm{kg}$ & \\
\hline EXTRACTO DE PIEL DE UVA & 163(ii) & 2011 & $200 \mathrm{mg} / \mathrm{kg}$ & 181 \\
\hline FOSFATOS & $\begin{array}{l}\text { 338; 339(i)-(iii); } \\
340 \text { (i)-(iii); 341(i)- } \\
\text { (iii); 342(i)-(ii); } \\
343(\mathrm{i}) \text {-(iii); } 450(\mathrm{i})- \\
\text { (iii),(v)-(vii), (ix); } \\
451 \text { (i),(ii); } 452(\mathrm{i})- \\
\text { (v); } 542\end{array}$ & 2012 & $7000 \mathrm{mg} / \mathrm{kg}$ & 33 \\
\hline GALATO DE PROPILO & 310 & 2001 & $90 \mathrm{mg} / \mathrm{kg}$ & $2 \& 15$ \\
\hline GLICÓSIDOS DE ESTEVIOL & $960 a, 960 b(i)$ & 2011 & $165 \mathrm{mg} / \mathrm{kg}$ & 26 \\
\hline
\end{tabular}


No. de Categoría de alimento 06.5

Postres a base de cereales y almidón (p. ej. pudines de arroz, pudines de mandioca)

\begin{tabular}{|c|c|c|c|c|}
\hline Aditivo & SIN & Año Adoptada & Dosis máxima & Notas \\
\hline INDIGOTINA (CARMÍN DE ÍNDIGO) & 132 & 2009 & $150 \mathrm{mg} / \mathrm{kg}$ & \\
\hline NEOTAMO & 961 & 2007 & $33 \mathrm{mg} / \mathrm{kg}$ & 161 \\
\hline NISINA & 234 & 2010 & $3 \mathrm{mg} / \mathrm{kg}$ & \\
\hline ÓXIDOS DE HIERRO & 172(i)-(iii) & 2005 & $75 \mathrm{mg} / \mathrm{kg}$ & \\
\hline POLISORBATOS & $432-436$ & 2005 & $3000 \mathrm{mg} / \mathrm{kg}$ & \\
\hline PONCEAU 4R (ROJO DE COCHINILLA A) & 124 & 2008 & $50 \mathrm{mg} / \mathrm{kg}$ & \\
\hline RIBOFLAVINAS & 101(i),(ii), (iii) & 2005 & $300 \mathrm{mg} / \mathrm{kg}$ & \\
\hline ROJO ALLURA AC & 129 & 2009 & $300 \mathrm{mg} / \mathrm{kg}$ & \\
\hline SACARINAS & 954(i)-(iv) & 2007 & $100 \mathrm{mg} / \mathrm{kg}$ & 161 \\
\hline SORBATOS & $200,202,203$ & 2012 & $1000 \mathrm{mg} / \mathrm{kg}$ & 42 \\
\hline $\begin{array}{l}\text { SUCRALOSA } \\
\text { (TRICLOROGALACTOSACAROSA) }\end{array}$ & 955 & 2007 & $400 \mathrm{mg} / \mathrm{kg}$ & 161 \\
\hline SUCROÉSTERES DE ÁCIDOS GRASOS & 473 & 2016 & $5000 \mathrm{mg} / \mathrm{kg}$ & 348 \\
\hline SUCROGLICÉRIDOS & 474 & 2016 & $5000 \mathrm{mg} / \mathrm{kg}$ & 348 \\
\hline $\begin{array}{l}\text { SUCROSE OLIGOESTERS, TYPE I AND } \\
\text { TYPE II }\end{array}$ & $473 a$ & 2016 & $5000 \mathrm{mg} / \mathrm{kg}$ & 348 \\
\hline TARTRATOS & 334, 335(ii), 337 & 2016 & $2860 \mathrm{mg} / \mathrm{kg}$ & 45 \\
\hline TOCOFEROLES & $307 a, b, c$ & 2016 & $500 \mathrm{mg} / \mathrm{kg}$ & 15 \\
\hline VERDE SÓLIDO FCF & 143 & 2009 & $100 \mathrm{mg} / \mathrm{kg}$ & 161 \\
\hline
\end{tabular}

No. de Categoría de alimento 06.6 Mezclas batidas para rebozar (p. ej. para empanizar o rebozar pescado o carne de aves de corral)

\begin{tabular}{|c|c|c|c|c|}
\hline Aditivo & SIN & Año Adoptada & Dosis máxima & Notas \\
\hline $\begin{array}{l}\text { CARAMELO III - CARAMELO AL } \\
\text { AMONÍACO }\end{array}$ & $150 \mathrm{c}$ & 2009 & $50000 \mathrm{mg} / \mathrm{kg}$ & \\
\hline $\begin{array}{l}\text { CARAMELO IV - CARAMELO AL SULFITO } \\
\text { AMÓNICO }\end{array}$ & $150 d$ & 2011 & $2500 \mathrm{mg} / \mathrm{kg}$ & \\
\hline CARMINES & 120 & 2005 & $500 \mathrm{mg} / \mathrm{kg}$ & 178 \\
\hline CAROTENOIDES & $160 a(i), a(i i i), e, f$ & 2009 & $500 \mathrm{mg} / \mathrm{kg}$ & \\
\hline CAROTENOS, BETA-, VEGETALES & $160 a(i i)$ & 2005 & $1000 \mathrm{mg} / \mathrm{kg}$ & \\
\hline DIMETILPOLISILOXANO & $900 a$ & 1999 & $10 \mathrm{mg} / \mathrm{kg}$ & \\
\hline $\begin{array}{l}\text { ÉSTERES DIACETILTARTÁRICOS Y DE } \\
\text { ÁCIDOS GRASOS DE GLICEROL }\end{array}$ & $472 \mathrm{e}$ & 2005 & $5000 \mathrm{mg} / \mathrm{kg}$ & \\
\hline FOSFATOS & $\begin{array}{l}\text { 338; 339(i)-(iii); } \\
\text { 340(i)-(iii); 341(i)- } \\
\text { (iii); 342(i)-(ii); } \\
343(\text { i)-(iii); } 450(\mathrm{i})- \\
\text { (iii),(v)-(vii), (ix); } \\
\text { 451(i),(ii); 452(i)- } \\
\text { (v); } 542\end{array}$ & 2012 & $5600 \mathrm{mg} / \mathrm{kg}$ & 33 \\
\hline FOSFATOS DE ALUMINIO Y SODIO & $541(\mathrm{i}),(\mathrm{ii})$ & 2013 & $1000 \mathrm{mg} / \mathrm{kg}$ & 6 \\
\hline POLISORBATOS & $432-436$ & 2007 & $5000 \mathrm{mg} / \mathrm{kg}$ & 2 \\
\hline RIBOFLAVINAS & 101(i),(ii), (iii) & 2005 & $300 \mathrm{mg} / \mathrm{kg}$ & \\
\hline
\end{tabular}




\begin{tabular}{|c|c|c|c|c|}
\hline \multicolumn{2}{|c|}{ No. de Categoría de alimento 06.6} & \multicolumn{3}{|c|}{$\begin{array}{l}\text { Mezclas batidas para rebozar (p. ej. } \\
\text { para empanizar o rebozar pescado o } \\
\text { carne de aves de corral) }\end{array}$} \\
\hline Aditivo & SIN & Año Adoptada & Dosis máxima & Notas \\
\hline SORBATOS & $200,202,203$ & 2009 & $2000 \mathrm{mg} / \mathrm{kg}$ & 42 \\
\hline SUCROÉSTERES DE ÁCIDOS GRASOS & 473 & 2016 & $10000 \mathrm{mg} / \mathrm{kg}$ & 348 \\
\hline SUCROGLICÉRIDOS & 474 & 2016 & $10000 \mathrm{mg} / \mathrm{kg}$ & 348 \\
\hline $\begin{array}{l}\text { SUCROSE OLIGOESTERS, TYPE I AND } \\
\text { TYPE II }\end{array}$ & $473 a$ & 2016 & $10000 \mathrm{mg} / \mathrm{kg}$ & 348 \\
\hline TOCOFEROLES & $307 a, b, c$ & 2016 & $100 \mathrm{mg} / \mathrm{kg}$ & \\
\hline
\end{tabular}

No. de Categoría de alimento 06.7

Productos a base de arroz precocidos 0 elaborados, incluidas las tortas de arroz (sólo del tipo oriental)

\begin{tabular}{|c|c|c|c|c|}
\hline Aditivo & SIN & Año Adoptada & Dosis máxima & Notas \\
\hline $\begin{array}{l}\text { CARAMELO III - CARAMELO AL } \\
\text { AMONÍACO }\end{array}$ & $150 c$ & 2009 & $50000 \mathrm{mg} / \mathrm{kg}$ & \\
\hline $\begin{array}{l}\text { CARAMELO IV - CARAMELO AL SULFITO } \\
\text { AMÓNICO }\end{array}$ & $150 d$ & 2011 & $2500 \mathrm{mg} / \mathrm{kg}$ & \\
\hline $\begin{array}{l}\text { SUCRALOSA } \\
\text { (TRICLOROGALACTOSACAROSA) }\end{array}$ & 955 & 2007 & 200 mg/kg & 72 \\
\hline SUCROÉSTERES DE ÁCIDOS GRASOS & 473 & 2016 & $10000 \mathrm{mg} / \mathrm{kg}$ & 348 \\
\hline SUCROGLICÉRIDOS & 474 & 2016 & $10000 \mathrm{mg} / \mathrm{kg}$ & 348 \\
\hline $\begin{array}{l}\text { SUCROSE OLIGOESTERS, TYPE I AND } \\
\text { TYPE II }\end{array}$ & $473 a$ & 2016 & 10000 mg/kg & 348 \\
\hline
\end{tabular}

\begin{tabular}{|c|c|c|c|c|}
\hline \multicolumn{4}{|c|}{ No. de Categoría de alimento 06.8.1 } & \multirow[b]{2}{*}{ Notas } \\
\hline Aditivo & $\operatorname{SIN}$ & Año Adoptada & Dosis máxima & \\
\hline $\begin{array}{l}\text { CARAMELO III - CARAMELO AL } \\
\text { AMONÍACO }\end{array}$ & $150 c$ & 2010 & $1500 \mathrm{mg} / \mathrm{kg}$ & \\
\hline CARMINES & 120 & 2010 & $100 \mathrm{mg} / \mathrm{kg}$ & 178 \\
\hline $\begin{array}{l}\text { ÉSTERES DIACETILTARTÁRICOS Y DE } \\
\text { ÁCIDOS GRASOS DE GLICEROL }\end{array}$ & $472 e$ & 2016 & $2000 \mathrm{mg} / \mathrm{kg}$ & 347 \\
\hline FOSFATOS & $\begin{array}{l}\text { 338; 339(i)-(iii); } \\
\text { 340(i)-(iii); 341(i)- } \\
\text { (iii); 342(i)-(ii); } \\
343(\text { i)-(iii); 450(i)- } \\
\text { (iii),(v)-(vii), (ix); } \\
451 \text { (i),(ii); 452(i)- } \\
\text { (v); } 542\end{array}$ & 2012 & $1300 \mathrm{mg} / \mathrm{kg}$ & 33 \\
\hline GLICÓSIDOS DE ESTEVIOL & $960 a, 960 b(i)$ & 2011 & $200 \mathrm{mg} / \mathrm{kg}$ & 26 \\
\hline RIBOFLAVINAS & 101(i),(ii), (iii) & 2010 & $50 \mathrm{mg} / \mathrm{kg}$ & \\
\hline $\begin{array}{l}\text { SUCRALOSA } \\
\text { (TRICLOROGALACTOSACAROSA) }\end{array}$ & 955 & 2012 & $400 \mathrm{mg} / \mathrm{kg}$ & \\
\hline SUCROÉSTERES DE ÁCIDOS GRASOS & 473 & 2017 & $20000 \mathrm{mg} / \mathrm{kg}$ & 348 \\
\hline SUCROGLICÉRIDOS & 474 & 2017 & 20000 mg/kg & 348 \\
\hline $\begin{array}{l}\text { SUCROSE OLIGOESTERS, TYPE I AND } \\
\text { TYPE II }\end{array}$ & $473 a$ & 2017 & $20000 \mathrm{mg} / \mathrm{kg}$ & 348 \\
\hline
\end{tabular}


No. de Categoría de alimento 06.8.3 Cuajada de soja (tofu)

\begin{tabular}{|c|c|c|c|c|}
\hline Aditivo & SIN & Año Adoptada & Dosis máxima & Notas \\
\hline FOSFATOS & $\begin{array}{l}\text { 338; 339(i)-(iii); } \\
340 \text { (i)-(iii); 341(i)- } \\
\text { (iii); 342(i)-(ii); } \\
343(\text { i)-(iii); 450(i)- } \\
\text { (iii),(v)-(vii), (ix); } \\
\text { 451(i),(ii); 452(i)- } \\
\text { (v); } 542\end{array}$ & 2012 & 100 mg/kg & 33 \\
\hline
\end{tabular}

\begin{tabular}{|c|c|c|c|c|}
\hline \multicolumn{2}{|c|}{ No. de Categoría de alimento 06.8.8 } & \multicolumn{3}{|c|}{$\begin{array}{l}\text { Otros productos a base de proteína de } \\
\text { soja }\end{array}$} \\
\hline Aditivo & SIN & Año Adoptada & Dosis máxima & Notas \\
\hline $\begin{array}{l}\text { CARAMELO III - CARAMELO AL } \\
\text { AMONÍACO }\end{array}$ & $150 c$ & 2019 & $20000 \mathrm{mg} / \mathrm{kg}$ & XS175 \\
\hline $\begin{array}{l}\text { CARAMELO IV - CARAMELO AL SULFITO } \\
\text { AMÓNICO }\end{array}$ & $150 d$ & 2019 & 20000 mg/kg & XS175 \\
\hline
\end{tabular}

\begin{tabular}{|c|c|c|c|c|}
\hline \multicolumn{2}{|c|}{ No. de Categoría de alimento 07.0} & \multicolumn{3}{|c|}{ Productos de panadería } \\
\hline Aditivo & SIN & Año Adoptada & Dosis máxima & Notas \\
\hline ACEITE MINERAL DE ALTA VISCOSIDAD & $905 d$ & 2004 & $3000 \mathrm{mg} / \mathrm{kg}$ & 125 \\
\hline BENZOATOS & $210-213$ & 2004 & $1000 \mathrm{mg} / \mathrm{kg}$ & 13 \\
\hline BUTILHIDROXIANISOL & 320 & 2007 & $200 \mathrm{mg} / \mathrm{kg}$ & $15 \& 180$ \\
\hline BUTILHIDROXITOLUENO & 321 & 2007 & $200 \mathrm{mg} / \mathrm{kg}$ & $15 \& 180$ \\
\hline CERA CARNAUBA & 903 & 2001 & BPF & 3 \\
\hline ÉSTERES DE ASCORBILO & 304,305 & 2003 & $1000 \mathrm{mg} / \mathrm{kg}$ & $10 \& 15$ \\
\hline $\begin{array}{l}\text { ÉSTERES DE PROPILENGLICOL DE } \\
\text { ÁCIDOS GRASOS }\end{array}$ & 477 & 2001 & $15000 \mathrm{mg} / \mathrm{kg}$ & $11 \& 72$ \\
\hline SORBATOS & $200,202,203$ & 2012 & $1000 \mathrm{mg} / \mathrm{kg}$ & 42 \\
\hline VERDE SÓLIDO FCF & 143 & 2009 & $100 \mathrm{mg} / \mathrm{kg}$ & 161 \\
\hline
\end{tabular}

No. de Categoría de alimento 07.1

ACESULFAME DE POTASIO
ASPARTAMO
AZUL BRILLANTE FCF
DIACETATO DE SODIO
ESTEARATOS DE POLIOXIETILENO
ÉSTERES DIACETILTARTÁRICOS Y DE
ÁCIDOS GRASOS DE GLICEROL
NEOTAMO
PROPILENGLICOL
SUCRALOSA
(TRICLOROGALACTOSACAROSA)
SUCROÉSTERES DE ÁCIDOS GRASOS
SUCROGLICÉRIDOS
SUCROSE OLIGOESTERS, TYPE I AND
TYPE II

$\begin{array}{lccc} & \text { Año Adoptada } & \text { Dosis máxima } & \text { Notas } \\ 950 & 2008 & 1000 \mathrm{mg} / \mathrm{kg} & 161 \& 188 \\ 951 & 2008 & 4000 \mathrm{mg} / \mathrm{kg} & 161 \& 191 \\ 133 & 2009 & 100 \mathrm{mg} / \mathrm{kg} & 161 \\ 262 \text { (ii) } & 2017 & 4000 \mathrm{mg} / \mathrm{kg} & \\ 430,431 & 2016 & 3000 \mathrm{mg} / \mathrm{kg} & \\ 472 \mathrm{e} & 2006 & 6000 \mathrm{mg} / \mathrm{kg} & \\ 961 & 2008 & 70 \mathrm{mg} / \mathrm{kg} & 161 \\ 1520 & 2016 & 1500 \mathrm{mg} / \mathrm{kg} & \\ 955 & 2008 & 650 \mathrm{mg} / \mathrm{kg} & 161 \\ 473 & 2017 & 3000 \mathrm{mg} / \mathrm{kg} & 348 \\ 474 & 2017 & 3000 \mathrm{mg} / \mathrm{kg} & 348 \\ 473 a & 2017 & 3000 \mathrm{mg} / \mathrm{kg} & 348\end{array}$


No. de Categoría de alimento 07.1

$$
\text { Aditivo }
$$

TARTRATOS

SIN

334, 335(ii), 337

Pan y productos de panadería ordinaria

\section{No. de Categoría de alimento 07.1.1}

Aditivo

ACEITE MINERAL, VISCOSIDAD MEDIA

ÉSTERES DE SORBITÁN DE ÁCIDOS

$$
\text { GRASOS }
$$

ÉSTERES POLIGLICÉRIDOS DE ÁCIDOS 475 GRASOS

POLISORBATOS

TERBUTILHIDROQUINONA

$\begin{array}{llcc}\text { SIN } & \text { Año Adoptada } & \text { Dosis máxima } & \text { Notas } \\ 905 \mathrm{e} & 2004 & 3000 \mathrm{mg} / \mathrm{kg} & 36 \text { \& } 126 \\ 491-495 & 2017 & 3000 \mathrm{mg} / \mathrm{kg} & \\ 475 & 2016 & 10000 \mathrm{mg} / \mathrm{kg} & 372 \\ 432-436 & 2008 & 3000 \mathrm{mg} / \mathrm{kg} & \\ 319 & 2006 & 200 \mathrm{mg} / \mathrm{kg} & 15 \& 195\end{array}$

\section{No. de Categoría de alimento 07.1.1.1 Panes leudados con levadura y panes}

\begin{tabular}{|c|c|c|c|c|}
\hline Aditivo & SIN & Año Adoptada & Dosis máxima & Notas \\
\hline ALGINATO DE PROPILENGLICOL & 405 & 2017 & $4000 \mathrm{mg} / \mathrm{kg}$ & \\
\hline ESTEAROIL LACTILATOS & 481(i), 482(i) & 2017 & $3000 \mathrm{mg} / \mathrm{kg}$ & 388 \\
\hline
\end{tabular}
especiales

\begin{tabular}{|c|c|c|c|c|}
\hline Aditivo & SIN & Año Adoptada & Dosis máxima & Notas \\
\hline ESTEAROIL LACTILATOS & 481(i), 482(i) & 2016 & $3000 \mathrm{mg} / \mathrm{kg}$ & \\
\hline FOSFATOS & $\begin{array}{l}338 ; 339(\mathrm{i})-(\mathrm{iii}) ; \\
340 \text { (i)-(iii); 341(i)- } \\
\text { (iii); 342(i)-(ii); } \\
\text { 343(i)-(iii); 450(i)- } \\
\text { (iii),(v)-(vii), (ix); } \\
\text { 451(i),(ii); 452(i)- } \\
\text { (v); } 542\end{array}$ & 2012 & $9300 \mathrm{mg} / \mathrm{kg}$ & $33 \& 229$ \\
\hline
\end{tabular}

No. de Categoría de alimento 07.1.1.2 Panes leudados con bicarbonato

\begin{tabular}{|c|c|c|c|c|}
\hline \multicolumn{2}{|c|}{ No. de Categoría de alimento 07.1.2 } & \multicolumn{3}{|c|}{$\begin{array}{l}\text { "Crackers" (galletas saladas o de } \\
\text { agua), excluidos los "crackers" dulces }\end{array}$} \\
\hline Aditivo & SIN & Añ̃o Adoptada & Dosis máxima & Notas \\
\hline ALGINATO DE PROPILENGLICOL & 405 & 2017 & $2000 \mathrm{mg} / \mathrm{kg}$ & \\
\hline $\begin{array}{l}\text { CARAMELO III - CARAMELO AL } \\
\text { AMONÍACO }\end{array}$ & $150 c$ & 2009 & $50000 \mathrm{mg} / \mathrm{kg}$ & 161 \\
\hline $\begin{array}{l}\text { CARAMELO IV - CARAMELO AL SULFITO } \\
\text { AMÓNICO }\end{array}$ & $150 d$ & 2010 & $50000 \mathrm{mg} / \mathrm{kg}$ & 161 \\
\hline CARMINES & 120 & 2008 & $200 \mathrm{mg} / \mathrm{kg}$ & 178 \\
\hline CAROTENOIDES & $160 a(i), a(i i i), e, f$ & 2009 & $1000 \mathrm{mg} / \mathrm{kg}$ & \\
\hline CAROTENOS, BETA-, VEGETALES & $160 a(i i)$ & 2005 & $1000 \mathrm{mg} / \mathrm{kg}$ & \\
\hline ESTEAROIL LACTILATOS & 481(i), 482(i) & 2016 & $3000 \mathrm{mg} / \mathrm{kg}$ & \\
\hline $\begin{array}{l}\text { ÉSTERES DE SORBITÁN DE ÁCIDOS } \\
\text { GRASOS }\end{array}$ & $491-495$ & 2016 & $10000 \mathrm{mg} / \mathrm{kg}$ & 11 \\
\hline $\begin{array}{l}\text { ÉSTERES POLIGLICÉRIDOS DE ÁCIDOS } \\
\text { GRASOS }\end{array}$ & 475 & 2016 & $6000 \mathrm{mg} / \mathrm{kg}$ & \\
\hline EXTRACTO DE PIEL DE UVA & 163(ii) & 2011 & $200 \mathrm{mg} / \mathrm{kg}$ & 181 \\
\hline
\end{tabular}




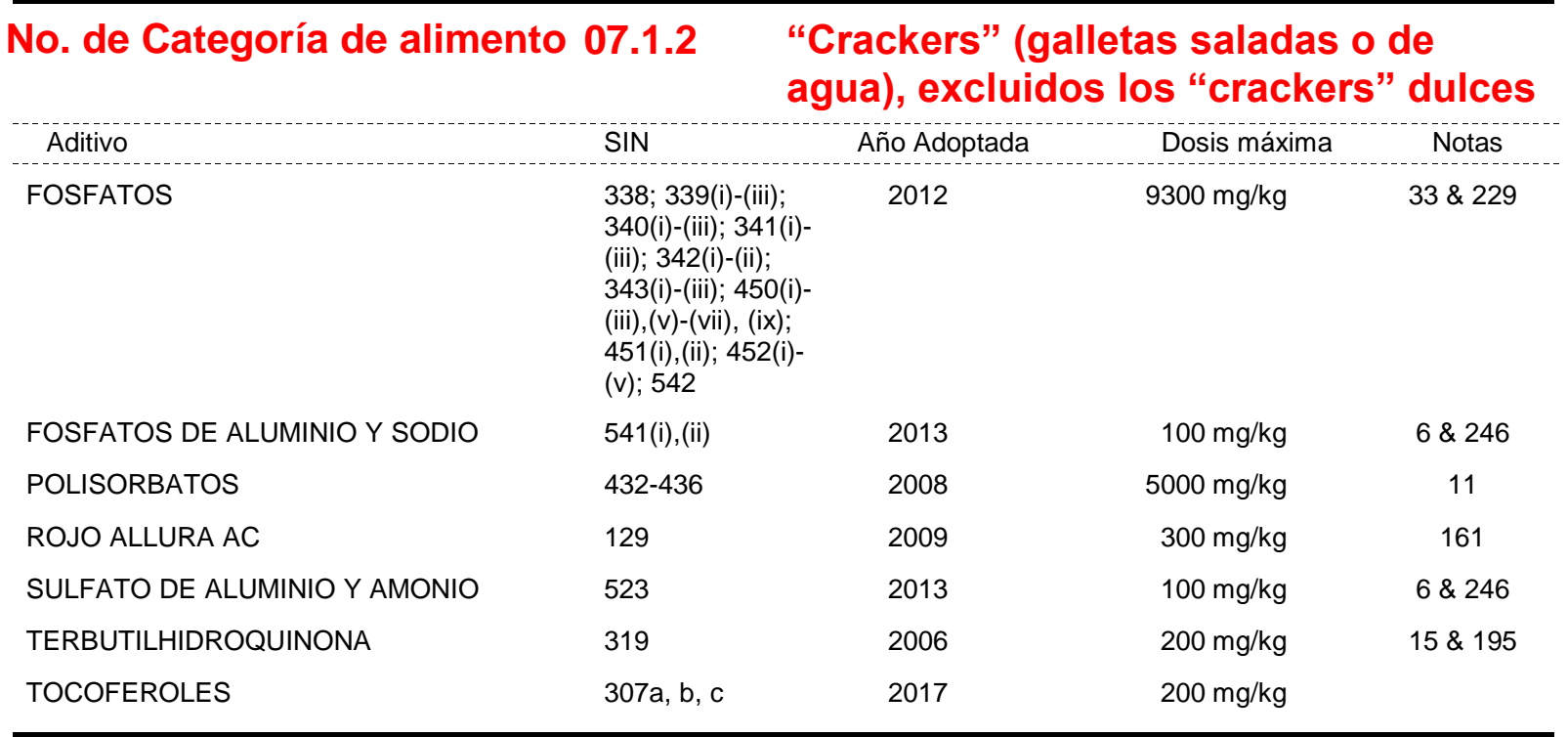

No. de Categoría de alimento 07.1.3 Otros productos de panadería ordinaria
(p. ej. panecillos tipo rosca "bagels", pan tipo mediterráneo "pita", panecillos ingleses chatos "muffins", etc.)

\begin{tabular}{|c|c|c|c|c|}
\hline Aditivo & $\sin$ & Año Adoptada & Dosis máxima & Notas \\
\hline $\begin{array}{l}\text { CARAMELO III - CARAMELO AL } \\
\text { AMONÍACO }\end{array}$ & $150 c$ & 2009 & $50000 \mathrm{mg} / \mathrm{kg}$ & 161 \\
\hline $\begin{array}{l}\text { CARAMELO IV - CARAMELO AL SULFITO } \\
\text { AMÓNICO }\end{array}$ & $150 d$ & 2010 & $50000 \mathrm{mg} / \mathrm{kg}$ & 161 \\
\hline CAROTENOIDES & $160 a(i), a(i i i), e, f$ & 2011 & $100 \mathrm{mg} / \mathrm{kg}$ & \\
\hline ESTEAROIL LACTILATOS & 481(i), 482(i) & 2016 & $5000 \mathrm{mg} / \mathrm{kg}$ & \\
\hline $\begin{array}{l}\text { ÉSTERES DE SORBITÁN DE ÁCIDOS } \\
\text { GRASOS }\end{array}$ & $491-495$ & 2016 & 10000 mg/kg & 11 \\
\hline $\begin{array}{l}\text { ÉSTERES POLIGLICÉRIDOS DE ÁCIDOS } \\
\text { GRASOS }\end{array}$ & 475 & 2016 & $6000 \mathrm{mg} / \mathrm{kg}$ & \\
\hline FOSFATOS & $\begin{array}{l}\text { 338; 339(i)-(iii); } \\
340 \text { (i)-(iii); 341(i)- } \\
\text { (iii); 342(i)-(ii); } \\
343(\text { i)-(iii); } 450 \text { (i)- } \\
\text { (iii),(v)-(vii), (ix); } \\
\text { 451(i),(ii); 452(i)- } \\
\text { (v); } 542\end{array}$ & 2012 & $9300 \mathrm{mg} / \mathrm{kg}$ & $33 \& 229$ \\
\hline FOSFATOS DE ALUMINIO Y SODIO & $541(\mathrm{i}),(\mathrm{ii})$ & 2013 & $100 \mathrm{mg} / \mathrm{kg}$ & $6,244 \& 246$ \\
\hline GALATO DE PROPILO & 310 & 2001 & $100 \mathrm{mg} / \mathrm{kg}$ & $15 \& 130$ \\
\hline POLISORBATOS & $432-436$ & 2008 & $3000 \mathrm{mg} / \mathrm{kg}$ & 11 \\
\hline ROJO ALLURA AC & 129 & 2009 & $300 \mathrm{mg} / \mathrm{kg}$ & 161 \\
\hline SULFATO DE ALUMINIO Y AMONIO & 523 & 2013 & $100 \mathrm{mg} / \mathrm{kg}$ & $6,244 \& 246$ \\
\hline TERBUTILHIDROQUINONA & 319 & 2006 & $200 \mathrm{mg} / \mathrm{kg}$ & $15 \& 130$ \\
\hline
\end{tabular}

No. de Categoría de alimento 07.1.4 Productos similares al pan, incluidos los rellenos a base de pan y el pan rallado

Aditivo SIN $\quad$ SIN Añoptada Aosis máxima Notas




\begin{tabular}{|c|c|c|c|c|}
\hline \multicolumn{2}{|c|}{ No. de Categoría de alimento 07.1.4 } & \multicolumn{3}{|c|}{$\begin{array}{l}\text { Productos similares al pan, incluidos } \\
\text { los rellenos a base de pan y el pan } \\
\text { rallado }\end{array}$} \\
\hline Aditivo & SIN & Año Adoptada & Dosis máxima & Notas \\
\hline $\begin{array}{l}\text { CARAMELO III - CARAMELO AL } \\
\text { AMONÍACO }\end{array}$ & $150 c$ & 2009 & $50000 \mathrm{mg} / \mathrm{kg}$ & 161 \\
\hline CARMINES & 120 & 2008 & $500 \mathrm{mg} / \mathrm{kg}$ & 178 \\
\hline CAROTENOIDES & $160 a(i), a(i i i), e, f$ & 2011 & $200 \mathrm{mg} / \mathrm{kg}$ & 116 \\
\hline CAROTENOS, BETA-, VEGETALES & 160a(ii) & 2005 & $1000 \mathrm{mg} / \mathrm{kg}$ & \\
\hline $\begin{array}{l}\text { CLOROFILAS Y CLOROFILINAS, } \\
\text { COMPLEJOS CUPRICOS }\end{array}$ & $141(\mathrm{i}),(\mathrm{ii})$ & 2009 & $6.4 \mathrm{mg} / \mathrm{kg}$ & $62 \& 161$ \\
\hline ESTEAROIL LACTILATOS & 481(i), 482(i) & 2016 & $5000 \mathrm{mg} / \mathrm{kg}$ & \\
\hline $\begin{array}{l}\text { ÉSTERES DE SORBITÁN DE ÁCIDOS } \\
\text { GRASOS }\end{array}$ & $491-495$ & 2016 & $10000 \mathrm{mg} / \mathrm{kg}$ & 11 \\
\hline $\begin{array}{l}\text { ÉSTERES POLIGLICÉRIDOS DE ÁCIDOS } \\
\text { GRASOS }\end{array}$ & 475 & 2016 & $10000 \mathrm{mg} / \mathrm{kg}$ & \\
\hline EXTRACTO DE PIEL DE UVA & 163(ii) & 2011 & $200 \mathrm{mg} / \mathrm{kg}$ & 181 \\
\hline FOSFATOS & $\begin{array}{l}\text { 338; 339(i)-(iii); } \\
340(\mathrm{i})-(\mathrm{iii)} ; 341(\mathrm{i})- \\
\text { (iii); } 342(\mathrm{i}) \text {-(ii); } \\
343(\mathrm{i})-(\mathrm{iii)} ; 450(\mathrm{i})- \\
\text { (iii),(v)-(vii), (ix); } \\
451 \text { (i),(ii); } 452 \text { (i)- } \\
\text { (v); } 542\end{array}$ & 2012 & $9300 \mathrm{mg} / \mathrm{kg}$ & $33 \& 229$ \\
\hline POLISORBATOS & $432-436$ & 2008 & $3000 \mathrm{mg} / \mathrm{kg}$ & 11 \\
\hline TERBUTILHIDROQUINONA & 319 & 2006 & $200 \mathrm{mg} / \mathrm{kg}$ & $15 \& 195$ \\
\hline
\end{tabular}

\begin{tabular}{|c|c|c|c|c|}
\hline \multicolumn{2}{|c|}{ No. de Categoría de alimento 07.1.5 } & \multicolumn{2}{|c|}{ Panes y bollos dulces al vapor } & \multirow[b]{2}{*}{ Notas } \\
\hline Aditivo & SIN & Año Adoptada & Dosis máxima & \\
\hline ALGINATO DE PROPILENGLICOL & 405 & 2017 & $500 \mathrm{mg} / \mathrm{kg}$ & \\
\hline $\begin{array}{l}\text { CARAMELO III - CARAMELO AL } \\
\text { AMONÍACO }\end{array}$ & $150 \mathrm{c}$ & 2009 & $50000 \mathrm{mg} / \mathrm{kg}$ & 161 \\
\hline CAROTENOIDES & 160a(i),a(iii),e,f & 2011 & $100 \mathrm{mg} / \mathrm{kg}$ & 216 \\
\hline ESTEAROIL LACTILATOS & $481(\mathrm{i}), 482(\mathrm{i})$ & 2016 & $3000 \mathrm{mg} / \mathrm{kg}$ & \\
\hline $\begin{array}{l}\text { ÉSTERES DE SORBITÁN DE ÁCIDOS } \\
\text { GRASOS }\end{array}$ & 491-495 & 2016 & $10000 \mathrm{mg} / \mathrm{kg}$ & 11 \\
\hline $\begin{array}{l}\text { ÉSTERES POLIGLICÉRIDOS DE ÁCIDOS } \\
\text { GRASOS }\end{array}$ & 475 & 2016 & $10000 \mathrm{mg} / \mathrm{kg}$ & \\
\hline FOSFATOS & $\begin{array}{l}\text { 338; 339(i)-(iii); } \\
340 \text { (i)-(iii); 341(i)- } \\
\text { (iii); 342(i)-(ii); } \\
343(\text { (i)-(iii); 450(i)- } \\
\text { (iii),(v)-(vii), (ix); } \\
\text { 451(i),(ii); 452(i)- } \\
\text { (v); } 542\end{array}$ & 2012 & $9300 \mathrm{mg} / \mathrm{kg}$ & $33 \& 229$ \\
\hline FOSFATOS DE ALUMINIO Y SODIO & 541 (i),(ii) & 2013 & $40 \mathrm{mg} / \mathrm{kg}$ & $6,246 \& 248$ \\
\hline POLISORBATOS & $432-436$ & 2008 & $3000 \mathrm{mg} / \mathrm{kg}$ & 11 \\
\hline SULFATO DE ALUMINIO Y AMONIO & 523 & 2013 & $40 \mathrm{mg} / \mathrm{kg}$ & $6,246 \& 248$ \\
\hline
\end{tabular}




\begin{tabular}{|c|c|c|c|c|}
\hline \multirow[t]{2}{*}{ No. de Categoría de alimento } & \multicolumn{4}{|c|}{$\begin{array}{l}\text { Mezclas para pan y productos de } \\
\text { panadería ordinaria }\end{array}$} \\
\hline & $\operatorname{SiN}$ & Año Adoptada & Dosis máxima & Notas \\
\hline ALGINATO DE PROPILENGLICOL & 405 & 2017 & $20000 \mathrm{mg} / \mathrm{kg}$ & 11 \\
\hline $\begin{array}{l}\text { CARAMELO III - CARAMELO AL } \\
\text { AMONÍACO }\end{array}$ & $150 \mathrm{c}$ & 2010 & $50000 \mathrm{mg} / \mathrm{kg}$ & 161 \\
\hline ESTEAROIL LACTILATOS & 481(i), 482(i) & 2016 & $5000 \mathrm{mg} / \mathrm{kg}$ & \\
\hline $\begin{array}{l}\text { ÉSTERES DE SORBITÁN DE ÁCIDOS } \\
\text { GRASOS }\end{array}$ & $491-495$ & 2016 & $10000 \mathrm{mg} / \mathrm{kg}$ & 11 \\
\hline $\begin{array}{l}\text { ÉSTERES POLIGLICÉRIDOS DE ÁCIDOS } \\
\text { GRASOS }\end{array}$ & 475 & 2016 & $15000 \mathrm{mg} / \mathrm{kg}$ & 11 \\
\hline FOSFATOS & $\begin{array}{l}\text { 338; 339(i)-(iii); } \\
\text { 340(i)-(iii); 341(i)- } \\
\text { (iii); 342(i)-(ii); } \\
343(\text { i)-(iii); 450(i)- } \\
\text { (iii),(v)-(vii), (ix); } \\
\text { 451(i),(ii); 452(i)- } \\
\text { (v); } 542\end{array}$ & 2012 & $9300 \mathrm{mg} / \mathrm{kg}$ & $33 \& 229$ \\
\hline FOSFATOS DE ALUMINIO Y SODIO & $541(\mathrm{i}),(\mathrm{ii})$ & 2013 & $40 \mathrm{mg} / \mathrm{kg}$ & $6,246 \& 249$ \\
\hline POLISORBATOS & $432-436$ & 2008 & $3000 \mathrm{mg} / \mathrm{kg}$ & 11 \\
\hline SULFATO DE ALUMINIO Y AMONIO & 523 & 2013 & $40 \mathrm{mg} / \mathrm{kg}$ & $6,246 \& 249$ \\
\hline TOCOFEROLES & $307 a, b, c$ & 2017 & $100 \mathrm{mg} / \mathrm{kg}$ & \\
\hline
\end{tabular}

No. de Categoría de alimento 07.2

Productos de panadería fina (dulces, salados, aromatizados) y mezclas

\begin{tabular}{|c|c|c|c|c|}
\hline Aditivo & $\operatorname{SIN}$ & Año Adoptada & Dosis máxima & Notas \\
\hline ACESULFAME DE POTASIO & 950 & 2007 & $1000 \mathrm{mg} / \mathrm{kg}$ & $165 \& 188$ \\
\hline AMARILLO OCASO FCF & 110 & 2008 & $50 \mathrm{mg} / \mathrm{kg}$ & \\
\hline ASPARTAMO & 951 & 2007 & $1700 \mathrm{mg} / \mathrm{kg}$ & $165 \& 191$ \\
\hline AZUL BRILLANTE FCF & 133 & 2009 & $200 \mathrm{mg} / \mathrm{kg}$ & 161 \\
\hline $\begin{array}{l}\text { CARAMELO III - CARAMELO AL } \\
\text { AMONÍACO }\end{array}$ & $150 \mathrm{c}$ & 2009 & $50000 \mathrm{mg} / \mathrm{kg}$ & 161 \\
\hline $\begin{array}{l}\text { CARAMELO IV - CARAMELO AL SULFITO } \\
\text { AMÓNICO }\end{array}$ & $150 d$ & 2011 & $1200 \mathrm{mg} / \mathrm{kg}$ & \\
\hline CARMINES & 120 & 2005 & $200 \mathrm{mg} / \mathrm{kg}$ & 178 \\
\hline CAROTENOIDES & $160 a(i), a(i i i), e, f$ & 2009 & $100 \mathrm{mg} / \mathrm{kg}$ & \\
\hline CAROTENOS, BETA-, VEGETALES & $160 a(i i)$ & 2005 & $1000 \mathrm{mg} / \mathrm{kg}$ & \\
\hline CERA CANDELILLA & 902 & 2001 & BPF & 3 \\
\hline CERA DE ABEJAS & 901 & 2001 & BPF & 3 \\
\hline CICLAMATOS & 952(i), (ii), (iv) & 2007 & $1600 \mathrm{mg} / \mathrm{kg}$ & $17 \& 165$ \\
\hline $\begin{array}{l}\text { CLOROFILAS Y CLOROFILINAS, } \\
\text { COMPLEJOS CUPRICOS }\end{array}$ & 141 (i),(ii) & 2009 & $75 \mathrm{mg} / \mathrm{kg}$ & \\
\hline ESTEARATOS DE POLIOXIETILENO & 430,431 & 2016 & $3000 \mathrm{mg} / \mathrm{kg}$ & \\
\hline ESTEAROIL LACTILATOS & 481(i), 482(i) & 2016 & $5000 \mathrm{mg} / \mathrm{kg}$ & \\
\hline $\begin{array}{l}\text { ÉSTERES DE SORBITÁN DE ÁCIDOS } \\
\text { GRASOS }\end{array}$ & 491-495 & 2016 & $10000 \mathrm{mg} / \mathrm{kg}$ & \\
\hline $\begin{array}{l}\text { ÉSTERES DIACETILTARTÁRICOS Y DE } \\
\text { ÁCIDOS GRASOS DE GLICEROL }\end{array}$ & $472 e$ & 2006 & $20000 \mathrm{mg} / \mathrm{kg}$ & \\
\hline
\end{tabular}




\begin{tabular}{|c|c|c|c|c|}
\hline \multirow[t]{2}{*}{ No. de Categoría de alimento } & \multicolumn{4}{|c|}{$\begin{array}{l}\text { Productos de panadería fina (dulces, } \\
\text { salados, aromatizados) y mezclas }\end{array}$} \\
\hline & SIN & Año Adoptada & Dosis máxima & Notas \\
\hline FOSFATOS & $\begin{array}{l}\text { 338; 339(i)-(iii); } \\
340(\mathrm{i})-(\mathrm{iii}) ; 341 \text { (i)- } \\
\text { (iii); 342(i)-(ii); } \\
343(\mathrm{i}) \text {-(iii); 450(i)- } \\
\text { (iii),(v)-(vii), (ix); } \\
\text { 451(i),(ii); 452(i)- } \\
\text { (v); } 542\end{array}$ & 2012 & $9300 \mathrm{mg} / \mathrm{kg}$ & $33 \& 229$ \\
\hline GOMA LACA, BLANQUEADA & 904 & 2001 & BPF & 3 \\
\hline HIDROXIBENZOATOS, PARA- & 214,218 & 2010 & $300 \mathrm{mg} / \mathrm{kg}$ & 27 \\
\hline INDIGOTINA (CARMÍN DE ÍNDIGO) & 132 & 2009 & $200 \mathrm{mg} / \mathrm{kg}$ & 161 \\
\hline NEOTAMO & 961 & 2008 & $80 \mathrm{mg} / \mathrm{kg}$ & $161 \& 165$ \\
\hline NISINA & 234 & 2016 & $6.25 \mathrm{mg} / \mathrm{kg}$ & 233 \\
\hline ÓXIDOS DE HIERRO & 172(i)-(iii) & 2005 & $100 \mathrm{mg} / \mathrm{kg}$ & \\
\hline POLISORBATOS & $432-436$ & 2008 & $3000 \mathrm{mg} / \mathrm{kg}$ & \\
\hline PONCEAU 4R (ROJO DE COCHINILLA A) & 124 & 2008 & $50 \mathrm{mg} / \mathrm{kg}$ & \\
\hline PROPILENGLICOL & 1520 & 2016 & $1500 \mathrm{mg} / \mathrm{kg}$ & \\
\hline RIBOFLAVINAS & 101(i),(ii), (iii) & 2005 & $300 \mathrm{mg} / \mathrm{kg}$ & \\
\hline ROJO ALLURA AC & 129 & 2009 & $300 \mathrm{mg} / \mathrm{kg}$ & 161 \\
\hline SACARINAS & 954(i)-(iv) & 2007 & $170 \mathrm{mg} / \mathrm{kg}$ & 165 \\
\hline SAL DE ASPARTAMO Y ACESULFAMO & 962 & 2009 & $1000 \mathrm{mg} / \mathrm{kg}$ & $77 \& 113$ \\
\hline $\begin{array}{l}\text { SUCRALOSA } \\
\text { (TRICLOROGALACTOSACAROSA) }\end{array}$ & 955 & 2008 & $700 \mathrm{mg} / \mathrm{kg}$ & $161 \& 165$ \\
\hline SUCROÉSTERES DE ÁCIDOS GRASOS & 473 & 2016 & $10000 \mathrm{mg} / \mathrm{kg}$ & 348 \\
\hline SUCROGLICÉRIDOS & 474 & 2016 & $10000 \mathrm{mg} / \mathrm{kg}$ & 348 \\
\hline $\begin{array}{l}\text { SUCROSE OLIGOESTERS, TYPE I AND } \\
\text { TYPE II }\end{array}$ & $473 a$ & 2016 & $10000 \mathrm{mg} / \mathrm{kg}$ & 348 \\
\hline SULFITOS & $220-225,539$ & 2006 & $50 \mathrm{mg} / \mathrm{kg}$ & 44 \\
\hline
\end{tabular}

No. de Categoría de alimento 07.2.1 Tortas, galletas y pasteles ( $p$. ej., rellenos de fruta o crema)

\begin{tabular}{lllrc}
\hline Aditivo & SIN & Año Adoptada & Dosis máxima & Notas \\
\hline ALGINATO DE PROPILENGLICOL & 405 & 2017 & $3000 \mathrm{mg} / \mathrm{kg}$ & \\
ÉSTERES POLIGLICÉRIDOS DE ÁCIDOS & 475 & 2016 & $10000 \mathrm{mg} / \mathrm{kg}$ & \\
GRASOS & & & & \\
TARTRATOS & $334,335(\mathrm{ii}), 337$ & 2017 & $5000 \mathrm{mg} / \mathrm{kg}$ & 45 \\
TOCOFEROLES & $307 \mathrm{a}, \mathrm{b}, \mathrm{c}$ & 2017 & $200 \mathrm{mg} / \mathrm{kg}$ & 389 \\
\hline
\end{tabular}

No. de Categoría de alimento 07.2.2 Otros productos de panadería fina ( $p$. ej. roscas fritas "donuts" (donas), panecillos dulces, "scones" y panecillos chatos "muffins")

\begin{tabular}{|c|c|c|c|c|}
\hline Aditivo & SIN & Año Adoptada & Dosis máxima & Notas \\
\hline ALGINATO DE PROPILENGLICOL & 405 & 2017 & $2000 \mathrm{mg} / \mathrm{kg}$ & \\
\hline $\begin{array}{l}\text { ÉSTERES POLIGLICÉRIDOS DE ÁCIDOS } \\
\text { GRASOS }\end{array}$ & 475 & 2016 & $10000 \mathrm{mg} / \mathrm{kg}$ & \\
\hline
\end{tabular}




\begin{tabular}{|c|c|c|c|c|}
\hline \multirow{2}{*}{$\begin{array}{l}\text { No. de Categ } \\
\text { Aditivo }\end{array}$} & $\begin{array}{l}0 \\
e \\
p \\
p\end{array}$ & \multicolumn{3}{|c|}{$\begin{array}{l}\text { Otros productos de panadería fina (p. } \\
\text { ej. roscas fritas "donuts" (donas), } \\
\text { panecillos dulces, "scones" y } \\
\text { panecillos chatos "muffins") }\end{array}$} \\
\hline & SIN & Año Adoptada & Dosis máxima & Notas \\
\hline TARTRATOS & 334, 335(ii), 337 & 2017 & $500 \mathrm{mg} / \mathrm{kg}$ & 45 \\
\hline TOCOFEROLES & $307 a, b, c$ & 2017 & 200 mg/kg & \\
\hline
\end{tabular}

No. de Categoría de alimento 07.2.3 Mezclas para pastelería fina (p. ej. tortas, tortitas o panqueques)

\begin{tabular}{llrrr} 
Aditivo & SIN & Año Adoptada & Dosis máxima & Notas \\
ALGINATO DE PROPILENGLICOL & 405 & 2017 & $10000 \mathrm{mg} / \mathrm{kg}$ & 11 \\
$\begin{array}{l}\text { ÉSTERES POLIGLICÉRIDOS DE ÁCIDOS } \\
\text { GRASOS }\end{array}$ & 475 & 2019 & $16000 \mathrm{mg} / \mathrm{kg}$ & 451 \\
GALATO DE PROPILO & 310 & 2001 & $200 \mathrm{mg} / \mathrm{kg}$ & $15 \& 196$ \\
TARTRATOS & $334,335(\mathrm{ii}), 337$ & 2017 & $8000 \mathrm{mg} / \mathrm{kg}$ & $11 \& 45$ \\
TOCOFEROLES & $307 \mathrm{a}, \mathrm{b}, \mathrm{c}$ & 2017 & $200 \mathrm{mg} / \mathrm{kg}$ & 11 \\
\hline
\end{tabular}

No. de Categoría de alimento 08.0

\begin{tabular}{|c|c|c|c|c|}
\hline Aditivo & SIN & Año Adoptada & Dosis máxima & Notas \\
\hline AZUL BRILLANTE FCF & 133 & 2014 & $100 \mathrm{mg} / \mathrm{kg}$ & $\begin{array}{c}\text { 4, 16, XS88, } \\
\text { XS89, XS96, XS97 } \\
\text { \& XS98 }\end{array}$ \\
\hline $\begin{array}{l}\text { CARAMELO III - CARAMELO AL } \\
\text { AMONÍACO }\end{array}$ & $150 c$ & 2014 & BPF & $\begin{array}{c}\text { 3, 4, 16, XS88, } \\
\text { XS89, XS96, XS97 } \\
\text { \& XS98 }\end{array}$ \\
\hline $\begin{array}{l}\text { CARAMELO IV - CARAMELO AL SULFITO } \\
\text { AMÓNICO }\end{array}$ & $150 d$ & 2014 & BPF & $\begin{array}{c}\text { 3, 4, 16, XS88, } \\
\text { XS89, XS96, XS97 } \\
\text { \& XS98 }\end{array}$ \\
\hline
\end{tabular}

Carne y productos cárnicos, incluidos los de aves de corral y caza
Carne fresca, incluida la de aves de corral y caza

\begin{tabular}{llccc} 
Aditivo & SIN & Año Adoptada & Dosis máxima & Notas \\
\hline AMARILLO OCASO FCF & 110 & 2008 & $300 \mathrm{mg} / \mathrm{kg}$ & $4 \& 16$ \\
GLUTAMATO MONOAMÓNICO, L- & 624 & 2014 & BPF & 16 \\
GLUTAMATO MONOSÓDICO, L- & 621 & 2014 & BPF & 16 \\
GUANILATO DISÓDICO, 5'- & 627 & 2014 & BPF & 16 \\
INOSINATO DISÓDICO, 5'- & 631 & 2014 & BPF & 16 \\
VERDE SÓLIDO FCF & 143 & 2009 & $100 \mathrm{mg} / \mathrm{kg}$ & $3,4 \& 16$ \\
\hline
\end{tabular}

No. de Categoría de alimento 08.1.1 Carne fresca, incluida la de aves de corral y caza, en piezas enteras o en cortes

\begin{tabular}{|c|c|c|c|c|}
\hline Aditivo & $\sin$ & Año Adoptada & Dosis máxima & Notas \\
\hline AGAR & 406 & 2015 & BPF & $16 \& 326$ \\
\hline ALGA EUCHEUMA ELABORADA & $407 a$ & 2015 & BPF & $16 \& 326$ \\
\hline ALGINATO DE SODIO & 401 & 2015 & BPF & $16 \& 326$ \\
\hline
\end{tabular}




\section{No. de Categoría de alimento 08.1.1 Carne fresca, incluida la de aves de corral y caza, en piezas enteras o en} cortes

\begin{tabular}{|c|c|c|c|c|}
\hline Aditivo & $\operatorname{SIN}$ & Año Adoptada & Dosis máxima & Notas \\
\hline ALMIDÓN HIDROXIPROPÍLICO & 1440 & 2015 & BPF & $16 \& 326$ \\
\hline ALMIDÓN OXIDADO & 1404 & 2015 & BPF & $16 \& 326$ \\
\hline BROMELINA & 1101(iii) & 2015 & BPF & $16 \& 326$ \\
\hline CARBONATO DE CALCIO & $170(i)$ & 2015 & BPF & $4,16 \& 326$ \\
\hline $\begin{array}{l}\text { CARBOXIMETILCELULOSA SÓDICA } \\
\text { (GOMA DE CELULOSA) }\end{array}$ & 466 & 2015 & BPF & $16 \& 326$ \\
\hline CARMINES & 120 & 2008 & $500 \mathrm{mg} / \mathrm{kg}$ & $4,16 \& 178$ \\
\hline CARRAGENINA & 407 & 2015 & BPF & $16 \& 326$ \\
\hline CELULOSA EN POLVO & 460(ii) & 2015 & BPF & $16 \& 326$ \\
\hline $\begin{array}{l}\text { CELULOSA MICROCRISTALINA (GEL DE } \\
\text { CELULOSA) }\end{array}$ & $460(i)$ & 2015 & BPF & $16 \& 326$ \\
\hline CITRATO DÍACIDO DE POTASIO & 332(i) & 2015 & BPF & $16 \& 326$ \\
\hline CITRATO DÍACIDO DE SODIO & 331 (i) & 2015 & BPF & $16 \& 326$ \\
\hline CITRATO TRIPOTÁSICO & 332(ii) & 2015 & BPF & $16 \& 326$ \\
\hline CITRATO TRISÓDICO & 331(iii) & 2015 & BPF & $16 \& 326$ \\
\hline CLORURO DE CALCIO & 509 & 2015 & BPF & $16 \& 326$ \\
\hline CLORURO DE MAGNESIO & 511 & 2015 & BPF & $16 \& 326$ \\
\hline CLORURO DE POTASIO & 508 & 2015 & BPF & $16 \& 326$ \\
\hline $\begin{array}{l}\text { ÉSTERES ACÉTICOS Y DE ÁCIDOS } \\
\text { GRASOS DE GLICEROL }\end{array}$ & $472 a$ & 2015 & BPF & $16 \& 326$ \\
\hline $\begin{array}{l}\text { ÉSTERES CÍTRICOS Y DE ÁCIDOS } \\
\text { GRASOS DE GLICEROL }\end{array}$ & $472 \mathrm{c}$ & 2015 & BPF & $16 \& 326$ \\
\hline $\begin{array}{l}\text { ÉSTERES LÁCTICOS Y DE ÁCIDOS } \\
\text { GRASOS DE GLICEROL }\end{array}$ & $472 b$ & 2015 & BPF & $16 \& 326$ \\
\hline FOSFATO DE DIALMIDÓN ACETILADO & 1414 & 2015 & BPF & $16 \& 326$ \\
\hline GLICEROL & 422 & 2015 & BPF & $16 \& 326$ \\
\hline GOMA ARÁBIGA (GOMA DE ACACIA) & 414 & 2015 & BPF & $16 \& 326$ \\
\hline GOMA GELLAN & 418 & 2015 & BPF & $16 \& 326$ \\
\hline GOMA KARAYA & 416 & 2015 & BPF & $16 \& 326$ \\
\hline GOMA TARA & 417 & 2015 & BPF & $16 \& 326$ \\
\hline GOMA TRAGACANTO & 413 & 2015 & BPF & $16 \& 326$ \\
\hline GOMA XANTANA & 415 & 2015 & BPF & $16 \& 326$ \\
\hline HARINA KONJAC & 425 & 2015 & BPF & $16 \& 326$ \\
\hline HIDROXIPROPILCELULOSA & 463 & 2015 & BPF & $16 \& 326$ \\
\hline HIDROXIPROPILMETILCELULOSA & 464 & 2015 & BPF & $16 \& 326$ \\
\hline LECITINA & $322(i)$ & 2015 & BPF & $16 \& 326$ \\
\hline MANITOL & 421 & 2015 & BPF & $16 \& 326$ \\
\hline METILCELULOSA & 461 & 2015 & BPF & $16 \& 326$ \\
\hline METILETILCELULOSA & 465 & 2015 & BPF & $16 \& 326$ \\
\hline MONOGLICÉRIDOS Y DIGLICÉRIDOS DE & 471 & 2015 & BPF & $16 \& 326$ \\
\hline
\end{tabular}




\begin{tabular}{|c|c|c|c|c|}
\hline \multicolumn{2}{|c|}{ No. de Categoría de alimento 08.1.1 } & \multicolumn{3}{|c|}{$\begin{array}{l}\text { Carne fresca, incluida la de aves de } \\
\text { corral y caza, en piezas enteras o en } \\
\text { cortes }\end{array}$} \\
\hline Aditivo & SIN & Año Adoptada & Dosis máxima & Notas \\
\hline PECTINAS & 440 & 2015 & BPF & $16 \& 326$ \\
\hline $\begin{array}{l}\text { SAL DE ÁCIDO OLEICO CON CALCIO, } \\
\text { POTASIO Y SODIO }\end{array}$ & 470(ii) & 2015 & BPF & $16 \& 326$ \\
\hline $\begin{array}{l}\text { SAL MIRÍSTICA, PALMÍTICA Y ÁCIDOS } \\
\text { ESTEÁRICOS CON AMONIO, CALCIO, } \\
\text { POTASIO Y SODIO }\end{array}$ & $470(i)$ & 2015 & BPF & $16,71 \& 326$ \\
\hline
\end{tabular}

\section{No. de Categoría de alimento 08.1.2 Carne fresca picada, incluida la de aves} de corral y caza

\begin{tabular}{|c|c|c|c|c|}
\hline Aditivo & SIN & Año Adoptada & Dosis máxima & Notas \\
\hline ÁCIDO ASCÓRBICO, L- & 300 & 2014 & BPF & 281 \\
\hline ÁCIDO CÍTRICO & 330 & 2014 & BPF & $15 \& 281$ \\
\hline $\begin{array}{l}\text { ÁCIDO ERITÓRBICO (ACIDO } \\
\text { ISOASCÓBICO) }\end{array}$ & 315 & 2014 & BPF & 281 \\
\hline AGAR & 406 & 2015 & BPF & 281 \\
\hline ALGA EUCHEUMA ELABORADA & $407 a$ & 2015 & BPF & 281 \\
\hline ALGINATO DE SODIO & 401 & 2014 & BPF & 281 \\
\hline ALMIDÓN HIDROXIPROPÍLICO & 1440 & 2014 & BPF & 281 \\
\hline ALMIDÓN OXIDADO & 1404 & 2014 & BPF & 281 \\
\hline ASCORBATO DE CALCIO & 302 & 2014 & BPF & 281 \\
\hline ASCORBATO DE SODIO & 301 & 2014 & BPF & 281 \\
\hline CARBONATO DE CALCIO & $170(\mathrm{i})$ & 2014 & BPF & $4,16 \& 281$ \\
\hline $\begin{array}{l}\text { CARBOXIMETILCELULOSA SÓDICA } \\
\text { (GOMA DE CELULOSA) }\end{array}$ & 466 & 2014 & BPF & 281 \\
\hline CARMINES & 120 & 2008 & $100 \mathrm{mg} / \mathrm{kg}$ & $4,16,117 \& 178$ \\
\hline CAROTENOIDES & $160 a(i), a(i i i), e, f$ & 2011 & $100 \mathrm{mg} / \mathrm{kg}$ & $4 \& 16$ \\
\hline CAROTENOS, BETA-, VEGETALES & $160 a(i i)$ & 2011 & $20 \mathrm{mg} / \mathrm{kg}$ & $4 \& 16$ \\
\hline CARRAGENINA & 407 & 2015 & BPF & 281 \\
\hline CELULOSA EN POLVO & 460 (ii) & 2014 & BPF & 281 \\
\hline $\begin{array}{l}\text { CELULOSA MICROCRISTALINA (GEL DE } \\
\text { CELULOSA) }\end{array}$ & $460(i)$ & 2014 & BPF & 281 \\
\hline CITRATO DÍACIDO DE POTASIO & 332(i) & 2014 & BPF & 281 \\
\hline CITRATO DÍACIDO DE SODIO & 331 (i) & 2014 & BPF & 281 \\
\hline CITRATO TRICÁLCICO & 333(iii) & 2014 & BPF & 281 \\
\hline CITRATO TRIPOTÁSICO & 332(ii) & 2014 & BPF & 281 \\
\hline CITRATO TRISÓDICO & 331 (iii) & 2014 & BPF & 281 \\
\hline CITRATOS DE ISOPROPILO & 384 & 2001 & $200 \mathrm{mg} / \mathrm{kg}$ & \\
\hline CLORURO DE MAGNESIO & 511 & 2014 & BPF & 281 \\
\hline $\begin{array}{l}\text { ÉSTERES ACÉTICOS Y DE ÁCIDOS } \\
\text { GRASOS DE GLICEROL }\end{array}$ & $472 a$ & 2014 & BPF & 281 \\
\hline $\begin{array}{l}\text { ÉSTERES CÍTRICOS Y DE ÁCIDOS } \\
\text { GRASOS DE GLICEROL }\end{array}$ & $472 \mathrm{c}$ & 2014 & BPF & 281 \\
\hline
\end{tabular}




\begin{tabular}{|c|c|c|c|c|}
\hline \multicolumn{2}{|c|}{ No. de Categoría de alimento 08.1.2 } & \multicolumn{3}{|c|}{$\begin{array}{l}\text { Carne fresca picada, incluida la de aves } \\
\text { de corral y caza }\end{array}$} \\
\hline Aditivo & $\operatorname{SiN}$ & Año Adoptada & Dosis máxima & Notas \\
\hline $\begin{array}{l}\text { ÉSTERES LÁCTICOS Y DE ÁCIDOS } \\
\text { GRASOS DE GLICEROL }\end{array}$ & $472 b$ & 2014 & BPF & 281 \\
\hline EXTRACTO DE PIEL DE UVA & 163(ii) & 2010 & $1000 \mathrm{mg} / \mathrm{kg}$ & $4,16 \& 94$ \\
\hline FOSFATO DE DIALMIDÓN ACETILADO & 1414 & 2014 & BPF & 281 \\
\hline GLICEROL & 422 & 2014 & BPF & \\
\hline GOMA ARÁBIGA (GOMA DE ACACIA) & 414 & 2014 & BPF & 281 \\
\hline GOMA DE SEMILLAS DE ALGARROBO & 410 & 2014 & BPF & 281 \\
\hline GOMA GELLAN & 418 & 2014 & BPF & 281 \\
\hline GOMA GUAR & 412 & 2014 & BPF & 281 \\
\hline GOMA KARAYA & 416 & 2014 & BPF & 281 \\
\hline GOMA TARA & 417 & 2015 & BPF & 281 \\
\hline GOMA TRAGACANTO & 413 & 2014 & BPF & 281 \\
\hline GOMA XANTANA & 415 & 2015 & BPF & 281 \\
\hline HARINA KONJAC & 425 & 2015 & BPF & 281 \\
\hline HIDROXIPROPILCELULOSA & 463 & 2014 & BPF & 281 \\
\hline HIDROXIPROPILMETILCELULOSA & 464 & 2014 & BPF & 281 \\
\hline LACTATO DE CALCIO & 327 & 2014 & BPF & 281 \\
\hline LECITINA & 322(i) & 2014 & BPF & 281 \\
\hline MANITOL & 421 & 2015 & BPF & 281 \\
\hline METILCELULOSA & 461 & 2014 & BPF & 281 \\
\hline METILETILCELULOSA & 465 & 2014 & BPF & 281 \\
\hline $\begin{array}{l}\text { MONOGLICÉRIDOS Y DIGLICÉRIDOS DE } \\
\text { ÁCIDOS GRASOS }\end{array}$ & 471 & 2014 & BPF & 281 \\
\hline PECTINAS & 440 & 2015 & BPF & 281 \\
\hline $\begin{array}{l}\text { SAL DE ÁCIDO OLEICO CON CALCIO, } \\
\text { POTASIO Y SODIO }\end{array}$ & 470(ii) & 2014 & BPF & 281 \\
\hline $\begin{array}{l}\text { SAL MIRÍSTICA, PALMÍTICA Y ÁCIDOS } \\
\text { ESTEÁRICOS CON AMONIO, CALCIO, } \\
\text { POTASIO Y SODIO }\end{array}$ & $470(\mathrm{i})$ & 2014 & BPF & $71 \& 281$ \\
\hline TOCOFEROLES & $307 a, b, c$ & 2017 & $300 \mathrm{mg} / \mathrm{kg}$ & $15 \& 281$ \\
\hline
\end{tabular}

No. de Categoría de alimento 08.2

Productos cárnicos, de aves de corral y caza elaborados, en piezas enteras o en cortes

\begin{tabular}{llccc}
\hline Aditivo & SIN & Año Adoptada & Dosis máxima & Notas \\
\hline AMARILLO OCASO FCF & 110 & 2014 & $300 \mathrm{mg} / \mathrm{kg}$ & $\begin{array}{c}16, \text { XS96 \& XS97 } \\
\text { BUTILHIDROXIANISOL }\end{array}$ \\
BUTILHIDROXITOLUENO & 320 & 2014 & $200 \mathrm{mg} / \mathrm{kg}$ & $\begin{array}{c}15,130, \text { XS96 \& } \\
\text { XS97 }\end{array}$ \\
CARMINES & 321 & 2014 & $100 \mathrm{mg} / \mathrm{kg}$ & $\begin{array}{c}15,130,167, \\
\text { XS96 \& XS97 }\end{array}$ \\
CAROTENOS, BETA-, VEGETALES & 120 & 2014 & $500 \mathrm{mg} / \mathrm{kg}$ & $\begin{array}{c}16,178, \text { XS96 \& } \\
\text { XS97 }\end{array}$ \\
DIACETATO DE SODIO & 160 a(ii) & 2014 & $5000 \mathrm{mg} / \mathrm{kg}$ & $\begin{array}{c}16, \text { XS96 \& XS97 } \\
\text { XS96 \& XS97 }\end{array}$
\end{tabular}




\begin{tabular}{|c|c|c|c|c|}
\hline \multicolumn{2}{|c|}{ No. de Categoría de alimento 08.2} & \multicolumn{3}{|c|}{$\begin{array}{l}\text { Productos cárnicos, de aves de corral y } \\
\text { caza elaborados, en piezas enteras o en } \\
\text { cortes }\end{array}$} \\
\hline Aditivo & SIN & Año Adoptada & Dosis máxima & Notas \\
\hline ERITROSINA & 127 & 2014 & 30 mg/kg & $\begin{array}{c}4,16, \text { XS96 \& } \\
\text { XS97 }\end{array}$ \\
\hline EXTRACTO DE PIEL DE UVA & 163(ii) & 2014 & $5000 \mathrm{mg} / \mathrm{kg}$ & 16, XS96 \& XS97 \\
\hline GALATO DE PROPILO & 310 & 2014 & 200 mg/kg & $\begin{array}{c}15,130, \text { XS96 \& } \\
\text { XS97 }\end{array}$ \\
\hline POLISORBATOS & $432-436$ & 2014 & $5000 \mathrm{mg} / \mathrm{kg}$ & XS96 \& XS97 \\
\hline RIBOFLAVINAS & 101(i),(ii), (iii) & 2014 & $1000 \mathrm{mg} / \mathrm{kg}$ & 16, XS96 \& XS97 \\
\hline TERBUTILHIDROQUINONA & 319 & 2014 & $100 \mathrm{mg} / \mathrm{kg}$ & $\begin{array}{l}15,130,167 \\
\text { XS96 \& XS97 }\end{array}$ \\
\hline TOCOFEROLES & $307 a, b, c$ & 2016 & $500 \mathrm{mg} / \mathrm{kg}$ & XS96 \& XS97 \\
\hline VERDE SÓLIDO FCF & 143 & 2014 & $100 \mathrm{mg} / \mathrm{kg}$ & 3,4, XS96 \& XS97 \\
\hline
\end{tabular}

\begin{tabular}{|c|c|c|c|c|}
\hline \multicolumn{2}{|c|}{ No. de Categoría de alimento 08.2.1 } & \multicolumn{3}{|c|}{$\begin{array}{l}\text { Productos cárnicos, de aves de corral y } \\
\text { caza elaborados sin tratamiento } \\
\text { térmico, en piezas enteras o en cortes }\end{array}$} \\
\hline Aditivo & SIN & Año Adoptada & Dosis máxima & Notas \\
\hline ETIL-LAUROIL ARGINATO & 243 & 2016 & $200 \mathrm{mg} / \mathrm{kg}$ & \\
\hline FOSFATOS & $\begin{array}{l}\text { 338; 339(i)-(iii); } \\
340(\mathrm{i})-(\mathrm{iii}) ; 341(\mathrm{i})- \\
\text { (iii); 342(i)-(ii); } \\
343(\mathrm{i})-(\mathrm{iii}) ; 450(\mathrm{i})- \\
\text { (iii),(v)-(vii), (ix); } \\
451(\mathrm{i}),(\mathrm{ii)} ; 452(\mathrm{i})- \\
\text { (v); } 542\end{array}$ & 2012 & $2200 \mathrm{mg} / \mathrm{kg}$ & 33 \\
\hline
\end{tabular}

No. de Categoría de alimento 08.2.1.1 Productos cárnicos, de aves de corral y caza elaborados, curados (incluidos los salados) y sin tratamiento térmico, en piezas enteras o en cortes

\begin{tabular}{|c|c|c|c|c|}
\hline Aditivo & SIN & Año Adoptada & Dosis máxima & Notas \\
\hline SORBATOS & $200,202,203$ & 2016 & $200 \mathrm{mg} / \mathrm{kg}$ & $3 \& 42$ \\
\hline
\end{tabular}

No. de Categoría de alimento 08.2.1.2 $\quad$ Productos cárnicos, de aves de corral y caza elaborados, curados (incluidos los salados), desecados y sin tratamiento térmico, en piezas enteras o en cortes

\begin{tabular}{|c|c|c|c|c|}
\hline Aditivo & SIN & Año Adoptada & Dosis máxima & Notas \\
\hline BENZOATOS & $210-213$ & 2005 & $1000 \mathrm{mg} / \mathrm{kg}$ & $3 \& 13$ \\
\hline CITRATOS DE ISOPROPILO & 384 & 2001 & $200 \mathrm{mg} / \mathrm{kg}$ & \\
\hline NATAMICINA (PIMARICINA) & 235 & 2001 & $6 \mathrm{mg} / \mathrm{kg}$ & \\
\hline SORBATOS & $200,202,203$ & 2016 & $2000 \mathrm{mg} / \mathrm{kg}$ & $3 \& 42$ \\
\hline
\end{tabular}


No. de Categoría de alimento 08.2.1.3 Productos cárnicos, de aves de corral y caza elaborados, fermentados y sin tratamiento térmico, en piezas enteras o en cortes

\begin{tabular}{|c|c|c|c|c|}
\hline Aditivo & SIN & Año Adoptada & Dosis máxima & Notas \\
\hline SORBATOS & $200,202,203$ & 2016 & $200 \mathrm{mg} / \mathrm{kg}$ & $3 \& 42$ \\
\hline No. de Categoría de alimento & $\begin{array}{l}\text { P } \\
\text { C } \\
\text { te } \\
\text { C }\end{array}$ & \multicolumn{3}{|c|}{$\begin{array}{l}\text { Productos cárnicos, de aves de corral y } \\
\text { caza elaborados, tratados } \\
\text { térmicamente, en piezas enteras o en } \\
\text { cortes }\end{array}$} \\
\hline Aditivo & SIN & Año Adoptada & Dosis máxima & Notas \\
\hline ESTEAROIL LACTILATOS & 481(i), 482(i) & 2016 & $2000 \mathrm{mg} / \mathrm{kg}$ & 373, XS96 \& XS97 \\
\hline ETIL-LAUROIL ARGINATO & 243 & 2019 & $200 \mathrm{mg} / \mathrm{kg}$ & 396 \\
\hline FOSFATOS & $\begin{array}{l}\text { 338; 339(i)-(iii); } \\
340(\mathrm{i})-(\mathrm{iii)} ; 341 \text { (i)- } \\
\text { (iii); 342(i)-(ii); } \\
343(\mathrm{i})-(\mathrm{iii)} ; 450(\mathrm{i})- \\
\text { (iii),(v)-(vii), (ix); } \\
\text { 451(i),(ii); 452(i)-- } \\
\text { (v); } 542\end{array}$ & 2014 & $1320 \mathrm{mg} / \mathrm{kg}$ & $33 \& 289$ \\
\hline NISINA & 234 & 2015 & $25 \mathrm{mg} / \mathrm{kg}$ & $\begin{array}{c}233,330, \text { XS96 \& } \\
\text { XS97 }\end{array}$ \\
\hline NITRITOS & 249,250 & 2014 & $80 \mathrm{mg} / \mathrm{kg}$ & $32 \& 288$ \\
\hline SACARINAS & 954(i)-(iv) & 2014 & $500 \mathrm{mg} / \mathrm{kg}$ & 161, XS96 \& XS97 \\
\hline SORBATOS & $200,202,203$ & 2016 & $200 \mathrm{mg} / \mathrm{kg}$ & $\begin{array}{c}\text { 3, 42, XS96 \& } \\
\text { XS97 }\end{array}$ \\
\hline SUCROÉSTERES DE ÁCIDOS GRASOS & 473 & 2016 & $5000 \mathrm{mg} / \mathrm{kg}$ & 15, XS96 \& XS97 \\
\hline SUCROGLICÉRIDOS & 474 & 2014 & $5000 \mathrm{mg} / \mathrm{kg}$ & 15, XS96 \& XS97 \\
\hline
\end{tabular}

No. de Categoría de alimento 08.2.3

Productos cárnicos, de aves de corral y caza elaborados, congelados, en piezas enteras o en cortes

\begin{tabular}{|c|c|c|c|c|}
\hline Aditivo & $\operatorname{SiN}$ & Año Adoptada & Dosis máxima & Notas \\
\hline ACEITE MINERAL DE ALTA VISCOSIDAD & $905 d$ & 2004 & $950 \mathrm{mg} / \mathrm{kg}$ & 3 \\
\hline ETIL-LAUROIL ARGINATO & 243 & 2016 & 200 mg/kg & $3 \& 374$ \\
\hline FOSFATOS & $\begin{array}{l}\text { 338; 339(i)-(iii); } \\
340 \text { (i)-(iii); 341(i)- } \\
\text { (iii); 342(i)-(ii); } \\
343(\text { i)-(iii); 450(i)- } \\
\text { (iii),(v)-(vii), (ix); } \\
\text { 451(i),(ii); } 452(i)- \\
\text { (v); } 542\end{array}$ & 2009 & $2200 \mathrm{mg} / \mathrm{kg}$ & 33 \\
\hline SORBATOS & $200,202,203$ & 2016 & 200 mg/kg & $3 \& 42$ \\
\hline No. de Categoría de alimento & 08.3 & \multicolumn{3}{|c|}{$\begin{array}{l}\text { Productos cárnicos, de aves de corral y } \\
\text { caza picados y elaborados }\end{array}$} \\
\hline Aditivo & $\operatorname{SiN}$ & Año Adoptada & Dosis máxima & Notas \\
\hline ALGINATO DE PROPILENGLICOL & 405 & 2016 & $3000 \mathrm{mg} / \mathrm{kg}$ & $\begin{array}{c}\text { XS88, XS89 \& } \\
\text { XS98 }\end{array}$ \\
\hline
\end{tabular}




\begin{tabular}{|c|c|c|c|c|}
\hline \multicolumn{2}{|c|}{ No. de Categoría de alimento 08.3} & \multicolumn{3}{|c|}{$\begin{array}{l}\text { Productos cárnicos, de aves de corral y } \\
\text { caza picados y elaborados }\end{array}$} \\
\hline Aditivo & SIN & Año Adoptada & Dosis máxima & Notas \\
\hline BUTILHIDROXIANISOL & 320 & 2014 & 200 mg/kg & $\begin{array}{r}15,130, \text { XS88, } \\
\text { XS89 \& XS98 }\end{array}$ \\
\hline BUTILHIDROXITOLUENO & 321 & 2014 & $100 \mathrm{mg} / \mathrm{kg}$ & $\begin{array}{l}15,130,162 \\
\text { XS88, XS89 \& } \\
\quad \text { XS98 }\end{array}$ \\
\hline DIACETATO DE SODIO & 262(ii) & 2016 & $1000 \mathrm{mg} / \mathrm{kg}$ & $\begin{array}{c}\text { XS88, XS89 \& } \\
\text { XS98 }\end{array}$ \\
\hline ERITROSINA & 127 & 2014 & $30 \mathrm{mg} / \mathrm{kg}$ & $4,290 \& X S 88$ \\
\hline EXTRACTO DE PIEL DE UVA & 163(ii) & 2014 & $5000 \mathrm{mg} / \mathrm{kg}$ & $\begin{array}{c}\text { 16, XS88, XS89 \& } \\
\text { XS98 }\end{array}$ \\
\hline FOSFATOS & $\begin{array}{l}338 ; 339(i)-(i i i) ; \\
340(\text { i)-(iii); } 341(\text { i)-- } \\
\text { (iii); 342(i)-(ii); } \\
343(\text { (i)-(iii); } 450(\text { i)- } \\
\text { (iii),(v)-(vii), (ix); } \\
451 \text { (i),(ii); 452(i)- } \\
\text { (v); } 542\end{array}$ & 2015 & $2200 \mathrm{mg} / \mathrm{kg}$ & $33,302 \&$ XS88 \\
\hline GALATO DE PROPILO & 310 & 2014 & $200 \mathrm{mg} / \mathrm{kg}$ & $\begin{array}{r}15,130, \text { XS88, } \\
\text { XS89 \& XS98 }\end{array}$ \\
\hline NITRITOS & 249,250 & 2014 & $80 \mathrm{mg} / \mathrm{kg}$ & $32,286 \& 287$ \\
\hline POLISORBATOS & $432-436$ & 2014 & $5000 \mathrm{mg} / \mathrm{kg}$ & $\begin{array}{c}\text { XS88, XS89 \& } \\
\text { XS98 }\end{array}$ \\
\hline RIBOFLAVINAS & 101(i),(ii), (iii) & 2014 & $1000 \mathrm{mg} / \mathrm{kg}$ & $\begin{array}{c}\text { 16, XS88, XS89 \& } \\
\text { XS98 }\end{array}$ \\
\hline SORBATOS & $200,202,203$ & 2016 & $1500 \mathrm{mg} / \mathrm{kg}$ & $\begin{array}{c}\text { 42, XS88, XS89 \& } \\
\text { XS98 }\end{array}$ \\
\hline TERBUTILHIDROQUINONA & 319 & 2014 & $100 \mathrm{mg} / \mathrm{kg}$ & $\begin{array}{l}15,130,162 \\
\text { XS88, XS89 \& } \\
\quad \text { XS98 }\end{array}$ \\
\hline TOCOFEROLES & $307 a, b, c$ & 2016 & $500 \mathrm{mg} / \mathrm{kg}$ & $\begin{array}{c}\text { XS88, XS89 \& } \\
\text { XS98 }\end{array}$ \\
\hline
\end{tabular}

\begin{tabular}{ll}
\hline No. de Categoría de alimento 08.3.1 & $\begin{array}{l}\text { Productos cárnicos, de aves de corral y } \\
\text { caza picados y elaborados sin } \\
\text { tratamiento térmico }\end{array}$
\end{tabular}

\begin{tabular}{|c|c|c|c|c|}
\hline Aditivo & SIN & Año Adoptada & Dosis máxima & Notas \\
\hline CAROTENOS, BETA-, VEGETALES & 160a(ii) & 2005 & $20 \mathrm{mg} / \mathrm{kg}$ & 118 \\
\hline ETIL-LAUROIL ARGINATO & 243 & 2016 & $315 \mathrm{mg} / \mathrm{kg}$ & \\
\hline TARTRATOS & 334, 335(ii), 337 & 2017 & $500 \mathrm{mg} / \mathrm{kg}$ & 45 \\
\hline
\end{tabular}

No. de Categoría de alimento 08.3.1.1 Productos cárnicos, de aves de corral y caza picados y elaborados, curados (incluidos los salados) y sin tratamiento térmico

\begin{tabular}{|c|c|c|c|c|}
\hline Aditivo & SIN & Año Adoptada & Dosis máxima & Notas \\
\hline AMARILLO OCASO FCF & 110 & 2008 & 300 mg/kg & 16 \\
\hline CANTAXANTINA & $161 \mathrm{~g}$ & 2011 & $100 \mathrm{mg} / \mathrm{kg}$ & $4,16 \& 118$ \\
\hline CARMINES & 120 & 2005 & $200 \mathrm{mg} / \mathrm{kg}$ & $118 \& 178$ \\
\hline
\end{tabular}




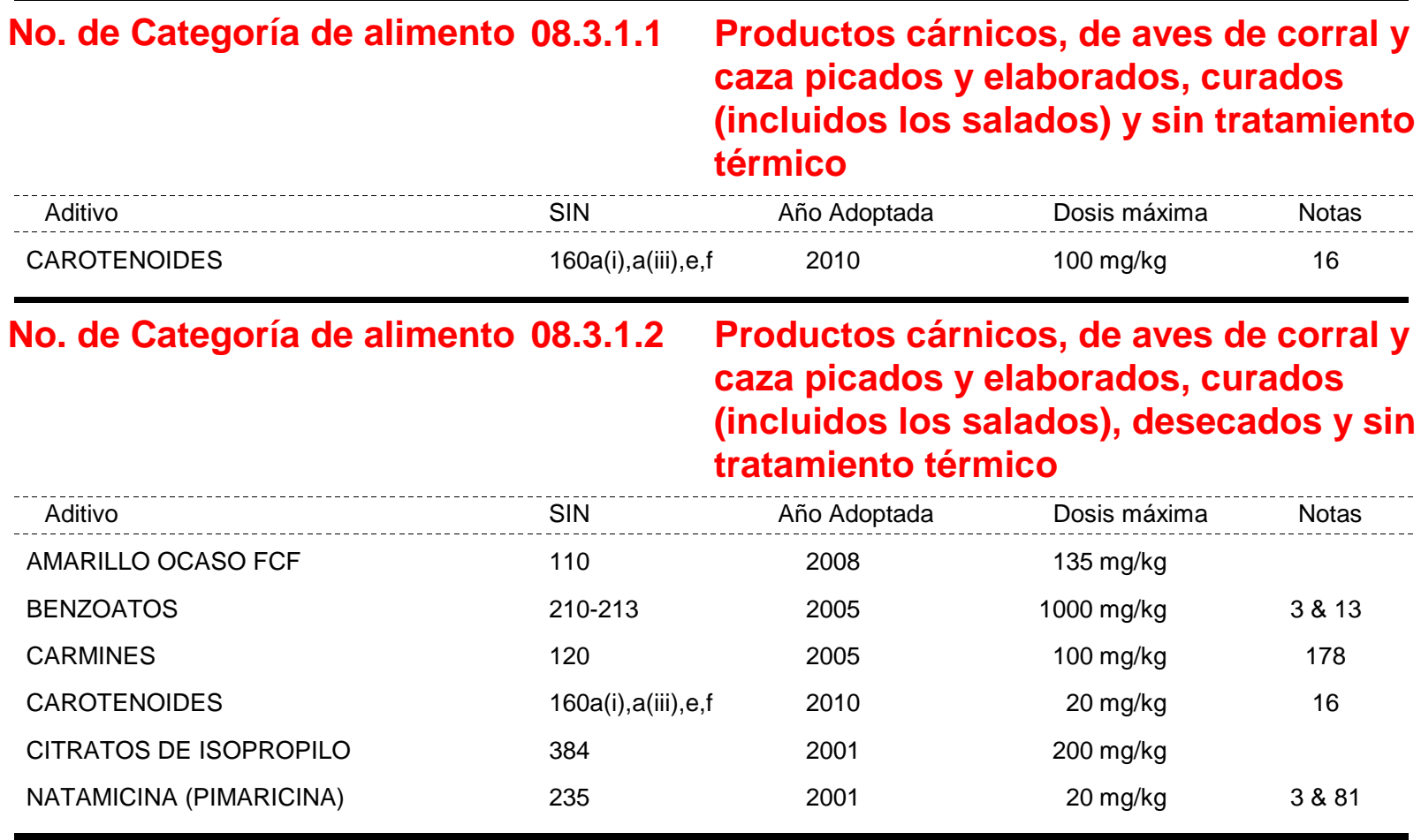

No. de Categoría de alimento 08.3.1.3 Productos cárnicos, de aves de corral y caza picados, elaborados, fermentados y sin tratamiento térmico

\begin{tabular}{llccc} 
Aditivo & SIN & Año Adoptada & Dosis máxima & Notas \\
\hdashline AMARILLO OCASO FCF & 110 & 2008 & $300 \mathrm{mg} / \mathrm{kg}$ & 16 \\
CARMINES & 120 & 2005 & $100 \mathrm{mg} / \mathrm{kg}$ & 178 \\
CAROTENOIDES & $160 \mathrm{a}(\mathrm{i}), \mathrm{a}(\mathrm{iii}), \mathrm{e}, \mathrm{f}$ & 2010 & $20 \mathrm{mg} / \mathrm{kg}$ & 16 \\
\hline
\end{tabular}

No. de Categoría de alimento 08.3.2 Productos cárnicos, de aves de corral y caza picados, elaborados y tratados térmicamente

\begin{tabular}{|c|c|c|c|c|}
\hline Aditivo & SIN & Año Adoptada & Dosis máxima & Notas \\
\hline AMARILLO OCASO FCF & 110 & 2014 & $300 \mathrm{mg} / \mathrm{kg}$ & $\begin{array}{c}\text { 16, XS88, XS89 \& } \\
\text { XS98 }\end{array}$ \\
\hline CARMINES & 120 & 2014 & $100 \mathrm{mg} / \mathrm{kg}$ & $\begin{array}{c}\text { 178, XS88, XS89 } \\
\text { \& XS98 }\end{array}$ \\
\hline CAROTENOIDES & 160a(i),a(iii),e,f & 2014 & $20 \mathrm{mg} / \mathrm{kg}$ & $\begin{array}{c}16, \text { XS88, XS89 \& } \\
\text { XS98 }\end{array}$ \\
\hline CAROTENOS, BETA-, VEGETALES & 160a(ii) & 2014 & $20 \mathrm{mg} / \mathrm{kg}$ & $\begin{array}{c}\text { XS88, XS89 \& } \\
\text { XS98 }\end{array}$ \\
\hline ESTEAROIL LACTILATOS & 481(i), 482(i) & 2016 & 2000 mg/kg & $\begin{array}{c}\text { XS88, XS89 \& } \\
\text { XS98 }\end{array}$ \\
\hline ETILEN DIAMINO TETRA ACETATOS & 385,386 & 2014 & $35 \mathrm{mg} / \mathrm{kg}$ & $\begin{array}{c}21, \text { XS88, XS89 \& } \\
\text { XS98 }\end{array}$ \\
\hline ETIL-LAUROIL ARGINATO & 243 & 2019 & $200 \mathrm{mg} / \mathrm{kg}$ & 377 \\
\hline GLICÓSIDOS DE ESTEVIOL & $960 \mathrm{a}, 960 \mathrm{~b}(\mathrm{i})$ & 2014 & $100 \mathrm{mg} / \mathrm{kg}$ & $\begin{array}{r}\text { 26, 202, XS88, } \\
\text { XS89 \& XS98 }\end{array}$ \\
\hline NISINA & 234 & 2016 & $25 \mathrm{mg} / \mathrm{kg}$ & $233 \& 377$ \\
\hline
\end{tabular}




\begin{tabular}{|c|c|c|c|c|}
\hline No. de Categoría de alimento & 08.3 .2 & \multicolumn{3}{|c|}{$\begin{array}{l}\text { Productos cárnicos, de aves de corral y } \\
\text { caza picados, elaborados y tratados } \\
\text { térmicamente }\end{array}$} \\
\hline Aditivo & SIN & Año Adoptada & Dosis máxima & Notas \\
\hline ROJO ALLURA AC & 129 & 2014 & $25 \mathrm{mg} / \mathrm{kg}$ & $\begin{array}{c}\text { 161, XS88, XS89 } \\
\& \text { XS98 }\end{array}$ \\
\hline SACARINAS & 954(i)-(iv) & 2014 & $500 \mathrm{mg} / \mathrm{kg}$ & $\begin{array}{c}161, \text { XS88, XS89 } \\
\& \text { XS98 }\end{array}$ \\
\hline SUCROÉSTERES DE ÁCIDOS GRASOS & 473 & 2016 & $5000 \mathrm{mg} / \mathrm{kg}$ & $\begin{array}{c}15,373, \text { XS96 \& } \\
\text { XS97 }\end{array}$ \\
\hline SUCROGLICÉRIDOS & 474 & 2014 & $5000 \mathrm{mg} / \mathrm{kg}$ & $\begin{array}{c}15, \text { XS88, XS89 \& } \\
\text { XS98 }\end{array}$ \\
\hline TARTRATOS & 334, 335(ii), 337 & 2017 & $500 \mathrm{mg} / \mathrm{kg}$ & $\begin{array}{c}45, \text { XS88, XS89 \& } \\
\text { XS98 }\end{array}$ \\
\hline No. de Categoría de alimento & 08.3 .3 & $\begin{array}{l}\text { ductos cá } \\
\text { za picados }\end{array}$ & $\begin{array}{l}\text { s, de aves } \\
\text { orados y c }\end{array}$ & $\begin{array}{l}\text { de corral y } \\
\text { ongelados }\end{array}$ \\
\hline Aditivo & $\operatorname{SIN}$ & Año Adoptada & Dosis máxima & Notas \\
\hline ACEITE MINERAL DE ALTA VISCOSIDAD & $905 d$ & 2004 & $950 \mathrm{mg} / \mathrm{kg}$ & 3 \\
\hline AMARILLO OCASO FCF & 110 & 2008 & $300 \mathrm{mg} / \mathrm{kg}$ & 16 \\
\hline CARMINES & 120 & 2005 & $500 \mathrm{mg} / \mathrm{kg}$ & $16 \& 178$ \\
\hline CAROTENOS, BETA-, VEGETALES & $160 a(i i)$ & 2005 & $5000 \mathrm{mg} / \mathrm{kg}$ & 16 \\
\hline ETIL-LAUROIL ARGINATO & 243 & 2016 & $315 \mathrm{mg} / \mathrm{kg}$ & $3 \& 374$ \\
\hline TARTRATOS & 334, 335(ii), 337 & 2017 & $500 \mathrm{mg} / \mathrm{kg}$ & 45 \\
\hline
\end{tabular}

No. de Categoría de alimento 08.4

Envolturas o tripas comestibles (p. ej. para embutidos)

\begin{tabular}{|c|c|c|c|c|}
\hline Aditivo & SIN & Año Adoptada & Dosis máxima & Notas \\
\hline AMARILLO OCASO FCF & 110 & 2008 & $300 \mathrm{mg} / \mathrm{kg}$ & 16 \\
\hline CARMINES & 120 & 2005 & $500 \mathrm{mg} / \mathrm{kg}$ & $16 \& 178$ \\
\hline CAROTENOIDES & $160 a(i), a(i i i), e, f$ & 2011 & $100 \mathrm{mg} / \mathrm{kg}$ & \\
\hline CAROTENOS, BETA-, VEGETALES & 160a(ii) & 2005 & $5000 \mathrm{mg} / \mathrm{kg}$ & \\
\hline ÉSTERES DE ASCORBILO & 304,305 & 2001 & $5000 \mathrm{mg} / \mathrm{kg}$ & 10 \\
\hline $\begin{array}{l}\text { ÉSTERES POLIGLICÉRIDOS DE ÁCIDO } \\
\text { RICINOLÉICO INTERESTERIFICADO }\end{array}$ & 476 & 2017 & $5000 \mathrm{mg} / \mathrm{kg}$ & 365 \\
\hline $\begin{array}{l}\text { ÉSTERES POLIGLICÉRIDOS DE ÁCIDOS } \\
\text { GRASOS }\end{array}$ & 475 & 2017 & $5000 \mathrm{mg} / \mathrm{kg}$ & 365 \\
\hline EXTRACTO DE PIEL DE UVA & 163(ii) & 2009 & $5000 \mathrm{mg} / \mathrm{kg}$ & \\
\hline FOSFATOS & $\begin{array}{l}\text { 338; 339(i)-(iii); } \\
340 \text { (i)-(iii); } 341 \text { (i)- } \\
\text { (iii); 342(i)-(ii); } \\
343 \text { (i)-(iii); 450(i)- } \\
\text { (iii),(v)-(vii), (ix); } \\
\text { 451(i),(ii); 452(i)- } \\
\text { (v); } 542\end{array}$ & 2010 & $1100 \mathrm{mg} / \mathrm{kg}$ & 33 \\
\hline HIDROXIBENZOATOS, PARA- & 214,218 & 2010 & $36 \mathrm{mg} / \mathrm{kg}$ & 27 \\
\hline NISINA & 234 & 2015 & $7 \mathrm{mg} / \mathrm{kg}$ & 233 \\
\hline ÓXIDOS DE HIERRO & 172(i)-(iii) & 2005 & $1000 \mathrm{mg} / \mathrm{kg}$ & 72 \\
\hline POLISORBATOS & $432-436$ & 2007 & $1500 \mathrm{mg} / \mathrm{kg}$ & \\
\hline
\end{tabular}


No. de Categoría de alimento 08.4

Envolturas o tripas comestibles (p. ej. para embutidos)

\begin{tabular}{lllrc} 
Aditivo & SIN & Año Adoptada & Dosis máxima & Notas \\
\hline PONCEAU 4R (ROJO DE COCHINILLA A) & 124 & 2008 & $500 \mathrm{mg} / \mathrm{kg}$ & 16 \\
RIBOFLAVINAS & 101 (i),(ii), (iii) & 2008 & $1000 \mathrm{mg} / \mathrm{kg}$ & 16 \\
ROJO ALLURA AC & 129 & 2009 & $300 \mathrm{mg} / \mathrm{kg}$ & 16 \\
SORBATOS & $200,202,203$ & 2016 & $10000 \mathrm{mg} / \mathrm{kg}$ & $42,222 \& 365$ \\
TARTRATOS & 334,335 (ii), 337 & 2017 & $2000 \mathrm{mg} / \mathrm{kg}$ & $45 \& 365$ \\
TOCOFEROLES & $307 \mathrm{a}, \mathrm{b}, \mathrm{c}$ & 2016 & $5000 \mathrm{mg} / \mathrm{kg}$ & 365 \\
VERDE SÓLIDO FCF & 143 & 2009 & $100 \mathrm{mg} / \mathrm{kg}$ & $3 \& 4$ \\
\hline
\end{tabular}

\begin{tabular}{|c|c|c|c|c|}
\hline \multicolumn{2}{|c|}{ No. de Categoría de alimento 09.1} & \multicolumn{3}{|c|}{$\begin{array}{l}\text { Pescado y productos pesqueros } \\
\text { frescos, incluidos los moluscos, } \\
\text { crustáceos y equinodermos }\end{array}$} \\
\hline Aditivo & SIN & Año Adoptada & Dosis máxima & Notas \\
\hline $\begin{array}{l}\text { CARAMELO III - CARAMELO AL } \\
\text { AMONÍACO }\end{array}$ & $150 \mathrm{c}$ & 2017 & $30000 \mathrm{mg} / \mathrm{kg}$ & $\begin{array}{l}\text { 4, 16, XS292, } \\
\text { XS312 \& XS315 }\end{array}$ \\
\hline
\end{tabular}

\begin{tabular}{llccc}
\hline No. de Categoría de alimento & 09.1 .1 & Pescado fresco & \\
\hline Aditivo & SIN & Año Adoptada & Dosis máxima & Notas \\
\hline AMARILLO OCASO FCF & 110 & 2008 & $300 \mathrm{mg} / \mathrm{kg}$ & $4,16 \& 50$ \\
AZUL BRILLANTE FCF & 133 & 2008 & $300 \mathrm{mg} / \mathrm{kg}$ & $4,16 \& 50$ \\
CARMINES & 120 & 2008 & $300 \mathrm{mg} / \mathrm{kg}$ & $4,16,50 \& 178$ \\
CAROTENOIDES & $160 \mathrm{a}(\mathrm{i}), \mathrm{a}(\mathrm{iiii}), \mathrm{e}, \mathrm{f}$ & 2011 & $300 \mathrm{mg} / \mathrm{kg}$ & 4 \\
CAROTENOS, BETA-, VEGETALES & $160 \mathrm{a}(\mathrm{ii})$ & 2010 & $100 \mathrm{mg} / \mathrm{kg}$ & $4,16 \& 50$ \\
INDIGOTINA (CARMíN DE ÍNDIGO) & 132 & 2009 & $300 \mathrm{mg} / \mathrm{kg}$ & $4,16 \& 50$ \\
\hline
\end{tabular}

No. de Categoría de alimento 09.1.2

Moluscos, crustáceos y equinodermos frescos

\begin{tabular}{|c|c|c|c|c|}
\hline Aditivo & SIN & Año Adoptada & Dosis máxima & Notas \\
\hline ÁCIDO ASCÓRBICO, L- & 300 & 2017 & BPF & $\begin{array}{c}\text { 390, XS312 \& } \\
\text { XS315 }\end{array}$ \\
\hline ÁCIDO CÍTRICO & 330 & 2017 & BPF & $\begin{array}{c}\text { 390, XS312 \& } \\
\text { XS315 }\end{array}$ \\
\hline $\begin{array}{l}\text { ÁCIDO ERITÓRBICO (ACIDO } \\
\text { ISOASCÓBICO) }\end{array}$ & 315 & 2017 & BPF & $\begin{array}{c}\text { 390, XS312 \& } \\
\text { XS315 }\end{array}$ \\
\hline AMARILLO OCASO FCF & 110 & 2017 & $300 \mathrm{mg} / \mathrm{kg}$ & $\begin{array}{c}\text { 4, 16, XS292, } \\
\text { XS312 \& XS315 }\end{array}$ \\
\hline ASCORBATO DE CALCIO & 302 & 2017 & BPF & $\begin{array}{c}\text { 390, XS312 \& } \\
\text { XS315 }\end{array}$ \\
\hline ASCORBATO DE SODIO & 301 & 2017 & BPF & $\begin{array}{c}\text { 390, XS312 \& } \\
\text { XS315 }\end{array}$ \\
\hline AZUL BRILLANTE FCF & 133 & 2017 & $500 \mathrm{mg} / \mathrm{kg}$ & $\begin{array}{l}4,16, \text { XS292, } \\
\text { XS312 \& XS315 }\end{array}$ \\
\hline CARMINES & 120 & 2017 & $500 \mathrm{mg} / \mathrm{kg}$ & $\begin{array}{r}4,16,178, \text { XS292 } \\
\text { XS312 \& XS315 }\end{array}$ \\
\hline CAROTENOIDES & 160a(i),a(iii),e,f & 2017 & $100 \mathrm{mg} / \mathrm{kg}$ & $\begin{array}{l}\text { 4, 16, XS292, } \\
\text { XS312 \& XS315 }\end{array}$ \\
\hline
\end{tabular}


No. de Categoría de alimento 09.1.2

Moluscos, crustáceos y equinodermos frescos

\begin{tabular}{|c|c|c|c|c|}
\hline Aditivo & SIN & Año Adoptada & Dosis máxima & Notas \\
\hline $\begin{array}{l}\text { ERITORBATO DE SODIO } \\
\text { (ISOASCORBATO DE SODIO) }\end{array}$ & 316 & 2017 & BPF & $\begin{array}{c}\text { 390, XS312 \& } \\
\text { XS315 }\end{array}$ \\
\hline $\begin{array}{l}\text { ÉSTERES CIITRICOS Y DE ÁCIDOS } \\
\text { GRASOS DE GLICEROL }\end{array}$ & $472 c$ & 2017 & BPF & $\begin{array}{c}\text { 390, XS312 \& } \\
\text { XS315 }\end{array}$ \\
\hline LECITINA & $322(i)$ & 2017 & BPF & $\begin{array}{c}\text { 390, XS312 \& } \\
\text { XS315 }\end{array}$ \\
\hline ÓXIDO NITROSO & 942 & 2017 & BPF & $\begin{array}{c}\text { 390, XS312 \& } \\
\text { XS315 }\end{array}$ \\
\hline SULFITOS & $220-225,539$ & 2017 & $100 \mathrm{mg} / \mathrm{kg}$ & $\begin{array}{c}44,390, \text { XS312 \& } \\
\text { XS315 }\end{array}$ \\
\hline
\end{tabular}

No. de Categoría de alimento 09.2

Pescado y productos pesqueros elaborados, incluidos los moluscos, crustáceos y equinodermos

\begin{tabular}{|c|c|c|c|c|}
\hline Aditivo & SIN & Año Adoptada & Dosis máxima & Notas \\
\hline ACESULFAME DE POTASIO & 950 & 2018 & 200 mg/kg & $\begin{array}{c}\text { 144, 188, XS36, } \\
\text { XS92, XS95, } \\
\text { XS165, XS166, } \\
\text { XS167, XS189, } \\
\text { XS190, XS191, } \\
\text { XS222, XS236, } \\
\text { XS244, XS292, } \\
\text { XS311, XS312 \& } \\
\text { XS315 }\end{array}$ \\
\hline ASCORBATO DE SODIO & 301 & 2018 & BPF & $\begin{array}{l}\text { 437, 307, 392, } \\
\text { XS92, XS167, } \\
\text { XS189, XS191, } \\
\text { XS222, XS236, } \\
\text { XS244, XS312 \& } \\
\text { XS315 }\end{array}$ \\
\hline ASPARTAMO & 951 & 2018 & $300 \mathrm{mg} / \mathrm{kg}$ & $\begin{array}{c}\text { 144, 191, XS36, } \\
\text { XS92, XS95, } \\
\text { XS165, XS166, } \\
\text { XS167, XS189, } \\
\text { XS190, XS191, } \\
\text { XS222, XS236, } \\
\text { XS244, XS292, } \\
\text { XS311, XS312 \& } \\
\text { XS315 }\end{array}$ \\
\hline $\begin{array}{l}\text { CARAMELO III - CARAMELO AL } \\
\text { AMONÍACO }\end{array}$ & $150 \mathrm{c}$ & 2018 & $30000 \mathrm{mg} / \mathrm{kg}$ & $\begin{array}{l}\text { XS36, XS92, } \\
\text { XS95, XS165, } \\
\text { XS166, XS167, } \\
\text { XS189, XS190, } \\
\text { XS191, XS222, } \\
\text { XS236, XS244, } \\
\text { XS292, XS311, } \\
\text { XS312 \& XS315 }\end{array}$ \\
\hline $\begin{array}{l}\text { CARAMELO IV - CARAMELO AL SULFITO } \\
\text { AMÓNICO }\end{array}$ & $150 d$ & 2018 & $30000 \mathrm{mg} / \mathrm{kg}$ & $\begin{array}{l}\text { 95, XS36, XS92, } \\
\text { XS95, XS165, } \\
\text { XS166, XS167, } \\
\text { XS189, XS190, } \\
\text { XS191, XS222, } \\
\text { XS236, XS244, } \\
\text { XS292, XS311, } \\
\text { XS312 \& XS315 }\end{array}$ \\
\hline
\end{tabular}




\section{No. de Categoría de alimento $09.2 \quad$ Pescado y productos pesqueros elaborados, incluidos los moluscos, crustáceos y equinodermos}

\begin{tabular}{|c|c|c|c|c|}
\hline Aditivo & $\operatorname{Sin}$ & Año Adoptada & Dosis máxima & Notas \\
\hline CAROTENOIDES & $160 a(i), a(i i i), e, f$ & 2018 & $100 \mathrm{mg} / \mathrm{kg}$ & $\begin{array}{l}\text { 95, 304, XS36, } \\
\text { XS92, XS95, } \\
\text { XS165, XS167, } \\
\text { XS189, XS190, } \\
\text { XS191, XS222, } \\
\text { XS236, XS244, } \\
\text { XS292, XS311, } \\
\text { XS312 \& XS315 }\end{array}$ \\
\hline CITRATO DÍACIDO DE POTASIO & 332(i) & 2018 & BPF & $\begin{array}{c}\text { 253, 391, XS36, } \\
\text { XS92, XS95, } \\
\text { XS167, XS189, } \\
\text { XS190, XS191, } \\
\text { XS222, XS236, } \\
\text { XS244, XS292, } \\
\text { XS311, XS312 \& } \\
\text { XS315 }\end{array}$ \\
\hline CITRATO DÍACIDO DE SODIO & $331(\mathrm{i})$ & 2018 & BPF & $\begin{array}{c}\text { 253, 391, XS36, } \\
\text { XS92, XS95, } \\
\text { XS167, XS189, } \\
\text { XS190, XS191, } \\
\text { XS222, XS236, } \\
\text { XS244, XS292, } \\
\text { XS311, XS312 \& } \\
\text { XS315 }\end{array}$ \\
\hline CITRATO TRICÁLCICO & 333(iii) & 2018 & BPF & $\begin{array}{l}\text { XS36, XS92, } \\
\text { XS95, XS165, } \\
\text { XS166, XS167, } \\
\text { XS189, XS190, } \\
\text { XS191, XS222, } \\
\text { XS236, XS244, } \\
\text { XS292, Xs311, } \\
\text { XS312 \& XS315 }\end{array}$ \\
\hline CITRATO TRIPOTÁSICO & 332(ii) & 2018 & BPF & $\begin{array}{c}\text { 253, 391, XS36, } \\
\text { XS92, XS95, } \\
\text { XS167, XS189, } \\
\text { XS190, XS191, } \\
\text { XS222, XS236, } \\
\text { XS244, XS292, } \\
\text { XS311, XS312 \& } \\
\text { XS315 }\end{array}$ \\
\hline CITRATO TRISÓDICO & 331 (iii) & 2018 & BPF & $\begin{array}{c}\text { 253, 391, XS36, } \\
\text { XS92, XS95, } \\
\text { XS167, XS189, } \\
\text { XS190, XS191, } \\
\text { XS222, XS236, } \\
\text { XS244, XS292, } \\
\text { XS311, XS312 \& } \\
\text { XS315 }\end{array}$ \\
\hline GLUCONATO DE SODIO & 576 & 2017 & BPF & $\begin{array}{l}\text { XS36, XS92, } \\
\text { XS95, XS165, } \\
\text { XS166, XS167, } \\
\text { XS189, XS190, } \\
\text { XS191, XS222, } \\
\text { XS236, XS244, } \\
\text { XS292, XS311, } \\
\text { XS312 \& XS315 }\end{array}$ \\
\hline
\end{tabular}




\section{No. de Categoría de alimento 09.2.1 Pescado, filetes de pescado y productos pesqueros congelados, incluidos los moluscos, crustáceos y equinodermos}

\begin{tabular}{|c|c|c|c|c|}
\hline Aditivo & SIN & Año Adoptada & Dosis máxima & Notas \\
\hline ÁCIDO ALGÍNICO & 400 & 2017 & BPF & $\begin{array}{c}\text { 16, XS36, XS92, } \\
\text { XS95, XS165, } \\
\text { XS190, XS191, } \\
\text { XS292, XS312 \& } \\
\text { XS315 }\end{array}$ \\
\hline ÁCIDO ASCÓRBICO, L- & 300 & 2017 & BPF & $\begin{array}{c}\text { 307, 392, XS189, } \\
\text { XS190, XS191, } \\
\text { XS222, XS236, } \\
\text { XS312 \& XS315 }\end{array}$ \\
\hline ÁCIDO CÍTRICO & 330 & 2017 & BPF & $\begin{array}{l}\text { 331, 391, 392, } \\
\text { XS36, XS95, } \\
\text { XS190, XS191, } \\
\text { XS312 \& XS315 }\end{array}$ \\
\hline $\begin{array}{l}\text { ÁCIDO ERITÓRBICO (ACIDO } \\
\text { ISOASCÓBICO) }\end{array}$ & 315 & 2017 & BPF & $\begin{array}{c}\text { 308, 392, XS36, } \\
\text { XS92, XS95, } \\
\text { XS165, XS190, } \\
\text { XS191, XS312 \& } \\
\text { XS315 }\end{array}$ \\
\hline AGAR & 406 & 2017 & BPF & $\begin{array}{c}\text { 3, 53, XS36, } \\
\text { XS92, XS95, } \\
\text { XS165, XS190, } \\
\text { XS191, XS292, } \\
\text { XS312 \& XS315 }\end{array}$ \\
\hline ALGA EUCHEUMA ELABORADA & 407a & 2017 & BPF & $\begin{array}{c}\text { 332, 391, XS36, } \\
\text { XS92, XS95, } \\
\text { XS190, XS191, } \\
\text { XS292, XS312 \& } \\
\text { XS315 }\end{array}$ \\
\hline ALGINATO DE AMONIO & 403 & 2017 & BPF & $\begin{array}{c}\text { XS36, XS92, } \\
\text { XS95, XS165, } \\
\text { XS190, XS191, } \\
\text { XS292, XS312 \& } \\
\text { XS315 }\end{array}$ \\
\hline ALGINATO DE CALCIO & 404 & 2017 & BPF & $\begin{array}{c}\text { XS36, XS92, } \\
\text { XS95, XS165, } \\
\text { XS190, XS191, } \\
\text { XS292, XS312 \& } \\
\text { XS315 }\end{array}$ \\
\hline ALGINATO DE POTASIO & 402 & 2017 & BPF & $\begin{array}{c}\text { XS36, XS92, } \\
\text { XS95, XS165, } \\
\text { XS190, XS191, } \\
\text { XS292, XS312 \& } \\
\text { XS315 }\end{array}$ \\
\hline ALGINATO DE SODIO & 401 & 2017 & BPF & $\begin{array}{c}\text { XS36, XS92, } \\
\text { XS95, XS191, } \\
\text { XS292, XS312 \& } \\
\text { XS315 }\end{array}$ \\
\hline ALMIDÓN HIDROXIPROPÍLICO & 1440 & 2017 & BPF & $\begin{array}{c}\text { XS36, XS92, } \\
\text { XS95, XS165, } \\
\text { XS190, XS191, } \\
\text { XS292, XS312 \& } \\
\text { XS315 }\end{array}$ \\
\hline
\end{tabular}




\section{No. de Categoría de alimento 09.2.1 Pescado, filetes de pescado y productos pesqueros congelados, incluidos los moluscos, crustáceos y equinodermos}

\begin{tabular}{|c|c|c|c|c|}
\hline Aditivo & $\operatorname{SiN}$ & Año Adoptada & Dosis máxima & Notas \\
\hline ALMIDÓN OXIDADO & 1404 & 2017 & BPF & $\begin{array}{c}\text { XS36, XS92, } \\
\text { XS95, XS165, } \\
\text { XS190, XS191, } \\
\text { XS292, XS312 \& } \\
\text { XS315 }\end{array}$ \\
\hline AMARILLO OCASO FCF & 110 & 2017 & $300 \mathrm{mg} / \mathrm{kg}$ & $\begin{array}{c}\text { 95, XS36, XS92, } \\
\text { XS95, XS165, } \\
\text { XS190, XS191, } \\
\text { XS292, XS312 \& } \\
\text { XS315 }\end{array}$ \\
\hline ASCORBATO DE CALCIO & 302 & 2017 & BPF & $\begin{array}{c}\text { 308, 392, XS36, } \\
\text { XS92, XS95, } \\
\text { XS165, XS190, } \\
\text { XS191, XS312 \& } \\
\text { XS315 }\end{array}$ \\
\hline AZUL BRILLANTE FCF & 133 & 2017 & $500 \mathrm{mg} / \mathrm{kg}$ & $\begin{array}{c}\text { 95, XS36, XS92, } \\
\text { XS95, XS165, } \\
\text { XS190, XS191, } \\
\text { XS292, XS312 \& } \\
\text { XS315 }\end{array}$ \\
\hline BUTILHIDROXIANISOL & 320 & 2017 & $200 \mathrm{mg} / \mathrm{kg}$ & $\begin{array}{c}\text { 15, 180, 392, } \\
\text { XS36, XS92, } \\
\text { XS95, XS165, } \\
\text { XS190, XS191, } \\
\text { XS312 \& XS315 }\end{array}$ \\
\hline BUTILHIDROXITOLUENO & 321 & 2017 & $200 \mathrm{mg} / \mathrm{kg}$ & $\begin{array}{c}\text { 15, 180, 392, } \\
\text { XS36, XS92, } \\
\text { XS95, XS165, } \\
\text { XS190, XS191, } \\
\text { XS312 \& XS315 }\end{array}$ \\
\hline CANTAXANTINA & $161 \mathrm{~g}$ & 2017 & $35 \mathrm{mg} / \mathrm{kg}$ & $\begin{array}{c}\text { 95, XS36, XS92, } \\
\text { XS95, XS165, } \\
\text { XS190, XS191, } \\
\text { XS292, XS312 \& } \\
\text { XS315 }\end{array}$ \\
\hline CARBONATO DE CALCIO & $170(i)$ & 2017 & BPF & $\begin{array}{c}\text { 95, XS36, XS92, } \\
\text { XS95, XS165, } \\
\text { XS190, XS191, } \\
\text { XS292, XS312 \& } \\
\text { XS315 }\end{array}$ \\
\hline $\begin{array}{l}\text { CARBOXIMETILCELULOSA SÓDICA } \\
\text { (GOMA DE CELULOSA) }\end{array}$ & 466 & 2017 & BPF & $\begin{array}{c}\text { 332, 391, XS36, } \\
\text { XS92, XS95, } \\
\text { XS190, XS191, } \\
\text { XS292, XS312 \& } \\
\text { XS315 }\end{array}$ \\
\hline CARMINES & 120 & 2017 & $100 \mathrm{mg} / \mathrm{kg}$ & $\begin{array}{c}95,178, \text { XS36, } \\
\text { XS92, XS95, } \\
\text { XS165, XS190, } \\
\text { XS191, XS292, } \\
\text { XS312 \& XS315 }\end{array}$ \\
\hline CARRAGENINA & 407 & 2017 & BPF & $\begin{array}{c}\text { 332, 391, XS36, } \\
\text { XS92, XS95, } \\
\text { XS190, XS191, } \\
\text { XS292, XS312 \& } \\
\text { XS315 }\end{array}$ \\
\hline
\end{tabular}




\section{No. de Categoría de alimento 09.2.1 Pescado, filetes de pescado y productos pesqueros congelados, incluidos los moluscos, crustáceos y equinodermos}

\begin{tabular}{|c|c|c|c|c|}
\hline Aditivo & SIN & Año Adoptada & Dosis máxima & Notas \\
\hline CELULOSA EN POLVO & 460(ii) & 2017 & BPF & $\begin{array}{c}\text { 16, XS36, XS92, } \\
\text { XS95, XS165, } \\
\text { XS190, XS191, } \\
\text { XS292, XS312 \& } \\
\text { XS315 }\end{array}$ \\
\hline $\begin{array}{l}\text { CELULOSA MICROCRISTALINA (GEL DE } \\
\text { CELULOSA) }\end{array}$ & $460(i)$ & 2017 & BPF & $\begin{array}{c}\text { 16, XS36, XS92, } \\
\text { XS95, XS165, } \\
\text { XS190, XS191, } \\
\text { XS292, XS312 \& } \\
\text { XS315 }\end{array}$ \\
\hline CLORURO DE MAGNESIO & 511 & 2017 & BPF & $\begin{array}{c}\text { XS36, XS92, } \\
\text { XS95, XS165, } \\
\text { XS190, XS191, } \\
\text { XS292, XS312 \& } \\
\text { XS315 }\end{array}$ \\
\hline CLORURO DE POTASIO & 508 & 2017 & BPF & $\begin{array}{c}\text { XS36, XS92, } \\
\text { XS95, XS165, } \\
\text { XS190, XS191, } \\
\text { XS292, XS312 \& } \\
\text { XS315 }\end{array}$ \\
\hline DEXTRINAS, ALMIDÓN TOSTADO & 1400 & 2017 & BPF & $\begin{array}{c}\text { 3, 53, XS36, } \\
\text { XS92, XS95, } \\
\text { XS165, XS190, } \\
\text { XS191, XS292, } \\
\text { XS312 \& XS315 }\end{array}$ \\
\hline $\begin{array}{l}\text { ERITORBATO DE SODIO } \\
\text { (ISOASCORBATO DE SODIO) }\end{array}$ & 316 & 2017 & BPF & $\begin{array}{c}\text { 308, 392, XS36, } \\
\text { XS92, XS95, } \\
\text { XS165, XS190, } \\
\text { XS191, XS312 \& } \\
\text { XS315 }\end{array}$ \\
\hline $\begin{array}{l}\text { ÉSTERES ACÉTICOS Y DE ÁCIDOS } \\
\text { GRASOS DE GLICEROL }\end{array}$ & $472 a$ & 2017 & BPF & $\begin{array}{c}\text { XS36, XS92, } \\
\text { XS95, XS165, } \\
\text { XS190, XS191, } \\
\text { XS292, XS312 \& } \\
\text { XS315 }\end{array}$ \\
\hline $\begin{array}{l}\text { ÉSTERES CÍTRICOS Y DE ÁCIDOS } \\
\text { GRASOS DE GLICEROL }\end{array}$ & $472 c$ & 2017 & BPF & $\begin{array}{c}\text { 392, XS36, XS92, } \\
\text { XS95, XS165, } \\
\text { XS190, XS191, } \\
\text { XS312 \& XS315 }\end{array}$ \\
\hline ÉSTERES DE ASCORBILO & 304,305 & 2017 & $1000 \mathrm{mg} / \mathrm{kg}$ & $\begin{array}{c}\text { 10, 392, XS36, } \\
\text { XS92, XS95, } \\
\text { XS190, XS191, } \\
\text { XS312 \& XS315 }\end{array}$ \\
\hline $\begin{array}{l}\text { ÉSTERES LÁCTICOS Y DE ÁCIDOS } \\
\text { GRASOS DE GLICEROL }\end{array}$ & $472 b$ & 2017 & BPF & $\begin{array}{c}\text { XS36, XS92, } \\
\text { XS95, XS165, } \\
\text { XS190, XS191, } \\
\text { XS292, XS312 \& } \\
\text { XS315 }\end{array}$ \\
\hline $\begin{array}{l}\text { ÉSTERES POLIGLICÉRIDOS DE ÁCIDOS } \\
\text { GRASOS }\end{array}$ & 475 & 2018 & $5000 \mathrm{mg} / \mathrm{kg}$ & 241 \\
\hline ETILEN DIAMINO TETRA ACETATOS & 385,386 & 2017 & $75 \mathrm{mg} / \mathrm{kg}$ & $\begin{array}{c}\text { 21, 392, XS36, } \\
\text { XS92, XS95, } \\
\text { XS165, XS190, } \\
\text { XS191, XS312 \& } \\
\text { XS315 }\end{array}$ \\
\hline
\end{tabular}




\section{No. de Categoría de alimento 09.2.1 Pescado, filetes de pescado y productos pesqueros congelados, incluidos los moluscos, crustáceos y equinodermos}

\begin{tabular}{|c|c|c|c|c|}
\hline Aditivo & SIN & Año Adoptada & Dosis máxima & Notas \\
\hline FOSFATO DE DIALMIDÓN ACETILADO & 1414 & 2017 & BPF & $\begin{array}{c}\text { XS36, XS92, } \\
\text { XS95, XS165, } \\
\text { XS190, XS191, } \\
\text { XS292, XS312 \& } \\
\text { XS315 }\end{array}$ \\
\hline FOSFATOS & $\begin{array}{l}\text { 338; 339(i)-(iii); } \\
340 \text { (i)-(iii); } 341 \text { (i)- } \\
\text { (iii); 342(i)-(ii); } \\
343(\text { i)-(iii); } 450(\mathrm{i})- \\
\text { (iii),(v)-(vii), (ix); } \\
451 \text { (i),(ii); 452(i)- } \\
\text { (v); } 542\end{array}$ & 2017 & $2200 \mathrm{mg} / \mathrm{kg}$ & $\begin{array}{c}\text { 33, 393, 394, } \\
\text { XS36, XS191, } \\
\text { XS292 \& XS312 }\end{array}$ \\
\hline GLUTAMATO MONOSÓDICO, L- & 621 & 2017 & BPF & $\begin{array}{c}\text { 95, XS36, XS92, } \\
\text { XS95, XS165, } \\
\text { XS190, XS191, } \\
\text { XS292, XS312 \& } \\
\text { XS315 }\end{array}$ \\
\hline GOMA ARÁBIGA (GOMA DE ACACIA) & 414 & 2017 & BPF & $\begin{array}{c}\text { 16, XS36, XS92, } \\
\text { XS95, XS165, } \\
\text { XS190, XS191, } \\
\text { XS292, XS312 \& } \\
\text { XS315 }\end{array}$ \\
\hline GOMA DE SEMILLAS DE ALGARROBO & 410 & 2017 & BPF & $\begin{array}{c}\text { 391, XS36, XS92, } \\
\text { XS95, XS190, } \\
\text { XS191, XS292, } \\
\text { XS312 \& XS315 }\end{array}$ \\
\hline GOMA GELLAN & 418 & 2017 & BPF & $\begin{array}{c}\text { XS36, XS92, } \\
\text { XS95, XS165, } \\
\text { XS190, XS191, } \\
\text { XS292, XS312 \& } \\
\text { XS315 }\end{array}$ \\
\hline GOMA GUAR & 412 & 2017 & BPF & $\begin{array}{c}\text { 73, 391, XS36, } \\
\text { XS92, XS95, } \\
\text { XS190, XS191, } \\
\text { XS292, XS312 \& } \\
\text { XS315 }\end{array}$ \\
\hline GOMA KARAYA & 416 & 2017 & BPF & $\begin{array}{c}\text { XS36, XS92, } \\
\text { XS95, XS165, } \\
\text { XS190, XS191, } \\
\text { XS292, XS312 \& } \\
\text { XS315 }\end{array}$ \\
\hline GOMA TARA & 417 & 2017 & BPF & $\begin{array}{c}\text { 73, XS36, XS92, } \\
\text { XS95, XS165, } \\
\text { XS190, XS191, } \\
\text { XS292, XS312 \& } \\
\text { XS315 }\end{array}$ \\
\hline GOMA TRAGACANTO & 413 & 2017 & BPF & $\begin{array}{c}\text { XS36, XS92, } \\
\text { XS95, XS165, } \\
\text { XS190, XS191, } \\
\text { XS292, XS312 \& } \\
\text { XS315 }\end{array}$ \\
\hline GOMA XANTANA & 415 & 2017 & BPF & $\begin{array}{c}\text { 391, XS36, XS92, } \\
\text { XS95, XS190, } \\
\text { XS191, XS292, } \\
\text { XS312 \& XS315 }\end{array}$ \\
\hline
\end{tabular}




\section{No. de Categoría de alimento 09.2.1 Pescado, filetes de pescado y productos pesqueros congelados, incluidos los moluscos, crustáceos y equinodermos}

\begin{tabular}{|c|c|c|c|c|}
\hline Aditivo & SIN & Año Adoptada & Dosis máxima & Notas \\
\hline GUANILATO DISÓDICO, 5'- & 627 & 2017 & BPF & $\begin{array}{c}\text { 95, XS36, XS92, } \\
\text { XS95, XS165, } \\
\text { XS190, XS191, } \\
\text { XS292, XS312 \& } \\
\text { XS315 }\end{array}$ \\
\hline HARINA KONJAC & 425 & 2017 & BPF & $\begin{array}{c}\text { 16, XS36, XS92, } \\
\text { XS95, XS165, } \\
\text { XS190, XS191, } \\
\text { XS292, XS312 \& } \\
\text { XS315 }\end{array}$ \\
\hline HIDROXIPROPILCELULOSA & 463 & 2017 & BPF & $\begin{array}{c}\text { 16, XS36, XS92, } \\
\text { XS95, XS165, } \\
\text { XS190, XS191, } \\
\text { XS292, XS312 \& } \\
\text { XS315 }\end{array}$ \\
\hline HIDROXIPROPILMETILCELULOSA & 464 & 2017 & BPF & $\begin{array}{c}\text { 16, XS36, XS92, } \\
\text { XS95, XS165, } \\
\text { XS190, XS191, } \\
\text { XS292, XS312 \& } \\
\text { XS315 }\end{array}$ \\
\hline INDIGOTINA (CARMÍN DE ÍNDIGO) & 132 & 2017 & $300 \mathrm{mg} / \mathrm{kg}$ & $\begin{array}{c}\text { 95, XS36, XS92, } \\
\text { XS95, XS165, } \\
\text { XS190, XS191, } \\
\text { XS292, XS312 \& } \\
\text { XS315 }\end{array}$ \\
\hline INOSINATO DISÓDICO, 5'- & 631 & 2017 & BPF & $\begin{array}{c}\text { 95, XS36, XS92, } \\
\text { XS95, XS165, } \\
\text { XS190, XS191, } \\
\text { XS292, XS312 \& } \\
\text { XS315 }\end{array}$ \\
\hline LECITINA & $322(i)$ & 2017 & BPF & $\begin{array}{c}\text { 392, XS36, XS92, } \\
\text { XS95, XS165, } \\
\text { XS190, XS191, } \\
\text { XS312 \& XS315 }\end{array}$ \\
\hline MANITOL & 421 & 2017 & BPF & $\begin{array}{c}\text { XS36, XS92, } \\
\text { XS95, XS165, } \\
\text { XS190, XS191, } \\
\text { XS292, XS312 \& } \\
\text { XS315 }\end{array}$ \\
\hline METILCELULOSA & 461 & 2017 & BPF & $\begin{array}{c}\text { 332, 391, XS36, } \\
\text { XS92, XS95, } \\
\text { XS190, XS191, } \\
\text { XS292, XS312 \& } \\
\text { XS315 }\end{array}$ \\
\hline METILETILCELULOSA & 465 & 2017 & BPF & $\begin{array}{c}\text { XS36, XS92, } \\
\text { XS95, XS165, } \\
\text { XS190, XS191, } \\
\text { XS292, XS312 \& } \\
\text { XS315 }\end{array}$ \\
\hline ÓXIDO NITROSO & 942 & 2017 & BPF & $\begin{array}{c}\text { 308, 392, XS36, } \\
\text { XS92, XS95, } \\
\text { XS165, XS190, } \\
\text { XS191, XS312 \& } \\
\text { XS315 }\end{array}$ \\
\hline
\end{tabular}




\begin{tabular}{|c|c|c|c|c|}
\hline \multicolumn{2}{|c|}{ No. de Categoría de alimento 09.2.1 } & \multicolumn{3}{|c|}{$\begin{array}{l}\text { Pescado, filetes de pescado y } \\
\text { productos pesqueros congelados, } \\
\text { incluidos los moluscos, crustáceos y } \\
\text { equinodermos }\end{array}$} \\
\hline Aditivo & $\sin$ & Año Adoptada & Dosis máxima & Notas \\
\hline PECTINAS & 440 & 2017 & BPF & $\begin{array}{l}\text { 16, 391, XS36, } \\
\text { XS92, XS95, } \\
\text { XS190, XS191, } \\
\text { XS292, XS312 \& } \\
\text { XS315 }\end{array}$ \\
\hline POLIDEXTROSA & 1200 & 2017 & BPF & $\begin{array}{c}\text { XS36, XS92, } \\
\text { XS95, XS165, } \\
\text { XS190, XS191, } \\
\text { XS292, XS312 \& } \\
\text { XS315 }\end{array}$ \\
\hline PONCEAU 4R (ROJO DE COCHINILLA A) & 124 & 2017 & $30 \mathrm{mg} / \mathrm{kg}$ & $\begin{array}{c}\text { 395, XS36, XS95, } \\
\text { XS165, XS190, } \\
\text { XS191, XS292, } \\
\text { XS312 \& XS315 }\end{array}$ \\
\hline RIBOFLAVINAS & 101(i),(ii), (iii) & 2017 & $1000 \mathrm{mg} / \mathrm{kg}$ & $\begin{array}{c}\text { 95, XS36, XS92, } \\
\text { XS95, XS165, } \\
\text { XS190, XS191, } \\
\text { XS292, XS312 \& } \\
\text { XS315 }\end{array}$ \\
\hline RIBONUCLEÓTIDOS DE SODIO, 5'- & 635 & 2017 & BPF & $\begin{array}{l}\text { 95, XS36, XS92, } \\
\text { XS95, XS165, } \\
\text { XS190, XS191, } \\
\text { XS292, XS312 \& } \\
\text { XS315 }\end{array}$ \\
\hline ROJO ALLURA AC & 129 & 2017 & $300 \mathrm{mg} / \mathrm{kg}$ & $\begin{array}{c}\text { 95, XS36, XS92, } \\
\text { XS95, XS165, } \\
\text { XS190, XS191, } \\
\text { XS292, XS312 \& } \\
\text { XS315 }\end{array}$ \\
\hline $\begin{array}{l}\text { SAL DE ÁCIDO OLEICO CON CALCIO, } \\
\text { POTASIO Y SODIO }\end{array}$ & 470(ii) & 2017 & BPF & $\begin{array}{c}\text { XS36, XS92, } \\
\text { XS95, XS165, } \\
\text { XS190, XS191, } \\
\text { XS292, XS312 \& } \\
\text { XS315 }\end{array}$ \\
\hline $\begin{array}{l}\text { SAL MIRÍSTICA, PALMÍTICA Y ÁCIDOS } \\
\text { ESTEÁRICOS CON AMONIO, CALCIO, } \\
\text { POTASIO Y SODIO }\end{array}$ & $470(i)$ & 2017 & BPF & $\begin{array}{c}\text { 71, XS36, XS92, } \\
\text { XS95, XS165, } \\
\text { XS190, XS191, } \\
\text { XS292, XS312 \& } \\
\text { XS315 }\end{array}$ \\
\hline SULFITOS & $220-225,539$ & 2017 & $100 \mathrm{mg} / \mathrm{kg}$ & $\begin{array}{l}19,44,139,392, \\
\text { XS36, XS165, } \\
\text { XS190, XS191, } \\
\text { XS312 \& XS315 }\end{array}$ \\
\hline
\end{tabular}

\section{No. de Categoría de alimento 09.2.2 Pescado, filetes de pescado y productos pesqueros rebozados congelados, incluidos los moluscos, crustáceos y equinodermos}

$\begin{array}{llllc}\text { Aditivo } & \text { SIN } & \text { Año Adoptada } & \text { Dosis máxima } & \text { Notas } \\ \text { ACETATO DE ALMIDÓN } & 1420 & 2014 & \text { BPF } & 63 \\ \text { ACETATO DE SODIO } & 262(i) & 2017 & \text { BPF } & 41 \& \text { XS166 } \\ \text { ÁCIDO ACÉTICO GLACIAL } & 260 & 2017 & \text { BPF } & 41 \& X S 166\end{array}$




\begin{tabular}{|c|c|c|c|c|}
\hline \multicolumn{2}{|c|}{ No. de Categoría de alimento 09.2.2 } & \multicolumn{3}{|c|}{$\begin{array}{l}\text { Pescado, filetes de pescado y } \\
\text { productos pesqueros rebozados } \\
\text { congelados, incluidos los moluscos, } \\
\text { crustáceos y equinodermos }\end{array}$} \\
\hline Aditivo & SIN & Año Adoptada & Dosis máxima & Notas \\
\hline ÁCIDO ALGÍNICO & 400 & 2015 & BPF & $41 \& 332$ \\
\hline ÁCIDO ASCÓRBICO, L- & 300 & 2015 & BPF & $306 \& 307$ \\
\hline ÁCIDO CÍTRICO & 330 & 2013 & BPF & 61 \\
\hline $\begin{array}{l}\text { ÁCIDO ERITÓRBICO (ACIDO } \\
\text { ISOASCÓBICO) }\end{array}$ & 315 & 2017 & BPF & $139 \&$ XS166 \\
\hline ÁCIDO FUMÁRICO & 297 & 2017 & BPF & $41 \&$ XS166 \\
\hline ÁCIDO MÁLICO, DL- & 296 & 2017 & BPF & $41 \& X S 166$ \\
\hline ADIPATO DE DIALMIDÓN ACETILADO & 1422 & 2014 & BPF & 63 \\
\hline AGAR & 406 & 2017 & BPF & XS166 \\
\hline ALGA EUCHEUMA ELABORADA & $407 a$ & 2015 & BPF & $177 \& 332$ \\
\hline ALGINATO DE AMONIO & 403 & 2017 & BPF & 63 \\
\hline ALGINATO DE CALCIO & 404 & 2017 & BPF & 63 \\
\hline ALGINATO DE POTASIO & 402 & 2017 & BPF & 63 \\
\hline ALGINATO DE SODIO & 401 & 2017 & BPF & $210 \& 332$ \\
\hline ALMIDÓN HIDROXIPROPÍLICO & 1440 & 2014 & BPF & 63 \\
\hline ALMIDÓN OXIDADO & 1404 & 2014 & BPF & 63 \\
\hline ALMIDÓN TRATADO CON ÁCIDO & 1401 & 2014 & BPF & 63 \\
\hline ALMIDÓN TRATADO CON ÁLCALIS & 1402 & 2014 & BPF & 63 \\
\hline AMARILLO OCASO FCF & 110 & 2017 & $300 \mathrm{mg} / \mathrm{kg}$ & $16 \& X S 166$ \\
\hline ASCORBATO DE CALCIO & 302 & 2017 & BPF & $139 \&$ XS166 \\
\hline AZUL BRILLANTE FCF & 133 & 2017 & $500 \mathrm{mg} / \mathrm{kg}$ & $16 \&$ XS166 \\
\hline BUTILHIDROXIANISOL & 320 & 2017 & $200 \mathrm{mg} / \mathrm{kg}$ & $15,180 \& X S 166$ \\
\hline BUTILHIDROXITOLUENO & 321 & 2017 & $200 \mathrm{mg} / \mathrm{kg}$ & $15,180 \& X S 166$ \\
\hline CARAMELO I - CARAMELO PURO & $150 a$ & 2017 & BPF & 41 \\
\hline CARBONATO ÁCIDO DE AMONIO & 503(ii) & 2017 & BPF & 63 \\
\hline CARBONATO ÁCIDO DE MAGNESIO & 504(ii) & 2017 & BPF & $16 \& X S 166$ \\
\hline CARBONATO ÁCIDO DE POTASIO & 501 (ii) & 2013 & BPF & 41 \\
\hline CARBONATO ÁCIDO DE SODIO & 500 (ii) & 2013 & BPF & 41 \\
\hline CARBONATO DE AMONIO & 503(i) & 2013 & BPF & 41 \\
\hline CARBONATO DE CALCIO & $170(\mathrm{i})$ & 2017 & BPF & $16 \& X S 166$ \\
\hline CARBONATO DE MAGNESIO & $504(i)$ & 2017 & BPF & $16 \&$ XS166 \\
\hline CARBONATO DE POTASIO & $501(\mathrm{i})$ & 2013 & BPF & 41 \\
\hline CARBONATO DE SODIO & 500 (i) & 2013 & BPF & 41 \\
\hline $\begin{array}{l}\text { CARBOXIMETILCELULOSA SÓDICA } \\
\text { (GOMA DE CELULOSA) }\end{array}$ & 466 & 2015 & BPF & $177 \& 332$ \\
\hline CARMINES & 120 & 2017 & $500 \mathrm{mg} / \mathrm{kg}$ & $\begin{array}{l}\text { 16, } 95,178, \& \\
\text { XS166 }\end{array}$ \\
\hline CAROTENOS, BETA-, VEGETALES & $160 \mathrm{a}(\mathrm{ii})$ & 2017 & $100 \mathrm{mg} / \mathrm{kg}$ & 304 \\
\hline CARRAGENINA & 407 & 2015 & BPF & $177 \& 332$ \\
\hline
\end{tabular}




\begin{tabular}{|c|c|c|c|c|}
\hline No. de Categoría de alimento 0 & \multicolumn{4}{|c|}{$\begin{array}{l}\text { Pescado, filetes de pescado y } \\
\text { productos pesqueros rebozados } \\
\text { congelados, incluidos los moluscos, } \\
\text { crustáceos y equinodermos }\end{array}$} \\
\hline Aditivo & $\operatorname{SiN}$ & Año Adoptada & Dosis máxima & Notas \\
\hline CELULOSA EN POLVO & 460(ii) & 2017 & BPF & $16 \& X S 166$ \\
\hline $\begin{array}{l}\text { CELULOSA MICROCRISTALINA (GEL DE } \\
\text { CELULOSA) }\end{array}$ & $460(\mathrm{i})$ & 2017 & BPF & $\begin{array}{l}41,325,332 \& \\
\text { XS166 }\end{array}$ \\
\hline CLORURO DE CALCIO & 509 & 2017 & BPF & $41 \&$ XS166 \\
\hline CLORURO DE MAGNESIO & 511 & 2017 & BPF & XS166 \\
\hline CLORURO DE POTASIO & 508 & 2017 & BPF & $41 \& X S 166$ \\
\hline DEXTRINAS, ALMIDÓN TOSTADO & 1400 & 2017 & BPF & XS166 \\
\hline $\begin{array}{l}\text { ÉSTERES ACÉTICOS Y DE ÁCIDOS } \\
\text { GRASOS DE GLICEROL }\end{array}$ & $472 a$ & 2017 & BPF & $16 \& X S 166$ \\
\hline $\begin{array}{l}\text { ÉSTERES CÍTRICOS Y DE ÁCIDOS } \\
\text { GRASOS DE GLICEROL }\end{array}$ & $472 c$ & 2017 & BPF & $16 \& X S 166$ \\
\hline ÉSTERES DE ASCORBILO & 304,305 & 2001 & $1000 \mathrm{mg} / \mathrm{kg}$ & 10 \\
\hline $\begin{array}{l}\text { ÉSTERES LÁCTICOS Y DE ÁCIDOS } \\
\text { GRASOS DE GLICEROL }\end{array}$ & $472 b$ & 2017 & BPF & $16 \& X S 166$ \\
\hline ETILEN DIAMINO TETRA ACETATOS & 385,386 & 2017 & $75 \mathrm{mg} / \mathrm{kg}$ & $21 \& X S 166$ \\
\hline EXTRACTO DE PIEL DE UVA & 163(ii) & 2017 & $500 \mathrm{mg} / \mathrm{kg}$ & $16 \& X S 166$ \\
\hline FOSFATO DE DIALMIDÓN & 1412 & 2014 & BPF & 63 \\
\hline FOSFATO DE DIALMIDÓN ACETILADO & 1414 & 2014 & BPF & 63 \\
\hline FOSFATO DE DIALMIDÓN FOSFATADO & 1413 & 2014 & BPF & 63 \\
\hline FOSFATO DE HIDROXIPROPIL DIALMIDÓN & 1442 & 2014 & BPF & 63 \\
\hline FOSFATO DE MONOALMIDÓN & 1410 & 2014 & BPF & 63 \\
\hline FOSFATOS & $\begin{array}{l}\text { 338; 339(i)-(iii); } \\
340(\mathrm{i})-(\mathrm{iii}) ; 341(\mathrm{i})- \\
\text { (iii); 342(i)-(ii); } \\
343(\mathrm{i})-(\mathrm{iii)} ; 450(\mathrm{i})- \\
\text { (iii),(v)-(vii), (ix); } \\
451(\mathrm{i}),(\mathrm{ii}) ; 452(\mathrm{i})- \\
\text { (v); } 542\end{array}$ & 2017 & $2200 \mathrm{mg} / \mathrm{kg}$ & $33 \& 299$ \\
\hline FUMARATO DE SODIO & 365 & 2017 & BPF & $41 \& X S 166$ \\
\hline GLICEROL & 422 & 2017 & BPF & $41 \& X S 166$ \\
\hline GLUTAMATO MONOPOTÁSICO, L- & 622 & 2015 & BPF & 41 \\
\hline GLUTAMATO MONOSÓDICO, L- & 621 & 2015 & BPF & 41 \\
\hline GOMA ARÁBIGA (GOMA DE ACACIA) & 414 & 2017 & BPF & $16 \& X S 166$ \\
\hline GOMA DE SEMILLAS DE ALGARROBO & 410 & 2014 & BPF & 177 \\
\hline GOMA GELLAN & 418 & 2017 & BPF & XS166 \\
\hline GOMA GUAR & 412 & 2014 & BPF & 177 \\
\hline GOMA KARAYA & 416 & 2017 & BPF & XS166 \\
\hline GOMA TARA & 417 & 2017 & BPF & $73 \& X S 166$ \\
\hline GOMA TRAGACANTO & 413 & 2017 & BPF & $16 \& X S 166$ \\
\hline GOMA XANTANA & 415 & 2014 & BPF & 177 \\
\hline GUANILATO DISÓDICO, 5'- & 627 & 2017 & BPF & $309 \&$ XS166 \\
\hline
\end{tabular}




\begin{tabular}{|c|c|c|c|c|}
\hline \multirow{2}{*}{$\begin{array}{l}\text { No. de Categoría de alimento } \\
\text { Aditivo }\end{array}$} & \multicolumn{4}{|c|}{$\begin{array}{l}\text { Pescado, filetes de pescado y } \\
\text { productos pesqueros rebozados } \\
\text { congelados, incluidos los moluscos, } \\
\text { crustáceos y equinodermos }\end{array}$} \\
\hline & SIN & Año Adoptada & Dosis máxima & Notas \\
\hline HARINA KONJAC & 425 & 2017 & BPF & $\begin{array}{c}41,325,332 \& \\
\text { XS166 }\end{array}$ \\
\hline HIDRÓXIDO DE MAGNESIO & 528 & 2017 & BPF & $16 \& X S 166$ \\
\hline HIDROXIPROPILCELULOSA & 463 & 2015 & BPF & $63 \& 332$ \\
\hline HIDROXIPROPILMETILCELULOSA & 464 & 2015 & BPF & $63 \& 332$ \\
\hline INOSINATO DISÓDICO, 5'- & 631 & 2017 & BPF & $309 \&$ XS166 \\
\hline LACTATO DE CALCIO & 327 & 2017 & BPF & $41 \&$ XS166 \\
\hline LACTATO DE SODIO & 325 & 2017 & BPF & $41 \&$ XS166 \\
\hline LECITINA & $322(i)$ & 2014 & BPF & 63 \\
\hline MALATO DE SODIO, DL- & 350(ii) & 2017 & BPF & $41 \&$ XS166 \\
\hline MANITOL & 421 & 2017 & BPF & XS166 \\
\hline METILCELULOSA & 461 & 2015 & BPF & $177 \& 332$ \\
\hline METILETILCELULOSA & 465 & 2014 & BPF & 63 \\
\hline $\begin{array}{l}\text { MONOGLICÉRIDOS Y DIGLICÉRIDOS DE } \\
\text { ÁCIDOS GRASOS }\end{array}$ & 471 & 2015 & BPF & 41 \\
\hline PECTINAS & 440 & 2014 & BPF & 177 \\
\hline PONCEAU 4R (ROJO DE COCHINILLA A) & 124 & 2017 & $500 \mathrm{mg} / \mathrm{kg}$ & $16,95 \& X S 166$ \\
\hline PULLULAN & 1204 & 2017 & BPF & $41 \&$ XS166 \\
\hline RIBOFLAVINAS & 101(i),(ii), (iii) & 2017 & $300 \mathrm{mg} / \mathrm{kg}$ & $16 \&$ XS166 \\
\hline RIBONUCLEÓTIDOS DE SODIO, 5'- & 635 & 2017 & BPF & $309 \&$ XS166 \\
\hline $\begin{array}{l}\text { SAL DE ÁCIDO OLEICO CON CALCIO, } \\
\text { POTASIO Y SODIO }\end{array}$ & 470(ii) & 2017 & BPF & $16 \& X S 166$ \\
\hline $\begin{array}{l}\text { SAL MIRÍSTICA, PALMÍTICA Y ÁCIDOS } \\
\text { ESTEÁRICOS CON AMONIO, CALCIO, } \\
\text { POTASIO Y SODIO }\end{array}$ & 470 (i) & 2017 & BPF & $16,71 \& X S 166$ \\
\hline SESQUICARBONATO DE SODIO & 500(iii) & 2013 & BPF & 41 \\
\hline TIODIPROPIONATOS & 388,389 & 2017 & $200 \mathrm{mg} / \mathrm{kg}$ & $15,46 \& X S 166$ \\
\hline TOCOFEROLES & $307 a, b, c$ & 2018 & 200 mg/kg & $15, \mathrm{XS} 166$ \\
\hline
\end{tabular}

No. de Categoría de alimento 09.2.3 Productos pesqueros picados, mezclados y congelados, incluidos los moluscos, crustáceos y equinodermos

\begin{tabular}{lllll}
\hline Aditivo & SIN & Año Adoptada & Dosis máxima & Notas \\
\hline ACETATO DE SODIO & $262(i)$ & 2015 & BPF & 16 \\
ÁCIDO ACÉTICO GLACIAL & 260 & 2015 & BPF & 16 \\
ÁCIDO ALGÍNICO & 400 & 2015 & BPF & \\
ÁCIDO ASCÓRBICO, L- & 300 & 2015 & BPF & 16 \\
ÁCIDO CÍTRICO & 330 & 2015 & BPF & 16 \\
ÁCIDO FUMÁRICO & 297 & 2013 & BPF & 16 \\
ÁCIDO MÁLICO, DL- & 296 & 2013 & BPF & 16
\end{tabular}


No. de Categoría de alimento 09.2.3 Productos pesqueros picados, mezclados y congelados, incluidos los moluscos, crustáceos y equinodermos

\begin{tabular}{|c|c|c|c|c|}
\hline Aditivo & $\sin$ & Año Adoptada & Dosis máxima & Notas \\
\hline AGAR & 406 & 2014 & BPF & \\
\hline ALGA EUCHEUMA ELABORADA & $407 a$ & 2014 & BPF & \\
\hline ALGINATO DE SODIO & 401 & 2014 & BPF & \\
\hline ALMIDÓN HIDROXIPROPÍLICO & 1440 & 2014 & BPF & 16 \\
\hline ALMIDÓN OXIDADO & 1404 & 2014 & BPF & 16 \\
\hline AMARILLO OCASO FCF & 110 & 2008 & $300 \mathrm{mg} / \mathrm{kg}$ & $16 \& 95$ \\
\hline AZUL BRILLANTE FCF & 133 & 2005 & $500 \mathrm{mg} / \mathrm{kg}$ & 16 \\
\hline CARBONATO ÁCIDO DE MAGNESIO & 504(ii) & 2013 & BPF & 16 \\
\hline CARBONATO DE CALCIO & 170 (i) & 2013 & BPF & 16 \\
\hline CARBONATO DE MAGNESIO & $504(i)$ & 2013 & BPF & 16 \\
\hline CARBONATO DE POTASIO & $501(\mathrm{i})$ & 2015 & BPF & \\
\hline CARBONATO DE SODIO & 500 (i) & 2015 & BPF & 16 \\
\hline $\begin{array}{l}\text { CARBOXIMETILCELULOSA SÓDICA } \\
\text { (GOMA DE CELULOSA) }\end{array}$ & 466 & 2014 & BPF & 16 \\
\hline CARMINES & 120 & 2005 & $500 \mathrm{mg} / \mathrm{kg}$ & $16 \& 178$ \\
\hline CAROTENOS, BETA-, VEGETALES & $160 a(i i)$ & 2005 & $1000 \mathrm{mg} / \mathrm{kg}$ & 16 \\
\hline CARRAGENINA & 407 & 2014 & BPF & \\
\hline CELULOSA EN POLVO & 460 (ii) & 2014 & BPF & 16 \\
\hline $\begin{array}{l}\text { CELULOSA MICROCRISTALINA (GEL DE } \\
\text { CELULOSA) }\end{array}$ & $460(i)$ & 2015 & BPF & \\
\hline $\begin{array}{l}\text { CLOROFILAS Y CLOROFILINAS, } \\
\text { COMPLEJOS CUPRICOS }\end{array}$ & 141 (i),(ii) & 2009 & $40 \mathrm{mg} / \mathrm{kg}$ & 95 \\
\hline CLORURO DE CALCIO & 509 & 2015 & BPF & \\
\hline CLORURO DE MAGNESIO & 511 & 2014 & BPF & 16 \\
\hline CLORURO DE POTASIO & 508 & 2015 & BPF & \\
\hline DEXTRINAS, ALMIDÓN TOSTADO & 1400 & 2014 & BPF & \\
\hline $\begin{array}{l}\text { ÉSTERES ACÉTICOS Y DE ÁCIDOS } \\
\text { GRASOS DE GLICEROL }\end{array}$ & $472 a$ & 2014 & BPF & 16 \\
\hline $\begin{array}{l}\text { ÉSTERES CÍTRICOS Y DE ÁCIDOS } \\
\text { GRASOS DE GLICEROL }\end{array}$ & $472 c$ & 2014 & BPF & 16 \\
\hline $\begin{array}{l}\text { ÉSTERES LÁCTICOS Y DE ÁCIDOS } \\
\text { GRASOS DE GLICEROL }\end{array}$ & $472 b$ & 2014 & BPF & 16 \\
\hline EXTRACTO DE PIEL DE UVA & 163(ii) & 2009 & BPF & $16 \& 95$ \\
\hline FOSFATO DE DIALMIDÓN ACETILADO & 1414 & 2014 & BPF & 16 \\
\hline FOSFATOS & $\begin{array}{l}\text { 338; 339(i)-(iii); } \\
340(\mathrm{i})-(\mathrm{iii)} ; 341(\mathrm{i})- \\
\text { (iii); 342(i)-(ii); } \\
\text { 343(i)-(iii); 450(i)- } \\
\text { (iii),(v)-(vii), (ix); } \\
\text { 451(i),(ii); 452(i)- } \\
\text { (v); } 542\end{array}$ & 2012 & $2200 \mathrm{mg} / \mathrm{kg}$ & 33 \\
\hline FUMARATO DE SODIO & 365 & 2013 & BPF & 16 \\
\hline GLICEROL & 422 & 2015 & BPF & \\
\hline GLUTAMATO MONOSÓDICO, L- & 621 & 2015 & BPF & 311 \\
\hline
\end{tabular}


No. de Categoría de alimento 09.2.3 Productos pesqueros picados mezclados y congelados, incluidos los moluscos, crustáceos y equinodermos

\begin{tabular}{|c|c|c|c|c|}
\hline Aditivo & SIN & Año Adoptada & Dosis máxima & Notas \\
\hline GOMA ARÁBIGA (GOMA DE ACACIA) & 414 & 2014 & BPF & 16 \\
\hline GOMA DE SEMILLAS DE ALGARROBO & 410 & 2014 & BPF & \\
\hline GOMA GELLAN & 418 & 2014 & BPF & \\
\hline GOMA GUAR & 412 & 2014 & BPF & \\
\hline GOMA KARAYA & 416 & 2014 & BPF & \\
\hline GOMA TARA & 417 & 2014 & BPF & \\
\hline GOMA TRAGACANTO & 413 & 2014 & BPF & 16 \\
\hline GOMA XANTANA & 415 & 2014 & BPF & \\
\hline GUANILATO DISÓDICO, 5'- & 627 & 2015 & BPF & 311 \\
\hline HARINA KONJAC & 425 & 2015 & BPF & \\
\hline HIDRÓXIDO DE MAGNESIO & 528 & 2013 & BPF & 16 \\
\hline HIDROXIPROPILCELULOSA & 463 & 2014 & BPF & 16 \\
\hline HIDROXIPROPILMETILCELULOSA & 464 & 2014 & BPF & 16 \\
\hline INOSINATO DISÓDICO, 5'- & 631 & 2015 & BPF & 311 \\
\hline LACTATO DE CALCIO & 327 & 2015 & BPF & 16 \\
\hline LACTATO DE SODIO & 325 & 2015 & BPF & 16 \\
\hline LECITINA & 322(i) & 2014 & BPF & 16 \\
\hline MALATO DE SODIO, DL- & 350(ii) & 2015 & BPF & 16 \\
\hline MANITOL & 421 & 2014 & BPF & \\
\hline METILCELULOSA & 461 & 2014 & BPF & 16 \\
\hline METILETILCELULOSA & 465 & 2014 & BPF & 16 \\
\hline $\begin{array}{l}\text { MONOGLICÉRIDOS Y DIGLICÉRIDOS DE } \\
\text { ÁCIDOS GRASOS }\end{array}$ & 471 & 2015 & BPF & \\
\hline PECTINAS & 440 & 2014 & BPF & \\
\hline PONCEAU 4R (ROJO DE COCHINILLA A) & 124 & 2008 & $500 \mathrm{mg} / \mathrm{kg}$ & $16 \& 95$ \\
\hline PULLULAN & 1204 & 2015 & BPF & \\
\hline RIBOFLAVINAS & 101(i),(ii), (iii) & 2005 & $300 \mathrm{mg} / \mathrm{kg}$ & 16 \\
\hline RIBONUCLEÓTIDOS DE SODIO, 5'- & 635 & 2015 & BPF & 311 \\
\hline $\begin{array}{l}\text { SAL DE ÁCIDO OLEICO CON CALCIO, } \\
\text { POTASIO Y SODIO }\end{array}$ & 470(ii) & 2014 & BPF & 16 \\
\hline $\begin{array}{l}\text { SAL MIRÍSTICA, PALMÍTICA Y ÁCIDOS } \\
\text { ESTEÁRICOS CON AMONIO, CALCIO, } \\
\text { POTASIO Y SODIO }\end{array}$ & 470 (i) & 2014 & BPF & 16 \\
\hline
\end{tabular}

No. de Categoría de alimento 09.2.4 Pescado y productos pesqueros cocidos y/o fritos, incluidos los moluscos, crustáceos y equinodermos

\begin{tabular}{lllll} 
& SIN & Año Adoptada & Dosis máxima & Notas \\
\hline ACditivo & $262(i)$ & 2015 & BPF \\
ÁCIDO ACÉTICO GLACIAL & 260 & 2015 & BPF \\
ÁCIDO ASCÓRBICO, L- & 300 & 2013 & BPF
\end{tabular}


$\begin{array}{ll}\text { No. de Categoría de alimento 09.2.4 } & \begin{array}{l}\text { Pescado y productos pesqueros } \\ \text { cocidos y/o fritos, incluidos los } \\ \text { moluscos, crustáceos y equinodermos }\end{array}\end{array}$

\begin{tabular}{|c|c|c|c|c|}
\hline Aditivo & SIN & Año Adoptada & Dosis máxima & Notas \\
\hline ÁCIDO CÍTRICO & 330 & 2015 & BPF & \\
\hline ÁCIDO FUMÁRICO & 297 & 2013 & BPF & \\
\hline ÁCIDO MÁLICO, DL- & 296 & 2013 & BPF & \\
\hline CARBONATO ÁCIDO DE MAGNESIO & 504(ii) & 2013 & BPF & \\
\hline CARBONATO DE CALCIO & 170(i) & 2013 & BPF & \\
\hline CARBONATO DE MAGNESIO & $504(i)$ & 2013 & BPF & \\
\hline CARBONATO DE POTASIO & $501(i)$ & 2015 & BPF & \\
\hline CARBONATO DE SODIO & $500(i)$ & 2015 & BPF & \\
\hline FUMARATO DE SODIO & 365 & 2013 & BPF & \\
\hline GLUTAMATO MONOSÓDICO, L- & 621 & 2015 & BPF & 312 \\
\hline GUANILATO DISÓDICO, 5'- & 627 & 2015 & BPF & 312 \\
\hline HIDRÓXIDO DE MAGNESIO & 528 & 2013 & BPF & \\
\hline INOSINATO DISÓDICO, 5'- & 631 & 2015 & BPF & 312 \\
\hline LACTATO DE CALCIO & 327 & 2015 & BPF & \\
\hline LACTATO DE SODIO & 325 & 2015 & BPF & \\
\hline MALATO DE SODIO, DL- & 350(ii) & 2015 & BPF & \\
\hline RIBONUCLEÓTIDOS DE SODIO, 5'- & 635 & 2015 & BPF & 312 \\
\hline
\end{tabular}

No. de Categoría de alimento 09.2.4.1 Pescado y productos pesqueros cocidos

\begin{tabular}{|c|c|c|c|c|}
\hline Aditivo & SIN & Año Adoptada & Dosis máxima & Notas \\
\hline ÁCIDO ALGÍNICO & 400 & 2015 & BPF & 325 \\
\hline AGAR & 406 & 2015 & BPF & 241 \\
\hline ALGA EUCHEUMA ELABORADA & $407 a$ & 2015 & BPF & $16 \& 325$ \\
\hline ALGINATO DE SODIO & 401 & 2015 & BPF & $16 \& 325$ \\
\hline ALMIDÓN HIDROXIPROPÍLICO & 1440 & 2014 & BPF & 241 \\
\hline ALMIDÓN OXIDADO & 1404 & 2014 & BPF & 241 \\
\hline AMARILLO OCASO FCF & 110 & 2008 & $300 \mathrm{mg} / \mathrm{kg}$ & 95 \\
\hline AZUL BRILLANTE FCF & 133 & 2009 & $100 \mathrm{mg} / \mathrm{kg}$ & 95 \\
\hline $\begin{array}{l}\text { CARBOXIMETILCELULOSA SÓDICA } \\
\text { (GOMA DE CELULOSA) }\end{array}$ & 466 & 2015 & BPF & $16 \& 325$ \\
\hline CARMINES & 120 & 2005 & $500 \mathrm{mg} / \mathrm{kg}$ & 178 \\
\hline CAROTENOS, BETA-, VEGETALES & 160a(ii) & 2009 & $1000 \mathrm{mg} / \mathrm{kg}$ & 95 \\
\hline CARRAGENINA & 407 & 2015 & BPF & $16 \& 325$ \\
\hline CELULOSA EN POLVO & 460(ii) & 2015 & BPF & $16 \& 325$ \\
\hline $\begin{array}{l}\text { CELULOSA MICROCRISTALINA (GEL DE } \\
\text { CELULOSA) }\end{array}$ & $460(i)$ & 2015 & BPF & $16 \& 325$ \\
\hline $\begin{array}{l}\text { CLOROFILAS Y CLOROFILINAS, } \\
\text { COMPLEJOS CUPRICOS }\end{array}$ & $141(\mathrm{i}),(\mathrm{ii})$ & 2009 & $30 \mathrm{mg} / \mathrm{kg}$ & $62 \& 95$ \\
\hline CLORURO DE CALCIO & 509 & 2015 & BPF & 241 \\
\hline
\end{tabular}




\section{No. de Categoría de alimento 09.2.4.1 Pescado y productos pesqueros} cocidos

\begin{tabular}{|c|c|c|c|c|}
\hline Aditivo & SIN & Año Adoptada & Dosis máxima & Notas \\
\hline CLORURO DE MAGNESIO & 511 & 2015 & BPF & 241 \\
\hline DEXTRINAS, ALMIDÓN TOSTADO & 1400 & 2014 & BPF & 241 \\
\hline $\begin{array}{l}\text { ÉSTERES ACÉTICOS Y DE ÁCIDOS } \\
\text { GRASOS DE GLICEROL }\end{array}$ & $472 a$ & 2015 & BPF & 241 \\
\hline $\begin{array}{l}\text { ÉSTERES CÍTRICOS Y DE ÁCIDOS } \\
\text { GRASOS DE GLICEROL }\end{array}$ & $472 \mathrm{c}$ & 2015 & BPF & 241 \\
\hline $\begin{array}{l}\text { ÉSTERES LÁCTICOS Y DE ÁCIDOS } \\
\text { GRASOS DE GLICEROL }\end{array}$ & $472 b$ & 2015 & BPF & 241 \\
\hline $\begin{array}{l}\text { ÉSTERES POLIGLICÉRIDOS DE ÁCIDO } \\
\text { RICINOLÉICO INTERESTERIFICADO }\end{array}$ & 476 & 2018 & $1000 \mathrm{mg} / \mathrm{kg}$ & 412 \\
\hline $\begin{array}{l}\text { ÉSTERES POLIGLICÉRIDOS DE ÁCIDOS } \\
\text { GRASOS }\end{array}$ & 475 & 2018 & $1000 \mathrm{mg} / \mathrm{kg}$ & 412 \\
\hline ETILEN DIAMINO TETRA ACETATOS & 385,386 & 2005 & $50 \mathrm{mg} / \mathrm{kg}$ & 21 \\
\hline ETIL-LAUROIL ARGINATO & 243 & 2018 & $200 \mathrm{mg} / \mathrm{kg}$ & \\
\hline EXTRACTO DE PIEL DE UVA & 163(ii) & 2009 & $500 \mathrm{mg} / \mathrm{kg}$ & 95 \\
\hline FOSFATO DE DIALMIDÓN ACETILADO & 1414 & 2014 & BPF & 241 \\
\hline FOSFATOS & $\begin{array}{l}\text { 338; 339(i)-(iii); } \\
340 \text { (i)-(iii); } 341 \text { (i)- } \\
\text { (iii); 342(i)-(ii); } \\
343(\text { i)-(iii); } 450 \text { (i)- } \\
\text { (iii),(v)-(vii), (ix); } \\
451 \text { (i),(ii); 452(i)- } \\
\text { (v); } 542\end{array}$ & 2012 & $2200 \mathrm{mg} / \mathrm{kg}$ & 33 \\
\hline GLICEROL & 422 & 2015 & BPF & 241 \\
\hline GOMA ARÁBIGA (GOMA DE ACACIA) & 414 & 2015 & BPF & $16 \& 325$ \\
\hline GOMA DE SEMILLAS DE ALGARROBO & 410 & 2014 & BPF & 241 \\
\hline GOMA GELLAN & 418 & 2014 & BPF & 241 \\
\hline GOMA GUAR & 412 & 2015 & BPF & 241 \\
\hline GOMA KARAYA & 416 & 2014 & BPF & 241 \\
\hline GOMA TARA & 417 & 2015 & BPF & 241 \\
\hline GOMA TRAGACANTO & 413 & 2014 & BPF & 241 \\
\hline GOMA XANTANA & 415 & 2015 & BPF & $241 \& 327$ \\
\hline HARINA KONJAC & 425 & 2015 & BPF & $16 \& 325$ \\
\hline HIDROXIPROPILCELULOSA & 463 & 2015 & BPF & $16 \& 325$ \\
\hline HIDROXIPROPILMETILCELULOSA & 464 & 2015 & BPF & $16 \& 325$ \\
\hline INDIGOTINA (CARMÍN DE ÍNDIGO) & 132 & 2009 & $300 \mathrm{mg} / \mathrm{kg}$ & 95 \\
\hline LECITINA & $322(i)$ & 2015 & BPF & 241 \\
\hline MANITOL & 421 & 2015 & BPF & 241 \\
\hline METILCELULOSA & 461 & 2015 & BPF & $16 \& 325$ \\
\hline METILETILCELULOSA & 465 & 2015 & BPF & 241 \\
\hline $\begin{array}{l}\text { MONOGLICÉRIDOS Y DIGLICÉRIDOS DE } \\
\text { ÁCIDOS GRASOS }\end{array}$ & 471 & 2015 & BPF & 241 \\
\hline PECTINAS & 440 & 2015 & BPF & 241 \\
\hline POLIDEXTROSA & 1200 & 2015 & BPF & 241 \\
\hline PONCEAU 4R (ROJO DE COCHINILLA A) & 124 & 2008 & $500 \mathrm{mg} / \mathrm{kg}$ & 95 \\
\hline
\end{tabular}




\begin{tabular}{|c|c|c|c|c|}
\hline \multicolumn{2}{|c|}{ No. de Categoría de alimento 09.2.4.1 } & \multicolumn{3}{|c|}{$\begin{array}{l}\text { Pescado y productos pesqueros } \\
\text { cocidos }\end{array}$} \\
\hline Aditivo & SIN & Año Adoptada & Dosis máxima & Notas \\
\hline PULLULAN & 1204 & 2015 & BPF & 241 \\
\hline RIBOFLAVINAS & 101(i),(ii), (iii) & 2008 & $300 \mathrm{mg} / \mathrm{kg}$ & 95 \\
\hline ROJO ALLURA AC & 129 & 2009 & $300 \mathrm{mg} / \mathrm{kg}$ & 95 \\
\hline SACARINAS & 954(i)-(iv) & 2008 & $500 \mathrm{mg} / \mathrm{kg}$ & 161 \\
\hline $\begin{array}{l}\text { SAL DE ÁCIDO OLEICO CON CALCIO, } \\
\text { POTASIO Y SODIO }\end{array}$ & 470(ii) & 2015 & BPF & 241 \\
\hline $\begin{array}{l}\text { SAL MIRÍSTICA, PALMÍTICA Y ÁCIDOS } \\
\text { ESTEÁRICOS CON AMONIO, CALCIO, } \\
\text { POTASIO Y SODIO }\end{array}$ & $470(i)$ & 2015 & BPF & 241 \\
\hline SORBATOS & $200,202,203$ & 2009 & $2000 \mathrm{mg} / \mathrm{kg}$ & 42 \\
\hline SUCROÉSTERES DE ÁCIDOS GRASOS & 473 & 2018 & $4500 \mathrm{mg} / \mathrm{kg}$ & 241,348 \\
\hline SUCROGLICÉRIDOS & 474 & 2018 & $4500 \mathrm{mg} / \mathrm{kg}$ & 241,348 \\
\hline $\begin{array}{l}\text { SUCROSE OLIGOESTERS, TYPE I AND } \\
\text { TYPE II }\end{array}$ & $473 a$ & 2018 & $4500 \mathrm{mg} / \mathrm{kg}$ & 241,348 \\
\hline VERDE SÓLIDO FCF & 143 & 1999 & $100 \mathrm{mg} / \mathrm{kg}$ & \\
\hline
\end{tabular}

No. de Categoría de alimento 09.2.4.2 Moluscos, crustáceos y equinodermos cocidos

\begin{tabular}{|c|c|c|c|c|}
\hline Aditivo & SIN & Año Adoptada & Dosis máxima & Notas \\
\hline ÁCIDO ALGÍNICO & 400 & 2015 & BPF & 16 \\
\hline AGAR & 406 & 2015 & BPF & 241 \\
\hline ALGA EUCHEUMA ELABORADA & $407 a$ & 2015 & BPF & 16 \\
\hline ALGINATO DE SODIO & 401 & 2015 & BPF & $16 \& 325$ \\
\hline AMARILLO OCASO FCF & 110 & 2008 & $250 \mathrm{mg} / \mathrm{kg}$ & \\
\hline AZUL BRILLANTE FCF & 133 & 2009 & $100 \mathrm{mg} / \mathrm{kg}$ & \\
\hline BENZOATOS & $210-213$ & 2003 & $2000 \mathrm{mg} / \mathrm{kg}$ & $13 \& 82$ \\
\hline $\begin{array}{l}\text { CARBOXIMETILCELULOSA SÓDICA } \\
\text { (GOMA DE CELULOSA) }\end{array}$ & 466 & 2015 & BPF & $16 \& 325$ \\
\hline CARMINES & 120 & 2005 & $250 \mathrm{mg} / \mathrm{kg}$ & 178 \\
\hline CAROTENOS, BETA-, VEGETALES & $160 a(i i)$ & 2005 & $1000 \mathrm{mg} / \mathrm{kg}$ & \\
\hline CARRAGENINA & 407 & 2015 & BPF & $16 \& 325$ \\
\hline CELULOSA EN POLVO & $460(i i)$ & 2015 & BPF & 16 \\
\hline $\begin{array}{l}\text { CELULOSA MICROCRISTALINA (GEL DE } \\
\text { CELULOSA) }\end{array}$ & $460(\mathrm{i})$ & 2015 & BPF & 16 \\
\hline ETIL-LAUROIL ARGINATO & 243 & 2018 & $200 \mathrm{mg} / \mathrm{kg}$ & \\
\hline EXTRACTO DE PIEL DE UVA & 163(ii) & 2011 & $1000 \mathrm{mg} / \mathrm{kg}$ & \\
\hline FOSFATOS & $\begin{array}{l}\text { 338; 339(i)-(iii); } \\
\text { 340(i)-(iii); 341(i)- } \\
\text { (iii); 342(i)-(ii); } \\
343(\text { i)-(iii); 450(i)- } \\
\text { (iii),(v)-(vii), (ix); } \\
\text { 451(i),(ii); 452(i)- } \\
\text { (v); } 542\end{array}$ & 2012 & $2200 \mathrm{mg} / \mathrm{kg}$ & 33 \\
\hline GOMA ARÁBIGA (GOMA DE ACACIA) & 414 & 2015 & BPF & 16 \\
\hline HARINA KONJAC & 425 & 2015 & BPF & 16 \\
\hline
\end{tabular}


No. de Categoría de alimento 09.2.4.2 Moluscos, crustáceos y equinodermos cocidos

\begin{tabular}{llccc} 
Aditivo & SIN & Año Adoptada & Dosis máxima & Notas \\
\hline HIDROXIPROPILCELULOSA & 463 & 2015 & BPF & 16 \\
HIDROXIPROPILMETILCELULOSA & 464 & 2015 & BPF & 16 \\
INDIGOTINA (CARMÍN DE ÍNDIGO) & 132 & 2009 & $250 \mathrm{mg} / \mathrm{kg}$ & 16 \\
METILCELULOSA & 461 & 2015 & BPF & 16 \\
PONCEAU 4R (ROJO DE COCHINILLA A) & 124 & 2008 & $250 \mathrm{mg} / \mathrm{kg}$ & $300 \mathrm{mg} / \mathrm{kg}$ \\
RIBOFLAVINAS & $101(\mathrm{i}),(\mathrm{ii}),(\mathrm{iii})$ & 2008 & $250 \mathrm{mg} / \mathrm{kg}$ & $42 \& 82$ \\
ROJO ALLURA AC & 129 & 2009 & $2000 \mathrm{mg} / \mathrm{kg}$ & $6 \& 250$ \\
SORBATOS & $200,202,203$ & 2009 & $200 \mathrm{mg} / \mathrm{kg}$ & 44 \\
SULFATO DE ALUMINIO Y AMONIO & 523 & 2013 & $150 \mathrm{mg} / \mathrm{kg}$ & \\
SULFITOS & $220-225,539$ & 2007 &
\end{tabular}

No. de Categoría de alimento 09.2.4.3 Pescado y productos pesqueros fritos, incluidos los moluscos, crustáceos y equinodermos

\begin{tabular}{|c|c|c|c|c|}
\hline Aditivo & SIN & Año Adoptada & Dosis máxima & Notas \\
\hline ÁCIDO ALGÍNICO & 400 & 2015 & BPF & $41 \& 332$ \\
\hline AGAR & 406 & 2015 & BPF & $41 \& 325$ \\
\hline ALGA EUCHEUMA ELABORADA & $407 a$ & 2015 & BPF & $41,325 \& 332$ \\
\hline ALGINATO DE SODIO & 401 & 2015 & BPF & $41,325 \& 332$ \\
\hline ALMIDÓN HIDROXIPROPÍLICO & 1440 & 2014 & BPF & 41 \\
\hline ALMIDÓN OXIDADO & 1404 & 2014 & BPF & 41 \\
\hline AMARILLO OCASO FCF & 110 & 2008 & $300 \mathrm{mg} / \mathrm{kg}$ & 16 \\
\hline AZUL BRILLANTE FCF & 133 & 2005 & $500 \mathrm{mg} / \mathrm{kg}$ & 16 \\
\hline $\begin{array}{l}\text { CARBOXIMETILCELULOSA SÓDICA } \\
\text { (GOMA DE CELULOSA) }\end{array}$ & 466 & 2015 & BPF & $41,325 \& 332$ \\
\hline CARMINES & 120 & 2008 & $500 \mathrm{mg} / \mathrm{kg}$ & $16,95 \& 178$ \\
\hline CAROTENOS, BETA-, VEGETALES & $160 a(i i)$ & 2005 & $1000 \mathrm{mg} / \mathrm{kg}$ & 16 \\
\hline CARRAGENINA & 407 & 2015 & BPF & $41,325 \& 332$ \\
\hline CELULOSA EN POLVO & 460(ii) & 2015 & BPF & $41,325 \& 332$ \\
\hline $\begin{array}{l}\text { CELULOSA MICROCRISTALINA (GEL DE } \\
\text { CELULOSA) }\end{array}$ & 460 (i) & 2015 & BPF & $41,325 \& 332$ \\
\hline $\begin{array}{l}\text { CLOROFILAS Y CLOROFILINAS, } \\
\text { COMPLEJOS CUPRICOS }\end{array}$ & 141(i),(ii) & 2009 & $40 \mathrm{mg} / \mathrm{kg}$ & 95 \\
\hline CLORURO DE CALCIO & 509 & 2015 & BPF & 41 \\
\hline CLORURO DE MAGNESIO & 511 & 2015 & BPF & 41 \\
\hline DEXTRINAS, ALMIDÓN TOSTADO & 1400 & 2014 & BPF & 41 \\
\hline $\begin{array}{l}\text { ÉSTERES ACÉTICOS Y DE ÁCIDOS } \\
\text { GRASOS DE GLICEROL }\end{array}$ & $472 a$ & 2015 & BPF & 41 \\
\hline $\begin{array}{l}\text { ÉSTERES CÍTRICOS Y DE ÁCIDOS } \\
\text { GRASOS DE GLICEROL }\end{array}$ & $472 \mathrm{c}$ & 2015 & BPF & 41 \\
\hline $\begin{array}{l}\text { ÉSTERES LÁCTICOS Y DE ÁCIDOS } \\
\text { GRASOS DE GLICEROL }\end{array}$ & $472 b$ & 2015 & BPF & 41 \\
\hline
\end{tabular}


No. de Categoría de alimento 09.2.4.3 Pescado y productos pesqueros fritos, incluidos los moluscos, crustáceos y equinodermos

\begin{tabular}{|c|c|c|c|c|}
\hline Aditivo & SIN & Año Adoptada & Dosis máxima & Notas \\
\hline $\begin{array}{l}\text { ÉSTERES POLIGLICÉRIDOS DE ÁCIDOS } \\
\text { GRASOS }\end{array}$ & 475 & 2018 & $5000 \mathrm{mg} / \mathrm{kg}$ & 41 \\
\hline ETIL-LAUROIL ARGINATO & 243 & 2018 & $200 \mathrm{mg} / \mathrm{kg}$ & 419 \\
\hline EXTRACTO DE PIEL DE UVA & 163(ii) & 2009 & $1000 \mathrm{mg} / \mathrm{kg}$ & $16 \& 95$ \\
\hline FOSFATO DE DIALMIDÓN ACETILADO & 1414 & 2014 & BPF & 41 \\
\hline GLICEROL & 422 & 2015 & BPF & 41 \\
\hline GOMA ARÁBIGA (GOMA DE ACACIA) & 414 & 2015 & BPF & $41,325 \& 332$ \\
\hline GOMA DE SEMILLAS DE ALGARROBO & 410 & 2014 & BPF & 41 \\
\hline GOMA GELLAN & 418 & 2014 & BPF & 41 \\
\hline GOMA GUAR & 412 & 2015 & BPF & 41 \\
\hline GOMA KARAYA & 416 & 2014 & BPF & 41 \\
\hline GOMA TARA & 417 & 2015 & BPF & 41 \\
\hline GOMA TRAGACANTO & 413 & 2014 & BPF & 41 \\
\hline GOMA XANTANA & 415 & 2015 & BPF & 41 \\
\hline HARINA KONJAC & 425 & 2015 & BPF & $41,325 \& 332$ \\
\hline HIDROXIPROPILCELULOSA & 463 & 2015 & BPF & $41,325 \& 332$ \\
\hline HIDROXIPROPILMETILCELULOSA & 464 & 2015 & BPF & $41,325 \& 332$ \\
\hline LECITINA & 322(i) & 2015 & BPF & 41 \\
\hline MANITOL & 421 & 2015 & BPF & 41 \\
\hline METILCELULOSA & 461 & 2015 & BPF & $41,325 \& 332$ \\
\hline METILETILCELULOSA & 465 & 2015 & BPF & 41 \\
\hline $\begin{array}{l}\text { MONOGLICÉRIDOS Y DIGLICÉRIDOS DE } \\
\text { ÁCIDOS GRASOS }\end{array}$ & 471 & 2015 & BPF & 41 \\
\hline PECTINAS & 440 & 2015 & BPF & 41 \\
\hline POLIDEXTROSA & 1200 & 2015 & BPF & 41 \\
\hline PULLULAN & 1204 & 2015 & BPF & 41 \\
\hline RIBOFLAVINAS & 101(i),(ii), (iii) & 2005 & 300 mg/kg & 16 \\
\hline $\begin{array}{l}\text { SAL DE ÁCIDO OLEICO CON CALCIO, } \\
\text { POTASIO Y SODIO }\end{array}$ & 470(ii) & 2015 & BPF & 41 \\
\hline $\begin{array}{l}\text { SAL MIRÍSTICA, PALMÍTICA Y ÁCIDOS } \\
\text { ESTEÁRICOS CON AMONIO, CALCIO, } \\
\text { POTASIO Y SODIO }\end{array}$ & $470(i)$ & 2015 & BPF & 41 \\
\hline
\end{tabular}

\section{No. de Categoría de alimento 09.2.5 Pescado y productos pesqueros} ahumados, desecados, fermentados y/o salados, incluidos los moluscos, crustáceos y equinodermos

\begin{tabular}{|c|c|c|c|c|}
\hline Aditivo & $\operatorname{SiN}$ & Año Adoptada & Dosis máxima & Notas \\
\hline ACETATO DE SODIO & 262(i) & 2018 & BPF & $\begin{array}{l}\text { XS167, XS189, } \\
\text { XS222, XS236, } \\
\text { XS244 \& XS311 }\end{array}$ \\
\hline
\end{tabular}


Pescado y productos pesqueros ahumados, desecados, fermentados y/o salados, incluidos los moluscos, crustáceos y equinodermos

\begin{tabular}{|c|c|c|c|c|}
\hline Aditivo & SIN & Año Adoptada & Dosis máxima & Notas \\
\hline ÁCIDO ACÉTICO GLACIAL & 260 & 2018 & BPF & $\begin{array}{c}\text { 437, XS167, } \\
\text { XS189, XS222, } \\
\text { XS236 \& XS244 }\end{array}$ \\
\hline ÁCIDO ALGÍNICO & 400 & 2018 & BPF & $\begin{array}{c}\text { 300, 332, XS167, } \\
\text { XS189, XS222, } \\
\text { XS236, XS244 \& } \\
\text { XS311 }\end{array}$ \\
\hline ÁCIDO ASCÓRBICO, L- & 300 & 2018 & BPF & $\begin{array}{c}\text { XS167, XS189, } \\
\text { XS222, XS236 \& } \\
\text { XS311 }\end{array}$ \\
\hline ÁCIDO CÍTRICO & 330 & 2018 & BPF & $\begin{array}{c}\text { 437, XS167, } \\
\text { XS189, XS222 \& } \\
\text { XS236 }\end{array}$ \\
\hline ÁCIDO FUMÁRICO & 297 & 2018 & BPF & $\begin{array}{l}\text { XS167, XS189, } \\
\text { XS222, XS236, } \\
\text { XS244 \& XS311 }\end{array}$ \\
\hline ÁCIDO LÁCTICO, L-, D- y DL- & 270 & 2018 & BPF & $\begin{array}{c}\text { 382, XS167, } \\
\text { XS189, XS222, } \\
\text { XS236 \& XS244 }\end{array}$ \\
\hline ÁCIDO MÁLICO, DL- & 296 & 2013 & BPF & $\begin{array}{l}\text { XS167, XS189, } \\
\text { XS222, XS236, } \\
\text { XS244 \& XS311 }\end{array}$ \\
\hline AGAR & 406 & 2018 & BPF & $\begin{array}{c}\text { 300, XS167, } \\
\text { XS189, XS222, } \\
\text { XS236, XS244 \& } \\
\text { XS311 }\end{array}$ \\
\hline ALGA EUCHEUMA ELABORADA & $407 a$ & 2018 & BPF & $\begin{array}{c}\text { 300, 332, XS167, } \\
\text { XS189, XS222, } \\
\text { XS236, XS244 \& } \\
\text { XS311 }\end{array}$ \\
\hline ALGINATO DE SODIO & 401 & 2018 & BPF & $\begin{array}{c}\text { 300, 332, XS167, } \\
\text { XS189, XS222, } \\
\text { XS236, XS244 \& } \\
\text { XS311 }\end{array}$ \\
\hline ALMIDÓN HIDROXIPROPÍLICO & 1440 & 2018 & BPF & $\begin{array}{c}\text { 300, XS167, } \\
\text { XS189, XS222, } \\
\text { XS236, XS244 \& } \\
\text { XS311 }\end{array}$ \\
\hline ALMIDÓN OXIDADO & 1404 & 2018 & BPF & $\begin{array}{c}\text { 300, XS167, } \\
\text { XS189, XS222, } \\
\text { XS236, XS244 \& } \\
\text { XS311 }\end{array}$ \\
\hline AMARILLO OCASO FCF & 110 & 2018 & $100 \mathrm{mg} / \mathrm{kg}$ & $\begin{array}{c}\text { 382, XS167, } \\
\text { XS189, XS222, } \\
\text { XS236 \& XS244 }\end{array}$ \\
\hline BENZOATOS & $210-213$ & 2018 & $200 \mathrm{mg} / \mathrm{kg}$ & $\begin{array}{c}\text { 13, 121, 333, } \\
\text { XS167, XS189, } \\
\text { XS222 \& XS236 }\end{array}$ \\
\hline BUTILHIDROXIANISOL & 320 & 2018 & 200 mg/kg & $\begin{array}{c}\text { 15, 196, XS167, } \\
\text { XS189, XS222, } \\
\text { XS236, XS244 \& } \\
\text { XS311 }\end{array}$ \\
\hline
\end{tabular}




\section{No. de Categoría de alimento 09.2.5 Pescado y productos pesqueros ahumados, desecados, fermentados y/o salados, incluidos los moluscos, crustáceos y equinodermos}

\begin{tabular}{|c|c|c|c|c|}
\hline Aditivo & SIN & Año Adoptada & Dosis máxima & Notas \\
\hline BUTILHIDROXITOLUENO & 321 & 2018 & $200 \mathrm{mg} / \mathrm{kg}$ & $\begin{array}{c}\text { 15, 196, XS167, } \\
\text { XS189, XS222, } \\
\text { XS236, XS244 \& } \\
\text { XS311 }\end{array}$ \\
\hline CANTAXANTINA & $161 \mathrm{~g}$ & 2018 & $15 \mathrm{mg} / \mathrm{kg}$ & $\begin{array}{c}\text { 22, XS167, } \\
\text { XS189, XS222, } \\
\text { XS236, XS244 \& } \\
\text { XS311 }\end{array}$ \\
\hline CARBONATO ÁCIDO DE MAGNESIO & 504(ii) & 2018 & BPF & $\begin{array}{l}\text { XS167, XS189, } \\
\text { XS222, XS236, } \\
\text { XS244 \& XS311 }\end{array}$ \\
\hline CARBONATO DE CALCIO & $170(\mathrm{i})$ & 2018 & BPF & $\begin{array}{l}\text { XS167, XS189, } \\
\text { XS222, XS236, } \\
\text { XS244 \& XS311 }\end{array}$ \\
\hline CARBONATO DE MAGNESIO & $504(i)$ & 2018 & BPF & $\begin{array}{l}\text { XS167, XS189, } \\
\text { XS222, XS236, } \\
\text { XS244 \& XS311 }\end{array}$ \\
\hline CARBONATO DE POTASIO & $501(\mathrm{i})$ & 2018 & BPF & $\begin{array}{c}\text { 230, XS167, } \\
\text { XS189, XS222, } \\
\text { XS236, XS244 \& } \\
\text { XS311 }\end{array}$ \\
\hline CARBONATO DE SODIO & $500(i)$ & 2018 & BPF & $\begin{array}{l}\text { XS167, XS189, } \\
\text { XS222, XS236, } \\
\text { XS244 \& XS311 }\end{array}$ \\
\hline $\begin{array}{l}\text { CARBOXIMETILCELULOSA SÓDICA } \\
\text { (GOMA DE CELULOSA) }\end{array}$ & 466 & 2018 & BPF & $\begin{array}{c}\text { 300, 332, XS167, } \\
\text { XS189, XS222, } \\
\text { XS236, XS244 \& } \\
\text { XS311 }\end{array}$ \\
\hline CARMINES & 120 & 2018 & $300 \mathrm{mg} / \mathrm{kg}$ & $\begin{array}{c}22,178, \text { XS167, } \\
\text { XS189, XS222, } \\
\text { XS236, XS244 \& } \\
\text { XS311 }\end{array}$ \\
\hline CAROTENOS, BETA-, VEGETALES & $160 a(i i)$ & 2018 & $1000 \mathrm{mg} / \mathrm{kg}$ & $\begin{array}{l}\text { XS167, XS189, } \\
\text { XS222, XS236, } \\
\text { XS244 \& XS311 }\end{array}$ \\
\hline CARRAGENINA & 407 & 2018 & BPF & $\begin{array}{c}\text { 300, 332, XS167, } \\
\text { XS189, XS222, } \\
\text { XS236, XS244 \& } \\
\text { XS311 }\end{array}$ \\
\hline CELULOSA EN POLVO & 460(ii) & 2018 & BPF & $\begin{array}{c}\text { 300, 332, XS167, } \\
\text { XS189, XS222, } \\
\text { XS236, XS244 \& } \\
\text { XS311 }\end{array}$ \\
\hline $\begin{array}{l}\text { CELULOSA MICROCRISTALINA (GEL DE } \\
\text { CELULOSA) }\end{array}$ & $460(i)$ & 2018 & BPF & $\begin{array}{c}\text { 300, 332, XS167, } \\
\text { XS189, XS222, } \\
\text { XS236, XS244 \& } \\
\text { XS311 }\end{array}$ \\
\hline $\begin{array}{l}\text { CLOROFILAS Y CLOROFILINAS, } \\
\text { COMPLEJOS CUPRICOS }\end{array}$ & 141(i),(ii) & 2018 & $200 \mathrm{mg} / \mathrm{kg}$ & $\begin{array}{l}\text { XS167, XS189, } \\
\text { XS222, XS236, } \\
\text { XS244 \& XS311 }\end{array}$ \\
\hline CLORURO DE CALCIO & 509 & 2018 & BPF & $\begin{array}{c}\text { 300, XS167, } \\
\text { XS189, XS222, } \\
\text { XS236, XS244 \& } \\
\text { XS311 }\end{array}$ \\
\hline
\end{tabular}




\section{No. de Categoría de alimento 09.2.5 Pescado y productos pesqueros ahumados, desecados, fermentados y/o salados, incluidos los moluscos, crustáceos y equinodermos}

\begin{tabular}{|c|c|c|c|c|}
\hline Aditivo & SIN & Año Adoptada & Dosis máxima & Notas \\
\hline CLORURO DE MAGNESIO & 511 & 2018 & BPF & $\begin{array}{c}\text { 300, XS167, } \\
\text { XS189, XS222, } \\
\text { XS236, XS244 \& } \\
\text { XS311 }\end{array}$ \\
\hline CLORURO DE POTASIO & 508 & 2018 & BPF & $\begin{array}{c}\text { 300, XS167, } \\
\text { XS189, XS222, } \\
\text { XS236, XS244 \& } \\
\text { XS311 }\end{array}$ \\
\hline DIÓXIDO DE CARBONO & 290 & 2018 & BPF & $\begin{array}{l}\text { 59, 382, XS167, } \\
\text { XS189, XS222, } \\
\text { XS236 \& XS244 }\end{array}$ \\
\hline $\begin{array}{l}\text { ERITORBATO DE SODIO } \\
\text { (ISOASCORBATO DE SODIO) }\end{array}$ & 316 & 2018 & BPF & $\begin{array}{c}\text { 382, XS167, } \\
\text { XS189, XS222, } \\
\text { XS236 \& XS244 }\end{array}$ \\
\hline $\begin{array}{l}\text { ÉSTERES ACÉTICOS Y DE ÁCIDOS } \\
\text { GRASOS DE GLICEROL }\end{array}$ & $472 a$ & 2018 & BPF & $\begin{array}{c}\text { 300, XS167, } \\
\text { XS189, XS222, } \\
\text { XS236, XS244 \& } \\
\text { XS311 }\end{array}$ \\
\hline $\begin{array}{l}\text { ÉSTERES CÍTRICOS Y DE ÁCIDOS } \\
\text { GRASOS DE GLICEROL }\end{array}$ & $472 c$ & 2018 & BPF & $\begin{array}{c}\text { 300, XS167, } \\
\text { XS189, XS222, } \\
\text { XS236, XS244 \& } \\
\text { XS311 }\end{array}$ \\
\hline $\begin{array}{l}\text { ÉSTERES LÁCTICOS Y DE ÁCIDOS } \\
\text { GRASOS DE GLICEROL }\end{array}$ & $472 b$ & 2018 & BPF & $\begin{array}{c}\text { 300, XS167, } \\
\text { XS189, XS222, } \\
\text { XS236, XS244 \& } \\
\text { XS311 }\end{array}$ \\
\hline ETIL-LAUROIL ARGINATO & 243 & 2018 & $200 \mathrm{mg} / \mathrm{kg}$ & $\begin{array}{l}\text { XS167, XS189, } \\
\text { XS222, XS236, } \\
\text { XS244, XS311 }\end{array}$ \\
\hline EXTRACTO DE PIEL DE UVA & 163(ii) & 2018 & $1000 \mathrm{mg} / \mathrm{kg}$ & $\begin{array}{c}\text { 22, XS167, } \\
\text { XS189, XS222, } \\
\text { XS236, XS244 \& } \\
\text { XS311 }\end{array}$ \\
\hline $\begin{array}{l}\text { EXTRACTOS DE ANNATO, BASE DE } \\
\text { BIXINA }\end{array}$ & $160 b(i)$ & 2018 & $10 \mathrm{mg} / \mathrm{kg}$ & $\begin{array}{l}\text { 8, 382, XS167, } \\
\text { XS189, XS222, } \\
\text { XS236 \& XS244 }\end{array}$ \\
\hline FOSFATO DE DIALMIDÓN ACETILADO & 1414 & 2018 & BPF & $\begin{array}{c}\text { 300, XS167, } \\
\text { XS189, XS222, } \\
\text { XS236, XS244 \& } \\
\text { XS311 }\end{array}$ \\
\hline FOSFATOS & $\begin{array}{l}\text { 338; 339(i)-(iii); } \\
\text { 340(i)-(iii); 341(i)- } \\
\text { (iii); 342(i)-(ii); } \\
\text { 343(i)-(iii); 450(i)- } \\
\text { (iii),(v)-(vii), (ix); } \\
\text { 451(i),(ii); 452(i)- } \\
\text { (v); } 542\end{array}$ & 2018 & $2200 \mathrm{mg} / \mathrm{kg}$ & $\begin{array}{c}\text { 33, 334, XS167, } \\
\text { XS189, XS236, } \\
\text { XS244, XS311, } \\
413,420\end{array}$ \\
\hline FUMARATO DE SODIO & 365 & 2018 & BPF & $\begin{array}{l}\text { XS167, XS189, } \\
\text { XS222, XS236, } \\
\text { XS244 \& XS311 }\end{array}$ \\
\hline GALATO DE PROPILO & 310 & 2018 & $100 \mathrm{mg} / \mathrm{kg}$ & $\begin{array}{c}15,196, X S 167, \\
\text { XS189, XS222, } \\
\text { XS236, XS244 \& } \\
\text { XS311 }\end{array}$ \\
\hline
\end{tabular}



salados, incluidos los moluscos, crustáceos y equinodermos

\begin{tabular}{|c|c|c|c|c|}
\hline Aditivo & $\sin$ & Año Adoptada & Dosis máxima & Notas \\
\hline GLICEROL & 422 & 2018 & BPF & $\begin{array}{c}\text { 300, XS167, } \\
\text { XS189, XS222, } \\
\text { XS236, XS244 \& } \\
\text { XS311 }\end{array}$ \\
\hline GLUTAMATO MONOSÓDICO, L- & 621 & 2018 & BPF & $\begin{array}{l}\text { 29, 313, XS167, } \\
\text { XS189, XS236, } \\
\text { XS244 \& XS311 }\end{array}$ \\
\hline GOMA ARÁBIGA (GOMA DE ACACIA) & 414 & 2018 & BPF & $\begin{array}{c}\text { 300, 332, XS167, } \\
\text { XS189, XS222, } \\
\text { XS236, XS244 \& } \\
\text { XS311 }\end{array}$ \\
\hline GOMA GUAR & 412 & 2018 & BPF & $\begin{array}{c}\text { 300, XS167, } \\
\text { XS189, XS222, } \\
\text { XS236, XS244 \& } \\
\text { XS311 }\end{array}$ \\
\hline GOMA TARA & 417 & 2018 & BPF & $\begin{array}{c}\text { 300, XS167, } \\
\text { XS189, XS222, } \\
\text { XS236, XS244 \& } \\
\text { XS311 }\end{array}$ \\
\hline GOMA TRAGACANTO & 413 & 2018 & BPF & $\begin{array}{c}\text { 300, XS167, } \\
\text { XS189, XS222, } \\
\text { XS236, XS244 \& } \\
\text { XS311 }\end{array}$ \\
\hline GOMA XANTANA & 415 & 2018 & BPF & $\begin{array}{c}\text { 300, XS167, } \\
\text { XS189, XS222, } \\
\text { XS236, XS244 \& } \\
\text { XS311 }\end{array}$ \\
\hline GUANILATO DISÓDICO, 5'- & 627 & 2018 & BPF & $\begin{array}{c}\text { 29, XS167, } \\
\text { XS189, XS222, } \\
\text { XS236, XS244 \& } \\
\text { XS311 }\end{array}$ \\
\hline HARINA KONJAC & 425 & 2018 & BPF & $\begin{array}{c}\text { 300, 332, XS167, } \\
\text { XS189, XS222, } \\
\text { XS236, XS244 \& } \\
\text { XS311 }\end{array}$ \\
\hline HIDRÓXIDO DE MAGNESIO & 528 & 2018 & BPF & $\begin{array}{l}\text { XS167, XS189, } \\
\text { XS222, XS236, } \\
\text { XS244 \& XS311 }\end{array}$ \\
\hline HIDROXIPROPILCELULOSA & 463 & 2018 & BPF & $\begin{array}{c}\text { 300, 332, XS167, } \\
\text { XS189, XS222, } \\
\text { XS236, XS244 \& } \\
\text { XS311 }\end{array}$ \\
\hline HIDROXIPROPILMETILCELULOSA & 464 & 2018 & BPF & $\begin{array}{c}\text { 300, 332, XS167, } \\
\text { XS189, XS222, } \\
\text { XS236, XS244 \& } \\
\text { XS311 }\end{array}$ \\
\hline INOSINATO DISÓDICO, 5'- & 631 & 2018 & BPF & $\begin{array}{c}\text { 29, XS167, } \\
\text { XS189, XS222, } \\
\text { XS236, XS244 \& } \\
\text { XS311 }\end{array}$ \\
\hline LACTATO DE CALCIO & 327 & 2018 & BPF & $\begin{array}{c}\text { 437, XS167, } \\
\text { XS189, XS222, } \\
\text { XS236, \& XS244 }\end{array}$ \\
\hline
\end{tabular}


Pescado y productos pesqueros ahumados, desecados, fermentados y/o salados, incluidos los moluscos, crustáceos y equinodermos

\begin{tabular}{|c|c|c|c|c|}
\hline Aditivo & $\sin$ & Año Adoptada & Dosis máxima & Notas \\
\hline LACTATO DE POTASIO & 326 & 2018 & BPF & $\begin{array}{c}\text { 382, XS167, } \\
\text { XS189, XS222, } \\
\text { XS236 \& XS244 }\end{array}$ \\
\hline LACTATO DE SODIO & 325 & 2018 & BPF & $\begin{array}{c}\text { 437, XS167, } \\
\text { XS189, XS222, } \\
\text { XS236 \& XS244 }\end{array}$ \\
\hline LECITINA & 322(i) & 2018 & BPF & $\begin{array}{c}\text { 300, XS167, } \\
\text { XS189, XS222, } \\
\text { XS236, XS244 \& } \\
\text { XS311 }\end{array}$ \\
\hline MALATO DE SODIO, DL- & 350(ii) & 2018 & BPF & $\begin{array}{l}\text { XS167, XS189, } \\
\text { XS222, XS236, } \\
\text { XS244 \& XS311 }\end{array}$ \\
\hline MANITOL & 421 & 2018 & BPF & $\begin{array}{c}\text { 300, XS167, } \\
\text { XS189, XS222, } \\
\text { XS236, XS244 \& } \\
\text { XS311 }\end{array}$ \\
\hline METILCELULOSA & 461 & 2018 & BPF & $\begin{array}{c}\text { 300, 332, XS167, } \\
\text { XS189, XS222, } \\
\text { XS236, XS244 \& } \\
\text { XS311 }\end{array}$ \\
\hline METILETILCELULOSA & 465 & 2018 & BPF & $\begin{array}{c}\text { 300, XS167, } \\
\text { XS189, XS222, } \\
\text { XS236, XS244 \& } \\
\text { XS311 }\end{array}$ \\
\hline $\begin{array}{l}\text { MONOGLICÉRIDOS Y DIGLICÉRIDOS DE } \\
\text { ÁCIDOS GRASOS }\end{array}$ & 471 & 2018 & BPF & $\begin{array}{c}\text { 300, XS167, } \\
\text { XS189, XS222, } \\
\text { XS236, XS244 \& } \\
\text { XS311 }\end{array}$ \\
\hline NITRÓGENO & 941 & 2018 & BPF & $\begin{array}{l}\text { 59, 382, XS167, } \\
\text { XS189, XS222, } \\
\text { XS236 \& XS244 }\end{array}$ \\
\hline ÓXIDOS DE HIERRO & 172(i)-(iii) & 2018 & $250 \mathrm{mg} / \mathrm{kg}$ & $\begin{array}{c}\text { 22, XS167, } \\
\text { XS189, XS222, } \\
\text { XS236, XS244 \& } \\
\text { XS311 }\end{array}$ \\
\hline PECTINAS & 440 & 2018 & BPF & $\begin{array}{c}\text { 300, XS167, } \\
\text { XS189, XS222, } \\
\text { XS236, XS244 \& } \\
\text { XS311 }\end{array}$ \\
\hline PONCEAU 4R (ROJO DE COCHINILLA A) & 124 & 2018 & $100 \mathrm{mg} / \mathrm{kg}$ & $\begin{array}{c}\text { 22, XS167, } \\
\text { XS189, XS222, } \\
\text { XS236, XS244 \& } \\
\text { XS311 }\end{array}$ \\
\hline PULLULAN & 1204 & 2018 & BPF & $\begin{array}{c}\text { 300, XS167, } \\
\text { XS189, XS222, } \\
\text { XS236, XS244 \& } \\
\text { XS311 }\end{array}$ \\
\hline RIBOFLAVINAS & 101(i),(ii), (iii) & 2018 & $300 \mathrm{mg} / \mathrm{kg}$ & $\begin{array}{c}\text { 22, XS167, } \\
\text { XS189, XS222, } \\
\text { XS236, XS244 \& } \\
\text { XS311 }\end{array}$ \\
\hline
\end{tabular}




\begin{tabular}{|c|c|c|c|c|}
\hline \multicolumn{2}{|c|}{ No. de Categoría de alimento 09.2.5 } & \multicolumn{3}{|c|}{$\begin{array}{l}\text { Pescado y productos pesqueros } \\
\text { ahumados, desecados, fermentados y/o } \\
\text { salados, incluidos los moluscos, } \\
\text { crustáceos y equinodermos }\end{array}$} \\
\hline Aditivo & $\sin$ & Año Adoptada & Dosis máxima & Notas \\
\hline RIBONUCLEÓTIDOS DE SODIO, 5'- & 635 & 2018 & BPF & $\begin{array}{c}\text { 29, XS167, } \\
\text { XS189, XS222, } \\
\text { XS236, XS244 \& } \\
\text { XS311 }\end{array}$ \\
\hline ROJO ALLURA AC & 129 & 2018 & $300 \mathrm{mg} / \mathrm{kg}$ & $\begin{array}{l}\text { 382, XS167, } \\
\text { XS189, XS222, } \\
\text { XS236 \& XS244 }\end{array}$ \\
\hline $\begin{array}{l}\text { SAL DE ÁCIDO OLEICO CON CALCIO, } \\
\text { POTASIO Y SODIO }\end{array}$ & 470(ii) & 2018 & BPF & $\begin{array}{c}\text { 300, XS167, } \\
\text { XS189, XS222, } \\
\text { XS236, XS244 \& } \\
\text { XS311 }\end{array}$ \\
\hline $\begin{array}{l}\text { SAL MIRÍSTICA, PALMÍTICA Y ÁCIDOS } \\
\text { ESTEÁRICOS CON AMONIO, CALCIO, } \\
\text { POTASIO Y SODIO }\end{array}$ & $470(i)$ & 2018 & BPF & $\begin{array}{c}\text { 300, XS167, } \\
\text { XS189, XS222, } \\
\text { XS236, XS244 \& } \\
\text { XS311 }\end{array}$ \\
\hline SORBATOS & $200,202,203$ & 2018 & $1000 \mathrm{mg} / \mathrm{kg}$ & $\begin{array}{l}\text { 20, 42, XS189, } \\
\text { XS222 \& XS236 }\end{array}$ \\
\hline SULFITOS & $220-225,539$ & 2018 & $30 \mathrm{mg} / \mathrm{kg}$ & $\begin{array}{c}\text { 44, XS167, } \\
\text { XS189, XS222, } \\
\text { XS236, XS244 \& } \\
\text { XS311 }\end{array}$ \\
\hline TARTRATOS & 334, 335(ii), 337 & 2018 & 200 mg/kg & $\begin{array}{c}\text { 45, 128, 382, } \\
\text { XS167, XS189, } \\
\text { XS222, XS236 \& } \\
\text { XS244 }\end{array}$ \\
\hline TARTRAZINA & 102 & 2018 & $100 \mathrm{mg} / \mathrm{kg}$ & $\begin{array}{l}\text { 382, XS167, } \\
\text { XS189, XS222, } \\
\text { XS236 \& XS244 }\end{array}$ \\
\hline VERDE SÓLIDO FCF & 143 & 2018 & $100 \mathrm{mg} / \mathrm{kg}$ & $\begin{array}{l}\text { XS167, XS189, } \\
\text { XS222, XS236, } \\
\text { XS244 \& XS311 }\end{array}$ \\
\hline
\end{tabular}

No. de Categoría de alimento 09.3

Pescado y productos pesqueros semiconservados, incluidos los moluscos, crustáceos y equinodermos

\begin{tabular}{|c|c|c|c|c|}
\hline Aditivo & SIN & Año Adoptada & Dosis máxima & Notas \\
\hline ACESULFAME DE POTASIO & 950 & 2018 & 200 mg/kg & $144,188 \&$ XS291 \\
\hline ASPARTAMO & 951 & 2018 & 300 mg/kg & $144,191 \&$ XS291 \\
\hline BENZOATOS & $210-213$ & 2018 & $2000 \mathrm{mg} / \mathrm{kg}$ & $13,120 \&$ XS291 \\
\hline BUTILHIDROXIANISOL & 320 & 2018 & $200 \mathrm{mg} / \mathrm{kg}$ & $15,180 \&$ XS291 \\
\hline BUTILHIDROXITOLUENO & 321 & 2018 & $200 \mathrm{mg} / \mathrm{kg}$ & $15,180 \&$ XS291 \\
\hline $\begin{array}{l}\text { CARAMELO III - CARAMELO AL } \\
\text { AMONÍACO }\end{array}$ & $150 \mathrm{c}$ & 2018 & $30000 \mathrm{mg} / \mathrm{kg}$ & $95 \&$ XS291 \\
\hline $\begin{array}{l}\text { CARAMELO IV - CARAMELO AL SULFITO } \\
\text { AMÓNICO }\end{array}$ & $150 d$ & 2018 & $30000 \mathrm{mg} / \mathrm{kg}$ & $95 \&$ XS291 \\
\hline CAROTENOIDES & $160 a(i), a(i i i), e, f$ & 2018 & $100 \mathrm{mg} / \mathrm{kg}$ & $95 \&$ XS291 \\
\hline HIDROXIBENZOATOS, PARA- & 214,218 & 2018 & $1000 \mathrm{mg} / \mathrm{kg}$ & $27 \& X S 291$ \\
\hline NEOTAMO & 961 & 2018 & $10 \mathrm{mg} / \mathrm{kg}$ & $161 \&$ XS291 \\
\hline
\end{tabular}


Pescado y productos pesqueros semiconservados, incluidos los moluscos, crustáceos y equinodermos

\begin{tabular}{lllrc} 
Aditivo & SIN & Año Adoptada & Dosis máxima & Notas \\
SAL DE ASPARTAMO Y ACESULFAMO & 962 & 2018 & $200 \mathrm{mg} / \mathrm{kg}$ & 113 \& XS291 \\
SORBATOS & $200,202,203$ & 2018 & $1000 \mathrm{mg} / \mathrm{kg}$ & $42 \&$ XS291 \\
SUCRALOSA & 955 & 2018 & $120 \mathrm{mg} / \mathrm{kg}$ & $144 \&$ XS 291 \\
(TRICLOROGALACTOSACAROSA) & & & & \\
\hline
\end{tabular}
marinados y/o en gelatina, incluidos los moluscos, crustáceos y equinodermos

\begin{tabular}{|c|c|c|c|c|}
\hline Aditivo & SIN & Año Adoptada & Dosis máxima & Notas \\
\hline AMARILLO OCASO FCF & 110 & 2008 & $300 \mathrm{mg} / \mathrm{kg}$ & 16 \\
\hline AZUL BRILLANTE FCF & 133 & 2005 & $500 \mathrm{mg} / \mathrm{kg}$ & 16 \\
\hline CARMINES & 120 & 2005 & $500 \mathrm{mg} / \mathrm{kg}$ & $16 \& 178$ \\
\hline CAROTENOS, BETA-, VEGETALES & $160 a(i i)$ & 2005 & $1000 \mathrm{mg} / \mathrm{kg}$ & 16 \\
\hline $\begin{array}{l}\text { CLOROFILAS Y CLOROFILINAS, } \\
\text { COMPLEJOS CUPRICOS }\end{array}$ & 141(i),(ii) & 2009 & $40 \mathrm{mg} / \mathrm{kg}$ & 16 \\
\hline $\begin{array}{l}\text { ÉSTERES POLIGLICÉRIDOS DE ÁCIDOS } \\
\text { GRASOS }\end{array}$ & 475 & 2018 & $1000 \mathrm{mg} / \mathrm{kg}$ & 414 \\
\hline ETIL-LAUROIL ARGINATO & 243 & 2018 & $200 \mathrm{mg} / \mathrm{kg}$ & \\
\hline EXTRACTO DE PIEL DE UVA & 163(ii) & 2009 & $500 \mathrm{mg} / \mathrm{kg}$ & 16 \\
\hline FOSFATOS & $\begin{array}{l}\text { 338; 339(i)-(iii); } \\
\text { 340(i)-(iii); 341(i)- } \\
\text { (iii); 342(i)-(ii); } \\
\text { 343(i)-(iii); 450(i)- } \\
\text { (iii),(v)-(vii), (ix); } \\
\text { 451(i),(ii); 452(i)- } \\
\text { (v); } 542\end{array}$ & 2012 & $2200 \mathrm{mg} / \mathrm{kg}$ & 33 \\
\hline GLICÓSIDOS DE ESTEVIOL & $960 a, 960 b(i)$ & 2011 & $100 \mathrm{mg} / \mathrm{kg}$ & $26 \& 144$ \\
\hline RIBOFLAVINAS & 101(i),(ii), (iii) & 2005 & $300 \mathrm{mg} / \mathrm{kg}$ & 16 \\
\hline SACARINAS & 954(i)-(iv) & 2007 & $160 \mathrm{mg} / \mathrm{kg}$ & 144 \\
\hline
\end{tabular}

\section{No. de Categoría de alimento 09.3.2 Pescado y productos pesqueros escabechados $\mathrm{y} / \mathrm{o}$ en salmuera, incluidos los moluscos, crustáceos y equinodermos}

\begin{tabular}{lllcc} 
Aditivo & SIN & Año Adoptada & Dosis máxima & Notas \\
\hline AMARILLO OCASO FCF & 110 & 2008 & $300 \mathrm{mg} / \mathrm{kg}$ & 16 \\
AZUL BRILLANTE FCF & 133 & 2005 & $500 \mathrm{mg} / \mathrm{kg}$ & 16 \\
CARMINES & 120 & 2005 & $500 \mathrm{mg} / \mathrm{kg}$ & $16 \& 178$ \\
CAROTENOS, BETA-, VEGETALES & $160 \mathrm{a}$ (ii) & 2005 & $1000 \mathrm{mg} / \mathrm{kg}$ & 16 \\
$\begin{array}{l}\text { CLOROFILAS Y CLOROFILINAS, } \\
\text { COMPLEJOS CUPRICOS }\end{array}$ & 141 (i),(ii) & 2009 & $40 \mathrm{mg} / \mathrm{kg}$ & 16 \\
$\begin{array}{l}\text { ÉSTERES POLIGLICÉRIDOS DE ÁCIDOS } \\
\text { GRASOS }\end{array}$ & 475 & 2018 & $1000 \mathrm{mg} / \mathrm{kg}$ & 415 \\
ETILEN DIAMINO TETRA ACETATOS & 385,386 & 2001 & $250 \mathrm{mg} / \mathrm{kg}$ & 21
\end{tabular}




\begin{tabular}{|c|c|c|c|c|}
\hline \multirow[t]{2}{*}{ No. de Categoría de } & \multicolumn{4}{|c|}{$\begin{array}{l}\text { Pescado y productos pesqueros } \\
\text { escabechados y/o en salmuera, } \\
\text { incluidos los moluscos, crustáceos y } \\
\text { equinodermos }\end{array}$} \\
\hline & SIN & Año Adoptada & Dosis máxima & Notas \\
\hline ETIL-LAUROIL ARGINATO & 243 & 2018 & $200 \mathrm{mg} / \mathrm{kg}$ & \\
\hline EXTRACTO DE PIEL DE UVA & 163(ii) & 2009 & $1500 \mathrm{mg} / \mathrm{kg}$ & 16 \\
\hline FOSFATOS & $\begin{array}{l}\text { 338; 339(i)-(iii); } \\
340 \text { (i)-(iii); } 341 \text { (i)- } \\
\text { (iii); 342(i)-(ii); } \\
343 \text { (i)-(iii); 450(i)- } \\
\text { (iii),(v)-(vii), (ix); } \\
\text { 451(i),(ii); 452(i)- } \\
\text { (v); } 542\end{array}$ & 2012 & $2200 \mathrm{mg} / \mathrm{kg}$ & 33 \\
\hline GLICÓSIDOS DE ESTEVIOL & $960 \mathrm{a}, 960 \mathrm{~b}(\mathrm{i})$ & 2011 & $165 \mathrm{mg} / \mathrm{kg}$ & 26 \\
\hline RIBOFLAVINAS & 101(i),(ii), (iii) & 2005 & $300 \mathrm{mg} / \mathrm{kg}$ & 16 \\
\hline SACARINAS & 954(i)-(iv) & 2007 & $160 \mathrm{mg} / \mathrm{kg}$ & 144 \\
\hline
\end{tabular}

\begin{tabular}{|c|c|c|c|c|}
\hline \multicolumn{2}{|c|}{ No. de Categoría de alimento 09.3.3 } & \multicolumn{3}{|c|}{$\begin{array}{l}\text { Sucedáneos de salmón, caviar y otros } \\
\text { productos pesqueros a base de huevas }\end{array}$} \\
\hline Aditivo & SIN & Año Adoptada & Dosis máxima & Notas \\
\hline AMARILLO OCASO FCF & 110 & 2018 & $300 \mathrm{mg} / \mathrm{kg}$ & XS291 \\
\hline AZUL BRILLANTE FCF & 133 & 2018 & $500 \mathrm{mg} / \mathrm{kg}$ & XS291 \\
\hline CANTAXANTINA & $161 \mathrm{~g}$ & 2018 & $15 \mathrm{mg} / \mathrm{kg}$ & XS291 \\
\hline CARMINES & 120 & 2018 & $500 \mathrm{mg} / \mathrm{kg}$ & $178 \&$ XS291 \\
\hline CAROTENOS, BETA-, VEGETALES & $160 a(i i)$ & 2018 & $1000 \mathrm{mg} / \mathrm{kg}$ & XS291 \\
\hline $\begin{array}{l}\text { CLOROFILAS Y CLOROFILINAS, } \\
\text { COMPLEJOS CUPRICOS }\end{array}$ & 141(i),(ii) & 2018 & $200 \mathrm{mg} / \mathrm{kg}$ & XS291 \\
\hline ETIL-LAUROIL ARGINATO & 243 & 2018 & $200 \mathrm{mg} / \mathrm{kg}$ & XS291 \\
\hline EXTRACTO DE PIEL DE UVA & 163(ii) & 2018 & $1500 \mathrm{mg} / \mathrm{kg}$ & XS291 \\
\hline FOSFATOS & $\begin{array}{l}\text { 338; 339(i)-(iii); } \\
\text { 340(i)-(iii); 341(i)- } \\
\text { (iii); 342(i)-(ii); } \\
343(\mathrm{i}) \text {-(iii); 450(i)- } \\
\text { (iii),(v)-(vii), (ix); } \\
\text { 451(i),(ii); 452(i)- } \\
\text { (v); } 542\end{array}$ & 2018 & $2200 \mathrm{mg} / \mathrm{kg}$ & 33 \& XS291 \\
\hline GLICÓSIDOS DE ESTEVIOL & $960 a, 960 b(i)$ & 2018 & $100 \mathrm{mg} / \mathrm{kg}$ & $26 \&$ XS291 \\
\hline INDIGOTINA (CARMÍN DE ÍNDIGO) & 132 & 2018 & $300 \mathrm{mg} / \mathrm{kg}$ & XS291 \\
\hline ÓXIDOS DE HIERRO & 172(i)-(iii) & 2018 & $100 \mathrm{mg} / \mathrm{kg}$ & XS291 \\
\hline PONCEAU 4R (ROJO DE COCHINILLA A) & 124 & 2018 & $500 \mathrm{mg} / \mathrm{kg}$ & XS291 \\
\hline RIBOFLAVINAS & 101(i),(ii), (iii) & 2018 & $300 \mathrm{mg} / \mathrm{kg}$ & XS291 \\
\hline ROJO ALLURA AC & 129 & 2018 & $300 \mathrm{mg} / \mathrm{kg}$ & XS291 \\
\hline VERDE SÓLIDO FCF & 143 & 2018 & $100 \mathrm{mg} / \mathrm{kg}$ & XS291 \\
\hline
\end{tabular}




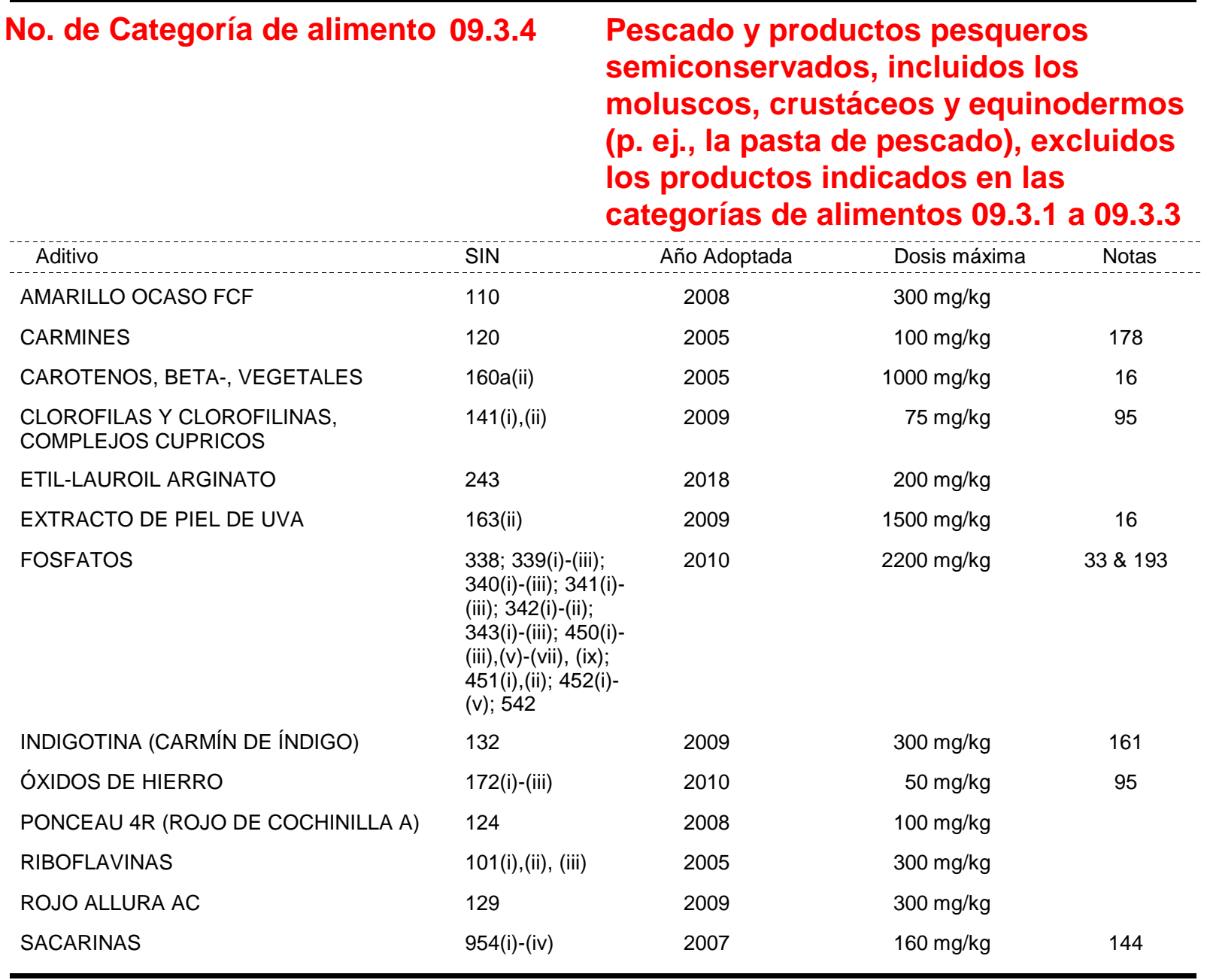

\begin{tabular}{|c|c|}
\hline No. de Categoría de alimento 09.4 & $\begin{array}{l}\text { Pescado y productos pesqueros } \\
\text { (incluidos los moluscos, crustáceos y } \\
\text { equinodermos) en conserva, con } \\
\text { inclusión de los enlatados y } \\
\text { fermentados }\end{array}$ \\
\hline
\end{tabular}

\begin{tabular}{|c|c|c|c|c|}
\hline Aditivo & SIN & Año Adoptada & Dosis máxima & Notas \\
\hline ACESULFAME DE POTASIO & 950 & 2018 & $200 \mathrm{mg} / \mathrm{kg}$ & $\begin{array}{c}144,188, \text { XS3, } \\
\text { XS37, XS70, } \\
\text { XS90, XS94 \& } \\
\text { XS119 }\end{array}$ \\
\hline AMARANTO & 123 & 2018 & $30 \mathrm{mg} / \mathrm{kg}$ & $\begin{array}{c}\text { 435, XS3, XS70 } \\
\text { XS90, XS94 \& } \\
\text { XS119 }\end{array}$ \\
\hline AMARILLO OCASO FCF & 110 & 2018 & $300 \mathrm{mg} / \mathrm{kg}$ & $\begin{array}{c}95,435, \text { XS3, } \\
\text { XS70, XS90, XS94 } \\
\text { \& XS119 }\end{array}$ \\
\hline ASPARTAMO & 951 & 2018 & $300 \mathrm{mg} / \mathrm{kg}$ & $\begin{array}{c}\text { 144, 191, XS3, } \\
\text { XS37, XS70, } \\
\text { XS90, XS94 \& } \\
\text { XS119 }\end{array}$ \\
\hline AZUL BRILLANTE FCF & 133 & 2018 & $500 \mathrm{mg} / \mathrm{kg}$ & $\begin{array}{c}\text { XS3, XS37, XS70, } \\
\text { XS90, XS94 \& } \\
\text { XS119 }\end{array}$ \\
\hline
\end{tabular}




\begin{tabular}{|c|c|c|c|c|}
\hline No. de Categoría de alimento & $\begin{array}{l}P \\
\text { (i } \\
\text { e } \\
\text { in } \\
\text { fe }\end{array}$ & $\begin{array}{l}\text { scado y pr } \\
\text { cluidos los } \\
\text { uinodermo } \\
\text { lusión de } \\
\text { mentados }\end{array}$ & $\begin{array}{l}\text { ctos pesque } \\
\text { luscos, cru } \\
\text { n conserva, } \\
\text { nlatados y }\end{array}$ & $\begin{array}{l}\text { eros } \\
\text { istáceos y } \\
\text { con }\end{array}$ \\
\hline Aditivo & $\sin$ & Año Adoptada & Dosis máxima & Notas \\
\hline BUTILHIDROXIANISOL & 320 & 2018 & $200 \mathrm{mg} / \mathrm{kg}$ & $\begin{array}{c}15,180, \text { XS3, } \\
\text { XS37, XS70, } \\
\text { XS90, XS94 \& } \\
\text { XS119 }\end{array}$ \\
\hline BUTILHIDROXITOLUENO & 321 & 2018 & $200 \mathrm{mg} / \mathrm{kg}$ & $\begin{array}{c}15,180, \text { XS3 } \\
\text { XS37, XS70, } \\
\text { XS90, XS94 \& } \\
\text { XS119 }\end{array}$ \\
\hline CANTAXANTINA & $161 \mathrm{~g}$ & 2018 & $15 \mathrm{mg} / \mathrm{kg}$ & $\begin{array}{c}\text { XS3, XS37, XS70 } \\
\text { XS90, XS94 \& } \\
\text { XS119 }\end{array}$ \\
\hline $\begin{array}{l}\text { CARAMELO III - CARAMELO AL } \\
\text { AMONÍACO }\end{array}$ & $150 c$ & 2018 & $500 \mathrm{mg} / \mathrm{kg}$ & $\begin{array}{c}\text { 50, XS3, XS37, } \\
\text { XS70, XS90, XS94 } \\
\text { \& XS119 }\end{array}$ \\
\hline $\begin{array}{l}\text { CARAMELO IV - CARAMELO AL SULFITO } \\
\text { AMÓNICO }\end{array}$ & $150 d$ & 2018 & $30000 \mathrm{mg} / \mathrm{kg}$ & $\begin{array}{c}95, \text { XS3, XS37 } \\
\text { XS70, XS90, XS94 } \\
\text { \& XS119 }\end{array}$ \\
\hline CARMINES & 120 & 2018 & $500 \mathrm{mg} / \mathrm{kg}$ & $\begin{array}{c}16,178, \text { XS3 } \\
\text { XS37, XS70, } \\
\text { XS90, XS94 \& } \\
\text { XS119 }\end{array}$ \\
\hline CAROTENOIDES & $160 a(i), a(i i i), e, f$ & 2018 & $100 \mathrm{mg} / \mathrm{kg}$ & $\begin{array}{c}\text { 95, XS3, XS37, } \\
\text { XS70, XS90, XS94 } \\
\text { \& XS119 }\end{array}$ \\
\hline CAROTENOS, BETA-, VEGETALES & $160 a(i i)$ & 2018 & $500 \mathrm{mg} / \mathrm{kg}$ & $\begin{array}{c}\text { XS3, XS37, XS70 } \\
\text { XS90, XS94 \& } \\
\text { XS119 }\end{array}$ \\
\hline $\begin{array}{l}\text { CLOROFILAS Y CLOROFILINAS, } \\
\text { COMPLEJOS CUPRICOS }\end{array}$ & 141 (i),(ii) & 2018 & $500 \mathrm{mg} / \mathrm{kg}$ & $\begin{array}{c}95, \text { XS3, XS37 } \\
\text { XS70, XS90, XS94 } \\
\text { \& XS119 }\end{array}$ \\
\hline ETILEN DIAMINO TETRA ACETATOS & 385,386 & 2018 & $340 \mathrm{mg} / \mathrm{kg}$ & $\begin{array}{c}21,310, X S 3 \\
\text { XS70, XS94 \& } \\
\text { XS119 }\end{array}$ \\
\hline EXTRACTO DE PIEL DE UVA & 163(ii) & 2018 & $1500 \mathrm{mg} / \mathrm{kg}$ & $\begin{array}{c}\text { 16, XS3, XS37, } \\
\text { XS70, XS90, XS94 } \\
\text { \& XS119 }\end{array}$ \\
\hline FOSFATOS & 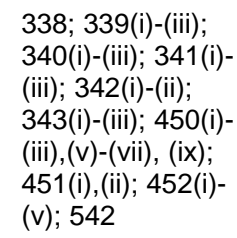 & 2018 & $2200 \mathrm{mg} / \mathrm{kg}$ & $\begin{array}{l}33,436, \text { XS3 } \\
\text { XS94 \& XS119 }\end{array}$ \\
\hline GLICÓSIDOS DE ESTEVIOL & $960 a, 960 b(i)$ & 2018 & $100 \mathrm{mg} / \mathrm{kg}$ & $\begin{array}{c}\text { 26, XS3, XS37, } \\
\text { XS70, XS90, XS94 } \\
\text { \& XS119 }\end{array}$ \\
\hline INDIGOTINA (CARMÍN DE ÍNDIGO) & 132 & 2018 & $300 \mathrm{mg} / \mathrm{kg}$ & $\begin{array}{c}\text { XS3, XS37, XS70 } \\
\text { XS90, XS94 \& } \\
\text { XS119 }\end{array}$ \\
\hline NEOTAMO & 961 & 2018 & $10 \mathrm{mg} / \mathrm{kg}$ & $\begin{array}{c}\text { 161, XS3, XS37, } \\
\text { XS70, XS90, XS94 } \\
\text { \& XS119 }\end{array}$ \\
\hline
\end{tabular}




\begin{tabular}{|c|c|c|c|c|}
\hline \multicolumn{2}{|c|}{ No. de Categoría de alimento 09.4} & \multicolumn{3}{|c|}{$\begin{array}{l}\text { Pescado y productos pesqueros } \\
\text { (incluidos los moluscos, crustáceos y } \\
\text { equinodermos) en conserva, con } \\
\text { inclusión de los enlatados y } \\
\text { fermentados }\end{array}$} \\
\hline Aditivo & $\sin$ & Año Adoptada & Dosis máxima & Notas \\
\hline ÓXIDOS DE HIERRO & 172(i)-(iii) & 2018 & $50 \mathrm{mg} / \mathrm{kg}$ & $\begin{array}{c}\text { 95, XS3, XS37, } \\
\text { XS70, XS90, XS94 } \\
\text { \& XS119 }\end{array}$ \\
\hline PONCEAU 4R (ROJO DE COCHINILLA A) & 124 & 2018 & $500 \mathrm{mg} / \mathrm{kg}$ & $\begin{array}{c}\text { 435, XS3, XS70, } \\
\text { XS90, XS94 \& } \\
\text { XS119 }\end{array}$ \\
\hline RIBOFLAVINAS & 101(i),(ii), (iii) & 2018 & $500 \mathrm{mg} / \mathrm{kg}$ & $\begin{array}{c}\text { 95, XS3, XS37, } \\
\text { XS70, XS90, XS94 } \\
\text { \& XS119 }\end{array}$ \\
\hline SACARINAS & 954(i)-(iv) & 2018 & $200 \mathrm{mg} / \mathrm{kg}$ & $\begin{array}{c}\text { 144, XS3, XS37, } \\
\text { XS70, XS90, XS94 } \\
\text { \& XS119 }\end{array}$ \\
\hline SAL DE ASPARTAMO Y ACESULFAMO & 962 & 2018 & 200 mg/kg & $\begin{array}{c}\text { 113, XS3, XS37, } \\
\text { XS70, XS90, XS94 } \\
\text { \& XS119 }\end{array}$ \\
\hline $\begin{array}{l}\text { SUCRALOSA } \\
\text { (TRICLOROGALACTOSACAROSA) }\end{array}$ & 955 & 2018 & $120 \mathrm{mg} / \mathrm{kg}$ & $\begin{array}{c}\text { 144, XS3, XS37, } \\
\text { XS70, XS90, XS94 } \\
\text { \& XS119 }\end{array}$ \\
\hline SULFITOS & $220-225,539$ & 2018 & $150 \mathrm{mg} / \mathrm{kg}$ & $\begin{array}{c}\text { 44, 140, XS3, } \\
\text { XS37, XS70, } \\
\text { XS90, XS94 \& } \\
\text { XS119 }\end{array}$ \\
\hline TARTRAZINA & 102 & 2018 & $30 \mathrm{mg} / \mathrm{kg}$ & $\begin{array}{c}\text { 435, XS3, XS70, } \\
\text { XS90, XS94 \& } \\
\text { XS119 }\end{array}$ \\
\hline VERDE SÓLIDO FCF & 143 & 2018 & $100 \mathrm{mg} / \mathrm{kg}$ & $\begin{array}{c}\text { 95, XS3, XS37, } \\
\text { XS70, XS90, XS94 } \\
\text { \& XS119 }\end{array}$ \\
\hline
\end{tabular}

No. de Categoría de alimento 10.1

AMARILLO OCASO FCF
AZUL BRILLANTE FCF
CANTAXANTINA
CARAMELO III - CARAMELO AL
AMONÍACO
CARAMELO IV - CARAMELO AL SULFITO
AMÓNICO
CARMINES
CAROTENOIDES
CAROTENOS, BETA-, VEGETALES
EXTRACTO DE PIEL DE UVA
INDIGOTINA (CARMÍN DE ÍNDIGO)
ÓXIDOS DE HIERRO
PONCEAU 4R (ROJO DE COCHINILLA A)
RIBOFLAVINAS

SIN

110

133

$161 \mathrm{~g}$

$150 \mathrm{c}$

150d

120

160a(i),a(iii),e,f

160a(ii)

163(ii)

132

172(i)-(iii)

124

101(i),(ii), (iii)

\section{Huevos frescos}

2008
2005
2005
2010
2010
2005
2011
2005
2010
2009
2005
2008
2005

Dosis máxima

Notas

BPF

4

BPF

BPF

4

\section{$20000 \mathrm{mg} / \mathrm{kg}$}

20000 mg/kg

4

$\begin{array}{rc}\mathrm{BPF} & 4 \& 178 \\ 1000 \mathrm{mg} / \mathrm{kg} & 4 \\ 1000 \mathrm{mg} / \mathrm{kg} & 4 \\ 1500 \mathrm{mg} / \mathrm{kg} & 4 \\ 300 \mathrm{mg} / \mathrm{kg} & 4 \& 161 \\ \mathrm{BPF} & 4 \\ 500 \mathrm{mg} / \mathrm{kg} & 4 \\ 300 \mathrm{mg} / \mathrm{kg} & 4\end{array}$




\begin{tabular}{|c|c|c|c|c|}
\hline \multicolumn{2}{|c|}{ No. de Categoría de alimento 10.1} & \multicolumn{3}{|c|}{ Huevos frescos } \\
\hline Aditivo & SIN & Año Adoptada & Dosis máxima & Notas \\
\hline ROJO ALLURA AC & 129 & 2009 & $100 \mathrm{mg} / \mathrm{kg}$ & 4 \\
\hline VERDE SÓLIDO FCF & 143 & 1999 & BPF & 4 \\
\hline \multicolumn{2}{|c|}{ No. de Categoría de alimento 10.2} & \multicolumn{3}{|c|}{ Productos a base de huevo } \\
\hline Aditivo & SIN & Año Adoptada & Dosis máxima & Notas \\
\hline $\begin{array}{l}\text { CARAMELO IV - CARAMELO AL SULFITO } \\
\text { AMÓNICO }\end{array}$ & $150 d$ & 2009 & $20000 \mathrm{mg} / \mathrm{kg}$ & 161 \\
\hline CAROTENOS, BETA-, VEGETALES & 160a(ii) & 2005 & $1000 \mathrm{mg} / \mathrm{kg}$ & \\
\hline $\begin{array}{l}\text { ÉSTERES POLIGLICÉRIDOS DE ÁCIDO } \\
\text { RICINOLÉICO INTERESTERIFICADO }\end{array}$ & 476 & 2018 & $1000 \mathrm{mg} / \mathrm{kg}$ & \\
\hline $\begin{array}{l}\text { ÉSTERES POLIGLICÉRIDOS DE ÁCIDOS } \\
\text { GRASOS }\end{array}$ & 475 & 2018 & $1000 \mathrm{mg} / \mathrm{kg}$ & \\
\hline ETIL-LAUROIL ARGINATO & 243 & 2011 & $200 \mathrm{mg} / \mathrm{kg}$ & \\
\hline
\end{tabular}

\section{No. de Categoría de alimento 10.2.1 Productos líquidos a base de huevo}

\begin{tabular}{|c|c|c|c|c|}
\hline Aditivo & SIN & Año Adoptada & Dosis máxima & Notas \\
\hline ACETATO DE SODIO & 262(i) & 2013 & BPF & \\
\hline ÁCIDO ACÉTICO GLACIAL & 260 & 2013 & BPF & \\
\hline ÁCIDO CÍTRICO & 330 & 2013 & BPF & \\
\hline ÁCIDO LÁCTICO, L-, D- y DL- & 270 & 2013 & BPF & \\
\hline AGAR & 406 & 2014 & BPF & \\
\hline ALGA EUCHEUMA ELABORADA & $407 a$ & 2014 & BPF & \\
\hline ALGINATO DE CALCIO & 404 & 2014 & BPF & \\
\hline ALGINATO DE PROPILENGLICOL & 405 & 2018 & $10000 \mathrm{mg} / \mathrm{kg}$ & \\
\hline ALGINATO DE SODIO & 401 & 2014 & BPF & \\
\hline BENZOATOS & $210-213$ & 2003 & $5000 \mathrm{mg} / \mathrm{kg}$ & 13 \\
\hline $\begin{array}{l}\text { CARBOXIMETILCELULOSA SÓDICA } \\
\text { (GOMA DE CELULOSA) }\end{array}$ & 466 & 2014 & BPF & \\
\hline CARRAGENINA & 407 & 2014 & BPF & \\
\hline $\begin{array}{l}\text { CELULOSA MICROCRISTALINA (GEL DE } \\
\text { CELULOSA) }\end{array}$ & $460(i)$ & 2014 & BPF & \\
\hline CITRATO DE TRIETILO & 1505 & 1999 & $2500 \mathrm{mg} / \mathrm{kg}$ & 47 \\
\hline CITRATO DÍACIDO DE SODIO & 331 (i) & 2013 & BPF & \\
\hline CITRATO TRISÓDICO & 331 (iii) & 2013 & BPF & \\
\hline DEXTRINAS, ALMIDÓN TOSTADO & 1400 & 2015 & BPF & \\
\hline ESTEAROIL LACTILATOS & $481(\mathrm{i}), 482(\mathrm{i})$ & 2018 & $500 \mathrm{mg} / \mathrm{kg}$ & \\
\hline $\begin{array}{l}\text { ÉSTERES DE SORBITÁN DE ÁCIDOS } \\
\text { GRASOS }\end{array}$ & 491-495 & 2019 & $500 \mathrm{mg} / \mathrm{kg}$ & \\
\hline FOSFATOS & $\begin{array}{l}\text { 338; 339(i)-(iii); } \\
\text { 340(i)-(iii); 341(i)- } \\
\text { (iii); 342(i)-(ii); } \\
\text { 343(i)-(iii); 450(i)- } \\
\text { (iii),(v)-(vii), (ix); } \\
\text { 451(i),(ii); 452(i)- } \\
\text { (v); } 542\end{array}$ & 2009 & $4400 \mathrm{mg} / \mathrm{kg}$ & $33 \& 67$ \\
\hline GOMA ARÁBIGA (GOMA DE ACACIA) & 414 & 2014 & BPF & \\
\hline
\end{tabular}




\begin{tabular}{|c|c|c|c|c|}
\hline \multicolumn{2}{|c|}{ No. de Categoría de alimento 10.2.1 } & \multicolumn{3}{|c|}{ Productos líquidos a base de huevo } \\
\hline Aditivo & SIN & Año Adoptada & Dosis máxima & Notas \\
\hline GOMA DE SEMILLAS DE ALGARROBO & 410 & 2014 & BPF & \\
\hline GOMA GELLAN & 418 & 2014 & BPF & \\
\hline GOMA GUAR & 412 & 2014 & BPF & \\
\hline GOMA KARAYA & 416 & 2014 & BPF & \\
\hline GOMA TARA & 417 & 2014 & BPF & \\
\hline GOMA XANTANA & 415 & 2014 & BPF & \\
\hline HARINA KONJAC & 425 & 2014 & BPF & \\
\hline LACTATO DE SODIO & 325 & 2013 & BPF & \\
\hline LECITINA & $322(i)$ & 2014 & BPF & \\
\hline $\begin{array}{l}\text { MONOGLICÉRIDOS Y DIGLICÉRIDOS DE } \\
\text { ÁCIDOS GRASOS }\end{array}$ & 471 & 2015 & BPF & \\
\hline NISINA & 234 & 2018 & $6.25 \mathrm{mg} / \mathrm{kg}$ & 233 \\
\hline $\begin{array}{l}\text { OCTENILSUCCIONATO SÓDICO DE } \\
\text { ALMIDÓN }\end{array}$ & 1450 & 2015 & BPF & \\
\hline PECTINAS & 440 & 2014 & BPF & \\
\hline POLIDEXTROSA & 1200 & 2014 & BPF & \\
\hline $\begin{array}{l}\text { SAL MIRÍSTICA, PALMÍTICA Y ÁCIDOS } \\
\text { ESTEÁRICOS CON AMONIO, CALCIO, } \\
\text { POTASIO Y SODIO }\end{array}$ & $470(\mathrm{i})$ & 2014 & BPF & \\
\hline SORBATOS & $200,202,203$ & 2009 & $5000 \mathrm{mg} / \mathrm{kg}$ & 42 \\
\hline SULFATO DE CALCIO & 516 & 2015 & BPF & \\
\hline
\end{tabular}

No. de Categoría de alimento 10.2.2 Productos congelados a base de huevo

\begin{tabular}{|c|c|c|c|c|}
\hline Aditivo & SIN & Año Adoptada & Dosis máxima & Notas \\
\hline ACETATO DE SODIO & 262(i) & 2013 & BPF & \\
\hline ÁCIDO ACÉTICO GLACIAL & 260 & 2013 & BPF & \\
\hline ÁCIDO CÍTRICO & 330 & 2013 & BPF & \\
\hline ÁCIDO LÁCTICO, L-, D- y DL- & 270 & 2013 & BPF & \\
\hline AGAR & 406 & 2014 & BPF & \\
\hline ALGA EUCHEUMA ELABORADA & $407 a$ & 2014 & BPF & \\
\hline ALGINATO DE CALCIO & 404 & 2014 & BPF & \\
\hline ALGINATO DE PROPILENGLICOL & 405 & 2018 & $10000 \mathrm{mg} / \mathrm{kg}$ & \\
\hline ALGINATO DE SODIO & 401 & 2014 & BPF & \\
\hline $\begin{array}{l}\text { CARBOXIMETILCELULOSA SÓDICA } \\
\text { (GOMA DE CELULOSA) }\end{array}$ & 466 & 2014 & BPF & \\
\hline CARRAGENINA & 407 & 2014 & BPF & \\
\hline $\begin{array}{l}\text { CELULOSA MICROCRISTALINA (GEL DE } \\
\text { CELULOSA) }\end{array}$ & $460(i)$ & 2014 & BPF & \\
\hline CITRATO DÍACIDO DE SODIO & $331(\mathrm{i})$ & 2013 & BPF & \\
\hline CITRATO TRISÓDICO & 331 (iii) & 2013 & BPF & \\
\hline DEXTRINAS, ALMIDÓN TOSTADO & 1400 & 2018 & BPF & \\
\hline ESTEAROIL LACTILATOS & 481(i), 482(i) & 2018 & $500 \mathrm{mg} / \mathrm{kg}$ & \\
\hline $\begin{array}{l}\text { ÉSTERES DE SORBITÁN DE ÁCIDOS } \\
\text { GRASOS }\end{array}$ & 491-495 & 2019 & $500 \mathrm{mg} / \mathrm{kg}$ & \\
\hline
\end{tabular}




\begin{tabular}{|c|c|c|c|c|}
\hline \multicolumn{2}{|c|}{ No. de Categoría de alimento 10.2 .2} & \multicolumn{3}{|c|}{ Productos congelados a base de hueve } \\
\hline Aditivo & SIN & Año Adoptada & Dosis máxima & Notas \\
\hline FOSFATOS & $\begin{array}{l}\text { 338; 339(i)-(iii); } \\
\text { 340(i)-(iii); 341(i)- } \\
\text { (iii); 342(i)-(ii); } \\
\text { 343(i)-(iii); 450(i)- } \\
\text { (iii),(v)-(vii), (ix); } \\
\text { 451(i),(ii); 452(i)- } \\
\text { (v); } 542\end{array}$ & 2009 & $1290 \mathrm{mg} / \mathrm{kg}$ & 33 \\
\hline GLICEROL & 422 & 2015 & BPF & \\
\hline GOMA ARÁBIGA (GOMA DE ACACIA) & 414 & 2014 & BPF & \\
\hline GOMA DE SEMILLAS DE ALGARROBO & 410 & 2014 & BPF & \\
\hline GOMA GELLAN & 418 & 2014 & BPF & \\
\hline GOMA GUAR & 412 & 2014 & BPF & \\
\hline GOMA KARAYA & 416 & 2014 & BPF & \\
\hline GOMA TARA & 417 & 2014 & BPF & \\
\hline GOMA XANTANA & 415 & 2014 & BPF & \\
\hline HARINA KONJAC & 425 & 2014 & BPF & \\
\hline LACTATO DE SODIO & 325 & 2013 & BPF & \\
\hline LECITINA & $322(i)$ & 2014 & BPF & \\
\hline MANITOL & 421 & 2014 & BPF & \\
\hline $\begin{array}{l}\text { MONOGLICÉRIDOS Y DIGLICÉRIDOS DE } \\
\text { ÁCIDOS GRASOS }\end{array}$ & 471 & 2014 & BPF & \\
\hline $\begin{array}{l}\text { OCTENILSUCCIONATO SÓDICO DE } \\
\text { ALMIDÓN }\end{array}$ & 1450 & 2015 & BPF & \\
\hline PECTINAS & 440 & 2014 & BPF & \\
\hline POLIDEXTROSA & 1200 & 2014 & BPF & \\
\hline PULLULAN & 1204 & 2015 & BPF & \\
\hline $\begin{array}{l}\text { SAL MIRÍSTICA, PALMÍTICA Y ÁCIDOS } \\
\text { ESTEÁRICOS CON AMONIO, CALCIO, } \\
\text { POTASIO Y SODIO }\end{array}$ & $470(\mathrm{i})$ & 2014 & BPF & \\
\hline SORBATOS & $200,202,203$ & 2009 & $1000 \mathrm{mg} / \mathrm{kg}$ & 42 \\
\hline
\end{tabular}

\begin{tabular}{|c|c|c|c|c|}
\hline \multicolumn{2}{|c|}{ No. de Categoría de alimento 10.2 .3} & \multicolumn{3}{|c|}{$\begin{array}{l}\text { Productos a base de huevo en polvo } \\
\text { y/o cuajados por calor }\end{array}$} \\
\hline Aditivo & SIN & Año Adoptada & Dosis máxima & Notas \\
\hline CITRATO DE TRIETILO & 1505 & 1999 & $2500 \mathrm{mg} / \mathrm{kg}$ & 47 \\
\hline ESTEAROIL LACTILATOS & $481(\mathrm{i}), 482(\mathrm{i})$ & 2018 & $5000 \mathrm{mg} / \mathrm{kg}$ & \\
\hline $\begin{array}{l}\text { ÉSTERES DE SORBITÁN DE ÁCIDOS } \\
\text { GRASOS }\end{array}$ & 491-495 & 2019 & $500 \mathrm{mg} / \mathrm{kg}$ & 452 \\
\hline $\begin{array}{l}\text { ÉSTERES DIACETILTARTÁRICOS Y DE } \\
\text { ÁCIDOS GRASOS DE GLICEROL }\end{array}$ & $472 e$ & 2005 & $5000 \mathrm{mg} / \mathrm{kg}$ & \\
\hline ETILEN DIAMINO TETRA ACETATOS & 385,386 & 2001 & 200 mg/kg & $21 \& 47$ \\
\hline SORBATOS & $200,202,203$ & 2009 & $1000 \mathrm{mg} / \mathrm{kg}$ & 42 \\
\hline
\end{tabular}

No. de Categoría de alimento 10.3

Huevos en conserva, incluidos los huevos en álcali, salados y envasados

Aditivo SIN $\quad$ Sño Adoptada Dosis máxima Notas


No. de Categoría de alimento 10.3

Huevos en conserva, incluidos los huevos en álcali, salados y envasados

\begin{tabular}{|c|c|c|c|c|}
\hline Aditivo & SIN & Año Adoptada & Dosis máxima & Notas \\
\hline $\begin{array}{l}\text { CARAMELO III - CARAMELO AL } \\
\text { AMONÍACO }\end{array}$ & $150 \mathrm{c}$ & 2010 & $20000 \mathrm{mg} / \mathrm{kg}$ & 4 \\
\hline $\begin{array}{l}\text { CARAMELO IV - CARAMELO AL SULFITO } \\
\text { AMÓNICO }\end{array}$ & $150 d$ & 2009 & $20000 \mathrm{mg} / \mathrm{kg}$ & \\
\hline FOSFATOS & $\begin{array}{l}\text { 338; 339(i)-(iii); } \\
340 \text { (i)-(iii); 341(i)- } \\
\text { (iii); 342(i)-(ii); } \\
343(\text { i)-(iii); 450(i)- } \\
\text { (iii),(v)-(vii), (ix); } \\
\text { 451(i),(ii); 452(i)- } \\
\text { (v); } 542\end{array}$ & 2012 & $1000 \mathrm{mg} / \mathrm{kg}$ & 33 \\
\hline
\end{tabular}

\begin{tabular}{|c|c|c|c|c|}
\hline \multicolumn{2}{|c|}{ No. de Categoría de alimento 10.4} & \multicolumn{3}{|c|}{ Postres a base de huevo (p. ej. flan) } \\
\hline Aditivo & SIN & Año Adoptada & Dosis máxima & Notas \\
\hline ACESULFAME DE POTASIO & 950 & 2019 & $350 \mathrm{mg} / \mathrm{kg}$ & $478 \& 188$ \\
\hline ALGINATO DE PROPILENGLICOL & 405 & 2018 & 3000 mg/kg & \\
\hline AMARILLO OCASO FCF & 110 & 2008 & $50 \mathrm{mg} / \mathrm{kg}$ & \\
\hline ASPARTAMO & 951 & 2019 & $1000 \mathrm{mg} / \mathrm{kg}$ & $478 \& 191$ \\
\hline AZUL BRILLANTE FCF & 133 & 2005 & $150 \mathrm{mg} / \mathrm{kg}$ & \\
\hline BENZOATOS & $210-213$ & 2003 & $1000 \mathrm{mg} / \mathrm{kg}$ & 13 \\
\hline CANTAXANTINA & $161 \mathrm{~g}$ & 2011 & $15 \mathrm{mg} / \mathrm{kg}$ & \\
\hline $\begin{array}{l}\text { CARAMELO III - CARAMELO AL } \\
\text { AMONÍACO }\end{array}$ & $150 \mathrm{c}$ & 2010 & $20000 \mathrm{mg} / \mathrm{kg}$ & \\
\hline $\begin{array}{l}\text { CARAMELO IV - CARAMELO AL SULFITO } \\
\text { AMÓNICO }\end{array}$ & $150 d$ & 2009 & $20000 \mathrm{mg} / \mathrm{kg}$ & \\
\hline CARMINES & 120 & 2005 & $150 \mathrm{mg} / \mathrm{kg}$ & 178 \\
\hline CAROTENOIDES & 160a(i),a(iii),e,f & 2009 & $150 \mathrm{mg} / \mathrm{kg}$ & \\
\hline CAROTENOS, BETA-, VEGETALES & 160a(ii) & 2005 & $150 \mathrm{mg} / \mathrm{kg}$ & \\
\hline CICLAMATOS & 952(i), (ii), (iv) & 2019 & $250 \mathrm{mg} / \mathrm{kg}$ & $17 \& 477$ \\
\hline $\begin{array}{l}\text { CLOROFILAS Y CLOROFILINAS, } \\
\text { COMPLEJOS CUPRICOS }\end{array}$ & 141(i),(ii) & 2009 & $300 \mathrm{mg} / \mathrm{kg}$ & 2 \\
\hline DIACETATO DE SODIO & 262(ii) & 2018 & 2000 mg/kg & \\
\hline ÉSTERES DE ASCORBILO & 304,305 & 2001 & $500 \mathrm{mg} / \mathrm{kg}$ & $2 \& 10$ \\
\hline $\begin{array}{l}\text { ÉSTERES DE PROPILENGLICOL DE } \\
\text { ÁCIDOS GRASOS }\end{array}$ & 477 & 2001 & $40000 \mathrm{mg} / \mathrm{kg}$ & \\
\hline $\begin{array}{l}\text { ÉSTERES DE SORBITÁN DE ÁCIDOS } \\
\text { GRASOS }\end{array}$ & 491-495 & 2018 & $5000 \mathrm{mg} / \mathrm{kg}$ & \\
\hline $\begin{array}{l}\text { ÉSTERES DIACETILTARTÁRICOS Y DE } \\
\text { ÁCIDOS GRASOS DE GLICEROL }\end{array}$ & $472 \mathrm{e}$ & 2005 & $5000 \mathrm{mg} / \mathrm{kg}$ & \\
\hline $\begin{array}{l}\text { ÉSTERES POLIGLICÉRIDOS DE ÁCIDO } \\
\text { RICINOLÉICO INTERESTERIFICADO }\end{array}$ & 476 & 2018 & $1000 \mathrm{mg} / \mathrm{kg}$ & \\
\hline $\begin{array}{l}\text { ÉSTERES POLIGLICÉRIDOS DE ÁCIDOS } \\
\text { GRASOS }\end{array}$ & 475 & 2018 & $6000 \mathrm{mg} / \mathrm{kg}$ & \\
\hline ETIL-LAUROIL ARGINATO & 243 & 2011 & 200 mg/kg & \\
\hline EXTRACTO DE PIEL DE UVA & 163(ii) & 2009 & $200 \mathrm{mg} / \mathrm{kg}$ & 181 \\
\hline
\end{tabular}




\begin{tabular}{|c|c|c|c|c|}
\hline \multicolumn{2}{|c|}{ No. de Categoría de alimento 10.4} & \multicolumn{3}{|c|}{ ostres a base de huevo (p. ej. flan) } \\
\hline Aditivo & $\operatorname{SIN}$ & Año Adoptada & Dosis máxima & Notas \\
\hline FOSFATOS & $\begin{array}{l}\text { 338; 339(i)-(iii); } \\
\text { 340(i)-(iii); 341(i)- } \\
\text { (iii); 342(i)-(ii); } \\
343 \text { (i)-(iii); } 450(\mathrm{i})- \\
\text { (iii),(v)-(vii), (ix); } \\
451 \text { (i),(ii); 452(i)- } \\
\text { (v); } 542\end{array}$ & 2012 & $1400 \mathrm{mg} / \mathrm{kg}$ & 33 \\
\hline GALATO DE PROPILO & 310 & 2001 & 90 mg/kg & $2 \& 15$ \\
\hline GLICÓSIDOS DE ESTEVIOL & $960 \mathrm{a}, 960 \mathrm{~b}(\mathrm{i})$ & 2011 & $330 \mathrm{mg} / \mathrm{kg}$ & 26 \\
\hline INDIGOTINA (CARMÍN DE ÍNDIGO) & 132 & 2009 & $300 \mathrm{mg} / \mathrm{kg}$ & 161 \\
\hline NEOTAMO & 961 & 2019 & $100 \mathrm{mg} / \mathrm{kg}$ & 478 \\
\hline ÓXIDOS DE HIERRO & 172(i)-(iii) & 2010 & $150 \mathrm{mg} / \mathrm{kg}$ & \\
\hline POLISORBATOS & $432-436$ & 2007 & $3000 \mathrm{mg} / \mathrm{kg}$ & \\
\hline PONCEAU 4R (ROJO DE COCHINILLA A) & 124 & 2008 & $50 \mathrm{mg} / \mathrm{kg}$ & \\
\hline RIBOFLAVINAS & 101(i),(ii), (iii) & 2005 & $300 \mathrm{mg} / \mathrm{kg}$ & \\
\hline ROJO ALLURA AC & 129 & 2009 & $300 \mathrm{mg} / \mathrm{kg}$ & 161 \\
\hline SACARINAS & 954(i)-(iv) & 2007 & $100 \mathrm{mg} / \mathrm{kg}$ & 144 \\
\hline SORBATOS & $200,202,203$ & 2009 & $1000 \mathrm{mg} / \mathrm{kg}$ & 42 \\
\hline $\begin{array}{l}\text { SUCRALOSA } \\
\text { (TRICLOROGALACTOSACAROSA) }\end{array}$ & 955 & 2019 & $400 \mathrm{mg} / \mathrm{kg}$ & 478 \\
\hline SUCROÉSTERES DE ÁCIDOS GRASOS & 473 & 2018 & $5000 \mathrm{mg} / \mathrm{kg}$ & 348 \\
\hline SUCROGLICÉRIDOS & 474 & 2018 & $5000 \mathrm{mg} / \mathrm{kg}$ & 348 \\
\hline $\begin{array}{l}\text { SUCROSE OLIGOESTERS, TYPE I AND } \\
\text { TYPE II }\end{array}$ & $473 a$ & 2018 & $5000 \mathrm{mg} / \mathrm{kg}$ & 348 \\
\hline TARTRATOS & 334, 335(ii), 337 & 2018 & $2000 \mathrm{mg} / \mathrm{kg}$ & 45 \\
\hline TOCOFEROLES & $307 a, b, c$ & 2019 & $500 \mathrm{mg} / \mathrm{kg}$ & 72 \\
\hline VERDE SÓLIDO FCF & 143 & 2009 & $100 \mathrm{mg} / \mathrm{kg}$ & \\
\hline
\end{tabular}

No. de Categoría de alimento 11.1.1 Azúcar blanco, dextrosa anhidra, dextrosa monohidrato y fructosa

\begin{tabular}{|c|c|c|c|c|}
\hline Aditivo & SIN & Año Adoptada & Dosis máxima & Notas \\
\hline SULFITOS & $220-225,539$ & 2005 & $15 \mathrm{mg} / \mathrm{kg}$ & 44 \\
\hline
\end{tabular}

No. de Categoría de alimento 11.1.2 Azúcar en polvo y dextrosa en polvo

\begin{tabular}{|c|c|c|c|c|}
\hline Aditivo & SIN & Año Adoptada & Dosis máxima & Notas \\
\hline CARBONATO DE MAGNESIO & $504(i)$ & 2019 & $15000 \mathrm{mg} / \mathrm{kg}$ & 56,465 \\
\hline DIÓXIDO DE SILICIO AMORFO & 551 & 2019 & $15000 \mathrm{mg} / \mathrm{kg}$ & 56,465 \\
\hline FOSFATOS & $\begin{array}{l}\text { 338; 339(i)-(iii); } \\
\text { 340(i)-(iii); 341(i)- } \\
\text { (iii); 342(i)-(ii); } \\
343(\mathrm{i}) \text {-(iii); 450(i)- } \\
\text { (iii),(v)-(vii), (ix); } \\
\text { 451(i),(ii); 452(i)- } \\
\text { (v); } 542\end{array}$ & 2019 & $6600 \mathrm{mg} / \mathrm{kg}$ & $33,56,465$ \\
\hline SILICATO DE CALCIO & 552 & 2019 & $15000 \mathrm{mg} / \mathrm{kg}$ & 56,465 \\
\hline SILICATO DE MAGNESIO, SINTÉTICO & $553(i)$ & 2019 & $15000 \mathrm{mg} / \mathrm{kg}$ & 56,465 \\
\hline SULFITOS & $220-225,539$ & 2005 & $15 \mathrm{mg} / \mathrm{kg}$ & 44 \\
\hline
\end{tabular}




\begin{tabular}{|c|c|c|c|c|}
\hline \multicolumn{2}{|c|}{ No. de Categoría de alimento 11.1 .3} & \multicolumn{3}{|c|}{$\begin{array}{l}\text { Azúcar blanco blando, azúcar moreno } \\
\text { blando, jarabe de glucosa, jarabe de } \\
\text { glucosa deshidratado y azúcar de caña } \\
\text { sin refinar }\end{array}$} \\
\hline Aditivo & SIN & Año Adoptada & Dosis máxima & Notas \\
\hline SULFITOS & $220-225,539$ & 2006 & $20 \mathrm{mg} / \mathrm{kg}$ & $44 \& 111$ \\
\hline No. de C & 11.1 .5 & \multicolumn{3}{|c|}{ Azúcar blanco de plantación o refinería } \\
\hline Aditivo & SIN & Año Adoptada & Dosis máxima & Notas \\
\hline SULFITOS & $220-225,539$ & 2005 & $70 \mathrm{mg} / \mathrm{kg}$ & 44 \\
\hline
\end{tabular}

No. de Categoría de alimento $\mathbf{1 1 . 2}$

Azúcar moreno, excluidos los

productos de la categoría de alimentos 11.1.3

\begin{tabular}{|c|c|c|c|c|}
\hline Aditivo & SIN & Año Adoptada & Dosis máxima & Notas \\
\hline $\begin{array}{l}\text { CELULOSA MICROCRISTALINA (GEL DE } \\
\text { CELULOSA) }\end{array}$ & 460(i) & 2015 & BPF & \\
\hline SULFITOS & $220-225,539$ & 2006 & $40 \mathrm{mg} / \mathrm{kg}$ & 44 \\
\hline
\end{tabular}

No. de Categoría de alimento 11.3

Soluciones azucaradas y jarabes, también azúcares (parcialmente) invertidos, incluida la melaza, excluidos los productos de la categoría de alimentos 11.1.3

\begin{tabular}{|c|c|c|c|c|}
\hline Aditivo & SIN & Año Adoptada & Dosis máxima & Notas \\
\hline RIBOFLAVINAS & 101(i),(ii), (iii) & 2005 & 300 mg/kg & \\
\hline SULFITOS & $220-225,539$ & 2007 & 70 mg/kg & 44 \\
\hline
\end{tabular}

No. de Categoría de alimento 11.4

\begin{tabular}{llccc} 
Aditivo & SIN & Año Adoptada & Dosis máxima & Notas \\
\hline ACESULFAME DE POTASIO & 950 & 2007 & $1000 \mathrm{mg} / \mathrm{kg}$ & $159 \& 188$ \\
ACETATO DE CALCIO & 263 & 2013 & BPF & 258 \\
ÁCIDO ALGÍNICO & 400 & 2014 & BPF & 258 \\
ADIPATO DE DIALMIDÓN ACETILADO & 1422 & 2014 & BPF & 258 \\
AGAR & 406 & 2014 & BPF & 258 \\
ALGA EUCHEUMA ELABORADA & $407 \mathrm{a}$ & 2014 & BPF & 258 \\
ALGINATO DE AMONIO & 403 & 2014 & BPF & 258 \\
ALGINATO DE CALCIO & 404 & 2014 & BPF & 258 \\
ALGINATO DE POTASIO & 402 & 2014 & BPF & 258 \\
ALGINATO DE PROPILENGLICOL & 405 & 2018 & BPF & 258 \\
ALGINATO DE SODIO & 401 & 2014 & $200 \mathrm{mg} / \mathrm{kg}$ & 159 \\
ALITAME & 956 & 2007 & BPF & 258 \\
ALMIDÓN BLANQUEADO & 1403 & 2014 & BPF & 258
\end{tabular}

Otros azúcares y jarabes (p. ej. xilosa, jarabe de arce y aderezos de azúcar)

Azúcar blanco blando, azúcar moreno

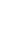


No. de Categoría de alimento 11.4
Otros azúcares y jarabes (p. ej. xilosa, jarabe de arce y aderezos de azúcar)

\begin{tabular}{|c|c|c|c|c|}
\hline Aditivo & SIN & Año Adoptada & Dosis máxima & Notas \\
\hline ALMIDÓN OXIDADO & 1404 & 2014 & BPF & 258 \\
\hline ALMIDÓN TRATADO CON ÁCIDO & 1401 & 2014 & BPF & 258 \\
\hline ALMIDÓN TRATADO CON ÁLCALIS & 1402 & 2014 & BPF & 258 \\
\hline ALMIDONES TRATADOS CON ENZIMAS & 1405 & 2014 & BPF & 258 \\
\hline ASPARTAMO & 951 & 2007 & $3000 \mathrm{mg} / \mathrm{kg}$ & $159 \& 191$ \\
\hline BENZOATOS & $210-213$ & 2003 & $1000 \mathrm{mg} / \mathrm{kg}$ & 13 \\
\hline CANTAXANTINA & $161 \mathrm{~g}$ & 2011 & $15 \mathrm{mg} / \mathrm{kg}$ & \\
\hline $\begin{array}{l}\text { CARAMELO III - CARAMELO AL } \\
\text { AMONÍACO }\end{array}$ & $150 c$ & 2010 & $50000 \mathrm{mg} / \mathrm{kg}$ & 100 \\
\hline CARBONATO ÁCIDO DE MAGNESIO & 504(ii) & 2013 & BPF & 258 \\
\hline CARBONATO DE MAGNESIO & $504(i)$ & 2013 & BPF & 258 \\
\hline $\begin{array}{l}\text { CARBOXIMETILCELULOSA SÓDICA } \\
\text { (GOMA DE CELULOSA) }\end{array}$ & 466 & 2014 & BPF & 258 \\
\hline CAROTENOIDES & $160 a(i), a(i i i), e, f$ & 2011 & $50 \mathrm{mg} / \mathrm{kg}$ & 217 \\
\hline CAROTENOS, BETA-, VEGETALES & 160a(ii) & 2005 & $50 \mathrm{mg} / \mathrm{kg}$ & \\
\hline CARRAGENINA & 407 & 2014 & BPF & 258 \\
\hline CELULOSA EN POLVO & 460(ii) & 2014 & BPF & 258 \\
\hline $\begin{array}{l}\text { CELULOSA MICROCRISTALINA (GEL DE } \\
\text { CELULOSA) }\end{array}$ & $460(i)$ & 2014 & BPF & 258 \\
\hline CICLAMATOS & 952(i), (ii), (iv) & 2007 & $500 \mathrm{mg} / \mathrm{kg}$ & $17 \& 159$ \\
\hline CITRATO DÍACIDO DE POTASIO & 332(i) & 2013 & BPF & 258 \\
\hline CITRATO DÍACIDO DE SODIO & $331(\mathrm{i})$ & 2013 & BPF & 258 \\
\hline CITRATO TRIPOTÁSICO & 332(ii) & 2013 & BPF & 258 \\
\hline CITRATO TRISÓDICO & 331 (iii) & 2013 & BPF & 258 \\
\hline $\begin{array}{l}\text { CLOROFILAS Y CLOROFILINAS, } \\
\text { COMPLEJOS CUPRICOS }\end{array}$ & 141(i),(ii) & 2005 & $64 \mathrm{mg} / \mathrm{kg}$ & 62 \\
\hline CLORURO DE MAGNESIO & 511 & 2014 & BPF & 258 \\
\hline $\begin{array}{l}\text { ÉSTERES ACÉTICOS Y DE ÁCIDOS } \\
\text { GRASOS DE GLICEROL }\end{array}$ & $472 a$ & 2014 & BPF & 258 \\
\hline $\begin{array}{l}\text { ÉSTERES CÍTRICOS Y DE ÁCIDOS } \\
\text { GRASOS DE GLICEROL }\end{array}$ & $472 c$ & 2014 & BPF & 258 \\
\hline ÉSTERES DE ASCORBILO & 304,305 & 2003 & $200 \mathrm{mg} / \mathrm{kg}$ & 10 \\
\hline $\begin{array}{l}\text { ÉSTERES DE PROPILENGLICOL DE } \\
\text { ÁCIDOS GRASOS }\end{array}$ & 477 & 2001 & $5000 \mathrm{mg} / \mathrm{kg}$ & \\
\hline $\begin{array}{l}\text { ÉSTERES LÁCTICOS Y DE ÁCIDOS } \\
\text { GRASOS DE GLICEROL }\end{array}$ & $472 b$ & 2014 & BPF & 258 \\
\hline FOSFATO DE DIALMIDÓN & 1412 & 2014 & BPF & 258 \\
\hline FOSFATO DE DIALMIDÓN ACETILADO & 1414 & 2014 & BPF & 258 \\
\hline FOSFATO DE DIALMIDÓN FOSFATADO & 1413 & 2014 & BPF & 258 \\
\hline FOSFATO DE HIDROXIPROPIL DIALMIDÓN & 1442 & 2014 & BPF & 258 \\
\hline FOSFATO DE MONOALMIDÓN & 1410 & 2014 & BPF & 258 \\
\hline
\end{tabular}




\section{No. de Categoría de alimento 11.4}

Otros azúcares y jarabes (p. ej. xilosa, jarabe de arce y aderezos de azúcar)

\begin{tabular}{|c|c|c|c|c|}
\hline Aditivo & SIN & Año Adoptada & Dosis máxima & Notas \\
\hline FOSFATOS & $\begin{array}{l}338 ; 339(\mathrm{i})-(\mathrm{iii}) ; \\
340(\mathrm{i})-(\mathrm{iii}) ; 341 \text { (i)- } \\
\text { (iii); 342(i)-(ii); } \\
343(\mathrm{i})-(\mathrm{iii)} ; 450(\mathrm{i})- \\
\text { (iii),(v)-(vii), (ix); } \\
451 \text { (i),(ii); 452(i)- } \\
\text { (v); } 542\end{array}$ & 2009 & $1320 \mathrm{mg} / \mathrm{kg}$ & 33 \\
\hline GLICEROL & 422 & 2015 & BPF & 258 \\
\hline GOMA ARÁBIGA (GOMA DE ACACIA) & 414 & 2014 & BPF & 258 \\
\hline GOMA DE SEMILLAS DE ALGARROBO & 410 & 2014 & BPF & 258 \\
\hline GOMA GELLAN & 418 & 2014 & BPF & 258 \\
\hline GOMA GUAR & 412 & 2014 & BPF & 258 \\
\hline GOMA KARAYA & 416 & 2014 & BPF & 258 \\
\hline GOMA TRAGACANTO & 413 & 2014 & BPF & 258 \\
\hline GOMA XANTANA & 415 & 2014 & BPF & 258 \\
\hline HARINA KONJAC & 425 & 2014 & BPF & 258 \\
\hline HIDROXIBENZOATOS, PARA- & 214,218 & 2012 & $100 \mathrm{mg} / \mathrm{kg}$ & 27 \\
\hline HIDRÓXIDO DE MAGNESIO & 528 & 2013 & BPF & 258 \\
\hline HIDROXIPROPILCELULOSA & 463 & 2014 & BPF & 258 \\
\hline HIDROXIPROPILMETILCELULOSA & 464 & 2014 & BPF & 258 \\
\hline INDIGOTINA (CARMÍN DE ÍNDIGO) & 132 & 2009 & $300 \mathrm{mg} / \mathrm{kg}$ & 161 \\
\hline LECITINA & 322(i) & 2014 & BPF & 258 \\
\hline MANITOL & 421 & 2014 & BPF & 258 \\
\hline METILCELULOSA & 461 & 2014 & BPF & 258 \\
\hline METILETILCELULOSA & 465 & 2014 & BPF & 258 \\
\hline $\begin{array}{l}\text { MONOGLICÉRIDOS Y DIGLICÉRIDOS DE } \\
\text { ÁCIDOS GRASOS }\end{array}$ & 471 & 2014 & BPF & 258 \\
\hline NEOTAMO & 961 & 2007 & $70 \mathrm{mg} / \mathrm{kg}$ & 159 \\
\hline ÓXIDO NITROSO & 942 & 2015 & BPF & \\
\hline PECTINAS & 440 & 2014 & BPF & 258 \\
\hline POLIDEXTROSA & 1200 & 2014 & BPF & 258 \\
\hline PONCEAU 4R (ROJO DE COCHINILLA A) & 124 & 2008 & $300 \mathrm{mg} / \mathrm{kg}$ & 159 \\
\hline PULLULAN & 1204 & 2015 & BPF & 258 \\
\hline RIBOFLAVINAS & 101(i),(ii), (iii) & 2005 & $300 \mathrm{mg} / \mathrm{kg}$ & \\
\hline ROJO ALLURA AC & 129 & 2009 & $300 \mathrm{mg} / \mathrm{kg}$ & 161 \\
\hline SACARINAS & 954(i)-(iv) & 2008 & $300 \mathrm{mg} / \mathrm{kg}$ & 159 \\
\hline $\begin{array}{l}\text { SAL DE ÁCIDO OLEICO CON CALCIO, } \\
\text { POTASIO Y SODIO }\end{array}$ & 470(ii) & 2014 & BPF & 258 \\
\hline $\begin{array}{l}\text { SAL MIRÍSTICA, PALMÍTICA Y ÁCIDOS } \\
\text { ESTEÁRICOS CON AMONIO, CALCIO, } \\
\text { POTASIO Y SODIO }\end{array}$ & 470(i) & 2014 & BPF & $71 \& 258$ \\
\hline SORBATOS & $200,202,203$ & 2009 & $1000 \mathrm{mg} / \mathrm{kg}$ & 42 \\
\hline $\begin{array}{l}\text { SUCRALOSA } \\
\text { (TRICLOROGALACTOSACAROSA) }\end{array}$ & 955 & 2008 & $1500 \mathrm{mg} / \mathrm{kg}$ & $159 \& 161$ \\
\hline
\end{tabular}




\begin{tabular}{|c|c|c|c|c|}
\hline \multicolumn{2}{|c|}{ No. de Categoría de alimento 11.4} & \multicolumn{3}{|c|}{$\begin{array}{l}\text { Otros azúcares y jarabes (p. ej. xilosa, } \\
\text { jarabe de arce y aderezos de azúcar) }\end{array}$} \\
\hline Aditivo & $\operatorname{SiN}$ & Año Adoptada & Dosis máxima & Notas \\
\hline SULFITOS & $220-225,539$ & 2006 & $40 \mathrm{mg} / \mathrm{kg}$ & 44 \\
\hline No. de Categoría de alimento & $\begin{array}{l}\text { E } \\
\text { q } \\
\text { in }\end{array}$ & \multicolumn{3}{|c|}{$\begin{array}{l}\text { Edulcorantes de mesa, incluidos los } \\
\text { que contienen edulcorantes de gran } \\
\text { intensidad }\end{array}$} \\
\hline Aditivo & SIN & Año Adoptada & Dosis máxima & Notas \\
\hline ACESULFAME DE POTASIO & 950 & 2007 & BPF & 188 \\
\hline ALITAME & 956 & 2007 & BPF & \\
\hline ASPARTAMO & 951 & 2007 & BPF & 191 \\
\hline BENZOATOS & $210-213$ & 2003 & $2000 \mathrm{mg} / \mathrm{kg}$ & 13 \\
\hline $\begin{array}{l}\text { CARAMELO IV - CARAMELO AL SULFITO } \\
\text { AMÓNICO }\end{array}$ & $150 d$ & 2011 & $1200 \mathrm{mg} / \mathrm{kg}$ & 213 \\
\hline CICLAMATOS & 952(i), (ii), (iv) & 2007 & BPF & 17 \\
\hline ETILEN DIAMINO TETRA ACETATOS & 385,386 & 2005 & $1000 \mathrm{mg} / \mathrm{kg}$ & $21 \& 96$ \\
\hline FOSFATOS & $\begin{array}{l}\text { 338; 339(i)-(iii); } \\
\text { 340(i)-(iii); 341(i)- } \\
\text { (iii); 342(i)-(ii); } \\
343(\text { i)-(iii); 450(i)- } \\
\text { (iii),(v)-(vii), (ix); } \\
451 \text { (i),(ii); 452(i)- } \\
\text { (v); } 542\end{array}$ & 2009 & $1000 \mathrm{mg} / \mathrm{kg}$ & 33 \\
\hline GLICÓSIDOS DE ESTEVIOL & $960 a, 960 b(i)$ & 2011 & BPF & 26 \\
\hline NEOTAMO & 961 & 2007 & BPF & \\
\hline POLIETILENGLICOL & 1521 & 2001 & $10000 \mathrm{mg} / \mathrm{kg}$ & \\
\hline POLIVINILPIRROLIDONA & 1201 & 1999 & $3000 \mathrm{mg} / \mathrm{kg}$ & \\
\hline SACARINAS & 954(i)-(iv) & 2007 & BPF & \\
\hline SAL DE ASPARTAMO Y ACESULFAMO & 962 & 2012 & BPF & \\
\hline SORBATOS & $200,202,203$ & 2010 & $1000 \mathrm{mg} / \mathrm{kg}$ & $42 \& 192$ \\
\hline $\begin{array}{l}\text { SUCRALOSA } \\
\text { (TRICLOROGALACTOSACAROSA) }\end{array}$ & 955 & 2007 & BPF & \\
\hline TARTRATOS & 334, 335(ii), 337 & 2018 & $2000 \mathrm{mg} / \mathrm{kg}$ & 45 \\
\hline
\end{tabular}

\section{No. de Categoría de alimento 12.1.1 Sal}

\begin{tabular}{|c|c|c|c|c|}
\hline Aditivo & SIN & Año Adoptada & Dosis máxima & Notas \\
\hline CARBONATO DE CALCIO & $170(i)$ & 2006 & BPF & \\
\hline CARBONATO DE MAGNESIO & $504(\mathrm{i})$ & 2006 & BPF & \\
\hline DIÓXIDO DE SILICIO AMORFO & 551 & 2006 & BPF & \\
\hline FERROCIANUROS & $535,536,538$ & 2006 & $14 \mathrm{mg} / \mathrm{kg}$ & $24 \& 107$ \\
\hline FOSFATOS & $\begin{array}{l}\text { 338; 339(i)-(iii); } \\
340 \text { (i)-(iii); 341(i)- } \\
\text { (iii); 342(i)-(ii); } \\
343 \text { (i)-(iii); 450(i)- } \\
\text { (iii),(v)-(vii), (ix); } \\
451 \text { (i),(ii); 452(i)- } \\
\text { (v); } 542\end{array}$ & 2006 & $8800 \mathrm{mg} / \mathrm{kg}$ & 33 \\
\hline ÓXIDO DE MAGNESIO & 530 & 2006 & BPF & \\
\hline
\end{tabular}




\begin{tabular}{|c|c|c|c|c|}
\hline \multicolumn{2}{|c|}{ No. de Categoría de alimento 12.1.1 } & \multicolumn{3}{|l|}{ Sal } \\
\hline Aditivo & $\sin$ & Año Adoptada & Dosis máxima & Notas \\
\hline POLISORBATOS & $432-436$ & 2006 & $10 \mathrm{mg} / \mathrm{kg}$ & \\
\hline $\begin{array}{l}\text { SAL MIRÍSTICA, PALMÍTICA Y ÁCIDOS } \\
\text { ESTEÁRICOS CON AMONIO, CALCIO, } \\
\text { POTASIO Y SODIO }\end{array}$ & $470(i)$ & 2006 & BPF & 71 \\
\hline SILICATO DE CALCIO & 552 & 2006 & BPF & \\
\hline SILICATO DE MAGNESIO, SINTÉTICO & $553(i)$ & 2006 & BPF & \\
\hline SILICATO DE SODIO Y ALUMINIO & 554 & 2013 & $1000 \mathrm{mg} / \mathrm{kg}$ & $6 \& 254$ \\
\hline
\end{tabular}

No. de Categoría de alimento 12.1.2 Sucedáneos de la sal

\begin{tabular}{|c|c|c|c|c|}
\hline Aditivo & SIN & Año Adoptada & Dosis máxima & Notas \\
\hline ACETATO DE SODIO & 262(i) & 2013 & BPF & \\
\hline ÁCIDO ACÉTICO GLACIAL & 260 & 2013 & BPF & \\
\hline ÁCIDO ALGÍNICO & 400 & 2014 & BPF & \\
\hline ÁCIDO ASCÓRBICO, L- & 300 & 2013 & BPF & \\
\hline ÁCIDO CÍTRICO & 330 & 2013 & BPF & \\
\hline ÁCIDO FUMÁRICO & 297 & 2013 & BPF & \\
\hline ÁCIDO GLUTÁMICO, L(+)- & 620 & 2015 & BPF & \\
\hline ÁCIDO GUANÍLICO, 5'- & 626 & 2015 & BPF & \\
\hline ÁCIDO INOSÍNICO, 5'- & 630 & 2015 & BPF & \\
\hline ÁCIDO LÁCTICO, L-, D- y DL- & 270 & 2013 & BPF & \\
\hline ÁCIDO MÁLICO, DL- & 296 & 2013 & BPF & \\
\hline AGAR & 406 & 2014 & BPF & \\
\hline ALMIDÓN HIDROXIPROPÍLICO & 1440 & 2014 & BPF & \\
\hline ALMIDÓN OXIDADO & 1404 & 2014 & BPF & \\
\hline ASCORBATO DE SODIO & 301 & 2015 & BPF & 314 \\
\hline CARBONATO ÁCIDO DE MAGNESIO & 504(ii) & 2013 & BPF & \\
\hline CARBONATO DE CALCIO & $170(i)$ & 2013 & BPF & \\
\hline CARBONATO DE MAGNESIO & $504(i)$ & 2013 & BPF & \\
\hline CARBONATO DE SODIO & $500(i)$ & 2013 & BPF & \\
\hline $\begin{array}{l}\text { CARBOXIMETILCELULOSA SÓDICA } \\
\text { (GOMA DE CELULOSA) }\end{array}$ & 466 & 2014 & BPF & \\
\hline CARRAGENINA & 407 & 2014 & BPF & \\
\hline CELULOSA EN POLVO & 460 (ii) & 2014 & BPF & \\
\hline $\begin{array}{l}\text { CELULOSA MICROCRISTALINA (GEL DE } \\
\text { CELULOSA) }\end{array}$ & 460 (i) & 2014 & BPF & \\
\hline CITRATO DÍACIDO DE POTASIO & $332(i)$ & 2013 & BPF & \\
\hline CITRATO DÍACIDO DE SODIO & 331 (i) & 2013 & BPF & \\
\hline CITRATO TRIPOTÁSICO & 332(ii) & 2013 & BPF & \\
\hline CITRATO TRISÓDICO & 331 (iii) & 2013 & BPF & \\
\hline CLORURO DE CALCIO & 509 & 2014 & BPF & 58 \\
\hline CLORURO DE MAGNESIO & 511 & 2014 & BPF & \\
\hline CLORURO DE POTASIO & 508 & 2014 & BPF & \\
\hline
\end{tabular}


No. de Categoría de alimento 12.1.2 Sucedáneos de la sal

\begin{tabular}{|c|c|c|c|c|}
\hline Aditivo & SIN & Año Adoptada & Dosis máxima & Notas \\
\hline DIÓXIDO DE SILICIO AMORFO & 551 & 2015 & BPF & \\
\hline $\begin{array}{l}\text { ÉSTERES ACÉTICOS Y DE ÁCIDOS } \\
\text { GRASOS DE GLICEROL }\end{array}$ & $472 a$ & 2014 & BPF & \\
\hline $\begin{array}{l}\text { ÉSTERES CÍTRICOS Y DE ÁCIDOS } \\
\text { GRASOS DE GLICEROL }\end{array}$ & $472 c$ & 2014 & BPF & \\
\hline $\begin{array}{l}\text { ÉSTERES DIACETILTARTÁRICOS Y DE } \\
\text { ÁCIDOS GRASOS DE GLICEROL }\end{array}$ & $472 \mathrm{e}$ & 2006 & $16000 \mathrm{mg} / \mathrm{kg}$ & \\
\hline $\begin{array}{l}\text { ÉSTERES LÁCTICOS Y DE ÁCIDOS } \\
\text { GRASOS DE GLICEROL }\end{array}$ & $472 b$ & 2014 & BPF & \\
\hline FERROCIANUROS & $535,536,538$ & 1999 & $20 \mathrm{mg} / \mathrm{kg}$ & 24 \\
\hline FOSFATO DE DIALMIDÓN ACETILADO & 1414 & 2014 & BPF & \\
\hline FOSFATOS & $\begin{array}{l}\text { 338; 339(i)-(iii); } \\
340 \text { (i)-(iii); } 341 \text { (i)- } \\
\text { (iii); 342(i)-(ii); } \\
343(\text { i)-(iii); } 450(\text { i)- } \\
\text { (iii),(v)-(vii), (ix); } \\
451 \text { (i),(ii); 452(i)- } \\
\text { (v); } 542\end{array}$ & 2012 & $4400 \mathrm{mg} / \mathrm{kg}$ & 33 \\
\hline FUMARATO DE SODIO & 365 & 2013 & BPF & \\
\hline GLICEROL & 422 & 2015 & BPF & \\
\hline GLUCONATO DE SODIO & 576 & 2014 & BPF & \\
\hline GLUTAMATO DE CALCIO, DI-L- & 623 & 2015 & BPF & \\
\hline GLUTAMATO DE MAGNÉSIO, DI-L- & 625 & 2015 & BPF & \\
\hline GLUTAMATO MONOAMÓNICO, L- & 624 & 2015 & BPF & \\
\hline GLUTAMATO MONOPOTÁSICO, L- & 622 & 2015 & BPF & \\
\hline GLUTAMATO MONOSÓDICO, L- & 621 & 2015 & BPF & \\
\hline GOMA ARÁBIGA (GOMA DE ACACIA) & 414 & 2014 & BPF & \\
\hline GOMA GELLAN & 418 & 2014 & BPF & \\
\hline GOMA GUAR & 412 & 2014 & BPF & \\
\hline GOMA KARAYA & 416 & 2014 & BPF & \\
\hline GOMA TRAGACANTO & 413 & 2014 & BPF & \\
\hline GOMA XANTANA & 415 & 2014 & BPF & \\
\hline GUANILATO DE CALCIO, 5'- & 629 & 2015 & BPF & \\
\hline GUANILATO DIPOTÁSICO, 5'- & 628 & 2015 & BPF & \\
\hline GUANILATO DISÓDICO, 5'- & 627 & 2015 & BPF & \\
\hline HARINA KONJAC & 425 & 2014 & BPF & \\
\hline HIDRÓXIDO DE MAGNESIO & 528 & 2013 & BPF & \\
\hline HIDROXIPROPILCELULOSA & 463 & 2014 & BPF & \\
\hline HIDROXIPROPILMETILCELULOSA & 464 & 2014 & BPF & \\
\hline INOSINATO DE CALCIO, 5'- & 633 & 2015 & BPF & \\
\hline INOSINATO DE POTASIO, 5'- & 632 & 2015 & BPF & \\
\hline INOSINATO DISÓDICO, 5'- & 631 & 2015 & BPF & \\
\hline LACTATO DE CALCIO & 327 & 2013 & BPF & \\
\hline LECITINA & 322(i) & 2014 & BPF & \\
\hline MANITOL & 421 & 2014 & BPF & \\
\hline
\end{tabular}




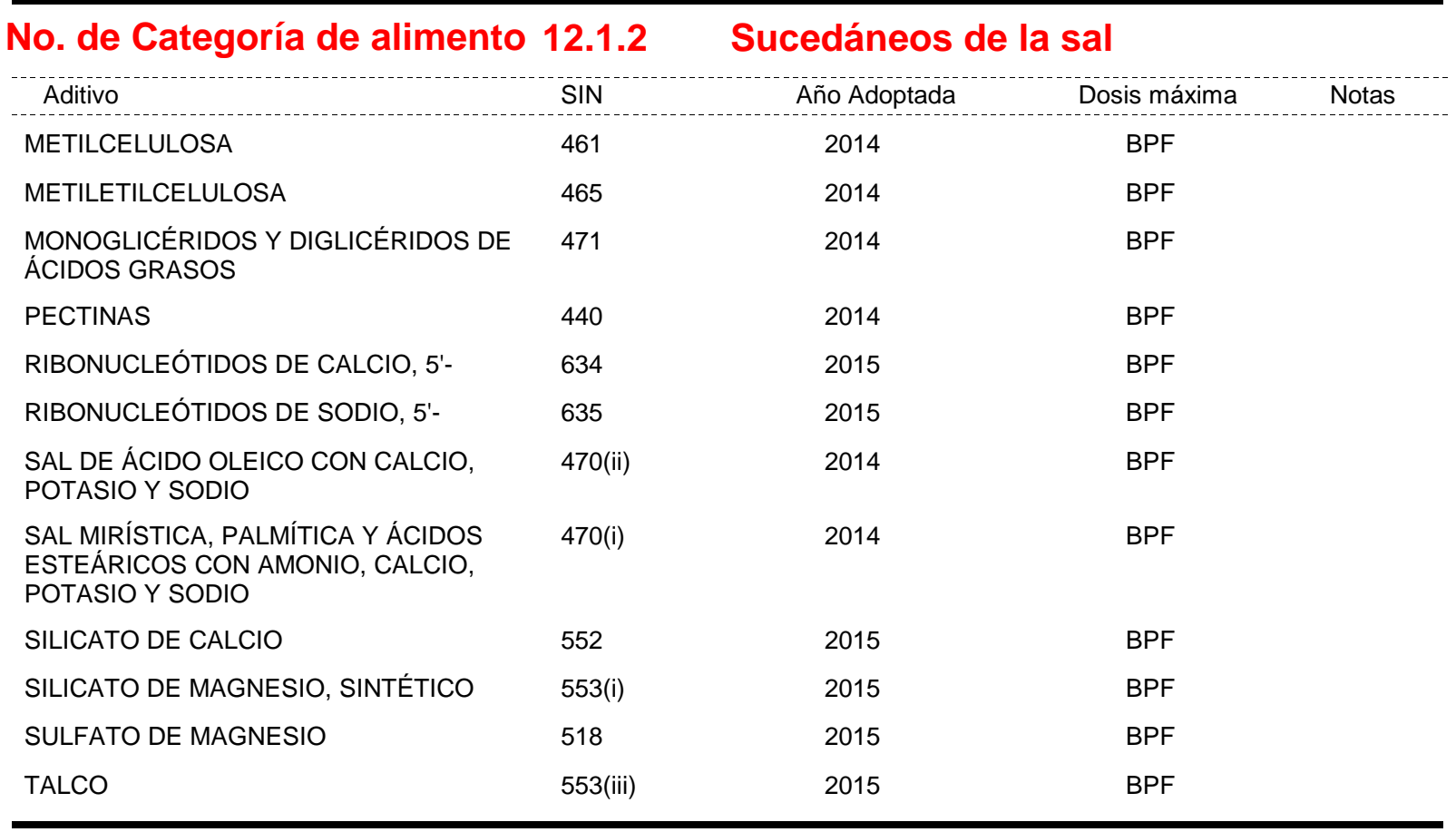

No. de Categoría de alimento 12.2

Hierbas aromáticas, especias, aderezos y condimentos (p. ej. el aderezo para fideos instantáneos)

\begin{tabular}{|c|c|c|c|c|}
\hline Aditivo & SIN & Año Adoptada & Dosis máxima & Notas \\
\hline ACESULFAME DE POTASIO & 950 & 2008 & $2000 \mathrm{mg} / \mathrm{kg}$ & $161 \& 188$ \\
\hline BUTILHIDROXIANISOL & 320 & 2005 & 200 mg/kg & $15 \& 130$ \\
\hline BUTILHIDROXITOLUENO & 321 & 2006 & $200 \mathrm{mg} / \mathrm{kg}$ & $15 \& 130$ \\
\hline $\begin{array}{l}\text { CARAMELO IV - CARAMELO AL SULFITO } \\
\text { AMÓNICO }\end{array}$ & $150 d$ & 2010 & $10000 \mathrm{mg} / \mathrm{kg}$ & \\
\hline ÉSTERES DE ASCORBILO & 304,305 & 2001 & $500 \mathrm{mg} / \mathrm{kg}$ & 10 \\
\hline ETILEN DIAMINO TETRA ACETATOS & 385,386 & 2001 & $70 \mathrm{mg} / \mathrm{kg}$ & 21 \\
\hline GALATO DE PROPILO & 310 & 2001 & $200 \mathrm{mg} / \mathrm{kg}$ & $15 \& 130$ \\
\hline NEOTAMO & 961 & 2008 & $32 \mathrm{mg} / \mathrm{kg}$ & 161 \\
\hline SORBATOS & $200,202,203$ & 2009 & $1000 \mathrm{mg} / \mathrm{kg}$ & 42 \\
\hline TERBUTILHIDROQUINONA & 319 & 2005 & $200 \mathrm{mg} / \mathrm{kg}$ & $15 \& 130$ \\
\hline TOCOFEROLES & $307 a, b, c$ & 2018 & $2000 \mathrm{mg} / \mathrm{kg}$ & $\begin{array}{l}421, \text { XS326, } \\
\text { XS327, XS328 }\end{array}$ \\
\hline
\end{tabular}

No. de Categoría de alimento 12.2.1 Hierbas aromáticas y especias

\begin{tabular}{llccc} 
Aditivo & SIN & Año Adoptada & Dosis máxima & Notas \\
\hline POLISORBATOS & $432-436$ & 2008 & $2000 \mathrm{mg} / \mathrm{kg}$ & \\
$\begin{array}{l}\text { SUCRALOSA } \\
\text { (TRICLOROGALACTOSACAROSA) }\end{array}$ & 955 & 2008 & $400 \mathrm{mg} / \mathrm{kg}$ & 161 \\
SUCROÉSTERES DE ÁCIDOS GRASOS & 473 & 2018 & $2000 \mathrm{mg} / \mathrm{kg}$ & 348,422 \\
$\begin{array}{l}\text { SUCROGLICÉRIDOS } \\
\text { SUCROSE OLIGOESTERS, TYPE I AND }\end{array}$ & 474 & 2018 & $2000 \mathrm{mg} / \mathrm{kg}$ & 348,422 \\
$\begin{array}{l}\text { TYPE II } \\
\text { SULFITOS }\end{array}$ & $220-225,539$ & 2006 & $2000 \mathrm{mg} / \mathrm{kg}$ & 348,422 \\
\end{tabular}


No. de Categoría de alimento 12.2.2 Aderezos y condimentos

\begin{tabular}{|c|c|c|c|c|}
\hline Aditivo & SIN & Año Adoptada & Dosis máxima & Notas \\
\hline AMARILLO OCASO FCF & 110 & 2008 & $300 \mathrm{mg} / \mathrm{kg}$ & \\
\hline ASPARTAMO & 951 & 2008 & $2000 \mathrm{mg} / \mathrm{kg}$ & $161 \& 191$ \\
\hline AZUL BRILLANTE FCF & 133 & 2009 & $100 \mathrm{mg} / \mathrm{kg}$ & \\
\hline BENZOATOS & $210-213$ & 2003 & $1000 \mathrm{mg} / \mathrm{kg}$ & 13 \\
\hline CANTAXANTINA & $161 \mathrm{~g}$ & 2011 & $20 \mathrm{mg} / \mathrm{kg}$ & \\
\hline $\begin{array}{l}\text { CARAMELO III - CARAMELO AL } \\
\text { AMONÍACO }\end{array}$ & $150 c$ & 2010 & $50000 \mathrm{mg} / \mathrm{kg}$ & \\
\hline CARMINES & 120 & 2005 & $500 \mathrm{mg} / \mathrm{kg}$ & 178 \\
\hline CAROTENOIDES & $160 a(i), a(i i i), e, f$ & 2009 & $500 \mathrm{mg} / \mathrm{kg}$ & \\
\hline CAROTENOS, BETA-, VEGETALES & $160 a(i i)$ & 2011 & $500 \mathrm{mg} / \mathrm{kg}$ & \\
\hline $\begin{array}{l}\text { CLOROFILAS Y CLOROFILINAS, } \\
\text { COMPLEJOS CUPRICOS }\end{array}$ & 141(i),(ii) & 2009 & $500 \mathrm{mg} / \mathrm{kg}$ & \\
\hline ETIL-LAUROIL ARGINATO & 243 & 2011 & $200 \mathrm{mg} / \mathrm{kg}$ & \\
\hline FERROCIANUROS & $535,536,538$ & 1999 & $20 \mathrm{mg} / \mathrm{kg}$ & 24 \\
\hline FOSFATOS & $\begin{array}{l}\text { 338; 339(i)-(iii); } \\
\text { 340(i)-(iii); 341(i)- } \\
\text { (iii); 342(i)-(ii); } \\
\text { 343(i)-(iii); 450(i)- } \\
\text { (iii),(v)-(vii), (ix); } \\
\text { 451(i),(ii); 452(i)- } \\
\text { (v); } 542\end{array}$ & 2012 & $2200 \mathrm{mg} / \mathrm{kg}$ & $33 \& 226$ \\
\hline GLICÓSIDOS DE ESTEVIOL & $960 a, 960 b(i)$ & 2011 & $30 \mathrm{mg} / \mathrm{kg}$ & 26 \\
\hline INDIGOTINA (CARMÍN DE ÍNDIGO) & 132 & 2009 & $300 \mathrm{mg} / \mathrm{kg}$ & \\
\hline ÓXIDOS DE HIERRO & 172(i)-(iii) & 2005 & $1000 \mathrm{mg} / \mathrm{kg}$ & \\
\hline POLISORBATOS & $432-436$ & 2007 & $5000 \mathrm{mg} / \mathrm{kg}$ & \\
\hline PONCEAU 4R (ROJO DE COCHINILLA A) & 124 & 2008 & $500 \mathrm{mg} / \mathrm{kg}$ & \\
\hline RIBOFLAVINAS & 101(i),(ii), (iii) & 2005 & $350 \mathrm{mg} / \mathrm{kg}$ & \\
\hline ROJO ALLURA AC & 129 & 2009 & $300 \mathrm{mg} / \mathrm{kg}$ & \\
\hline SACARINAS & 954(i)-(iv) & 2008 & $1500 \mathrm{mg} / \mathrm{kg}$ & 161 \\
\hline SILICATO DE SODIO Y ALUMINIO & 554 & 2013 & $1000 \mathrm{mg} / \mathrm{kg}$ & $6 \& 255$ \\
\hline $\begin{array}{l}\text { SUCRALOSA } \\
\text { (TRICLOROGALACTOSACAROSA) }\end{array}$ & 955 & 2008 & $700 \mathrm{mg} / \mathrm{kg}$ & 161 \\
\hline SUCROÉSTERES DE ÁCIDOS GRASOS & 473 & 2018 & $20000 \mathrm{mg} / \mathrm{kg}$ & $423,424,425$ \\
\hline $\begin{array}{l}\text { SUCROSE OLIGOESTERS, TYPE I AND } \\
\text { TYPE II }\end{array}$ & $473 a$ & 2018 & $20000 \mathrm{mg} / \mathrm{kg}$ & $423,424,425$ \\
\hline SULFITOS & $220-225,539$ & 2006 & $200 \mathrm{mg} / \mathrm{kg}$ & 44 \\
\hline TARTRATOS & 334, 335(ii), 337 & 2018 & $7500 \mathrm{mg} / \mathrm{kg}$ & 45 \\
\hline VERDE SÓLIDO FCF & 143 & 2009 & $100 \mathrm{mg} / \mathrm{kg}$ & \\
\hline
\end{tabular}

\section{No. de Categoría de alimento $12.3 \quad$ Vinagres}

$\begin{array}{lllcc}\text { Aditivo } & \text { SIN } & \text { Año Adoptada } & \text { Dosis máxima } & \text { Notas } \\ \text { ACESULFAME DE POTASIO } & 950 & 2008 & 2000 \mathrm{mg} / \mathrm{kg} & 161 \& 188 \\ \text { ASPARTAMO } & 951 & 2008 & 3000 \mathrm{mg} / \mathrm{kg} & 161 \& 191 \\ \text { BENZOATOS } & 210-213 & 2003 & 1000 \mathrm{mg} / \mathrm{kg} & 13\end{array}$




\begin{tabular}{|c|c|c|c|c|}
\hline \multicolumn{2}{|c|}{ No. de Categoría de alimento 12.3} & \multicolumn{2}{|c|}{ Vinagres } & \multirow[b]{2}{*}{ Notas } \\
\hline Aditivo & $\sin$ & Año Adoptada & Dosis máxima & \\
\hline $\begin{array}{l}\text { CARAMELO III - CARAMELO AL } \\
\text { AMONÍACO }\end{array}$ & $150 c$ & 2010 & $1000 \mathrm{mg} / \mathrm{kg}$ & 78 \\
\hline $\begin{array}{l}\text { CARAMELO IV - CARAMELO AL SULFITO } \\
\text { AMÓNICO }\end{array}$ & $150 d$ & 2011 & $50000 \mathrm{mg} / \mathrm{kg}$ & \\
\hline HIDROXIBENZOATOS, PARA- & 214,218 & 2012 & $100 \mathrm{mg} / \mathrm{kg}$ & 27 \\
\hline NEOTAMO & 961 & 2008 & $12 \mathrm{mg} / \mathrm{kg}$ & 161 \\
\hline POLIVINILPIRROLIDONA & 1201 & 1999 & $40 \mathrm{mg} / \mathrm{kg}$ & \\
\hline SACARINAS & 954(i)-(iv) & 2008 & $300 \mathrm{mg} / \mathrm{kg}$ & \\
\hline $\begin{array}{l}\text { SUCRALOSA } \\
\text { (TRICLOROGALACTOSACAROSA) }\end{array}$ & 955 & 2008 & $400 \mathrm{mg} / \mathrm{kg}$ & 161 \\
\hline SULFITOS & $220-225,539$ & 2006 & $100 \mathrm{mg} / \mathrm{kg}$ & 44 \\
\hline
\end{tabular}

\begin{tabular}{|c|c|c|c|c|}
\hline \multicolumn{2}{|c|}{ No. de Categoría de alimento 12.4} & \multicolumn{2}{|c|}{ Mostazas } & \multirow[b]{2}{*}{ Notas } \\
\hline Aditivo & SIN & Año Adoptada & Dosis máxima & \\
\hline ACESULFAME DE POTASIO & 950 & 2007 & $350 \mathrm{mg} / \mathrm{kg}$ & 188 \\
\hline AMARILLO OCASO FCF & 110 & 2008 & $300 \mathrm{mg} / \mathrm{kg}$ & \\
\hline ASPARTAMO & 951 & 2007 & $350 \mathrm{mg} / \mathrm{kg}$ & 191 \\
\hline AZUL BRILLANTE FCF & 133 & 2009 & $100 \mathrm{mg} / \mathrm{kg}$ & \\
\hline BENZOATOS & $210-213$ & 2003 & $1000 \mathrm{mg} / \mathrm{kg}$ & 13 \\
\hline $\begin{array}{l}\text { CARAMELO III - CARAMELO AL } \\
\text { AMONÍACO }\end{array}$ & $150 c$ & 2010 & $50000 \mathrm{mg} / \mathrm{kg}$ & \\
\hline $\begin{array}{l}\text { CARAMELO IV - CARAMELO AL SULFITO } \\
\text { AMÓNICO }\end{array}$ & $150 d$ & 2011 & $50000 \mathrm{mg} / \mathrm{kg}$ & \\
\hline CARMINES & 120 & 2005 & $300 \mathrm{mg} / \mathrm{kg}$ & 178 \\
\hline CAROTENOIDES & $160 a(i), a(i i i), e, f$ & 2009 & 300 mg/kg & \\
\hline CAROTENOS, BETA-, VEGETALES & $160 a(i i)$ & 2005 & $1000 \mathrm{mg} / \mathrm{kg}$ & \\
\hline $\begin{array}{l}\text { CLOROFILAS Y CLOROFILINAS, } \\
\text { COMPLEJOS CUPRICOS }\end{array}$ & 141(i),(ii) & 2009 & $500 \mathrm{mg} / \mathrm{kg}$ & \\
\hline ÉSTERES DE ASCORBILO & 304,305 & 2003 & $500 \mathrm{mg} / \mathrm{kg}$ & 10 \\
\hline $\begin{array}{l}\text { ÉSTERES DIACETILTARTÁRICOS Y DE } \\
\text { ÁCIDOS GRASOS DE GLICEROL }\end{array}$ & $472 e$ & 2005 & $10000 \mathrm{mg} / \mathrm{kg}$ & \\
\hline ETILEN DIAMINO TETRA ACETATOS & 385,386 & 2001 & $75 \mathrm{mg} / \mathrm{kg}$ & 21 \\
\hline EXTRACTO DE PIEL DE UVA & 163(ii) & 2009 & 200 mg/kg & 181 \\
\hline GLICÓSIDOS DE ESTEVIOL & $960 \mathrm{a}, 960 \mathrm{~b}(\mathrm{i})$ & 2011 & $130 \mathrm{mg} / \mathrm{kg}$ & 26 \\
\hline HIDROXIBENZOATOS, PARA- & 214,218 & 2010 & 300 mg/kg & 27 \\
\hline INDIGOTINA (CARMÍN DE ÍNDIGO) & 132 & 2009 & 300 mg/kg & \\
\hline NEOTAMO & 961 & 2007 & $12 \mathrm{mg} / \mathrm{kg}$ & \\
\hline PONCEAU 4R (ROJO DE COCHINILLA A) & 124 & 2008 & 300 mg/kg & \\
\hline RIBOFLAVINAS & 101(i),(ii), (iii) & 2005 & 300 mg/kg & \\
\hline ROJO ALLURA AC & 129 & 2009 & 300 mg/kg & \\
\hline SACARINAS & 954(i)-(iv) & 2007 & 320 mg/kg & \\
\hline SORBATOS & $200,202,203$ & 2012 & $1000 \mathrm{mg} / \mathrm{kg}$ & 42 \\
\hline $\begin{array}{l}\text { SUCRALOSA } \\
\text { (TRICLOROGALACTOSACAROSA) }\end{array}$ & 955 & 2007 & $140 \mathrm{mg} / \mathrm{kg}$ & \\
\hline
\end{tabular}




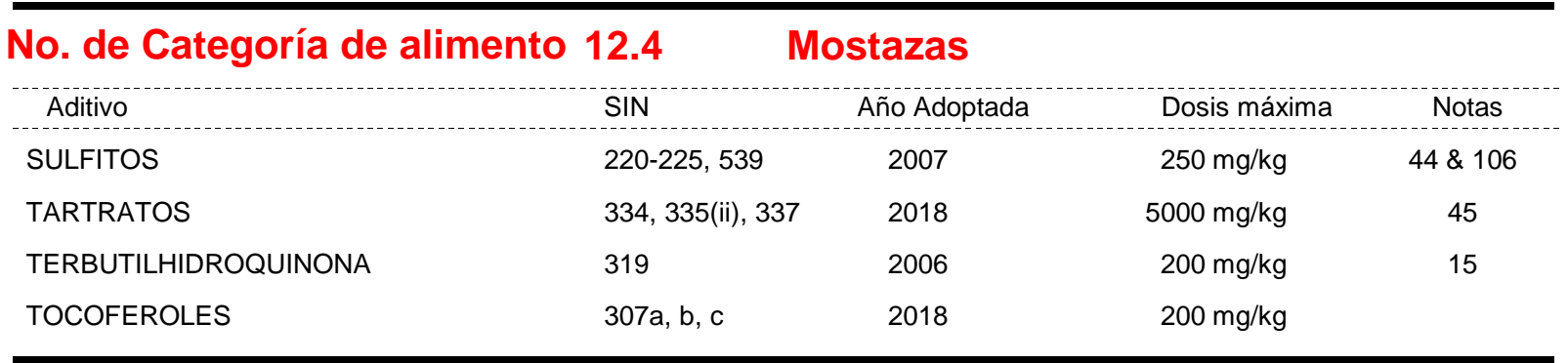

\begin{tabular}{|c|c|c|c|c|}
\hline \multicolumn{2}{|c|}{ No. de Categoría de alimento 12.5} & \multicolumn{2}{|c|}{ opas y caldos } & \multirow[b]{2}{*}{ Notas } \\
\hline Aditivo & SIN & Año Adoptada & Dosis máxima & \\
\hline ACESULFAME DE POTASIO & 950 & 2019 & $110 \mathrm{mg} / \mathrm{kg}$ & 478,188 \& XS117 \\
\hline ALITAME & 956 & 2015 & $40 \mathrm{mg} / \mathrm{kg}$ & $161 \& X S 117$ \\
\hline AMARILLO DE QUINOLEÍNA & 104 & 2015 & $50 \mathrm{mg} / \mathrm{kg}$ & 99 \\
\hline AMARILLO OCASO FCF & 110 & 2008 & $50 \mathrm{mg} / \mathrm{kg}$ & \\
\hline ASPARTAMO & 951 & 2019 & $1200 \mathrm{mg} / \mathrm{kg}$ & 478,188 \& XS117 \\
\hline AZORRUBINA (CARMOISINA) & 122 & 2015 & $50 \mathrm{mg} / \mathrm{kg}$ & 99 \\
\hline AZUL BRILLANTE FCF & 133 & 2009 & $50 \mathrm{mg} / \mathrm{kg}$ & \\
\hline BENZOATOS & $210-213$ & 2015 & $500 \mathrm{mg} / \mathrm{kg}$ & $13,338 \& 339$ \\
\hline BUTILHIDROXIANISOL & 320 & 2006 & $200 \mathrm{mg} / \mathrm{kg}$ & $15 \& 130$ \\
\hline BUTILHIDROXITOLUENO & 321 & 2015 & $200 \mathrm{mg} / \mathrm{kg}$ & $15,130 \& 340$ \\
\hline $\begin{array}{l}\text { CARAMELO III - CARAMELO AL } \\
\text { AMONÍACO }\end{array}$ & $150 \mathrm{c}$ & 2010 & $25000 \mathrm{mg} / \mathrm{kg}$ & \\
\hline $\begin{array}{l}\text { CARAMELO IV - CARAMELO AL SULFITO } \\
\text { AMÓNICO }\end{array}$ & $150 d$ & 2011 & $25000 \mathrm{mg} / \mathrm{kg}$ & 212 \\
\hline CARMINES & 120 & 2005 & $50 \mathrm{mg} / \mathrm{kg}$ & 178 \\
\hline CAROTENOIDES & 160a(i),a(iii),e,f & 2015 & $300 \mathrm{mg} / \mathrm{kg}$ & 341 \\
\hline CAROTENOS, BETA-, VEGETALES & 160a(ii) & 2015 & $1000 \mathrm{mg} / \mathrm{kg}$ & 341 \\
\hline $\begin{array}{l}\text { CLOROFILAS Y CLOROFILINAS, } \\
\text { COMPLEJOS CUPRICOS }\end{array}$ & 141 (i),(ii) & 2015 & $400 \mathrm{mg} / \mathrm{kg}$ & 342 \\
\hline CURCUMINA & $100(\mathrm{i})$ & 2015 & $50 \mathrm{mg} / \mathrm{kg}$ & 99 \\
\hline DIACETATO DE SODIO & 262(ii) & 2018 & $500 \mathrm{mg} / \mathrm{kg}$ & XS117 \\
\hline DIMETILPOLISILOXANO & $900 a$ & 1999 & $10 \mathrm{mg} / \mathrm{kg}$ & \\
\hline ÉSTERES DE ASCORBILO & 304,305 & 2001 & $200 \mathrm{mg} / \mathrm{kg}$ & 10 \\
\hline $\begin{array}{l}\text { ÉSTERES DIACETILTARTÁRICOS Y DE } \\
\text { ÁCIDOS GRASOS DE GLICEROL }\end{array}$ & $472 e$ & 2015 & $5000 \mathrm{mg} / \mathrm{kg}$ & $\mathrm{XS} 117$ \\
\hline ETIL-LAUROIL ARGINATO & 243 & 2015 & $200 \mathrm{mg} / \mathrm{kg}$ & XS117 \\
\hline EXTRACTO DE PIEL DE UVA & 163(ii) & 2015 & $500 \mathrm{mg} / \mathrm{kg}$ & $181 \& X S 117$ \\
\hline FOSFATOS & $\begin{array}{l}\text { 338; 339(i)-(iii); } \\
340(\mathrm{i})-(\mathrm{iii}) ; 341 \text { (i)- } \\
\text { (iii); 342(i)-(ii); } \\
343(\mathrm{i}) \text {-(iii); } 450 \text { (i)- } \\
\text { (iii),(v)-(vii), (ix); } \\
\text { 451(i),(ii); 452(i)- } \\
\text { (v); } 542\end{array}$ & 2015 & $1500 \mathrm{mg} / \mathrm{kg}$ & $33 \& 343$ \\
\hline GALATO DE PROPILO & 310 & 2012 & $200 \mathrm{mg} / \mathrm{kg}$ & $15,127 \& 130$ \\
\hline GLICÓSIDOS DE ESTEVIOL & $960 \mathrm{a}, 960 \mathrm{~b}(\mathrm{i})$ & 2015 & $50 \mathrm{mg} / \mathrm{kg}$ & $26 \& X S 117$ \\
\hline INDIGOTINA (CARMÍN DE ÍNDIGO) & 132 & 2009 & $50 \mathrm{mg} / \mathrm{kg}$ & \\
\hline NEOTAMO & 961 & 2019 & $20 \mathrm{mg} / \mathrm{kg}$ & 478 \& XS117 \\
\hline
\end{tabular}




\begin{tabular}{|c|c|c|c|c|}
\hline \multicolumn{2}{|c|}{ No. de Categoría de alimento 12.5} & \multicolumn{2}{|c|}{ Sopas y caldos } & \multirow[b]{2}{*}{ Notas } \\
\hline Aditivo & $\sin$ & Año Adoptada & Dosis máxima & \\
\hline ÓXIDOS DE HIERRO & 172(i)-(iii) & 2015 & $100 \mathrm{mg} / \mathrm{kg}$ & $\mathrm{XS} 117$ \\
\hline POLISORBATOS & $432-436$ & 2005 & $1000 \mathrm{mg} / \mathrm{kg}$ & \\
\hline PONCEAU 4R (ROJO DE COCHINILLA A) & 124 & 2008 & $50 \mathrm{mg} / \mathrm{kg}$ & \\
\hline RIBOFLAVINAS & 101(i),(ii), (iii) & 2015 & $200 \mathrm{mg} / \mathrm{kg}$ & 344 \\
\hline ROJO ALLURA AC & 129 & 2015 & $300 \mathrm{mg} / \mathrm{kg}$ & $161 \& 337$ \\
\hline SACARINAS & 954(i)-(iv) & 2019 & $110 \mathrm{mg} / \mathrm{kg}$ & $477 \&$ XS117 \\
\hline SORBATOS & 200, 202, 203 & 2015 & $1000 \mathrm{mg} / \mathrm{kg}$ & $42,338 \& 339$ \\
\hline $\begin{array}{l}\text { SUCRALOSA } \\
\text { (TRICLOROGALACTOSACAROSA) }\end{array}$ & 955 & 2019 & $600 \mathrm{mg} / \mathrm{kg}$ & $478 \&$ XS117 \\
\hline SUCROÉSTERES DE ÁCIDOS GRASOS & 473 & 2015 & $2000 \mathrm{mg} / \mathrm{kg}$ & 345 \\
\hline SUCROGLICÉRIDOS & 474 & 2015 & $2000 \mathrm{mg} / \mathrm{kg}$ & 345 \\
\hline TARTRATOS & 334, 335(ii), 337 & 2018 & $5000 \mathrm{mg} / \mathrm{kg}$ & $45, \mathrm{XS} 117$ \\
\hline TARTRAZINA & 102 & 2015 & $50 \mathrm{mg} / \mathrm{kg}$ & 99 \\
\hline TERBUTILHIDROQUINONA & 319 & 2006 & $200 \mathrm{mg} / \mathrm{kg}$ & $15 \& 130$ \\
\hline TOCOFEROLES & $307 a, b, c$ & 2015 & $50 \mathrm{mg} / \mathrm{kg}$ & 346 \\
\hline
\end{tabular}

No. de Categoría de alimento 12.5.1 Sopas y caldos listos para el consumo, incluidos los envasados, embotellados y congelados

\begin{tabular}{lcccc} 
& SIN & Año Adoptada & Dosis máxima & Notas \\
\hline ALGINATO & 405 & 2018 & $10000 \mathrm{mg} / \mathrm{kg}$ & XS117 \\
ÉSTERES POLIGLICÉRIDOS DE ÁCIDOS & 475 & 2018 & $400 \mathrm{mg} / \mathrm{kg}$ & XS117 \\
GRASOS & 234 & 2018 & $5 \mathrm{mg} / \mathrm{kg}$ & 233,339 \\
NISINA & 234 & &
\end{tabular}

No. de Categoría de alimento 12.5.2 Mezclas para sopas y caldos

\begin{tabular}{llccc} 
& SIN & Año Adoptada & Dosis máxima & Notas \\
\hline Aditivo & $161 \mathrm{~g}$ & 2015 & $30 \mathrm{mg} / \mathrm{kg}$ & XS117 \\
$\begin{array}{l}\text { EANTAXANTINA } \\
\text { GRASOS }\end{array}$ & $491-495$ & 2018 & $250 \mathrm{mg} / \mathrm{kg}$ & 127, XS117 \\
$\begin{array}{l}\text { ÉSTERES POLIGLICÉRIDOS DE ÁCIDOS } \\
\text { GRASOS }\end{array}$ & 475 & 2018 & $3000 \mathrm{mg} / \mathrm{kg}$ & 127, XS117 \\
\begin{tabular}{l} 
SILICATO DE SODIO Y ALUMINIO \\
\hline
\end{tabular} & 554 & 2015 & $570 \mathrm{mg} / \mathrm{kg}$ & 6 \& XS117 \\
\hline
\end{tabular}

\section{No. de Categoría de alimento $12.6 \quad$ Salsas y productos análogos}

\begin{tabular}{llccc} 
Aditivo & SIN & Año Adoptada & Dosis máxima & Notas \\
\hline ACESULFAME DE POTASIO & 950 & 2007 & $1000 \mathrm{mg} / \mathrm{kg}$ & 188 \\
AMARILLO OCASO FCF & 110 & 2018 & $300 \mathrm{mg} / \mathrm{kg}$ & XS302 \\
ASPARTAMO & 951 & 2007 & $350 \mathrm{mg} / \mathrm{kg}$ & 191 \\
AZUL BRILLANTE FCF & 133 & 2018 & $100 \mathrm{mg} / \mathrm{kg}$ & $X S 302$ \\
BENZOATOS & $210-213$ & 2003 & $1000 \mathrm{mg} / \mathrm{kg}$ & 13 \\
BUTILHIDROXIANISOL & 320 & 2018 & $200 \mathrm{mg} / \mathrm{kg}$ & $15,130 \& X S 302$ \\
BUTILHIDROXITOLUENO & 321 & 2018 & $100 \mathrm{mg} / \mathrm{kg}$ & $15,130 \& X S 302$
\end{tabular}




\begin{tabular}{|c|c|c|c|c|}
\hline \multicolumn{2}{|c|}{ No. de Categoría de alimento 12.6} & \multicolumn{3}{|c|}{ Salsas y productos análogos } \\
\hline Aditivo & SIN & Año Adoptada & Dosis máxima & Notas \\
\hline CANTAXANTINA & $161 \mathrm{~g}$ & 2018 & $30 \mathrm{mg} / \mathrm{kg}$ & XS302 \\
\hline $\begin{array}{l}\text { CARAMELO III - CARAMELO AL } \\
\text { AMONÍACO }\end{array}$ & $150 c$ & 2010 & $50000 \mathrm{mg} / \mathrm{kg}$ & \\
\hline $\begin{array}{l}\text { CARAMELO IV - CARAMELO AL SULFITO } \\
\text { AMÓNICO }\end{array}$ & $150 d$ & 2018 & $30000 \mathrm{mg} / \mathrm{kg}$ & XS302 \\
\hline CARMINES & 120 & 2018 & $500 \mathrm{mg} / \mathrm{kg}$ & $178 \&$ XS302 \\
\hline CAROTENOIDES & 160a(i),a(iii),e,f & 2018 & $500 \mathrm{mg} / \mathrm{kg}$ & XS302 \\
\hline $\begin{array}{l}\text { CLOROFILAS Y CLOROFILINAS, } \\
\text { COMPLEJOS CUPRICOS }\end{array}$ & $141(\mathrm{i}),(\mathrm{ii})$ & 2018 & $100 \mathrm{mg} / \mathrm{kg}$ & XS302 \\
\hline $\begin{array}{l}\text { ÉSTERES DIACETILTARTÁRICOS Y DE } \\
\text { ÁCIDOS GRASOS DE GLICEROL }\end{array}$ & $472 \mathrm{e}$ & 2018 & $10000 \mathrm{mg} / \mathrm{kg}$ & XS302 \\
\hline FOSFATOS & $\begin{array}{l}338 ; 339 \text { (i)-(iii); } \\
\text { 340(i)-(iii); 341(i)- } \\
\text { (iii); 342(i)-(ii); } \\
\text { 343(i)-(iii); 450(i)- } \\
\text { (iii),(v)-(vii), (ix); } \\
\text { 451(i),(ii); 452(i)- } \\
\text { (v); } 542\end{array}$ & 2018 & $2200 \mathrm{mg} / \mathrm{kg}$ & $33 \&$ XS302 \\
\hline GALATO DE PROPILO & 310 & 2018 & $200 \mathrm{mg} / \mathrm{kg}$ & $15,130 \&$ XS302 \\
\hline HIDROXIBENZOATOS, PARA- & 214,218 & 2018 & $1000 \mathrm{mg} / \mathrm{kg}$ & $27 \&$ XS302 \\
\hline INDIGOTINA (CARMÍN DE ÍNDIGO) & 132 & 2018 & $300 \mathrm{mg} / \mathrm{kg}$ & XS302 \\
\hline ÓXIDOS DE HIERRO & 172(i)-(iii) & 2018 & $75 \mathrm{mg} / \mathrm{kg}$ & XS302 \\
\hline PONCEAU 4R (ROJO DE COCHINILLA A) & 124 & 2018 & $50 \mathrm{mg} / \mathrm{kg}$ & XS302 \\
\hline RESINA DE GUAYACO & 314 & 2018 & $600 \mathrm{mg} / \mathrm{kg}$ & $15 \& X S 302$ \\
\hline RIBOFLAVINAS & 101(i),(ii), (iii) & 2018 & $350 \mathrm{mg} / \mathrm{kg}$ & XS302 \\
\hline ROJO ALLURA AC & 129 & 2018 & $300 \mathrm{mg} / \mathrm{kg}$ & XS302 \\
\hline SACARINAS & 954(i)-(iv) & 2018 & $160 \mathrm{mg} / \mathrm{kg}$ & XS302 \\
\hline SORBATOS & $200,202,203$ & 2012 & $1000 \mathrm{mg} / \mathrm{kg}$ & $42 \& 127$ \\
\hline $\begin{array}{l}\text { SUCRALOSA } \\
\text { (TRICLOROGALACTOSACAROSA) }\end{array}$ & 955 & 2007 & $450 \mathrm{mg} / \mathrm{kg}$ & 127 \\
\hline SULFITOS & $220-225,539$ & 2018 & $300 \mathrm{mg} / \mathrm{kg}$ & $44 \& X S 302$ \\
\hline TERBUTILHIDROQUINONA & 319 & 2018 & $200 \mathrm{mg} / \mathrm{kg}$ & $15,130 \times S 302$ \\
\hline
\end{tabular}

No. de Categoría de alimento 12.6.1 Salsas emulsionadas y salsas para mojar (p.ej. mayonesa, aderezos para ensaladas, salsa para mojar de cebollas)

\begin{tabular}{|c|c|c|c|c|}
\hline Aditivo & SIN & Año Adoptada & Dosis máxima & Notas \\
\hline ALGINATO DE PROPILENGLICOL & 405 & 2018 & $8000 \mathrm{mg} / \mathrm{kg}$ & \\
\hline CAROTENOS, BETA-, VEGETALES & $160 a(i i)$ & 2005 & $2000 \mathrm{mg} / \mathrm{kg}$ & \\
\hline CICLAMATOS & 952(i), (ii), (iv) & 2008 & $500 \mathrm{mg} / \mathrm{kg}$ & $17 \& 161$ \\
\hline DIACETATO DE SODIO & 262(ii) & 2018 & $2500 \mathrm{mg} / \mathrm{kg}$ & \\
\hline ESTEAROIL LACTILATOS & 481(i), 482(i) & 2018 & $2500 \mathrm{mg} / \mathrm{kg}$ & 427 \\
\hline ÉSTERES DE ASCORBILO & 304,305 & 2001 & $500 \mathrm{mg} / \mathrm{kg}$ & $10 \& 15$ \\
\hline $\begin{array}{l}\text { ÉSTERES DE SORBITÁN DE ÁCIDOS } \\
\text { GRASOS }\end{array}$ & 491-495 & 2018 & $5000 \mathrm{mg} / \mathrm{kg}$ & \\
\hline
\end{tabular}


No. de Categoría de alimento 12.6.1 Salsas emulsionadas y salsas para mojar (p.ej. mayonesa, aderezos para ensaladas, salsa para mojar de cebollas)

\begin{tabular}{|c|c|c|c|c|}
\hline Aditivo & SIN & Año Adoptada & Dosis máxima & Notas \\
\hline $\begin{array}{l}\text { ÉSTERES POLIGLICÉRIDOS DE ÁCIDO } \\
\text { RICINOLÉICO INTERESTERIFICADO }\end{array}$ & 476 & 2018 & $5000 \mathrm{mg} / \mathrm{kg}$ & \\
\hline $\begin{array}{l}\text { ÉSTERES POLIGLICÉRIDOS DE ÁCIDOS } \\
\text { GRASOS }\end{array}$ & 475 & 2018 & $5000 \mathrm{mg} / \mathrm{kg}$ & \\
\hline ETILEN DIAMINO TETRA ACETATOS & 385,386 & 2001 & $100 \mathrm{mg} / \mathrm{kg}$ & 21 \\
\hline ETIL-LAUROIL ARGINATO & 243 & 2011 & $200 \mathrm{mg} / \mathrm{kg}$ & \\
\hline EXTRACTO DE PIEL DE UVA & 163(ii) & 2009 & $300 \mathrm{mg} / \mathrm{kg}$ & 181 \\
\hline GLICÓSIDOS DE ESTEVIOL & $960 a, 960 b(i)$ & 2011 & $350 \mathrm{mg} / \mathrm{kg}$ & 26 \\
\hline NEOTAMO & 961 & 2007 & $65 \mathrm{mg} / \mathrm{kg}$ & \\
\hline POLISORBATOS & $432-436$ & 2007 & $3000 \mathrm{mg} / \mathrm{kg}$ & \\
\hline PROPILENGLICOL & 1520 & 2018 & $1000 \mathrm{mg} / \mathrm{kg}$ & 426 \\
\hline SUCROÉSTERES DE ÁCIDOS GRASOS & 473 & 2018 & $2000 \mathrm{mg} / \mathrm{kg}$ & 348,426 \\
\hline SUCROGLICÉRIDOS & 474 & 2018 & $2000 \mathrm{mg} / \mathrm{kg}$ & 348,426 \\
\hline $\begin{array}{l}\text { SUCROSE OLIGOESTERS, TYPE I AND } \\
\text { TYPE II }\end{array}$ & $473 a$ & 2018 & $2000 \mathrm{mg} / \mathrm{kg}$ & 348,426 \\
\hline TARTRATOS & 334, 335(ii), 337 & 2018 & $2000 \mathrm{mg} / \mathrm{kg}$ & 45 \\
\hline TOCOFEROLES & $307 a, b, c$ & 2018 & $600 \mathrm{mg} / \mathrm{kg}$ & \\
\hline VERDE SÓLIDO FCF & 143 & 2009 & $100 \mathrm{mg} / \mathrm{kg}$ & \\
\hline
\end{tabular}

No. de Categoría de alimento 12.6.2

Salsas no emulsionadas (p. ej. salsa de tomate "ketchup", salsas a base de queso, salsas a base de nata (crema) y salsas hechas con jugo de carne asada "gravy")

\begin{tabular}{|c|c|c|c|c|}
\hline Aditivo & $\operatorname{SIN}$ & Año Adoptada & Dosis máxima & Notas \\
\hline CAROTENOS, BETA-, VEGETALES & $160 a(i i)$ & 2005 & $2000 \mathrm{mg} / \mathrm{kg}$ & \\
\hline DIACETATO DE SODIO & 262(ii) & 2018 & $2500 \mathrm{mg} / \mathrm{kg}$ & XS306R \\
\hline ESTEAROIL LACTILATOS & 481(i), 482(i) & 2018 & $2500 \mathrm{mg} / \mathrm{kg}$ & XS306R \\
\hline ÉSTERES DE ASCORBILO & 304,305 & 2005 & $500 \mathrm{mg} / \mathrm{kg}$ & 10 \\
\hline $\begin{array}{l}\text { ÉSTERES POLIGLICÉRIDOS DE ÁCIDOS } \\
\text { GRASOS }\end{array}$ & 475 & 2018 & $5000 \mathrm{mg} / \mathrm{kg}$ & XS306R \\
\hline ETILEN DIAMINO TETRA ACETATOS & 385,386 & 2001 & $75 \mathrm{mg} / \mathrm{kg}$ & 21 \\
\hline ETIL-LAUROIL ARGINATO & 243 & 2011 & $200 \mathrm{mg} / \mathrm{kg}$ & \\
\hline EXTRACTO DE PIEL DE UVA & 163(ii) & 2009 & $300 \mathrm{mg} / \mathrm{kg}$ & 181 \\
\hline GLICÓSIDOS DE ESTEVIOL & $960 a, 960 b(i)$ & 2011 & $350 \mathrm{mg} / \mathrm{kg}$ & 26 \\
\hline NEOTAMO & 961 & 2007 & $70 \mathrm{mg} / \mathrm{kg}$ & \\
\hline POLISORBATOS & $432-436$ & 2007 & $5000 \mathrm{mg} / \mathrm{kg}$ & \\
\hline SUCROÉSTERES DE ÁCIDOS GRASOS & 473 & 2018 & $10000 \mathrm{mg} / \mathrm{kg}$ & 348 \\
\hline SUCROGLICÉRIDOS & 474 & 2018 & $10000 \mathrm{mg} / \mathrm{kg}$ & 348 \\
\hline $\begin{array}{l}\text { SUCROSE OLIGOESTERS, TYPE I AND } \\
\text { TYPE II }\end{array}$ & $473 a$ & 2018 & $10000 \mathrm{mg} / \mathrm{kg}$ & 348 \\
\hline TARTRATOS & 334, 335(ii), 337 & 2018 & $5000 \mathrm{mg} / \mathrm{kg}$ & 45, XS306R \\
\hline
\end{tabular}




\begin{tabular}{|c|c|c|c|c|}
\hline \multirow[t]{2}{*}{ No. de Categoría de alimento } & 12.6 .2 & \multicolumn{3}{|c|}{$\begin{array}{l}\text { Salsas no emulsionadas (p. ej. salsa de } \\
\text { tomate "ketchup", salsas a base de } \\
\text { queso, salsas a base de nata (crema) y } \\
\text { salsas hechas con jugo de carne asada } \\
\text { "gravy") }\end{array}$} \\
\hline & $\sin$ & Año Adoptada & Dosis máxima & Notas \\
\hline TOCOFEROLES & $307 a, b, c$ & 2018 & $600 \mathrm{mg} / \mathrm{kg}$ & \\
\hline \multicolumn{2}{|c|}{ No. de Categoría de alimento 12.6.3 } & \multicolumn{3}{|c|}{ Mezclas para salsas y "gravies" } \\
\hline Aditivo & $\operatorname{SiN}$ & Año Adoptada & Dosis máxima & Notas \\
\hline ALGINATO DE PROPILENGLICOL & 405 & 2018 & $8000 \mathrm{mg} / \mathrm{kg}$ & 127 \\
\hline CAROTENOS, BETA-, VEGETALES & $160 a(i i)$ & 2005 & $2000 \mathrm{mg} / \mathrm{kg}$ & \\
\hline DIACETATO DE SODIO & 262(ii) & 2018 & $2500 \mathrm{mg} / \mathrm{kg}$ & 127 \\
\hline ÉSTERES DE ASCORBILO & 304,305 & 2001 & $200 \mathrm{mg} / \mathrm{kg}$ & 10 \\
\hline $\begin{array}{l}\text { ÉSTERES DE SORBITÁN DE ÁCIDOS } \\
\text { GRASOS }\end{array}$ & 491-495 & 2018 & $50 \mathrm{mg} / \mathrm{kg}$ & 127 \\
\hline $\begin{array}{l}\text { ÉSTERES POLIGLICÉRIDOS DE ÁCIDO } \\
\text { RICINOLÉICO INTERESTERIFICADO }\end{array}$ & 476 & 2018 & $5000 \mathrm{mg} / \mathrm{kg}$ & 127 \\
\hline $\begin{array}{l}\text { ÉSTERES POLIGLICÉRIDOS DE ÁCIDOS } \\
\text { GRASOS }\end{array}$ & 475 & 2018 & $5000 \mathrm{mg} / \mathrm{kg}$ & 127 \\
\hline EXTRACTO DE PIEL DE UVA & 163(ii) & 2009 & $300 \mathrm{mg} / \mathrm{kg}$ & 181 \\
\hline GLICÓSIDOS DE ESTEVIOL & $960 \mathrm{a}, 960 \mathrm{~b}(\mathrm{i})$ & 2011 & $350 \mathrm{mg} / \mathrm{kg}$ & $26 \& 127$ \\
\hline NEOTAMO & 961 & 2007 & $12 \mathrm{mg} / \mathrm{kg}$ & \\
\hline POLISORBATOS & $432-436$ & 2007 & $5000 \mathrm{mg} / \mathrm{kg}$ & 127 \\
\hline SILICATO DE SODIO Y ALUMINIO & 554 & 2013 & $570 \mathrm{mg} / \mathrm{kg}$ & 6 \\
\hline SUCROÉSTERES DE ÁCIDOS GRASOS & 473 & 2018 & $10000 \mathrm{mg} / \mathrm{kg}$ & $127 \& 348$ \\
\hline SUCROGLICÉRIDOS & 474 & 2018 & $10000 \mathrm{mg} / \mathrm{kg}$ & $127 \& 348$ \\
\hline $\begin{array}{l}\text { SUCROSE OLIGOESTERS, TYPE I AND } \\
\text { TYPE II }\end{array}$ & $473 a$ & 2018 & $10000 \mathrm{mg} / \mathrm{kg}$ & $127 \& 348$ \\
\hline TARTRATOS & 334, 335(ii), 337 & 2018 & $5000 \mathrm{mg} / \mathrm{kg}$ & 45,127 \\
\hline TOCOFEROLES & $307 a, b, c$ & 2018 & $300 \mathrm{mg} / \mathrm{kg}$ & 127 \\
\hline
\end{tabular}

No. de Categoría de alimento 12.6.4 Salsas ligeras (p. ej. salsa de pescado)

\begin{tabular}{llrrr}
\hline Aditivo & SIN & Año Adoptada & Dosis máxima & Notas \\
DIACETATO DE SODIO & $262(\mathrm{ii})$ & 2018 & $2500 \mathrm{mg} / \mathrm{kg}$ & XS302 \\
ÉSTERES DE ASCORBILO & 304,305 & 2018 & $200 \mathrm{mg} / \mathrm{kg}$ & $10 \&$ XS302 \\
GLICÓSIDOS DE ESTEVIOL & $960 \mathrm{a}, 960 \mathrm{~b}(\mathrm{i})$ & 2018 & $350 \mathrm{mg} / \mathrm{kg}$ & $26 \&$ XS302 \\
NEOTAMO & 961 & 2018 & $12 \mathrm{mg} / \mathrm{kg}$ & XS302 \\
POLISORBATOS & $432-436$ & 2018 & $5000 \mathrm{mg} / \mathrm{kg}$ & XS302 \\
SUCROÉSTERES DE ÁCIDOS GRASOS & 473 & 2018 & $10000 \mathrm{mg} / \mathrm{kg}$ & $348 \&$ XS302 \\
SUCROGLICÉRIDOS & 474 & 2018 & $10000 \mathrm{mg} / \mathrm{kg}$ & $348 \&$ XS302 \\
SUCROSE OLIGOESTERS, TYPE I AND & $473 \mathrm{a}$ & 2018 & $10000 \mathrm{mg} / \mathrm{kg}$ & $348 \&$ XS302
\end{tabular}


Ensaladas (p. ej., la ensalada de macarrones, la ensalada de patatas (papas)) y productos para untar en emparedados, excluidos los productos para untar a base de cacao y nueces de las categorías de alimentos 04.2.2.5 y 05.1.3

\begin{tabular}{|c|c|c|c|c|}
\hline Aditivo & $\sin$ & Año Adoptada & Dosis máxima & Notas \\
\hline ACESULFAME DE POTASIO & 950 & 2007 & 350 mg/kg & $161 \& 188$ \\
\hline ASPARTAMO & 951 & 2007 & $350 \mathrm{mg} / \mathrm{kg}$ & $161 \& 166$ \\
\hline BENZOATOS & $210-213$ & 2003 & $1500 \mathrm{mg} / \mathrm{kg}$ & 13 \\
\hline $\begin{array}{l}\text { CARAMELO III - CARAMELO AL } \\
\text { AMONÍACO }\end{array}$ & $150 \mathrm{c}$ & 2012 & $50000 \mathrm{mg} / \mathrm{kg}$ & 89 \\
\hline $\begin{array}{l}\text { CARAMELO IV - CARAMELO AL SULFITO } \\
\text { AMÓNICO }\end{array}$ & $150 d$ & 2011 & $50000 \mathrm{mg} / \mathrm{kg}$ & \\
\hline CAROTENOIDES & $160 a(i), a(i i i), e, f$ & 2009 & $50 \mathrm{mg} / \mathrm{kg}$ & \\
\hline CAROTENOS, BETA-, VEGETALES & $160 a(i i)$ & 2005 & $1000 \mathrm{mg} / \mathrm{kg}$ & \\
\hline CICLAMATOS & 952(i), (ii), (iv) & 2008 & $500 \mathrm{mg} / \mathrm{kg}$ & $17 \& 161$ \\
\hline ÉSTERES DE ASCORBILO & 304,305 & 2001 & 200 mg/kg & 10 \\
\hline $\begin{array}{l}\text { ÉSTERES DIACETILTARTÁRICOS Y DE } \\
\text { ÁCIDOS GRASOS DE GLICEROL }\end{array}$ & $472 e$ & 2005 & $5000 \mathrm{mg} / \mathrm{kg}$ & \\
\hline ETILEN DIAMINO TETRA ACETATOS & 385,386 & 2001 & $100 \mathrm{mg} / \mathrm{kg}$ & 21 \\
\hline ETIL-LAUROIL ARGINATO & 243 & 2011 & $200 \mathrm{mg} / \mathrm{kg}$ & \\
\hline EXTRACTO DE PIEL DE UVA & 163(ii) & 2009 & $1500 \mathrm{mg} / \mathrm{kg}$ & \\
\hline GLICÓSIDOS DE ESTEVIOL & $960 \mathrm{a}, 960 \mathrm{~b}(\mathrm{i})$ & 2011 & $115 \mathrm{mg} / \mathrm{kg}$ & 26 \\
\hline NEOTAMO & 961 & 2007 & $33 \mathrm{mg} / \mathrm{kg}$ & $161 \& 166$ \\
\hline POLISORBATOS & $432-436$ & 2007 & $2000 \mathrm{mg} / \mathrm{kg}$ & \\
\hline PONCEAU 4R (ROJO DE COCHINILLA A) & 124 & 2008 & $200 \mathrm{mg} / \mathrm{kg}$ & \\
\hline RIBOFLAVINAS & 101(i),(ii), (iii) & 2005 & $300 \mathrm{mg} / \mathrm{kg}$ & \\
\hline SACARINAS & 954(i)-(iv) & 2010 & $200 \mathrm{mg} / \mathrm{kg}$ & $161 \& 166$ \\
\hline SORBATOS & $200,202,203$ & 2009 & $1500 \mathrm{mg} / \mathrm{kg}$ & 42 \\
\hline $\begin{array}{l}\text { SUCRALOSA } \\
\text { (TRICLOROGALACTOSACAROSA) }\end{array}$ & 955 & 2007 & $1250 \mathrm{mg} / \mathrm{kg}$ & $161 \& 169$ \\
\hline
\end{tabular}

No. de Categoría de alimento 12.8

Levadura y productos análogos

\begin{tabular}{|c|c|c|c|c|}
\hline Aditivo & SIN & Año Adoptada & Dosis máxima & Notas \\
\hline BUTILHIDROXIANISOL & 320 & 2006 & 200 mg/kg & 15 \\
\hline $\begin{array}{l}\text { ÉSTERES DE SORBITÁN DE ÁCIDOS } \\
\text { GRASOS }\end{array}$ & $491-495$ & 2018 & $15000 \mathrm{mg} / \mathrm{kg}$ & \\
\hline
\end{tabular}

No. de Categoría de alimento 12.9

Aderezos y condimentos a base de soja 
No. de Categoría de alimento 12.9

$$
\text { Aditivo }
$$

FOSFATOS

SIN

338; 339(i)-(iii); 340(i)-(iii); 341(i)(iii); 342(i)-(ii); 343(i)-(iii); 450(i)(iii),(v)-(vii), (ix); 451(i),(ii); 452(i)(v); 542
Aderezos y condimentos a base de soja

2012 Años máxima $\quad 33$

\begin{tabular}{llccc}
\hline No. de Categoría de alimento & 12.9 .1 & Pasta de soja fermentada (por ej. miso) \\
\hline Aditivo & SiN & Año Adoptada & Dosis máxima & Notas \\
\hline RIBOFLAVINAS & 101 (i),(ii), (iii) & 2010 & $30 \mathrm{mg} / \mathrm{kg}$ & \\
SACARINAS & $954($ (i)-(iv) & 2012 & $200 \mathrm{mg} / \mathrm{kg}$ & \\
SORBATOS & $200,202,203$ & 2010 & $1000 \mathrm{mg} / \mathrm{kg}$ & 42 \\
\hline
\end{tabular}

\section{No. de Categoría de alimento 12.9.2.1 Salsa de soja fermentada}

\begin{tabular}{|c|c|c|c|c|}
\hline Aditivo & SIN & Año Adoptada & Dosis máxima & Notas \\
\hline $\begin{array}{l}\text { CARAMELO III - CARAMELO AL } \\
\text { AMONÍACO }\end{array}$ & $150 c$ & 2011 & $20000 \mathrm{mg} / \mathrm{kg}$ & 207 \\
\hline $\begin{array}{l}\text { CARAMELO IV - CARAMELO AL SULFITO } \\
\text { AMÓNICO }\end{array}$ & $150 d$ & 2011 & $60000 \mathrm{mg} / \mathrm{kg}$ & \\
\hline GLICÓSIDOS DE ESTEVIOL & $960 a, 960 b(i)$ & 2011 & $30 \mathrm{mg} / \mathrm{kg}$ & 26 \\
\hline SACARINAS & 954(i)-(iv) & 2012 & $500 \mathrm{mg} / \mathrm{kg}$ & \\
\hline SORBATOS & $200,202,203$ & 2010 & $1000 \mathrm{mg} / \mathrm{kg}$ & 42 \\
\hline
\end{tabular}

No. de Categoría de alimento 12.9.2.2 Salsa de soja no fermentada

\begin{tabular}{|c|c|c|c|c|}
\hline Aditivo & SIN & Año Adoptada & Dosis máxima & Notas \\
\hline $\begin{array}{l}\text { CARAMELO III - CARAMELO AL } \\
\text { AMONÍACO }\end{array}$ & $150 \mathrm{c}$ & 2011 & $1500 \mathrm{mg} / \mathrm{kg}$ & \\
\hline GLICÓSIDOS DE ESTEVIOL & $960 a, 960 b(i)$ & 2011 & $165 \mathrm{mg} / \mathrm{kg}$ & 26 \\
\hline
\end{tabular}

\begin{tabular}{lcccc}
\hline No. de Categoría de alimento & $\mathbf{1 2 . 9 . 2 . 3}$ & Otras salsas de soja & \\
\hline Aditivo & SIN & Año Adoptada & Dosis máxima & Notas \\
\hline CARAMELO III - CARAMELO AL & $150 \mathrm{c}$ & 2011 & $20000 \mathrm{mg} / \mathrm{kg}$ & \\
AMONÍACO & & & & \\
GLICÓSIDOS DE ESTEVIOL & $960 \mathrm{a}, 960 \mathrm{~b}(\mathrm{i})$ & 2011 & $165 \mathrm{mg} / \mathrm{kg}$ & 26 \\
SORBATOS & $200,202,203$ & 2010 & $1000 \mathrm{mg} / \mathrm{kg}$ & 42 \\
\hline
\end{tabular}

No. de Categoría de alimento 13.1

Fórmulas (preparados) para lactantes, fórmulas de continuación y fórmulas para usos médicos especiales destinados a los lactantes

\begin{tabular}{|c|c|c|c|c|}
\hline Aditivo & SIN & Año Adoptada & Dosis máxima & Notas \\
\hline $\begin{array}{l}\text { ÉSTERES CÍTRICOS Y DE ÁCIDOS } \\
\text { GRASOS DE GLICEROL }\end{array}$ & $472 c$ & 2016 & $9000 \mathrm{mg} / \mathrm{kg}$ & $380 \& 381$ \\
\hline
\end{tabular}

No. de Categoría de alimento 13.1.1

Aditivo SIN

Fórmulas (preparados) para lactantes 
No. de Categoría de alimento 13.1.1 Fórmulas (preparados) para lactantes

\begin{tabular}{|c|c|c|c|c|}
\hline Aditivo & $\operatorname{SIN}$ & Año Adoptada & Dosis máxima & Notas \\
\hline ÁCIDO CÍTRICO & 330 & 2015 & BPF & 72 \\
\hline ÁCIDO LÁCTICO, L-, D- y DL- & 270 & 2015 & BPF & $72 \& 83$ \\
\hline ALMIDÓN HIDROXIPROPÍLICO & 1440 & 2014 & $5000 \mathrm{mg} / \mathrm{kg}$ & $72,150,284 \& 292$ \\
\hline CARBONATO ÁCIDO DE POTASIO & 501(ii) & 2013 & $2000 \mathrm{mg} / \mathrm{kg}$ & $55 \& 72$ \\
\hline CARBONATO ÁCIDO DE SODIO & 500 (ii) & 2013 & $2000 \mathrm{mg} / \mathrm{kg}$ & $55 \& 72$ \\
\hline CARBONATO DE POTASIO & $501(\mathrm{i})$ & 2013 & $2000 \mathrm{mg} / \mathrm{kg}$ & $55 \& 72$ \\
\hline CARBONATO DE SODIO & $500(i)$ & 2013 & $2000 \mathrm{mg} / \mathrm{kg}$ & $55 \& 72$ \\
\hline CARRAGENINA & 407 & 2016 & $300 \mathrm{mg} / \mathrm{kg}$ & $378 \& 381$ \\
\hline CITRATO DÍACIDO DE POTASIO & $332(i)$ & 2014 & BPF & $55 \& 72$ \\
\hline CITRATO DÍACIDO DE SODIO & $331(\mathrm{i})$ & 2014 & BPF & $55 \& 72$ \\
\hline CITRATO TRIPOTÁSICO & 332(ii) & 2014 & BPF & $55 \& 72$ \\
\hline CITRATO TRISÓDICO & 331 (iii) & 2014 & BPF & $55 \& 72$ \\
\hline DIÓXIDO DE CARBONO & 290 & 2015 & BPF & 59 \\
\hline ÉSTERES DE ASCORBILO & 304,305 & 2019 & $10 \mathrm{mg} / \mathrm{kg}$ & $72 \& 187$ \\
\hline FOSFATO DE DIALMIDÓN & 1412 & 2014 & $5000 \mathrm{mg} / \mathrm{kg}$ & $72,150,284 \& 292$ \\
\hline FOSFATO DE DIALMIDÓN ACETILADO & 1414 & 2014 & $5000 \mathrm{mg} / \mathrm{kg}$ & $72,150,284 \& 292$ \\
\hline FOSFATO DE DIALMIDÓN FOSFATADO & 1413 & 2014 & $5000 \mathrm{mg} / \mathrm{kg}$ & $72,150,284 \& 292$ \\
\hline GOMA DE SEMILLAS DE ALGARROBO & 410 & 2014 & $1000 \mathrm{mg} / \mathrm{kg}$ & 72 \\
\hline GOMA GUAR & 412 & 2014 & $1000 \mathrm{mg} / \mathrm{kg}$ & $14 \& 72$ \\
\hline HIDRÓXIDO DE CALCIO & 526 & 2013 & $2000 \mathrm{mg} / \mathrm{kg}$ & $55 \& 72$ \\
\hline HIDRÓXIDO DE POTASIO & 525 & 2013 & $2000 \mathrm{mg} / \mathrm{kg}$ & $55 \& 72$ \\
\hline HIDRÓXIDO DE SODIO & 524 & 2013 & 2000 mg/kg & $55 \& 72$ \\
\hline LECITINA & 322(i) & 2014 & $5000 \mathrm{mg} / \mathrm{kg}$ & 72 \\
\hline $\begin{array}{l}\text { MONOGLICÉRIDOS Y DIGLICÉRIDOS DE } \\
\text { ÁCIDOS GRASOS }\end{array}$ & 471 & 2014 & $4000 \mathrm{mg} / \mathrm{kg}$ & 72 \\
\hline NITRÓGENO & 941 & 2015 & BPF & 59 \\
\hline TOCOFEROLES & $307 a, b, c$ & 2018 & $10 \mathrm{mg} / \mathrm{kg}$ & 72,416 \\
\hline
\end{tabular}

No. de Categoría de alimento 13.1.2 Fórmulas (preparados) de continuación

\begin{tabular}{|c|c|c|c|c|}
\hline Aditivo & SIN & Año Adoptada & Dosis máxima & Notas \\
\hline ÁCIDO ASCÓRBICO, L- & 300 & 2015 & $50 \mathrm{mg} / \mathrm{kg}$ & $72,242 \& 315$ \\
\hline ÁCIDO CÍTRICO & 330 & 2013 & BPF & 72 \\
\hline ÁCIDO LÁCTICO, L-, D- y DL- & 270 & 2013 & BPF & $72 \& 83$ \\
\hline ADIPATO DE DIALMIDÓN ACETILADO & 1422 & 2014 & $5000 \mathrm{mg} / \mathrm{kg}$ & $72,150,285 \& 292$ \\
\hline ASCORBATO DE CALCIO & 302 & 2015 & $50 \mathrm{mg} / \mathrm{kg}$ & $70,72 \& 315$ \\
\hline ASCORBATO DE SODIO & 301 & 2015 & $50 \mathrm{mg} / \mathrm{kg}$ & $70,72,315 \& 316$ \\
\hline CARBONATO ÁCIDO DE POTASIO & 501 (ii) & 2013 & BPF & 72 \\
\hline CARBONATO ÁCIDO DE SODIO & 500 (ii) & 2015 & BPF & $72 \& 316$ \\
\hline CARBONATO DE POTASIO & $501(i)$ & 2013 & BPF & 72 \\
\hline CARBONATO DE SODIO & 500 (i) & 2015 & BPF & $72 \& 316$ \\
\hline CARRAGENINA & 407 & 2015 & 300 mg/kg & $72,151,328 \& 329$ \\
\hline
\end{tabular}




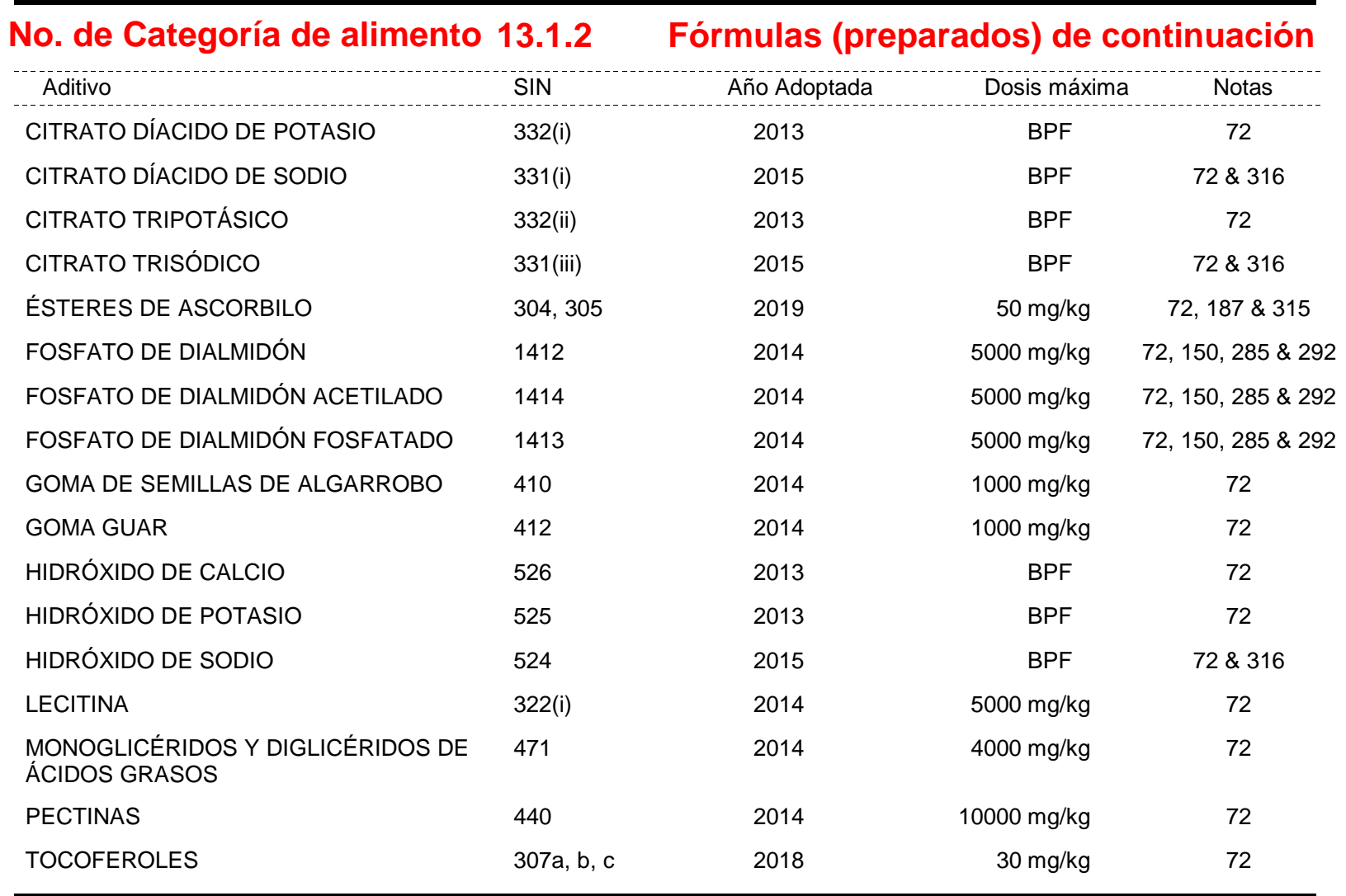

No. de Categoría de alimento 13.1.3 Fórmulas (preparados) para usos médicos especiales destinados a los lactantes

\begin{tabular}{|c|c|c|c|c|}
\hline Aditivo & SIN & Año Adoptada & Dosis máxima & Notas \\
\hline ÁCIDO CÍTRICO & 330 & 2015 & BPF & 72 \\
\hline ÁCIDO LÁCTICO, L-, D- y DL- & 270 & 2015 & BPF & $72 \& 83$ \\
\hline ALMIDÓN HIDROXIPROPÍLICO & 1440 & 2014 & $5000 \mathrm{mg} / \mathrm{kg}$ & $72,150 \& 292$ \\
\hline CARBONATO ÁCIDO DE POTASIO & 501 (ii) & 2013 & $2000 \mathrm{mg} / \mathrm{kg}$ & $55 \& 72$ \\
\hline CARBONATO ÁCIDO DE SODIO & 500 (ii) & 2013 & $2000 \mathrm{mg} / \mathrm{kg}$ & $55 \& 72$ \\
\hline CARBONATO DE POTASIO & $501(i)$ & 2013 & $2000 \mathrm{mg} / \mathrm{kg}$ & $55 \& 72$ \\
\hline CARBONATO DE SODIO & 500 (i) & 2013 & $2000 \mathrm{mg} / \mathrm{kg}$ & $55 \& 72$ \\
\hline CARRAGENINA & 407 & 2016 & $1000 \mathrm{mg} / \mathrm{kg}$ & $379 \& 381$ \\
\hline CITRATO DÍACIDO DE POTASIO & 332(i) & 2014 & BPF & $55 \& 72$ \\
\hline CITRATO DÍACIDO DE SODIO & $331(\mathrm{i})$ & 2014 & BPF & $55 \& 72$ \\
\hline CITRATO TRIPOTÁSICO & 332(ii) & 2014 & BPF & $55 \& 72$ \\
\hline CITRATO TRISÓDICO & 331 (iii) & 2014 & BPF & $55 \& 72$ \\
\hline DIÓXIDO DE CARBONO & 290 & 2015 & BPF & 59 \\
\hline ÉSTERES DE ASCORBILO & 304,305 & 2019 & $10 \mathrm{mg} / \mathrm{kg}$ & $72 \& 187$ \\
\hline FOSFATO DE DIALMIDÓN & 1412 & 2014 & $5000 \mathrm{mg} / \mathrm{kg}$ & $72,150 \& 292$ \\
\hline FOSFATO DE DIALMIDÓN ACETILADO & 1414 & 2014 & $5000 \mathrm{mg} / \mathrm{kg}$ & $72,150 \& 292$ \\
\hline FOSFATO DE DIALMIDÓN FOSFATADO & 1413 & 2014 & $5000 \mathrm{mg} / \mathrm{kg}$ & $72,150 \& 292$ \\
\hline GOMA DE SEMILLAS DE ALGARROBO & 410 & 2014 & $1000 \mathrm{mg} / \mathrm{kg}$ & 72 \\
\hline
\end{tabular}


No. de Categoría de alimento 13.1.3 Fórmulas (preparados) para usos médicos especiales destinados a los lactantes

\begin{tabular}{|c|c|c|c|c|}
\hline Aditivo & $\operatorname{Sin}$ & Año Adoptada & Dosis máxima & Notas \\
\hline GOMA GUAR & 412 & 2014 & $1000 \mathrm{mg} / \mathrm{kg}$ & $14 \& 72$ \\
\hline HIDRÓXIDO DE CALCIO & 526 & 2013 & $2000 \mathrm{mg} / \mathrm{kg}$ & $55 \& 72$ \\
\hline HIDRÓXIDO DE POTASIO & 525 & 2013 & $2000 \mathrm{mg} / \mathrm{kg}$ & $55 \& 72$ \\
\hline HIDRÓXIDO DE SODIO & 524 & 2013 & $2000 \mathrm{mg} / \mathrm{kg}$ & $55 \& 72$ \\
\hline LECITINA & 322(i) & 2014 & $5000 \mathrm{mg} / \mathrm{kg}$ & 72 \\
\hline $\begin{array}{l}\text { MONOGLICÉRIDOS Y DIGLICÉRIDOS DE } \\
\text { ÁCIDOS GRASOS }\end{array}$ & 471 & 2014 & $4000 \mathrm{mg} / \mathrm{kg}$ & 72 \\
\hline NITRÓGENO & 941 & 2015 & BPF & 59 \\
\hline $\begin{array}{l}\text { OCTENILSUCCIONATO SÓDICO DE } \\
\text { ALMIDÓN }\end{array}$ & 1450 & 2016 & $20000 \mathrm{mg} / \mathrm{kg}$ & $376 \& 381$ \\
\hline TOCOFEROLES & $307 a, b, c$ & 2018 & $10 \mathrm{mg} / \mathrm{kg}$ & 72,416 \\
\hline
\end{tabular}

No. de Categoría de alimento 13.2

Alimentos complementarios para lactantes y niños pequeños

\begin{tabular}{|c|c|c|c|c|}
\hline Aditivo & SIN & Año Adoptada & Dosis máxima & Notas \\
\hline ACETATO DE ALMIDÓN & 1420 & 2014 & $50000 \mathrm{mg} / \mathrm{kg}$ & $239 \& 269$ \\
\hline ACETATO DE CALCIO & 263 & 2013 & BPF & 239 \\
\hline ACETATO DE POTASIO & 261(i) & 2013 & BPF & 239 \\
\hline ACETATO DE SODIO & 262(i) & 2015 & BPF & $239,319 \& 320$ \\
\hline ÁCIDO ACÉTICO GLACIAL & 260 & 2013 & $5000 \mathrm{mg} / \mathrm{kg}$ & 238 \\
\hline ÁCIDO ASCÓRBICO, L- & 300 & 2013 & $500 \mathrm{mg} / \mathrm{kg}$ & 242 \\
\hline ÁCIDO CÍTRICO & 330 & 2013 & $5000 \mathrm{mg} / \mathrm{kg}$ & 238 \\
\hline ÁCIDO CLORHÍDRICO & 507 & 2013 & BPF & 239 \\
\hline ÁCIDO LÁCTICO, L-, D- y DL- & 270 & 2013 & $2000 \mathrm{mg} / \mathrm{kg}$ & $83 \& 238$ \\
\hline ÁCIDO MÁLICO, DL- & 296 & 2013 & BPF & 239 \\
\hline ADIPATO DE DIALMIDÓN ACETILADO & 1422 & 2014 & $50000 \mathrm{mg} / \mathrm{kg}$ & $269 \& 270$ \\
\hline ALMIDÓN ACETILADO OXIDADO & 1451 & 2014 & $50000 \mathrm{mg} / \mathrm{kg}$ & $239 \& 269$ \\
\hline ALMIDÓN HIDROXIPROPÍLICO & 1440 & 2014 & $60000 \mathrm{mg} / \mathrm{kg}$ & $237 \& 276$ \\
\hline ALMIDÓN OXIDADO & 1404 & 2014 & $50000 \mathrm{mg} / \mathrm{kg}$ & $239 \& 269$ \\
\hline ASCORBATO DE CALCIO & 302 & 2015 & $200 \mathrm{mg} / \mathrm{kg}$ & $239 \& 317$ \\
\hline ASCORBATO DE SODIO & 301 & 2015 & $500 \mathrm{mg} / \mathrm{kg}$ & $317,319 \& 320$ \\
\hline CARBONATO ÁCIDO DE AMONIO & 503 (ii) & 2013 & BPF & $239 \& 248$ \\
\hline CARBONATO ÁCIDO DE POTASIO & 501 (ii) & 2013 & BPF & \\
\hline CARBONATO ÁCIDO DE SODIO & 500 (ii) & 2015 & BPF & $240,319 \& 320$ \\
\hline CARBONATO DE AMONIO & $503(i)$ & 2013 & BPF & $239 \& 248$ \\
\hline CARBONATO DE CALCIO & $170(\mathrm{i})$ & 2013 & BPF & \\
\hline CARBONATO DE SODIO & $500(i)$ & 2015 & BPF & $\begin{array}{c}240,243,295,319 \\
\& 320\end{array}$ \\
\hline CITRATO DÍACIDO DE POTASIO & 332(i) & 2013 & BPF & 239 \\
\hline CITRATO DÍACIDO DE SODIO & $331(\mathrm{i})$ & 2015 & $5000 \mathrm{mg} / \mathrm{kg}$ & $\begin{array}{c}238,240,319 \& \\
320\end{array}$ \\
\hline
\end{tabular}


No. de Categoría de alimento 13.2

Alimentos complementarios para lactantes y niños pequeños

\begin{tabular}{|c|c|c|c|c|}
\hline Aditivo & SIN & Año Adoptada & Dosis máxima & Notas \\
\hline CITRATO TRICÁLCICO & 333(iii) & 2015 & BPF & 239 \\
\hline CITRATO TRIPOTÁSICO & 332(ii) & 2013 & BPF & 239 \\
\hline CITRATO TRISÓDICO & 331(iii) & 2015 & $5000 \mathrm{mg} / \mathrm{kg}$ & $\begin{array}{c}238,240,319 \& \\
320\end{array}$ \\
\hline DIÓXIDO DE CARBONO & 290 & 2015 & BPF & 59 \\
\hline DIÓXIDO DE SILICIO AMORFO & 551 & 2015 & $2000 \mathrm{mg} / \mathrm{kg}$ & $65 \& 318$ \\
\hline $\begin{array}{l}\text { ÉSTERES ACÉTICOS Y DE ÁCIDOS } \\
\text { GRASOS DE GLICEROL }\end{array}$ & $472 \mathrm{a}$ & 2014 & $5000 \mathrm{mg} / \mathrm{kg}$ & $239 \& 268$ \\
\hline $\begin{array}{l}\text { ÉSTERES CÍTRICOS Y DE ÁCIDOS } \\
\text { GRASOS DE GLICEROL }\end{array}$ & $472 c$ & 2014 & $5000 \mathrm{mg} / \mathrm{kg}$ & $239 \& 268$ \\
\hline ÉSTERES DE ASCORBILO & 304,305 & 2018 & $200 \mathrm{mg} / \mathrm{kg}$ & 15,187 \\
\hline $\begin{array}{l}\text { ÉSTERES LÁCTICOS Y DE ÁCIDOS } \\
\text { GRASOS DE GLICEROL }\end{array}$ & $472 b$ & 2014 & $5000 \mathrm{mg} / \mathrm{kg}$ & $239 \& 268$ \\
\hline FOSFATO DE DIALMIDÓN & 1412 & 2014 & $50000 \mathrm{mg} / \mathrm{kg}$ & $269 \& 270$ \\
\hline FOSFATO DE DIALMIDÓN ACETILADO & 1414 & 2014 & $50000 \mathrm{mg} / \mathrm{kg}$ & $269 \& 270$ \\
\hline FOSFATO DE DIALMIDÓN FOSFATADO & 1413 & 2014 & $50000 \mathrm{mg} / \mathrm{kg}$ & $269 \& 270$ \\
\hline FOSFATO DE MONOALMIDÓN & 1410 & 2014 & $50000 \mathrm{mg} / \mathrm{kg}$ & $239 \& 269$ \\
\hline FOSFATOS & $\begin{array}{l}\text { 338; 339(i)-(iii); } \\
\text { 340(i)-(iii); 341(i)- } \\
\text { (iii); 342(i)-(ii); } \\
\text { 343(i)-(iii); 450(i)- } \\
\text { (iii),(v)-(vii), (ix); } \\
\text { 451(i),(ii); 452(i)- } \\
\text { (v); } 542\end{array}$ & 2012 & $4400 \mathrm{mg} / \mathrm{kg}$ & $33 \& 230$ \\
\hline GLUCONO-DELTA-LACTONA & 575 & 2013 & BPF & 239 \\
\hline GOMA ARÁBIGA (GOMA DE ACACIA) & 414 & 2014 & $10000 \mathrm{mg} / \mathrm{kg}$ & $239 \& 273$ \\
\hline GOMA DE SEMILLAS DE ALGARROBO & 410 & 2014 & $2000 \mathrm{mg} / \mathrm{kg}$ & $271 \& 272$ \\
\hline GOMA GUAR & 412 & 2014 & $2000 \mathrm{mg} / \mathrm{kg}$ & $271 \& 272$ \\
\hline GOMA XANTANA & 415 & 2014 & $10000 \mathrm{mg} / \mathrm{kg}$ & $239 \& 273$ \\
\hline HIDRÓXIDO DE CALCIO & 526 & 2013 & BPF & 239 \\
\hline HIDRÓXIDO DE POTASIO & 525 & 2013 & BPF & 239 \\
\hline HIDRÓXIDO DE SODIO & 524 & 2015 & BPF & $239,319 \& 320$ \\
\hline LACTATO DE CALCIO & 327 & 2013 & BPF & $83 \& 239$ \\
\hline LACTATO DE POTASIO & 326 & 2013 & BPF & $83 \& 239$ \\
\hline LACTATO DE SODIO & 325 & 2015 & BPF & $83,239,319 \& 320$ \\
\hline LECITINA & $322(i)$ & 2014 & $5000 \mathrm{mg} / \mathrm{kg}$ & $271 \& 274$ \\
\hline $\begin{array}{l}\text { MONOGLICÉRIDOS Y DIGLICÉRIDOS DE } \\
\text { ÁCIDOS GRASOS }\end{array}$ & 471 & 2014 & $5000 \mathrm{mg} / \mathrm{kg}$ & $268 \& 275$ \\
\hline NITRÓGENO & 941 & 2015 & BPF & 59 \\
\hline $\begin{array}{l}\text { OCTENILSUCCIONATO SÓDICO DE } \\
\text { ALMIDÓN }\end{array}$ & 1450 & 2014 & $50000 \mathrm{mg} / \mathrm{kg}$ & $239 \& 269$ \\
\hline PECTINAS & 440 & 2014 & $10000 \mathrm{mg} / \mathrm{kg}$ & $273,282 \& 283$ \\
\hline TARTRATOS & 334, 335(ii), 337 & 2018 & $5000 \mathrm{mg} / \mathrm{kg}$ & $45,364, X S 73,428$ \\
\hline TOCOFEROLES & $307 a, b, c$ & 2018 & $300 \mathrm{mg} / \mathrm{kg}$ & 15 \\
\hline
\end{tabular}


Alimentos dietéticos para usos médicos especiales (excluidos los productos de la categoría de alimentos 13.1)

\begin{tabular}{|c|c|c|c|c|}
\hline Aditivo & $\sin$ & Año Adoptada & Dosis máxima & Notas \\
\hline ACESULFAME DE POTASIO & 950 & 2007 & $500 \mathrm{mg} / \mathrm{kg}$ & 188 \\
\hline ALGINATO DE PROPILENGLICOL & 405 & 2018 & $1200 \mathrm{mg} / \mathrm{kg}$ & \\
\hline AMARILLO OCASO FCF & 110 & 2008 & $50 \mathrm{mg} / \mathrm{kg}$ & \\
\hline ASPARTAMO & 951 & 2007 & $1000 \mathrm{mg} / \mathrm{kg}$ & 191 \\
\hline AZUL BRILLANTE FCF & 133 & 2005 & $50 \mathrm{mg} / \mathrm{kg}$ & \\
\hline BENZOATOS & $210-213$ & 2003 & $1500 \mathrm{mg} / \mathrm{kg}$ & 13 \\
\hline $\begin{array}{l}\text { CARAMELO III - CARAMELO AL } \\
\text { AMONÍACO }\end{array}$ & $150 c$ & 2010 & $20000 \mathrm{mg} / \mathrm{kg}$ & \\
\hline $\begin{array}{l}\text { CARAMELO IV - CARAMELO AL SULFITO } \\
\text { AMÓNICO }\end{array}$ & $150 d$ & 2009 & $20000 \mathrm{mg} / \mathrm{kg}$ & \\
\hline CARMINES & 120 & 2005 & $50 \mathrm{mg} / \mathrm{kg}$ & 178 \\
\hline CAROTENOIDES & $160 a(i), a(i i i), e, f$ & 2009 & $50 \mathrm{mg} / \mathrm{kg}$ & \\
\hline CAROTENOS, BETA-, VEGETALES & $160 a(i i)$ & 2005 & $600 \mathrm{mg} / \mathrm{kg}$ & \\
\hline CICLAMATOS & 952(i), (ii), (iv) & 2007 & $400 \mathrm{mg} / \mathrm{kg}$ & 17 \\
\hline DIMETILPOLISILOXANO & $900 a$ & 2004 & $50 \mathrm{mg} / \mathrm{kg}$ & \\
\hline ESTEAROIL LACTILATOS & 481(i), 482(i) & 2018 & $2000 \mathrm{mg} / \mathrm{kg}$ & \\
\hline $\begin{array}{l}\text { ÉSTERES DE PROPILENGLICOL DE } \\
\text { ÁCIDOS GRASOS }\end{array}$ & 477 & 2001 & $5000 \mathrm{mg} / \mathrm{kg}$ & \\
\hline $\begin{array}{l}\text { ÉSTERES DE SORBITÁN DE ÁCIDOS } \\
\text { GRASOS }\end{array}$ & $491-495$ & 2018 & $1000 \mathrm{mg} / \mathrm{kg}$ & \\
\hline $\begin{array}{l}\text { ÉSTERES DIACETILTARTÁRICOS Y DE } \\
\text { ÁCIDOS GRASOS DE GLICEROL }\end{array}$ & $472 e$ & 2005 & $5000 \mathrm{mg} / \mathrm{kg}$ & \\
\hline $\begin{array}{l}\text { ÉSTERES POLIGLICÉRIDOS DE ÁCIDOS } \\
\text { GRASOS }\end{array}$ & 475 & 2018 & $1000 \mathrm{mg} / \mathrm{kg}$ & \\
\hline EXTRACTO DE PIEL DE UVA & 163(ii) & 2009 & $250 \mathrm{mg} / \mathrm{kg}$ & 181 \\
\hline FOSFATOS & $\begin{array}{l}\text { 338; 339(i)-(iii); } \\
340 \text { (i)-(iii); } 341 \text { (i)- } \\
\text { (iii); 342(i)-(ii); } \\
343 \text { (i)-(iii); 450(i)- } \\
\text { (iii),(v)-(vii), (ix); } \\
\text { 451(i),(ii); 452(i)- } \\
\text { (v); } 542\end{array}$ & 2009 & $2200 \mathrm{mg} / \mathrm{kg}$ & 33 \\
\hline GLICÓSIDOS DE ESTEVIOL & $960 a, 960 b(i)$ & 2011 & $350 \mathrm{mg} / \mathrm{kg}$ & 26 \\
\hline INDIGOTINA (CARMÍN DE ÍNDIGO) & 132 & 2009 & $50 \mathrm{mg} / \mathrm{kg}$ & \\
\hline NEOTAMO & 961 & 2007 & $33 \mathrm{mg} / \mathrm{kg}$ & \\
\hline POLISORBATOS & $432-436$ & 2005 & $1000 \mathrm{mg} / \mathrm{kg}$ & \\
\hline PONCEAU 4R (ROJO DE COCHINILLA A) & 124 & 2008 & $50 \mathrm{mg} / \mathrm{kg}$ & \\
\hline RIBOFLAVINAS & 101(i),(ii), (iii) & 2005 & $300 \mathrm{mg} / \mathrm{kg}$ & \\
\hline ROJO ALLURA AC & 129 & 2009 & $50 \mathrm{mg} / \mathrm{kg}$ & \\
\hline SACARINAS & 954(i)-(iv) & 2007 & $200 \mathrm{mg} / \mathrm{kg}$ & \\
\hline SAL DE ASPARTAMO Y ACESULFAMO & 962 & 2012 & $500 \mathrm{mg} / \mathrm{kg}$ & 113 \\
\hline SORBATOS & $200,202,203$ & 2009 & $1500 \mathrm{mg} / \mathrm{kg}$ & 42 \\
\hline
\end{tabular}


Alimentos dietéticos para usos médicos especiales (excluidos los productos de la categoría de alimentos 13.1)

\begin{tabular}{|c|c|c|c|c|}
\hline Aditivo & SIN & Año Adoptada & Dosis máxima & Notas \\
\hline $\begin{array}{l}\text { SUCRALOSA } \\
\text { (TRICLOROGALACTOSACAROSA) }\end{array}$ & 955 & 2007 & $400 \mathrm{mg} / \mathrm{kg}$ & \\
\hline SUCROÉSTERES DE ÁCIDOS GRASOS & 473 & 2018 & $5000 \mathrm{mg} / \mathrm{kg}$ & 348 \\
\hline SUCROGLICÉRIDOS & 474 & 2018 & $5000 \mathrm{mg} / \mathrm{kg}$ & 348 \\
\hline $\begin{array}{l}\text { SUCROSE OLIGOESTERS, TYPE I AND } \\
\text { TYPE II }\end{array}$ & $473 a$ & 2018 & $5000 \mathrm{mg} / \mathrm{kg}$ & 348 \\
\hline TOCOFEROLES & $307 a, b, c$ & 2018 & 30 mg/kg & \\
\hline
\end{tabular}

\begin{tabular}{|c|c|c|c|c|}
\hline \multicolumn{2}{|c|}{ No. de Categoría de alimento 13.4} & \multicolumn{3}{|c|}{$\begin{array}{l}\text { Preparados dietéticos para } \\
\text { adelgazamiento y control del peso }\end{array}$} \\
\hline Aditivo & SIN & Año Adoptada & Dosis máxima & Notas \\
\hline ACESULFAME DE POTASIO & 950 & 2007 & $450 \mathrm{mg} / \mathrm{kg}$ & 188 \\
\hline ALGINATO DE PROPILENGLICOL & 405 & 2018 & $1200 \mathrm{mg} / \mathrm{kg}$ & \\
\hline AMARILLO OCASO FCF & 110 & 2008 & $50 \mathrm{mg} / \mathrm{kg}$ & \\
\hline ASPARTAMO & 951 & 2007 & $800 \mathrm{mg} / \mathrm{kg}$ & 191 \\
\hline AZUL BRILLANTE FCF & 133 & 2005 & $50 \mathrm{mg} / \mathrm{kg}$ & \\
\hline BENZOATOS & $210-213$ & 2003 & $1500 \mathrm{mg} / \mathrm{kg}$ & 13 \\
\hline $\begin{array}{l}\text { CARAMELO III - CARAMELO AL } \\
\text { AMONÍACO }\end{array}$ & $150 c$ & 2010 & $20000 \mathrm{mg} / \mathrm{kg}$ & \\
\hline $\begin{array}{l}\text { CARAMELO IV - CARAMELO AL SULFITO } \\
\text { AMÓNICO }\end{array}$ & $150 d$ & 2009 & $20000 \mathrm{mg} / \mathrm{kg}$ & \\
\hline CARMINES & 120 & 2005 & $50 \mathrm{mg} / \mathrm{kg}$ & 178 \\
\hline CAROTENOIDES & $160 a(i), a(i i i), e, f$ & 2009 & $50 \mathrm{mg} / \mathrm{kg}$ & \\
\hline CAROTENOS, BETA-, VEGETALES & 160a(ii) & 2005 & $600 \mathrm{mg} / \mathrm{kg}$ & \\
\hline CICLAMATOS & 952(i), (ii), (iv) & 2007 & $400 \mathrm{mg} / \mathrm{kg}$ & 17 \\
\hline DIMETILPOLISILOXANO & $900 a$ & 2004 & $50 \mathrm{mg} / \mathrm{kg}$ & \\
\hline ESTEAROIL LACTILATOS & 481(i), 482(i) & 2018 & $2000 \mathrm{mg} / \mathrm{kg}$ & \\
\hline ÉSTERES DE ASCORBILO & 304,305 & 2005 & $500 \mathrm{mg} / \mathrm{kg}$ & 10 \\
\hline $\begin{array}{l}\text { ÉSTERES DE PROPILENGLICOL DE } \\
\text { ÁCIDOS GRASOS }\end{array}$ & 477 & 2001 & $5000 \mathrm{mg} / \mathrm{kg}$ & \\
\hline $\begin{array}{l}\text { ÉSTERES DE SORBITÁN DE ÁCIDOS } \\
\text { GRASOS }\end{array}$ & $491-495$ & 2018 & $1000 \mathrm{mg} / \mathrm{kg}$ & \\
\hline $\begin{array}{l}\text { ÉSTERES DIACETILTARTÁRICOS Y DE } \\
\text { ÁCIDOS GRASOS DE GLICEROL }\end{array}$ & $472 e$ & 2005 & $5000 \mathrm{mg} / \mathrm{kg}$ & \\
\hline $\begin{array}{l}\text { ÉSTERES POLIGLICÉRIDOS DE ÁCIDOS } \\
\text { GRASOS }\end{array}$ & 475 & 2018 & $1000 \mathrm{mg} / \mathrm{kg}$ & \\
\hline EXTRACTO DE PIEL DE UVA & 163(ii) & 2009 & $250 \mathrm{mg} / \mathrm{kg}$ & 181 \\
\hline FOSFATOS & $\begin{array}{l}\text { 338; 339(i)-(iii); } \\
340(\mathrm{i})-(\mathrm{iii)} ; 341 \text { (i)- } \\
\text { (iii); } 342(\mathrm{i}) \text {-(ii); } \\
343(\mathrm{i})-(\mathrm{iii)} ; 450(\mathrm{i})- \\
\text { (iii),(v)-(vii), (ix); } \\
451 \text { (i),(ii); } 452(\mathrm{i})- \\
\text { (v); } 542\end{array}$ & 2009 & $2200 \mathrm{mg} / \mathrm{kg}$ & 33 \\
\hline
\end{tabular}




\begin{tabular}{|c|c|c|c|c|}
\hline \multirow{2}{*}{$\begin{array}{l}\text { No. de Categoría de alimento } \\
\text { Aditivo }\end{array}$} & \multicolumn{4}{|c|}{$\begin{array}{l}\text { Preparados dietéticos para } \\
\text { adelgazamiento y control del peso }\end{array}$} \\
\hline & $\sin$ & Año Adoptada & Dosis máxima & Notas \\
\hline GLICÓSIDOS DE ESTEVIOL & $960 a, 960 b(i)$ & 2011 & $270 \mathrm{mg} / \mathrm{kg}$ & 26 \\
\hline INDIGOTINA (CARMÍN DE ÍNDIGO) & 132 & 2009 & $50 \mathrm{mg} / \mathrm{kg}$ & \\
\hline NEOTAMO & 961 & 2007 & $33 \mathrm{mg} / \mathrm{kg}$ & \\
\hline POLISORBATOS & $432-436$ & 2005 & $1000 \mathrm{mg} / \mathrm{kg}$ & \\
\hline PONCEAU 4R (ROJO DE COCHINILLA A) & 124 & 2008 & $50 \mathrm{mg} / \mathrm{kg}$ & \\
\hline RIBOFLAVINAS & 101(i),(ii), (iii) & 2005 & $300 \mathrm{mg} / \mathrm{kg}$ & \\
\hline ROJO ALLURA AC & 129 & 2009 & $50 \mathrm{mg} / \mathrm{kg}$ & \\
\hline SACARINAS & 954(i)-(iv) & 2007 & $300 \mathrm{mg} / \mathrm{kg}$ & \\
\hline SAL DE ASPARTAMO Y ACESULFAMO & 962 & 2009 & $450 \mathrm{mg} / \mathrm{kg}$ & 113 \\
\hline SORBATOS & $200,202,203$ & 2009 & $1500 \mathrm{mg} / \mathrm{kg}$ & 42 \\
\hline $\begin{array}{l}\text { SUCRALOSA } \\
\text { (TRICLOROGALACTOSACAROSA) }\end{array}$ & 955 & 2007 & $320 \mathrm{mg} / \mathrm{kg}$ & \\
\hline SUCROÉSTERES DE ÁCIDOS GRASOS & 473 & 2018 & $5000 \mathrm{mg} / \mathrm{kg}$ & 348 \\
\hline SUCROGLICÉRIDOS & 474 & 2018 & $5000 \mathrm{mg} / \mathrm{kg}$ & 348 \\
\hline $\begin{array}{l}\text { SUCROSE OLIGOESTERS, TYPE I AND } \\
\text { TYPE II }\end{array}$ & $473 a$ & 2018 & $5000 \mathrm{mg} / \mathrm{kg}$ & 348 \\
\hline TOCOFEROLES & $307 a, b, c$ & 2018 & $300 \mathrm{mg} / \mathrm{kg}$ & \\
\hline
\end{tabular}

\begin{tabular}{|c|c|c|c|c|}
\hline No. de Categoría de alimento & 13.5 & $\begin{array}{l}\text { nentos die } \\
\text { nplemento } \\
\text { téticos), ex } \\
\text { categorías } \\
3.6\end{array}$ & $\begin{array}{l}\text { cos (p. ej. Io } \\
\text { imenticios } \\
\text { idos los ind } \\
\text { alimentos }\end{array}$ & $\begin{array}{l}\text { usos } \\
\text { os en } \\
\text { a } 13.4\end{array}$ \\
\hline Aditivo & SIN & Año Adoptada & Dosis máxima & Notas \\
\hline ACESULFAME DE POTASIO & 950 & 2007 & $450 \mathrm{mg} / \mathrm{kg}$ & 188 \\
\hline ALITAME & 956 & 2007 & $300 \mathrm{mg} / \mathrm{kg}$ & \\
\hline AMARILLO OCASO FCF & 110 & 2008 & $300 \mathrm{mg} / \mathrm{kg}$ & \\
\hline ASPARTAMO & 951 & 2007 & $1000 \mathrm{mg} / \mathrm{kg}$ & 191 \\
\hline AZUL BRILLANTE FCF & 133 & 2005 & $300 \mathrm{mg} / \mathrm{kg}$ & \\
\hline BENZOATOS & $210-213$ & 2003 & $2000 \mathrm{mg} / \mathrm{kg}$ & 13 \\
\hline $\begin{array}{l}\text { CARAMELO III - CARAMELO AL } \\
\text { AMONÍACO }\end{array}$ & $150 \mathrm{c}$ & 2010 & $20000 \mathrm{mg} / \mathrm{kg}$ & \\
\hline $\begin{array}{l}\text { CARAMELO IV - CARAMELO AL SULFITO } \\
\text { AMÓNICO }\end{array}$ & $150 d$ & 2009 & $20000 \mathrm{mg} / \mathrm{kg}$ & \\
\hline CARMINES & 120 & 2005 & $300 \mathrm{mg} / \mathrm{kg}$ & 178 \\
\hline CAROTENOIDES & $160 a(i), a(i i i), e, f$ & 2009 & $300 \mathrm{mg} / \mathrm{kg}$ & \\
\hline CAROTENOS, BETA-, VEGETALES & 160a(ii) & 2005 & $600 \mathrm{mg} / \mathrm{kg}$ & \\
\hline CICLAMATOS & 952(i), (ii), (iv) & 2007 & $400 \mathrm{mg} / \mathrm{kg}$ & 17 \\
\hline DIMETILPOLISILOXANO & $900 a$ & 2004 & $50 \mathrm{mg} / \mathrm{kg}$ & \\
\hline ÉSTERES DE ASCORBILO & 304,305 & 2009 & $500 \mathrm{mg} / \mathrm{kg}$ & 10 \\
\hline $\begin{array}{l}\text { ÉSTERES DE SORBITÁN DE ÁCIDOS } \\
\text { GRASOS }\end{array}$ & $491-495$ & 2018 & $5000 \mathrm{mg} / \mathrm{kg}$ & \\
\hline
\end{tabular}




\begin{tabular}{|c|c|c|c|c|}
\hline No. de Categoría de alimento & 3.5 & $\begin{array}{l}\text { nentos die } \\
\text { nplemento } \\
\text { téticos), ex } \\
\text { categorías } \\
3.6\end{array}$ & $\begin{array}{l}\text { os (p. ej. lo } \\
\text { menticios p } \\
\text { dos los ind } \\
\text { alimentos } 1\end{array}$ & $\begin{array}{l}\text { ara usos } \\
\text { ados en } \\
.1 \text { a } 13.4\end{array}$ \\
\hline Aditivo & $\sin$ & Año Adoptada & Dosis máxima & Notas \\
\hline $\begin{array}{l}\text { ÉSTERES DIACETILTARTÁRICOS Y DE } \\
\text { ÁCIDOS GRASOS DE GLICEROL }\end{array}$ & $472 e$ & 2005 & $5000 \mathrm{mg} / \mathrm{kg}$ & \\
\hline EXTRACTO DE PIEL DE UVA & 163(ii) & 2009 & $250 \mathrm{mg} / \mathrm{kg}$ & 181 \\
\hline FOSFATOS & $\begin{array}{l}\text { 338; 339(i)-(iii); } \\
340(\mathrm{i})-(\mathrm{iii}) ; 341 \text { (i)- } \\
\text { (iii); 342(i)-(ii); } \\
343(\mathrm{i})-(\mathrm{iii)} ; 450(\mathrm{i})- \\
\text { (iii),(v)-(vii), (ix); } \\
\text { 451(i),(ii); 452(i)- } \\
\text { (v); } 542\end{array}$ & 2009 & $2200 \mathrm{mg} / \mathrm{kg}$ & 33 \\
\hline GLICÓSIDOS DE ESTEVIOL & $960 a, 960 b(i)$ & 2011 & $660 \mathrm{mg} / \mathrm{kg}$ & $26,198 \& 294$ \\
\hline INDIGOTINA (CARMÍN DE ÍNDIGO) & 132 & 2009 & $300 \mathrm{mg} / \mathrm{kg}$ & \\
\hline NEOTAMO & 961 & 2007 & $65 \mathrm{mg} / \mathrm{kg}$ & \\
\hline PONCEAU 4R (ROJO DE COCHINILLA A) & 124 & 2008 & $300 \mathrm{mg} / \mathrm{kg}$ & \\
\hline RIBOFLAVINAS & 101(i),(ii), (iii) & 2005 & $300 \mathrm{mg} / \mathrm{kg}$ & \\
\hline ROJO ALLURA AC & 129 & 2009 & $300 \mathrm{mg} / \mathrm{kg}$ & \\
\hline SACARINAS & 954(i)-(iv) & 2007 & $200 \mathrm{mg} / \mathrm{kg}$ & \\
\hline SAL DE ASPARTAMO Y ACESULFAMO & 962 & 2009 & $450 \mathrm{mg} / \mathrm{kg}$ & 113 \\
\hline SORBATOS & $200,202,203$ & 2012 & $1500 \mathrm{mg} / \mathrm{kg}$ & 42 \\
\hline $\begin{array}{l}\text { SUCRALOSA } \\
\text { (TRICLOROGALACTOSACAROSA) }\end{array}$ & 955 & 2007 & $400 \mathrm{mg} / \mathrm{kg}$ & \\
\hline TOCOFEROLES & $307 a, b, c$ & 2018 & 300 mg/kg & \\
\hline
\end{tabular}

No. de Categoría de alimento 13.6

Complementos alimenticios

\begin{tabular}{|c|c|c|c|c|}
\hline Aditivo & SIN & Año Adoptada & Dosis máxima & Notas \\
\hline ACEITE DE RICINO & 1503 & 2007 & $1000 \mathrm{mg} / \mathrm{kg}$ & \\
\hline ACESULFAME DE POTASIO & 950 & 2007 & $2000 \mathrm{mg} / \mathrm{kg}$ & 188 \\
\hline ALCOHOL POLIVINÍLICO & 1203 & 2007 & $45000 \mathrm{mg} / \mathrm{kg}$ & \\
\hline ALGINATO DE PROPILENGLICOL & 405 & 2018 & $1000 \mathrm{mg} / \mathrm{kg}$ & \\
\hline AMARILLO OCASO FCF & 110 & 2008 & $300 \mathrm{mg} / \mathrm{kg}$ & \\
\hline ASPARTAMO & 951 & 2007 & $5500 \mathrm{mg} / \mathrm{kg}$ & 191 \\
\hline AZUL BRILLANTE FCF & 133 & 2005 & 300 mg/kg & \\
\hline BENZOATOS & $210-213$ & 2003 & $2000 \mathrm{mg} / \mathrm{kg}$ & 13 \\
\hline BUTILHIDROXIANISOL & 320 & 2006 & $400 \mathrm{mg} / \mathrm{kg}$ & $15 \& 196$ \\
\hline BUTILHIDROXITOLUENO & 321 & 2006 & $400 \mathrm{mg} / \mathrm{kg}$ & $15 \& 196$ \\
\hline $\begin{array}{l}\text { CARAMELO III - CARAMELO AL } \\
\text { AMONÍACO }\end{array}$ & $150 \mathrm{c}$ & 2010 & 20000 mg/kg & \\
\hline $\begin{array}{l}\text { CARAMELO IV - CARAMELO AL SULFITO } \\
\text { AMÓNICO }\end{array}$ & $150 d$ & 2009 & $20000 \mathrm{mg} / \mathrm{kg}$ & \\
\hline CARMINES & 120 & 2005 & $300 \mathrm{mg} / \mathrm{kg}$ & 178 \\
\hline CAROTENOIDES & $160 a(i), a(i i i), e, f$ & 2009 & $300 \mathrm{mg} / \mathrm{kg}$ & \\
\hline
\end{tabular}




\begin{tabular}{|c|c|c|c|c|}
\hline No. de Categoría de alimento & 13.6 & mplementc & alimenticios & \\
\hline Aditivo & $\operatorname{SiN}$ & Año Adoptada & Dosis máxima & Notas \\
\hline CAROTENOS, BETA-, VEGETALES & $160 a(i i)$ & 2005 & $600 \mathrm{mg} / \mathrm{kg}$ & \\
\hline CERA CANDELILLA & 902 & 2001 & BPF & 3 \\
\hline CERA CARNAUBA & 903 & 2006 & $5000 \mathrm{mg} / \mathrm{kg}$ & 3 \\
\hline CERA DE ABEJAS & 901 & 2001 & BPF & 3 \\
\hline CICLAMATOS & 952(i), (ii), (iv) & 2007 & $1250 \mathrm{mg} / \mathrm{kg}$ & 17 \\
\hline $\begin{array}{l}\text { CLOROFILAS Y CLOROFILINAS, } \\
\text { COMPLEJOS CUPRICOS }\end{array}$ & 141 (i),(ii) & 2009 & $500 \mathrm{mg} / \mathrm{kg}$ & 3 \\
\hline $\begin{array}{l}\text { COPOLÍMERO CON INJERTO DE } \\
\text { POLIVINILALCOHOL (PVA)- } \\
\text { POLIETILENGLICOL (PEG) }\end{array}$ & 1209 & 2018 & $100000 \mathrm{mg} / \mathrm{kg}$ & 417 \\
\hline DIMETILPOLISILOXANO & $900 a$ & 2004 & $50 \mathrm{mg} / \mathrm{kg}$ & \\
\hline ÉSTERES DE ASCORBILO & 304,305 & 2003 & $500 \mathrm{mg} / \mathrm{kg}$ & 10 \\
\hline $\begin{array}{l}\text { ÉSTERES DE SORBITÁN DE ÁCIDOS } \\
\text { GRASOS }\end{array}$ & $491-495$ & 2018 & $10000 \mathrm{mg} / \mathrm{kg}$ & 364 \\
\hline $\begin{array}{l}\text { ÉSTERES DIACETILTARTÁRICOS Y DE } \\
\text { ÁCIDOS GRASOS DE GLICEROL }\end{array}$ & $472 e$ & 2005 & $5000 \mathrm{mg} / \mathrm{kg}$ & \\
\hline $\begin{array}{l}\text { ÉSTERES POLIGLICÉRIDOS DE ÁCIDOS } \\
\text { GRASOS }\end{array}$ & 475 & 2018 & $18000 \mathrm{mg} / \mathrm{kg}$ & \\
\hline ETILEN DIAMINO TETRA ACETATOS & 385,386 & 2001 & $150 \mathrm{mg} / \mathrm{kg}$ & 21 \\
\hline EXTRACTO DE PIEL DE UVA & 163(ii) & 2009 & $500 \mathrm{mg} / \mathrm{kg}$ & 181 \\
\hline FOSFATOS & $\begin{array}{l}\text { 338; 339(i)-(iii); } \\
340(\text { i)-(iii); } 341 \text { (i)- } \\
\text { (iii); 342(i)-(ii); } \\
343(\text { i)-(iii); 450(i)- } \\
\text { (iii),(v)-(vii), (ix); } \\
451(\text { i),(ii); } 452(\text { i)- } \\
\text { (v); } 542\end{array}$ & 2010 & $2200 \mathrm{mg} / \mathrm{kg}$ & 33 \\
\hline GALATO DE PROPILO & 310 & 2001 & $400 \mathrm{mg} / \mathrm{kg}$ & $15 \& 196$ \\
\hline GLICÓSIDOS DE ESTEVIOL & $960 a, 960 b(i)$ & 2011 & $2500 \mathrm{mg} / \mathrm{kg}$ & $26 \& 203$ \\
\hline GOMA LACA, BLANQUEADA & 904 & 2001 & BPF & 3 \\
\hline INDIGOTINA (CARMÍN DE ÍNDIGO) & 132 & 2009 & $300 \mathrm{mg} / \mathrm{kg}$ & \\
\hline NEOTAMO & 961 & 2007 & $90 \mathrm{mg} / \mathrm{kg}$ & \\
\hline ÓXIDOS DE HIERRO & 172(i)-(iii) & 2009 & $7500 \mathrm{mg} / \mathrm{kg}$ & 3 \\
\hline POLIETILENGLICOL & 1521 & 2001 & $70000 \mathrm{mg} / \mathrm{kg}$ & \\
\hline POLISORBATOS & $432-436$ & 2007 & $25000 \mathrm{mg} / \mathrm{kg}$ & \\
\hline POLIVINILPIRROLIDONA & 1201 & 1999 & BPF & \\
\hline PONCEAU 4R (ROJO DE COCHINILLA A) & 124 & 2008 & $300 \mathrm{mg} / \mathrm{kg}$ & \\
\hline PROPILENGLICOL & 1520 & 2018 & $2000 \mathrm{mg} / \mathrm{kg}$ & 417 \\
\hline RIBOFLAVINAS & 101(i),(ii), (iii) & 2005 & $300 \mathrm{mg} / \mathrm{kg}$ & \\
\hline ROJO ALLURA AC & 129 & 2009 & $300 \mathrm{mg} / \mathrm{kg}$ & \\
\hline SACARINAS & 954(i)-(iv) & 2007 & $1200 \mathrm{mg} / \mathrm{kg}$ & \\
\hline SAL DE ASPARTAMO Y ACESULFAMO & 962 & 2012 & $2000 \mathrm{mg} / \mathrm{kg}$ & 113 \\
\hline SORBATOS & $200,202,203$ & 2012 & $2000 \mathrm{mg} / \mathrm{kg}$ & 42 \\
\hline $\begin{array}{l}\text { SUCRALOSA } \\
\text { (TRICLOROGALACTOSACAROSA) }\end{array}$ & 955 & 2007 & $2400 \mathrm{mg} / \mathrm{kg}$ & \\
\hline SUCROÉSTERES DE ÁCIDOS GRASOS & 473 & 2018 & $20000 \mathrm{mg} / \mathrm{kg}$ & 348 \\
\hline
\end{tabular}




\begin{tabular}{|c|c|c|c|c|}
\hline \multicolumn{5}{|c|}{ No. de Categoría de alimento 13.6} \\
\hline Aditivo & SIN & Año Adoptada & Dosis máxima & Notas \\
\hline SUCROGLICÉRIDOS & 474 & 2018 & 20000 mg/kg & 348 \\
\hline $\begin{array}{l}\text { SUCROSE OLIGOESTERS, TYPE I AND } \\
\text { TYPE II }\end{array}$ & $473 a$ & 2018 & $20000 \mathrm{mg} / \mathrm{kg}$ & 348 \\
\hline TARTRATOS & 334, 335(ii), 337 & 2018 & $5000 \mathrm{mg} / \mathrm{kg}$ & 45 \\
\hline TOCOFEROLES & $307 a, b, c$ & 2018 & $2000 \mathrm{mg} / \mathrm{kg}$ & 418 \\
\hline VERDE SÓLIDO FCF & 143 & 2009 & $600 \mathrm{mg} / \mathrm{kg}$ & \\
\hline
\end{tabular}

\section{No. de Categoría de alimento 14.1.1.1 Aguas minerales naturales y aguas de} manantial

\begin{tabular}{|c|c|c|c|c|}
\hline Aditivo & SIN & Año Adoptada & Dosis máxima & Notas \\
\hline DIÓXIDO DE CARBONO & 290 & 2019 & BPF & 466 \\
\hline
\end{tabular}

No. de Categoría de alimento 14.1.1.2 Aguas de mesa y gaseosas

\begin{tabular}{|c|c|c|c|c|}
\hline Aditivo & SIN & Año Adoptada & Dosis máxima & Notas \\
\hline DIÓXIDO DE CARBONO & 290 & 2019 & BPF & 466 \\
\hline
\end{tabular}

\begin{tabular}{|c|c|c|c|c|}
\hline Aditivo & SIN & Año Adoptada & Dosis máxima & Notas \\
\hline ÁCIDO ASCÓRBICO, L- & 300 & 2005 & BPF & \\
\hline ÁCIDO CÍTRICO & 330 & 2005 & $3000 \mathrm{mg} / \mathrm{kg}$ & 122 \\
\hline ÁCIDO MÁLICO, DL- & 296 & 2005 & BPF & 115 \\
\hline ASCORBATO DE CALCIO & 302 & 2005 & BPF & \\
\hline ASCORBATO DE SODIO & 301 & 2005 & BPF & \\
\hline BENZOATOS & $210-213$ & 2004 & $1000 \mathrm{mg} / \mathrm{kg}$ & $13,91 \& 122$ \\
\hline DIÓXIDO DE CARBONO & 290 & 2005 & BPF & 69 \\
\hline FOSFATOS & $\begin{array}{l}\text { 338; 339(i)-(iii); } \\
340 \text { (i)-(iii); } 341 \text { (i)- } \\
\text { (iii); 342(i)-(ii); } \\
343(\text { (i)-(iii); 450(i)- } \\
\text { (iii),(v)-(vii), (ix); } \\
451 \text { (i),(ii); } 452(\text { i)- } \\
\text { (v); } 542\end{array}$ & 2005 & $1000 \mathrm{mg} / \mathrm{kg}$ & $33,40 \& 122$ \\
\hline PECTINAS & 440 & 2005 & BPF & 35 \\
\hline SORBATOS & $200,202,203$ & 2005 & $1000 \mathrm{mg} / \mathrm{kg}$ & $42,91 \& 122$ \\
\hline SULFITOS & $220-225,539$ & 2005 & $50 \mathrm{mg} / \mathrm{kg}$ & $44 \& 122$ \\
\hline TARTRATOS & 334, 335(ii), 337 & 2005 & $4000 \mathrm{mg} / \mathrm{kg}$ & $45,128 \& 129$ \\
\hline
\end{tabular}

\section{No. de Categoría de alimento 14.1.2.2 Zumos (jugos) de hortalizas}

\begin{tabular}{lllll} 
Aditivo & SIN & Año Adoptada & Dosis máxima & Notas \\
\hline ÁCIDO ASCÓRBICO, L- & 300 & 2013 & BPF & \\
ÁCIDO CÍTRICO & 330 & 2013 & BPF & \\
ÁCIDO MÁLICO, DL- & 296 & 2013 & BPF & \\
SULFITOS & $220-225,539$ & 2006 & $50 \mathrm{mg} / \mathrm{kg}$ & $44 \& 122$
\end{tabular}




\begin{tabular}{|c|c|c|c|c|}
\hline No. de Categoría o & 14.1.2.3 & $\begin{array}{l}\text { ncentrado } \\
\text { tas }\end{array}$ & 'a zumos (j) & ugos) de \\
\hline Aditivo & SIN & Año Adoptada & Dosis máxima & Notas \\
\hline ÁCIDO ASCÓRBICO, L- & 300 & 2005 & BPF & 127 \\
\hline ÁCIDO CÍTRICO & 330 & 2005 & $3000 \mathrm{mg} / \mathrm{kg}$ & $122 \& 127$ \\
\hline ÁCIDO MÁLICO, DL- & 296 & 2005 & BPF & $115 \& 127$ \\
\hline ASCORBATO DE CALCIO & 302 & 2005 & BPF & 127 \\
\hline ASCORBATO DE SODIO & 301 & 2005 & BPF & 127 \\
\hline BENZOATOS & $210-213$ & 2004 & $1000 \mathrm{mg} / \mathrm{kg}$ & $13,91,122 \& 127$ \\
\hline DIÓXIDO DE CARBONO & 290 & 2005 & BPF & $69 \& 127$ \\
\hline FOSFATOS & $\begin{array}{l}338 ; 339(i)-(i i i) ; \\
340(\text { i)-(iii); 341(i)-- } \\
\text { (iii); 342(i)-(ii); } \\
343(\text { (i)-(iii); } 450(\text { i)- } \\
\text { (iii),(v)-(vii), (ix); } \\
451(\text { (i),(ii); } 452(\mathrm{i})- \\
\text { (v); } 542\end{array}$ & 2005 & $1000 \mathrm{mg} / \mathrm{kg}$ & $33,40,122 \& 127$ \\
\hline PECTINAS & 440 & 2005 & BPF & $35 \& 127$ \\
\hline SORBATOS & $200,202,203$ & 2005 & $1000 \mathrm{mg} / \mathrm{kg}$ & $42,91,122 \& 127$ \\
\hline SULFITOS & $220-225,539$ & 2005 & $50 \mathrm{mg} / \mathrm{kg}$ & $44,122 \& 127$ \\
\hline TARTRATOS & 334, 335(ii), 337 & 2005 & $4000 \mathrm{mg} / \mathrm{kg}$ & $45,127,128 \& 12 c$ \\
\hline
\end{tabular}

No. de Categoría de alimento 14.1.2.4 Concentrados para zumos (jugos) de hortalizas

\begin{tabular}{llccc}
\hline Aditivo & SIN & Año Adoptada & Dosis máxima & Notas \\
\hline ÁCIDO ASCÓRBICO, L- & 300 & 2013 & BPF & \\
ÁCIDO CÍTRICO & 330 & 2013 & BPF & \\
ÁCIDO MÁLICO, DL- & 296 & 2013 & BPF & \\
SULFITOS & $220-225,539$ & 2006 & $50 \mathrm{mg} / \mathrm{kg}$ & $44,122 \& 127$ \\
\hline
\end{tabular}

No. de Categoría de alimento 14.1.3 Néctares de frutas y hortalizas

\begin{tabular}{|c|c|c|c|c|}
\hline Aditivo & SIN & Año Adoptada & Dosis máxima & Notas \\
\hline GLICÓSIDOS DE ESTEVIOL & $960 a, 960 b(i)$ & 2011 & $200 \mathrm{mg} / \mathrm{kg}$ & 26 \\
\hline
\end{tabular}

\section{No. de Categoría de alimento 14.1.3.1 Néctares de frutas}

\begin{tabular}{llccc} 
Aditivo & SIN & Año Adoptada & Dosis máxima & Notas \\
\hline ACESULFAME DE POTASIO & 950 & 2005 & $350 \mathrm{mg} / \mathrm{kg}$ & 188 \\
ÁCIDO ASCÓRBICO, L- & 300 & 2005 & BPF \\
ÁCIDO CÍTRICO & 330 & 2005 & $5000 \mathrm{mg} / \mathrm{kg}$ \\
ÁCIDO MÁLICO, DL- & 296 & 2005 & BPF \\
ASCORBATO DE CALCIO & 302 & 2005 & BPF \\
ASCORBATO DE SODIO & 301 & 2005 & BPF & 191 \\
ASPARTAMO & 951 & 2005 & $600 \mathrm{mg} / \mathrm{kg}$ & $13,91 \& 122$ \\
BENZOATOS & $210-213$ & 2004 & $1000 \mathrm{mg} / \mathrm{kg}$ & $17 \& 122$ \\
CICLAMATOS & $952(\mathrm{i})$, (ii), (iv) & 2005 & $400 \mathrm{mg} / \mathrm{kg}$ & 69
\end{tabular}




\section{No. de Categoría de alimento 14.1.3.1 Néctares de frutas}

\begin{tabular}{|c|c|c|c|c|}
\hline Aditivo & SIN & Año Adoptada & Dosis máxima & Notas \\
\hline FOSFATOS & $\begin{array}{l}\text { 338; 339(i)-(iii); } \\
340 \text { (i)-(iii); 341(i)- } \\
\text { (iii); 342(i)-(ii); } \\
343(\text { i)-(iii); 450(i)- } \\
\text { (iii),(v)-(vii), (ix); } \\
\text { 451(i),(ii); 452(i)- } \\
\text { (v); } 542\end{array}$ & 2005 & $1000 \mathrm{mg} / \mathrm{kg}$ & $33,40 \& 122$ \\
\hline PECTINAS & 440 & 2005 & BPF & \\
\hline SACARINAS & 954(i)-(iv) & 2005 & 80 mg/kg & \\
\hline SORBATOS & 200, 202, 203 & 2005 & $1000 \mathrm{mg} / \mathrm{kg}$ & $42,91 \& 122$ \\
\hline $\begin{array}{l}\text { SUCRALOSA } \\
\text { (TRICLOROGALACTOSACAROSA) }\end{array}$ & 955 & 2005 & 300 mg/kg & \\
\hline SULFITOS & $220-225,539$ & 2005 & $50 \mathrm{mg} / \mathrm{kg}$ & $44 \& 122$ \\
\hline TARTRATOS & 334, 335(ii), 337 & 2005 & $4000 \mathrm{mg} / \mathrm{kg}$ & $45 \& 128$ \\
\hline
\end{tabular}

No. de Categoría de alimento 14.1.3.2 Néctares de hortalizas

\begin{tabular}{|c|c|c|c|c|}
\hline Aditivo & SIN & Año Adoptada & Dosis máxima & Notas \\
\hline ACESULFAME DE POTASIO & 950 & 2008 & $350 \mathrm{mg} / \mathrm{kg}$ & $161 \& 188$ \\
\hline ÁCIDO ASCÓRBICO, L- & 300 & 2013 & BPF & \\
\hline ÁCIDO CÍTRICO & 330 & 2013 & BPF & \\
\hline ÁCIDO MÁLICO, DL- & 296 & 2013 & BPF & \\
\hline ASPARTAMO & 951 & 2007 & $600 \mathrm{mg} / \mathrm{kg}$ & $161 \& 191$ \\
\hline CICLAMATOS & 952(i), (ii), (iv) & 2007 & $400 \mathrm{mg} / \mathrm{kg}$ & $17 \& 161$ \\
\hline NEOTAMO & 961 & 2007 & $65 \mathrm{mg} / \mathrm{kg}$ & 161 \\
\hline PECTINAS & 440 & 2014 & BPF & \\
\hline SACARINAS & 954(i)-(iv) & 2008 & $80 \mathrm{mg} / \mathrm{kg}$ & 161 \\
\hline $\begin{array}{l}\text { SUCRALOSA } \\
\text { (TRICLOROGALACTOSACAROSA) }\end{array}$ & 955 & 2007 & $300 \mathrm{mg} / \mathrm{kg}$ & 161 \\
\hline SULFITOS & $220-225,539$ & 2006 & $50 \mathrm{mg} / \mathrm{kg}$ & $44 \& 122$ \\
\hline
\end{tabular}

No. de Categoría de alimento 14.1.3.3 Concentrados para néctares de frutas

\begin{tabular}{llccc}
\hline Aditivo & SIN & Año Adoptada & Dosis máxima & Notas \\
ACESULFAME DE POTASIO & 950 & 2005 & $350 \mathrm{mg} / \mathrm{kg}$ & $127 \& 188$ \\
ÁCIDO ASCÓRBICO, L- & 300 & 2005 & BPF & 127 \\
ÁCIDO CÍTRICO & 330 & 2005 & $5000 \mathrm{mg} / \mathrm{kg}$ & 127 \\
ÁCIDO MÁLICO, DL- & 296 & 2005 & BPF & 127 \\
ASCORBATO DE CALCIO & 302 & 2005 & BPF & 127 \\
ASCORBATO DE SODIO & 301 & 2005 & $600 \mathrm{mg} / \mathrm{kg}$ & $127 \& 191$ \\
ASPARTAMO & 951 & 2005 & $1000 \mathrm{mg} / \mathrm{kg}$ & $13,91,122 \& 127$ \\
BENZOATOS & $210-213$ & 2004 & $400 \mathrm{mg} / \mathrm{kg}$ & $17,122 \& 127$ \\
CICLAMATOS & $952(\mathrm{i}),(\mathrm{ii}),(\mathrm{iv})$ & 2005 & BPF & $69 \& 127$
\end{tabular}




\begin{tabular}{|c|c|c|c|c|}
\hline Aditivo & SIN & Año Adoptada & Dosis máxima & Notas \\
\hline FOSFATOS & $\begin{array}{l}338 ; 339(\mathrm{i})-(\mathrm{iii}) ; \\
340(\mathrm{i})-(\mathrm{iii}) ; 341(\mathrm{i})- \\
\text { (iii); 342(i)-(ii); } \\
343(\mathrm{i})-(\mathrm{iii}) ; 450(\mathrm{i})- \\
\text { (iii),(v)-(vii), (ix); } \\
451(\mathrm{i}),(\mathrm{ii}) ; 452(\mathrm{i})- \\
\text { (v); } 542\end{array}$ & 2005 & $1000 \mathrm{mg} / \mathrm{kg}$ & $33,40,122 \& 127$ \\
\hline PECTINAS & 440 & 2005 & BPF & 127 \\
\hline SACARINAS & 954(i)-(iv) & 2005 & $80 \mathrm{mg} / \mathrm{kg}$ & 127 \\
\hline SORBATOS & $200,202,203$ & 2005 & $1000 \mathrm{mg} / \mathrm{kg}$ & $42,91,122 \& 127$ \\
\hline $\begin{array}{l}\text { SUCRALOSA } \\
\text { (TRICLOROGALACTOSACAROSA) }\end{array}$ & 955 & 2005 & 300 mg/kg & 127 \\
\hline SULFITOS & $220-225,539$ & 2005 & $50 \mathrm{mg} / \mathrm{kg}$ & $44,122 \& 127$ \\
\hline TARTRATOS & 334, 335(ii), 337 & 2005 & 4000 mg/kg & $45,127 \& 128$ \\
\hline
\end{tabular}

No. de Categoría de alimento 14.1.3.4 Concentrados para néctares de hortalizas

\begin{tabular}{|c|c|c|c|c|}
\hline Aditivo & SIN & Año Adoptada & Dosis máxima & Notas \\
\hline ACESULFAME DE POTASIO & 950 & 2007 & $350 \mathrm{mg} / \mathrm{kg}$ & $127,161 \& 188$ \\
\hline ÁCIDO ASCÓRBICO, L- & 300 & 2013 & BPF & \\
\hline ÁCIDO CÍTRICO & 330 & 2013 & BPF & \\
\hline ÁCIDO MÁLICO, DL- & 296 & 2013 & BPF & \\
\hline ASPARTAMO & 951 & 2007 & $600 \mathrm{mg} / \mathrm{kg}$ & $127 \& 161$ \\
\hline BENZOATOS & $210-213$ & 2004 & $600 \mathrm{mg} / \mathrm{kg}$ & 13 \\
\hline CICLAMATOS & 952(i), (ii), (iv) & 2007 & $400 \mathrm{mg} / \mathrm{kg}$ & $17,127 \& 161$ \\
\hline NEOTAMO & 961 & 2007 & $65 \mathrm{mg} / \mathrm{kg}$ & $127 \& 161$ \\
\hline PECTINAS & 440 & 2014 & BPF & \\
\hline $\begin{array}{l}\text { SUCRALOSA } \\
\text { (TRICLOROGALACTOSACAROSA) }\end{array}$ & 955 & 2007 & $300 \mathrm{mg} / \mathrm{kg}$ & $127 \& 161$ \\
\hline SULFITOS & $220-225,539$ & 2006 & $50 \mathrm{mg} / \mathrm{kg}$ & $44,122 \& 127$ \\
\hline
\end{tabular}

No. de Categoría de alimento 14.1.4 Bebidas a base de agua aromatizadas, incluidas las bebidas para deportistas, bebidas energéticas o bebidas electrolíticas y bebidas con partículas añadidas

\begin{tabular}{lllrc} 
Aditivo & SIN & Año Adoptada & Dosis máxima & Notas \\
\hline ACESULFAME DE POTASIO & 950 & 2007 & $600 \mathrm{mg} / \mathrm{kg}$ & $161 \& 188$ \\
ACETATO ISOBUTIRATO DE SACAROSA & 444 & 1999 & $500 \mathrm{mg} / \mathrm{kg}$ & 161 \\
ALITAME & 956 & 2007 & $40 \mathrm{mg} / \mathrm{kg}$ & $127 \& 161$ \\
AMARILLO OCASO FCF & 110 & 2008 & $600 \mathrm{mg} / \mathrm{kg}$ & $478 \& 191$ \\
ASPARTAMO & 951 & 2019 & $100 \mathrm{mg} / \mathrm{kg}$ & \\
AZUL BRILLANTE FCF & 133 & 2005 & $250 \mathrm{mg} / \mathrm{kg}$ & $13 \& 301$ \\
BENZOATOS & $210-213$ & 2016 & &
\end{tabular}


Bebidas a base de agua aromatizadas, incluidas las bebidas para deportistas, bebidas energéticas o bebidas electrolíticas y bebidas con partículas añadidas

\begin{tabular}{|c|c|c|c|c|}
\hline Aditivo & $\sin$ & Año Adoptada & Dosis máxima & Notas \\
\hline $\begin{array}{l}\text { CARAMELO III - CARAMELO AL } \\
\text { AMONÍACO }\end{array}$ & $150 \mathrm{c}$ & 2010 & $5000 \mathrm{mg} / \mathrm{kg}$ & 9 \\
\hline $\begin{array}{l}\text { CARAMELO IV - CARAMELO AL SULFITO } \\
\text { AMÓNICO }\end{array}$ & $150 d$ & 2009 & $50000 \mathrm{mg} / \mathrm{kg}$ & \\
\hline CARMINES & 120 & 2008 & $100 \mathrm{mg} / \mathrm{kg}$ & 178 \\
\hline CAROTENOIDES & 160a(i),a(iii),e,f & 2009 & 100 mg/kg & \\
\hline CAROTENOS, BETA-, VEGETALES & $160 a(i i)$ & 2005 & $2000 \mathrm{mg} / \mathrm{kg}$ & \\
\hline CERA CANDELILLA & 902 & 2006 & 200 mg/kg & 131 \\
\hline CERA CARNAUBA & 903 & 2003 & $200 \mathrm{mg} / \mathrm{kg}$ & 131 \\
\hline CERA DE ABEJAS & 901 & 2006 & $200 \mathrm{mg} / \mathrm{kg}$ & 131 \\
\hline CICLAMATOS & 952(i), (ii), (iv) & 2010 & $350 \mathrm{mg} / \mathrm{kg}$ & $17 \& 127$ \\
\hline CICLODEXTRINA, BETA- & 459 & 2001 & $500 \mathrm{mg} / \mathrm{kg}$ & \\
\hline CITRATO DE ESTEARILO & 484 & 1999 & $500 \mathrm{mg} / \mathrm{kg}$ & \\
\hline CITRATO DE TRIETILO & 1505 & 1999 & 200 mg/kg & \\
\hline CITRATOS DE ISOPROPILO & 384 & 2001 & 200 mg/kg & \\
\hline $\begin{array}{l}\text { CLOROFILAS Y CLOROFILINAS, } \\
\text { COMPLEJOS CUPRICOS }\end{array}$ & $141(\mathrm{i}),(\mathrm{ii})$ & 2009 & $300 \mathrm{mg} / \mathrm{kg}$ & \\
\hline CLORURO ESTAÑOSO & 512 & 2001 & $20 \mathrm{mg} / \mathrm{kg}$ & 43 \\
\hline DIMETIL DICARBONATO & 242 & 1999 & $250 \mathrm{mg} / \mathrm{kg}$ & 18 \\
\hline DIMETILPOLISILOXANO & $900 a$ & 1999 & $20 \mathrm{mg} / \mathrm{kg}$ & \\
\hline ÉSTERES DE ASCORBILO & 304,305 & 2001 & $1000 \mathrm{mg} / \mathrm{kg}$ & $10 \& 15$ \\
\hline ÉSTERES DE GLICEROL DE COLOFONIA & 445(iii) & 1999 & $150 \mathrm{mg} / \mathrm{kg}$ & \\
\hline $\begin{array}{l}\text { ÉSTERES DE PROPILENGLICOL DE } \\
\text { ÁCIDOS GRASOS }\end{array}$ & 477 & 2001 & $500 \mathrm{mg} / \mathrm{kg}$ & \\
\hline $\begin{array}{l}\text { ÉSTERES DIACETILTARTÁRICOS Y DE } \\
\text { ÁCIDOS GRASOS DE GLICEROL }\end{array}$ & $472 e$ & 2005 & $5000 \mathrm{mg} / \mathrm{kg}$ & \\
\hline $\begin{array}{l}\text { ÉSTERES POLIGLICÉRIDOS DE ÁCIDOS } \\
\text { GRASOS }\end{array}$ & 475 & 2019 & $5000 \mathrm{mg} / \mathrm{kg}$ & 127 \\
\hline ETILEN DIAMINO TETRA ACETATOS & 385,386 & 2001 & $200 \mathrm{mg} / \mathrm{kg}$ & 21 \\
\hline EXTRACTO DE PIEL DE UVA & 163(ii) & 2009 & $300 \mathrm{mg} / \mathrm{kg}$ & 181 \\
\hline EXTRACTOS DE QUILAYA & 999(i),(ii) & 2016 & $50 \mathrm{mg} / \mathrm{kg}$ & $132 \& 293$ \\
\hline FOSFATOS & $\begin{array}{l}\text { 338; 339(i)-(iii); } \\
340 \text { (i)-(iii); } 341 \text { (i)- } \\
\text { (iii); 342(i)-(ii); } \\
343(\text { i)-(iii); } 450(\mathrm{i})- \\
\text { (iii),(v)-(vii), (ix); } \\
451 \text { (i),(ii); 452(i)- } \\
\text { (v); } 542\end{array}$ & 2012 & $1000 \mathrm{mg} / \mathrm{kg}$ & 33 \\
\hline GALATO DE PROPILO & 310 & 2001 & $1000 \mathrm{mg} / \mathrm{kg}$ & 15 \\
\hline GLICÓSIDOS DE ESTEVIOL & $960 a, 960 b(i)$ & 2011 & 200 mg/kg & 26 \\
\hline HIDROXIBENZOATOS, PARA- & 214,218 & 2010 & $500 \mathrm{mg} / \mathrm{kg}$ & 27 \\
\hline INDIGOTINA (CARMÍN DE ÍNDIGO) & 132 & 2009 & $100 \mathrm{mg} / \mathrm{kg}$ & \\
\hline
\end{tabular}




\begin{tabular}{|c|c|c|c|c|}
\hline No. de Categoría de alimento & |4.1.4 & $\begin{array}{l}\text { bidas a ba } \\
\text { luidas las } \\
\text { oidas ener } \\
\text { ctrolíticas } \\
\text { adidas }\end{array}$ & $\begin{array}{l}\text { agua aron } \\
\text { das para de } \\
\text { as o bebid } \\
\text { bidas con }\end{array}$ & $\begin{array}{l}\text { atizadas, } \\
\text { ortistas, }\end{array}$ \\
\hline Aditivo & SIN & Año Adoptada & Dosis máxima & Notas \\
\hline NEOTAMO & 961 & 2019 & $33 \mathrm{mg} / \mathrm{kg}$ & 478 \\
\hline ÓXIDOS DE HIERRO & 172(i)-(iii) & 2005 & $100 \mathrm{mg} / \mathrm{kg}$ & \\
\hline POLIETILENGLICOL & 1521 & 2001 & $1000 \mathrm{mg} / \mathrm{kg}$ & \\
\hline POLISORBATOS & $432-436$ & 2007 & $500 \mathrm{mg} / \mathrm{kg}$ & 127 \\
\hline PONCEAU 4R (ROJO DE COCHINILLA A) & 124 & 2008 & $50 \mathrm{mg} / \mathrm{kg}$ & \\
\hline RIBOFLAVINAS & 101(i),(ii), (iii) & 2005 & $50 \mathrm{mg} / \mathrm{kg}$ & \\
\hline ROJO ALLURA AC & 129 & 2009 & $300 \mathrm{mg} / \mathrm{kg}$ & $127 \& 161$ \\
\hline SORBATOS & $200,202,203$ & 2012 & $500 \mathrm{mg} / \mathrm{kg}$ & $42 \& 127$ \\
\hline $\begin{array}{l}\text { SUCRALOSA } \\
\text { (TRICLOROGALACTOSACAROSA) }\end{array}$ & 955 & 2019 & $300 \mathrm{mg} / \mathrm{kg}$ & $127 \& 478$ \\
\hline SUCROÉSTERES DE ÁCIDOS GRASOS & 473 & 2018 & 200 mg/kg & 219,348 \\
\hline SUCROGLICÉRIDOS & 474 & 2018 & $200 \mathrm{mg} / \mathrm{kg}$ & 219,348 \\
\hline $\begin{array}{l}\text { SUCROSE OLIGOESTERS, TYPE I AND } \\
\text { TYPE II }\end{array}$ & $473 a$ & 2018 & 200 mg/kg & 219,348 \\
\hline SULFITOS & $220-225,539$ & 2006 & $70 \mathrm{mg} / \mathrm{kg}$ & $44,127 \& 143$ \\
\hline TARTRATOS & 334, 335(ii), 337 & 2018 & 800 mg/kg & 45 \\
\hline TIODIPROPIONATOS & 388,389 & 1999 & $1000 \mathrm{mg} / \mathrm{kg}$ & $15 \& 46$ \\
\hline TOCOFEROLES & $307 a, b, c$ & 2018 & 200 mg/kg & 434 \\
\hline VERDE SÓLIDO FCF & 143 & 1999 & $100 \mathrm{mg} / \mathrm{kg}$ & \\
\hline
\end{tabular}

No. de Categoría de alimento 14.1.4.1 Bebidas a base de agua aromatizadas con gas

\begin{tabular}{|c|c|c|c|c|}
\hline Aditivo & $\operatorname{SiN}$ & Año Adoptada & Dosis máxima & Notas \\
\hline ALGINATO DE PROPILENGLICOL & 405 & 2018 & $500 \mathrm{mg} / \mathrm{kg}$ & \\
\hline CANTAXANTINA & $161 \mathrm{~g}$ & 2011 & $5 \mathrm{mg} / \mathrm{kg}$ & \\
\hline $\begin{array}{l}\text { ÉSTERES DE SORBITÁN DE ÁCIDOS } \\
\text { GRASOS }\end{array}$ & 491-495 & 2018 & $500 \mathrm{mg} / \mathrm{kg}$ & \\
\hline ETIL-LAUROIL ARGINATO & 243 & 2011 & $50 \mathrm{mg} / \mathrm{kg}$ & \\
\hline SACARINAS & 954(i)-(iv) & 2008 & $300 \mathrm{mg} / \mathrm{kg}$ & 161 \\
\hline
\end{tabular}

No. de Categoría de alimento 14.1.4.2 Bebidas a base de agua aromatizadas sin gas, incluidos los ponches de fruta y las limonadas y bebidas similares

\begin{tabular}{|c|c|c|c|c|}
\hline Aditivo & SIN & Año Adoptada & Dosis máxima & Notas \\
\hline ALGINATO DE PROPILENGLICOL & 405 & 2018 & $500 \mathrm{mg} / \mathrm{kg}$ & \\
\hline CANTAXANTINA & $161 \mathrm{~g}$ & 2011 & $5 \mathrm{mg} / \mathrm{kg}$ & \\
\hline $\begin{array}{l}\text { ÉSTERES DE SORBITÁN DE ÁCIDOS } \\
\text { GRASOS }\end{array}$ & $491-495$ & 2018 & $500 \mathrm{mg} / \mathrm{kg}$ & \\
\hline ETIL-LAUROIL ARGINATO & 243 & 2011 & $50 \mathrm{mg} / \mathrm{kg}$ & \\
\hline
\end{tabular}


No. de Categoría de alimento 14.1.4.2 Bebidas a base de agua aromatizadas sin gas, incluidos los ponches de fruta y las limonadas y bebidas similares

\begin{tabular}{|c|c|c|c|c|}
\hline Aditivo & $\operatorname{SiN}$ & Año Adoptada & Dosis máxima & Notas \\
\hline SACARINAS & 954(i)-(iv) & 2008 & $300 \mathrm{mg} / \mathrm{kg}$ & 161 \\
\hline
\end{tabular}

No. de Categoría de alimento 14.1.4.3 Concentrados (líquidos o sólidos) para bebidas a base de agua aromatizadas

\begin{tabular}{|c|c|c|c|c|}
\hline Aditivo & SIN & Año Adoptada & Dosis máxima & Notas \\
\hline ALGINATO DE PROPILENGLICOL & 405 & 2018 & $500 \mathrm{mg} / \mathrm{kg}$ & 127 \\
\hline CANTAXANTINA & $161 \mathrm{~g}$ & 2011 & $5 \mathrm{mg} / \mathrm{kg}$ & 127 \\
\hline CITRATO DE AMONIO FÉRRICO & 381 & 1999 & $10 \mathrm{mg} / \mathrm{kg}$ & 23 \\
\hline $\begin{array}{l}\text { ÉSTERES DE SORBITÁN DE ÁCIDOS } \\
\text { GRASOS }\end{array}$ & $491-495$ & 2018 & $500 \mathrm{mg} / \mathrm{kg}$ & 127 \\
\hline ETIL-LAUROIL ARGINATO & 243 & 2011 & $50 \mathrm{mg} / \mathrm{kg}$ & 127 \\
\hline POLIVINILPIRROLIDONA & 1201 & 1999 & $500 \mathrm{mg} / \mathrm{kg}$ & \\
\hline SACARINAS & 954(i)-(iv) & 2008 & 300 mg/kg & $127 \& 161$ \\
\hline
\end{tabular}

No. de Categoría de alimento 14.1.5 Café, sucedáneos del café, té, infusiones de hierbas y otras bebidas calientes a base de cereales y granos, excluido el cacao

\begin{tabular}{|c|c|c|c|c|}
\hline Aditivo & SIN & Año Adoptada & Dosis máxima & Notas \\
\hline ACESULFAME DE POTASIO & 950 & 2007 & $600 \mathrm{mg} / \mathrm{kg}$ & $160,161 \& 188$ \\
\hline ACETATO DE SODIO & 262(i) & 2013 & BPF & 160 \\
\hline ÁCIDO ACÉTICO GLACIAL & 260 & 2013 & BPF & 160 \\
\hline ÁCIDO ALGÍNICO & 400 & 2014 & BPF & 160 \\
\hline ÁCIDO ASCÓRBICO, L- & 300 & 2013 & BPF & 160 \\
\hline ÁCIDO CÍTRICO & 330 & 2013 & BPF & 160 \\
\hline ÁCIDO FUMÁRICO & 297 & 2013 & BPF & 160 \\
\hline ÁCIDO MÁLICO, DL- & 296 & 2013 & BPF & 160 \\
\hline ADIPATO DE DIALMIDÓN ACETILADO & 1422 & 2014 & BPF & 160 \\
\hline AGAR & 406 & 2014 & BPF & 160 \\
\hline ALGA EUCHEUMA ELABORADA & $407 a$ & 2014 & BPF & 160 \\
\hline ALGINATO DE PROPILENGLICOL & 405 & 2018 & $500 \mathrm{mg} / \mathrm{kg}$ & 160 \\
\hline ALGINATO DE SODIO & 401 & 2014 & BPF & 160 \\
\hline ALMIDÓN BLANQUEADO & 1403 & 2014 & BPF & 160 \\
\hline ALMIDÓN HIDROXIPROPÍLICO & 1440 & 2014 & BPF & 160 \\
\hline ALMIDÓN OXIDADO & 1404 & 2014 & BPF & 160 \\
\hline ALMIDÓN TRATADO CON ÁCIDO & 1401 & 2014 & BPF & 160 \\
\hline ALMIDÓN TRATADO CON ÁLCALIS & 1402 & 2014 & BPF & 160 \\
\hline ALMIDONES TRATADOS CON ENZIMAS & 1405 & 2014 & BPF & 160 \\
\hline ASCORBATO DE SODIO & 301 & 2015 & BPF & 160 \\
\hline ASPARTAMO & 951 & 2019 & $600 \mathrm{mg} / \mathrm{kg}$ & $160 \& 478$ \\
\hline
\end{tabular}


Café, sucedáneos del café, té, infusiones de hierbas y otras bebidas calientes a base de cereales y granos, excluido el cacao

\begin{tabular}{|c|c|c|c|c|}
\hline Aditivo & SIN & Año Adoptada & Dosis máxima & Notas \\
\hline BENZOATOS & $210-213$ & 2004 & $1000 \mathrm{mg} / \mathrm{kg}$ & 13 \\
\hline $\begin{array}{l}\text { CARAMELO III - CARAMELO AL } \\
\text { AMONÍACO }\end{array}$ & $150 c$ & 2010 & $10000 \mathrm{mg} / \mathrm{kg}$ & $7 \& 160$ \\
\hline $\begin{array}{l}\text { CARAMELO IV - CARAMELO AL SULFITO } \\
\text { AMÓNICO }\end{array}$ & $150 d$ & 2011 & $10000 \mathrm{mg} / \mathrm{kg}$ & $7 \& 127$ \\
\hline CARBONATO ÁCIDO DE MAGNESIO & 504(ii) & 2013 & BPF & 160 \\
\hline CARBONATO ÁCIDO DE SODIO & 500 (ii) & 2013 & BPF & 160 \\
\hline CARBONATO DE CALCIO & $170(\mathrm{i})$ & 2013 & BPF & 160 \\
\hline CARBONATO DE MAGNESIO & $504(i)$ & 2013 & BPF & 160 \\
\hline CARBONATO DE POTASIO & $501(i)$ & 2013 & BPF & 160 \\
\hline CARBONATO DE SODIO & $500(i)$ & 2013 & BPF & 160 \\
\hline $\begin{array}{l}\text { CARBOXIMETILCELULOSA SÓDICA } \\
\text { (GOMA DE CELULOSA) }\end{array}$ & 466 & 2014 & BPF & 160 \\
\hline CARRAGENINA & 407 & 2014 & BPF & 160 \\
\hline CELULOSA EN POLVO & 460 (ii) & 2014 & BPF & 160 \\
\hline $\begin{array}{l}\text { CELULOSA MICROCRISTALINA (GEL DE } \\
\text { CELULOSA) }\end{array}$ & $460(i)$ & 2014 & BPF & 160 \\
\hline CERA CANDELILLA & 902 & 2001 & BPF & 108 \\
\hline CERA CARNAUBA & 903 & 2006 & 200 mg/kg & 108 \\
\hline CERA DE ABEJAS & 901 & 2001 & BPF & 108 \\
\hline CITRATO DÍACIDO DE POTASIO & 332(i) & 2013 & BPF & 160 \\
\hline CITRATO DÍACIDO DE SODIO & $331(i)$ & 2013 & BPF & 160 \\
\hline CITRATO TRIPOTÁSICO & 332(ii) & 2013 & BPF & 160 \\
\hline CITRATO TRISÓDICO & 331 (iii) & 2013 & BPF & 160 \\
\hline CLORURO DE CALCIO & 509 & 2014 & BPF & 160 \\
\hline CLORURO DE MAGNESIO & 511 & 2014 & BPF & 160 \\
\hline CLORURO DE POTASIO & 508 & 2014 & BPF & 160 \\
\hline DEXTRINAS, ALMIDÓN TOSTADO & 1400 & 2014 & BPF & $90 \& 160$ \\
\hline DIMETIL DICARBONATO & 242 & 2004 & $250 \mathrm{mg} / \mathrm{kg}$ & 18 \\
\hline DIÓXIDO DE CARBONO & 290 & 2015 & BPF & $59 \& 160$ \\
\hline DIÓXIDO DE SILICIO AMORFO & 551 & 2015 & BPF & 321 \\
\hline $\begin{array}{l}\text { ÉSTERES ACÉTICOS Y DE ÁCIDOS } \\
\text { GRASOS DE GLICEROL }\end{array}$ & $472 a$ & 2014 & BPF & 160 \\
\hline $\begin{array}{l}\text { ÉSTERES CÍTRICOS Y DE ÁCIDOS } \\
\text { GRASOS DE GLICEROL }\end{array}$ & $472 c$ & 2014 & BPF & 160 \\
\hline $\begin{array}{l}\text { ÉSTERES DE SORBITÁN DE ÁCIDOS } \\
\text { GRASOS }\end{array}$ & $491-495$ & 2018 & $500 \mathrm{mg} / \mathrm{kg}$ & 429 \\
\hline $\begin{array}{l}\text { ÉSTERES DIACETILTARTÁRICOS Y DE } \\
\text { ÁCIDOS GRASOS DE GLICEROL }\end{array}$ & $472 \mathrm{e}$ & 2006 & $500 \mathrm{mg} / \mathrm{kg}$ & 142 \\
\hline $\begin{array}{l}\text { ÉSTERES LÁCTICOS Y DE ÁCIDOS } \\
\text { GRASOS DE GLICEROL }\end{array}$ & $472 b$ & 2014 & BPF & 160 \\
\hline
\end{tabular}


No. de Categoría de alimento 14.1.5 Café, sucedáneos del café, té, infusiones de hierbas y otras bebidas calientes a base de cereales y granos, excluido el cacao

\begin{tabular}{|c|c|c|c|c|}
\hline Aditivo & SIN & Año Adoptada & Dosis máxima & Notas \\
\hline $\begin{array}{l}\text { ÉSTERES POLIGLICÉRIDOS DE ÁCIDOS } \\
\text { GRASOS }\end{array}$ & 475 & 2019 & $5000 \mathrm{mg} / \mathrm{kg}$ & 127 \\
\hline ETILEN DIAMINO TETRA ACETATOS & 385,386 & 2001 & $35 \mathrm{mg} / \mathrm{kg}$ & 21 \\
\hline FOSFATO DE DIALMIDÓN & 1412 & 2014 & BPF & 160 \\
\hline FOSFATO DE DIALMIDÓN ACETILADO & 1414 & 2014 & BPF & 160 \\
\hline FOSFATO DE DIALMIDÓN FOSFATADO & 1413 & 2014 & BPF & 160 \\
\hline FOSFATO DE HIDROXIPROPIL DIALMIDÓN & 1442 & 2014 & BPF & 160 \\
\hline FOSFATO DE MONOALMIDÓN & 1410 & 2014 & BPF & 160 \\
\hline FOSFATOS & $\begin{array}{l}\text { 338; 339(i)-(iii); } \\
340 \text { (i)-(iii); } 341 \text { (i)- } \\
\text { (iii); 342(i)-(ii); } \\
343(\text { i)-(iii); } 450(\mathrm{i})- \\
\text { (iii),(v)-(vii), (ix); } \\
451 \text { (i),(ii); 452(i)- } \\
\text { (v); } 542\end{array}$ & 2012 & $300 \mathrm{mg} / \mathrm{kg}$ & $33 \& 160$ \\
\hline FUMARATO DE SODIO & 365 & 2013 & BPF & 160 \\
\hline GLICEROL & 422 & 2015 & BPF & 160 \\
\hline GLICÓSIDOS DE ESTEVIOL & $960 a, 960 b(i)$ & 2011 & $200 \mathrm{mg} / \mathrm{kg}$ & $26 \& 160$ \\
\hline GLUCONATO DE SODIO & 576 & 2014 & BPF & 160 \\
\hline GLUTAMATO MONOSÓDICO, L- & 621 & 2015 & BPF & 201 \\
\hline GOMA ARÁBIGA (GOMA DE ACACIA) & 414 & 2014 & BPF & 160 \\
\hline GOMA DE SEMILLAS DE ALGARROBO & 410 & 2014 & BPF & 160 \\
\hline GOMA GELLAN & 418 & 2014 & BPF & 160 \\
\hline GOMA GUAR & 412 & 2014 & BPF & 160 \\
\hline GOMA KARAYA & 416 & 2014 & BPF & 160 \\
\hline GOMA LACA, BLANQUEADA & 904 & 2001 & BPF & 108 \\
\hline GOMA TARA & 417 & 2014 & BPF & 160 \\
\hline GOMA TRAGACANTO & 413 & 2014 & BPF & 160 \\
\hline GOMA XANTANA & 415 & 2014 & BPF & 160 \\
\hline GUANILATO DISÓDICO, 5'- & 627 & 2015 & BPF & 201 \\
\hline HARINA KONJAC & 425 & 2014 & BPF & 160 \\
\hline HIDROXIBENZOATOS, PARA- & 214,218 & 2012 & $450 \mathrm{mg} / \mathrm{kg}$ & $27 \& 160$ \\
\hline HIDRÓXIDO DE MAGNESIO & 528 & 2013 & BPF & 160 \\
\hline HIDROXIPROPILCELULOSA & 463 & 2014 & BPF & 160 \\
\hline HIDROXIPROPILMETILCELULOSA & 464 & 2014 & BPF & 160 \\
\hline INOSINATO DISÓDICO, 5'- & 631 & 2015 & BPF & 201 \\
\hline LACTATO DE CALCIO & 327 & 2013 & BPF & 160 \\
\hline LACTATO DE SODIO & 325 & 2013 & BPF & 160 \\
\hline LECITINA & 322(i) & 2014 & BPF & 160 \\
\hline MALATO DE SODIO, DL- & 350(ii) & 2013 & BPF & 160 \\
\hline METILCELULOSA & 461 & 2014 & BPF & 160 \\
\hline
\end{tabular}




\begin{tabular}{|c|c|c|c|c|}
\hline No. de Categoría de alimento & 14.1 .5 & $\begin{array}{l}\text { fé, sucedá } \\
\text { usiones de } \\
\text { ientes a be } \\
\text { luido el c }\end{array}$ & $\begin{array}{l}\text { del café, te } \\
\text { bas y otras } \\
\text { e cereales }\end{array}$ & $\begin{array}{l}\text { ebidas } \\
\text { granos, }\end{array}$ \\
\hline Aditivo & SIN & Año Adoptada & Dosis máxima & Notas \\
\hline METILETILCELULOSA & 465 & 2014 & BPF & 160 \\
\hline $\begin{array}{l}\text { MONOGLICÉRIDOS Y DIGLICÉRIDOS DE } \\
\text { ÁCIDOS GRASOS }\end{array}$ & 471 & 2014 & BPF & 160 \\
\hline NEOTAMO & 961 & 2007 & $50 \mathrm{mg} / \mathrm{kg}$ & 160 \\
\hline NITRÓGENO & 941 & 2015 & BPF & $59 \& 160$ \\
\hline $\begin{array}{l}\text { OCTENILSUCCIONATO SÓDICO DE } \\
\text { ALMIDÓN }\end{array}$ & 1450 & 2015 & BPF & 160 \\
\hline PECTINAS & 440 & 2014 & BPF & 160 \\
\hline $\begin{array}{l}\text { PROTEASA DE ASPERGILLUS ORYZAE. } \\
\text { VAR }\end{array}$ & $1101(\mathrm{i})$ & 2018 & BPF & 160 \\
\hline PULLULAN & 1204 & 2015 & BPF & 160 \\
\hline RIBONUCLEÓTIDOS DE SODIO, 5'- & 635 & 2015 & BPF & 201 \\
\hline SACARINAS & 954(i)-(iv) & 2007 & $200 \mathrm{mg} / \mathrm{kg}$ & 160 \\
\hline $\begin{array}{l}\text { SAL DE ÁCIDO OLEICO CON CALCIO, } \\
\text { POTASIO Y SODIO }\end{array}$ & 470 (ii) & 2014 & BPF & 160 \\
\hline $\begin{array}{l}\text { SAL MIRÍSTICA, PALMÍTICA Y ÁCIDOS } \\
\text { ESTEÁRICOS CON AMONIO, CALCIO, } \\
\text { POTASIO Y SODIO }\end{array}$ & 470(i) & 2014 & BPF & 160 \\
\hline SORBATOS & $200,202,203$ & 2012 & $500 \mathrm{mg} / \mathrm{kg}$ & $42 \& 160$ \\
\hline $\begin{array}{l}\text { SUCRALOSA } \\
\text { (TRICLOROGALACTOSACAROSA) }\end{array}$ & 955 & 2019 & $300 \mathrm{mg} / \mathrm{kg}$ & $160 \& 478$ \\
\hline SUCROÉSTERES DE ÁCIDOS GRASOS & 473 & 2018 & $1000 \mathrm{mg} / \mathrm{kg}$ & 176,348 \\
\hline SUCROGLICÉRIDOS & 474 & 2018 & $1000 \mathrm{mg} / \mathrm{kg}$ & 176,348 \\
\hline $\begin{array}{l}\text { SUCROSE OLIGOESTERS, TYPE I AND } \\
\text { TYPE II }\end{array}$ & $473 a$ & 2018 & $1000 \mathrm{mg} / \mathrm{kg}$ & 176,348 \\
\hline
\end{tabular}

\begin{tabular}{|c|c|c|c|c|}
\hline \multicolumn{2}{|c|}{ No. de Categoría de alimento 14.2.1 } & \multicolumn{3}{|c|}{ Cerveza y bebidas a base de malta } \\
\hline Aditivo & SIN & Año Adoptada & Dosis máxima & Notas \\
\hline ALGINATO DE PROPILENGLICOL & 405 & 2018 & $500 \mathrm{mg} / \mathrm{kg}$ & \\
\hline $\begin{array}{l}\text { CARAMELO III - CARAMELO AL } \\
\text { AMONÍACO }\end{array}$ & $150 \mathrm{c}$ & 2010 & $50000 \mathrm{mg} / \mathrm{kg}$ & \\
\hline $\begin{array}{l}\text { CARAMELO IV - CARAMELO AL SULFITO } \\
\text { AMÓNICO }\end{array}$ & $150 d$ & 2011 & $50000 \mathrm{mg} / \mathrm{kg}$ & \\
\hline CARMINES & 120 & 2005 & $100 \mathrm{mg} / \mathrm{kg}$ & 178 \\
\hline CAROTENOS, BETA-, VEGETALES & 160a(ii) & 2005 & $600 \mathrm{mg} / \mathrm{kg}$ & \\
\hline DIMETILPOLISILOXANO & $900 a$ & 1999 & $10 \mathrm{mg} / \mathrm{kg}$ & \\
\hline ETILEN DIAMINO TETRA ACETATOS & 385,386 & 2004 & $25 \mathrm{mg} / \mathrm{kg}$ & 21 \\
\hline POLIVINILPIRROLIDONA & 1201 & 1999 & $10 \mathrm{mg} / \mathrm{kg}$ & 36 \\
\hline SULFITOS & $220-225,539$ & 2006 & $50 \mathrm{mg} / \mathrm{kg}$ & 44 \\
\hline TARTRATOS & 334, 335(ii), 337 & 2018 & $2000 \mathrm{mg} / \mathrm{kg}$ & 45 \\
\hline
\end{tabular}

\section{No. de Categoría de alimento 14.2.2 Sidra y sidra de pera}




\begin{tabular}{|c|c|c|c|c|}
\hline \multicolumn{2}{|c|}{ No. de Categoría de alimento 14.2 .2} & \multicolumn{2}{|c|}{ Sidra y sidra de pera } & \multirow[b]{2}{*}{ Notas } \\
\hline Aditivo & SIN & Año Adoptada & Dosis máxima & \\
\hline AZUL BRILLANTE FCF & 133 & 2005 & 200 mg/kg & \\
\hline BENZOATOS & $210-213$ & 2004 & $1000 \mathrm{mg} / \mathrm{kg}$ & $13 \& 124$ \\
\hline $\begin{array}{l}\text { CARAMELO III - CARAMELO AL } \\
\text { AMONÍACO }\end{array}$ & $150 c$ & 2010 & $1000 \mathrm{mg} / \mathrm{kg}$ & \\
\hline $\begin{array}{l}\text { CARAMELO IV - CARAMELO AL SULFITO } \\
\text { AMÓNICO }\end{array}$ & $150 d$ & 2009 & $1000 \mathrm{mg} / \mathrm{kg}$ & \\
\hline CARMINES & 120 & 2005 & 200 mg/kg & 178 \\
\hline CAROTENOIDES & 160a(i),a(iii),e,f & 2009 & $200 \mathrm{mg} / \mathrm{kg}$ & \\
\hline CAROTENOS, BETA-, VEGETALES & $160 a(i i)$ & 2005 & $600 \mathrm{mg} / \mathrm{kg}$ & \\
\hline DIMETIL DICARBONATO & 242 & 2004 & $250 \mathrm{mg} / \mathrm{kg}$ & 18 \\
\hline DIMETILPOLISILOXANO & $900 a$ & 1999 & $10 \mathrm{mg} / \mathrm{kg}$ & \\
\hline $\begin{array}{l}\text { ÉSTERES DIACETILTARTÁRICOS Y DE } \\
\text { ÁCIDOS GRASOS DE GLICEROL }\end{array}$ & $472 \mathrm{e}$ & 2005 & $5000 \mathrm{mg} / \mathrm{kg}$ & \\
\hline EXTRACTO DE PIEL DE UVA & 163(ii) & 2009 & $300 \mathrm{mg} / \mathrm{kg}$ & 181 \\
\hline FOSFATOS & $\begin{array}{l}\text { 338; 339(i)-(iii); } \\
\text { 340(i)-(iii); 341(i)- } \\
\text { (iii); 342(i)-(ii); } \\
343(\mathrm{i}) \text {-(iii); } 450(\mathrm{i})- \\
\text { (iii),(v)-(vii), (ix); } \\
\text { 451(i),(ii); 452(i)- } \\
\text { (v); } 542\end{array}$ & 2010 & $880 \mathrm{mg} / \mathrm{kg}$ & 33 \\
\hline HIDROXIBENZOATOS, PARA- & 214,218 & 2010 & $200 \mathrm{mg} / \mathrm{kg}$ & 27 \\
\hline INDIGOTINA (CARMÍN DE ÍNDIGO) & 132 & 2009 & $200 \mathrm{mg} / \mathrm{kg}$ & \\
\hline LYSOZYME & 1105 & 2004 & $500 \mathrm{mg} / \mathrm{kg}$ & \\
\hline POLIVINILPIRROLIDONA & 1201 & 1999 & $2 \mathrm{mg} / \mathrm{kg}$ & 36 \\
\hline RIBOFLAVINAS & 101 (i),(ii), (iii) & 2005 & $300 \mathrm{mg} / \mathrm{kg}$ & \\
\hline ROJO ALLURA AC & 129 & 2009 & $200 \mathrm{mg} / \mathrm{kg}$ & \\
\hline SORBATOS & $200,202,203$ & 2012 & $500 \mathrm{mg} / \mathrm{kg}$ & 42 \\
\hline SULFITOS & $220-225,539$ & 2006 & $200 \mathrm{mg} / \mathrm{kg}$ & 44 \\
\hline TARTRATOS & 334, 335(ii), 337 & 2018 & $2000 \mathrm{mg} / \mathrm{kg}$ & 45 \\
\hline
\end{tabular}

\section{No. de Categoría de alimento 14.2.3 Vinos de uva}

\begin{tabular}{llccc} 
Aditivo & SIN & Año Adoptada & Dosis máxima & Notas \\
\hline DIMETIL DICARBONATO & 242 & 2004 & $200 \mathrm{mg} / \mathrm{kg}$ & 18 \\
DIÓXIDO DE CARBONO & 290 & 2015 & BPF & 60 \\
LYSOZYME & 1105 & 2004 & $500 \mathrm{mg} / \mathrm{kg}$ & \\
SORBATOS & $200,202,203$ & 2012 & $200 \mathrm{mg} / \mathrm{kg}$ & 42 \\
SULFITOS & $220-225,539$ & 2006 & $350 \mathrm{mg} / \mathrm{kg}$ & $44 \& 103$ \\
\hline
\end{tabular}

No. de Categoría de alimento 14.2.3.3 Vino de uva enriquecido, vino de uva licoroso y vino de uva dulce

\begin{tabular}{|c|c|c|c|c|}
\hline Aditivo & SIN & Año Adoptada & Dosis máxima & Notas \\
\hline $\begin{array}{l}\text { CARAMELO III - CARAMELO AL } \\
\text { AMONÍACO }\end{array}$ & $150 c$ & 2010 & $50000 \mathrm{mg} / \mathrm{kg}$ & \\
\hline $\begin{array}{l}\text { CARAMELO IV - CARAMELO AL SULFITO } \\
\text { AMÓNICO }\end{array}$ & $150 d$ & 2011 & $50000 \mathrm{mg} / \mathrm{kg}$ & \\
\hline
\end{tabular}




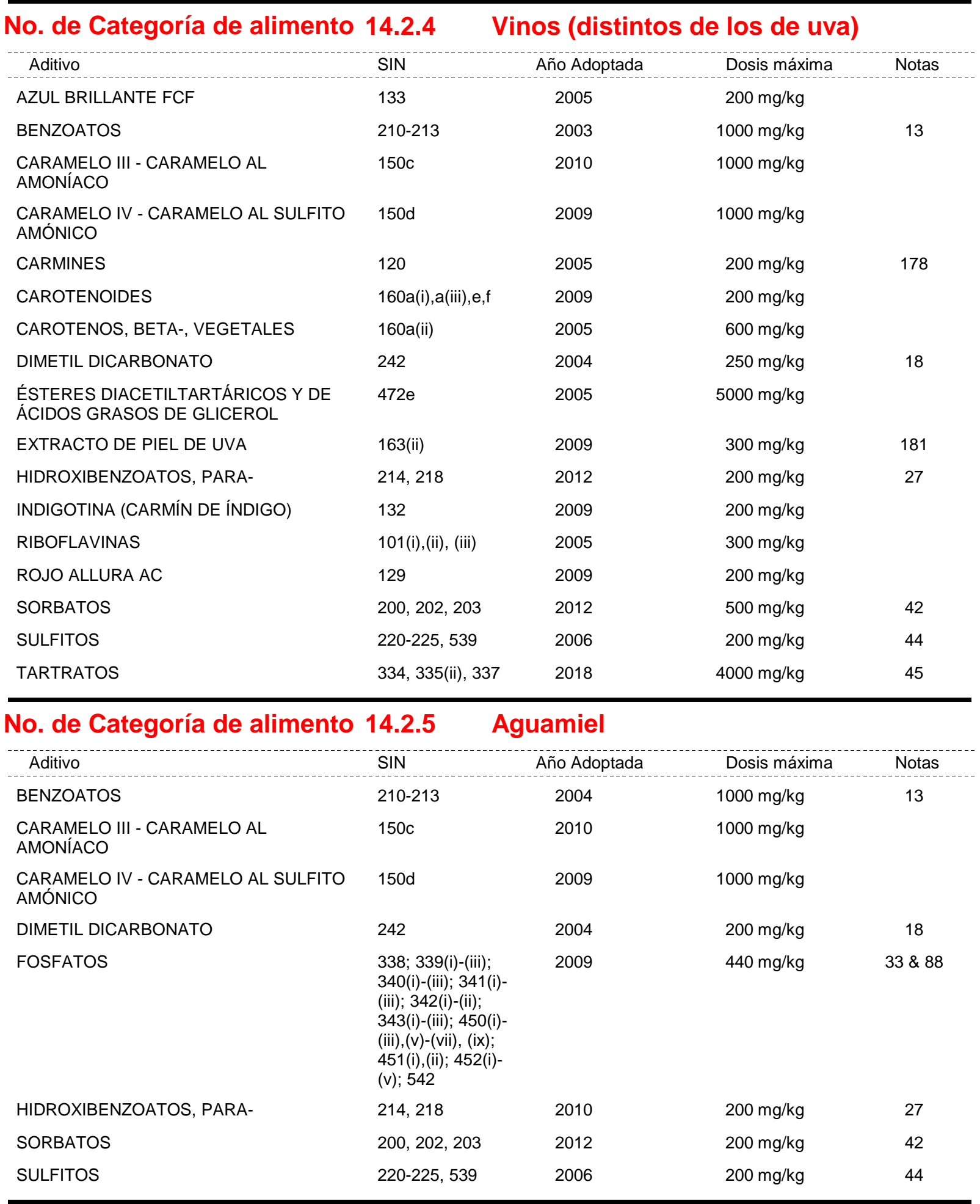

\section{No. de Categoría de alimento 14.2.6 Licores destilados que contengan más} de un 15 por ciento de alcohol

\begin{tabular}{|c|c|c|c|c|}
\hline Aditivo & SIN & Año Adoptada & Dosis máxima & Notas \\
\hline AMARILLO OCASO FCF & 110 & 2008 & 200 mg/kg & \\
\hline AZUL BRILLANTE FCF & 133 & 2005 & 200 mg/kg & \\
\hline CANTAXANTINA & $161 \mathrm{~g}$ & 2011 & $5 \mathrm{mg} / \mathrm{kg}$ & \\
\hline
\end{tabular}




\begin{tabular}{|c|c|c|c|c|}
\hline \multirow[t]{2}{*}{ No. de Categoría de alimento } & \multicolumn{4}{|c|}{$\begin{array}{l}\text { Licores destilados que contengan más } \\
\text { de un } 15 \text { por ciento de alcohol }\end{array}$} \\
\hline & SIN & Año Adoptada & Dosis máxima & Notas \\
\hline $\begin{array}{l}\text { CARAMELO III - CARAMELO AL } \\
\text { AMONÍACO }\end{array}$ & $150 c$ & 2010 & $50000 \mathrm{mg} / \mathrm{kg}$ & \\
\hline $\begin{array}{l}\text { CARAMELO IV - CARAMELO AL SULFITO } \\
\text { AMÓNICO }\end{array}$ & $150 d$ & 2011 & $50000 \mathrm{mg} / \mathrm{kg}$ & \\
\hline CARMINES & 120 & 2005 & $200 \mathrm{mg} / \mathrm{kg}$ & 178 \\
\hline CAROTENOIDES & $160 a(i), a(i i i), e, f$ & 2009 & $200 \mathrm{mg} / \mathrm{kg}$ & \\
\hline CAROTENOS, BETA-, VEGETALES & $160 a(i i)$ & 2005 & $600 \mathrm{mg} / \mathrm{kg}$ & \\
\hline ESTEAROIL LACTILATOS & $481(\mathrm{i}), 482(\mathrm{i})$ & 2018 & $8000 \mathrm{mg} / \mathrm{kg}$ & 430 \\
\hline $\begin{array}{l}\text { ÉSTERES DIACETILTARTÁRICOS Y DE } \\
\text { ÁCIDOS GRASOS DE GLICEROL }\end{array}$ & $472 \mathrm{e}$ & 2005 & $5000 \mathrm{mg} / \mathrm{kg}$ & \\
\hline ETILEN DIAMINO TETRA ACETATOS & 385,386 & 2005 & $25 \mathrm{mg} / \mathrm{kg}$ & 21 \\
\hline EXTRACTO DE PIEL DE UVA & 163(ii) & 2010 & $300 \mathrm{mg} / \mathrm{kg}$ & 181 \\
\hline FOSFATOS & $\begin{array}{l}338 ; 339(i)-(i i i) ; \\
340(\text { (i)-(iii); } 341(\text { i)-- } \\
\text { (iii); 342(i)-(ii); } \\
343(\text { (i)-(iii); } 450(\text { i)- } \\
\text { (iii),(v)-(vii), (ix); } \\
451(\text { (i),(ii); } 452(\mathrm{i})- \\
\text { (v); } 542\end{array}$ & 2009 & $440 \mathrm{mg} / \mathrm{kg}$ & $33 \& 88$ \\
\hline INDIGOTINA (CARMÍN DE ÍNDIGO) & 132 & 2009 & $300 \mathrm{mg} / \mathrm{kg}$ & \\
\hline POLISORBATOS & $432-436$ & 2007 & $120 \mathrm{mg} / \mathrm{kg}$ & \\
\hline PONCEAU 4R (ROJO DE COCHINILLA A) & 124 & 2008 & $200 \mathrm{mg} / \mathrm{kg}$ & \\
\hline ROJO ALLURA AC & 129 & 2009 & $300 \mathrm{mg} / \mathrm{kg}$ & \\
\hline SUCROÉSTERES DE ÁCIDOS GRASOS & 473 & 2018 & $5000 \mathrm{mg} / \mathrm{kg}$ & 348,431 \\
\hline SUCROGLICÉRIDOS & 474 & 2018 & $5000 \mathrm{mg} / \mathrm{kg}$ & 348,431 \\
\hline $\begin{array}{l}\text { SUCROSE OLIGOESTERS, TYPE I AND } \\
\text { TYPE II }\end{array}$ & $473 a$ & 2018 & $5000 \mathrm{mg} / \mathrm{kg}$ & 348,431 \\
\hline SULFITOS & $220-225,539$ & 2006 & $200 \mathrm{mg} / \mathrm{kg}$ & 44 \\
\hline TARTRATOS & 334, 335(ii), 337 & 2018 & $3000 \mathrm{mg} / \mathrm{kg}$ & 45,431 \\
\hline VERDE SÓLIDO FCF & 143 & 1999 & $100 \mathrm{mg} / \mathrm{kg}$ & \\
\hline
\end{tabular}

No. de Categoría de alimento 14.2.7 Bebidas alcohólicas aromatizadas ( $p$. ej. cerveza, vino y bebidas con licor tipo bebida gaseosa, bebidas refrescantes con bajo contenido de alcohol)

\begin{tabular}{|c|c|c|c|c|}
\hline Aditivo & SIN & Año Adoptada & Dosis máxima & Notas \\
\hline ACESULFAME DE POTASIO & 950 & 2007 & $350 \mathrm{mg} / \mathrm{kg}$ & 188 \\
\hline AMARILLO OCASO FCF & 110 & 2008 & $200 \mathrm{mg} / \mathrm{kg}$ & \\
\hline ASPARTAMO & 951 & 2007 & $600 \mathrm{mg} / \mathrm{kg}$ & 191 \\
\hline AZUL BRILLANTE FCF & 133 & 2005 & $200 \mathrm{mg} / \mathrm{kg}$ & \\
\hline BENZOATOS & $210-213$ & 2003 & $1000 \mathrm{mg} / \mathrm{kg}$ & 13 \\
\hline CANTAXANTINA & $161 \mathrm{~g}$ & 2011 & $5 \mathrm{mg} / \mathrm{kg}$ & \\
\hline $\begin{array}{l}\text { CARAMELO III - CARAMELO AL } \\
\text { AMONÍACO }\end{array}$ & $150 c$ & 2010 & $50000 \mathrm{mg} / \mathrm{kg}$ & \\
\hline
\end{tabular}




\begin{tabular}{|c|c|c|c|c|}
\hline \multirow[t]{2}{*}{ No. de Categoría de alimento } & \multicolumn{4}{|c|}{$\begin{array}{l}\text { Bebidas alcohólicas aromatizadas ( } p \text {. } \\
\text { ej. cerveza, vino y bebidas con licor } \\
\text { tipo bebida gaseosa, bebidas } \\
\text { refrescantes con bajo contenido de } \\
\text { alcohol) }\end{array}$} \\
\hline & $\operatorname{SIN}$ & Año Adoptada & Dosis máxima & Notas \\
\hline $\begin{array}{l}\text { CARAMELO IV - CARAMELO AL SULFITO } \\
\text { AMÓNICO }\end{array}$ & $150 d$ & 2011 & $50000 \mathrm{mg} / \mathrm{kg}$ & \\
\hline CARMINES & 120 & 2008 & 200 mg/kg & 178 \\
\hline CAROTENOIDES & $160 a(i), a(i i i), e, f$ & 2009 & 200 mg/kg & \\
\hline CAROTENOS, BETA-, VEGETALES & 160a(ii) & 2005 & $600 \mathrm{mg} / \mathrm{kg}$ & \\
\hline CICLAMATOS & 952(i), (ii), (iv) & 2007 & $250 \mathrm{mg} / \mathrm{kg}$ & 17 \\
\hline DIMETILPOLISILOXANO & $900 a$ & 1999 & $10 \mathrm{mg} / \mathrm{kg}$ & \\
\hline $\begin{array}{l}\text { ÉSTERES DIACETILTARTÁRICOS Y DE } \\
\text { ÁCIDOS GRASOS DE GLICEROL }\end{array}$ & $472 \mathrm{e}$ & 2005 & $10000 \mathrm{mg} / \mathrm{kg}$ & \\
\hline $\begin{array}{l}\text { ÉSTERES POLIGLICÉRIDOS DE ÁCIDOS } \\
\text { GRASOS }\end{array}$ & 475 & 2018 & $20 \mathrm{mg} / \mathrm{kg}$ & \\
\hline ETILEN DIAMINO TETRA ACETATOS & 385,386 & 2007 & $25 \mathrm{mg} / \mathrm{kg}$ & 21 \\
\hline EXTRACTO DE PIEL DE UVA & 163(ii) & 2009 & $300 \mathrm{mg} / \mathrm{kg}$ & 181 \\
\hline GLICÓSIDOS DE ESTEVIOL & $960 a, 960 b(i)$ & 2011 & $200 \mathrm{mg} / \mathrm{kg}$ & 26 \\
\hline HIDROXIBENZOATOS, PARA- & 214,218 & 2012 & $1000 \mathrm{mg} / \mathrm{kg}$ & $27 \& 224$ \\
\hline INDIGOTINA (CARMÍN DE ÍNDIGO) & 132 & 2009 & $200 \mathrm{mg} / \mathrm{kg}$ & \\
\hline NEOTAMO & 961 & 2007 & $33 \mathrm{mg} / \mathrm{kg}$ & \\
\hline POLISORBATOS & $432-436$ & 2007 & $120 \mathrm{mg} / \mathrm{kg}$ & \\
\hline PONCEAU 4R (ROJO DE COCHINILLA A) & 124 & 2008 & $200 \mathrm{mg} / \mathrm{kg}$ & \\
\hline RIBOFLAVINAS & 101(i),(ii), (iii) & 2005 & $100 \mathrm{mg} / \mathrm{kg}$ & \\
\hline ROJO ALLURA AC & 129 & 2009 & $200 \mathrm{mg} / \mathrm{kg}$ & \\
\hline SACARINAS & 954(i)-(iv) & 2007 & $80 \mathrm{mg} / \mathrm{kg}$ & \\
\hline SAL DE ASPARTAMO Y ACESULFAMO & 962 & 2010 & $350 \mathrm{mg} / \mathrm{kg}$ & 113 \\
\hline SORBATOS & $200,202,203$ & 2012 & $500 \mathrm{mg} / \mathrm{kg}$ & $42 \& 224$ \\
\hline $\begin{array}{l}\text { SUCRALOSA } \\
\text { (TRICLOROGALACTOSACAROSA) }\end{array}$ & 955 & 2008 & $700 \mathrm{mg} / \mathrm{kg}$ & 161 \\
\hline SUCROGLICÉRIDOS & 474 & 2012 & $5000 \mathrm{mg} / \mathrm{kg}$ & \\
\hline SULFITOS & $220-225,539$ & 2011 & $250 \mathrm{mg} / \mathrm{kg}$ & 44 \\
\hline TARTRATOS & 334, 335(ii), 337 & 2018 & $4000 \mathrm{mg} / \mathrm{kg}$ & 45 \\
\hline TOCOFEROLES & $307 a, b, c$ & 2018 & $5 \mathrm{mg} / \mathrm{kg}$ & \\
\hline VERDE SÓLIDO FCF & 143 & 1999 & $100 \mathrm{mg} / \mathrm{kg}$ & \\
\hline
\end{tabular}

No. de Categoría de alimento $\mathbf{1 5 . 0}$

\section{Aperitivos listos para el consumo}

\begin{tabular}{|c|c|c|c|c|}
\hline Aditivo & $\sin$ & Año Adoptada & Dosis máxima & Notas \\
\hline ACESULFAME DE POTASIO & 950 & 2007 & $350 \mathrm{mg} / \mathrm{kg}$ & 188 \\
\hline ASPARTAMO & 951 & 2008 & $500 \mathrm{mg} / \mathrm{kg}$ & 191 \\
\hline BUTILHIDROXITOLUENO & 321 & 2006 & $200 \mathrm{mg} / \mathrm{kg}$ & $15 \& 130$ \\
\hline CARAMELO III - CARAMELO AL & $150 c$ & 2009 & $10000 \mathrm{mg} / \mathrm{kg}$ & \\
\hline
\end{tabular}




\begin{tabular}{|c|c|c|c|c|}
\hline \multicolumn{2}{|c|}{ No. de Categoría de alimento 15.0} & \multicolumn{3}{|c|}{ peritivos listos para el consumo } \\
\hline Aditivo & SIN & Año Adoptada & Dosis máxima & Notas \\
\hline $\begin{array}{l}\text { CARAMELO IV - CARAMELO AL SULFITO } \\
\text { AMÓNICO }\end{array}$ & $150 d$ & 2009 & $10000 \mathrm{mg} / \mathrm{kg}$ & \\
\hline CERA CANDELILLA & 902 & 2001 & BPF & 3 \\
\hline CERA CARNAUBA & 903 & 2006 & $200 \mathrm{mg} / \mathrm{kg}$ & 3 \\
\hline CERA DE ABEJAS & 901 & 2001 & BPF & 3 \\
\hline FOSFATOS & $\begin{array}{l}\text { 338; 339(i)-(iii); } \\
340(\mathrm{i})-(\mathrm{iii}) ; 341 \text { (i)- } \\
\text { (iii); 342(i)-(ii); } \\
343 \text { (i)-(iii); 450(i)- } \\
\text { (iii),(v)-(vii), (ix); } \\
\text { 451(i),(ii); 452(i)- } \\
\text { (v); } 542\end{array}$ & 2009 & $2200 \mathrm{mg} / \mathrm{kg}$ & 33 \\
\hline GLICÓSIDOS DE ESTEVIOL & $960 a, 960 b(i)$ & 2011 & $170 \mathrm{mg} / \mathrm{kg}$ & 26 \\
\hline GOMA LACA, BLANQUEADA & 904 & 2001 & BPF & 3 \\
\hline NEOTAMO & 961 & 2007 & $32 \mathrm{mg} / \mathrm{kg}$ & \\
\hline SACARINAS & 954(i)-(iv) & 2007 & $100 \mathrm{mg} / \mathrm{kg}$ & \\
\hline $\begin{array}{l}\text { SUCRALOSA } \\
\text { (TRICLOROGALACTOSACAROSA) }\end{array}$ & 955 & 2008 & $1000 \mathrm{mg} / \mathrm{kg}$ & 161 \\
\hline TARTRATOS & 334, 335(ii), 337 & 2018 & $2000 \mathrm{mg} / \mathrm{kg}$ & 45 \\
\hline TERBUTILHIDROQUINONA & 319 & 2005 & $200 \mathrm{mg} / \mathrm{kg}$ & $15 \& 130$ \\
\hline TIODIPROPIONATOS & 388,389 & 1999 & $200 \mathrm{mg} / \mathrm{kg}$ & 46 \\
\hline
\end{tabular}

\begin{tabular}{|c|c|c|c|c|}
\hline \multirow{2}{*}{$\begin{array}{l}\text { No. de Categoría de alimento } \\
\text { Aditivo }\end{array}$} & \multicolumn{4}{|c|}{$\begin{array}{l}\text { Aperitivos a base de patatas (papas), } \\
\text { cereales, harina o almidón (derivados } \\
\text { de raíces y tubérculos, legumbres y } \\
\text { leguminosas) }\end{array}$} \\
\hline & $\operatorname{SIN}$ & Año Adoptada & Dosis máxima & Notas \\
\hline ALGINATO DE PROPILENGLICOL & 405 & 2018 & $3000 \mathrm{mg} / \mathrm{kg}$ & \\
\hline AMARILLO OCASO FCF & 110 & 2008 & 200 mg/kg & \\
\hline AZUL BRILLANTE FCF & 133 & 2005 & $200 \mathrm{mg} / \mathrm{kg}$ & \\
\hline BENZOATOS & $210-213$ & 2004 & $1000 \mathrm{mg} / \mathrm{kg}$ & 13 \\
\hline BUTILHIDROXIANISOL & 320 & 2005 & $200 \mathrm{mg} / \mathrm{kg}$ & $15 \& 130$ \\
\hline CANTAXANTINA & $161 \mathrm{~g}$ & 2011 & $45 \mathrm{mg} / \mathrm{kg}$ & \\
\hline CARMINES & 120 & 2005 & $200 \mathrm{mg} / \mathrm{kg}$ & 178 \\
\hline CAROTENOIDES & $160 a(i), a(i i i), e, f$ & 2010 & $100 \mathrm{mg} / \mathrm{kg}$ & \\
\hline CAROTENOS, BETA-, VEGETALES & $160 a(i i)$ & 2009 & $100 \mathrm{mg} / \mathrm{kg}$ & \\
\hline CICLODEXTRINA, BETA- & 459 & 2004 & $500 \mathrm{mg} / \mathrm{kg}$ & \\
\hline $\begin{array}{l}\text { CLOROFILAS Y CLOROFILINAS, } \\
\text { COMPLEJOS CUPRICOS }\end{array}$ & 141(i),(ii) & 2009 & $350 \mathrm{mg} / \mathrm{kg}$ & \\
\hline DIACETATO DE SODIO & 262(ii) & 2018 & $1000 \mathrm{mg} / \mathrm{kg}$ & \\
\hline ESTEAROIL LACTILATOS & $481(\mathrm{i}), 482(\mathrm{i})$ & 2018 & $5000 \mathrm{mg} / \mathrm{kg}$ & 432 \\
\hline ÉSTERES DE ASCORBILO & 304,305 & 2001 & $200 \mathrm{mg} / \mathrm{kg}$ & 10 \\
\hline $\begin{array}{l}\text { ÉSTERES DE SORBITÁN DE ÁCIDOS } \\
\text { GRASOS }\end{array}$ & 491-495 & 2018 & $300 \mathrm{mg} / \mathrm{kg}$ & \\
\hline $\begin{array}{l}\text { ÉSTERES DIACETILTARTÁRICOS Y DE } \\
\text { ÁCIDOS GRASOS DE GLICEROL }\end{array}$ & $472 e$ & 2005 & 20000 mg/kg & \\
\hline
\end{tabular}



leguminosas)

\begin{tabular}{|c|c|c|c|c|}
\hline Aditivo & SIN & Año Adoptada & Dosis máxima & Notas \\
\hline $\begin{array}{l}\text { ÉSTERES POLIGLICÉRIDOS DE ÁCIDOS } \\
\text { GRASOS }\end{array}$ & 475 & 2018 & $2000 \mathrm{mg} / \mathrm{kg}$ & \\
\hline EXTRACTO DE PIEL DE UVA & 163(ii) & 2009 & $500 \mathrm{mg} / \mathrm{kg}$ & 181 \\
\hline GALATO DE PROPILO & 310 & 2005 & $200 \mathrm{mg} / \mathrm{kg}$ & $15 \& 130$ \\
\hline HIDROXIBENZOATOS, PARA- & 214,218 & 2009 & $300 \mathrm{mg} / \mathrm{kg}$ & 27 \\
\hline INDIGOTINA (CARMÍN DE ÍNDIGO) & 132 & 2009 & $200 \mathrm{mg} / \mathrm{kg}$ & \\
\hline ÓXIDOS DE HIERRO & 172(i)-(iii) & 2005 & $500 \mathrm{mg} / \mathrm{kg}$ & \\
\hline PONCEAU 4R (ROJO DE COCHINILLA A) & 124 & 2008 & $200 \mathrm{mg} / \mathrm{kg}$ & \\
\hline PROPILENGLICOL & 1520 & 2018 & $300 \mathrm{mg} / \mathrm{kg}$ & \\
\hline RIBOFLAVINAS & 101(i),(ii), (iii) & 2005 & $1000 \mathrm{mg} / \mathrm{kg}$ & \\
\hline ROJO ALLURA AC & 129 & 2009 & $200 \mathrm{mg} / \mathrm{kg}$ & 161 \\
\hline SORBATOS & $200,202,203$ & 2009 & $1000 \mathrm{mg} / \mathrm{kg}$ & 42 \\
\hline SUCROÉSTERES DE ÁCIDOS GRASOS & 473 & 2018 & $5000 \mathrm{mg} / \mathrm{kg}$ & 348,433 \\
\hline SUCROGLICÉRIDOS & 474 & 2018 & $5000 \mathrm{mg} / \mathrm{kg}$ & 348,433 \\
\hline $\begin{array}{l}\text { SUCROSE OLIGOESTERS, TYPE I AND } \\
\text { TYPE II }\end{array}$ & $473 a$ & 2018 & $5000 \mathrm{mg} / \mathrm{kg}$ & 348,433 \\
\hline SULFITOS & $220-225,539$ & 2006 & $50 \mathrm{mg} / \mathrm{kg}$ & 44 \\
\hline TOCOFEROLES & $307 a, b, c$ & 2018 & $200 \mathrm{mg} / \mathrm{kg}$ & \\
\hline
\end{tabular}

\begin{tabular}{|c|c|c|c|c|}
\hline \multicolumn{2}{|c|}{ No. de Categoría de alimento 15.2} & \multicolumn{3}{|c|}{$\begin{array}{l}\text { Nueces elaboradas, incluidas las } \\
\text { nueces revestidas y las mezclas de } \\
\text { nueces (p. ej. con frutas secas) }\end{array}$} \\
\hline Aditivo & SIN & Año Adoptada & Dosis máxima & Notas \\
\hline AZUL BRILLANTE FCF & 133 & 2005 & $100 \mathrm{mg} / \mathrm{kg}$ & \\
\hline BUTILHIDROXIANISOL & 320 & 2005 & $200 \mathrm{mg} / \mathrm{kg}$ & $15 \& 130$ \\
\hline CARMINES & 120 & 2005 & $100 \mathrm{mg} / \mathrm{kg}$ & 178 \\
\hline CAROTENOIDES & $160 a(i), a(i i i), e, f$ & 2009 & $100 \mathrm{mg} / \mathrm{kg}$ & \\
\hline CAROTENOS, BETA-, VEGETALES & $160 a(i i)$ & 2011 & $20000 \mathrm{mg} / \mathrm{kg}$ & 3 \\
\hline $\begin{array}{l}\text { CLOROFILAS Y CLOROFILINAS, } \\
\text { COMPLEJOS CUPRICOS }\end{array}$ & $141(\mathrm{i}),(\mathrm{ii})$ & 2009 & $100 \mathrm{mg} / \mathrm{kg}$ & \\
\hline ÉSTERES DE ASCORBILO & 304,305 & 2001 & $200 \mathrm{mg} / \mathrm{kg}$ & 10 \\
\hline $\begin{array}{l}\text { ÉSTERES DIACETILTARTÁRICOS Y DE } \\
\text { ÁCIDOS GRASOS DE GLICEROL }\end{array}$ & $472 e$ & 2005 & $10000 \mathrm{mg} / \mathrm{kg}$ & \\
\hline EXTRACTO DE PIEL DE UVA & 163(ii) & 2009 & $300 \mathrm{mg} / \mathrm{kg}$ & 181 \\
\hline GALATO DE PROPILO & 310 & 2005 & $200 \mathrm{mg} / \mathrm{kg}$ & $15 \& 130$ \\
\hline HIDROXIBENZOATOS, PARA- & 214,218 & 2010 & $300 \mathrm{mg} / \mathrm{kg}$ & 27 \\
\hline INDIGOTINA (CARMÍN DE ÍNDIGO) & 132 & 2009 & $100 \mathrm{mg} / \mathrm{kg}$ & \\
\hline ÓXIDOS DE HIERRO & 172(i)-(iii) & 2005 & $400 \mathrm{mg} / \mathrm{kg}$ & \\
\hline PONCEAU 4R (ROJO DE COCHINILLA A) & 124 & 2008 & $100 \mathrm{mg} / \mathrm{kg}$ & \\
\hline RIBOFLAVINAS & 101(i),(ii), (iii) & 2005 & $1000 \mathrm{mg} / \mathrm{kg}$ & \\
\hline
\end{tabular}


No. de Categoría de alimento $15.2 \quad$ Nueces elaboradas, incluidas las nueces revestidas y las mezclas de nueces (p. ej. con frutas secas)

\begin{tabular}{|c|c|c|c|c|}
\hline Aditivo & $\operatorname{SiN}$ & Año Adoptada & Dosis máxima & Notas \\
\hline ROJO ALLURA AC & 129 & 2009 & 100 mg/kg & \\
\hline SORBATOS & $200,202,203$ & 2009 & $1000 \mathrm{mg} / \mathrm{kg}$ & 42 \\
\hline TOCOFEROLES & $307 a, b, c$ & 2018 & 200 mg/kg & \\
\hline
\end{tabular}

No. de Categoría de alimento $15.3 \quad$ Aperitivos a base de pescado

\begin{tabular}{|c|c|c|c|c|}
\hline Aditivo & SIN & Año Adoptada & Dosis máxima & Notas \\
\hline CARMINES & 120 & 2009 & $200 \mathrm{mg} / \mathrm{kg}$ & 178 \\
\hline CAROTENOS, BETA-, VEGETALES & $160 a(i i)$ & 2010 & $100 \mathrm{mg} / \mathrm{kg}$ & \\
\hline $\begin{array}{l}\text { CLOROFILAS Y CLOROFILINAS, } \\
\text { COMPLEJOS CUPRICOS }\end{array}$ & 141(i),(ii) & 2009 & $350 \mathrm{mg} / \mathrm{kg}$ & \\
\hline EXTRACTO DE PIEL DE UVA & 163(ii) & 2011 & $400 \mathrm{mg} / \mathrm{kg}$ & \\
\hline
\end{tabular}




\section{Notas a la Norma general para los aditivos alimentarios}

$\begin{array}{ll}\text { Nota } & 1 \\ \text { Nota } & 2 \\ \text { Nota } & 3 \\ \text { Nota } & 4 \\ \text { Nota } & 5 \\ & \\ \text { Nota } & 6 \\ \text { Nota } & 7 \\ \text { Nota } & 8 \\ \text { Nota } & 9 \\ \text { Nota } & 10 \\ \text { Nota } & 11 \\ \text { Nota } & 12 \\ \text { Nota } & 13 \\ \text { Nota } & 14 \\ \text { Nota } & 15 \\ \text { Nota } & 16 \\ & \\ \text { Nota } & 17 \\ \text { Nota } & 18 \\ & \\ \text { Nota } & 19\end{array}$

Nota 20

Nota 21

Nota 22

Nota 23

Nota 24

Nota 25

Nota 26

Nota 27

Nota 28

Nota 29

Nota 30

Nota 31

Nota 32

Nota 33

Nota 34

Nota 35

Nota 36
Como ácido adípico.

Sobre la base del ingrediente seco, peso en seco, mezcla seca, o concentrado.

Para uso en tratamiento superficial solamente.

Para uso en decoración, sellado, marcado o marcado a fuego del producto solamente.

Quedan excluidos los productos que corresponden a la Norma para las confituras, jaleas y mermeladas (CODEX STAN 296-2009).

Como aluminio.

Para uso en sucedáneos del café solamente.

Como bixina.

Excepto para uso en productos de café listos para el consumo a 10000 mg/kg.

Como estearato de ascorbilo.

Sobre la base de la harina.

Como resultado de transferencia procedente de sustancias aromatizantes.

Como ácido benzoico.

Sólo para su uso en preparados líquidos a base de proteína hidrolizada.

Sobre la base de las grasas o los aceites.

Para uso en el glaseado, rebozado o decoración de frutas, hortalizas, carnes o pescados solamente.

Como ácido ciclámico.

Como dosis añadida; residuos no detectados en los alimentos listos para el consumo.

Para uso en productos que corresponden a la Norma para los camarones congelados rápidamente (CODEX STAN 92-1981) y a la Norma para las langostas congeladas rápidamente (CODEX STAN 95-1981): dióxido de azufre (SIN 220), sulfito de sodio (SIN 221), hidrogensulfito de sodio (SIN 222), metabisulfito de sodio (SIN 223), pirosulfito potásico (INS 224), y sulfito de potasio (SIN 225) como conservantes en dosis de $100 \mathrm{mg} / \mathrm{kg}$ en la parte comestible del producto crudo, 0 $30 \mathrm{mg} / \mathrm{kg}$ en la parte comestible del producto cocido.

Excepto para uso en los productos regulados por la Norma para pescado salado y pescado seco salado de la familia Gadidae (CODEX STAN 167-1989), la Norma para el arenque del Atlántico salado y el espadín salado ( CODEX STAN 244-2004) a $200 \mathrm{mg} / \mathrm{kg}$, y en el pescado ahumado y pescado con sabor a humo en los productos regulados por la Norma para el pescado ahumado, pescado con sabor a humo y pescado secado con humo (CODEX STAN 311-2013) a $2000 \mathrm{mg} / \mathrm{kg}$ para productos envasados con oxígeno reducido solamente.

Como etilendiamitetraacetato de cálcio disódico.

Sólo para uso en productos pesqueros ahumados.

Como hierro.

Como ferrocianuro de sodio anhidro.

Para uso a BPF únicamente en harinas de soya con toda su grasa.

Como equivalentes de esteviol.

Como ácido para-hidroxibenzoico.

Excepto para uso en harinas de trigo que correspondan a la Norma para la harina de trigo (CODEX STAN 152-1985) a $2000 \mathrm{mg} / \mathrm{kg}$.

Para alimentos no normalizados únicamente.

Como ion residual de NO3.

Sobre la base del puré que se use.

Como ion residual de NO2.

Como fósforo.

Sobre la base el anhidro.

Sólo para uso en los zumos (jugos) turbios.

Sobre la base de la dosis residual. 


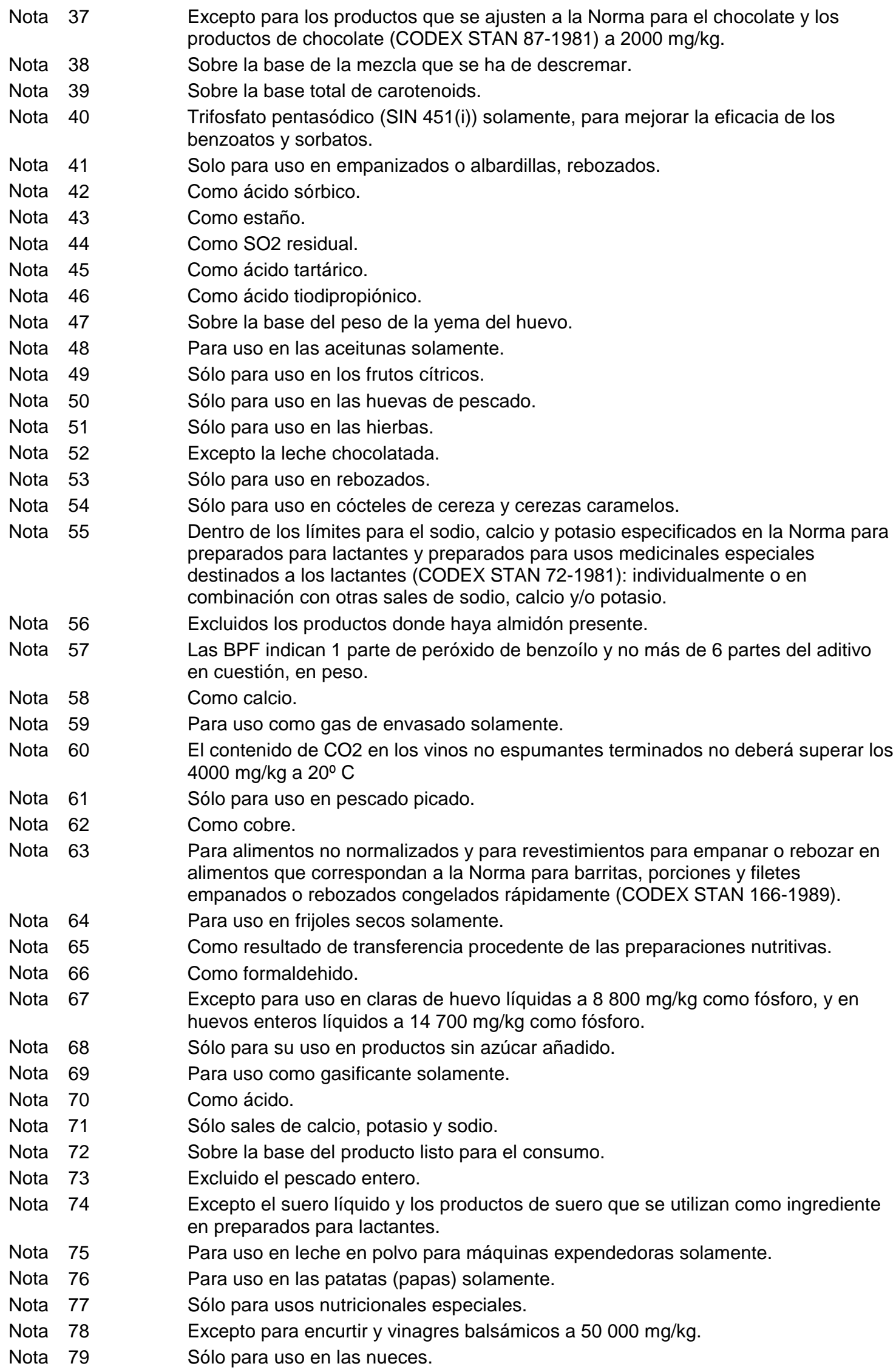


Nota 80

Nota 81

Nota 82

Nota 83

Nota 84

Nota 85

Nota 86

Nota 87

Nota 88

Nota 89

Nota 90

Nota 91

Nota 92

Nota 93

Nota 94

Nota 95

Nota 96

Nota 97

Nota 98

Nota 99

Nota 100

Nota 101

Nota 102

Nota 103

Nota 104

Nota 105

Nota 106

Nota 107

Nota 108

Nota 109

Nota 110

Nota 111

Nota 112
Equivalente a una aplicación superficial de $2 \mathrm{mg} / \mathrm{dm} 2$ por una profundidad máxima de $5 \mathrm{~mm}$.

Equivalente a una aplicación superficial de $1 \mathrm{mg} / \mathrm{dm} 2$ por una profundidad máxima de $5 \mathrm{~mm}$.

Excepto para uso en camarones, (Crangon crangon y Crangon vulgaris) a 6000 $\mathrm{mg} / \mathrm{kg}$.

Sólo la forma $L(+)$

Para uso en productos para lactantes mayores de 1 año de edad solamente.

Dosis de utilización en embutidos de tripas comestibles; los residuos en las salchichas preparadas con esas tripas no deberán exceder $100 \mathrm{mg} / \mathrm{kg}$.

Para uso en aderezos batidos para postres, distintos a la crema (nata) solamente. Sobre la base de la dosis de tratamiento.

Como resultado de transferencia procedente del ingrediente.

Para uso en productos para untar en emparedados solamente.

Para uso en mezclas de leche y sacarosa utilizadas en el producto terminado solamente.

Separados o combinados: Benzoatos y sorbatos.

Excepto las salsas a base de tomate.

Excluido el vino natural producido a partir de las uvas Vitis vinifera.

Sólo para uso en longaniza (embutido fresco, sin curar).

Para uso en alimentos no normalizados: sólo para uso en productos de surimi y huevas de pescado.

Sobre la base del peso seco de un edulcorante de alta intensidad.

Sobre la base de los productos finales a base de cacao y productos del chocolate.

Para uso en el control del polvo solamente.

Para uso en productos regulados por la Norma del Codex para los "bouillons" y consomés (CODEX STAN 117-1981) únicamente.

Para uso en productos cristalinos y cubiertas de azúcar solamente.

Cuando se usan en combinación como emulsionantes: sales amónicas del ácido fosfatídico (SIN 442), ésteres poliglicéridos de ácido ricinoléico interesterificado (SIN 476), monoestearato de sorbitán (SIN 491), triestearato de sorbitán (SIN 492) y polisorbatos (polioxietileno (20) monolaurato de sorbitán (INS 432), polioxietileno (20) monooleato de sorbitán (SIN 433), polioxietileno (20) monostearato de sorbitán (SIN 435) y polioxietileno (20) triestearato de sorbitán (SIN 436)), el total del nivel de uso combinado no excederá de $15000 \mathrm{mg} / \mathrm{kg}$.

Sólo para uso en emulsiones de grasa para hornear.

Excepto para uso en vinos blancos especiales a $400 \mathrm{mg} / \mathrm{kg}$.

Excluidas las peras en conserva (excepto para uso en envases especiales de vacaciones) y piña en conserva reguladas por la Norma para algunas frutas en conserva (CODEX STAN 319-2015).

Excepto para uso en tiras de calabaza (calabacín) secas (Kampyo) a $5000 \mathrm{mg} / \mathrm{kg}$. Excepto para uso en mostaza de Dijon a $500 \mathrm{mg} / \mathrm{kg}$.

Excepto para uso de ferrocianuro de sodio (SIN 535) en sal dendrítica de calidad alimentaria en un nivel de $29 \mathrm{mg} / \mathrm{kg}$ como ferrocianuro de sodio anhidro.

Sólo para uso en café en grano.

Dosis de utilización expresada como $25 \mathrm{lbs} / 1000 \mathrm{gal} \times(0.45 \mathrm{~kg} / \mathrm{lb}) \times(1 \mathrm{gal} / 3.75 \mathrm{~L})$ $x(1 \mathrm{~L} / \mathrm{kg}) \times(10 \mathrm{E} 6 \mathrm{mg} / \mathrm{kg})=3000 \mathrm{mg} / \mathrm{kg}$.

Sólo para uso en patatas (papas) fritas congeladas.

Excepto para uso en jarabe de glucosa seco usado en la fabricación de confitería de azúcar a $150 \mathrm{mg} / \mathrm{kg}$ y jarabe de glucosa usado en la fabricación de confitería de azúcar a $400 \mathrm{mg} / \mathrm{kg}$.

Sólo para uso en queso rallado. 
Nota 113

Nota 114

Nota 115

Nota 116

Nota 117

Nota 118

Nota 119

Nota 120

Nota 121

Nota 122

Nota 123

Nota 124

Nota 125

Nota 126

Nota 127

Nota 128

Nota 129

Nota 130

Nota 131

Nota 132

Nota 133

Nota 134

Nota 135

Nota 136

Nota 137

Nota 138

Nota 139

Nota 140

Nota 141

Nota 142

Nota 143

Nota 144
Como equivalentes de acesulfame potásico (la dosis máxima registrada puede convertirse a una base de sal de aspartamo y acesulfame dividiéndola por 0,44). El uso combinado de la sal de aspartamo y acesulfame con acesulfame potásico o aspartamo individual no debe ser superior a las dosis máximas individuales para acesulfame potásico o aspartamo (la dosis máxima de uso registrada puede convertirse al equivalente de aspartamo dividiéndola por 0,68 ).

Excepto para uso en micropastillas y pastillas de menta para refrescar el aliento en dosis de $100 \mathrm{mg} / \mathrm{kg}$.

Sólo para uso en el zumo (jugo) de piña.

Sólo para el uso en masas.

Excepto para uso en longaniza (embutido fresco, sin curar) a $1000 \mathrm{mg} / \mathrm{kg}$.

Excepto para uso en tocino (embutido fresco, curado) a $1000 \mathrm{mg} / \mathrm{kg}$.

Como equivalentes de aspartamo (la dosis máxima registrada puede convertirse a una base de sal de aspartamo y acesulfame dividiéndola por 0,64). El uso combinado de la sal de aspartamo y acesulfame con aspartamo o acesulfame potásico individual no debe ser superior a las dosis máximas individuales para aspartamo o acesulfame potásico (la dosis máxima de uso registrada puede convertirse a equivalentes de acesulfame potásico dividiéndola por 0,68).

Excepto para uso en sucedáneos de caviar a $2500 \mathrm{mg} / \mathrm{kg}$.

Excepto para uso en productos pesqueros fermentados a $1000 \mathrm{mg} / \mathrm{kg}$.

Sujeto a las leyes nacionales del país importador.

Para el uso de monoestearato de sorbitán (SIN 491), triestearato de sorbitán (SIN 492), monolaurato de sorbitán (SIN 493), monooleato de sorbitán (SIN 494) y monopalmitato de sorbitán (SIN 495) en combinación hasta un nivel máximo dea $2000 \mathrm{mg} / \mathrm{kg}$ en la base final de cacao y de chocolate como emulsionantes en productos que correspondan a la Norma para el cacao en polvo (cacaos) y las mezclas de cacao y azúcares (CODEX STAN 105-1981).

Para uso en productos que contienen menos de $7 \%$ de etanol solamente.

Para uso en una mezcla con aceite vegetal solo, como agente antiadherente para moldes para hornear.

Para uso en efectos antiadherentes en la masa, al dividirla y hornearla solamente. Sobre la base que se sirve al consumidor.

Ácido tartárico (SIN 334) solamente.

Para uso como un regulador de la acidez en el zumo (jugo) de uva solamente. Individualmente o en combinación: butilhidroxianisol (INS 320), butilhidroxitolueno (INS 321), terbutilhidroquinona (INS 319), y galato de propilo (INS 310).

Para uso como sustancia inerte aromatizante solamente.

Excepto para uso en bebidas semicongeladas a $130 \mathrm{mg} / \mathrm{kg}$ sobre una base seca.

Toda combinación de butilhidroxianisol (SIN 320), butilhidroxitolueno (SIN 321) y galato de propilo (SIN 310) en una dosis de $200 \mathrm{mg} / \mathrm{kg}$, siempre que no se superen las doses individuales de uso.

Excepto para uso en pudines a base de cereales a $500 \mathrm{mg} / \mathrm{kg}$.

Excepto para uso en albaricoques secos con un nivel de $2000 \mathrm{mg} / \mathrm{kg}$, uvas pasas blanqueadas en un nivel de $1500 \mathrm{mg} / \mathrm{kg}$, coco desecado en un nivel de $200 \mathrm{mg} / \mathrm{kg}$, y coco del que se ha extraído parcialmente el aceite en un nivel de $50 \mathrm{mg} / \mathrm{kg}$.

Para uso para prevenir el pardeamiento de ciertas hortalizas de color claro solamente.

Excepto para uso en aguacate congelado en un nivel de $300 \mathrm{mg} / \mathrm{kg}$.

Para uso en productos de contenido energético reducido únicamente.

Sólo para uso en productos de contenido energético reducido.

Sólo para uso en moluscos, crustáceos y equinodermos.

Excluidas las peras en conserva y piña en conserva reguladas por la Norma para algunas frutas en conserva (CODEX STAN 319-2015).

Excepto el café y el té.

Sólo para uso en bebidas a base de zumo (jugo) de frutas y dry ginger ale.

Sólo para uso en productos agridulces. 


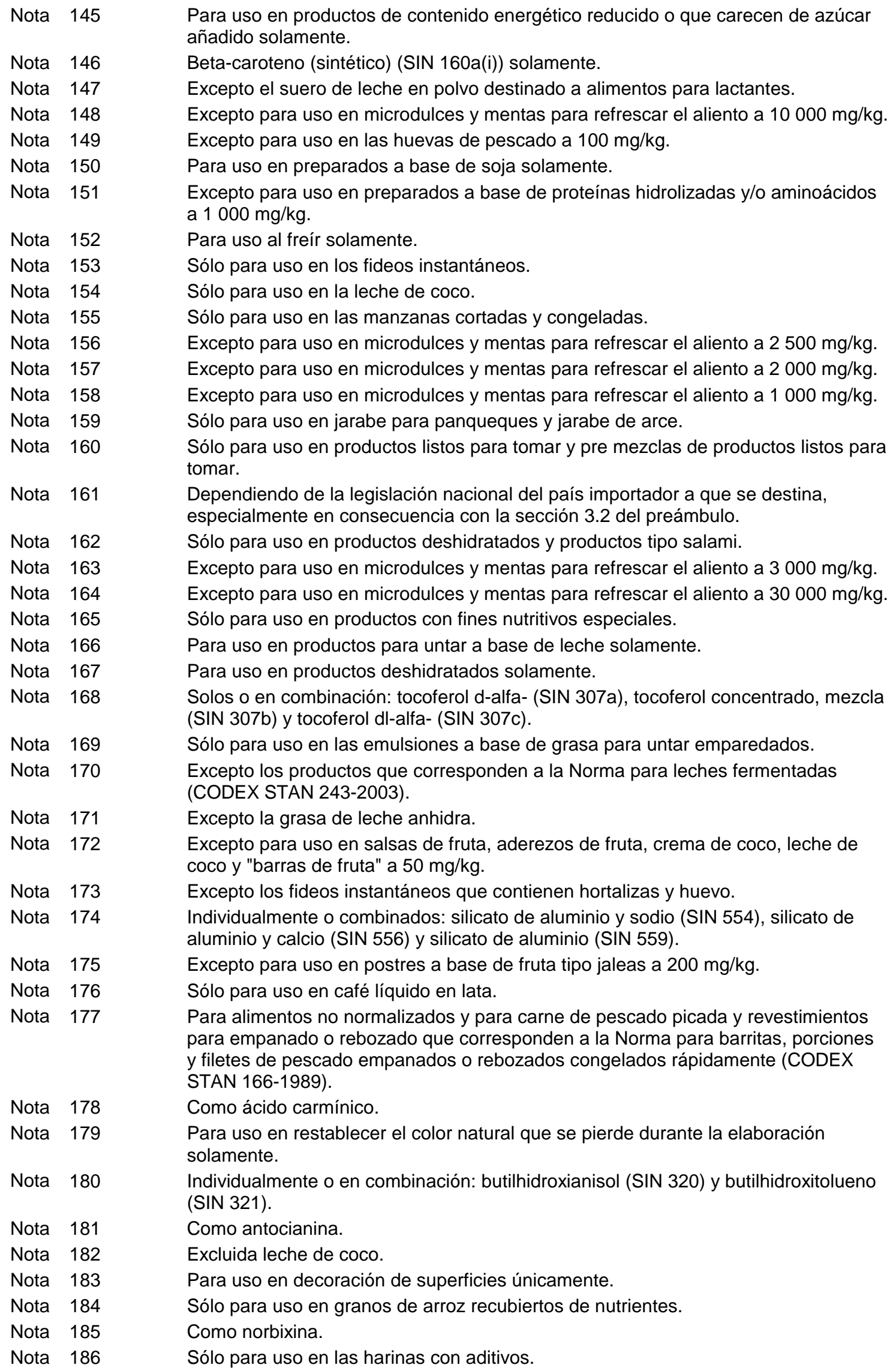


Nota 187

Nota 188

Nota 189

Nota 190

Nota 191

Nota 192

Nota 193

Nota 194

Nota 195

Nota 196

Nota 197

Nota 198

Nota 199

Nota 200

Nota 201

Nota 202

Nota 203

Nota 204

Nota 205

Nota 206

Nota 207

Nota 208

Nota 209

Nota 210

Nota 211

Nota 212

Nota 213

Nota 214

Nota 215

Nota 216

Nota 217

Nota 218
Sólo para SIN 304 (palmitato de ascorbilo).

Si se utiliza en combinación con la sal de aspartamo y acesulfamo (SIN 962), la dosis máxima de uso combinada, expresada como acesulfame de potasio, no será superior a esta dosis.

Excepto los copos de avena.

Excepto para uso en bebidas a base de leche fermentada a $500 \mathrm{mg} / \mathrm{kg}$.

Si se utiliza en combinación con la sal de aspartamo y acesulfamo (SIN 962), la dosis máxima de uso combinada, expresada como aspartamo, no será superior a esta dosis.

Para uso en productos líquidos solamente.

Sólo para uso en pastas de crustáceos o de pescado.

Para uso en fideos instantáneos de conformidad con la Norma para fideos instantáneos (CODEX STAN 249-2006) solamente.

Individualmente o en combinación: butilhidroxianisol (SIN 320), butilhidroxitolueno (SIN 321) y terbutilhidroquinona (SIN 319).

Individualmente o en combinación: butilhidroxianisol (SIN 320), butilhidroxitolueno (SIN 321) y galato de propilo (SIN 310).

Individualmente o en combinación: butilhidroxitolueno (SIN 321) y galato de propilo (SIN 310).

Para uso en productos sólidos (p.ej., barras energéticas, sustituyentes de comidas o enriquecidas) solamente.

Excepto para uso en microdulces y mentas para refrescar el aliento a $6000 \mathrm{mg} / \mathrm{kg}$ como equivalentes de esteviol.

Excepto para uso en el "jamón asalmonado" o filete de cerdo (curado y sin haber recibido tratamiento térmico) en dosis de $120 \mathrm{mg} / \mathrm{kg}$ como equivalentes de esteviol. Sólo para uso en productos aromatizados.

Sólo para uso en la salmuera para la producción de embutidos.

Sólo para uso en complementos masticables.

Excepto para en longans y lichis a $50 \mathrm{mg} / \mathrm{kg}$.

Excepto para uso para prevenir la coloración café de algunas hortalizas de color claro a $50 \mathrm{mg} / \mathrm{kg}$.

Excepto para uso como blanqueador en productos que corresponden a la Norma para los productos acuosos de coco (CODEX STAN 240-2003) a $30 \mathrm{mg} / \mathrm{kg}$.

Excepto para uso en la salsa de soja destinada a ulterior elaboración a 50000 $\mathrm{mg} / \mathrm{kg}$.

Sólo para uso en productos secos y deshidratados.

Quedan excluidos los productos que corresponden a la Norma para mezclas de leche desnatada (descremada) y grasa vegetal en polvo (CODEX STAN 251 2006).

Para alimentos no normalizados y para uso como humectante en productos que corresponden a la Norma para barritas, porciones y filetes de pescado empanados o rebozados congelados rápidamente (CODEX STAN 166-1989); y para uso como espesante en empanados o rebozados para productos que correspondan a la Norma para barritas, porciones y filetes de pescado empanados o rebozados congelados rápidamente (CODEX STAN 166-1989).

Sólo para uso en los fideos.

Excepto para uso en los productos que corresponden a la Norma para los "bouillons" y consomés (CODEX STAN 117-1981) a dosis de $3000 \mathrm{mg} / \mathrm{kg}$.

Sólo para uso en productos líquidos que contengan edulcorantes de alta intensidad.

Excepto los productos que corresponden a la Norma para materias grasas lácteas para untar (CODEX STAN 253-2006).

Excepto los productos que corresponden a la Norma para grasas para untar y mezclas de grasas para untar (CODEX STAN 256-2007).

Sólo para uso en productos a base de maíz.

Excepto para uso en cubiertas a $300 \mathrm{mg} / \mathrm{kg}$.

En los productos regulados por la Norma para el Coco Rallado Desecado solamente pueden utilizarse sulfitos como conservantes y antioxidantes (CODEX STAN 177-1991). 
Nota 219

Nota 220

Nota 221

Nota 222

Nota 223

Nota 224

Nota 225

Nota 226

Nota 227

Nota 228

Nota 229

Nota 230

Nota 231

Nota 232

Nota 233

Nota 234

Nota 235

Nota 236

Nota 237

Nota 238

Nota 239

Nota 240

Nota 241

Nota 242

Nota 243

Nota 244

Nota 245

Nota 246

Nota 247

Nota 248

Nota 249

Nota 250

Nota 251

Nota 252

Nota 253
Excepto para uso en bebidas no alcohólicas a base de anís, coco y almendras a 5 $000 \mathrm{mg} / \mathrm{kg}$.

Para uso en productos aromatizados tratados térmicamente después de fermentación solamente.

Para uso en pasta de patatas (papas) y rodajas de patatas prefritas solamente.

Para uso en cubiertas a base de colágeno con una actividad acuosa superior a 0,6 solamente.

Excepto para uso en productos que contienen frutas, hortalizas o carnes añadidas a $3000 \mathrm{mg} / \mathrm{kg}$.

Excluida la cerveza aromatizada.

Excepto para uso en harina autoleudante a $12.000 \mathrm{mg} / \mathrm{kg}$.

Excepto para uso como ablandador de la carne a $35.000 \mathrm{mg} / \mathrm{kg}$.

Para uso en leches esterilizadas y UHT solamente.

Excepto para uso para estabilizar el suero líquido de alto contenido en proteínas utilizado para la elaboración de concentrados de proteínas de suero a $1320 \mathrm{mg} / \mathrm{kg}$.

Para uso como agente de tratamiento de las harinas, leudante o agente de fermentación solamente.

Para uso como regulador de la acidez solamente.

Para uso en leches fermentadas aromatizadas y leches fermentadas aromatizadas tratadas térmicamente después de la fermentación solamente.

Para uso en grasas de hortalizas conforme a la Norma general para grasas y aceites comestibles no regulados por normas individuales (CODEX STAN 19-1981), solamente.

Como nisina.

Para uso como un estabilizador o espesante solamente.

Para uso como un estabilizador o espesante solamente.

Excluidos los productos regulados por la Norma para las Natas (Cremas) y las Natas (Cremas) Preparadas (nata (crema) recombinada, nata (crema) líquida preenvasada) (CODEX STAN 288-1976).

Excluidos los productos regulados por la Norma para Alimentos Elaborados a base de Cereales para Lactantes y Niños Pequeños (CODEX STAN 74-1981).

Excepto para uso en productos correspondientes a la Norma para Alimentos Elaborados a base de Cereales para Lactantes y Niños Pequeños (CODEX STAN 74-1981) según BPF.

Excluidos los productos regulados por la Norma para Alimentos Envasados para Lactantes y Niños (CODEX STAN 73-1981).

La dosis de uso está dentro del límite para sodio que se indica en la Norma para Alimentos Envasados para Lactantes y Niños (CODEX STAN 73-1981).

Para uso en productos de surimi únicamente.

Para uso como antioxidante solamente.

Para uso en productos regulados por la Norma para Alimentos Elaborados a base de Cereales para Lactantes y Niños Pequeños (CODEX STAN 74-1981) solamente, como leudante.

Para uso en masa para galletas solamente.

Para uso en hortalizas encurtidas en salmuera solamente.

Individualmente o en combinación: sulfato de aluminio y amonio (SIN 523) y fosfato de aluminio y sodio (ácido y básico; (SIN 541(i), (ii)).

Sólo para uso en "kuzukiri" y harusame.

Para uso como leudante solamente.

Para uso como leudante en mezclas para panes y bollos dulces al vapor solamente.

Sólo para uso en moluscos y tsukudani cocidos.

Sólo para uso en queso americano elaborado.

Sólo para uso en harina autoleudante y harina de maíz autoleudante.

Para alimentos no normalizados y para uso en carne picada de pescado, únicamente en productos que corresponden a la Norma para barritas, porciones y filetes de pescado empanados o rebozados congelados rápidamente (CODEX STAN 166-1989). 
Nota 254

Nota 255

Nota 256

Nota 257

Nota 258

Nota 259

Nota 260

Nota 261

Nota 262

Nota 263

Nota 264

Nota 265

Nota 266

Nota 267

Nota 268

Nota 269

Nota 270

Nota 271

Nota 272

Nota 273

Nota 274

Nota 275

Nota 276

Nota 277

Nota 278

Nota 279

Nota 280
Para uso en sal aplicada a quesos secos salados durante la fabricación solamente. Excepto para uso en aderezos aplicados a alimentos de la categoría de alimentos 15.1 a $1700 \mathrm{mg} / \mathrm{kg}$.

Sólo para uso en fideos, pasta sin gluten y pasta destinada a dietas hipoproteicas.

Excepto para uso en empanados o rebozados en los productos que corresponden a la Norma para barritas, porciones y filetes de pescado empanados o rebozados congelados rápidamente (CODEX STAN 166-1989), sólo en dosis de 25 mg(kg como bixina.

Excluido jarabe de arce.

Individualmente o en combinación: silicato de aluminio y sodio (SIN 554) y silicato de aluminio y calcio (SIN 556).

Sólo para uso en blanqueadores de bebidas en polvo.

Sólo para uso en suero de mantequilla sometido a tratamiento térmico.

Para uso en hongos comestibles y productos de hongos solamente.

Excepto para uso en hongos encurtidos en salmuera a $20000 \mathrm{mg} / \mathrm{kg}$.

Excepto para uso en hongos esterilizados a 5000 mg/kg: ácido cítrico (SIN 330) y ácido láctico (SIN 270), individualmente o en combinación.

Para uso en patatas (papas) fritas francesas congeladas rápidamente solamente, como secuestrante.

Excluidos los mangos en conserva y las peras en conserva regulados por la Norma para algunas frutas en conserva (CODEX STAN 319-2015).

Excluidos los productos regulados por la Norma para algunas frutas en conserva (CODEX STAN 319-2015), excepto para uso en envases especiales de vacaciones para peras en conserva reguladas por la norma.

Separados o combinados: SIN 471, 472a, 472 b y 472 c en productos que correspondan a la Norma para alimentos elaborados a base de cereales para lactantes y niños pequeños (CODEX STAN 74-1981).

Separados o combinados con otros almidones modificados utilizados como espesantes en productos que corresponden a la Norma para alimentos elaborados a base de cereales para lactantes y niños pequeños (CODEX STAN 74-1981).

Para uso a $60000 \mathrm{mg} / \mathrm{kg}$, separados o combinados con otros almidones espesantes en productos que corresponden a la Norma para alimentos envasados para lactantes y niños (CODEX STAN 73-1981).

Para uso en productos que corresponden a la Norma para alimentos envasados para lactantes y niños (CODEX STAN 73-1981).

Separados o combinados: SIN 410, 412, 414, 415 y 440 a 20000 mg/kg en alimentos sin gluten a base de cereales, y $10000 \mathrm{mg} / \mathrm{kg}$ en otros productos que correspondan a la Norma para alimentos elaborados a base de cereales para lactantes y niños pequeños (CODEX STAN 74-1981).

Separados o combinados: SIN 410, 412, 414, 415 y 440 excepto para uso a 20000 $\mathrm{mg} / \mathrm{kg}$ en alimentos sin gluten a base de cereales que correspondan a la Norma para alimentos elaborados a base de cereales para lactantes y niños pequeños (CODEX STAN 74-1981).

Para uso a $15000 \mathrm{mg} / \mathrm{kg}$ en productos que correspondan a la Norma para alimentos elaborados a base de cereales para lactantes y niños pequeños (CODEX STAN 74-1981).

Para uso a $1500 \mathrm{mg} / \mathrm{kg}$ en productos que corresponden a la Norma para alimentos envasados para lactantes y niños (CODEX STAN 73-1981).

Separados o combinados con otros almidones espesantes en productos que corresponden a la Norma para alimentos envasados para lactantes y niños (CODEX STAN 73-1981).

Excluidos los aceites vírgenes y los aceites prensados en frío, así como los productos que corresponden a la Norma para los aceites de oliva y aceites de orujo de oliva (CODEX STAN 33-1981).

Para uso en nata (crema) batida y en nata envasada a presión solamente.

Excepto para los productos que corresponden a la Norma para los hongos comestibles y sus productos (CODEX STAN 38-1981).

Para uso en rábanos encurtidos solamente. 
Nota 281

Nota 282

Nota 283

Nota 284

Nota 285

Nota 286

Nota 287

Nota 288

Nota 289

Nota 290

Nota 291

Nota 292

Nota 293

Nota 294

Nota 295

Nota 296

Nota 297

Nota 298
Para uso en carne fresca picada que contenga otros ingredientes aparte de la carne molida solamente.

Únicamente pectinas no amidadas se pueden utilizar en la Norma para alimentos envasados para lactantes y niños (CODEX STAN 73-1981).

Para uso en alimentos envasados a base de fruta para lactantes, que correspondan a la Norma para alimentos envasados para lactantes y niños (CODEX STAN 731981) solamente.

Separados o combinados: SIN 1412, 1413, 1414 y 1440 en productos que correspondan a la Norma para preparados para lactantes y preparados para usos medicinales especiales destinados a los lactantes (CODEX STAN 72-1981). Separados o combinados: SIN 1412, 1413, 1414 y 1422 en productos que correspondan a la Norma para preparados complementarios (CODEX STAN 1561987).

Para uso en productos que corresponden a la Norma para la "carne luncheon" (CODEX STAN 89-1981) y la Norma para la carne picada curada cocida (CODEX STAN 98-1981).

Excepto para uso en productos que corresponden a la Norma para la carne tipo "corned beef" (CODEX STAN 88-1981) a 30 mg/kg como ion NO2 residuo. Para uso en productos que corresponden a la Norma para el jamón curado cocido (CODEX STAN 96-1981) y la Norma para la espaldilla de cerdo curada cocida (CODEX STAN 97-1981).

Para uso de fosfato diácido de sodio (SIN 339(i)), hidrogenofosfato disódico (SIN 339(ii)), fosfato trisódico (SIN 339(iii)), fosfato diácido de potasio (SIN 340(i)), hidrogenofosfato dipotásico (SIN 340(ii)), fosfato tripotásico (SIN 340(iii)), fosfato diácido de calcio (SIN 341(i)), hidrogenofosfato de calcio (SIN 341(ii)), fosfato tricálcico (SIN 341(iii), difosfato disódico (SIN 450(i)), difosfato trisódico (SIN 450(ii)), difosfato tetrasódico (SIN 450(iii)), difosfato tetrapotásico (SIN 450(v)), difosfato diácido cálcico (SIN 450(vii)), trifosfato pentasódico (SIN 451(i)), trifosfato pentapotásico (SIN 451(ii)), polifosfato de sodio (SIN 452(i)), polifosfato de potasio (SIN 452(ii)), polifosfato de sodio y calcio (SIN 452(iii)), polifosfato de calcio (SIN 452(iv)), polifosfato de amonio (SIN 452(v)) y fosfato de huesos (SIN 542) como humectantes en los productos que correspondan a la Norma para el jamón curado cocido (CODEX STAN 96-1981) y la Norma para la espaldilla de cerdo curada cocida (CODEX STAN 97-1981). La cantidad del total de fosfatos (naturalmente presentes y añadidos) no excederá $3520 \mathrm{mg} / \mathrm{kg}$ como fósforo.

Para uso en productos que corresponden a la Norma para la "carne luncheon" (CODEX STAN 89-1981) y la Norma para la carne picada curada cocida (CODEX STAN 98-1981) a $15 \mathrm{mg} / \mathrm{kg}$ para sustituir la pérdida de color en el producto únicamente con aglutinantes.

Excepto para uso de beta-apo-8'-carotenal (SIN 160e) y el éster metílico o etílico del ácido beta-apo-8'-carotenoico (SIN 160f) a $35 \mathrm{mg} / \mathrm{kg}$.

Excepto para uso en preparados a base de proteínas hidrolizadas y/o aminoácidos a $25000 \mathrm{mg} / \mathrm{kg}$.

Sobre la base de saponina.

Excepto para uso en productos líquidos a $600 \mathrm{mg} / \mathrm{kg}$ como equivalentes de esteviol.

Para uso en productos regulados por la Norma para Alimentos Envasados para Lactantes y Niños (CODEX STAN 73-1981) solamente, como regulador de la acidez.

Excepto para uso en perilla en salmuera a $780 \mathrm{mg} / \mathrm{kg}$.

La dosis en el alimento listo para el consumo no excederá de $200 \mathrm{mg} / \mathrm{kg}$ tomando como base el anhidro.

Para uso solamente en los productos que corresponden a la Norma para Provolone (CXS 272-1968). 
Para uso en alimentos no normalizados; y en productos que correspondan a la Norma del Codex para barritas, porciones y filetes de pescado empanados 0 rebozados congelados rápidamente (CODEX STAN 166-1989): los siguientes fosfatos para uso como humectantes en dosis de $2200 \mathrm{mg} / \mathrm{kg}$ como fósforo, SIN 339(i), 339(ii), 339(iii), 340(i), 340(ii), 340(iii), 341(i), 341(ii), 341(iii), 450(i), 450(ii), 450(iii), 450(v), 450(vii), 451(i), 451(ii), 452(i), 452(ii), 452(iii), 452(iv), 452(v), y 542; y los siguientes fosfatos para uco como leudantest en empanados y rebozados sólo en dosis de $440 \mathrm{mg} / \mathrm{kg}$ como fósforo, SIN 339(i), 340(iii), 341(i), 341(ii), 341(iii), 450(i), 450(ii), 450(iii), 450(v), 450(vi), 450(vii), 450(ix), 452(i), 452(ii), 452(iii) y 452(iv).

Nota 300

Nota 301

Nota 302

Nota 303

Nota 304

Nota 305

Nota 306

Nota 307

Nota 308

Nota 309

Nota 310

Nota 311

Nota 312

Nota 313

Nota 314
Para uso en calamar salado solamente.

Dosis máxima provisional hasta la CCFA53.

Para uso de fosfato diácido de sodio (SIN 339(i)), hidrogenofosfato disódico (SIN 339(ii)), fosfato trisódico (SIN 339(iii)), fosfato diácido de potasio (SIN 340(i)), hidrogenofosfato dipotásico (SIN 340(ii)), fosfato tripotásico (SIN 340(iii)), fosfato diácido de calcio (SIN 341(i)), hidrogenofosfato de calcio (SIN 341(ii)), fosfato tricálcico (SIN 341(iii), difosfato disódico (SIN 450(i)), difosfato trisódico (SIN 450(ii)), difosfato tetrasódico (SIN 450(iii)), difosfato tetrapotásico (SIN 450(v)), difosfato diácido cálcico (SIN 450(vii)), trifosfato pentasódico (SIN 451(i)), trifosfato pentapotásico (SIN 451(ii)), polifosfato de sodio (SIN 452(i)), polifosfato de potasio (SIN 452(ii)), polifosfato de sodio y calcio (SIN 452(iii)), polifosfato de calcio (SIN 452 (iv)), polifosfato de amonio (SIN 452(v)) y fosfato de huesos (SIN 542) como humectantes en los productos que correspondan a la Norma para la "carne luncheon" (CODEX STAN 89-1981) y Norma para la carne picada curada cocida (CODEX STAN 98-1981). La cantidad del total de fosfatos (naturalmente presentes y añadidos) no excederá $3520 \mathrm{mg} / \mathrm{kg}$ como fósforo.

Excluidos los productos (distintos del chocolate blanco) que corresponden a la Norma para el chocolate y los productos de chocolate (CODEX STAN 87-1981). Solo para uso en empanados o rebozados en productos que correspondan a la Norma para barritas, porciones y filetes de pescado empanados o rebozados congelados rápidamente (CODEX STAN 166-1989), solo o en combinación: carotenos (carotenos, beta-, sintéticos (SIN 160a(i)), carotenos beta-, Blakeslea trispora (SIN 160a(iii)), carotenal, beta-apo-8' (SIN 160e) y éster etílico del ácido beta-apo-8'-carotenoico (SIN 160f) y carotenos beta-, vegetales (SIN 160a(ii)).

Excepto para uso en empanados o rebozados en los productos que corresponden a la Norma del Codex para barritas, porciones y filetes de pescado empanados o rebozados congelados rápidamente (CODEX STAN 166-1989), únicamente en dosis de $25 \mathrm{mg} / \mathrm{kg}$ como norbixina.

Excluidos los productos correspondientes a la Norma para las aletas de tiburón secas (CODEX STAN 189-1993), la Norma para galletas de pescado marino y de agua dulce y de mariscos, crustáceos y moluscos (CODEX STAN 222-2001), la Norma para las anchoas hervidas secas saladas (CODEX STAN 236-2003), la Norma relativa al abalón vivo y al abalón crudo, fresco, refrigerado o congelado destinado al consumo directo o a su procesamiento ulterior (CODEX STAN 3122013), y la Norma para los productos de pectínidos frescos y pectínidos crudos congelados rápidamente (CODEX STAN 315-2014).

Excluidos los calamares crudos.

Sólo para uso en moluscos crudos.

Sólo para uso en alimentos empanados o rebozados aplicado únicamente a los alimentos no normalizados.

Excepto para uso en productos regulados por la Norma para los camarones en conserva (CODEX STAN 37-1981) y la Norma para la carne de cangrejo en conserva (CODEX STAN 90-1981) a $250 \mathrm{mg} / \mathrm{kg}$.

Sólo para uso en terrinas.

Sólo para uso en productos de tsukudani y de surimi.

Para uso en productos correspondientes a la Norma para galletas de pescado marino y de agua dulce y de mariscos, crustáceos y moluscos (CODEX STAN 2222001).

Para uso en extractos de levadura. 
Nota 315

Nota 316

Nota 317

Nota 318

Nota 319

Nota 320

Nota 321

Nota 322

Nota 323

Nota 324

Nota 325

Nota 326

Nota 327

Nota 328

Nota 329

Nota 330

Nota 331

Nota 332

Nota 333

Nota 334

Nota 335

Nota 336

Nota 337

Nota 338

Nota 339

Nota 340

Nota 341

Nota 342
Separado o combinado: ácido ascórbico (SIN 300), ascorbato de sodio (SIN 301), ascorbato cálcico (SIN 302) y palmitato de ascorbilo (SIN 304).

Dentro de los límites para el sodio especificados en la Norma para preparados complementarios (Codex Stan 156-1987): por separado o en combinación con otros aditivos que contengan sodio.

Como ácido ascórbico.

Sólo en cereal seco.

Dentro de los límites para el sodio especificados en la Norma para alimentos envasados para lactantes y niños (Codex Stan 73-1981): por separado o en combinación con otros aditivos que contengan sodio.

Dentro de los límites para el sodio especificados en la Norma para alimentos elaborados a base de cereales para lactantes y niños pequeños (Codex Stan 741981): por separado o en combinación con otros aditivos que contengan sodio.

Sólo para uso en mezclas en polvo.

Para uso en productos regulados por la Norma general para grasas y aceites comestibles no regulados por normas individuales (CODEX STAN 19-1981) y la Norma para grasas animales no especificadas (CODEX STAN 211-1999).

Para uso como agente endurecedor.

Sólo para uso en áloe vera.

Para uso general en productos de surimi.

Sólo para uso en productos de carne, de aves de corral y carne de caza frescas.

Para uso en productos de pescado cocido en salsa de soja.

Separados o combinados con otros espesantes.

La dosis de uso en los productos de leche y productos a base de soya.

Excepto para uso en productos envasados.

Para productos no normalizados: para uso en carne picada de pescado, camarones y langostinos únicamente.

Para uso general como agente de glaseado.

En los alimentos regulados por la Norma para el pescado ahumado, pescado con sabor a humo y pescado secado con humo (CODEX STAN 311-2013), para uso en los productos envasados con oxígeno reducido en pescado ahumado y productos de pescado con sabor a humo solamente.

Para pescado salado con un contenido de sal mayor o igual al 18 por ciento durante la elaboración.

Para uso en productos que contengan proteínas vegetales únicamente.

Para uso en los zumos de ciruelas chinas únicamente.

Para uso en productos regulados por la Norma del Codex para los "bouillons" y consomés (CODEX STAN 117-1981) a $50 \mathrm{mg} / \mathrm{kg}$.

Para uso en productos regulados por la Norma del Codex para los "bouillons" y consomés (CODEX STAN 117-1981) por separado o en combinación: ácido sórbico (SIN 200), sorbato de potasio (SIN 202), sorbato de calcio (SIN 203), ácido benzoico (SIN 210), benzoato de sodio (SIN 211), benzoato de potasio (SIN 212) y benzoato de calcio (SIN 213) a $500 \mathrm{mg} / \mathrm{kg}$ como ácido sórbico (SIN 200-203) o como ácido benzoico (SIN 210-213).

Excluidos los bouillons y consomés en conserva.

Excepto para los productos que no correspondan a la Norma del Codex para los "bouillons" y consomés (CODEX STAN 117-1981) a $100 \mathrm{mg} / \mathrm{kg}$.

Para uso en productos que se ajusten a la Norma del Codex para los "bouillons" y consomés (CODEX STAN 117-1981) por separado o en combinación: carotenos, beta-, vegetales (SIN 160a(ii)), -carotenal, beta-apo-8 '- (SIN 160e) y éster etílico del ácido beta-apo-8'-carotenoico (SIN 160f) a $50 \mathrm{mg} / \mathrm{kg}$.

Para el uso de las clorofilas, complejos cúpricos (SIN 141 (i) sólo en los productos que se ajustan a la Norma del Codex para los "bouillons" y consomés (CODEX STAN 117-1981). 
Para uso en productos regulados por la Norma del Codex para los "bouillons" y consomés (CODEX STAN 117-1981): fosfato diácido de sodio (SIN 339 (i)), hidrogenfosfato disódico(SIN 339ii), fosfato trisódico (SIN 339iii), fosfato diácido de potasio (SIN 340 (i)), hidrogenfosfato dipotásico (SIN 340ii), fosfato tripotásico (SIN 340 (iii)), difosfato disódico (SIN 450 (i)), difosfato trisódico (SIN 450ii), difosfato tetrasódico (SIN 450iii), difosfato tetrapotásico (SIN 450(v)), trifosfato pentasódico (SIN 451(i)), trifosfato pentapotásico (SIN 451(ii)), polifosfato de sodio (SIN 452(i)) y polifosfato de potasio (SIN 452(ii) como reguladores de la acidez a $440 \mathrm{mg} / \mathrm{kg}$ como fósforo; fosfato diácido de calcio (SIN 341 (i)), hidrogenfosfato de calcio (SIN 341 (ii)) y fosfato tricálcico (SIN 341 (iii)) como aglutinantes a $800 \mathrm{mg} / \mathrm{kg}$ como fósforo en materia seca sólo en productos deshidratados; y difosfato dicálcico (SIN 450 (vi)) y polifosfato de calcio (SIN 452(iv) como emulsionantes, estabilizadores y espesantes a $1320 \mathrm{mg} / \mathrm{kg}$ como fósforo.

Nota 344

Nota 345

Nota 346

Nota 347

Nota 348

Nota 349

Nota 350

Nota 351

Nota 352

Nota 353

Nota 354

Nota 355

Nota 356

Nota 357

Nota 358

Nota 359

Nota 360

Nota 361

Nota 362

Nota 363

Nota 364

Nota 365

Nota 366
Para el uso de riboflavina, sintética (SIN 101(i)) sólo en productos regulados por la Norma del Codex para los "bouillons" y consomés (CODEX STAN 117-1981).

Para uso en productos regulados por la Norma del Codex para los "bouillons" y consomés (CODEX STAN 117-1981): ésteres de ácidos grasos y sacarosa (SIN 473), sucroglicéridos (SIN 474) individualmente o en combinación a 2000 mg/kg. Para uso en productos regulados por la Norma del Codex para los "bouillons" y consomés (CODEX STAN 117-1981), solos o en combinación: tocoferol d-alfa- (SIN 307a), tocoferol concentrado, mezcla (SIN 307b), y tocoferol dl-alfa- (SIN 307c) a $50 \mathrm{mg} / \mathrm{kg}$.

Excluidos los productos naturales.

Sólo o en combinación: sucroésteres de ácidos grasos (SIN 473), oligoésteres de sucrosa tipo I y II (SIN 473a) y sucroglicéridos (SIN 474).

Para uso en dosis de $7000 \mathrm{mg} / \mathrm{kg}$ únicamente en rellenos de nata para panadería.

Para uso en dosis de $10000 \mathrm{mg} / \mathrm{kg}$ únicamente en productos análogos a la crema en polvo.

Para uso en productos que correspondan a la Norma para el queso crema (CODEX STAN 275-1973).

Excepto para uso en dosis de $6000 \mathrm{mg} / \mathrm{kg}$ en productos con $>20 \%$ de contenido de grasa.

En seco.

Para uso en dosis de $2000 \mathrm{mg} / \mathrm{kg}$ en productos aromatizados que correspondan a la Norma para las leches fermentadas (CODEX STAN 243-2003) únicamente.

Para uso en dosis de $10000 \mathrm{mg} / \mathrm{kg}$ en productos aromatizados que correspondan a la Norma para las leches fermentadas (CODEX STAN 243-2003) únicamente.

Excluidos los aceites vírgenes o prensados en frío.

Excepto para uso en aceite de oliva refinado, aceite de oliva, aceite de orujo de oliva refinado y aceite de orujo de oliva en dosis de $200 \mathrm{mg} / \mathrm{kg}$ para restablecer los tocoferoles naturales perdidos en la producción.

Excepto para uso en aceites de pescado a $6000 \mathrm{mg} / \mathrm{kg}$, individualmente o en combinación.

Excepto las grasas lácteas para untar con $\geq 70 \%$ de contenido de materias grasas de la leche.

En grasas lácteas para untar limitado a productos con $<70 \%$ de materia grasa o para el horno.

Para uso en dosis de $5000 \mathrm{mg} / \mathrm{kg}$ como ácido tartárico en productos que correspondan a la Norma para materias lácteas grasas para untar (CODEX STAN 253-2006).

Excluidos los productos naturales que correspondan a la Norma para las leches fermentadas (CODEX STAN 243-2003).

Para uso en dosis de $50000 \mathrm{mg} / \mathrm{kg}$ para los aceites emulsionados utilizados en la producción de fideos o productos de panadería.

Individualmente o en combinación.

En las tripas para embutido.

Para uso en dosis de $10000 \mathrm{mg} / \mathrm{kg}$ en sucedáneos del chocolate con $>5 \%$ de contenido de agua. 
Nota 367

Nota 368

Nota 369

Nota 370

Nota 371

Nota 372

Nota 373

Nota 374

Nota 375

Nota 376

Nota 377

Nota 378

Nota 379

Nota 380

Nota 381

Nota 382

Nota 383

Nota 384

Nota 385

Nota 386

Nota 387

Nota 388

Nota 389

Nota 390

Nota 391

Nota 392
Para uso en dosis de $10000 \mathrm{mg} / \mathrm{kg}$ en los dulces que contengan no menos del $10 \%$ de aceite.

Para uso en dosis de $10000 \mathrm{mg} / \mathrm{kg}$ en decoraciones batidas.

Para uso en cereales de desayuno tipo granola únicamente.

Para uso en fideos, cubiertas o envolturas para rollitos de primavera, wontons y shou mai únicamente.

Para uso en dosis de $10000 \mathrm{mg} / \mathrm{kg}$ en fideos hervidos únicamente.

Para uso en bollos únicamente.

Para uso en salchichas únicamente.

Para su uso en productos cárnicos cocidos congelados únicamente.

Excluidos los productos que corresponden a la Norma para el chocolate y los productos de chocolate (CODEX STAN 87-1981), excepto para el chocolate blanco, en que se puede usar el palmitato de ascorbilo (SIN 304) únicamente como antioxidante en dosis de $200 \mathrm{mg} / \mathrm{kg}$, calculada sobre la base del contenido de grasa. Para uso únicamente en preparados líquidos a base de proteínas hidrolizadas y/o aminoácidos para lactantes.

Para los productos que correspondan a la Norma para la "carne luncheon" (CODEX STAN 89-1981), Norma para la carne picada curada cocida (CODEX STAN 981981), y Norma para la carne tipo "corned beef" (CODEX STAN 88-1981) el uso está limitado a los productos listos para el consumo que requieren refrigeración. Para aceites y grasas para freír.

Para uso únicamente en preparados líquidos a base de proteínas hidrolizadas y/o aminoácidos para lactantes.

Excepto para uso en preparados en polvo para lactantes en dosis de $7500 \mathrm{mg} / \mathrm{kg}$. Según se consumen.

Para uso solamente en el pescado ahumado y productos de pescado con sabor a humo que correspondan a la Norma para para el pescado ahumado, pescado con sabor a humo y pescado secado con humo (CODEX STAN 311-2013).

Para uso en gelatina en polvo solamente.

Sobre la base de la gelatina en polvo.

Como humectante para la humectación de ácido fumárico (SIN 297).

Excepto para su uso en la Norma para pepinos encurtidos (encurtido de pepinos) (CODEX STAN 115-1981) en dosis de $500 \mathrm{mg} / \mathrm{kg}$, solo o en combinación con otros emulsionantes.

Excepto para uso en dosis de $20000 \mathrm{mg} / \mathrm{kg}$ en azúcar en polvo para productos de panadería fina.

Excluido el pan preparado únicamente con harina de trigo, agua, levadura o leudante y sal.

Excepto para su uso en dosis de $500 \mathrm{mg} / \mathrm{kg}$ en productos que contengan pasta de nueces.

Para su uso como antioxidante para alimentos no normalizados y para moluscos crudos sin concha refrigerados que corresponden a la Norma para los moluscos bivalvos vivos y los moluscos bivalvos crudos (CODEX STAN 292-2008).

Para alimentos no normalizados y para carne de pescado picada en los productos que corresponden a la Norma para bloques de filetes de pescado, carne de pescado picada y mezclas de filetes y de carne de pescado picada congelados rápidamente (CODEX STAN 165-1989).

Para alimentos no normalizados y para productos que corresponden a la Norma para los moluscos bivalvos vivos y los moluscos bivalvos crudos (CODEX STAN 292-2008): para uso como antioxidante para los moluscos crudos congelados. 
Para uso en carne de pectínidos congelada rápidamente y carne de pectínidos con huevas congeladas rápidamente elaborada con fosfatos conforme a la Norma para los productos de pectínidos frescos y pectínidos crudos congelados rápidamente (CODEX STAN 315-2014) como sigue: los siguientes fosfatos a $2200 \mathrm{mg} / \mathrm{kg}$ como fósforo para usar como reguladores de la acidez: SIN 338, 339(i,ii,iii), 340(i,ii,iii), 341(i,ii,iii), 342(i,ii), 343(i,ii,iii), 450(i,ii,iii,v,vi,vii,ix), 451(i,ii), 452(i,ii,iii,iv,v); los siguientes para uso como humectantes:SIN 339(i,ii,iii), 340(i,ii,iii), 341(i,ii,iii), 450(i,ii,iii,v,vii), 451(i,ii), INS 452(i,ii,iii,iv,v), y 542; los siguientes para uso como secuestrantes: SIN 338, 339(i,ii,iii), 340(i,ii,iii), 341(i), 450(i,ii,iii,v,vi,vii), 451 (i,ii,), 452(i,ii,iii,iv,v); y los siguientes para uso como estabilizadores: SIN 339(i,ii,ii), 340(i,ii,iii), 341(i,ii,iii), 342(i,ii), 343(i,ii,iii), I450(i), INS 450(ii), INS 450(iii,v,vi,vii,ix), 451 (i,ii), 452(i,ii,iii,iv,v) y 542.

Nota $394 \quad$ Para uso en alimentos no normalizados; $y$ en los productos que corresponden a la Norma para los camarones congelados rápidamente (CODEX STAN 92-1981); Norma para langostas congeladas rápidamente (CODEX STAN 95-1981); Norma para bloques de filetes de pescado, carne de pescado picada y mezclas de filetes y de carne de pescado picada congelados rápidamente (CODEX STAN 165-1989); y Norma para filetes de pescado congelados rápidamente (CODEX STAN 190-1995) como humectantes en dosis de $2200 \mathrm{mg} / \mathrm{kg}$ como fósforo: SIN 339(i), SIN 339(ii), SIN 339(iii), SIN 340(i), SIN 340(ii), SIN 340(iii), SIN 341(i), SIN 341(ii), SIN 450(iii), SIN 450(v), SIN 450(vii), SIN 451(i), SIN 451(ii), SIN 452(i), SIN 452(ii), SIN 452(iii), SIN 452(iv), SIN 452(v) y SIN 542.

Nota $395 \quad$ Para uso en productos con tratamiento térmico que corresponden a la Norma para los camarones congelados rápidamente (CODEX STAN 92-1981).

Nota 396 Para productos regulados por la Norma para el jamón curado cocido (CXS 96 1981) y la Norma para la espaldilla de cerdo curada cocida (CXS 97 -1981), el uso está limitado a productos listos para el consumo que requieren refrigeración.

Nota 397

Nota 398

Nota 399

Nota 400

Nota 401

Nota 402

Nota 403

Nota 404

Nota 405

Nota 406

Nota 407

Nota 408

Nota 409

Nota $410 \quad$ Excluidas leches con contenido reducido en lactosa. Para uso en dosis de $1000 \mathrm{mg} / \mathrm{kg}$ en sueros de leche no UHT y no esterilizados. Para uso en productos que se ajustan a la Norma para Leche Fermentada (CODEX STAN 243-2003) a $1000 \mathrm{mg} / \mathrm{kg}$.

Para uso en productos que se ajustan a la Norma para Leche Fermentada (CODEX STAN 243-2003) a $10.000 \mathrm{mg} / \mathrm{kg}$.

Para uso en productos que se ajustan a la Norma para Leche Fermentada (CODEX STAN 243-2003) a $150 \mathrm{mg} / \mathrm{kg}$.

Para uso en productos que se ajustan a la Norma para Leche Fermentada (CODEX STAN 243-2003) a $600 \mathrm{mg} / \mathrm{kg}$.

Para uso en productos que se ajustan a la Norma para Leche Fermentada (CODEX STAN 243-2003) a $100 \mathrm{mg} / \mathrm{kg}$.

Excluyendo las leches fermentadas y las bebidas no tratadas térmicamente después de la fermentación.

Para uso en los productos de valor energético reducido o sin azúcares añadidos correspondientes a la Norma para leches fermentadas (CODEX STAN 243-2003), en dosis de $400 \mathrm{mg} / \mathrm{kg}$.

Para uso en los productos de valor energético reducido o sin azúcares añadidos correspondientes a la Norma para leches fermentadas (CODEX STAN 243-2003), en dosis de $1000 \mathrm{mg} / \mathrm{kg}$.

Para uso en los productos de valor energético reducido o sin azúcares añadidos correspondientes a la Norma para leches fermentadas (CODEX STAN 243-2003), en dosis de $100 \mathrm{mg} / \mathrm{kg}$.

Excluidas todas las leches líquidas que no estén enriquecidas con minerales o vitaminas.

Solo para uso como emulsionante en los productos regulados por la Norma para aceites de pescado (CODEX STAN 329-2017), o como antiespumante en aceites y grasas para freír regulados para la Norma para grasas y aceites comestibles no regulados por normas individuales (CODEX STAN 19-1981).

Solo para uso en productos destinados a elaboración ulterior o usos dietéticos especiales, de contenido de azúcar bajo o reducido, o donde las propiedades edulcorantes han sido sustituidas entera o parcialmente por edulcorantes aditivos alimentarios. 
Nota 411

Nota 412

Nota 413

Nota 414

Nota 415

Nota 416

Nota 417

Nota 418

Nota 419

Nota 420

Nota 421

Nota 422

Nota 423

Nota 424

Nota 425

Nota 426

Nota 427

Nota 428

Nota 429

Nota 430

Nota 431

Nota 432

Nota 433

Nota 434

Nota 435

Nota 436

Nota 437

Nota 438

Nota 439

Nota 440

Nota 441

Nota 442

Nota 443

Nota 444

Nota 445
Excepto para uso en leches con contenido reducido en lactosa a $500 \mathrm{mg} / \mathrm{kg}$.

Solo para uso en salsas de pescado.

SIN 452(i-v) solo para uso en los productos regulados por la Norma para galletas de pescado marino y de agua dulce y de mariscos, crustáceos y moluscos (CODEX STAN 222-2001).

Solo para uso en productos marinados.

Solo para uso en encurtidos.

Tocoferol concentrado, mezcla (SIN 307b) solo.

Para uso en forma de cápsulas y tabletas.

Excepto para uso a $6000 \mathrm{mg} / \mathrm{kg}$, solo o en combinación, sobre la base de aceites de pescado.

Solo para uso en productos listos para el consumo que requieren refrigeración.

Excepto para uso a $700 \mathrm{mg} / \mathrm{kg}$ en moluscos ahumados y moluscos salados.

Solo para uso en pastas y productos condimentados que contienen aceites vegetales.

Solo para uso en roux de curry.

Solo para uso en dashi y furikake.

Para uso como agente de glaseado.

Solos o en combinación: sucroésteres de ácidos grasos (SIN 473), y oligoésteres de sucrosa, tipo I y tipo II (SIN 473a).

Excepto para uso en marinadas concentradas aplicadas a alimentos a $20000 \mathrm{mg} / \mathrm{kg}$.

Excepto para uso en marinadas concentradas aplicadas a alimentos a $10000 \mathrm{mg} / \mathrm{kg}$.

Como residuo en bizcochos y galletas.

Excepto para uso en café con leche envasado a $2000 \mathrm{mg} / \mathrm{kg}$.

Solo para uso en licores emulsionados.

Excluido el uso en whiskey.

Solo para uso en masas utilizadas en aperitivos salados a base de cereals.

Solo para uso en galletas de arroz y aperitivos de patatas (papas).

Transferencia del uso como antioxidante en aromatizantes, colorantes, ingredientes de zumos (jugos) y preparados nutritivos.

Para uso de tartrazina (SIN 102), amarillo ocaso FCF (SIN 110), amaranto (SIN 123) y ponceau $4 R$ (rojo de cochinilla A) (SIN 124) solos o en combinación, hasta una dosis máxima de $30 \mathrm{mg} / \mathrm{kg}$ en el producto final como colorantes solamente para restaurar el color perdido en el procesado de los productos regulados por la Norma para los camarones en conserva (CODEX STAN 37-1991).

Solo para uso como reguladores de la acidez: en los productos regulados por la Norma para los camarones en conserva (CODEX STAN 37-1991) solo está permitido ácido fosfórico (SIN 338) hasta un máximo de $540 \mathrm{mg} / \mathrm{kg}$ como fósforo; en los productos regulados por la Norma para el atún y el bonito en conserva (CODEX STAN 70-1981) solo está permitido el difosfato disódico (SIN 450(i)) hasta un máximo de $4400 \mathrm{mg} / \mathrm{kg}$ como fósforo (incluyendo fosfatos naturales); en los productos regulados por la Norma para la carne de cangrejo en conserva (CODEX STAN 90-1981) solo está permitido ácido fosfórico (SIN 338) y difosfato disódico (SIN 450(i)) hasta un máximo de $4400 \mathrm{mg} / \mathrm{kg}$, solos o en combinación, como fósforo (incluyendo fosfatos naturales).

Excluido el uso en el pescado secado con humo regulado por la Norma para el pescado ahumado, pescado con sabor a humo y pescado secado con humo (CODEX STAN 311-2013).

Para uso como emulsionante o estabilizador solamente.

Para la leche UHT de especies no bovinas únicamente.

Excepto para uso a $200 \mathrm{mg} / \mathrm{kg}$ en caramelos con revestimiento duro de azúcar.

Excepto para uso a $300 \mathrm{mg} / \mathrm{kg}$ en caramelos con sabor a frutas rojas.

Excepto para uso a $300 \mathrm{mg} / \mathrm{kg}$ en caramelos con sabor a limón.

Excepto para uso a $200 \mathrm{mg} / \mathrm{kg}$ en tofes de leche.

Excepto para uso a $700 \mathrm{mg} / \mathrm{kg}$ en fruta amarilla o goma de mascar con sabor a especias.

Excepto para uso a $300 \mathrm{mg} / \mathrm{kg}$ en productos aromatizados con limón y cítricos. 
Nota 446

Nota 447

Nota 448

Nota 449

Nota 450

Nota 451

Nota 452

Nota 453

Nota 454

Nota 455

Nota 456

Nota 457

Nota 458

Nota 459

Nota 460

Nota 461

Nota 462

Nota 463
Excepto para uso a $100 \mathrm{mg} / \mathrm{kg}$ en glaseados a base de azúcar.

Excepto para uso a $500 \mathrm{mg} / \mathrm{kg}$ en productos a base de grasa o gaseados.

Para uso en la leche UHT de especies bovinas para compensar el contenido de citrato o de calcio para evitar la sedimentación debido a las condiciones climáticas solamente.

Excluidas las leches fermentadas naturales/simples a base de leches fermentadas sin tratamiento térmico después de la fermentación contempladas por CXS 2432003.

Excepto para uso a $20000 \mathrm{mg} / \mathrm{kg}$ en productos dulces afrutados.

Sobre la base de la mezcla en seco.

Excepto para uso a $5200 \mathrm{mg} / \mathrm{kg}$ en claras de huevo secas utilizadas para elaboración posterior solamente.

Para uso como glaseado cuando ese tratamiento de superficie está permitido para la aplicación a la superficie de la fruta fresca.

Para uso en ceras, revestimientos o glaseados cuando esos tratamientos de superficie están permitidos para la aplicación a la superficie de la fruta fresca.

Para uso como glaseado cuando ese tratamiento de superficie está permitido para la aplicación a la superficie de hortalizas frescas, algas o nueces y semillas.

Para uso en ceras, revestimientos o glaseados cuando esos tratamientos de superficie están permitidos para la aplicación a la superficie de hortalizas frescas, algas o nueces y semillas.

Excepto para uso en los productos correspondientes a las normas para el Cheddar (CXS 263-1966), Danbo (CXS 264-1966), Edam (CXS 265-1966), Gouda (CXS 2661966), Havarti (CXS 267-1966), Samsø (CXS 268-1966), Emmental (CXS 269-

1967), Tilsiter (CXS 270-1968), Saint-Paulin (CXS 271-1968) y Provolone (CXS $272-$ 1968): a una dosis máxima de $1000 \mathrm{mg} / \mathrm{kg}$ para el tratamiento de la superficie solamente.

Excepto para uso en pasta de queso solo para los productos correspondientes a las normas para el Cheddar (CXS 263-1966), Danbo (CXS 264-1966), Edam (CXS 2651966), Gouda (CXS 266-1966), Havarti (CXS 267-1966), Samsø (CXS 268-1966), Emmental (CXS 269-1967), Tilsiter (CXS 270-1968), Saint-Paulin (CXS 271-1968), Provolone (CXS 272-1968), Coulommiers (CXS 274-1969), Camembert (CXS 2761973) y Brie (CXS 277-1973); solos o en combinación a $35 \mathrm{mg} / \mathrm{kg}$.

Excepto para uso a $10000 \mathrm{mg} / \mathrm{kg}$, solo o en combinación: dióxido de silicio, amorfo (SIN 551), silicato de calcio (SIN 552), silicato de magnesio, sintético (SIN 553(i)) y talco (SIN 553(iii)) en los productos correspondientes a las Normas para el Cheddar (CXS 263-1966), Danbo (CXS 264-1966), Edam (CXS 265-1966), Gouda (CXS 2661966), Havarti (CXS 267-1966), Samsø (CXS 268-1966), Emmental (CXS 269-

1967), Tilsiter (CXS 270-1968), Saint-Paulin (CXS 271-1968) y Provolone (CXS 2721968), como antiaglutinante solamente: silicatos calculados como dióxido de silicio. Excepto para uso a $3000 \mathrm{mg} / \mathrm{kg}$, solo o en combinación: ácido propiónico (SIN 280 ), propionato de sodio (SIN 281) y propionato de calcio (SIN 282) en los productos correspondientes a las normas para el Cheddar (CXS 263-1966), Danbo (CXS 264-1966), Edam (CXS 265-1966), Gouda (CXS 266-1966), Havarti (CXS 267-1966), Samsø (CXS 268-1966), Tilsiter (CXS 270-1968), Saint-Paulin (CXS 271-1968) y Provolone (CXS 272-1968).

Para el tratamiento de superficie del queso en lonchas, cortado, desmenuzado o rallado en los productos correspondientes a las normas para el Cheddar (CXS 2631966), Danbo (CXS 264-1966), Edam (CXS 265-1966), Gouda (CXS 266-1966), Havarti (CXS 267-1966), Samsø (CXS 268-1966), Emmental (CXS 269-1967), Tilsiter (CXS 270-1968), Saint-Paulin (CXS 271-1968) y Provolone (CXS 272-1968) solo como antiaglutinantes.

Para uso en la pasta de queso solo para los productos correspondientes a las normas para el Cheddar (CXS 263-1966) y Danbo (CXS 264-1966).

Para uso en la pasta de queso solo para los productos correspondientes a las normas para el Cheddar (CXS 263-1966), Danbo (CXS 264-1966), Edam (CXS 2651966), Gouda (CXS 266-1966), Havarti (CXS 267-1966), Samsø (CXS 268-1966), Emmental (CXS 269-1967), Tilsiter (CXS 270-1968), Saint-Paulin (CXS 271-1968), Provolone (CXS 272-1968), Coulommiers (CXS 274-1969), Camembert (CXS 2761973) y Brie (CXS 277-1973). 
Para uso en los productos correspondientes a las normas para el Cheddar (CXS 263-1966), Danbo (CXS 264-1966), Edam (CXS 265-1966), Gouda (CXS 2661966), Havarti (CXS 267-1966), Samsø (CXS 268-1966), Emmental (CXS 2691967), Tilsiter (CXS 270-1968), Saint-Paulin (CXS 271-1968) y Provolone (CXS 2721968) como conservante solamente.

Nota $465 \quad$ Para los productos correspondientes a la Norma para los azúcares (CXS 212-1999) como antiaglutinantes solamente: dihidrógeno fosfato de calcio (SIN 341(i)), hidrógeno fosfato de calcio (SIN 341(ii)), fosfato tricálcico (SIN 341(iii)), dihidrógeno fosfato de magnesio (SIN 343(i)), hidrógeno fosfato de magnesio (SIN 343(ii)), fosfato de trimagnesio (SIN 343(iii)), carbonato de magnesio (SIN 504(i)), fosfato de huesos (SIN 542), dióxido de silicio, amorfo (SIN 551), silicato de calcio (SIN 552) y silicato de magnesio, sintético (SIN 553(i)) solos o en combinación, pero todavía dentro de las distintas dosis máximas separadas prescritas.

Nota $466 \quad$ Solo para uso para elaborar productos con gas.

Nota $467 \quad$ Para las harinas para el pan leudado solo en los productos correspondientes a la Norma para la harina de trigo (CXS 152-1985).

Nota $468 \quad$ Excepto para uso en los productos correspondientes a la Norma para la harina de trigo (CXS 152-1985) como agente de tratamiento de la harina solamente, a una dosis máxima de $60 \mathrm{mg} / \mathrm{kg}$.

Nota $469 \quad$ Para uso en los productos correspondientes a la Norma para la harina de trigo (CXS 152-1985) como agente de tratamiento de la harina: dihidrógeno fosfato de calcio (SIN 341(i)), hidrógeno fosfato de calcio (SIN 341(ii)), fosfato tricálcico (SIN 341 (iii)), dihidrógeno fosfato de amonio (SIN 342(i)) e hidrógeno fosfato diamónico (SIN 342(ii)) solamente.

Nota $470 \quad$ En los productos correspondientes a la Norma para la harina de trigo (CXS 1521985), solo para uso como agente de tratamiento de la harina en las harinas para la fabricación de galletas y pasteles: dióxido de azufre (SIN 220), sulfito de sodio (SIN 221), metabisulfito de sodio (SIN 223) y metabisulfito de potasio (SIN 224) solamente.

Nota 471

En los productos correspondientes a la Norma para la harina de trigo (CXS 1521985), solo para uso en las harinas para pasteles que contienen más agua y azúcar que harina.

Nota $472 \quad$ Para uso en los productos correspondientes a la Norma para la harina de trigo (CXS 152-1985) como agente de tratamiento de la harina solamente.

Nota 473 Excepto para uso en los productos correspondientes a la Norma para los fideos instantáneos (CXS 249-2006) a $200 \mathrm{mg} / \mathrm{kg}$.

Nota 474 Excepto para uso de beta-carotenos, Blakeslea trispora (SIN 160a(iii)) a 1000 $\mathrm{mg} / \mathrm{kg}$, carotenal, beta-apo-8' (SIN 160e) a $200 \mathrm{mg} / \mathrm{kg}$, y éster etílico del ácidobetaapo-8'-carotenoico (SIN 160f) a $1000 \mathrm{mg} / \mathrm{kg}$ en los productos correspondientes a la Norma para los fideos instantáneos (CXS 249-2006).

Nota $475 \quad$ Excepto en los productos correspondientes a la Norma para los fideos instantáneos (CXS 249-2006): dihidrógeno fosfato de sodio (SIN 339(i)), hidrógeno fosfato de sodio (SIN 339(ii)), fosfato trisódico (SIN 339(iii)), dihidrógeno fosfato de potasio (SIN 340(i)), hidrógeno fosfato dipotásico (SIN 340(ii)), fosfato tripotásico (SIN 340(iii)), dihidrógeno fosfato de calcio (SIN 341(i)), hidrógeno fosfato de calcio (SIN 341 (ii)), fosfato tricálcico (SIN 341(iii)), difosfato disódico (SIN 450(i)), fosfato trisódico (SIN 450(ii)), difosfato tetrasódico (SIN 450(iii)), difosfato dipotásico (SIN 450(iv)), difosfato tetrapotásico (SIN 450(v)), dihidrógeno fosfato de calcio (SIN 450 (vii)), trifosfato pentapotásico (SIN 451(i)), trifosfato pentapotásico(SIN 451(ii)), polifosfato de sodio (SIN 452(i)), polifosfato de potasio (SIN 452(ii)), polifosfato de sodio y calcio (SIN 452(iii)), polifosfato de calcio (SIN 452(iv)), y polifosfato de amonio (SIN 452(v)) solo para uso como humectantes a $2000 \mathrm{mg} / \mathrm{kg}$, solos o en combinación, como fósforo.

Nota $476 \quad$ Para los productos correspondientes a la Norma para los fideos instantáneos (CXS 249-2006): dióxido de azufre (SIN 220), sulfito de sodio (SIN 221), metabisulfito de sodio (SIN 223) y metabisulfito de potasio (SIN 224) para uso como agentes de tratamiento de la harina solo.

Nota $477 \quad$ Algunos miembros del Codex permiten el uso de aditivos con función de edulcorante en todos los alimentos de esta categoría de alimentos mientras que otros limitan los aditivos con función de edulcorante a los alimentos con reducción significativa del contenido de energía o sin azúcares añadidos. 
Nota 478

Nota XS13

Nota XS36

Nota XS38

Nota XS57

Nota XS66

Nota XS86

Nota XS87

Nota XS88

Nota XS89

Nota XS92

Nota XS95

Nota XS96

Nota XS97

Nota XS98

Nota XS105

Nota XS115

Nota XS117

Nota XS141

Nota XS145

Nota XS165

Nota XS166

Nota XS189

Nota XS190

Nota XS191

Nota XS208

Algunos miembros del Codex permiten el uso de aditivos con función de edulcorante en todos los alimentos de esta categoría de alimentos mientras que otros limitan los aditivos con función de edulcorante a los alimentos con reducción significativa del contenido de energía o sin azúcares añadidos. Esta limitación puede no ser aplicable al uso conveniente como potenciador del sabor.

Excluidos los productos que corresponden a la Norma para los tomates en conserva (CODEX STAN 13 1981).

Excluidos los productos que corresponden a la Norma para pescados no eviscerados y eviscerados congelados rápidamente (CODEX STAN 36-1981).

Excluidos los productos que correspondan a la Norma general para los hongos comestibles y sus productos (CODEX STAN 38-1981).

Excluidos los productos que corresponden a la Norma para los concentrados de tomate elaborados (CODEX STAN 57-1981).

Excluidos los productos que corresponden a la Norma para las aceitunas de mesa (CODEX STAN 66-1981).

Excluidos los productos que correspondan a la Norma para la manteca de cacao (CODEX STAN 86-1981).

Excluidos los productos que corresponden a la Norma para el chocolate y los productos de chocolate (CODEX STAN 87-1981).

Excluidos los productos que corresponden a la Norma para la carne tipo "corned beef" (CODEX STAN 88-1981).

Excluidos los productos que corresponden a la Norma para la "carne luncheon" (CODEX STAN 89-1981).

Excluidos los productos que corresponden a la Norma para los camarones congelados rápidamente (CODEX STAN 92-1981).

Excluidos los productos que corresponden a la Norma para para langostas congeladas rápidamente (CODEX STAN 95-1981).

Excluidos los productos que corresponden a la Norma para el jamón curado cocido (CODEX STAN 96-1981).

Excluidos los productos que corresponden a la Norma para la espaldilla de cerdo curada cocida (CODEX STAN 97-1981).

Excluidos los productos que corresponden a y la Norma para la carne picada curada cocida (CODEX STAN 98-1981).

Excluidos los productos que corresponden a la Norma para el cacao en polvo (cacaos) y las mezclas secas de cacao y azúcares (CODEX STAN 105-1981).

Excluidos los productos que correspondan a la Norma para pepinos encurtidos (encurtidos de pepinos) (CODEX STAN 115-1981).

Excluidos los productos regulados por la Norma del Codex para los "bouillons" y consomés (CODEX STAN 117-1981).

de cacao/chocolate) y la torta de cacao (CODEX STAN 141-1983).

Excluidos los productos que corresponden a la Norma para las castañas en conserva y el puré de castañas en conserva (CODEX STAN 145-1985).

Excluidos los productos que corresponden a la Norma para bloques de filetes de pescado, carne de pescado picada y mezclas de filetes y de carne de pescado picada congelados rápidamente (CODEX STAN 165-1989).

Excluidos los productos que corresponden a la Norma para barritas, porciones y filetes de pescado empanados o rebozados congelados rápidamente (CODEX STAN 166-1989).

Excluidos los productos que corresponden a la Norma para las aletas de tiburón secas (CODEX STAN 189-1993).

Excluidos los productos que corresponden a la Norma para filetes de pescado congelados rápidamente (CODEX STAN 190-1995).

Excluidos los productos que corresponden a la Norma para los calamares congelados rápidamente (CODEX STAN 191-1995).

Excluidos los productos que correspondan a la Norma para los quesos en salmuera (CODEX STAN 208-1999). 


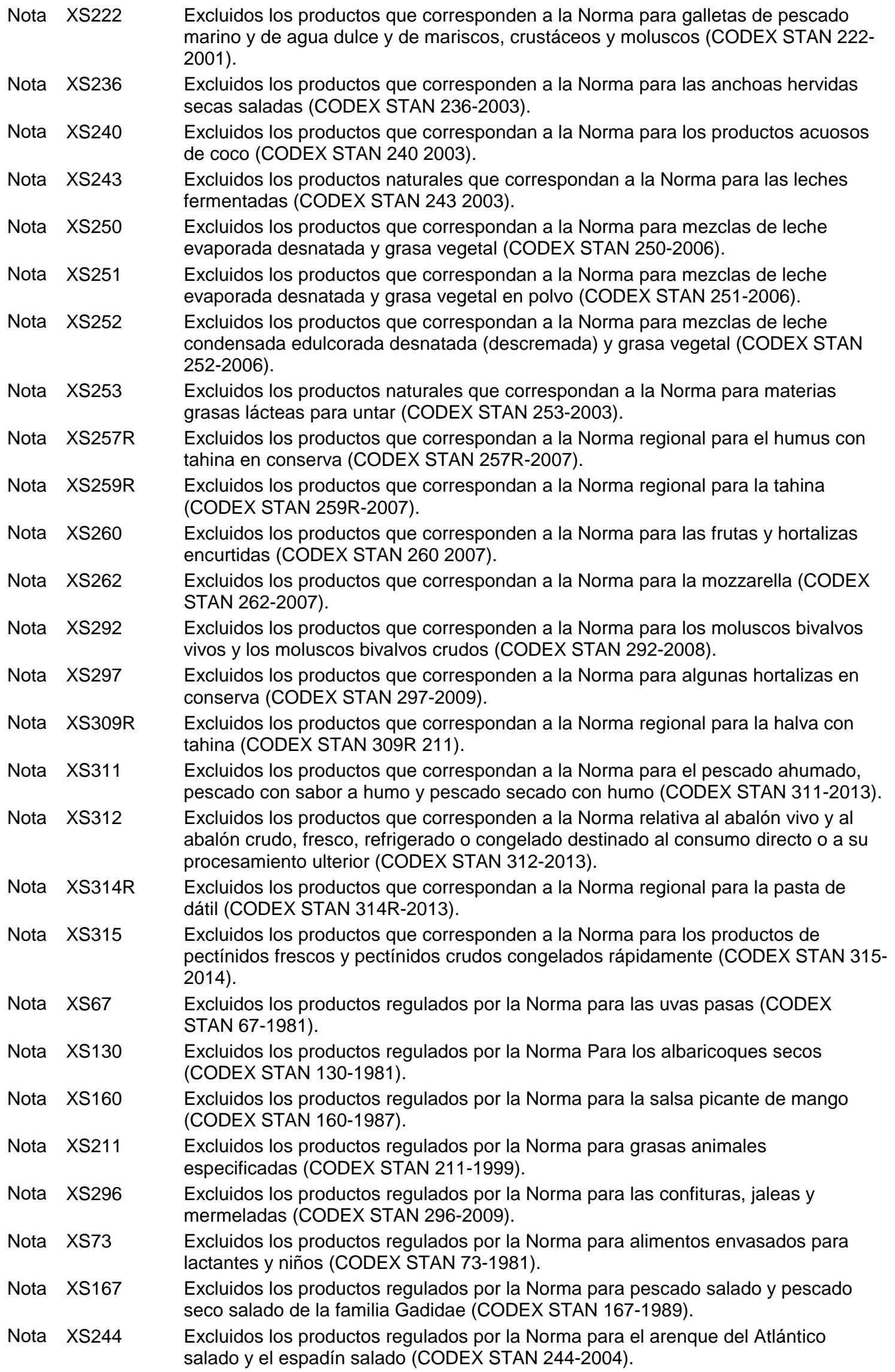




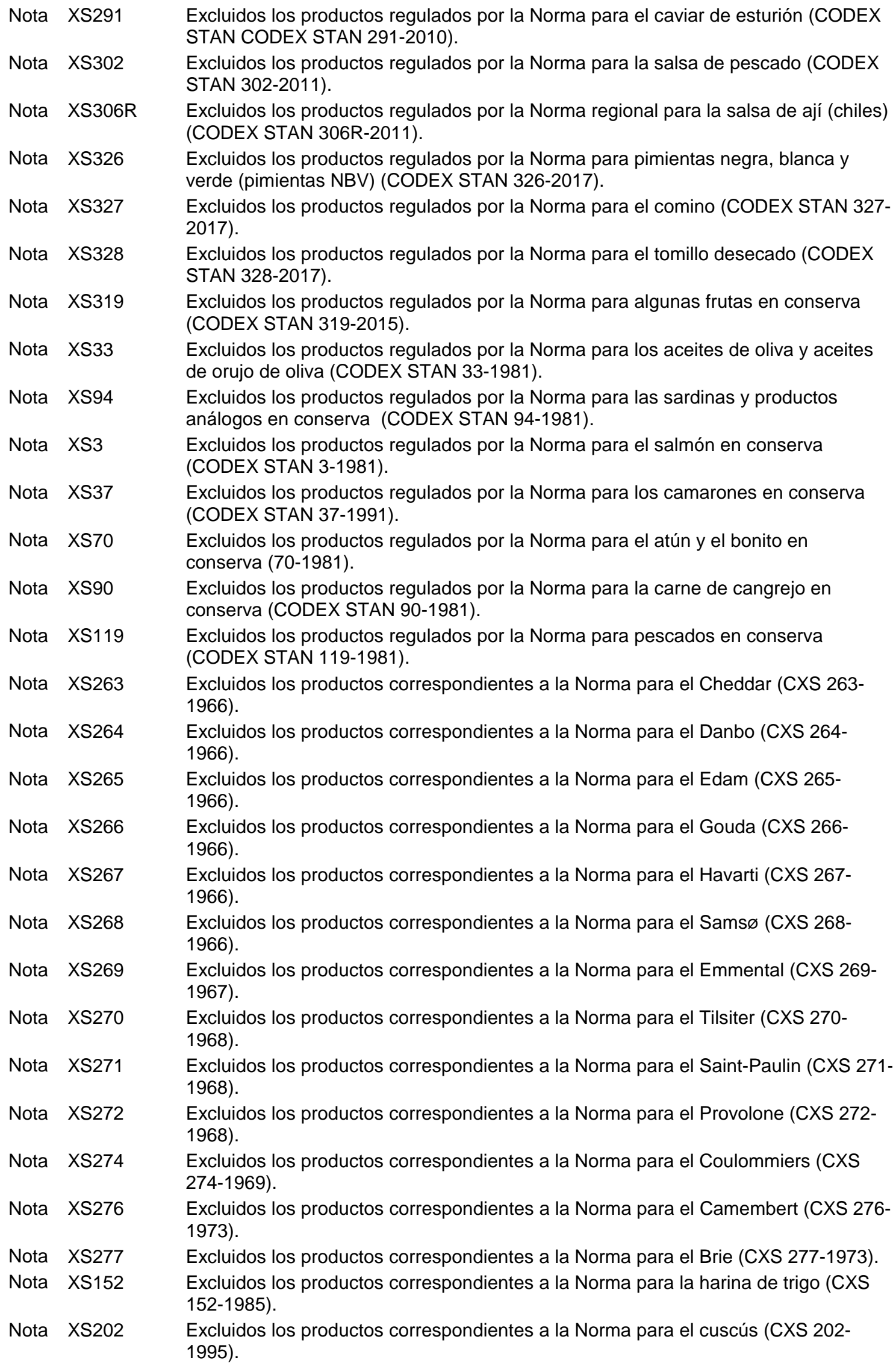




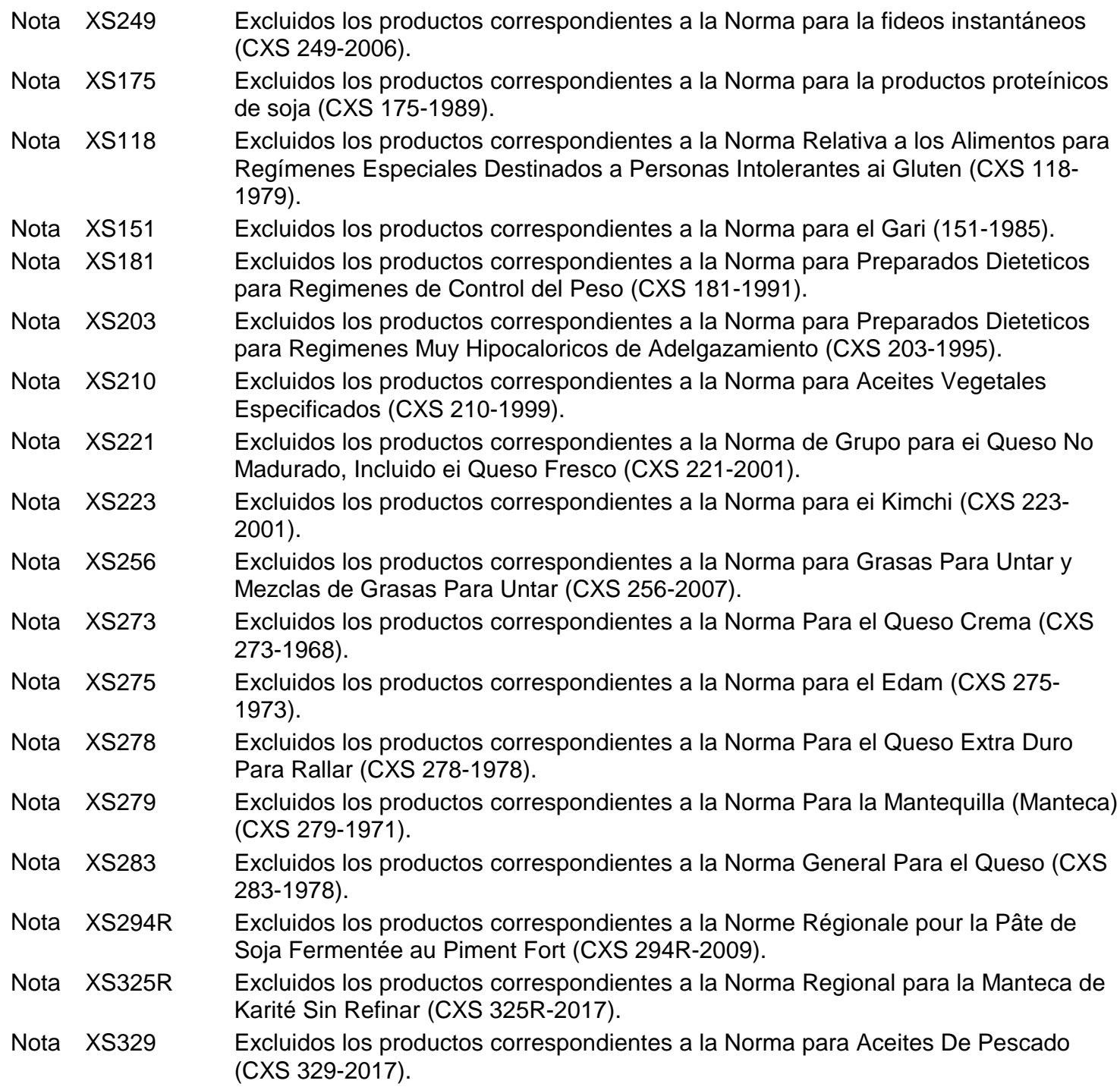




\section{NORMA GENERAL PARA LOS ADITIVOS ALIMENTARIOS \\ CUADRO III}

\section{Aditivos cuya uso se permite en los alimentos en general, salvo indicación en contrario, de conformidad con las Buenas Prácticas de Fabricación (BPF)}

\begin{tabular}{|c|c|c|c|c|}
\hline No. SIN & Additivo & Clases funcionales & $\begin{array}{l}\text { Año de } \\
\text { adopción }\end{array}$ & $\begin{array}{c}\text { Autorización específica en } \\
\text { las siguientes normas } \\
\text { sobre productos } 1\end{array}$ \\
\hline 260 & Ácido acético, glacial & $\begin{array}{l}\text { Reguladores de la acidez, } \\
\text { Sustancias conservadoras }\end{array}$ & 1999 & $\begin{array}{l}\text { CS } 70-1981, \text { CS 94-1981, } \\
\text { CS 119-1981, CS 302- } \\
2011, \text { CS 249-2006 }\end{array}$ \\
\hline $472 a$ & $\begin{array}{l}\text { Ésteres acéticos y de ácidos } \\
\text { grasos de glicerol }\end{array}$ & $\begin{array}{l}\text { Emulsionantes, Secuestrantes, } \\
\text { Estabilizadores }\end{array}$ & 1999 & \\
\hline 1422 & Adipato de dialmidón acetilado & $\begin{array}{l}\text { Emulsionantes, Estabilizadores, } \\
\text { Espesantes }\end{array}$ & 1999 & $\begin{array}{l}\text { CS 70-1981, CS 94-1981, } \\
\text { CS 119-1981, CS 249-2006 }\end{array}$ \\
\hline 1414 & Fosfato de dialmidón acetilado & $\begin{array}{l}\text { Emulsionantes, Estabilizadores, } \\
\text { Espesantes }\end{array}$ & 1999 & $\begin{array}{l}\text { CS 70-1981, CS 94-1981, } \\
\text { CS 119-1981, CS 249-2006 }\end{array}$ \\
\hline 1451 & Almidón acetilado oxidado & $\begin{array}{l}\text { Emulsionantes, Estabilizadores, } \\
\text { Espesantes }\end{array}$ & 2005 & CS 249-2006 \\
\hline 1401 & Almidón tratado con ácido & $\begin{array}{l}\text { Emulsionantes, Estabilizadores, } \\
\text { Espesantes }\end{array}$ & 1999 & $\begin{array}{l}\text { CS 105-1981, CS 70-1981, } \\
\text { CS 94-1981, CS 119-1981, } \\
\text { CS 249-2006 }\end{array}$ \\
\hline 406 & Agar & $\begin{array}{l}\text { Incrementadores del volumen, } \\
\text { Sustancias inertes, Emulsionantes, } \\
\text { Agentes gelificantes, Agentes de } \\
\text { glaseado, Humectantes, } \\
\text { Estabilizadores, Espesantes }\end{array}$ & 1999 & $\begin{array}{l}\text { CS 96-1981, CS 97-1981, } \\
\text { CS 70-1981 (para uso en } \\
\text { medios de envasado solo), } \\
\text { CS 94-1981 (para uso en } \\
\text { medios de envasado solo), } \\
\text { CS } 119-1981 \text { (para uso en } \\
\text { medios de envasado solo), } \\
\text { CS 249-2006 }\end{array}$ \\
\hline 400 & Ácido algínico & $\begin{array}{l}\text { Incrementadores del volumen, } \\
\text { Sustancias inertes, Emulsionantes, } \\
\text { Espumantes, Agentes gelificantes, } \\
\text { Agentes de glaseado, Humectantes, } \\
\text { Secuestrantes, Estabilizadores, } \\
\text { Espesantes }\end{array}$ & 1999 & $\begin{array}{l}\text { CS 105-1981, CS 70-1981 } \\
\text { (para uso en medios de } \\
\text { envasado solo), CS 94- } \\
1981 \text { (para uso en medios } \\
\text { de envasado solo), CS } 119 \text { - } \\
1981 \text { (para uso en medios } \\
\text { de envasado solo), CS } 249 \text { - } \\
2006\end{array}$ \\
\hline
\end{tabular}

1 En esta columna solo figuran las normas para productos que permiten el uso de aditivos específicos del Cuadro 3 . Si una norma para productos permite el uso de aditivos del Cuadro 3 de forma general o con base en la clase funcional, esa información figura en la sección del Cuadro 3 de la NGAA

"Referencias a las normas para productos para los aditivos del Cuadro 3 de la NGAA" 


$\begin{array}{ll}1402 & \text { Almidón tratado con álcalis } \\ 1100(\mathrm{i}) \quad \begin{array}{l}\text { alfa-Amilasa de Aspergillus oryzae } \\ \text { var. }\end{array} & \begin{array}{l}\text { alfa-Amilasa de Bacillus } \\ \text { megaterium expresada en Bacillus } \\ \text { subtilis }\end{array} \\ 1100 \text { (iv) } & \begin{array}{l}\text { alfa-Amilasa de Bacillus } \\ \text { stearothermophilus }\end{array} \\ 1100(\mathrm{v}) \quad \begin{array}{l}\text { alfa-Amilasa de Bacillus } \\ \text { stearothermophilus expresada en } \\ \text { Bacillus subtilis }\end{array} & \begin{array}{l}\text { alfa-Amilasa de Bacillus subtilis } \\ 1100(\text { iii) }\end{array}\end{array}$

403 Alginato de amonio

503(i) Carbonato de amonio

510 Cloruro de amonio

503(ii) Carbonato ácido de amonio

527 Hidróxido de amónio

300 Ácido ascórbico, L-

162

Rojo de remolacha
Emulsionantes, Estabilizadores, Espesantes

Agentes de tratamiento de las harinas

Agentes de tratamiento de las harinas

Agentes de tratamiento de las harinas

Agentes de tratamiento de las

harinas

Agentes de tratamiento de las harinas

Incrementadores del volumen, Sustancias inertes, Emulsionantes, Espumantes, Agentes gelificantes, Agentes de glaseado, Humectantes, Secuestrantes, Estabilizadores,

Espesantes

Reguladores de la acidez, Leudantes

Agentes de tratamiento de las harinas

Reguladores de la acidez, Leudantes

Reguladores de la acidez

Reguladores de la acidez, Antioxidantes, Agentes de tratamiento de las harinas,

Secuestrantes

Colorantes

Emulsionantes, Estabilizadores, Espesantes
1999

1999

1999

1999

CS 105-1981, CS 70-1981, CS 94-1981, CS 119-1981, CS 249-2006

1999

1999

CS 87-1981, CS 105-1981, CS 141-1983

CS 87-1981, CS 105-1981, CS 141-1983

CS 87-1981, CS 105-1981, CS 141-1983

1999 CS 88-1981, CS 89-1981

CS 96-1981, CS 97-1981,

CS 98-1981, CS 13-1981,

CS 57-1981, CS 302-2011, CS 319-2015 (reguladores de la acidez en general y como antioxidantes en la piña en conserva), CS 2492006

CS 319-2015 (peras en conserva en envase especial de vacaciones solo), CS 249-2006

CS 105-1981, CS 249-2006

1 En esta columna solo figuran las normas para productos que permiten el uso de aditivos específicos del Cuadro 3 . Si una norma para productos permite el uso de aditivos del Cuadro 3 de forma general o con base en la clase funcional, esa información figura en la sección del Cuadro 3 de la NGAA

"Referencias a las normas para productos para los aditivos del Cuadro 3 de la NGAA" 


\section{1(iii) Bromelina}

629 Guanilato de calcio, 5'-

633 Inosinato de calcio, 5'-

634 Ribonucleótidos de calcio, 5'-

Acetato de calcio

Alginato de calcio
Acentuadores del sabor, Agentes de 1999 tratamiento de las harinas

Estabilizadores

Acentuadores del sabor

Acentuadores del sabor

1999

Acentuadores del sabor

Reguladores de la acidez,

Sustancias conservadoras,

Estabilizadores

Antiespumantes, Incrementadores del volumen, Sustancias inertes, Espumantes, Agentes gelificantes, Agentes de glaseado, Humectantes, Secuestrantes, Estabilizadores, Espesantes

Antioxidantes

Reguladores de la acidez, Antiaglutinantes, Colorantes, Agentes endurecedores, Agentes de tratamiento de las harinas, Estabilizadores

Agentes endurecedores, Estabilizadores, Espesantes

Reguladores de la acidez, Agentes endurecedores, Secuestrantes

Reguladores de la acidez, Agentes endurecedores

Reguladores de la acidez, Sales emulsionantes, Agentes endurecedores, Agentes de tratamiento de las harinas, Espesantes

Reguladores de la acidez
1999

CS 70-1981 (para uso en medios de envasado solo), CS 94-1981 (para uso en medios de envasado solo), CS 119-1981 (para uso en medios de envasado solo)

CS 319-2015 (mangos en conserva solo)

CS 87-1981, CS 105-1981, CS 141-1983, CS 2492006, CS 263-1966, CS 264-1966, CS 265-1966, CS 266-1966, CS 2671966, CS 268-1966, CS 269-1967, CS 270-1968, CS 271-1968, CS 272-1968 (solo para uso en la pasta de queso en estas normas)

\section{CS 319-2015 (mangos en} conserva solo)

CS $87-1981$, CS 105-1981, CS $141-1983$

1999

CS 249-2006

1 En esta columna solo figuran las normas para productos que permiten el uso de aditivos específicos del Cuadro 3. Si una norma para productos permite el uso de aditivos del Cuadro 3 de forma general o con base en la clase funcional, esa información figura en la sección del Cuadro 3 de la NGAA

"Referencias a las normas para productos para los aditivos del Cuadro 3 de la NGAA" 
Reguladores de la acidez, Agentes de tratamiento de las harinas

Sustancias conservadoras

Antiaglutinantes

Reguladores de la acidez, Agentes endurecedores, Agentes de tratamiento de las harinas,

Secuestrantes, Estabilizadores

Colorantes

Agentes de tratamiento de las harinas

Gasificantes, Espumantes, Gases de envasado, Sustancias conservadoras, Propulsores

Emulsionantes, Estabilizadores, Espesantes

Incrementadores del volumen, Sustancias inertes, Emulsionantes, Agentes gelificantes, Agentes de glaseado, Humectantes, Estabilizadores, Espesantes

Emulsionantes, Agentes gelificantes, Estabilizadores, Espesantes

Colorantes
1999

CS $105-1981$

1999

CS 249-2006

1999

CS 249-2006

CS 319-2015 (peras en conserva en envase especial de vacaciones solo), CS 249-2006

CS 105-1981, CS 70-1981 (para uso en medios de envasado solo), CS 941981 (para uso en medios de envasado solo), CS 1191981 (para uso en medios de envasado solo), CS 2492006

CS 96-1981, CS 97-1981, CS 105-1981, CS 70-1981 (para uso en medios de envasado solo), CS 941981 (para uso en medios de envasado solo), CS 1191981 (para uso en medios de envasado solo), CS 2492006
CS 319-2015 (peras en conserva en envase especial de vacaciones solo), CS 263-1966, CS 264-1966 (solo para uso en la pasta de queso en estas normas)

1 En esta columna solo figuran las normas para productos que permiten el uso de aditivos específicos del Cuadro 3 . Si una norma para productos permite el uso de aditivos del Cuadro 3 de forma general o con base en la clase funcional, esa información figura en la sección del Cuadro 3 de la NGAA

"Referencias a las normas para productos para los aditivos del Cuadro 3 de la NGAA" 
330 Ácido cítrico

Ésteres cítricos y de ácidos grasos de glicerol

Carboximetilcelulosa sódica reticulada (Goma de celulosa reticulada)

\section{$424 \quad$ Curdlan}

457 Ciclodextrina, alfa-

458 Ciclodextrina, gamma-

1504(i) Ciclotetraglucosa

1504(ii) Jarabe de ciclotetraglucosa

1400 Dextrinas, almidón tostado

628

Guanilato dipotásico, 5'-

627

Inosinato disódico, 5'-

Ribonucleótidos de sodio, 5'-

Fosfato de dialmidón

Ácido eritórbico (Ácido isoascóbico) Antioxidantes Espesantes Espesantes
Reguladores de la acidez, Antioxidantes, Agentes de retención de color, Secuestrantes

Antioxidantes, Emulsionantes, Agentes de tratamiento de las harinas, Secuestrantes, Estabilizadores

Estabilizadores, Espesantes

Agentes endurecedores, Agentes gelificantes, Estabilizadores,

Estabilizadores, Espesantes

Estabilizadores, Espesantes

Sustancias inertes

Sustancias inertes

Sustancias inertes, Emulsionantes, Estabilizadores, Espesantes

Acentuadores del sabor

Acentuadores del sabor

Acentuadores del sabor

Acentuadores del sabor

Emulsionantes, Estabilizadores,

Acentuadores del sabor, Humectantes, Edulcorantes
1999

1999

CS 87-1981, CS 105-1981, CS 141-1983, CS 13-1981, CS 57-1981, CS 37-1991, CS 70-1981, CS 90-1981, CS 94-1981, CS 119-1981, CS 302-2011, CS 249-2006

CS 319-2015 (mangos en conserva solo)

CS 302-2011

CS 319-2015 (mangos en conserva solo), CS 249 2006

CS 89-1981, CS 96-1981, CS 97-1981, CS 98-1981, CS 302-2011, CS 249-2006

CS 89-1981, CS 96-1981, CS 97-1981, CS 98-1981, CS 302-2011, CS 249-2006

CS 249-2006

CS 70-1981, CS 94-1981, CS 119-1981, CS 249-2006

CS 88-1981, CS 89-1981, CS 96-1981, CS 97-1981, CS 98-1981, CS 319-2015 (mangos en conserva solo) 


\begin{tabular}{|c|c|c|c|c|}
\hline 462 & Etil celulosa & $\begin{array}{l}\text { Incrementadores del volumen, } \\
\text { Sustancias inertes, Agentes de } \\
\text { glaseado, Espesantes }\end{array}$ & 1999 & \\
\hline 467 & Etilhidroxietilcelulosa & $\begin{array}{l}\text { Emulsionantes, Estabilizadores, } \\
\text { Espesantes }\end{array}$ & 1999 & \\
\hline 297 & Ácido fumárico & Reguladores de la acidez & 1999 & \\
\hline 418 & Goma gellan & $\begin{array}{l}\text { Agentes gelificantes, } \\
\text { Estabilizadores, Espesantes }\end{array}$ & 1999 & $\begin{array}{l}\text { CS 105-1981, CS 309R- } \\
2011, \text { CS 249-2006 }\end{array}$ \\
\hline 575 & Glucono-delta-lactona & $\begin{array}{l}\text { Reguladores de la acidez, } \\
\text { Leudantes, Secuestrantes }\end{array}$ & 1999 & $\begin{array}{l}\text { CS 89-1981, CS 98-1981, } \\
\text { CS 13-1981, CS 57-1981, } \\
\text { CS 263-1966, CS 264- } \\
\text { 1966, CS 265-1966, CS } \\
\text { 266-1966, CS 267-1966, } \\
\text { CS 268-1966, CS 269- } \\
\text { 1967, CS 270-1968, CS } \\
\text { 271-1968, CS 272-1968, } \\
\text { CS 274-1969, CS276-1973, } \\
\text { CS277-1973 (solo para uso } \\
\text { en la pasta de queso en } \\
\text { estas normas) }\end{array}$ \\
\hline 1102 & Oxidasa de glucosa & Antioxidantes & 1999 & $\begin{array}{l}\text { CS 319-2015 (mangos en } \\
\text { conserva solo) }\end{array}$ \\
\hline 620 & Ácido glutámico, L(+)- & Acentuadores del sabor & 1999 & CS 249-2006 \\
\hline 422 & Glicerol & Humectantes, Espesantes & 1999 & CS 87-1981 \\
\hline 626 & Ácido guanílico, 5'- & Acentuadores del sabor & 1999 & \\
\hline 412 & Goma guar & $\begin{array}{l}\text { Emulsionantes, Estabilizadores, } \\
\text { Espesantes }\end{array}$ & 1999 & $\begin{array}{l}\text { CS } 105-1981, \text { CS } 70-1981 \\
\text { (para uso en medios de } \\
\text { envasado solo), CS 94- } \\
1981 \text { (para uso en medios } \\
\text { de envasado solo), CS } 119- \\
1981 \text { (para uso en medios } \\
\text { de envasado solo), CS } 249- \\
2006\end{array}$ \\
\hline 414 & Goma arábiga (Goma de acacia) & $\begin{array}{l}\text { Incrementadores del volumen, } \\
\text { Sustancias inertes, Emulsionantes, } \\
\text { Agentes de glaseado, } \\
\text { Estabilizadores, Espesantes }\end{array}$ & 1999 & $\begin{array}{l}\text { CS } 87-1981, \text { CS 105-1981, } \\
\text { CS } 249-2006\end{array}$ \\
\hline 419 & Goma ghatti & $\begin{array}{l}\text { Sustancias inertes, Emulsionantes, } \\
\text { Estabilizadores, Espesantes }\end{array}$ & 2019 & $\begin{array}{l}\text { CS 243-2003, CS 256- } \\
2007, \text { CS 296-2009 }\end{array}$ \\
\hline 507 & Ácido clorhídrico & Reguladores de la acidez & 1999 & $\begin{array}{l}\text { CS 98-1981, CS 13-1981, } \\
\text { CS 57-1981 }\end{array}$ \\
\hline
\end{tabular}

\footnotetext{
1 En esta columna solo figuran las normas para productos que permiten el uso de aditivos específicos del Cuadro 3 . Si una norma para productos permite el uso de aditivos del Cuadro 3 de forma general o con base en la clase funcional, esa información figura en la sección del Cuadro 3 de la NGAA
} "Referencias a las normas para productos para los aditivos del Cuadro 3 de la NGAA" 
Emulsionantes, Espumantes, Agentes de glaseado,

Estabilizadores, Espesantes

1442 Fosfato de hidroxipropil dialmidón

Antiaglutinantes, Emulsionantes, Estabilizadores, Espesantes

Incrementadores del volumen Emulsionantes, Agentes de glaseado, Estabilizadores, Espesantes

1440 Almidón hidroxipropílico

630 Ácido inosínico, 5'-

953 Isomaltol (Isomaltulosa hidrogenada)

$416 \quad$ Goma karaya
$425 \quad$ Harina konjac

270 Ácido láctico, L-, D- y DL-

Reguladores de la acidez

472b Ésteres lácticos y de ácidos grasos de glicerol

Emulsionantes, Secuestrantes, Estabilizadores

$966 \quad$ Lactitol

322(i) Lecitina

Emulsionantes, Edulcorantes, Espesantes

Antioxidantes, Emulsionantes

Acentuadores del sabor

$\begin{array}{ll}1104 & \text { Lipasas } \\ 161 b(i i i) & \begin{array}{l}\text { Ésteres de luteína de Tagetes } \\ \text { erecta }\end{array}\end{array}$

Colorantes

160d(iii) Licopeno, Blakeslea trispora
Colorantes
1999

1999

CS 70-1981, CS 94-1981, CS 119-1981, CS 249-2006

1999

CS 302-2011

CS 87-1981, CS 105-1981

CS 105-1981, CS 249-2006

CS $87-1981$, CS 105-1981

CS 87-1981, CS 105-1981, CS 141-1983, CS 319-2015 (mangos en conserva solo), CS 249-2006

CS 87-1981 (Para uso en decoración de superficies únicamente)
CS 319-2015 (peras en conserva en envase especial de vacaciones solo)

1 En esta columna solo figuran las normas para productos que permiten el uso de aditivos específicos del Cuadro 3 . Si una norma para productos permite el uso de aditivos del Cuadro 3 de forma general o con base en la clase funcional, esa información figura en la sección del Cuadro 3 de la NGAA

"Referencias a las normas para productos para los aditivos del Cuadro 3 de la NGAA" 
160d(i) Licopeno, sintético

Colorantes

160d(ii) Licopeno, tomate

Colorantes

504(i) Carbonato de magnesio

$511 \quad$ Cloruro magnésico

625 Glutamato de magnesio, di-L-

580 Gluconato de magnésio

528 Hidróxido de magnesio

504(ii) Carbonato ácido de magnesio

329 Lactato de magnésio, DL-

$530 \quad$ Óxido de magnesio

553(i) Silicato de magnesio, sintético

470(iii) Estearato de magnesio

518 Sulfato de magnesio

296 Ácido málico, DL-
Reguladores de la acidez, Antiaglutinantes, Agentes de retención de color

Agentes de retención de color Agentes endurecedores,

Estabilizadores

Acentuadores del sabor

1999

Reguladores de la acidez, Agentes endurecedores, Acentuadores del sabor

Reguladores de la acidez, Agentes de retención de color

Reguladores de la acidez, Agentes de retención de color

Reguladores de la acidez, Agentes de tratamiento de las harinas

Reguladores de la acidez, Antiaglutinantes

Antiaglutinantes

Antiaglutinantes, Emulsionantes,

Espesantes

Agentes endurecedores, Acentuadores del sabor

Reguladores de la acidez, Secuestrantes

1999 Antiaglutinantes, Sustancias inertes,
2012

2012

CS 319-2015 (peras en conserva en envase especial de vacaciones solo)

CS 319-2015 (peras en conserva en envase especial de vacaciones solo)

CS 87-1981, CS 105-1981, CS 141-1983, CS 2631966, CS 264-1966, CS 265-1966, CS 266-1966, CS 267-1966, CS 268-

1966, CS 269-1967, CS 270-1968, CS 271-1968, CS 272-1968 (solo para uso en la pasta de queso en estas normas)

CS 319-2015 (mangos en conserva solo)

CS 87-1981, CS 105-1981, CS 141-1983

CS 87-1981, CS 105-1981, CS 141-1983

CS 105-1981

CS 319-2015 (mangos en conserva solo)

1 En esta columna solo figuran las normas para productos que permiten el uso de aditivos específicos del Cuadro 3 . Si una norma para productos permite el uso de aditivos del Cuadro 3 de forma general o con base en la clase funcional, esa información figura en la sección del Cuadro 3 de la NGAA

"Referencias a las normas para productos para los aditivos del Cuadro 3 de la NGAA" 
965(i) Maltitol

965(ii) Jarabe de maltitol

Manitol

461

Metilcelulosa

Metiletilcelulosa

460(i) Celulosa microcristalina (Gel de celulosa)

$471 \quad$ Monoglicéridos y diglicéridos de ácidos grasos

624 Glutamato monoamónico, L-

622 Glutamato monopotassium, L-

621 Glutamato monosódico, L-

Nitrógeno
Incrementadores del volumen, Emulsionantes, Humectantes, Estabilizadores, Edulcorantes, Espesantes

Incrementadores del volumen, Emulsionantes, Humectantes, Estabilizadores, Edulcorantes, Espesantes

Antiaglutinantes, Incrementadores del volumen, Humectantes, Estabilizadores, Edulcorantes, Espesantes

Incrementadores del volumen, Emulsionantes, Agentes de glaseado, Estabilizadores, Espesantes

Emulsionantes, Espumantes, Estabilizadores, Espesantes

Antiaglutinantes, Incrementadores del volumen, Sustancias inertes, Emulsionantes, Espumantes, Agentes de glaseado,

Estabilizadores, Espesantes

Antiespumantes, Emulsionantes, Agentes de glaseado, Estabilizadores

Acentuadores del sabor

Acentuadores del sabor

Acentuadores del sabor

Emulsionantes, Estabilizadores, Espesantes

Espumantes, Gases de envasado, Propulsores

Antioxidantes, Espumantes, Gases de envasado, Propulsores
1999

1999

CS 87-1981, CS 105-1981

CS 87-1981, CS 105-1981

CS 87-1981, CS 105-1981

CS 105-1981, CS 2631966, CS 264-1966, CS 265-1966, CS 266-1966, CS 267-1966, CS 268-

1966, CS 269-1967, CS 270-1968, CS 271-1968, CS 272-1968 (solo para el tratamiento de superficie del queso en lonchas, cortado, desmenuzado o rallado en estas normas del queso)

CS 87-1981, CS 105-1981, CS 141-1983, CS 249-2006

CS 89-1981, CS 96-1981, CS 97-1981, CS 98-1981, CS 90-1981, CS 302-2011, CS 249-2006

CS 70-1981, CS 94-1981, CS 119-1981, CS 249-2006

1999

1999

CS 319-2015 (mangos en conserva solo)

1 En esta columna solo figuran las normas para productos que permiten el uso de aditivos específicos del Cuadro 3 . Si una norma para productos permite el uso de aditivos del Cuadro 3 de forma general o con base en la clase funcional, esa información figura en la sección del Cuadro 3 de la NGAA

"Referencias a las normas para productos para los aditivos del Cuadro 3 de la NGAA" 


$\begin{array}{lll}423 & \begin{array}{l}\text { Ácido octenilsuccínico (OSA) goma } \\ \text { de acacia modificada }\end{array} & \text { Emulsionantes } \\ 1404 & \text { Almidón oxidado } & \begin{array}{l}\text { Emulsionantes, Estabilizadores, } \\ \text { Espesantes }\end{array} \\ 1101 \text { (ii) Papaína } & \text { Acentuadores del sabor } \\ 440 & \text { Pectinas } & \begin{array}{l}\text { Emulsionantes, Agentes } \\ \text { gelificantes, Agentes de glaseado, } \\ \text { Estabilizadores, Espesantes }\end{array}\end{array}$

1413 Fosfato de dialmidón fosfatado

Polidextrosa

Polivinilpirrolidona insoluble

261(i) Acetato de potasio

Alginato de potasio

Cloruro de potasio
2018

1999

1999

1999 Estabilizadores, Espesantes

Emulsionantes, Estabilizadores, Espesantes

Incrementadores del volumen, Agentes de glaseado, Humectantes, Estabilizadores, Espesantes

Edulcorantes

Agentes de retención de color, Estabilizadores

Acentuadores del sabor

Reguladores de la acidez, Sustancias conservadoras

Incrementadores del volumen, Sustancias inertes, Emulsionantes, Espumantes, Agentes gelificantes, Agentes de glaseado, Humectantes, Secuestrantes, Estabilizadores, Espesantes

Reguladores de la acidez, Estabilizadores

Agentes endurecedores,

Acentuadores del sabor,

Estabilizadores, Espesantes

Reguladores de la acidez, Sales emulsionantes, Secuestrantes, Estabilizadores

1999
CS 13-1981, CS 66-1981, CS 254-2007

CS 105-1981, CS 70-1981, CS 94-1981, CS 119-1981, CS 249-2006

CS 87-1981, CS 70-1981 (para uso en medios de envasado solo), CS 94 1981 (para uso en medios de envasado solo), CS 1191981 (para uso en medios de envasado solo), CS 2492006

CS 70-1981, CS 94-1981, CS 119-1981, CS 249-2006

CS 87-1981, CS 105-1981

CS 96-1981, CS 97-1981, CS 70-1981 (para uso en medios de envasado solo), CS 94-1981 (para uso en medios de envasado solo), CS 119-1981 (para uso en medios de envasado solo)

CS 87-1981, CS 105-1981, CS 141-1983, CS 249-2006

1999 CS 88-1981, CS 89-1981,

CS 96-1981, CS 97-1981,

CS 98-1981, CS 319-2015 (mangos en conserva solo) CS 249-2006

CS 13-1981, CS 57-1981, CS 302-2011

1 En esta columna solo figuran las normas para productos que permiten el uso de aditivos específicos del Cuadro 3 . Si una norma para productos permite el uso de aditivos del Cuadro 3 de forma general o con base en la clase funcional, esa información figura en la sección del Cuadro 3 de la NGAA

"Referencias a las normas para productos para los aditivos del Cuadro 3 de la NGAA" 
Autorización específica en las siguientes normas sobre productos 1

Reguladores de la acidez, Secuestrantes

501(ii) Carbonato ácido de potasio

Hidróxido de potasio

Lactato de potasio

Propionato de potásio

515(i) Sulfato de potásio

460(ii) Celulosa en polvo

Incrementadores del volumen,
Proteasa de Aspergillus orizae var.

Pullulan

470(i)

Sal mirística, palmítica y ácidos esteáricos con amonio, calcio. potasio y sodio

470(ii) Sal de ácido oleico con calcio, potasio y sodio

\section{Dióxido de silicio amorfo} Sustancias inertes, Emulsionantes, Agentes gelificantes, Agentes de glaseado, Humectantes, Estabilizadores, Espesantes

Antiaglutinantes, Incrementadores del volumen, Emulsionantes, Agentes de glaseado, Humectantes, Estabilizadores, Espesantes

Reguladores de la acidez, Leudantes, Estabilizadores

Reguladores de la acidez, Antioxidantes, Emulsionantes,

Sustancias conservadoras

Sustancias conservadoras

Acentuadores del sabor, Agentes de tratamiento de las harinas

Estabilizadores

Agentes de glaseado, Espesantes

Antiaglutinantes, Emulsionantes, Estabilizadores

Antiaglutinantes, Emulsionantes, Estabilizadores

Antiaglutinantes, Antiespumantes, Sustancias inertes
1999

1999

CS 13-1981, CS 57-1981

1999

CS 87-1981, CS 105-1981, CS 141-1983

CS 87-1981, CS 105-1981, CS 141-1983

CS 13-1981, CS 57-1981

CS 105-1981, CS 263-

1966, CS 264-1966, CS

265-1966, CS 266-1966,

CS 267-1966, CS 268-

1966, CS 269-1967, CS

270-1968, CS 271-1968,

CS 272-1968 (solo para el

tratamiento de superficie

del queso en lonchas,

cortado, desmenuzado o

rallado en estas normas del queso)

CS 70-1981 (para uso en medios de envasado solo), CS 94-1981 (para uso en medios de envasado solo), CS 119-1981 (para uso en medios de envasado solo), CS 249-2006

1 En esta columna solo figuran las normas para productos que permiten el uso de aditivos específicos del Cuadro 3 . Si una norma para productos permite el uso de aditivos del Cuadro 3 de forma general o con base en la clase funcional, esa información figura en la sección del Cuadro 3 de la NGAA

"Referencias a las normas para productos para los aditivos del Cuadro 3 de la NGAA" 


\section{2(i) \\ Acetato de sodio}

401

Alginato de sodio

Carboximetilcelulosa sódica (Goma de celulosa)

Carboximetilcelulosa sódica, hidrolizada mediante enzimas (Goma de celulosa hidrolizada mediante enzimas)

331(i) Citrato díacido de sodio

350(ii) Malato de sodio, DLde sodio)

Reguladores de la acidez, Emulsionantes, Sales Estabilizadores

Reguladores de la acidez, Humectantes

Antioxidantes

Reguladores de la acidez
Reguladores de la acidez, Antiaglutinantes, Sales emulsionantes, Leudantes, Estabilizadores, Espesantes

Reguladores de la acidez, Sustancias conservadoras Secuestrantes

Incrementadores del volumen, Sustancias inertes, Emulsionantes, Espumantes, Agentes gelificantes, Agentes de glaseado, Humectantes, Secuestrantes, Estabilizadores, Espesantes

ncrementadores del volumen, Emulsionantes, Agentes endurecedores, Agentes gelificantes, Agentes de glaseado, Humectantes, Estabilizadores, Espesantes

Estabilizadores, Espesantes emulsionantes, Secuestrantes,

CS 249-2006

CS 96-1981, CS 97-1981, CS 70-1981 (para uso en medios de envasado solo), CS 94-1981 (para uso en medios de envasado solo), CS 119-1981 (para uso en medios de envasado solo) CS 249-2006

CS 88-1981, CS 89-1981, CS 96-1981, CS 97-1981, CS 98-1981, CS 319-2015 (mangos en conserva solo)

CS 87-1981, CS 105-1981, CS 141-1983, CS 249-2006

CS 105-1981, CS 70-1981 (para uso en medios de envasado solo), CS 94 1981 (para uso en medios de envasado solo), CS 119 1981 (para uso en medios de envasado solo), CS 3022011, CS 319-2015 (mangos en conserva solo), CS 249-2006

CS 89-1981, CS 96-1981, CS 97-1981, CS 98-1981, CS 13-1981, CS 57-1981, CS 302-2011

CS 302-2011, CS 249-2006

CS 88-1981, CS 89-1981, CS 96-1981, CS 97-1981, CS 98-1981

Secuestrantes, Estabilizadores, Espesantes 
Autorización específica en las siguientes normas sobre productos 1

\section{No. SIN}

Additivo

Clases funcionales

Año de

adopción

500(ii) Carbonato ácido de sodio

350(i) Hidrogenmalato de sodio, DL-

514(ii) Hidrogensulfato de sodio

$524 \quad$ Hidróxido de sodio

Lactato de sodio

281

Propionato de sodio

500(iii) Sesquicarbonato de sodio

514(i) Sulfato de sodio

420(i) Sorbitol

420(ii) Jarabe de sorbitol

1420

Acetato de almidón

1450 Octenilsuccionato sódico de almidón

1405 Almidones tratados con enzimas

553(iii) Talco
Reguladores de la acidez, Antiaglutinantes, Leudantes,

Estabilizadores, Espesantes

Reguladores de la acidez, Humectantes

Reguladores de la acidez

Reguladores de la acidez

Reguladores de la acidez, Antioxidantes, Incrementadores del volumen, Emulsionantes, Sales emulsionantes, Humectantes, Espesantes

Sustancias conservadoras

Reguladores de la acidez, Antiaglutinantes, Leudantes

Reguladores de la acidez

volumen, Humectantes, Secuestrantes, Estabilizadores, Edulcorantes Espesantes

Incrementadores del volumen, Humectantes, Secuestrantes,

Estabilizadores, Edulcorantes,

Espesantes

Emulsionantes, Estabilizadores, Espesantes

Emulsionantes, Estabilizadores, Espesantes

Emulsionantes, Estabilizadores, Espesantes

Antiaglutinantes, Agentes de glaseado, Espesantes
1999

CS 87-1981, CS 105-1981, CS 141-1983, CS 249-2006

1999

CS 98-1981, CS 302-2011

2012

1999

CS 87-1981, CS 105-1981, CS 141-1983

1999

CS 302-2011, CS 249-2006

1999

1999

CS 87-1981, CS 105-1981, CS 249-2006

CS 70-1981, CS 94-1981, CS 119-1981, CS 249-2006

1999

CS 249-2006

1999

CS 105-1981, CS 249-2006

1999

CS 105-1981

1 En esta columna solo figuran las normas para productos que permiten el uso de aditivos específicos del Cuadro 3 . Si una norma para productos permite el uso de aditivos del Cuadro 3 de forma general o con base en la clase funcional, esa información figura en la sección del Cuadro 3 de la NGAA

"Referencias a las normas para productos para los aditivos del Cuadro 3 de la NGAA" 
$437 \quad$ Polisacárido de semillas de tamarindo

417

\section{Goma tara}

Taumatina

171

Dióxido de titanio

413

Goma tragacanto

Triacetina

Citrato de triamonio

333(iii) Citrato tricálcico

332(ii) Citrato tripotásico

331(iii) Citrato trisódico
Sales emulsionantes, Agentes gelificantes, Estabilizadores Espesantes
2019

CS 309R-2011, CS 941981, CS 119-1981, CS 243-2003, CS 249-2006, CS 256-2007, CS 273-1968 (como estabilizador en pasta de queso solamente) CS 275-1973 (como estabilizador, espesante y emulsionante en pasta de queso solamente), CS 2881976, CS 296-2009

Agentes gelificantes,

CS 105-1981, CS 249-2006

Estabilizadores, Espesantes

1999

CS 87-1981, CS 105-1981

Acentuadores del sabor Edulcorantes

1999

Colorantes

CS 319-2015 (peras en conserva en envase especial de vacaciones solo), CS 272-1968 (solo para uso en la pasta de queso en estas normas)

Emulsionantes, Estabilizadores, Espesantes

Sustancias inertes, Emulsionantes,

1999 Humectantes

Reguladores de la acidez

CS 13-1981, CS 57-1981

Reguladores de la acidez, Sales emulsionantes, Agentes endurecedores, Secuestrantes, Estabilizadores

Reguladores de la acidez, Sales emulsionantes, Secuestrantes, Estabilizadores

CS 13-1981, CS 57-1981, CS 302-2011

Reguladores de la acidez, Emulsionantes, Sales CS 105-1981, CS 70-1981 (para uso en medios de envasado solo), CS 941981 (para uso en medios de envasado solo), CS 1191981 (para uso en medios de envasado solo)

emulsionantes, Secuestrantes,

Estabilizadores
CS 89-1981, CS 96-1981,

CS 97-1981, CS 98-1981,

CS 13-1981, CS 57-1981, CS 302-2011, CS 249-2006

1 En esta columna solo figuran las normas para productos que permiten el uso de aditivos específicos del Cuadro 3 . Si una norma para productos permite el uso de aditivos del Cuadro 3 de forma general o con base en la clase funcional, esa información figura en la sección del Cuadro 3 de la NGAA

"Referencias a las normas para productos para los aditivos del Cuadro 3 de la NGAA" 
Autorización específica en las siguientes normas

Año de adopción sobre productos 1

CS 105-1981, CS 70-1981

(para uso en medios de envasado solo), CS 941981 (para uso en medios de envasado solo), CS 119 1981 (para uso en medios de envasado solo), CS 249 2006

Nota explicativa: determinación del uso de aditivos del Cuadro 3 en los alimentos regulados por normas para productos con base en el enfoque revisado

- Si una norma para productos incluye el uso de alimentos de las categorías de alimentos que figuran en el Anexo al Cuadro 3 , entonces, el Cuadro 3 no es aplicable a la norma para productos.

- Todos los aditivos alimentarios autorizados en los alimentos abarcados por las categorías de alimentos que figuran en el Anexo al Cuadro 3 deben figurar en los cuadros 1 y 2 de la NGAA.

- Si una norma para productos incluye una categoría de alimentos que no figura en el Anexo al Cuadro 3, entonces el usuario debe remitirse a la sección del Cuadro 3 "Referencias a normas para productos para aditivos del Cuadro 3 de la NGAA".

- Si la sección específica a la norma para productos indica que está permitido el uso de todos los aditivos del Cuadro 3 en los alimentos regulados por la norma, entonces cualquier aditivo alimentario que figure en el Cuadro 3 puede utilizarse en los alimentos regulados por la norma.

- Si el texto indica que solo pueden utilizarse los aditivos del Cuadro 3 con clases funcionales específicas (por ejemplo, reguladores de la acidez), entonces cualquier aditivo del Cuadro 3 que contenga la clase funcional anotada en la columna 3 del Cuadro 3 podrá utilizarse en los alimentos regulados por la norma sobre productos.

- Si el texto indica que en los alimentos regulados por la norma para productos "solo está permitido el uso de determinados aditivos alimentarios del Cuadro 3 (como se indica en el Cuadro 3)", entonces el usuario puede remitirse a la columna 5 del Cuadro 3 donde estará el número de la norma para productos para esos aditivos alimentarios específicos del Cuadro 3 cuyo uso está permitido en la norma para productos.

1 En esta columna solo figuran las normas para productos que permiten el uso de aditivos específicos del Cuadro 3 . Si una norma para productos permite el uso de aditivos del Cuadro 3 de forma general o con base en la clase funcional, esa información figura en la sección del Cuadro 3 de la NGAA

"Referencias a las normas para productos para los aditivos del Cuadro 3 de la NGAA" 


\section{ANEXO AL CUADRO III}

\section{Categorías de alimentos o productos alimenticios excluidos de las condiciones generales del Cuadro III}

El uso de los aditivos del cuadro III en los siguientes alimentos está sujeto a las disposiciones de los cuadros I y II.

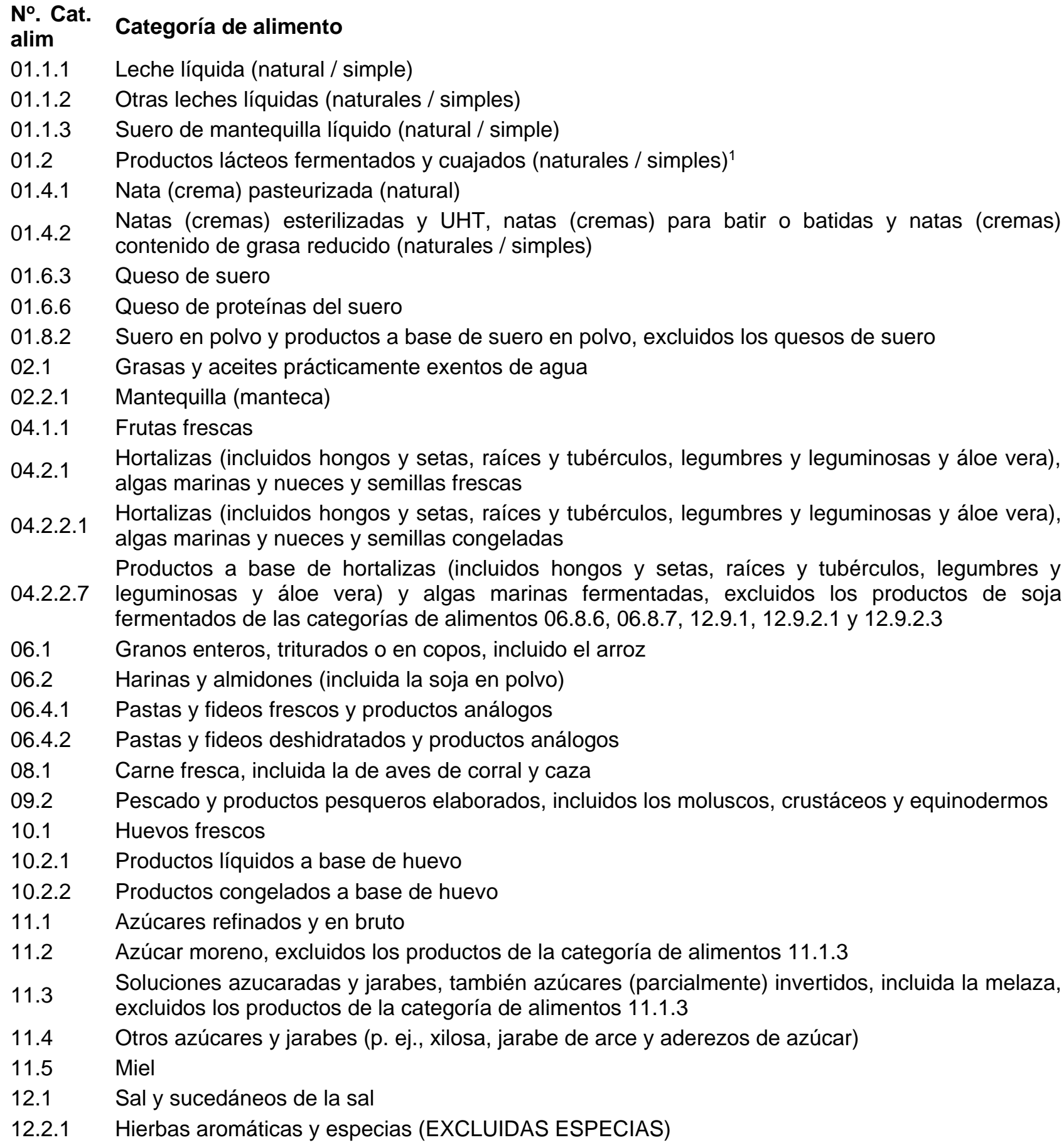

1 El uso de reguladores de la acidez, gases de envasado, estabilizadores y espesantes que figuran en el Cuadro 3 es aceptable en leches fermentadas, tratadas térmicamente después de la fermentación, de acuerdo con la definición de la Norma para leches fermentadas (CODEX STAN 243-2004) que corresponde a la categoría de alimentos 01.2.1.2 "Leches fermentadas (naturales) tratadas térmicamente después de la fermentación". 
$N^{\circ}$. Cat.

alim

13.1

\section{Categoría de alimento}

13.2 Alimentos complementarios para lactantes y niños pequeños

14.1.1 Aguas

14.1.2 Zumos (jugos) de frutas y hortalizas

14.1.3 Néctares de frutas y hortalizas

14.1.5 Café, sucedáneos del café, té, infusiones de hierbas y otras bebidas calientes a base de cereales y granos, excluido el cacao

14.2.3 Vinos de uva

Referencias a las normas del Codex sobre productos para los Aditivos en la Tabla 3 de la NGAA $3^{2}$

\begin{tabular}{|l|l|}
\hline 01.6.2.1 & Queso madurado, incluida la corteza \\
\hline & $\begin{array}{l}\text { En los alimentos correspondientes a estas normas solo es aceptable el uso de } \\
\text { determinados aditivos alimentarios del Cuadro } 3 \text { (que se indican en el Cuadro 3). El uso de } \\
\text { reguladores de la acidez solo es aceptable en la pasta de queso. En la pasta de queso } \\
\text { solo se utilizan colorantes para obtener las características de color tal como se describe en } \\
\text { la sección } 2 \text { de la norma para productos. Los antiaglutinantes solo están justificados para } \\
\text { el tratamiento de superficie del queso en lonchas, cortado, desmenuzado o rallado. }\end{array}$ \\
\hline $\begin{array}{l}\text { Normas del } \\
\text { Codex }\end{array}$ & $\begin{array}{l}\text { Cheddar (CXS 263-1966), Danbo (CXS 264-1966), Edam (CXS 265-1966), Gouda (CXS } \\
\text { 266-1966), Havarti (CXS 267-1966), Samsø (CXS 268-1966), Emmental (CXS 269-1967), } \\
\text { Tilsiter(CXS 270-1968), Saint-Paulin (CXS 271-1968), Provolone (CXS 272-1968), } \\
\text { Coulommiers (CXS 274-1969), Camembert (CXS 276-1973) y Brie (CXS 277-1973). }\end{array}$ \\
\hline
\end{tabular}

\begin{tabular}{|l|l|}
\hline 04.1.2.4 & Frutas en conserva, enlatadas o en frascos (pasterizadas) \\
\hline & $\begin{array}{l}\text { El uso de los reguladores de la acidez que figuran en el Cuadro } 3 \text { es aceptable en todos } \\
\text { los productos regulados por la norma. El uso de los antioxidantes y agentes } \\
\text { endurecedores que figuran en el Cuadro } 3 \text { es aceptable en los mangos en conserva } \\
\text { regulados por la norma. El uso de los colorantes que figuran en el Cuadro } 3 \text { es aceptable } \\
\text { en las peras en conserva en envase especial de vacaciones reguladas por la norma. En } \\
\text { la piña en conserva regulada por la norma solo es aceptable el uso de determinados } \\
\text { antioxidantes del Cuadro 3 (como se indica en el Cuadro 3). }\end{array}$ \\
\hline $\begin{array}{l}\text { Norma del } \\
\text { Codex }\end{array}$ & \begin{tabular}{l} 
algunas frutas en conserva (CODEX STAN 319-2015) \\
\hline
\end{tabular} \\
\hline
\end{tabular}

\begin{tabular}{|l|l|}
\hline 04.1.2.4 & Frutas en conserva, enlatadas o en frascos (pasteurizadas) \\
\hline & $\begin{array}{l}\text { Los reguladores de la acidez y agentes endurecedores que figuran en el Cuadro } 3 \text { son } \\
\text { aceptables para uso en los alimentos que corresponden a esta norma. }\end{array}$ \\
\hline $\begin{array}{l}\text { Norma del } \\
\text { Codex }\end{array}$ & Algunos frutos cítricos en conserva (CODEX STAN 254-2007) \\
\hline
\end{tabular}

\begin{tabular}{|l|l|}
\hline 04.2.2.3 & $\begin{array}{l}\text { Hortalizas (incluidos hongos y setas, raíces y tubérculos, legumbres y } \\
\text { leguminosas y áloe vera) y algas marinas en vinagre, aceite, salmuera o } \\
\text { salsa de soja }\end{array}$ \\
\hline & $\begin{array}{l}\text { Los reguladores de la acidez, antioxidantes, agentes de retención de color (aceitunas de } \\
\text { mesa ennegrecidas por oxidación únicamente), agentes endurecedores, acentuadores } \\
\text { del sabor, conservantes y espesantes (sólo en aceitunas de mesa con relleno) que }\end{array}$ \\
\hline
\end{tabular}

\footnotetext{
${ }^{2}$ En esta Sección figuran solamente normas sobre productos en que la categoría de alimentos correspondiente de la NGAA no figura en el anexo del Cuadro 3. Las disposiciones para el uso de determinados aditivos del Cuadro 3 en normas para productos en que la categoría de alimentos correspondiente de la NGAA figura en el anexo del Cuadro 3 pueden encontrarse en las categorías de alimentos correspondientes en los cuadros 1 y 2 . Debe tenerse en cuenta que el proceso de armonización de la disposiciones sobre aditivos alimentarios en las normas para productos con la NGAA es un trabajo en curso, y debido a ello no todas las normas para productos figuran todavía en esta Sección.
} 


\begin{tabular}{|l|l|}
\hline & $\begin{array}{l}\text { figuran en el Cuadro 3 son aceptables para uso en alimentos que correspondan a la } \\
\text { norma. }\end{array}$ \\
\hline $\begin{array}{l}\text { Norma del } \\
\text { Codex }\end{array}$ & Aceitunas de mesa (CODEX STAN 66-1981) \\
\hline $\mathbf{0 4 . 2 . 2 . 4}$ & $\begin{array}{l}\text { Hortalizas (incluidos hongos y setas, raíces y tubérculos, legumbres y } \\
\text { leguminosas y áloe vera) y algas marinas en conserva, en latas o frascos } \\
\text { (pasterizadas) o en bolsas de esterilización }\end{array}$ \\
\hline $\begin{array}{l}\text { Nodos los agentes endurecedores que figuran en el Cuadro 3 y otros determinados } \\
\text { aditivos del Cuadro 3 (como se indica en el Cuadro 3) son aceptables para uso en los } \\
\text { alimentos que corresponden a las normas. }\end{array}$ \\
\hline $\begin{array}{l}\text { Tomates en conserva (CODEX STAN 13-1981) } \\
\text { Codex }\end{array}$ & $\begin{array}{l}\text { Únicamente determinados aditivos alimentarios que figuran en el Cuadro 3 (indicados en } \\
\text { el Cuadro 3) son aceptables para uso en los alimentos que corresponden a la norma. }\end{array}$ \\
\hline
\end{tabular}

\begin{tabular}{|l|l|}
\hline 04.2.2.5 & $\begin{array}{l}\text { Purés y preparados para untar elaborados con hortalizas (incluidos hongos y } \\
\text { setas, raíces y tubérculos, legumbres y leguminosas y áloe vera), algas marinas y } \\
\text { nueces y semillas (p. ej. la mantequilla de maní (cacahuete)) }\end{array}$ \\
\hline & $\begin{array}{l}\text { Únicamente determinados aditivos alimentarios que figuran en el Cuadro } 3 \text { (indicados en } \\
\text { el Cuadro 3) son aceptables para uso en los alimentos que corresponden a estas } \\
\text { normas. }\end{array}$ \\
\hline $\begin{array}{l}\text { Norma del } \\
\text { Codex }\end{array}$ & \begin{tabular}{l} 
Concentrados de tomate elaborados (CODEX STAN 57-1981) \\
\hline
\end{tabular} \\
\hline
\end{tabular}

\begin{tabular}{|l|l|}
\hline 04.2.2.6 & $\begin{array}{l}\text { Pulpas y preparados de hortalizas (incluidos hongos y setas, raíces y } \\
\text { tubérculos, legumbres y leguminosas y áloe vera), algas marinas y nueces y } \\
\text { semillas (como los postres y las salsas a base de hortalizas y hortalizas } \\
\text { confitadas) distintos de los indicados en la categoría de alimentos 04.2.2.5 }\end{array}$ \\
\hline & $\begin{array}{l}\text { Únicamente determinados aditivos alimentarios que figuran en el Cuadro } 3 \text { (indicados en } \\
\text { el Cuadro 3) son aceptables para uso en los alimentos que corresponden a estas } \\
\text { normas. }\end{array}$ \\
\hline $\begin{array}{l}\text { Norma del } \\
\text { Codex }\end{array}$ & \begin{tabular}{l} 
Concentrados de tomate elaborados (CODEX STAN 57-1981) \\
\hline
\end{tabular} \\
\hline
\end{tabular}

\begin{tabular}{|l|l|}
\hline 05.1.1 & Mezclas de cacao (en polvo) y cacao en pasta/torta de cacao \\
\hline & $\begin{array}{l}\text { Sólo ciertos aditivos alimentarios del Cuadro } 3 \text { (como se indica en el Cuadro 3) son } \\
\text { aceptables para uso en alimentos que correspondan a estas normas. }\end{array}$ \\
\hline $\begin{array}{l}\text { Norma del } \\
\text { Codex }\end{array}$ & $\begin{array}{l}\text { Cacao en polvo (cacaos) y las mezclas de cacao y azúcares (CODEX STAN 105-1981) y } \\
\text { Cacao en pasta (licor de cacao/chocolate) y la torta de cacao (CODEX STAN 141-1983) }\end{array}$ \\
\hline
\end{tabular}

\begin{tabular}{|l|l|}
\hline 05.1.4 & Productos de cacao y chocolate \\
\hline & $\begin{array}{l}\text { Sólo ciertos aditivos alimentarios del Cuadro 3 (como se indica en el Cuadro 3) son } \\
\text { aceptables para uso en alimentos que correspondan a esta norma. }\end{array}$ \\
\hline $\begin{array}{l}\text { Norma del } \\
\text { Codex }\end{array}$ & Chocolate y los productos del chocolate (CODEX STAN 87-1981) \\
\hline
\end{tabular}




\begin{tabular}{|l|l|}
\hline $\mathbf{0 5 . 2 . 2}$ & Caramelos blandos \\
\hline & $\begin{array}{l}\text { Los reguladores de la acidez y emulsionantes que figuran en el Cuadro 3 son aceptables } \\
\text { para uso en los alimentos que corresponden a esta norma. }\end{array}$ \\
\hline $\begin{array}{l}\text { Norma del } \\
\text { Codex }\end{array}$ & Halva con tahina (CODEX STAN 309R-2011) (Norma regional) \\
\hline
\end{tabular}

\begin{tabular}{|l|l|}
\hline $\mathbf{0 6 . 4 . 3}$ & Pastas y fideos precocidos y productos análogos \\
\hline & $\begin{array}{l}\text { En los alimentos correspondientes a esta Norma solo es aceptable el uso de } \\
\text { determinados aditivos alimentarios del Cuadro 3 (como se indica en el Cuadro 3). }\end{array}$ \\
\hline $\begin{array}{l}\text { Normas del } \\
\text { Codex }\end{array}$ & fideos instantáneos (CXS 249-2006) \\
\hline
\end{tabular}

\begin{tabular}{|l|l|}
\hline $\mathbf{0 6 . 8 . 8}$ & Otros productos a base de proteína de soja \\
\hline $\begin{array}{l}\text { Normas del } \\
\text { Codex }\end{array}$ & No se permiten aditivos alimentarios en los productos regulados por esta Norma. \\
\hline
\end{tabular}

\begin{tabular}{|l|l|}
\hline 08.2.2 & $\begin{array}{l}\text { Productos cárnicos, de aves de corral y caza elaborados, tratados térmicamente } \\
\text { en piezas enteras o en cortes }\end{array}$ \\
\hline & $\begin{array}{l}\text { Sólo algunos aditivos del Cuadro 3 (como se indica en el Cuadro 3) son aceptables para } \\
\text { uso en los alimentos que corresponden a estas normas. }\end{array}$ \\
\hline $\begin{array}{l}\text { Norma del } \\
\text { Codex }\end{array}$ & $\begin{array}{l}\text { Jamón curado cocido (CODEX STAN 96-1981) y Espaldilla de cerdo curada cocida } \\
\text { (CODEX STAN 97-1981). }\end{array}$ \\
\hline
\end{tabular}

\begin{tabular}{|l|l|}
\hline 08.3.2 & $\begin{array}{l}\text { Productos cárnicos, de aves de corral y caza picados, elaborados y tratados } \\
\text { térmicamente }\end{array}$ \\
\hline & $\begin{array}{l}\text { Sólo algunos aditivos del Cuadro 3 (como se indica en el Cuadro 3) son aceptables para } \\
\text { uso en los alimentos que corresponden a estas normas. }\end{array}$ \\
\hline $\begin{array}{l}\text { Norma del } \\
\text { Codex }\end{array}$ & $\begin{array}{l}\text { Carne tipo "Corned beef" (CODEX STAN 88-1981), Carne "Luncheon" (CODEX STAN } \\
89-1981), \text { y Carne picada curada cocida (CODEX STAN 98-1981). }\end{array}$ \\
\hline
\end{tabular}

\begin{tabular}{|l|l|}
\hline 09.3.3 & Sucedáneos de salmón, caviar y otros productos pesqueros a base de huevas \\
\hline & $\begin{array}{l}\text { En los alimentos regulados por esta norma es aceptable el uso de los reguladores de la } \\
\text { acidez, antioxidantes y sustancias conservadoras que figuran en el Cuadro } 3 .\end{array}$ \\
\hline $\begin{array}{l}\text { Norma del } \\
\text { Codex }\end{array}$ & Caviar de esturión (CODEX STAN 291-2010) \\
\hline
\end{tabular}

\begin{tabular}{|l|l|}
\hline 09.4 & $\begin{array}{l}\text { Pescado y productos pesqueros (incluidos moluscos, crustáceos y equinodermos) } \\
\text { en conserva, con inclusión de los enlatados y fermentados }\end{array}$ \\
\hline $\begin{array}{l}\text { En los alimentos regulados por estas normas solo es aceptable el uso de determinados } \\
\text { aditivos alimentarios del Cuadro 3 (como se indica en el Cuadro 3). }\end{array}$ \\
\hline Codex & $\begin{array}{l}\text { camarones en conserva (CXS 37-1991) } \\
\text { atún y bonito en conserva(CXS 70-1981) } \\
\text { carne de cangrejo en conserva (CXS 90-1981) } \\
\text { sardinas y productos análogos en conserva (CXS 94-1981) } \\
\text { pescados en conserva (CODEX STAN 119-1981) }\end{array}$ \\
\hline
\end{tabular}




\begin{tabular}{|l|l|}
\hline 12.5 & Sopas y caldos \\
\hline & $\begin{array}{l}\text { El uso de reguladores de la acidez, antiaglutinantes (sólo en productos deshidratados), } \\
\text { agentes antiespumantes, antioxidantes, colorantes, emulsionantes, acentuadores del } \\
\text { sabor, humectantes, gases de envasado, conservantes, estabilizadores, edulcorantes y } \\
\text { espesantes del Cuadro 3 es aceptable en los alimentos regulados por la norma. }\end{array}$ \\
\hline $\begin{array}{l}\text { Norma del } \\
\text { Codex }\end{array}$ & "Bouillons" y consomés (CODEX STAN 117-1981) \\
\hline
\end{tabular}

\begin{tabular}{|l|l|}
\hline $\mathbf{1 2 . 6 . 4}$ & Salsas ligeras (p. ej., salsa de pescado) \\
\hline & $\begin{array}{l}\text { En los alimentos regulados por esta Norma solo es aceptable el uso de determinados } \\
\text { aditivos alimentarios del Cuadro 3 (como se indica en el Cuadro 3). }\end{array}$ \\
\hline $\begin{array}{l}\text { Norma del } \\
\text { Codex }\end{array}$ & salsa de pescado (CODEX STAN 302-2011) \\
\hline
\end{tabular}

\begin{tabular}{|l|l|}
\hline $\mathbf{1 2 . 1 0}$ & Productos proteínicos distintos a los de soja \\
\hline $\begin{array}{l}\text { Normas del } \\
\text { Codex }\end{array}$ & $\begin{array}{l}\text { Productos de proteínas de trigo incluido el gluten de trigo (CXS 163-1987), productos } \\
\text { proteínicos vegetales (PPV) (CXS 174-1989) }\end{array}$ \\
\hline
\end{tabular}

